\title{
DE LA MALEABILIDAD DEL TIEMPO CINEMATOGRÁFICO A LA PLASTICIDAD DEL ESPACIO DIGITAL ANálLSIS PRÁCTICO DE CONSTRUCCIONES EN LA IMAGEN CÓDIGO
}

\section{Tesis doctoral dirigida POR José LuIs Molinuevo}

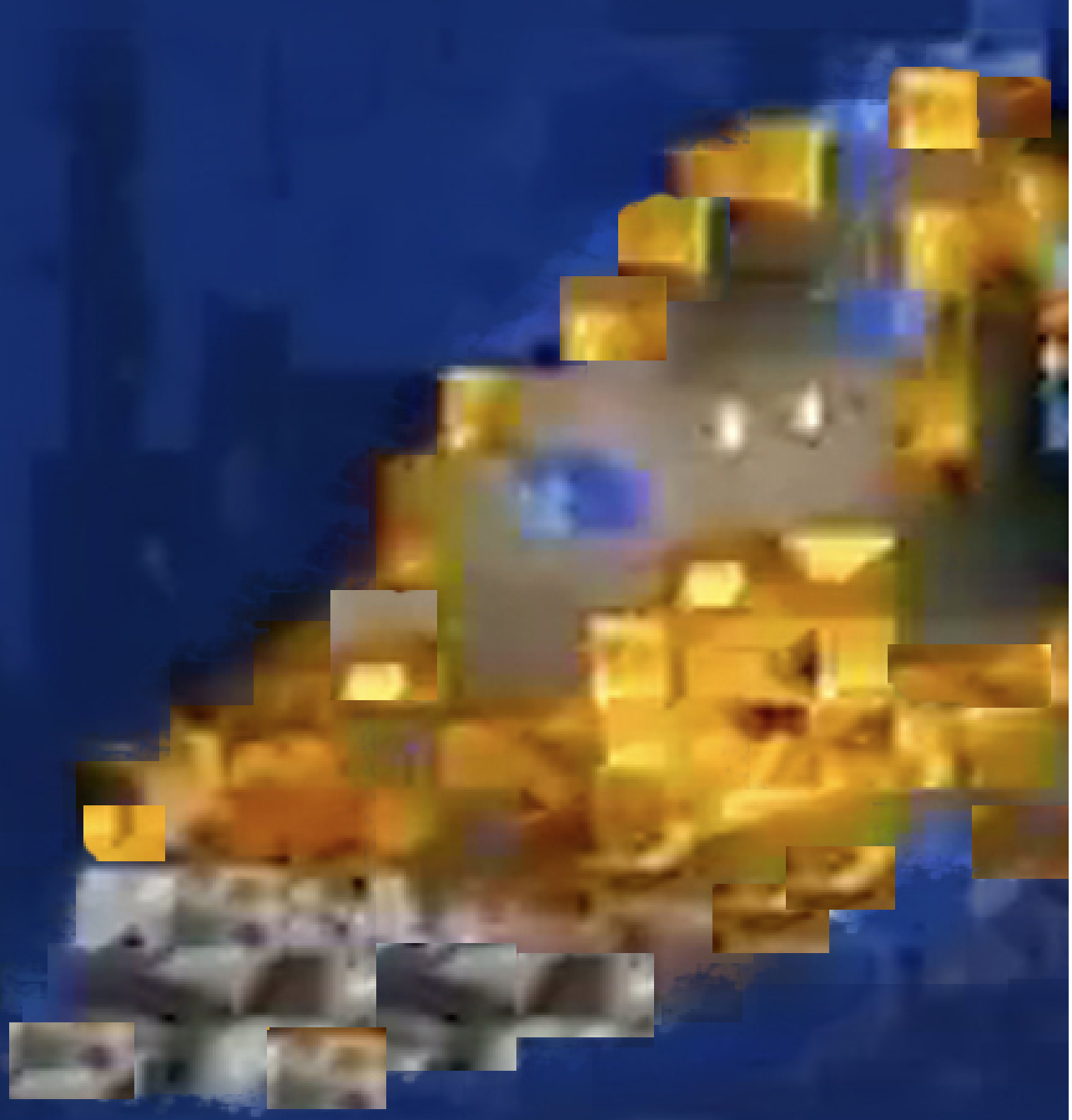

UNIVERSIDAD DE SALAMANCA

Facultad de Filosofía, 2013 


\title{
DE LA MALEABILIDAD DEL TIEMPO CINEMATOGRÁFICO A LA PLASTICIDAD DEL ESPACIO DIGITAL Análisis práctico de construcciones en la imagen código
}

\author{
Autora: Raquel Santos Ortiz \\ Director: José Luis Molinuevo Martínez de Bujo
}

Departamento de Filosofía, Lógica y Estética

Universidad de Salamanca

2013 
"De la maleabilidad del tiempo cinematográfico a la plasticidad del espacio digital. Análisis práctico de construcciones en la imagen código”.

Tesis doctoral presentada por Raquel Santos Ortiz y dirigida por José Luis Molinuevo Martínez de Bujo. 
El presente trabajo ha sido posible gracias a una Ayuda para la Formación de Personal Investigador de la Universidad de Salamanca, financiada por el Banco Santander. 


\section{AGRADECIMIENTOS}

Siento una profunda gratitud hacia José Luis Molinuevo, catedrático de la Universidad de Salamanca y director de esta tesis doctoral, por sus sabios consejos, por sus siempre atentas correcciones y por su permanente apoyo intelectual. Valoro muy sinceramente su confianza, tanto profesional como personal, que tanto me ha ayudado en los momentos difíciles.

Quiero expresar también mi agradecimiento a Laurent Creton por su invitación al Institut de Recherche sur le Cinéma et l'Audiovisuel de la Universidad Sorbonne Nouvelle Paris III; dicha estancia me permitió, entre otras cosas importantes, hacer uso de la biblioteca del centro y de la Cinémathèque Française. En este sentido, fue inestimable la intercesión de Jacques Aumont, director de mi trabajo de Máster que, presentado en la École des Hautes Études en Sciences Sociales de París bajo el título Les origines de l'image numérique dans le cinéma des avant-gardes, precedió al proyecto de la presente investigación.

Por último, al repasar los últimos años, pienso en mi familia, en mis padres, Mercedes y Luis, y en mis hermanos, Carmen y Pablo, y en todo el cariño y apoyo incondicional que siempre me han dado. También en la intimidad, sería inimaginable concebir este trabajo sin la motivación diaria de mi pareja, Sascha; primero en la distancia y, por fin, en la cálida proximidad de nuestra casa, su ayuda, su fe en el futuro y el esfuerzo intelectual no se expresan con palabras. 
A mi hermana 


\section{ÍNDICE}

\section{CAPÍTULO I. LA CONSTRUCCIÓN DEL ESPACIO EN EL INTERIOR DEL CUADRO}

DE LA REPRODUCCIÓN A LA TRANSFORMACIÓN......................15

El rechazo a la representación en perspectiva.........................22

La imagen como materia prima para la distorsión.......................29

EL MONTAJE ESPACIAL ............................................41

La cohabitación de las imágenes........................................43

La exploración de la simultaneidad.................................52

La influencia del cubismo pictórico..............................63

La mezcla de las imágenes............................................69

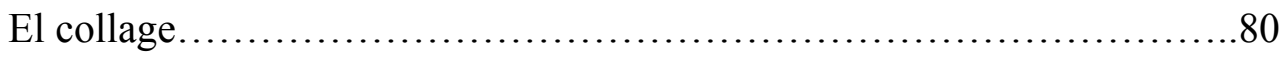

La profundidad de la imagen...................................85

La sobreimpresión............................................ 89

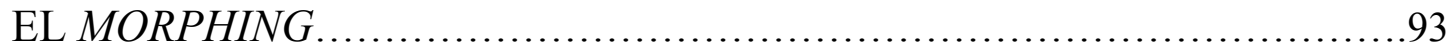

El anhelo de metamorfosis..........................................93

El morphing dentro de la ficción...................................98

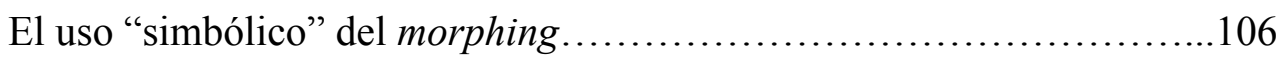

La polémica del "morphing racial" ..................................110

LAS TRANSICIONES ESPACIO-TEMPORALES CONTINUAS ..........117

Del fundido encadenado al morphing..............................117

La transformación lumínica y la estratificación en capas.................124 


\section{CAPÍTULO II. LA CÁMARA VIRTUAL COMO CONSTRUCCIÓN ESPACIAL}

LA OMNIPOTENCIA DE LA CÁMARA VIRTUAL ........................141

La liberación del punto de vista...................................143

El movimiento como metamorfosis...............................152

La trayectoria en un medio lleno...................................... 159

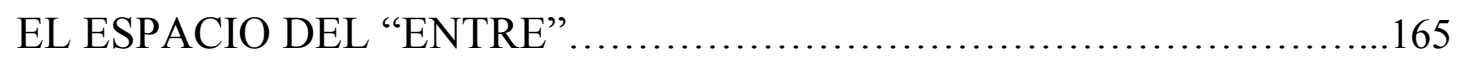

Entre sujetos y objetos........................................ 166

Entre la segunda y la tercera dimensión............................172

Entre fijación y movimiento........................................ 177

EL ZOOM DIGITAL.................................................... 183

La dimensión fractal.............................................189

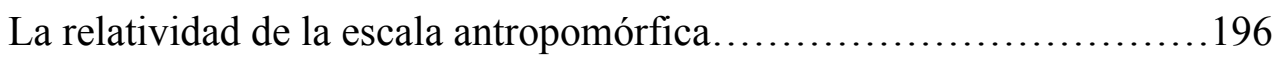

EL PLANO SECUENCIA DIGITAL ........................................209

La elasticidad espacial como condensación temporal..................209

El collage en profundidad.......................................222

LA INSTANTÁNEA TRIDIMENSIONAL ..............................229

Los orígenes de la idea.............................................230

La independencia de la cámara virtual...............................237

\section{CAPÍTULO III. LA CONSTRUCCIÓN DE ESPACIOS NO- EUCLIDIANOS E HIPERESPACIOS}

EL MOVIMIENTO COMO FORMA CONTINUA.........................253

El motion blur o la influencia del futurismo...........................253

La multiexposición o la influencia de la cronofotografía................263

La animación mediante morphing.................................269 
EL CONTINUO ESPACIO-TEMPORAL .................................277

La slit scan ......................................................284

La cuarta dimensión del espacio..................................290

DEL POLITOPO AL VIAJE INTERDIMENSIONAL ........................301

La proyección de hiperobjetos......................................304

La visualización del puente..........................................310

La metáfora líquida.......................................... 322

DINÁMICAS DE LA DISTORSIÓN Y DE LA METAMORFOSIS...........331

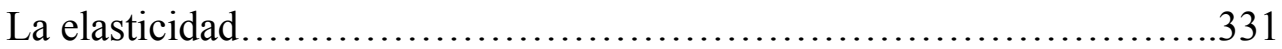

La condensación................................................. 342

DE LA VARIABILIDAD A LA GÉNESIS ESPACIAL .........................357

La estética permutacional........................................357

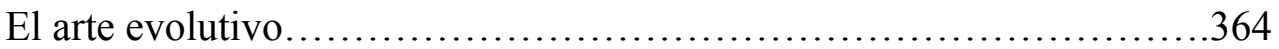

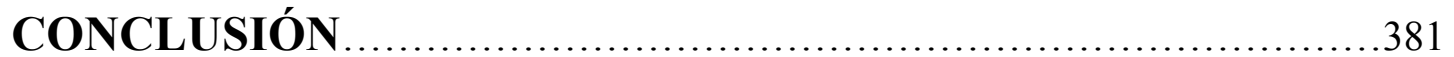

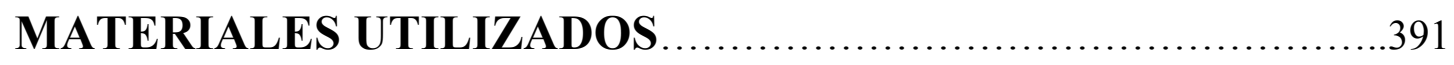




\section{INTRODUCCIÓN}

Ponemos punto final a este trabajo en 2013: han pasado exactamente cincuenta años desde de la primera animación por ordenador de la historia ${ }^{1}$ y la imagen digital es omnipresente. Al volver la vista atrás hasta sus primeras manifestaciones en los años 60, descubrimos hiperobjetos, metamorfosis, reinterpretaciones del arte moderno, animaciones abstractas y geométricas... En paralelo a estas imágenes de síntesis, los artistas que exploran la imagen videográfica acuden a la informática en su anhelo de plasticidad: primero como señal electrónica y después como código cifrado, la luz se registra para hacer de ella una materia prima modelable. Se trate de este videoarte o de aquel "computer art", no cabe duda: el espacio fascina a quienes se acercan por primera vez a la nueva herramienta interactiva.

Por su parte, el cine acoge poco a poco las cómodas innovaciones en la edición y el retoque. Sin embargo, el reconocimiento por parte de la práctica cinematográfica de las posibilidades de la imagen código implica un aspecto negativo: la creación digital se subordina a la narración ${ }^{2}$ y se encarrila por la vía única del "fotorrealismo". Esta exhibición de la potencia mimética del medio deja relegada otras formas de exploración plástica. Precisamente a éstas, dedicamos nuestro empeño.

De hecho, al analizar detenidamente los efectos especiales en el cine de las últimas dos décadas, descubrimos también construcciones imposibles para una cámara física, transiciones espacio-temporales continuas, distorsiones, pixelizaciones... En este sentido, el cine contemporáneo se confunde con las imágenes impactantes que pueblan, primero, la publicidad o el videoclip y, después, el arte en Internet. En todas ellas, hallamos un anhelo de empujar la imagen más allá de los límites del registro; de jugar con la sorpresa y el imposible; de explorar el espacio multidimensional en las entrañas del ordenador.

\footnotetext{
1 Simulation of a Two-Gyro Gravity-Gradient Attitude Control System (1963), del ingeniero estadounidense Edward E. Zajac, simula el movimiento de un satélite en su órbita en torno a la Tierra.

${ }^{2}$ El cine clásico subordina el espacio a la causalidad narrativa: "In making narrative causality the dominant system in the films' total form, the classical Hollywood cinema chooses to subordinate space". BORDWELL, David. "Space in the classical film". En: BORDWELL, D.; STAIGER, J.; THOMPSON, K.. The Classical Hollywood Cinema: Film Style and Mode of Production to 1960. London: Routledge, 1985, p. 50.
} 
No obstante, la imagen código suele considerarse como un sucedáneo de la imagen cinematográfica: un mero adorno de la narración. Aunque, desde sus inicios, la práctica digital muestra un gran interés por el espacio de la imagen animada, este hecho no ha hallado un eco consecuente en la teoría. De este modo, nuestro objetivo ha sido doble: por un lado, contribuir a llenar este vacío y, por otro, probar y documentar esa preponderancia del aspecto espacial en la imagen digital, frente a la primacía del tiempo en la imagen cinematográfica.

Si el dispositivo cinematográfico se caracteriza por la "maleabilidad del tiempo" (es decir, el registro puede ralentizarse, acelerarse, invertirse...), la imagen digital presenta una "plasticidad espacial" sin precedentes. Como comprobaremos a lo largo de este trabajo, ni la elasticidad se agota en el efecto espectacular del morphing, ni la plasticidad se reduce a esta condición elástica. Plasticidad es, también, condensación, permutabilidad y génesis del espacio mismo. Así, nos esforzamos tanto por probar la plasticidad del espacio digital como por dar cuenta de sus diversas manifestaciones.

Nuestra investigación consiste en el análisis de prácticas espaciales en la imagen digital desde sus inicios hasta hoy. Para ello, proponemos el concepto de "construcción" como clave de una estética de la imagen código ligada a la potencia plástica del espacio digital. A efectos de este trabajo, entendemos por "imagen código" o "imagen digital" aquélla constituida por píxeles, almacenada en el ordenador como un lenguaje cifrado en unos y ceros, y contemplada a través de una pantalla. Abordamos la imagen no en un sentido abstracto (“¿qué es una imagen?”), sino en su aspecto tecnológico, en relación al proceso de elaboración que la sustenta. ${ }^{3}$ Así concebida, la imagen digital comprende tanto la síntesis total como la transformación de un material de partida.

Contraponemos el concepto de "construcción" al de "re-producción": no se trata de producir de nuevo a partir de un registro (mecánico, analógico o digital), sino de construir una entidad espacial autorreferencial. Por ello, obviamos la veracidad de la imagen, su autenticidad o realismo. ${ }^{4}$ Si hay registro, esa imagen pierde su calidad de

\footnotetext{
3 Retomamos la definición de "imagen digital" dada por Edmond Couchot: "Sur l'écran de l'ordinateur, l'image numérique se présente alors sous l'aspect d'une matrice à deux dimensions de points élémentaires lumineux et colorés - les pixels - coïncidant exactement avec une matrice numérique - dite 'mémoire d'image' - qui contient les valeurs mathématiques (couleur et lumière) attribués aux pixels." COUCHOT, Edmond. L'art numérique. Comment la technologie vient au monde de l'art. Paris: Éditions Flammarion, 2003, pp. 22-23.

4 "Desde un punto de vista estético una imagen digital no tiene por qué ser verdadera, en el sentido de que copie o represente algo. Tampoco tiene sentido hablar de si es auténtica o no, pues su misma naturaleza es la de la manipulación. Y en cuanto a la originalidad, no existe un original, sino tan sólo
} 
índice en la digitalización, sea ésta en la toma mediante vídeo digital o en un proceso de conversión de la señal analógica en dígitos; a partir de ese momento, las imágenes son una materia prima, un conjunto de números con los que jugar. En lo que concierne a nuestra investigación, poco importa si esa imagen primera era fotográfica o no: hablamos desde el ordenador, no desde la cámara.

La imagen digital suele abordarse con dicotomías de tipo real/virtual, representación/simulación, viejo/nuevo... Sin embargo, la complejidad y la variedad de las construcciones espaciales nos reta a plantear otras cuestiones. Así, estamos convencidos de que merece la pena analizar con detenimiento los casos concretos para no caer en el error de imponer a tales imágenes una terminología estéril.

Se trata de reformular lo estético a través de lo técnico. A veces artistas que exploran la informática, a veces ingenieros devenidos artistas, los mismos creadores personifican la conexión del arte y la tecnología en la imagen código. Por ello, un análisis de las prácticas digitales impone un enfoque que combine los aspectos técnicos con elementos provenientes de la historia del arte, la teoría cinematográfica, la de los nuevos medios... Nos situamos así en una actitud interdisciplinar y dinámica, entre el acercamiento y el distanciamiento con respecto a estas disciplinas: aunque de ellas tomamos prestados ingredientes que convienen al caso concreto, cada una de manera aislada se revela insuficiente.

Puesto que el espacio es una idea difícil de acotar, hemos intentado no constreñir su significado imponiéndole una u otra teoría: al contrario, éstas vendrán a complementar el análisis si (y sólo si) son pertinentes para el ejemplo concreto. No se trata de definir "el" espacio, sino de analizar caso por caso construcciones espaciales en la imagen digital; partir de la praxis; ir de lo que de hecho se construye hacia aspectos espaciales comunes. Esto es: que el concepto siga a la experiencia.

Hemos querido concentrarnos en la imagen animada, tan ligada normalmente al aspecto temporal. ${ }^{5}$ Esto no quiere decir que no hallemos algunas propuestas

una fecha de composición, que además puede ser modificada." MOLINUEVO, José Luis. Humanismo y nuevas tecnologías. Madrid: Alianza Editorial, 2004, p. 216.

${ }^{5}$ La preponderancia que, generalmente, se da al tiempo en la teoría cinematográfica puede resumirse en la siguiente afirmación de Marcel Martin: "la domination absolue que le cinéma exerce sur le temps est un phénomène tout à fait spécifique. Non seulement il le valorise, mais il le bouleverse. (...) On peut donc dire que l'univers filmique est un complexe espace-temps (... ) où la nature de l'espace n'est pas fondamentalement modifiée (mais seulement nos possibilités de l'expérimenter et de le parcourir), alors que la durée s'y voit conférer une liberté et une fluidité absolues, son écoulement pouvant être accéléré, ralenti, inversé ou stoppé, ou tout simplement ignoré.” MARTIN, Marcel. Le langage cinématographique (1955). Paris: Les éditions du Cerf, 2001, p. 231. 
semejantes en la imagen fija, sino que los aspectos más interesantes radican, como veremos, en la síntesis de dinámicas más allá de la reproducción del movimiento. Tal y como la definimos en este trabajo, la "imagen animada" abarca tecnologías diversas, más allá de la digital que nos ocupa: la imagen cinematográfica ${ }^{6}$, los dibujos animados, la animación ${ }^{7}$, la imagen electrónica analógica... Las comparaciones que establecemos entre imágenes elaboradas con distintas tecnologías no pretenden dar a entender una dicotomía analógico/digital ni una relación de tipo histórico, sino iluminar aspectos espaciales.

En este sentido, hemos constatado varias líneas de continuidad entre la imagen digital, el videoarte y las "vanguardias históricas" punto de partida, sino el de llegada: es el análisis práctico el que ha revelado las continuidades y las rupturas que se podrán constatar a lo largo del texto. Aunque nuestra intención es abordar la imagen digital ligada a su aspecto tecnológico, este enfoque no quiere ser reduccionista: buena parte de las construcciones espaciales analizadas remiten a obras (si no creadas, sí, al menos) concebidas, "soñadas" antes de que la plasticidad sin igual de la tecnología digital permitiera su realización.

Así, artistas como John Whitney, Zbig Rybczynski o Steina y Woody Vasulka dan cuenta en sus trayectorias personales del paso fluido entre cine, vídeo analógico e imagen digital. Al ligar la obra al proceso de construcción, la tecnología cuenta: no es determinismo tecnológico, sino posibilidad creadora. Los casos que analizamos revelan una conciencia por parte de los propios autores de esa potencia plástica ligada a la tecnología y suponen, por ello, un valioso material para la constitución de una estética de la imagen código.

Las prácticas digitales contempladas abarcan desde el presente hasta los balbuceos de la imagen por ordenador en los años 60. Con todo, no se ha de esperar una cronología del desarrollo tecnológico: si nos remontamos a los inicios del

\footnotetext{
${ }^{6}$ Reservamos la expresión "imagen cinematográfica" a aquélla constituida por la película fotográfica y cuyo dispositivo consiste en la proyección de los fotogramas a una velocidad tal que produzca la sensación de movimiento en la imagen. Por su parte, nos referimos al "cine" como el producto cultural, tenga como soporte una película de $35 \mathrm{~mm}$, un vídeo analógico o digital, etc.

${ }^{7}$ Como aclara Alain Lioret: "Le film d'animation est victime d'une erreur de classification -ou plutôt de deux erreurs. L'une consiste à le confondre avec le dessin animé et la seconde à le considérer comme une sorte de 'cinéma' alors qu'il pourrait s'agir tout aussi bien de peinture, de dessin, de gravure ou même de sculpture en mouvement”. LIORET, Alain. Émergences de nouvelles esthétiques du mouvement. Paris: L'Harmattan, 2004, p. 31.

${ }^{8}$ No debe confundirse el cine de las "vanguardias históricas" con el cine "de vanguardia". Después de la Segunda Guerra Mundial, este último comenzó a designar el cine experimental, a contracorriente. Sin embargo, las llamadas "vanguardias históricas" se agrupan durante los años 20, en corrientes como el cubismo, el dadaísmo, el surrealismo...
} 
llamado "computer art", lo hacemos con la convicción de que el primer contacto con una nueva técnica motiva a los creadores a explorar sus posibilidades plásticas. De hecho, como veremos, aquellos pioneros son hoy una vanguardia que inspira a autores contemporáneos y abre caminos futuros para la imagen código.

Este trabajo ni puede ni quiere ser exhaustivo; a cambio, selecciona, describe y clasifica casos prácticos. Para ello, se ha partido de la identificación misma del material, del visionado de imágenes y la elección de obras significativas a efectos de nuestro objeto de estudio.

En lo que respecta a la selección de las obras, nos concentramos en la exploración de espacios más allá de la perspectiva, del espacio euclidiano o de la mímesis de la representación. Abordamos los llamados "efectos especiales" en tanto que fenómenos visuales que afectan fundamentalmente al espacio. A este respecto, conviene matizar dos aspectos. Por un lado, teniendo en cuenta que buena parte de estos efectos digitales provienen del cine de ficción, se encontrarán alusiones al relato o al contenido dramático. No obstante, la narración es un aspecto secundario, que se saca a colación en la medida en que permite hacer hincapié en las posibilidades plásticas ligadas al constructo espacial. Por otro lado, se constatará la abundancia de ejemplos de grandes producciones cinematográficas; la explicación se reduce al hecho de que, durante décadas, el trabajo con ordenador impuso sumas millonarias.

Como cabía esperar, es en la exploración solitaria de los artistas, en piezas de apenas unos minutos, donde hallamos los tratamientos del espacio más osados y, por ello, más atractivos para nuestro cometido. Maticemos, sin embargo, que este trabajo no pretende definir el concepto de "arte" en sí, y contempla otros productos de la cultura popular como el citado cine comercial, la publicidad o el videoclip. El hecho de abordar las imágenes en términos de "construcción espacial” permite establecer puentes entre diversas prácticas, lejanas en su función o en su forma de consumo.

En lo que a la redacción del texto se refiere, el contenido se articula en una "trenza" de ejemplos que describen aspectos espaciales. Acompañamos estas explicaciones de reproducciones de las obras con la esperanza de que se consiga distinguir en ellas las cuestiones analizadas. A fin de diferenciar entre capturas de imágenes animadas e imágenes en sí fijas (pintura, fotografía...), citamos en cursiva y comillas respectivamente.

En relación a la clasificación de los ejemplos, lejos de constreñir las prácticas en una lista cerrada, nuestra intención es constatar tendencias que apunten a 


\section{INTRODUCCIÓN}

posibilidades estéticas ligadas a la construcción del espacio en la imagen digital. La propuesta pretende ser acumulativa: para entender los aspectos analizados en el segundo capítulo, se necesitan las claves del primero; y, consecuentemente, el último retoma aspectos analizados ya en los anteriores, abriendo la puerta a otras claves plásticas. Nuestra intención no es crear un modelo de estudio extrapolable a otras investigaciones; la compartimentación es fruto del análisis práctico de las imágenes. Así, el texto se divide en los tres capítulos siguientes:

I. La construcción del espacio en el interior del cuadro

II. La cámara virtual como construcción espacial

III. La construcción de espacios no-euclidianos e hiperespacios

El primer capítulo presenta distintas formas de lo que hemos dado en llamar "construcción en el interior del cuadro". Por "cuadro", entendemos los cuatro lados del borde rectangular que limita la imagen. Con ello, tratamos de subrayar la elaboración de la misma, su condición de constructo frente a la mera reproducción. Así, reservamos el concepto de "encuadre" al registro, es decir, la posición de la cámara en el momento de la toma y el recorte del espacio profílmico. Por último, nos servimos del anglicismo "frame" para referirnos a cada una de las unidades en las que puede subdividirse la imagen videográfica.

Comenzamos subrayando la tendencia a la transformación de la imagen frente a la mera reproducción del registro; tendencia que prueba, además, un rechazo a la tradición de la perspectiva, caracterizada por la representación de un espacio tridimensional en el plano bidimensional. A continuación, contraponemos el montaje espacial al montaje temporal, esencia del lenguaje cinematográfico: si la edición secuencial de los planos permite "construir" el espacio fílmico, en las prácticas digitales que analizamos, la construcción se realiza en el interior del cuadro. En este sentido, clasificamos las diversas manifestaciones según el grado de interpenetración de las imágenes de partida: hablamos, así, de "cohabitación” y de "mezcla". Mientras la primera hace referencia a la compartimentación del cuadro, la segunda explota la estratificación de la imagen en capas, desde la composición hasta la sobreimpresión.

La combinación entre la transformación de la imagen y el montaje espacial nos permitirá dar paso al morphing, figura paradigmática de la metamorfosis digital. Al analizarlo en relación a la tecnología, mostraremos cómo no se trata sólo de un efecto 
espectacular, sino de una construcción ligada a la potencia plástica del espacio digital. Si bien apuntamos el debate en torno al "morphing racial", nuestro interés radica en lo que ocurre en y con el espacio de la imagen. De hecho, el efecto ha pasado a formar parte de la sintaxis audiovisual digital y es usado como transición espacio-temporal continua, como veremos en el último apartado de este primer capítulo.

Si hasta aquí se tratan, principalmente, obras caracterizadas por la inmovilidad del cuadro, el segundo capítulo introduce una figura esencial de la exploración espacial en la imagen digital: la cámara virtual. Lejos de reducirla a una mera simulación del registro temporal, la definiremos como una entidad exclusivamente espacial. Nuestro objetivo es comprobar en qué medida las prácticas analizadas exhiben este constructo no como sucedáneo de la óptica fotográfica, sino, por el contrario, subrayando su omnipotencia frente a los límites del aparato físico.

Para comprender la potencia plástica de la cámara virtual, la comparamos con la liberación de la cámara física llevada a cabo por las vanguardias históricas en los años 20. Con ellas, comparte la exploración de la "profundidad cinética", ligada al movimiento y encarnada en el zoom y el plano secuencia; ahora, en la imagen digital, éstos tienen características propias. Así, definiremos estas dos figuras por oposición a sus homónimas en la imagen registro y veremos cómo, en las versiones digitales, la referencia no es la visión humana o la óptica fotográfica, sino la imaginación: la posibilidad plástica.

Cerraremos el capítulo con la "instantánea tridimensional", paradigma de la independencia de la cámara virtual y que corresponde al famoso "bullet time" o "tiempo muerto". De nuevo, el análisis espacial de esta "extrañeza visual" pasará por "desmenuzar" el constructo, explicando el proceso de elaboración de la imagen. Al trazar sus orígenes, descubriremos antecedentes ya en la obra del fotógrafo Eadweard Muybridge; no obstante, a pesar de esta línea de continuidad con el experimento precinematográfico, la cámara virtual es una síntesis de dinámicas en el interior del cuadro. Así, comprobaremos cómo los dos efectos especiales más populares de los años 90, el bullet time y el morphing, comparten el cálculo de imágenes intermedias para la síntesis de la animación.

Llegados a este punto, habiendo tratado de manera general la construcción de la imagen en el interior del cuadro y el caso específico de ésta que es la cámara virtual, daremos paso al último capítulo. En él, agrupamos prácticas que muestran un anhelo de experimentación plástica más allá de la reproducción del movimiento en un 
espacio euclidiano. En este sentido, constataremos una línea de continuidad entre la imagen digital y el arte moderno: en su huida de la perspectiva, ambos se inspiran en las teorías científicas y filosóficas de finales del siglo XIX.

Comenzaremos, así, con la construcción de espacios llenos, en los cuales el movimiento se revela como la transformación de una forma continua. Si en este apartado señalamos diversas estrategias de montaje espacial, en el siguiente veremos una forma de edición distinta, específica de la imagen digital; ésta consiste en abordar el registro previo no como una tira horizontal de fotogramas, sino en bloque, como un objeto espacio-temporal accesible de manera tridimensional (desde cualquier punto de vista) y atómica (en cada uno de sus píxeles). La imagen resultante de esta transformación muestra la continuidad entre figura $\mathrm{y}$ fondo, $\mathrm{y}$ propone nuevas mutaciones, producto de la recombinación del material de partida. Los dos apartados citados comparten la concepción del tiempo como una dimensión más del espacio, idea que nos permitirá dar paso a la visualización de "hiperespacios": desde las animaciones sintéticas de los pioneros del computer art hasta las metáforas espaciales en portales líquidos y puentes interdimensionales.

Para finalizar, haremos un recorrido por la síntesis de dinámicas frente a la reproducción del movimiento en la imagen-registro. En primer lugar, analizaremos las activaciones basadas tanto en la elasticidad del espacio digital como en su condensación. Por último y en contraste con esta transformación de imágenes de partida, explicaremos la generación misma del espacio a partir del código, en el arte "generativo", en general, y el "evolutivo", en particular. Si bien a lo largo de todo el trabajo subrayamos la estrecha relación entre el concepto de "construcción espacial" y la elaboración subyacente, este último apartado evidencia el proceso como propuesta estética en sí misma. 


\section{ESTADO DE LA CUESTIÓN}

Escribimos en un momento en el que el espacio ha adquirido una relevancia en el pensamiento no comparable a ninguna época anterior. Este "giro espacial" se remonta, al menos, hasta la obra de Gaston Bachelard (1958), Michel Foucault (1967) o Henri Lefebvre (1974), y se instala en la postmodernidad con autores como Fredric Jameson (1991). El concepto espacial recorre, así, la poética, la geografía, la política, la economía, la antropología, la sociología, la comunicación y el arte. Prueba de esta ubicuidad es la aparición de trabajos que recogen aproximaciones al concepto tanto en las ciencias como en las humanidades, y que muestran la necesidad no sólo de enfoques múltiples, sino interdisciplinares (Sobieszczanski, 2004).

Esta importancia de la categoría espacial se consolida gracias a las nuevas formas de comunicación ligadas a la tecnología digital: con la interfaz gráfica de usuario del ordenador personal Apple Macintosh (1984) y la World Wide Web (1990), la informática se extiende desde la producción a la distribución y el almacenamiento, revolucionando prácticamente todos los ámbitos de la cultura. En respuesta a este fenómeno, se define una estética de los nuevos medios en general y del software en particular, encabezada por la obra de Lev Manovich The Language of New Media (2001). En ella, el teórico y artista moscovita afirma: "la era del ordenador introduce un nuevo paradigma. Este paradigma tiene que ver no con el tiempo, sino con el espacio." "Junto al libro de Manovich, podríamos citar otros como Technospaces: Inside the New Media (Munt, 2001), Mediaspace: Place, Scale, and Culture in a Media Age (Couldry y McCarthy, 2004) o el más reciente Code/space: Software and Everyday Life (Dodge y Kitchin, 2011). Todos ellos conceden al espacio un rol fundamental.

Dado este interés por el espacio en relación a la tecnología, extraña la ausencia de análisis específicamente dedicados a la imagen digital animada. Si autores como el propio Manovich realizan un seguimiento de las prácticas contemporáneas, éstas se extienden a todo producto de los "nuevos medios": la web en su conjunto, los

\footnotetext{
${ }^{1}$ MANOVICH, Lev. The Language of New Media (2001). Cambridge: The MIT Press, 2005, p. 145.
} 
videojuegos, el CD-ROM, los hipermedia, las interfaces, las instalaciones interactivas o los entornos virtuales. De hecho, el grueso de The Language of New Media trata la influencia del lenguaje cinematográfico sobre éstos; tan sólo la última parte presenta el proceso inverso: cómo la informatización cambia la imagen animada.

Entre las investigaciones ligadas al arte digital es especialmente interesante el enfoque de Susanne Jaschko. La curadora examina tanto la idea de "proceso" (2005) como las relaciones espacio-temporales que la tecnología digital permite (2002). Con todo, Jaschko muestra una inclinación por las obras interactivas. En realidad, si el giro espacial es patente en la literatura de los nuevos medios, el análisis del espacio parece reservado a la interactividad: principalmente, videojuegos (Wolf, 2001, y Nitsche, 2008), panoramas (Jacobs, 2004) y realidad virtual (Thomas, 2009); los aspectos estudiados son, así, la ergonomía, la inmersión, la navegabilidad...

Ahora bien, merecen un comentario aparte los análisis provenientes de la disciplina bautizada como "estudios comparativos de los medios", : el enfoque tiene el aliciente añadido de mostrar cómo los nuevos medios pueden iluminar a los anteriores. A este respecto, cabe destacar el trabajo de Stephen Boyd Davis, Media space. An analysis of spatial practices in planar pictorial media (2002), en el cual, antes de abordar las obras interactivas, contempla las convenciones espaciales del cine clásico de ficción y de la imagen televisiva. Este acercamiento es enriquecedor teniendo en cuenta la escasez de análisis espaciales de la imagen audiovisual.

En relación a la imagen cinematográfica, de haberlo, el estudio del espacio se limita a una sola obra (Rohmer, 1977), a la relación con la pintura (Aumont, 1989), la comparación con la arquitectura y el urbanismo (Fitzmaurice y Shiel, 2003, Lamster, 2000) o al género de la ciencia ficción (Sobchack, 1987). Fuera de estos enfoques, las referencias al espacio se reducen a algún apartado en los manuales de lenguaje cinematográfico; éstos coinciden en distinguir: el espacio bidimensional de la pantalla (el encuadre o la composición de las masas en el plano), el tridimensional de la escena (filmado o sugerido en el fuera de campo) y el "espacio fílmico" (producto del montaje temporal de los planos). En este sentido, sobresalen los trabajos de David Bordwell (1985) y André Gardies (1993); no obstante, ambos se concentran en el cine de ficción, de modo que el análisis del espacio se reduce a su vínculo directo con la narración.

\footnotetext{
${ }^{2}$ Pensamos, por ejemplo, en el programa "Comparative Media Studies" que el Massachusetts Institute of Technology (MIT) propone desde 1999.
} 
En lo que concierne a la imagen digital, descuella Digital Storytelling. The Narrative Power of Visual Effects in Film (2007) de Shilo McClean. Su propuesta tiene el incentivo de abordar los efectos especiales no como adornos de la postproducción, sino como parte del storyboard que definirá el relato. Con todo, no trata de manera específica el aspecto espacial y el análisis se limita a la narración en las producciones cinematográficas de ficción.

La obra de McClean se inserta en el contexto general del impacto que las nuevas tecnologías tienen sobre el cine. Si bien, en los últimos diez años, se han multiplicado las publicaciones en este sentido, la tendencia no se acompaña de un análisis espacial consecuente. Al acercarse al asunto, el investigador se ve desbordado por una amalgama de textos que, bajo la misma nomenclatura, se refieren a aspectos tan dispares como la financiación de proyectos o los puramente técnicos. Paradigmático de esta tendencia es el número 603 de la revista francesa Positif (mayo de 2011), titulado: “Cine y digital: una revolución?”. El conjunto de artículos trata la aplicación de las nuevas tecnologías al medio cinematográfico, desde el montaje hasta la restauración, pasando por el decorado, el sonido o la distribución. ${ }^{3}$

En relación a la estética, pervive el problema de la terminología: "cine digital" (McKernan, 2005), "cinematografía digital" (Donati, 2007), "imagen digital y cine" (Bernard, 2000), “cine en la era digital” (Rombes, 2012), "cine del futuro" (Alfonsi, 2005), "cine y últimas tecnologías" (Beau, Dubois y Leblanc, 1998), etc. El uso de nexos diversos no hace sino evidenciar la falta de un marco delimitador.

En general, los trabajos referidos no tienen en cuenta la pista espacial. Como excepción a la regla, justo es citar New Digital Cinema: Reinventing the Moving Image (2005), de Holly Willis. La autora llega a afirmar que el collage, la composición surrealista o el found footage "son emblemáticos de un deseo y una preocupación sostenida por la rearticulación de la noción del espacio.”“ No obstante, el opúsculo de Willis no se dedica al análisis espacial, sino que sobrevuela los efectos de la tecnología digital sobre la imagen en el periodo comprendido, exclusivamente, entre 1995 y 2005. Willis acierta en subrayar la contaminación mutua entre cine, animación, videoarte, performance y videoclip. Sin embargo, al retroceder

\footnotetext{
3 “Cinéma et numérique : une révolution ?". Positif. Mai 2011, núm 603.

${ }^{4}$ WILLIS, Holly. New Digital Cinema: Reinventing the Moving Image. London: Wallflower Press, 2005. pp. 51-52.
} 
únicamente hasta mediados de los 90, deja fuera, entre otros, a los pioneros del computer art.

Lo cierto es que, la tendencia general es a separar la imagen digital en dos campos: por un lado, el citado "cine digital" y, por otro, el "arte por ordenador". En lo que concierne a este último, destaca la obra Émergence de nouvelles esthétiques $d u$ mouvement (2004) de Alain Lioret. En su recorrido por las diversas técnicas de animación, pone el acento en la síntesis y el arte generativo, y subraya la potencia de la informática para la creación de otras formas de movimiento en la imagen.

En suma, son muy raros los enfoques que engloben a la imagen sintética y a los efectos especiales bajo el paraguas digital. A este respecto, merece la pena recordar la propuesta de un "cine expandido" que Gene Youngblood hiciera hace más de cuatro décadas, y en la que sumaba al cine el vídeo y el computer art nacientes (1970).

En lo que toca a este último, es llamativa la carencia de estudios pormenorizados de aquellas construcciones espaciales. Contemporánea a la obra de Youngblood y a la creación de los propios pioneros, que ella misma ayudó a propulsar, se yergue casi en solitario el trabajo de la curadora Jasia Reichardt (1971). Así, aunque a lo largo de toda nuestra investigación damos prioridad a la voz de los propios autores, este partir de la práctica ha sido imperativo para la comprensión de aquellas primeras tentativas.

La presente investigación intenta trazar puentes entre imágenes de diversa procedencia: de los efectos especiales a la imagen de síntesis, del cine de ficción a la animación abstracta, del trabajo solitario de los pioneros a las obras generativas en Internet... El punto de partida es un hilo invisible que une estas prácticas a lo largo de los últimos cincuenta años: la exploración del espacio de la imagen, ligada a la tecnología digital que la sustenta. 


\section{CAPÍTULO I}

LA CONSTRUCCIÓN DEL ESPACIO EN EL INTERIOR DEL CUADRO 


\section{DE LA REPRODUCCIÓN A LA TRANSFORMACIÓN}

El pintor estadounidense Charles Csuri es uno de los primeros artistas en aproximarse al ordenador a fin de explorar una estética ligada a la informática. A principios de los años 60, escanea obras de los grandes maestros de la historia del arte: entre ellos, Durero, Klee, Ingres, Picasso, Goya o Mondrian. Su objetivo es someter a esas formas, popularmente reconocibles, a todo tipo de distorsiones geométricas: rotaciones, estiramientos, cambios de escala... Admirador de la anamorfosis en el arte ${ }^{1}$, Csuri había explorado ya este tipo de deformación en sus pinturas al óleo. En 1963, el artista crea un ordenador analógico a partir de un pantógrafo. Normalmente, este sencillo instrumento permite copiar una forma en el plano cambiando la escala, pero manteniendo constante sus proporciones; no obstante, el artista altera el útil con el objeto de transformar los dibujos iniciales, tanto en su tamaño como en su forma y disposición. Frente a la copia mimética, Csuri se decanta por la distorsión.

Apenas un año después, en 1964, el artista se hace con un ordenador digital y se lanza a la exploración de la potencia de transformación de la imagen código. Para la elaboración de "Sine Curve Man" (1967), sometió un dibujo de un hombre a la función trigonométrica del seno $^{2}$ : las coordenadas en el eje X permanecieron constantes, mientras que, a aquéllas del eje $\mathrm{Y}$, les aplicó una sinusoide. Csuri alaba la potencia de las matemáticas a la hora de crear formas más allá de los espacios euclidianos, típicos de la representación naturalista. Sus construcciones espaciales reflejan la revolución en la física y la matemática de finales del siglo XIX y principios del XX; en concreto, Csuri se refiere a la "transformación de Lorentz" y la visualización de lo que ocurre a una masa al alcanzar la velocidad de la luz. ${ }^{3}$

\footnotetext{
${ }^{1}$ La anamorfosis es un efecto óptico calculado por el artista, el cual, conocedor de las técnicas de la perspectiva, obliga al espectador a situarse en un determinado punto o a servirse de alguna superficie reflectante para "corregir" la imagen. Uno de los casos más célebres en la pintura es la calavera bidimensional del cuadro de Hans Holbein el Joven "Die Gesandten" (1533).

2 "Given the $\mathrm{X}$ and $\mathrm{Y}$ coordinates for each point, the figure was plotted by the computer from $\mathrm{X}^{\prime}=\mathrm{X}$ $\mathrm{Y}^{\prime}+\mathrm{C}^{*} \mathrm{SIN}(\mathrm{X})$ where $\mathrm{C}$ is increased for each successive image." CSURI, Charles; SHAFFER, James. "Art, computers, and mathematics". En: AFIPS, Conference Proceedings. Columbus, Ohio: Ohio State University. December 9-11, 1968, vol. 33, p. 1295.

3 "It's the potentiality of mathematics that is of special interest to me (...). One can use things like Ndimensional geometry or like a hundred-dimensional geometry rather than a three dimensional geometry." Charles Csuri. Apud. REICHARDT, Jasia. Cybernetic Serendipity: The Computer and the Arts. London: Studio International, 1968, pp. 81-84.
} 


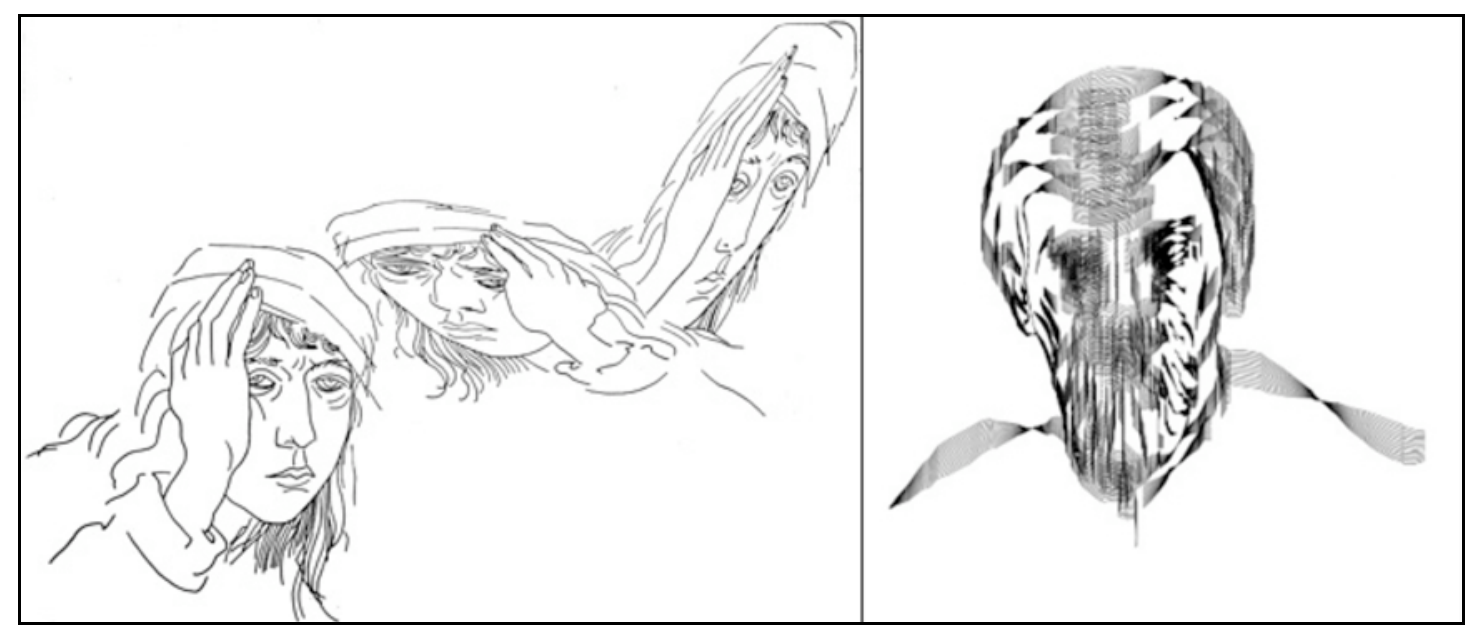

Charles Csuri: izquierda, “After Albrecht Dürer” (1963); derecha, "Sine Curve Man” (1967)

$\mathrm{Su}$ interés por la transformación geométrica no es diferente del de otros pioneros del llamado "arte por ordenador" o "computer art". Éste es el caso, por ejemplo, de Leslie Mezei, quien se sirve de los símbolos nacionales canadienses, como el castor o la hoja de arce, en tanto que materia prima para sus distorsiones. Las transformaciones geométricas responden al interés del autor por la cibernética ${ }^{5}$. Partir de un elemento y someterlo a variaciones permite a los pioneros reflexionar sobre conceptos como "sistema", "estructura" o "proceso", así como sobre la tensión azar/control, presente ya en el arte contemporáneo. De acuerdo con Mezei, la experimentación con este "azar controlado" no aspira ni a la precisión científica ni a la belleza artística, sino simplemente a subrayar nuevas posibilidades. ${ }^{6}$

Por su parte, el artista alemán Manfred Mohr se concentra en la figura geométrica del cubo, a la que somete a todo tipo de transformaciones. Su objetivo es "romper con la simetría" de la figura para generar "nuevas construcciones y

\footnotetext{
${ }^{4}$ Mike King enmarca la primera fase de este "arte por ordenador" entre 1956 y 1986, y cita más de 20 pioneros: Ben Laposky, Herbert Franke, John Whitney Sr., Charles Csuri, Michael Noll, Frieder Nake, Edward Zajec, Kenneth Knowlton, Ruth Leavitt, Lillian Schwartz, Vera Molnar, Georg Nees, Manfred Mohr, Harold Cohen, Joan Truckenbrod, Yoichiro Kawaguchi, Laurence Gartel, Jean-Pierre Hébert, Mark Wilson, Roman Verotsko, David Em, Rejane Spitz, Paul Brown y Yoshiyuki Abe. KING, Mike. "Computers and modern art: digital art museum". En: Proceedings of the 4th conference on Creativity \& cognition, New York, October 13-16, 2002, pp. 88-94.

${ }^{5}$ Introducida por Norbert Wiener en 1948, la cibernética es la ciencia encargada de encontrar mecanismos de control de la información, como la comunicación, para resolver sistemas complejos. WIENER, Norbert (1948). Cybernetics: or Control and Communication in the Animal and the Machine (1948). Cambridge: The MIT Press, 1973.

6 "My own work, all done a few years ago, has tried to make a novel beginning in the exploration of controlled randomness, of various distortions and transformations. These were neither systematic enough to be scientific, nor did they try to achieve the ultimate exploitation of their medium to be really good art. They merely tried to point the way toward new possibilities." MEZEI, Leslie. En: LEAVITT, Ruth (ed.). Artist and Computer. New York: Harmony Books, 1976, p. 26.
} 
relaciones". ${ }^{7}$ La forma se abate sobre el plano bidimensional dando como resultando, entre otros, la visualización en dos dimensiones del hipercubo ${ }^{8}$. Como el castor de Mezei, el hexaedro es un elemento primario, cuyas transformaciones dan lugar a todo un abecedario de nuevas formas.

Mohr se concentra en la potencia de la matemática: añadir, restar, combinar, permutar, variar... Aunque estos procesos algorítmicos ${ }^{9}$ están presentes ya en la música, el diseño o la literatura, la informática permite un grado de complejidad en su formulación y aplicación sin parangón en las prácticas artísticas. Dicho de otro modo, la plasticidad digital es posibilidad de construcción y ésta se ve enormemente ampliada gracias a las matemáticas. ${ }^{10}$

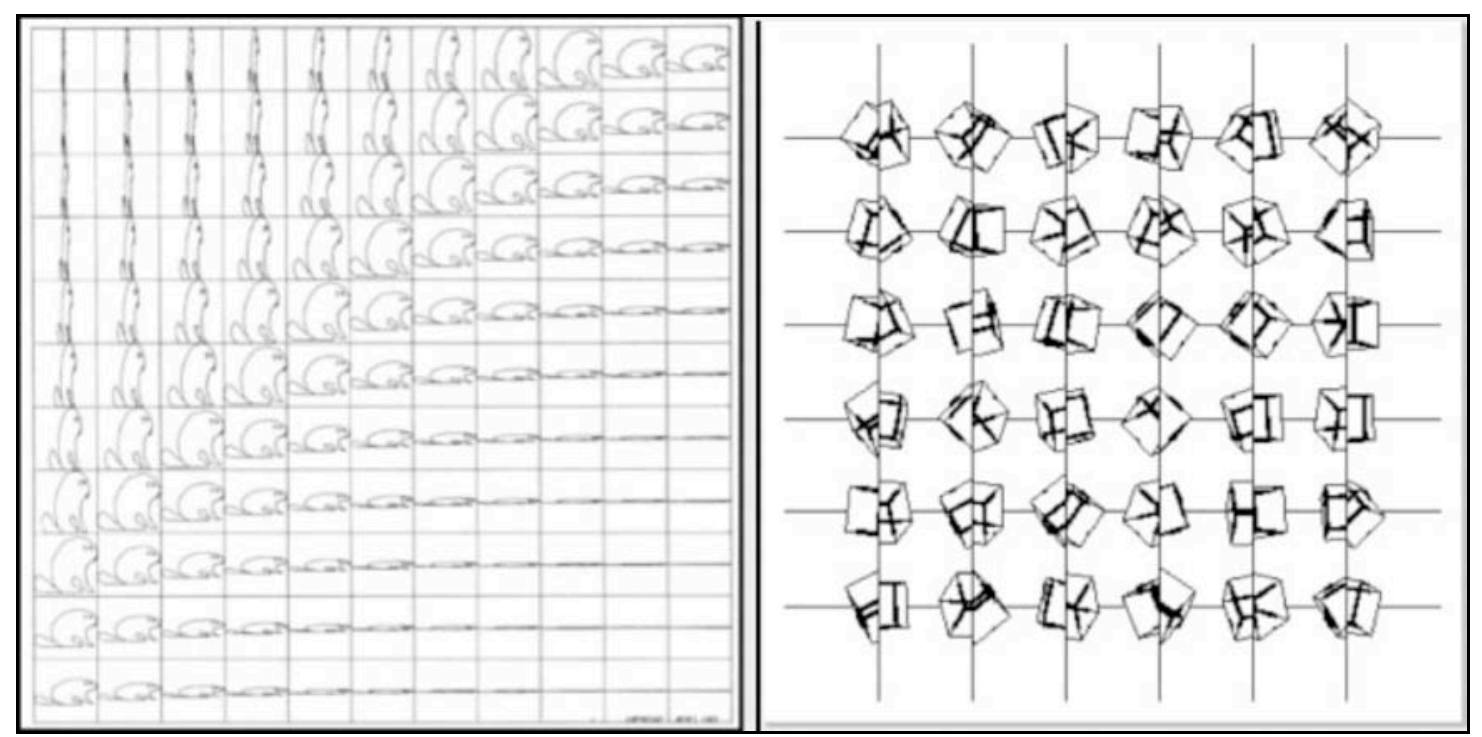

Izquierda. Leslie Mezei: “Beaver scaled” (1967). Derecha. Manfred Mohr: "P-197/S” (1977)

Por su parte, Charles Csuri extenderá su interés por la transformación de la imagen hacia la animación. Como veremos más adelante, con obras como Artist into Frog o Aging Process, ambas de 1968, el estadounidense se adelanta más de una década a la invención del morphing. No obstante, si éste se caracteriza por el flujo

\footnotetext{
${ }^{7}$ MOHR, Manfred. "Generativ art”. En: CANDY, Linda; EDMONDS, Ernest A. Explorations in Art and Technology. London: Springer-Verlag, 2002, p. 111.

${ }^{8}$ En el último capítulo, profundizaremos en la construcción de hiperespacios y veremos cómo el hipercubo o "teseracto" es el equivalente de un cubo en un espacio de cuatro dimensiones.

${ }^{9}$ Un algoritmo es, en esencia, un conjunto de reglas predefinidas, ordenadas y finitas, que permiten encontrar la solución a un problema.

${ }^{10}$ El mismo interés por las matemáticas destaca en el libro sobre el "computer art" escrito por el pionero Herbert W. Franke y publicado en 1971. En Computer Graphics, Computer Art, el científico austriaco afirma: "If one is engaged, as we are, with an inventory of all mathematical branches and with an interest in visualising all forms that come to light, one can obtain plenty of forms, shapes and structures never seen before - an expansion of our treasury of forms." Herbert W. Franke. Computer Graphics - Computer Art (1971). Berlin, New York: Springer-Verlag, 1985, p. 95.
} 
continuo y armónico entre las formas, el artista se decanta por la abstracción y la deformación. De hecho, en su animación Hummingbird (1968), no se trata de mutar un ser en otro, sino de distorsionar el diseño de un colibrí. Como las imágenes fijas descritas, la animación parte de un dibujo realizado a mano y escaneado después. En el proceso informático, las líneas que definen el pájaro se desligan unas de otras, dando lugar a un garabato informe; a continuación, se reagrupan y reconstruyen la figura.

Hummingbird es una de las primeras animaciones artísticas por ordenador de la historia. ${ }^{11}$ En lugar de intentar reproducir el vuelo del ave, las dinámicas de la imagen tienen que ver con esa recombinación de las líneas: a la mímesis del movimiento, a la reproducción de la locomoción animal, el artista sustituye la transformación, subrayando así el aspecto espacial de la imagen animada. El interés recae en el proceso de mutación de la figura, su distorsión y su regreso al orden. Dicha mutación es, en realidad, una redistribución de elementos: una permutación. ${ }^{12}$ De acuerdo con el propio Csuri, la cuestión es: “¿Cuántos puntos conforman esta línea? ¿Cómo puedo cambiar su distribución?"13

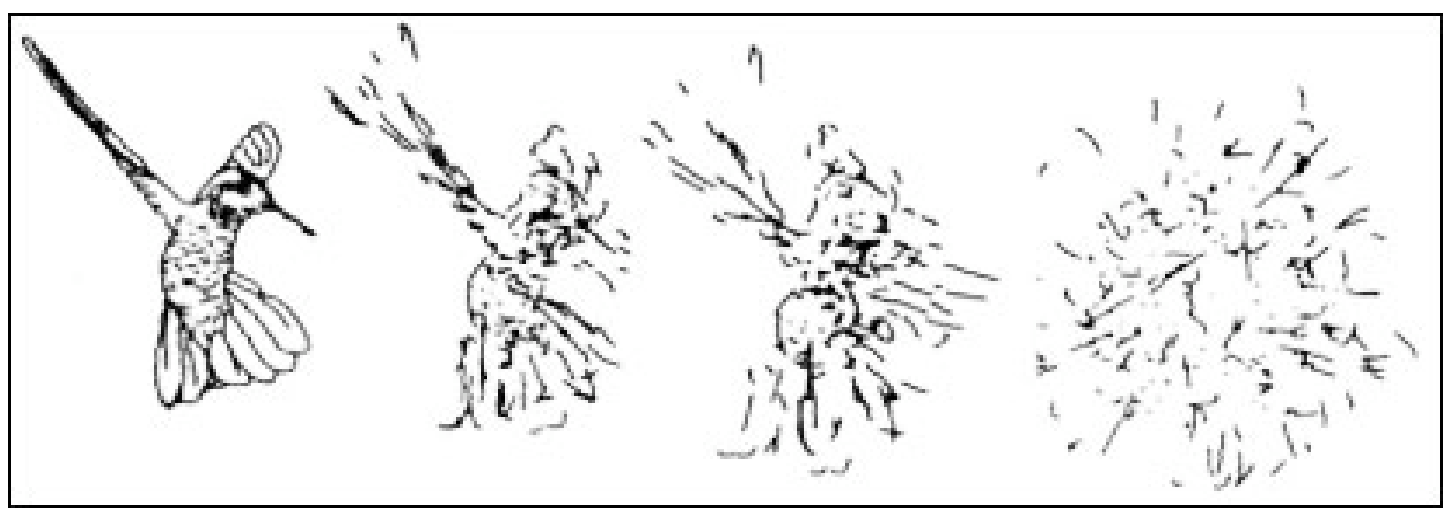

Hummingbird (1968), de Charles Csuri

El ordenador convierte los trazos manuales, el gesto del dibujante, en una serie de puntos y líneas dentro de un sistema de coordenadas bidimensional. Como en “Sine Curve Man", la distorsión es fruto del acceso espacial a través de los ejes X e Y. En este sentido, Csuri reconoce la influencia del biólogo y matemático D’Arcy W.

\footnotetext{
${ }^{11}$ Aunque ya en 1963 Edward E. Zajac presenta la órbita de un satélite, el científico se conforma con visualizar la trayectoria del objeto y no tiene ninguna intención estética.

${ }^{12}$ Acabaremos este trabajo con otros ejemplos de esta "estética permutacional"; por ahora, retengamos la transformación de una imagen fuente frente a la mera reproducción del registro, y la construcción de otro tipo de espacios, no miméticos.

${ }^{13}$ Charles Csuri. Apud. REICHARDT, Jasia. Op. cit., p. 83.
} 
Thompson" ${ }^{14}$. En On Growth and Form (1917), sus "transformaciones cartesianas"15 permiten comparar formas al representarlas geométricamente dentro de un sistema de coordenadas bidimensional. ${ }^{16}$

Si bien Thompson pretende explicar fenómenos naturales como la evolución animal, Csuri retoma la idea con fines exclusivamente plásticos: en sus piezas digitales, no se trata de representar de manera naturalista las figuras en la cuadrícula bidimensional; al contrario, el artista se sirve del sistema de coordenadas X e Y para la distorsión, para la construcción de espacios específicos de la imagen.

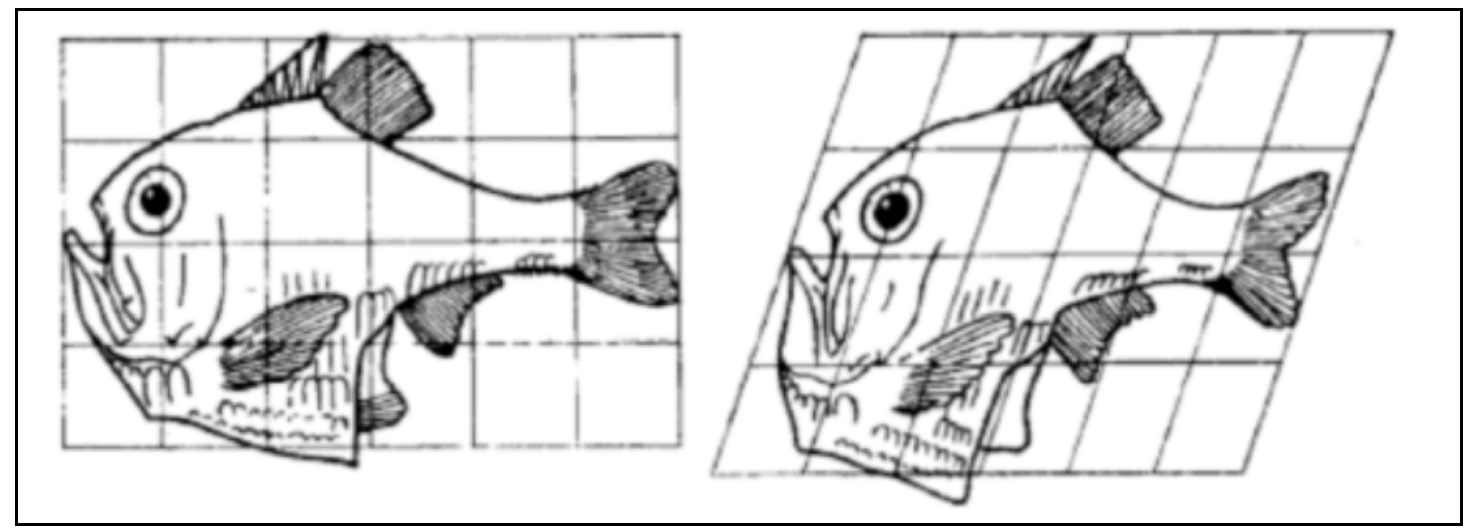

Ilustración de On Growth and Form (1917), de D’Arcy Thompson

En la misma época en que Csuri explora una estética digital ligada a la deformación del espacio, Lawrence G. Roberts aplica, por primera vez, las reglas de la perspectiva al diseño tridimensional por ordenador. En 1963, el entonces doctorando del Massachusetts Institute of Technology (MIT) describe un programa informático capaz de convertir una fotografía en un dibujo, recuperando los contornos de las formas reproducidas en aquélla gracias a las normas geométricas de la proyección central. $^{17}$

Tras la propuesta de Roberts, los paquetes de software de diseño y animación en 3D (como Blender o Maya) partirán de un sistema de coordenadas tridimensional.

\footnotetext{
14 "I was fascinated by the idea of being able to do transformations on a drawing. The work of Sir D'Arcy Thompson the noted biologist and mathematician was of great interest to me." CSURI, Charles. Siggraph.org. Disponible en Web: < http://www.siggraph.org/artdesign/profile/csuri/>

15 THOMPSON, D'Arcy W.. "Cartesians transformations". En: On growth and form (1917). Cambridge: Cambridge University Press, 2004, p. 276.

${ }^{16}$ Alberto Durero había inventado ya un sistema semejante. DÜRER, Albrecht. Hierin sind begriffen vier Bücher von menschlicher Proportion, Verlag Bibliophile Drucke von Josef Stocker (1528). Dietikon-Zürich: Verlag Bibliophile Drucke von Josef Stocker, 1969.

${ }^{17}$ Roberts no se contenta con proponer una imagen fija y presenta un ente contemplable desde cualquier punto de vista. ROBERTS, Lawrence G.. "Machine Perception Of Three-Dimensional Solids". MIT Lincoln Laboratory, May 22, 1963, núm. 315.
} 


\title{
DE LA REPRODUCCIÓN A LA TRANSFORMACIÓN
}

Básicamente, el algoritmo subyacente reduce los objetos a planos ("polígonos"), constituidos por líneas rectas ("vectores”), y éstas son definidas, a su vez, por puntos ("vértices"). Cada punto corresponde a una coordenada (XYZ) que define su posición en el espacio tridimensional. Las formas resultantes componen una especie de armadura, que en lenguaje informático se llama "mesh" ("malla") o "wireframe model" ("modelo de armazón de alambre"). ${ }^{18}$

Esta estructuración asume la concepción espacial de la perspectiva renacentista: un espacio vacío, homogéneo y mesurable matemáticamente, que rompe con la tradición medieval. Tal y como resume Ana García Varas:

\begin{abstract}
"un espacio por completo racionalizado: homogéneo, infinito, continuo, un espacio matemático que construye mediante las leyes de la geometría un orden con el que medir y dominar la multiplicidad de lo representado, y que poco tiene que ver con el espacio psico-físico del observador y sus asimetrías entre izquierda y derecha, arriba y abajo o delante y detrás." 19
\end{abstract}

Una forma de concebir el espacio implícita en la técnica de la perspectiva, teorizada por primera vez por Leon Battista Alberti (1404-1472). En su De Pictura (1436), el humanista genovés parte, entre otros, de los diseños arquitectónicos de Filippo Brunelleschi (1377-1446) y la pintura de Masaccio (1401-1428). Alberti justifica la perspectiva en conexión directa con su concepción (errónea) de los rayos de luz como líneas rectas; estas líneas convergerían en el ojo, formando una pirámide, de la cual el plano pictórico representaría una sección. La perspectiva lineal parte de la definición de un punto de vista único, que permite no sólo medir el espacio vacío entre los objetos, sino la distancia de esos objetos al espectador, colocando a éste como unidad de medida y centro organizador del espacio representado.

\footnotetext{
${ }^{18}$ En honor al proceso descrito, este tipo de imagen de síntesis se conoce como "gráfico vectorial". La alternativa a este formato es el "mapa de bits" o "imagen matricial" ("raster graphics"), es decir, una red de píxeles. La gran cantidad de memoria requerida para almacenar este tipo de imágenes explica la preeminencia de los gráficos vectoriales en las primeras décadas del diseño por ordenador. Hoy, normalmente, los gráficos vectoriales se convierten en imágenes matriciales, de mayor resolución. En general, en este trabajo, la imagen digital hará referencia a esta red de píxeles.

19 GARCÍA VARAS, Ana. "Sentidos de la imagen: espacio y tiempo en el medio icónico". En: GARCÍA VARAS, A. (ed.). Filosofia e(n) imágenes. Interpretaciones desde el arte y el pensamiento contemporáneos. Zaragoza: IFC, 2012, p. 102.
} 


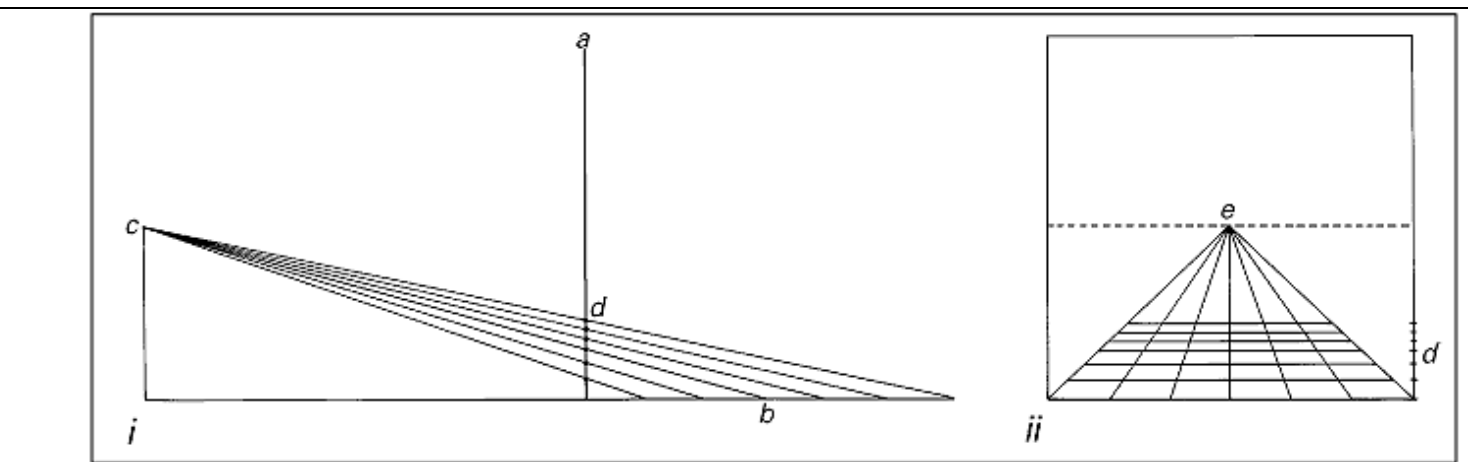

Gráfico de la perspectiva lineal central según Alberti

Donde $a$ es el plano pictórico; $b$, la partición en fragmentos iguales del espacio observado, perpendicular a $a$; $c$, el punto de vista; $d$, los puntos en los que las líneas cortan el plano de proyección para formar $i i$; $i$, la rejilla en perspectiva; y $e$, el punto de fuga.

Para explicar la situación del espectador inmóvil, Alberti acude a la metáfora de una "ventana" abierta a la "historia" a través de un cuadro fijo. ${ }^{20}$ Esta manera de concebir el espacio representado en la imagen reina hasta la aparición de la fotografía cuatro siglos después $^{21}$. La revolución de la pintura moderna parte de la constatación de que la lente fotográfica puede reproducir automáticamente un espacio tridimensional en el plano bidimensional. En consecuencia, el lienzo se libera del imperativo mimético en aras de la construcción de un espacio específico de la imagen. Sin este cambio de paradigma, sería imposible comprender las prácticas digitales que veremos a continuación.

Aunque es cierto que (a partir del algoritmo de Lawrence G. Roberts) las leyes de la proyección central son la base de la simulación tridimensional, la construcción del espacio de la imagen digital no tiene por qué atenerse a las normas de la perspectiva: como bien intuyeron Csuri, Mezei y Mohr, la imagen código puede concebir otros espacios fruto de la imaginación del creador y de las posibilidades de la informática, que construye el espacio en lugar de reproducirlo y que poco o nada debe a un referente profílmico. ${ }^{22}$ Las limitaciones disminuyen a medida que la imagen se aleja de la condición de huella y se acerca a la posibilidad visual como paradigma.

\footnotetext{
20 "Primero, dibujo en la superficie a pintar un rectángulo, tan grande cuanto me place, que es para mí como una ventana abierta desde la cual se verá la 'historia' (...)." ALBERTI, Leon Battista. De la pintura y otros escritos sobre arte (1436). Madrid: Ed. Tecnos, 1999, p. 84.

${ }^{21} \mathrm{Su}$ nacimiento suele fecharse en 1839, con la publicación del descubrimiento del daguerrotipo. FRIZOT, Michel (dir.). Nouvelle histoire de la photographie. Paris: Larousse, 2001, p. 15.

22 "J'appelle réfèrent photographique, non pas la chose facultativement réelle à quoi renvoie une image ou un signe, mais la chose nécessairement réelle qui a été placée devant l'objectif, faute de quoi, il n'y aurait pas de photographie. (...) Il y a double conjointe : de réalité et de passé. Et puisque cette contrainte ne semble exister que pour elle, on doit la tenir, par réduction, pour l'essence même, pour le
} 


\section{El rechazo a la representación en perspectiva}

En el apartado que nos ocupa, la síntesis de la imagen no es total: no se trata de generar un espacio desde cero, sino de transformarlo. Esta transformación de una imagen previa permite mantener una relación entre el constructo final y la forma original. Al partir de un espacio figurativo, la distorsión subraya el desprecio a la mímesis: la construcción frente a la reproducción. Más concretamente, si el punto de partida es un espacio tridimensional, la transformación pasa por la negación de las leyes básicas de la perspectiva: el rechazo es, pues, explícito.

Este "ataque" va dirigido a uno de los tres aspectos siguientes: el punto de vista único en el que debe situarse el espectador para calcular las posiciones y el tamaño de los objetos; el espacio vacío, semejante a una escenografía teatral; y/o el escalonamiento de los planos en profundidad, tanto en lo que respecta a la distancia de los objetos al espectador como en las relaciones figura/fondo.

Treinta años después de la primera animación de Charles Csuri, el artista húngaro Tamás Waliczky realiza una serie de piezas digitales con el cometido explícito de explorar alternativas a la perspectiva y la reproducción mimética de un espacio tridimensional, que inunda la creación de síntesis. En The Way (1994), Waliczky combina un vídeo de personas que corren en la calle con una animación sintética en tres dimensiones. El artista húngaro invierte el sistema de la perspectiva desplazando el punto de fuga en el que convergen las líneas (en el horizonte que corresponde al infinito) hasta colocarlo a la altura del punto de vista en el que debería situarse el espectador para la consecución de la trampa visual. Esta dislocación, esta inversión geométrica de la proyección, desbarata también las relaciones espaciales. El resultado es una extraña sensación de profundidad, en la que los objetos más grandes corresponden a los más alejados en el espacio y viceversa:

\footnotetext{
“Como el punto de vista y el punto de fuga están casi en el mismo lugar en este sistema, cada objeto desaparece antes de alcanzar al observador. Cuanto más lejos está un objeto del observador, más grande aparece. Cuanto más cerca, más pequeño. (...) Como la cámara sigue a los hombres que corren, su tamaño no varía. Son como un punto de referencia en este extraño mundo invertido."23
}

noème de la Photographie... Le nom du noème de la Photographie sera donc : ça a été." BARTHES, Roland. La chambre claire. Note sur la photographie. Paris: Gallimard, 1980, p. 119.

${ }^{23}$ WALICZKY, Tamás. The Way [En línea]. Waliczky.net, 1995. Disponible en Web: 


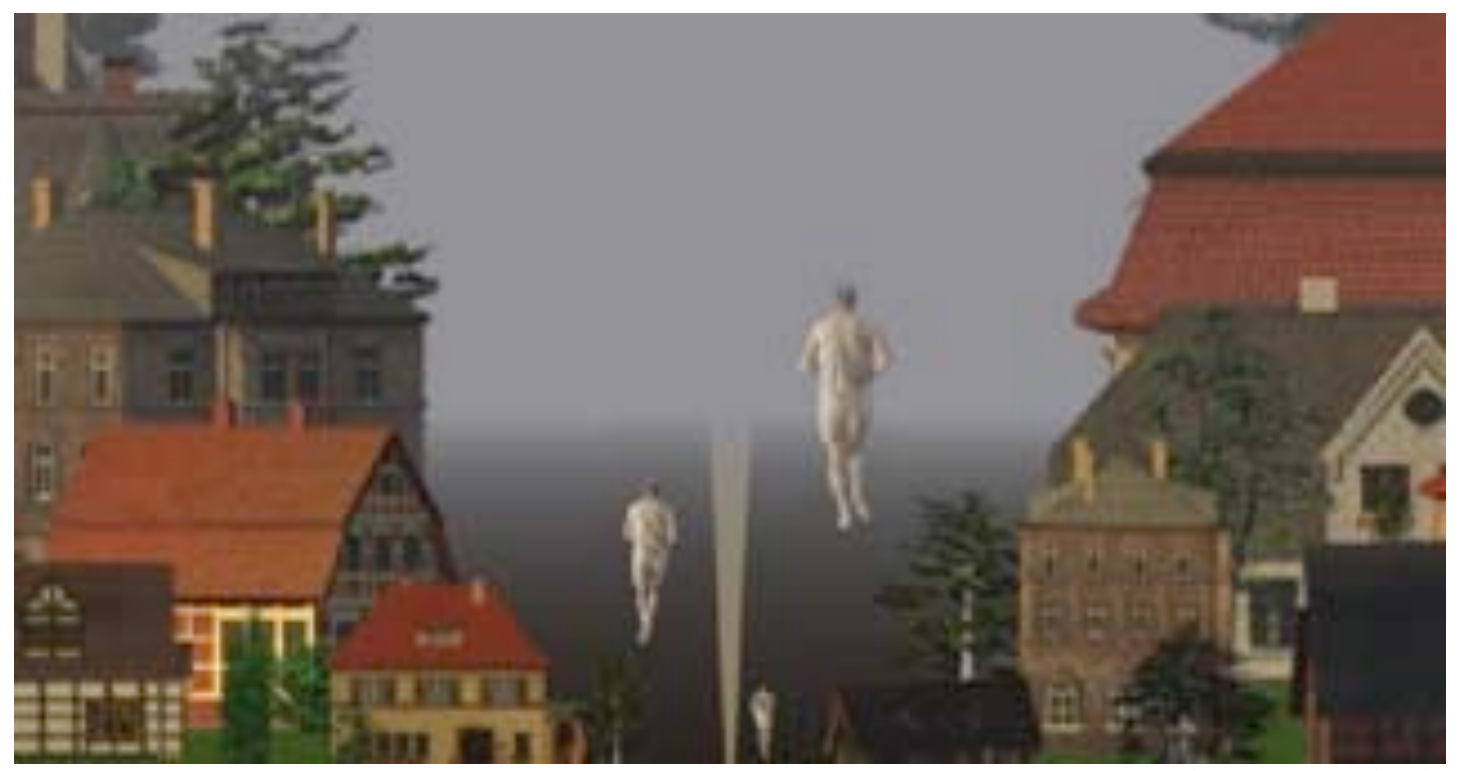

The Way (1994), de Tamás Waliczky

Comparemos esta obra digital con el vídeo de Marcel Odenbach, Dans la vision périphérique du témoin (1986). El artista alemán divide la imagen en tres secciones verticales. La central muestra un plano de sí mismo corriendo de espaldas por una calle de París; en blanco y negro, el fragmento contrasta con los laterales en color, pertenecientes a una misma toma de un pasillo del Palacio de Versalles. A pesar de la marcada heterogeneidad del constructo, la relación proporcional entre la figura humana y la arquitectura permite conectar espacialmente las tres secciones: el hombre parece desplazarse por el interior mismo del palacio. Aunque las franjas verticales evidencian la bidimensionalidad de la pantalla, las líneas que fugan en el horizonte hacen referencia a la perspectiva. En la sección central, la cámara permanece inmóvil mientras el personaje se aleja en ralentí. Por el contrario, en las dos laterales, la cámara se desplaza en un travelling hacia atrás, de modo que los objetos inmóviles cambian de tamaño gracias al desplazamiento del cuadro. Como resultado, se establece una relación entre el movimiento de las dos imágenes fuente, corresponda éste al desplazamiento de la figura (en el centro) o de la cámara (en los laterales).

Tanto Dans la vision périphérique du témoin como The Way parten de imágenes heterogéneas; pero, mientras que Odenbach propone una "cohabitación" (las tomas conservan su autonomía gracias a las líneas fronterizas entre ellas), Waliczky se decanta por la "mezcla" de la síntesis y el registro. Si el artista francés conserva la reproducción del espacio tridimensional, el objetivo del húngaro es, claramente, negar

\footnotetext{
$<$ http://www.waliczky.net/pages/waliczky_way1-frame.htm>
} 
las bases geométricas de la proyección central. La imagen digital permite un acceso atómico a los elementos, a las coordenadas del sistema, que Waliczky aprovecha para explorar un espacio no-euclidiano. En este sentido, el proceso es semejante al llevado a cabo por Csuri al partir del sistema de coordenadas XY en busca de hiperespacios y distorsiones.

Si Odenbach guarda la proporción entre las formas de las diversas imágenes fuente, el objetivo de Waliczky es, precisamente, el contrario: al intercambiar el punto de fuga y el punto de vista, se invierte también la escala de las figuras. Esta renuncia a la proporcionalidad directa del tamaño de éstas con respecto a la distancia al observador supone la negación del espectador como centro organizador del espacio en el plano. En este sentido, la propuesta de Waliczky tiene un antecedente en el fotomontaje y el collage de principios de siglo XX. Pongamos como ejemplo la pieza del también húngaro László Moholy-Nagy: “Sport Makes Appetite” (1927).

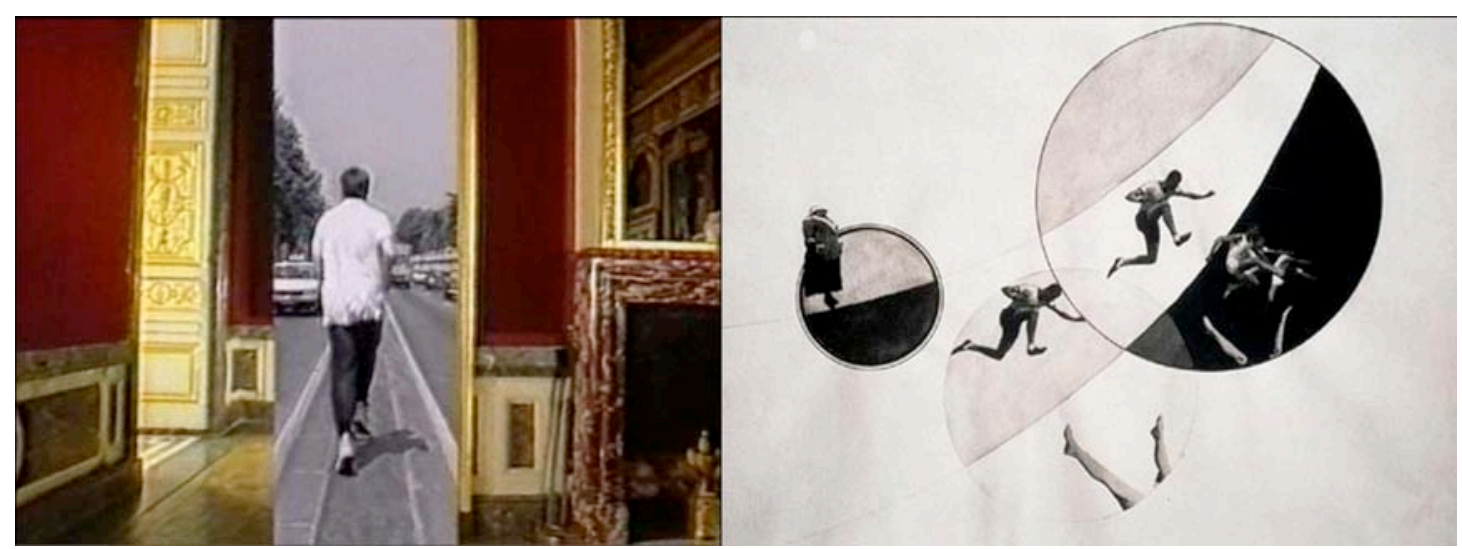

Izquierda. Dans la vision périphérique du témoin (1986), de Odenbach. Derecha. Moholy-Nagy: "Sport Makes Appetite" (1927).

Moholy-Nagy persigue un nuevo lenguaje fotográfico que corresponda a las experiencias visuales de la metrópoli. La modernidad exige un "nuevo hombre", una "nueva visión", una "nueva cultura de los ojos" y, para lograrlo, se impone una "limpieza" de la representación visual. La propuesta estética de esta "nueva fotografía" parte del rechazo de la mera reproducción en aras de una construcción específica de la imagen: el aparato fotográfico no debe reproducir un espacio en perspectiva, sino generar nuevas relaciones entre las formas. Así, en "Sport Makes Appetite", el espacio se estructura mediante formas geométricas: el círculo y la diagonal producen ritmos visuales semejantes a la pintura suprematista. El objetivo es romper con las convenciones de la visión antropocéntrica, caracterizada por el eje 
vertical del cuerpo humano y su perpendicular, el horizonte. En resumen: el espectador deja de ser el centro organizador, la unidad de medida del espacio.

Admirador del trabajo de Moholy-Nagy ${ }^{24}$, Tamás Waliczky sabe que la imagen digital (como la pintura primero y la fotografía después) puede independizarse de la perspectiva. Veamos otro ejemplo en The Garden (1992-1996). Waliczky crea una animación por ordenador a partir de la digitalización de una película en Super-8 de una niña jugando en un jardín. La transformación del registro consistió en inventar un nuevo tipo de proyección: "el sistema de gota de agua". Llamado así por su aparente espacio curvo, dicho sistema se estructura alrededor de la niña, que funciona como centro de su mundo. Los objetos cambian de tamaño a medida que aquélla se acerca o se aleja de ellos, de modo que el punto de vista no es ya aquél en el que debe situarse el espectador, sino que pertenece exclusivamente al personaje de la imagen:

"El mundo representado es el universo privado de la niña, al que dan forma sus movimientos; es independiente del observador, que permanece fuera y ve el sueño de otro. ${ }^{, 25}$

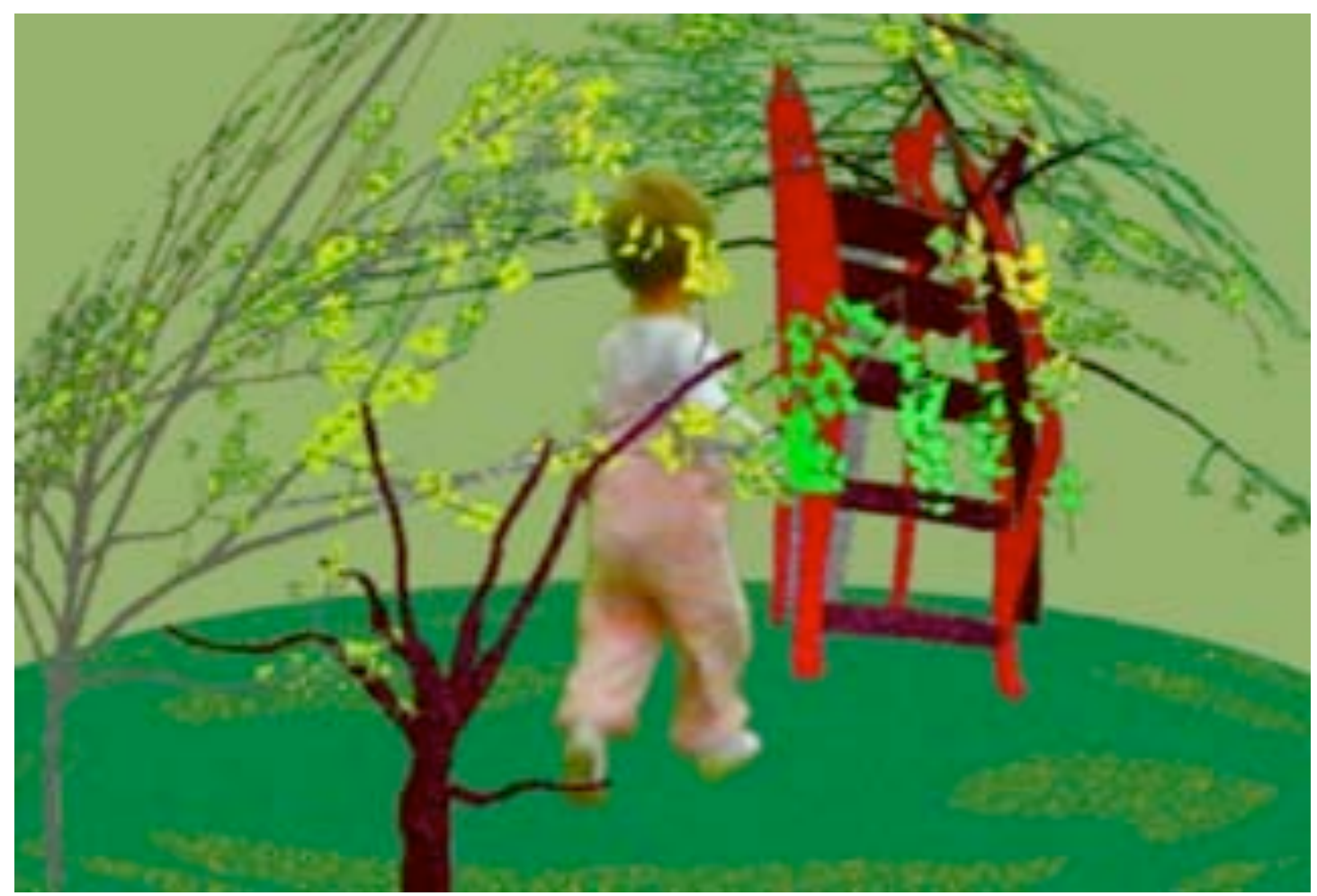

The Garden (1992-1996), de Tamás Waliczky

\footnotetext{
${ }^{24}$ En 1990, Waliczky había titulado ya una de sus animaciones sintéticas "Memory of Moholy-Nagy". Disponible en Web: <http://www.waliczky.net/pages/waliczky_moholy1.htm>

${ }^{25}$ Anna Szepesi. 1995. Disponible en Web: <http://www.waliczky.net/waliczky_start.htm>
} 
Siguiendo el ejemplo de Waliczky, Tania Ruiz Gutiérrez se aleja de la perspectiva en busca de un espacio exclusivo de la imagen. En La Plaza II (2004), adapta el registro de unos viandantes a la superficie de un toro, un cuerpo geométrico cuya forma característica de rosquilla resulta de curvar un cilindro. Un "mapping” le permite modelar la imagen-fuente, que se comporta como una textura que envuelve la superficie del objeto tridimensional. ${ }^{26}$ Aunque el espacio es curvo como en The Garden, la imagen final no muestra la superficie del toro, sino que la autora elige un rectángulo que hace coincidir con la pantalla. Esta decisión altera la escala de los personajes como en The Way: la artista rompe así con la proporción directa entre el tamaño de las figuras y la distancia al espectador, propia de la perspectiva; con ello, renuncia también al punto de vista único que estructura el espacio homogéneo.

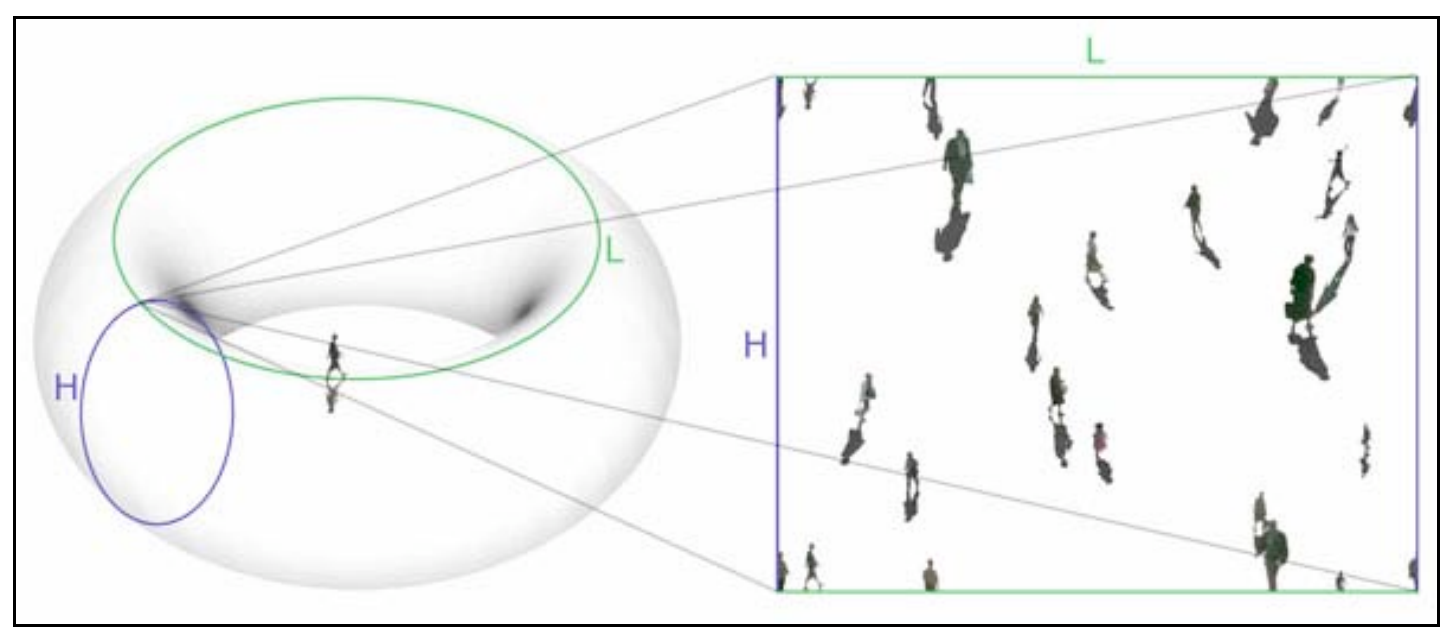

La Plaza II (2004), de Tania Ruiz Gutiérrez

El videoclip By and By (2009), de los Snorri Bros para Lay Low, comparte con The Garden la estructuración del espacio en torno a la protagonista. Tal y como afirman los autores, el mundo construido es el universo privado de la cantante:

\begin{abstract}
"Sentimos que la heroína de la canción es la figura que controla, que manipula la vida de la persona sobre la que canta. Así que comenzamos a trabajar con la idea de que, de algún modo, ella es superior o está por encima de ese mundo."27
\end{abstract}

El espacio no es estructurado a la medida de un espectador externo, sino como una espiral de la que brotan las formas. Como veremos más adelante, esta

\footnotetext{
${ }^{26}$ Tania Ruiz Gutiérrez. Disponible en Web: <http://www.taniaruiz.info/la_plaza.html>

${ }^{27}$ SNORRI BROS. Entrevista realizada por Bran Dougherty-Johnson [En línea]. Motionographer. 11 de noviembre de 2009. Disponible en Web: <http://motionographer.com/theater/by-and-by-qa//>
} 
composición centrípeta, este torbellino que nace y muere en el centro del cuadro, es una construcción frecuente en la figuración de espacios no-euclidianos e hiperespacios en la imagen digital.

La obra prueba un cambio en la concepción espacial de la imagen animada con respecto a la reproducción del registro: del vacío por el que se desplazan los seres a una entidad llena, conductora, más próxima a un entorno plástico habitable. Esta construcción espacial es semejante a los universos imposibles del artista francés François Vogel. En el corto Trois petits chats (2002), el registro se comporta como una pasta modelable; un espacio elástico, sometido a fuerzas que lo retuercen sin diferenciar entre figura y fondo. Vogel había explorado ya en tanto que fotógrafo la distorsión con una cámara estenopeica. ${ }^{28}$ Como Charles Csuri, su interés por la distorsión precede al trabajo con la herramienta digital: a ella se dirige con la certitud de hallar un aliado para su exploración de la deformación de la imagen.

Esta concepción de la imagen animada como un entorno lleno, continuo, es explorada ya, entre los años 10 y 30 del siglo XX, por las llamadas "vanguardias históricas". Si el cine clásico continúa con la metáfora de la ventana de Alberti de modo que la pantalla es considerada como apertura a un espacio representado en la película, las vanguardias históricas se inspiran en la pintura moderna en busca de un espacio plástico propio de la imagen animada. Estas investigaciones visuales permiten hablar de "un espacio de la imagen", en cuanto privilegian la superficie bidimensional de la misma. Ligadas a la narración o como pura expresión visual, las deformaciones desarticulan la reproducción del espacio tridimensional.

Así, por ejemplo, Abel Gance se sirve de lentes curvas para dar forma a las alucinaciones de los personajes en La folie du Docteur Tube (1915) e identifica el desenfoque con la visión de un hombre prácticamente ciego en La Roue (1922). Un año antes, Marcel L'Herbier da forma a los estados de ánimo de la protagonista de $E l$ Dorado (1921) mediante la borrosidad de la imagen. Más allá, destacan casos difícilmente clasificables como el objetivo granuloso de L'étoile de mer (1928) o las superficies convexas de Emak Bakia (1926), ambas de Man Ray. A medio camino entre la figuración y la abstracción, las anamorfosis destruyen la profundidad: las formas heterogéneas se entremezclan en un plasma de contrastes mutantes.

\footnotetext{
${ }^{28}$ Una cámara estenopeica es, básicamente, un aparato sin lente que permite deformar la imagen mediante la alteración manual del plano del material fotosensible. VOGEL, François. Nouveau traité du sténopé. Bastia: Éditions Éoliennes, 2011.
} 


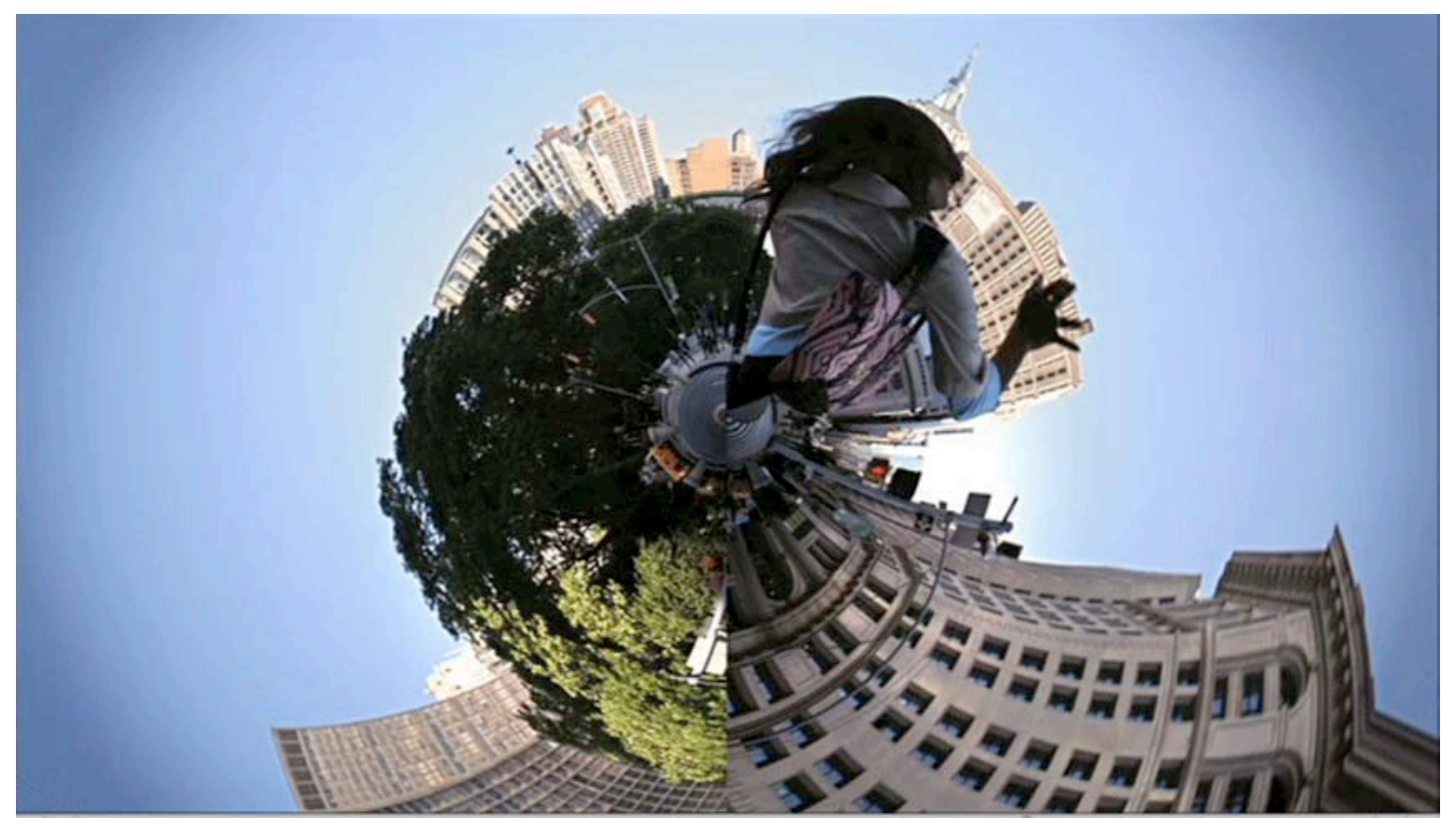

By and By (2009), de los Snorri Bros para Lay Low

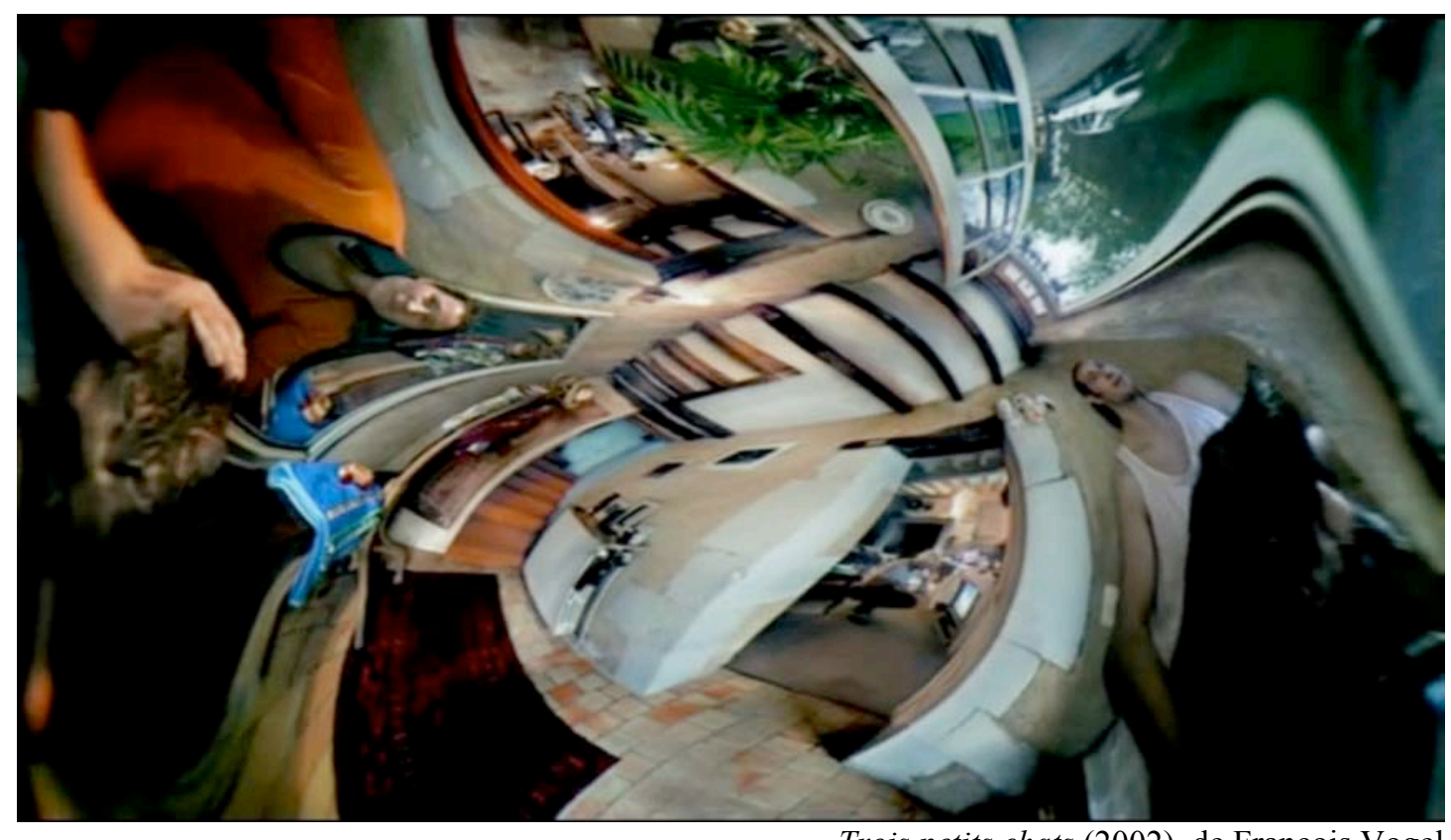

Trois petits chats (2002), de François Vogel
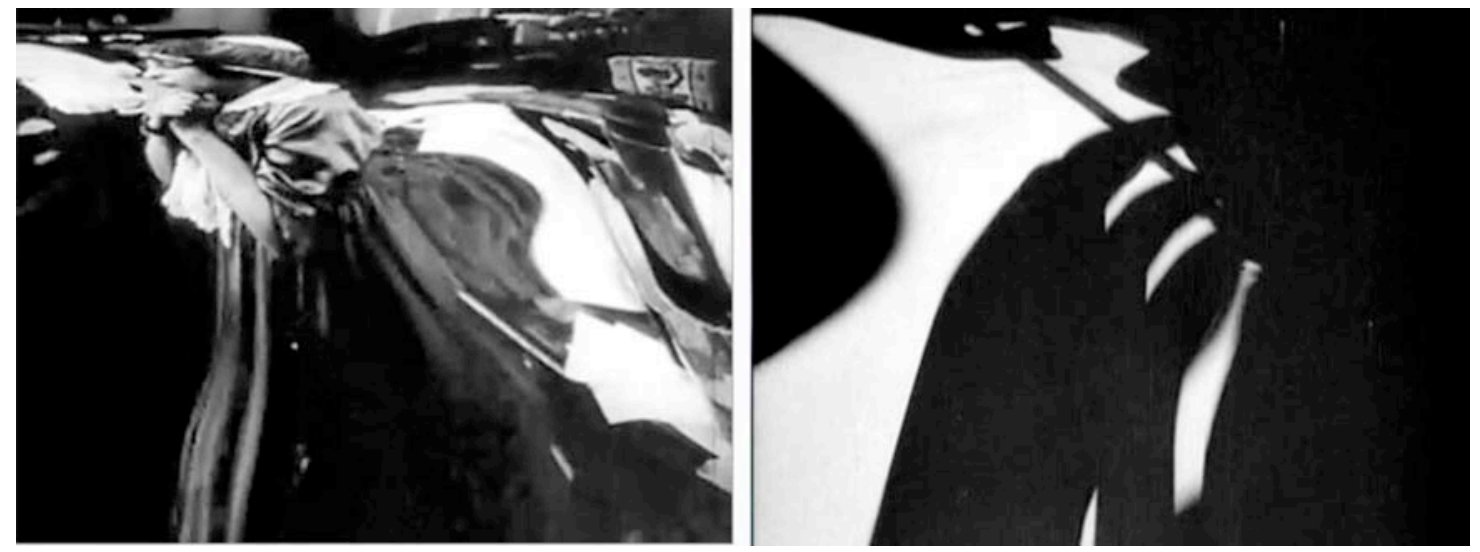

Izquierda. La folie du Docteur Tube (1915), de Abel Gance. Derecha. Emak Bakia (1926), de Man Ray 


\section{La imagen como materia prima para la distorsión}

Las prácticas digitales que analizamos comparten con el cine de las vanguardias históricas la concepción de la imagen-registro como un mero ente bidimensional, que puede funcionar como soporte y materia prima de diversas transformaciones. Con todo, las distorsiones de las vanguardias son ópticas, mecánicas o manuales: es decir, se producen mediante la filmación de superficies en sí curvas o la alteración de la película o el objetivo. Por su parte, la imagen digital no posee un equivalente del soporte material que es la película cinematográfica, sino que los datos son almacenados en la memoria como cualquier otra información. Una vez en el ordenador, la matriz de píxeles es susceptible a todo tipo de manipulaciones: su aspecto numérico, abstracto, permite un acceso atómico y con él, una transformabilidad sin precedentes.

Ahora bien, lo cierto es que buena parte de los experimentos de las vanguardias históricas fueron retomados, primero, por los videoartistas de los años 60 y 70 en el soporte electromagnético. Pongamos como ejemplo la obra de Toshio Matsumoto. El artista japonés reconoce, así, su inspiración en el cine de las vanguardias históricas:

\footnotetext{
"Durante mis estudios, aprendí por primera vez que hubo una vanguardia cinematográfica en Europa en los años 20, que visualmente mantuvo una relación profunda con el arte que le era contemporáneo - hecho que me sacudió como un rayo. (...) Sentí que esto, esta área en la que el arte y el cine se superponen, era lo que había estado buscando."29
}

Esta combinación de pintura e imagen animada es palpable en obras como Mona Lisa (1973). Partiendo de una reproducción del célebre retrato de Leonardo da Vinci, Toshio Matsumoto dinamiza la imagen mediante distorsiones cromáticas. Las variaciones del cuadro recuerdan las series pop de Andy Warhol, entre otras, los famosos retratos de Mao Zedong, de la misma época.

\footnotetext{
${ }^{29}$ MATSUMOTO, Toshio. Entrevista realizada por Aaron Gerow [En línea]. Yamagata International Documentary Film Festival, 2009. Disponible en Web: <http://www.yidff.jp/docbox/9/box9-2-e.html>
} 


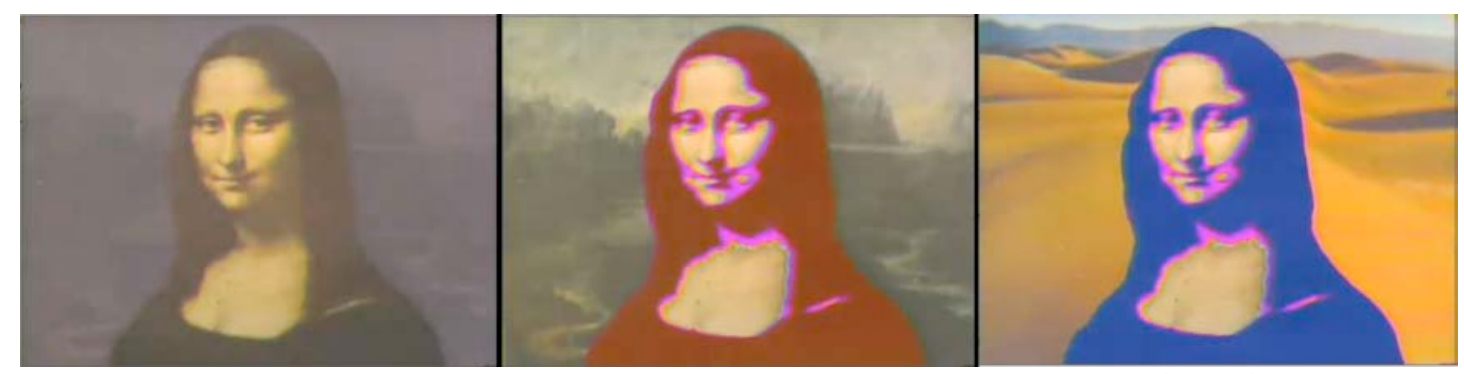

Mona Lisa (1973), de Toshio Matsumoto

Como las vanguardias, el videoarte de los años 60 se posiciona frente al mimetismo del cine clásico, como un campo de exploración artística de espacios propios a la imagen. Pero, si los artistas de los años 20 trabajan con el dispositivo cinematográfico, que simula el movimiento a partir de fotografías, el vídeo se basa en un proceso electromagnético: un punto de luz se desplaza horizontalmente en la superficie de la pantalla formando líneas que, sumadas, reproducen la imagen captada por la cámara. En este sentido, de acuerdo con Bill Viola, el vídeo esta más cerca del sonido que de la fotografía o del cinematógrafo:

\begin{abstract}
"Tecnológicamente, el vídeo se ha desarrollado a partir del sonido (del electromagnetismo). La estrecha relación que mantiene con el cine es engañosa porque el cine y su ancestro, el proceso fotográfico, pertenecen a una rama muy distinta de su árbol genealógico (la mecánica y la química). La cámara de vídeo, en cuanto traduce electrónicamente la imagen física en impulsos eléctricos, originalmente, está más cerca de un micrófono que de una cámara de cine.”30
\end{abstract}

Entre 1968 y 1969, Nam June Paik crea su Electronic Opera \#1 para el programa The Medium is the Medium, emitido en 1969 por la televisión pública de Boston WGBH-TV. Paik distorsiona la imagen electromagnética con un imán durante la grabación en la cinta de vídeo. Si bien las formas ondulantes retoman la exploración plástica de espacios curvos del cine de las vanguardias, la deformación es el resultado de la alteración de la señal electrónica. Entre las imágenes así distorsionadas, destaca una emisión del presidente de los Estados Unidos Richard Nixon. El artista bautiza el resultado como "efecto Cage" en honor al músico John Cage, quien investigara el azar en la composición musical y marcara con ello al

\footnotetext{
${ }^{30}$ VIOLA, Bill. Reasons for Knocking at an Empty House. Writings 1973-1994. Cambridge: The MIT Press, 1995, pp. 158-159.
} 
movimiento Fluxus ${ }^{31}$. La transformación del espacio se relaciona, por un lado, con la escritura automática del dadaísmo ${ }^{32}$ o el surrealismo ${ }^{33} \mathrm{y}$, por otro, con el "azar controlado" de los pioneros del arte por ordenador.

En la misma época, Paik concibe con ayuda del técncio de televisión Shuya Abe el que es considerado el primer sintetizador analógico. Éste le permite editar siete fuentes de vídeo de manera simultánea en "tiempo real"; cada cámara recibe y transmite un solo color, distinto al de las otras seis. Con su sintetizador, Paik mezcla e invierte los colores (desde el ultravioleta al infrarrojo): una paleta cromática para el "lienzo" en el que convierte la pantalla de televisión. A ésta da forma "con la misma precisión de Leonardo, la libertad de Picasso, el color de Renoir, la profundidad de Mondrian, la violencia de Pollock y la lírica de Jasper Johns." 34

Los efectos del sintetizador Paik/Abe aparecen en el programa Video Commune: Beatles from beginning to end, en agosto de 1970. Cuatro horas de explosión cromática al ritmo de los Beatles: la imagen fluctúa entre la abstracción y la distorsión de emisiones previas, entre ellas, tomas de la famosa banda de Liverpool. Frente al registro de la imagen cinematográfica, Paik apuesta por la plasticidad de la imagen videográfica, que retuerce, colorea, procesa y distorsiona. La clave está en la interferencia, en la desmaterialización de la imagen. El artista coreano experimenta con la señal electrónica en busca de un lenguaje videográfico caracterizado por la transformación: "Mi televisión experimental es (...) como la naturaleza, que es bella no porque cambie de forma bella, sino simplemente porque cambia."

Podemos hacer con la imagen videográfica lo mismo que con el sonido ${ }^{36}$ : no es de extrañar que los sintetizadores de música de los años 50 den paso a los sintetizadores de vídeo, primero analógicos como el Paik/Abe (1969), el Sandin Image processor (1971-74) o el Rutt-Etra Scan Processor (1972), y después digitales,

\footnotetext{
${ }^{31}$ Iniciado por George Macunias a principios de los años 60 y con miembros como Joseph Beuys o Yoko Ono, Fluxus tomó del pop art la mezcla del arte académico y el arte popular.

${ }^{32}$ El dadaísmo nace en Zurich en 1916 en el cabaret Voltaire. Sus principales fundadores son Hugo Ball, Richard Huelsenbeck, Tristan Tzara y Hans Arp, y su objetivo, ridiculizar el arte y la figura del artista. El movimiento se extenderá después a Nueva York, Alemania y París.

${ }^{33}$ La sesión de "Coeur à barbe", organizada por Tristan Tzara el 6 de julio de 1923, señala el nacimiento del surrealismo, cuyo manifiesto será publicado por André Breton el 15 de octubre de 1924. ${ }^{34}$ PAIK, Nam June. Videa 'n'Videology (1959-1973). Syracuse, New York: Emerson Museum of Art, 1974, p. 55.

${ }^{35}$ Nam June Paik. Apud. YOUNGBLOOD, Gene. Expanded Cinema. Toronto, Vancouver: Clarke, Irwin \& Company Limited, 1970, p. 302.

36 "There are no special restrictions inherent in the video signal as opposed to the audio signal. Anything that can be done with sound can be done with video if the proper hardware is available. The basic ingredient of alternating current is identical in both processes, and represents potential for as many variations as the equipment will allow". Ibídem, p. 265.
} 
como el Digital Image Articulator (1978), de Woody Vasulka y Jeffrey Schier. Diseñados para distorsionar la imagen, los sintetizadores se basan en la transformación de una señal ya existente. Como veíamos, este interés por la variación es compartido por los pioneros del computer art: ambos exploran espacios específicos de la imagen y de la tecnología que la sustenta mediante la distorsión. Así, tanto la variabilidad como el acceso atómico al espacio que permite la tecnología digital tienen un antecedente en la imagen electrónica: la transición de ésta a la imagen código se produce de manera fluida, sin ruptura. ${ }^{37}$
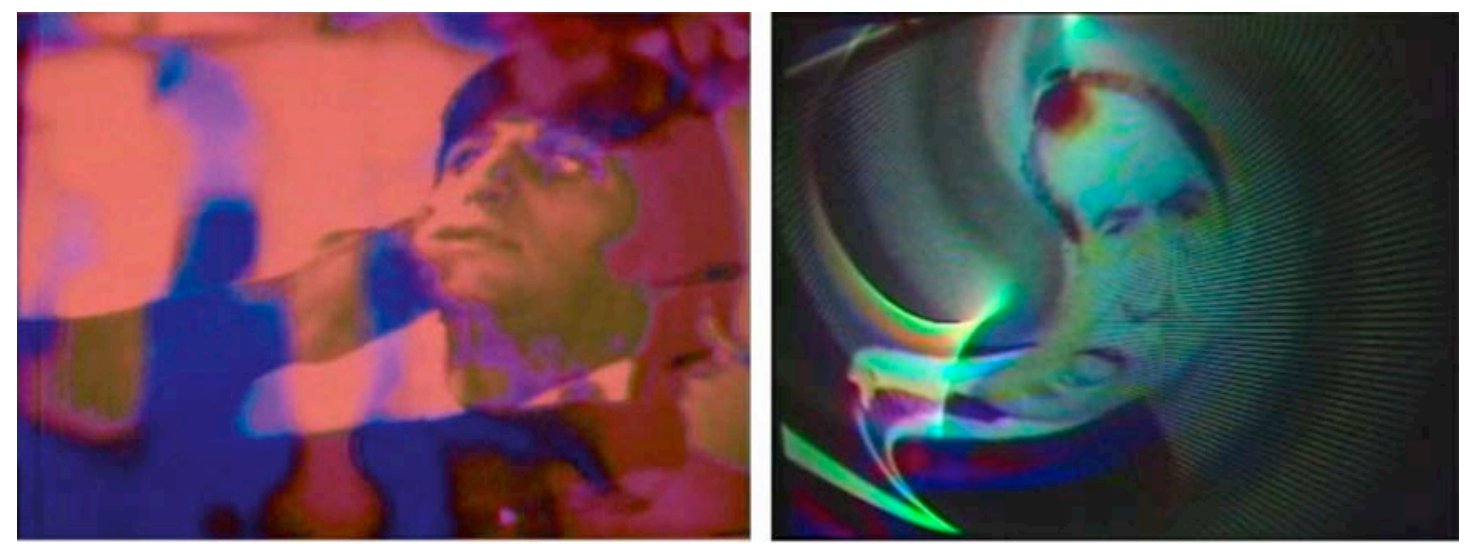

Izquierda, Video Commune (1970); derecha, Electronic Opera \#1 (1968). Ambas de Nam June Paik

En septiembre de 1968, la Tokio Gallery presenta la exposición "Computer Art: Media Transformation through Electronics", con obras creadas por el Computer Technique Group (CTG) en el IBM Scientific Data Center de Japón. Entre ellas, destacan las imágenes digitales de Masao Kohmura. Como Csuri, Mezei o Mohr, el diseñador explora las transformaciones geométricas que posibilita el cálculo informático; y, al igual que Paik en la imagen electrónica, continúa con la pista abierta por el pop art al manipular imágenes de la cultura popular. Las distorsiones afectan a dibujos de celebridades de la época como los recién desaparecidos John F. Kennedy o Marilyn Monroe, así como a la iconografía de la publicidad. Si en "Diffused Kennedy" Kohmura deforma el rostro del político americano, en "Running cola is Africa", presenta las fases intermedias entre la figura de un hombre corriendo, una botella de Coca-Cola y la silueta del continente africano. Como veremos más adelante, este tipo de transformación es la base del "warping”, la distorsión necesaria de las imágenes fuente para la creación de la animación mediante "morphing”.

\footnotetext{
37 "All that happens when we move from analog electronics to digital computers is that the range of variations is greatly expanded." MANOVICH, Lev. The Language of New Media. Op. cit., p. 128.
} 
Con todo, las obras de Kohmura son imágenes fijas. En la imagen animada, destaca Digital Einstein (1973), de Herbert Franke. Como en Hummingbird de Csuri, las dinámicas no corresponden a un registro de un movimiento, sino a la mismísima distorsión: partiendo del sistema "Bildspeicher $\mathrm{N} " 38$, una herramienta de diagnosis médica, el artista descontextualiza el útil científico al aplicarlo a una fotografía en blanco y negro de Albert Einstein. Como resultado, el rostro del físico alemán es pulverizado por colores psicodélicos, en círculos concéntricos.
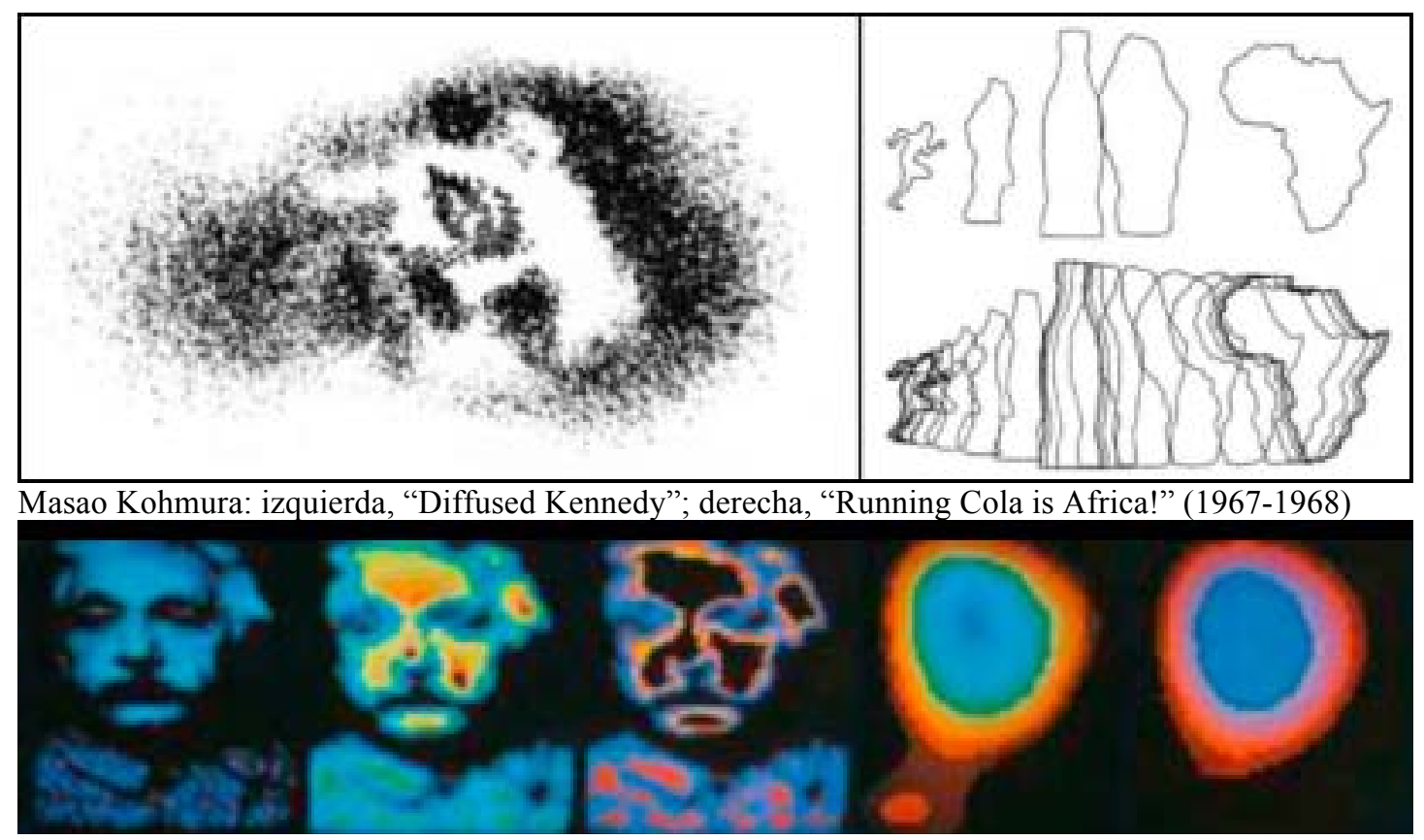

Digital Einstein (1973), de Herbert Franke

Franke acude a una imagen de Einstein; Kohmura, a Kennedy y Marilyn Monroe; Paik, a Nixon y los Beatles; y Matsumoto, a la Gioconda. Al partir de iconos populares, la transformación guarda una conexión con la imagen-base, reconocible a pesar de las distorsiones. Estas construcciones se encuadran dentro de una tendencia artística contemporánea, presente en el videoarte, la pintura y la instalación ${ }^{39}$, y que comparte la manipulación del found footage o "material encontrado"40. Esta

\footnotetext{
${ }^{38}$ ROSEN, Margit (ed.). A Little-Known Story about a Movement, a Magazine, and the Computer's Arrival in Art: New Tendencies and Bit International, 1961-1973. Karlsruhe, Cambridge: ZKM, The MIT Press, 2011.

${ }^{39}$ Lev Manovich asocia esta tendencia que surge en los años 60 con el paso de la sociedad industrial a la sociedad de la información o lo que él define como la "sociedad meta-media". MANOVICH, Lev. Avant-garde as software [En línea]. ArtNodes, December 2002. Disponible en Web: $<\mathrm{http} / /$ www.uoc.edu/artnodes/espai/eng/art/manovich1002/manovich1002.html $>$

${ }^{40}$ Cfr. BOURRIAUD, Nicolas. Postproduction (2003). Paris: Les Presses du réel, 2009. WEINRICHTER, Antonio. Metraje encontrado. La apropiación en el cine documental y experimental. Navarra: Festival Punto de Vista/Gobierno de Navarra, 2009.
} 
apropiación de imágenes ajenas pasa por la concepción de las mismas como entes susceptibles a todo tipo de transformaciones. Si bien la expresión "found footage" se populariza en los años 80 , la recuperación de imágenes se remonta a los años 20 . Una de las primeras películas montadas con materiales desechados es Padenie dinastii romanovykh (1927) de Esfir Shub. En realidad, no es de extrañar que esta transformación de materiales previos aparezca en el contexto de las vanguardias históricas: el proceso tiene antecedentes en el collage (de los "papiers collés" cubistas a los fotomontajes dadaístas) o el "ready made" de Marcel Duchamp.

A partir de los años 90, la reutilización de found footage se multiplica exponencialmente; bautizado como "mash-up" (término musical que significa "mezclar" o "samplear"), este fenómeno tiene que ver, por un lado, con el intercambio de información facilitado por la "World Wide Web". La web redefine la apropiación: no se trata ya de la cita y la deconstrucción postmodernas, sino de una cultura basada en compartir e intercambiar información. ${ }^{41}$ Por otro lado, la tendencia está ligada a la democratización de la tecnología y el acceso simplificado a la edición. Así, por ejemplo, Nicolas Provost reutiliza fragmentos de Hiroshima, mon amour de Alain Resnais (1959) y Rashomon (1950) de Akira Kurosawa, para la creación de Pommes d'amour (2001) y Papillon d'amour (2003), respectivamente. A la hora de explicar las obras, el artista las relaciona, exclusivamente, con las posibilidades de transformación que permite la tecnología digital:

\begin{abstract}
“A principios de los años 2000, todo el mundo tenía su ordenador, Final Cut y una cámara. Así que lo primero en lo que pensé fue importar películas que ya existían y retrabajarlas. (...) Pero nunca antes había oído hablar de found footage."42
\end{abstract}

\footnotetext{
${ }^{41}$ Así lo muestra el artículo de The New York Times titulado "Apropos appropriation" y firmado por Randy Kennedy. El autor recoge declaraciones de artistas contemporáneos como Stephen Frailey: "For the generation that I spend my days with, there's not even any ideological baggage that comes along with appropriation anymore. (...) They feel that once an image goes into a shared digital space, it's just there for them to change, to elaborate on, to add to, to improve, to do whatever they want with it. They don't see this as a subversive act. They see the Internet as a collaborative community and everything on it as raw material." KENNEDY, Randy. Apropos appropriation [En línea]. The New York Times, December 28, 2011. Disponible en Web: <http://www.nytimes.com/2012/01/01/arts/design/richardprince-lawsuit-focuses-on-limits-of-appropriation.html?pagewanted=all\&_r $=0>$

${ }_{42}$ PROVOST, Nicolas. Entrevista realizada por Fabrice Marquat. Nicolas Provost, le cinéma revisité par notre imaginaire [En línea]. Bref Magazine, Avril 2008, núm 83. Disponible en Web: $<$ http://www.nicolasprovost.com/text/>
} 


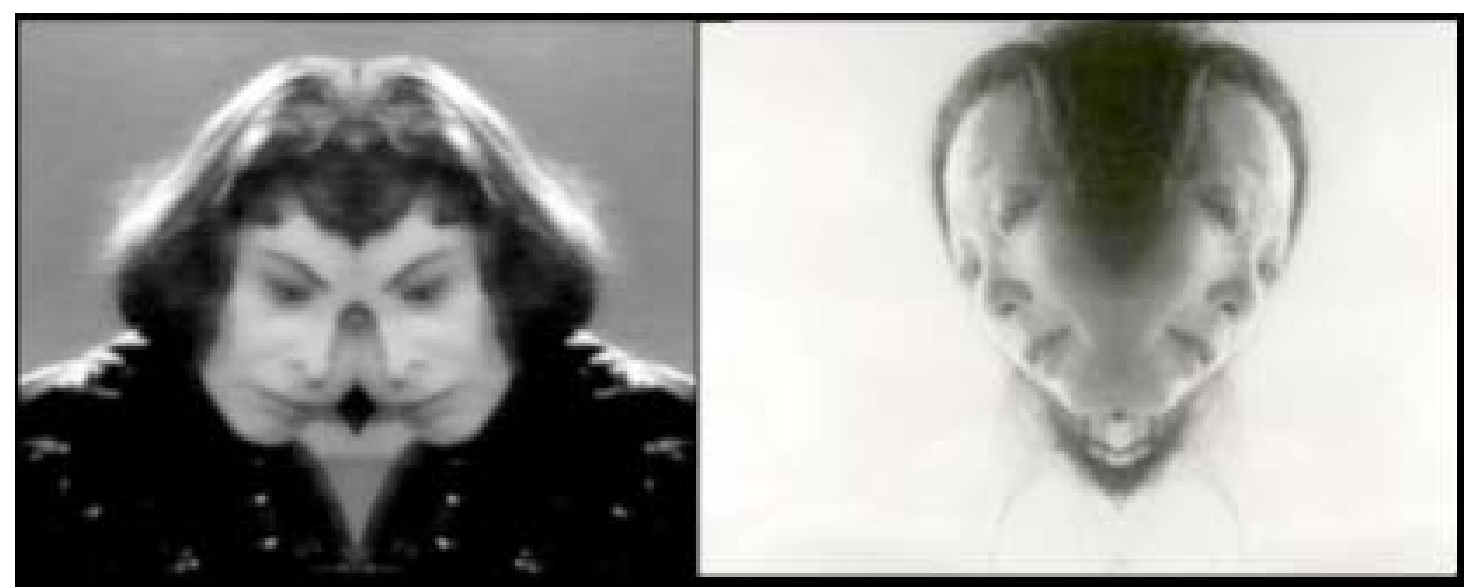

Izquierda, Pommes d'amour (2001). Derecha, Papillon d'amour (2003), ambas de Provost

En The Late Night Triad (2003), Jason Salavon presenta un tríptico formado por tres constructos espaciales, cada uno de los cuales es el producto de la transformación de un show televisivo estadounidense; de izquierda a derecha, los shows de Jay Leno, O’Brian y Letterman. Si bien las secciones se caracterizan por la borrosidad y por un efecto de aceleración, esta dinamización no se produce por desenfoque o por forward videográfico, sino que es el resultado de la aplicación a la imagen de un algoritmo: el ordenador compara grupos de píxeles de la secuencia de partida y, tras detectar una tendencia, propone "imágenes media". Cercano a los experimentos futuristas, que recuperaremos en el tercer capítulo, el constructo resultante es un espacio 1leno; una membrana lumínica que evidencia los aspectos estables y repetitivos, mientras deja esfumarse los cambios. De este modo, la borrosidad no es ruido, sino información: así como la cohabitación de las tres imágenes permite comparar los tres programas entre sí, el espesor de cada una de ellas evidencia los elementos invariables (el fondo, la postura, el plano, la ropa...).

La propuesta de Salavon se enmarca en una corriente artística que se apodera de las técnicas estadísticas de "data visualization" con un objetivo estético. ${ }^{43}$ Lev Manovich propone en 2010 el término "media visualization"44 para definir aquellos constructos que preservan el medio de partida: es decir, al tratarse de found footage, el resultado es, también, una imagen.

\footnotetext{
43 "Data Visualization offers the possibility of fundamental new insights, a moment of understanding that reveals hidden processes or complex relationships, breaks through existing barriers and sharpens the focus on knowledge while providing visual pleasure." DIAMOND, Sara. Lenticular Galaxies: The Polyvalent Aesthetics of Data Visualization [En línea]. Ctheory. Essays in Critical Digital Studies, January 6, 2010. Disponible en Web: <http://www.ctheory.net/articles.aspx?id=651>

44 MANOVICH, Lev. What is Visualization? [En línea]. Manovich.net, March-October 2010. Disponible en Web: <http://manovich.net/2010/10/25/new-article-what-is-visualization/>
} 

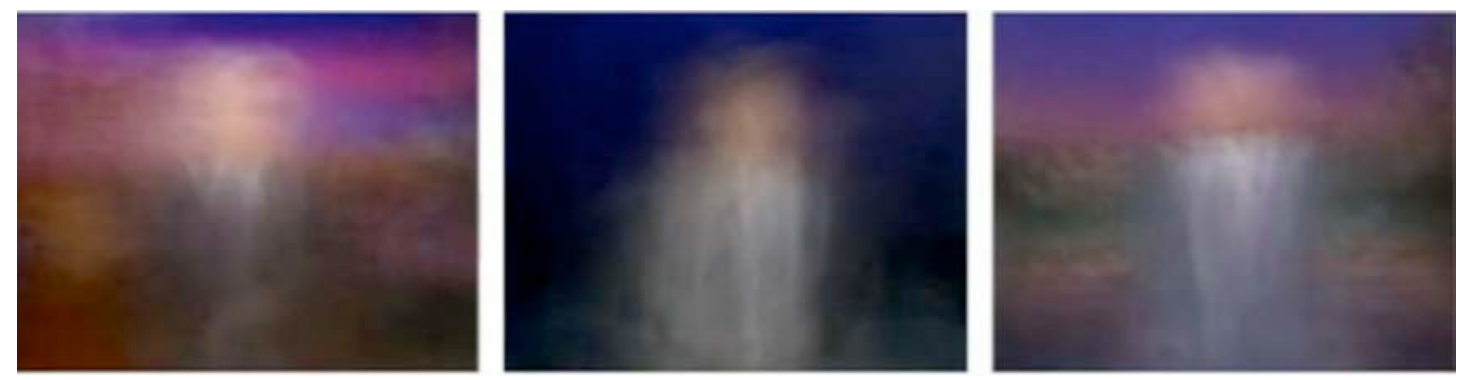

The Late Night Triad (2003), de Jason Salavon

Más allá de esta "visualización de datos" y de la apropiación de found footage, de los cuales veremos otros ejemplos a lo largo de este trabajo, quisiéramos hacer notar las distintas formas de construcción que subyacen a las obras de Jason Salavon y Nicolas Provost. Mientras que la transformación espacial en The Late Night Triad se basa en el análisis de información, es decir, en el tratamiento de la imagen en tanto que código abstracto, la distorsión propuesta por Provost es un simple montaje espacial.

Así, podemos distinguir diversas formas de construcción digital: a través del lenguaje de programación mismo (hablamos entonces de "procesamiento" de las imágenes) o a través de un programa que funciona como intermediario entre el hombre y la máquina, y que posee un lenguaje simbólico hecho de iconos (gráficos 2D y 3D, programas de edición...). Evidentemente, ambas pueden y suelen mezclarse.

En lo que respecta a los programas de edición, Provost se refiere a Final Cut Pro (1999), pero podríamos citar otros tantos: en los años 80, aparecen Quantel Paintbox (1981), ADO (Ampex Digital Optics, 1981) y AVID (1989); en los 90, Adobe Photoshop (1990), Adobe Premiere (1991) y Adobe After Effects (1993). Si bien es cierto que el desarrollo de estos programas debe mucho a la producción cinematográfica hollywoodiense $\mathrm{e}^{45}$, dichos paquetes asumen y popularizan las construcciones de los pioneros del arte por ordenador. Así, por ejemplo, ADO permite rotar las imágenes de forma semejante a las transformaciones geométricas de Csuri o Mezei.

A mediados de los 80, Peter Weibel se sirve de los programas ADO y Quantel para construir su Gesänge des Pluriversums (1986). Imágenes de síntesis, vídeo,

\footnotetext{
${ }^{45}$ Photoshop fue creado por los hermanos John y Thomas Knoll a partir de las herramientas de grafismo desarrolladas específicamente para la construcción de imágenes de síntesis en la película The Abyss (1989). LOUGUET, Patrick; MAHEU, Fabien (coords.). Cinéma(s) et nouvelles technologies : continuités et ruptures créatives. Paris: Editions L'Harmattan, 2011, p. 209.
} 
películas y fotografías son sometidas a transformaciones de escala y posición. Una "plasticidad" de la imagen descrita así por el propio Weibel:

\begin{abstract}
"Este video es sobre todo una plástica. Pero no, en materiales clásicos y sustancias tales como el mármol, la madera o la grasa, sino en el medio electrónico, relativo, insustancial, inmaterial. (...) La plástica electrónica articula el nuevo espacio-tiempo, que los medios electrónicos han importado, visualiza un nuevo espacio pictórico." 46
\end{abstract}

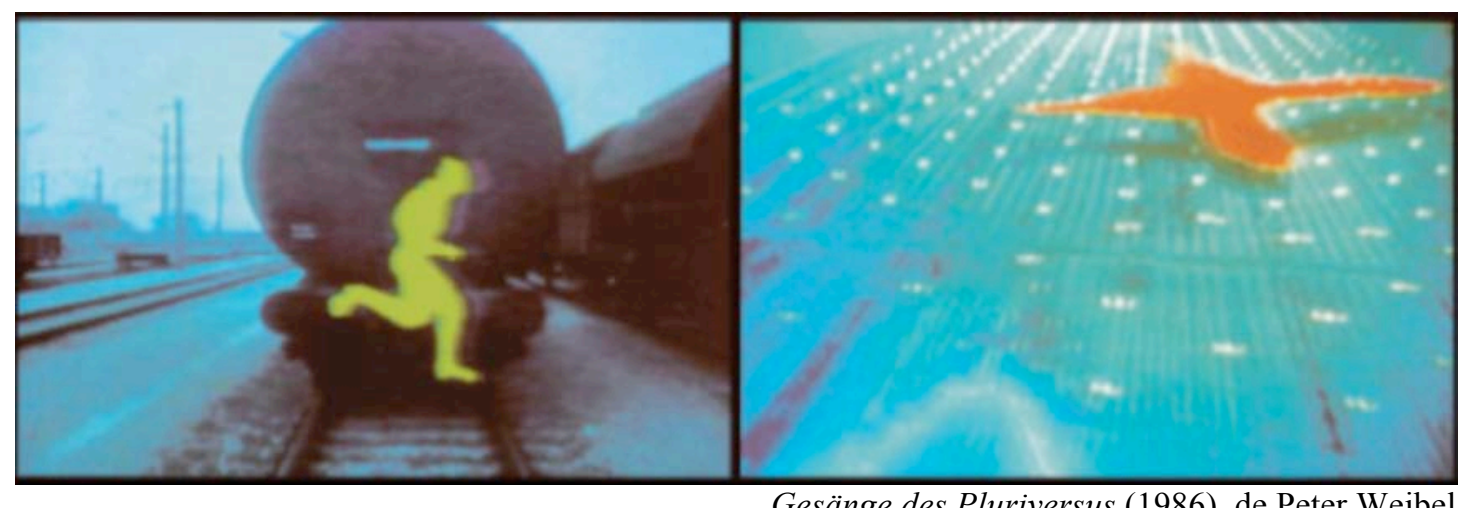

El mismo año, Money for nothing (1986), de Steve Barron para el grupo musical Dire Straits, aparece en la cadena MTV como el primer videoclip en contener imágenes de síntesis junto a las tomas tradicionales. Los registros fueron retocados con colores estridentes a modo de un collage naif que evidencia el carácter plano de la imagen, de manera semejante a los experimentos de las vanguardias históricas. Si Alberto Cavalcanti (Rien que les heures, 1926) y Len Lye (Rainbow Dance, 1936) alteran el material registrado en el fotograma, Norman McLaren (Hand-Painted Abstraction, 1933) pinta sobre la película bruta, sin ser expuesta a la luz. Las imágenes abstractas de este último revelan un rechazo tanto a la narración como al objetivo de la cámara en tanto que principio organizador del espacio. ${ }^{47}$

\footnotetext{
${ }^{46}$ WEIBEL, Peter. Gesänge des Pluriversums [En línea]. Ars Electronica Archiv. 1986. Disponible en Web:

http://90.146.8.18/de/archives/festival_archive/festival_catalogs/festival_artikel.asp?iProjectID=9269

47 Éste es el caso también de las "fotografías sin cámara" o "fotogramas" de Moholy-Nagy: "Cameraless pictures, photograms, however, bring a completely new form of space articulation. It no longer has anything to do with the record of an existing space (or space-time) structure." MOHOLYNAGY, László. "Space-Time and the Photographer" (1942). En: KOSTELANETZ, Richard (ed.). Moholy-Nagy. New York: Praeger, 1970, p. 61.
} 


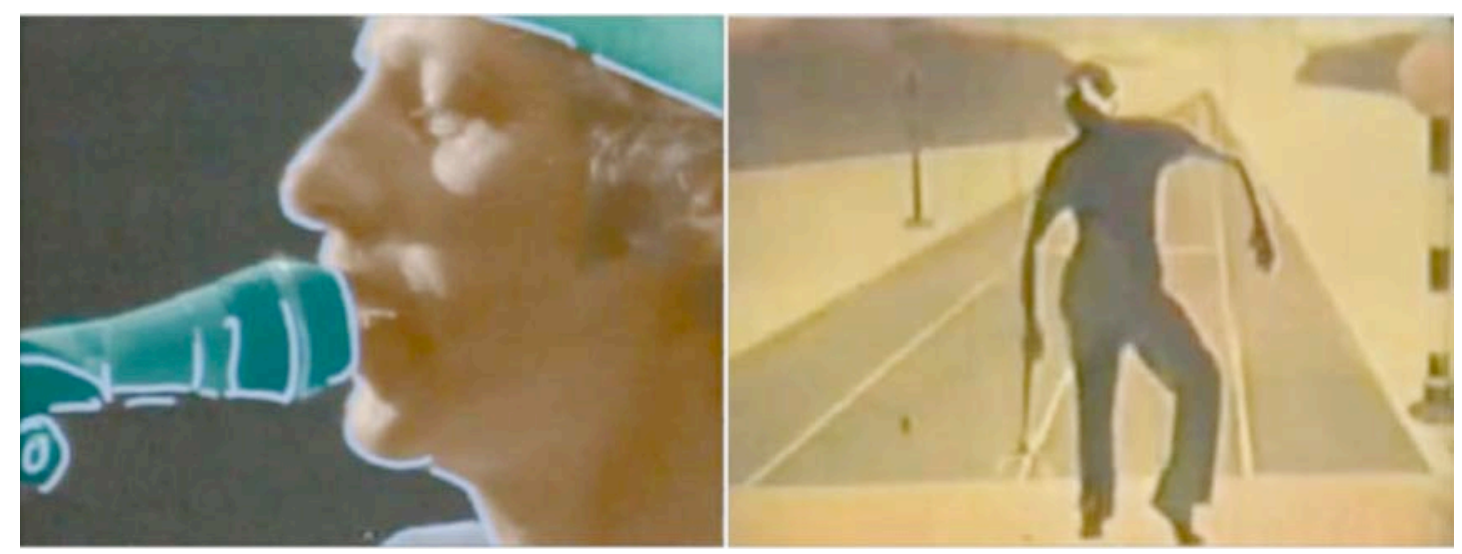

Izquierda, Money for nothing (1986) de Steve Barron. Derecha, Rainbow Dance (1936), de Len Lye

Ahora bien, las experiencias de las vanguardias eran minoritarias, mientras que prácticas semejantes se han incorporado en los programas de edición, simplificando el proceso de elaboración y contribuyendo a su democratización. ${ }^{48}$ De hecho, esta "pintura digital", consistente en alterar o colorear la imagen registrada trabajando el interior del cuadro, se usa incluso como estrategia narrativa dentro del cine de fícción. En Schindler's List (1993) de Steven Spielberg, el abrigo rojo de una niña judía destaca en la imagen en blanco y negro. El recurso cromático capta la atención del observador, que sigue los movimientos de la pequeña hasta su trágico final. Si Spielberg subraya la enunciación en sí, otra película, cinco años posterior, introduce detalles cromáticos en un conjunto en blanco y negro como parte del contenido diegético: Pleasantville (1998), de Gary Ross, narra la inmersión de dos hermanos en una serie televisiva de los años 50. La llegada de los protagonistas a ese mundo rutinario y prefijado, en blanco y negro, altera a sus habitantes, los cuales ven su cuerpo y su ropa teñirse de color a medida que experimentan pasiones. ${ }^{49}$

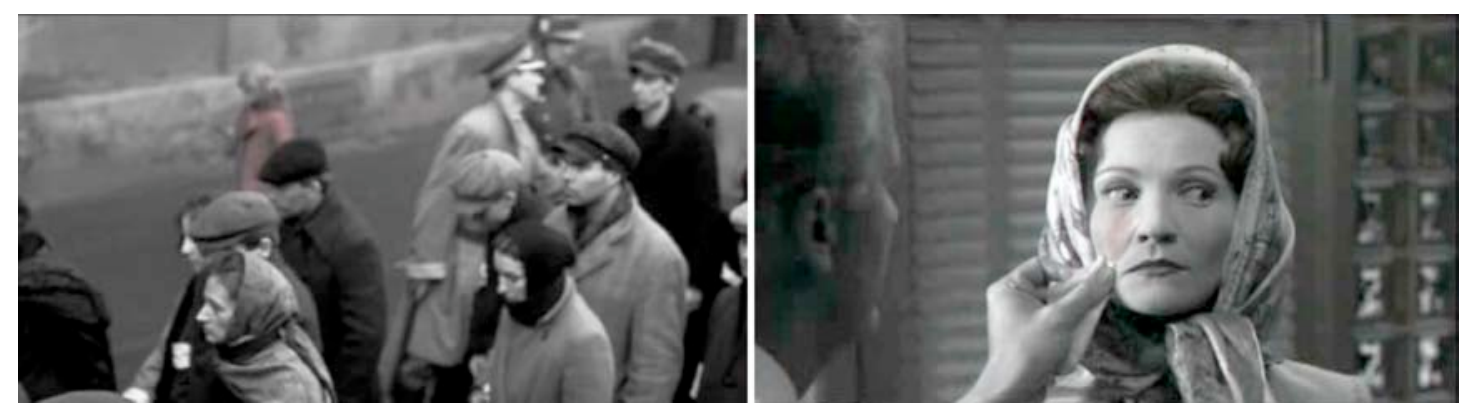

Izquierda, Schindler's List (1993) de Steven Spielberg. Derecha, Pleasantville (1998), de Gary Ross

\footnotetext{
${ }^{48}$ MANOVICH, Lev. The Language of New Media. Op. cit., pp. 306-307.

${ }^{49}$ En su argumentación sobre la potencia narrativa de los efectos digitales, McClean cita Pleasantville y Schindler's List como ejemplos de uso simbólico del color. MCCLEAN, Shilo. Digital Storytelling. The Narrative Power of Visual Effects in Film. Massachusetts: The MIT Press, 2007, p. 9.
} 
En (500) Days of Summer (2009), de Marc Webb, un plano general del protagonista caminando por la calle cobra la textura de un dibujo a carboncillo: los trazos invaden el espacio de arriba a abajo, transformando el registro en color en un diseño en blanco y negro. Al final de la metamorfosis, las formas del fondo en claroscuro se difuminan dando paso a una nube informe de carbón digital, sobre la que destaca la silueta del joven. Aunque el boceto guarda cierta sensación de profundidad, la transición al espacio no-fotorrealista (NPR $)^{50}$ provoca la descomposición del trampantojo, evidenciando el artificio de la imagen.

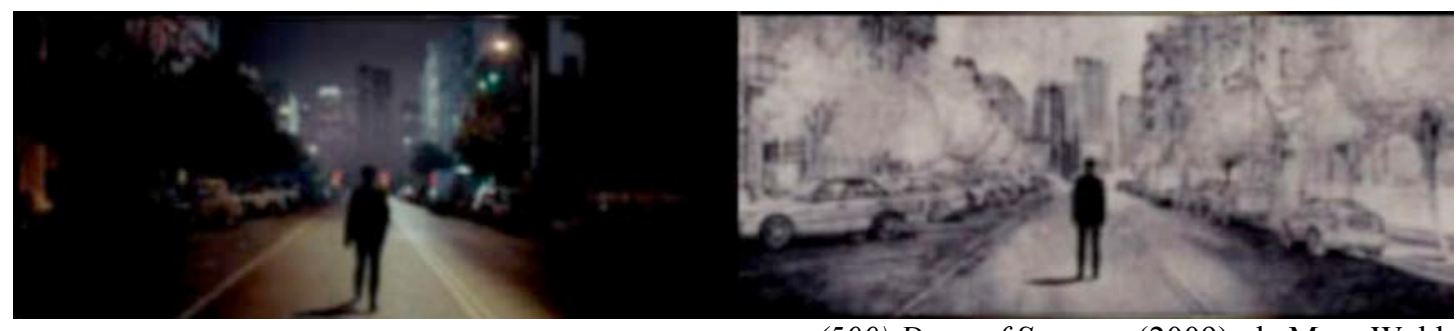

(500) Days of Summer (2009), de Marc Webb
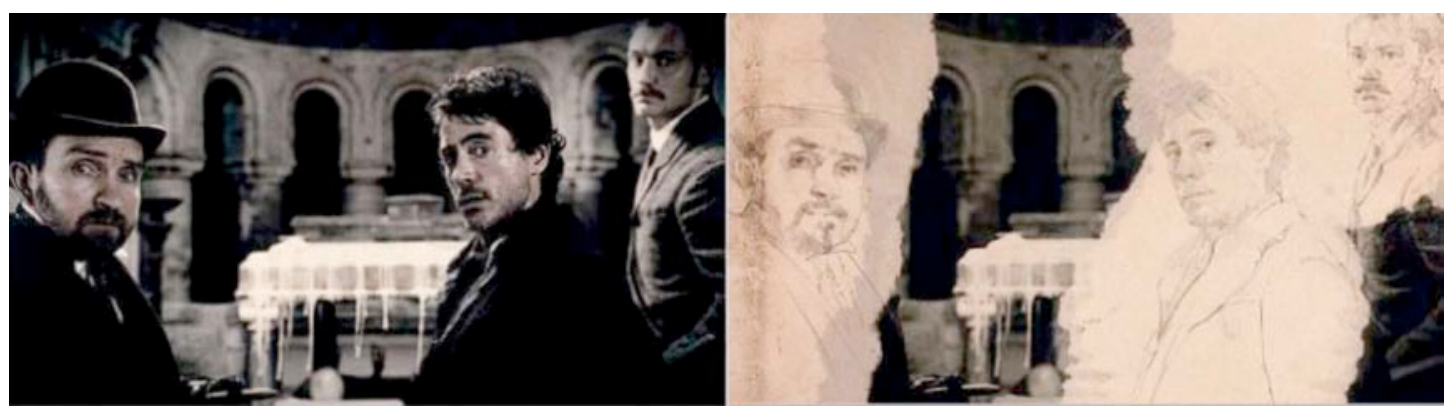

Sherlock Holmes (2009), de Guy Ritchie

El mismo año, Guy Ritchie se sirve de un efecto semejante en los créditos de Sherlock Holmes (2009). De nuevo, se presenta de manera explícita el paso de la imagen registrada al dibujo; la transformación paulatina posibilita la cohabitación del espacio tridimensional figurado y el bidimensional de las capas que componen la imagen. O dicho de otro modo: el efecto hace aflorar el proceso de elaboración, subrayando el espesor de la imagen. Más adelante, veremos otros ejemplos de esta

\footnotetext{
${ }^{50}$ Este tipo de acabado asociado a técnicas tradicionales como la pintura, el carboncillo, la acuarela, etc. se conoce en el campo de la imagen digital como "no fotorrealista" (Non Photorrealistic Rendering), prueba de la preponderancia del fotorrealismo.

El término "fotorrealismo", atribuido a Louis K. Meisel, define a una generación de artistas americanos que, en los años 60 , reaccionaron al modernismo y la abstracción mediante una figuración que recuperaba la cámara fotográfica como filtro estético del espacio visible. En lo que respecta a la imagen de síntesis, el fotorrealismo hace referencia a la capacidad de simular cualquier objeto o espacio de tal manera que su imagen informática no se diferencie de la que sería su fotografía. En este sentido, el referente no es la visión humana de la naturaleza, sino el propio lenguaje cinematográfico, la imagen que del mundo ha construido el cine. Cfr. MEISEL, Louis K.. Photo-realism. New York: Abradale Press, 1989. MANOVICH, Lev. The Language of New Media. Op. cit., p. 199.
} 
construcción de una "profundidad de la imagen" que contrasta con la representación de la profundidad en el plano. Si hasta aquí hemos tratado principalmente la transformación de una imagen fuente, en los dos próximos apartados, nos detendremos en el montaje espacial de varias imágenes dentro del cuadro y la construcción de una entidad heterogénea, que se aleja de la mera reproducción mimética. 


\section{EL MONTAJE ESPACIAL}

El termino ruso montazh, adaptación de la palabra francesa montage, proviene del ámbito fabril: del montaje en cadena hasta el ensamblaje del constructivismo, el "montaje" describe el proceso de elaboración de una obra a partir de los elementos separados que la configuran. ${ }^{1}$ En el ámbito cinematográfico, la concepción popular del término hace referencia a lo que conocemos como "montaje temporal": es decir, la yuxtaposición de los planos mediante cortes, unos junto a otros, en la tira horizontal de la película y la posterior progresión vertical de los mismos en el momento de la proyección.

Sin embargo, la tecnología digital ha renovado el interés por otro tipo de montaje, minoritario en la práctica cinematográfica: el "montaje espacial". Tal y como explica Lev Manovich:

"Si la tecnología, la práctica y la teoría cinematográficas privilegian el desarrollo temporal de la imagen en movimiento, la tecnología informática privilegia las dimensiones espaciales. ${ }^{2}$

Mientras que el montaje temporal es horizontal o diacrónico, el montaje espacial es vertical o sincrónico; o dicho de otro modo: frente a la edición temporal, basada en la secuencialidad, la edición espacial explora la simultaneidad. Al plano como unidad básica entre dos cortes, el montaje espacial sustituye la construcción dentro del cuadro.

Agrupamos bajo el título "La cohabitación de las imágenes" tanto manifestaciones de "pantalla partida" (split screen) como de introducción de subcuadros dentro del cuadro. Las imágenes heterogéneas conviven gracias a una demarcación explícita, que funciona como límite interno. Si estas construcciones espaciales subrayan la superficie de la pantalla, en el apartado "La mezcla de las imágenes", se analizan obras que hacen aflorar la estratificación de la imagen en capas, bien mediante una composición opaca, bien mediante una fusión transparente.

\footnotetext{
${ }^{1}$ AUMONT, Jacques. Montage Eisenstein (1979). Paris: Images modernes, 2005, p. 150.

${ }^{2}$ MANOVICH, Lev. The Language of New Media. Op. cit., p. 157.
} 


\section{LA COHABITACIÓN DE LAS IMÁGENES}

En 2003, Peter Greenaway lanza la polémica diatriba: "El cine ha muerto, larga vida al cine."1 El realizador inglés fecha la defunción en 1983, con la popularización del mando a distancia del televisor y las subsiguientes innovaciones tecnológicas. Si el cine puede sobrevivir, afirma, será admitiendo la revolución de las nuevas tecnologías y sus posibilidades plásticas. Aquel otro cine, condenado a desaparecer, está gobernado por "cuatro tiranías" que encorsetan la potencia estética del medio ${ }^{2}$ : el cuadro, el texto, el actor y la cámara. El cine "que ha muerto" es, pues, el cine del montaje temporal de los planos; de la narrativa cronológica basada en la mera ilustración de un texto. Ese cine, poco más que un "teatro grabado", reserva a los actores un rol desproporcionado; una supremacía de la acción humana sobre las relaciones espaciales. Un cine que, basado en el mero registro de la cámara, es un signo de pereza, de pasividad mimética. ${ }^{3}$

En su manifiesto, Greenaway se pregunta por qué el cine confina la imagen a la forma de un rectángulo, a un solo cuadro unitario: “¿por qué no fragmentarlo, hacerlo explotar, reinventarlo?" El cuadro, responde el artista, es una entidad artificial, creada por el ser humano y, en cuanto tal, puede ser transformada. Si bien Greenaway pone como ejemplo práctico su obra interactiva The Tulse Luper Suitcases (2003), su cine anterior contiene ya numerosos ejemplos de exploración del multi-cuadro. Las imágenes centrípetas de Prospero's Books (1991) y The Pillow Book (1996) resultan de apilar en capas una serie de sub-imágenes de distinto tamaño; entre la opacidad y la transparencia, el efecto exalta la complejidad formal: la imagen se pliega sobre sí misma, negando el fuera de campo para generar otros nuevos en las junturas entre los sub-cuadros.

\footnotetext{
${ }^{1}$ GREENAWAY, Peter. Cinema Militants Lecture. Toward a re-invention of cinema [En línea]. September 28, 2003. Disponible en Web: <http://petergreenaway.org.uk/essay3.htm>

2 "The absolute strength of the medium is in its aesthetic, its relationship of language to content, its relevance to now, the ability to stimulate and entrance, provide stimulus to dream, legitimize imagination, set fire to possibilities, indicate what happens next, encourage wholehearted participation (...) to the point of the panic of overexcitement. I believe cinema as we know it now, simply fails to do this. And I believe this, in some good measure, is due to four tyrannies." Ibídem.

3 "There is a necessity in a curious way to bypass the lazy, mimetic, passive recording eye - human or mechanical - and jump straight to the brain, the imagination, the seat of creation. (...) The Renaissance contribution to the modern world in visual terms is usually couched in terms of forever and forever successfully reproducing reality." Ibídem.
} 

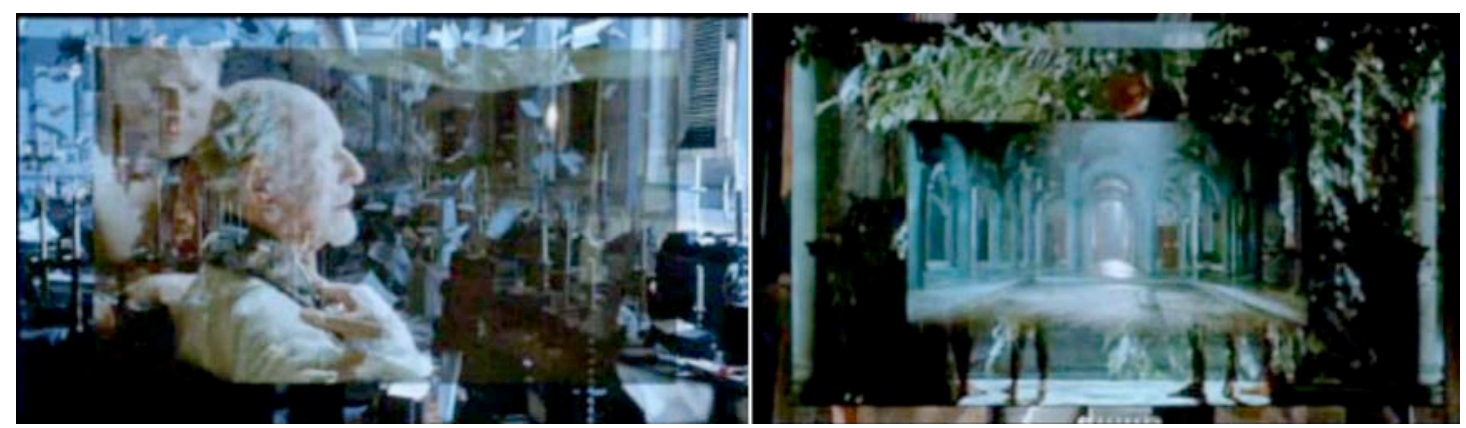

Prospero's Books (1991), de Peter Greenaway

Tal y como hace notar el artista multimedia, este tipo de construcción es minoritaria en la historia del cine; hay que esperar hasta la popularización de la edición digital para ver un interés generalizado por el montaje espacial. El propio Greenaway cita como gran excepción Napoléon (1927), de Abel Gance. En la secuencia de la campaña de Italia, el realizador francés proyecta simultáneamente tres películas de $35 \mathrm{~mm}$ sobre tres pantallas contiguas, creando una especie de tríptico en movimiento. ${ }^{4}$ La composición responde a su teoría de la "polivisión", equivalente visual de la polifonía:

"El cine tiende a igualarse cada vez más a la música. Una gran película debe ser concebida como una sinfonía, como una sinfonía en el tiempo y como una sinfonía en el espacio"s.

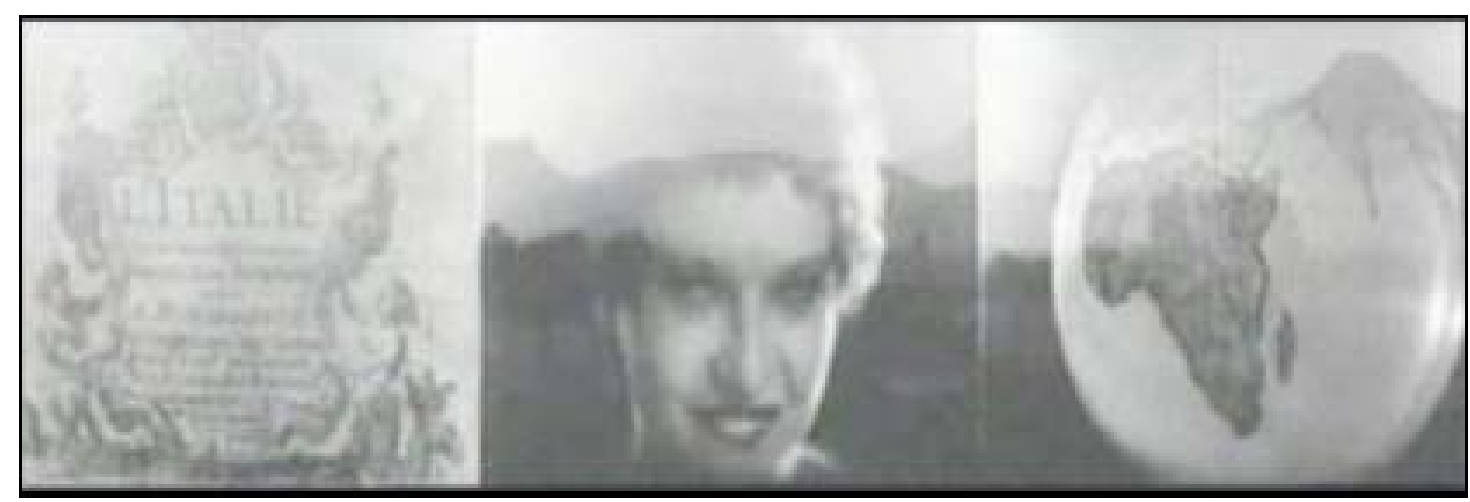

Napoléon (1927), de Abel Gance

\footnotetext{
4 La propuesta de Gance puede ser considerada, también, como un antecedente de la pantalla panorámica por cuanto alarga la imagen hacia los extremos laterales; tal comparación es especialmente pertinente en el caso de tres imágenes contiguas en su contenido. Sin embargo, la polivisión nos interesa, aquí, en tanto que subdivisión de la imagen y cohabitación de distintos espacios.

${ }^{5}$ Abel Gance. Apud. L'HERMINIER, Pierre. L'art du cinéma. Paris: Seghers, 1960, p. 165.
} 
En una escena anterior, Gance anticipa ya el efecto de compartimentación del cuadro: en la pelea entre los niños en el dormitorio común, la imagen se subdivide en cuatro y, después, en 9 puntos de vista de la misma acción, contribuyendo a la sensación de alboroto. Hallamos una compartimentación muy semejante en L'étoile de mer (1928), de Man Ray. Ahora bien, en esta ocasión, la subdivisión de la imagen en doce secciones responde a una extravagancia visual del surrealismo.

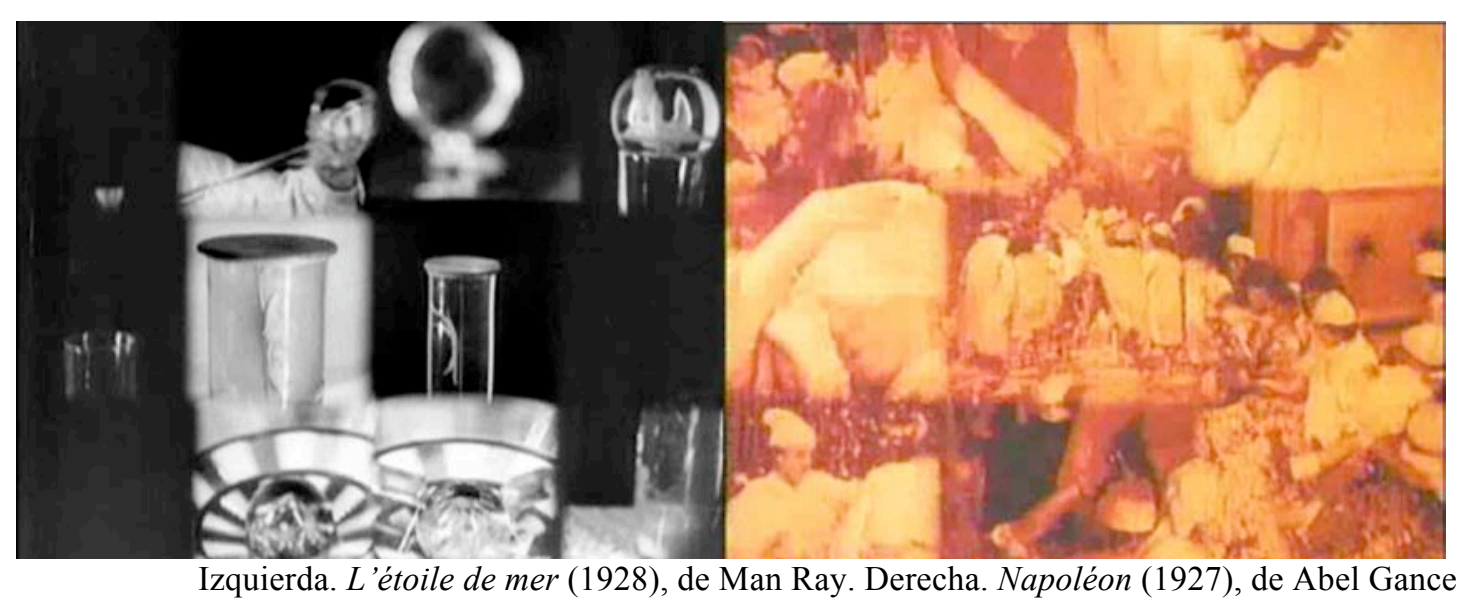

Frente a la triple pantalla sincronizada por Gance, estas construcciones fueron creadas de manera mecánica mediante un tapado/contratapado ("matte painting" en inglés o "cache/contrecache" en francés). Grosso modo, éste consiste en la protección de una sección de la película durante el tiempo de exposición de la otra; a continuación, se rebobina y se invierten las secciones, cubriendo esta vez la zona descubierta.

Aunque minoritaria, la técnica se usa desde los inicios del cine ${ }^{6}$ : ya en 1903, Edwin S. Porter fragmenta un plano de Life of an American Fireman mediante la superposición del contenido de un sueño sobre la cabeza de un hombre que duerme. Inspirado por Fire (1901) de James Williamson, Porter narra la premonición de un bombero que, en sueños, prevé el peligro que correrán una mujer y su bebé. De este modo, no sólo realidad y ensoñación, sino presente y futuro conviven en el interior del cuadro. La construcción supone, también, una de las primeras manifestaciones de un flash forward en el cine, esto es, la irrupción del futuro en el presente.

Una década después, en Suspense (1913) de Phillips Smalley y Lois Weber, el proceso permite compartimentar la pantalla en tres triángulos interrelacionados:

\footnotetext{
${ }^{6}$ El procedimiento fue inventado por George Méliès alrededor del año 1898. BRISELANCE, MarieFrance; MORIN, Jean-Claude. Grammaire du cinéma. Paris: Nouveau Monde Éditions, 2010, p. 55.
} 
abajo, un hombre llama por teléfono a su mujer, la cual aparece en el fragmento superior derecho; arriba, a la izquierda, un vagabundo acecha a la puerta de la vivienda. Como indica el título, la escena se basa en una estructura típica del suspense: el espectador conoce el peligro antes que los personajes implicados. Así, la presentación simultánea de las acciones colabora a la tensión narrativa.
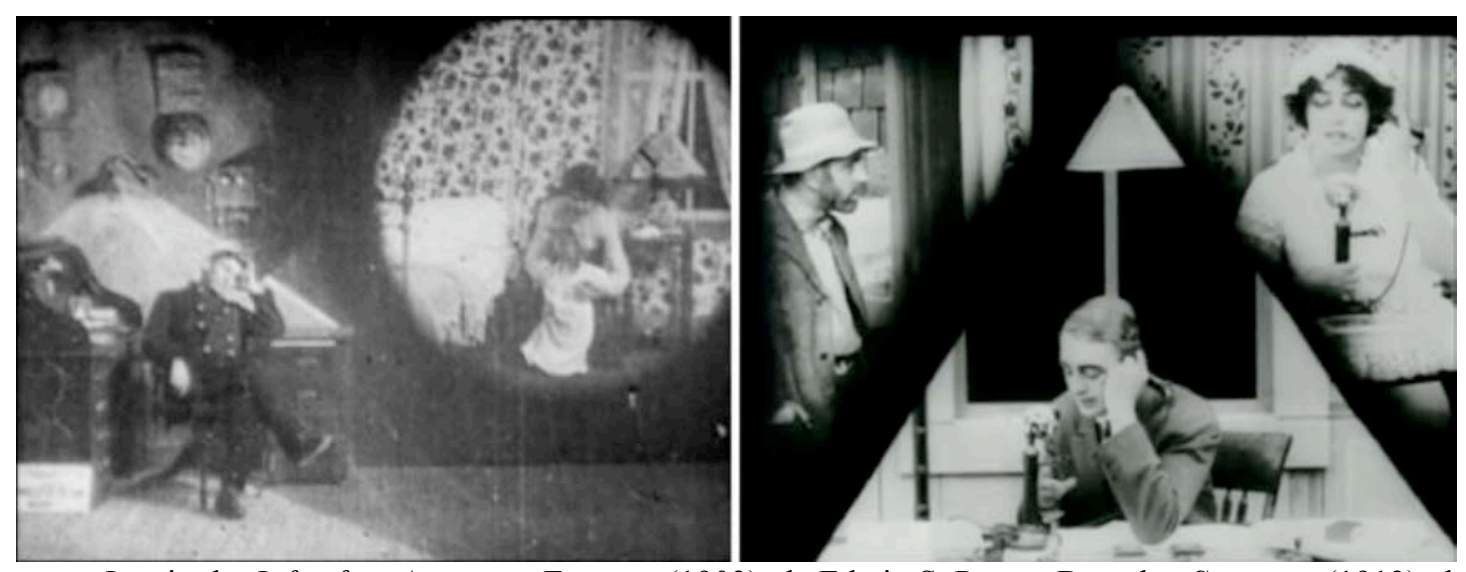

Izquierda. Life of an American Fireman (1903), de Edwin S. Porter. Derecha. Suspense (1913), de Phillips Smalley y Lois Weber

Los sub-cuadros corresponden, en esta ocasión, a figuras geométricas distintas del rectángulo unificador del cuadro global. En este sentido, es interesante comparar tal compartimentación con la siguiente reproducción de un dibujo japonés, rescatado por el realizador soviético Serguei Eisenstein en su artículo "El principio cinematográfico y el ideograma" (1929). A la hora de comparar la formación pictórica occidental con la nipona, el cineasta, destaca la siguiente técnica: de una rama de cerezo, los alumnos japoneses cortan secciones con distintas formas que configuran, así, nuevas unidades compositivas. El realizador considera el procedimiento como una forma de introducir nuevos cuadros en el interior del cuadro. ${ }^{7}$

\footnotetext{
${ }^{7}$ Eisenstein se exclama: "He frames a shot!". EISENSTEIN, Sergei. “The Cinematographic Principle and the Ideogram" (1929). En: Film Form: Essays in Film Theory (1949). New York: Harcourt, 1969, p. 41.
} 


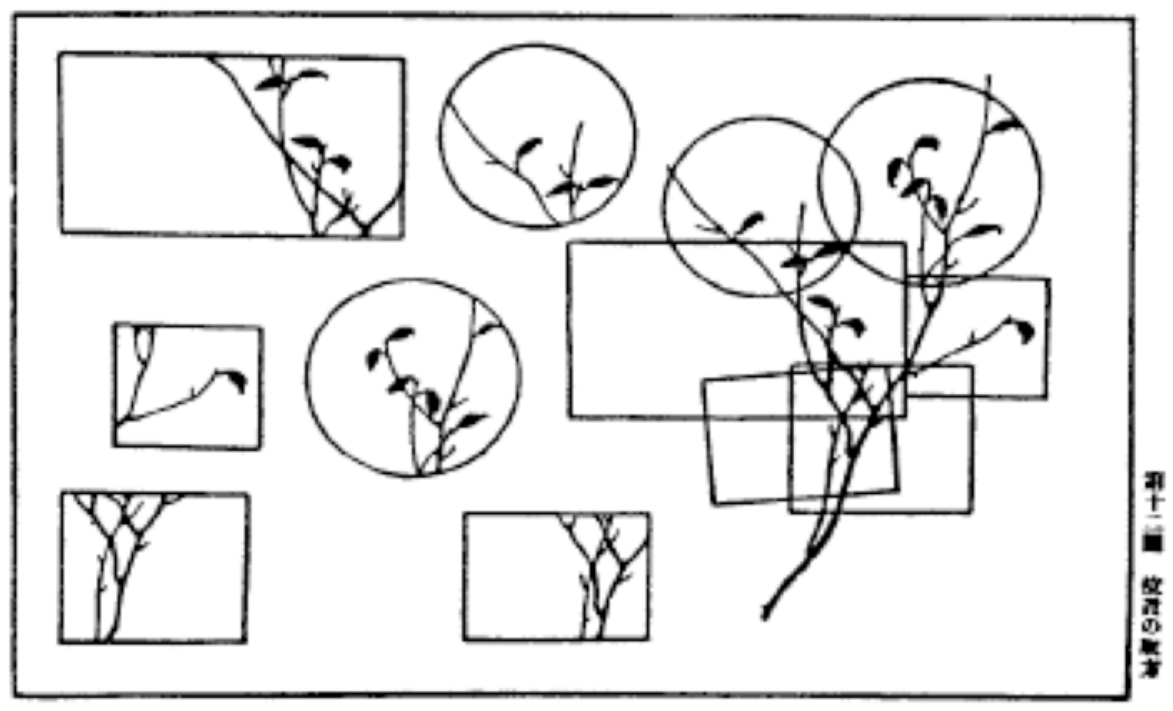

Si bien el grueso de su obra teórica se concentra en el montaje temporal como clave de la estética cinematográfica, lo cierto es que Eisenstein concede gran importancia a la composición, casi pictórica, de cada plano. Así, en Staroe i novoe, "Lo viejo y lo nuevo" (1929), el gran angular utilizado por Eduard Tissé exagera y desnaturaliza las proporciones, creando relaciones simbólicas entre las figuras y, con ellas, distintos espacios.

La misma técnica será utilizada por Orson Welles en Citizen Kane (1941); en el flash back que presenta la infancia del protagonista, el realizador hace coincidir en la escena dos acciones paralelas: la conversación de los padres en el interior de la casa y, a través de la ventana, el niño jugando fuera, ajeno a las negociaciones sobre su futuro. De este modo, la compartimentación del plano tiene lugar mediante una estrategia doble: por un lado, la manipulación del tamaño de las figuras; y, por otra, la inserción de un cuadro más que coincide con la ventana.
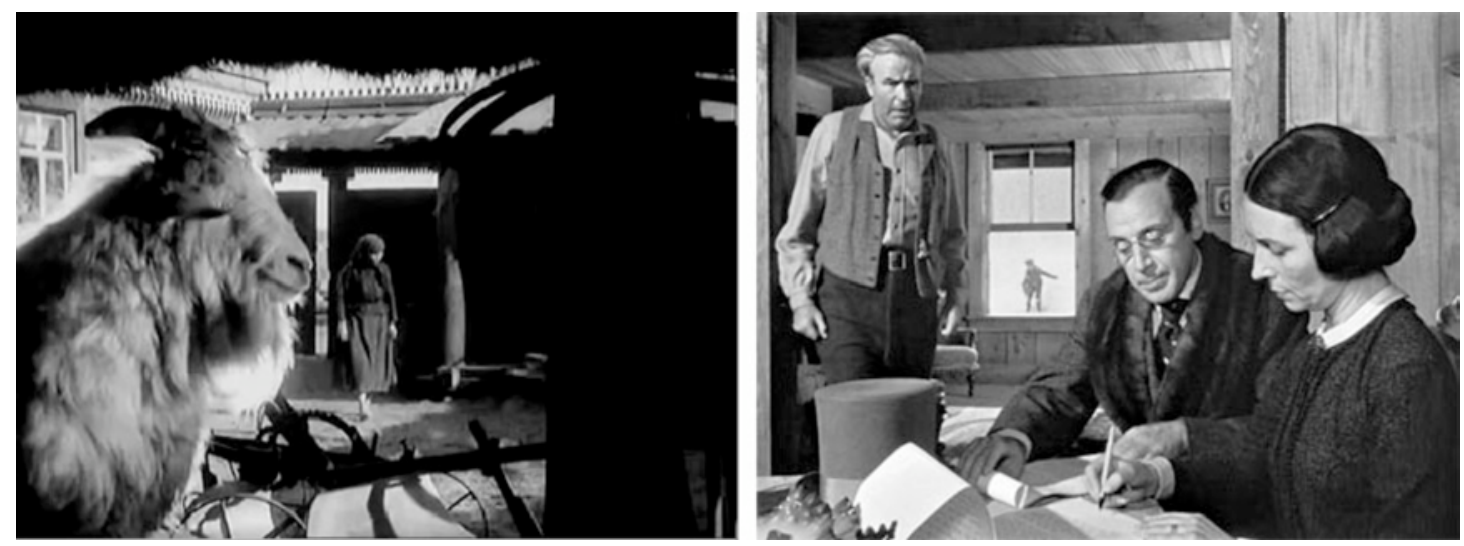

Izquierda. Staroe i novoe (1929), de Eisenstein. Derecha, Citizen Kane (1941), de Orson Welles 
En realidad, el uso de ventanas, puertas, cortinas, etc. como cuadros en el interior del cuadro es frecuente en el cine de ficción. No obstante, esta simultaneidad no rompe con la sensación de una tridimensionalidad compartida. Así, por ejemplo, en Rear Window (1954) de Alfred Hitchcock, dos ventanas permiten contemplar desde fuera el interior de dos habitaciones contiguas. El muro externo de la pared compartimenta el espacio, permitiendo presentar a la vez hechos simultáneos.

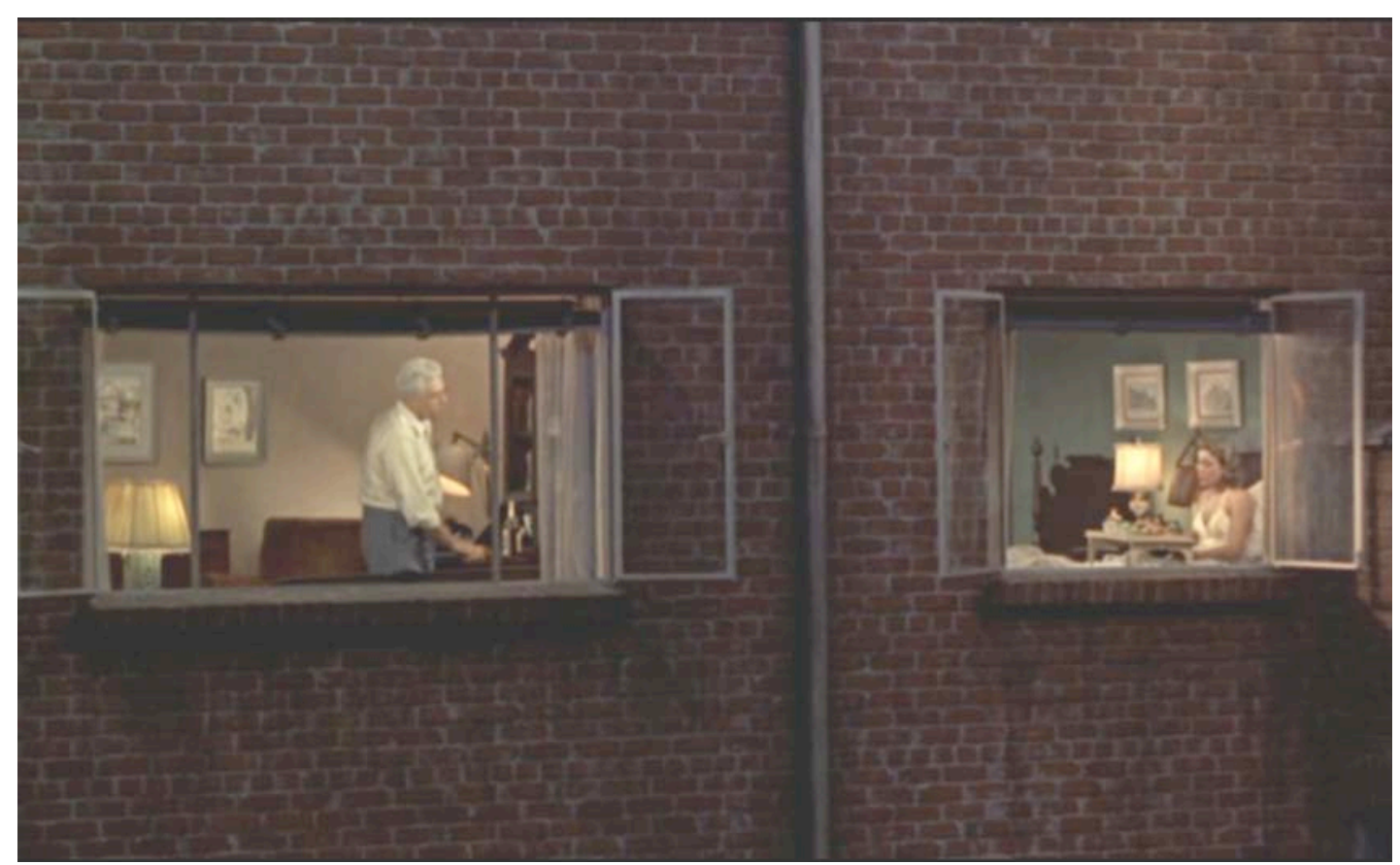

Rear Window (1954), de Alfred Hitchcock

Cincuenta años después del clásico de Hitchcock, el artista inglés Steve McQueen presenta su primer largometraje Hunger (2008). La cinta contiene una construcción espacial que se sitúa en la tradición de los encuadres anteriores: como en Rear Window, un muro marca el split screen. No obstante, McQueen exhibe las entrañas de la pared en un corte transversal imposible, de modo que el punto de vista presenta de manera simultánea dos espacios separados físicamente. La construcción remite a la reivindicación que Greenaway hiciera en su manifiesto, de una "ubicuidad divina, que permite ver los dos lados de la pared, interiores y exteriores, abajo y arriba, el macrocosmos y el microcosmos, todos al mismo tiempo". ${ }^{8}$ En el próximo capítulo, veremos cómo la cámara virtual omnipotente permite explorar este tipo de puntos de vista, presentando de manera continua no sólo espacios contiguos, sino

\footnotetext{
${ }^{8}$ GREENAWAY, Peter. Op. cit. Pássim.
} 
opuestos, dualismos, etc. En este apartado, nos concentramos en la simultaneidad que permite el montaje espacial.

Gracias a la edición digital es posible controlar el tiempo de cada sección de manera independiente. En Hunger, las acciones presentadas a la vez son, también, simultáneas en la diégesis; no obstante, cada sección contiene tiempos diferentes: sólo la izquierda está ralentizada, en contraste con la porción derecha, reproducida a una velocidad "normal". Frente al encuadre en el momento de una toma, el constructo espacial digital permite un acceso al espacio en el interior del cuadro y, con él, un control atómico del tiempo en la imagen: cada fracción puede contener una ralentización, una aceleración, una inversión o una congelación de manera independiente a las otras y complementaria para el efecto del conjunto de la obra. La afirmación de Manovich "El tiempo queda espacializado y se distribuye por la superficie de la pantalla"9 debe ser entendida no sólo como la presentación simultánea de hechos separados en el tiempo, sino como la posibilidad de cohabitación de tiempos diferentes en sí.

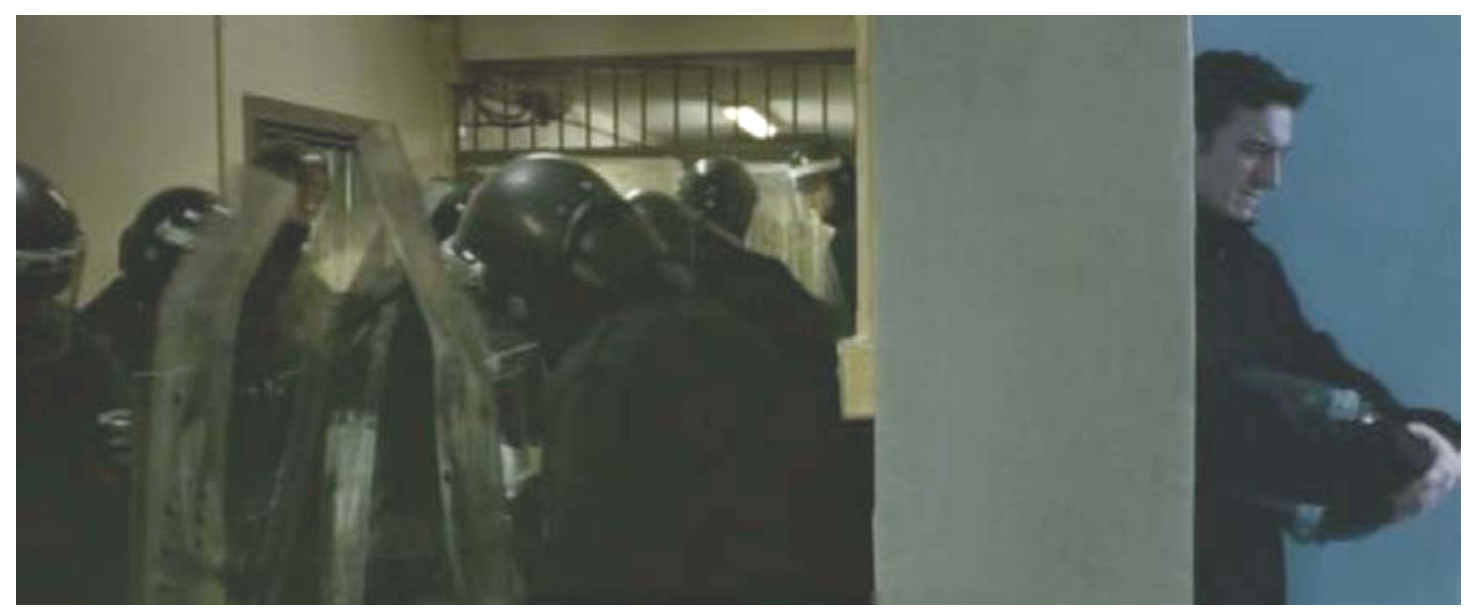

Hunger (2008), de Steve McQueen

Ahora bien, aunque el hecho de mostrar el interior del muro evidencia la calidad de constructo de la imagen, la pared forma parte del espacio tridimensional figurado. Por el contrario, los casos que analizamos en adelante marcan la bidimensionalidad de la pantalla, subdividiéndola de forma explícita y subrayando, con ello, tanto la enunciación como la idea misma de "constructo espacial”; por muy fina que sea, existe una frontera visual, extradiegética, que separa una sección de otra, produciendo una parcelación de la superficie de la pantalla.

\footnotetext{
${ }^{9}$ MANOVICH, Lev. The Language of New Media. Op. cit., p. 324.
} 
Comenzábamos este apartado con la propuesta de Greenaway de romper con la unidad intocable del cuadro. Para el inglés, el montaje espacial es una provocación; una afirmación rotunda de la construcción frente a la transparencia del cine clásico y la subordinación del espacio a la narración. La división de la pantalla subraya la condición de imagen de ésta en dos sentidos: como superficie bidimensional y como artificio. La construcción espacial explícita destaca la enunciación.

Veamos un ejemplo en Inglourious Basterds (2009), de Quentin Tarantino. Mientras la voz del narrador omnisciente explica la facilidad con la que arde la película fotográfica, un split screen redunda en la idea, mostrando diversas imágenes de archivo. Al contrario que en Hunger, los dos espacios que aparecen de manera simultánea no son contiguos: la línea blanca que los separa es un elemento extradiegético, que nada tiene que ver con la historia, sino con la reivindicación de la forma elegida para contarla.
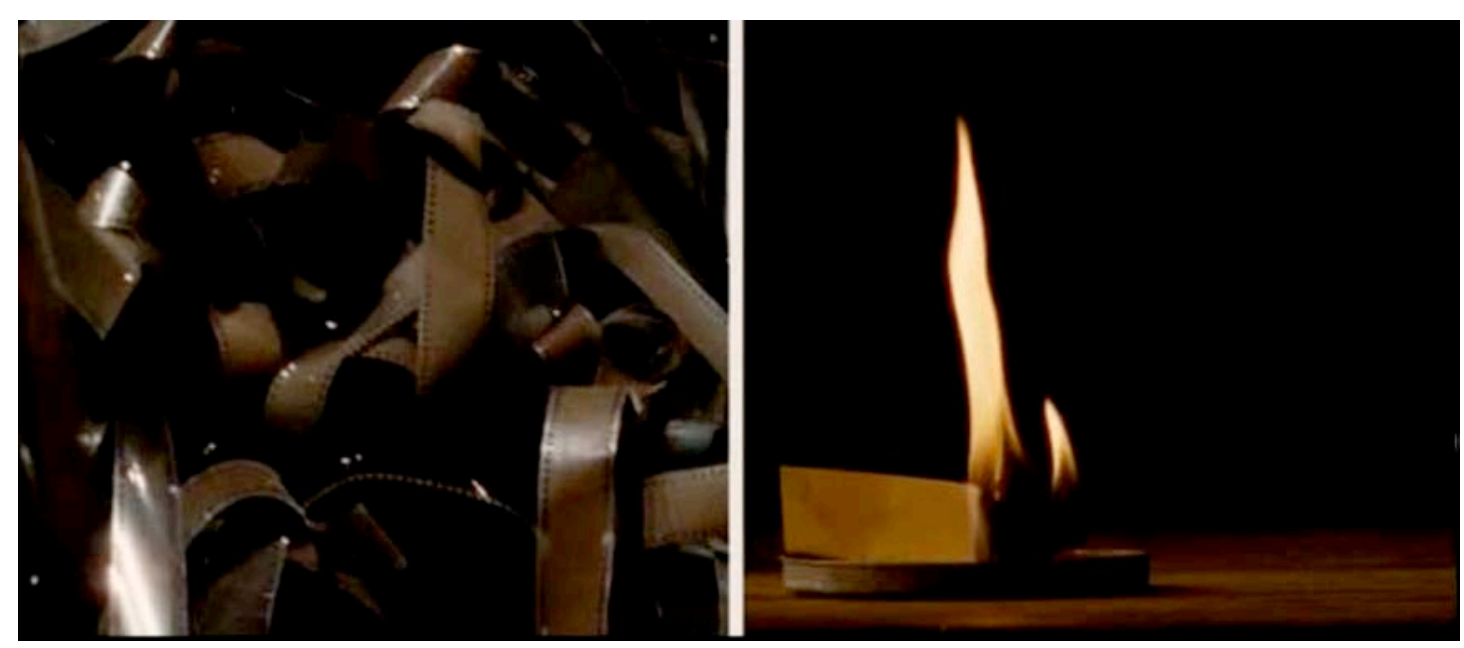

Inglourious Basterds (2009), de Quentin Tarantino

Minoritario en el cine de ficción, este tipo de montaje espacial que aparca la transparencia a favor de la enunciación es típico de formatos televisivos asociados a la información. ${ }^{10}$ En ellos, coexisten elementos heterogéneos como el presentador en el plató, la imagen de la noticia (registrada o en directo), la infografía (diagramas,

\footnotetext{
${ }^{10}$ En su análisis sobre la "televisión factual", Stephen Boyd Davis se concentra en las prácticas espaciales típicas de los informativos y documentales. De acuerdo con el autor, la forma viene a apoyar el contenido: "For television it is again clear that while technology may set the outer of what can be done, it is genre which determines which spatial practices flourish and which decay." BOYD DAVIS, Stephen. "Media Space. An analysis of spatial practices in planar pictorial media". Supervisors: Huw Jones and Gordon Davies. Middlesex University, Lansdown Centre for Electronic Arts, London, June 2002, p. 141.
} 
mapas) y, por supuesto, el logo de la cadena. ${ }^{11}$ La digitalización de la televisión no ha hecho más que facilitar y multiplicar este tipo de prácticas espaciales. Sirva como ejemplo la cobertura televisiva de los juegos olímpicos de Montreal en 1976: tres años después de la conversión de la señal analógica en digital ${ }^{12}$, el canal canadiense CBC introdujo el efecto conocido como "picture in picture", una combinación de imágenes de orígenes diversos, separadas por una línea de demarcación clara.

Los cuadrantes de la publicidad citada son comparables a la arriesgada estructura de la película Timecode (2000), de Mike Figgis. El experimento se basa en la subdivisión de la pantalla en cuatro secciones que presentan a la vez acciones simultáneas, previamente registradas con cuatro cámaras digitales durante 93 minutos. En lugar de trabajar las tomas mediante cortes, la edición del material bruto se limita a la subdivisión del cuadro: al montaje temporal, el director sustituye el montaje espacial. Tan provocador como Greenaway, Figgis afirma:

\footnotetext{
"El verdadero criminal en la corrupción del cine es la edición y el sistema basado en contar mentiras a través del corte (...). Así que esta película es, de algún modo, un intento de mostrar lo que se puede editar de otra forma, a través del montaje [espacial] en vez del corte, y tener acciones simultáneas. Esto permite a cada individuo una interpretación diferente."13
}
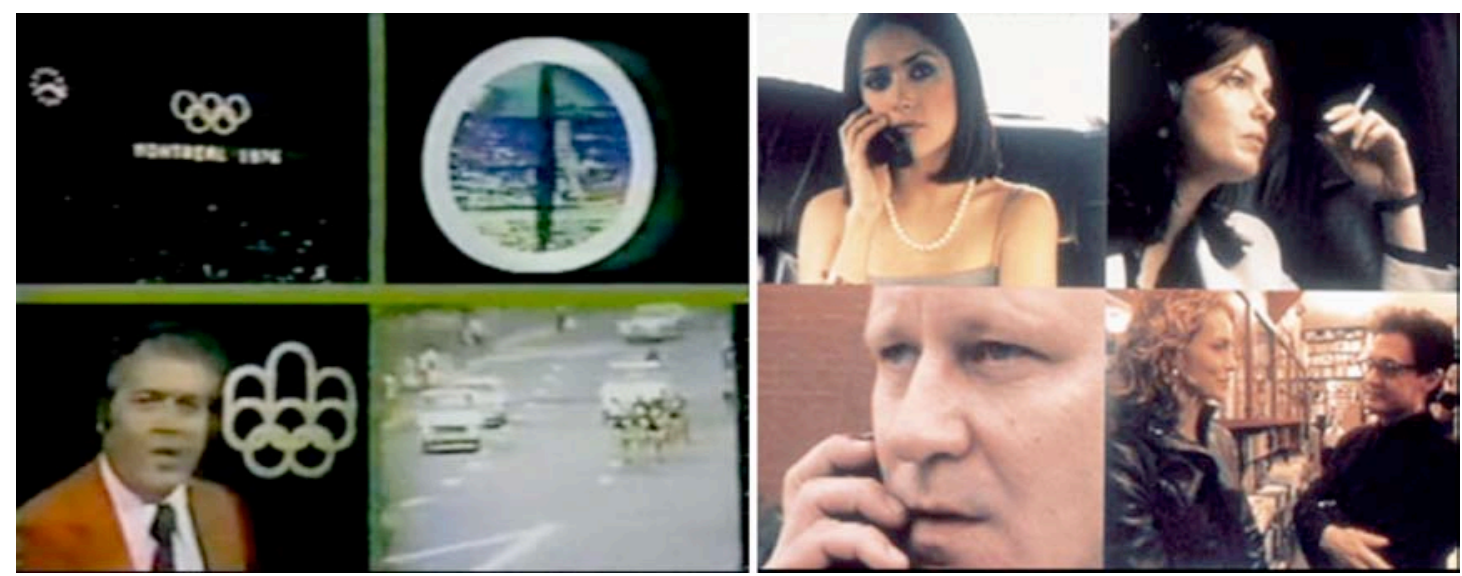

Izquierda. Publicidad de los juegos olímpicos de Montreal en el canal canadiense CBC (1976) Derecha. Timecode (2000), de Mike Figgis

\footnotetext{
${ }^{11}$ Greenaway afirma: "it is becoming common now for the screen itself to be self referenced with fixed company logos -which really do demonstrate to the viewer that he is watching a screen, and not merely what is conveyed through it." GREENAWAY. Peter. Op. cit. Pássim.

12 En 1973, la compañía inglesa Quantel consiguió convertir las señales de televisión analógicas en formato digital y, con ello, manipular la imagen en el ordenador. BIZONY, Piers. Digital Domain. The Leading Edge of Visual Effects. London: Bilboard Books, 2001, p. 19.

${ }^{13}$ Mike Figgis. Apud. HANSON, Matt. The End of Celluloid: Film Futures in the Digital Age. Hove: Rotovision, 2004, p. 70.
} 
En Timecode, la cohabitación de las imágenes concuerda con la simultaneidad de los hechos. En realidad, si éstos se producen al tiempo, ¿por qué no presentarlos también simultáneamente? Frente al montaje temporal cinematográfico que impone una secuencialidad artificial a hechos que coexisten en el mismo instante, el montaje espacial permite presentarlos al unísono. ${ }^{14}$

\section{La exploración de la simultaneidad}

Como veíamos en Suspense, una estrategia a la hora de subrayar la simultaneidad de las acciones es el uso del teléfono. Éste es el caso, también, del videoclip How are you doing (2011) del grupo musical Living Sisters. El director Michel Gondry compartimenta la pantalla en tres franjas con sendos personajes que hablan entre sí por el móvil.

Otra manera de marcar la simultaneidad es la introducción de la hora. En Lola rennt (1998), Tom Tykwer utiliza un split screen para subrayar la tensión de la carrera de la protagonista, que da título a la película. Lola aparece a la derecha de la composición mientras, en el fragmento izquierdo, su novio espera inquieto su llegada; una franja horizontal abajo muestra un primerísimo primer plano de un reloj que marca no sólo la premura del chico, sino el tiempo que engloba las sub-imágenes.

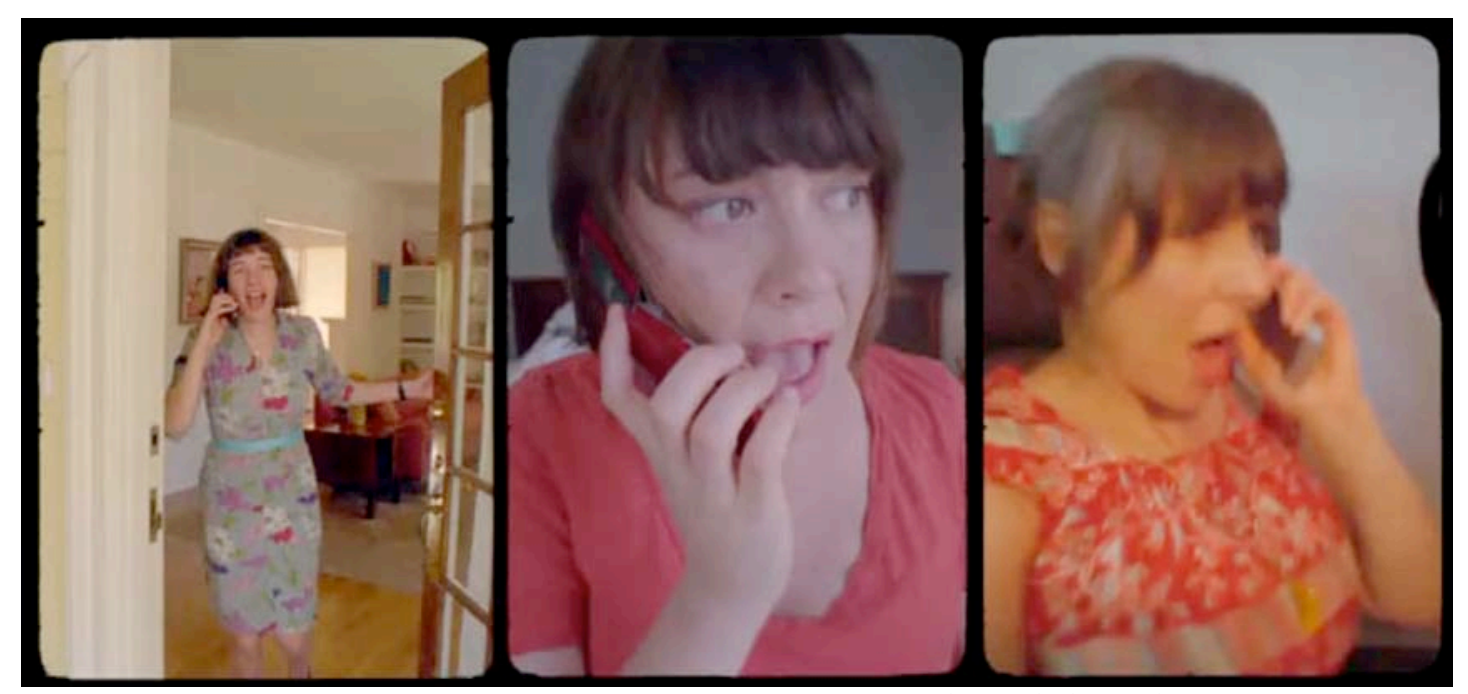

How are you doing? (2011), de Michel Gondry para Living Sisters

\footnotetext{
${ }^{14}$ El lenguaje cinematográfico privilegia el montaje temporal incluso en la narración de acciones simultáneas. El llamado "montaje paralelo" aparece por primera vez en The Great Train Robbery (1903), de E. S. Porter, si bien será D. W. Griffith quien perfeccione esta edición de los planos al asumir la elipsis temporal en The Adventures of Dollie (1908). BRISELANCE, Marie-France. Op. cit., p. 124.
} 
Aunque muy corta, la construcción referida evidencia una conciencia de las posibilidades estéticas del montaje espacial frente al temporal. Tykwer llega incluso a proponer una versión espacializada del típico campo/contracampo ${ }^{15}$, como hiciera ya Brian de Palma en Sisters (1973). En ambas, la pantalla se divide verticalmente en dos secciones simétricas que presentan dos puntos de vista diametralmente opuestos de la misma escena. ${ }^{16}$ En lugar de construir el espacio diegético a través de la secuencialidad y la sustitución de un punto de vista por el otro de modo que el espectador imagine una escena global, la cohabitación de campo y contracampo produce un efecto distinto: a la transparencia de un espacio tridimensional, Tykwer y De Palma sustituyen el espacio construido de la imagen.
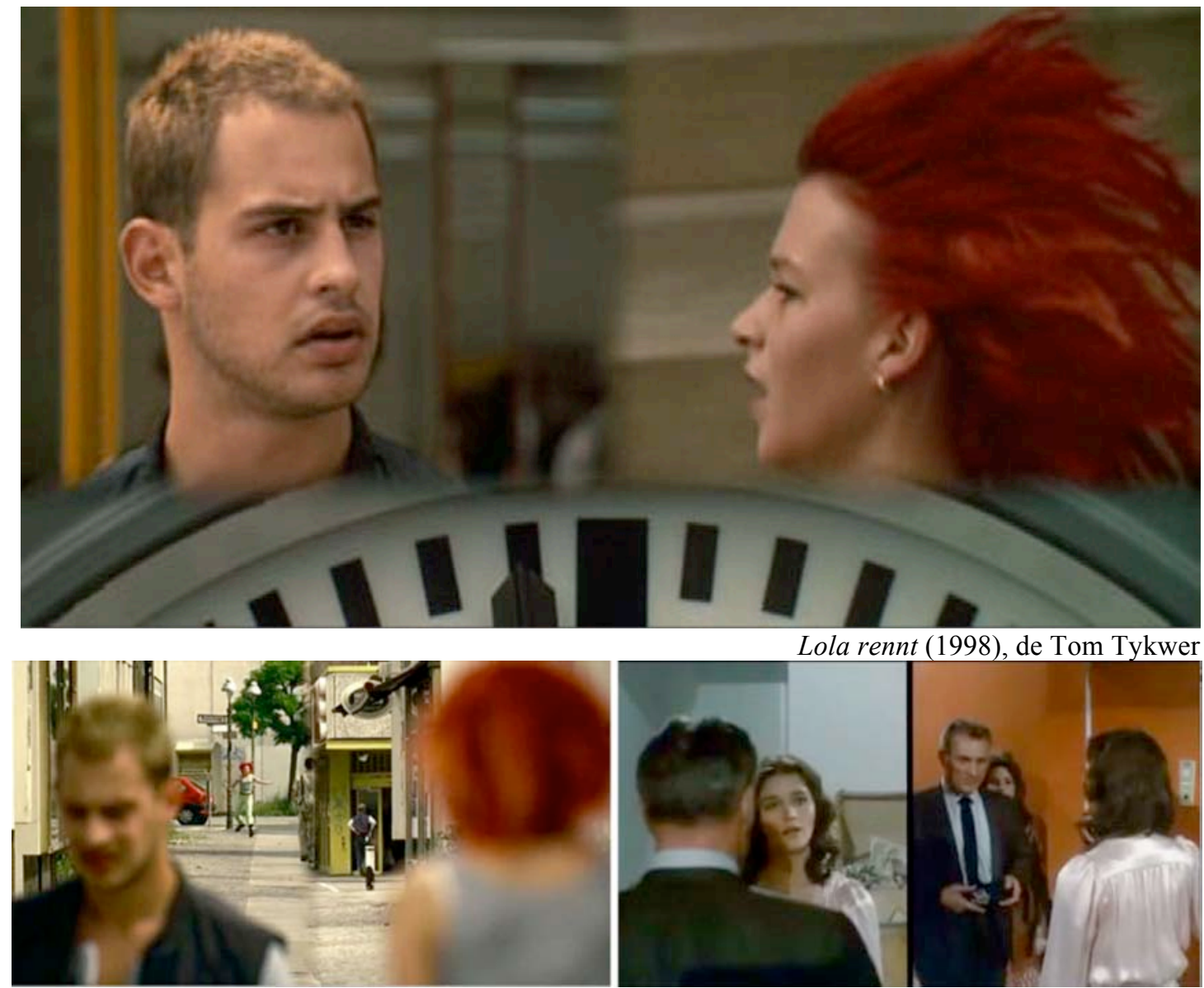

Izquierda. Lola rennt (1998), de Tom Tykwer. Derecha. Sisters (1973), de Brian de Palma

\footnotetext{
15 "Shot/reverse-shot cutting assumes that the series of shots alternates a view of one end-point of the line with a view of the other. (...) Typically, shot/reverse-shot editing joins shots of characters facing one another, but it need not." BORDWELL, D.; STAIGER, J.; THOMPSON, K.. The Classical Hollywood Cinema: Film Style \& Mode of Production to 1960. Op. cit., p. 56.

${ }^{16}$ A propósito de Sisters, Anne Friedberg afirma: "Separate 'point of view' -of seeing and be seeingcan be combined, compared, placed simultaneous and adjacent. In terms of theories of suture, replacing the sequence of shot/countershot with this form of nonsequential simultaneity skews the sense that the spectator is somehow sutured into the film, between the shots." FRIEDBERG, Anne. The Virtual Window: From Alberti to Microsoft. Cambridge: The MIT Press, 2006, p. 202.
} 
Tykwer dinamiza el split screen desplazando la frontera entre las sub-imágenes, primero en horizontal y después en vertical. Esta activación de los cuadros internos es comparable al efecto de cortina en The Thomas Crown affair (1968), de Norman Jewison; la película contiene no una, sino varias de estas compartimentaciones dinámicas de la pantalla, realizadas con la ayuda de una impresora óptica. En realidad, Jewison se inspiró en la obra de Christopher Chapman A Place to Stand, presentada en la Expo'67 de Montreal, y que retrata el estado de Ontario mediante la cohabitación de hasta quince imágenes que aparecen, desaparecen o se desplazan en el interior del cuadro.

La obra de Chapman se encuadra en un movimiento artístico bautizado como "expanded cinema"17 : este "cine expandido" reúne a una serie de artistas que trabajan la imagen audiovisual en el extrarradio del cine y, entre cuyos experimentos, destacan la proyección multipantalla y la multicuadro. ${ }^{18}$ Aunque en contadas ocasiones, la producción hollywoodiense contemporánea se hace eco de aquellas exploraciones artísticas. Junto a The Thomas Crown affair, Anne Friedberg repasa los casos más célebres: It's Always Fair Weather (1955) de Gene Kelly y Stanley Donen, Pillow Talk (1959) de Michael Gordon, Grand Prix (1966) de John Frankenheimer o The Boston Strangler (1968) de Richard Fleischer. ${ }^{19}$
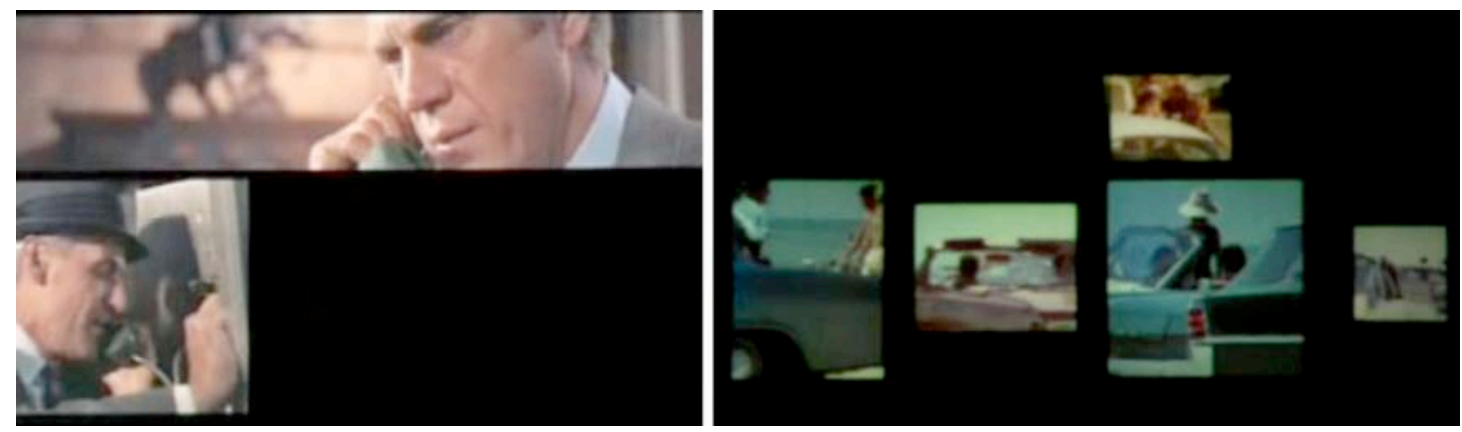

Izquierda. The Thomas Crown affair (1968), de Norman Jewison. Derecha. A Place to Stand (1967), de Christopher Chapman

\footnotetext{
${ }^{17}$ En otoño de 1965, la Film-Makers' Cinematheque de Nueva York acoge el festival "Expanded Cinema", a cargo de Jonas Mekas; en él, se exponen obras de artistas como Andy Warhol o Nam June Paik, entre las que se hallan varios ejemplos de proyección múltiple. Dos años después, Sheldon Renan define ese "cine expandido": "Currently it takes the form of film as environment, film as part of intermedia, film examined as a phenomenon of time and of light. It is sometimes called 'expanded cinema'." RENAN, Sheldon. Introduction to the American Underground Film. New York: Dutton, 1967, p. 104. El concepto es desarrollado por Gene Youngblood en Expanded Cinema. YOUNGBLOOD, Gene. Op. cit., 1970.

${ }^{18}$ Para un análisis detallado de aquellas instalaciones ver: MICHALKA, Matthias (ed.). X-Screen: Film installations and actions in the 1960s and 1970s. Cologne: Verlag, 2003.

${ }^{19}$ FRIEDBERG, Anne. Op. cit., p. 218.
} 
También a finales de los años 60, la interfaz gráfica de usuario del ordenador adopta la forma de un "escritorio" en el que apilar "ventanas" interactivas que permiten acceder a distintas informaciones. ${ }^{20}$ Esta nueva pantalla influencia hasta hoy la construcción de la imagen animada. Así, por ejemplo, descubrimos un claro homenaje a aquel escritorio ${ }^{21}$ al final de la película de Jean Pierre Jeunet Micmacs à tire-larigot (2009). La conversación telefónica como marca de la simultaneidad, Jeunet la sustituye por la conexión a Internet. El realizador francés se sirve del montaje espacial como metáfora de la posibilidad de compartir información: las imágenes se multiplican de manera rítmica a medida que el mensaje se propaga. De este modo, el multicuadro no sólo remite a las ventanas del escritorio, sino que su estructura descentrada recuerda, también, a un mapa del ciberespacio. ${ }^{22}$ El dibujo reproducido presenta uno de los primeros diagramas de una conexión descentralizada entre cuatro nodos (círculos) y cuatro ordenadores (cuadrados) mediante líneas telefónicas (rectas). El diagrama corresponde a ARPANET, instalada por primera vez en la Universidad de California (Los Ángeles) en septiembre de $1969 .{ }^{23}$
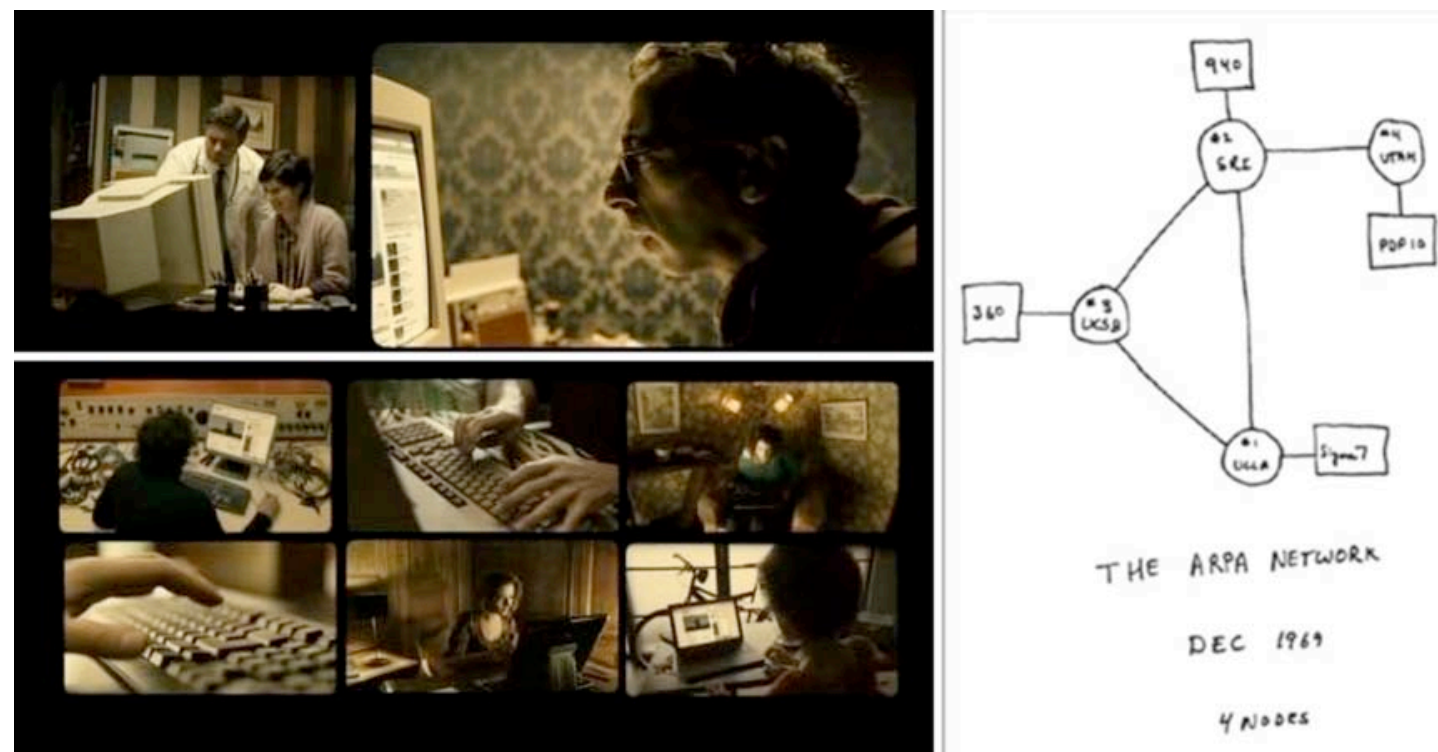

Izquierda. Micmacs à tire-larigot (2009), de Jeunet. Derecha. Diagrama de ARPANET (1969)

\footnotetext{
${ }^{20}$ El hecho de poder acumular "ventanas" fue propuesto por primera vez por el pionero de la interfaz gráfica de usuario Alan Kay en 1969. MANOVICH, Lev. "Avant-garde as software”. Op. cit.

${ }^{21}$ Holly Willis se refiere a esta influencia de las ventanas de la interfaz del ordenador sobre la imagen animada como "desktop aesthetics". WILLIS, Holly. Op. cit., p. 4.

${ }^{22}$ Aunque hoy ya superada, la metáfora del "ciberespacio" caló en las décadas de los ochenta y noventa. Sobre el concepto de ciberespacio ver: DODGE, Martin; KITCHIN, Rob. Atlas of cyberspace. London: Adisson Wesley, 2001.

${ }^{23}$ ARPANET fue concebida (entre otros) por Lawrence G. Roberts, quien adaptara seis años antes las normas de la perspectiva al diseño por ordenador.
} 
Como señalábamos al principio de este apartado, Greenaway justifica explícitamente su exploración plástica en relación a la transformación digital: "Las nuevas tecnologías han preparado y fortalecido la imaginación humana (...) un nuevo mundo de actividades multimedia, que han metamorfoseado intrínsecamente el cine mismo." 24 Su manifiesto va acompañado por una explicación de su proyecto transmedia The Tulse Luper Suitcases. La obra incluye tres películas realizadas entre 2003 y 2005 (Part 1. The Moab Story, Part 2. Vaux to the Sea y Part 3. From Sark to the Finish) y varias publicaciones que complementan el proyecto interactivo en sí, consistente en un juego en línea. ${ }^{25}$ En lo que concierne a la construcción espacial, Greenaway establece un paralelismo entre el diseño de la interfaz de dicha página web y el multicuadro que marca la estética de las tres películas.

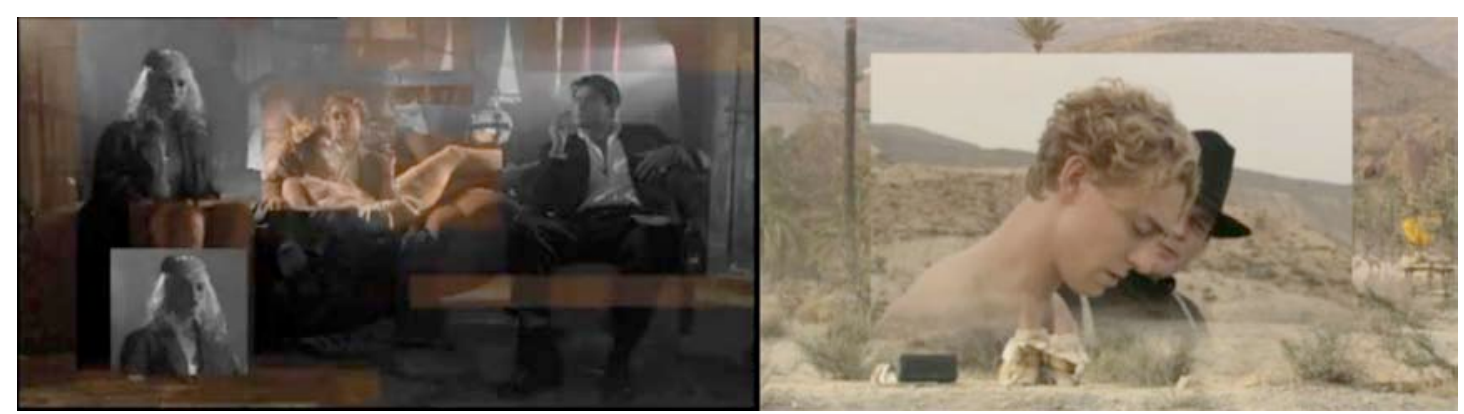

The Tulse Luper Suitcases (2003-2005), de Peter Greenaway

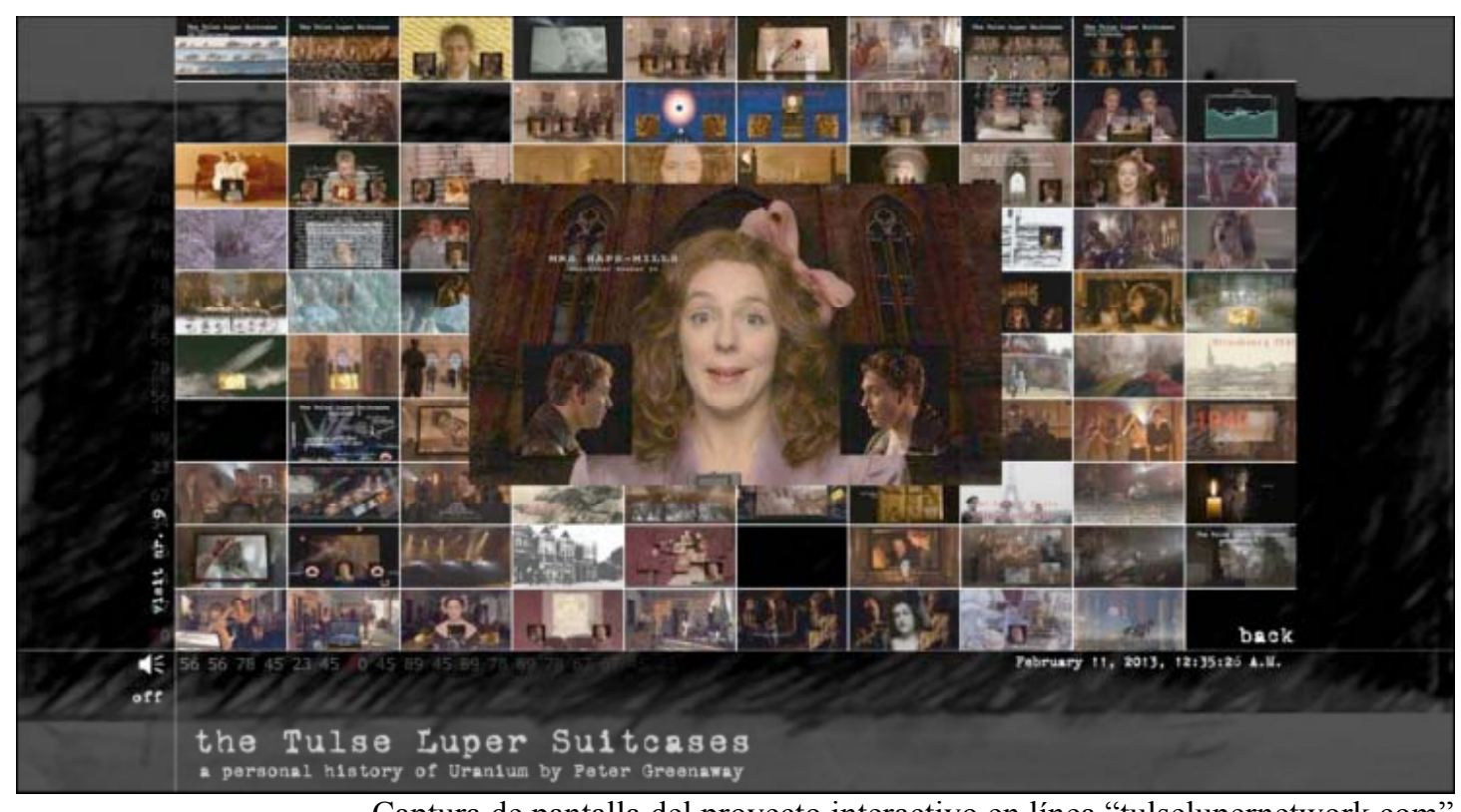

Captura de pantalla del proyecto interactivo en línea "tulselupernetwork.com"

\footnotetext{
${ }^{24}$ GREENAWAY, Peter. Op. cit. Pássim.

${ }^{25}$ Ver la página del proyecto: <http://www.tulselupernetwork.com/basis.html>
} 
Junto a Greenaway o Figgis, de haber algún otro autor que defienda con tanta vehemencia la primacía del montaje espacial sobre el montaje temporal en la imagen código es, sin duda, Julie Talen. La directora estadounidense explica la multiplicación del split screen en relación directa con la tecnología: por un lado, considera que, a diferencia del contexto en el que Gance presentó su Napoléon, el público actual está preparado para recibir este tipo de imagen compleja porque es omnipresente, ${ }^{26}$ por otro lado, en lo que respecta a las motivaciones del autor, es el proceso mismo de elaboración el que emerge a la superficie:

"La aparición de los sistemas de edición no lineal (es decir, en el ordenador) como Avid, el barato Final Cut Pro y After Effects, es quizás el mayor motivo del regreso de la división del cuadro." 27

No sólo el trabajo se simplifica, sino que los programas de edición digital como Avid ("la madre del trabajo multicanal"28) presentan dos cuadros simultáneos en los que visualizar y tratar vídeos independientes. De acuerdo con la directora estadounidense, tanto Greenaway como Figgis han utilizado en algún momento dicho programa, cuya interfaz habría influido en sus respectivas propuestas estéticas. Así, si el montaje temporal de los cortes en el cine clásico es la consecuencia misma de la tira horizontal que es la película fotográfica, el montaje espacial se justifica por la mismísima edición digital, que presenta ya una simultaneidad, una cohabitación de las imágenes en el propio programa. Como su nombre indica, las posibilidades plásticas ligadas a los sistemas de Digital Non-Linear Editing (DNLE) están íntimamente relacionadas con el acceso no lineal y aleatorio. ${ }^{29}$

\footnotetext{
26 "Could Gance have foreseen that the necessary visual education would come from our contemporary glimpse culture: computer screens, channel-zapping, video games, CNN crawls, JumboTrons, surveillance cameras, Web sites, screens in our stores, on our desktops and in our nurseries? The muchmaligned shortened attention span is actually, as Gance predicted, an ability to navigate through simultaneous images. It's the alphabet of our eyes." TALEN, Julie. '24': Split screen's big comeback [En línea]. Salon, May 14, 2002. Disponible en Web: <http://www.salon.com/2002/05/14/24_split/>

27 "Peter Greenaway had Avid make up a special software program just for his 1996 multiscreen film 'The Pillow Book'. (...) Figgis shot his film of the Strindberg play "Miss Julie" on two cameras and thus found himself looking at these side-by-side images in the editing room all day long." Ibídem.

${ }^{28}$ Talen prefiere "multichannel" a "multiframe", por la ambigüedad de "frame". Nótese que, en nuestra investigación, nos referimos a "cuadro" como el rectángulo que limita la imagen; reservamos el anglicismo "frame" para cada una de las imágenes en las que se subdivide el registro vídeo.

29 Algunos sistemas analógicos contaban con dichas características, que el almacenamiento digital consolida y populariza.
} 
En Pretend (2003), la directora cuenta la historia de una niña que simula el rapto de su hermana para impedir la separación de sus padres. Talen explora las posibilidades de la división del cuadro, desde la expresión puramente visual hasta la convivencia de varios puntos de vista, varios tiempos o, incluso, la fantasía y los hechos. Tal y como explica la autora: "Vemos lo que podría haber ocurrido, lo que ella desearía que hubiera ocurrido (...). Se trata del poder de la imaginación."30

La cohabitación de las imágenes permite, así, presentar a la vez dos desarrollos distintos de una misma historia. En (500) Days of Summer (2009), Marc Webb confronta las expectativas del personaje a la realidad. La coexistencia de ambas versiones permite subrayar el contraste entre ambas y exagerar la situación dramática. Frente a la complejidad de las construcciones espaciales de Talen, Webb se decanta por un sencillo split screen, acompañado por dos subtítulos aclarativos: a la izquierda, las "expectativas" del protagonista (junto a la chica de sus sueños); a la derecha, la "realidad" (solo, bebiendo una cerveza).
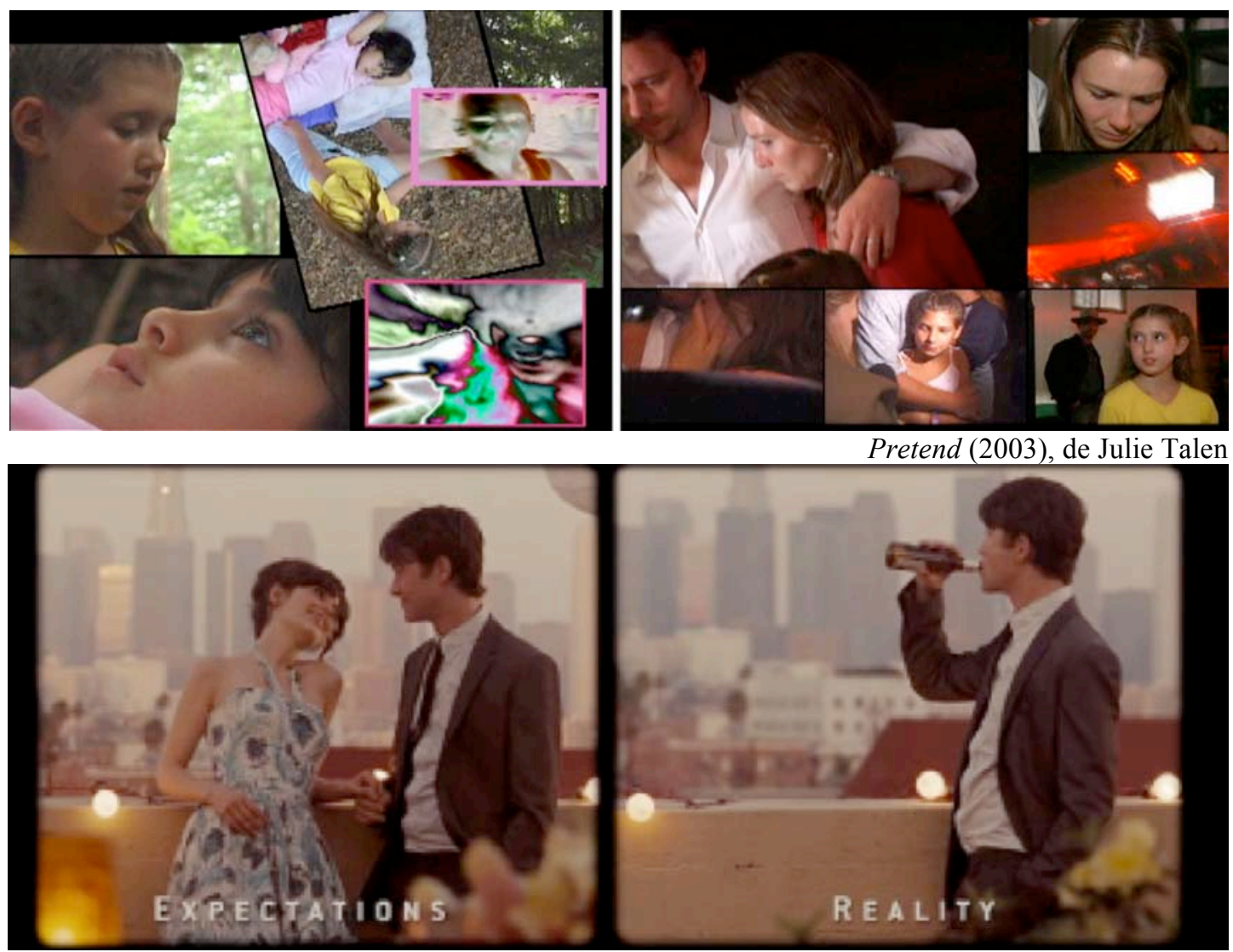

(500) Days of Summer (2009), de Marc Webb

\footnotetext{
${ }^{30}$ TALEN, Julie. Entrevista realizada por Cara O'Connor. When You Cut Up the Frame: An Interview with Julie Talen [En línea]. Senses of cinema. 17 de febrero de 2004. Disponible en Web: $<$ http://sensesofcinema.com/2004/feature-articles/julie_talen/>
} 
A diferencia de Timecode o Lola rennt, la cohabitación de las imágenes no se utiliza para presentar acciones también simultáneas. Aquí, la partición de la pantalla permite mezclar los hechos y la imaginación. En este sentido, veíamos como Porter proponía ya en 1903 la coexistencia de un personaje y sus sueños en Life of an American Fireman. Ahora, si comparamos ambos casos, veremos cómo en (500) Days of Summer la clave está en la repetición exacta del decorado y la introducción de un elemento distinto: el hecho de que el protagonista, en realidad, no ha conquistado a la chica. La simultaneidad corresponde, así, a una comparación entre los sub-espacios.

Un ejemplo de cohabitación como tensión entre las imágenes es el corto Symmetry (2011), del trío de realizadores Everynone (Will Hoffman, Daniel Mercadante y Julius Metoyer). Aunque el título "simetría” destaca la semejanza entre las mitades, lo cierto es que la relación establecida entre los sub-cuadros es más bien de: complementariedad (una cerradura y una llave); causa-consecuencia (unas pesas y un torso); depredador/presa (un gato y un ratón); positivo/negativo (una nube y un charco); opuestos (reír/llorar); principio/fin (nacer/morir), etc. La idea de simetría se confunde, aquí, con la de equilibrio de contrarios; y éste es asociado, explícitamente, con la digitalización y su lenguaje binario.

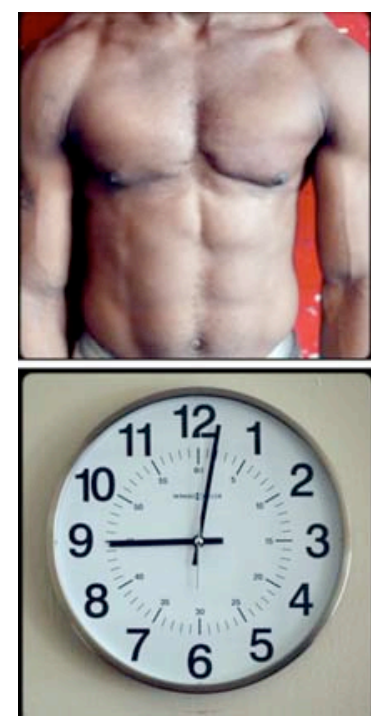

Si buscamos una verdadera simetría entre las formas, podríamos citar un sencillo ejemplo en La soledad (2007), de Jaime Rosales, película que presenta el $30 \%$ del metraje en forma de "polivisión". En una de esas compartimentaciones, Rosales juega sobre la redundancia en la composición del espacio al presentar dos escenas distantes que comparten el mismo tipo de encuadre sobre sendos bancos. 
El mismo año, en The Inevitable (2007), Kurt Ralske no basa la comparación entre las dos secciones de un split screen en la repetición de una figura (el banco en La soledad) o del fondo (Nueva York en (500) Days of Summer), sino en un cálculo realizado por el ordenador a partir de un algoritmo. Ralske escribió un programa informático para localizar pares de frames semejantes en una base de datos formada por archivos de vídeo. Éstos corresponden a películas ajenas, de modo que la obra se encuadra en la tendencia a la apropiación de found footage, marca de la preponderancia de la transformación sobre la mera reproducción, como explicábamos ya en el apartado anterior. ${ }^{31}$ Ahora, frente a aquellas distorsiones, aquí, la transformación tiene que ver con el acceso y el análisis de información en bases de datos. $^{32}$
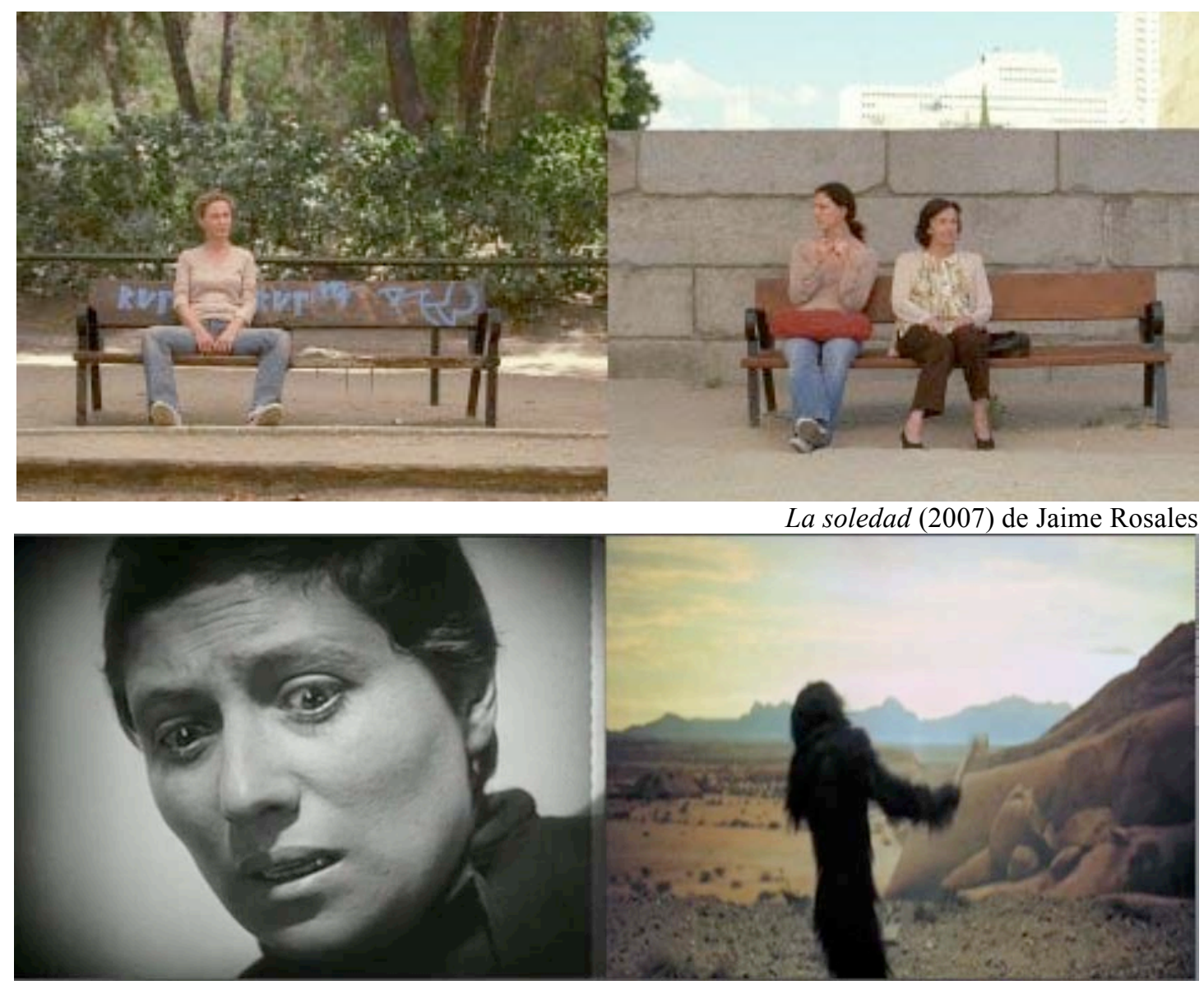

The Inevitable (2007), de Kurt Ralske

\footnotetext{
31 "My way of working is to locate an interesting pre-existing artifact or system, and subtly intervene to allow a transformation to occur." RALSKE, Kurt. Zero Frames per Second [En línea]. Exhibition Notes for Zero Frames per Second. MFA Computer Art Gallery, New York City. August 18 September 19, 2008. Disponible en Web: <http://www.retnull.com/crit_ZeroFrames.html>

32 "Data mining techniques allow us to search for significant relationships in large volumes of data. Image processing allows us to reveal detail which may be hidden in an image and to automatically compare sets of images." MANOVICH, Lev. "Avant-garde as software”. Op. cit.
} 
La semejanza no responde al significado de las imágenes, sino que el programa se limita a un análisis "frío" de las formas, excluyendo incluso el color y proponiendo nuevas asociaciones inesperadas, basadas exclusivamente en la concordancia de las figuras en el espacio. Así, la conexión se establece entre películas tan dispares como La Passion de Jeanne d'Arc (1929), de Carl Theodor Dreyer, y 2001: A Space Odyssey (1968), de Stanley Kubrick. ${ }^{33}$ La clave de la presentación simultánea de las dos imágenes es la comparación, la relación sorprendente que establece el cálculo informático. En el último capítulo, recuperaremos la figura de Kurt Ralske, artista contemporáneo que se apropia de found footage para someterlo a diversos procesamientos digitales; por el momento, nos conformamos con su propuesta de montaje espacial.

En el videoclip Sugar Water (1997), para el grupo musical Cibo Matto, Michel Gondry lleva al máximo la exploración de la simetría en el split screen. La pantalla se divide en dos secciones: a la izquierda, la película se desarrolla hacia delante, mientras que, a la derecha, lo hace hacia atrás. En el momento en el que las historias de cada fragmento convergen (cuando la chica a la izquierda atropella a la de la derecha), se produce una inversión de las secciones. Como en Hunger, la compartimentación permite un acceso espacial al tiempo. Frente a propuestas como la de Figgis en Timecode, el split screen no presenta escenas simultáneas: por el contrario, se trata de construir una entidad espacio-temporal imaginada, específica de la imagen.

Esta interconexión entre los diversos sub-cuadros tiene un claro antecedente en un experimento del artista polaco Zbigniew Rybczynski, cuya obra encarna la continuidad entre videoarte e imagen digital. Nowa ksiazka, "Nuevo libro"(1975), es una pieza de unos diez minutos, caracterizada por la subdivisión de la pantalla en nueve secciones, al modo de los experimentos de Man Ray en L'étoile de mer o Abel Gance en su Napoléon. Ahora bien, mucho más compleja que estas construcciones, Nowa ksiazka exige al receptor un esfuerzo de interpretación de las relaciones entre los fragmentos comparable a la maraña creada por Gondry.

\footnotetext{
${ }^{33}$ Curiosamente, la escena inicial de la película de Stanley Kubrick contiene un caso célebre de raccord o continuidad entre dos planos: el hueso lanzado por uno de los simios da paso a un satélite. A pesar del cambio brusco de escala que el corte impone, la semejanza entre las formas alargadas de ambas figuras garantiza una continuidad narrativa que permite el enorme flash forward. En el apartado dedicado a las transiciones espacio-temporales continuas, veremos ejemplos de raccord que sustituyen este corte temporal por la continuidad de la mutación de la imagen.
} 

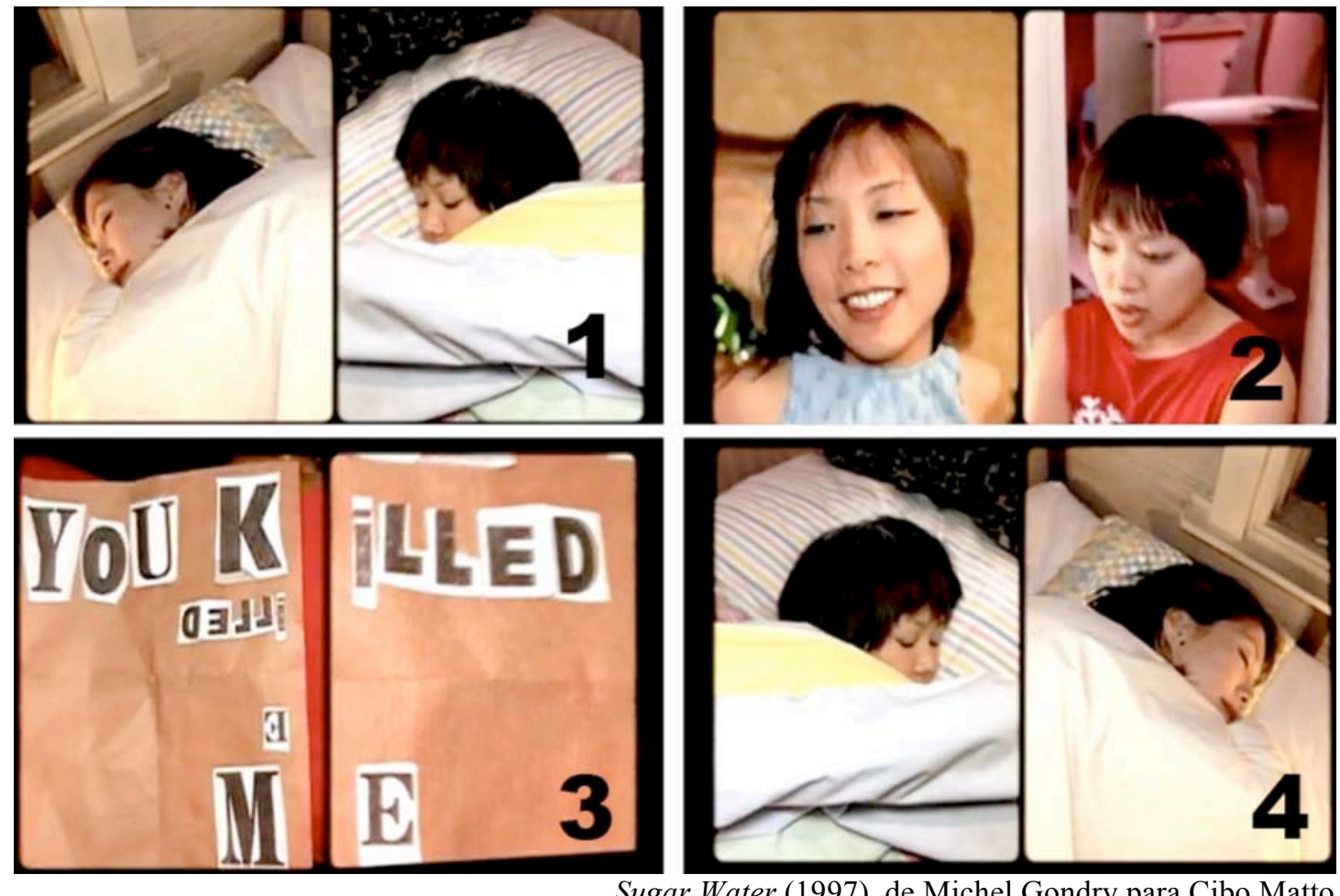

Sugar Water (1997), de Michel Gondry para Cibo Matto

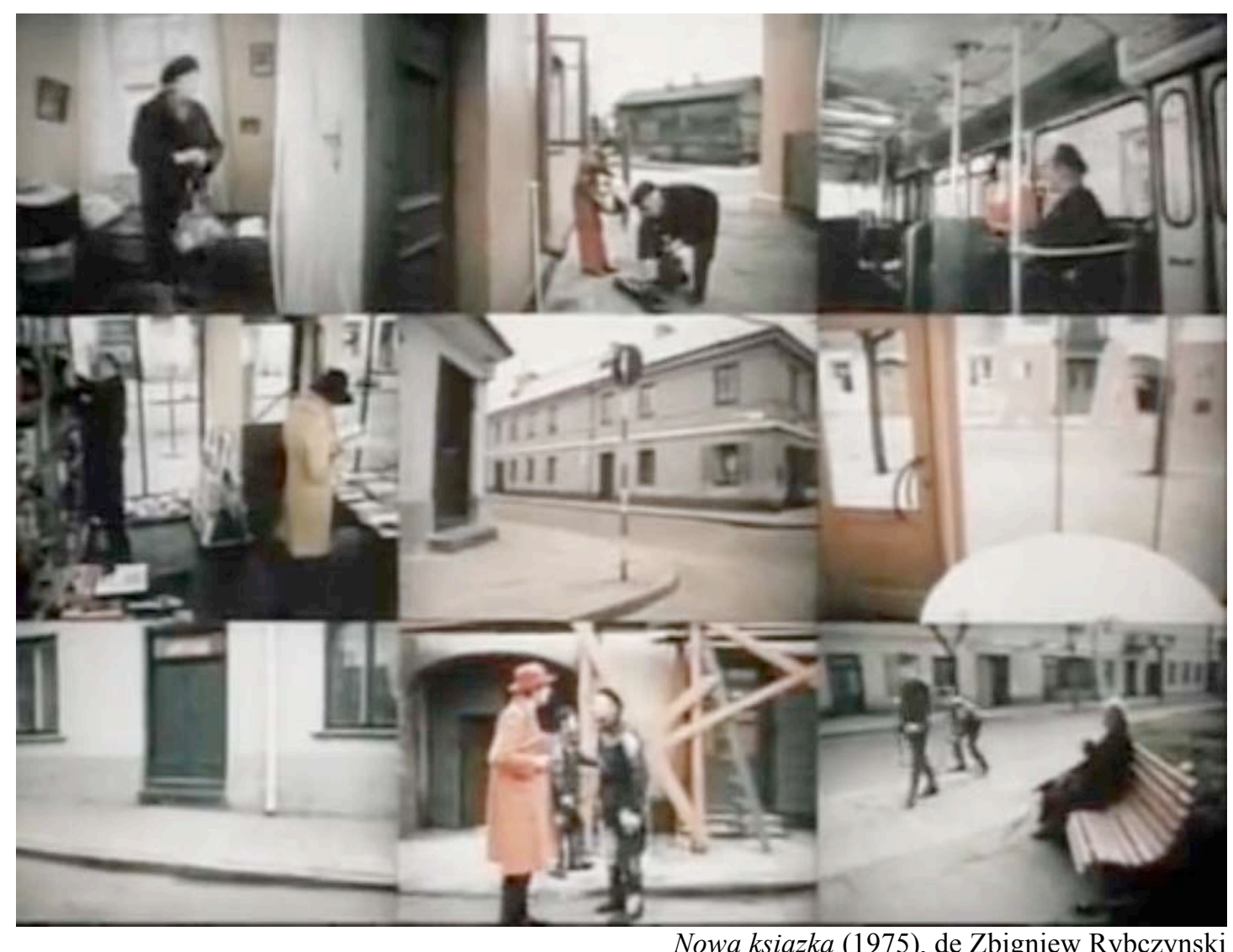

Si bien durante los primeros minutos las diversas secciones parecen inconexas, pronto las líneas que separan las sub-imágenes se vuelven permeables, dejando entrar y salir a los personajes, y dando con ello a entender cierta proximidad entre escenas 
simultáneas. Al modo de un "cubo de Rubik visual", el receptor persigue con la mirada a los personajes, saltando de un cuadrado a otro, en busca de alguna referencia espacio-temporal.

Rybczynski acude a la cohabitación para construir una entidad espacial nueva a partir de la multiplicación del punto de vista. En este sentido, la propuesta tiene como antecedente la revolución del cubismo pictórico, llevada a cabo a principios del siglo XX por artistas como Pablo Picasso o Georges Braque.

\section{La influencia del cubismo pictórico}

Como explicábamos en el apartado anterior, la perspectiva estructura el espacio tridimensional en el plano a partir de un punto de vista único y fijo, que permite medir el vacío entre los objetos y la distancia de éstos al espectador; esta concepción del espacio coloca al ser humano como centro perceptivo constitutivo de la realidad y de su representación. La ruptura de la pintura moderna se fundamenta en la descomposición y la multiplicación de este punto de vista único y la constitución de un nuevo espacio plástico. ${ }^{34} \mathrm{O}$ dicho de otro modo: se renuncia a la copia mimética a favor de un objeto artístico independiente. ${ }^{35}$

A este respecto, el propio Peter Greenaway recupera en su manifiesto la cita de Picasso "No pinto lo que veo, sino lo que pienso" y no duda en referirse a la exploración de un "cubismo animado" ${ }^{36}$. Esta propuesta teórica toma forma en una escena de The Pillow Book (1996), en la cual el cineasta retrata mediante una cohabitación la descomposición psicológica del personaje y la alteración de la percepción espacio-temporal provocada por el consumo de drogas. En una suerte de canon visual, una imagen funciona como base mientras otras aparecen y desaparecen, presentando un momento de la acción posterior en el tiempo y que puede reproducirse, después, en la imagen-base.

\footnotetext{
34 “On abandonne l'idée que l'univers est l'agrandissement à l'infini du cube scénographique au centre duquel se déplace l'homme-acteur." FRANCASTEL, Pierre. Peinture et société : naissance et destruction d'un espace plastique de la Renaissance au cubisme (1951). Paris: Gallimard, 1965, p. 198. 35 'Ce qui différencie le cubisme de l'ancienne peinture, c'est qu'il n'est pas un art d'imitation, mais un art de conception qui tend à s'élever jusqu'à la création." APOLLINAIRE, Guillaume. "Les peintres cubistes, méditations esthétiques" (1913). En : APOLLINAIRE, Guillaume; EIMERT, Dorothea. Le Cubisme. New York: Parkstone International, 2012, p. 21.

36 "The digital revolution technologies can re-explore these issues to make - to use a convenience concept-word - an animated cubism." GREENAWAY, Peter. Op. cit. Pássim.
} 
Como Talen, Greenaway asegura que no se trata de imitar la visión, sino la imaginación, la emoción, la experiencia:

\begin{abstract}
“Antes, durante, después; pasado, presente, futuro; rápido, lento, más lento, repeticiones, reanudaciones, a través de estrategias de la pantalla de innumerables continuidades, desarrollando un lenguaje que corresponde mejor a la experiencia humana en su interacción entre la realidad, la memoria y la imaginación.".37
\end{abstract}

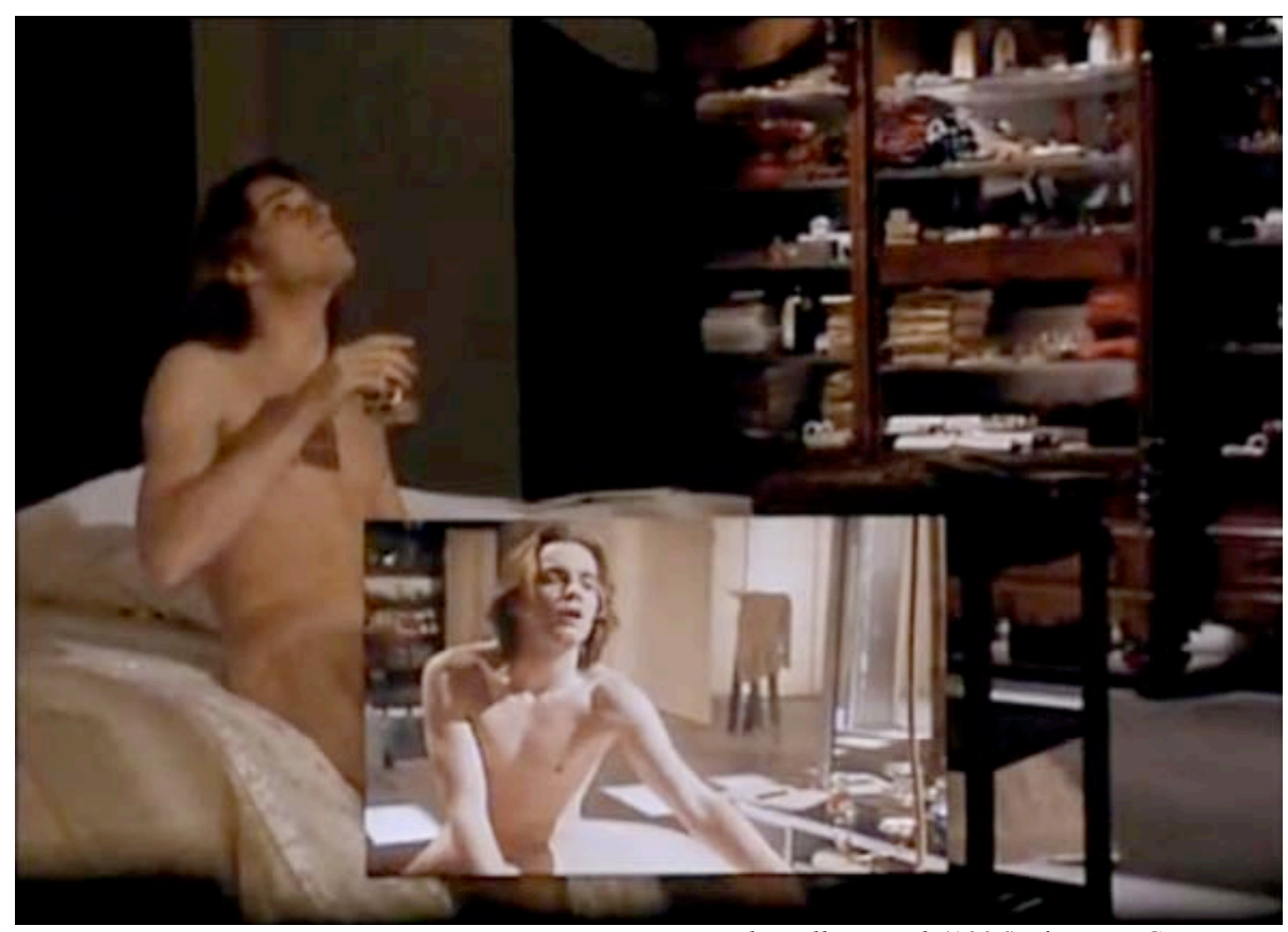

The Pillow Book (1996), de Peter Greenaway

En 127 hours (2010), Danny Boyle acude también a una fragmentación cercana a la propuesta cubista como descomposición psicológica del protagonista. La cinta cuenta la historia real del joven Aron Ralston (James Franco), quien, tras quedar atrapado por una roca en las montañas de Canyonlands (Utah, EE.UU), decide cortarse el brazo para sobrevivir. La puesta en escena combina la apariencia de un documental con un trabajo de compartimentación de la pantalla, homenaje a la pequeña cámara digital que el protagonista utiliza a modo de diario y testamento de su calvario. Primeros planos y planos generales coexisten en el interior del cuadro, provocando una fragmentación que hace eco al drama del relato.

\footnotetext{
${ }^{37}$ Ibídem.
} 


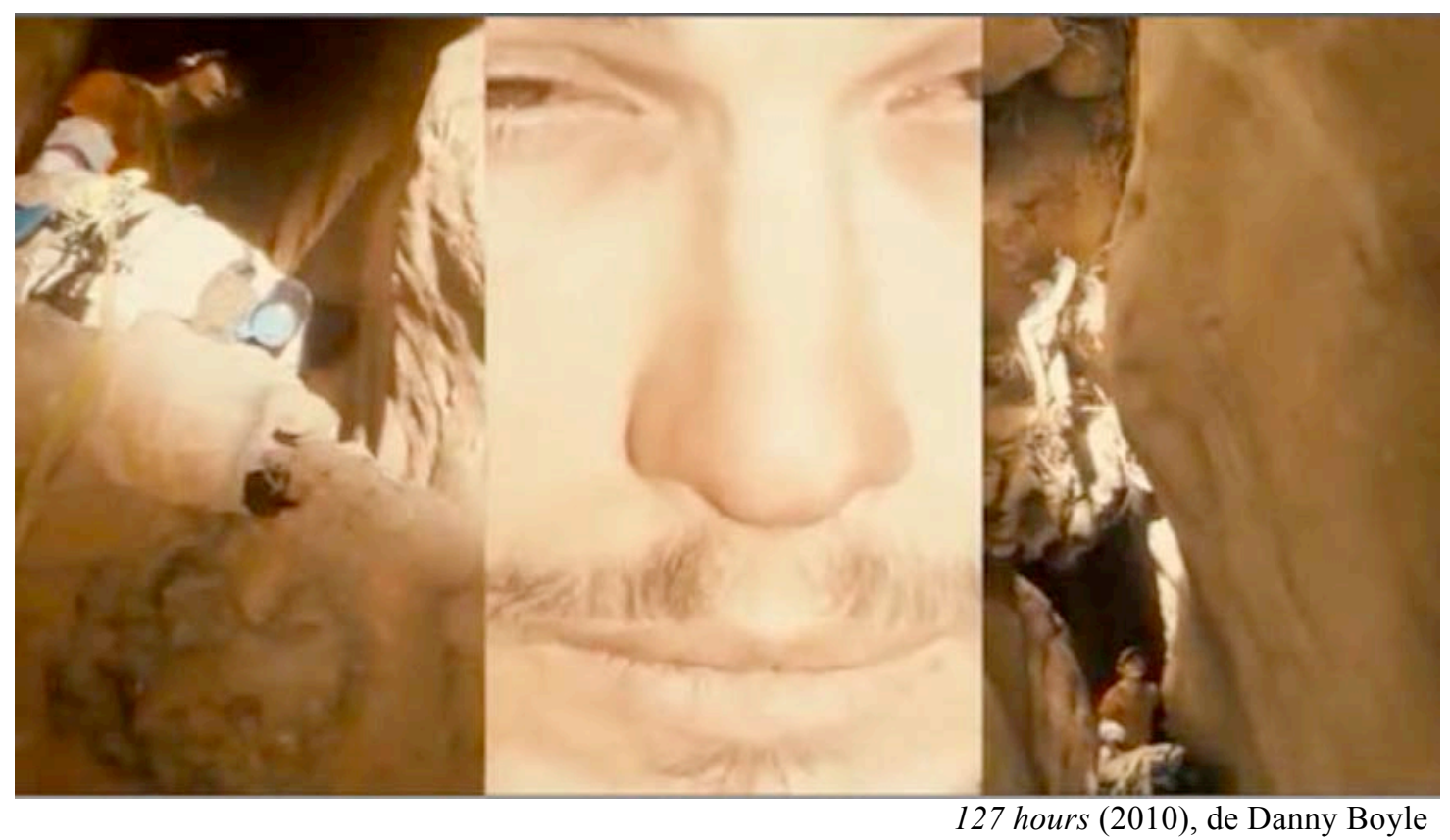

En la publicidad Nars Pure Matte (2010), dirigida por Tim Richardson para Baron\&Baron, el punto de vista fijo estalla en pedazos y se despliega por la pantalla. Las líneas de demarcación varían, se multiplican y cambian de posición, componiendo un mosaico caleidoscópico. No es de extrañar que, de nuevo, encontremos el mismo tipo de construcción en los experimentos de las vanguardias históricas. Así, basta comparar la imagen digital citada con la multiplicación del rostro de Kiki de Montparnasse en el Ballet mécanique (1924) de Fernand Léger.

Esta construcción puede dar lugar, también, a un "monstruo visual". A medio camino entre la cohabitación que nos ocupa y la mezcla, que estudiaremos en el próximo apartado, el límite entre las sub-imágenes se vuelve permeable y deja a las formas fluir en un espacio lleno. Éste es el caso tanto del personaje bicéfalo de Vormittagsspuk (1928), de Hans Richter, como de las criaturas de Nicolas Provost, que veíamos en relación a la transformación. La barrera explícita del split screen desaparece: el intersticio se vuelve pasaje interdimensional.

Con su corto Manifesto (2011), Giovanni Martins se libra a la construcción de estos espacios caleidoscópicos. Tal y como indica el título de la obra, homenaje al Manifeste du surréalisme de André Breton, el artista se inspira en el movimiento de vanguardia y su canto a la imaginación por encima de la razón. ${ }^{38}$

\footnotetext{
38 "Chère imagination, ce que j'aime surtout en toi, c'est que tu ne pardonnes pas." BRETON, André. Manifestes du surréalisme (1924). Paris: Gallimard, 1965, p. 12.
} 

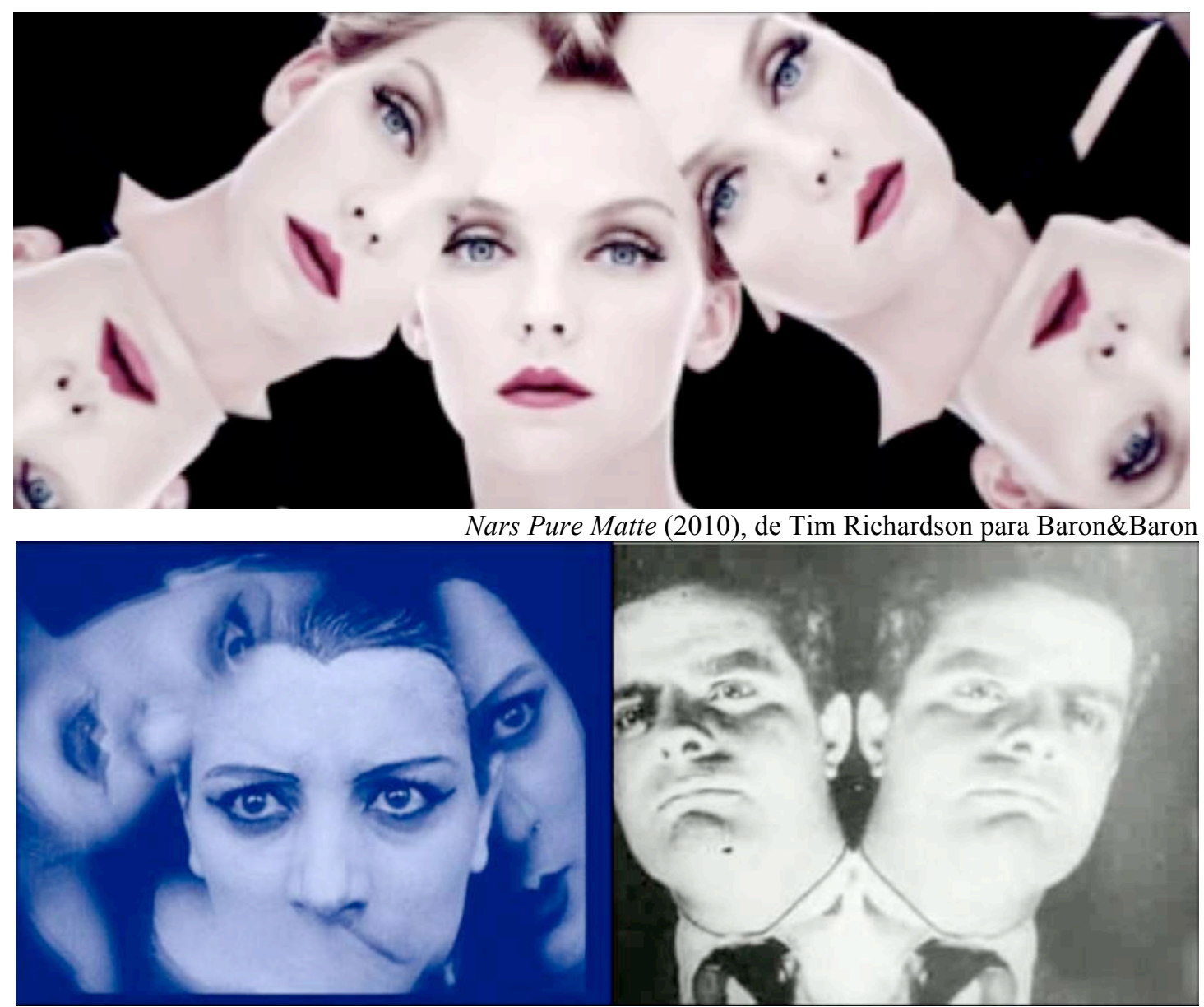

Izquierda. Ballet mécanique (1924), de Léger. Derecha. Vormittagsspuk (1928), de Hans Richter
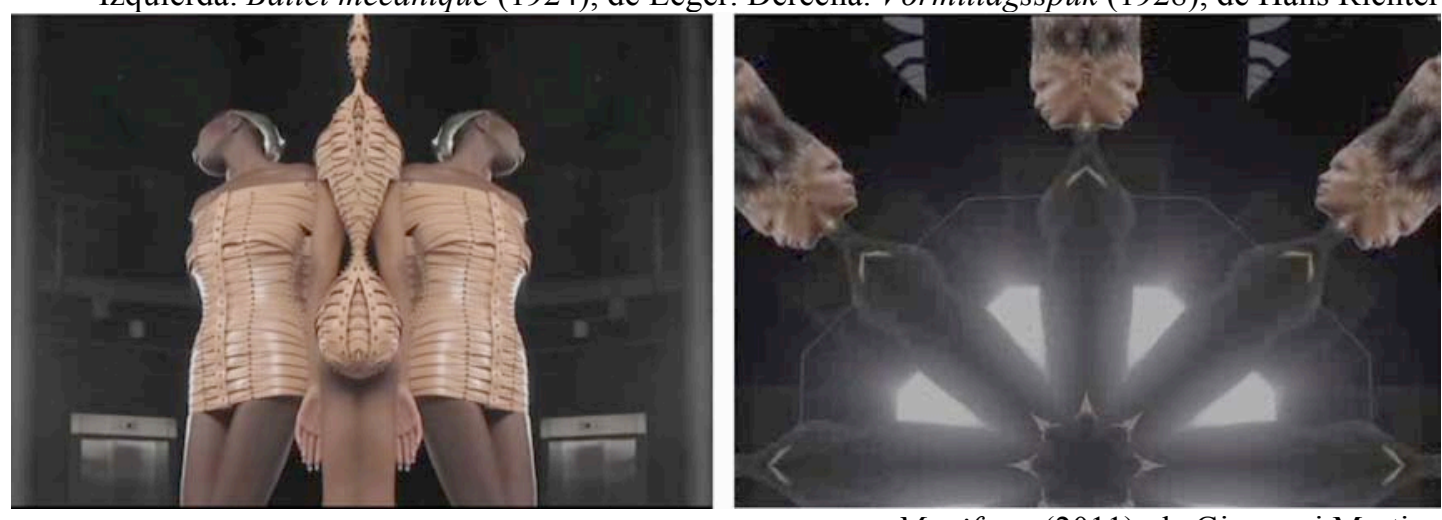

Manifesto (2011), de Giovanni Martins

En el videoclip Maledict car (2008) para el grupo Jemapur, el artista japonés Kosai Sekine altera vistas de Tokio mediante inversiones, split screen y collages, de manera semejante a la película de Dziga Vertov: Chelovek s kinoapparatom, "El hombre con la cámara" (1929). La propuesta del realizador soviético se enmarca en la tendencia de las vanguardias históricas a la identificación de la metrópoli con el lenguaje cinematográfico. Las llamadas "sinfonías de ciudad"39 tienen como objeto la

\footnotetext{
${ }^{39}$ Pensamos en obras contemporáneas a la de Vertov como: Manhatta (Strand y Sheeler, 1921), Rien que les heures (Cavalcanti, 1926), Berliner Stilleben (Moholy-Nagy, ca 1926), Moskva (Mikhail
} 
visualización de la esencia de lo urbano y son, en este sentido, paradigmáticas de la mirada moderna: "No es el mundo proyectado desde la mirada sino la mirada como reflejo del mundo". 40

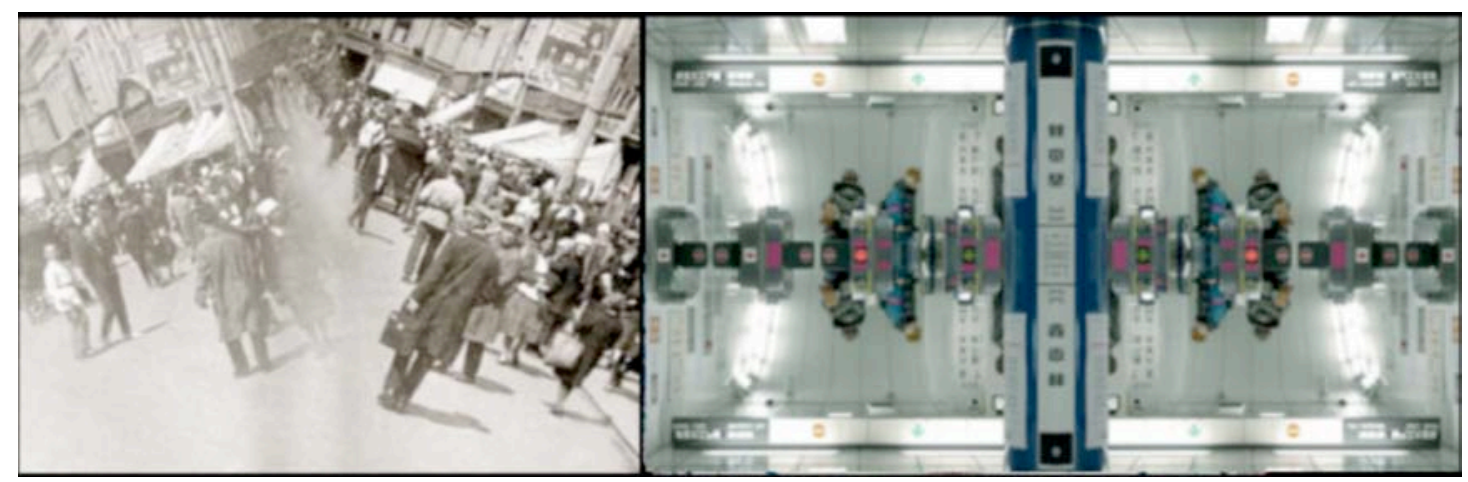

Izquierda. Chelovek s kinoapparatom (1929), de Vertov. Derecha. Maledict car (2008), de Sekine

La saturación de impulsos visuales se suma a los medios de transporte, que condensan el espacio y permiten relacionar lo distante. El punto de vista fijo de la perspectiva es sustituido por una visión dinámica. A principios del siglo $\mathrm{XX}$, lo urbano se concibe como la suma de sus energías heterogéneas; la metrópoli es un cúmulo de imágenes superpuestas: una ciudad palimpsesto. Esta transformación se ve reflejada en la imagen cinematográfica. El cine de las vanguardias históricas retoma del arte moderno la exaltación de la superficie de la imagen. Así, la fragmentación y la simultaneidad se traducen tanto en la "cohabitación" como en la "mezcla" mediante collage y sobreimpresión, que veremos a continuación.

Las construcciones digitales que nos ocupan comparten con aquellas vanguardias históricas la exploración de un espacio de la imagen mediante el montaje espacial. Hasta aquí, nos hemos concentrado en la subdivisión explícita del cuadro; en el próximo apartado, nos detenemos en otra forma de construcción en el interior del mismo, que pone de relieve el proceso de elaboración en capas. Si la cohabitación subraya la superficie bidimensional de la pantalla, la mezcla juega con la profundidad del espacio; eso sí, no se trata de la tridimensionalidad simulada por la perspectiva, sino de los estratos que componen la imagen heterogénea. La cuestión no es la profundidad del espacio representado en el plano, sino, una vez más, la del mismísimo espacio de la imagen.

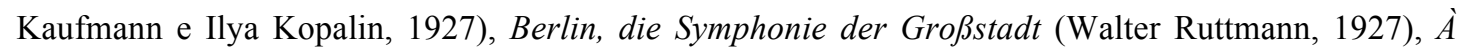
propos de Nice (Jean Vigo, 1929) y Douro, faina fluvial (Manoel de Oliveira, 1930).

${ }^{40}$ MOLINUEVO, José Luis. Retorno a la imagen. Estética del cine en la modernidad melancólica. Salamanca: Archipiélagos, 2010, p. 35. Disponible en Web:

$<$ http://joseluismolinuevo.blogspot.com/2010/07/nuevo-libroretorno-la-imagendescarga.html> 


\section{LA MEZCLA DE LAS IMÁGENES}

Frente a la demarcación explícita entre las diversas imágenes que "cohabitan" en el interior del cuadro, por "mezcla" entendemos aquel montaje espacial que permite una imbricación, una fusión de las imágenes de partida. Se trate de una construcción opaca (collage) o transparente (sobreimpresión), el resultado es un espacio compuesto, formado a partir de fuentes heterogéneas y desconectado de cualquier referente externo; un espacio creado, que funciona como totalidad y no sólo como la suma de las partes aisladas que lo componen.

Veamos un ejemplo en la película Spider-Man (2002), de Sam Raimi. El montaje espacial es utilizado para presentar a la vez al protagonista y su pensamiento, en la línea de Life of an American Fireman (1903), que veíamos al principio del apartado anterior; no obstante, frente a la cohabitación creada por Edwin S. Porter, Raimi juega con la estructuración en capas: la construcción en el interior del cuadro no tiene que ver aquí con la introducción de otros sub-cuadros, sino con la estratificación del espacio, haciendo emerger el proceso mismo de elaboración de la imagen. Esta condición "hojaldrada" es la clave de las múltiples posibilidades de composición y retoque de la imagen código: los programas de edición digital (Premiere Pro, Photoshop, After Effects, Avid, Final Cut Pro...) parten de la concepción de la imagen como una serie de estratos accesibles de manera independiente. Así, en la escena citada de Spider-Man, son precisamente estas capas las que salen a la superficie.

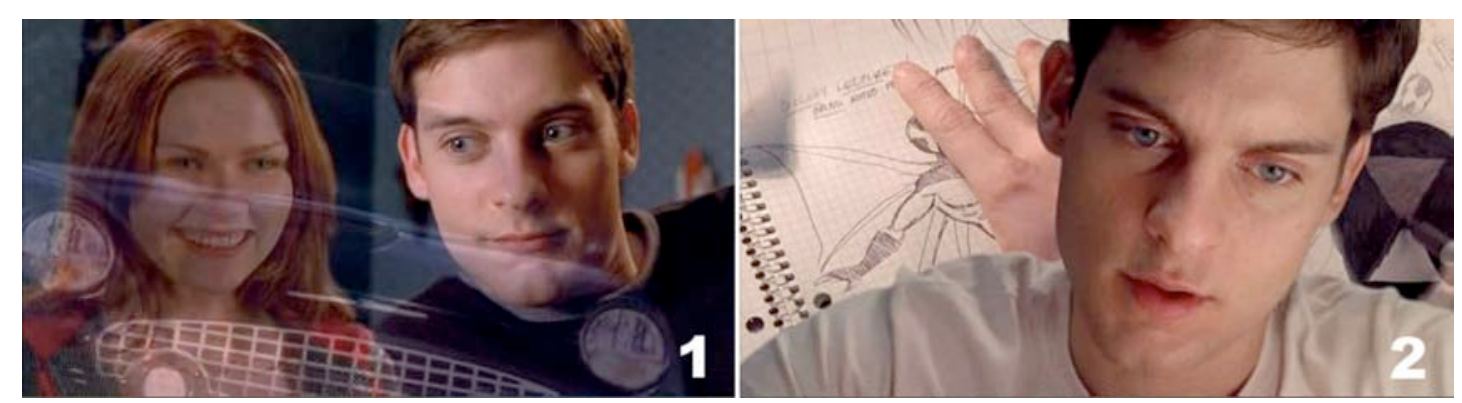

Spider-Man (2002), de Sam Raimi: izquierda, sobreimpresión transparente; derecha, efecto opaco.

Como veíamos en el apartado anterior, el montaje espacial (aunque minoritario) ha acompañado al medio cinematográfico desde sus inicios. A principios del siglo $\mathrm{XX}$, el proceso mecánico consistía en rebobinar la película ya expuesta para grabar sobre ella una segunda impresión. Mediante este procedimiento, es posible crear 
cuadros en el interior del cuadro o, al contrario, eliminar las fronteras abruptas entre las imágenes, mezclando los espacios de las imágenes fuente. De hecho, el mismo Porter propone, en Dream of a Rarebit Fiend (1906), una sobreimpresión que da forma al estado de embriaguez del protagonista; si bien una de las tomas funciona como figura (el borracho abrazado a la farola) y la otra como fondo (los edificios de la calle), la transparencia de las capas se mantiene, haciendo evidente la elaboración de la mezcla. Por su parte, Georges Méliès (1861-1931) se decanta por la composición opaca en los mundos fantásticos de sus "films à trucs"; en Le voyage dans la lune (1902), registro, animación y modelos en miniatura se integran perfectamente en un todo homogéneo.

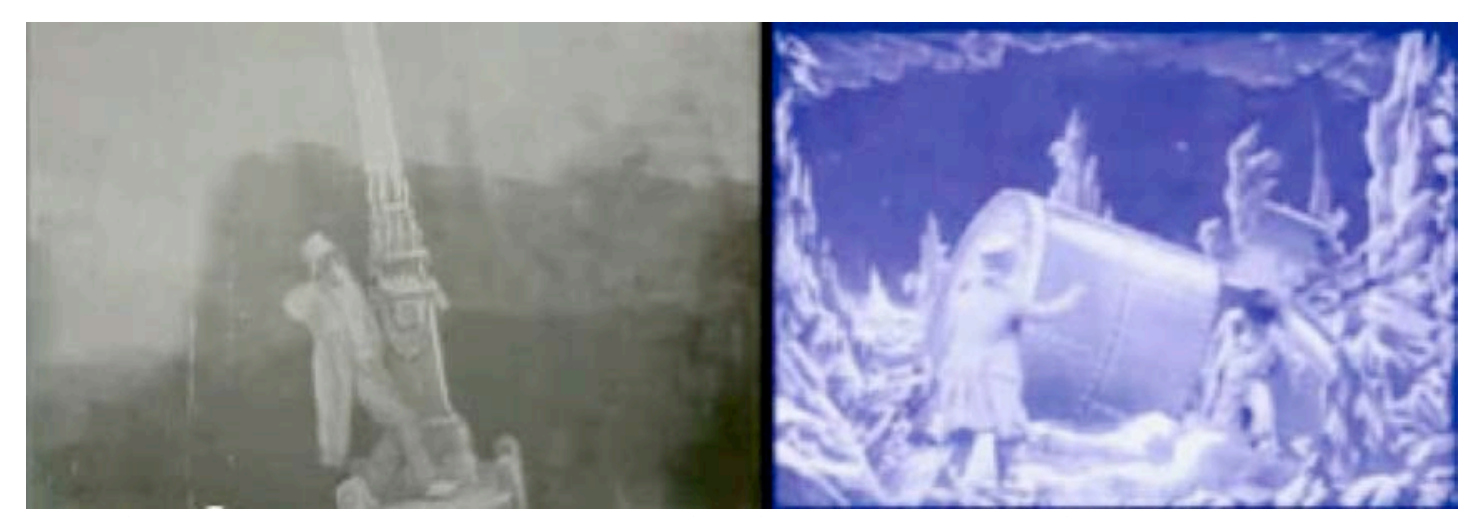

Izquierda, Dream of a Rarebit Fiend (1906), de Edwin S. Porter. Derecha, Le voyage dans la lune (1902), de Georges Méliès

Frente a la construcción del realizador americano, en la cual coexisten las dos imágenes fuente, su contemporáneo francés intenta ocultar el constructo; es decir, la "magia" depende de ese hacer desaparecer el proceso de elaboración de la imagen. ${ }^{1}$ En realidad, ambos usos del montaje espacial son asimilados por el cine clásico: si la sobreimpresión es utilizada a menudo como marca de la subjetividad, de la percepción o del pensamiento de un personaje, la composición opaca permite crear todo tipo de efectos visuales. A partir de los años 50, las grandes producciones hollywoodienses acuden al montaje espacial, eso sí, para simular un espacio unitario, aparentemente tridimensional y homogéneo, en la tradición de la perspectiva renacentista.

Evidentemente, la tecnología digital permite un grado de fusión entre las imágenes que supera aquellas composiciones mecánicas y ópticas. El hecho de que

\footnotetext{
${ }^{1}$ De este modo, Méliès no hace sino adaptar al cine las composiciones fotográficas creadas por Oscar Gustav Rejlander (1813-1875) y Henry Peach Robinson (1830-1901) en la imagen fija.
} 
los fondos puedan ser creados por ordenador posibilita, además, la construcción de espacios imposibles. En una escena de Inception (2010), de Christopher Nolan, París se pliega sobre sí misma a la manera de los dibujos de Maurits Cornelis Escher; de hecho, la película contiene un homenaje explícito a la escalera de Penrose ${ }^{2}$. Ahora bien, frente al dibujo del artista neerlandés, el espacio de la imagen animada es un constructo heterogéneo formado por dos capas: la primera corresponde al registro de los actores, mientras que la segunda es una imagen sintética, creada por ordenador. Para incrustar de manera transparente los personajes sobre la ciudad plegable, se utilizó la técnica del "green screen".

El "green screen" o "blue screen" facilita el silueteado de las figuras y la incrustación de otra imagen en el espacio vacío. Aunque en la imagen digital puede utilizarse cualquier tono, lo más frecuente es el uso del verde o el azul, gracias a su distanciamiento de la piel: cuanto más artificial, más sencillo será dibujar el contorno y recortar la figura humana. De hecho, el verde fosforito es ya una metáfora de la composición digital. El videoclip de Hot Chip Over and over (2006), dirigido por Nima Nourizadeh, exhibe las entrañas del proceso de elaboración de la imagen al presentar, precisamente, el green screen como fondo del espacio.

Si bien el uso de una pantalla azul para siluetear los personajes se remonta a los años $40^{3}$, la estrategia se multiplica con la incrustación videográfica. Con la tecnología electrónica primero y la digital después, la técnica del tapado/contratapado es sustituida por el "keying". Este término define el proceso de recorte de una imagen-fuente y la inserción de otra en el hueco así producido. ${ }^{4}$ La selección del fragmento que será sustituido se realiza mediante una clave de color (chroma key), de luz (luma key) o de contraste (difference matting). ${ }^{5}$

\footnotetext{
${ }^{2}$ Según el nombre del científico inglés Lionel S. Penrose (1898-1972), admirador de la obra gráfica de Escher y quien, a su vez, influyó al artista con la publicación de sus artículos sobre efectos ópticos. Cfr. PENROSE, Lionel S.; PENROSE, Roger. "Impossible objects: a special type of visual illusion". British Journal of Psychology. February 1958, vol. 49, pp. 31-33.

${ }^{3}$ The Thief of Bagdad (1940) de Ludwig Berger, Michael Powell y Tim Whelan, con Larry Butler a cargo de los efectos especiales, fue una de las primeras películas en servirse de una pantalla azul para aislar las figuras del fondo y componer así la imagen.

${ }^{4}$ Uno de los antecedentes de la incrustación videográfica es el electronigraph de Abel Gance, un sistema que permite pegar un personaje en un decorado filmado separadamente. PARFAIT, Françoise. Vidéo : un art contemporain. Paris: Éditions du Regard, 2001, pp. 69-70.

${ }^{5}$ La más frecuente es el chroma key. Para una historia de esta técnica desde el matte painting hasta la tecnología digital, ver la tesis doctoral: FURIÓ VITA, Dolores. "Posibilidades artísticas de la imagen electrónica: el chroma key". Directora: Amparo Carbonell Tatay. Universidad Politécnica de Valencia, Departamento de Escultura, Valencia, julio 2008. Disponible en Web:

$<$ http://riunet.upv.es/bitstream/handle/10251/3343/tesisUPV2900.pdf.txt;jsessionid=D7DFEE1D3AFE E8386FAA074F01CDE0C4? sequence $=6>$
} 

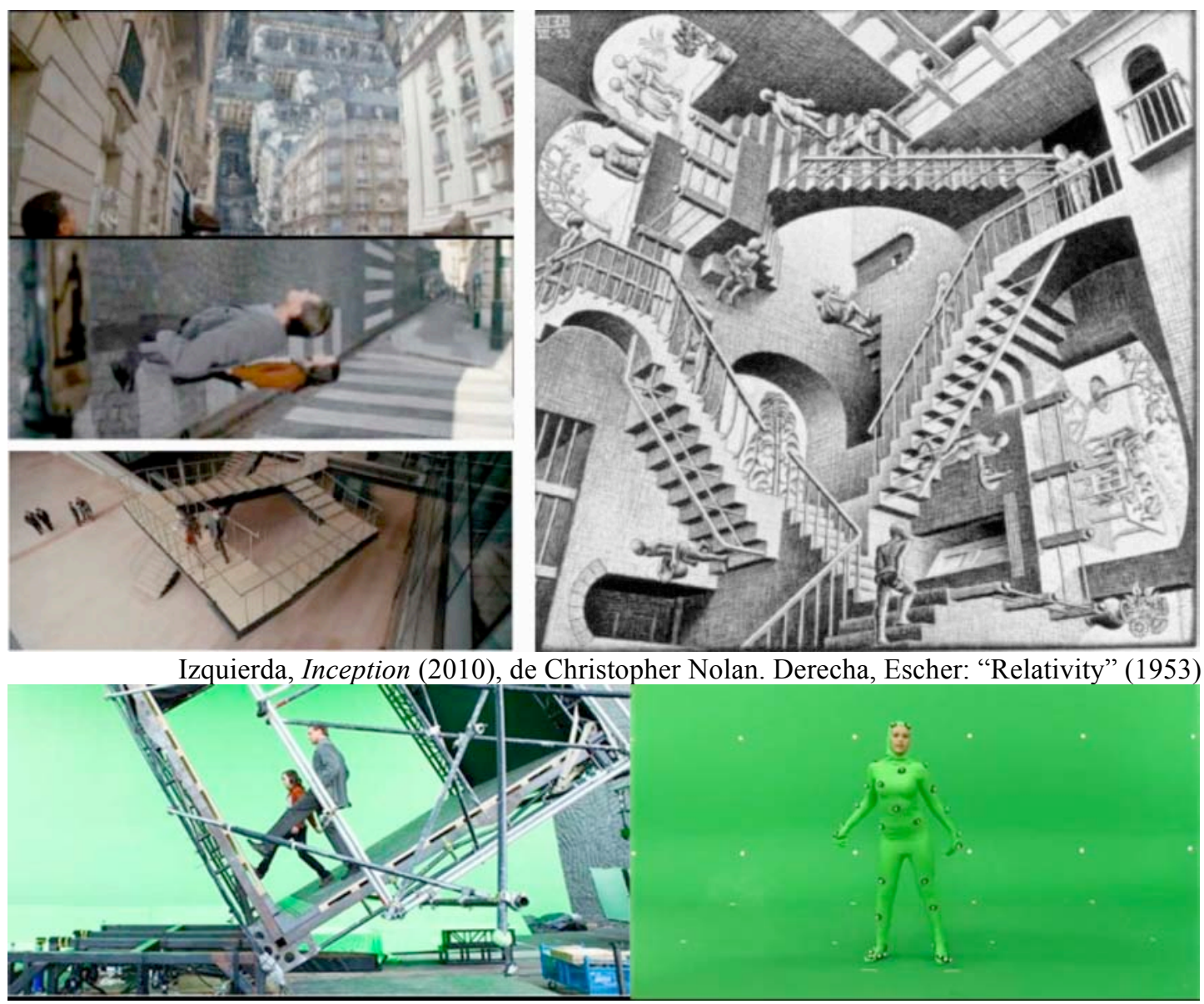

Izquierda. Making of de Inception (2010). Derecha. Over and over (2006), de Nourizadeh

Si Inception mezcla imagen sintética y registro, lo hace ocultando el origen digital del fondo. Es decir, el acabado de la imagen persigue un fotorrealismo ${ }^{6}$ que permita fundir al máximo las imágenes, en la tradición de Méliès. No obstante, nuestro interés recae en otro tipo de mezcla, aquélla que exhibe orgullosa su heterogeneidad, tanto en lo que concierne a la procedencia de las imágenes-fuente, como al proceso de elaboración en capas. El espacio construido no tiene como referente la mímesis, sino las posibilidades plásticas de la construcción de un espacio específico de la imagen. La estrategia más evidente es la de presentar dos imágenes provenientes de medios distintos, por ejemplo, el registro y el dibujo. La película Tron (1982), de Steven Lisberger, contiene varias escenas en las que el fondo fue

\footnotetext{
${ }^{6}$ Frente al registro fotográfico, una imagen generada enteramente por ordenador no tiene grano, puesto que no se compone de haluros de plata, y no contiene ninguna región desenfocada, puesto que no existe la profundidad de campo ni la lente que la produzca. No obstante, a la hora de mezclar el metraje cinematográfico tradicional con las imágenes de síntesis, la calidad de éstas se degrada para que adquieran la apariencia del medio fotográfico. MITCHELL, William J.. The Reconfigured Eye: Visual Truth in the Post-Photographic Era. Cambridge: The MIT Press, 1994, pp. 160-161.
} 
construido digitalmente. Frente a la película de Nolan, la construcción espacial se hace explícita al exhibir la heterogeneidad de la mezcla.

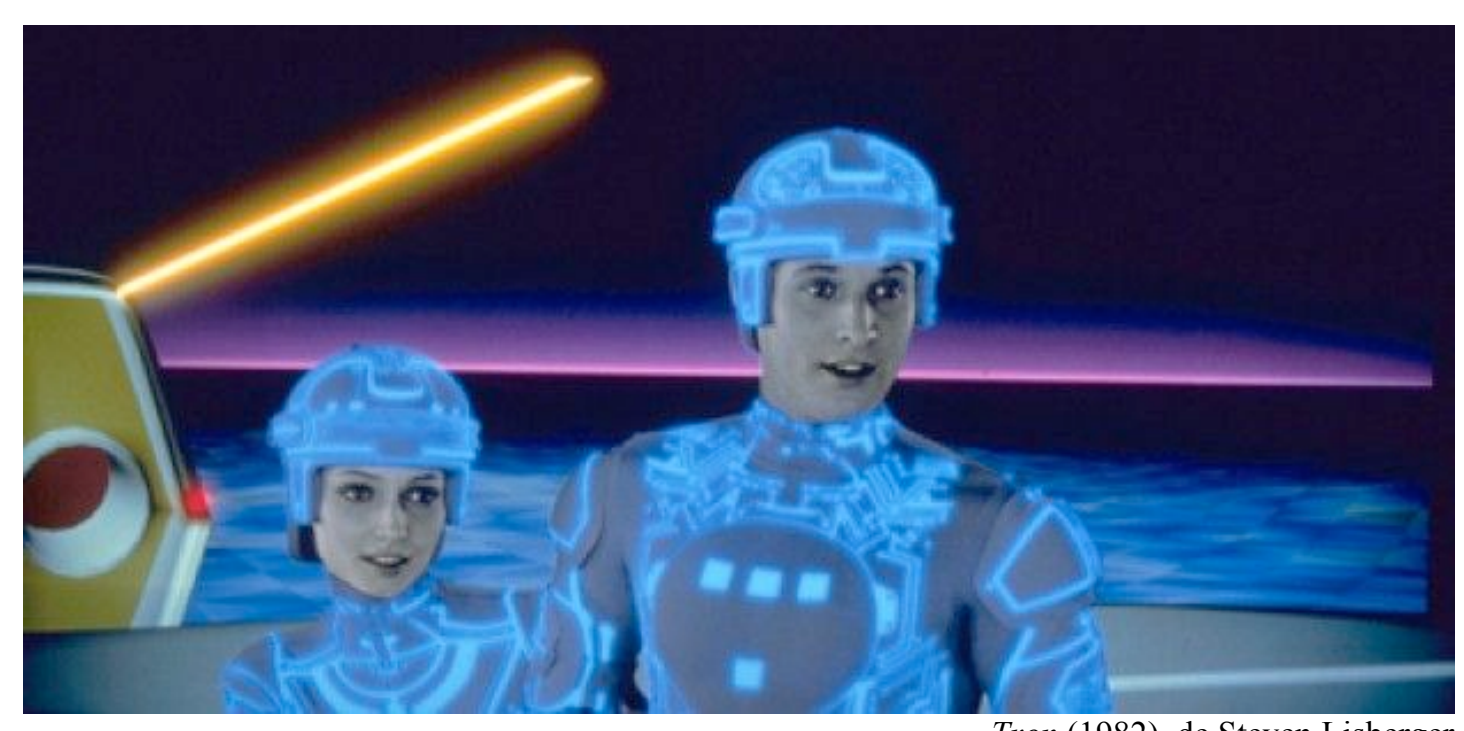

Tron (1982), de Steven Lisberger

En Mary Poppins (1964) de Robert Stevenson, los personajes se sumergen en un dibujo de tiza en el suelo: la pintura del fondo, realizada por Peter Ellenshaw, es un verdadero dibujo animado, que contrasta con los actores incrustados sobre el mismo. Dreams (1990) de Akira Kurosawa contiene una construcción espacial semejante. En el episodio titulado "Crows", un pintor japonés se pasea por los paisajes de Arles creados por el neerlandés Vincent Van Gogh: el protagonista atraviesa literalmente el espacio de la pintura. El tamaño del personaje aumenta al acercarse al primer plano y disminuye en el horizonte; el resultado es una extraña dimensión, entre la tridimensionalidad así sugerida y la bidimensionalidad de la pintura, que conserva los trazos del óleo que el pintor cargara sobre el lienzo. ${ }^{7}$

Si bien en la película de Stevenson la heterogeneidad de la mezcla es explícita, el espacio global respeta las reglas de la perspectiva y se presenta como un vacío en el que se sitúan los objetos. ${ }^{8}$ En cambio, Kurosawa sumerge al protagonista en un

\footnotetext{
7 Ocho años después, Vincent Ward propone en What Dreams May Come (1998) un paisaje fotorrealista que emula a la perfección la masa plástica del óleo y su textura viscosa. La composición e iluminación de la imagen sintética se inspiran en las obras de pintores del siglo XIX como Caspar David Friedrich, Thomas Cole o Albert Bierstadt. No obstante, a pesar del logrado acabado, el constructo espacial se presenta como un mundo tridimensional. Al contrario, Kurosawa parece deleitarse en el contraste entre la imagen fija de la pintura y el movimiento del registro, entre la bidimensionalidad del lienzo y la tridimensionalidad del personaje que recorre el espacio.

${ }^{8}$ La artista Char Davies se refiere a este paradigma como el síndrome de "hard-edged-objects-in empty space". DAVIES, Char. "Virtual Space”. En: HOWELL, Robert; PENZ, François; RADICK, Gregory (eds.). Space: in Science, Art and Society. Cambridge: Cambridge University Press, 2004, p. 71.
} 
entorno plástico: un espacio lleno. La concepción de Alberti se debilita en aras de una vibración general, más próxima al tratamiento espacial de la pintura moderna. Por poner otro ejemplo, baste comparar la atmósfera gaseosa de la película Dreamkeeper (2003) de Steve Barron con el cuadro de Odilon Redon “Ophélie au milieu des fleurs" (1905).

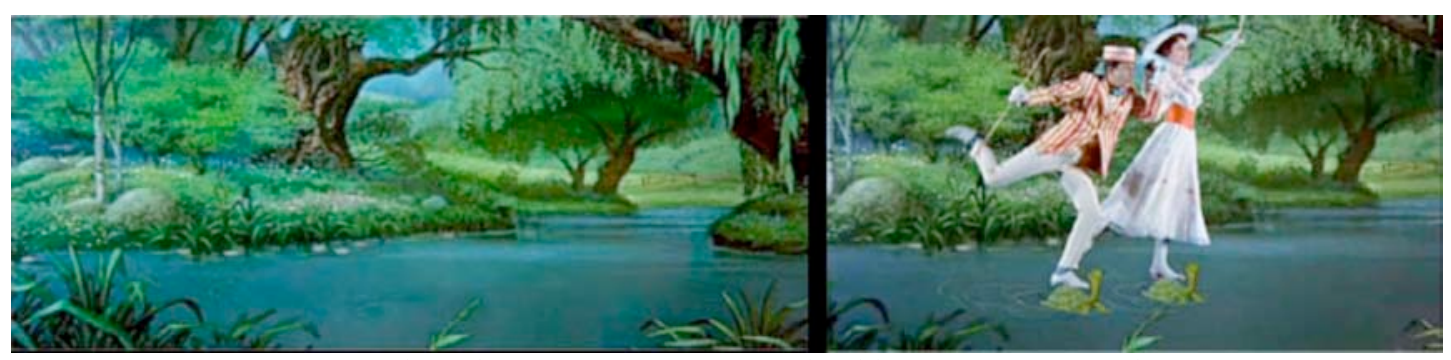

Mary Poppins (1964), de Robert Stevenson. Izquierda, dibujo previo. Derecha, imagen compuesta

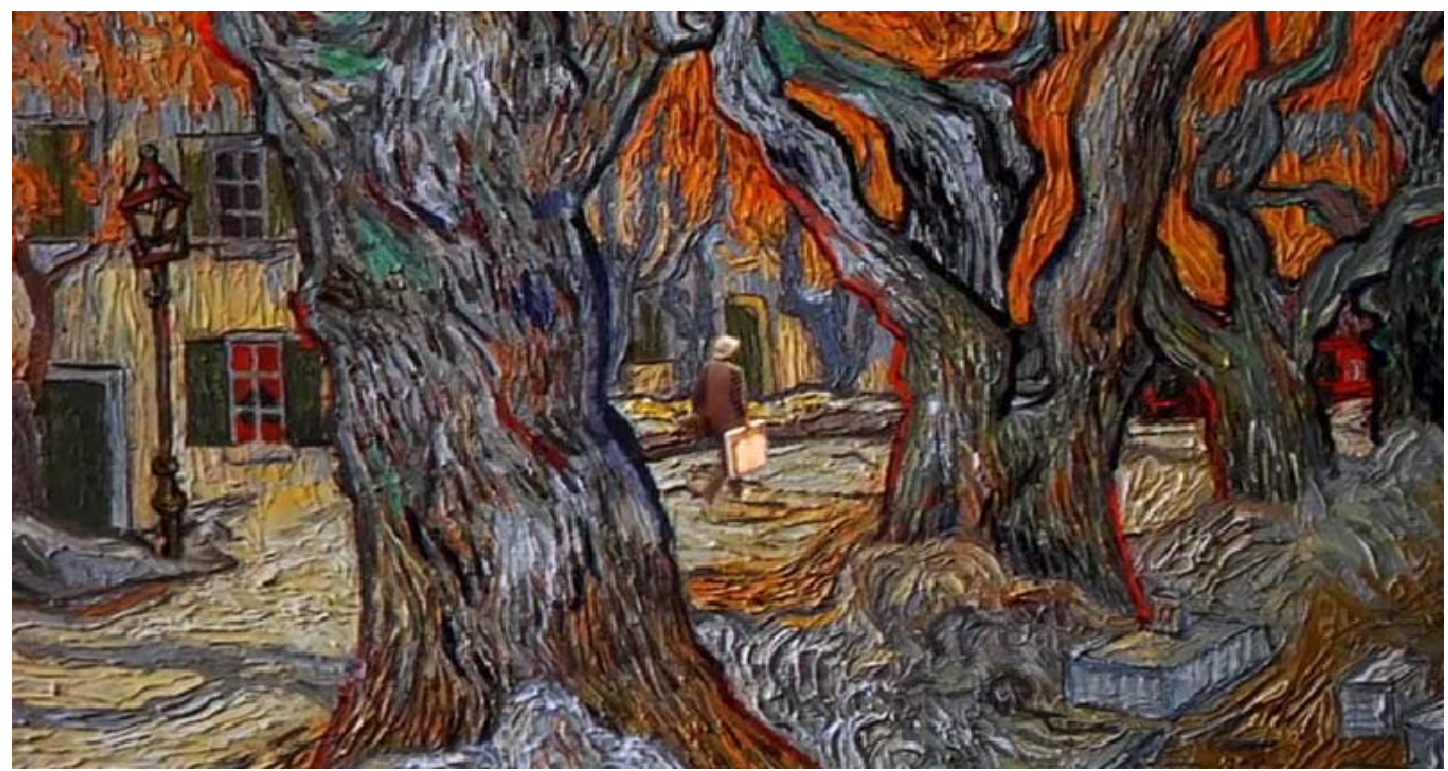

Dreams (1990) de Akira Kurosawa

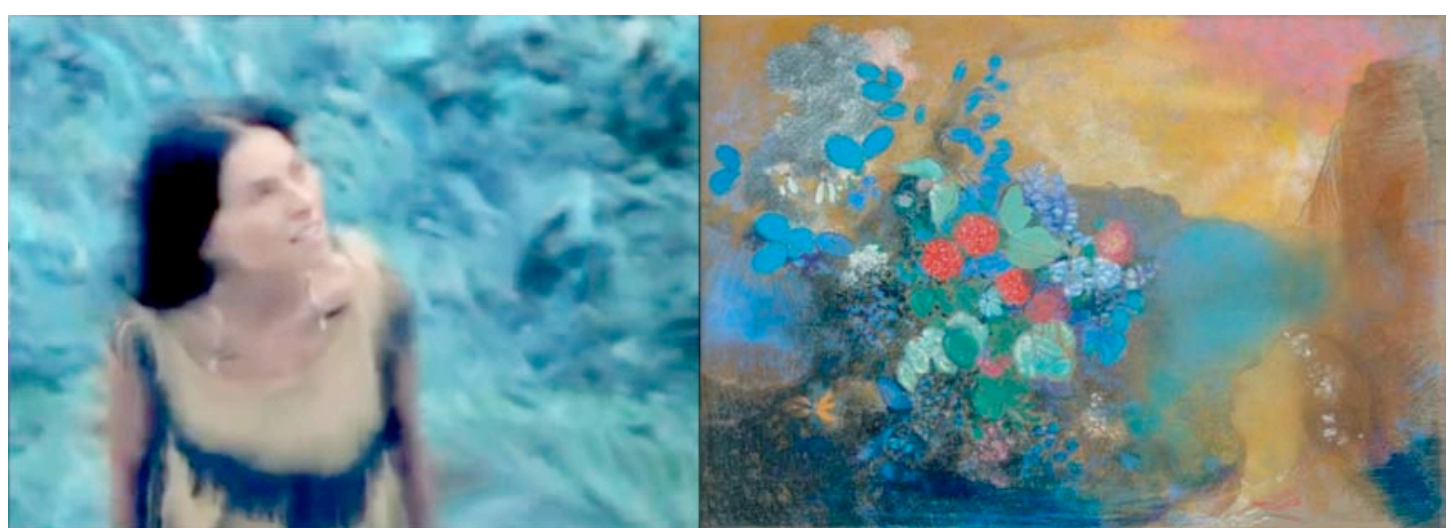

Izquierda. Dreamkeeper (2003), de Barron. Derecha. Redon: “Ophélie au milieu des fleurs” (1905) 
En el videoclip Viva la vida (2008) para Coldplay, Hype Williams crea una mezcla semejante a la propuesta de Kurosawa al introducir a la banda musical en una pintura: en esta ocasión, "La liberté guidant le peuple" (1830) del pintor francés Eugène Delacroix. Como en Dreamkeeper, el espacio es un entorno lleno, fluido, y el fondo no se sitúa tras las figuras, sino alrededor, envolviéndolas en un continuo cromático. Más aún, la luz no es la propia del impacto en la película fotográfica, sino la del pigmento blanco sobre un lienzo. La construcción digital se acerca, aquí, al espacio plástico de la pintura, llegando a sugerir la superficie de la pantalla mediante un efecto de agrietamiento físico del óleo.

En Love Profusion (2003), Madonna se apoya milagrosamente sobre la superficie del agua, que coincide con el plano de la imagen. Como en las grietas de la pintura de Viva la vida, el director del videoclip, Luc Besson, hace presente la imagen en tanto que ente bidimensional. El trabajo en capas permite al realizador construir un espacio imposible: la cantante aparece en primer plano, caminando hacia la cámara, en un paraíso psicodélico que no esconde su calidad sintética. Madonna marcha sobre el cielo mientras un océano en suspensión desafía la ley gravitatoria.
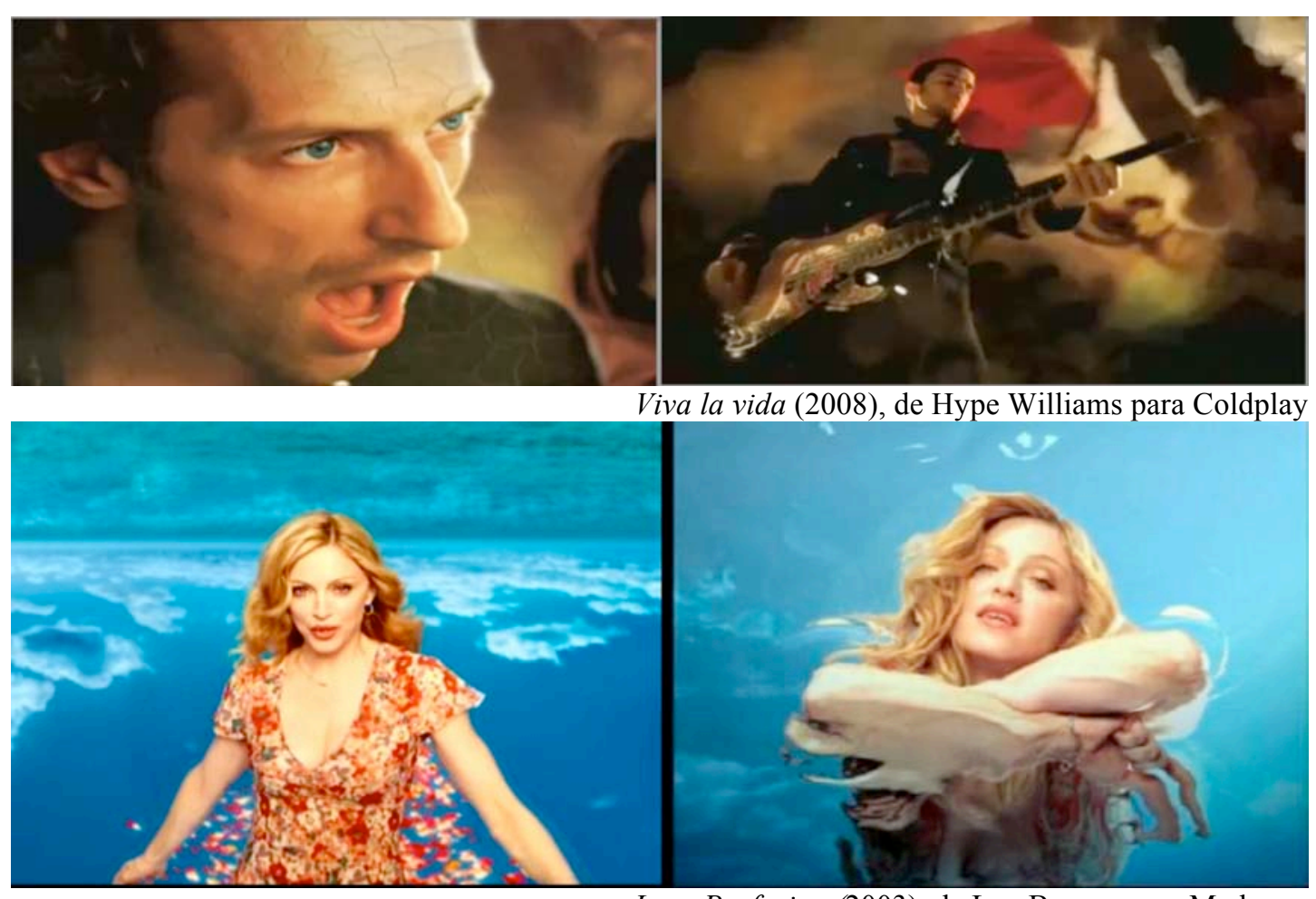

Love Profusion (2003), de Luc Besson para Madonna 
La película The Lovely Bones (2009), de Peter Jackson, contiene una escena probablemente inspirada en el vídeo de Besson'. El limbo en el que se halla la protagonista da forma a los sueños de la adolescente; el imaginario naif refleja, por un lado, la publicidad y los videoclips televisivos y, por otro, un mundo semejante a las ilustraciones de Le Petit Prince $(1943)^{10}$, de Antoine de Saint-Exupéry. Un espacio surrealista, en el cual la escala de los objetos se altera al modo de los paisajes de Salvador Dalí, y día y noche conviven como en el cuadro de René Magritte “L’Empire des lumières" (1954).

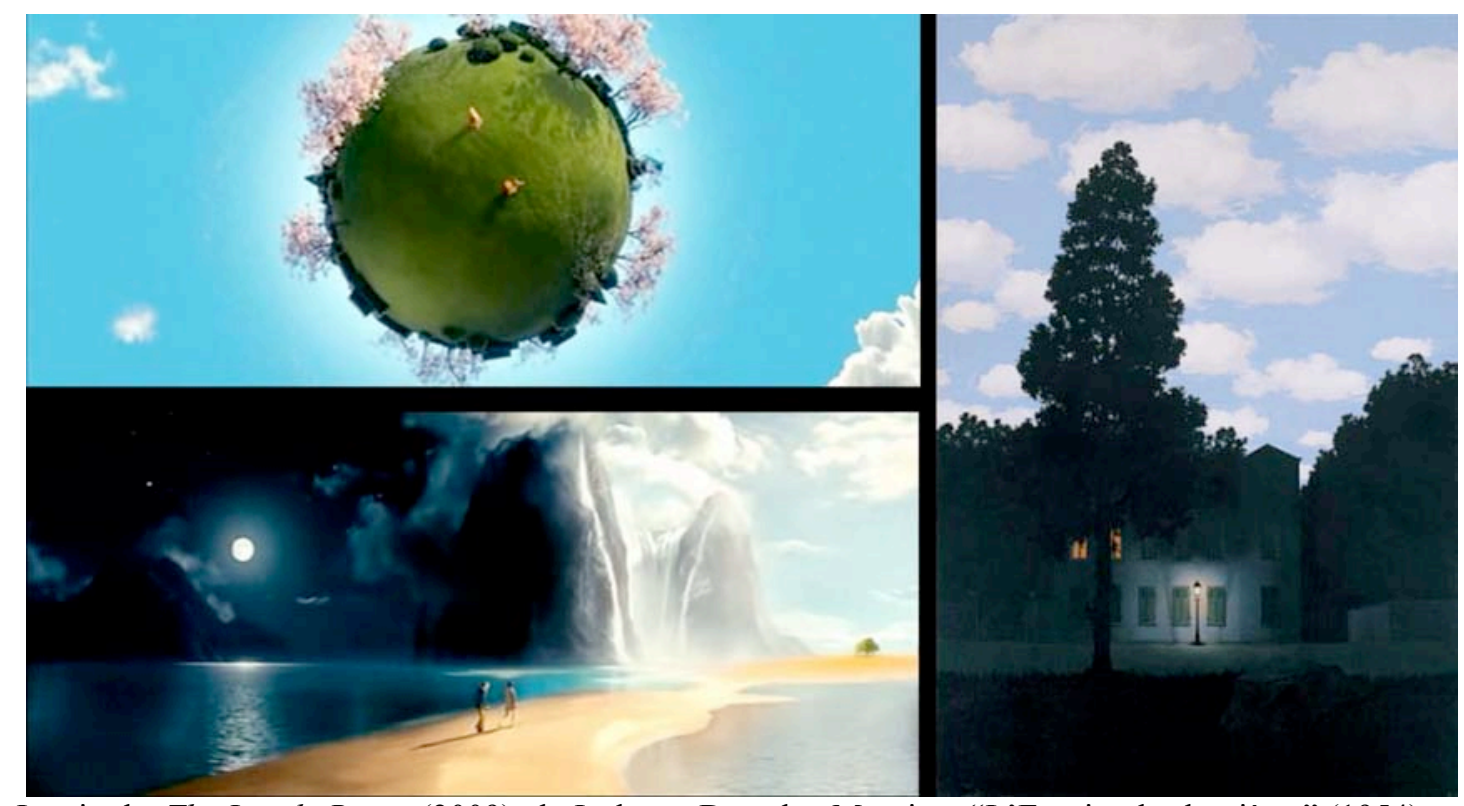

Izquierda. The Lovely Bones (2009), de Jackson. Derecha. Magritte: “L’Empire des lumières” (1954)

En el videoclip de David Fincher Love Is Strong (1994), los Rolling Stones y algunas modelos aparecen en un tamaño gigante sobre las calles de Nueva York. La desproporción entre figura y fondo es el fruto de una composición digital de la imagen mediante un green screen: las personas fueron grabadas sobre un fondo verde que permitió siluetear las figuras e incrustarlas, después, sobre las calles de la ciudad estadounidense. ${ }^{11}$ Los personajes dominan la ciudad con la que parecen identificarse.

\footnotetext{
${ }^{9}$ La comparación entre la escena de la película y el videoclip prueba la contaminación mutua entre medios. "The influence of music video direction, far from being something invidious and degenerating for the cinema, has been essentially invigorating to an art form entering only its second century." HANSON, Matt. Op. cit., p. 85.

${ }^{10}$ DE SAINT-EXUPÉRY, Antoine. Le Petit Prince (1943). Paris: Gallimard, 2004.

${ }^{11}$ Como Madonna en Love Profusion, Mick Jagger parece caminar hacia el espectador a través de una gran avenida. En realidad, el cantante andaba sin desplazarse sobre un cinta de correr, delante de un green screen. Para lograr una sutura convincente entre las tomas, Fincher utilizó la técnica del "pixel tracking". El "rastreo de píxel" consiste en localizar en el fondo un elemento pequeño y firme de modo
} 
Esta equiparación entre la figura que ocupa un lugar y el lugar mismo permite relacionar la imagen con el cuadro "La Virgen en la iglesia" de Jan van Eyck (ca 1425). La Virgen María con el niño en brazos invade el interior de una catedral gótica. La desproporción simbólica de la figura funciona como identificación de la Virgen con el espacio.
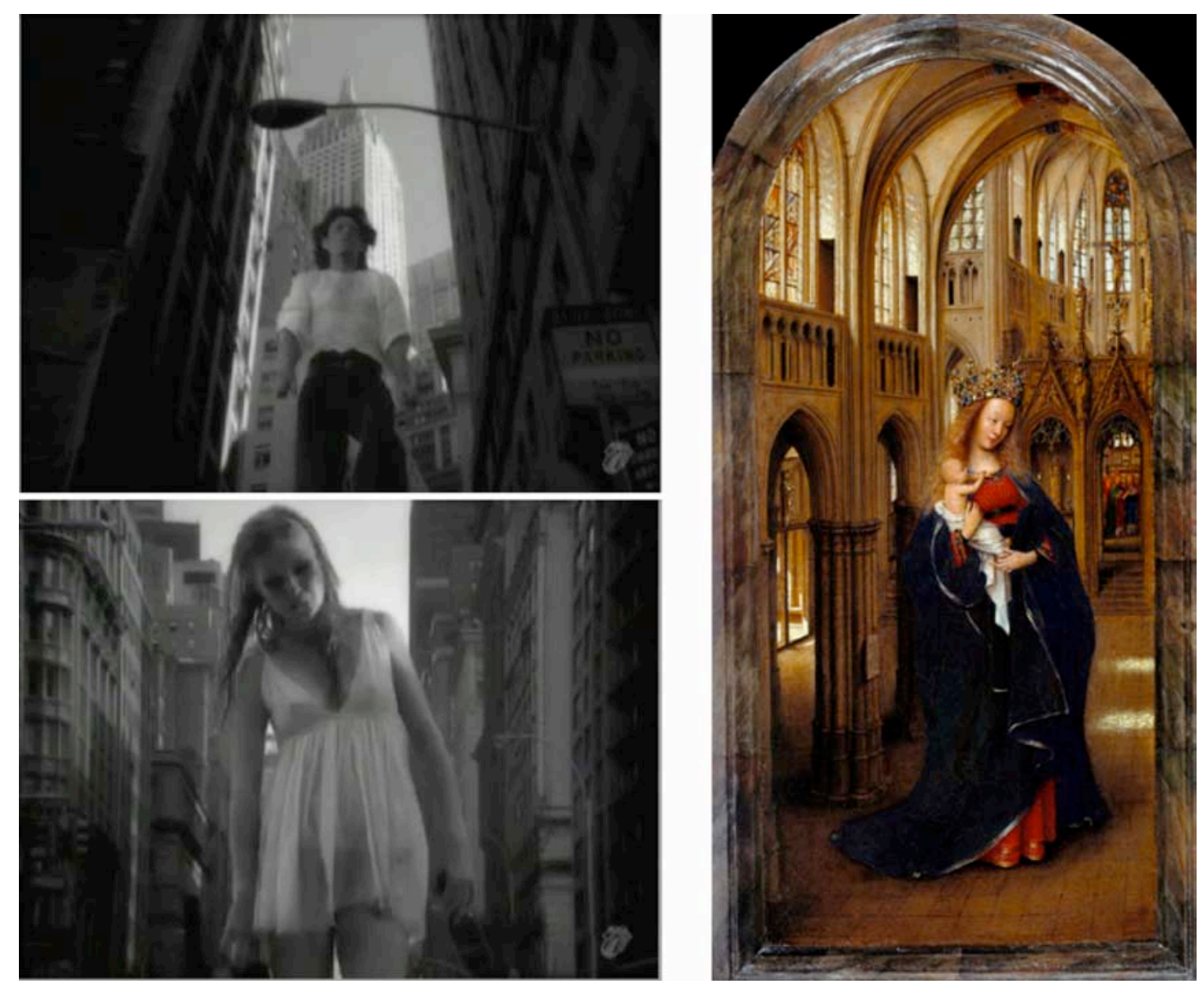

Izquierda. Love Is Strong (1994), de Fincher. Derecha. Van Eyck: “La Virgen en la iglesia” (ca 1425)

Lo cierto es que el arte medieval reservaba un valor simbólico al tamaño de las figuras en el plano. Este es el caso, por ejemplo, del arte románico, en el que el pantocrátor puede llegar a ser muy superior a los ángeles y apóstoles que lo rodean. La representación pictórica oriental, ajena a la teoría de Alberti, se decanta también por este tipo de construcción de espacios simbólicos. En su ensayo dedicado al arte japonés, Eisenstein destaca la desproporción como una forma más cercana a dicho cambio, manteniendo así la unidad espacial. BIZONY, Piers. Op. cit., p. 82. 
determinados aspectos de la percepción que la pautada perspectiva y su empequeñecimiento gradual hacia el punto de fuga. ${ }^{12}$

Ya hemos visto cómo el realizador soviético altera el tamaño de las figuras mediante un gran angular, generando nuevas relaciones espaciales en el interior del cuadro $^{13}$. Paradigmática de este uso simbólico de la desproporción es la escena del sueño de la protagonista de Staroe i novoe. Tras reunir el dinero necesario para comprar el ansiado toro que fecundará las vacas de la comitiva, el macho aparece sobreimpreso en el cielo, por encima de las hembras que pastan, en una escala mucho menor, en la parte inferior de la imagen.

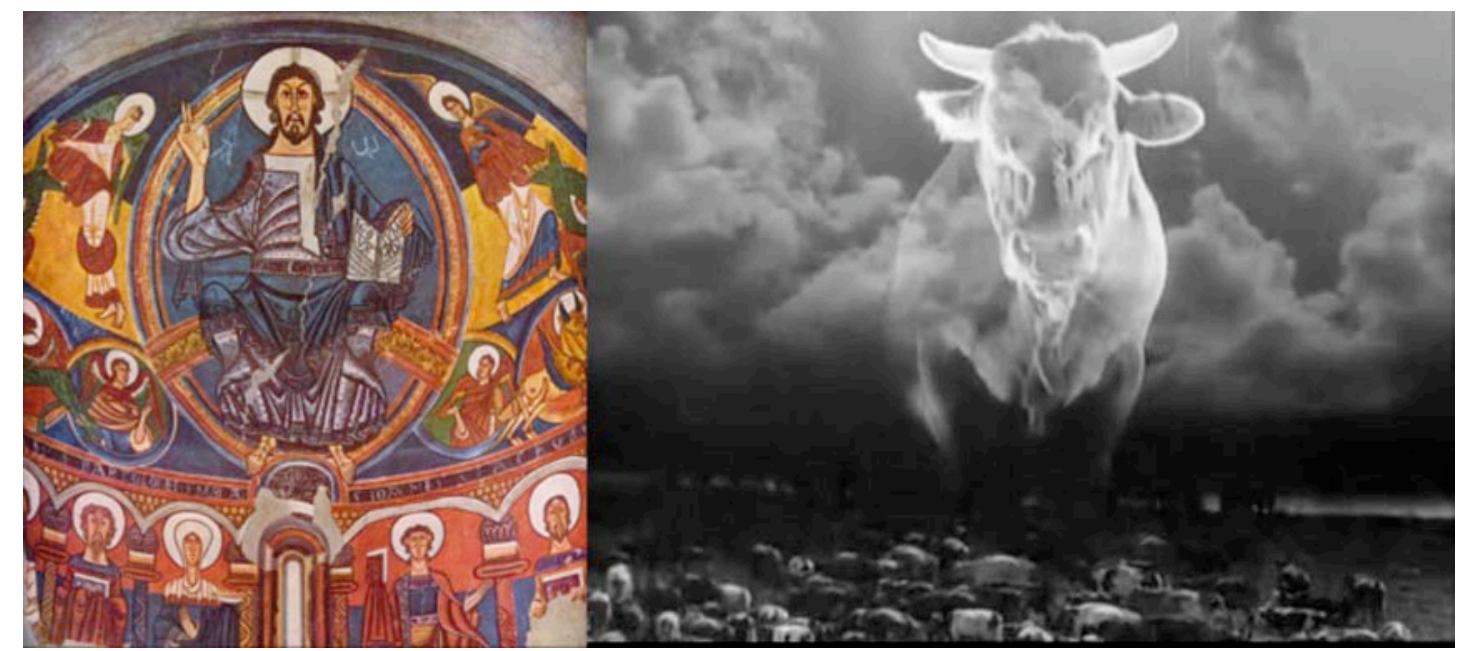

Izquierda. Pantocrátor de la iglesia de San Clemente de Tahull en Lérida (s. XII), del llamado "maestro de Tahull”. Derecha. Staroe i novoe (1929), de Eisenstein

En Cha no aji o "El sabor del té" (2004), el realizador japonés Katsuhito Ishii se sirve de la incrustación digital para crear escenas surrealistas y proyecciones de la imaginación de los personajes. Como en el limbo de The Lovely Bones, las composiciones reflejan un mundo pueril, en el que las leyes de la proporción se alteran. Así, por ejemplo, la benjamina de la familia tiene visiones de una versión gigantesca de sí misma y de un girasol que crece desmesuradamente hasta alcanzar la talla de un enorme planeta y desvanecerse, a continuación, sin explicación alguna.

En otra escena, cuando el hijo mayor acude a despedir a la chica de la que está enamorado, el tren en el que ella viaja no sólo vuela por los aires, sino que surge en miniatura de la frente del personaje que lo contempla alejarse. Esta construcción

\footnotetext{
12 "Absolute realism is by no means the correct form of perception. It is simply the function of a certain form of social structure.” EISENSTEIN, Sergei. Op. cit., pp. 131-132.

13 "Les lois de la perspective au cinéma sont telles qu'un cafard filmé en gros plan paraît sur l'écran cent fois plus redoutable qu'une centaine d'éléphants pris en plan d'ensemble." EISENSTEIN, Sergueï. Au-delà des étoiles. Paris: Union générale d'édition, 1974, pp. 112-113.
} 
espacial puede ser interpretada como una propuesta extrema de sustitución del montaje temporal por el montaje espacial: el plano subjetivo (que coincide con la visión del personaje) se presenta dentro del mismo cuadro. Aunque es frecuente hallar este tipo de montaje espacial mediante una sobreimpresión, la elección opaca de Ishii impone un cambio radical de escala y proporción entre los elementos. Cuando la locomotora brota del rostro del muchacho, absurdo y lirismo se combinan en una construcción espacial cercana al collage surrealista.
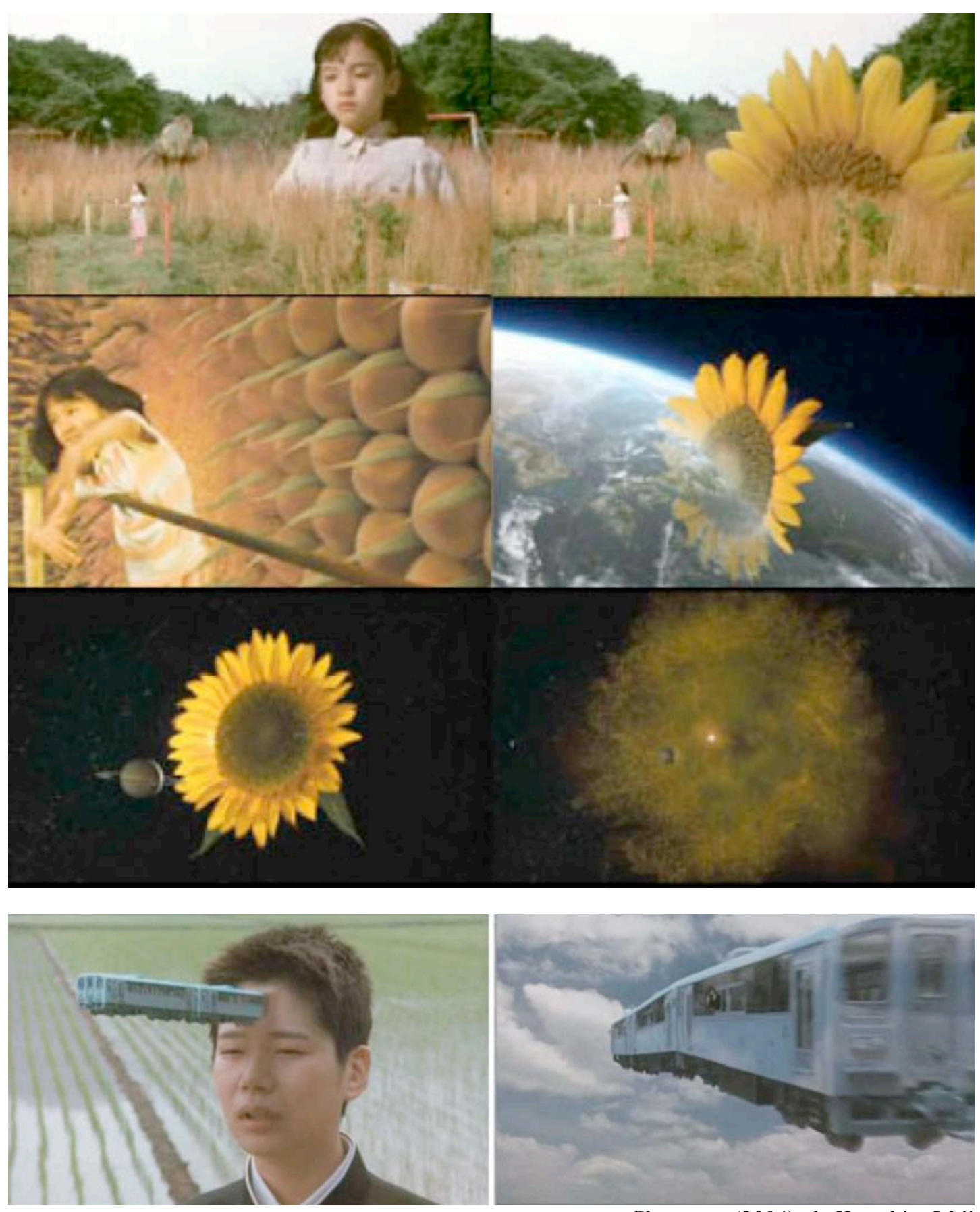

Cha no aji (2004), de Katsuhito Ishii 


\section{El collage}

Los collages surrealistas de Dora Maar y Man Ray conservan la tridimensionalidad de manera semejante a las construcciones de Ishii. En cambio, el fotomontaje dadaísta destaca por su bidimensionalidad y recorte abrupto, superponiendo los retazos de manera aparentemente descuidada. Todos ellos comparten con el collage cubista el alejamiento de la representación mimética y de la reproducción en aras de la construcción de entidades plásticas auto-referenciales. ${ }^{14}$

El fotomontaje dadaísta nace en Berlín en los años 10 como una actividad más próxima al montaje industrial que al arte en el sentido tradicional. ${ }^{15}$ Sus fundadores (Raoul Hausmann, Hannah Höch, Georg Grosz y John Heartfield) destacan la construcción y la transformación del found footage, en una crítica tanto a la fotografía de los medios de comunicación de masas (que consideran manipuladora y propagandística) como al academicismo armónico de la pintura clásica. Así, no es de extrañar que los constructivistas acojan con los brazos abiertos la nueva técnica del fotomontaje; entre ellos, El Lissitzky, László Moholy-Nagy o Alexander Rodchenko.

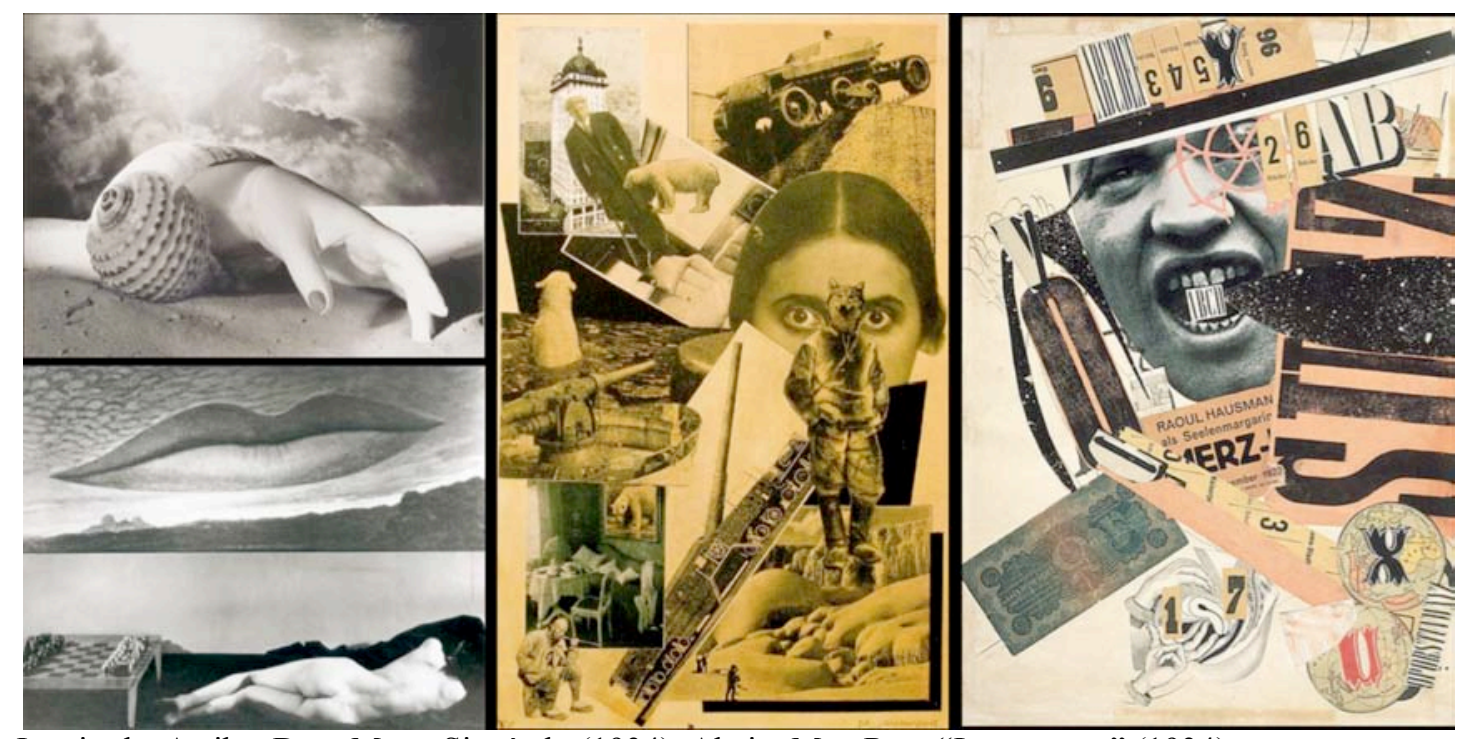

Izquierda. Arriba. Dora Maar: Sin título (1934). Abajo. Man Ray: "Les amants" (1934)

Centro. Alexander Rodchenko: fotomontaje para el libro de Mayakovski Pro Eto (1923/1950)

Derecha. Raoul Hausmann: “ABCD” (1923-1924)

\footnotetext{
${ }^{14}$ Cfr. HOFFMAN, Katherine (ed.). Collage: Critical Views. Ann Arbor: UMI Research Press, 1989.

15 "Nous savions que suivant l'exemple des futuristes, Picasso employait des matériaux 'véritables' (...), des natures mortes de différents morceaux de papier coloré, procédé qu'on appelait 'collage'. Je commençais à faire des tableaux avec des coupures de journaux et d'affiches en été 1918. (...) d'un commun accord avec George Grosz, John Heartfield, Johannes Baader et Hannah Höch, nous décidâmes d'appeler ces travaux 'photomontages'." HAUSMANN, Raoul. Courrier Dada (1958). Paris: Éditions Allia, 2004, p. 42.
} 


\section{EL MONTAJE ESPACIAL}

El montaje espacial del constructivismo, el dadaísmo o el surrealismo se manifiesta, también, en la imagen animada; como adelantábamos ya en el apartado anterior, el cine de las vanguardias históricas contiene numerosos ejemplos de collage y sobreimpresión. No obstante, hemos visto que, tras ellos, el montaje espacial se reservará a la composición transparente y la simulación de un espacio tridimensional homogéneo. No será hasta los años 60 y la aparición del videoarte cuando estos efectos se vuelvan a exhibir de manera explícita: en esta ocasión, no mediante un montaje espacial mecánico, óptico o manual de la película fotográfica, sino por incrustación electrónica.

Frente al medio narrativo en el que se había convertido la imagen cinematográfica, el videoarte nace con un cometido marcadamente experimental. Lo minoritario en el cine es, precisamente, el camino perseguido por los nuevos videoartistas. Con ellos, el proceso de transformación de la imagen forma parte de la obra misma, que mantiene así una relación directa con la tecnología que la sustenta. Con el videoarte, el espacio de la imagen animada recobra la importancia perdida: los artistas que en los años 60 y 70 se acercan a la nueva tecnología del vídeo revisan las creaciones de las vanguardias históricas, eliminando el componente ideológico e inspirándose de la libertad creadora del dadaísmo y el surrealismo.

Así, por ejemplo, el pionero del videoarte francés Jean-Christophe Averty explora las posibilidades plásticas del medio televisivo. En el especial Histoire de Melody Nelson (1971), el cantante Serge Gainsbourg y su pareja Jane Birkin bailan sobre un fondo compuesto por un collage de reminiscencias dadaístas y cuadros surrealistas (Salvador Dalí o Paul Delvaux).

Poco después de la emisión Video Commune: Beatles from beginning to end, Nam June Paik presenta el que es considerado el manifiesto visual del videoarte: Global Groove (1973). En él, explota todas las formas de transformación de la imagen televisiva: a la distorsión de found footage, añade el trabajo de incrustación mediante claves de luz y de color. La tecnología electrónica le permite, entre otros, mezclar medios distintos (televisión, películas, publicidad...), variar la escala o invertir la figura y el fondo. 

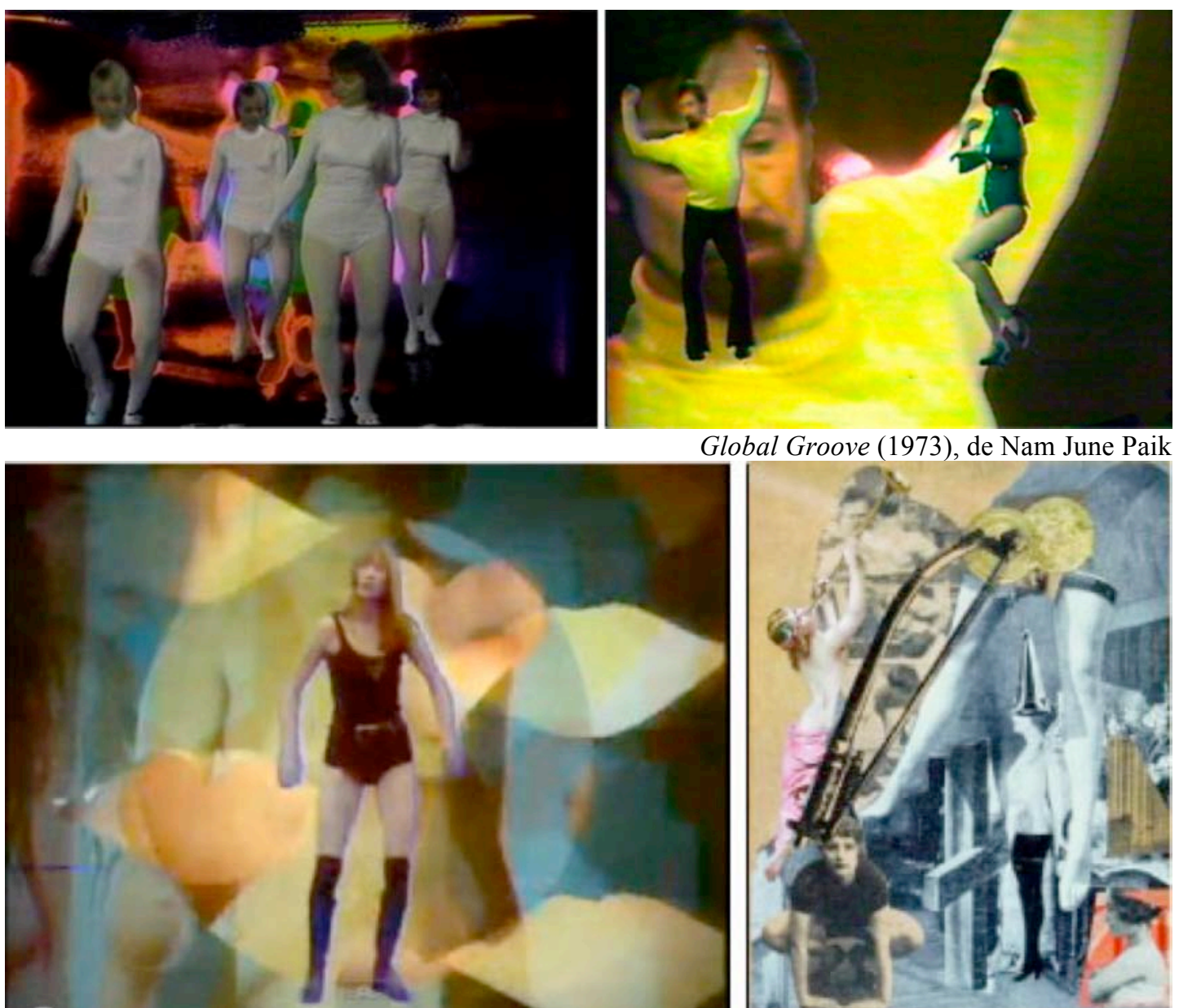

Izquierda. Histoire de Melody Nelson (1971), de Averty. Derecha. Höch: "DADA-ERNST" (1920-21)

El corto digital Ryan (2004), dirigido por Chris Landreth, es un homenaje al artista canadiense Ryan Larkin, quien fuera nominado a un Oscar por su animación Walking (1969). Landreth insiste en el contraste entre la personalidad del dibujante y el glamour de las estrellas de Hollywood durante la entrega de los premios de la Academia de aquel año. Lejos de reproducir un registro de la ceremonia, el autor retrata la época mediante la misma construcción espacial que reinaba en el videoarte contemporáneo: un collage semejante al de Averty. En lugar de fundir figura y fondo en una composición transparente, la exhibición de las capas del constructo juega con la falta de integración de los dos "outsiders". La estratificación de la imagen se subraya no sólo mediante un recorte bruto, sino gracias a una coloración expresiva, que forma parte de lo que Landreth define como "psicorrealismo"" , marca gráfica de todo el cortometraje.

\footnotetext{
${ }^{16} \mathrm{El}$ autor se refiere así al uso de gráficos por ordenador: "Unlike the way they're generally used, to doggedly recreate photorealism or to tell superficially imaginative stories, what I think they can also be used for is to show (...) the psychological makeup of people and characters." LANDRETH, Chris.
} 


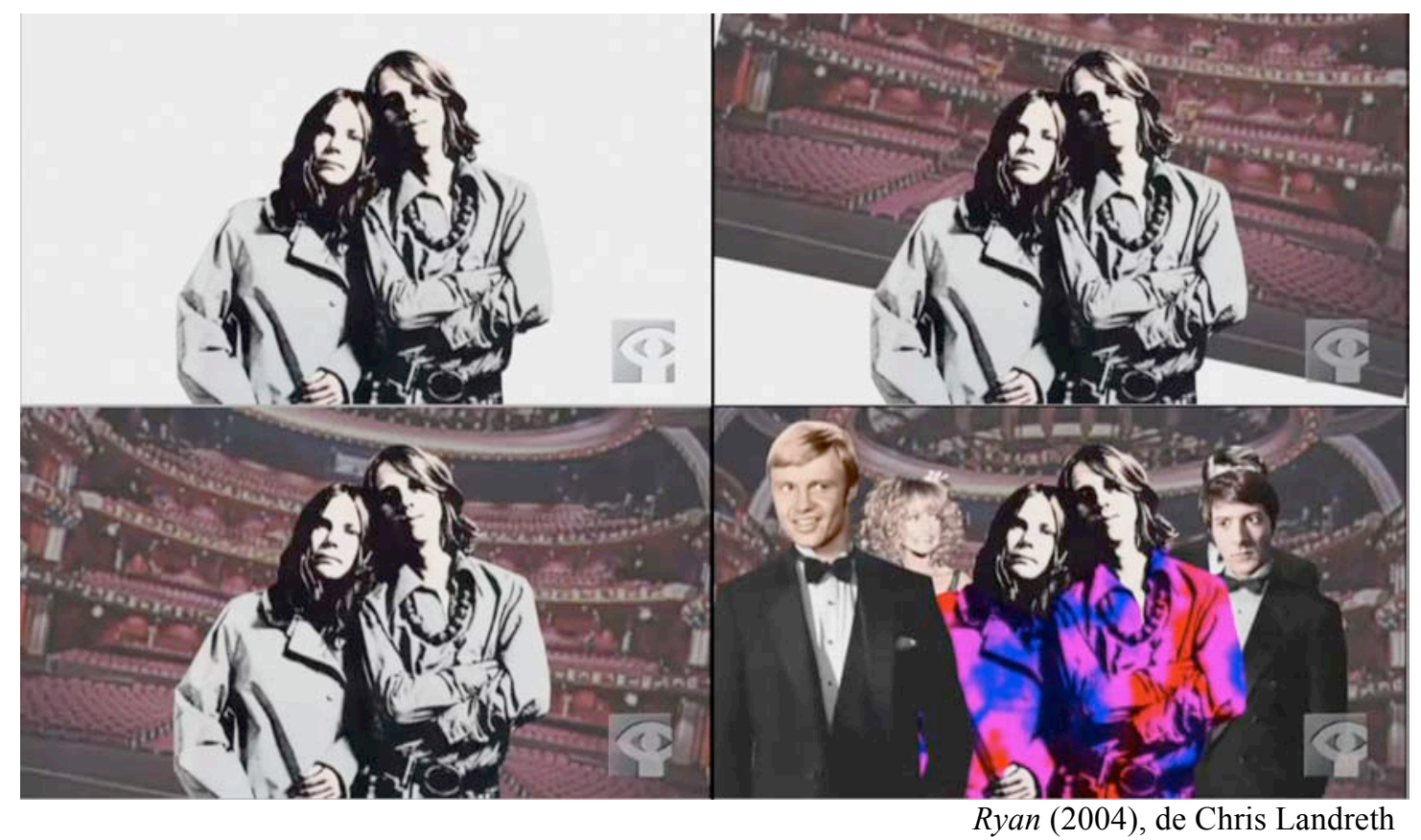

En Steps (1987), Zbigniew Rybczynski incrusta digitalmente un grupo de turistas americanos sobre la escena de la escalinata de Odessa en Bronenósets Potiomkin ("El acorazado Potemkin”) (1925), de Eisenstein. El contraste entre los grises de la película original y el vídeo en color acentúa la heterogeneidad de la mezcla en dos sentidos: por un lado, las distintas tecnologías (película fotográfica y vídeo) y, por otro, las dos temporalidades de las imágenes-fuente.

Comparemos la propuesta de Rybczynski con una escena de la película Forrest Gump (1994), dirigida por Robert Zemeckis. Seis años después de Who Framed Robert Rabbit? ${ }^{17}$, Zemeckis retoma la composición digital para mezclar diferentes medios en la imagen, manteniendo la continuidad espacial, pero subrayando el contraste provocado por la heterogeneidad de las imágenes de partida. Así, en Forrest Gump, el blue screen sirve para incrustar, sin rastro de montaje alguno, una toma del actor Tom Hanks en un archivo televisivo del presidente de los Estados Unidos John Fitzgerald Kennedy. La imagen en blanco y negro presenta un espacio tridimensional, integrado, por el que se desplaza el protagonista. La misma idea se repite con una imagen de John Lennon, esta vez, en color. A pesar de la perfecta fusión de la mezcla, el público reconoce tanto al actor como al presidente y al

Entrevista realizada por Gregory Singer. Landreth on Ryan [En línea]. Animation World Network, 4 de junio de 2004. Disponible en Web:

$<$ http://www.awn.com/articles/profiles/landreth-iryani/page/3\%2C1>

${ }^{17}$ En 1988, Robert Zemeckis lleva al cine la novela Who censored Rober Rabbit? (1981) de Gary K. Wolf. En la adaptación cinematográfica, los famosos personajes animados de Walt Disney interactúan con actores reales en espacios físicos registrados por la cámara. 
cantante, así como los distintos tiempos asociados a cada uno. Un contraste que alimenta la comicidad de la escena.
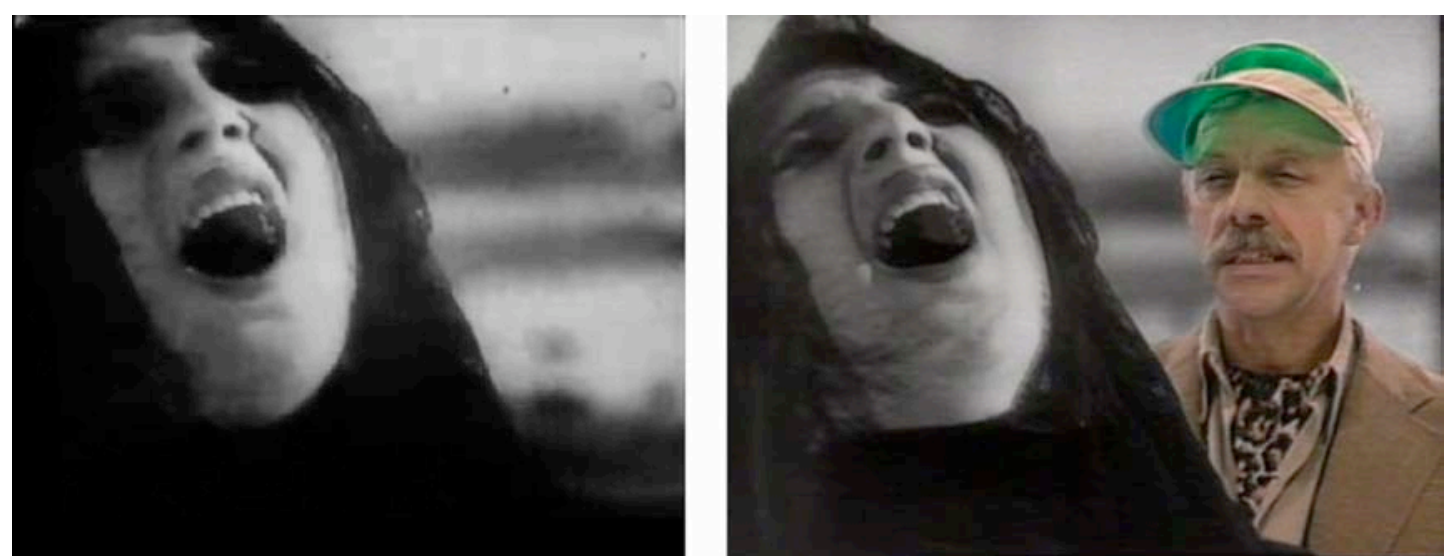

Izquierda. Bronenósets Potiomkin (1925), de Eisenstein. Derecha. Steps (1987), de Rybczynski

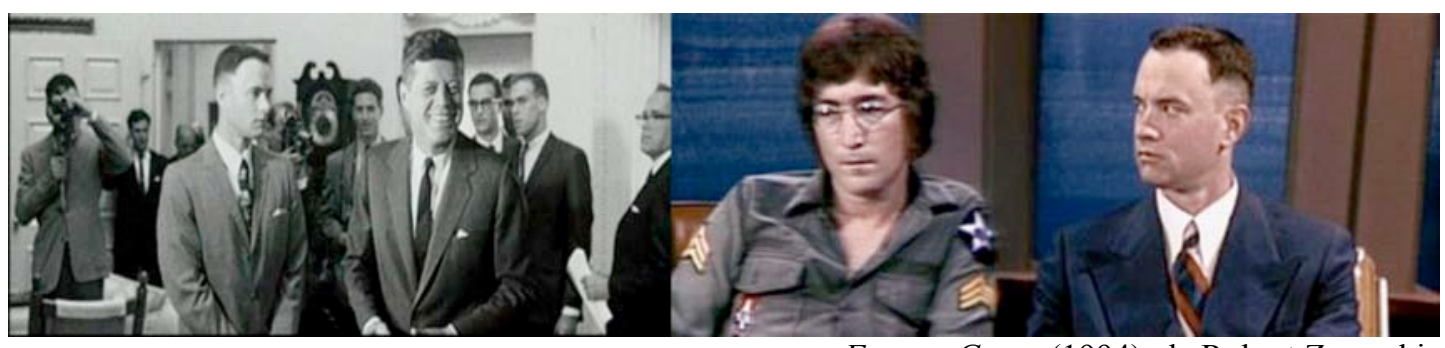

Forrest Gump (1994), de Robert Zemeckis

Tanto Zemeckis como Rybczynski juegan con la doble lectura que permite el found footage: la del material original en contraste con la nueva significación ligada a la apropiación. No obstante, allí donde Forrest Gump presenta una mezcla homogénea, Steps subraya la heterogeneidad de las imágenes-fuente y la construcción en capas. Esta exhibición del proceso de elaboración resalta el espacio de la imagen a expensas de la tridimensionalidad reproducida en los registros de partida. O dicho de otro modo: la "profundidad de la imagen" contrasta con la profundidad del espacio representado. Esta composición digital se basa en la concepción de la imagen como superficie bidimensional espesa; un "dessus/dessous" ("encima/debajo"), siguiendo la terminología de Philippe Dubois. ${ }^{18}$

\footnotetext{
${ }^{18}$ DUBOIS, Philippe. "La questions vidéo face au cinéma : déplacements esthétiques". En: BEAU, Frank; DUBOIS, Philippe; LEBLANC, Gérard. Cinéma et dernières technologies. Paris: De Boeck Université, 1998, p. 201.
} 


\section{La profundidad de la imagen}

Descubrimos un antecedente de este tipo de construcción espacial en una película de los años 20: Sunrise (1927), de Friedrich Wilhelm Murnau. La escena presenta el ensimismamiento del matrimonio mediante un efecto metacinematográfico: como en Steps, los personajes atraviesan, literalmente, la imagen ${ }^{19}$. Murnau presenta a la vez el espacio reproducido en la imagen y la condición de superficie de la misma. ${ }^{20}$

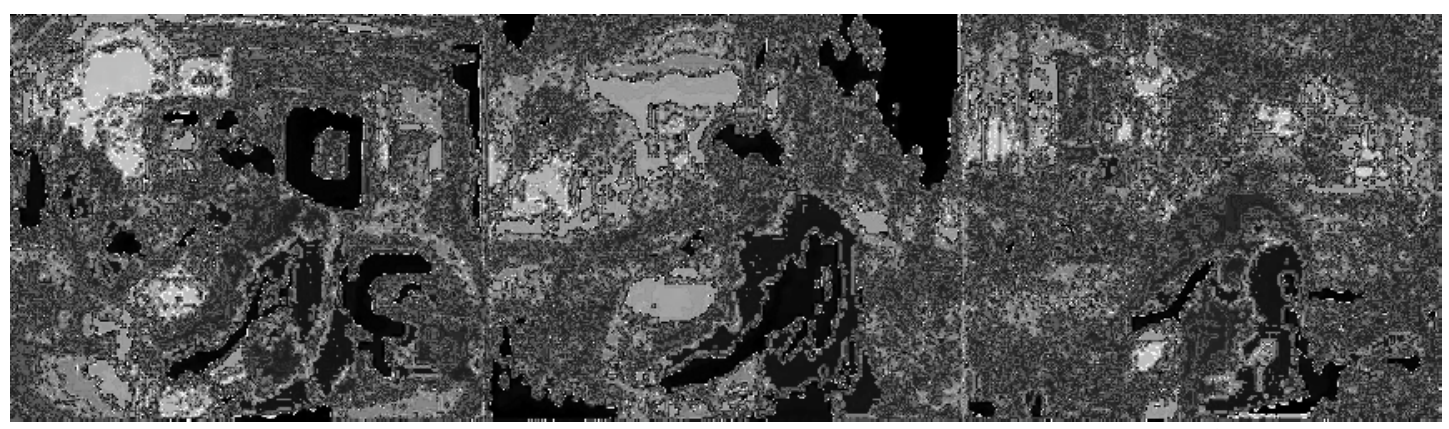

Sunrise (1927), de F. W. Murnau

En realidad, siete años antes de Steps, Rybczynski había explorada ya esta profundidad de la imagen y la mezcla heterogénea en Tango (1980). Desarrollado en una única habitación, el corto presenta una extraña estructura en bucle: repetidas de forma periódica, las acciones se acumulan en el espacio construido mediante la incrustación en capas.

La obra se inserta en una tendencia a la transformación del registro propia del videoarte de los años 70. El estadounidense Ed Emshwiller trabaja la imagen videográfica combinándola con gráficos por ordenador. Su Crossings and Meetings (1974) contiene pistas de exploración plástica presentes en Tango: las incrustaciones permiten apilar copias de la misma toma. Con todo, frente a la gran cantidad de personajes que Rybczynski hace convivir en la pequeña habitación, Emshwiller se conforma con un hombre y una mujer, cuyas siluetas acumula sobre un fondo neutro. Si el polaco apuesta por el alboroto, el estadounidense persigue el ritmo: la

\footnotetext{
${ }^{19}$ Tal y como lo describe Jacques Aumont: "La fiction est plus troublante - et plus euphorique lorsque, au lieu de jouer sur la latéralité et sur la profondeur de l'espace, cette intégration du cadre au film joue sur une profondeur d'image, comme dans le passage de L'Aurore où les deux époux, tout à leur rêve de bonheur, ne savent plus qu'ils marchent dans la rue d'une ville et croient tout bonnement marcher dans l'image (...)." AUMONT, Jacques. Matière d'images. Paris: Images modernes, 2005, p. 92.

${ }^{20}$ El especialista en efectos fotográficos Frank Williams compuso la imagen mediante un "travelling matte", una máscara negra que cambia de posición o de forma al tiempo que los objetos que oculta.
} 
multiplicación de las figuras se acompaña de modulaciones del sonido, aceleraciones y rebobinados. Explorando el paralelismo entre la composición visual y la musical, Emshwiller se refiere al constructo como una "fuga visual" 21 .

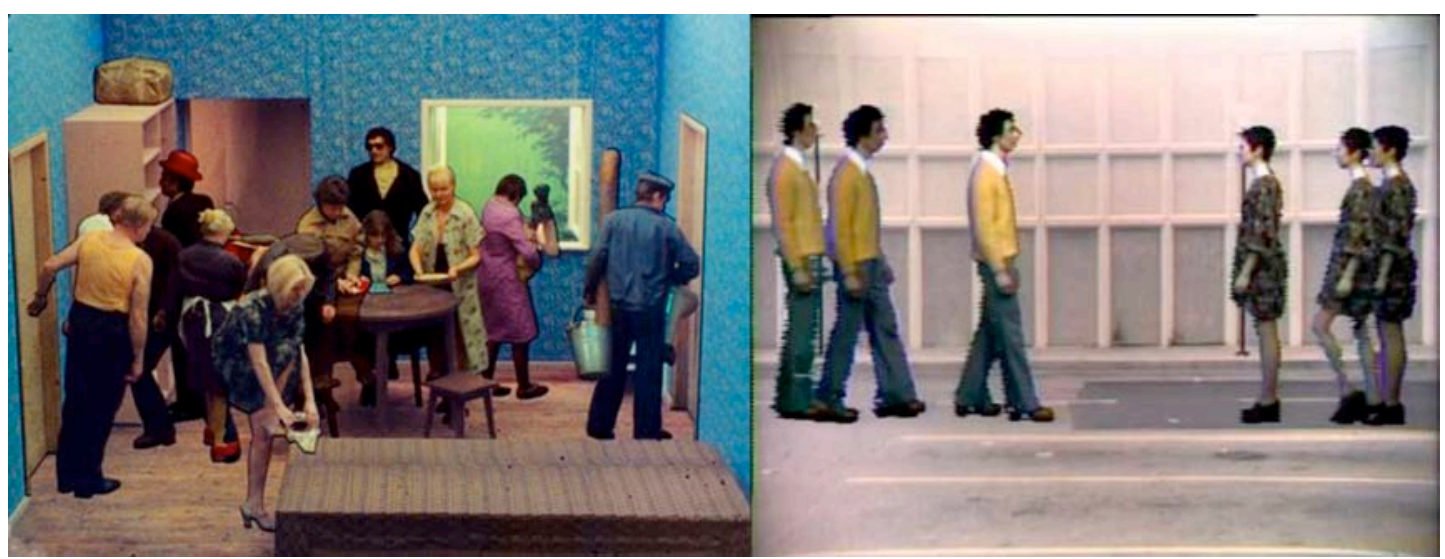

Izquierda. Tango (1980), de Rybczynski. Derecha. Crossings and Meetings, (1974), de Ed Emshwiller

Rybczynski ve en el vídeo una apertura a un espacio-tiempo variable: "El vídeo no es de ninguna manera una ventana abierta al mundo, salvo si se hace coincidir ese espacio homogéneo con un tiempo que no lo es." 22 Este rechazo a la metáfora de Alberti, a la concepción de la imagen como una ventana abierta al espacio tridimensional representado, es palpable ya en la pintura moderna. La revolución artística de mediados del siglo XIX se basó, precisamente, en la reivindicación contraria: la de la materia pictórica del lienzo y los pigmentos, ligada al espacio bidimensional del cuadro. Durante los años 20, esta concepción del espacio de la imagen continúa en el medio cinematográfico.

Uno de los ejemplos más claros es la aparente rotura del cristal del objetivo en L'étoile de mer (1928) de Man Ray. Como resultado del resquebrajamiento, se generan dos capas: la que da la impresión de ser el mismísimo objetivo de la cámara (la ventana abierta al mundo de los símbolos, manifestándose como trucaje cinematográfico) y la imagen fotográfica detrás, aplanada por la falta de nitidez. De este modo, en lugar de limitarse a la reproducción del espacio tridimensional registrado por la cámara, Man Ray concede el protagonismo a la profundidad de la imagen, dividida en dos capas paralelas. Encontramos un efecto semejante en el videoclip Get On Your Boots (2009) de Alex Courtes para U2 y en Welcome to

\footnotetext{
${ }^{21}$ ZIPPAY, Lori (ed.). Artists' Video: An International Guide. New York: Cross River Press, 1991, p. 77.

${ }^{22}$ Zbig Rybczynski. Apud. PARFAIT, Françoise. Op. cit., p. 116.
} 
Heartbreak (2009), de Nabil para Kanye West. Ambas imágenes digitales se presentan, así, como reivindicación del constructo espacial frente a la reproducción, encarnada en la metáfora de la ventana.

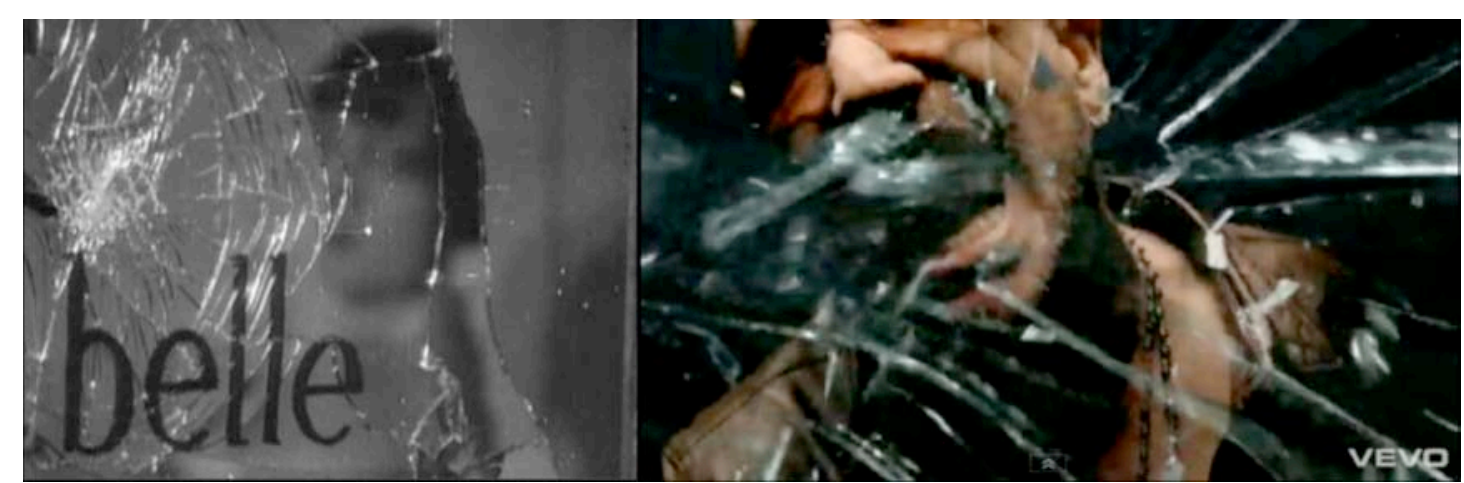

Izquierda. L'étoile de mer (1928) de Man Ray. Derecha. Get On Your Boots (2009), de Alex Courtes
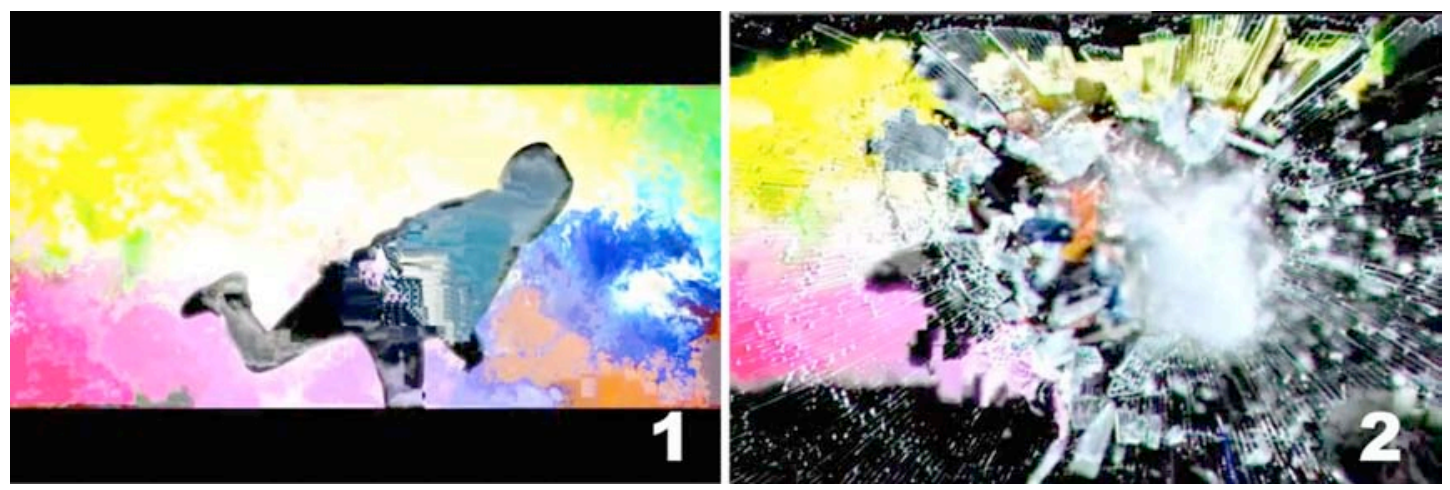

Welcome to Heartbreak (2009), de Nabil para Kanye West

Habiendo construido su Digital Image Articulator (1978), Woody Vasulka explica así su admiración por el sintetizador analógico Rutt-Etra Scan Processor (1972): "Su poder estaba en la transformación del fotograma tradicional de la película en un objeto ilimitado, flotando en un espacio indefinido de identidad perdida: ya no más la ventana a 'la' realidad, ya no más la 'verdad'."23 Con su rechazo a la metáfora de Alberti, Vasulka subraya el distanciamiento de la perspectiva y de la reproducción de la imagen huella.

En su Art of Memory $(1987)^{24}$, el artista se sirve de la tecnología digital para desarrollar el proyecto estético que había iniciado con la imagen electrónicaanalógica: en busca de lo específicamente videográfico, se distancia del lenguaje cinematográfico y el montaje temporal de los planos. Frente al corte, la imagen

\footnotetext{
${ }^{23}$ Woody Vasulka. Apud. DUNN, David (ed.). Eigenwelt der Apparate-Welt. Pioneers of Electronic Art. Linz: Ars Electronica, 1992.

${ }^{24}$ El título hace referencia al libro de la historiadora inglesa Frances Yates, The Art of Memory (1966). YATES, Francis A.. The Art of Memory (1966). Pimlico, 1992.
} 
electrónica (analógica primero y digital después) se define por la continuidad en las mutaciones espaciales.

Sobre bellos paisajes americanos, Vasulka incrusta imágenes de archivo que dan cuenta del horror del siglo XX: la revolución rusa, la guerra civil española, la segunda guerra mundial, la bomba atómica... Las siete secciones en que se estructura Art of Memory se ligan entre sí mediante metamorfosis; esto es, el corte es sustituido por la mezcla. Frente a la huella de la instantánea fotográfica o de la toma documental, Vasulka subraya la plasticidad de la memoria, que halla un eco en la plasticidad de la imagen electrónica y su manipulación digital.

En realidad, son varios los artistas que exploran la conexión de la imagen electrónica y la memoria visual. ${ }^{25}$ Así, Jean-Luc Godard presenta en Histoire(s) $d u$ cinema (1988-1998) una historia visual del cine a través de sus imágenes. La propuesta encaja con la definición de Hans Belting del medio videográfico como "una prótesis de nuestra memoria visual" ${ }^{, 26}$. Godard funde las imágenes de tal forma que unas quedan engarzadas en otras, generando una cadena continua de apariciones y desapariciones, sólo interrumpida por el juego irónico de los intertítulos. Nuevamente, la discontinuidad del corte da paso a la fusión. Ahora, si Vasulka acude a la incrustación opaca, Godard prefiere la transparencia de la sobreimpresión.

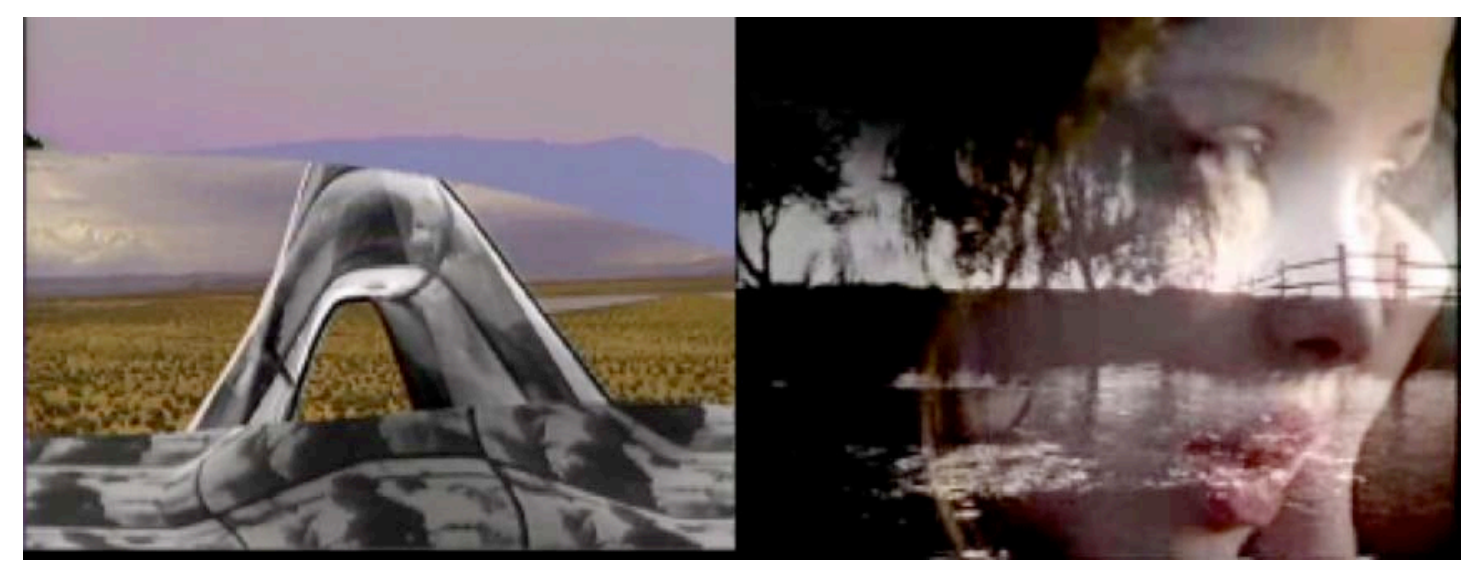

Izquierda. Art of Memory (1987), de Vasulka. Derecha. Histoire(s) du cinéma (1997), de Godard

\footnotetext{
${ }^{25}$ Tal y como explica Marita Sturken: "video has increasingly become a medium in which issues of collective and individual memory are being examined. The politics of memory and identity, the elusiveness of personal memory, and the relationship of camera images to national and cultural memory have become topics explored by artists in video." STURKEN, Marita. "The Politics of Video Memory: Electronic Erasures and Inscriptions". En: RENOV, M.; SUDERBURG, E. (eds.). Resolutions: Contemporary Video Practices. Minneapolis: University of Minnesota Press, 1996, p. 2.

${ }^{26}$ BELTING, Hans. Bild-Anthropologie: Entwürfe für eine Bildwissenschaft. München: W. Fink, 2001, p. 83.
} 


\section{La sobreimpresión}

Tal y como apuntábamos al principio de este apartado en relación a la película Spider-Man de Sam Raimi, la mezcla puede mantener la opacidad de las capas o, por el contrario, potenciar la confusión visual entre las mismas acentuando su transparencia. Frente a la composición, que puede dar forma a un espacio tridimensional integrado, toda sobreimpresión pone en evidencia la bidimensionalidad de la imagen: su condición hojaldrada. Con todo, frente a las construcciones espaciales que subrayan la profundidad de la imagen, la transparencia de las capas puede descomponer, incluso, la relación figura/fondo. ${ }^{27}$

La sobreimpresión es una superposición de imágenes de modo que cada estrato incorporado tenga un grado de transparencia tal que permita ver los demás de forma simultánea. Percibida como conjunto, la imagen resultante es un todo heterogéneo pero unitario, una especie de palimpsesto esencialmente complejo. Esta complejidad es el resultado no tanto de la cantidad de información apilada, sino de la falta de códigos de interpretación de los que dispone el receptor. La suma de varias imágenes no es la suma de sus contenidos, sino el producto de la interacción entre ellos:

"No podemos comprender la mezcla de dos imágenes como el simple pensamiento de 'I+I'; el ojo lo rechaza, las imágenes mezcladas no se suman ni se restan, sino que interactúan, forman una nueva entidad compleja."28

Aunque el uso de la sobreimpresión se remonta a los inicios del cinematógrafo $^{29}$, este tipo de montaje espacial es especialmente frecuente en el cine de las vanguardias históricas, las cuales, como veíamos más arriba, exploran un espacio específico de la imagen. ${ }^{30}$ La transparencia de las capas permite, por ejemplo, presentar sobre el rostro de un personaje su punto de vista, su estado de ánimo o su

\footnotetext{
${ }^{27}$ Arnheim explica así esta relación: "La bidimensionalidad como sistema de planos frontales está representada en su forma más elemental por la relación de figura y fondo. Aquí no se tienen en cuenta más que dos planos. Uno de ellos ha de ocupar más espacio que el otro, y de hecho tiene que ser ilimitado; la parte directamente visible del otro tiene que ser más pequeña y estar delimitada por un borde. Uno de ellos se sitúa delante del otro. Uno es la figura, el otro es el fondo." ARNHEIM, Rudolf. Arte y percepción visual. Madrid: Alianza Editorial, 1995, p. 255.

${ }^{28}$ AUMONT, Jacques. Matière d'images. Redux. Paris: Éditions de la Différence, 2009, p. 274.

${ }^{29}$ El propio Méliès se sirve de la sobreimpresión en Le chateau hanté (1897) y en Barbe-bleue (1901).

${ }^{30}$ Maticemos que la sobreimpresión es frecuente en el cine experimental en general. Así, en los años 60, la corriente de vanguardia contemporánea al videoarte hará uso de este montaje espacial en sus experimentos. Éste es el caso de Dog Star Man (1964), de Stan Brakhage.
} 
pensamiento, de manera semejante al caso citado de Spider-man. Hallamos un ejemplo paradigmático en La coquille et le clergyman (1928), de Germaine Dulac.

La sobreimpresión es una forma fundamental de lo onírico, que el cine surrealista ha sabido explotar, como muestra Un chien andalou (1929) de Luis Buñuel y Salvador Dalí. Fascinados por el inconsciente, el azar y las conexiones improbables, los surrealistas acuden al montaje espacial como visualización del sueño y de sus relaciones espacio-temporales: lo distante y lo opuesto se funden en una sola entidad. Tal y como afirma Moholy-Nagy: "La sobreimpresión es la mejor técnica visual para registrar el sueño porque sobrepasa el tiempo y el espacio, y permite fundir en un solo conjunto coherente sujetos heterogéneos." 31

Por su parte, el realizador soviético Dziga Vertov pretende crear una interacción entre puntos distantes en el espacio y/o en el tiempo. El "intervalo" como fundamento de su teoría del montaje consiste en las relaciones abstractas (forma, duración, encuadre...) que se establecen entre varias imágenes. Generalmente, este concepto se refiere al montaje temporal; no obstante, las sobreimpresiones de Chelovek $s$ kinoapparatom pueden ser interpretadas en el mismo sentido.

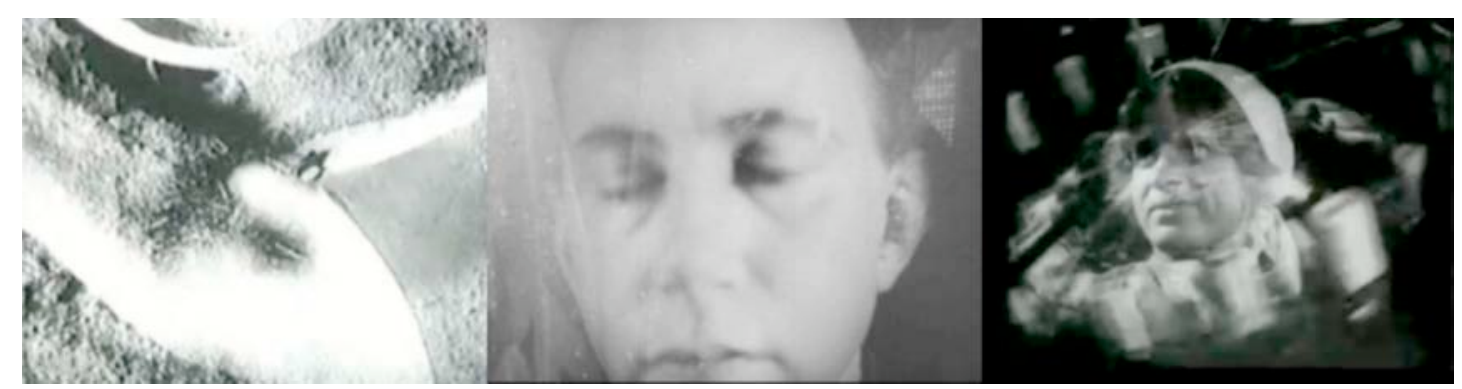

Izquierda. Un chien andalou (1929), de Luis Buñuel. Centro. La coquille et le clergyman (1928), de Dulac. Derecha. Chelovek s kinoapparatom (1929), de Dziga Vertov

Cuando la sobreimpresión permite el paso fluido y progresivo entre las imágenes se habla de "fundido encadenado". Encontramos numerosos ejemplos en la película Varieté (1925) de E. A. Dupont y en Citizen Kane (1941), de Orson Welles. En la primera, el fundido encadenado sirve para presentar los números de un espectáculo circense. Este elemento descriptivo aparece también en la apertura de Citizen Kane y la presentación del palacio Xanadu; en lugar de utilizar un zoom, Welles se sirve de una cadena de sobreimpresiones desde la verja del jardín hasta la ventana de la habitación de Kane. Si en Varieté el montaje espacial permite condensar

\footnotetext{
${ }^{31}$ MOHOLY-NAGY, László. Peinture, photographie, film, et autres écrits sur la photographie (1925). Nîmes: Jacqueline Chambon, 1993, p. 252.
} 
la duración del espectáculo, en Citizen Kane implica un ligero pasaje del tiempo. Más adalante, trataremos este tipo de transiciones espacio-temporales, caracterizadas por la continuidad espacial en contraste con el corte del montaje temporal.

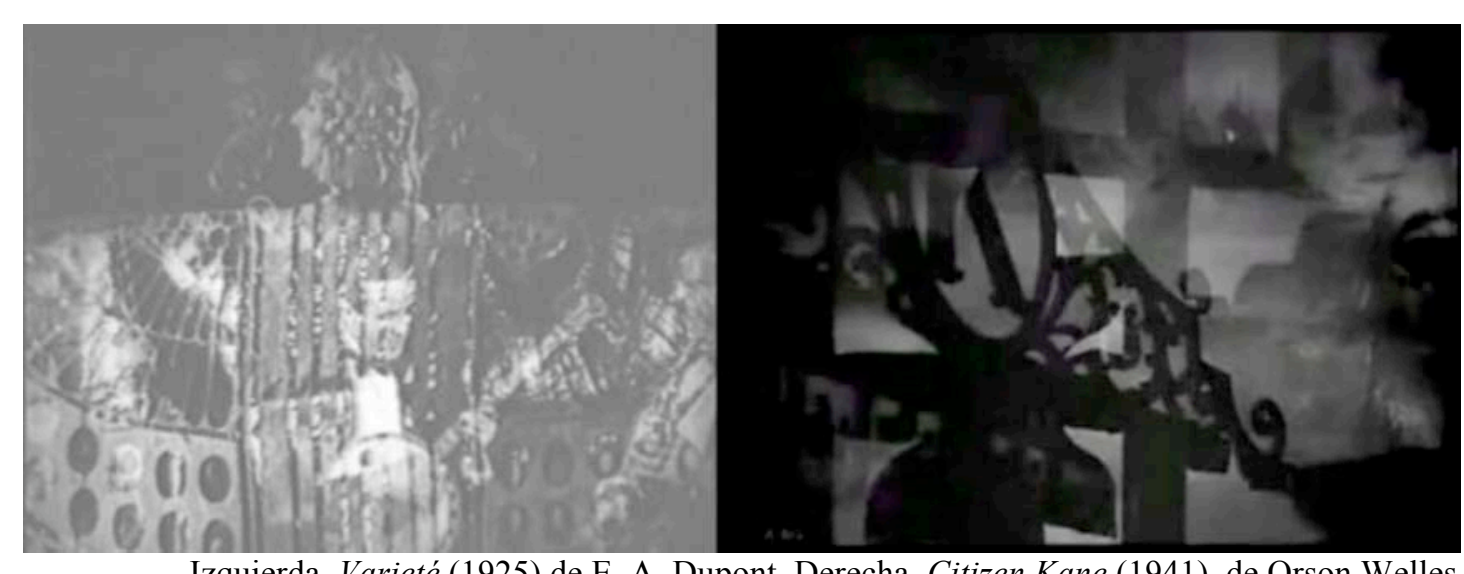

Izquierda. Varieté (1925) de E. A. Dupont. Derecha. Citizen Kane (1941), de Orson Welles

En la creación digital, el fundido encadenado se utiliza, también, como dinamización de imágenes fijas. Esta forma de construcción espacial es frecuente en la obra del artista Jeremy Blake (1971-2007). En el videoclip Round The Bend (2002) para Beck, el rostro del cantante es invadido por masas cromáticas abstractas. El flujo de transformaciones presenta una activación específica de la imagen, que nada debe al registro de un movimiento profílmico. Acabaremos nuestro trabajo con un recorrido por distintas formas de dinamización digital más allá de la mera reproducción; por el momento, nos interesamos por el fundido encadenado en cuanto forma parte del proceso de elaboración del morphing, este sí, exclusivamente digital.
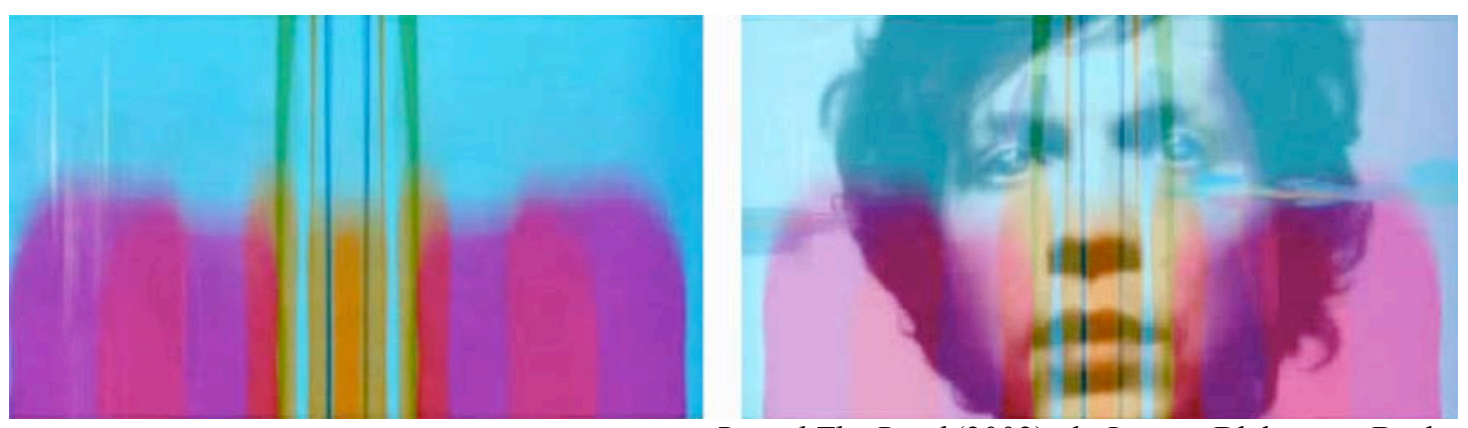

Round The Bend (2002), de Jeremy Blake para Beck

Como explicaremos detenidamente en el próximo apartado, mientras que el fundido encadenado se produce de manera simultánea en las distintas capas que forman la imagen compuesta, subrayando la heterogeneidad del constructo, con la 
tecnología digital, es posible crear una mezcla homogénea que tenga lugar a nivel atómico. La matriz digital es un mosaico de píxeles, cada uno de los cuales indica su posición en el espacio, su color y su brillo. Gracias a esta red numérica, cualquier imagen, sea cual sea su procedencia, es ilimitadamente modificable. Uno de los máximos exponentes de esta plasticidad es el morphing. 


\section{EL MORPHING}

Comenzamos este apartado con el nacimiento y la descripción técnica de este efecto digital, apuntando la relación del mismo con el fundido encadenado. A continuación, distinguiremos entre la visualización de metamorfosis dentro de la ficción y un uso más "simbólico" de esta construcción espacial. Para acabar, recordaremos el debate en torno al llamado "morphing racial", que nos permitirá profundizar en las implicaciones del carácter continuo de la transformación digital.

\section{El anhelo de metamorfosis}

La construcción de metamorfosis es frecuente entre las primeras animaciones por ordenador de la historia. Dábamos inicio a este trabajo con la obra de Charles Csuri. A mediados de los años 60, el pionero del arte por ordenador escanea sus propios dibujos, que utiliza a continuación como materia prima para la transformación digital: si en Aging Process (1968) una joven se transforma en una anciana, Artist into Frog (1968) exhibe la metamorfosis de un rostro humano en una rana. La cuestión no es el naturalismo de los dibujos iniciales o la mímesis de un movimiento, sino la recombinación continua de las líneas. Csuri explora, así, la activación de la imagen mediante el cálculo informático: a partir de los dibujos iniciales, el ordenador calcula la combinación más sencilla para dar paso de uno a otro. Un proceso de "interpolación" semejante será más tarde integrado en programas de animación digital como Adobe Flash, basados en la definición de "key frames", que corresponden a los elementos primero y final de una mutación.

En la misma época, el húngaro Peter Foldes crea su cortometraje Visages des femmes (1968). Si bien en papel y celuloide, la animación da cuenta del interés del autor por la transformación. El descubrimiento posterior del ordenador le permitirá profundizar en la metamorfosis como dinámica. De su colaboración con Nestor Burtnyk y Marceli Wein, nacerán los cortos Metadata (1971) y La faim (1974). En ambos, los diseños son realizados a mano con un bolígrafo electrónico, directamente sobre la pantalla, para a continuación calcular las imágenes intermedias.

En las antípodas del montaje temporal que caracteriza el cine clásico y que adopta también el dibujo animado, La faim presenta una transición entre las imágenes 
que funciona como enlace y contenido de la narración. El corto muestra a un hombre que come cuanto lo rodea, engordando y deformándose hasta acabar devorado por niños hambrientos. La acción se desarrolla a través de la mutación de las formas en un fluido constante en el interior del cuadro: el hombre se transforma en el mismo coche que va a transportarlo o en la mesa en la que se dispone a comer; la carta del restaurante muta en camarera; la camarera, en helado; el hombre y la camarera se convierten en un mismo coche... Todas las figuras de la imagen son potencialmente intercambiables, de modo que el movimiento no corresponde al desplazamiento de la figura, sino a la transformación de la misma.

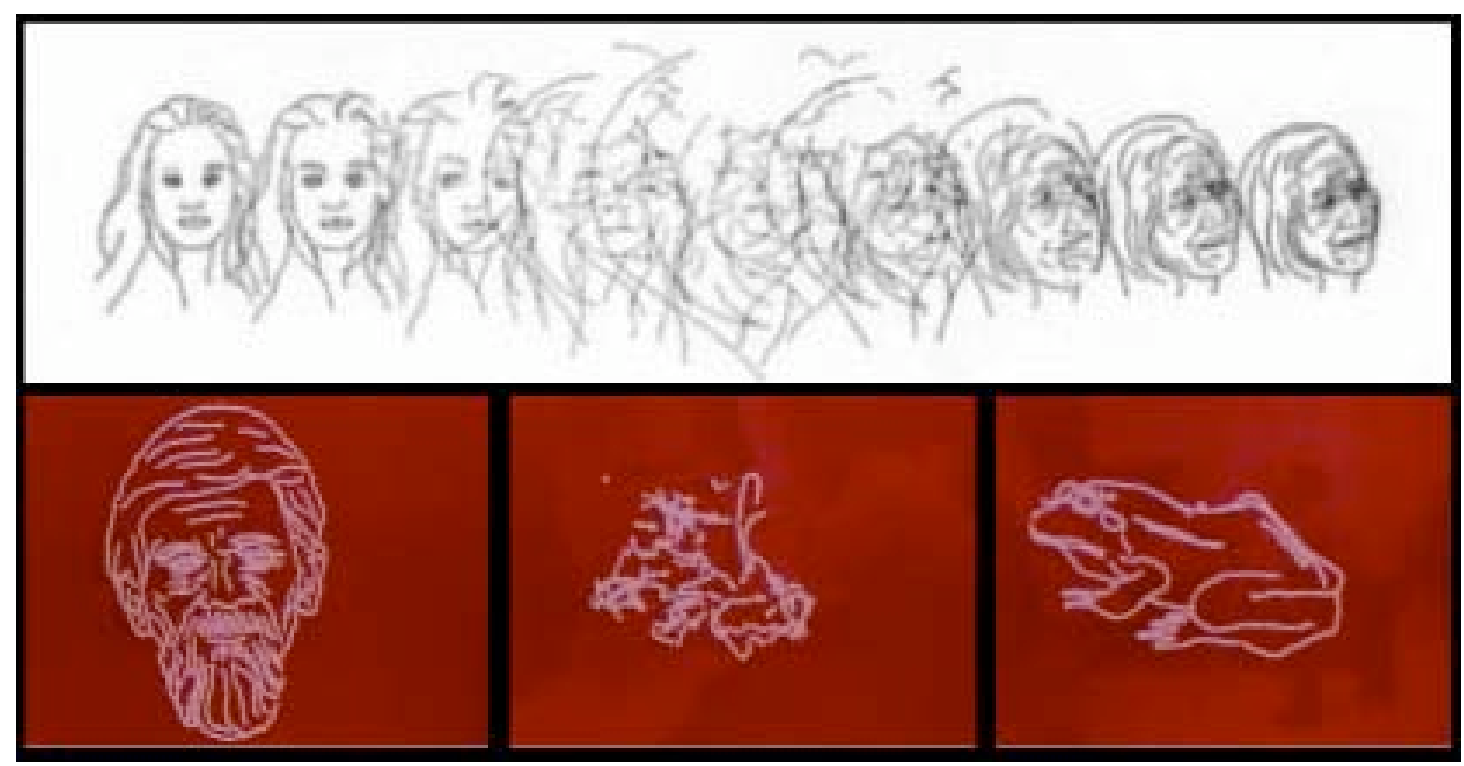

Arriba, Aging Process. Abajo, Artist into Frog. Ambas de Charles Csuri (1968)
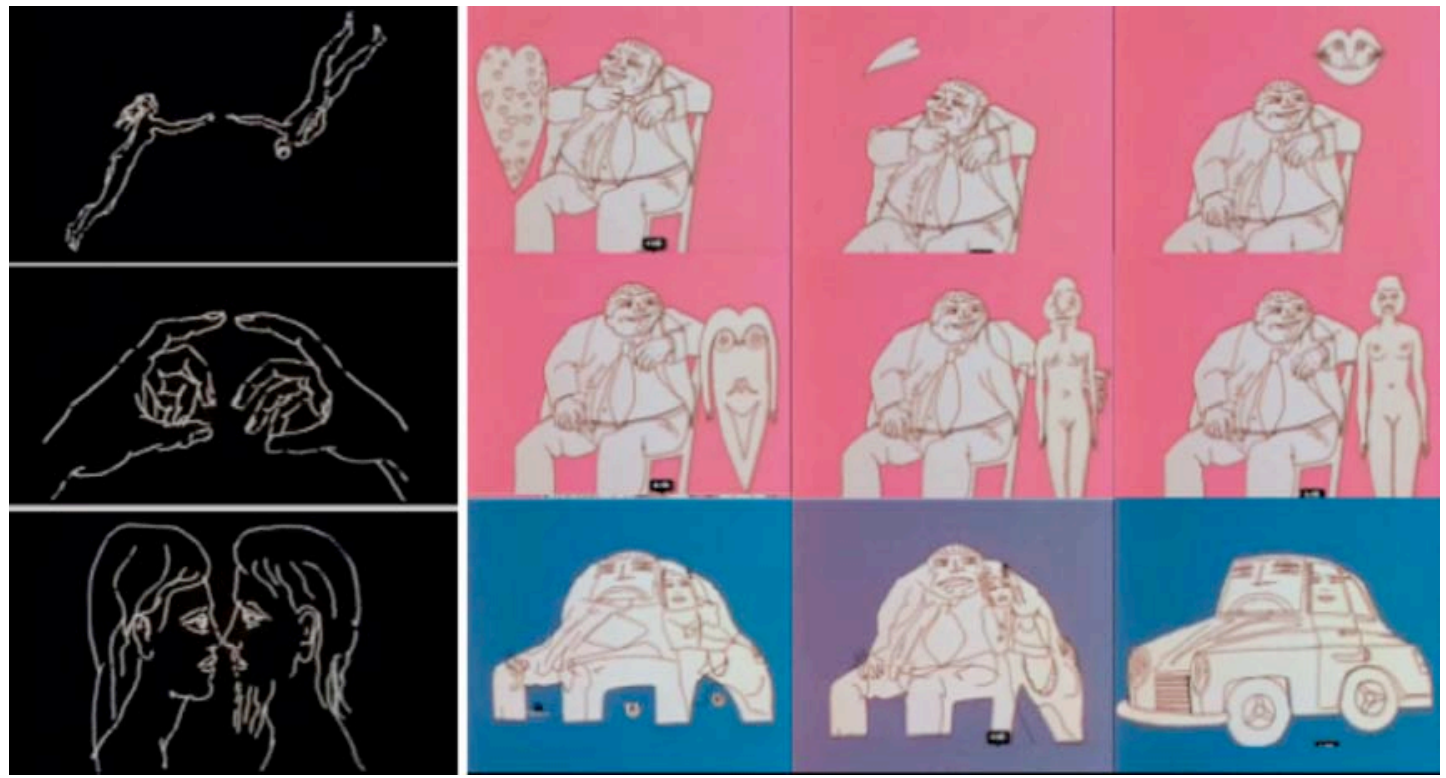

Izquierda. Metadata (1971). Derecha. La faim (1974). Ambas de Peter Foldes 
Conviene aclarar que la metamorfosis no es exclusiva de la imagen digital: en realidad, hallamos ejemplos en los primeros dibujos animados. Pensemos, por ejemplo, en la obra del caricaturista francés Emile Cohl. En Fantasmagorie (1908), la metamorfosis de los objetos permite hacer avanzar la historia: la botella en la que se encuentra el protagonista se transforma en flor, la cual cambia en elefante, y éste, en una casa. Las transformaciones se producen de forma lisa, sin tener en cuenta la proporción. Dos años después, en The Hasher's Delirium (1910), Cohl presenta un hombre borracho que contempla sus propias alucinaciones; las figuras mutan entre sí en una cadena de metamorfosis: de "vin" a "vino" y a "wine"; de las letras a un racimo de uvas; de éste a una persona, a un faro, a una botella de champán, etc.
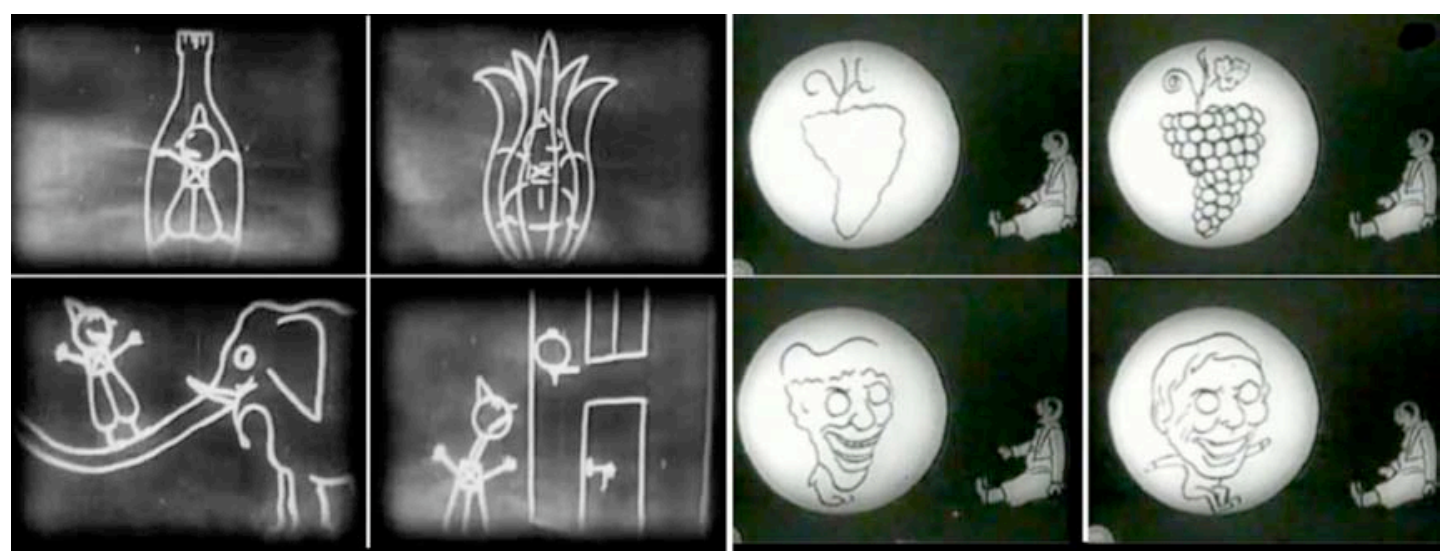

Izquierda. Fantasmagorie (1908). Derecha. The Hasher's Delirium (1910). Ambas de Emile Cohl

Aunque los dibujos animados de Emile Cohl y las animaciones sintéticas de Foldes y Csuri comparten la exhibición de la metamorfosis del espacio, un aspecto diferencia claramente las propuestas digitales: los pioneros del arte por ordenador exhiben el cálculo informático; las fases intermedias aparecen como una suerte de garabato que recombina las líneas del dibujo inicial. La tensión entre figuración y desfiguración es, así, explícita. Una distorsión semejante no es frecuente en la animación tradicional ${ }^{1}$. En general, la continuidad figurativa se explota como exhibición de las posibilidades del dibujo animado frente a la película fotográfica; en comparación con aquél, la imagen cinematográfica parece encorsetada en su condición de huella.

\footnotetext{
${ }^{1}$ No obstante, citamos como excepción la pieza experimental de Robert Breer A Man and His Dog Out for Air (1957): el dibujo animado muestra la mutación de las líneas en una cadena de composiciones abstractas.
} 
Así, la plasticidad del dibujo animado es anhelada por cineastas ávidos de nuevas imágenes. Entre ellos, Eisenstein afirma a propósito de su contemporáneo Walt Disney:

“¡Qué mágica reestructuración del mundo según su propia fantasía! De un mundo ficticio. De un mundo de líneas y de colores. Al cual se le ordena que se someta, que cambie de forma (...). Dices al pulpo que sea un elefante y él se convierte en elefante." 2

Artistas como Hans Richter se vuelcan tanto en la animación abstracta como en las posibilidades de la imagen cinematográfica, figurativa, más allá del mero registro del movimiento. En este contexto, el deseo de construir metamorfosis con la película fotográfica es explícito. El propio Richter se expresa así respecto a su Filmstudie (1926):

"Era en efecto un sueño lo que había inspirado primitivamente mi cortometraje Filmstudie, aunque el sueño se prolongó hasta el día. El resultado fue, sobre un ritmo lento, un cortejo de cabezas en suspensión que se metamorfosean en ojos, ojos que cambian en lunas, lunas en guisantes, guisantes en lluvia, que hace ondular la superficie del agua hasta formar olas, las cuales, finalmente, arrastran las cabezas, etc..."3
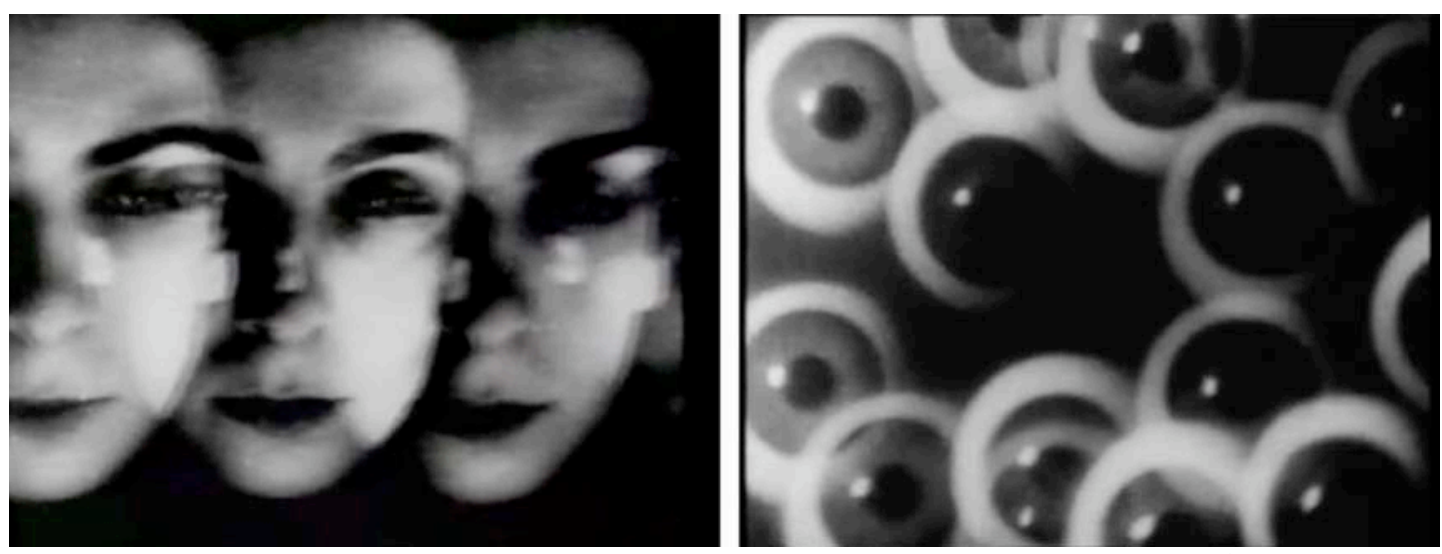

Filmstudie (1926), de Hans Richter

\footnotetext{
${ }^{2}$ EISENSTEIN, Sergueï. Walt Disney (1941). Strasbourg: Circé, 1991, p. 13.

${ }^{3}$ Hans Richter. Apud. MITRY, Jean. Le cinéma expérimental, histoire et perspectives (1971). Paris: Éditions Seghers, 1974, p. 143.
} 
En busca de ese efecto de metamorfosis, Richter se sirve de la sobreimpresión como convivencia de los momentos primero y último de la transformación, y de la multiplicación de las figuras, como las fases intermedias de la misma. Aunque la anhelada metamorfosis de la imagen cinematográfica no será posible hasta varias décadas después, Richter no se equivocó en su intuición: el efecto conocido como morphing es, en realidad, una variante digital del fundido encadenado; esto es, como adelantábamos ya en el apartado anterior, la mezcla de varias imágenes en el tiempo y la desaparición progresiva de la primera.

La animación por morphing (“image metamorphosis") permite la transición de una imagen a otra mediante la combinación de un fundido encadenado (crossdissolving) y la distorsión de las imágenes fuente (warping). ${ }^{4}$ Es decir, la diferencia frente a la sobreimpresión radica en una primera fase de elaboración consistente en deformar las imágenes de partida. La construcción espacial así creada se sitúa entre la interpolación de los pioneros del arte por ordenador y la mezcla por fundido encadenado. Si de ésta conserva la desaparición paulatina de la primera imagen a favor de la segunda, de aquélla toma el proceso intermedio de deformación. Ahora bien, nótese que, generalmente, en el morphing, el cálculo sintético aspira a la creación de un flujo armónico, figurativo, lejos de los garabatos abstractos creados por Csuri o Foldes.

Mientras que los precursores del arte por ordenador se limitan a dinamizar el contorno de las figuras, en el morphing, el cálculo de los valores intermedios afecta a la condición lumínica de los píxeles seleccionados. Grosso modo, el proceso se realiza mediante la designación de segmentos en las dos imágenes-fuente, de manera que las líneas definidas en la primera y el área que las rodea acaben por coincidir con las coordenadas prefijadas en la segunda. Frente al fundido encadenado, en el que las imágenes conviven en distintas capas, la información cromática de los píxeles de una imagen se transforma gradualmente hasta corresponder con la red de la segunda. La mezcla, heterogénea en la sobreimpresión, es homogénea en el morphing.

La imagen digital se caracteriza por su condición discreta ${ }^{5}$ : es decir, frente al frame o el fotograma, la unidad mínima es el píxel, accesible y manipulable de manera independiente. Siguiendo con la acertada fórmula de Roman Gubern, es

\footnotetext{
${ }^{4}$ BEIER, Thaddeus; NEELY, Shawn. "Feature-Based Image Metamorphosis". En: SIGGRAPH '92, Proceedings of the 19th annual conference on Computer graphics and interactive techniques. July 1992, vol. 26, núm 2, p. 36.

${ }^{5}$ MITCHELL, William J.. Op. cit., pp. 4-5.
} 
precisamente esta discontinuidad de los píxeles la que permite la continuidad evolutiva de las formas. ${ }^{6}$ Así, este aspecto atómico, lejos de implicar un desmembramiento del conjunto, garantiza la conexión formal entre las partes, dotando al espacio de su elasticidad característica.

Suele considerarse al informático Tom Brigham como el padre del morphing digital. $^{7}$ En 1982, Brigham fue premiado por el SIGGRAPH (Special Interest Group of Computer Graphics) tras presentar la metamorfosis fotorrealista de una mujer en un lince. El primer algoritmo de morphing aparece como la realización de un sueño: la metamorfosis de las formas registradas por la cámara fotográfica. Tal y como afirma Scott Bukatman: "si el siglo XIX soñaba con el cine, el siglo XX soñaba con el morphing., 8

\section{El morphing dentro de la ficción}

Como cabía esperar, los géneros cinematográficos de la ciencia-ficción y la fantasía dan buena cuenta del efecto para exhibir todo tipo de transformaciones dentro de la historia. En este caso, el morphing forma parte de la diégesis. ${ }^{9}$ Así, en The Golden Child (1986), Michael Ritchie retoma el ejemplo de Brigham para transformar un hombre en animal y viceversa. Dos años después, otra película, Willow (1988) de Ron Howard, muestra la mutación en cadena de distintos animales en una mujer. ${ }^{10}$ En general, el efecto de morphing se asocia con esta metamorfosis entre seres heterogéneos dentro de la ficción.

\footnotetext{
${ }^{6}$ GUBERN, Roman. "El laberinto digital". En: Del bisonte a la realidad virtual. La escena y el laberinto. Barcelona: Anagrama, 1996, pp. 133-155.

${ }^{7}$ Así es considerado en el programa del simposio sobre efectos especiales celebrado el 11 y 12 de febrero de 2000 en la Universidad de Stanford. Special Effects. The Stanford Presidential Lectures and Symposia [En línea]. Stanford, Cantor Arts Centre, February 11th-12th, 2000. Disponible en Web: $<$ http://prelectur.stanford.edu/symposia/effectsbios.html $>$

${ }^{8}$ BUKATMAN, Scott. "Morphing. Taking shape and the performance of self". En: SOBCHACK, Vivian. Meta-Morphing: Visual Transformation and the Culture of Quick Change. Minneapolis: University of Minnesota Press, 2000, p. 225.

9 "La diégèse est donc l'histoire comprise comme pseudo-monde, comme univers fictif dont les éléments s'accordent pour former une globalité. Il faut dès lors la comprendre comme le signifié ultime du récit: c'est la fiction au moment où non seulement celle-ci prend corps, mais aussi où elle fait corps." AUMONT, Jacques et al. Esthétique du film. Paris: Nathan, 1983, p. 80.

${ }^{10}$ Tras escanear los registros, las imágenes digitales así obtenidas fueron tratadas en un programa desarrollado por Doug Smythe. La técnica fue bautizada por su autor como "mesh warping". SMYTHE, Douglas B.. "A Two-Pass Mesh Warping Algorithm for Object Transformation and Image Interpolation”. ILM Technical Memo \#1030, Computer Graphics Department, Lucasfilm Ltd., 1990.
} 


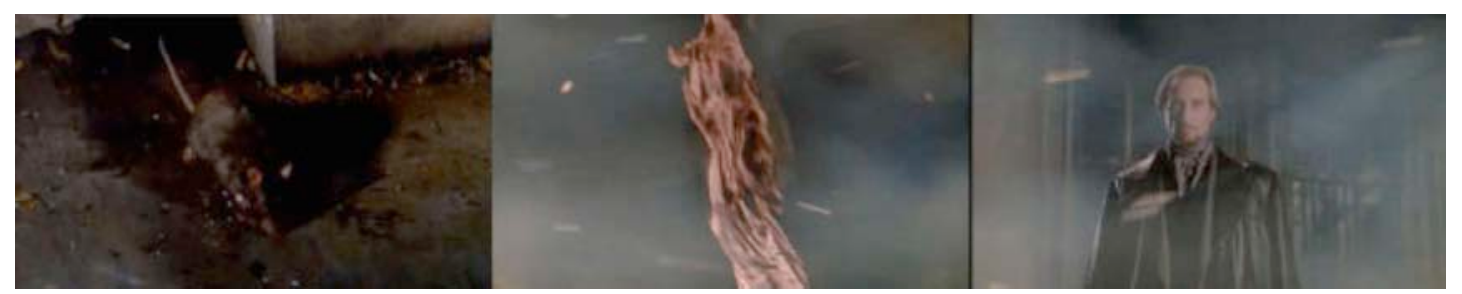

The Golden Child (1986), de Michael Ritchie
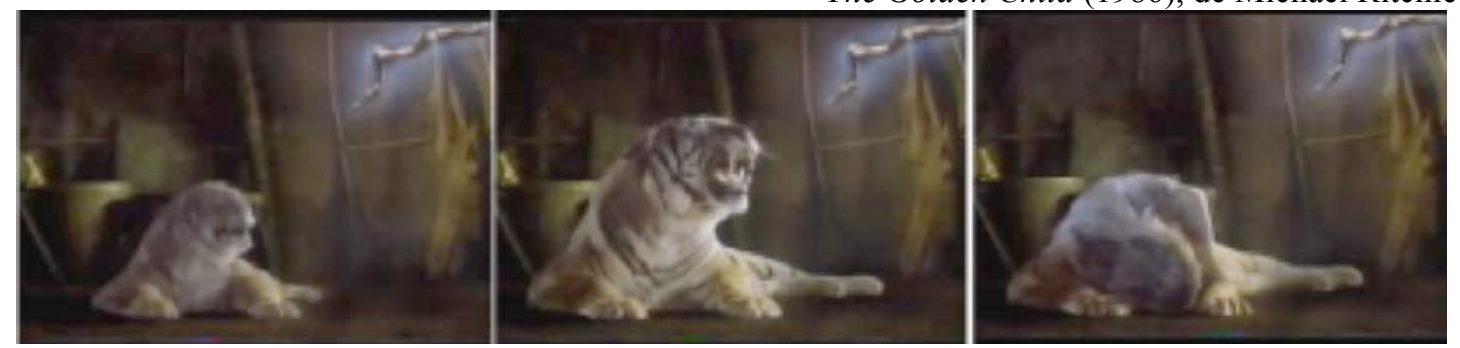

Willow (1988), de Ron Howard

Más de una década después, hallamos un caso paradigmático en la película Harry Potter and the Chamber of Secrets (2002), basada en el libro de J. K. Rowling ${ }^{11}$ y dirigida por Chris Columbus. Cuando la profesora de "Transfiguración" Minerva McGonagall (Maggie Smith) convierte un ave en una copa de cristal, el morphing de la figura presenta tanto el cambio continuo de la forma, como el paso de una sustancia a otra. No obstante, como veremos a continuación, la mutación puede, también, concentrarse en un solo ser deformándolo, envejeciéndolo, rejuveneciéndolo...

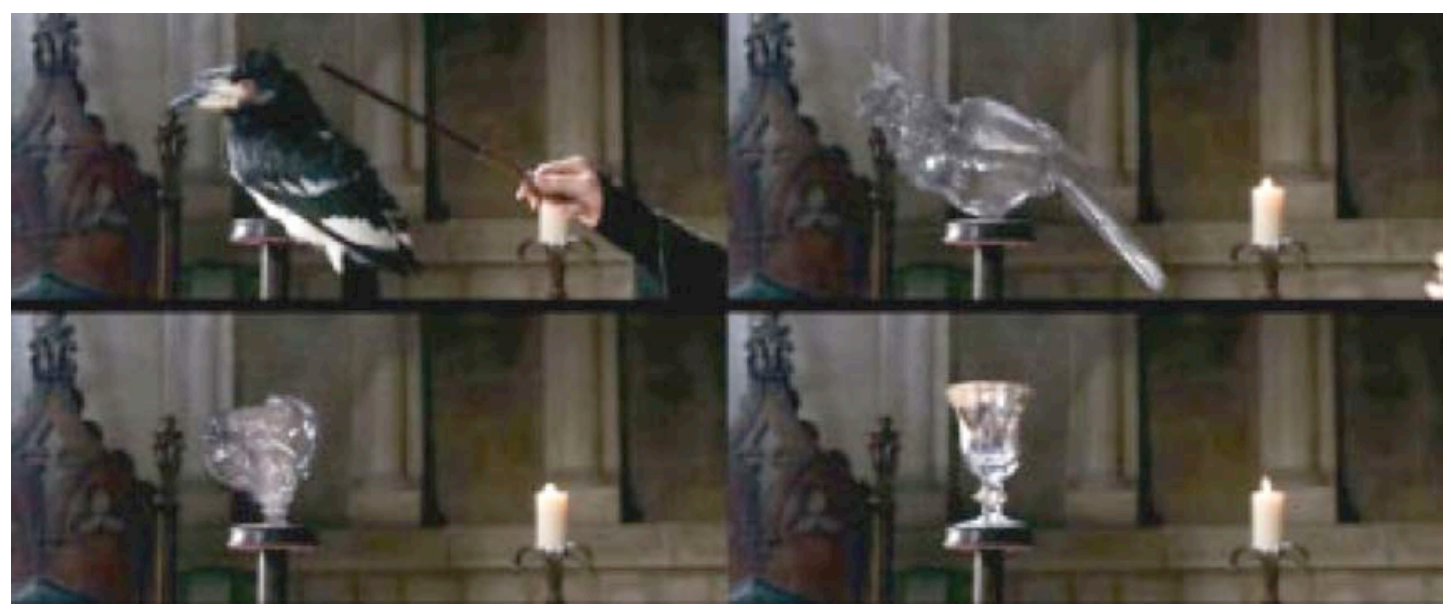

Harry Potter and the Chamber of Secrets (2002), de Chris Columbus

En la película Snow White and the Huntsman (2012), de Rupert Sanders, la malvada madrastra se encarna en otros seres y rejuvenece robándoles la energía vital. Un morphing figura el lifting del rostro de Charlize Theron, eco a los retoques de

\footnotetext{
${ }^{11}$ ROWLING, J. K.. Harry Potter and the Chamber of Secrets. London: Bloomsbury, 1998.
} 
Photoshop, típicos de las revistas de belleza. La transformación se presenta como una inversión: no se trata de un retroceso en el tiempo, sino de negar sus efectos. En Indiana Jones and the Last Crusade (1989), Steven Spielberg se deleita en el proceso contrario: la descomposición macabra del rostro del personaje de Walter Donovan, interpretado por Julian Glover.
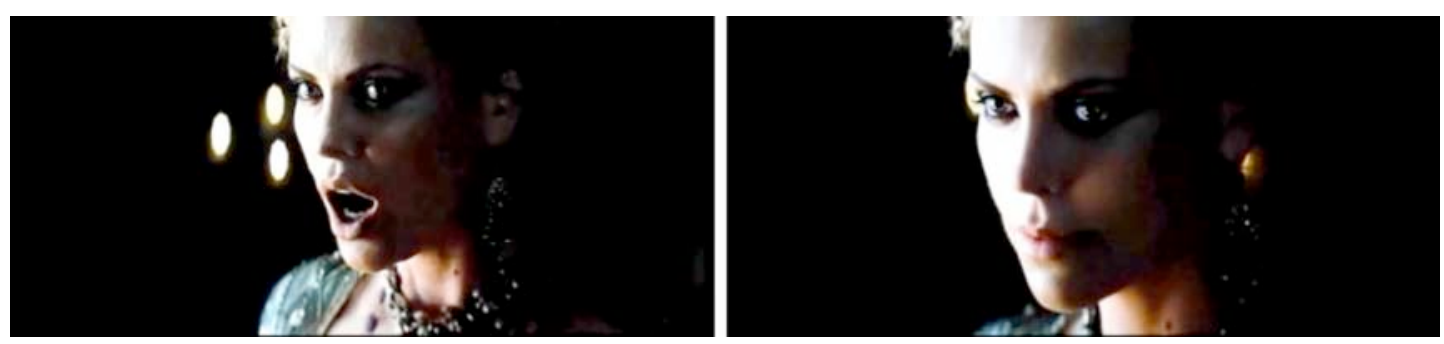

Snow White and the Huntsman (2012), de Rupert Sanders

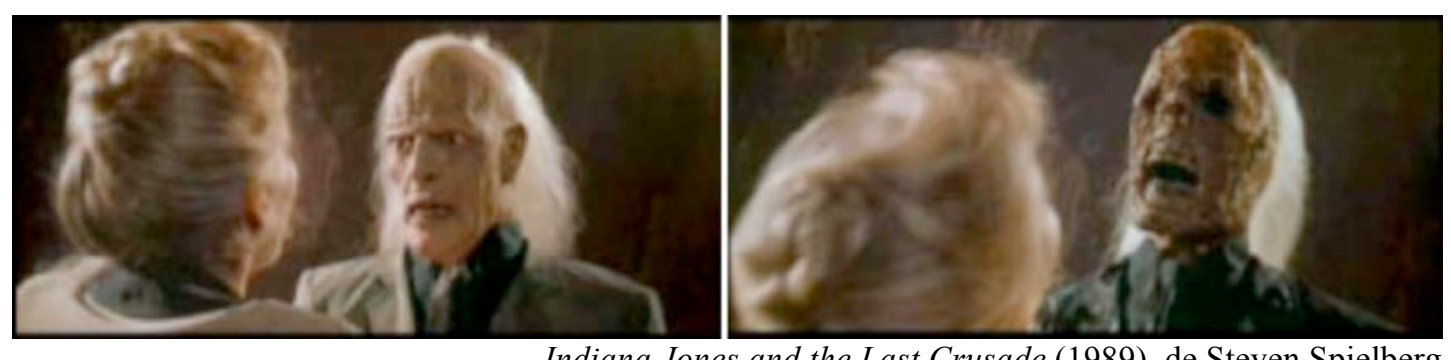

Indiana Jones and the Last Crusade (1989), de Steven Spielberg

En su empeño por "mostrar el monstruo", Spielberg acude al efecto digital en una película posterior: Minority Report (2002). Basada en el corto de Philip K. Dick $^{13}$, la cinta presenta una contra-utopía. En el año 2054, Washington es una ciudad en la que no se producen asesinatos gracias al sistema del "PreCrime"; éste se funda en las visiones de tres mutantes o "precogs" capaces de predecir asesinatos y señalar a sus futuros autores, que son condenados incluso antes de haber actuado. El protagonista de la cinta es John Anderton (Tom Cruise), agente del sistema y uno de sus máximos defensores. Cuando la profecía apunta hacia él como autor del próximo crimen, Anderton decide huir y desfigurarse para no ser reconocido. Para visualizar la transformación física del rostro del personaje, Spielberg se sirve de un morphing: la cámara se acerca a la cara de Cruise, permitiendo contemplar con todo detalle la deformación.

\footnotetext{
12 Nótese la relación etimológica entre el sustantivo "monstruo" (en latín, monstrum) y el verbo "mostrar" (monstrāre).

${ }^{13}$ DICK, Philip K. "The Minority Report" (1956). En: Selected Stories of Philip K. Dick. Boston: Houghton Mifflin Harcourt, 2013, pp. 223-261.
} 
Resulta clarificador comparar esta exhibición de la metamorfosis digital con el uso de la sobreimpresión en una escena anterior. En el momento en el que la previsión le señala como futuro asesino, el personaje contempla incrédulo la imagen que muestra su perfil al cometer el crimen. La sobreimpresión de su reflejo y la terrible previsión presenta un ser deformado: ¿es él verdaderamente un asesino? El desgarro emocional se figura no mediante un morphing, excesivamente explícito, sino gracias a una sobreimpresión; en ella, conviven las dos capas de la imagen como los dos momentos (presente/futuro) y las dos caras (bien/mal) del mismo ser.

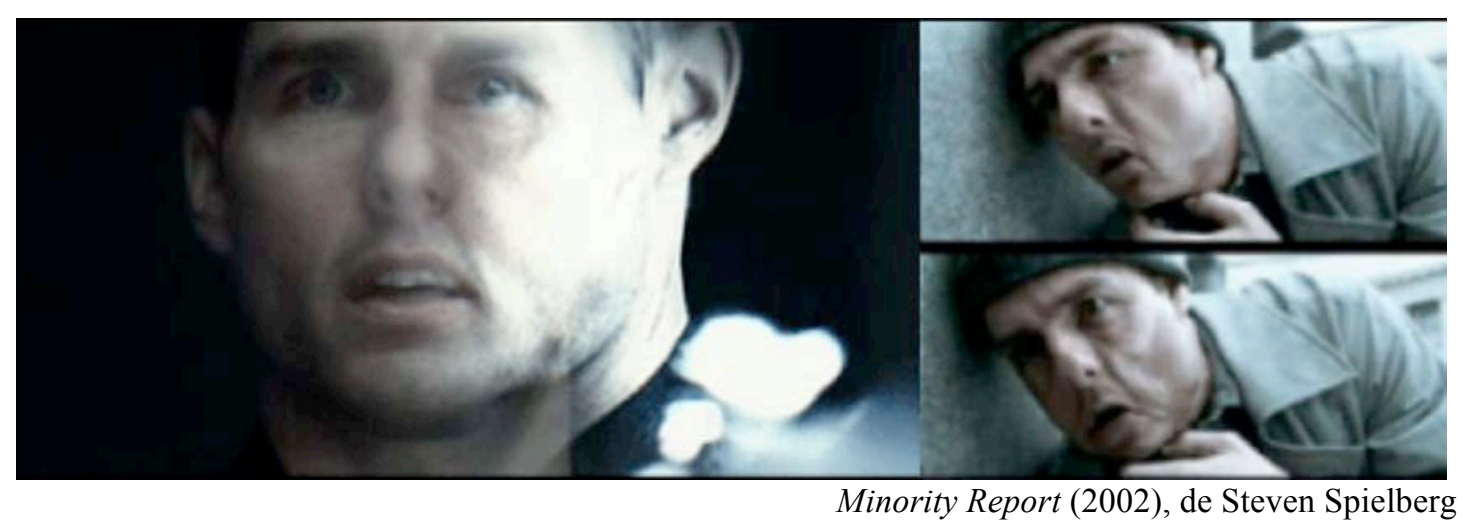

Para dar forma a la fragmentación de la identidad, Spielberg se decanta por una simple sobreimpresión: la continuidad lisa del morphing sería excesiva. A la misma conclusión parece haber llegado David Lynch. En la última escena de Lost Highway (1997), el protagonista Fred Madison huye de la policía y sufre en su coche una segunda metamorfosis. Según el croquis inicial, la terrible transformación debía mostrar la descomposición del rostro y la deformación total del cráneo. Sin embargo, Lynch decide deliberadamente no utilizar el morphing y lo hace, justamente, como consecuencia de su carácter continuo:

"David Lynch se planteaba realizar varios moldes que corresponderían a las diferentes etapas de la metamorfosis y el resultado final se obtendría gracias a un morphing para alisar las transiciones. Ahora bien, David quería cualquier cosa menos un aspecto alisado, quería que la imagen misma sugiriese el profundo desorden interior de Madison, y el morphing no podía aportarle tal resultado."14

${ }^{14}$ KERMAREC, Roland. Lynchland. Paris: Éditions Objectif Cinéma, 2004, pp. 39-40. 


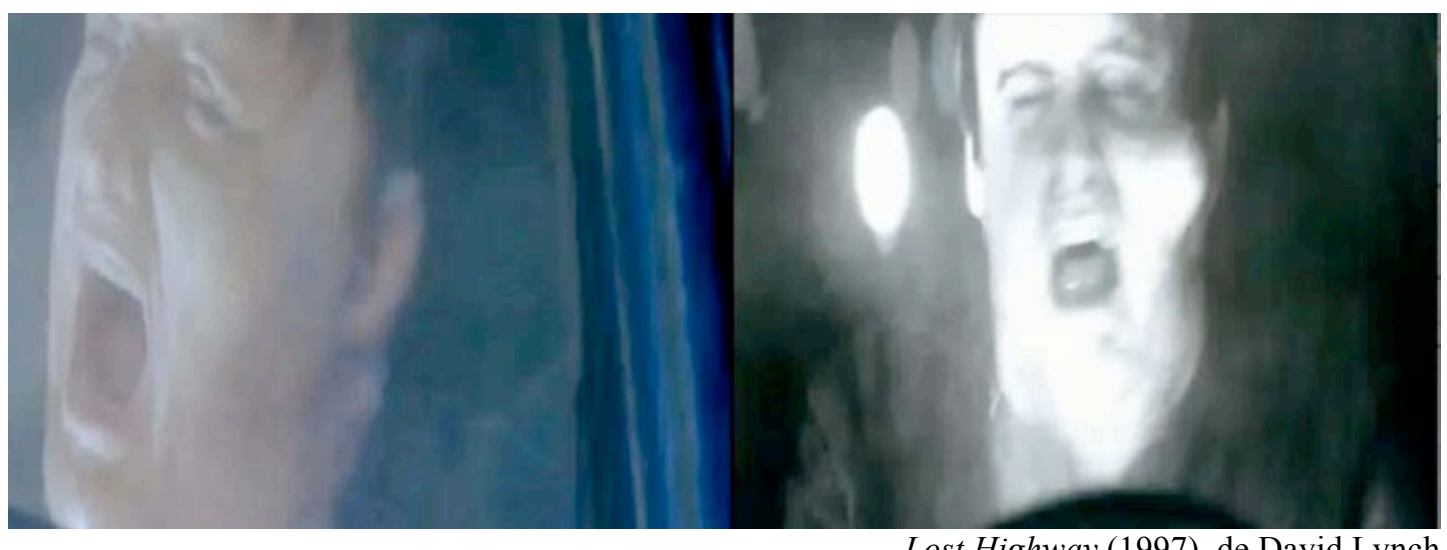

Lost Highway (1997), de David Lynch

Efectivamente, el morphing se caracteriza por la continuidad de la transformación, frente a la fragmentación y el montaje corto por el que se decanta el realizador. La metamorfosis digital exhibe la potencia plástica de la imagen digital mediante un cambio liso, homogéneo, fluido. De hecho, otro tipo de morphing es aquél en el que una sustancia toma todo tipo de formas sin alterarse, con ello, la materia original. En la película The Last Airbender (2010), de M. Night Shyamalan, el morphing permite crear diversas figuras a partir de los tres elementos naturales: aire, agua y tierra. Encontramos otros ejemplos en el monstruo de arena de Mission to Mars (2000), de Brian de Palma, en la figura de fuego de Percy Jackson \& the Olympians: The Lightning thief (2010), de Chris Columbus, y en el riachuelo viscoso de The Imaginarium of Doctor Parnassus (2009), de Terry Gilliam. Con todo, uno de los casos más espectaculares es el "pseudópodo" de The Abyss (1989), de James Cameron. La criatura de agua puede imitar todo tipo de formas, entre ellas, el rostro de los actores Mary Elizabeth Mastrantonio y Ed Harris.

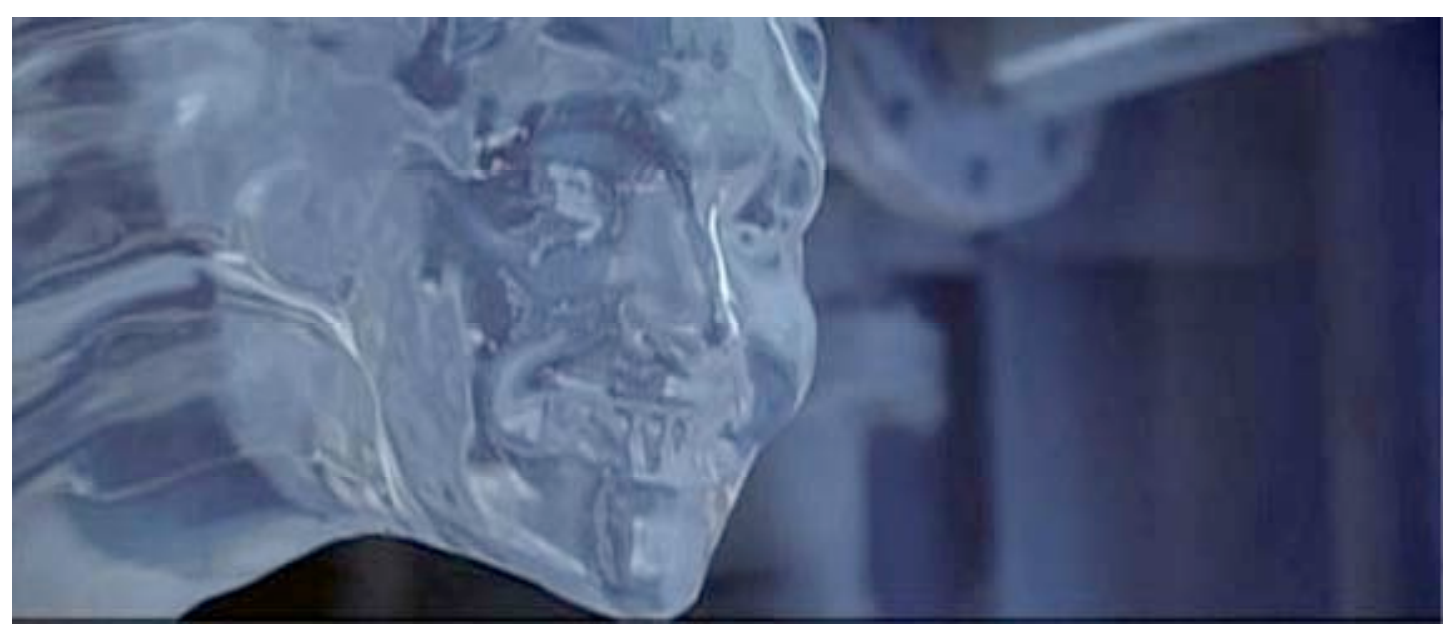

The Abyss (1989), de James Cameron 
Dos años después de The Abyss, el mismo James Cameron hace coincidir la figura del morphing con un personaje de ficción: el T-1000 de Terminator 2: Judgement Day (1991) adquiere todo tipo de formas a partir de una sustancia metálica líquida. Gracias a esta extraordinaria capacidad de mímesis, el androide consigue imitar a la perfección otros caracteres de la historia. Entre los numerosos ejemplos de metamorfosis, la cinta contiene un morphing espectacular: el suelo de baldosas en contrapicado funciona como fondo del que nace, poco a poco, la figura del T-1000. ${ }^{15}$

Hallamos una imagen de gran parecido en la película de Alan Parker, Pink Floyd. The Wall (1982), basada en el disco homónimo de Pink Floyd (1979). En la animación realizada por el ilustrador inglés Gerald Scarfe, un rostro fantasmagórico sale del muro que da título a la obra. La comparación con el morphing de Terminator prueba la relación de continuidad entre la plasticidad de la animación tradicional y la que permite la imagen digital. Es decir, ésta puede ser considerada una de las mayores aportaciones del morphing: la plasticidad de la imagen se desliga de su procedencia; poco importa ya si se trata de un dibujo animado o de un registro fotográfico.

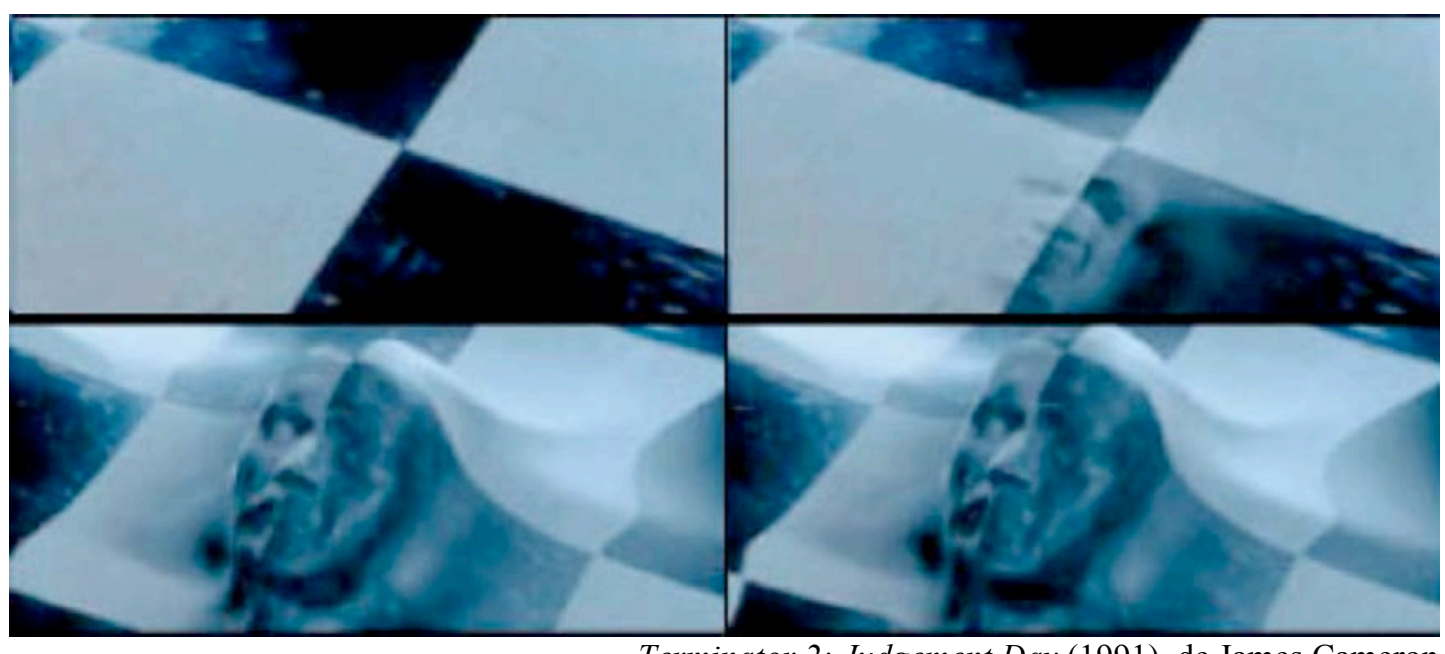

Terminator 2: Judgement Day (1991), de James Cameron

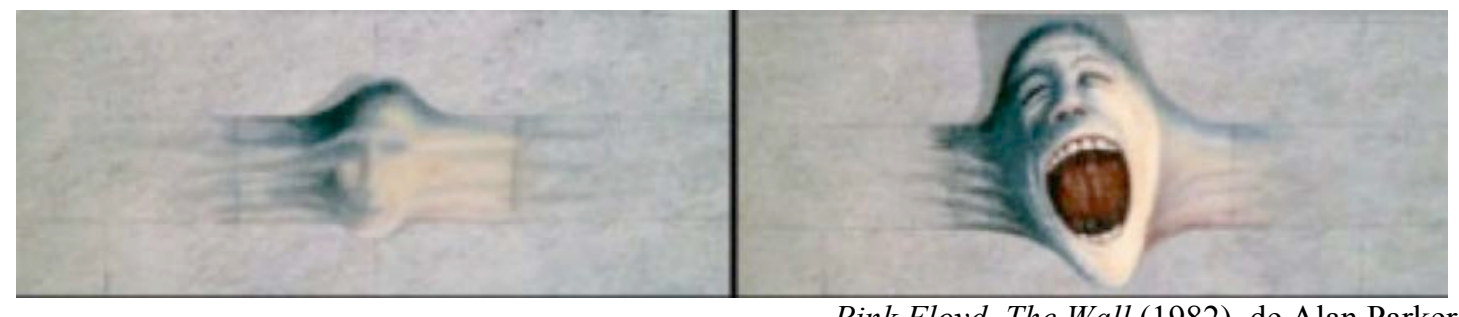

Pink Floyd. The Wall (1982), de Alan Parker

\footnotetext{
${ }^{15}$ Esta formación explícita de la figura a partir de una superficie bidimensional se repite en The Haunting (1999), de Jan de Bont. Para visualizar el espíritu que habita la casa, las sábanas se pliegan figurando el rostro de una joven.
} 
Un caso menos frecuente de morphing es aquél que afecta exclusivamente al fondo mientras las figuras permanecen constantes. A menudo, la dificultad a la hora de generar una metamorfosis convincente radica, precisamente, en la continuidad de la figura y el fondo, situados en el mismo plano; por ello, se suele acudir al green screen para aislar la sección que sufrirá la transformación. La combinación de esta estratificación con el morphing permite construir imágenes como las descritas a continuación.

En Dark City (1998), de Alex Proyas, unas criaturas llamadas "strangers" paralizan el tiempo para cambiar las identidades de los seres humanos y transformar la ciudad a su antojo. Mientras el psiquiatra Daniel Poe Schreber (Kiefer Sutherland) borra la memoria de las víctimas y les inyecta nuevos falsos recuerdos, los espacios en los que se encuentran son transformados en consonancia. En la escena seleccionada, la metamorfosis del espacio tiene lugar como un morphing del fondo mientras la figura del doctor permanece inmutable.
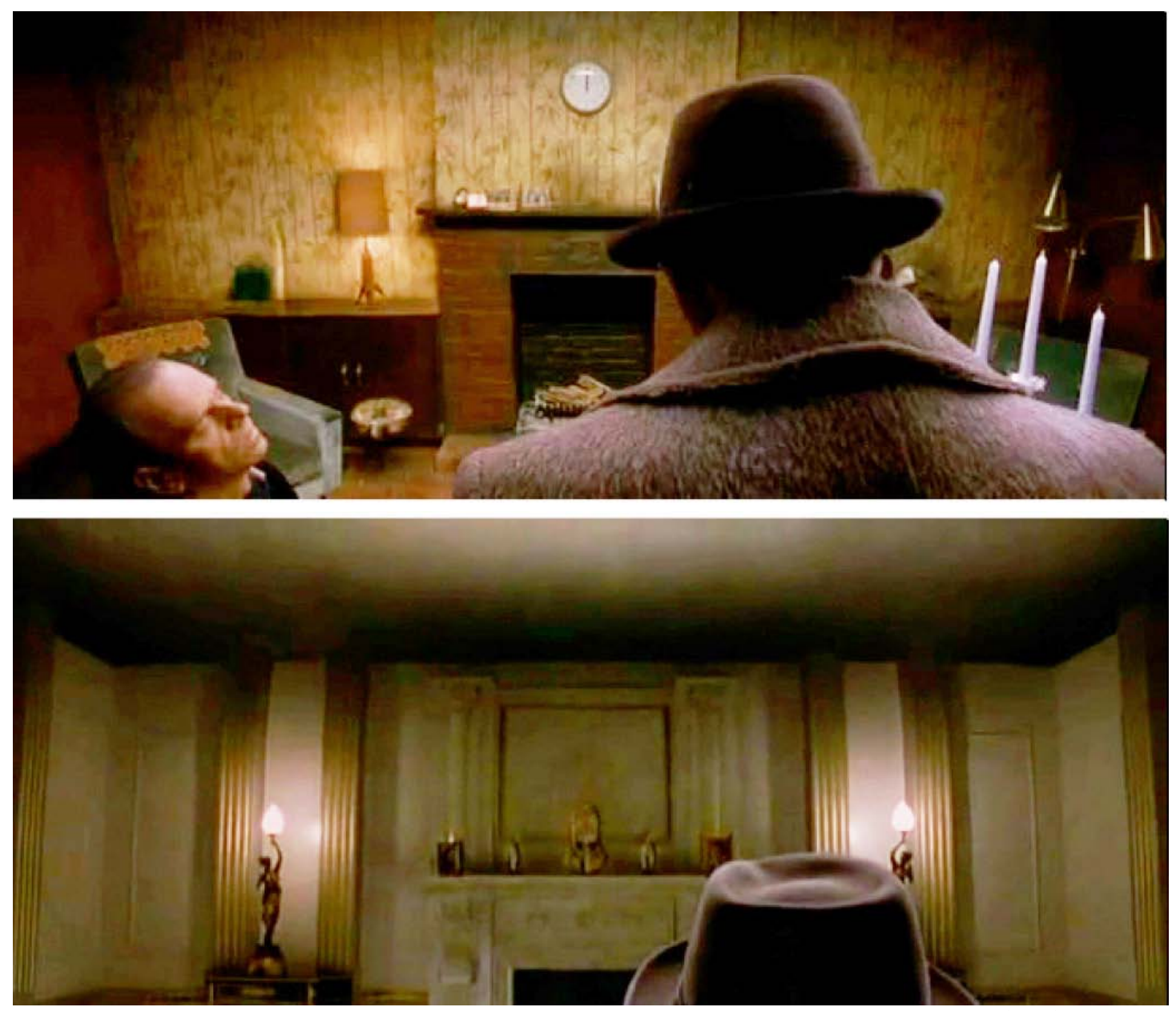

Dark City (1998), de Alex Proyas 
Otro ejemplo de metamorfosis del fondo es el de la película Heavenly Creatures (1994), de Peter Jackson. El guión, escrito por el propio Jackson y su mujer Fran Walsh, parte de un macabro suceso acaecido en 1954 en Nueva Zelanda: dos adolescentes matan a la madre de una de ellas, después de que ésta prohíba a su hija continuar con su amistad.

La película comienza con el asesinato de la madre, Nora Parker (Sarah Peirse), para saltar después en el tiempo y localizar la historia un año antes, momento en el que la extrovertida Juliet Hulme (Kate Winslet) y la tímida Pauline Parker (Melanie Lynskey) se conocen. Heavenly Creatures se centra en la estrecha relación entre ambas y el mundo de fantasía en el que viven hasta su separación forzosa y el horrible desenlace, con el que empieza la película. Ese estado de ensoñación alcanza su súmmum en la aparición de lo que las protagonistas llaman el "Cuarto Mundo": un espacio fantástico al que ambas creen pertenecer y en el que se sienten felices juntas.

El Cuarto Mundo se hace explícito mediante un morphing del paisaje: las siluetas de Juliet y Pauline destacan sobre un fondo de hierbas secas, que se curva y deforma hasta convertirse en un jardín paradisiaco. Las niñas contemplan maravilladas el espectáculo que nace ante sus ojos: del paisaje agostado y monótono, crecen plantas, flores de colores y una fuente rodeada de estatuas de mármol. Un mundo en el que viven unicornios y mariposas gigantes brota de la nada ante ellas.
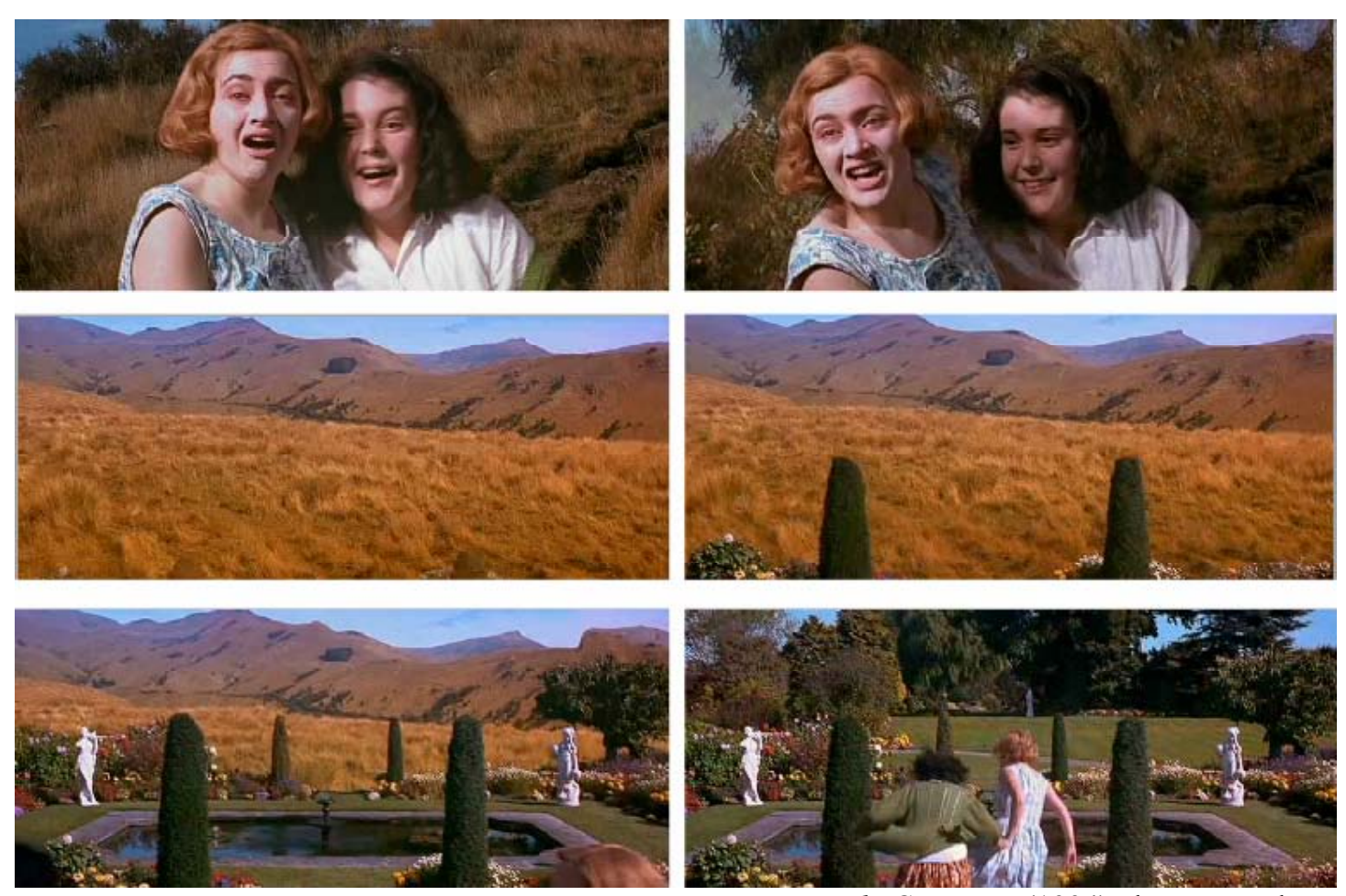

Heavenly Creatures (1994), de Peter Jackson 
Hasta aquí, hemos analizado diversos tipos de morphing dentro de la diégesis; es decir, la exhibición de metamorfosis que forman parte de la ficción, de la historia narrada, imposibles en la imagen cinematográfica tradicional y reservadas, exclusivamente, al dibujo animado. No obstante, constatamos también una tendencia a un uso más "simbólico" del efecto digital; esto es, el morphing permite dar forma a ideas, a conceptos.

\section{El uso "simbólico" del morphing}

Pongamos por caso la obra Morphing of the Telephone (1997), de Lillian Schwartz. Aquí, las imágenes fuente corresponden a fotografías de diversos teléfonos, desde el patentado por Alexander Graham Bell en 1876 hasta los inalámbricos. La metamorfosis da forma a un invento: un aparato ligado a la telecomunicación. Con todo, una vez llegados a los ejemplares de los años 90, la mutación retoma los primeros tipos: al preferir la estructura de "palíndromo visual" a la línea ascendente del antes-después, la autora subraya la comparación entre las formas por encima de la idea de progreso tecnológico.

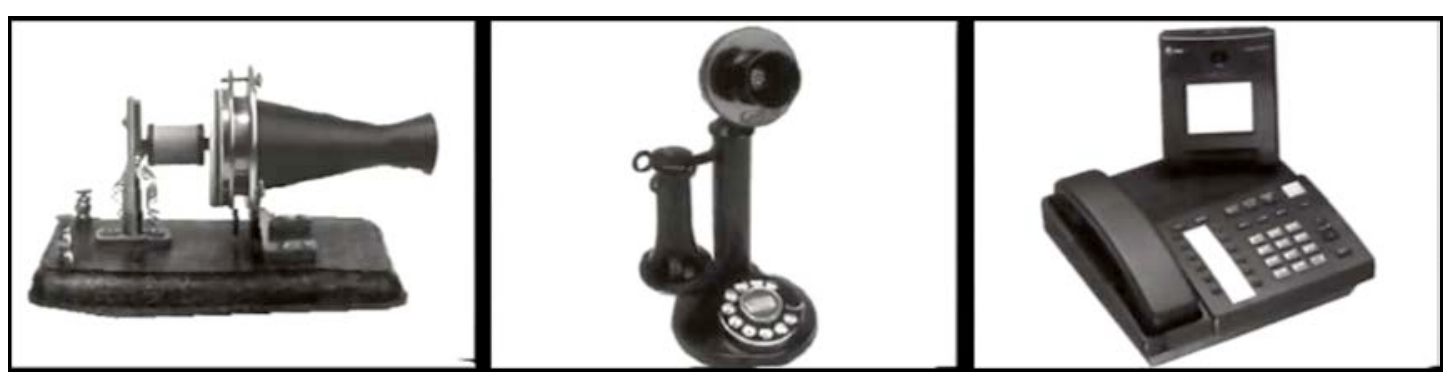

Morphing of the Telephone (1997), de Lillian Schwartz

Las formas son tan distintas que la interpolación resulta en una masa que adquiere uno $\mathrm{u}$ otro aspecto como un pegote de plastilina. En este sentido, la propuesta se asemeja a las animaciones sintéticas de Charles Csuri o Peter Foldes treinta años antes. De hecho, Lillian Schwartz fue también pionera del arte por ordenador. Basta citar las piezas creadas por ella en colaboración con Ken Knowlton, tituladas precisamente Mutations (1973) y Metamorphosis (1974). Ahora bien, estas piezas exploran la animación abstracta y la "estética permutacional", que veremos con detenimiento en el último apartado de este trabajo; por el momento, nos conformamos 
con hacer notar el interés compartido por la construcción de metamorfosis frente al registro de un movimiento, típico del cinematógrafo.

Tres años después de Morphing of the Telephone, el director estadounidense Brian de Palma presenta la evolución de las especies en una secuencia de su película Mission to Mars (2000): la cadena de metamorfosis tiene lugar entre varios ejemplares, distantes en el espacio y en el tiempo, sin tener en cuenta las leyes físicas de la materia. La discontinuidad de los diferentes sujetos queda abolida gracias a la continuidad de la mutación digital; de este modo, la idea abstracta de la evolución biológica de la especie en su conjunto se encarna artificialmente en un único sujeto.

De acuerdo con la teoría de la evolución, cambios particulares se acumulan a lo largo de miles de años y provocan el desarrollo de la especie. Así, la metamorfosis de la escena implica una transición espacio-temporal en la que el tiempo se condensa mientras el espacio se dilata. En el próximo apartado, veremos otros ejemplos de estas "transiciones espacio-temporales continuas".

Comparemos la imagen de Mission to Mars con las ilustraciones de D’Arcy W. Thompson en su obra On Growth and Form (1917). El biólogo dibuja una serie de cinco pelvis que pretenden mostrar las fases evolutivas entre dos especies prehistóricas: un archaeopteryx y un apatornix. ${ }^{16}$ Los diseños de Thompson presentan tres hipotéticas pelvis intermedias, que corresponderían a distintos sujetos dentro de las fases evolutivas. ${ }^{17}$ La presentación simultánea en la imagen fija permite relacionar cada hueso (real o imaginario) con un ejemplar específico en cinco momentos distintos. Frente a esta correspondencia de las fases intermedias con sendos especímenes, De Palma propone una animación continua: un único ejemplar sufre en algunos segundos la mutación de su cuerpo, desde el pez al ser humano.

Al decantarse por el morphing, el realizador opta por dar forma no sólo a lo invisible (como sería el caso de una aceleración cinematográfica), sino a lo que nunca ocurrió de ese modo: no se trata de reproducir miméticamente la realidad o de revelar lo oculto a la percepción, sino de plasmar una idea. Aquí, esa idea es la mismísima teoría de la evolución biológica de las especies, pero puede ser también una metáfora. Así, por ejemplo, el videoclip de Michael Jackson Black or White

\footnotetext{
${ }^{16}$ THOMPSON, D’Arcy W.. Op. cit., p. 307.

${ }^{17}$ La ilustración de Thompson es considerada por Mark J. P. Wolf como un antecedente del warping necesario para la construcción del morphing. WOLF, Mark J. P.. “A Brief History of Morphing”. En: SOBCHACK, Vivian. Op. cit., p. 87.
} 
(1991), dirigido por John Landis, presenta la metamorfosis reversible del cantante en pantera. La transformación funciona como identificación del artista con el felino.

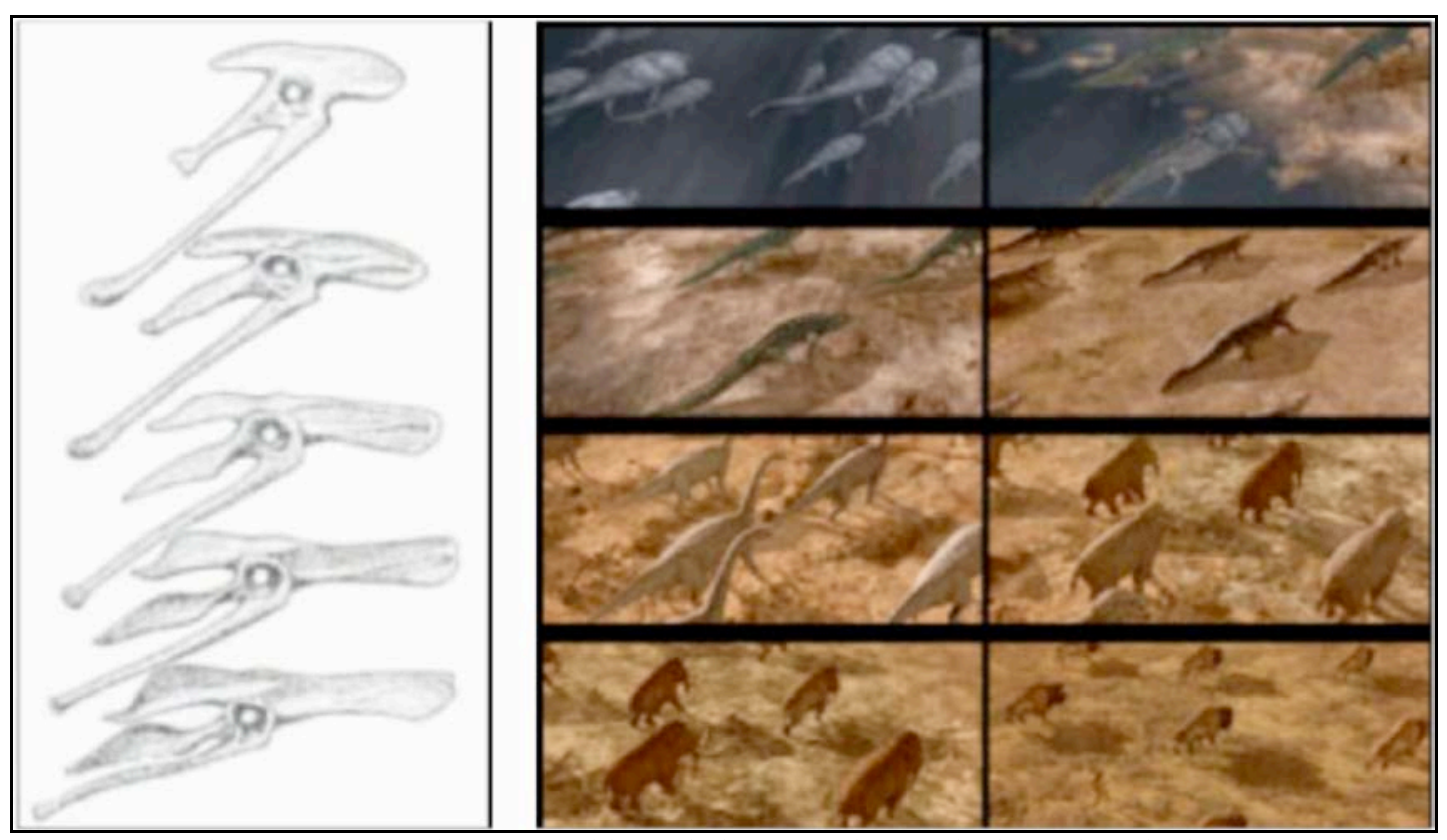

Izquierda. D’Arcy W. Thompson: dibujo de la interpolación de dos pelvis de dinosaurios (1917)

Derecha. Mission to Mars (2000), de Brian de Palma

En el lenguaje cinematográfico, la forma visual del símil puede corresponder a una sobreimpresión. Encontramos dos casos paradigmáticos en la superposición del águila sobre el pequeño Bonaparte en Napoléon (1927), de Abel Gance, y en las mezclas de cuatro personajes y sendos animales en Stachka o "La huelga" (1924), de Eisenstein.

Setenta años después de estos experimentos del cine de las vanguardias, el videoclip Hunter (1997) de Paul White para Björk muestra una cadena de mutaciones reversibles de la cantante en un oso metálico: la islandesa se transforma en el predador al tiempo que canta "soy una cazadora" ("I'm a hunter"). Frente a la convivencia de las dos capas en la sobreimpresión cinematográfica, el morphing digital se produce en un solo plano. El rostro de Björk surge poco a poco de una imagen monocroma blanca. La transformación de la luz en carne y de la carne en metal para, finalmente, disolverse de nuevo en el lumen de los píxeles exalta la imagen matricial, esa red de puntos lumínicos de los que brota la forma y a través de los cuales ésta muta en un proceso continuo. 

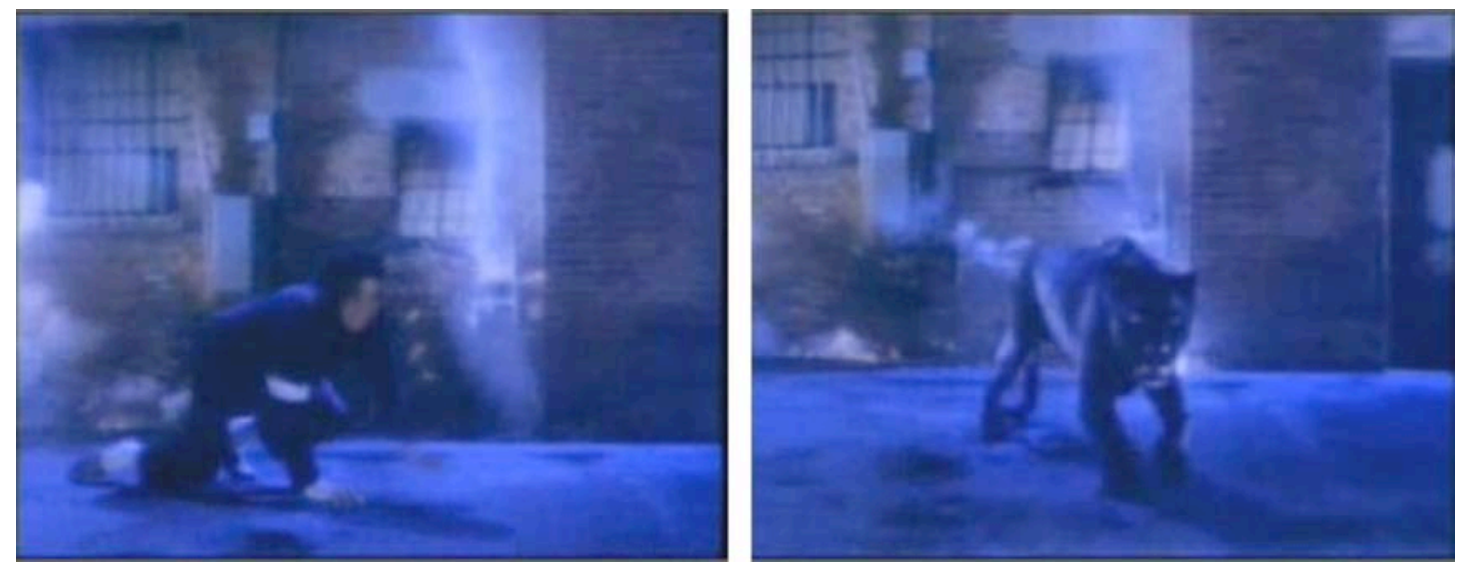

Black or White (1991), de John Landis para Michael Jackson

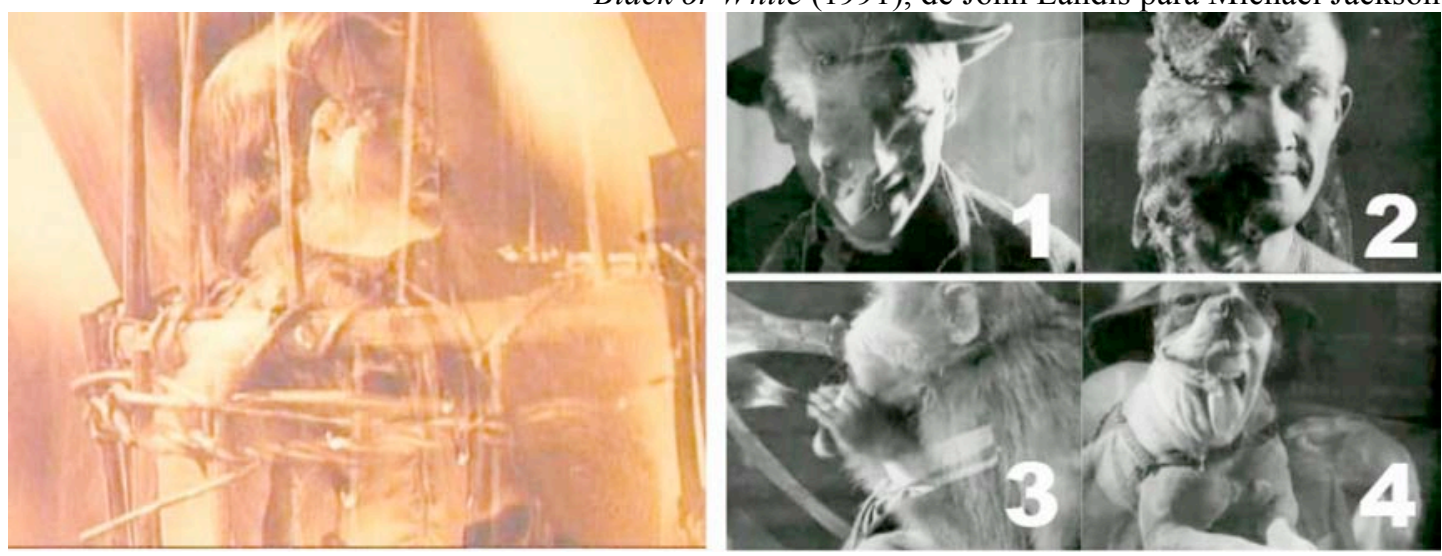

Izquierda. Napoléon (1927), de Abel Gance. Derecha. Stachka (1924), de Eisenstein

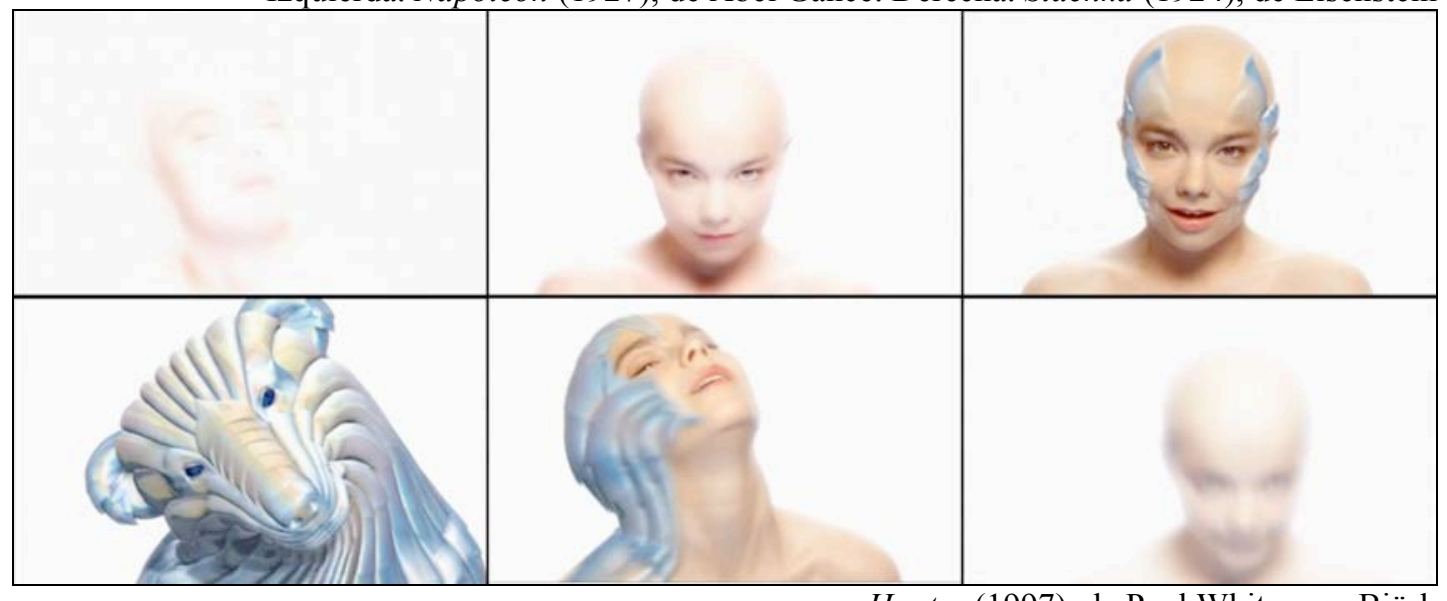

Hunter (1997), de Paul White para Björk

La continuidad lisa del morphing da forma a una comparación explícita entre la cantante y el oso, basada en una semejanza: el hecho de ser un predador. Si esta construcción digital encaja con la figura literaria de la metáfora, la convivencia de las capas en la sobreimpresión parece sugerir una comparación más débil. Dicho de otro modo, la continuidad de la metamorfosis digital implica una identificación fuerte de las partes: "A = B" frente al "A es como B" de la sobreimpresión y el símil. Esta identificación entre las imágenes fuente es la clave del debate generado en torno al llamado "morphing racial". 


\section{La polémica del "morphing racial"}

Otra secuencia de Black or White provocó, en su momento, una marea de críticas. Una cadena de transformaciones entre individuos de ambos géneros y distintas razas da forma al discurso igualitario de la canción: ni el sexo ni la raza impiden que formemos parte de la misma "sustancia" que nos hace humanos. El mensaje integrador va acompañado por un criterio de belleza que radica, en cambio, en la riqueza de la variación, en la diferencia. A una realidad heterogénea, múltiple, corresponde una imagen-metamorfosis.

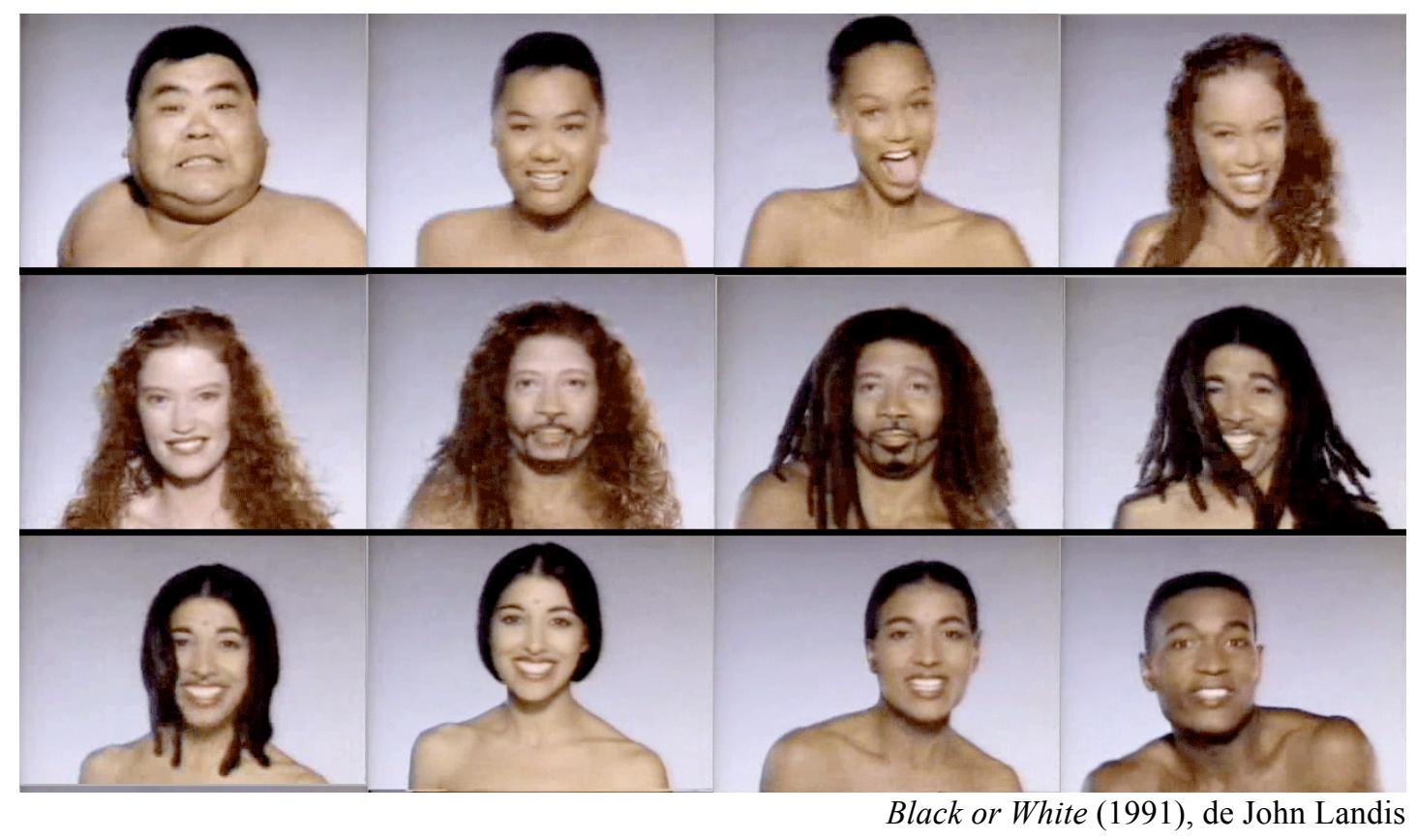

Durante la década de los años 90, el efecto del morphing aparecerá a menudo asociado a esta idea de transformación identitaria. La propuesta de Landis se enmarca en la concepción mística de las nuevas tecnologías de la información y la comunicación (NTIC), resumida en la afirmación de Scott Bukatman: "Las identidades terminales de la cultura cibernética prometen una liberación del espacio, del tiempo, de la carne y de la historia". ${ }^{18}$ Hoy, las NTIC no se asocian con seres humanos conectados a redes, sino con la ciudadanía, con lo cotidiano; no hay oda a la desmaterialización, sino conciencia de la participación, por un lado, y del elemento táctil de la técnica, por otro. No obstante, la popularización del morphing durante la última década del siglo XX estuvo ligada a esta superación de los límites físicos del

\footnotetext{
${ }^{18}$ BUKATMAN, Scott. Op. cit., p. 245.
} 
cuerpo; en este contexto, la figura de la metamorfosis digital se convirtió en un paradigma del tecnorromanticismo. ${ }^{19}$

De hecho, el morphing racial de Black or White no fue, de ningún modo, una propuesta aislada. Recordemos la campaña publicitaria "All colors of the world" (1984) de Benetton, realizada por el fotógrafo italiano Oliviero Toscani, o la revista Colors, creada por éste y perteneciente a la misma compañía. En 1992, la publicación presenta una serie de retratos bajo el título "Race" y la pregunta "What if...?": la reina Elizabeth II de Inglaterra es una mujer negra; Spike Lee, un hombre blanco; y el Papa Juan Pablo II, un asiático. ${ }^{20}$ Frente a las fotografías formato "carnet" en la publicidad, casi una década después, los retratos ficticios de Colors reflejan la mezcla entre esas mismas razas. Al año siguiente, la revista Time dedica su portada a un personaje ficticio: "el nuevo rostro de America"21 es el de una mujer mestiza inexistente, imaginada por Milton Glaser y creada por Kim Wah Lam mediante un morphing de instantáneas de distintas razas, tomadas por el fotógrafo Ted Thai.

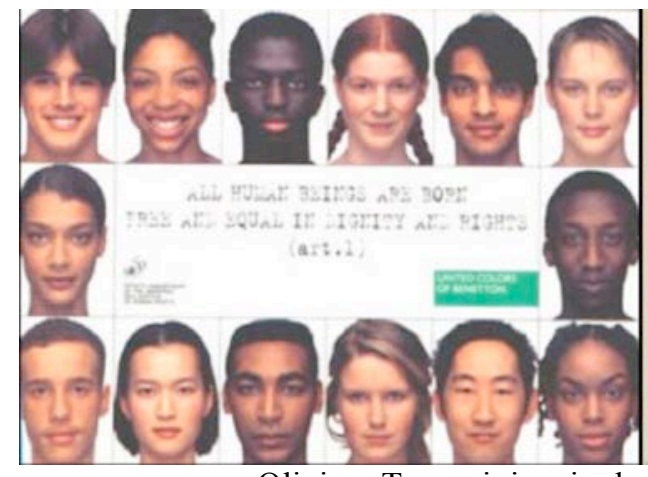

Oliviero Toscani: izquierda, "All colors of the world" (1984); centro, "Colors" (1992).

Derecha. Kim Wah Lam: "New face of America" (1993)

Ya en los años 80, la artista estadounidense Nancy Burson crea sus series de retratos híbridos. En "Mankind” (1983-1985), combina individuos de raza asiática,

\footnotetext{
19 "El cuerpo ya no sirve, está obsoleto (...). La uniformidad totalitaria no es ahora la de lo mismo sino la de lo diverso. El tecnorromaticismo es el núcleo de una industria cultural volcada en los efectos especiales que prolonga la de los afectos especiales románticos." MOLINUEVO, José Luis. Magnífica miseria. Dialéctica del romanticismo. Murcia: CENDEAC, 2009, p. 29.

${ }^{20}$ El debate identitario va más allá de la raza o el género. Louise Krasniewicz cita, además, la revista Games (junio 1993), cuya portada, acompañada por la pregunta Who are this?, presenta una serie de morphing de personajes célebres con el único criterio de compartir nombre o apellido. KRASNIEWICZ, Louise. "Magical Transformations". En: SOBCHACK, Vivian. Op. cit., p. 51.

${ }^{21}$ The New Face of America: How Immigrants Are Shaping the World's First Multicultural Society. Time, Nov. 18, 1993. Disponible en Web:

$<$ http://www.time.com/time/covers/0,16641,19931118,00.html>
} 
caucasiana y negra; puesto que la mezcla respeta las proporciones de la población mundial en ese momento, puede ser considerada como una visualización de datos.

Si bien con el acabado digital, la propuesta no se diferencia sustancialmente de las "imágenes media" creadas un siglo antes por el eugenista inglés Francis Galton (1822-1911). En busca de una tipificación de rasgos degenerativos del ser humano, Galton se sirvió de lo que él mismo denominó "Composite portraiture" (1883). Los rostros híbridos resultantes de la sobreimpresión de retratos fotográficos no representan individuos concretos, sino tipos, grupos étnicos así identificables. Esto es: unas "características promedio" ("average features") ${ }^{22}$ que aspiran a la misma precisión de una media aritmética. El ejemplo presentado a continuación evidenciaría, supuestamente, los rasgos comunes degenerativos de la comunidad judía. A la izquierda, cuatro tipos resultantes de la mezcla de los originales, en el centro.

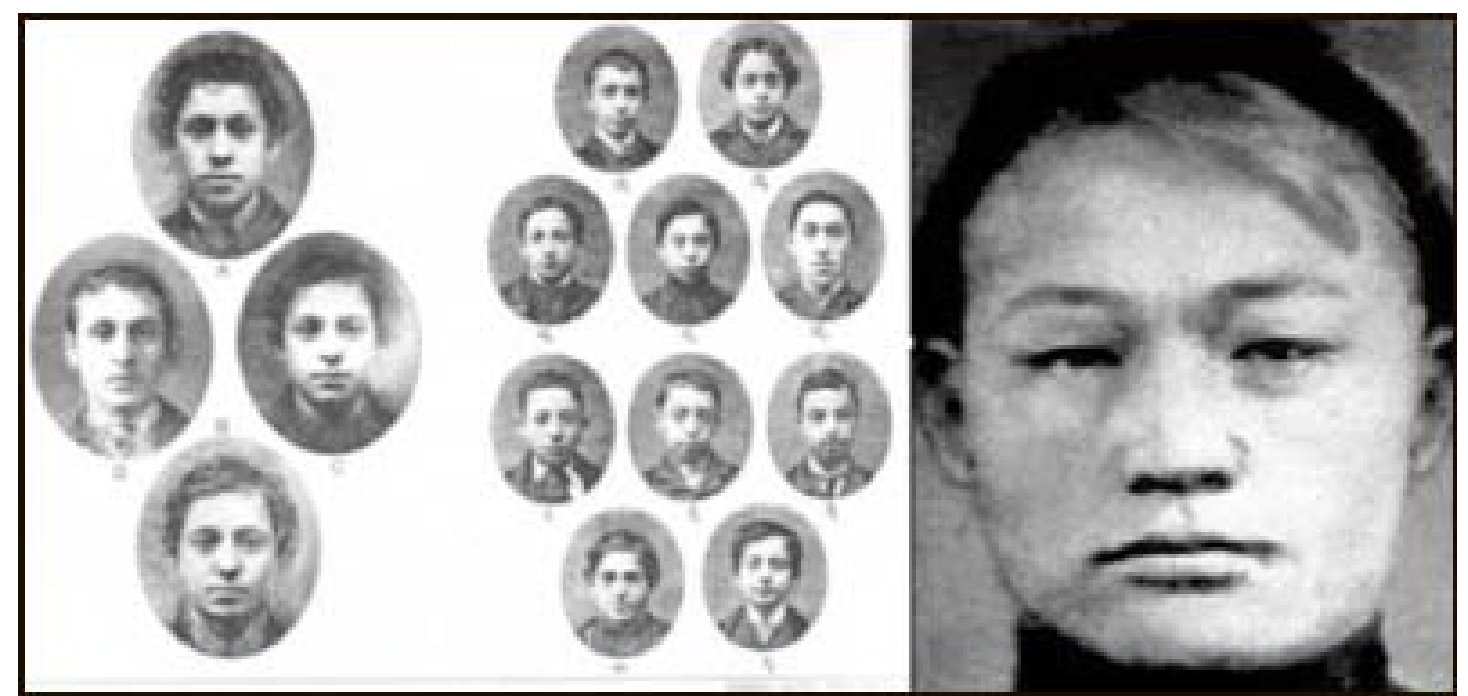

Izquierda y centro. Galton: "Composite portraiture" (1883). Derecha. Burson: "Mankind” (1982)

Ahora bien, los morphing de la revista Colors y la portada de Time vehiculan un mensaje universalista en las antípodas del eugenismo del antropólogo inglés: a principios de los años 90, en pleno apogeo multiculturalista, la nueva técnica digital se usa como herramienta de comunicación para luchar contra el racismo. No obstante, no son pocas las voces en cuestionar la eficacia de la técnica digital en este sentido. El artículo de Jessica Walker “Only Screen Deep: Racial morphing” resume el debate en

\footnotetext{
22 "To the best of my judgement the original photograph is the very exact average of its components." GALTON, Francis. Inquiries into human faculty and its development (1883). London: JM Dent \& Co., Everyman, 1907, p. 225.
} 
torno a las implicaciones del morphing racial. ${ }^{23}$ Apoyándose en los artículos de Lisa Lowe $^{24}$ y Vivian Sobchack ${ }^{25}$, la autora ve en aquél un producto de la tendencia hegemónica multiculturalista en EE.UU y la reinstauración del mito de la "uniformidad" (“sameness") frente al concepto humanista de "igualdad" (“equality").

La clave del rechazo al morphing racial reside en la extrema continuidad que permite la tecnología digital. Si la convivencia de las imágenes en distintas capas (propia de la sobreimpresión) subraya la heterogeneidad de la mezcla, el morphing homogeniza. ${ }^{26}$ Con su imagen-metamorfosis, Landis da forma al enunciado "todos somos lo mismo", típico del discurso multiculturalista. Esa idea de una única identidad humana negaría, según Walker, las diferencias culturales históricas:

"En el caso del morphing racial mediante manipulación digital, se debe comprender las implicaciones de la transición fluida, en cuanto sugiere una mitología de la uniformidad (sameness) y limpia negligentemente una historia racial de la diferencia y la alteridad. (...) La secuencia de morphings no exhibe un orden natural de metamorfosis, sino una transformación irreal, digital, que no existe en el mundo real., 27

En lo que respecta a la imagen fija, las críticas inciden en la diferencia entre la estadística del grupo y el verdadero mestizaje genético en un solo individuo. O dicho de otro modo, la pretendida "cara de America" no es más que un concepto y no corresponde a ninguna mujer real. Ahora bien, en el vídeo de Landis, no se trata tanto de exhibir las imágenes media, sino de presentar el proceso de metamorfosis en sí. A diferencia de las imágenes híbridas, las capturas originales sí aparecen, al modo de los key frames que estructuran la cadena de mutaciones. Con todo, el vídeo provocó tanto o más rechazo que las composiciones fotográficas descritas. Pero, ¿habría causado el mismo revuelo un fundido encadenado de las imágenes? Probablemente no.

\footnotetext{
${ }^{23}$ El texto se estructura en torno a cinco obras: a las tres ya citadas se suman dos instalaciones interactivas (Human Race Machine (2000), de Nancy Burson, y A World of Choices en el Museum of the African Diaspora de San Francisco). WALKER, Jessica. Only Screen Deep: Racial Morphing [En línea]. 2006. Disponible en Web: <http://www.jessicawalker.net/screendeep.htm>

${ }^{24}$ LOWE, Lisa. "Imagining Los Angeles in the Production of Multiculturalism". En: STYGALL, Gail (ed.). Academic Discourse: Readings for Argument and Analysis. Mason, OH: Thomson Custom Publishing, 2002, pp. 525-538.

${ }^{25}$ SOBCHACK, Vivian. "At the Still Point of the Turning World: Meta-Morphing and Meta-Stasis". En: SOBCHACK, Vivian. Op. cit.

26 "Through the literalism of morphing, as in used in Jackson's Black or White or The Mask, difference is erased - heterogeneity becomes continuity.” BUKATMAN, Scott. Op. cit., p. 232.

${ }^{27}$ WALKER, Jessica. Op. cit.
} 
En realidad, seis años antes de Black or White, el videoclip Cry (1985), de Godley \& Creme (Kevin Godley y Lol Creme), presentaba un fundido electrónico de los miembros del grupo, también de diversas razas. Si bien el paso entre las imágenes es fluido, las líneas de barrido revelan la naturaleza videográfica de la imagen: las franjas horizontales se desplazan de arriba a abajo, en una cortina que sustituye una imagen por la siguiente. Aunque lograda, la mutación analógica no es ni transparente ni homogénea. Sobra decir que el vídeo no provocó ningún debate.
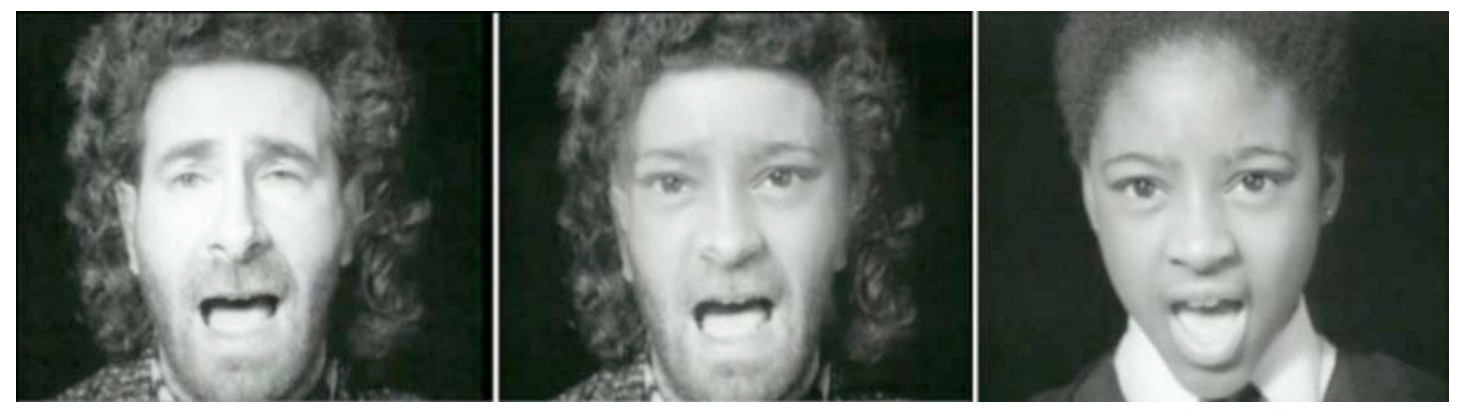

Cry (1985), de Godley \& Creme

Si bien el morphing racial parte, lógicamente, de rostros bien diferentes, el flujo continuo de la forma ensalza las semejanzas entre aquéllos. Como en "la cohabitación", el efecto digital permite cotejar las imágenes de partida. No obstante, allí donde el split screen posibilita el contraste formal entre las partes, la metamorfosis anula la oposición: frente al blanco/negro, el morphing visualiza la gama de grises intermedios. Es precisamente el proceso de cambio hilvanado el que plantea cuestiones éticas como las citadas arriba. Es decir, la supuesta homogenización entre los individuos es mayor cuanto más verosímil la transformación y ésta depende, justamente, del carácter liso del cambio.

La cuestión aquí es esa correspondencia entre la fluidez de la metamorfosis y la identificación de las partes. Así, más allá del “morphing racial”, el efecto digital puede servir, por ejemplo, para subrayar un canon de belleza. Éste es el caso del vídeo Faces of Fashion (2011), del artista digital estadounidense Philip Scott Johnson. Si bien el morphing liga los rostros de modelos de distintas razas (en las capturas reproducidas, Liu Wen se transforma en Tyra Banks), la propuesta está lejos del multiculturalismo de Black or White.

De nuevo, las animaciones hacen eco a otra obra de Nancy Burson. Al tiempo que compone "Mankind", la artista suma las instantáneas de actrices de reconocida belleza. Sus "Beauty Composites" (1982) parten de los rostros de Bette Davis, 
Audrey Hepburn, Grace Kelly, Sophia Loren y Marilyn Monroe ("First Beauty Composite") o de Jane Fonda, Jacqueline Bisset, Diane Keaton, Brooke Shields y Meryl Streep ("Second Beauty Composite"). Las caras resultantes no pertenecen a ningún individuo, sino a un ideal de belleza compartido: un "tipo", siguiendo el vocabulario de Francis Galton.
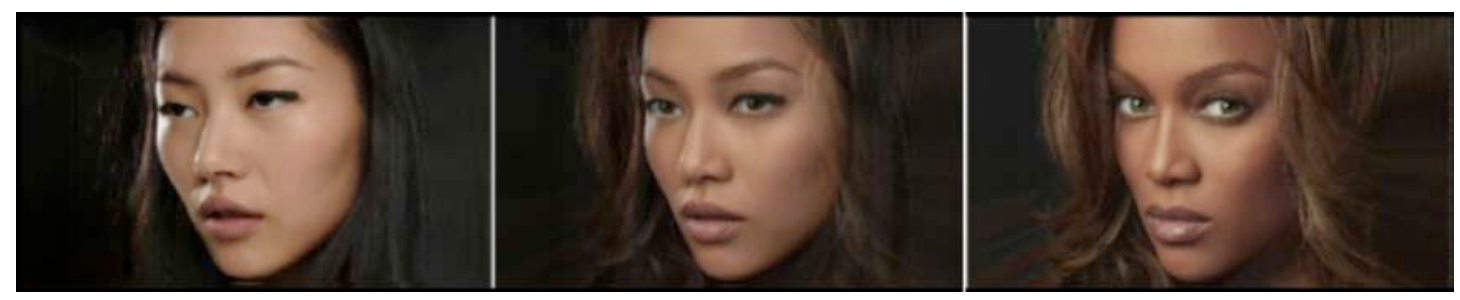

Faces of Fashion (2011), de Philip Scott Johnson
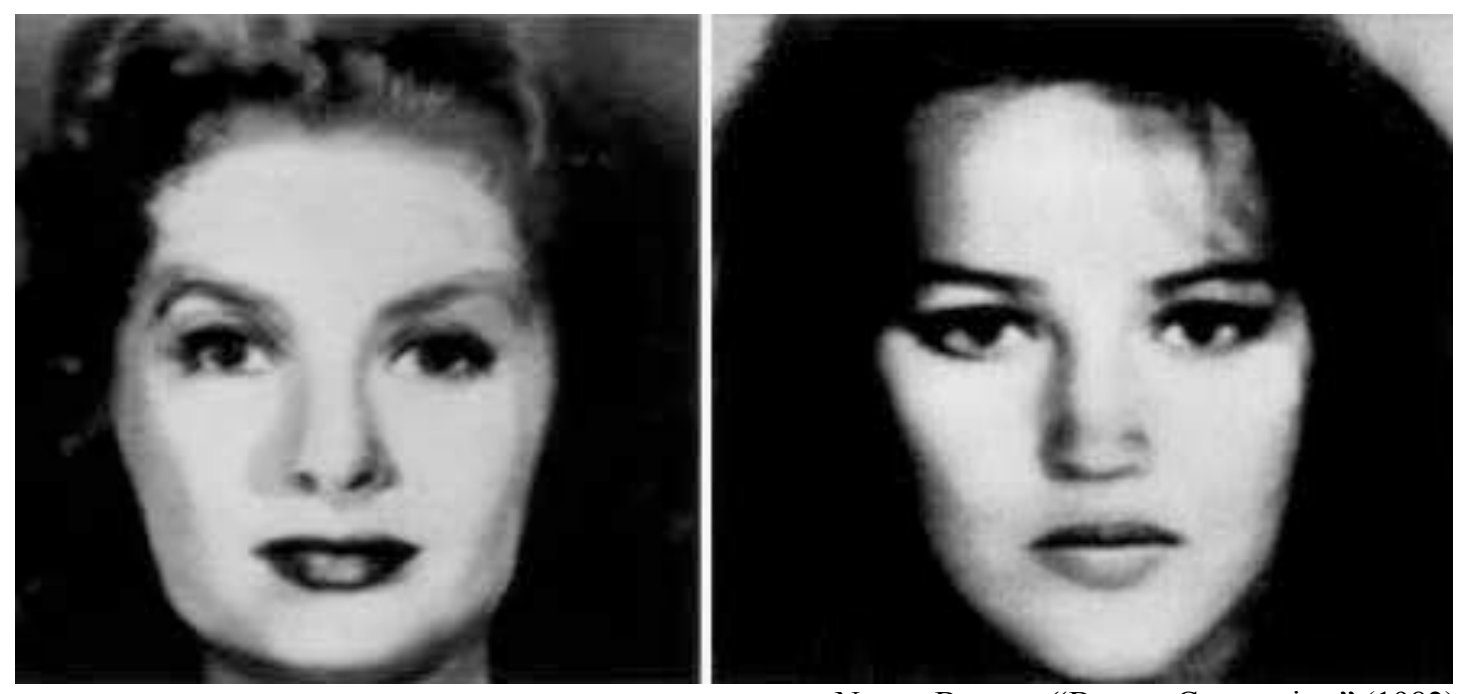

Nancy Burson: “Beauty Composites” (1982)

En el último capítulo de esta investigación, recuperaremos la experimentación de Philip Scott Johnson con el morphing y veremos cómo la interpolación de imágenes le permite crear dinámicas que difieren de la mera reproducción de un movimiento. Por el momento, nos concentramos en este uso de la metamorfosis digital más allá de la visualización de transformaciones dentro de la ficción. En el próximo apartado, comprobaremos cómo, lejos del tecnorromanticismo que caracteriza el morphing racial, el efecto digital ha sido asimilado ya como parte de la gramática audiovisual y permite crear transiciones espacio-temporales continuas. 


\section{LAS TRANSICIONES ESPACIO-TEMPORALES CONTINUAS}

Las diversas formas de construcción que hemos visto a lo largo de todo este primer capítulo pueden servir, también, para figurar transiciones espacio-temporales continuas. Frente al corte cinematográfico, la "sutura" entre planos no se basa en la elipsis, sino, muy al contrario, en una exhibición del espacio construido entre ellos. $\mathrm{O}$ dicho de otro modo: la transformación gradual de la imagen, ese deleitarse en la continuidad de la mutación, prueba, una vez más, el rechazo al montaje temporal clásico y la exploración de espacios específicos de la imagen.

Comenzamos por analizar la sustitución del fundido encadenado por el morphing, tanto para figurar el paso del tiempo en el relato como para crear relaciones de raccord entre los planos. Seguidamente, daremos paso a otras transiciones continuas construidas gracias al trabajo atómico de la imagen: mediante una variación lumínica de los píxeles y/o mediante la composición en capas.

\section{Del fundido encadenado al morphing}

Tal y como adelantábamos en el apartado anterior, la animación mediante morphing puede implicar una transición espacio-temporal. Éste era el caso de la figura de la evolución en Mission to Mars (2000) de Brian de Palma. Al encarnar en un mismo sujeto las mutaciones que tienen lugar, en realidad, en diversos ejemplares a lo largo de millones de años, la discontinuidad (espacial y temporal) se elimina a favor de la construcción de una metamorfosis. La mutación implica una enorme condensación del tiempo y permite hacer avanzar la historia.

Hallamos dos casos paradigmáticos del uso del morphing como flash forward y flash back en la película Titanic (1997) de James Cameron. La transición espaciotemporal entre 1912 (fecha del hundimiento del barco) y los años 90 se lleva a cabo a través de la transformación del rostro de la actriz Kate Winslet (la joven protagonista) al de Gloria Stuart (el mismo personaje en su vejez). El salto temporal contrario, del presente a principios del siglo $\mathrm{XX}$, toma forma en la metamorfosis del mismísimo Titanic: de la carcasa del trasatlántico hundido en el océano a la imagen sintética de su apariencia recién estrenado. El retroceso temporal supone una inversión causal y va acompañado, inevitablemente, de un cambio espacial: del fondo del mar, en el que 
yacen los restos del naufragio, a la superficie del agua y el puerto de Southampton, en el que se sitúa el flamante barco a punto de alzar anclas.

En el primer caso, la rapidez con la que se marchita el bello rostro de la actriz podría equivocarse con una aceleración; sin embargo, lo cierto es que este constructo digital no tiene nada que ver con la alteración del tiempo del registro. Recordemos que la aceleración de la imagen cinematográfica puede lograrse mediante la captura a una velocidad menor a la de la posterior reproducción. Como tendremos ocasión de ver en el segundo capítulo, en el cine científico, esta estrategia permite contemplar las metamorfosis de las plantas y otros fenómenos profílmicos, invisibles al ojo desnudo por demasiado lentos. Por el contrario, en el morphing, no se trata de hacer visible lo invisible, sino de exhibir la construcción espacial; no es cuestión de registrar una metamorfosis, sino de crearla. Aunque la plasticidad del espacio digital permite simular la maleabilidad del tiempo cinematográfico, la imagen digital está lejos de ser un mero sucedáneo de la imagen cinematográfica.

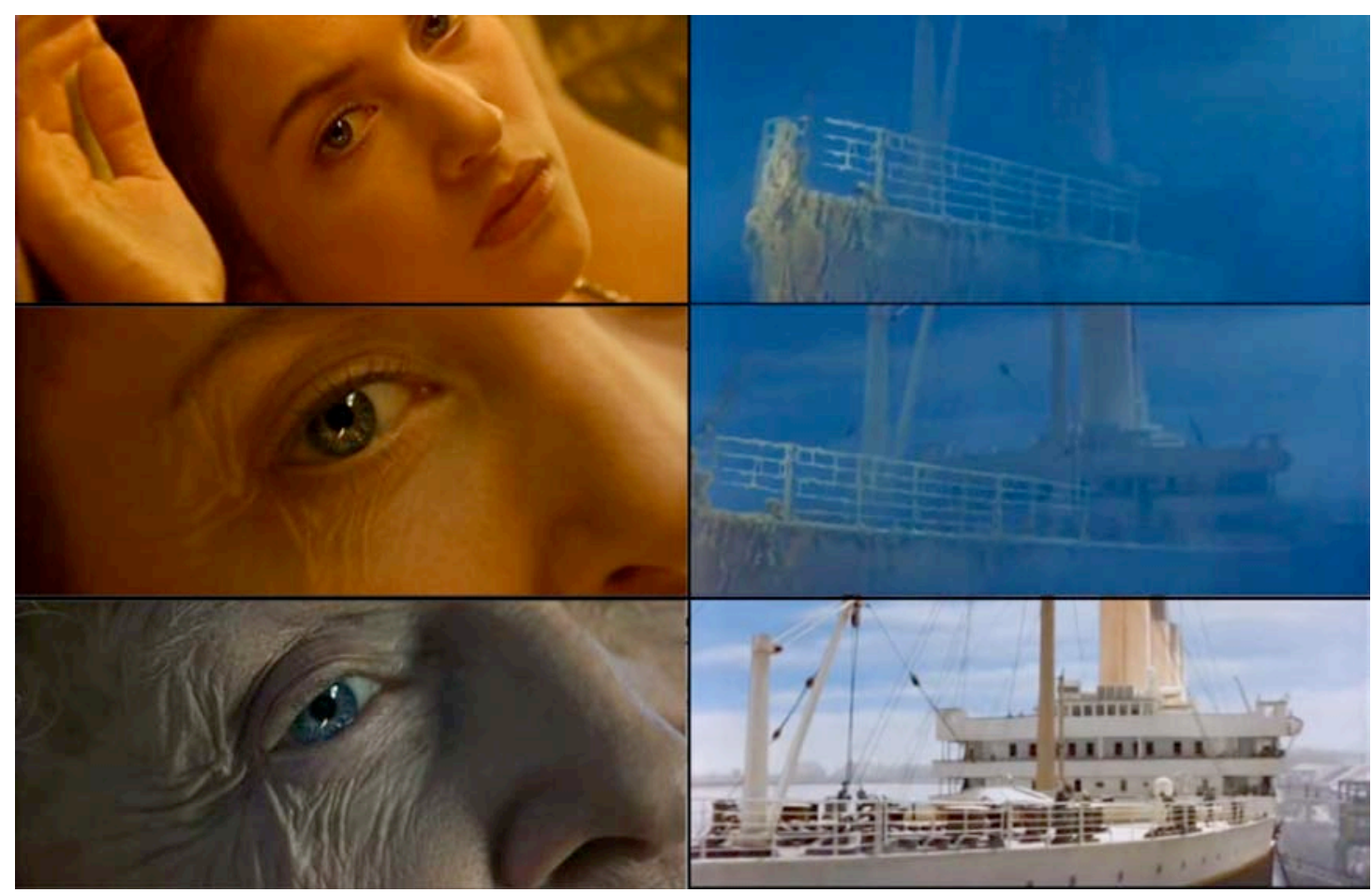

Titanic (1997), de James Cameron

La interpolación digital parte de dos imágenes A y B, no de dos momentos antes/después. A pesar del parecido entre la alteración temporal y la interpolación digital que nos ocupa, el proceso que sustenta cada imagen es el opuesto: la aceleración se produce por sustracción, obviando los lapsos entre dos capturas. El 
morphing funciona a la inversa, por llenado de los intersticios, por adición espacial, creando fases intermedias artificialmente. ${ }^{1}$ En la metamorfosis digital, la continuidad de la transformación es un artificio, un cálculo. No extraña, pues, que el morphing sea paradigmático de una estética basada, justamente, en presentar en continuidad lo esencialmente discontinuo.

En Titanic, la mutación no forma parte de la diégesis, de la historia, sino del discurso, de la enunciación, de la sintaxis narrativa: es un nexo, un lazo artificial que debe poco o nada a un proceso físico externo. La cuestión no es el envejecimiento del personaje (aspecto evidente teniendo en cuenta que han pasado varias décadas desde el accidente), la cuestión es ese dar forma al paso del tiempo. Si el montaje temporal cinematográfico hace coincidir la elipsis con el vacío del corte entre los planos, las construcciones digitales que nos ocupan dan forma a ese espacio intermedio, a una continuidad paradójica, sólo posible en la imagen.

En este sentido, los morphing de Titanic sustituyen al clásico fundido encadenado como transición espacio-temporal. Esta sobreimpresión gradual que produce una mezcla heterogénea es una de las pocas construcciones espaciales explícitas usadas por el cine clásico. En Smultronstället ("Fresas salvajes”, 1957) de Ingmar Bergman, un fundido encadenado permite pasar de la realidad al sueño: la casa cerrada y abandonada que contempla el protagonista es sustituida, poco a poco, por una imagen con el mismo ángulo y escala de la vivienda varias décadas antes. A la transición explícita acompaña la voz en off del narrador, que subraya la fusión de las imágenes en la mente: "La realidad clara del día se disolvió en las aún más claras imágenes de la memoria." La mezcla de las imágenes en blanco y negro forma hermosos tejidos de luces y sombras. Así, esta sobreimpresión no sólo permite condensar el relato, sino que funciona como metáfora visual del paso del tiempo. ${ }^{2}$

Comparemos el morphing del barco en Titanic con el fundido encadenado de la casa en Smultronstället, cuarenta años antes. Como ya apuntábamos en el apartado anterior, la diferencia fundamental entre ambos tipos de cross-dissolve es el warping

\footnotetext{
${ }^{1}$ Más adelante, veremos cómo la interpolación permite la creación de ralentíes extremos, como es el caso del efecto de "bullet time". En lugar de registrar un gran número de fotogramas por segundo, el cálculo informático permite crear imágenes intermedias de manera prácticamente infinita.

2 "Le fondu enchaîné consiste en la substitution d'un plan à un autre par surimpression momentanée d'une image qui apparaît sur la précédente qui s'évanouit. Il a toujours, sauf des rares exceptions, la mission de signifier un écoulement du temps en faisant se remplacer graduellement deux aspects temporellement différents (dans le sens de l'avenir ou du passé selon le contexte) d'un même personnage ou d'un même objet." MARTIN, Marcel. Op. cit., p. 97.
} 
digital: la deformación de las imágenes fuente de modo que la mezcla entre ambas sea homogénea y se produzca en un único flujo continuo. En este sentido, podríamos clasificar el grado de viscosidad del constructo según la fricción entre las imágenes o su resistencia a la transformación: el fundido encadenado se situaría a medio camino entre el "líquido" del morphing y el sólido del corte temporal.
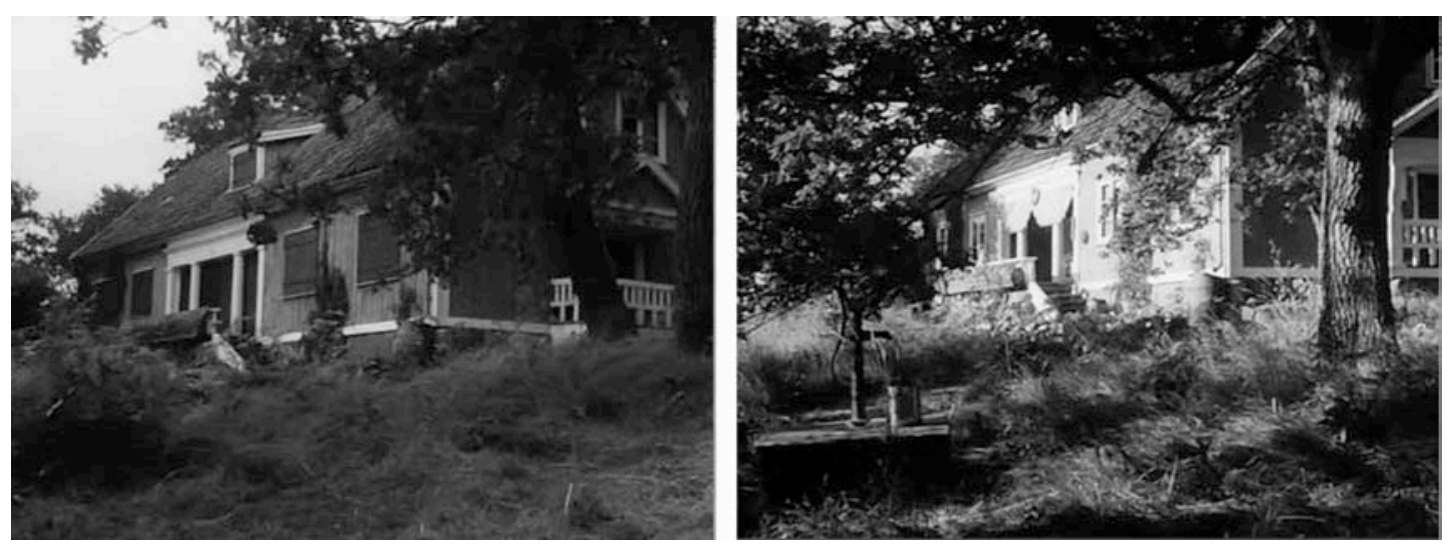

Smultronstället (1957), de Ingmar Bergman

Tanto en el fundido encadenado como en el morphing, la primera imagen desaparece a medida que se va formando la segunda, la cual, finalmente, se impone como resultado de la mutación. Pero si en el fundido las imágenes conviven en diversas capas, en el morphing, la metamorfosis supone la síntesis de las fases intermedias. La discontinuidad de las imágenes de partida queda abolida gracias a la creación de un flujo continuo de variaciones. Esta continuidad sólo es posible gracias al carácter discreto de la red de píxeles. En resumen: la mayor fluidez del morphing frente al fundido encadenado tiene que ver con el acceso atómico a la transformación. Aunque en ninguno de los dos tipos de cross-dissolve existe vacío entre las imágenes ${ }^{3}$, el morphing presenta una homogeneidad, una continuidad matricial; el flujo entre las imágenes es tan liso que se colma, incluso, el vacío entre las capas.

En The Lord of the Rings: The Fellowship of the Ring (2001) de Peter Jackson, una transición espacio-temporal combina a la perfección morphing y fundido, reservando a cada efecto una significación diferente. El flash forward toma forma en un proceso doble: por un lado, el paso del cuerpo sin vida de Aragorn (Viggo Mortensen) a su estatua funeraria; por otro y al mismo tiempo, la figura de Arwen (Liv Tyler), junto al cuerpo yacente en el funeral, se desvanece poco a poco al compás

\footnotetext{
3 “Avec le fondu enchaîné, avec le mélange d'images en général, il n’y a plus de vide 'entre' les images.” AUMONT, Jacques. Matière d'images. Redux. Op. cit., p. 273.
} 
de la transustanciación del muerto. La combinación de morphing y fundido prueba la semejanza entre ambos. No obstante, la metamorfosis digital funciona como metáfora de la muerte y la descomposición del cuerpo como una auténtica transformación de la materia: de la carne al polvo. Por el contrario, el desvanecimiento paulatino de la imagen de ella no implica un cambio de sustancia o la defunción del personaje, sino, simplemente, su desaparición del plano como consecuencia del paso del tiempo.

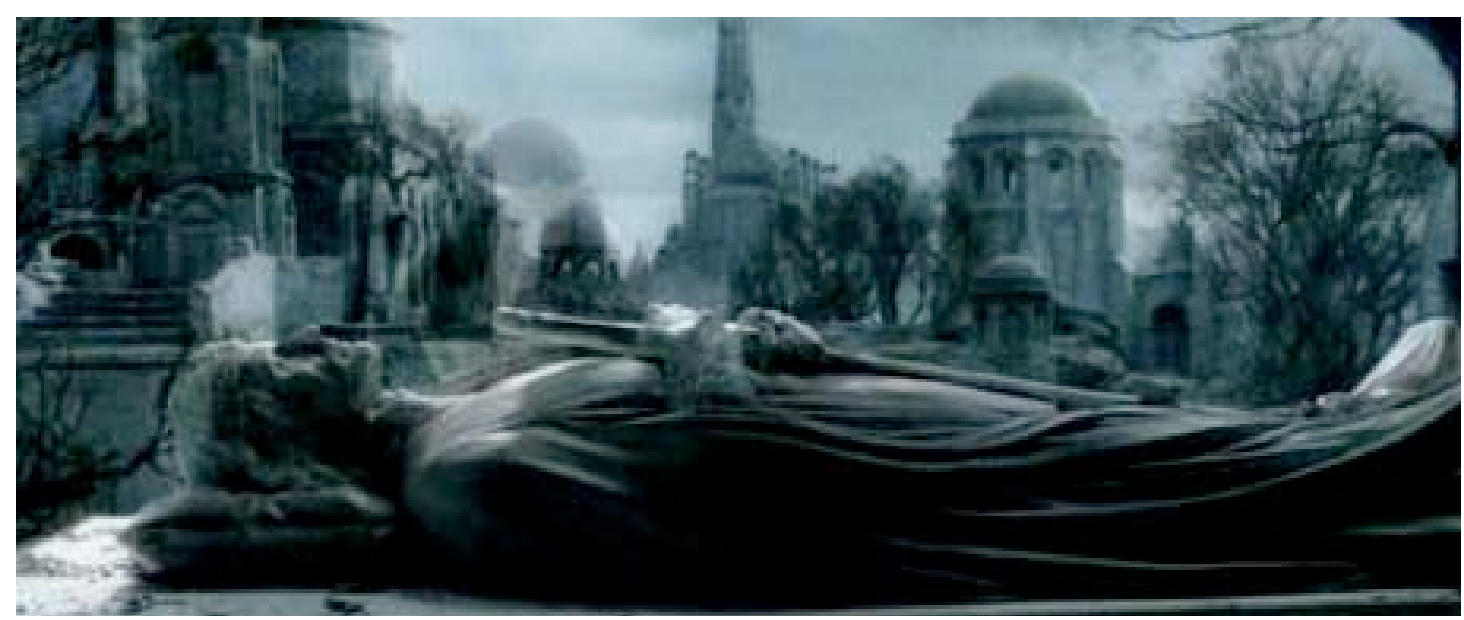

The Lord of the Rings: The Fellowship of the Ring (2001), de Peter Jackson

En el lenguaje cinematográfico, el fundido encadenado puede sustentarse, simplemente, en el paralelismo entre las composiciones de las imágenes-fuente, facilitando una transición armónica entre espacios y tiempos distantes. Este tipo de montaje espacial garantiza el raccord entre los planos ${ }^{4}$. De este modo, a la redundancia entre las formas se une la continuidad del flujo entre las imágenes.

Así, por ejemplo, en Pleasantville (1998), a la hora de enlazar dos escenas no sucesivas y no conectadas causalmente, Gary Ross acude a una sobreimpresión de este tipo, que permite el salto temporal antes-después. La sutura elegida es una figura de la sintaxis audiovisual que corresponde grosso modo al "más tarde, en otro lugar" del relato oral. Los dos planos de partida comparten la disposición de las figuras: un contrapicado de un primer plano de un bombero da paso a una imagen del protagonista con la misma escala y ángulo.

\footnotetext{
4 “Les raccords sont précisément autour du point du montage (...) un moyen de jouer sur la continuité des plans. 'Raccorder' c'est faire en sorte, comme le terme l'indique, que le cut ne soit pas ressenti comme une rupture définitive et radicale, mais comme l'occasion d'une couture, qui permet d'assembler des morceaux différents avec la plus grande discrétion. Il s'agit de camoufler la césure, d'en effacer l'impression, tout en conservant la qualité d'articulation qui est au principe des changements des plans." AMIEL, V.. Esthétique du montage (2001). Paris: Armand Colin, 2010, p. 25.
} 


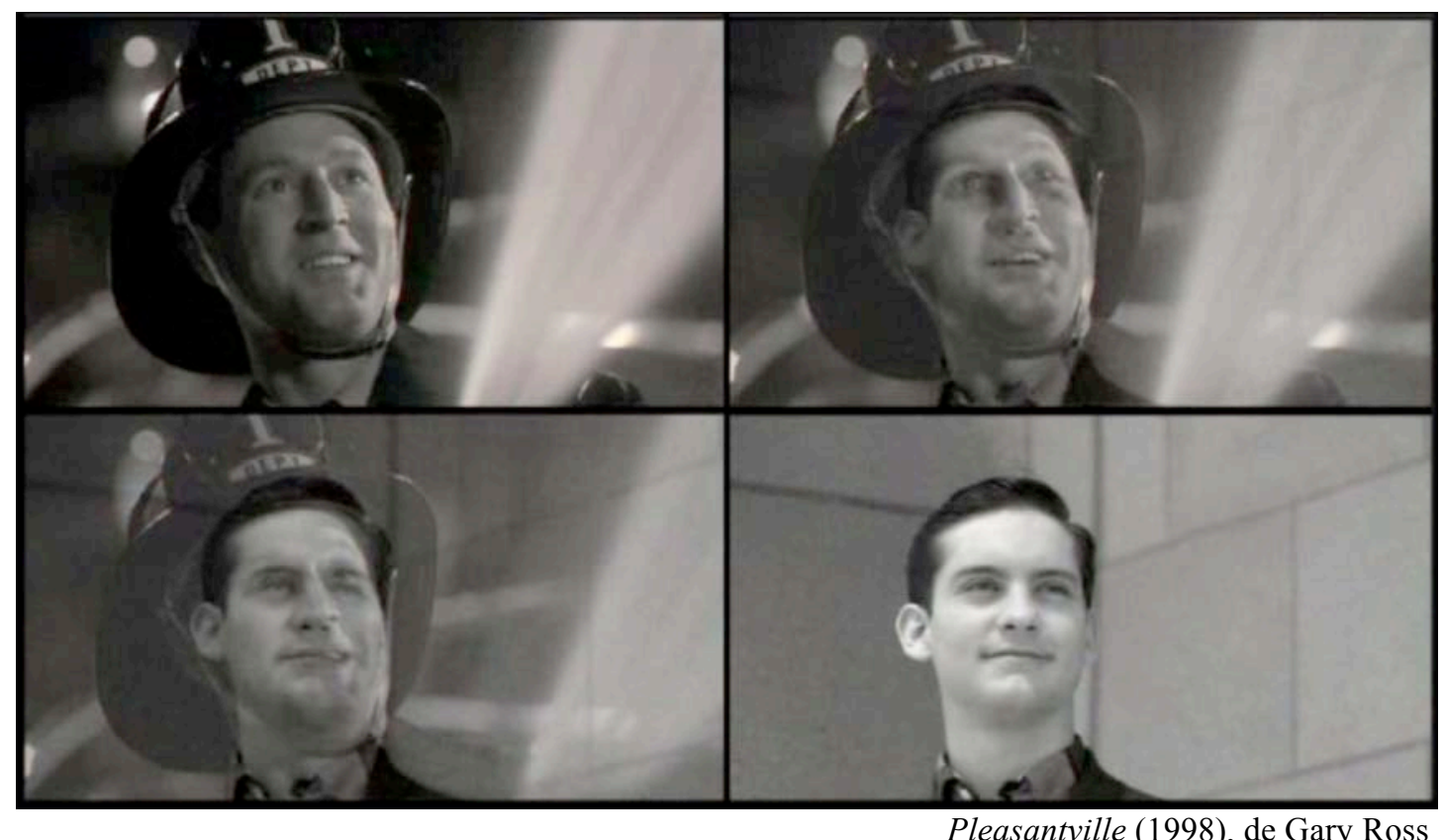

The Fall (2006), de Tarsem Singh, contiene un buen ejemplo de morphing como raccord: el paso de un primer plano de una mariposa a uno general de una isla con forma semejante se lleva a cabo mediante una metamorfosis digital de toda la imagen en su conjunto. En esta ocasión, la transformación gradual de la caja que contiene el insecto muerto a la superficie ondulante del océano impone una contracción continua de la escala.

La mezcla heterogénea en la película de Ross no deja lugar a dudas: el fundido es simplemente una elipsis que permite hacer avanzar la historia. Por su parte, el morphing en The Fall es una figura sintáctica más compleja. Imaginemos que la transición espacio-temporal de Pleasantville se hubiera realizado mediante un morphing: la continuidad transparente de la metamorfosis produciría un efecto ambiguo de verdadera transformación de un personaje en otro, al modo del videoclip de Landis. El morphing da forma a una metamorfosis fiel a como se produciría, de ser posible, entre dos personajes u dos objetos materiales. La experiencia estética se basa, precisamente, en ese verismo imposible.

El efecto digital insiste en el proceso de cambio, sea éste un reflejo de la mutación que el paso del tiempo cronológico conlleva (Titanic) o un proceso imaginario, pura y exclusivamente visual, que pertenece a la imagen sin pretender representar ningún fenómeno profílmico. Dicho de otro modo, mientras que la protagonista de Titanic sí había envejecido y el barco sí se había oxidado, en The Fall, 
la mariposa no se había convertido en isla, por mucho que la imagen muestre exactamente lo contrario.

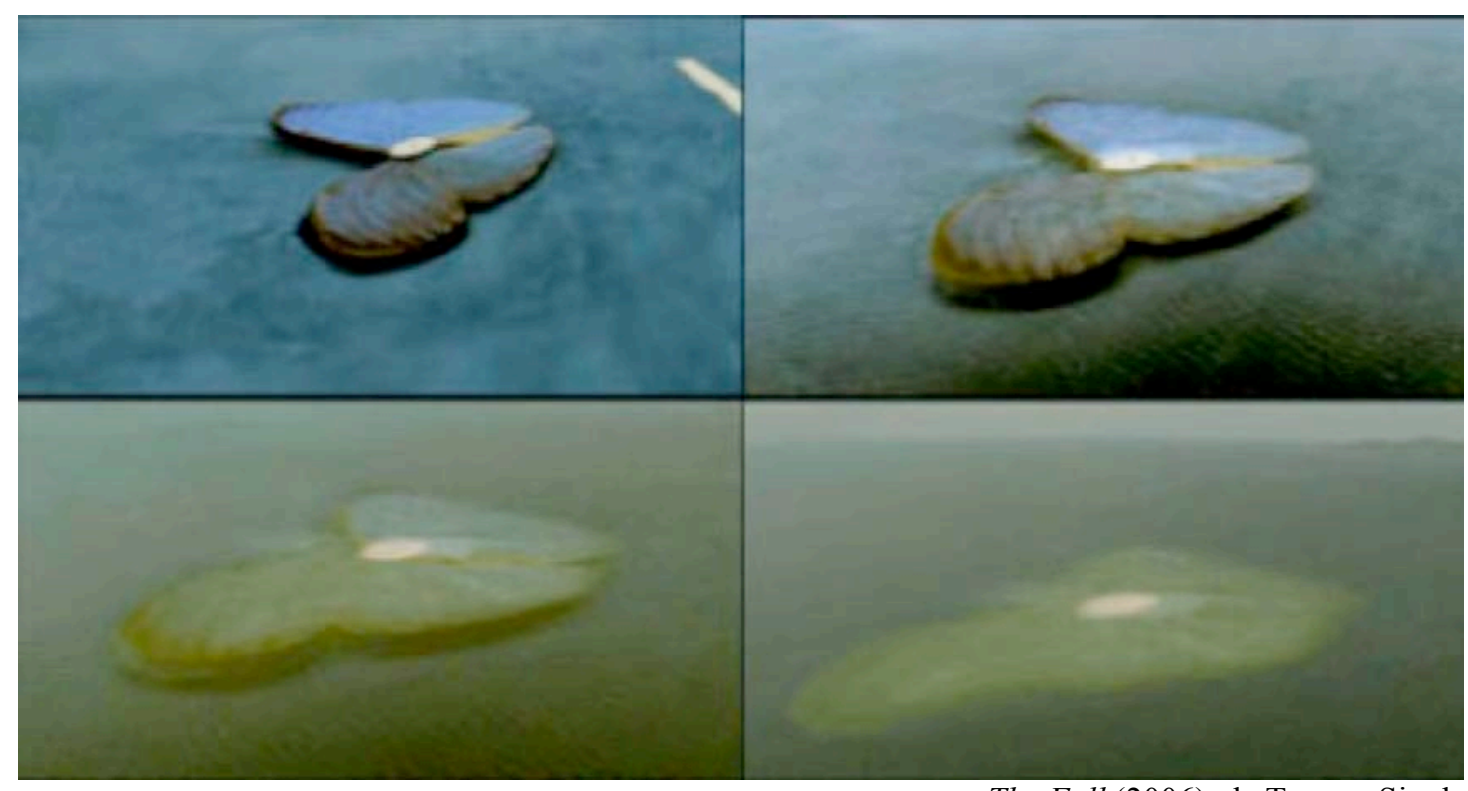

The Fall (2006), de Tarsem Singh

En ambas películas, la metamorfosis de la imagen supone un cambio de medio: si en The Fall la caja que contiene el insecto se transforma en una inmensa masa acuática, el morphing del Titanic implica una traslación del fondo del océano a la superficie. De modo semejante, en Big Fish (2003) de Tim Burton, el coche del protagonista sale de la profundidad marina gracias a un simple cambio lumínico. Ahora bien, nótese que, en esta ocasión, no se produce una mutación de la figura, sino una gradación de la luminosidad. En realidad, el uso del morphing como signo de puntuación de la gramática audiovisual digital no representa un caso aislado: la mutación continua de la imagen puede lograrse, también, mediante el retoque y la composición, como veremos detenidamente a continuación.

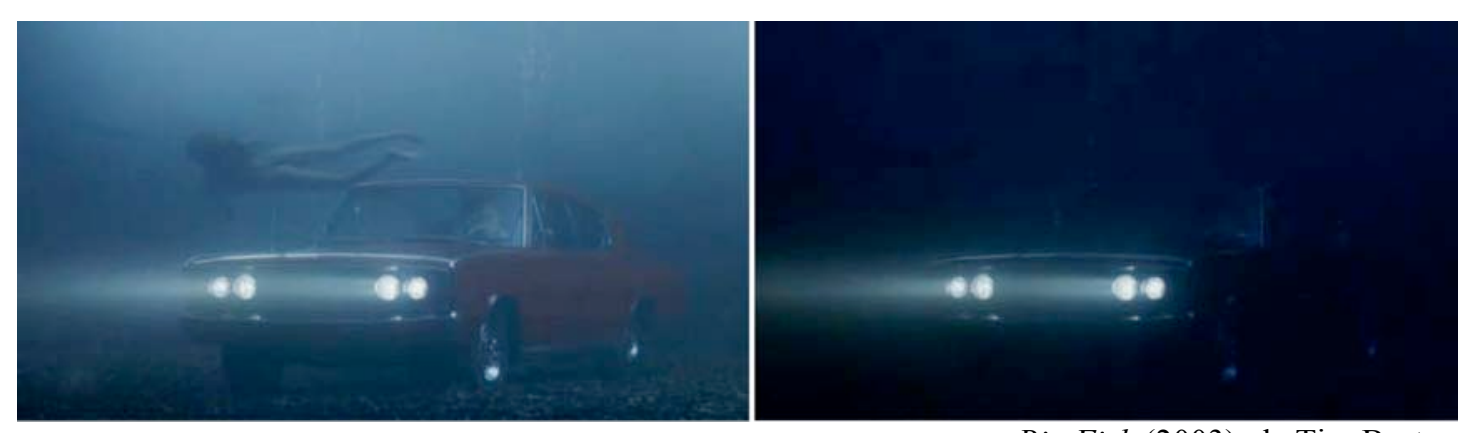

Big Fish (2003), de Tim Burton 


\section{La transformación lumínica y la estratificación en capas}

Un caso semejante de alteración lumínica como transición entre el medio acuático y el terrestre es el de la apertura de Tideland (2005), de Terry Gilliam. La película comienza con la voz en off de la protagonista sobre un fundido en negro. A continuación, aparece un fondo marino repleto de algas mecidas por el agua. Poco a poco, la imagen va tomando un tono verde hasta convertirse en un campo amarillo, ondeado por el aire. Esta transformación gradual supone la transición de la imaginación de la niña a la realidad física en la que se sitúa. En el cine clásico, el paso del sueño a la realidad o viceversa suele figurarse bien mediante un desenfoque, bien mediante un fundido encadenado semejante al descrito en la película de Bergman. ${ }^{5}$ Por su parte, Gilliam se decanta por una transformación cromática continua que permite, además, contemplar la metamorfosis del medio.

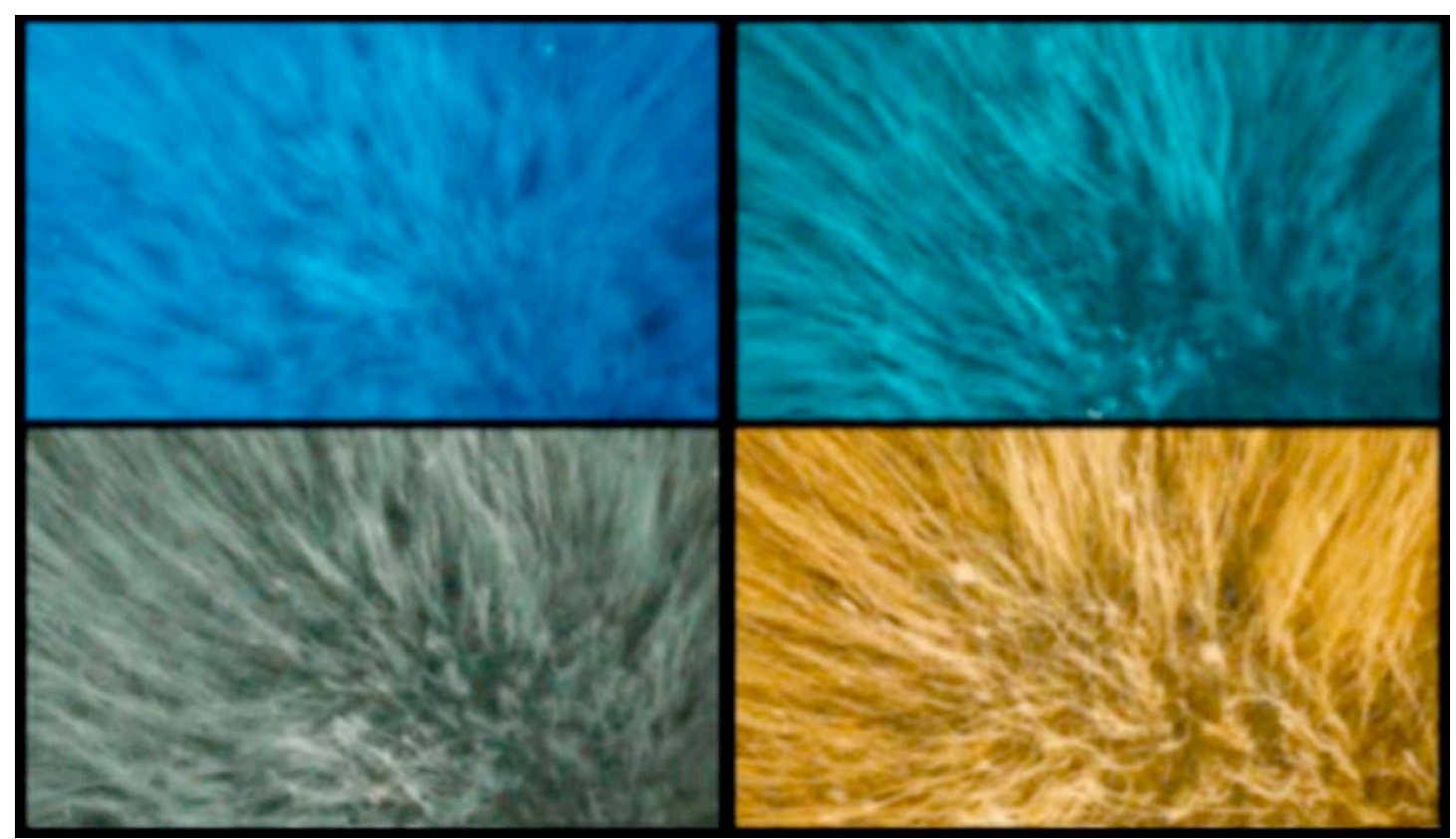

Tideland (2005), de Terry Gilliam

El proceso de transformación opuesto, del exterior a la inmersión acuática, se lleva a cabo mediante un montaje espacial que permite una continuidad artificial entre los dos espacios. Guiño al cuadro de Andrew Wyeth “Christina's World” (1948), la protagonista, sentada entre las hierbas secas, observa al fondo una casa. Ahora bien,

\footnotetext{
${ }^{5}$ Ambos efectos se remontan a los inicios del cine: el desenfoque es usado por George Albert Smith en Let Me Dream Again (1900), mientras que Ferdinand Zecca elige un fundido encadenado en su versión del anterior, Rêve et réalité (1901).
} 
frente a la témpera de la artista americana, en la imagen digital animada, el campo no funciona como límite, sino como superficie permeable. La transición al mundo acuático se produce mediante un cabeceado de la cámara y un montaje espacial de las imágenes que permite un movimiento continuo, como si ese mundo marino se situara inmediatamente debajo del paisaje agostado.

Cuatro años después, Gilliam incluye una imagen semejante en The Imaginarium of Doctor Parnassus (2009). En un espacio simétrico, la cámara virtual cabecea $180^{\circ}$, volteando la imagen sobre su propio eje horizontal, que coincide con la superficie del agua, en la que se refleja la barca con dos de los personajes. Aunque la sección superior corresponde a la escena diurna, el reflejo del lago (abajo) anticipa la noche. A medida que la imagen rota y gracias a un cambio lumínico gradual, la sección inferior se sitúa arriba, permitiendo así la condensación temporal.

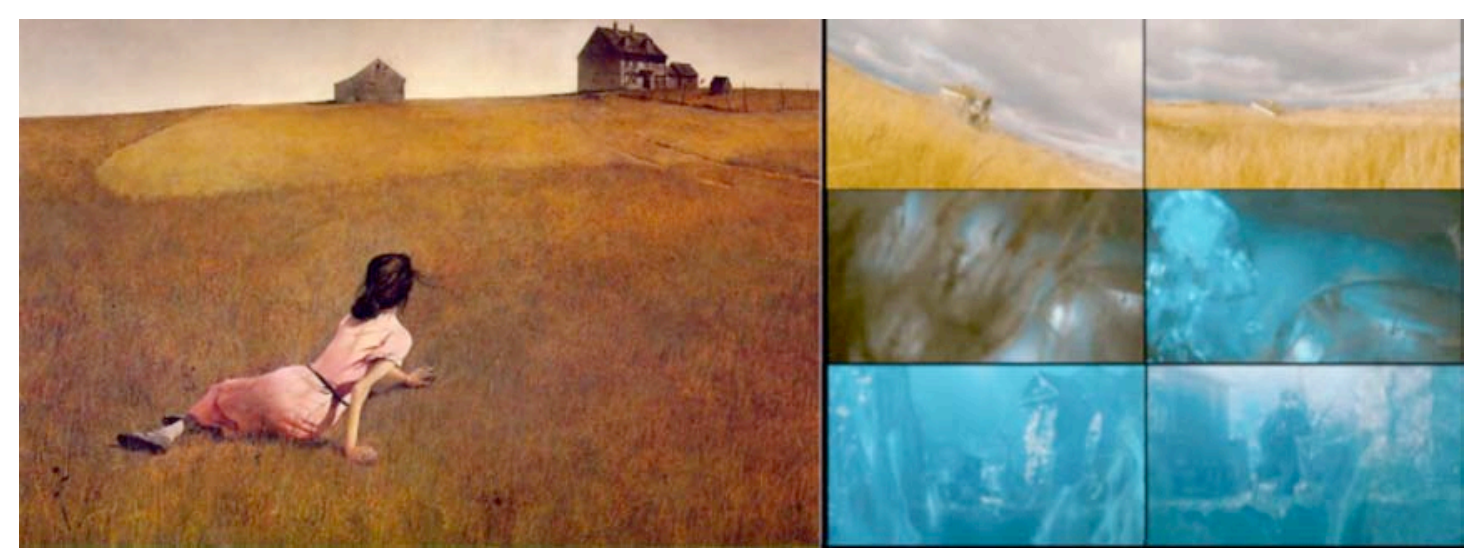

Izquierda. Andrew Wyeth: "Christina’s World” (1948). Derecha. Tideland (2005), de Terry Gilliam

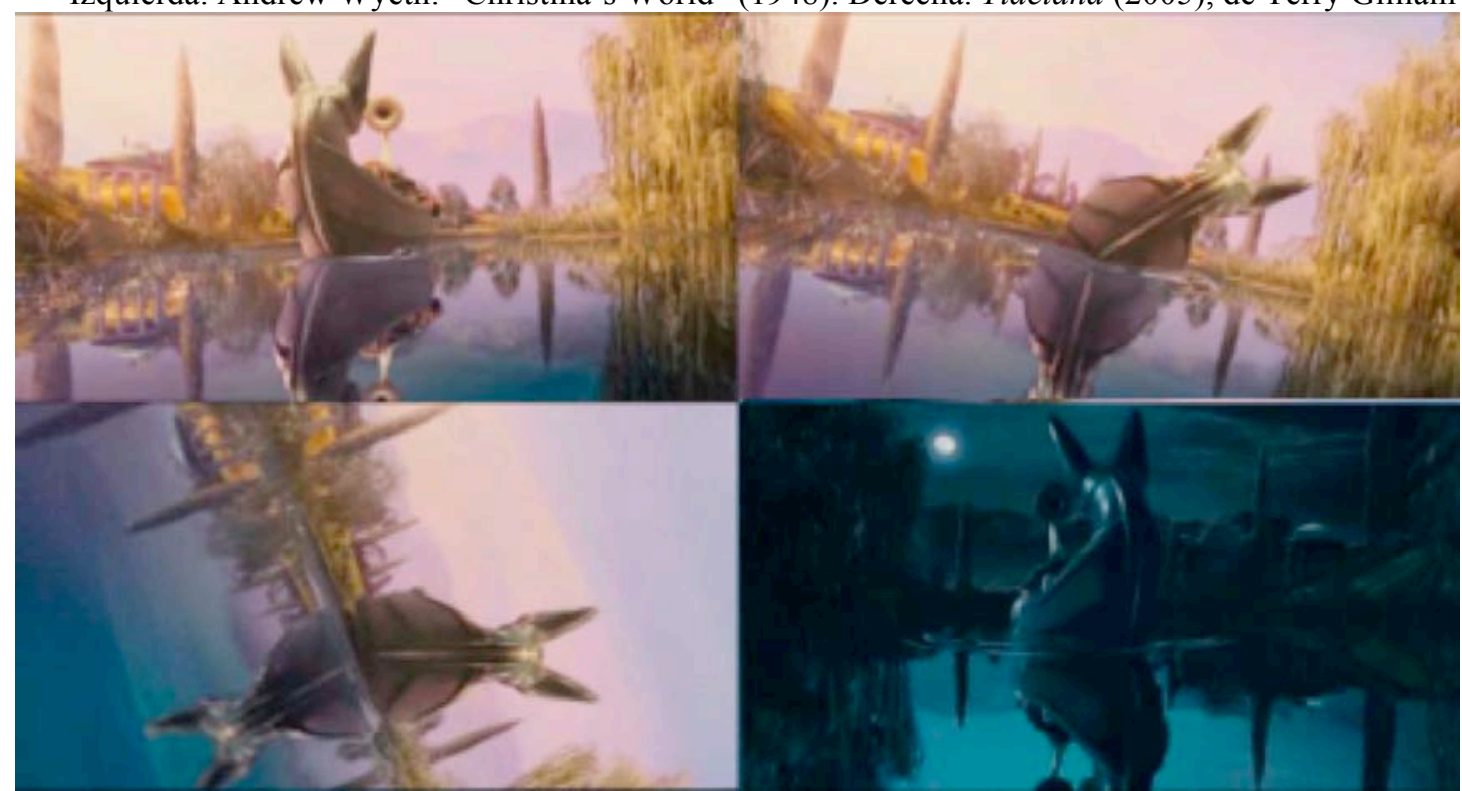

The Imaginarium of Doctor Parnassus (2009), de Terry Gilliam 
Esta combinación de transformación lumínica y cámara virtual para dar forma al paso del tiempo es especialmente clara y frecuente en la película Moulin Rouge (2001), de Baz Luhrmann. En el ejemplo seleccionado, la cámara virtual atraviesa las aspas de un molino y, suspendida en el aire, se aproxima a la ventana del piso en el que el protagonista escribe a máquina la historia de amor del famoso cabaret. El zoom in va acompañado de un cambio de la noche al día, que se produce gradualmente en la imagen, de izquierda a derecha, a medida que giran los brazos del molino. Antes de que la noche caiga, conviven en la imagen las dos iluminaciones al modo del cuadro de René Magritte “L’Empire de lumières”, que veíamos ya en el apartado dedicado a la mezcla de las imágenes.

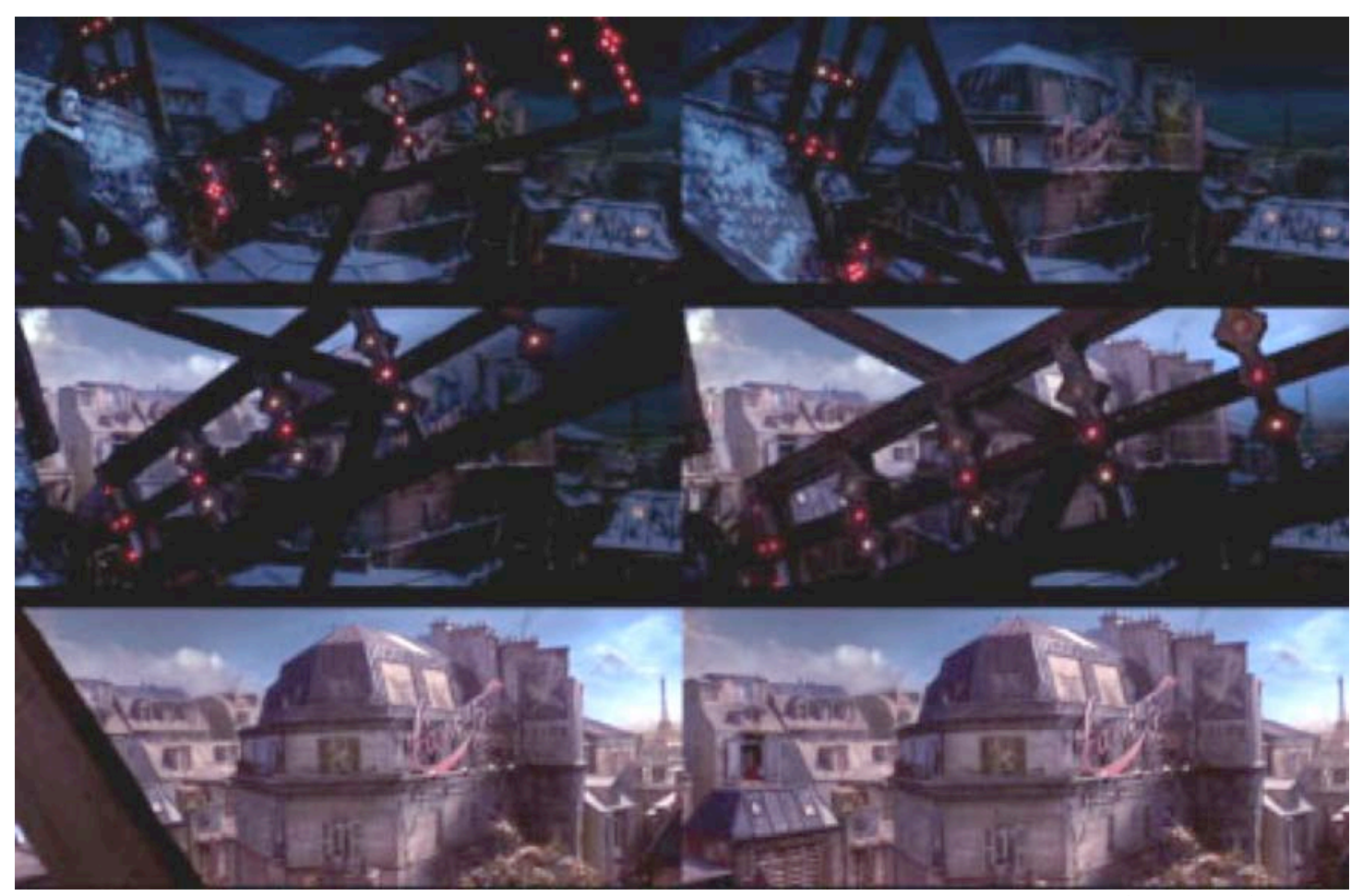

Moulin Rouge (2001), de Baz Luhrmann

Un aspecto interesante de tal transformación de la imagen es que el trabajo bidimensional de la composición no impide que el movimiento de la cámara virtual se produzca en profundidad. Así, mientras el cambio lumínico lateral resalta la condición plana de la imagen, el desplazamiento perpendicular de la cámara genera un efecto de volumen. En el próximo capítulo, nos detendremos tanto en la exploración de esta "profundidad cinética" como en la omnipotencia de la cámara virtual, que subraya el espacio intermedio y permite unir opuestos. 
En The Fall de Tarsem Singh, otra mutación de la imagen como alternativa al corte cinematográfico se consigue gracias a la combinación del montaje espacial y la dinamización del punto de vista. Mediante un giro de $360^{\circ}$, el fondo se transforma permitiendo la transición de unas ruinas clásicas a un paisaje desértico. El uso del green screen permite el acceso independiente al fondo. El resultado es una transformación espacial que hace eco al proceso de cambio que el narrador en off describe con palabras: "Y no estaba en medio de ningún edificio antiguo: estaba perdido en medio de un vasto desierto."

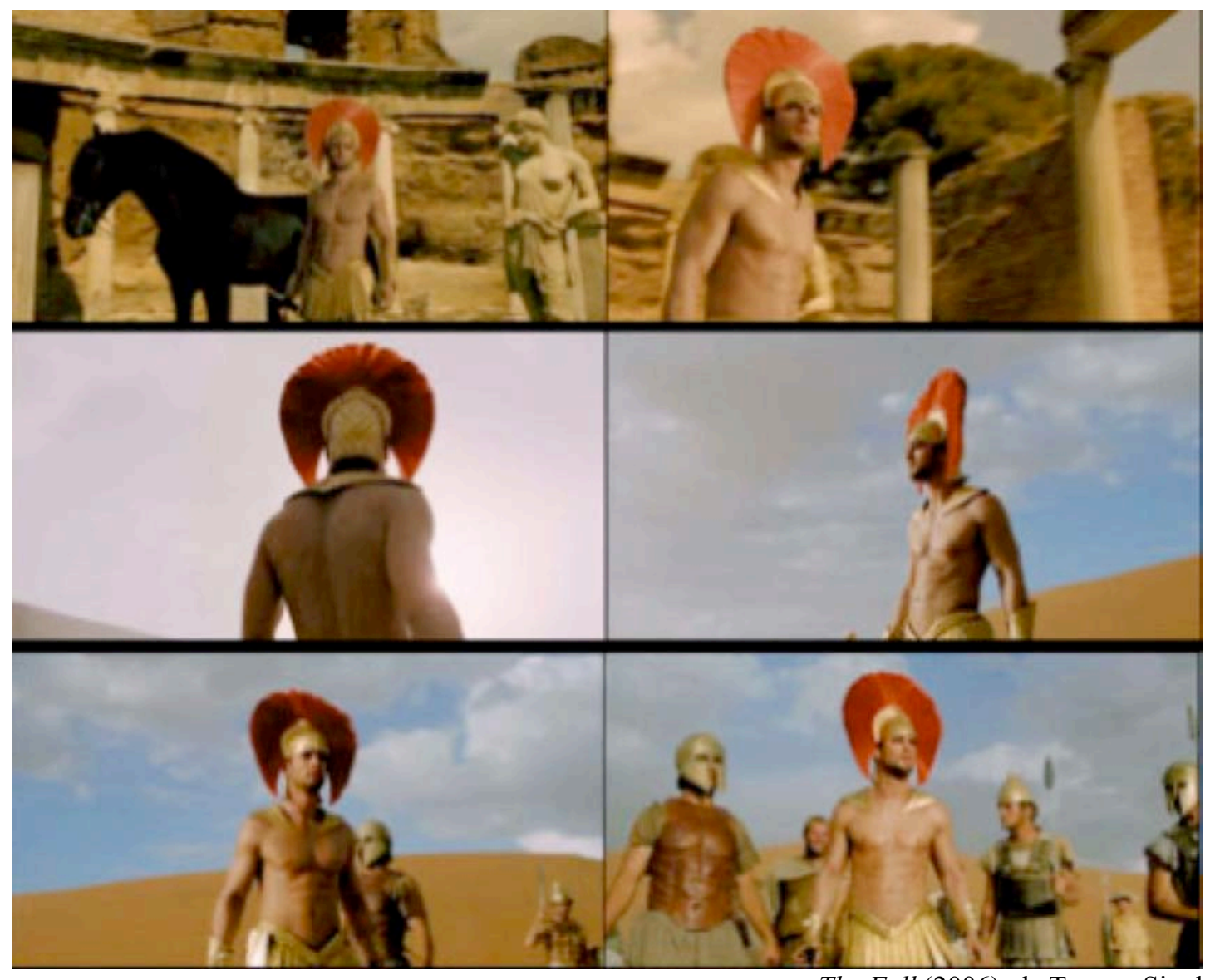

The Fall (2006), de Tarsem Singh

Como veíamos en el apartado dedicado a la mezcla de las imágenes, este trabajo en capas bebe de procedimientos ópticos y mecánicos anteriores, generalmente ocultados en aras de la transparencia del constructo. Con todo, conviene tener presente que las obras de realizadores que conceden una gran importancia al espacio cinematográfico anteceden a las creaciones digitales que nos ocupan y prueban, una vez más, ese anhelo de plasticidad en relación a la imagen registro. 
Citemos como una de estas excepciones la película Vertigo (1958), de Alfred Hitchcock. El protagonista, John Ferguson (James Stewart), sufre alucinaciones en las que cree ver a un antiguo amor, Madeleine (Kim Novak), cuyo suicidio no pudo impedir. En una de estas apariciones, la cámara gira en torno a la pareja, que se besa mientras el fondo se transforma; esta metamorfosis les traslada de la habitación de un hotel a una plaza de San Juan Bautista en California, en la que se habían declarado justo antes de la muerte de ella. Hitchcock logra aislar las figuras del fondo gracias a un antecedente del green screen conocido como "rear projection". Éste consiste, básicamente, en situar a los actores delante de una pantalla que será registrada en la toma sin revelar sus márgenes.
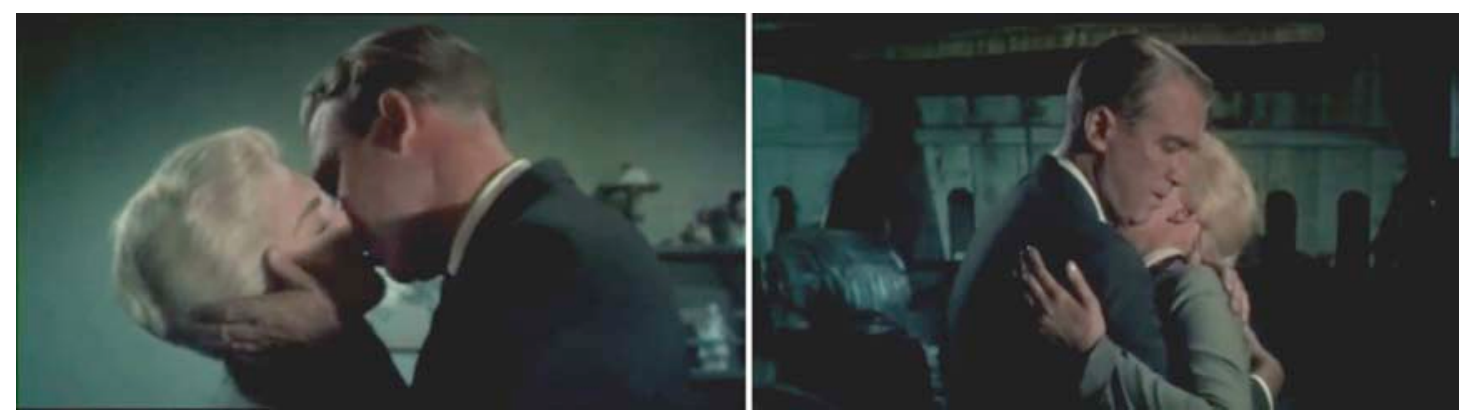

Vertigo (1958), de Alfred Hitchcock

Si en The Fall la metamorfosis del fondo corresponde a la visualización del relato oral del narrador, estableciendo un eco entre el lenguaje y la imagen código, en Vertigo, la rear projection permite introducir la alucinación del protagonista de modo semejante a la escena que veíamos en Sunrise (1927). En la película de Murnau, mientras la pareja atraviesa la calzada, un fundido encadenado transforma el fondo bullicioso del tráfico urbano en un paisaje bucólico. La mutación del espacio da forma, así, a la ensoñación de los personajes.

Como veíamos, la escena de Sunrise destaca por una extraña coexistencia entre la profundidad del espacio representado en la imagen y la profundidad de la imagen misma. Esta rareza es explotada por las prácticas digitales gracias al proceso de elaboración en capas que proponen los programas de edición. De hecho, hallamos numerosas transiciones espacio-temporales basadas en este tipo de construcción.

Éste es el caso, por ejemplo, del videoclip de Little X Coming Undone (2006), para Korn. Hemos señalado ya la aparente rotura del objetivo como rechazo explícito a la metáfora de la ventana. En esta ocasión, no es la superficie de la pantalla, sino el 
fondo el que se descompone: el cielo azul cae en pedazos sólidos, dejando tras él una noche estrellada; a continuación, ésta se desintegra dando paso a un blanco luminoso.

The Imaginarium of Doctor Parnassus contiene una fragmentación semejante. Los pedazos en los que se divide la imagen se desplazan desvelando el fondo monocromo: el "fondo" tal y como es entendido en el proceso de composición y en la barra de herramientas del programa de edición digital. Esta vez, la descomposición del espacio tridimensional representado no sólo afecta al espacio de la imagen, sino que forma parte del espacio diegético de la película. Gran parte de la historia narrada por Gilliam se desarrolla "al otro lado del espejo", en un mundo de imágenes construidas gracias a la mente del doctor Parnassus. Dentro del "imaginarium”, el paso de un espacio a otro se presenta como un salto abrupto entre la imagen aparentemente tridimensional y la capa bidimensional que la contiene, en un juego de activación y desactivación del trampantojo.
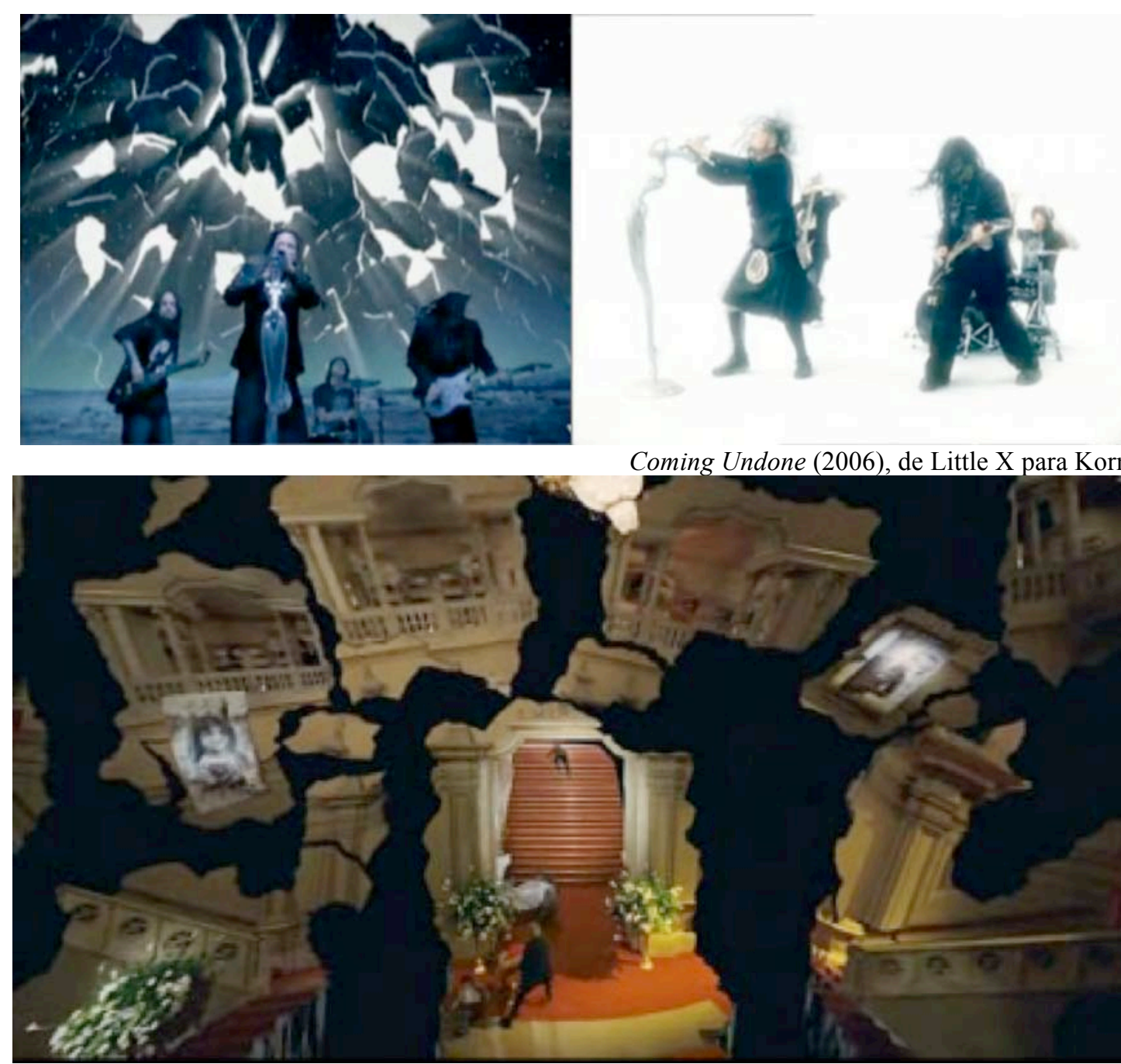

The Imaginarium of Doctor Parnassus (2009), de Terry Gilliam 
La escena final de la película Enchanted (2007), de Kevin Lima, presenta a los personajes en su final feliz como parte de un libro desplegable en tres dimensiones o “pop-up book". El cambio de la imagen registrada a las siluetas bidimensionales que componen las páginas del cuento se produce a través de una congelación que sustituye al espacio tridimensional reproducido el espacio bidimensional del constructo. A pesar de la parálisis de los personajes, no se anula todo movimiento en la imagen: las páginas del libro se pasan, plegando y desplegando las escenas.

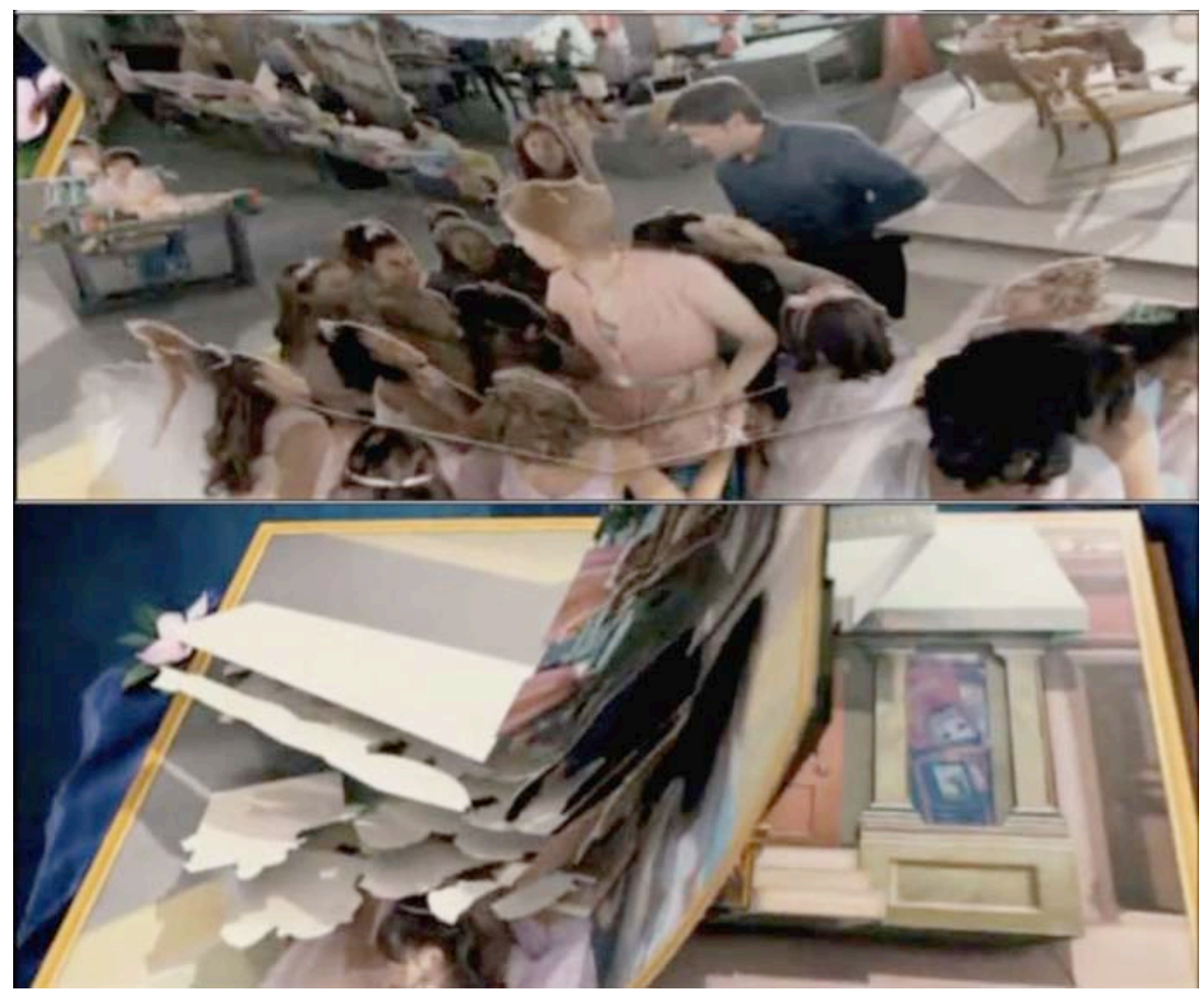

Enchanted (2007), de Kevin Lima

Veamos otro ejemplo de esta transición espacial basada en la exhibición de las capas que componen la imagen. En la publicidad Life moves fast, don't miss a thing (2010), realizada por los Snorri Bros para el teléfono móvil Palm Pre, una mujer camina hacia la cámara mientras la pantalla de su móvil, sobreimpresa en primer plano y a gran escala, muestra un mapa interactivo que permite geolocalizar las direcciones seleccionadas. A medida que la protagonista pulsa sobre la pantalla táctil, el fondo se transforma, tele-transportándola al lugar elegido. Es decir, la mutación del fondo corresponde a las páginas web por las que navega el personaje. Las transiciones 
se producen en un desplazamiento horizontal al modo de las cortinillas de Lola rennt, que veíamos en el apartado dedicado a la "cohabitación de las imágenes".

Estos saltos espaciales pueden relacionarse con la película Sherlock Jr. (1924) de Buster Keaton, en la cual el protagonista es absorbido por la pantalla cinematográfica. Los cambios repentinos de localización, que se producen independientemente de la situación del personaje, ponen al sujeto en peligro. El montaje temporal de Sherlock $J r$. se reduce a un control exhaustivo de la composición de manera que el actor aparece exactamente en la misma posición de un corte a otro, asegurando así la continuidad de la figura mientras el fondo cambia bruscamente.

Mientras en la publicidad es la propia mujer la que decide su situación geográfica, en la película, la imagen cambia sin contar con el personaje. La comicidad de la escena creada por Keaton radica en la propuesta de un espacio tridimensional creíble para una situación imposible. En cambio, Life moves fast, don't miss a thing juega con el choque entre dos espacios: el tridimensional de las calles y el bidimensional de la pantalla táctil del smartphone. Como en Sunrise de Murnau, el juego visual se basa en la competición entre el espacio representado y la profundidad de la imagen.

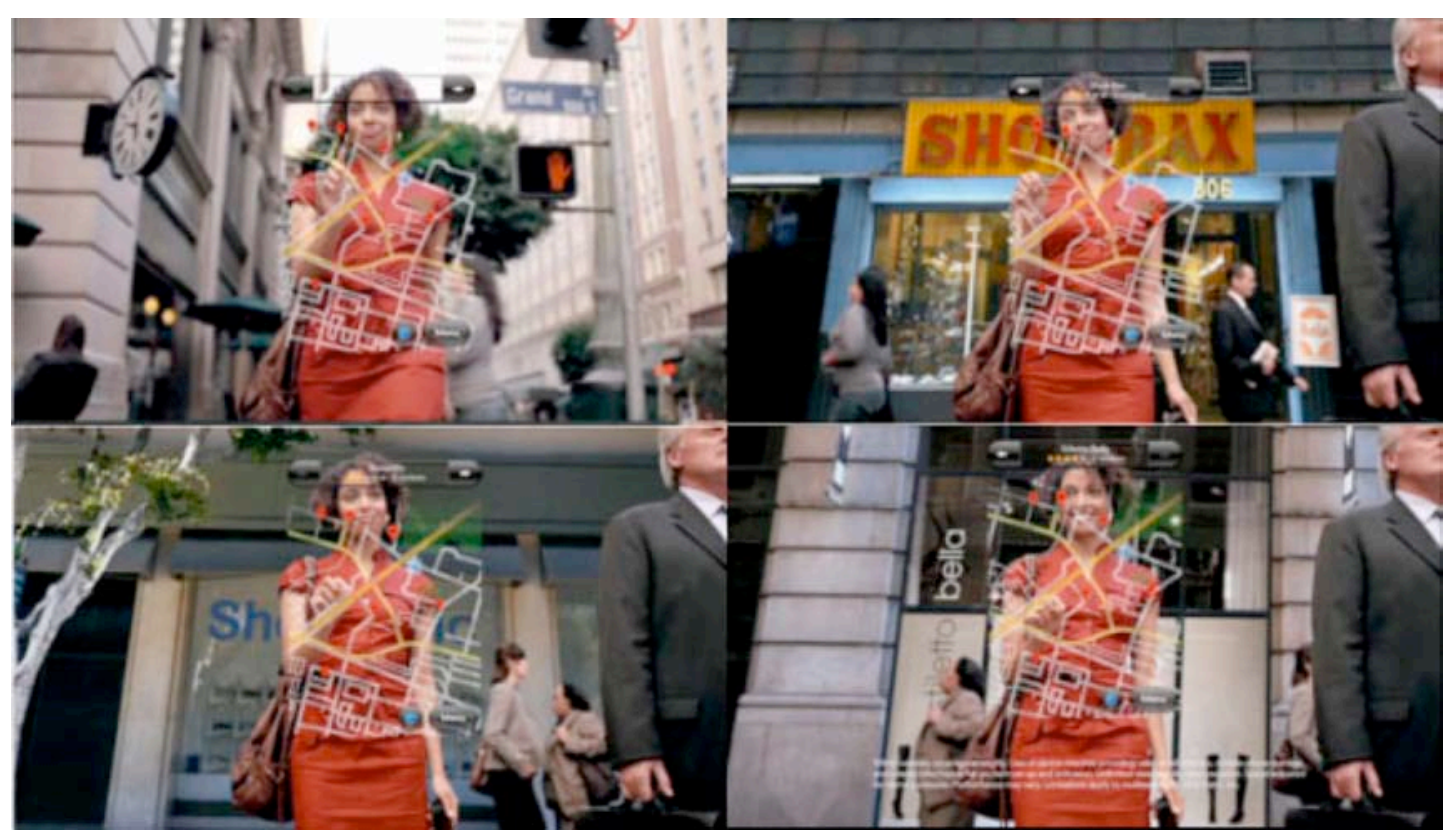

Life moves fast, don't miss a thing (2010), de los Snorri Bros 

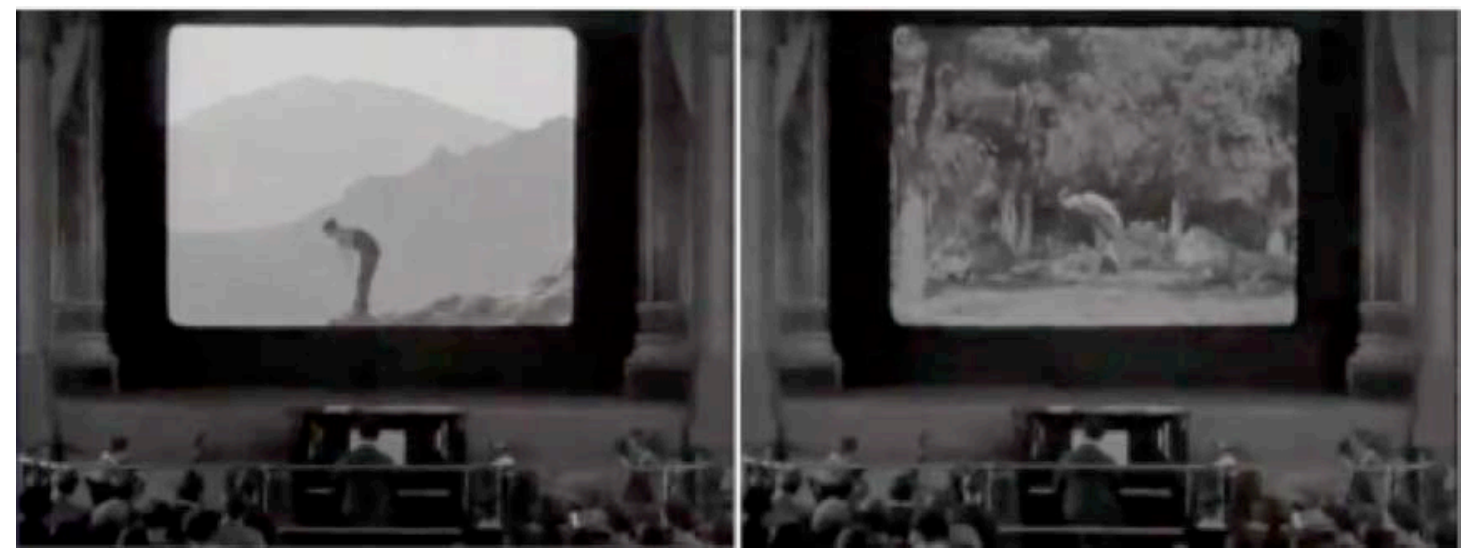

Sherlock Jr. (1924), de Buster Keaton

Basada en la novela homónima de Steven Gould ${ }^{6}$, la película Jumper (2008), de Doug Liman, presenta a un joven capaz de tele-transportarse y "saltar" de un lugar a otro de manera instantánea. Aunque los primeros "saltos" se producen de manera inesperada (como en Sherlock $J r$.), a medida que toma conciencia de su extraordinaria capacidad, el protagonista decide cuándo y dónde tele-trasportarse (en la línea de la publicidad de los Snorri Bros). Ahora bien, en esta ocasión, las transiciones espaciales no corresponden a un trabajo de la profundidad de la imagen, sino de su elasticidad, de su densidad. Se trata de materializar el puente interdimensional.

El salto se produce al modo de una grieta en el espacio-tiempo. La forma se distorsiona y se mezcla con el entorno que la envuelve. Curiosamente, esta elasticidad da forma a una contracción espacial, a una negación de la distancia entre las dos localizaciones. Frente a Sherlock $J r$, no hay vacío entre las imágenes, no hay corte, sino un proceso continuo de transformación. Joel Hynek, supervisor de los efectos visuales de la película, explica que el objetivo de esta transición explícita era crear un punto de vista distinto, el del "jumper", de modo que el receptor tuviera acceso a la experiencia del salto: al mismísimo corte transversal del espacio-tiempo. ${ }^{7}$ En el último capítulo, tendremos oportunidad de estudiar detenidamente otros ejemplos de viaje interdimensional y constataremos la frecuencia de la metáfora líquida como visualización del puente.

\footnotetext{
${ }^{6}$ GOULD, Steven. Jumper (1992). New York: Starscape Books, 2002.

7 "Teleporting has almost always been seen from an objective view - in others words, you're in a place and you suddenly see somebody arrive or depart. But we've created true POV jumps so that you get a sense of what it looks and feels like from the Jumper's perspective to move from one place to another on the other side of the earth or the other side of a wall. In other words, this time the audience gets to go along for the ride." HYNEK, Joel. Entrevista realizada por Bill Dawes. Jumping around with Weta [En línea]. Fxguide. 23 de febrero de 2008. Disponible en Web:

$<$ http://www.fxguide.com/featured/Jumping_Around_with_Weta/>
} 


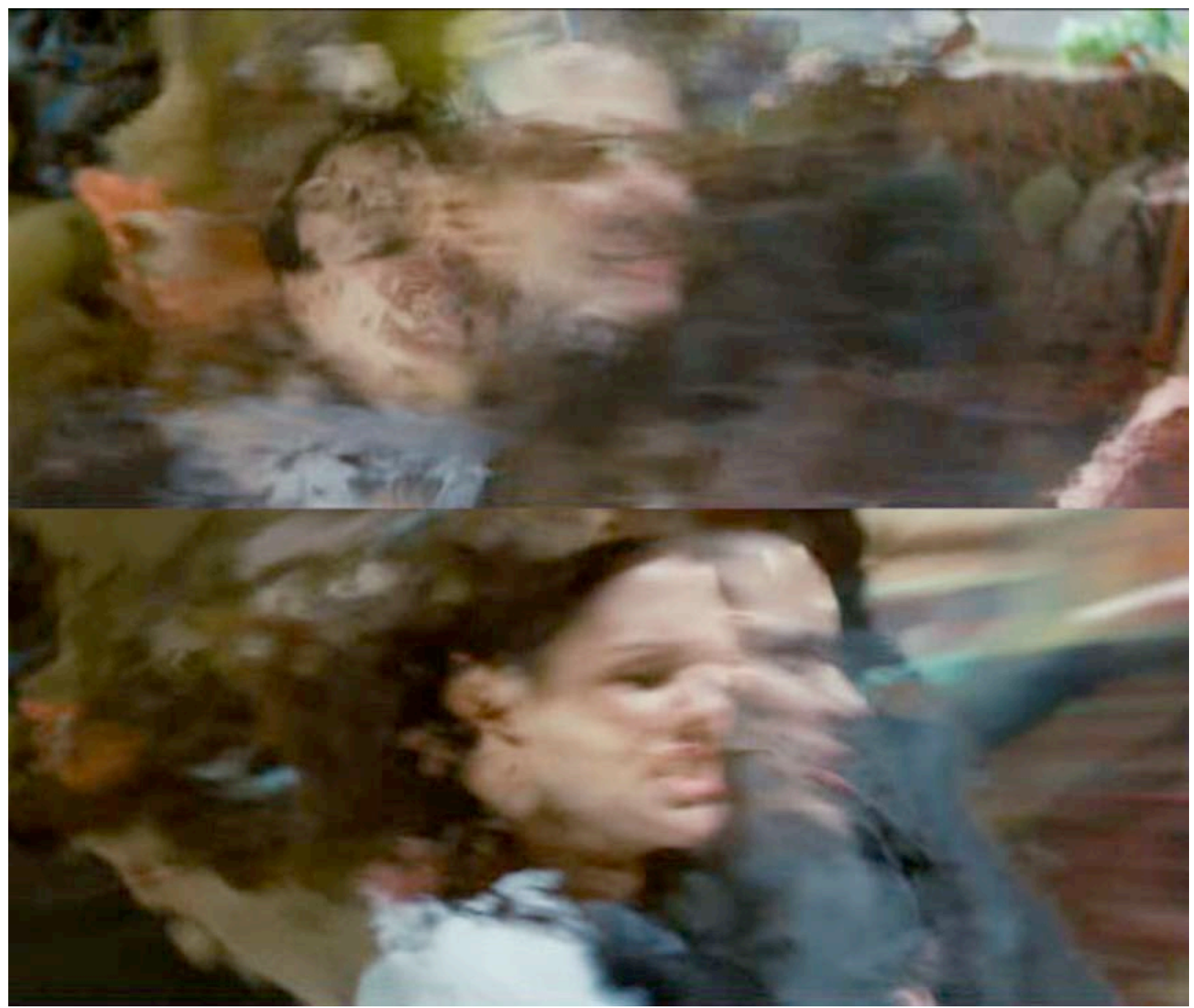

Jumper (2008), de Doug Liman

En otra escena de la misma película, el protagonista intenta huir ayudándose de una fotografía que le permite concentrarse en el salto hacia el espacio en ella reproducido: la instantánea del famoso puente de Carlos (Praga) se vuelve viscosa, desborda la barrera transparente del papel impreso e invade el espacio en el que se halla el personaje.

Merece la pena comparar este efecto con la escena del dibujo de tiza en Mary Poppins (1964) de Robert Stevenson. El salto al interior de la pintura fue creado por Eustace Lycett mediante un travelling matte que permitió reducir ópticamente la silueta de los actores para hacerlos encajar en la escala del diseño. La transición de un espacio a otro se figura mediante un brinco de los actores, obviando el paso a través de la superficie plana del suelo. Por el contrario, el interés del efecto en Jumper es, precisamente, la construcción de ese espacio intermedio. 


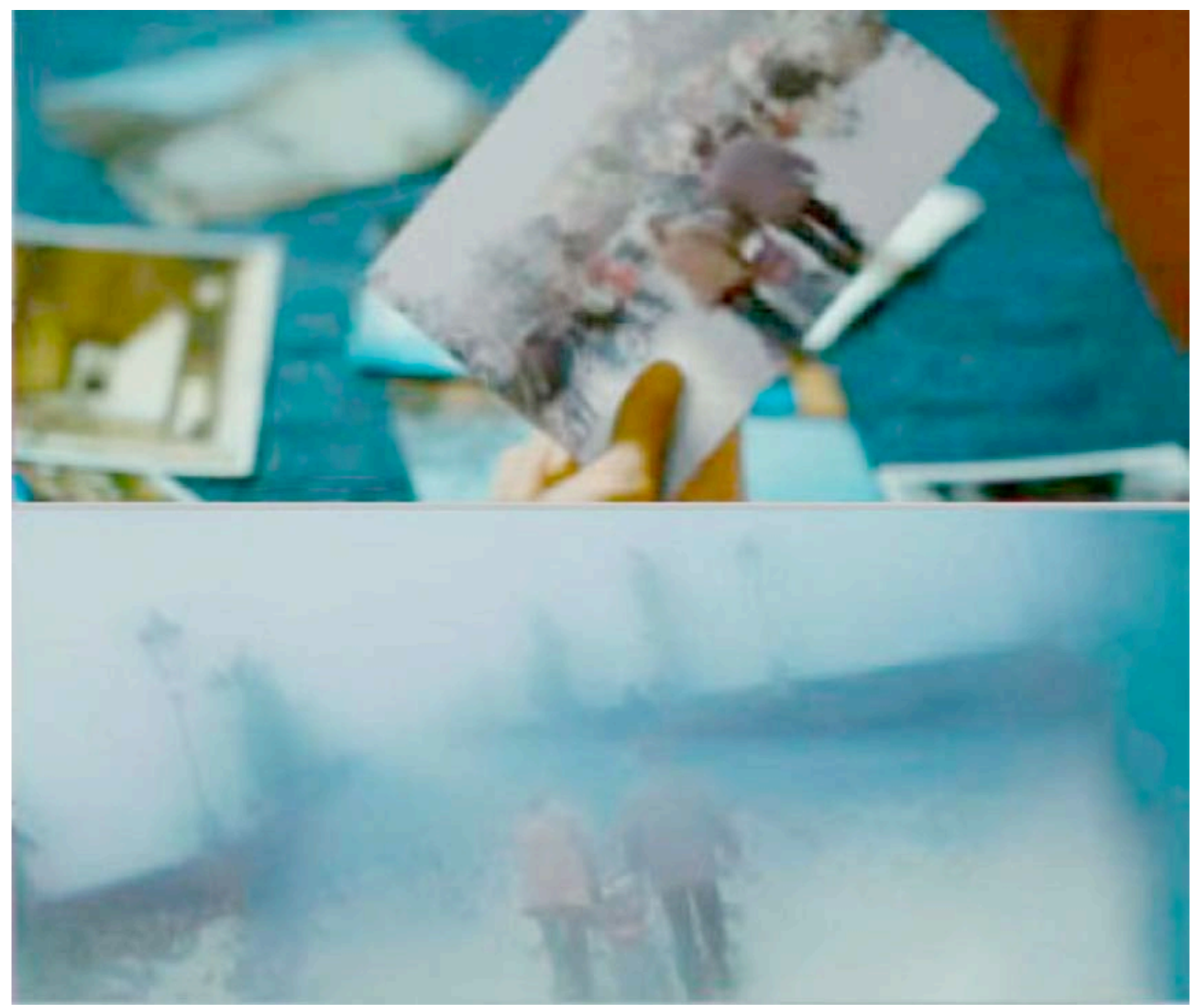

Jumper (2008), de Doug Liman

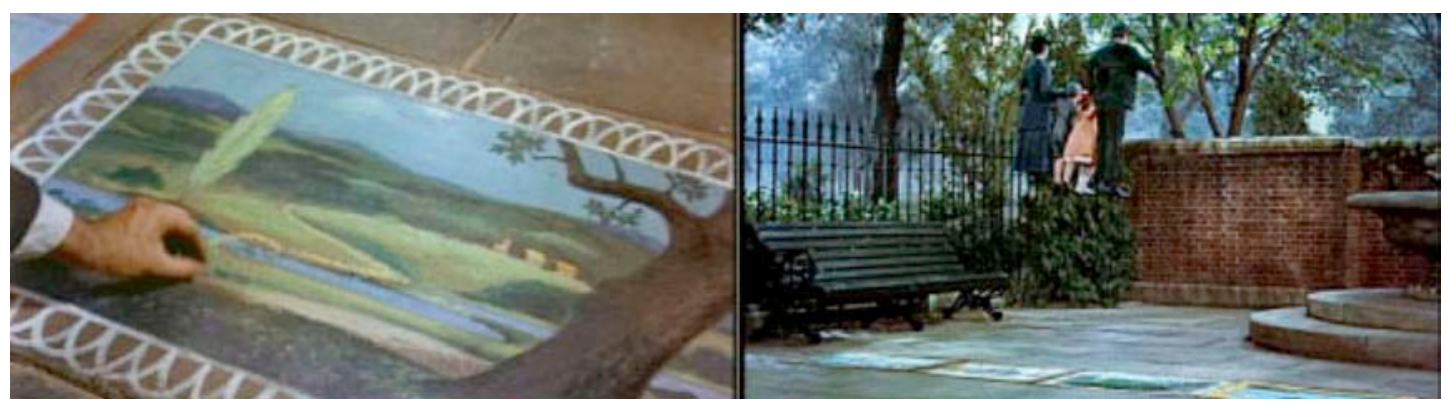

Mary Poppins (1964), de Robert Stevenson

En Contact (1997), de Robert Zemeckis, la protagonista Ellie Arroway (Jena Malone) descubre a su padre muerto y corre en vano en busca de alguna medicina. La cámara se sitúa frente a la niña y retrocede al tiempo que ésta se aproxima al objetivo. La actriz sube las escaleras de su casa y atraviesa el pasillo hasta el baño; de pronto, la imagen resulta ser el reflejo en el espejo. La pantalla se comporta como una superficie reversible: allí donde parece desplegarse en profundidad, el espacio se muestra, de golpe, como situado en el proscenio de la imagen. La presentación continua de los puntos de vista (la cámara frente a la protagonista y, a continuación, frente al espejo en paralelo a la niña) es imposible en cuanto registro fotográfico. No 
hay corte ni giro de $180^{\circ}$ : la mutación repentina se produce de manera transparente, de un extremo al otro del mismo eje, sin recorrer el arco en forma de semicircunferencia que impondría la lógica de la imagen huella.

En esta ocasión, el montaje espacial sirve no como sutura o transición temporal antes-después, sino como elemento de sorpresa, quedando la ambigüedad espacial sin respuesta. En los próximos capítulos, volveremos sobre la película de Zemeckis y veremos cómo este uso del espejo ${ }^{8}$ es un guiño al imaginario hiperdimensional y el "contacto" al que hace referencia el título.

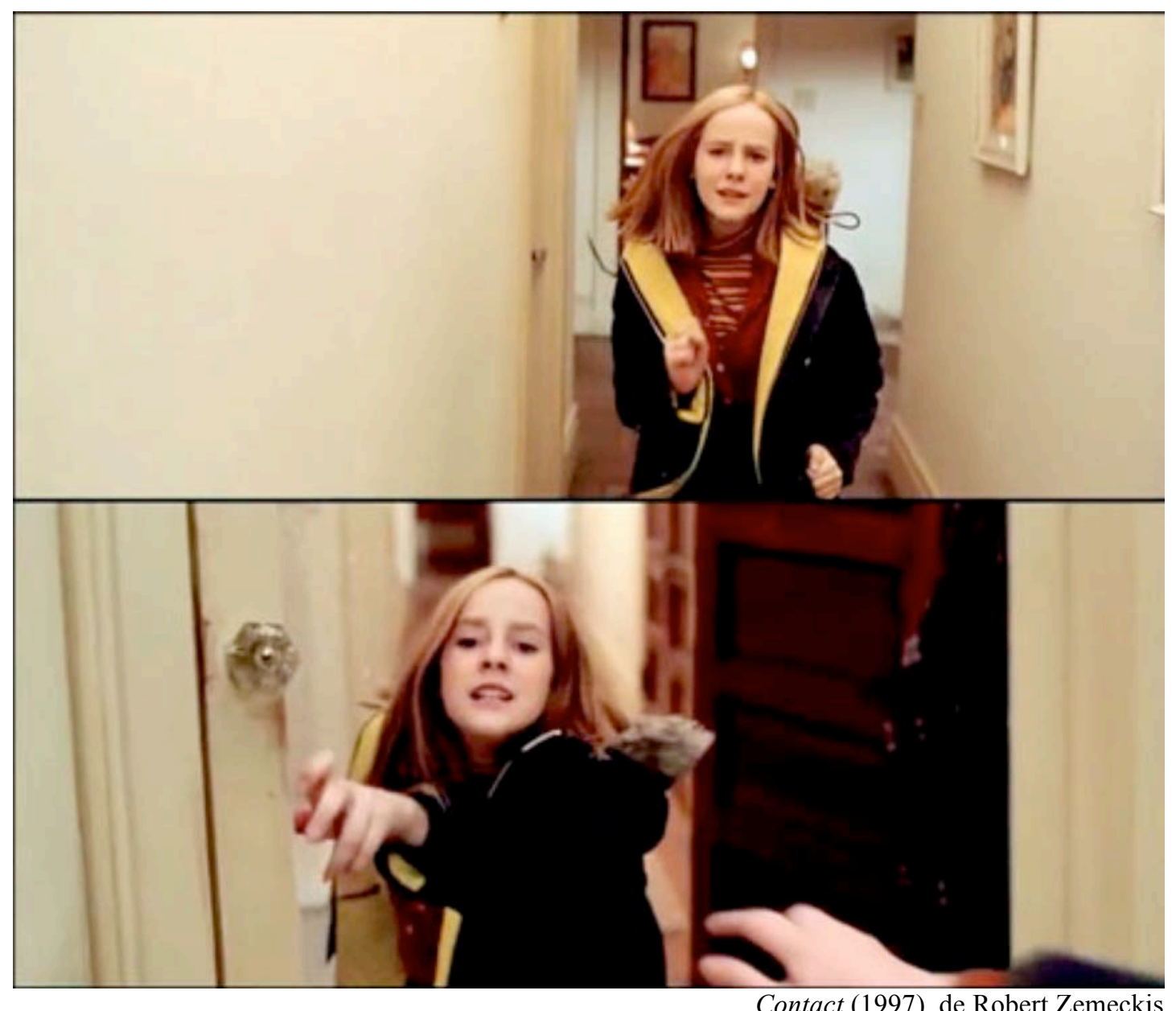

\footnotetext{
${ }^{8}$ De hecho, el uso del espejo como apertura a otros espacios y alusión a mundos paralelos es un tópico cinematográfico: "C'est en raison de cette position sémiotiquement complexe que les miroirs dans les films sont toujours si ambigus, toujours si suggestifs et troublantes. Au fond, ce qui apparaît dans le miroir filmé (comme, autrement, dans le miroir peint) n'est jamais absolument déductible du reste de l'image, qui vient la compliquer et, parfois, la refendre." AUMONT, Jacques. Matière d'images. Redux. Op. cit., p. 95.
} 
Se trate de este efecto de ambigüedad espacial, de una tele-transportación (Jumper), de un flash forward (Titanic) o de una composición fantástica (Tideland), la continuidad en las transiciones espacio-temporales se fundamenta en la plasticidad del espacio de la imagen digital. Entre las nuevas posibilidades estéticas que esta cualidad conlleva, destaca la construcción de planos secuencia imposibles en la imagen registro, y que analizaremos con detenimiento en el próximo capítulo. 
En este primer capítulo, hemos introducido varias formas de construcción en el interior del cuadro. La contraposición entre la transformación y la mera reproducción del registro nos ha permitido apuntar la creación de espacios no miméticos, exclusivos de la imagen. Es decir, la representación tridimensional en el plano bidimensional da paso a una exploración del espacio de la imagen misma.

En este empeño, los creadores privilegian el montaje espacial sobre la edición temporal. Con la tecnología digital, el plano como unidad mínima es sustituido por la construcción en el interior del cuadro. Si en "La cohabitación de las imágenes" nos hemos concentrado en la simultaneidad, en "La mezcla" hemos subrayado la elaboración en capas. Ambas formas de montaje espacial exhiben la heterogeneidad de las imágenes fuente y renuncian a la simulación tridimensional: allí donde la cohabitación subraya la superficie bidimensional, la mezcla permite explorar la profundidad del espacio de la imagen.

La suma de este montaje espacial y aquella transformación de imágenes previas nos ha permitido explicar la construcción del morphing, paradigma de la metamorfosis de la imagen digital. En su renuncia al corte, las prácticas digitales analizadas profundizan en la continuidad de la mutación, propia del arte electrónico. Ahora, la tecnología digital va más allá de la incrustación y la modificación de la señal electromagnética. Gracias a su condición discreta, la imagen código posibilita todo tipo de manipulaciones: su aspecto numérico facilita el acceso atómico y, con él, una transformabilidad sin precedentes.

Estas construcciones pueden servir, también, como transición espacio-temporal. Lejos de la elipsis y del vacío del corte cinematográfico, la transformación gradual construye y exhibe el espacio intermedio. En el próximo capítulo, ahondaremos en este aspecto y presentaremos una figura clave en la exploración del espacio digital: la cámara virtual.

Si hasta aquí hemos atendido, casi exclusivamente, a obras que mantienen el cuadro fijo, los próximos apartados se dedican, por el contrario, a la dinamización del punto de vista. Como veremos, la continuidad del movimiento puede lograrse mediante interpolación, gracias al empalme de varias tomas o a la composición. Frente al aparato de registro, eminentemente temporal, la cámara virtual es, precisamente, un constructo en el interior del cuadro. 


\section{CAPÍTULO II}

LA CÁMARA VIRTUAL COMO CONSTRUCCIÓN ESPACIAL 


\section{LA OMNIPOTENCIA DE LA CÁMARA VIRTUAL}

La película Hugo (2011), de Martin Scorsese, termina con el siguiente plano secuencia: la cámara sobrevuela el piso en el que celebran Méliès, sus familiares y amigos, apunta hacia una de las ventanas, se acerca al cristal y lo atraviesa sin problemas; una vez en el interior, recorre el pasillo hasta el salón en el que festejan los personajes. Frente al que podría haber sido un simple montaje temporal de dos planos (el exterior del edificio y el interior del apartamento), Scorsese decide presentar un desplazamiento continuo. Esta continuidad subraya la importancia del espacio en sí mismo y hace presente la cámara como una entidad clave de la narración; un ente que no corresponde al aparato físico (incapaz de pasar a través del cristal sólido de la ventana), sino a un constructo resultante del "cosido" de dos tomas mediante un montaje espacial.

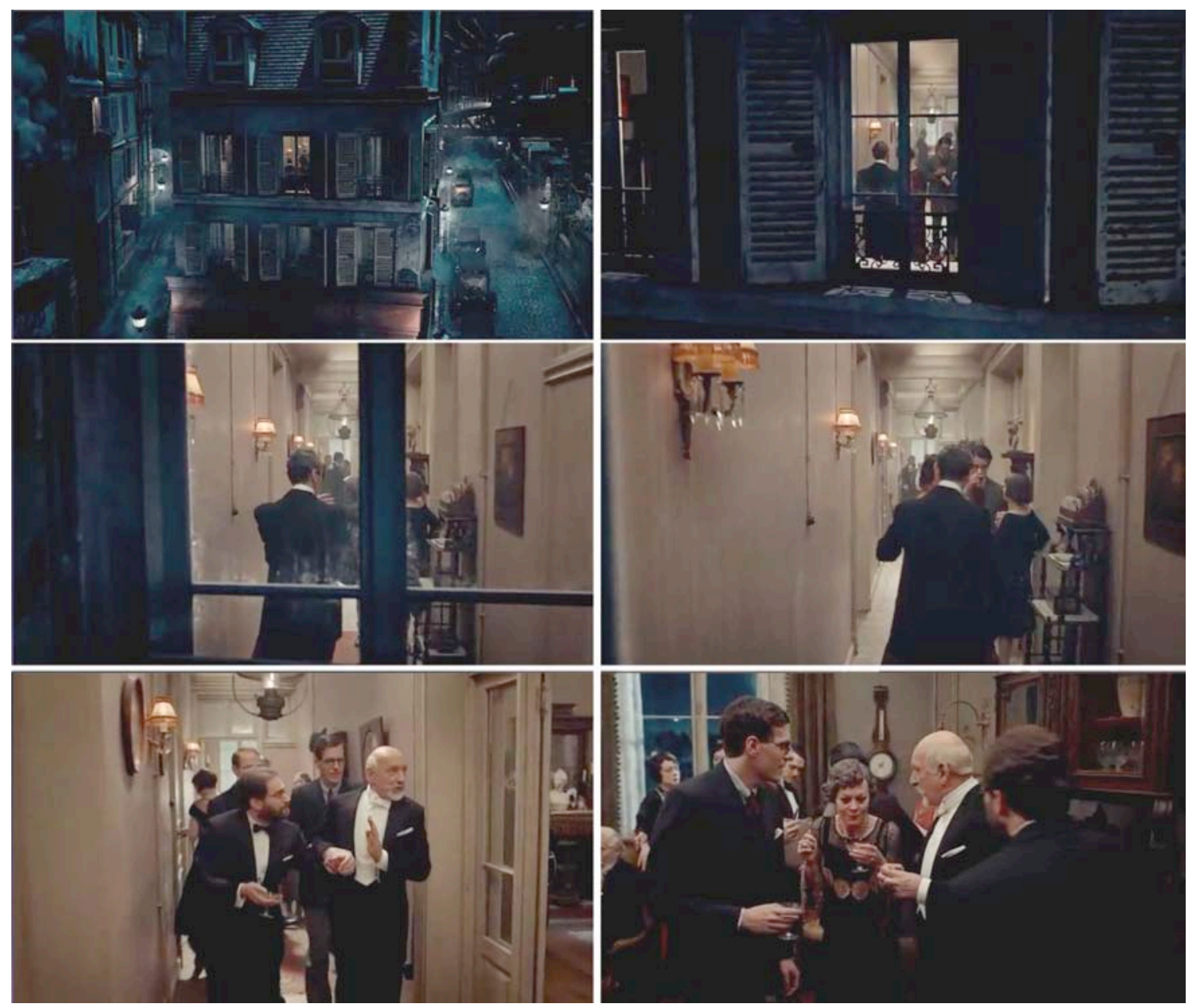

Hugo (2011), de Martin Scorsese 
La propuesta retoma la escena de Der letzte Mann (1924), de F. W. Murnau, en la que el viejo botones, interpretado por Emil Jannings, recibe la carta de despido. En el momento en el que el protagonista lee la terrible noticia, la cámara, situada fuera de la habitación, se dirige hacia el personaje, atravesando el cristal de la puerta que se interpone en su camino. El procedimiento, realizado mediante un fundido encadenado, muestra un anhelo de desmaterialización del aparato físico, sustituido por un ente omnipotente, no humano, que se desplazaría a su antojo a través del espacio.
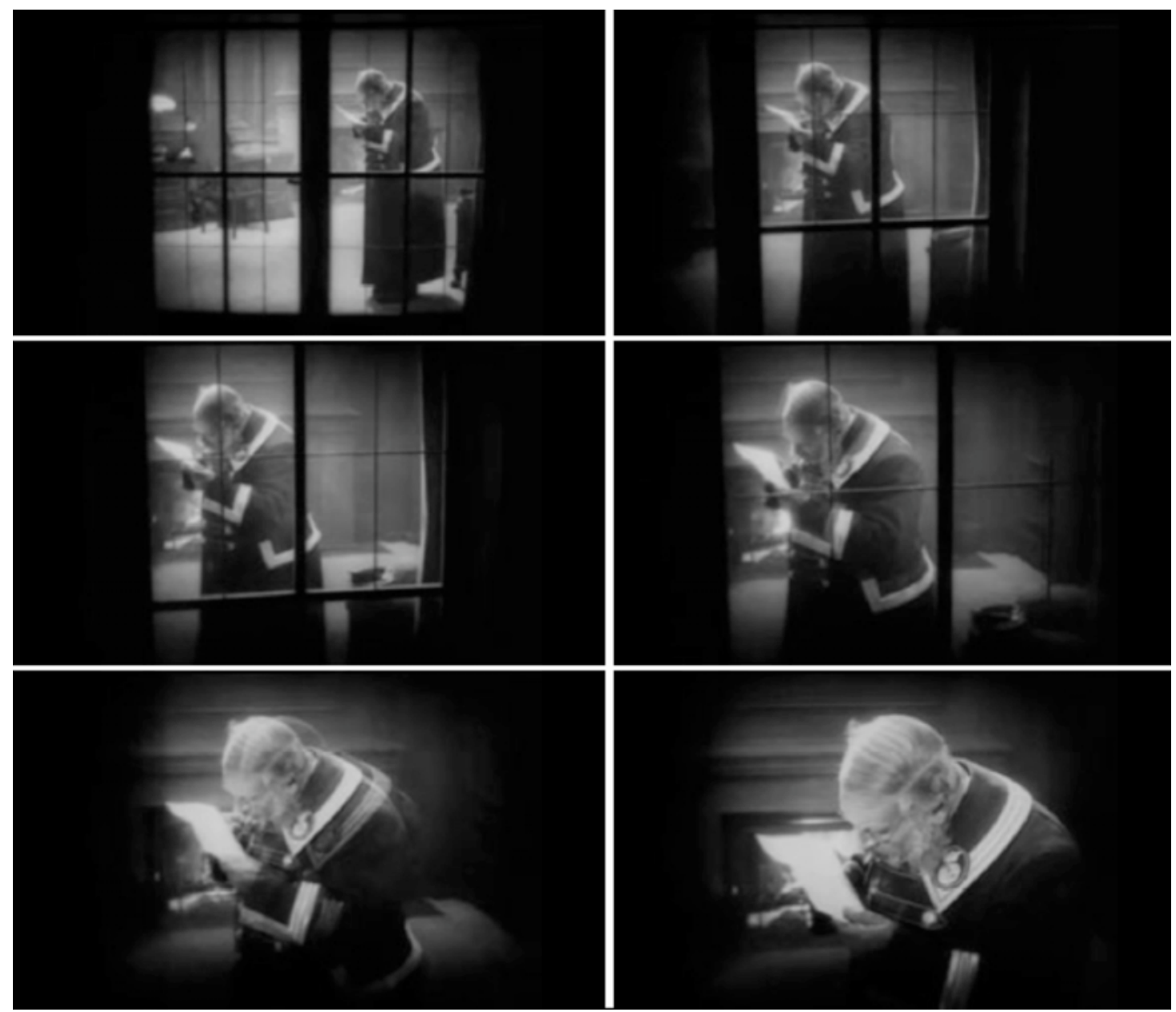

Der letzte Mann (1924), de F. W. Murnau

Tras dos décadas de inmovilidad de la cámara, de un cine que, aún balbuciente, continuaba con el punto de vista fijo del espectador de teatro, en la década de los años 20, el aparato se libera, por fin, de su estatismo. Con las vanguardias históricas, la cámara se convierte no sólo en la herramienta fundamental de la narración, sino en un verdadero personaje que se desplaza por el espacio imponiendo su mirada móvil. 


\section{La liberación del punto de vista}

Esta tendencia a la traslación de la cámara se ve reflejada durante la República de Weimar en un nuevo concepto cinematográfico: la "entfesselte Kamera" o "cámara desencadenada", encabezada por películas como la citada Der letzte Mann de Murnau o Varieté (1925) de Ewald André Dupont. En su alejamiento del caligarismo y del Kammerspielfilm, la corriente desarrolla, entre otros, la construcción de un espacio fílmico mediante la relación plano/contraplano. ${ }^{1}$ Aunque esta aportación marcará la transparencia del montaje temporal en el lenguaje cinematográfico clásico, como su nombre indica, la "cámara desencadenada" se caracteriza por la dinamización del aparato de registro, haciendo presente una entidad antes ocultada.

Esta presencia permite, por ejemplo, materializar el sonido; aspecto especialmente interesante teniendo en cuenta que se trata de películas mudas. Así, en la cinta de Dupont, el trapecista Artinelli (Warwick Ward) planea seducir a BertaMarie (Lya De Putti), pareja de Boss Huller (Emil Jannings). El personaje se esconde tras una puerta y escucha atento para salir al paso de la mujer, simulando un encuentro fortuito. Dupont se sirve de un travelling hacia delante para dibujar el recorrido del sonido hacia el oído de Artinelli.

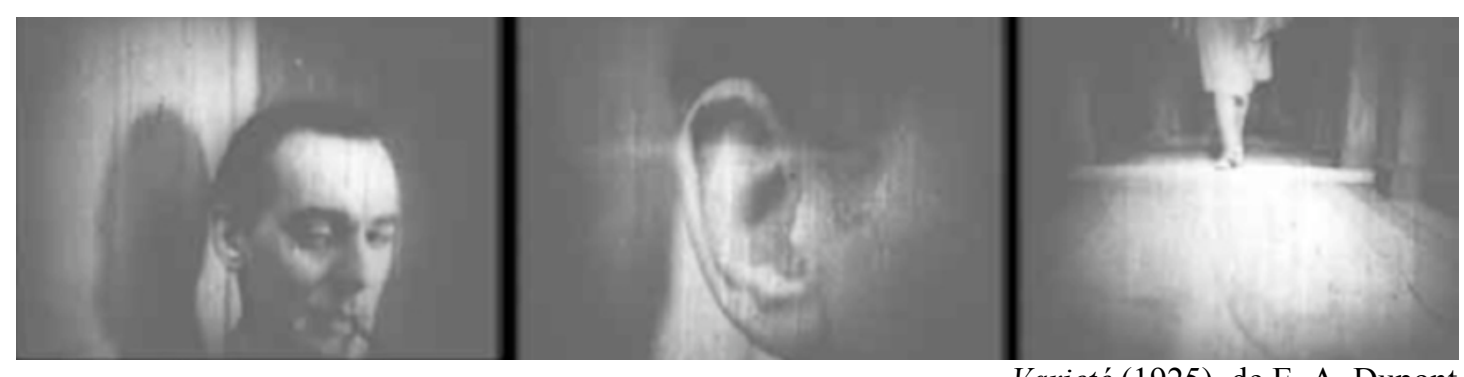

Varieté (1925), de E. A. Dupont

Un año antes, el propio Murnau había acudido ya a un procedimiento muy semejante en Der letzte Mann. La propagación de un rumor (el hecho de que el viejo portero ha sido despedido) se hace coincidir con el desplazamiento de la cámara; el espacio que ésta recorre figura la voz de una vecina que grita a otra, de ventana a ventana del mismo edificio. En otra escena, un borracho toca una trompeta bajo la ventana de la casa del protagonista, recién terminada la celebración de la boda de su

\footnotetext{
${ }^{1}$ El uso del plano/contraplano se remonta a la película de James Williamson Attack on a China Mission (1900). BRISELANCE, Marie-France. Op. cit., p. 80.
} 
hija. Un travelling hacia atrás da forma al recorrido del sonido desde el interior del instrumento hasta el apartamento, desde el cual el viejo portero escucha la melodía.
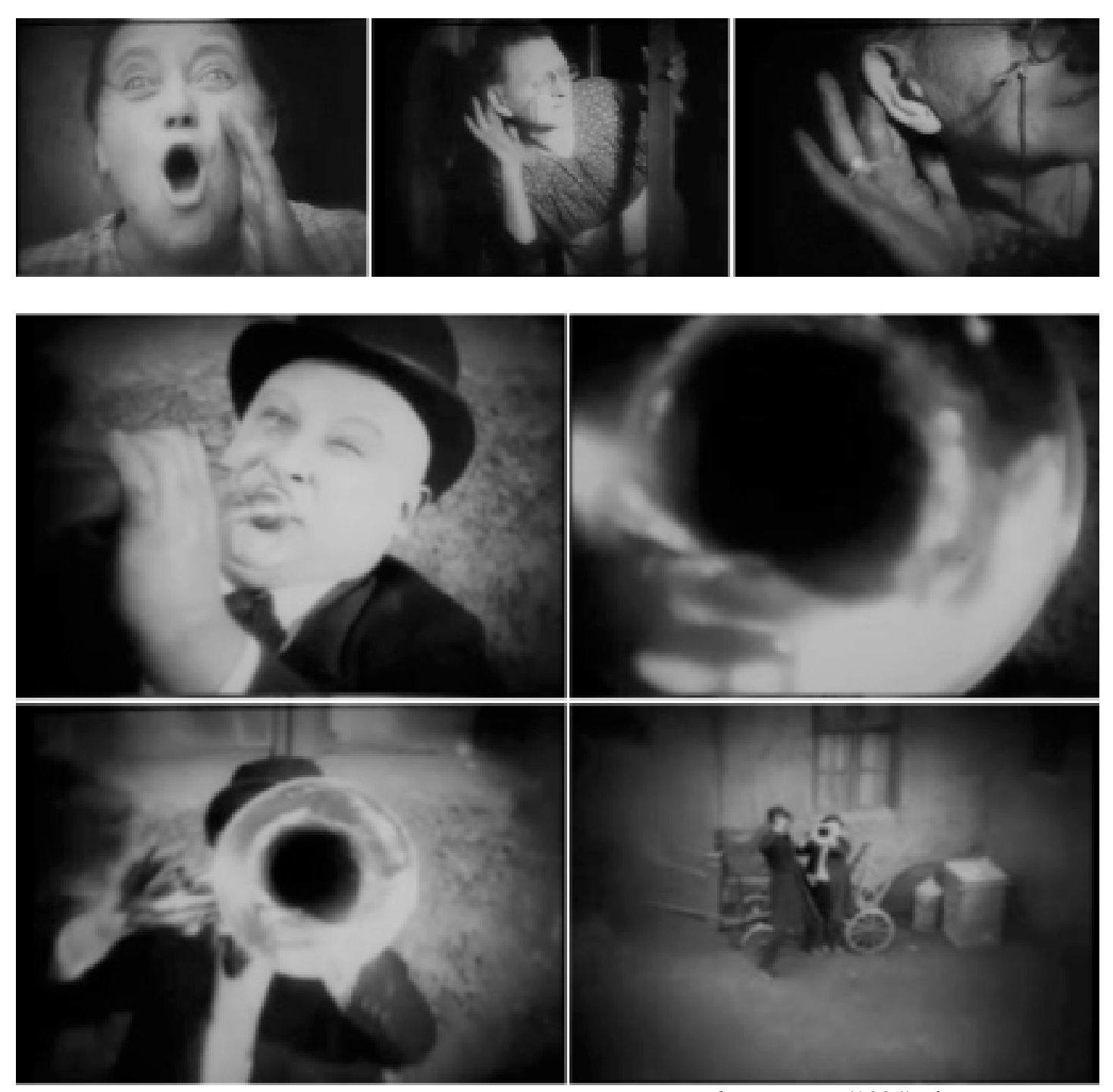

Der letzte Mann (1924), de F. W. Murnau

Ochenta años después, hallamos una estrategia visual muy parecida en Panic Room (2002), de David Fincher. La película se desarrolla en un único espacio: la enorme casa en la que se instalan una mujer divorciada (Jodie Foster) y su hija (Kristen Stewart). El lujoso edificio cuenta con la última tecnología antirrobo, entre otros, una "habitación del pánico" donde refugiarse en caso de que el resto de la maquinaria falle. Fincher pone en escena esta remota posibilidad, la primera noche de madre e hija en la casa. Una vez en el interior de la estancia de seguridad, la cámara virtual sigue el movimiento del sonido, que se propaga por el aire como el único elemento capaz de salir y entrar libremente de la habitación del pánico. 
Tras descubrir un pequeño tubo de ventilación a ras del suelo, madre e hija intentan llamar la atención del vecino de enfrente mediante señales luminosas. Cuando aquél mira extrañado la luz parpadeante que sale de la casa, las secuestradas gritan pidiendo auxilio. En ese momento, la cámara virtual se retrotrae mediante un zoom out: atraviesa el tubo de ventilación y flota en el aire hasta quedarse paralizada a medio camino entre los dos edificios. Los gritos son en vano.

En Der letzte Mann, Murnau comienza el travelling hacia atrás con un primer plano del instrumento musical. Armado con las posibilidades de la tecnología digital, Fincher va más lejos al proponer atravesar el mismísimo tubo de ventilación. La continuidad del desplazamiento presenta el espacio intermedio con la misma atención que el interior y el exterior de la casa. En el próximo apartado, veremos otros ejemplos de esta estética basada en la exhibición del "espacio del entre", de la cual la cinta de Fincher es paradigmática.
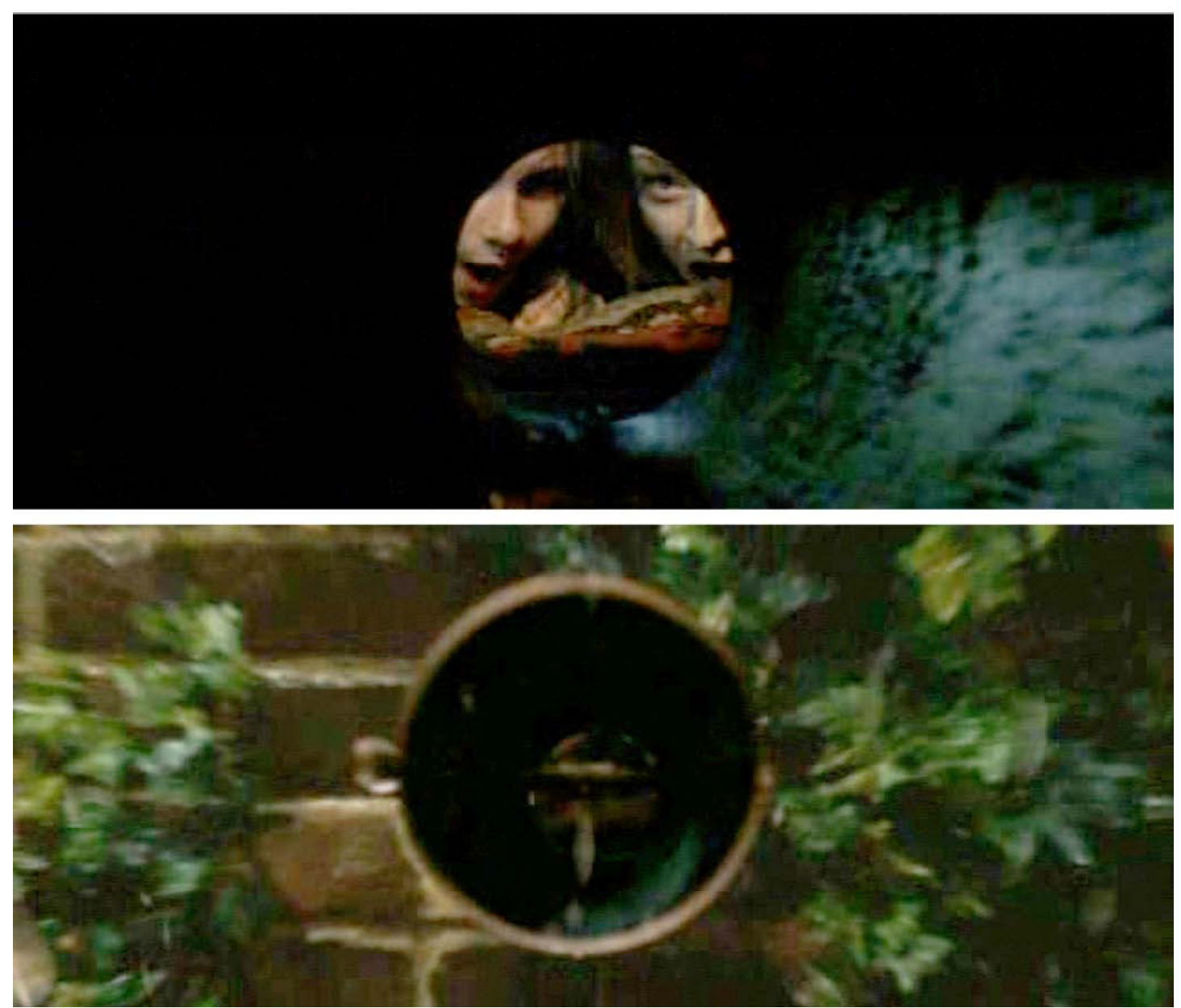

Panic Room (2002), de David Fincher 
Es evidente que un aparato de registro tiene limitaciones físicas. Por el contrario, la cámara virtual es, como su nombre indica, inmaterial. Gracias al hecho de que se trata de un constructo espacial, puede atravesar no sólo cristales (como muy bien supo simular Murnau), sino todo tipo de superficies, subrayando con ello el espacio intermedio. Es más, el punto de vista se sitúa en lugares imposibles y en todo tipo de escalas.

En Fight Club (1999), el propio David Fincher había explorado ya las posibilidades de la cámara virtual en este sentido. Cuando el gas escapa de la cocina, haciendo estallar el apartamento del protagonista, la cámara virtual persigue el fluido por el aire, rodea la placa donde comienza la fuga y se aleja mediante un zoom out, dando forma al esparcimiento del fluido por la habitación; a continuación, recorre el espacio entre los cables hasta dar con la chispa que genera la explosión.

Tres años después de Fight Club, en otra escena de la citada Panic Room, la cámara virtual sigue el camino que recorre el gas desde la bombona que lo contiene, a través del tubo de salida, hasta la habitación del pánico; en su desplazamiento continuo, atraviesa la superficie plástica de dicho tubo, adquiere el punto de vista del combustible y recorre con él la cavidad hasta desembocar en el conducto de ventilación. En su camino, la cámara virtual persigue el movimiento de una pluma impulsada por el aire, detalle que remite al comienzo de Forrest Gump (1994), de Robert Zemeckis.

Basada en la novela homónima de Winston Groom $^{2}$, la película se abre con un largo plano secuencia: durante dos minutos, la cámara sigue el balanceo lento, apacible, de una pluma en el aire, hasta posarse en el pie del protagonista (Tom Hanks). Debido a la imposibilidad de predecir la caótica trayectoria de un verdadero ejemplar en el espacio, se dibujó digitalmente el elemento y se introdujo éste, después, en la toma aérea; finalmente, para hacer aterrizar el objeto exactamente en el pie del actor, se situó una pluma verdadera en ese punto y se la fundió después con su doble digital. El resultado de tan laboriosa sutura es que el cuadro persigue el objeto con extraordinaria precisión.

\footnotetext{
${ }^{2}$ GROOM, Winston. Forrest Gump (1986). Knopf Doubleday Publishing Group, 2012.
} 

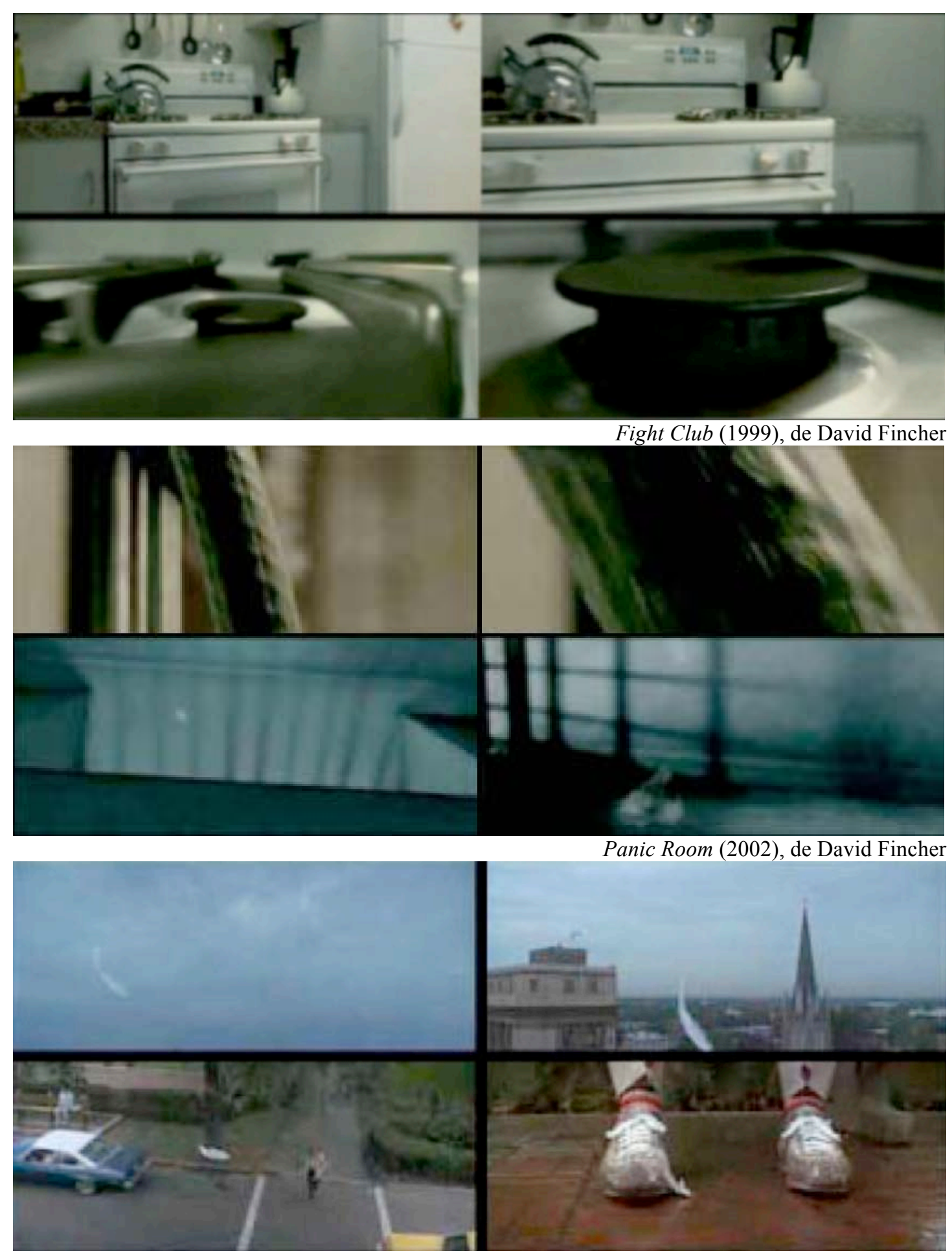

Forrest Gump (1994), de Robert Zemeckis

Descubrimos dos casos de este punto de vista desde un objeto en movimiento en dos películas de Yimou Zhang: Hero (2002) y House of Flying Daggers (2004). En ambas, la cámara virtual adquiere el punto de vista de unas flechas proyectadas en el espacio, desde el momento en el que abandonan el arco hasta que alcanzan su 
objetivo. Tomando prestada la expresión de José Luis Molinuevo, la cuestión no es tanto "el estado de ánimo de los sujetos, como de los objetos". 3

Es más, en el caso concreto de Hero, los proyectiles atraviesan el tejado y el techo de una escuela de caligrafía; ni corte, ni fundido: en un movimiento continuo, la cámara virtual pasa a través de la cubierta para aterrizar, junto a la flecha que acompaña, en uno de los recipientes de arena con los que se entrenan los escribas. Como en Hugo o en Panic Room, el montaje espacial permite atravesar la superficie y presentar de manera continua el desplazamiento.
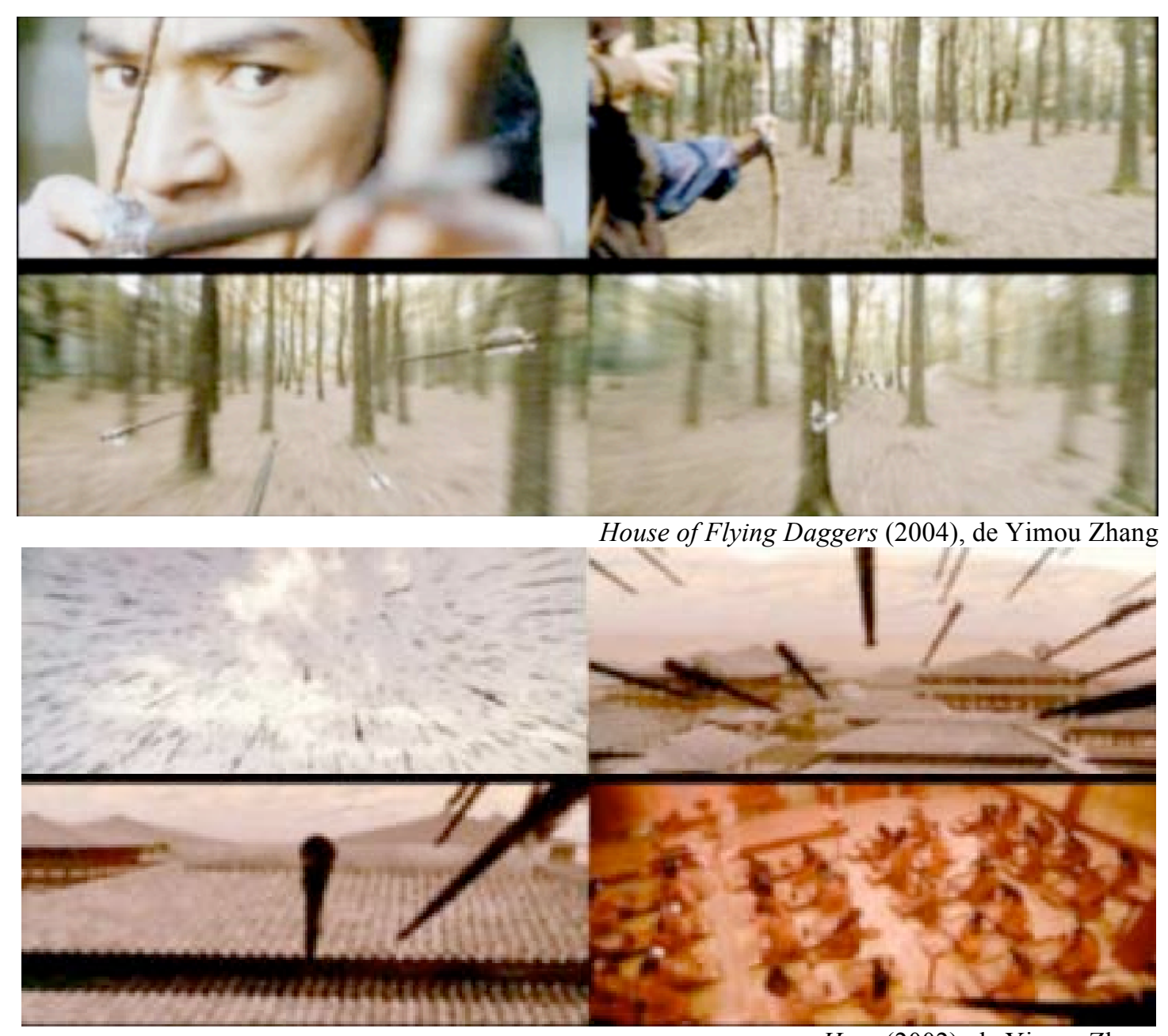

Hero (2002), de Yimou Zhang

Un caso parecido es el del videoclip Freak on a Leash (1999), dirigido por Todd McFarlane para el grupo musical Korn. La cámara virtual sigue la trayectoria de una bala perdida, atravesando con ella las paredes como si tuviera el tamaño de un pequeño perdigón. Para reforzar la sensación de velocidad, las acciones de los

\footnotetext{
${ }^{3}$ MOLINUEVO, José Luis. Retorno a la imagen. Estética del cine en la modernidad melancólica. Op. cit., p. 36.
} 


\section{LA OMNIPOTENCIA DE LA CÁMARA VIRTUAL}

personajes se presentan congeladas. Esta lentificación extrema se consiguió mediante un "bullet time", cuyo proceso de elaboración veremos detenidamente más adelante. Por el momento, hacemos notar el hecho de que la denominación misma del efecto retoma, precisamente, la idea del punto de vista desde la bala.
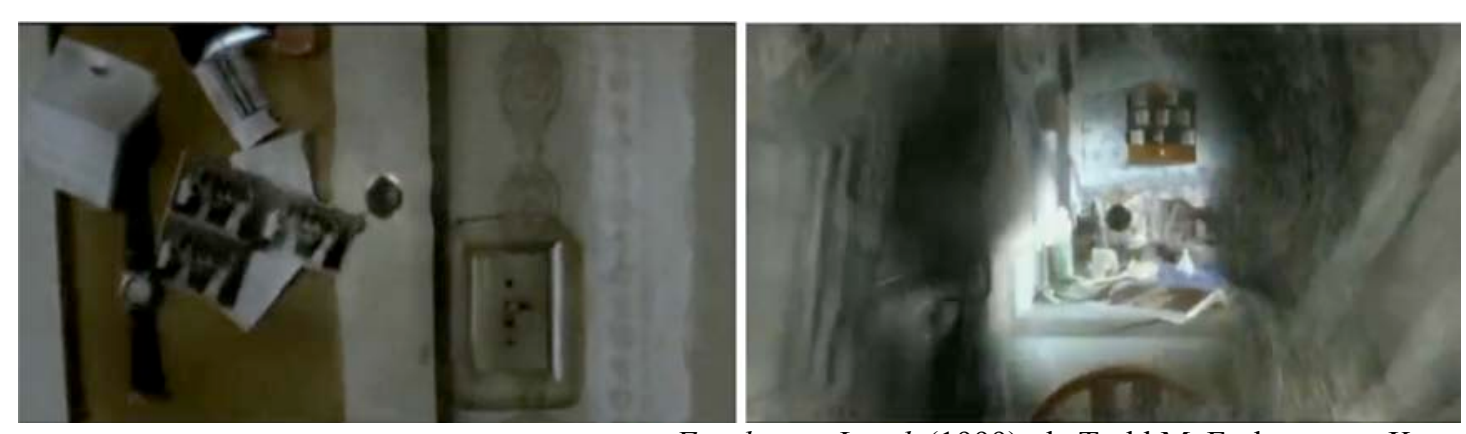

Freak on a Leash (1999), de Todd McFarlane para Korn

Varias décadas antes, Abel Gance había experimentado ya con el punto de vista desde un objeto en movimiento. Su Napoléon (1927) comienza con una batalla invernal entre los alumnos de la escuela militar de Brienne-le-Château (Francia). Para dinamizar la escena el director introdujo planos muy breves desde el punto de vista de las bolas de nieve: encerró la cámara cinematográfica en un balón de fútbol y la lanzó después al aire, registrando el movimiento gracias al "portativo", un aparato que gravaba automáticamente sin necesidad de un operador que hiciera girar la manivela. De este modo, la cámara se desplazaba a toda velocidad por el aire, deformando a su paso las imágenes que registraba. Gance describía así aquella liberación:

"Nosotros la hemos puesto en movimiento y yo creo ser uno de los que la han llevado al corazón del espectáculo de la vida: la he colocado sobre un carro; la he hecho rodar como un balón sobre la tierra; la he atado a la cola, al vientre de caballos al galope; la he suspendido de un hilo como un péndulo, y la he hecho tocar en el espacio; yo la he hecho subir y bajar; la he lanzado al aire como una bola de cañón; la he hecho surgir hacia un pecho como un sable; la he lanzado contra las olas; al fin, la he atado al hombre, y la he hecho caminar, correr, volver la cabeza, ponerse de rodillas, levantar el ojo de su objetivo hacia el cielo; yo he hecho de ella un ser viviente, un cerebro; y lo que es mejor aún: he intentado hacer de ella un corazón."4

\footnotetext{
${ }^{4}$ GANCE, Abel. "L'harmonie visuelle est devenue symphonie" (1929). Apud. L'HERMINIER, Pierre. L'art du cinéma. Paris: Seghers, 1960, p. 164.
} 
La liberación del aparato de registro permite a las vanguardias históricas explorar puntos de vista "desfamiliarizadores" ". Así, por ejemplo, René Clair sitúa la cámara sobre un vagón de una montaña rusa en la última escena de Entr'acte (1924); Man Ray la lanza por los aires en Emak Bakia (1926); y Dziga Vertov la monta sobre los medios de transporte en Chelovek s kinoapparatom (1929). Estas propuestas visuales aplican al cine conceptos espaciales de la "nueva fotografía". László Moholy-Nagy se lanza a la captura de nuevos puntos de vista inesperados: oblicuos, picados, contrapicados... En la misma línea, Alexander Rodchenko persigue liberar la fotografía de la visión antropomórfica, marcada por el eje del cuerpo humano, perpendicular al horizonte. En 1928, escribe: "Si queremos enseñar al ojo humano a ver de una forma nueva, es necesario mostrarle los objetos cotidianos y familiares bajo perspectivas y ángulos totalmente inesperados."
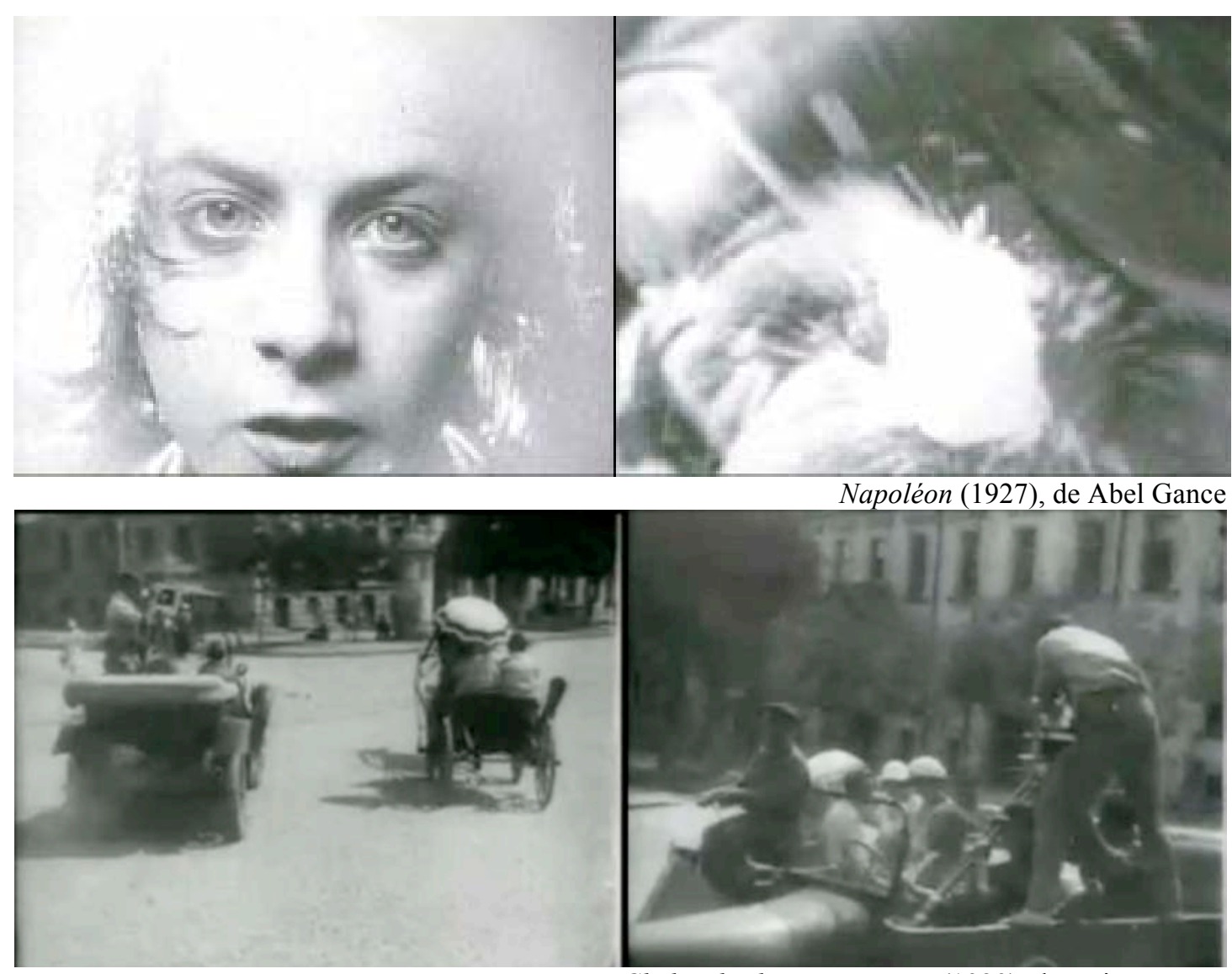

Chelovek s kinoapparatom (1929), de Dziga Vertov

\footnotetext{
5 Debemos el término "desfamiliarización” (“ostrenanie”) à Víktor Shklovsky (1893-1984). El formalista ruso lo define como una manera de llamar la atención con aspectos formales sorprendentes que rompen con los hábitos perceptivos. Apud. BURGOYNE, R. et al. New Vocabularies in Film Semiotics: Structuralism, Post-structuralism, and Beyond (1992). London: Routledge, 2002, pp. 10-11.

6 Alexander Rodchenko. Apud. MIßELBECK, R. et al. La fotografia del s. XX. Colonia: Taschen, 1997, pp. 544-549.
} 
En la misma época, Vsevolod Illarionovich Pudovkin publica su teoría cinematográfica. $^{7}$ En ella, se refiere a un observador exterior e invisible, un espectador antropomórfico, cuya visión correspondería a la imagen registrada por la cámara, y los cambios en su atención, a los movimientos de la misma y el montaje temporal. Esta edición transparente se convertirá en la Biblia del montaje temporal clásico y de las teorías miméticas.

No obstante, la liberación de la cámara por parte de las vanguardias históricas pasa, al contrario, por el cuestionamiento mismo de esa figura antropomórfica. Si el observador exterior de Pudovkin es idealmente móvil, ¿por qué ha de encorsetar su punto de vista en las posibilidades limitadas de un espectador humano? De ser un testigo antropomórfico, difícilmente se justifican los puntos de vista "de gusano", cenitales o desde los objetos; $\mathrm{y}$, de ningún modo, el hecho de atravesar superficies. ${ }^{8}$ Así, para entender la liberación de la cámara por las vanguardias históricas, nos vemos forzados a considerar un ente no antropomórfico que podría desplazarse sin límites en el espacio. No se trata sólo de estar allí donde los hechos ocurren o de poder saltar en el tiempo si es preciso para el relato. La cuestión no es sólo la omnisciencia, sino la omnipotencia. Y ésta es la que asegura la cámara virtual. ${ }^{9}$

La imagen digital permite profundizar en la emancipación del punto de vista. Por un lado, gracias a su inmaterialidad, la cámara virtual se desplaza sin obstáculo que la detenga: si Murnau simula el paso a través del cristal mediante un encadenado gracias a la transparencia del vidrio, la cámara virtual atraviesa también superficies opacas, deleitándose en ese mostrar las entrañas del espacio intermedio de manera macroscópica. Por otro lado, si la nueva visión de las vanguardias históricas ensalza los puntos de vista no convencionales y desde objetos, la cámara virtual permite pasar de uno a otro de forma continua y sin ruptura de la escala.

En consecuencia, la auténtica liberación del punto de vista pasa por la mismísima supresión del aparato de registro. Un sueño presente ya en Der letzte

\footnotetext{
${ }^{7}$ PUDOVKIN, Vsevolod I.. Film technique and film acting (1926). New York: Grove Press, 1970.

8 "It is not hard to find empirical fault with the invisible observer account. It must ignore many stylized techniques, which cannot correspond to optical processes (split screen, wipes, negative filming, 'impossible' camera positions and movements)." BORDWELL, David. Narration in the fiction film. London: Routledge, 1985, p. 10.

9 "This omnipotent point of view, this transubstantiation, frees the storyteller, allowing images to flow smoothly and seamlessly, drawing the narrative point of view where it needs to go without limitations from the amount of film in the can, scope of a physical set, or location." MCCLEAN, Shilo. Op. cit., p. 47.
} 
Mann y reivindicado, entre otros, por Peter Greenaway ${ }^{10}$ o Bill Viola:

\begin{abstract}
“Espero que podamos llegar a ver eso: ¡el fin de la cámara! Cuando esté en París, compraré una gran botella de champán y la guardaré para ese día, para el día en el que no habrá cámaras. Haré saltar el tapón para celebrar no una muerte, sino una de las mutaciones más importantes en la historia de las imágenes."
\end{abstract}

En realidad, en lo que respecta al análisis de la imagen y no a su registro, toda “cámara” es, en sí, un espacio en off: un fenómeno mental. A este respecto, David Bordwell aclara: “esta 'cámara' no es el creador de las cualidades espaciales de la narración, sino el producto de ellas." ${ }^{\prime 2}$ Curiosamente, la matización respecto a la imagen fílmica resulta clave para comprender la cámara virtual. Así, la idea de que la cámara es, en realidad, una construcción mental casa perfectamente con la inmaterialidad del constructo espacial. Dicho de otro modo: es la mutación del espacio la que genera la sensación de movimiento del cuadro y no a la inversa. El protagonismo paradójico de la cámara virtual radica en la marcada presencia de un ente, en principio, inexistente. Gracias a esta existencia sólo a posteriori, la cámara virtual se caracteriza por una auténtica omnipotencia.

\title{
El movimiento como metamorfosis
}

Los ejemplos citados hasta aquí exhiben la inmaterialidad de este constructo que no halla barrera a su paso, adquiere puntos de vista imposibles y cambia entre ellos y de escala en un flujo ilimitado. Ya hemos visto cómo esta continuidad del movimiento puede ser producto del montaje espacial. Es decir, la "cámara virtual" resultaría o bien del empalme entre varias tomas (Hugo), o bien de la incrustación de unas imágenes en otras (Forrest Gump).

En lo que concierne a la elaboración de una animación sintética, la cámara virtual es una herramienta del programa de diseño, cuyos punto de vista y desplazamiento se definen mediante los siguientes parámetros: coordenada, dirección

\footnotetext{
10 "We have to get rid of the camera. The camera is a recording device. It gives us an image of the world that is mimetic, it reproduces what we put in front of it." GREENAWAY, Peter. Op. cit.

${ }^{11}$ Bill Viola. Apud. BELLOUR, Raymond, "L'espace à pleine dent". En: FARGIER, Jean Paul (ed.).

Où va la vidéo ?. Paris: Cahiers du cinéma, 1986, p. 70.

${ }^{12}$ BORDWELL, David. Narration in the fiction film. Op. cit., p. 119.
} 
o ángulo y zoom. En ese cálculo, es el espacio mismo el que se transforma: la metamorfosis continua de la imagen produce la sensación de movimiento del cuadro. La cámara virtual es, así, producto de un "keyframing"; este anglicismo define el cálculo intermedio de las fases entre dos "puntos de vista clave" o "key frames". Como explicábamos ya en relación al morphing, el proceso por el cual el ordenador deduce las imágenes intermedias que crearán la transición continua es una “interpolación”.

Encontramos un ejemplo clarificador de esta relación entre el morphing y la cámara virtual en la película Interview with the Vampire: The Vampire Chronicles (1994). Neil Jordan se deleita en la metamorfosis de la pequeña Claudia (Kirsten Dunst) en vampiro: los cabellos se rizan, el rostro palidece y los colmillos se alargan. Para exhibir en todo su esplendor el fenómeno sobrenatural, el punto de vista se sitúa de perfil, de manera que el espectador pueda recrearse en el crecimiento desmesurado de los caninos. Poco a poco la cámara virtual, resultado de la interpolación del propio morphing, gira hasta mostrar un escorzo del rostro. En el proceso de metamorfosis de la imagen, el tiempo parece congelado mientras el espacio se dilata. ${ }^{13}$

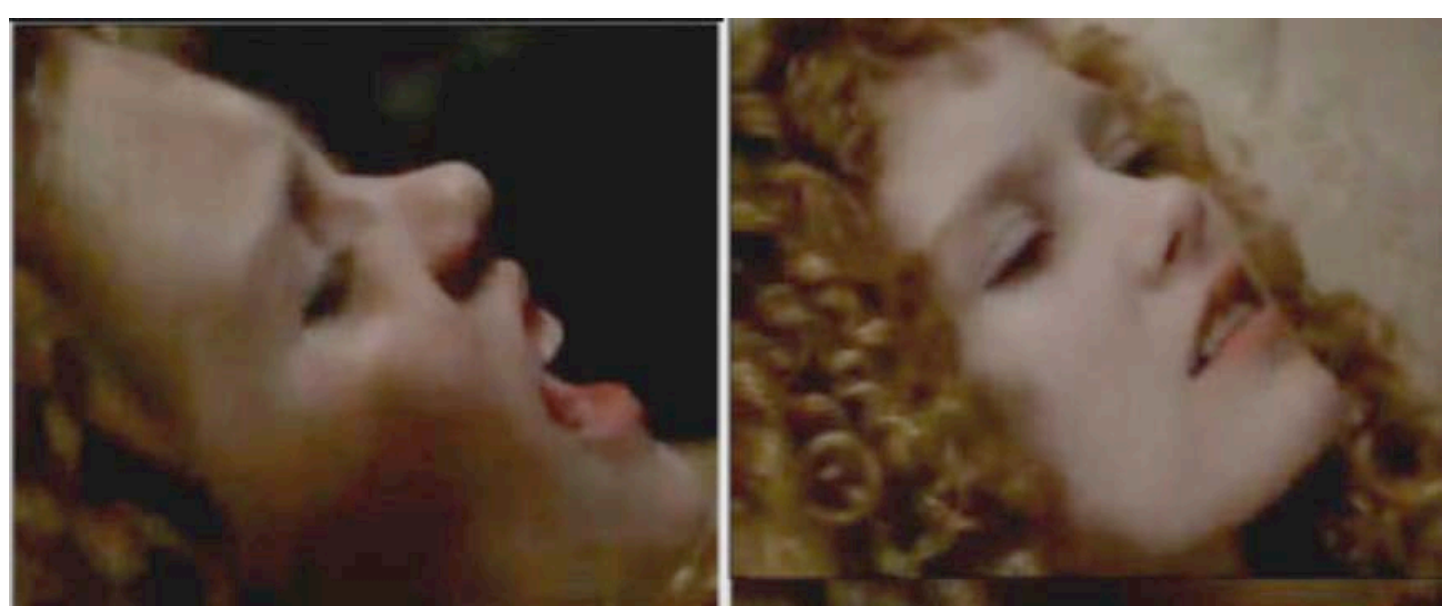

Interview with the Vampire: The Vampire Chronicles (1994), de Neil Jordan

De manera semejante, la cámara virtual de una animación sintética es una construcción, producto de la interpolación entre distintas vistas de una misma escena tridimensional. El ordenador calcula las fases intermedias entre los puntos de vista

\footnotetext{
${ }^{13}$ Apenas un año antes, Chen y Williams presentan su algoritmo de "interpolación de vistas" (1993), que permite animar una cámara virtual en torno a un objeto gracias al morphing entre diversos puntos de vista del mismo. CHEN, S. E.; WILLIAMS, L. "View Interpolation for Image Synthesis". En: $A C M$ SIGGRAPH '93, Proceedings of the 20th annual conference on Computer graphics and interactive techniques, ACM SIGGRAPH Computer Graphics. Vol. 27, pp. 279-288.
} 
seleccionados; como resultado, una mutación espacial provoca el efecto de desplazamiento del cuadro.

En la instalación Still Life (Vanitas) (2009), Jason Salavon repite en bucle una animación lenta, pero constante. Aunque el título hace referencia a la vanitas barroca $^{14}$, el aspecto temporal es secundario: el autor no registra una mutación profílmica, sino que el concepto mismo de "movimiento" es sustituido por el de "transformación". El artista se decanta por la estructura de "palíndromo visual": la animación empieza y acaba con la misma imagen. Frente a la inversión cinematográfica, no hay alteración de la causa-consecuencia, sino una exhibición del espacio elástico: la imagen se comporta como una goma que regresara a su forma al cesar la fuerza que la deformaba.

En su exaltación de la elasticidad del espacio, Salavon muestra no sólo una metamorfosis de figura y fondo, sino del punto de vista: el cuadro se desplaza lateralmente, como un péndulo que dibuja un arco de $180^{\circ}$. De este modo, al cambio de ángulo corresponde un cambio de escenario: cámara virtual y metamorfosis se producen al unísono, como dos siameses en un mismo cuerpo espacial.

Esta variación del punto de vista provoca, además, una sensación de profundidad asociada al movimiento. Más adelante, veremos cómo los creadores digitales aprovechan esta "profundidad cinética" $" 15$ para construir entidades espaciotemporales imposibles.

Como los elementos en la escena son figuras inertes, el cambio en la imagen se reduce a la dinamización sintética, a la metamorfosis creada por el artista y que se manifiesta tanto en el desplazamiento del punto de vista como en la transformación de figura y fondo. El cráneo humano muda en la osamenta de diversos mamíferos: oso, babuino y jabalí. Entre las cuatro calaveras se crean multitud de estados intermedios, los cuales, aunque igualmente naturalistas, no corresponden a ninguna especie. En 2010, Salavon recupera estas construcciones imaginarias en un par de imágenes fijas, a las que titula con los distintos porcentajes de los cuatro mamíferos iniciales, en una

\footnotetext{
${ }^{14}$ La composición remite a la tradición holandesa del bodegón en el siglo XVII. Entre otros, a los óleos de Pieter Claesz (1596-1691).

${ }^{15}$ Tomamos prestada la fórmula "profundidad cinética" de Ivan Sutherland. El informático se refiere a un entorno de realidad virtual en el que los cambios espaciales dependen del desplazamiento del operador. Por nuestra parte, reservamos la expresión a la sensación de volumen asociada al movimiento de la cámara virtual y al cambio del punto de vista en la imagen animada. SUTHERLAND, Ivan. "A head mounted three-dimensional display". En: AFIPS '68, Proceedings of the fall joint computer conference. New York, December 9-11, 1968, part I, p. 757.
} 
suerte de receta alquímica: "Generic Mammal Skull (13\% baboon, 36\% bear, 46\% human, 5\% wild boar)" y "Generic Mammal Skull (21\% baboon, 18\% bear, 17\% human, 44\% wild Boar)". La imagen media recuerda las ilustraciones de D'Arcy W. Thompson que veíamos en relación al morphing; no obstante, el artista se aleja de la hipótesis científica, continuando con la tradición de las criaturas híbridas de Nancy Burson.
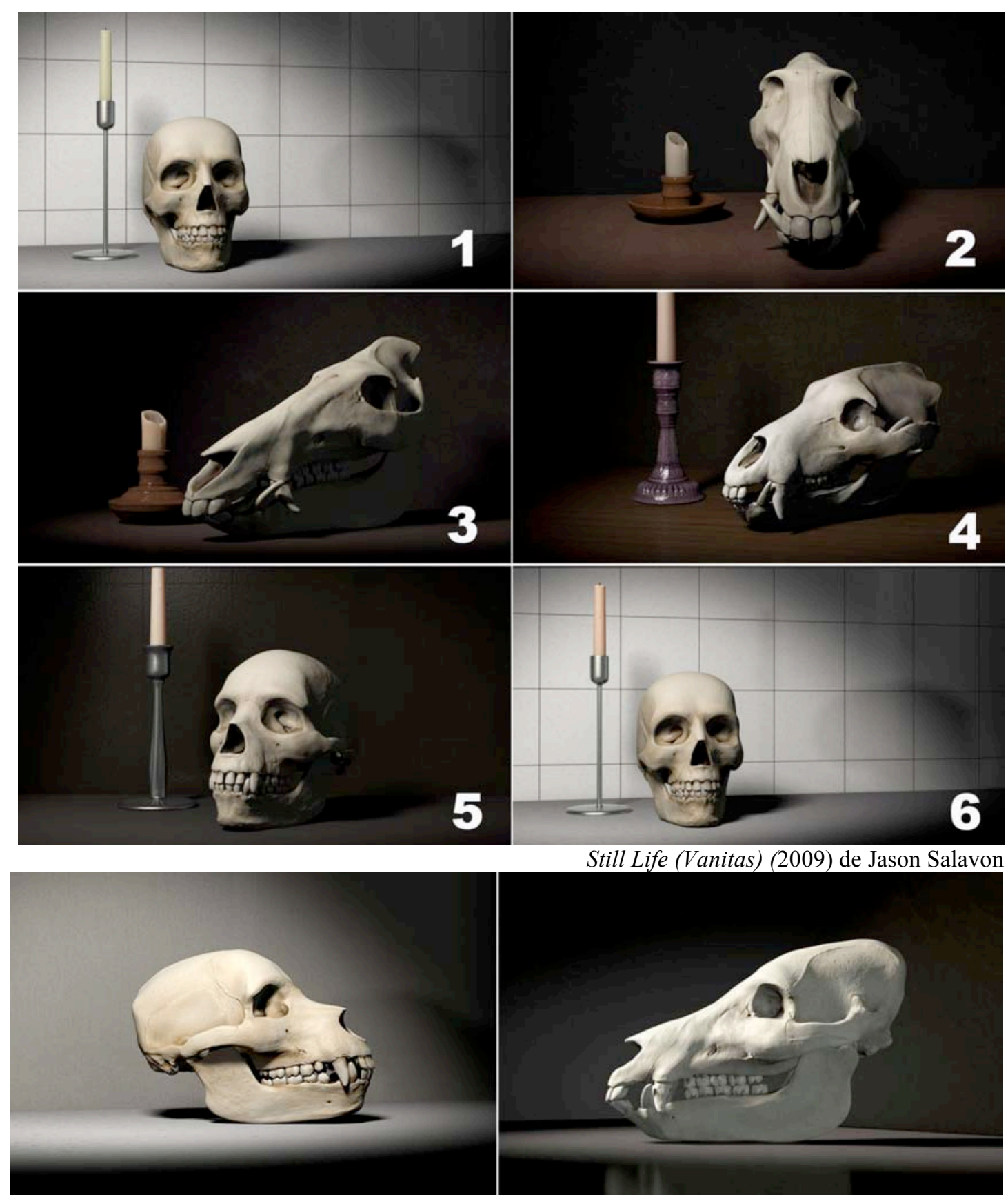

Salavon (2010): Izquierda. "Generic Mammal Skull (13\% baboon, 36\% bear, 46\% human, $5 \%$ wild boar)". Derecha. "Generic Mammal Skull (21\% baboon, 18\% bear, 17\% human, 44\% wild Boar)" 
Las imágenes media en las que puede descomponerse la animación de Salavon no tienen nada que ver con el concepto de "fotograma". Definido por Étienne-Jules Marey en su obra Le mouvement ${ }^{16}$, el "photogramme" nace ligado a la técnica de la cronofotografía, como forma de acceso a las fases del movimiento. Así, su origen es fundamentalmente analítico. El dispositivo cinematográfico se basa, precisamente, en la negación de la fijación del fotograma mediante la síntesis que produce el efecto visual. Frente a la temporalidad inherente al dispositivo cinematográfico, las imágenes sintéticas de Salavon son esencialmente espaciales: la síntesis no es tan sólo un proceso óptico, sino que afecta a la construcción misma de la imagen.

En realidad, una de las primeras secuencias cinematográficas totalmente sintética presenta ya una mutación espacial comparable a la creada por Salavon. En Star Trek II: The Wrath of Khan (1982), Nicholas Meyer da forma al "efecto Génesis" mediante una metamorfosis de la imagen que afecta tanto a la figura como al desplazamiento del punto de vista: la cámara virtual sobrevuela un planeta que va tomando, al mismo tiempo, el aspecto de la Tierra ("terraforming"). Creada por Lucasfilm Computer Graphics (más tarde, Pixar), la transformación del cuerpo celeste se inspiró en la animación Vol libre, que Loren Carpenter había mostrado dos años antes en el SIGGRAPH (1980). ${ }^{17}$
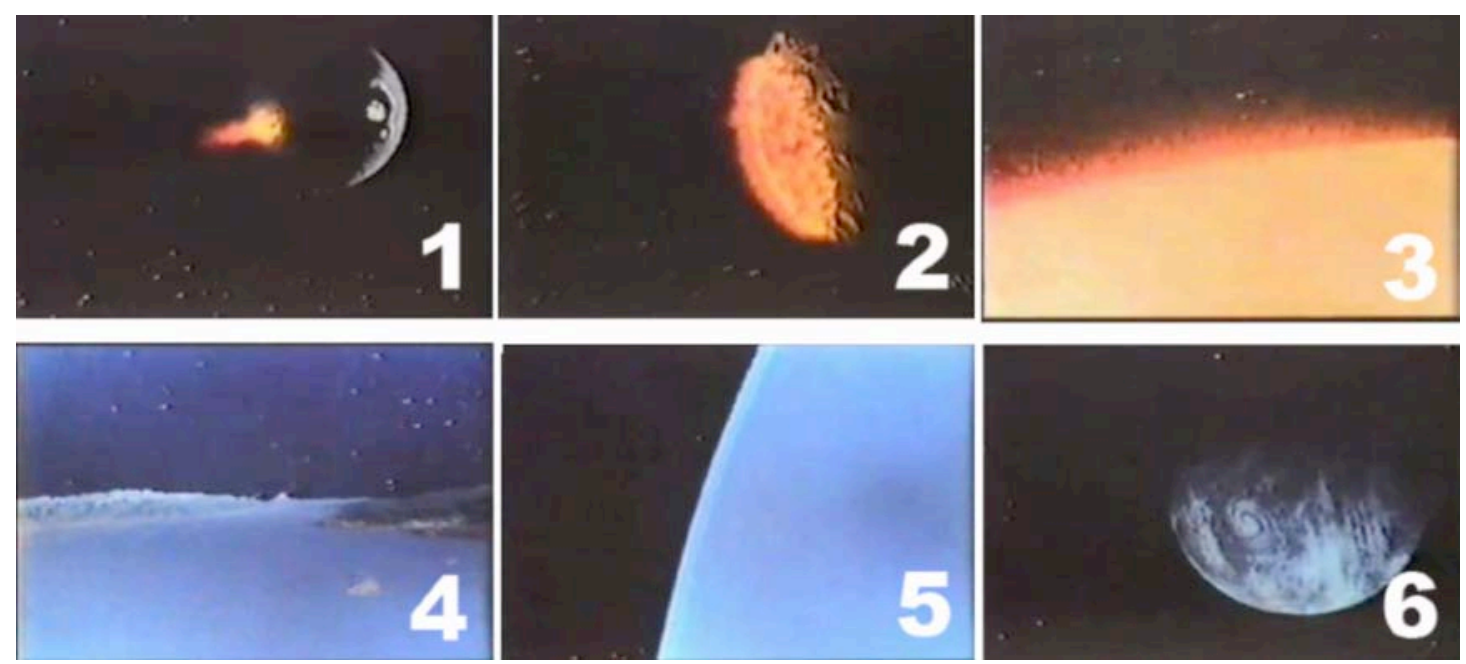

Star Trek II: The Wrath of Khan (1982), de Nicholas Meyer

\footnotetext{
${ }^{16}$ MAREY, Étienne-Jules. Le mouvement (1894). Nîmes: Jacqueline Chambon, 1994, p. 189.

${ }^{17}$ Para elaborar el paisaje sintético, Carpenter acudió a algoritmos fractales, los cuales le permitieron calcular la apariencia caótica de la naturaleza. Más adelante, profundizaremos en esta dimensión fractal, definida por Benoît Mandelbrot en los años 70.
} 
En 1982, al tiempo que Star Trek II: The Wrath of Khan, se estrena Tron, dirigida por Steven Lisberger. Como la cinta de Nicholas Meyer, la película incluye una secuencia generada exclusivamente por ordenador y caracterizada por la exhibición de la omnipotencia de la cámara virtual. La competición entre las "motos de luz" tiene lugar sobre una red tridimensional, una cuadrícula que recuerda la interfaz de programas de animación en 3D. De hecho, también en 1982, aparecía uno de los primeros programas de "Diseño Asistido por Ordenador" o CAD para uso personal: AutoCAD, de Autodesk.

Tanto éste como Maya o Blender pueden presentar cuatro compartimentaciones o "viewports": normalmente, cenital, lateral, frontal y en perspectiva. Partiendo del sistema cartesiano, cada punto corresponde a una coordenada en un espacio tridimensional conceptual. Sin embargo, frente al punto de vista único de la perspectiva, los viewports están interconectadas entre sí al modo de cuatro cámaras enfocando el mismo objeto, al mismo tiempo y desde distintos puntos de vista. Esta distribución espacial apela a una concepción de la forma más próxima a la escultura que a la perspectiva. O dicho de otro modo: el paradigma del punto de fuga es sustituido por el de los $360^{\circ}$. Esta compartimentación interconectada es heredera de la primera interfaz gráfica: el "Sketchpad"18 de Ivan Sutherland permite crear "objetos" mediante la presentación simultánea de cuatro vistas. ${ }^{19}$ El estadounidense concibe el Sketchpad en el MIT en los años 60, al tiempo que Lawrence G. Roberts adapta el algoritmo de la perspectiva al ordenador.

Aunque en Tron la cuadrícula remite a las tres coordenadas del sistema cartesiano $(\mathrm{X} / \mathrm{Y} / \mathrm{Z})$, Lisberger no se contenta con equiparar el espacio dentro del ordenador y la representación en perspectiva. Frente al punto de vista fijo de la proyección lineal, la construcción espacial remite a las interfaces gráficas de diseño $3 \mathrm{D}$ y, como acabamos de ver, éstas adoptan una lógica espacial cercana a la escultura y la multiplicación del punto de vista. En el último apartado de este capítulo, comprobaremos cómo ésta es la base, también, de la instalación multicámara: la transformación de las capturas de varios aparatos físicos permite, entre otros, la creación de (lo que hemos dado en llamar) “instantáneas tridimensionales”.

\footnotetext{
${ }^{18}$ SUTHERLAND, Ivan Edward. Sketchpad: A man-machine graphical communication system [En línea]. University of Cambridge, 1963, Technical report, núm 574. Disponible en Web: $<$ http://www.cl.cam.ac.uk/TechReports/>

19 "Sutherland's breakthrough technique was to describe not the picture that he wanted to see but the object." RICKITT, Richard. Special Effects: The History and Technique. London: Aurum, 2006, p. 154.
} 

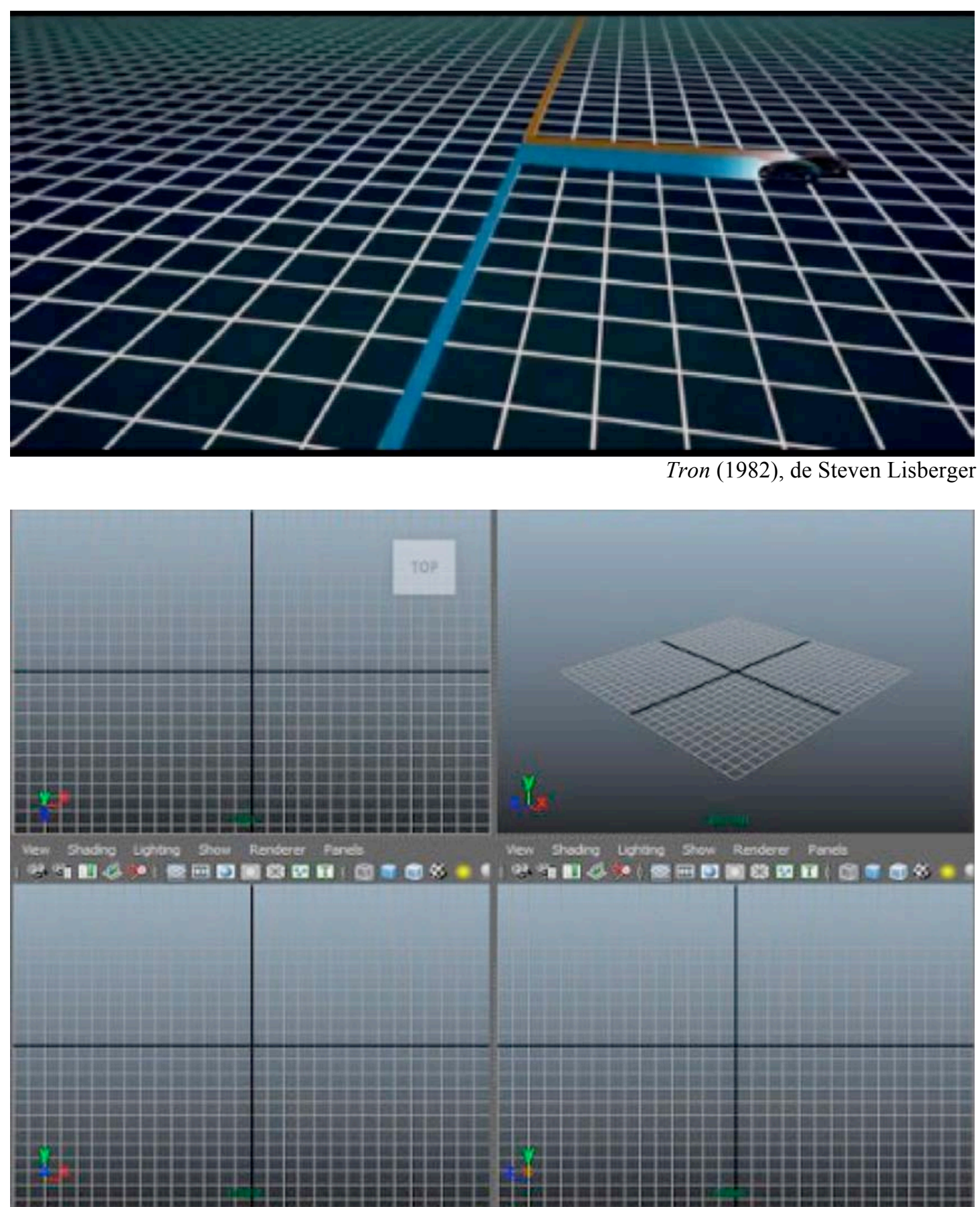

Captura de pantalla de los cuatro viewports de Maya

En la escena de la competición de las motos de luz, Lisberger explota la elasticidad de la imagen digital, haciendo presente una dimensión distinta, variable, unida al desplazamiento de la cámara virtual y la mutación fluida de la escala. Richard Taylor, co-supervisor de los efectos digitales de Tron junto a Harrison Ellenshaw, ve en la película un antecedente de las posibilidades de desplazamiento de la cámara virtual en un espacio construido en 3D: "Nos dimos cuenta de que podíamos coreografiar ilimitadamente los movimientos de la cámara e ir del micro al 
macro sin límites físicos para la cámara o los objetos. ${ }^{~} 20$ Ésta conciencia de la potencia plástica del constructo espacial halla un eco en la "elektronische Plastik" de Peter Weibel. El artista austriaco destaca la posibilidad que la imagen electrónica brinda de transformar la imagen en su escala y en su posición. ${ }^{21}$

\section{La trayectoria en un medio lleno}

Aunque es cierto que en la construcción de la cámara virtual se suele imitar patrones cinematográficos (los movimientos, las lentes y la manera de enfocar de una cámara física), esta construcción espacial no tiene por qué someterse a las limitaciones del aparato de registro ni a la concepción de un espacio euclidiano.

Daniel Franke aprovecha la potencia plástica de la cámara virtual en su animación Unnamed soundsculpture (2012). Frente a la síntesis total de Tron y Star Trek II, el constructo presenta una transformación de una grabación previa. Ahora bien, Franke sustituye la fotografía por una "captura de movimiento" ("motion capture" o "mo-cap"): las tres cámaras Kinect no registraron la luz, sino tan sólo los movimientos de una figura. El artista pidió a una bailarina que "visualizara" una pieza musical (Kreukeltape, de Machinefabriek), y su performance fue almacenada en el ordenador como una "nube de puntos". Los movimientos así capturados se revistieron con la apariencia de partículas en suspensión. No lejos de las preocupaciones de los pioneros del computer art, Franke parte del punto como unidad mínima; la suma de varios de estos puntos y su recombinación le permite reflexionar tanto sobre la complejidad del conjunto como sobre la tensión entre figuración y desfiguración.

En lugar de simular la profundidad mediante la fuga de las líneas en el horizonte, localiza las coordenadas en un sistema cartesiano. Este registro minucioso de la situación relativa de los puntos permite la creación de una escena tridimensional; y, como en Tron, la cámara virtual puede navegar libremente a través de ella. Tal y

\footnotetext{
${ }^{20}$ Richard Taylor. Apud. Tron then and now [En línea]. Creativeplanetnetwork.com. Disponible en Web: <http://www.creativeplanetnetwork.com/node/41956>

21 "Diese relative und veränderbare Größe der Dinge im Bild selbst, die ich Skalierung nenne, ermöglicht es, die Objekte der Welt beliebig zu verkleinern und zu vergrößern; als frei flottierende Zeichen des Raums kann ich sodann diese Objekte beliebig verschieben und in eine neue Art von Mikro- bzw. Makro-Architektur verwandeln. Alle Objekte werden frei verfügbar, in ihrer Größe veränderbar und in jeder Position einsetzbar.” WEIBEL, Peter. Op. cit.
} 


\section{LA OMNIPOTENCIA DE LA CÁMARA VIRTUAL}

como explica el propio Franke: "la imagen tridimensional permitió una manipulación totalmente libre de la cámara digital, sin limitación del punto de vista."22

Como la bailarina que diera forma a la pieza musical, la cámara virtual reacciona al sonido ${ }^{23}$, sigue su trayectoria ${ }^{24}$. En este sentido, la concepción espacial remite, más bien, a la de la danza que a la del teatro clásico: frente a un espacio vacío que llenar, el baile plasma el espacio como el reverso del movimiento; es decir, como un medio fluido, definido por los cambios en los seres que lo moran. Así, aunque partiendo de un sistema de coordenadas tridimensional, Franke no se limita a la perspectiva: al contrario, presenta una entidad llena, un entorno plástico habitable.

En L'analyse des spectacles, el teórico teatral francés Patrice Pavis describe dos espacios antitéticos: el "espacio objetivo exterior" y el "espacio gestual”. El primero engloba el edificio, la arquitectura, el escenario, el auditorio o las bambalinas, y corresponde a una concepción del espacio como vacío. Al contrario, el segundo recupera el gesto como acción:

"Se considera el espacio como invisible, ilimitado y ligado a sus usuarios, a partir de las coordenadas de estos, de sus desplazamientos, de sus trayectorias, como una sustancia no tanto que llenar, sino que extender."25

Tal y como afirma Lev Manovich, más allá de la topología, la geometría y la lógica del espacio estático, en la cultura del ordenador, el espacio funciona como una "trayectoria" en lugar de cómo un "área"26. Al analizar detenidamente ambos términos, comprobamos que, efectivamente, la idea de "trayectoria" se adapta perfectamente al espacio dinámico de la imagen digital: mientras que el "área” define una superficie generalmente bidimensional o plana comprendida dentro de un perímetro, la "trayectoria" se refiere a la dirección de un movimiento en el espacio y subraya el desplazamiento continuo del punto de vista. Este espacio mutante cobra protagonismo como medio y no tanto como lugar.

\footnotetext{
22 FRANKE, Daniel. Unnamed soundsculpture [En línea]. Daniel-franke.com, May 6, 2012. Disponible en Web: $<$ http://daniel-franke.com/?p=6>

23 "The camera also reacts to the sound and supports the physical imitation of the musical piece by the performer." Ibídem.

24 "A musical work has a trajectory, engendering a kind of internal voyage in the listener." BELKIN, Alan. A Practical Guide to Musical Composition [En línea]. 2008. Disponible en Web:

$<$ https://www.webdepot.umontreal.ca/Usagers/belkina/MonDepotPublic/bk/>

${ }^{25}$ PAVIS, Patrice. L'analyse des spectacles. Paris: Nathan Université, 1996, pp. 140-141.

${ }^{26}$ MANOVICH, Lev. The Language of New Media. Op. cit., p. 279.
} 

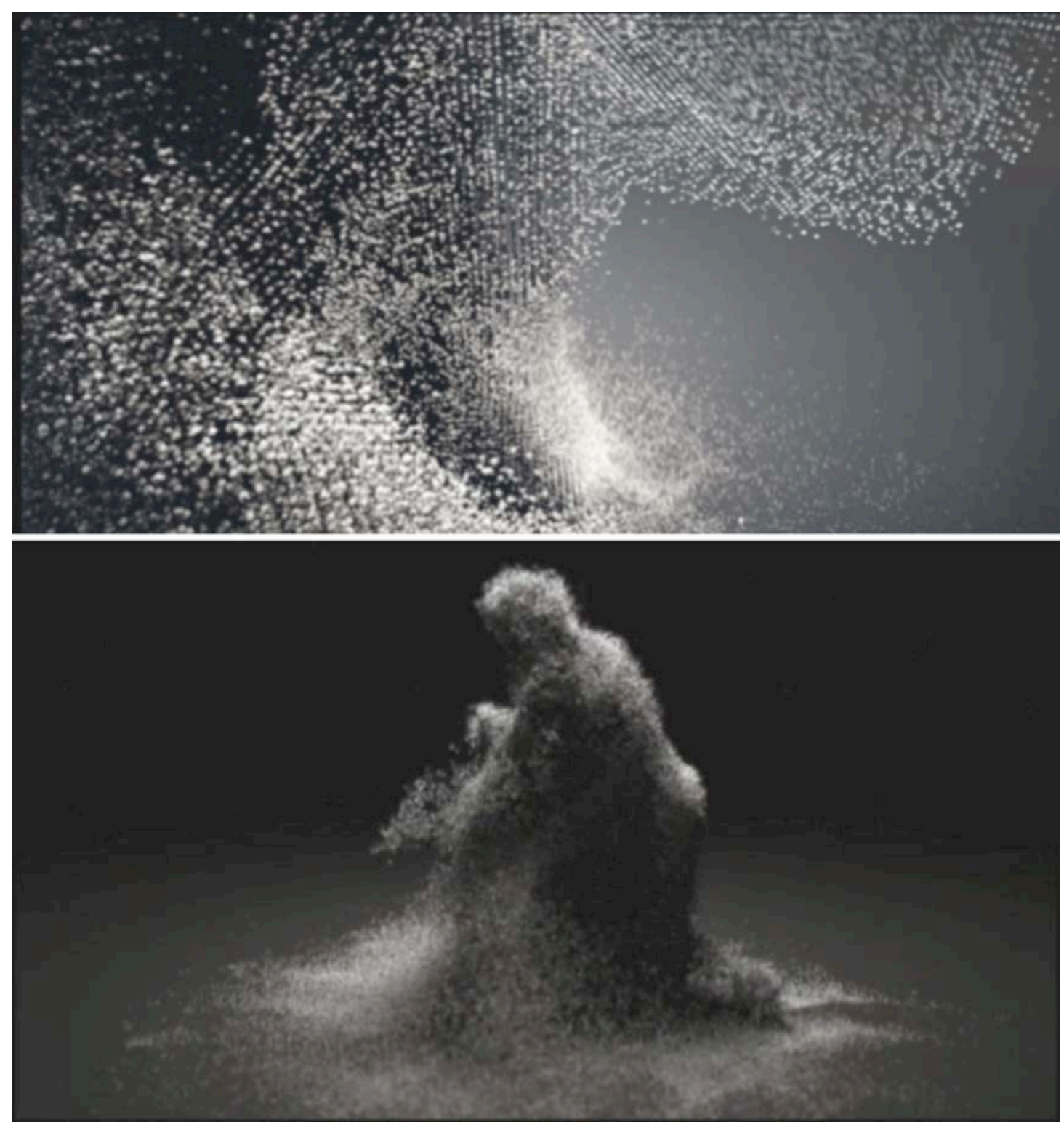

Unnamed soundsculpture (2012), de Daniel Franke

Puesto que la cámara virtual puede atravesar todo tipo de superficies, no es de extrañar que los creadores exploren las relaciones espaciales entre dentro y fuera: frente a la dicotomía o la oposición, el movimiento continuo permite presentar el espacio como una entidad isotópica, que comparte las mismas características en todos sus puntos. Pongamos por caso la animación del pionero Charles Csuri: Hommage II (2006). Como en la Unnamed soundsculpture de Franke, la cámara virtual cambia de escala y atraviesa las figuras, dotando al espacio de una dimensionalidad distinta a la de la perspectiva. Lejos del centro organizador antropocéntrico, las relaciones espaciales producidas por la dinamización del punto de vista tienen que ver con la idea de "relación" de la cibernética: la cámara virtual de Csuri bebe de sus exploraciones plásticas en tanto que pionero del computer art allá por los años 60 . 
Así, no se trata de una representación mimética de las formas, sino de las relaciones entre éstas y el espacio que las contiene.

Csuri sigue interesándose por la activación de la imagen más allá de la reproducción; interés que veíamos ya en obras como Hummingbird, Aging Process o Artist into Frog. Si en sus primeras obras acudía al sistema de coordenadas bidimensional en busca de deformaciones y espacios no-euclidianos, aquí, parte de la tridimensionalidad para explorar las relaciones espaciales. Al dinamizar el punto de vista, el espacio se aleja del punto de fuga y se acerca al de un escultor que girara $360^{\circ}$ en torno a su pieza.

Entre caligrafía y escultura, Hommage II bosqueja la forma de la famosa Venus de Milo (ca 100 a. C). Si bien la obra de arte de la escultura helenística destaca por su tridimensionalidad $^{27}$, el tratamiento espacial de Csuri tiene más que ver con la escultura "biomórfica" de artistas como Barbara Hepworth. La relación se establece entre el interior mismo de la obra y el entorno en el que ésta se inserta. Tal y como afirmara la artista británica: "Busco dar la sensación de estar contenida en la forma tanto como de contenerla." 28

Esta reversibilidad espacial es comparable a la animación de Csuri. La cámara virtual atraviesa las entrañas de las cáscaras que asemejan la célebre Afrodita de Milos: entra, sale, cambia de escala... El espacio es el producto de la relación entre formas, cuadro y punto de vista. En las últimas páginas de esta investigación, compararemos la escultura biomórfica con el arte evolutivo, y volveremos sobre esta interrelación entre forma y espacio; por ahora, nos conformamos con subrayar la continuidad del movimiento de la cámara virtual, que permite la rica integración de opuestos como dentro y fuera.

A medio camino entre la síntesis de Csuri y el montaje espacial en Hugo de Scorsese (con el que comenzábamos este apartado), Obras (2004) de Hendrick Dusollier insiste en la potencia plástica de la cámara virtual. Mediante un plano

\footnotetext{
27 “L'œuvre reflète cependant les innovations apparues durant la période hellénistique, entre le IIIe et le Ier siècle avant notre ère. La composition hélicoïdale, l'insertion de la figure dans un espace tridimensionnel et l'allongement du torse à la poitrine menue sont caractéristiques de cette époque." Descripción de la Afrodita de Milos en el sitio web del museo del Louvre:

$<$ http://www.louvre.fr/oeuvre-notices/aphrodite-dite-venus-de-milo?selection=2421>

${ }^{28}$ Barbara Hepworth. Apud. DINER, Simon. Le biomorphisme dans la culture artistique moderne [En línea]. Texto para la exposición "Sculpture numérique et biomorphisme". Nancy, Octobre 2007, p. 10. Disponible en Web : <www.peiresc.org/DINER/Biomorphisme.pdf>
} 
secuencia digital de algo más de diez minutos de duración, el corto retrata una Barcelona en constante mutación.

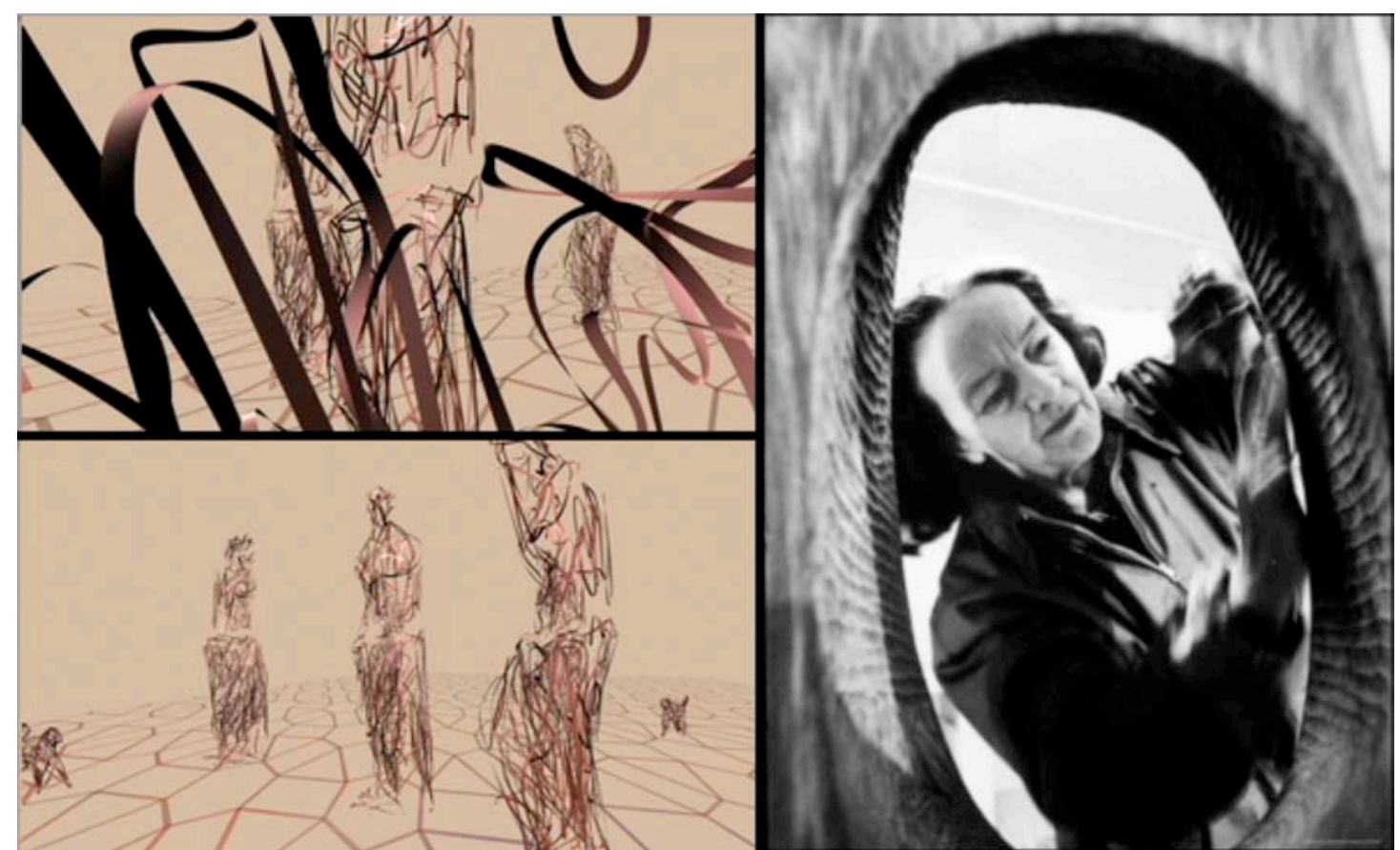

Izquierda, Hommage II (2006), de Charles Csuri. Derecha, Barbara Hepworth con una de sus esculturas
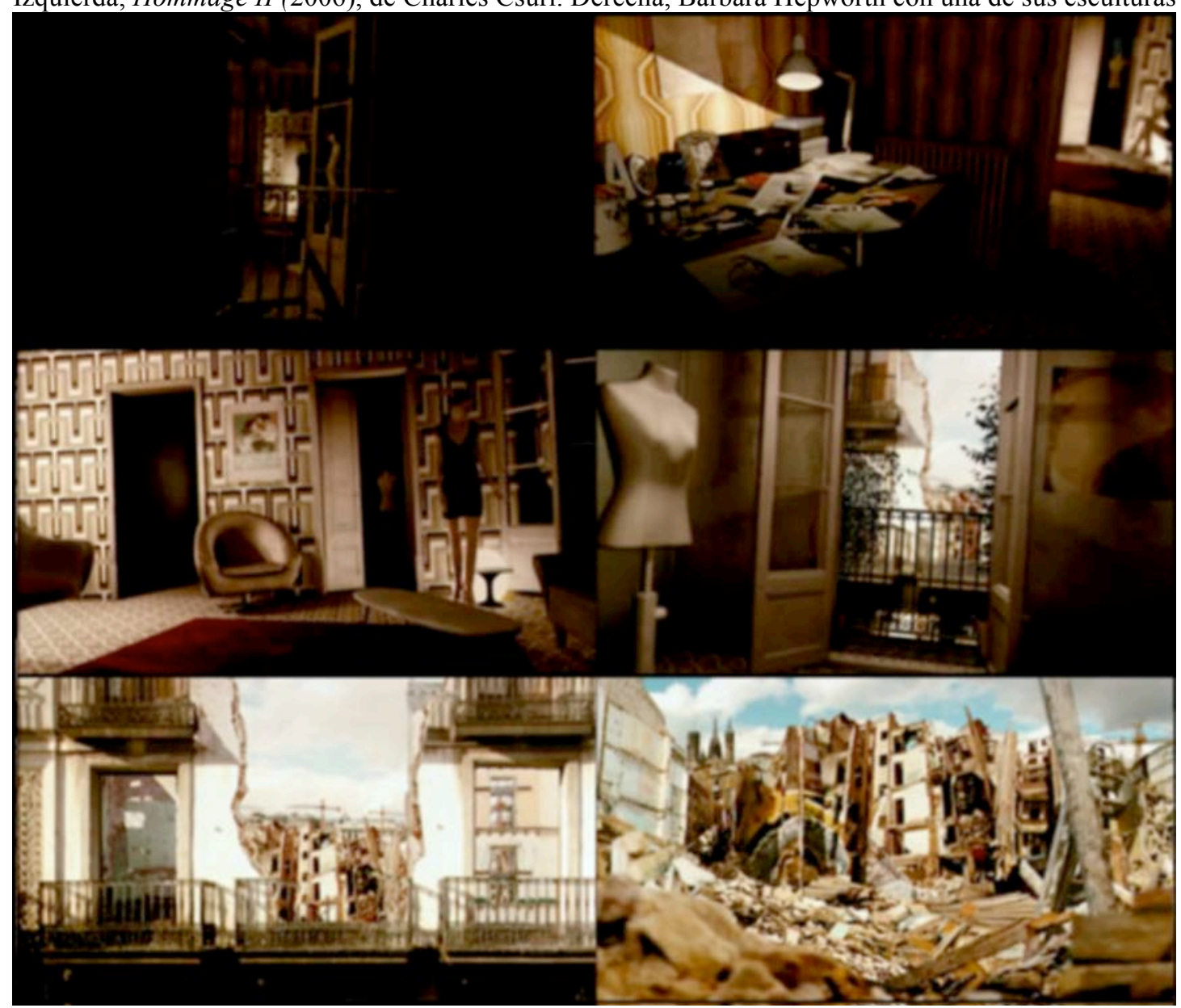

Obras (2004), de Hendrick Dusollier 
La imagen híbrida combina registros fotográficos y animación, fundidos en un todo continuo que recorre la cámara virtual. Mediante la composición de distintas tomas, Dusollier crea edificios agrupados, a su vez, en las distintas capas de la imagen. La cámara virtual se desplaza entre las mismas, sorteando los inmuebles, que mantienen, con todo, su bidimensionalidad. Gracias a la continuidad del movimiento, se establece una relación entre el dentro de las viviendas y el fuera del espacio urbano mutante. El espacio es el protagonista absoluto de la obra: entre sujetos y objetos; entre imagen fija y animada; entre las tres dimensiones asociadas al movimiento y las dos dimensiones de las capas que componen la imagen, Obras es un paradigma del espacio "del entre", que definimos a continuación. 


\section{EL ESPACIO DEL "ENTRE"}

Acabamos de ver cómo la cámara virtual de Panic Room (2002) se libera y exhibe su potencia plástica; adquiere todo tipo de puntos de vista; cambia de escala, y atraviesa superficies a su antojo. La película de David Fincher contiene un plano secuencia especialmente interesante: la cámara se aleja de la habitación en la que duerme la madre, atraviesa sin problemas la barandilla de la escalera, desciende verticalmente hasta la planta baja y se acerca a una ventana, desde la cual se intuyen las sombras de los intrusos que intentan allanar la casa. A partir de entonces, se desplaza siguiendo los movimientos de éstos sin salir, por ello, del inmueble. Mientras uno de los ladrones intenta forzar la cerradura, la cámara virtual penetra en el hueco reservado a la llave. Ante la imposibilidad de forzar la entrada principal, los ladrones ponen a prueba la puerta trasera. Mientras rodean el edificio, la cámara virtual recorre la encimera de la cocina, entre los objetos, en un movimiento rectilíneo imposible para un instrumento físico.

En los tres minutos que dura el desplazamiento libre de la cámara, Fincher no introduce ni un solo plano del exterior de la casa, contribuyendo a la sensación de claustrofobia que domina toda la película. Atrapada entre las paredes de la vivienda, la cámara no se desplaza como un testigo antropomórfico: no sube los peldaños de las escaleras, sino que traspasa sin problema las barreras que se interponen a su paso, adquiere puntos de vista desde los objetos y cambia de uno a otro de forma continua.

Generalmente, en un cine "de sujetos", la narración se sustenta en un drama humano o en la interacción entre los personajes, y de éstos con los objetos, pero no, en el espacio en el que se insertan ${ }^{1}$. Por el contrario, en Panic Room, el espacio mismo es un personaje clave de la trama. En su desplazamiento continuo, la cámara virtual adopta un punto de vista a medio camino entre los sujetos y los objetos. Siguiendo con la fórmula de José Luis Molinuevo, se trata de una construcción "no interesada ni en personas ni en cosas, sino en lo que hay 'entre' personas y cosas." 2

\footnotetext{
1 "Given classical viewing priorities, we are more concern with the distinct persons and things visible within space than with the spaces between and around them." BORDWELL, David. The Classical Hollywood Cinema. Film Style \& Mode of Production to 1960. Op. cit., p. 59.

${ }^{2}$ MOLINUEVO, José Luis. Retorno a la imagen. Estética de cine en la modernidad melancólica. Op. cit., p. 43.
} 

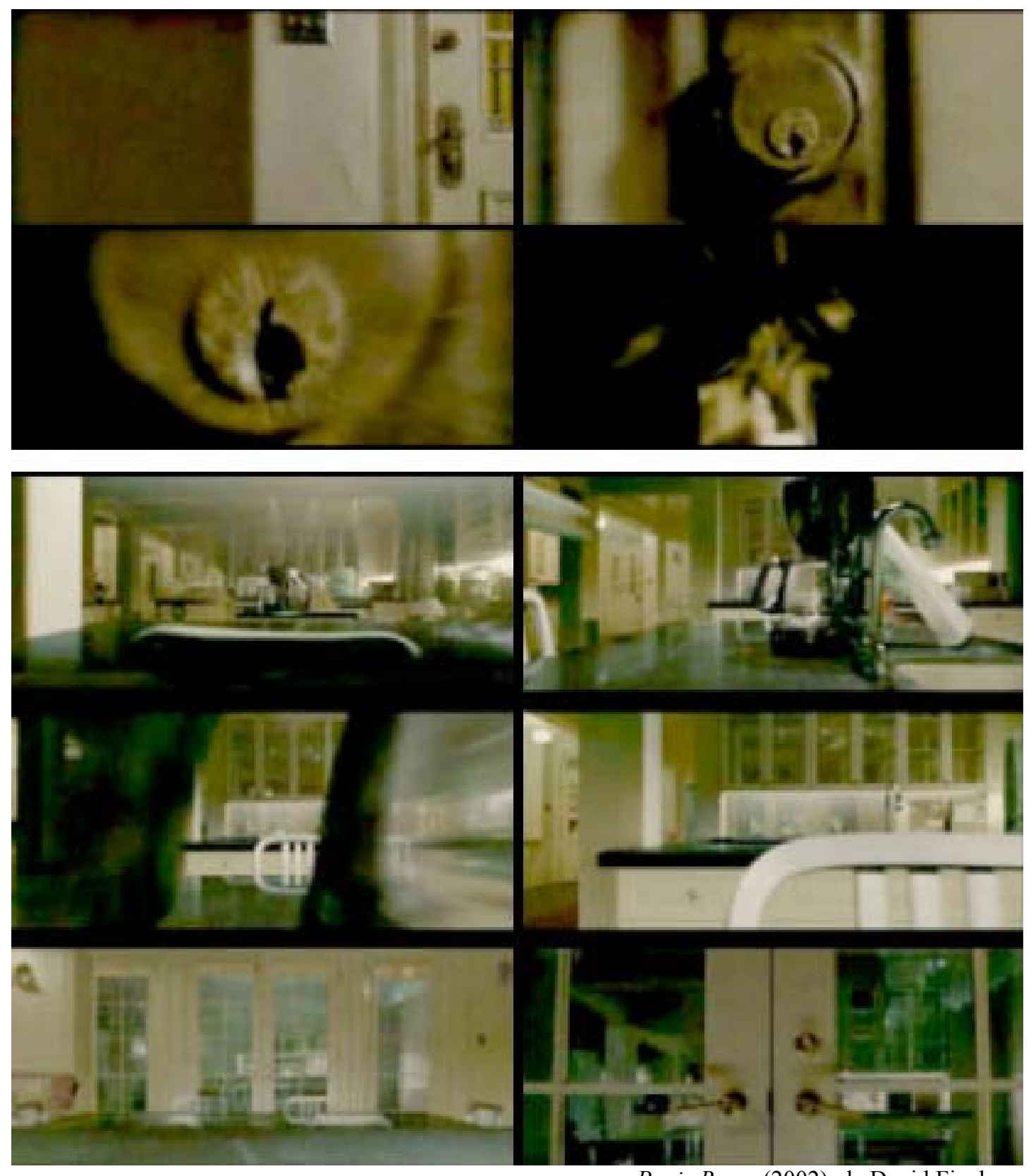

Panic Room (2002), de David Fincher

\section{Entre sujetos y objetos}

El plano secuencia de Panic Room permite diferenciar entre el narrador y la cámara. La equiparación de ambos es un error común de las teorías miméticas, en las cuales la omnisciencia de aquél se confunde con la omnipresencia de ésta. ${ }^{3}$ En la película de Fincher, si el narrador conoce tanto las intenciones de los ladrones como

\footnotetext{
3 "The most evident trace of narration's omniscience is its omnipresence. The narration is unwilling to tell all, but it is willing to go anywhere. This is surely the basis of the tendency to collapse narration into camerawork." BORDWELL, David et al. The Classical Hollywood Cinema: Film Style and Mode of Production to 1960. Op. cit., p. 30.
} 
el recorrido de los mismos alrededor de la casa, prefiere no mostrar el otro lado del muro; a cambio, se deleita en exhibir la omnipotencia de la cámara virtual, que atraviesa las paredes y los objetos en el interior del hogar.

Veamos otra escena de la misma película. Con madre e hija ya atrapadas en la habitación del pánico, los ladrones ponen a prueba su ingenio para acceder a ella y hacerse con las grabaciones de las cámaras de seguridad. En una de sus tentativas, los malhechores, situados en la planta inmediatamente inferior, se proponen destrozar el techo. Las secuestradas se agachan para escuchar los ruidos provenientes del piso de abajo. En ese momento, Fincher desplaza la cámara hacia el suelo, atraviesa las entrañas del piso y muestra a los secuestradores golpeando con mazos la parte superior de la estancia.

Encontramos un ejemplo muy semejante en Inglourious Basterds (2009), de Quentin Tarantino. Ambientada en la Francia ocupada por el nazismo, la película comienza en 1941, en una cabaña de una provincia francesa, la casa de Monsieur LaPadite (Denis Menochet) y sus tres hijas. El coronel de las SS, Hans Landa (Christoph Waltz), encargado de encontrar los judíos que queden en el territorio, se acerca al lugar en busca de la única familia aún no localizada. Con la sospecha de que Monsieur LaPadite conoce su paradero, el militar le somete a un interrogatorio. En el momento en el que la cuestión se refiere a Shoshanna (Mélanie Laurent), la cámara se desplaza hacia el suelo y lo traspasa hasta mostrar el hueco oscuro en el que se esconde la chica junto a toda su familia.

La escena podría haber sido montada cortando en el momento en el que el travelling vertical enfoca el suelo para, después, mostrar un plano de Shoshanna en el subsuelo. Sin embargo, la continuidad del movimiento genera un sentimiento de espacio único. Esta estrategia permite a Tarantino dibujar de manera mucho más precisa la trampa en la que se encuentran las víctimas. Además, el hecho de mostrar el interior del suelo dota al espacio arquitectónico de una presencia clave en la escena, a la misma altura que los personajes que dialogan.

Aunque invertidos los lugares en los que se sitúan perseguidores y perseguidos (en Inglourious Basterds las víctimas abajo y en Panic Room arriba), la tensión dramática en las dos escenas se basa en el mismo principio: generar un espacio común; exaltar no sólo la contigüidad (y con ella, la proximidad del peligro), sino la continuidad de un movimiento imposible, que destaca como una firma de la narración. 

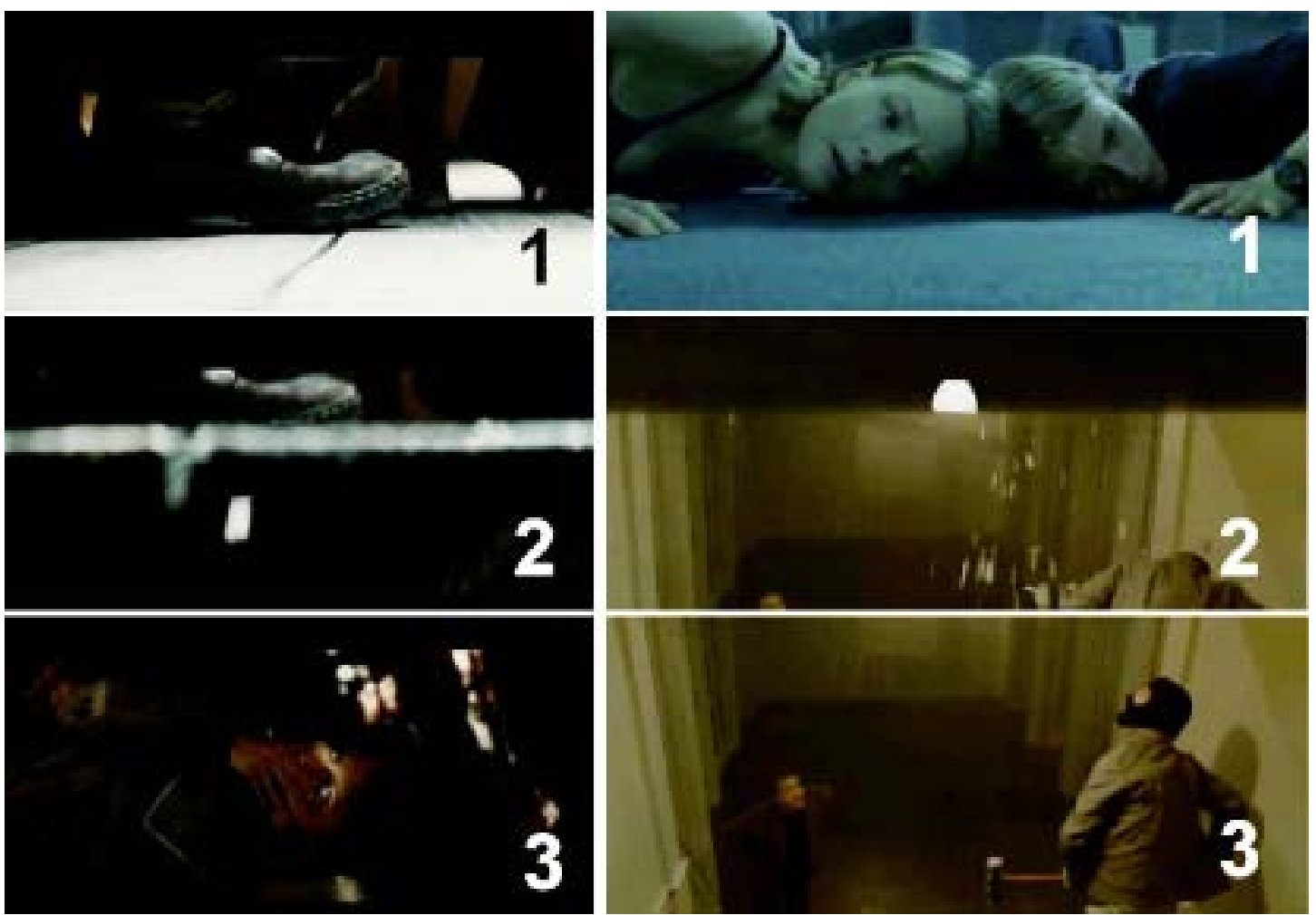

Columna de la izquierda: Inglourious Basterds (2009), de Quentin Tarantino Columna de la derecha: Panic Room (2002), de David Fincher

Minority Report (2002), de Steven Spielberg, contiene un acertado plano secuencia basado en este posicionamiento narrativo entre el drama de los personajes y el espacio que los rodea. La escena se desarrolla en un edificio destartalado e insalubre, en el que el fugitivo acaba de someterse a una operación ilegal de sustitución de ojos como parte de su cambio de identidad. Las fuerzas del PreCrime, en busca y captura de Anderton, envían pequeños robots arácnidos que detectan la identidad de las personas analizando sus pupilas. Conocedores de los métodos del PreCrime, los habitantes de la casa se someten sin mostrar resistencia al examen ocular, que dura apenas unos segundos. En el proceso, los robots rastrean los distintos apartamentos, paralizando por unos instantes la vida de la gente.

Para mostrar la tensión de la redada, Spielberg se sitúa en el techo común de la vivienda y recorre la superficie, pasando de una habitación a la siguiente e invadiendo la intimidad de los vecinos. Durante ese movimiento continuo, que atraviesa paredes, techos y cuanto se interpone en su camino, el punto de vista no es el del perseguido ni el de los perseguidores, sino que, en la más pura tradición del cine de terror, el observador se sitúa en una perspectiva intermedia y omnisciente: conoce la situación de ambas partes y posee, así, más información que cada una de ellas. La cámara 
virtual persigue el movimiento de los robots sin someterse por ello al punto de vista de los mismos, lo que supondría desconocer la situación del protagonista y renunciar a gran parte de la tensión y el ritmo de la escena.
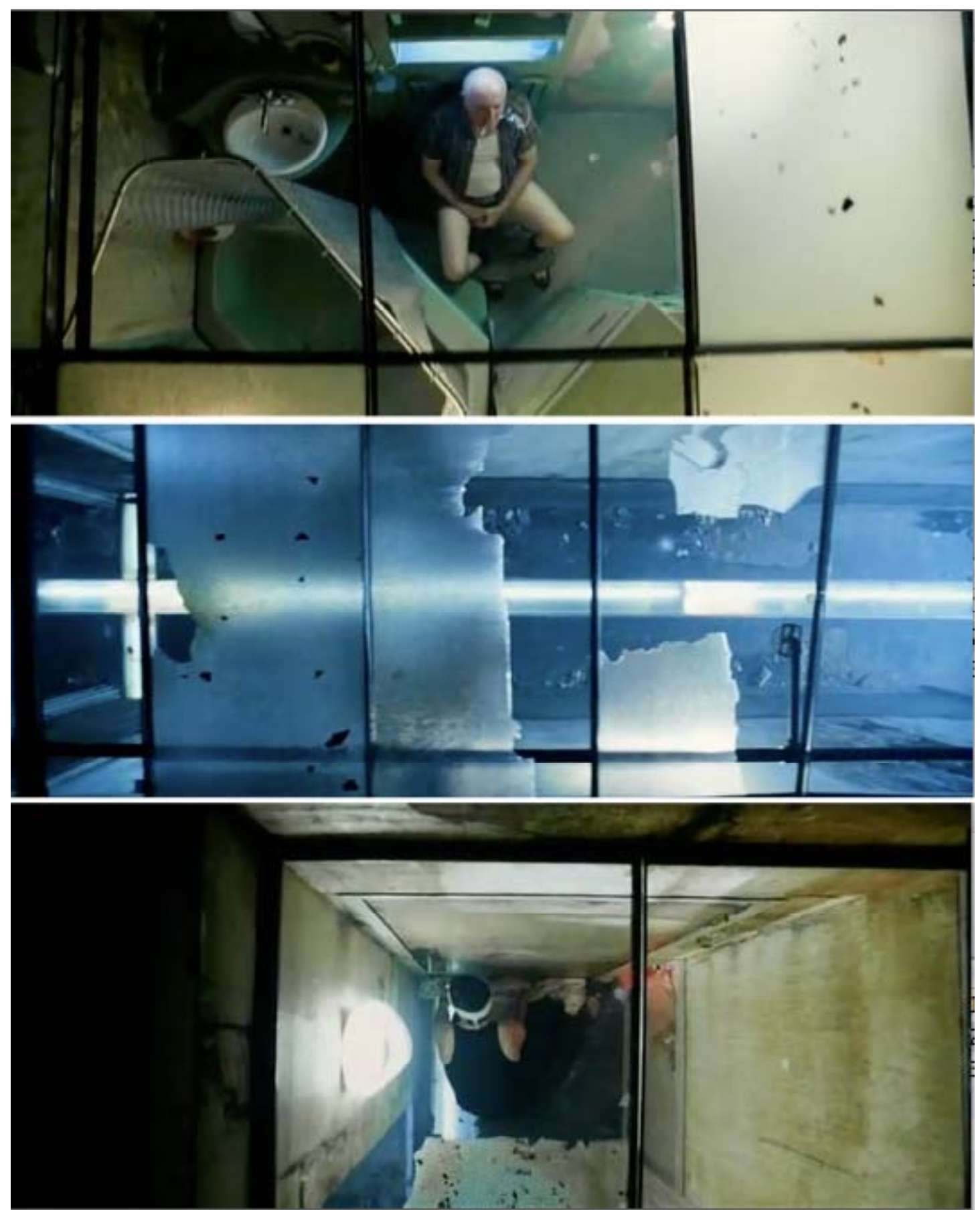

Minority Report (2002), de Steven Spielberg

En el primer capítulo veíamos cómo, de acuerdo con Peter Greenaway, el lenguaje cinematográfico se ha visto limitado por cuatro "tiranías": el cuadro, el texto, la cámara y el actor. En lo que concierne a este último imperativo, el realizador inglés 
considera abusiva la importancia concedida a los sujetos en el cine de ficción; un cine que, marcado por la narrativa cronológica del texto, no hace más que reproducir con la cámara un teatro pasivo, en el que el espacio es tan sólo un vacío inerte. Frente a esta concepción mimética del espacio representado, el también pintor se inspira de la pintura moderna y el rol que ésta reserva a la figura humana: simplemente, una más en el plano pictórico. ${ }^{4}$ Con ello, matiza, no aboga por un cine sin actores, sino por insertarlos en el espacio, al cual se le restituye su protagonismo. ${ }^{5}$

Con todo, como veíamos, la propuesta práctica de Greenaway se concentra en el montaje espacial, en la cohabitación y la mezcla en el interior de un cuadro inmóvil. Éste es el caso de las películas ya citadas Prospero's Books, The Pillow Book y The Tulse Luper suitcases. Sin embargo, a este alejamiento del cine subjetivo y la primacía del actor puede contribuir, también, la cámara virtual. Ésta posibilita la exploración del espacio intermedio, liberando el punto de vista de las limitaciones del testigo antropomórfico. Y lo hace, precisamente, en tanto que construcción espacial.

Veamos otro ejemplo en la película Source Code (2011), dirigida por Duncan Jones. Cuando el soldado mutilado Colter Stevens (Jake Gyllenhaal) es desconectado de la máquina que lo mantiene con vida, el tiempo del mundo paralelo en el que actúa se para. No obstante, mientras todos los elementos de la escena aparecen congelados, la cámara virtual recorre el pasillo del vagón entre los personajes, detenidos en sus posturas respectivas.

Comparemos este efecto con el famoso final de Les quatre cents coups (1959), de François Truffaut. El realizador de la "Nouvelle Vague" cierra su película con un "arrêt sur image"6 de un plano del joven actor Jean-Pierre Léaud. La parada abrupta revela el trucaje cinematográfico: el movimiento en la imagen es, en sí, un efecto visual creado a partir del paso rápido de las imágenes fijas. Esta exhibición impúdica

\footnotetext{
4 “Le conflit autour de l'objet a joué, pour cette génération, un rôle qui remplace celui du sujet à l'époque romantique. (...) même quand la figure humain apparaît dans cette peinture, elle est encore traité comme objet." FRANCASTEL, Pierre. Op. cit., p. 193.

5 "There are many genres of painting in which the actor is absent, or reduced to the concept of a figure in a landscape. I am not advocating a cinema where there are no actors, where the human figure is not by inference the centre of our interest, but I will argue that the actor has to seriously share the cinematic space with other evidences of the world, has to be, in essence a figure in a landscape which is likely to give attention to space, ideas, inanimacy, architecture, light and colour and texture itself." GREENAWAY, Peter. Op. cit.

"Para profundizar en el "arrêt sur image" en la imagen cinematográfica, ver: DANEY, Serge. "La dernière image”. En: BELLOUR, R.; DAVID, C.; VAN ASSCHE, C. (eds.). Passages de l'image. Paris: Éditions du Centre Pompidou, 1989, pp. 57-59.
} 
de las entrañas del dispositivo denuncia la ilusión de la imagen; la intervención casi quirúrgica hace aflorar la unidad mínima que es el fotograma.

Por su parte, Duncan Jones no propone la descomposición de la ficción del movimiento, sino la congelación de personajes y objetos, mientras que la cámara virtual "se desencadena". Así, en la imagen digital no se trata de una desactivación, sino más bien de una activación distinta; la cuestión no es la interrupción de todo movimiento en la imagen, sino la reivindicación de otro: el de la cámara virtual como construcción espacial.

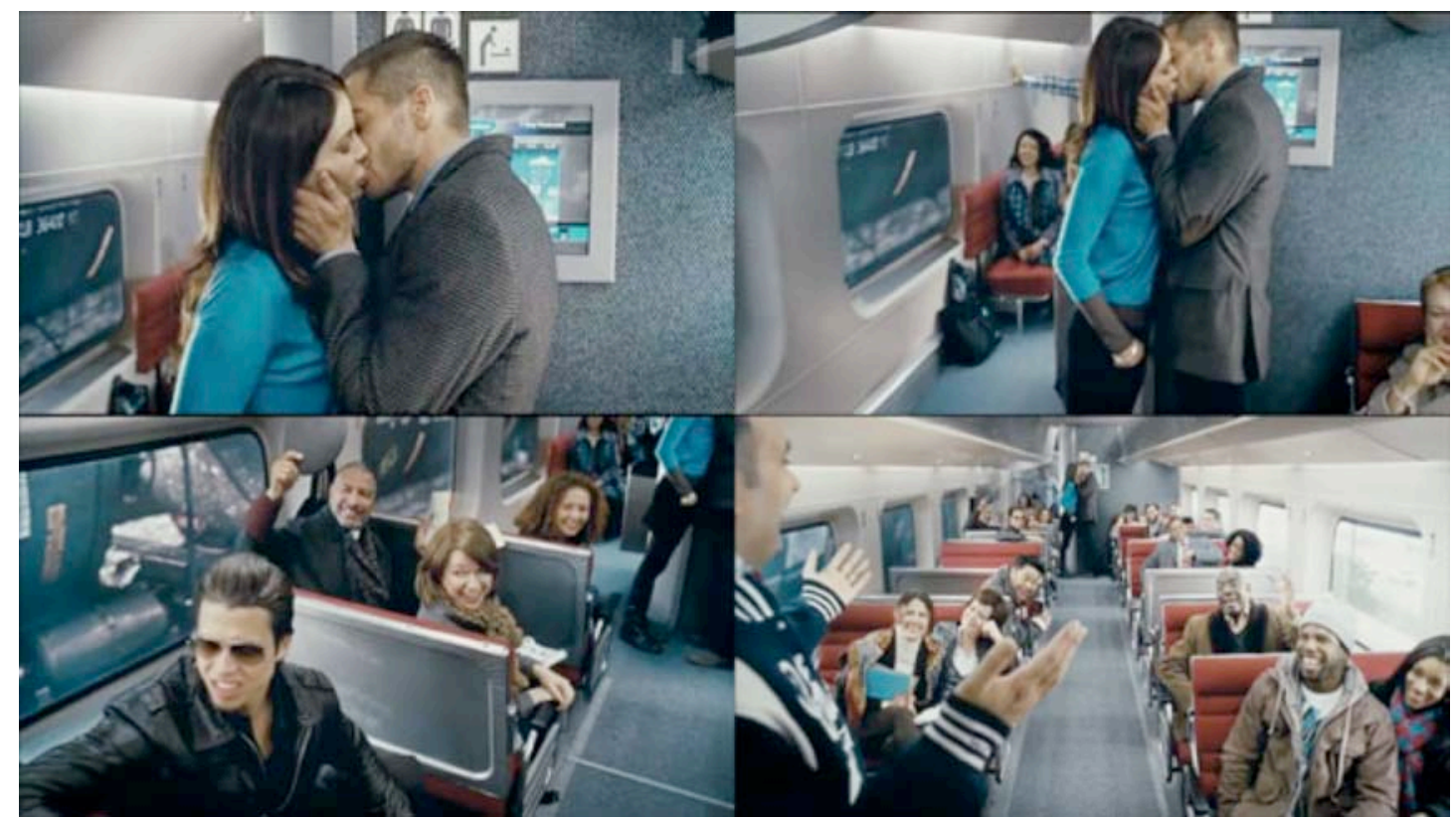

Source Code (2011), de Duncan Jones

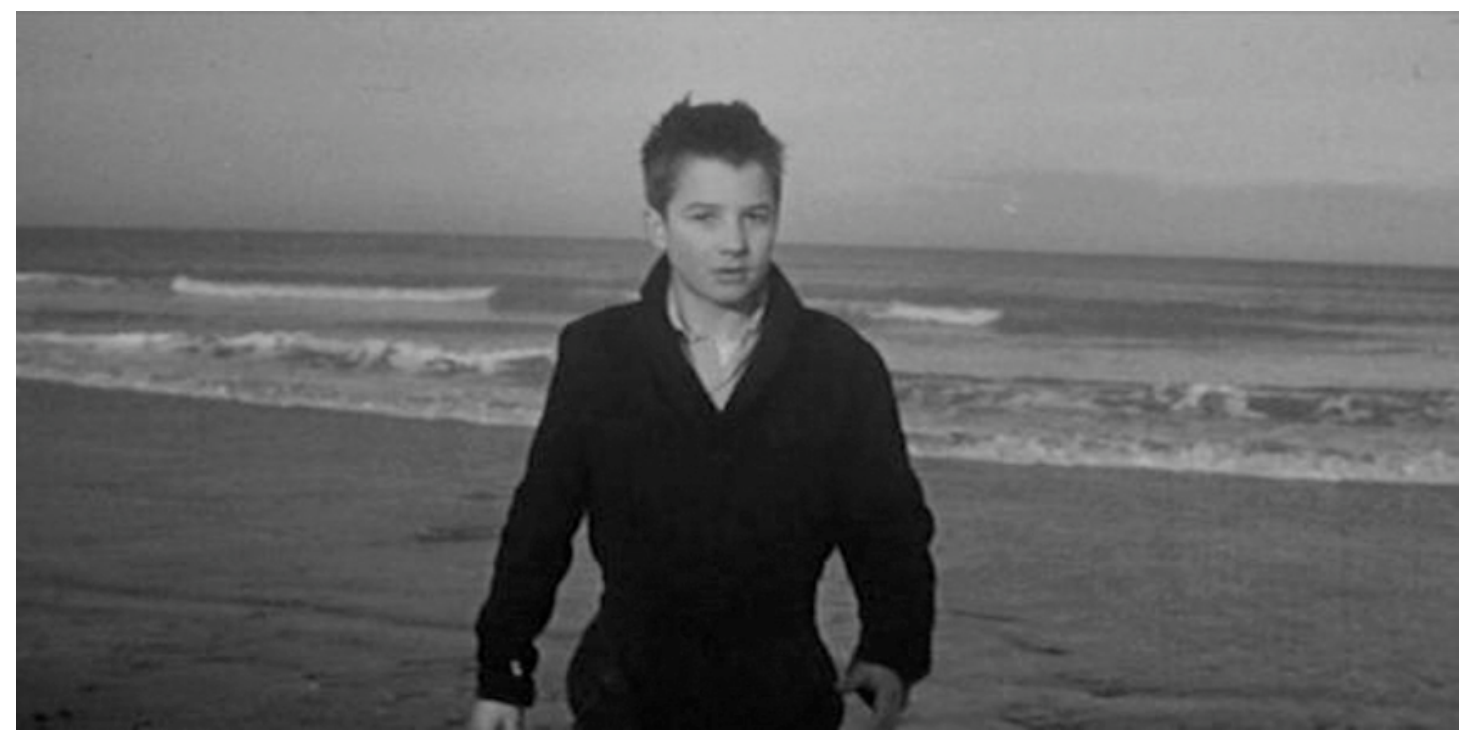

Les quatre cents coups (1959), de François Truffaut 
Si la congelación de la imagen cinematográfica está íntimamente relacionada con el tiempo, la construcción digital descrita subraya el carácter espacial de la imagen. Es más, si el "arrêt sur image" pone punto y final a la película de Truffaut, la cámara virtual en Source Code funciona como apertura: en la escena siguiente, con la que acaba definitivamente la cinta, el protagonista aparece sano en una dimensión paralela.

Frente a la congelación de la imagen cinematográfica, que destaca el carácter bidimensional del fotograma, el zoom out de Source Code desvela y construye al mismo tiempo el espacio tridimensional. La pieza ejemplifica a la perfección la tendencia de las prácticas digitales contemporáneas a la exploración tanto de un espacio entre las dos y las tres dimensiones, como de la tensión entre fijación y movimiento. Así, la cámara virtual no subraya sólo el espacio entre los personajes y los objetos, sino incluso entre las diversas dimensiones de la imagen.

\section{Entre la segunda y la tercera dimensión}

Más de veinte años antes, Tamás Waliczky había explorado ya este estado intermedio entre las dos y las tres dimensiones que permite la cámara virtual. Pictures (1988) es una animación de cinco minutos de duración, creada a partir de las instantáneas de un álbum familiar. La cámara virtual se desplaza por el interior de dichas fotografías, que se revelan, a su vez, como aperturas a otros espacios. Aunque el movimiento genera una sensación de tridimensionalidad, ésta no implica un espacio euclidiano u homogéneo.
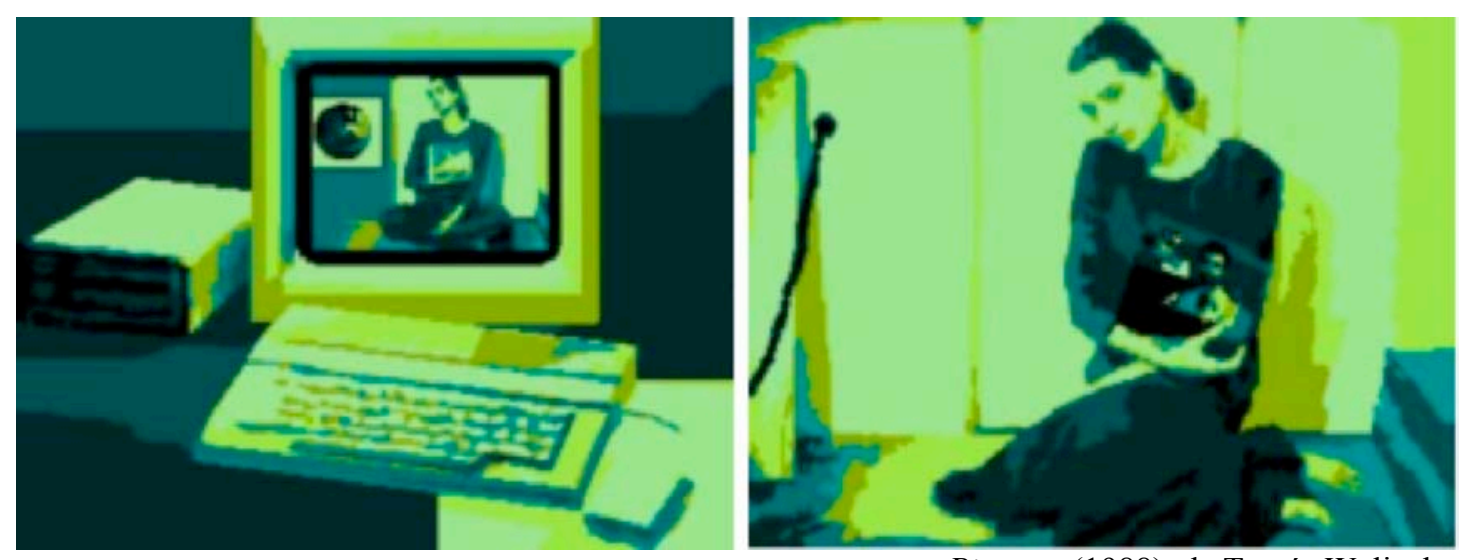

Pictures (1988), de Tamás Waliczky 
Waliczky se sirve de la transformación digital en su huída de la representación en perspectiva; en realidad, las ya citadas The Way y The Garden forman parte de una trilogía completada por la animación The Forest (1993). En ésta, la cámara virtual se desplaza en varias direcciones, dibujando líneas de movimiento curvas. Anna Szepesi, cocreadora del guión gráfico, explica del siguiente modo la construcción del espacio de la imagen:

\begin{abstract}
"Waliczky altera todo el sistema de coordenadas del que depende la representación del espacio. Mientras que las tres dimensiones (X, Y y Z) corresponden normalmente a vectores rectos, el sistema de coordenadas de Waliczky emplea líneas curvas que se enrollan sobre sí mismas. Esto provoca un sentimiento de espacio ilimitado: el espectador siente que no hay salida del bosque, que se extiende en todas direcciones."7
\end{abstract}

A pesar de la profundidad cinética ligada a la cámara virtual, las figuras de los árboles no son más que formas en dos dimensiones. Salvando un sutil trabajo de iluminación, Waliczky mantiene deliberadamente su planitud en contraste con el movimiento del cuadro. A menudo, las ramas o el tronco de algún árbol invaden la superficie de la imagen, subrayando el carácter no antropomórfico de la cámara virtual, que atraviesa la superficie plana de las formas.

Esta diferencia entre la creación de la ilusión tridimensional en la imagen fija y mediante la cámara virtual nos lleva a plantearnos un salto conceptual fundamental hacia la comprensión de la imagen como "camino". En los estudios sobre entornos virtuales, este término diferencia la imagen bidimensional ("map") de la tridimensional ("path"). ${ }^{8}$ Mientras el "mapa" define un espacio finito presentado en dos dimensiones, el "camino" es un espacio construido con el fin de ser transitado. El mapa presenta una visión de conjunto, gracias a la cual el espectador puede vincular un punto específico con otro en la misma escala. Con la cámara virtual, esa relación distante entre el "lector" y el mapa se acorta, situando al receptor dentro de un espacio que se desvela poco a poco, sucesivamente y no de forma simultánea. De este modo, la

\footnotetext{
${ }^{7}$ SZEPESI, Anna. Der Wald (The Forest) [En línea]. Waliczky.net, 1995. Disponible en Web: $<$ http://www.waliczky.net/waliczky_start.htm>

8 "With VE [Virtual Environments] we are moving away from the metaphor of the map to that of the path.” CODOGNET, Philippe. "Artificial Nature and Natural Artifice”. En: SHAW, J.; WEIBEL, P. (eds.). Future Cinema: The Cinematic Imaginary after Film. Cambridge: The MIT Press, 2003, p. 463.
} 
relación no se establece tanto entre los objetos dentro del espacio (como en el mapa), sino entre el receptor y el espacio cambiante.

Lejos del punto de fuga de la proyección lineal central, Waliczky elimina cualquier indicio de horizonte y propone una construcción frontal que remite, una vez más, a la pintura moderna. A finales del siglo XIX, el pintor francés Paul Cézanne (1839-1906) renunciaba a la construcción del espacio tridimensional en el cuadro siguiendo las normas de la perspectiva. En lugar de ello, el artista se servía de un espacio frontal, configurado a partir de la yuxtaposición de los planos bidimensionales; con ello, recuperaba el estilo "primitivo", pero sin renunciar a los logros de sus contemporáneos impresionistas en torno a la luz y el color. Ahora bien, allí donde Cézanne buscaba un equilibrio cromático y una composición armónica de las formas, Waliczky privilegia la sensación de inestabilidad.

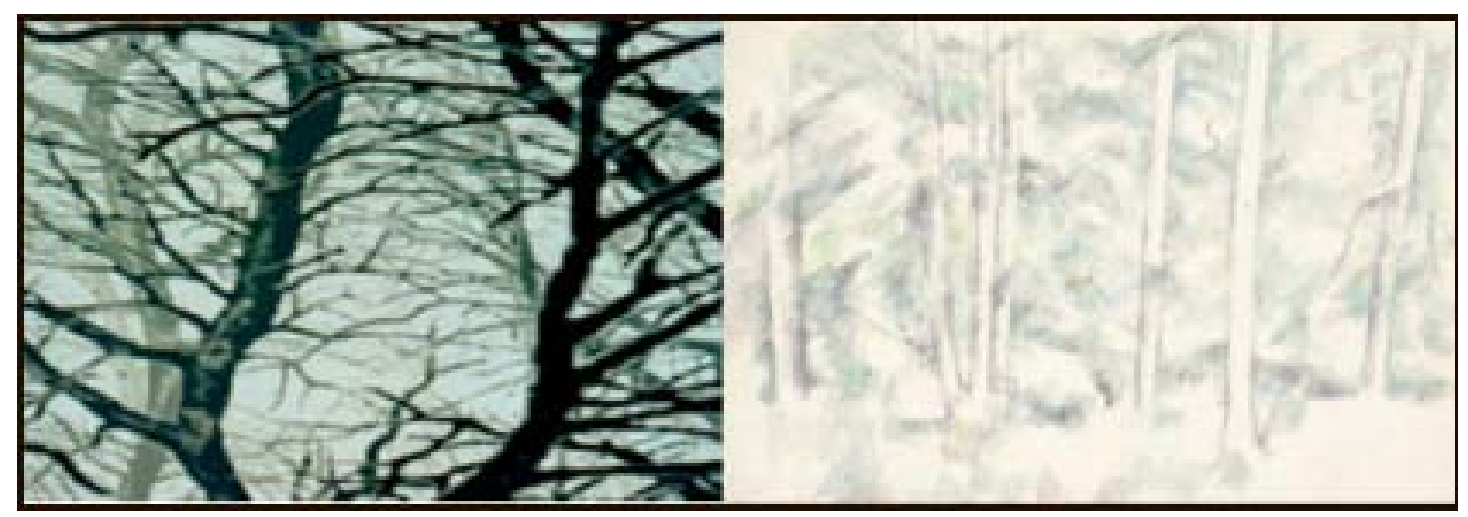

Izquierda. The Forest (1993), de Tamás Waliczky. Derecha. Paul Cézanne: "Forêt" (1890)

Encontramos un buen ejemplo de este espacio frontal en los créditos de la película 300 (2006), dirigida por Zack Snyder. La animación recuerda las siluetas de la alemana Lotte Reiniger ${ }^{9}$ (1899-1981), caracterizadas por un espacio bidimensional en capas. Sin embargo, la cámara virtual se desplaza entre las mismas, acercándose y alejándose de las formas negras recortadas sobre el fondo luminoso, y confiriendo al espacio una tercera dimensión en profundidad. La animación combina panorámicas, zoom y giros, permitiendo a la imagen desplegarse en todas direcciones. En este sentido, el constructo muestra una elasticidad de los márgenes laterales, aspecto en el que profundizaremos más adelante.

\footnotetext{
${ }^{9}$ Die Abenteuer des Prinzen Achmed (1926) es el largometraje animado más antiguo que se conserva y fue realizado por Reiniger con la técnica de animación de siluetas que ella misma había inventado.
} 

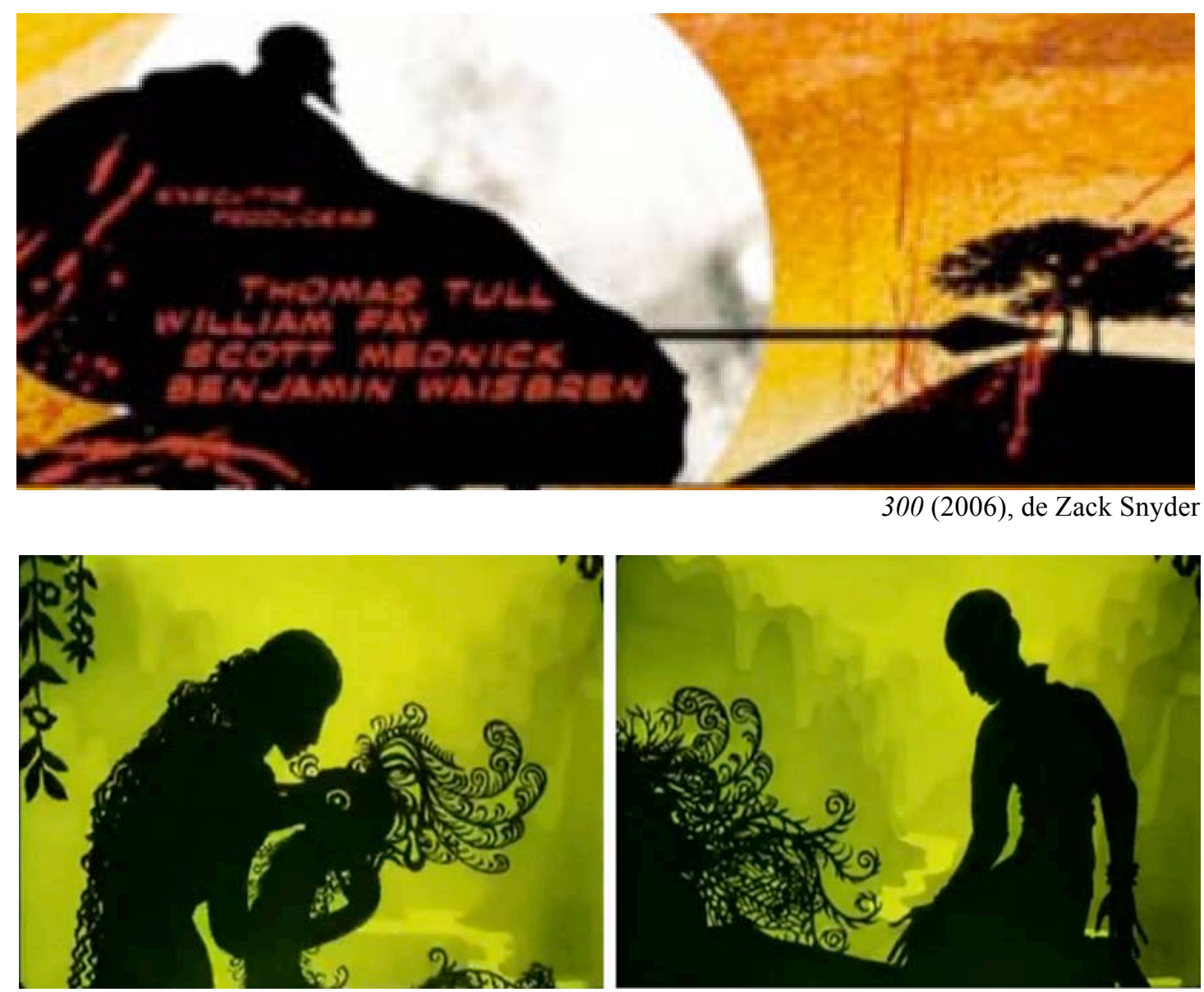

Die Abenteuer des Prinzen Achmed (1926), de Lotte Reiniger

Un año antes de la película de Snyder, Rob Chiu crea Black Day to Freedom (2005). Partiendo de dibujos bidimensionales, la animación de la escena depende de la variación del punto de vista y ésta genera una sensación de tridimensionalidad, de volumen, que contrasta con las siluetas. Una vez más, la cámara virtual recorre el espacio no sólo entre sujetos y objetos, sino entre los distintos planos en profundidad, en los que se insertan las figuras bidimensionales. Dichos planos corresponden, en realidad, a las mismísimas capas en el proceso de elaboración de la imagen. De hecho, el corto se realizó por entero en Adobe After Effects, programa que, como veíamos en el primer capítulo, permite descomponer el espacio de la imagen en capas y trabajar en ellas de forma independiente.

Black Day to Freedom se sitúa, así, entre la ilusión de profundidad que genera la cámara virtual y la superficie de las siluetas que componen la imagen. En el campo de los gráficos en movimiento, esta condición del espacio se conoce como "2'5 dimension" o "The Kid Stays in the Picture effect". 


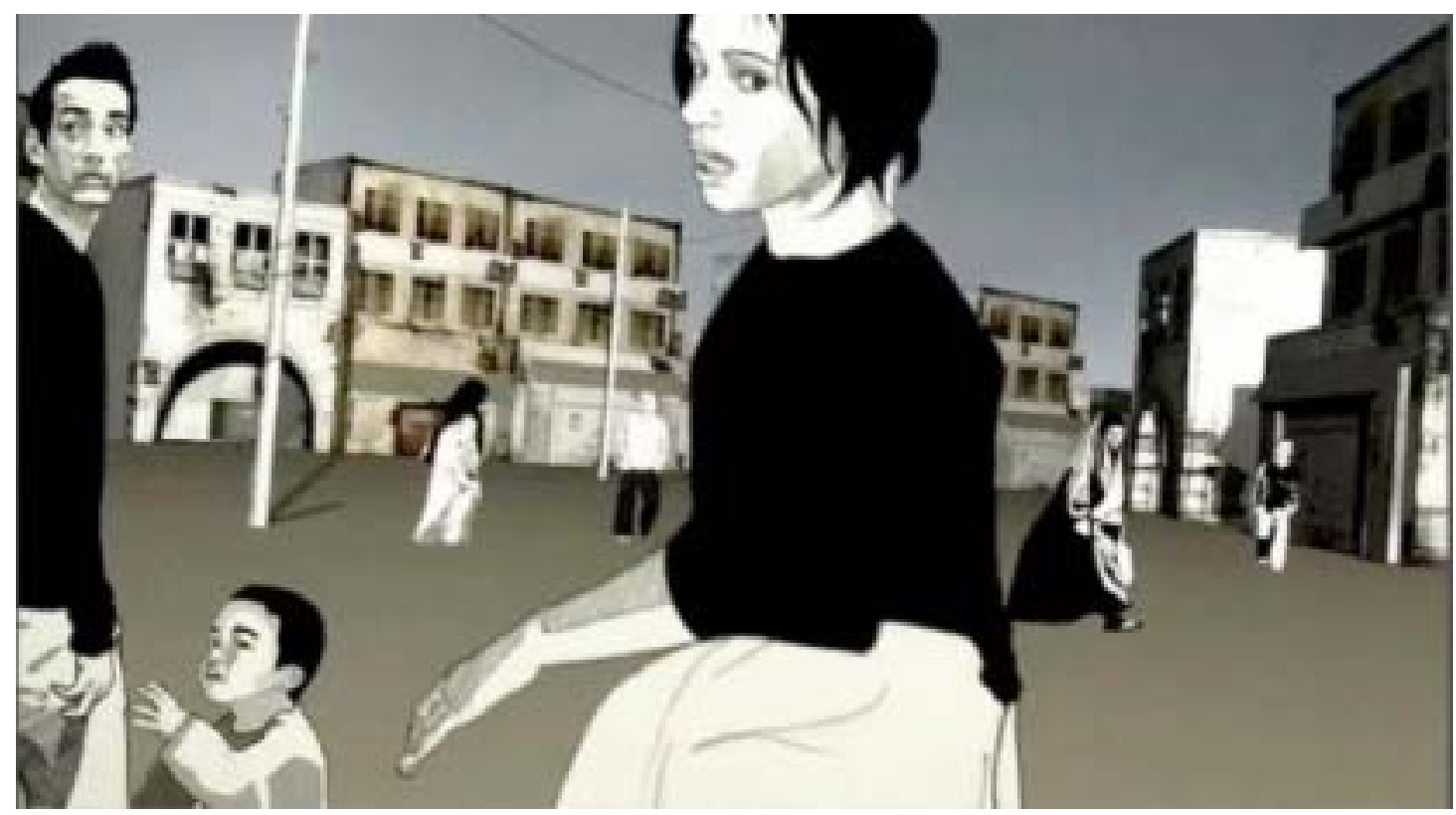

Black Day to Freedom (2005), de Rob Chiu

The Kid Stays in the Picture (2002) es un documental dirigido por Nanette Burstein y Brett Morgen, basado en la autobiografía del productor Robert Evans (1994). Partiendo de found footage, la película presenta fotografías desplegadas en profundidad. Una animación semejante se realiza mediante la selección de determinadas zonas de la composición y su distribución en capas yuxtapuestas. A continuación, se determinan los parámetros de una cámara virtual: su distancia a los distintos planos, el ángulo y la dirección del movimiento, la velocidad de desplazamiento, etc. El resultado es un espacio frontal similar al de Pictures de Waliczky, en el cual la sensación de profundidad es fruto del recorrido que dibuja la cámara virtual entre las capas bidimensionales.

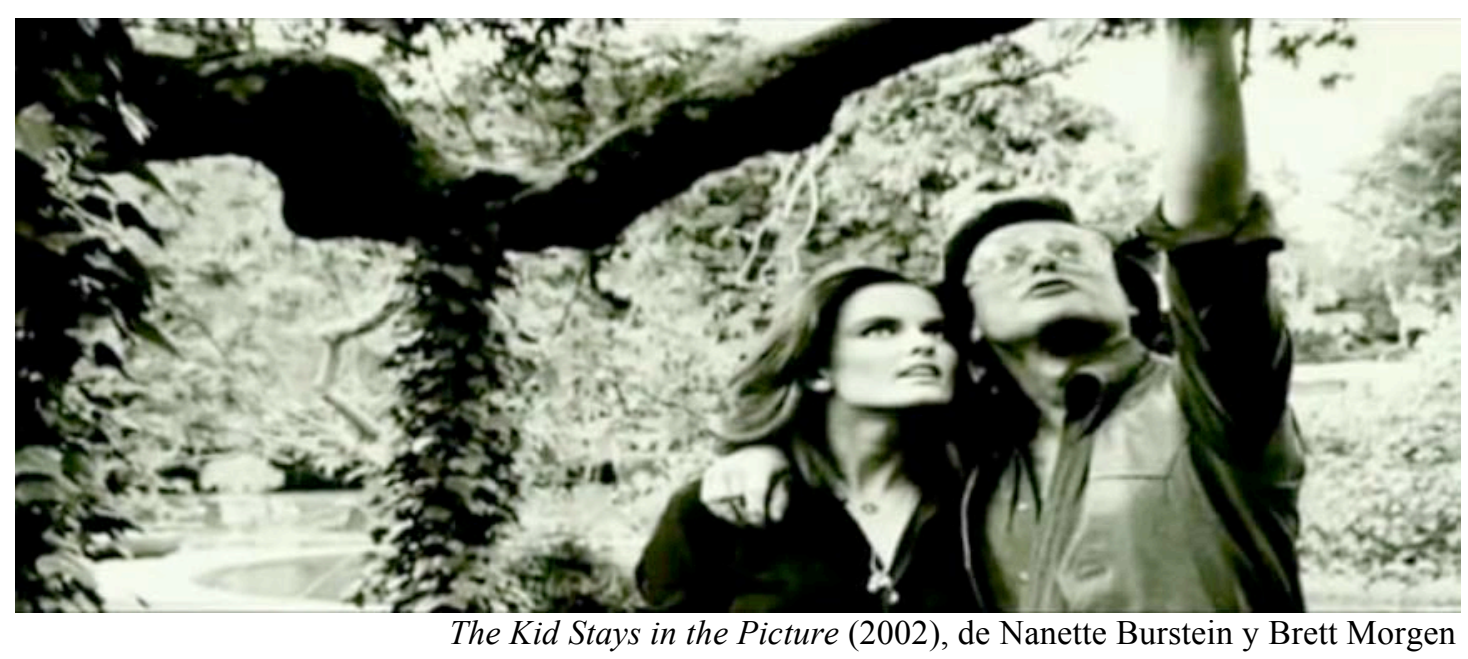


Frente al espacio tridimensional fotorrealista, en la "dimensión 2'5", la clave está en conservar voluntariamente la bidimensionalidad de las imágenes-fuente y hacerla convivir con la profundidad cinética. De este modo, aunque el punto de vista cambie, no se produce una rotación en torno a las figuras, que se mantienen sin volumen alguno. La dilatación del espacio se consigue mediante una diseminación calculada de las siluetas a lo largo del eje Z. Una vez construido este cubo estratificado, la cámara virtual permite realizar un "tour en la imagen"10.

Al partir de fotografías y no de tomas en sí animadas, toda activación de la imagen depende, exclusivamente, del desplazamiento de la cámara virtual. En general, la construcción de espacios entre la segunda y la tercera dimensión va acompañada de esta tensión entre fijación y movimiento en la imagen.

\section{Entre fijación y movimiento}

El videoclip La musique (2010), de We are from L.A para Yelle, es un buen ejemplo de combinación de la cámara virtual y el collage de reminiscencias dadaístas. La composición "pop" se sirve de found footage de personajes de ficción (Jon Hamm como el Don Draper de Mad Men, Pierce Brosnan como James Bond...) y otras celebridades (Madonna, Paris Hilton...) reconocibles y omnipresentes en Internet. La propuesta juega con la comicidad del absurdo, la incoherencia y el recorte abrupto de manera semejante a Steps de Rybczynski. Sin embargo, en esta ocasión, a la exploración de la "profundidad de la imagen" (su estratificación en capas) se añade la "profundidad cinética", asociada al desplazamiento de la cámara virtual.

Comenzábamos esta investigación apuntando la tendencia a la apropiación y el mash-up. Citábamos entonces las obras de Nicolas Provost Pommes d'amour (2001) y Papillon d'amour (2003). Mientras que éste parte de tomas animadas, el videoclip que nos ocupa se construyó a partir de fotografías. Ahora bien, no se trata simplemente de imágenes fijas (como es el caso en Pictures o en The Kid Stays in the Picture), sino que los autores de La musique proponen una serie de GIFs animados. Así, el movimiento de la cámara virtual se suma a las variaciones entrecortadas y

\footnotetext{
${ }^{10}$ Tomamos la expresión del artículo: HORRY, Y.; ANJYO, K.; ARAI, K.. "Tour Into the Picture: Using a Spidery Mesh Interface to Make Animation from a Single Image". ACM SIGGRAPH'97 Proceedings of the 24th annual conference on Computer. Los Ángeles, CA, August 1997, pp. 225-232.
} 
repetitivas de este formato caracterizado, precisamente, por su estado entre imagen fija y animada. ${ }^{11}$

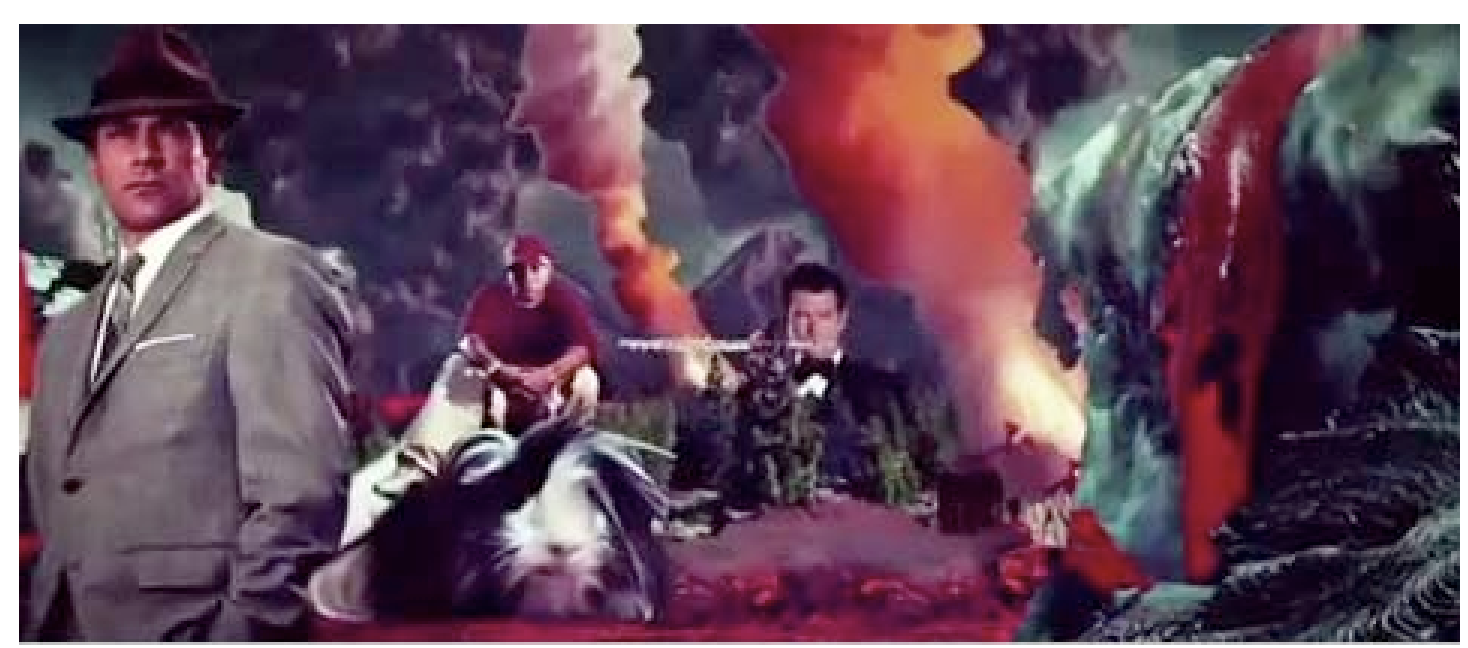

La musique (2010), de We are from L.A para Yelle

Descubrimos una combinación semejante de GIF y cámara virtual en la película One Hour Photo (2002), de Mark Romanek. El protagonista (Robin Williams) observa una fotografía de la familia de la que desearía formar parte. A un zoom in hacia el rostro del personaje, sigue otro hacia su objeto de contemplación. Cuando los márgenes de la fotografía coinciden con los del cuadro en el zoom, el fondo de la imagen fija se anima: las luces que decoran el árbol de Navidad comienzan a parpadear y la nieve cae en el jardín. La combinación de la cámara virtual y la activación de la imagen fija permite la transición espacial.

Mientras las luces titilan en el árbol, la familia en primer plano continúa inmóvil, en la misma postura y sin pestañear, como si la silueta triangular formada por padres e hijo perteneciera aún a otro tiempo: el instante capturado por la cámara fotográfica. Imagen fija e imagen animada conviven en un estado intermedio entre la segunda y la tercera dimensión.

El constructo es semejante a los "cinemagraph"12, cuya fabricación en el programa de edición pasa por la descomposición del registro vídeo en una serie de imágenes fijas. Durante el trabajo "frame a frame", se separan las regiones que perdurarán inmóviles. Es como si la paleta de herramientas incluyera el tiempo como

\footnotetext{
${ }^{11}$ El formato llamado "GIF" permite almacenar imágenes fijas o animaciones en una estructura en bucle. La cuestión no es el soporte (el material en cuya superficie se registra la información), sino el formato de archivo (la estructura de almacenaje de la información).

${ }^{12}$ El término se atribuye a los artistas Jamie Beck y Kevin Burg. Ver la página web:

$<\mathrm{http}: / /$ cinemagraphs.com/>
} 
un "filtro" más a disposición del constructor de la imagen. La alteración temporal se vuelve aquí retoque espacial. O dicho de otro modo: la elección de la inclusión o no del movimiento es una cuestión cercana a la "touche" de la pintura.

Al zoom de One Hour Photo sigue una panorámica de $45^{\circ}$, de izquierda a derecha, que desvela el resto de la habitación, fuera de campo en la fotografía original; en la esquina contigua, el protagonista sonríe a cámara, feliz tras haber recibido su regalo de Navidad. Gracias al hecho de que la cámara virtual es una construcción, los límites definitivos de la instantánea en tanto que encuadre y recorte del espacio profílmico se vuelven permeables. Más adelante, veremos cómo esta elasticidad de los márgenes es una característica fundamental de la figura que definimos como "plano secuencia digital".
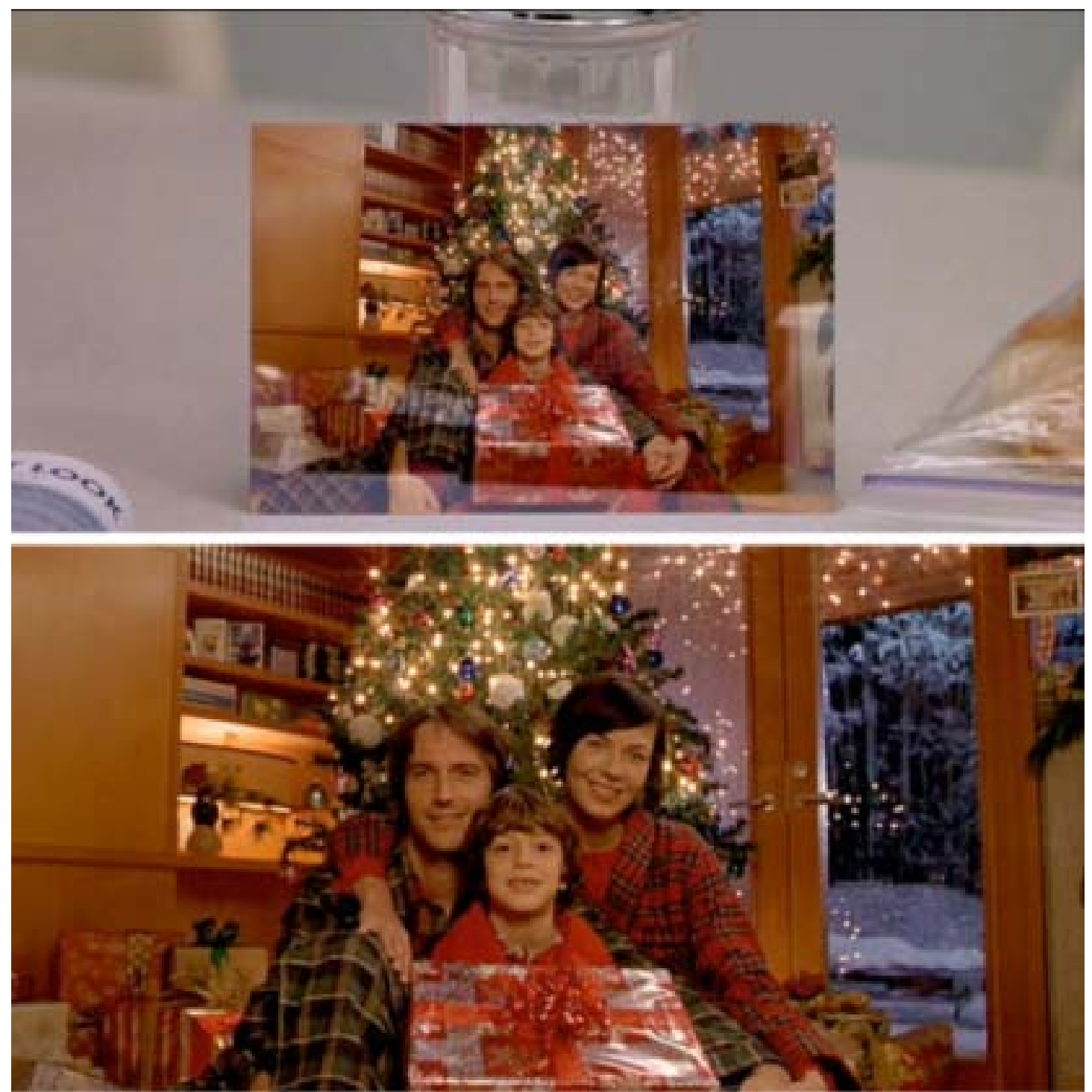

One Hour Photo (2002), de Mark Romanek 
Esta combinación de la cámara virtual y los efectos de congelación o activación prueba, nuevamente, el carácter espacial del constructo: el aparente desplazamiento del cuadro es, en realidad, una mutación, una transformación del espacio. Veamos otro ejemplo en la película The Nanny Diaries (2007), codirigida por Shari Springer Berman y Robert Pulcini. Cuando la protagonista, Annie (Scarlett Johansson), contempla a otra mujer, la imagen de ésta se congela, adquiriendo una textura pictórica. La mutación implica no sólo una parálisis, sino un paso de las tres a las dos dimensiones: un zoom out desvela que la imagen corresponde, en realidad, a un cuadro del museo en el que se haya Annie. A continuación, una panorámica hacia la izquierda muestra otra pintura en la sala, esta vez, de una vagabunda en Central Park. Un zoom in combinado con la activación de la imagen permite la sumersión en el lienzo y el paso fluido del museo al famoso parque neoyorquino.

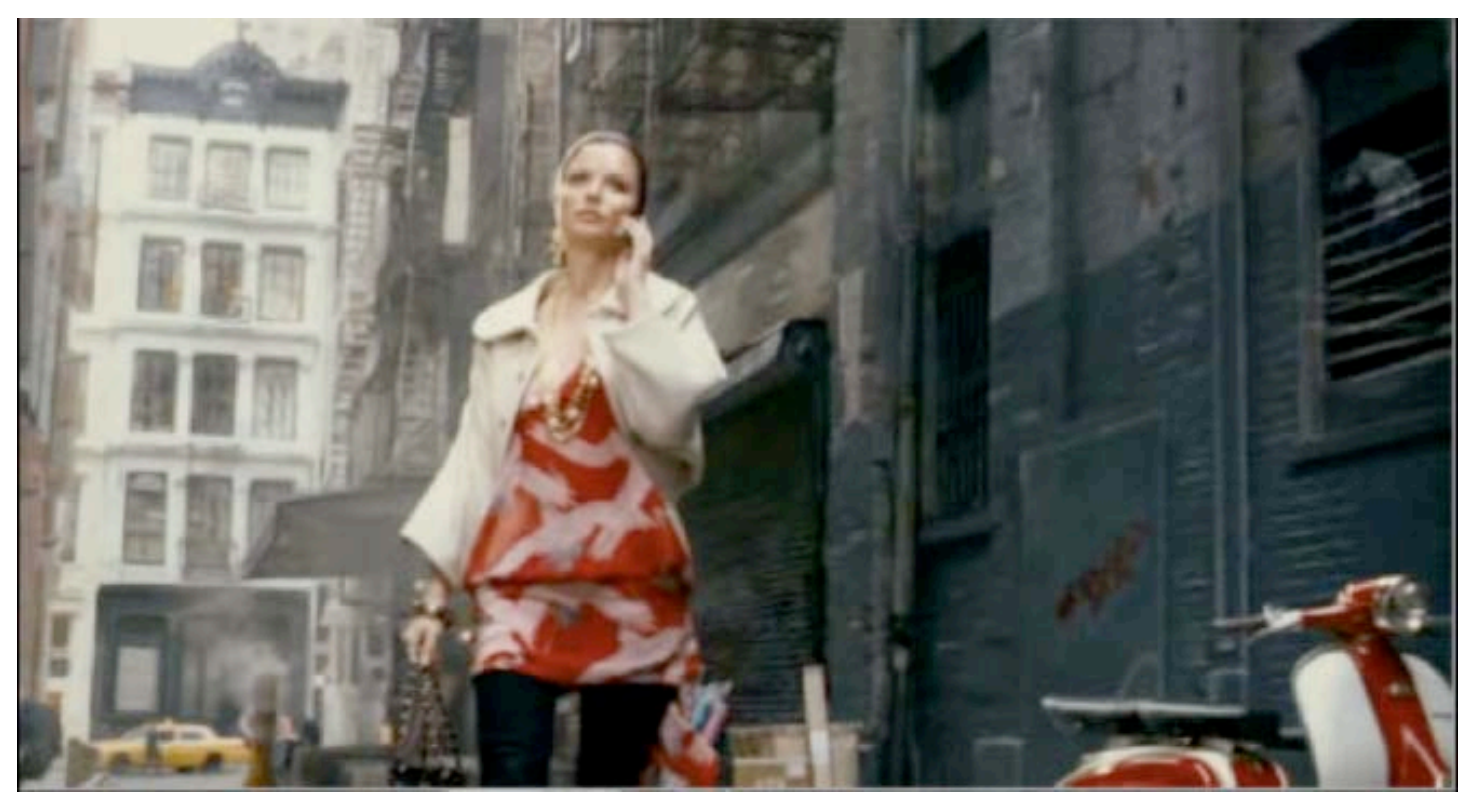

The Nanny Diaries (2007), de Shari Springer Berman y Robert Pulcini

De manera semejante, en New Moon (2009) de Chris Weitz, mientras los protagonistas contemplan un cuadro, la suma de un zoom in y la activación de esa imagen fija permite la transición continua entre ambos espacios. Al final del capítulo anterior, analizábamos los "saltos" en Jumper (2008) de Doug Liman y veíamos cómo el protagonista intenta teletransportarse a Praga gracias a una instantánea del puente Carlos. Para visualizar la transición espacial, Liman muestra la activación de la fotografía. Si bien la dinamización de New Moon es semejante, en este caso, no son los personajes los que se sumergen en el cuadro como parte de la historia fantástica; 
aquí, la dinamización de la imagen fija no forma parte de la ficción ${ }^{13}$, sino del discurso. De este modo, la cámara virtual adquiere una posición intermedia, entre las acciones de los sujetos y el espacio en el que se insertan.

Comparemos un momento esta construcción digital con una escena de la película Twelve Monkeys (1995), de Terry Gilliam. El realizador parece querer penetrar en una pintura renacentista ${ }^{14}$, potenciando gracias a un zoom la tridimensionalidad simulada por la perspectiva. Dicho zoom se comporta al modo de una cámara física que se desplazara siguiendo las líneas que fugan en el horizonte. El movimiento parte de un primer plano de un arco de estilo clásico y va desvelando poco a poco el monumento, a cuyos lados se alzan diversos edificios. A continuación, asoma el marco que encuadra la pintura y, delante, en primer plano, el rostro de una mujer, cuya voz (hasta entonces en off) acompaña el zoom desde su inicio.

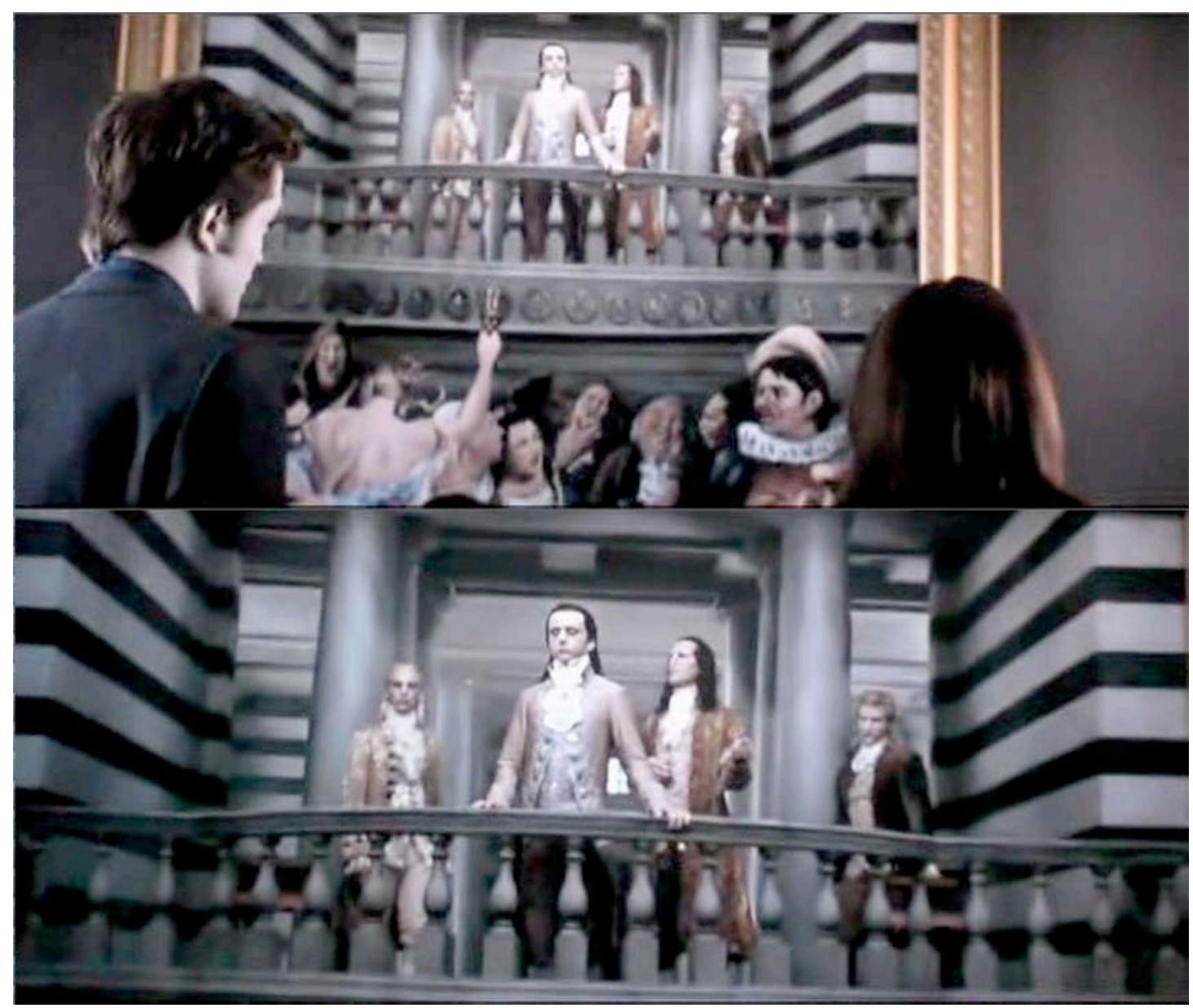

New Moon (2009), de Chris Weitz

\footnotetext{
${ }^{13}$ Como sí es el caso en Harry Potter and the Chamber of Secrets (2002), de Chris Columbus. En la película, los cuadros mágicos de Hogwarts cobran vida.

${ }^{14}$ La pintura reproducida es la Veduta di Città Ideale en el Walters Art Museum de Baltimore y fue creada entre 1480 y 1484. Aunque su autoría es polémica, el museo la atribuye a Fra Carnevale.
} 

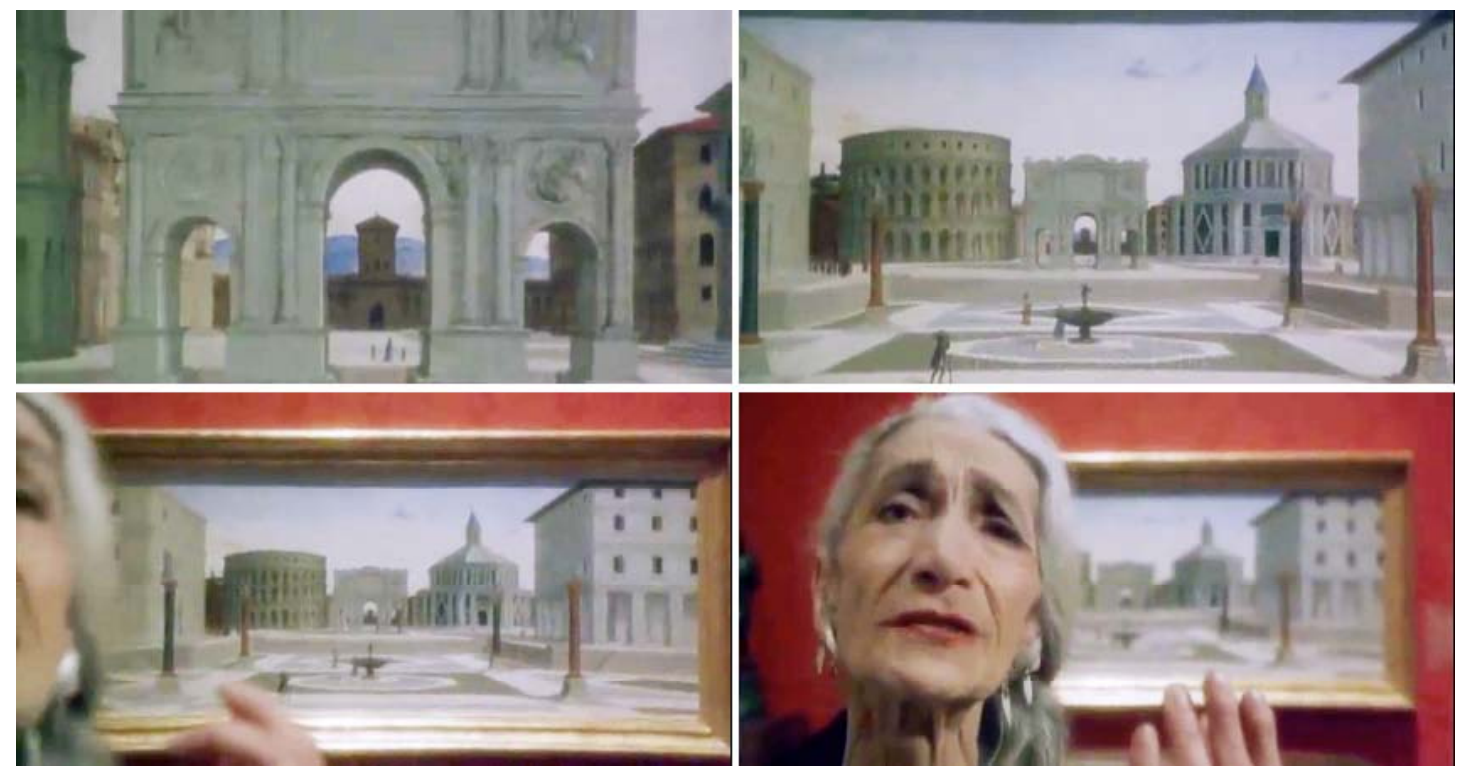

Twelve Monkeys (1995), de Terry Gilliam

La cámara virtual de New Moon provoca un efecto de inmersión muy superior al generado por esta combinación del zoom y la perspectiva. Esto es debido, por un lado, a la activación de la imagen fija; y, por otro, a la construcción espacial que es, en sí, la cámara virtual. La proyección central parte de un solo punto de vista fijo, en el que debe posicionarse el espectador para que se produzca la sensación de continuidad entre el espacio físico y el espacio representado; es decir, una vez establecido y fijado dicho punto de vista, el espacio tridimensional es un conjunto invariable y cerrado. Si bien el zoom de la cámara física alimenta la tridimensionalidad de la perspectiva, al mismo tiempo, provoca un desfase entre la fijación de la pintura y la movilidad del plano. ${ }^{15}$ Por el contrario, la cámara virtual no sólo permite una variación y adaptación constante del punto de vista, sino que, siendo ella misma el producto de la construcción espacial, toda mutación, toda activación, queda perfectamente integrada en el conjunto.

La comparación entre Twelve Monkeys y New Moon nos permite distinguir entre el zoom óptico del objetivo de una cámara física (efecto ligado a la temporalidad del registro) y la "figura del zoom digital" tal y como la entendemos en este trabajo. A la descripción de este constructo espacial dedicamos el próximo apartado.

\footnotetext{
15 "Cette différence inscrite, cette disjonction accentuée entre le mouvement du plan et l'immobilité du tableau, porte un nom : dialogisme. La fonction du plan-tableau est dialogique. Ambivalence, discours à deux voix, mélange instable du haut (la peinture) et du bas (le cinéma), du mouvement (le plan) et de l'immobilité (le tableau)." BONITZER, Pascal. Peinture et cinéma, décadrages. Paris: Éditions de l’Étoile, 1985 , p. 30.
} 


\section{EL ZOOM DIGITAL}

En los dos últimos apartados, hemos comprobado cómo David Fincher explota las posibilidades de la cámara virtual para recorrer los espacios más minúsculos, mostrándolos desde una perspectiva no antropomórfica. Fight Club (1999), basada en la novela homónima de Chuck Palahniuk (1996) ${ }^{1}$, está narrada en primera persona por su protagonista, un personaje depresivo y anónimo (Edward Norton), que sufre episodios de desdoblamiento de personalidad. Ya en los títulos de crédito, la película comienza con un zoom out desde algún recóndito rincón de la mente del personaje hasta un primer plano de éste, visto desde una pistola insertada en su boca. En el interior del cerebro, la cámara virtual se desplaza hacia atrás, entre neuronas y dendritas; atraviesa los lóbulos frontal y temporal; ya en la frente, transita sobre la piel, con sus poros, folículos y gotas de sudor; finalmente, recorre de espaldas el cañón del arma para mostrar, por primera vez, el rostro de Norton.

El final de la película revela el contexto de la escena: es el propio personaje el que apunta la pistola hacia sí mismo, preso de un ataque de esquizofrenia. Evidentemente, el hecho de comenzar el relato en el interior del cerebro del protagonista remite a la misma enfermedad mental. No obstante, el director estadounidense no propone un punto de vista subjetivo ni antropomórfico, sino que dota de la misma o más importancia a los objetos que al personaje. Como veíamos, gracias al hecho de que la cámara virtual es una construcción espacial, la liberación del punto de vista es total: no se trata sólo de situarse en el interior de la cabeza, sino de explorar el espacio intermedio, de recorrer sus entrañas pormenorizadamente; es decir, deleitarse en mostrar ese espacio minúsculo, invisible al ojo desnudo, tanto por su tamaño como por su ubicación.

Es más, la cámara virtual pasa sin corte alguno del punto de vista desde las neuronas a las gotas de sudor, y de éstas a la pistola. Como en Tron o en Unnamed soundsculpture, esta "coreografía" de la cámara virtual afecta tanto a la posición del punto de vista como al paso continuo entre escalas. La visión macro de las neuronas y dendritas supone una ampliación gigantesca del tamaño de las mismas; la redimensión que se produce al mostrar, finalmente, el rostro del protagonista implica una disminución forzosa de la escala. No obstante, este cambio repentino queda perfectamente fundido en la imagen gracias a la transformación continua que permite

\footnotetext{
${ }^{1}$ PALAHNIUK, Chuck. Fight Club (1996). New York: W. W. Norton \& Company Inc, 2005.
} 
la cámara virtual. El espacio de la imagen digital es infinitamente explorable, desde múltiples puntos de vista y en diversas escalas; potencialmente agrandable, empequeñecible y redimensionable.
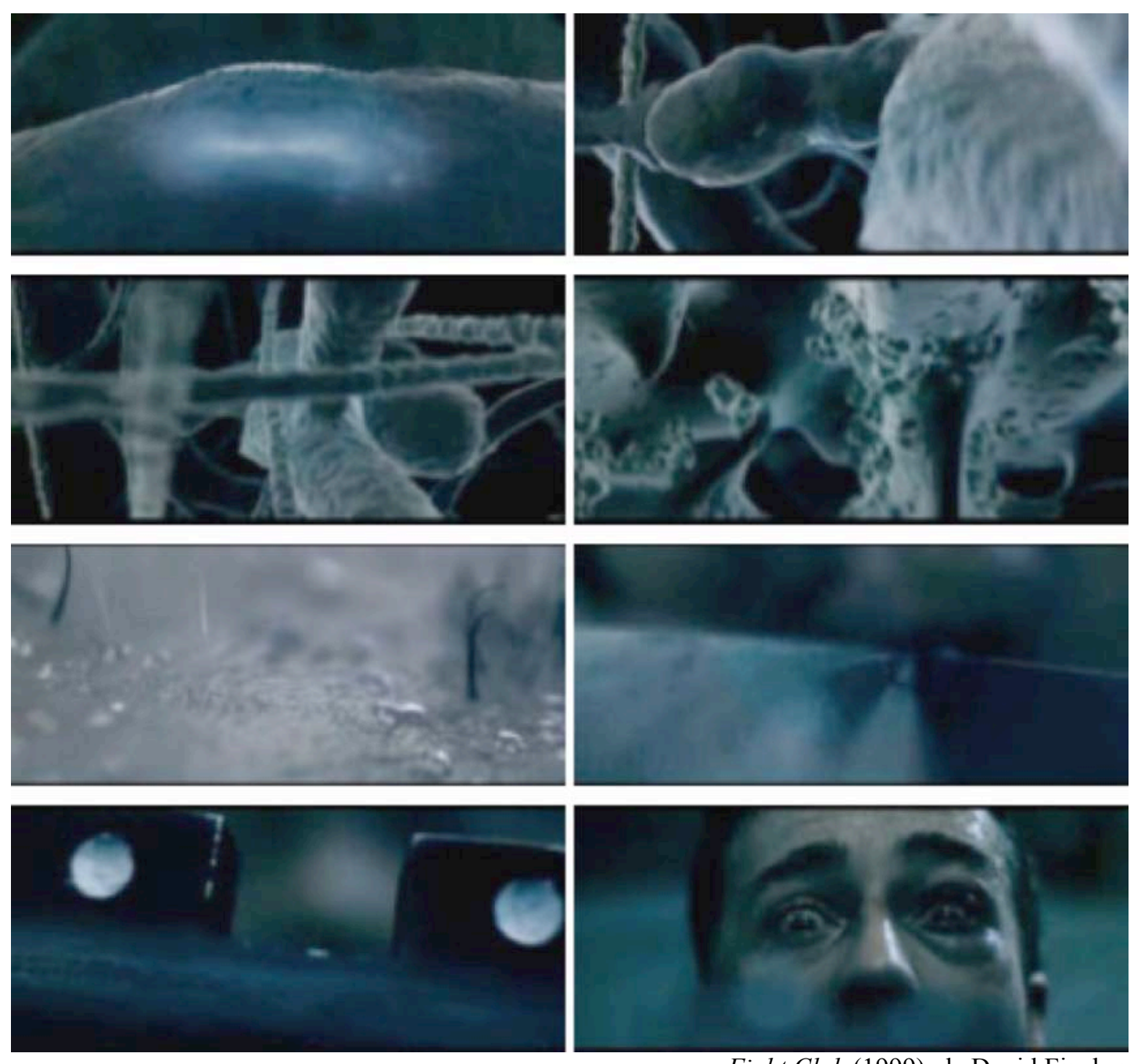

Fight Club (1999), de David Fincher

Esta mutación continua de la imagen hace eco a la plasticidad cerebral. La construcción del cerebro del protagonista respeta la estructura del órgano humano; para su creación, se diseñó un "sistema de crecimiento" de las distintas neuronas hasta formar un "bosque de dendritas". El L-system es un programa informático de ramificación ("branching”) utilizado normalmente para reproducir el desarrollo de las plantas, el cual, de acuerdo con los científicos Aristid Lindenmayer y Przemyslaw Prusinkiewicz, responde a determinadas reglas. ${ }^{2}$ Grosso modo, el sistema se basa en la recursividad, la repetición y la acumulación de formas: cada rama contiene

\footnotetext{
${ }^{2}$ LINDENMAYER, A.; PRUSINKIEWICZ, P.. The Algorithmic Beauty of Plants. New York: Springer-Verlag, 1994.
} 
pequeñas ramas, que contienen a su vez otras, etc. Esto es: no se trata de modelar la forma, sino de hacerla evolucionar. En el último apartado de esta investigación, analizaremos la generación del espacio en el arte evolutivo; por ahora, nos concentramos en la figura del zoom. Ambos tipos de construcción espacial comparten la exhibición de la plasticidad de la imagen digital.

Aunque el bosque de dendritas se construyó respetando la estructura y la anatomía de un órgano humano, la imagen no muestra un mapa del cerebro: por el contrario, la cámara virtual se sumerge en el espacio laberíntico, microscópico, mostrándolo tan de cerca que es imposible orientarse en la maraña de conexiones eléctricas. ${ }^{3}$ La finalidad del mapa es la orientación, es decir, la visión global permite localizar un punto específico en el plano de acuerdo con una escala común prefijada. Muy al contrario, en el zoom de Fight Club, la clave está en la desorientación: se trata de introducir el punto de vista en el espacio mismo, de hacer mutar ambos al unísono y con la escala. Como en The Forest de Waliczky, la cámara virtual no antropomórfica sustituye la fuga de las líneas en el horizonte por la profundidad cinética. Es más, Fincher alimenta la confusión mediante un zoom out. Tal y como explica el encargado de los efectos generados por ordenador, Matthew Butler:

\begin{abstract}
"Sabíamos que el viaje a través del cerebro sería un suave movimiento hacia atrás [zoom out] más que un paseo hacia delante [zoom in] porque, cuando vas al revés, la audiencia no puede ver qué va a pasar a continuación detrás de ellos y eso aumenta la ansiedad. (...) nunca acabas de abarcar la totalidad del entorno con el que estás tratando."4
\end{abstract}

Por su parte, el supervisor de los efectos especiales Kevin Mack hace hincapié en la sensación de sumersión en un medio acuático:

\begin{abstract}
"David Fincher quería crear el ambiente de una zambullida nocturna, con una luz tenue que viniera, aparentemente, desde el punto de vista de la cámara, como si dependieras de las luces débiles de la cabeza de un submarino."
\end{abstract}

\footnotetext{
${ }^{3}$ Para conseguir el efecto de una imagen vista a través de un microscopio, se forzó una profundidad de campo muy pequeña, típica de la macrofotografía. Es decir, como el punto de vista está muy cerca del objeto, éste aparece nítido en la imagen mientras que el fondo queda borroso.

${ }^{4}$ Matthew Butler. Apud. BIZONY, Piers. Op. cit., pp. 106-107.

${ }^{5}$ Kevin Mack. Apud. Ibídem.
} 
La cámara virtual serpentea por un camino, siguiendo una trayectoria caótica. En lugar de presentar la estructura global del cerebro, Fincher sitúa el punto de vista en medio de un entorno, que desvela en el desplazamiento hacia atrás. Frente al mapa, no se trata de colocar los objetos en un espacio que funciona como soporte neutro, sino, muy al contrario, las mutaciones del cuadro construyen relaciones espaciales cambiantes. Lejos de la posición fija del espectador de la perspectiva, que organiza con su punto de vista único y externo el espacio en el plano bidimensional, la cámara virtual se sitúa dentro de ese entorno mutante, variando constantemente el punto de vista.

El zoom de Fight Club se halla a medio camino entre la "nueva visión" y el biomorfismo. Ambas corrientes artísticas asimilan en el siglo XX las imágenes provenientes de la ciencia; entre las cuales la radiografía es paradigmática. El hecho de mostrar el interior del cuerpo humano con una finalidad estética tiene un antecedente en la "nueva fotografía" de las vanguardias históricas, que hemos recuperado ya en varias ocasiones a lo largo de este trabajo. Como veíamos, ésta persigue desestabilizar los hábitos perceptivos y llamar la atención del espectador gracias a las distorsiones mediante lentes, el collage o la elección de puntos de vista desfamiliarizadores; a éstos se une la experimentación con nuevos instrumentos no sometidos a los límites de la percepción humana y que permiten hacer visible lo invisible. László Moholy-Nagy hace referencia a las investigaciones en botánica (principalmente, el uso del microscopio como amplificador) y a los estudios del movimiento (se sobreentiende el trabajo de Étienne-Jules Marey y Eadweard Muybridge, que tendremos oportunidad de recordar más abajo). En este contexto, el fotógrafo húngaro se hace eco del descubrimiento de los rayos $X^{6}$ y llama al uso artístico de la radiografía. $^{7}$

Ahora bien, más allá de esta "visión intensificada", las prácticas digitales que analizamos parecen movidas por una motivación distinta, que tiene que ver con la construcción del espacio y no, con su mero registro: la cuestión no es tanto los límites de la percepción como los de la imaginación. Por un lado, frente a la radiografía fija y bidimensional, el desplazamiento continuo de la cámara virtual en Fight Club genera una profundidad cinética y un cambio de escala continuo. Por otro lado, Fincher no se

\footnotetext{
${ }^{6} \mathrm{El}$ hallazgo se asigna al físico alemán Wilhelm Röntgen en 1895.

${ }^{7}$ MOHOLY- NAGY, László. Peinture, photographie, film, et autres écrits sur la photographie. Op. cit., p. 156.

${ }^{8}$ Ibídem, pp. 213-214.
} 


\section{EL ZOOM DIGITAL}

limita al espacio interior de la cabeza y la cámara virtual sale sin dificultad al exterior del cuerpo del protagonista. Así, no se trata sólo de la capacidad de simular el interior del cerebro humano, sino de establecer relaciones espaciales: del receptor con la imagen; del cuadro con el espacio mutante; del interior y el exterior de las formas; de éstas con el espacio que las alberga...

Como en Hommage II de Charles Csuri, el movimiento fluido reúne opuestos: frente al dualismo dentro/fuera, se exalta la continuidad, la complementariedad del todo. El recorrido de la cámara virtual elimina las fronteras físicas y, con ello, no sólo vincula espacios contiguos, sino que debilita dualismos, reconcilia contrarios. Recordemos que en la animación de Csuri el concepto de "relación espacial" remite tanto a la cibernética que marcara su trabajo como pionero en los años 60, como a la escultura orgánica, en particular, y al biomorfismo, en general. Tal y como explica Simon Diner en su artículo "Le biomorphisme dans la culture artistique moderne":

"El biocentrismo mantiene una concepción holística del mundo, donde existe una unidad de todas las formas y una identidad del todo más allá de la suma de las partes. El movimiento es una característica esencial de la naturaleza que contribuye a unir los opuestos."9

El biocentrismo se contrapone al antropocentrismo en cuanto aquella concepción espacial reserva al ser humano un puesto secundario frente a la naturaleza: el hombre no buscaría dominarla, sino vivir en armonía con ella. El arte biomórfico persigue la emancipación de la racionalidad y, como el surrealismo, acude al inconsciente, "recurre a la empatía, a la intuición, a la meditación y la experiencia mística." 10 Este mismo pensamiento biocéntrico subyace en la película Contact (1997) de Robert Zemeckis, adaptación cinematográfica de la novela homónima del científico Carl Sagan ${ }^{11}$.

La película comienza con un zoom out intergaláctico: partiendo de un primer plano de la Tierra, la cámara virtual se aleja y deja atrás algunos planetas del Sistema Solar; a continuación, se adentra en las profundidades de la Vía Láctea y sale de ella para mostrar diversas galaxias. De pronto, el Espacio exterior se revela como contenido en el ojo de la protagonista, que no cesa en su empeño de conectar por

\footnotetext{
${ }^{9}$ DINER, Simon. Op. cit., p. 4.

${ }^{10}$ Ibídem.

${ }^{11}$ SAGAN, Carl. Contact. New York: Simon and Schuster, 1985.
} 
radio con su madre muerta. En ese movimiento continuo, la inmensidad del universo acaba convergiendo en la pupila de una niña.

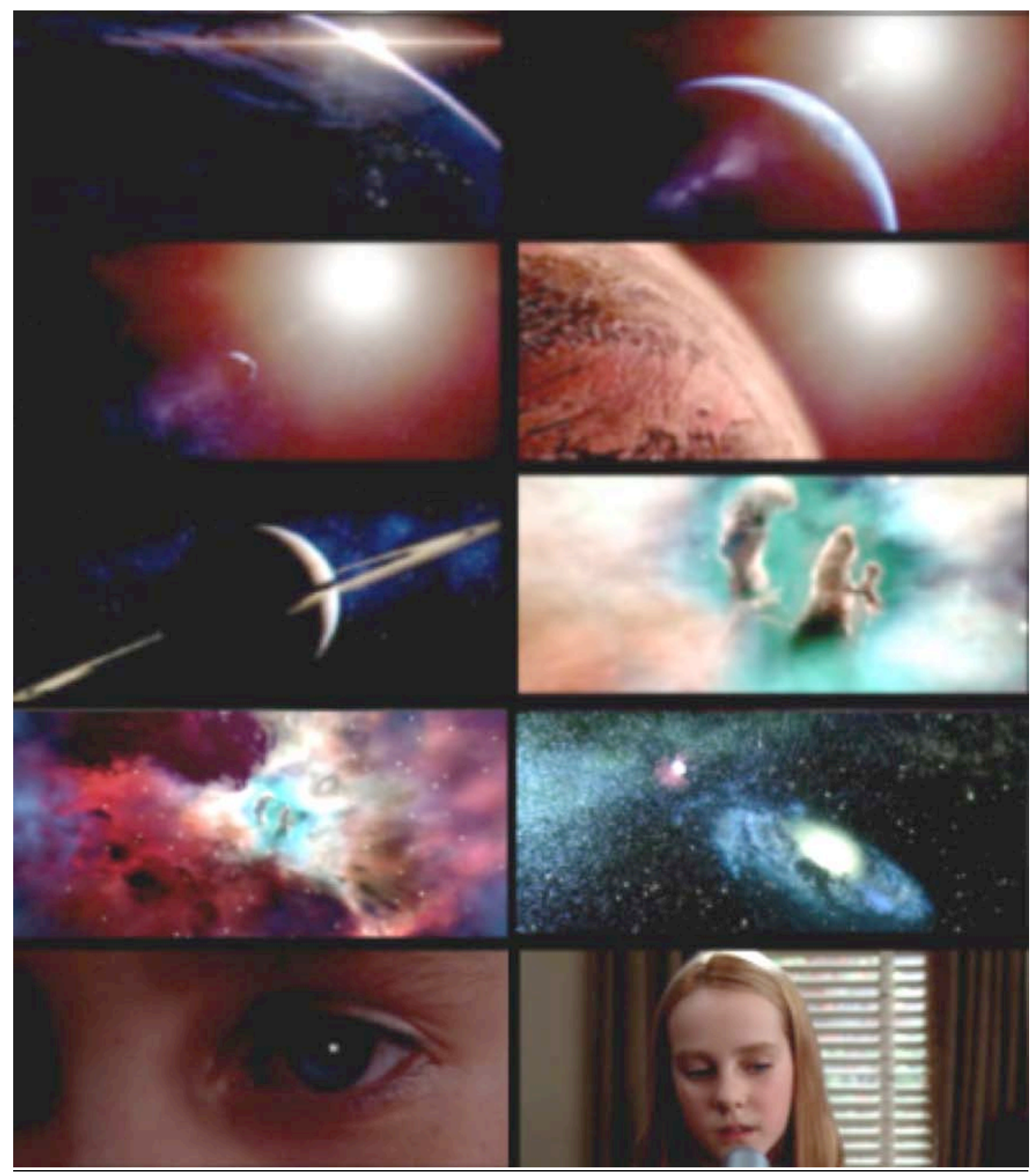

Contact (1997), de Robert Zemeckis

En este sentido, podemos relacionar el zoom digital de Contact con la transformación y el collage de la obra Gesänge des Pluriversums de Peter Weibel, que veíamos en el primer apartado de esta investigación. Con su construcción espacial, Weibel pretende exhibir la potencia plástica del medio electrónico, la 
"conquista del micro y el macro"; una "oda cosmológica"12 que el autor resume en los siguientes versos de William Blake:

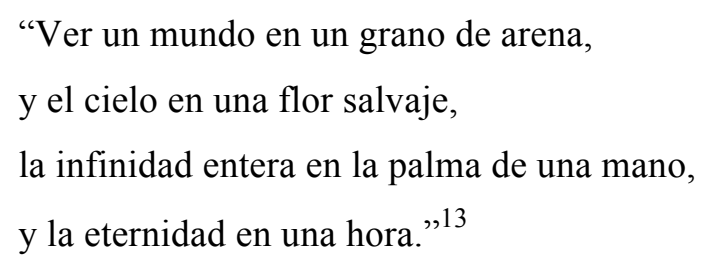

Como en Fight Club, el zoom out de Contact permite un cambio de escala continuo: la cámara virtual fluye sin contemplar ruptura alguna entre la talla del universo y la del ser humano. Sin embargo, frente a la contracción en la cinta de Fincher (de las dendritas al punto de vista desde el arma), la redimensión que propone Zemeckis (del universo a la pupila de la niña) implica no sólo un aumento de la escala, sino una estructura autocontenida, más próxima a la dimensión fractal.

\section{La dimensión fractal}

Definida por Benoît Mandelbrot en los años 70, la "dimensión fractal" es un número que mide la irregularidad de una forma y que, frente a las tres dimensiones del espacio euclidiano, tiene la particularidad de poder corresponder a una fracción. ${ }^{14}$ Tras constatar que algunas formas de la naturaleza escapan a las matemáticas clásicas, Mandelbrot se propone explicar la formación de estos "objetos fractales", hasta entonces, ignorados en tanto que aberraciones excepcionales. Con ello, cuestiona la geometría clásica, marcada por la teoría euclidiana ${ }^{15}$. Su investigación es heredera de un contexto matemático particular, el de finales del siglo XIX y principios del XX, en el cual, como veremos detenidamente en el próximo capítulo, se baraja la posibilidad

\footnotetext{
${ }^{12}$ WEIBEL, Peter. Op. cit.

${ }^{13}$ BLAKE, William. "Auguries of Innocence" (ca 1803). En: The selected poems of William Blake. Ware: Wordsworth Editions, 2000, p. 135.

14 "Une des caractéristiques principales de tout objet fractal est sa dimension fractale, qui sera dénotée par D. Elle mesure son degré d'irrégularité et de brisure. Fait très important: contrairement aux nombres de dimensions habituels, la dimension fractale peut très bien être une fraction simple (...)." MANDELBROT, Benoît. Les objets fractals. Forme, hasard et dimension (1975). Paris: Flammarion, 1995 , p. 6.

${ }^{15}$ El libro de Euclides (ca 330-275 a.C.) Elementos marca la tradición matemática desde la Antigüedad hasta la ciencia moderna. Considerado como un paradigma de rigor, el tratado inspira los programas racionalistas del siglo XVII (René Descartes, Blaise Pascal o Gottfried Leibnitz). La llamada "geometría euclidiana" hace referencia a esta apropiación y desarrollo de la geometría de Euclides. EUCLIDES. Elementos (ca 300 a C). Madrid: Biblioteca clásica. Editorial Gredos, 1994.
} 
de espacios no-euclidianos e hiperespacios. Gracias a la aportación de Mandelbrot, la estructura aparentemente caótica de estas formas irregulares se revela no sólo ordenada, sino muy frecuente.

Una de las características principales del fractal es su autosimilaridad, su homotecia y estructura "en cascada". ${ }^{16}$ Grosso modo, al cambiar de escala, aumentándola o disminuyéndola, la forma se repite al infinito. Es decir, la misma estructura gobierna el todo y la parte. Ya hemos explicado cómo el bosque de dendritas de Fight Club fue construido mediante un método generativo conocido como "L-system". Apuntábamos entonces que la técnica parte de la recursividad y la iteración de patrones. De manera semejante, la curva de Koch (1904) ${ }^{17}$, también llamada "copo de nieve" o "estrella" de Koch en referencia a su peculiar apariencia, muestra cómo generar una forma compleja a partir de la acumulación de ligeras variaciones repetitivas; en concreto, cada línea recta es sustituida por un ángulo.

Mandelbrot recupera la curva de Koch como modelo simplificado de una costa. A la hora de explicar esta forma geométrica, el francés acude a la bella descripción que de ella hiciera el matemático italiano Ernesto Cesàro en 1905:

"Es esta similitud entre el todo y sus partes, incluso infinitesimales, lo que nos lleva a considerar la curva de Von Koch como una línea verdaderamente maravillosa entre todas. Si estuviera dotada de vida, no sería posible destruirla sin suprimirla de entrada porque siempre renacería de las profundidades de sus triángulos, como la vida en el universo."18

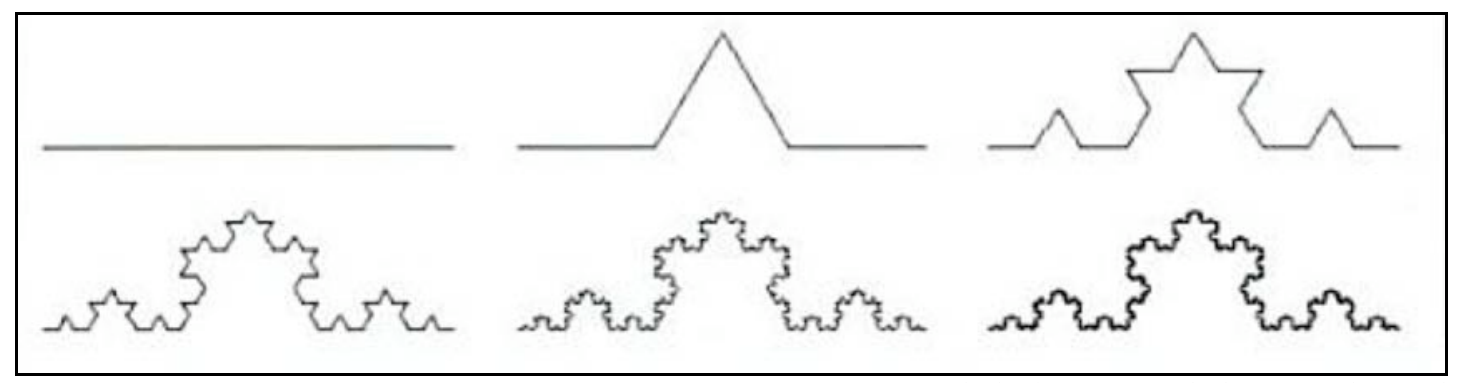

Esquema de la formación de la curva de Koch

\footnotetext{
16 “'On peut penser à ce mécanisme comme une sorte de cascade, ou plutôt comme un feu d'artifices à étages, chaque étage engendrant des détails plus petits que l'étage précédent. Statistiquement parlant, tout morceau d'une côte ainsi engendrée est homothétique au tout (...). Une telle côte sera dite posséder une homothétie interne, ou être self-similaire.” MANDELBROT, Benoît. Op. cit., p. 25.

${ }^{17}$ Descrita por el matemático sueco Helge Von Koch en 1904. VON KOCH, Helge. "Sur une courbe continue sans tangente, obtenue par une construction géométrique élémentaire". Aktiv för Matematik, Astronomie och Fysik 1, 1904, pp. 681-704. Apud. Ibídem. p. 191.

${ }^{18}$ Ernesto Cesàro (1905). Apud. Ibídem., p. 26.
} 
Al permitir el flujo constante entre diversas escalas, la figura del zoom se adapta perfectamente a esta autosimilaridad. De hecho, puesto que la dimensión fractal puede corresponder a una fracción, podría tratarse de un estado entre las dos y las tres dimensiones, semejante al espacio frontal que analizábamos en el apartado anterior. Como veíamos, en una dimensión 2'5, la cámara virtual permite añadir profundidad al espacio manteniendo las siluetas bidimensionales. En comparación con la pirámide finita de la perspectiva, la construcción de dimensión fractal corresponde a un espacio infinitamente elástico.

Así lo muestra, por ejemplo, el zoom sobre un fractal que Godfrey Reggio incluye en su Naqoyqatsi (2002) y sobre el que volveremos en el próximo capítulo. La cámara virtual permite sumergirse en ese extraño espacio y cambiar de escala gradualmente, evidenciando la autosimilaridad de la forma. En este caso, no se trata de la curva de Koch, sino de un "conjunto de Mandelbrot". Definida por primera vez por los matemáticos franceses Pierre Fatou y Gaston Julia, la forma que caracteriza este "conjunto" es bautizada con el nombre de Benoît Mandelbrot, autor de la primera visualización por ordenador de la misma. ${ }^{19}$

Con el zoom fractal en mente, pensemos en la composición del videoclip de la canción Seven Nation Army (2003) de The White Stripes, realizado por Alex Courtes y Martin Fougerol. La imagen se estructura a partir de una serie de triángulos que nacen y crecen sucesivamente, sustituyéndose unos a otros al ritmo de la batería. Los miembros del grupo musical aparecen enmarcados en las figuras geométricas. Gracias al zoom, las formas aumentan de tamaño hasta invadir la pantalla y desbordar los márgenes; inmediatamente, las figuras reaparecen de nuevo, diminutas, en el centro de la imagen. Lejos del punto de fuga de la perspectiva, este espacio frontal de estructura recursiva y en cascada remite a la dimensión fractal: la autosimilaridad de la forma más allá del cambio de escala encaja a la perfección con la exploración del espacio en profundidad propia del zoom.

\footnotetext{
19 "On the 1st of March 1980, Benoit Mandelbrot first glimpsed what would become known as the Mandelbrot Set. In the intervening years, it has assumed iconic status, conquering the world's computer screens in the role of the ultimate screen-saver." SPROTT, J.C.; TAYLOR, R.P.. "Biophilic Fractals and the Visual Journey of Organic Screen-savers". Nonlinear Dynamics, Psychology, and Life Sciences. 2008, vol. 12, núm. 1, p. 117. Disponible en Web:

$<$ http://sprott.physics.wisc.edu/pubs/paper311.pdf $>$
} 


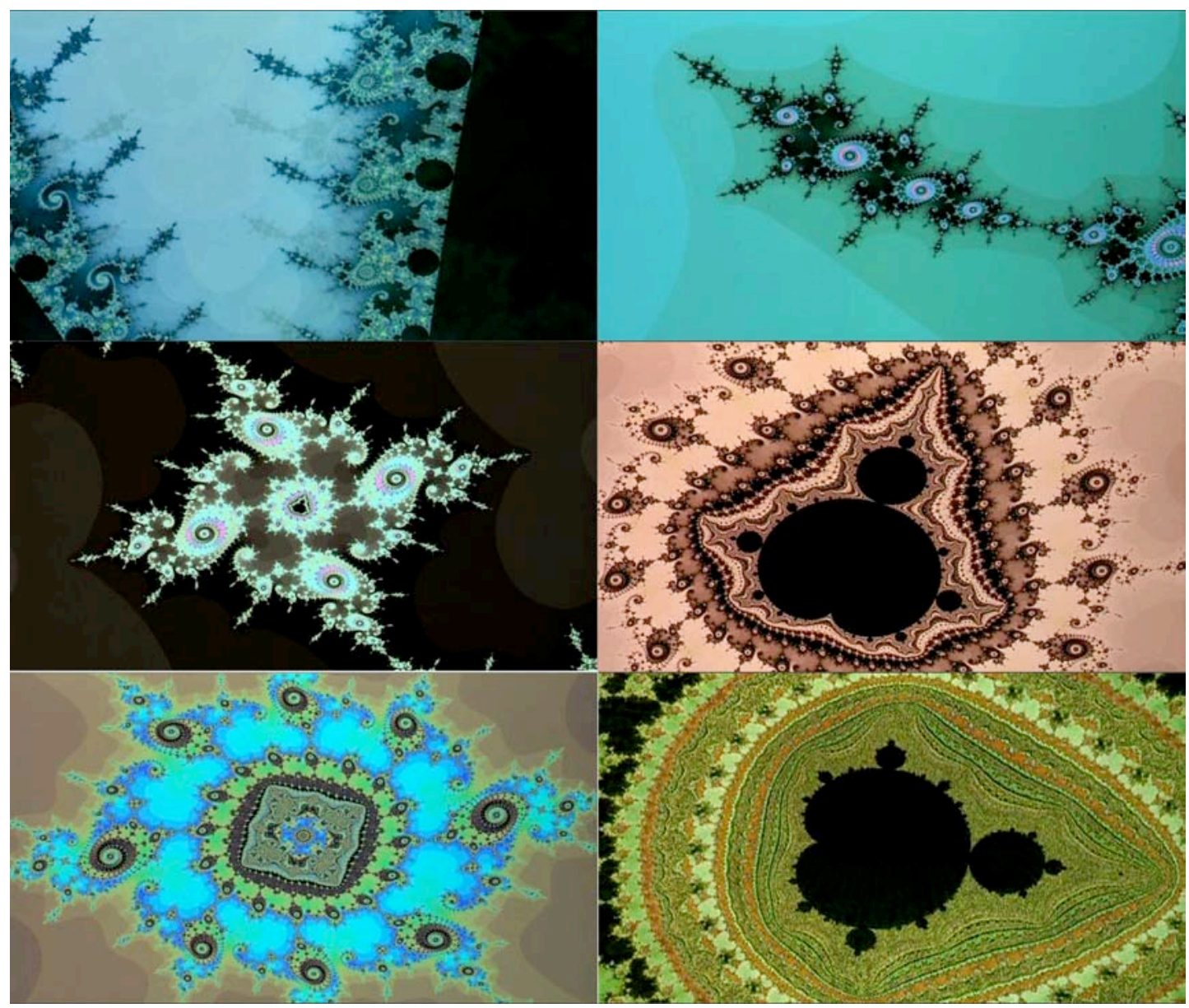

Naqoyqatsi (2002), de Godfrey Reggio

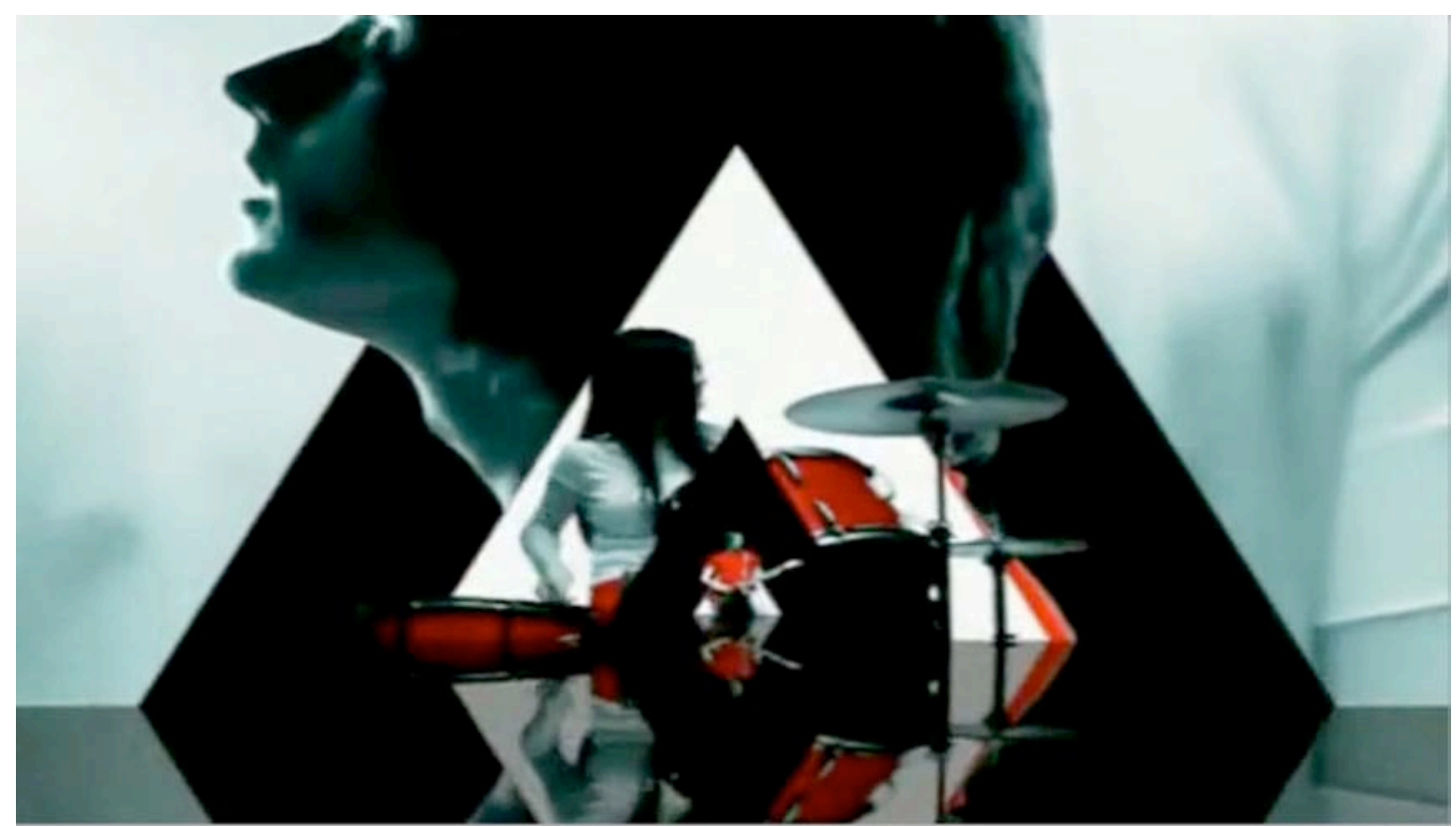

Seven Nation Army (2003), de Alex Courtes y Martin Fougerol para The White Stripes 
Semejante al anterior, el vídeo musical Brave Bulging Buoyant Clairvoyants (2008), dirigido por OneInThree para el grupo Wild Beasts, debe su estructura espacial a la obra "Prentententoonstelling" (1956) de Maurits Cornelis Escher. En la litografía del artista neerlandés, un armazón con forma de hélice une varios espacios. Para la compleja realización del videoclip, las imágenes fueron retocadas en After Effects y se aplicó la técnica desarrollada por el artista Josh Sommers en la imagen fija. Las transiciones fueron animadas a través de un trucaje del marco sostenido por el cantante y que repite el mismo motivo en forma de espiral. La cámara virtual penetra a través de esos cuadros dentro del cuadro en un movimiento en staccato. El resultado es una especie de "matrioska" en profundidad. Como veremos detenidamente en el próximo capítulo, la figura de la espiral remite tanto a un espacio infinito como a la visualización de hiperespacios.

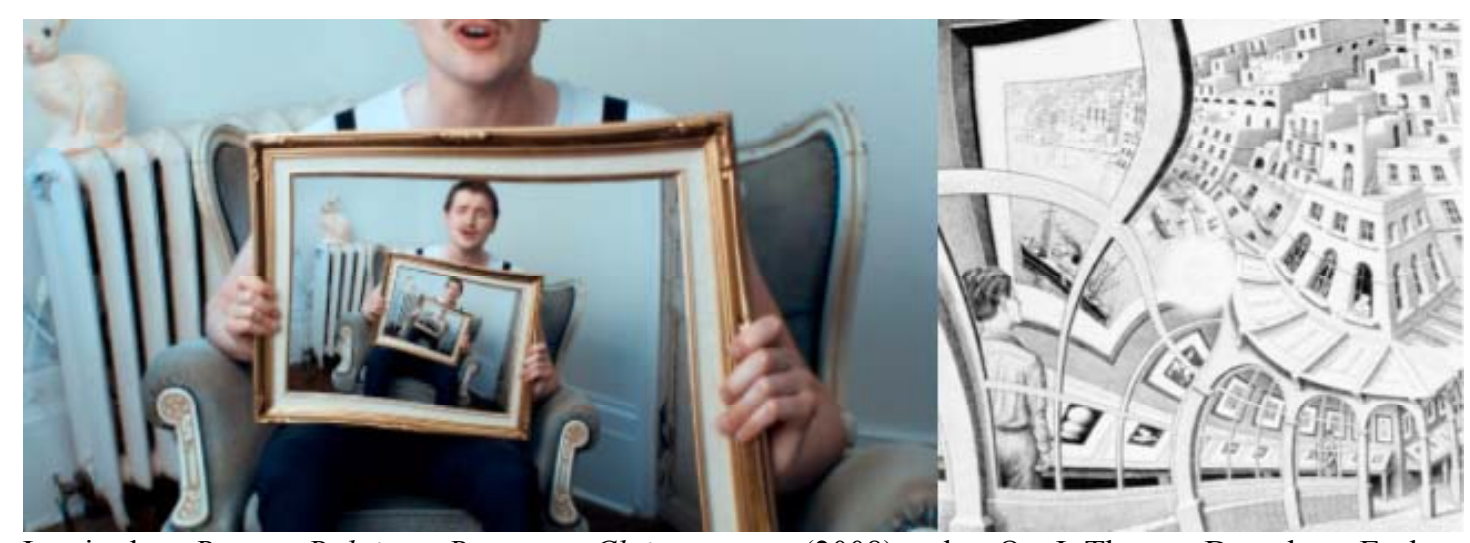

Izquierda. Brave Bulging Buoyant Clairvoyants (2008), de OneInThree. Derecha. Escher: "Prentententoonstelling" (1956)

En la propuesta geométrica del zoom sobre un fractal, buena parte de la potencia visual reside en crear un ritmo gracias a la iteración. Poco importa si la cámara virtual se desplaza hacia delante o hacia atrás: la clave reside en que la forma se repita en cualquiera de los sentidos..$^{20}$ No obstante, en el caso particular de la apertura de Contact, el universo converge en la pupila de la protagonista, contenida a su vez en el universo. Aquí, como en Fight Club, el hecho de elegir un zoom out en lugar de un zoom in es fundamental: mientras que éste presenta primero una visión global (el todo que contiene las partes) para acercarse a continuación a un detalle particular, el zoom out permite jugar con el imprevisto.

\footnotetext{
${ }^{20}$ Así, por ejemplo, los zoom out del videoclip Kick It Out (2009), de Boom Boom Satellites, no se diferencian sustancialmente del zoom in de Seven Nation Army (2003), de The White Stripes.
} 
Pensemos, por ejemplo, en el desconcertante comienzo de Citizen Kane (1941), de Orson Welles. Una cabaña aparece en medio de una tormenta de nieve. Poco a poco, la cámara se aleja hasta mostrar la mano del magnate moribundo, que sujeta una bola de cristal, en cuyo interior se halla la minúscula casa. El zoom out no sólo contextualiza la imagen, sino que supone una redimensión implícita de la figura. El distanciamiento permite introducir el fuera de campo y, con él, la sorpresa.

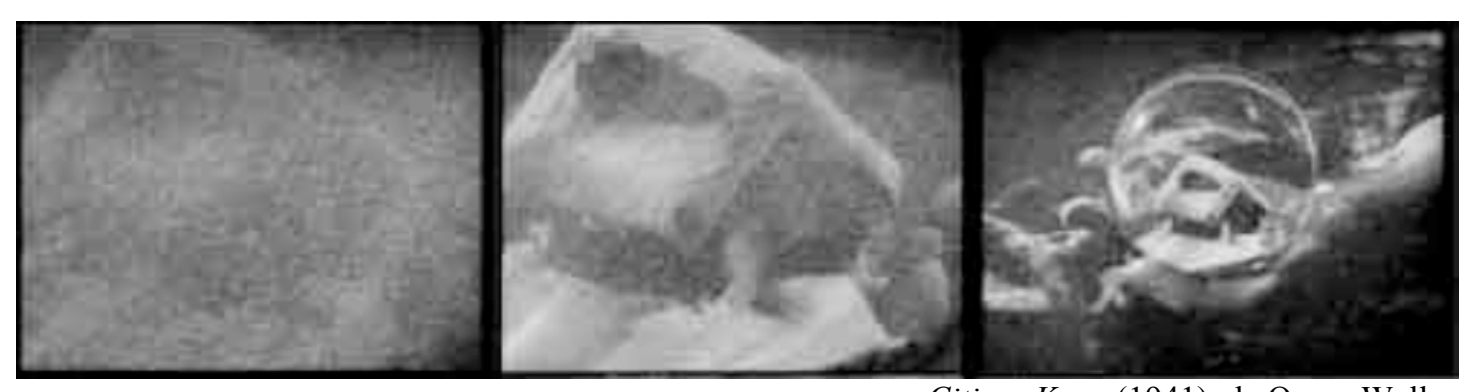

Citizen Kane (1941), de Orson Welles

Tal y como la definimos en este trabajo, la figura del zoom digital no es un efecto óptico ligado al aparato de registro ${ }^{21}$, sino una construcción espacial que exhibe la potencia plástica de la imagen digital. Dicho de otro modo, precisamente al tratarse de una construcción, la cámara virtual no debe nada al espacio profílmico; no encuentra límite alguno, si no es el de la imaginación. El zoom óptico redimensiona la figura y, en este sentido, supone también un cambio de escala. Ahora bien, en el zoom digital, esta redimensión no sólo puede ser muy superior, sino que corresponde a una mutación del espacio: la dilatación y la contracción de la escala van acompañadas de una metamorfosis. Así, en Contact, se pasa como por arte de magia del universo al ojo de la niña.

En el apartado dedicado a la omnipotencia de la cámara virtual, describíamos ésta como un producto: un constructo. Poníamos entonces como prueba el hecho de que la mismísima variación del punto de vista, puede ser entendida como una transformación en el interior del cuadro. Recordemos la metamorfosis de la imagen en

\footnotetext{
21 El zoom óptico en tanto que lente fotográfica variable comienza a usarse en los años 20 como sustituto o complemento del travelling, es decir, del desplazamiento físico de la cámara en el espacio: "The development of the zoom was associated with the name of Joseph Walker who constructed a prototype in the '20s. However, it wasn't until after World War II and the considerable investment in the technology of aerial photography reinforced by the emergence of television in the USA that the zoom lens became integrated into cinematographic technology." WILLEMEN, Paul. The Zoom in Popular Cinema. A Question of Performance. [En línea]. Inter-Asia Cultural Studies. 2012. Vol. 14, núm 1. Disponible en Web: <http://www.rouge.com.au/1/zoom.html>
} 
Star Trek II: The wrath of Khan (1982), de Nicholas Meyer: la cámara virtual gira en torno al planeta al compás del proceso de terraforming.

Más allá, los planos secuencia de Contact y Star Trek II comparten la visualización idealizada de la Tierra. Ambos recuerdan la fotografía de nuestro planeta tomada por el astronauta William A. Anders en $1968 .{ }^{22}$ Conocida como "Earthrise", la instantánea presenta en primer plano la superficie del satélite, dejando en un segundo plano la Tierra, iluminada parcialmente por el Sol, fuera de campo. La fotografía forma parte, desde entonces, del imaginario colectivo global como símbolo de la fragilidad del planeta y del puesto del ser humano en el cosmos. ${ }^{23}$
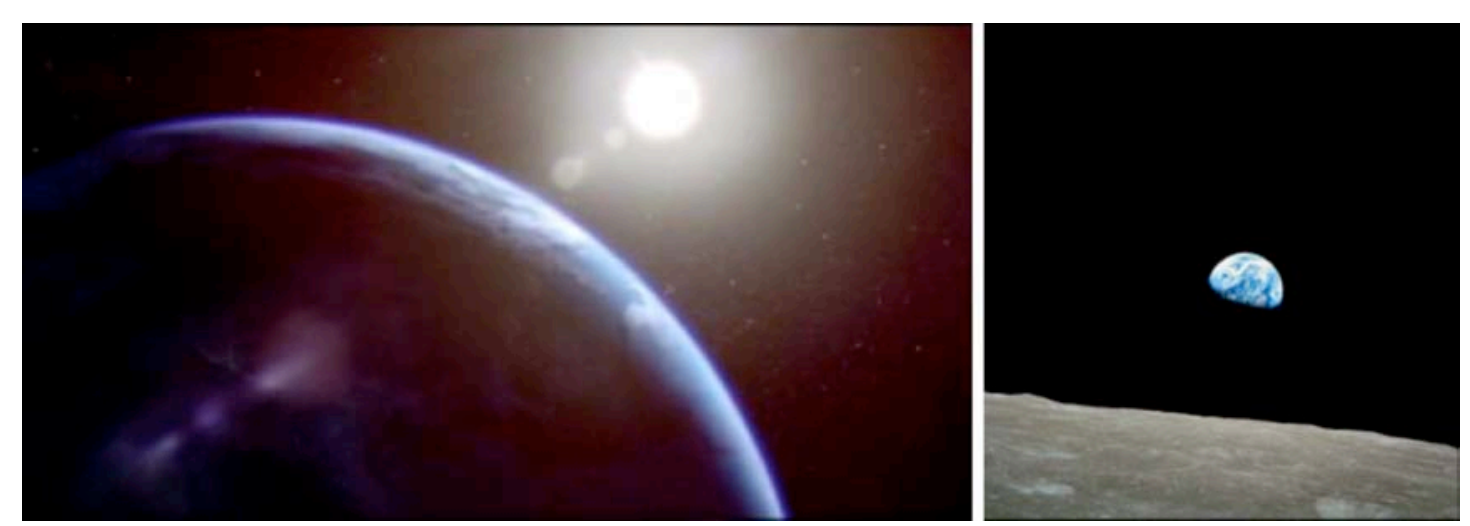

Izquierda, Contact (1997), de Robert Zemeckis. Derecha, William A. Anders: "Earthrise" (1968)

Apenas un año tras la publicación de "Earthrise", Gene Youngblood afirma:

"El foco de atención de las artes, especialmente el cine, ha girado ya hacia la conciencia cósmica. 'Las consecuencias de las imágenes', decía McLuhan, 'serán las imágenes de las consecuencias'. Un vocabulario completamente nuevo de lenguaje gráfico está a disposición del creador de imágenes ahora que nuestros sentidos "vídeo" se han extendido hasta Marte y más allá."24

\footnotetext{
${ }^{22}$ Realizada el 24 de diciembre de 1968, la instantánea no fue presentada hasta la primera semana de enero de 1969. O'BRIEN, Frank; WOODS, David. Apollo 8 Flight Journal. [En línea]. National Aeronautics and Space Administration. NASA History Division, May 5, 2009. Disponible en Web: $<$ http://history.nasa.gov/ap08fj/14day4_orbits456.htm>

${ }^{23}$ Éste es el caso de la película 2012 (2009), de Roland Emmerich. Tras la hecatombe prevista por el calendario maya, la cinta termina con un zoom out desde las naves que albergan los últimos seres humanos hasta un primer plano de la Tierra, de claro mensaje ecológico.

${ }^{24}$ YOUNGBLOOD, Gene. Op. cit., p. 139.
} 


\section{La relatividad de la escala antropomórfica}

En los años 60, la tecnología informática comienza a desarrollarse, justamente, como herramienta para la visualización del Espacio exterior. ${ }^{25}$ Pensemos, por ejemplo, en la primera animación por ordenador de la historia: en su Simulation of a Two-Gyro Gravity-Gradient Attitude Control System (1963), el estadounidense Edward E. Zajac simula la órbita de un satélite en torno a la Tierra. Un año más tarde, científicos de la NASA tratan digitalmente fotografías de la luna. Del mismo modo, la imagen del primer paso del hombre sobre el satélite, en 1969, es retocada en el ordenador para eliminar algunas imperfecciones.

En la misma época, dos cortos de animación, Cosmic Zoom de Eva Szasz y Powers of Ten de Ray y Charles Eames (ambos de 1968), adaptan el libro de Kees Boeke Cosmic View: The Universe in 40 Jumps $^{26}$ (1957). Con su ensayo divulgativo, el autor neerlandés pretendía evidenciar la relatividad de la escala antropomórfica mediante la combinación de dos puntos de vista imposibles para el ojo humano "desnudo": la perspectiva telescópica y la microscópica.

La obra describe el proceso de alejamiento desde un ser humano en la Tierra hasta el Espacio intergaláctico; y, a la inversa, la inmersión en el interior del cuerpo de esa misma persona para mostrar uno de los átomos que lo componen. De este modo, el ser humano pasa de centro organizador a superficie permeable. El texto se acompaña de ilustraciones de dichos cambios de escala en potencias de 10 , de manera que se establece un paralelismo entre el Espacio exterior y el interior del cuerpo humano. Sin embargo, en este último caso, el número de planos se reduce a la mitad; es decir, la profundidad alcanzada funciona como metáfora de los límites de la ciencia en ese momento.

Partiendo del libro de Boeke, Eva Szasz crea su Cosmic Zoom (1968), una animación por ordenador de ocho minutos de duración. El zoom out comienza con un primer plano de un niño en una barca y se aleja hasta el Espacio intergaláctico, desvelando poco a poco la estructura del universo; seguidamente, el sentido del movimiento se invierte y la cámara virtual avanza hasta el niño, adentrándose en su cuerpo.

\footnotetext{
${ }^{25}$ MITCHELL, William J.. Op. cit., p. 11.

${ }^{26}$ BOEKE, Kees. Cosmic View: The Universe in 40 Jumps. New York: John Day Company, 1957.
} 


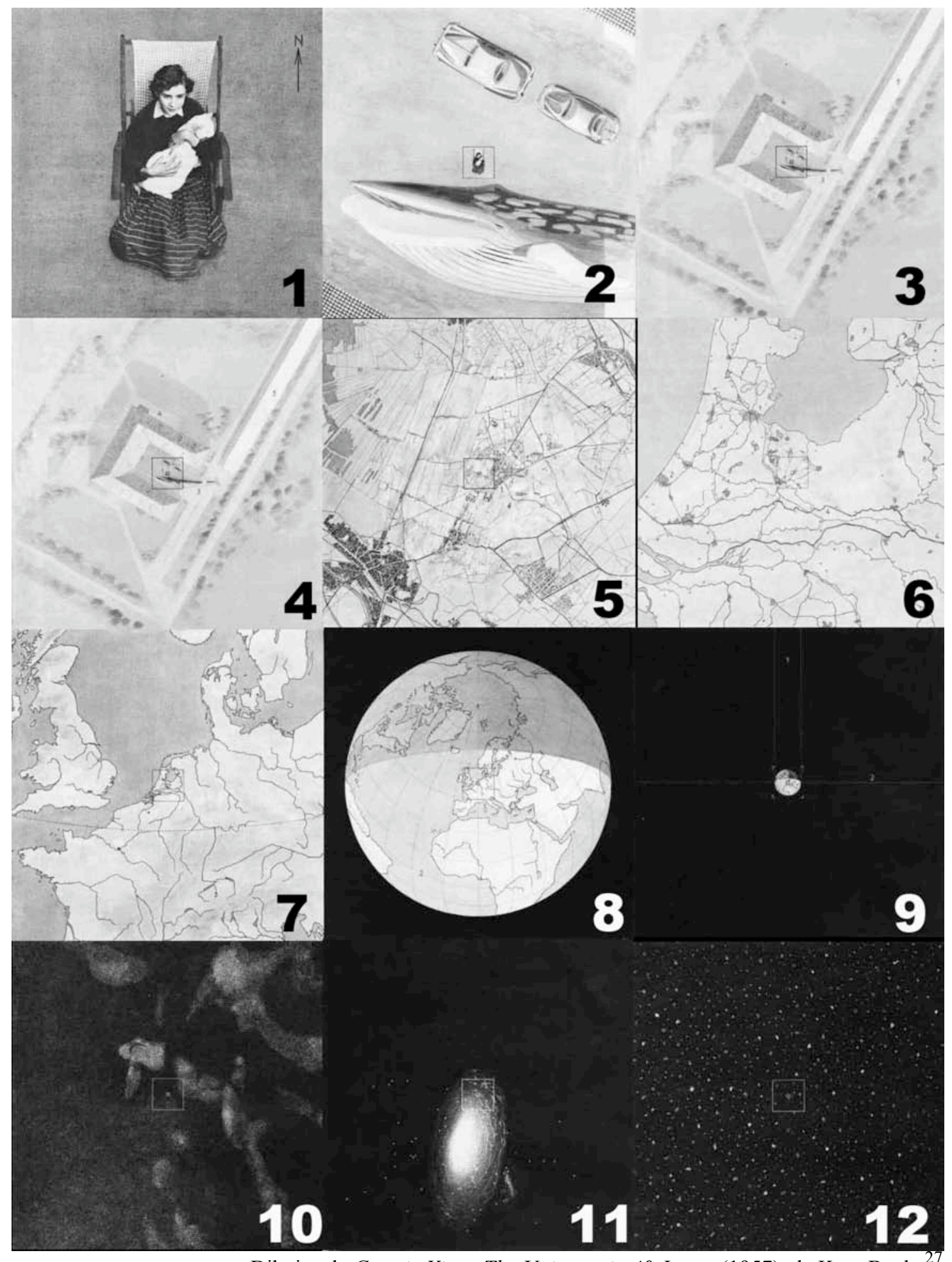

Dibujos de Cosmic View: The Universe in 40 Jumps (1957), de Kees Boeke ${ }^{27}$

\footnotetext{
${ }^{27}$ Se han seleccionado solamente los dibujos más representativos. En la obra original, se presentan hasta 26 imágenes.
} 
EL ZOOM DIGITAL

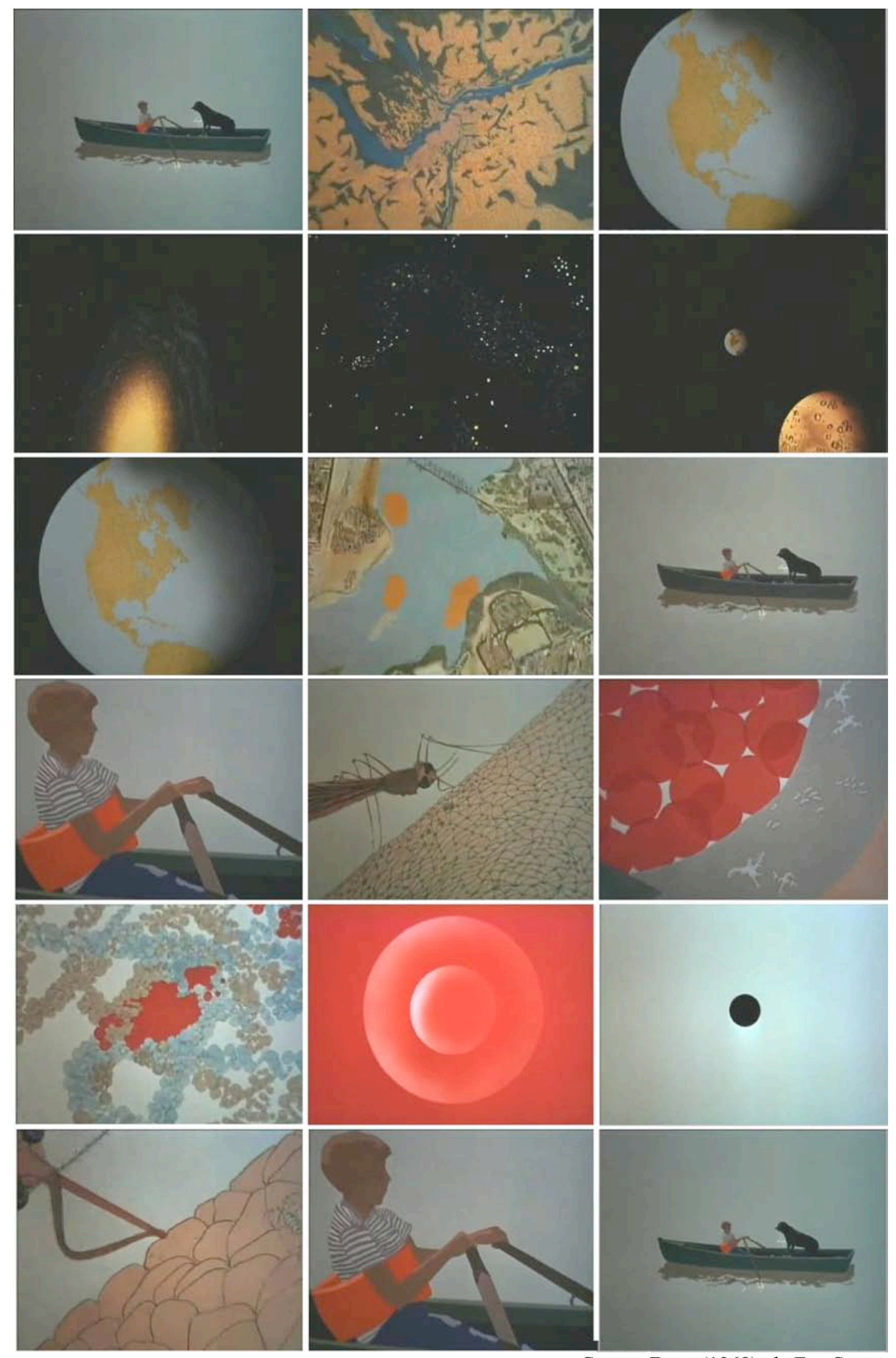

Cosmic Zoom (1968), de Eva Szasz 


\section{EL ZOOM DIGITAL}

Frente a los dibujos del escritor, en la animación de Szasz, el punto de vista varía gracias a la síntesis de las transiciones. Al espacio bidimensional de las imágenes fijas de partida se suma la profundidad cinética asociada a la cámara virtual. El resultado es una dimensión 2'5, un espacio frontal semejante a los estudiados en el apartado anterior. El espacio construido en Cosmic Zoom se sitúa a medio camino entre la fijación de los dibujos-base y el movimiento asociado a la transformación de la escala. Una vez más, la cámara virtual no subraya sólo el espacio entre los personajes y los objetos, sino entre las mismísimas dimensiones de la imagen.

Las costuras sintéticas entre las imágenes fijas permiten relacionar la obra de Eva Szasz con la de su contemporáneo Charles Csuri, al que reservábamos las primeras líneas de este trabajo. Ambos parten de diseños que animan gracias al cálculo informático del espacio intermedio y explotan el carácter elástico de la imagen digital. Si Csuri se concentra en la activación como tensión entre figuración y distorsión, dejando el cuadro inmóvil, Szasz dinamiza la imagen gracias, precisamente, al cambio del punto de vista. En este caso, la elasticidad no es la de la figura, sino la del espacio en su conjunto: la dilatación en profundidad que permite el desplazamiento de la cámara virtual.

Una construcción muy semejante es la de la otra adaptación del libro de Boeke, Powers of Ten, realizada por Ray y Charles Eames en 1968 y revisada en 1977. La cámara virtual se aleja hacia el cielo y van apareciendo, sucesivamente, Norte América, el Globo terráqueo, el Sistema Solar, etc. A continuación, el zoom in opuesto no finaliza en el que fuera el punto de partida del primer zoom out, sino que continúa con una inmersión en el cuerpo de un hombre. La cámara virtual se aproxima a la mano derecha del personaje, atraviesa la superficie de la piel y profundiza en su interior hasta mostrar, progresivamente, una célula, una porción de cromosoma, un núcleo de un átomo de carbono y, finalmente, un quark. 

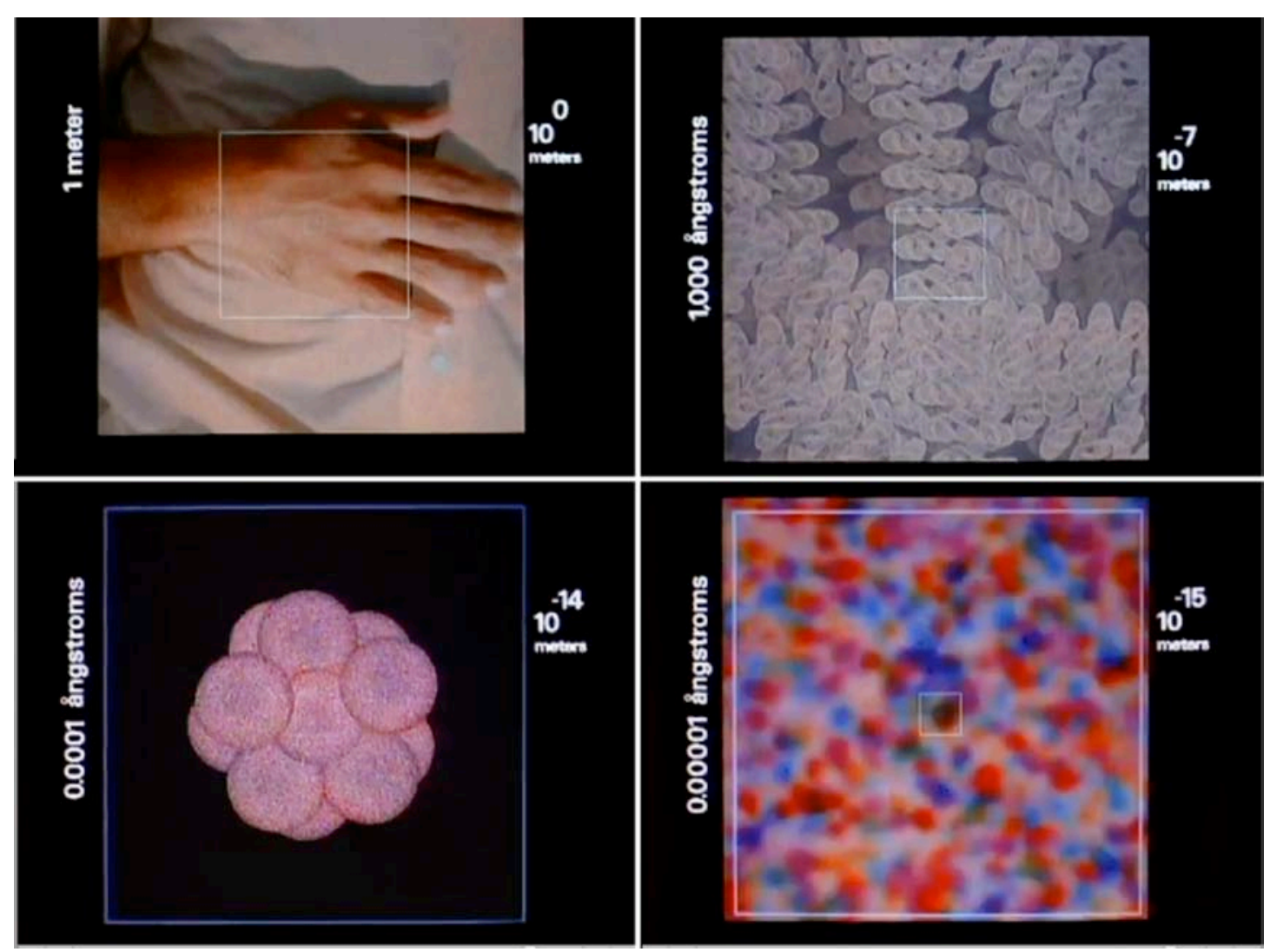

Powers of Ten (1977), de Ray y Charles Eames

En 1996, el documental Cosmic Voyage, dirigido por Bayley Silleck, presenta otra versión de Cosmic View: The Universe in 40 Jumps, esta vez, en formato IMAX. Como en las versiones precedentes, el zoom reúne en un mismo movimiento el espacio exterior de Contact y el interior de Fight Club. Es decir, el punto de vista telescópico y el microscópico aparecen como dos manifestaciones complementarias de la misma idea: la relatividad de la escala antropomórfica.

Comúnmente, el concepto de "profundo" se refiere a algo inalcanzable, bien por lejano bien por oculto. ${ }^{28}$ Con la tecnología digital, no sólo lo inmenso se vuelve abarcable; lo pequeño, escudriñable; y lo profundo, superficie aparente ${ }^{29}$. Más aún, todos ellos quedan perfectamente enlazados en un movimiento continuo y fluido: en un espacio mutante.

\footnotetext{
28 "Depth refers to what is hidden and inside (either literally or metaphorically), what is deep (in the earth, in space, or in profundity), and what is distant or far from the immediately perceivable." ROOF, Judith. "Depth Technologies". En: MUNT, Sally (ed.). Technospaces: Inside the New Media. London: Continuum International Publishing Group, 2001, p. 22.

29 "Una cultura de superficies es una cultura de imágenes. Es el espacio del 'entre' la sensibilidad y el concepto, cielo y tierra, profundidad y meras apariencias". MOLINUEVO, José Luis. Humanismo y nuevas tecnologías. Op. cit., p. 210.
} 


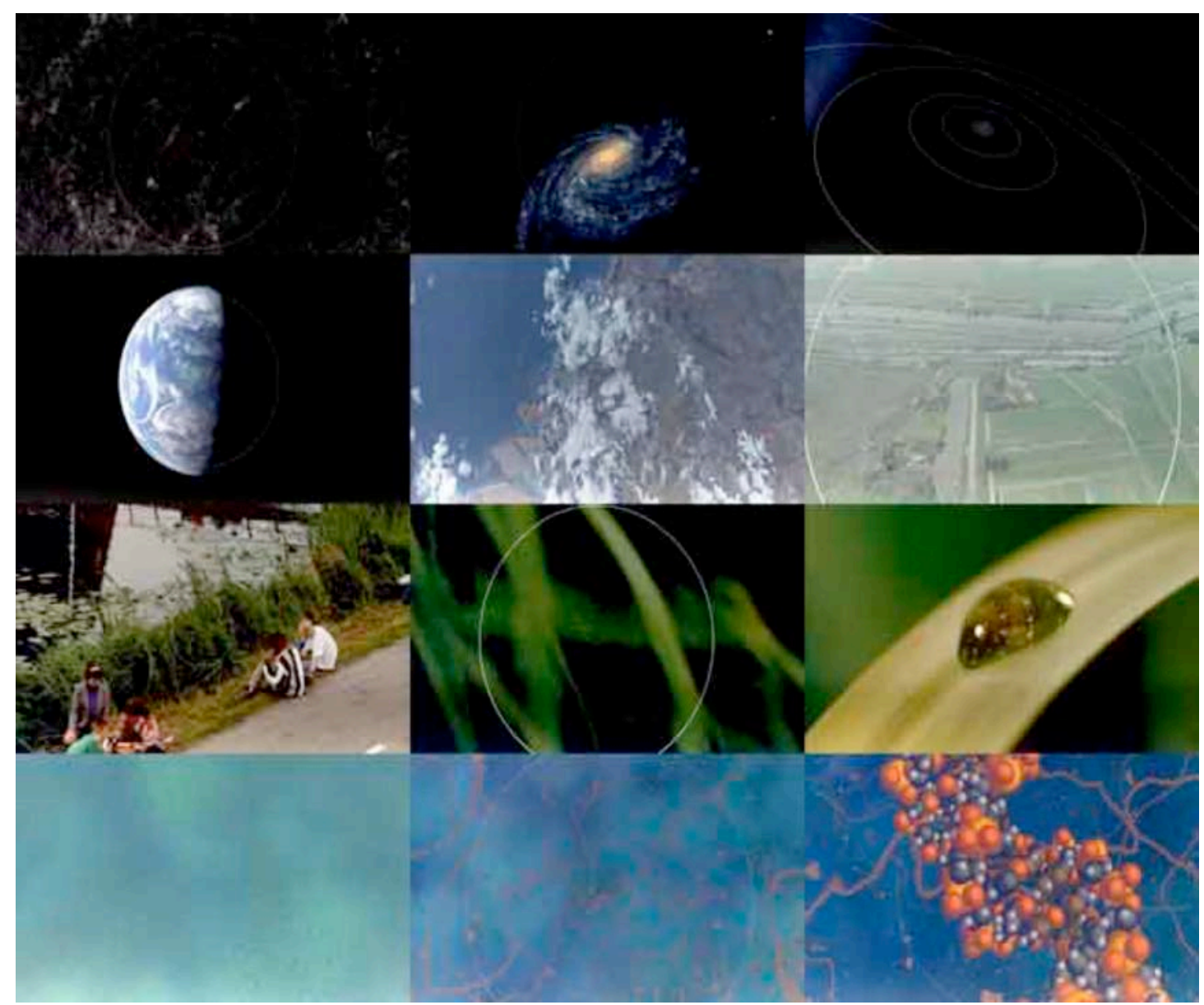

Cosmic Voyage (1996), de Bayley Silleck

La vista de pájaro de Utrecht (Holanda) del libro original Cosmic View: The Universe in 40 Jumps es, en Cosmic Zoom, la capital de Canadá atravesada por el río Ottawa; en Powers of Ten (1977), se trata de Chicago (EE.UU); y, en Cosmic Voyage (1996), de Venecia. No obstante, la construcción digital en todas ellas se aleja del "mapa" bidimensional y se acerca a la idea de "camino" en tanto que espacio intermedio: entre el punto de partida y el de llegada. Como veíamos ya en relación a Fight Club, frente al mapa estático, bidimensional, marcado por una escala común y fija, la mutación del espacio provoca el cambio continuo de escala; un espacio dinámico, una trayectoria.

La película de Tom Tykwer Lola rennt (1998) se abre con un zoom in que parte de un primer plano del centro de Berlín dividido por el río Spree. La cámara virtual avanza en caída libre desde la vista cenital del barrio Mitte de la capital alemana hasta el teléfono que suena en la casa de la protagonista: Lola (Franka Potente) recibe la llamada de su novio Manny (Moritz Bleibtreu), que ha olvidado en el metro una bolsa llena de dinero negro; a partir de ese momento, la joven tendrá que encontrar 100.000 
marcos en 20 minutos antes de que su novio atraque un supermercado. La figura del zoom in funciona, así, como "disparo de salida", punto de partida de la acción: el relato se inicia directamente en el nudo de la trama, como en una presentación de las normas de un juego que ha de comenzar de forma inmediata.

En el primer capítulo, analizábamos otra escena de Lola rennt y subrayábamos el uso del montaje espacial frente al montaje temporal de los planos. Decíamos entonces que Tom Tykwer explora la simultaneidad y la cohabitación de varios puntos de vista frente a la secuencialidad. De manera semejante, podemos ver en el zoom in que nos ocupa una propuesta alternativa al montaje "analítico" o "spatial overlap". Esta forma de edición temporal va del todo a la parte: el espacio fílmico se organiza presentando primero el contexto general para dar paso, a continuación, a un detalle concreto de éste. Con su elección del zoom frente al mero montaje temporal, Tykwer se decanta de nuevo por la continuidad frente al corte. Es más, al servirse de la cámara virtual, hace presente el espacio intermedio.

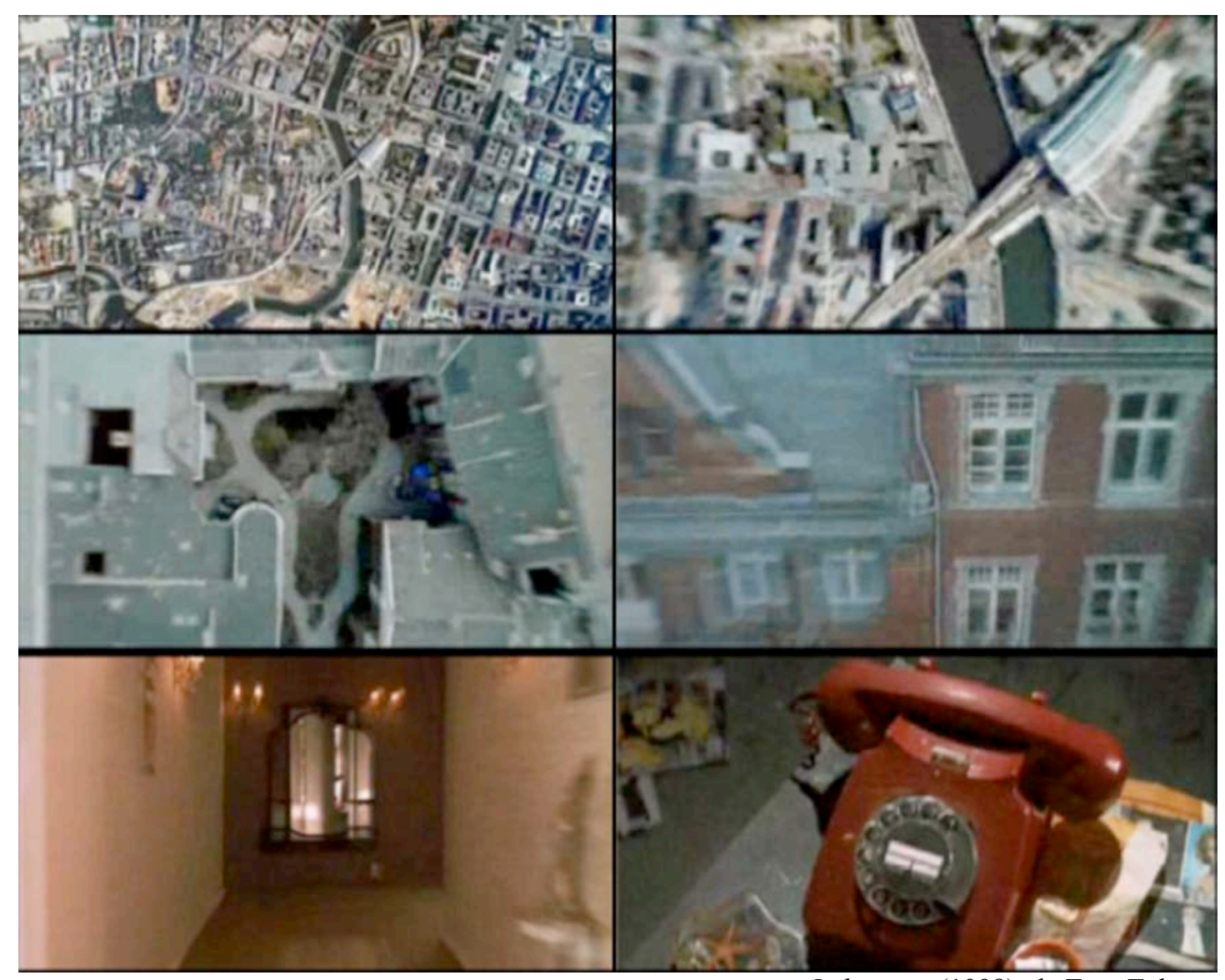

Lola rennt (1998), de Tom Tykwer 
Prácticamente al tiempo que se estrena Lola rennt, se gesta el programa que será popularizado como Google Earth. Algunos miembros del Silicon Graphics Inc. (SGI) realizan una demostración llamada "From outer Space to your face", consistente en un zoom in digital desde un primer plano de Europa vista desde el cielo (a través del lago Lemán y los Alpes suizos) hasta un modelo tridimensional de una videoconsola Nintendo 64, cuyas entrañas son atravesadas por la cámara virtual. El desplazamiento del cuadro se detiene en un chip con el logotipo del SGI en el interior de la máquina; por último, la imagen se funde, nuevamente, con un plano de la Tierra.

Entre otros, la animación se inspiró en el corto de Ray y Charles Eames Powers of Ten. ${ }^{30}$ Sin embargo, recordemos que, en la animación que sirviera de modelo, el zoom in acaba con la partícula más pequeña conocida en el interior del cuerpo humano. Los autores continuaban, así, con la propuesta del libro de Boeke Cosmic View: The Universe in 40 Jumps, que se remonta a 1957. En la versión realizada en el SGI cuatro décadas después, esa unidad mínima es un chip. Podemos interpretar esta elección como una metáfora de la capacidad de compresión de los datos, de la plasticidad del espacio digital, cuya verdadera naturaleza es el código subyacente, almacenable en un minúsculo circuito integrado. En este sentido, Peter Weibel se refiere al microchip como metáfora de la revolución en el concepto espacial que la tecnología electrónica conlleva:

"El microchip es una reducción del espacio y el tiempo, pero esa reducción es, a la vez, una enorme expansión de sus capacidades y, por eso, se ha convertido en una metáfora y en un modelo del mundo electrónico. (...) El microchip es, pues, el verdadero monumento de nuestra época." 31

Varios años después de la demostración From outer Space to your face, aparece Google Earth (2004-2005). Esta aplicación interactiva es un programa de búsqueda y presentación de datos geolocalizados, que permite al usuario navegar a través del espacio. La imagen se compone mediante la superposición de fotografías, cuyo

\footnotetext{
30 "Silicon Graphics (SGI) invented a hardware component called the 'Clip-Map' texture unit, which made it relatively painless to render a "Powers of Ten" style animation in real-time. They called their demo 'Space to Face', which was amazingly cool, though fairly limited in scope - you zoomed down from space to one spot on Earth." BAR-ZEEV, Avi. Geography 2.0: Virtual Globes: Notes on the origin of Google Earth and Ogle Earth: Google Earth Origin Myths. [En línea]. RealityPrime, July 24, 2006. Disponible en Web:

$<\mathrm{http}: / /$ www.realityprime.com/blog/2006/07/notes-on-the-origin-of-google-earth/>

${ }^{31}$ WEIBEL, Peter. Op. cit. Pássim.
} 


\section{EL ZOOM DIGITAL}

fundido en un programa 3D permite buscar datos espaciales concretos y compartirlos. Siempre con la instantánea "Earthrise" de 1968 como referencia, el usuario de Google Earth parte de una imagen de la Tierra vista desde el Espacio pudiendo después "hacer zoom" a su antojo. Si bien los Sistemas de Información Geográfica fueron incialmente concebidos para uso exclusivamente militar, en la última década, la popularización de Google Earth ha estandarizado este tipo de imagen, perteneciente ya al canon audiovisual y al imaginario colectivo global. ${ }^{32}$ Un buen ejemplo lo encontramos en la película de Alejandro Amenábar Ágora (2009).

La historia se sitúa en la Alejandría (Egipto) de los siglos IV y V d.C., bajo el Imperio romano en decadencia. La protagonista es una astrónoma, Hipatia (Rachel Weisz), quien, varios siglos antes del científico alemán Johannes Kepler (1571-1630), habría descubierto que la Tierra dibuja una órbita elíptica alrededor del Sol. Tras la toma de la célebre biblioteca de la ciudad por parte de los cristianos, un flash forward de varios años sitúa el relato en el mismo edificio, ocupado ahora por los fieles de la religión en expansión. A la hora de dar forma a este salto adelante en el tiempo, Amenábar recurre a un zoom in digital al estilo Google Earth.

El movimiento parte de un primer plano de la Tierra. La cámara virtual se acerca poco a poco al mar Mediterráneo y a la costa de la ciudad egipcia, urbanizada mediante un trazado hipodámico; sobrevuela sus calles y aterriza en la biblioteca, a través de cuyos pilares se distingue el féretro del antiguo patriarca, Theophilus I (Manuel Cauchi), rodeado de las plañideras que lloran en su funeral.

El relato termina con un zoom out que realiza el mismo recorrido a la inversa, desde la ventana cenital con forma de elipse en el techo de la biblioteca (guiño al hallazgo científico de Hipatia) hasta un plano general del Globo terrestre. La construcción permite romper con el punto de vista antropomórfico y establecer relaciones espaciales entre sujetos y objetos: si en Contact la protagonista no cesa en su empeño de contactar con su madre muerta, Hipatia se obsesiona con el espacio exterior y la forma de la elipse.

\footnotetext{
${ }^{32}$ Cfr. FARMAN, Jason. Mapping the Digital Empire: Google Earth and the Process of Postmodern Cartography [En línea]. Washington State University, New Media \& Society, 2010. Disponible en Web: <http://nms.sagepub.com/content/12/6/869>
} 

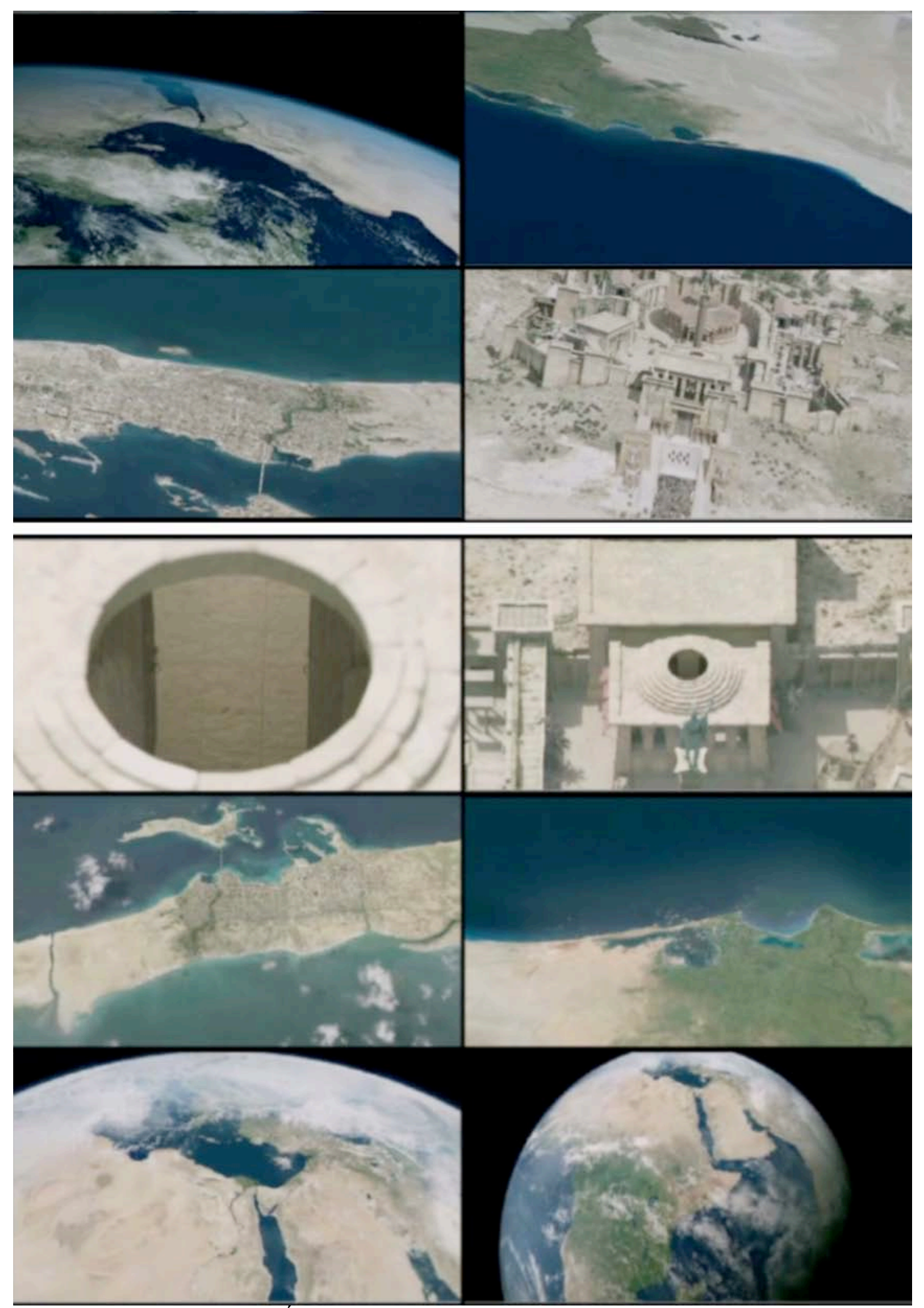

Ágora (2009), de Alejandro Amenábar. Arriba, zoom in. Abajo, zoom out

Amenábar abre con un zoom in y cierra con un zoom out, estableciendo una relación entre el principio y el final del relato, y un paralelismo entre éstos con el “dentro" (“in”) y el "fuera" (“out”) del movimiento. Como veíamos más arriba, las 


\section{EL ZOOM DIGITAL}

adaptaciones del libro de Boeke juegan también con esta reversibilidad espacial del zoom, llegando incluso a presentar las mismas imágenes de partida, ordenadas al revés. De manera semejante a la equiparación entre el espacio telescópico y el microscópico, zoom in y zoom out se conciben como las dos caras de la misma moneda: dos figuras opuestas, pero complementarias. Esta estructuración hace hincapié en la elasticidad del espacio digital, que, como un acordeón, se dilata y contrae al gusto del creador. En este sentido, la combinación de zoom in y zoom out muestra la misma concepción del espacio digital que la animación Morphing of the Telephone (1997) de Lillian Schwartz. Como veíamos en el capítulo anterior, la pionera del arte por ordenador presenta el morphing como un palíndromo visual, legible por igual en ambos sentidos.

Ahora bien, como hacíamos notar ya en relación a Contact y Fight Club, las figuras del zoom in y el zoom out no son siempre intercambiables. En 2007, la campaña publicitaria Dos equis iguales diferentes, de la cerveza mejicana XX Lager, se hace eco tanto de las posibilidades ilimitadas de la cámara virtual como de las diferencias entre zoom out y zoom in. El anuncio televisivo comienza con un primer plano de una joven en una sala de fiesta. La cámara virtual se aleja de espaldas, atravesando sin problema todo tipo de superficies (una pecera, una nevera...) hasta salir a la calle por la puerta principal. Una vez fuera, se topa con un hombre que pasa frente al bar. En ese momento, el movimiento se invierte para recorrer exactamente el mismo espacio al revés, hasta el primer plano de la mujer con el que empezaba el anuncio.

La propuesta muestra de forma muy simplificada las diferentes aportaciones del zoom out y del zoom in: mientras que aquél presenta a los dos personajes subrayando el espacio que los separa, y juega con la sorpresa al desvelar poco a poco el fuera de campo, el zoom in insiste en la inmersión en ese espacio, la conquista del mismo y de la mujer en él contenida.

Como en Cosmic Zoom y Powers of Ten, la publicidad reutiliza las mismas imágenes de partida para construir dos movimientos opuestos: ordenadas a la inversa, las tomas se presentan encadenadas en un único espacio continuo. Este proceso de elaboración prueba la condición eminentemente espacial de la cámara virtual: la linealidad del antes/después se disuelve a favor de una construcción específica de la imagen. 


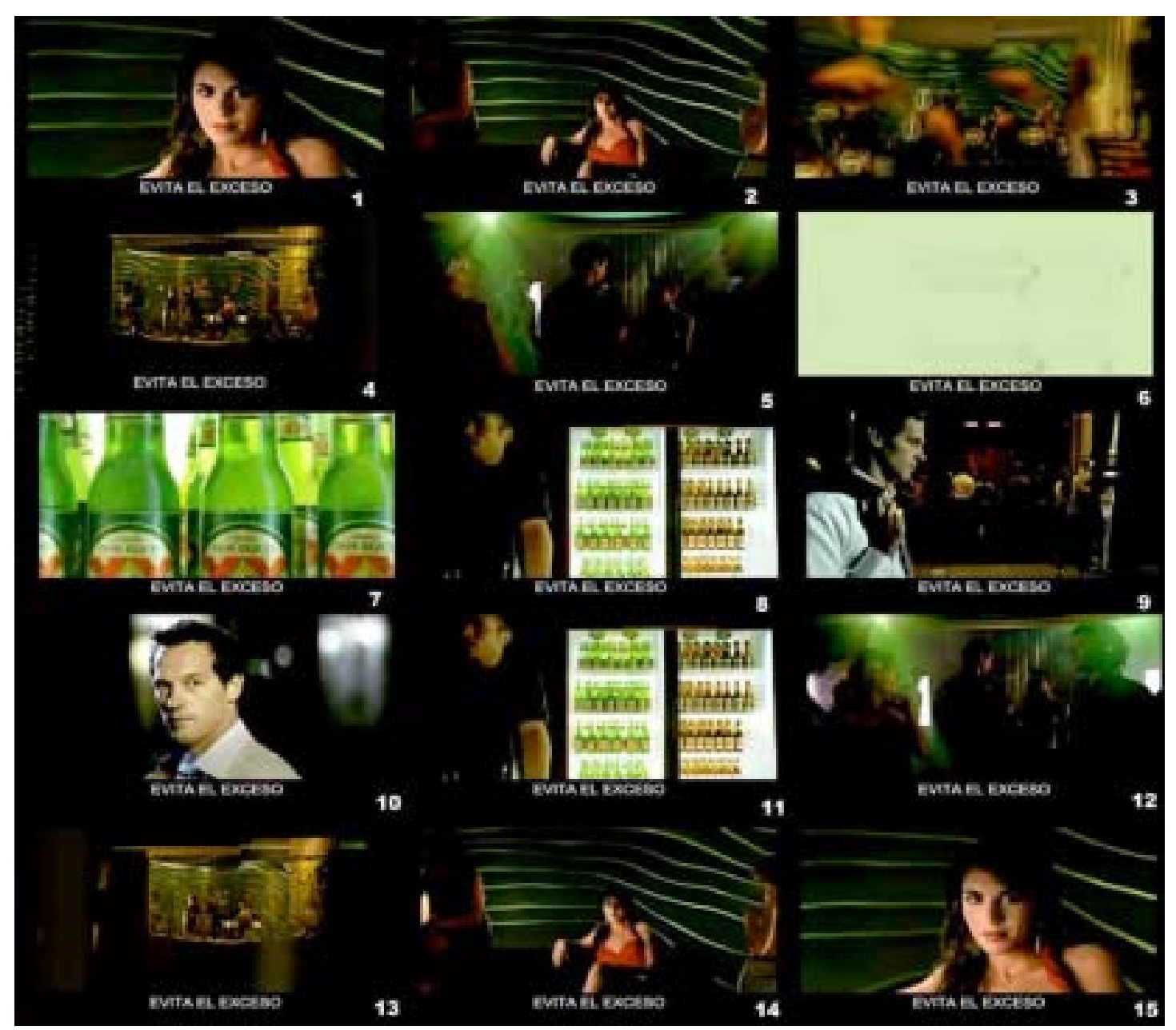

Campaña "Dos equis iguales diferentes" de la cerveza XX Lager (2007)

A lo largo de las últimas páginas, hemos intentado mostrar cómo la cámara virtual permite establecer todo tipo de relaciones espaciales: no sólo unir lo distante, sino reconciliar opuestos (dentro/fuera; tele/micro; grande/pequeño...). Estas relaciones espaciales reservan a la figura humana un puesto secundario, lejos del antropocentrismo de la perspectiva renacentista o de la subjetividad del cine clásico.

Hasta aquí, nos hemos concentrado en las posibilidades de exploración espacial que permite la dilatación en profundidad. En el próximo apartado, analizaremos pormenorizadamente esta elasticidad espacial no sólo hacia delante o hacia atrás, sino más allá de los cuatro márgenes laterales del cuadro. Así entendida, la imagen digital es un ente fluido, sometido a las fuerzas de los seis lados que la contienen. 


\section{EL PLANO SECUENCIA DIGITAL}

Las páginas que siguen describen la figura del "plano secuencia digital" en contraposición a su homónima en la imagen registro. Tras demostrar en qué medida la plasticidad espacial permite controlar el tiempo en la narración, veremos obras digitales que exploran la construcción de "collages en profundidad" gracias al movimiento continuo de la cámara virtual.

\section{La elasticidad espacial como condensación temporal}

Vida Maria (2006), de Márcio Ramos, es un corto animado en 3D que narra la vida de su protagonista en un solo movimiento continuo de siete minutos. La cámara virtual permite ligar los distintos momentos en una única entidad espacial. Como en las transiciones espacio-temporales analizadas en el primer capítulo, el espacio intermedio cobra protagonismo frente a la mera elipsis del corte. Ramos presenta al personaje llevando a cabo distintas acciones. Si bien el contexto espacial se mantiene (el jardín de la casa en la que pasa su vida Maria), los cambios de actividad van acompañados de una transformación en el personaje: en cada quehacer rutinario, Maria es un poco más vieja. La cámara virtual permite el paso liso y explícito entre las diversas escenas: tras mostrar al personaje en una tarea específica, se aleja dejándolo fuera de campo, para volver de nuevo y encontrarlo, varios años después, en otra faena cotidiana. Así, la continuidad del movimiento de la cámara virtual contrasta con la discontinuidad de las acciones. El corto termina con otra niña en la misma posición de partida, dando a entender una estructura circular, que aleja el relato de la simple progresión lineal.

Como en el flash forward mediante morphing de Titanic, el plano secuencia digital permite dar forma al envejecimiento acelerado de la protagonista y hace avanzar el relato. En ambos, la dilatación espacial posibilita la contracción temporal. Ahora bien, si en aquella metamorfosis se trataba de exhibir la transformación del rostro mientras el cuadro permanecía inmóvil, en el corto que nos ocupa, la mutación afecta al espacio en su conjunto y da forma al desplazamiento de la cámara virtual. Es más, el cambio físico del personaje se deja fuera de campo y se sustituye por la exhibición el espacio entre sujetos y objetos. 


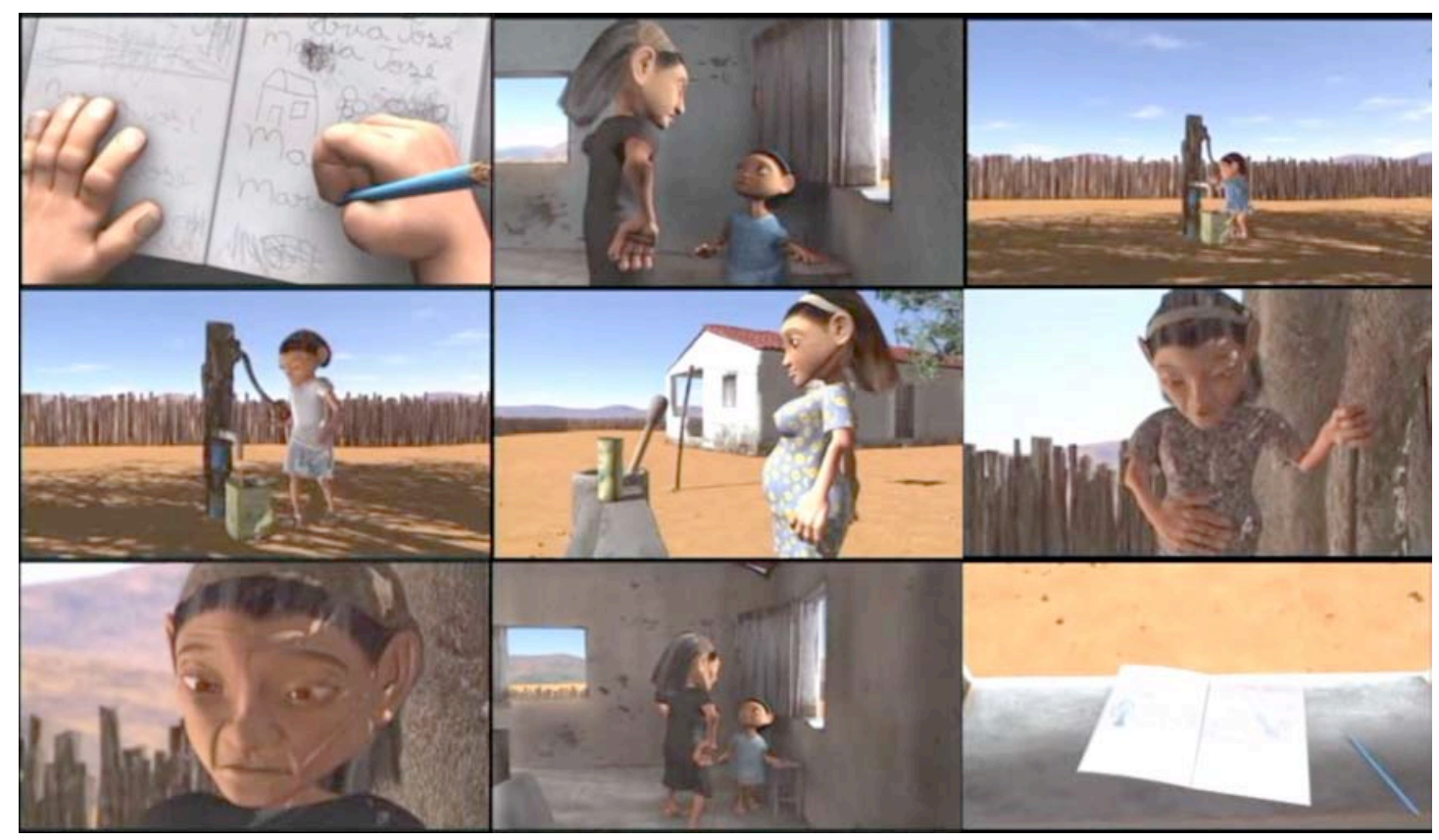

Vida Maria (2006), de Márcio Ramos

La figura que bautizamos como "plano secuencia digital" se funda en la omnipotencia de la cámara virtual. Podríamos incluir en esta categoría las imágenes analizadas en Panic Room o Minority Report: en su desplazamiento continuo y mantenido, la cámara virtual se hace presente, exhibiendo el espacio "del entre". Con todo, hemos preferido destacar en este apartado aquellos casos de plano secuencia digital que explotan un aspecto específico de la plasticidad espacial: la elasticidad de los seis fueras de campo de la imagen.

Siguiendo la definición de Noël Burch ${ }^{1}$, en la teoría cinematográfica, el fuera de campo corresponde al espacio imaginario situado al otro lado de los seis "segmentos" del cubo escénico: los cuatro bordes del encuadre, "más allá del decorado" y "detrás de la cámara". En la imagen cinematográfica, estos márgenes se comportan como un límite permeable, es decir, un objeto puede entrar y salir "de campo".

Así, por ejemplo, como veíamos en el apartado anterior, el zoom out en Citizen Kane permite a Orson Welles explorar esta permeabilidad, introduciendo un elemento de sorpresa. Ahora bien, como subrayábamos con respecto al zoom out intergaláctico de Contact, en la construcción digital, no se trata sólo de contextualizar o cambiar la proporción de un objeto, sino de unir lo distante, lo opuesto, en un movimiento continuo que subraya el espacio intermedio.

\footnotetext{
${ }^{1}$ BURCH, Noël. Praxis du cinema (1969). Paris: Folio Essais, 1986, p. 30.
} 
En otras palabras, gracias al hecho de que la imagen digital es una construcción y no una reproducción, el espacio cobra una elasticidad sin igual, que le permite extenderse de manera centrífuga sin atender a la lógica espacio-temporal de la imagen registro. En ésta, el encuadre "recorta" una sección del espacio profílmico. Así, no es de extrañar que teorías miméticas como la de André Bazin retomen la metáfora de la ventana de Leon-Battista Alberti² ${ }^{2}$ Para el teórico francés, no hay por qué considerar que la imagen cinematográfica se pare en el rectángulo de la pantalla: el fuera de campo se imagina como una continuación homogénea del espacio euclidiano y tridimensional que reproduce la imagen registrada.

Lejos de esta idea, en la construcción espacial de la imagen sintética, no existe encuadre puesto que no hay lente alguna que registre la realidad. Con ello, las posibilidades de explorar el fuera de campo se amplían ilimitadamente. Veamos otros ejemplos de esta potencialidad.

Cinco años antes de Vida Maria, el realizador Daniele Lunghini y el animador gráfico Diego Zuelli crean Le foto dello scandalo (2001), una animación en 3D consistente en un plano secuencia digital de unos seis minutos de duración. El corto narra la persecución a un fotógrafo de prensa, quien, tras haber tomado una instantánea comprometida de un político con su amante, acaba por asesinar a sus acosadores. Aunque la iluminación imita la estética del cine negro (la historia se ambienta en Nueva York, en los años 40), la narración se distancia del lenguaje clásico y explota las posibilidades de la imagen digital: sin pronunciar palabra ni realizar corte alguno, los autores construyen el relato gracias al movimiento continuo de la cámara virtual, que desvela en cada giro un momento posterior de la trama.

Como en Vida Maria, el espacio continuo alberga momentos discontinuos; sin embargo, en esta ocasión, tanto los personajes como los objetos se muestran paralizados mientras la cámara virtual se desplaza entre ellos a su antojo. Como en Source Code, que comentábamos en el apartado dedicado al espacio "del entre", la animación de la imagen corresponde, exclusivamente, a ese desplazamiento. No se trata de congelar todo movimiento en la imagen, sino de la construcción y exhibición de otro: el de la cámara virtual. Esto es, la propuesta no hace sino subrayar el aspecto eminentemente espacial del constructo.

\footnotetext{
${ }^{2}$ BAZIN, André. Qu'est-ce que le cinéma ? (1958). Paris: Éditions du Cerf, 2011, p. 166.
} 
La cámara virtual atraviesa muros y puertas de manera no antropomórfica y subraya el espacio entre sujetos y objetos. Es más, ese espacio intermedio no sólo cobra un protagonismo excepcional, sino que es esa misma construcción espacial la que permite hacer avanzar el relato. Frente a la elipsis del corte cinematográfico, en el plano secuencia digital, se llena el intersticio.
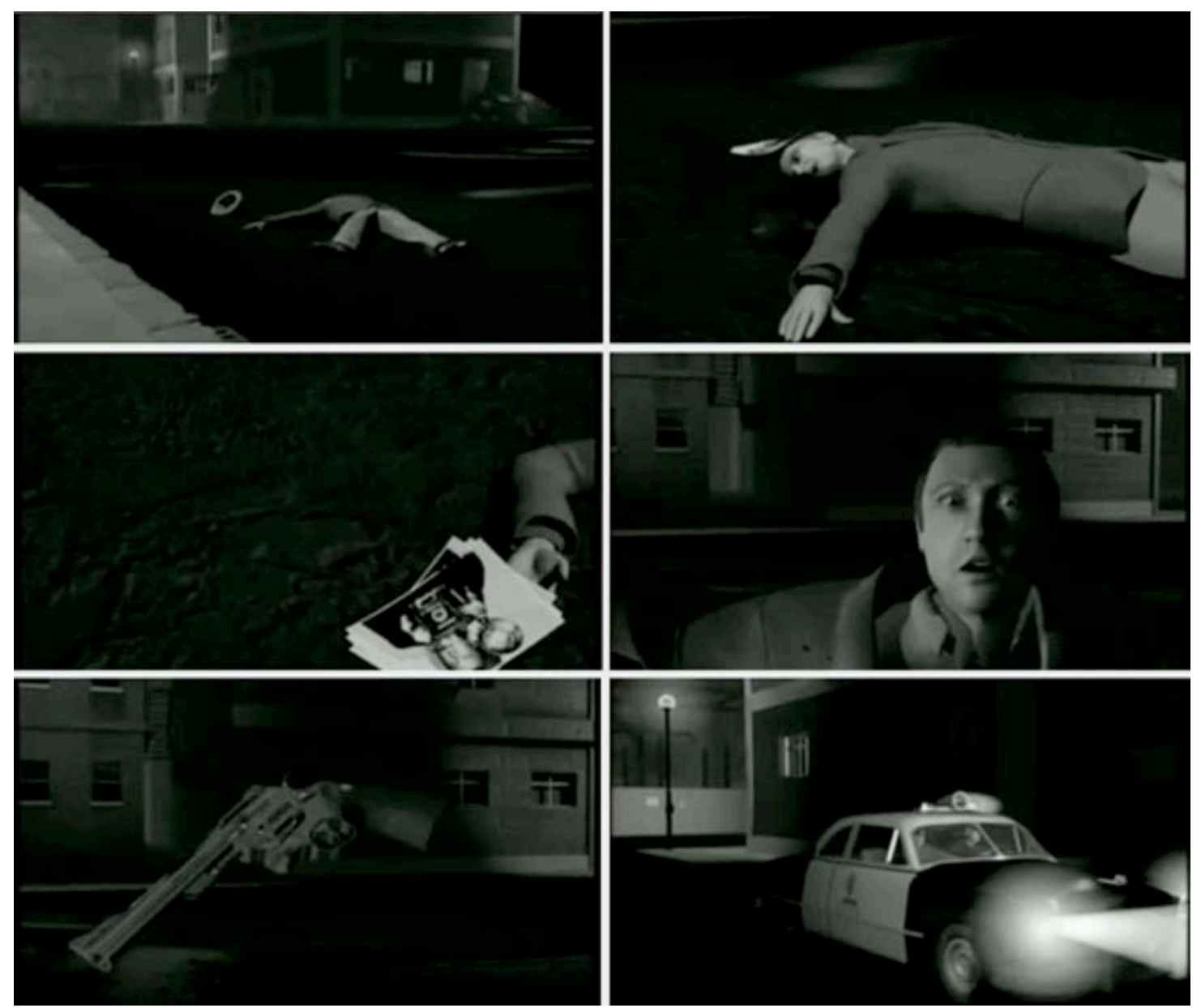

Le foto dello scandalo (2001), de Daniele Lunghini y Diego Zuelli

Hallamos un caso similar en otro corto de animación 3D: Apnée (2006) de Claude Chabot narra mediante un flash back la muerte de un fotógrafo de prensa. El salto hacia atrás no se produce mediante un corte cinematográfico, sino que el desplazamiento continuo permite crear un relato circular, que acaba y comienza con el personaje fallecido. Como en Le foto dello scandalo, la cámara virtual desvela uno tras otro los momentos clave de la trama mientras todos los elementos aparecen congelados. En comparación con la animación de Daniele Lunghini y Diego Zuelli, cinco años anterior, el corto de Claude Chabot destaca por una perfecta adaptación entre forma y contenido, gracias a la simplificación de la historia. 


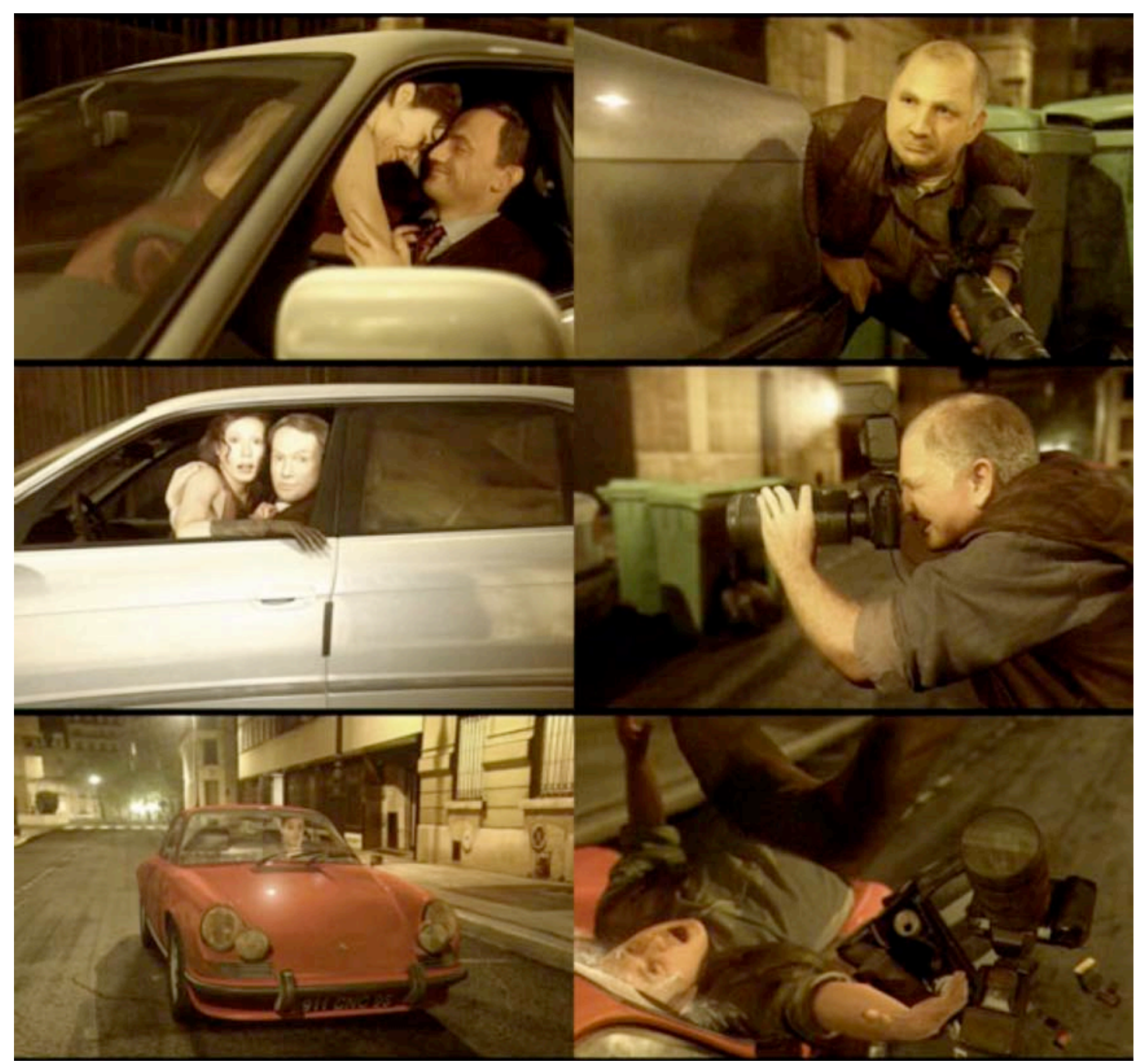

Apnée (2006), de Claude Chabot

El plano secuencia digital de Apnée comienza con un giro en torno a una cámara de fotos suspendida en el aire; el objetivo de ésta refleja al protagonista mientras su cabeza atraviesa un cristal, cuyos pedazos quedan en suspensión. En el suelo, unas revistas muestran en portada al hombre que será presentado inmediatamente después: la cámara virtual se desliza por encima de un BMW, dentro del cual el personaje en cuestión se abraza a una mujer. El fotógrafo, oculto ahora tras el vehículo, sostiene en la mano la cámara con la que daba comienzo el corto. El movimiento continúa hasta mostrar a la pareja en un gesto de sorpresa. Un giro desvela el contracampo: el protagonista está tomando una instantánea comprometida de ambos. Al fondo, tras él, un coche rojo se aproxima; a través del parabrisas, se ve el rostro horrorizado del conductor. De nuevo, un giro de $180^{\circ}$ muestra la causa del espanto: tras ser atropellado, el personaje principal cae sobre el capó y su cabeza rompe el cristal, como en el reflejo del objetivo al inicio de la escena. La cámara virtual continúa rastreando 
el suelo de la calle, en el que quedan esparcidos el material fotográfico y las revistas del principio. La secuencia acaba con un plano cenital que rota sobre el cuerpo yacente del fotógrafo.

La publicidad para la televisión Philips Carousel (2009), realizada por el sueco Adam Berg, presenta un plano secuencia, en principio, comparable a la obra de Chabot. El movimiento ininterrumpido comienza con un primer plano de un policía arrodillado sobre un coche; el desplazamiento continúa en medio de una explosión para adentrarse en un hospital, donde otros policías intentan capturar a una serie de ladrones disfrazados de payasos. Tras recorrer el espacio interior y mostrar el enfrentamiento entre el cuerpo de seguridad y los delincuentes, la cámara sale por la ventana y desciende hasta el primer personaje, que oculta una de las máscaras circenses: el primer policía resulta ser un infiltrado. La congelación de las acciones no impide un desarrollo del relato gracias a la estructura circular, que permite introducir el elemento de sorpresa.

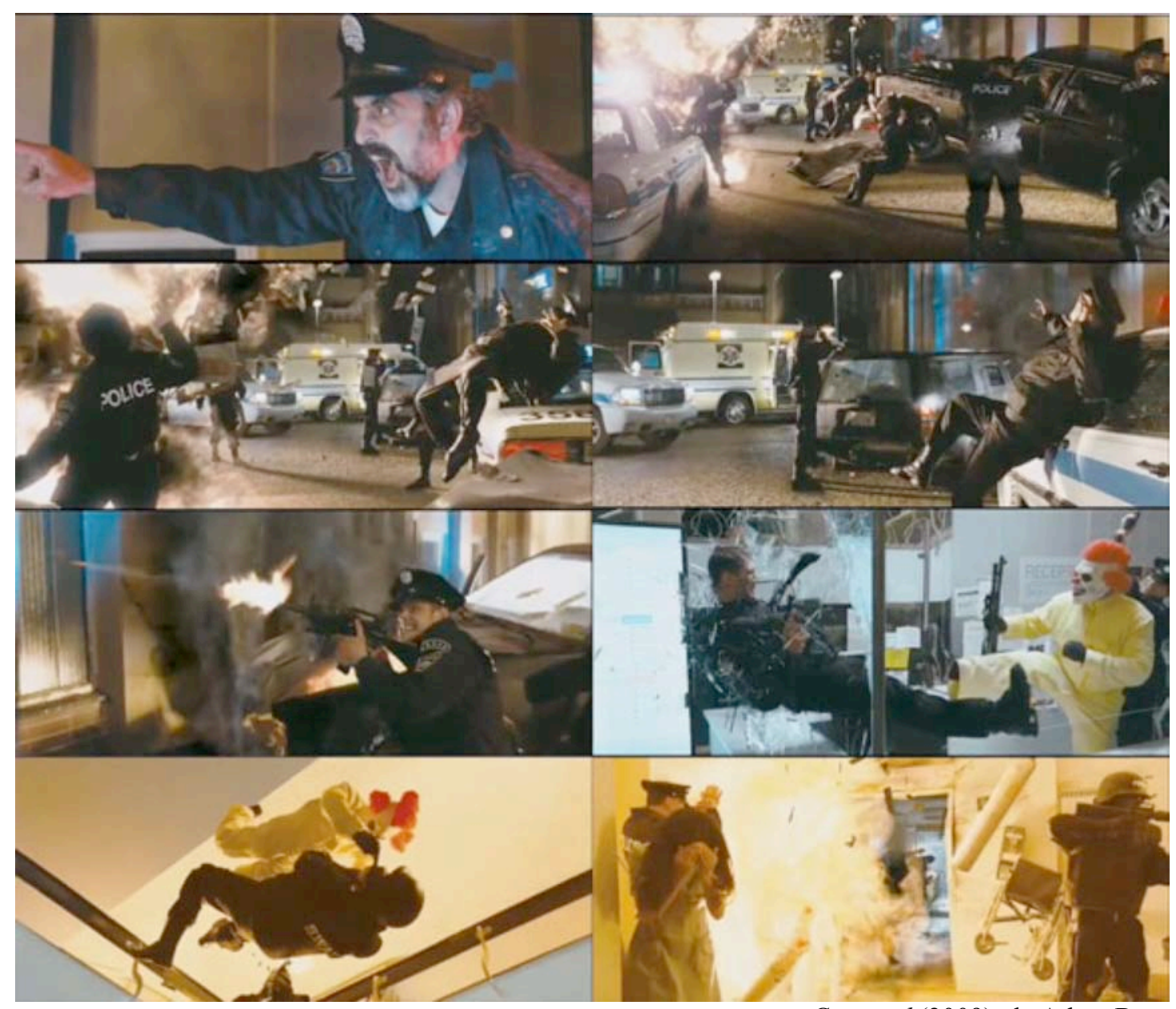

Carousel (2009), de Adam Berg 
En realidad, en esta ocasión, no se trata de una animación en $3 \mathrm{D}$, sino que la escena fue registrada con una cámara física montada sobre raíles. Para lograr el efecto de congelación de los personajes, los actores debieron mantenerse en equilibrio, paralizados como mimos, mientras el aparato se desplazaba siguiendo meticulosamente el programa fijado. Con todo, a pesar de su carácter fotográfico, el plano secuencia tuvo que ser retocado digitalmente en post-producción para eliminar los carriles del travelling y añadir algunos elementos tridimensionales que aparecen suspendidos en el aire.

Aunque el realizador parece querer demostrar cierta banalidad de los efectos digitales, lo cierto es que Carousel no trata el espacio como los planos secuencia digitales analizados. En el anuncio, hay límites físicos que deben ser sorteados rigurosamente, no hay cambio de escala ni una verdadera elasticidad espacial. El incuestionable logro de la obra de Berg es la simulación de la congelación de los personajes. Sin embargo, en lo que respecta al análisis de la continuidad espacial, lo que realmente nos interesa es la omnipotencia de la cámara virtual y la elasticidad del espacio digital.

Es cierto que, frente a la película fotográfica, el vídeo digital HD permite realizar tomas cada vez más largas y complejas gracias a la capacidad de registro o almacenamiento, y al tamaño y manejabilidad de los aparatos. ${ }^{3}$ Junto a Carousel, un buen ejemplo de las posibilidades de esta mejora técnica es la película Russkiy kovcheg (2002) de Aleksandr Sokurov. Grabado en el interior del museo Hermitage en San Petersburgo, el largometraje se constituye de un único plano secuencia de 88 minutos de duración. El "Arca Rusa" resume trescientos años de historia en un plano continuo de hora y media: desde la creación de la nueva capital por Pedro I hasta la llegada de los bolcheviques y el fin de la monarquía. Una captura semejante sólo pudo ser posible gracias al uso de una steadicam digital HD, especialmente diseñada para la película y cargada a lo largo de toda la toma por el cámara Tilman Büttner. Sokurov presenta de manera continua los saltos temporales que permiten la condensación de tres siglos. Con todo, el larguísimo plano secuencia de Russkiy kovcheg no se aleja del concepto cinematográfico ligado al registro ininterrumpido: poco importa si la tecnología usada en la grabación es digital o no.

\footnotetext{
${ }^{3}$ Cfr. PRÉDAL, René. Le cinéma à l'heure des petites caméras. Paris: Klincksieck, 2008.
} 
De hecho, en el cine clásico, existen también planos secuencia que presentan una condensación temporal. ${ }^{4}$ Pensemos, por ejemplo, en la película de Alfred Hitchcock Rope (1948), adaptación de la obra de teatro Rope's end de Patrick Hamilton. Para figurar el paso del tiempo en el relato, la ventana del piso muestra los cambios de iluminación en el exterior. Respetando la unidad de decorado de la versión teatral, la acción se desarrolla en un único lugar mientras la cámara registra las conversaciones entre los personajes. Aunque el resultado parece compuesto por una sola toma de 75 minutos, en realidad, debido a la imposibilidad técnica de realizar tal registro (la película debía cambiarse cada 10 minutos), el realizador tuvo que acudir a un trucaje que disimulase los empalmes. Así, el traje de chaqueta de un personaje funciona como un fundido en negro, que permite acoplar dos tomas sin romper el movimiento continuo. Curiosamente, es precisamente este "trucaje", que será criticado en Rope, el que explota sin complejo la experimentación digital.

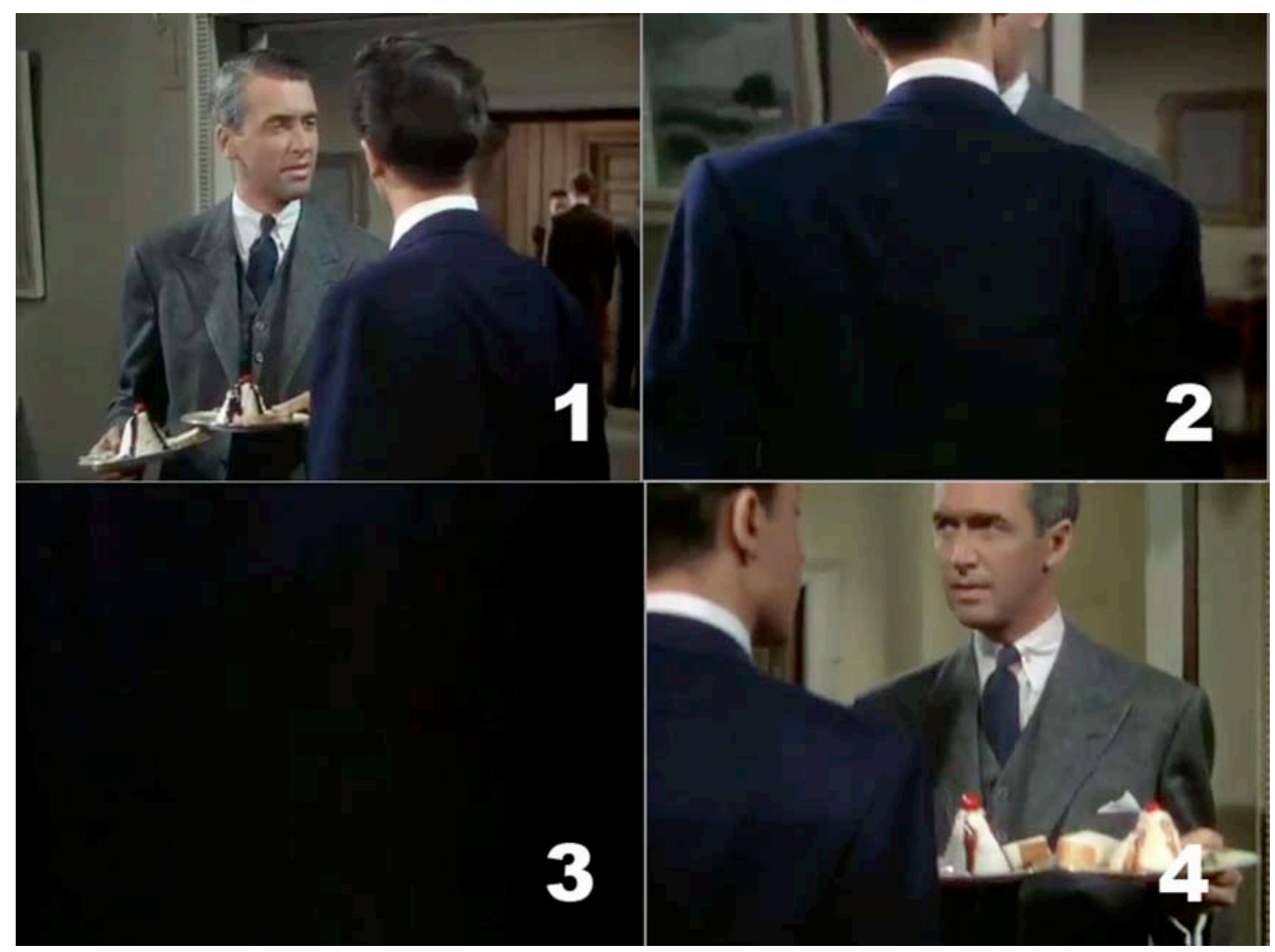

Rope (1948), de Alfred Hitchcock

\footnotetext{
${ }^{4}$ Normalmente, en un plano secuencia cinematográfico, el tiempo representado en la imagen coincide, grosso modo, con el tiempo cronológico compartido por el espectador; éste es el caso, por ejemplo, de la célebre apertura de 12 Angry Men (1957), de Sidney Lumet.
} 
Evidentemente, este uso del montaje espacial como sutura entre las imágenes aleja las construcciones que analizamos del concepto de plano secuencia defendido por André Bazin. Su teoría del "montage interdit" ("montaje prohibido") responde a la búsqueda de lo específicamente cinematográfico. Para el fundador de los Cahiers du cinéma, las figuras inherentes a este medio serán aquéllas que correspondan a la percepción humana. De ahí, la sustitución del corte a favor del plano secuencia. ${ }^{5}$

Las posibilidades ilimitadas del plano secuencia digital no deben confundirse, tampoco, con la célebre sentencia de Pier Paolo Pasolini (1922-1975): “el cine es un plano-secuencia infinito"6. El italiano comparte con las vanguardias de los años 20 la búsqueda de un lenguaje específicamente cinematográfico, que ha de ser, además, universal. De acuerdo con Pasolini, el cine reproduce la realidad visual. Sin embargo, al contrario que Bazin, rechaza el plano secuencia como paradigma del cine directo, que se limitaría a copiar la realidad visual sin darle un lenguaje articulado.

Tal y como lo definimos en este trabajo, el plano secuencia digital no corresponde a la imitación de la visión humana perseguida por Bazin ni al concepto de "realidad visual" de Pasolini: lejos de la reproducción y la representación, el plano secuencia digital hace referencia a la construcción de un espacio específico de la imagen. Este espacio elástico está íntimamente ligado a la omnipotencia de la cámara virtual, sea ésta un cálculo puramente sintético o producto de la sutura entre diversas imágenes fuente.

Este último caso es el que hallamos en la siguiente escena de la película $\mathrm{New}$ Moon (2009), de Chris Weitz. El desplazamiento comienza detrás de la protagonista, que mira a través de la ventana de su cuarto. Con la palabra "octubre" sobreimpresa en la imagen, la cámara sobrevuela la cabeza de la chica y desvela, poco a poco, la habitación al fondo. Completado el giro de $360^{\circ}$, nos situamos de nuevo en el punto de partida. Bajo los títulos "noviembre" y "diciembre", se repite la misma trayectoria circular, mostrando a través de la ventana las inclemencias meteorológicas. Han pasado dos meses, es invierno fuera $\mathrm{y}$, sin embargo, dentro todo continúa igual: la misma postura, la misma ropa...

\footnotetext{
5 "La spécificité cinématographique, saisie pour une fois à l'état pur, réside (...) dans le simple respect photographique de l'unité de l'espace." BAZIN, André. Op. cit., p. 55.

6 "Il cinema è un piano-sequenza infinito - $l$ 'ho detto ormai dozzine di volte - è ideale e virtuale riproduzione infinita dovuta a una macchina invisibile che riproduce tali e quali tutti i gesti, gli atti, le parole di un uomo da quando nasce a quando muore." PASOLINI, Pier Paolo. Empirismo eretico (1972). Milano: Garzanti, 1991, p. 229.
} 

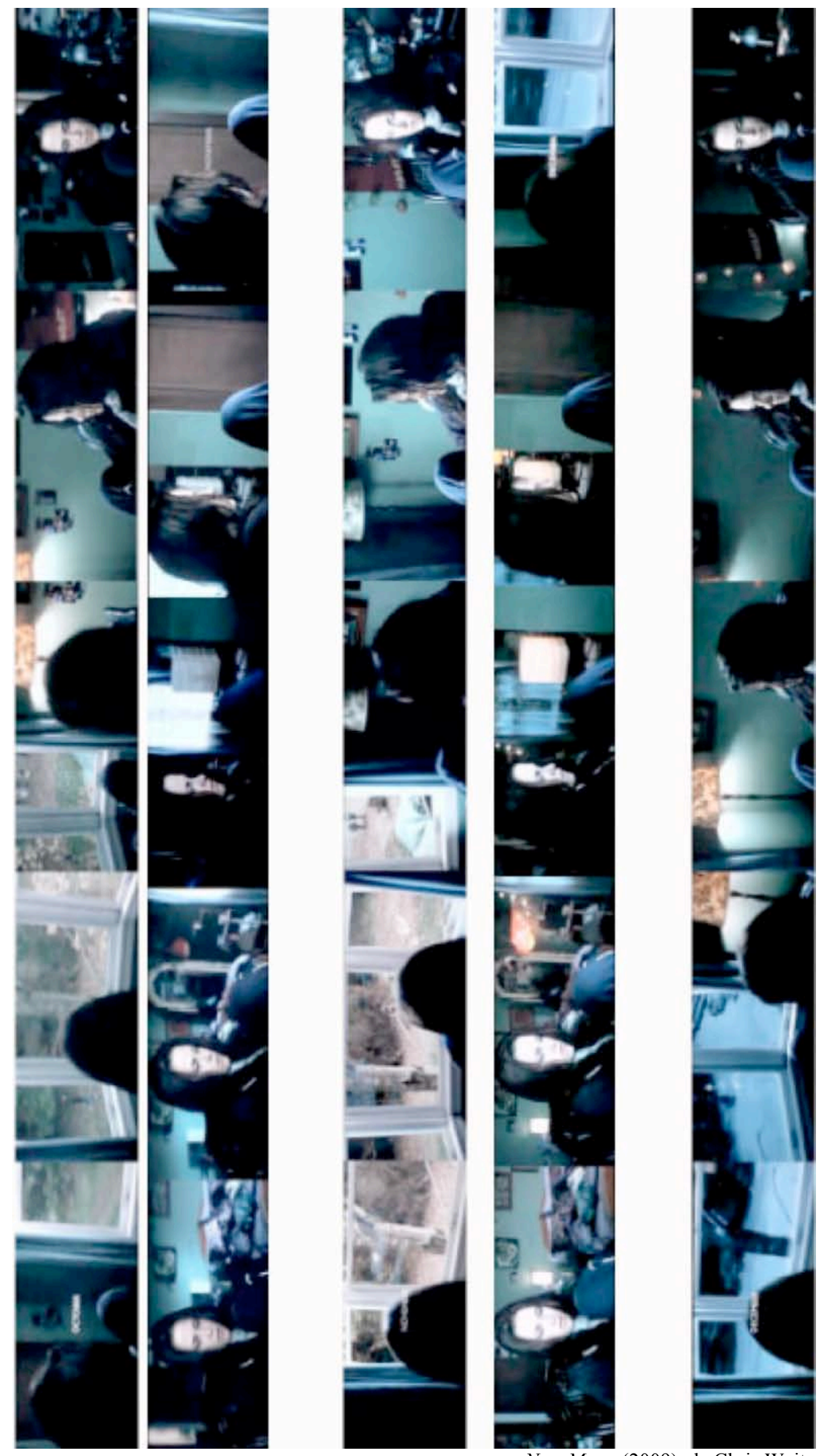

New Moon (2009), de Chris Weitz 
Un análisis atento permite comprobar que las dos vueltas completas son, en realidad, la misma toma transformada digitalmente. Un trabajo de la imagen en capas permitió introducir cambios en el espacio enmarcado por la ventana. Gracias a esta composición, dos tiempos conviven en la imagen: el del exterior, que refleja el paso de las estaciones, y el de dentro de la habitación, vivido por la protagonista. El movimiento circular de la cámara da acceso a las variaciones meteorológicas y funciona como metáfora de la repetición cíclica de las estaciones.

Este uso de la ventana como marca del paso del tiempo remite a la misma estrategia en Rope. Sin embargo, en lo que respecta al movimiento continuo de la cámara, Hitchcock se ve obligado a acudir a un trucaje para empalmar las tomas como si el registro hubiera tenido lugar en una sola captura continua. Al contrario, en el plano secuencia digital de New Moon, la cuestión no es la simulación del aparato físico, sino la construcción de una entidad espacio-temporal imposible, exclusiva de la imagen. Los márgenes adquieren más elasticidad a medida que el espacio se aleja de la imagen huella.

Como en la animación sintética Vida Maria, el movimiento de la cámara virtual permite ligar en un espacio continuo momentos discontinuos. O dicho de otro modo: la dilatación espacial posibilita la condensación temporal. Ahora, si Ramos retrata una vida entera, Weitz sintetiza varios meses en algunos segundos. Por ello, en el corto, el fondo continúa igual mientras el personaje va envejeciendo; en cambio, en la película, la protagonista permanece inmutable mientras el decorado y el espacio fuera de la ventana cambian. Con todo, en ambas, la cámara virtual no sólo permite avanzar el relato, sino que exhibe un punto de vista a medio camino entre el sujeto y el espacio que lo alberga. Esta comparación entre los dos planos secuencia digitales, uno construido mediante síntesis y el otro gracias al montaje espacial, permite constatar una concepción común del espacio.

La publicidad de la obra social de La Caixa (2011), realizada por Ene, presenta un plano secuencia digital que recorre de un vistazo el último siglo. El constructo se creó a partir de siete tomas, ambientadas en diversas épocas. Los registros retocados por ordenador se ordenaron cronológicamente y se "cosieron", de modo que la cámara virtual parece recorrer un espacio unitario. Aunque el cuadro funciona como entidad 
unificadora del espacio, ésta no tiene por qué implicar una unidad temporal. ${ }^{7}$ De nuevo, la discontinuidad de los fragmentos da paso a una continuidad espacial, acompañada por una condensación temporal. Ahora bien, si en los giros centrípetos de New Moon el trabajo del fuera de campo se concentra en los márgenes laterales del cuadro, la publicidad de Ene explora la elasticidad del espacio en profundidad de manera semejante a los zoom en el apartado anterior.

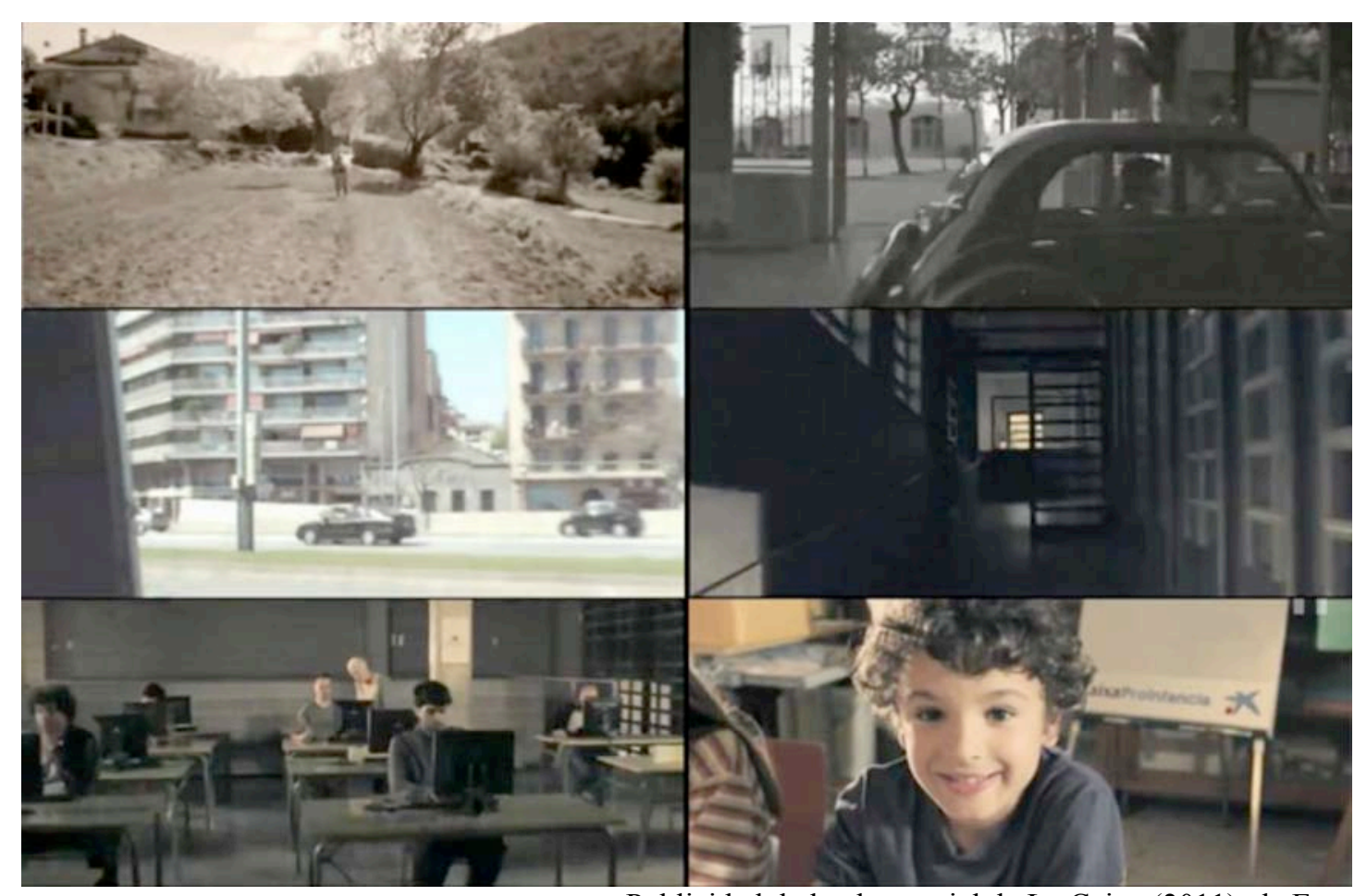

Publicidad de la obra social de La Caixa (2011), de Ene

Más de veinte años antes, el artista Zbigniew Rybczynski había explorado ya la construcción de un plano secuencia digital. En el videoclip Imagine (1986) para la canción de John Lennon, la composición presenta una suerte de panorámica. La cámara virtual se desliza de izquierda a derecha, mostrando el interior de un edificio imposible. Rybczynski se deleita en el intersticio, haciéndolo coincidir con los muros y puertas que conectan las diversas habitaciones.

En el apartado dedicado a "La cohabitación de las imágenes", analizábamos la obra del mismo autor Nowa ksiazka (1975) y veíamos cómo las líneas que demarcan

\footnotetext{
7 "As moving images follow each other in sequence -frame-by-frame, shot-by-shot- they are held within the fixed frame of a screen, a surface that holds its constancy regardless of the continuous or radically discontinuous spatial and temporal relation between shots. In this way, the prevailing format for moving-image media did not follow literary, painterly, or even architectural challenges to the perspectival frame but held on much longer to the strictures of its 'symbolic form'." FRIEDBERG, Anne. Op. cit., p. 192.
} 
los sub-cuadros dejan entrar y salir a los personajes. En Imagine, Rybczynski añade a esta investigación de un espacio-tiempo videográfico las posibilidades plásticas de la cámara virtual. Ésta acompaña el deambular de aquéllos y liga los cuadrantes en un único espacio heterogéneo. La panorámica digital desvela poco a poco los cambios en el tiempo. Como en Vida Maria, el crecimiento de los personajes se muestra mediante la costura espacial continua de momentos discontinuos.

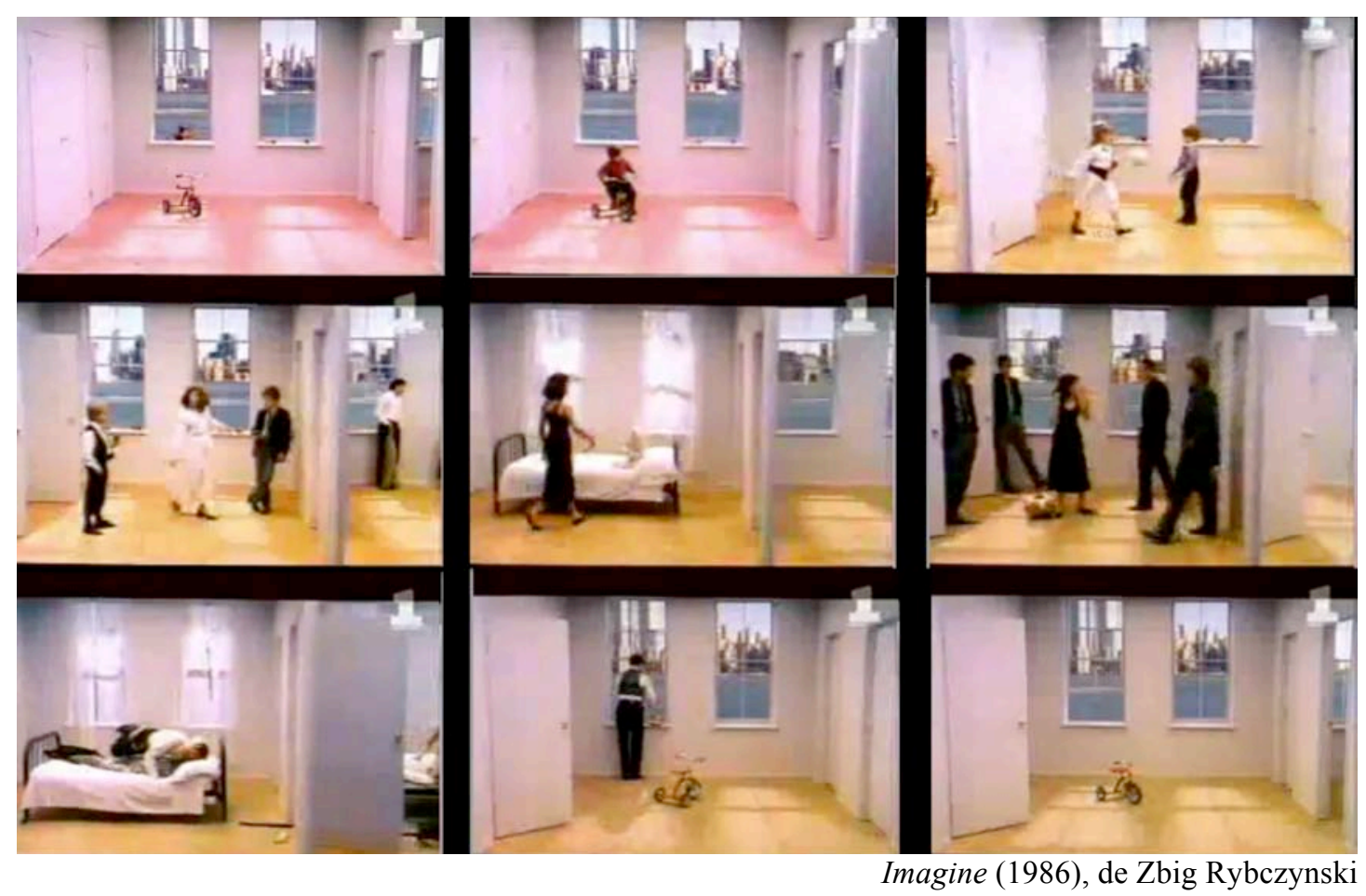

La panorámica como movimiento de un aparato físico fue inventada en $1900^{8}$. Aquella dinamización lateral pretendía imitar la percepción humana: el giro de la cámara sobre su propio eje correspondía al de la cabeza de un testigo antropomórfico. Como veíamos, esta interpretación será recogida más tarde por Pudovkin y adoptada, también, por las teorías miméticas como la de André Bazin. No obstante, en las antípodas de esta idea, la figura del plano secuencia digital no corresponde al registro ininterrumpido del espacio profílmico; no debe nada a esta mímesis de la percepción humana ni a un pretendido testigo antropomórfico. Como bien entendió Rybczynski, la cuestión es, por el contrario, construir un espacio-tiempo exclusivo de la imagen, una entidad autorreferencial que presenta en continuidad lo discontinuo.

\footnotetext{
${ }^{8}$ BRISELANCE, Marie-France. Op. cit., p. 92.
} 
Se trate de un movimiento lateral o en profundidad, los ejemplos citados subrayan la potencia de la elasticidad del espacio digital como forma de condensación temporal. No obstante, la continuidad del movimiento de la cámara virtual puede servir, también, para la construcción de "collage en profundidad", más cerca de las preocupaciones plásticas del surrealismo o el dadaísmo que de la sintaxis audiovisual.

\section{El collage en profundidad}

La película de Tarsem Singh The Cell (2000) da forma a la inmersión en la mente de un psicópata mediante un plano secuencia digital. Aunque de diversa procedencia y escala, las imágenes quedan perfectamente ligadas entre sí de manera transparente. La lograda composición explota la elasticidad del espacio digital tanto en lo que concierne a los márgenes laterales como en profundidad: la cámara virtual se libera desplazándose hacia delante, hacia arriba, hacia abajo y en forma de arco; permitiendo a la imagen desplegarse en todas direcciones.

El plano secuencia digital comienza con un zoom in a través de un tejido psicodélico, cuyas entrañas se exhiben en una escala macro semejante al zoom out de Fight Club. La cámara virtual desemboca en el interior de un pantano y se desplaza verticalmente hasta salir a la superficie. Una vez fuera y a través de la vegetación, muestra la celebración de un bautizo; dibujando un arco de $180^{\circ}$, deja ver el punto de vista cenital de la escena. A continuación, se sumerge en el líquido y muestra los glúteos desnudos de un personaje; la cámara virtual se desplaza verticalmente, descubriendo poco a poco las piernas hasta llegar a los pies, los cuales, contra todo pronóstico, se presentan a la inversa. La unión de las diversas partes anatómicas da lugar a una composición imposible, antinatural. De este modo, el movimiento continuo de la cámara virtual no sólo destruye la dicotomía dentro/fuera, sino la oposición delante/detrás.

En este aspecto, la propuesta de Tarsem Singh, podría asociarse con la escena del baile de los cosacos en la película Staroe i novoe (1929), de Serguei Eisenstein. Mediante un montaje rápido, el realizador crea una unidad corporal heterogénea gracias a la suma de los pies de los cosacos y el torso de un bolchevique. Recordemos que, en los años 20, el cine soviético lleva al extremo la reestructuración del material fílmico gracias al montaje temporal. Tal y como subraya David Bordwell: "El descubrimiento más radical fue que se podía pedir a los espectadores que unificaran 
espacios de manera físicamente imposible. (...) un espacio 'abstracto' que no podría existir empíricamente." 9

Ahora bien, en esta edición secuencial de los planos, la continuidad afecta al espacio fílmico. En el plano secuencia digital, no basta con sugerir o dar a entender unas conexiones espaciales entre los planos, que ha de descifrar el receptor de la imagen: aquí, la continuidad es la del movimiento mismo de la cámara virtual, de modo que la propuesta pasa por la exhibición explícita de ese constructo imposible.
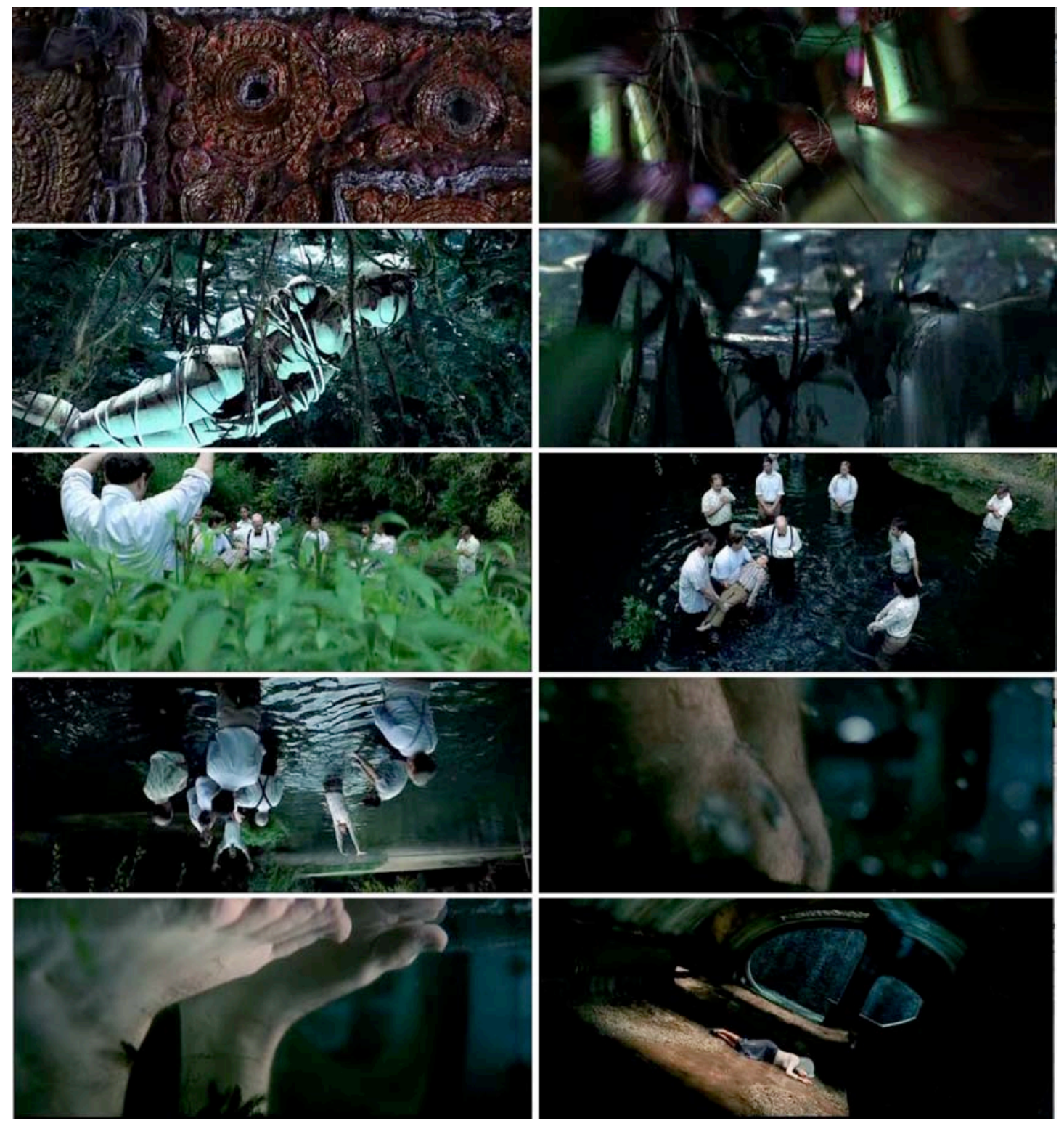

The Cell (2000), de Tarsem Singh

\footnotetext{
${ }^{9}$ BORDWELL, David. Narration in the fiction film. Op. cit., p. 243.
} 
Con el videoclip Je danse le Mia (1994) para el grupo musical IAM, Michel Gondry presenta una inmersión en continuidad a través de imágenes antes inconexas. La sutura se consigue mediante un montaje espacial que el ojo no alcanza a distinguir. Así, la continuidad del desplazamiento es subrayada por la transparencia con que se producen las transiciones. El constructo es fruto de la descomposición del espacio profílmico y la recomposición en un espacio propio a la imagen; un espacio que concuerda con la afirmación de Pierre Francastel respecto a la pintura moderna: "El principio de unidad es exigido a la visión y no a la intelección, los valores ópticos lo llevan a la imaginación." 10
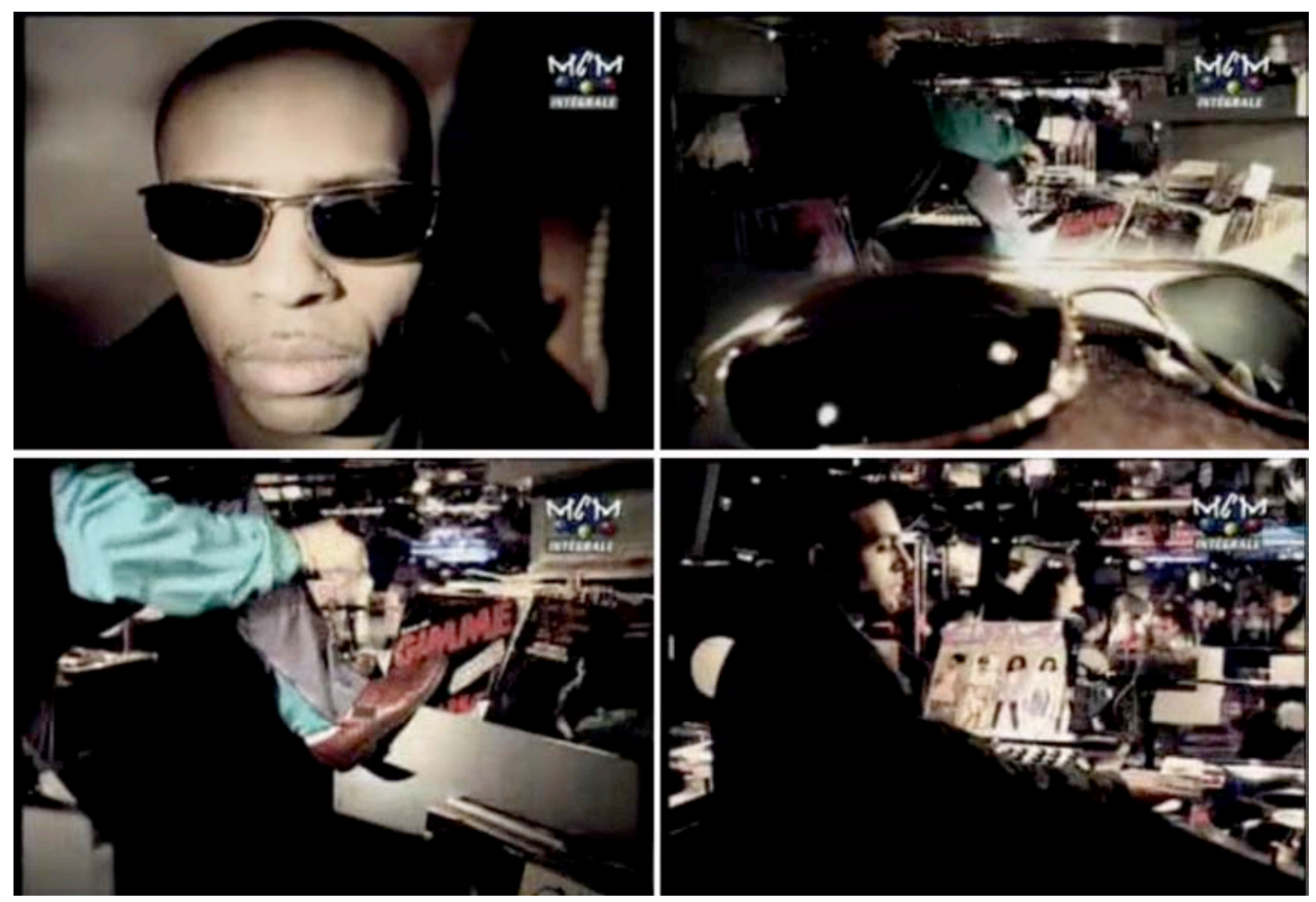

Je danse le Mia (1994), de Michel Gondry

En el videoclip Thinking About You (2007) de Ace Norton para Norah Jones, un largo zoom in une imágenes heterogéneas que, enmarcadas en nubes, simulan los pensamientos de los personajes. En esta ocasión, no se trata sólo de ligar las tomas de manera transparente, sino que las diversas imágenes fuente coexisten de manera simultánea en el interior del cuadro. Esta combinación de la cohabitación y la cámara virtual permite relacionar el videoclip con una obra veinte años anterior: Pictures, de Waliczky. Con todo, en Thinking About You, las imágenes fuente no son fotografías fijas, sino tomas en movimiento.

\footnotetext{
${ }^{10}$ FRANCASTEL, Pierre. Op. cit., p. 232.
} 


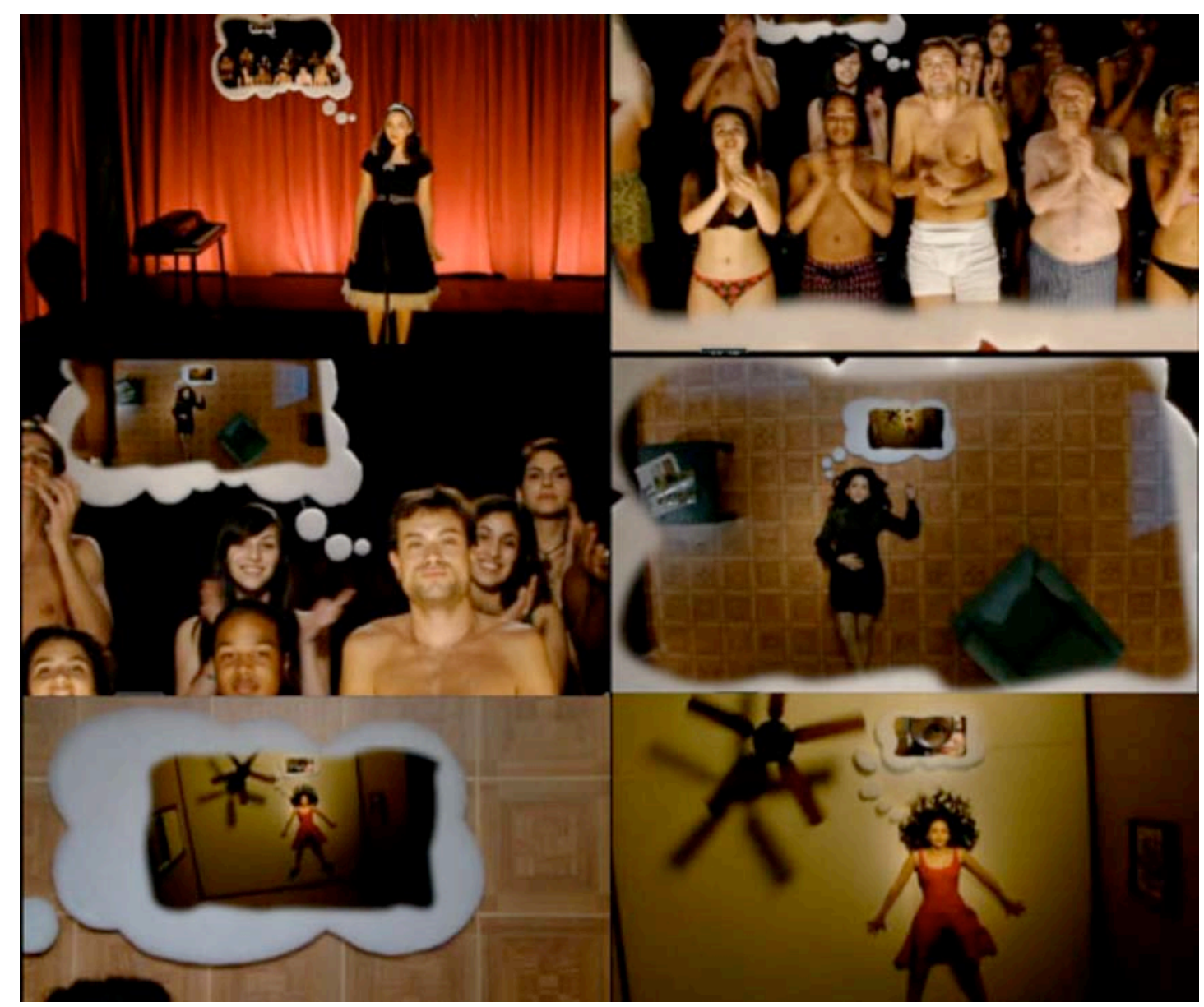

Thinking About You (2007), de Ace Norton para Norah Jones

En el apartado anterior, veíamos cómo el zoom out puede introducir un elemento de sorpresa. En este sentido, el clip de $\mathrm{AB} / \mathrm{CD} / \mathrm{CD}$ para la canción de Uffie Difficult (2010) refuerza la comicidad del espacio surrealista al decantarse por el retroceso de la cámara virtual. Ésta se desplaza "de espaldas", al ritmo del paso seguro de la cantante, de modo que la distancia relativa entre ambas se mantiene constante. El zoom out revela un largo pasillo, dividido en varios tramos por puertas, que la cámara virtual omnipotente atraviesa sin dejar rastro. Aunque las distintas secciones del corredor parecen repetir, una y otra vez, el mismo espacio (con los mismos personajes realizando las mismas acciones), en realidad, se añaden nuevos aspectos a medida que la cámara retrocede.

Esta construcción en bucle es comparable a Tango de Rybczynski, que estudiamos en el primer capítulo como ejemplo de mezcla espacial. Sin embargo, mientras que el realizador polaco se concentra en la profundidad de la imagen constituida por capas, en el videoclip que nos ocupa, el montaje espacial permite crear el plano secuencia digital. 


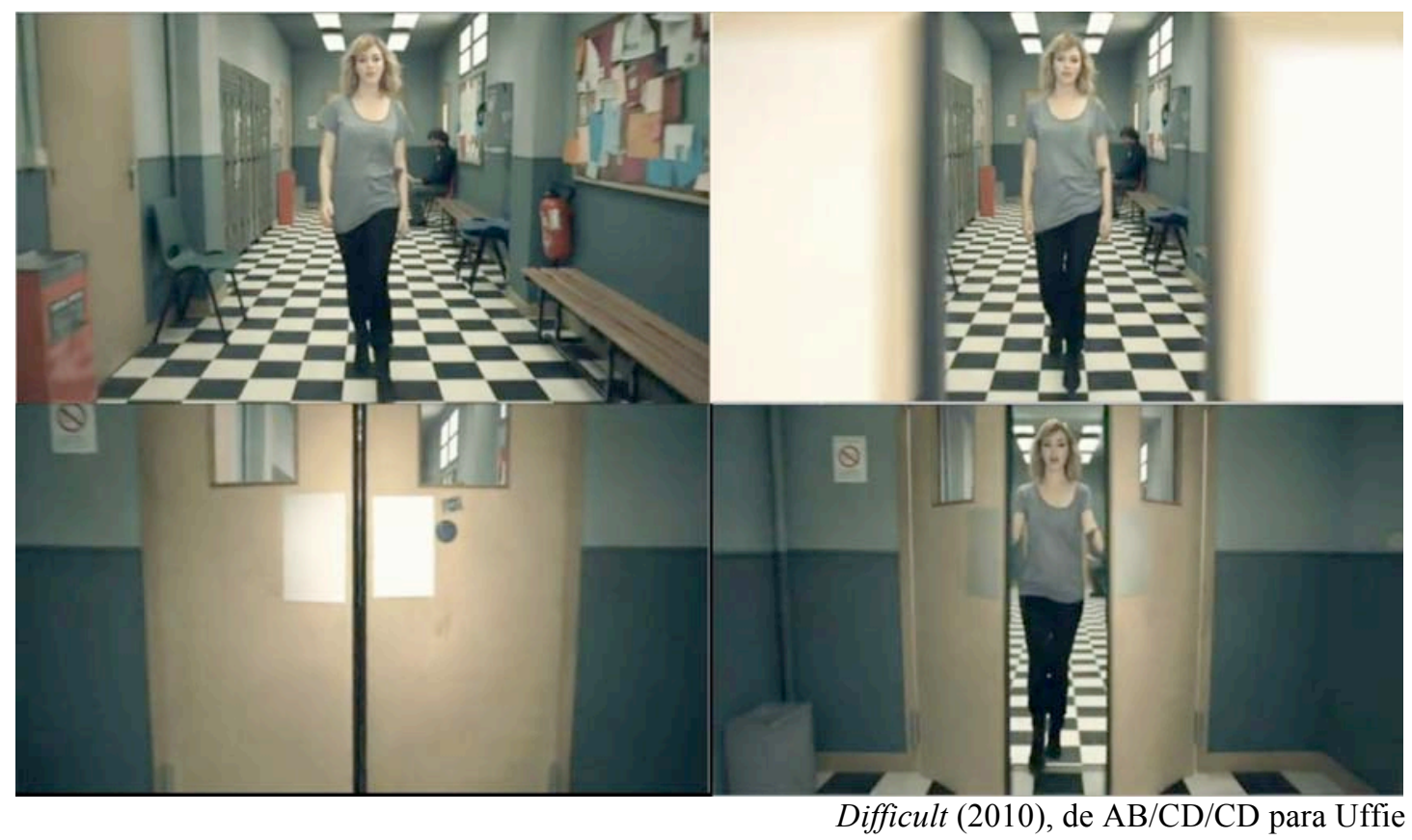

En general, esta construcción del plano secuencia digital mediante montaje espacial pasa por erradicar cualquier huella del empalme en aras de la continuidad del desplazamiento de la cámara virtual. No se trata de negar el constructo (como en Rope, de Hitchcock), sino de fluidificar el movimiento y exaltar la continuidad frente al corte temporal. No obstante, existen casos de esta figura digital en los que las suturas se subrayan deliberadamente. Veamos un ejemplo en el corto The Parthenon (2004), dirigido por Paul Debevec para la Foundation of the Hellenic World. La idea central de la obra es la de insertar en el templo de la Acrópolis (Atenas) las esculturas exhibidas en el British Museum (Londres), reuniendo así en la imagen lo que la historia ha separado.

La animación contiene un plano secuencia digital compuesto por varios crossdissolve, que permiten la transición continua entre ambas capitales. La cámara se aproxima al friso frontal del Partenón en ruinas al tiempo que una sobreimpresión restituye la metopa ausente. Por un instante, el relieve reaparece en su emplazamiento original, antes de dar paso a su localización actual en el museo británico. Tras repetir el mismo proceso varias veces, un zoom out muestra la Acrópolis con la apariencia que se le atribuye en el siglo $\mathrm{V}$ a.C. Nuevamente, el movimiento de retroceso incorpora un elemento de sorpresa que supone una redimensión espacial: en realidad, no se trata más que de una maqueta de la ciudad griega en la sala del British Museum. 


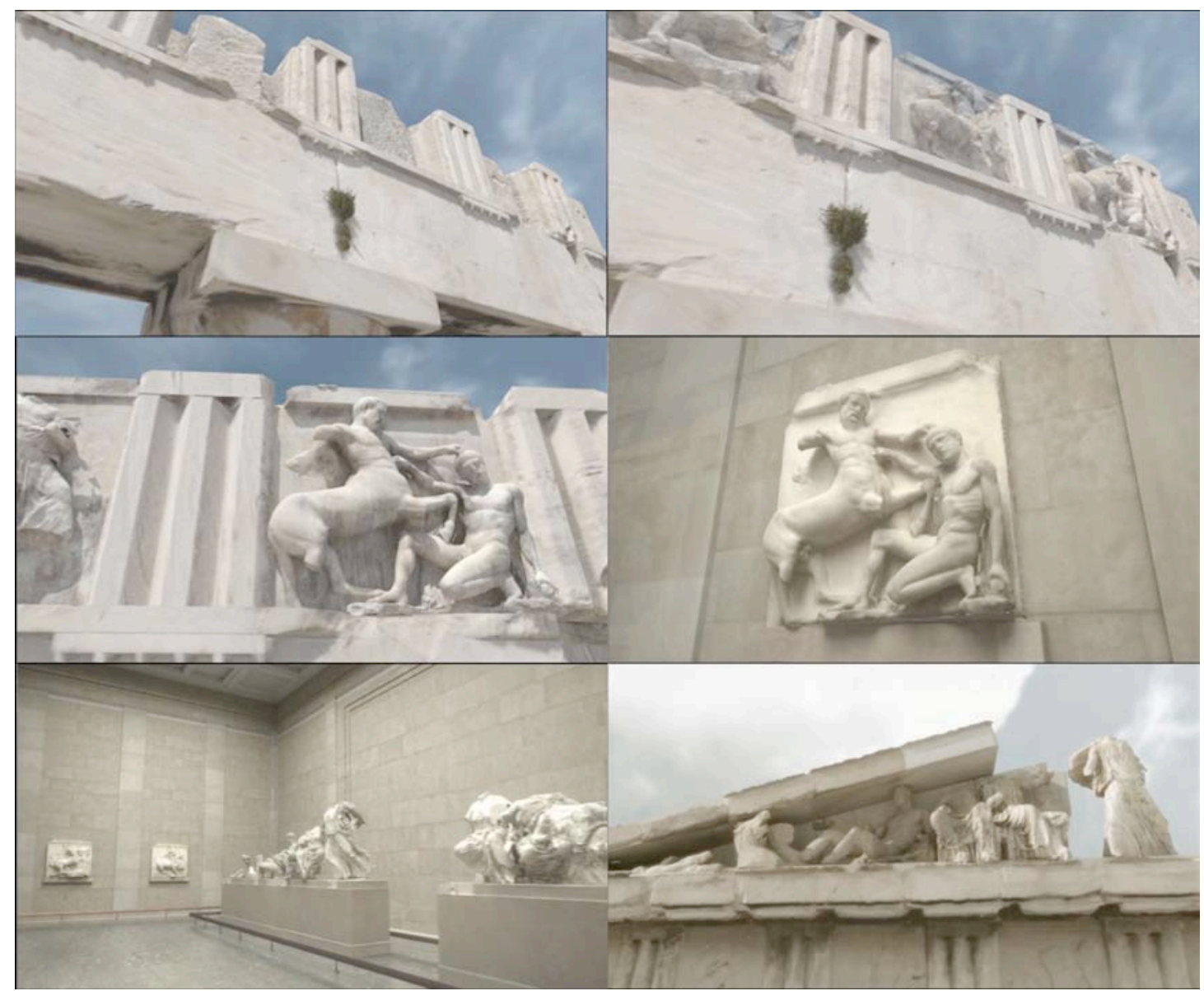

The Parthenon (2004), de Paul Debevec

En lugar de presentar simplemente una imagen sintética del Partenón con todas sus piezas restituidas, Debevec se decanta por un ir y venir entre Atenas y Londres, condensando el viaje espacial en las costuras explícitas entre las imágenes. Esas imágenes-mezcla subrayan el espacio intermedio. Frente a la teletransportación en Jumper de Doug Liman, que describíamos en el capítulo anterior, las transiciones del museo británico a la Acrópolis subrayan la distancia física entre los dos emplazamientos.

En realidad, Debevec recibió el encargo de The Parthenon en 1996, inmediatamente después de haber presentado una técnica de síntesis 3D en el SIGGRAPH. ${ }^{11}$ Grosso modo, la propuesta combinaba técnicas de síntesis geométrica con métodos basados en la recolección de imágenes y su tratamiento digital. El

\footnotetext{
${ }^{11}$ DEBEVEC, P. E.; MALIK, J.; TAYLOR, C. J.. "Modeling and Rendering Architecture from Photographs: A hybrid geometry- and image-based approach". En: ACM SIGGRAPH'96, Proceedings of the 23rd annual conference on Computer Graphics and interactive techniques. New Orleans. August 1996, pp. 11-20.
} 
proceso de "multiple-view reconstruction"12 permite construir un volumen tridimensional a partir de varias fotografías de un mismo espacio desde distintos puntos de vista; entre ellas, el ordenador calcula el espacio intermedio. El autor realizó una demostración con el corto The Campanile Movie (1997), en el que la cámara virtual gira libremente en torno a una torre de la universidad de Berkeley.

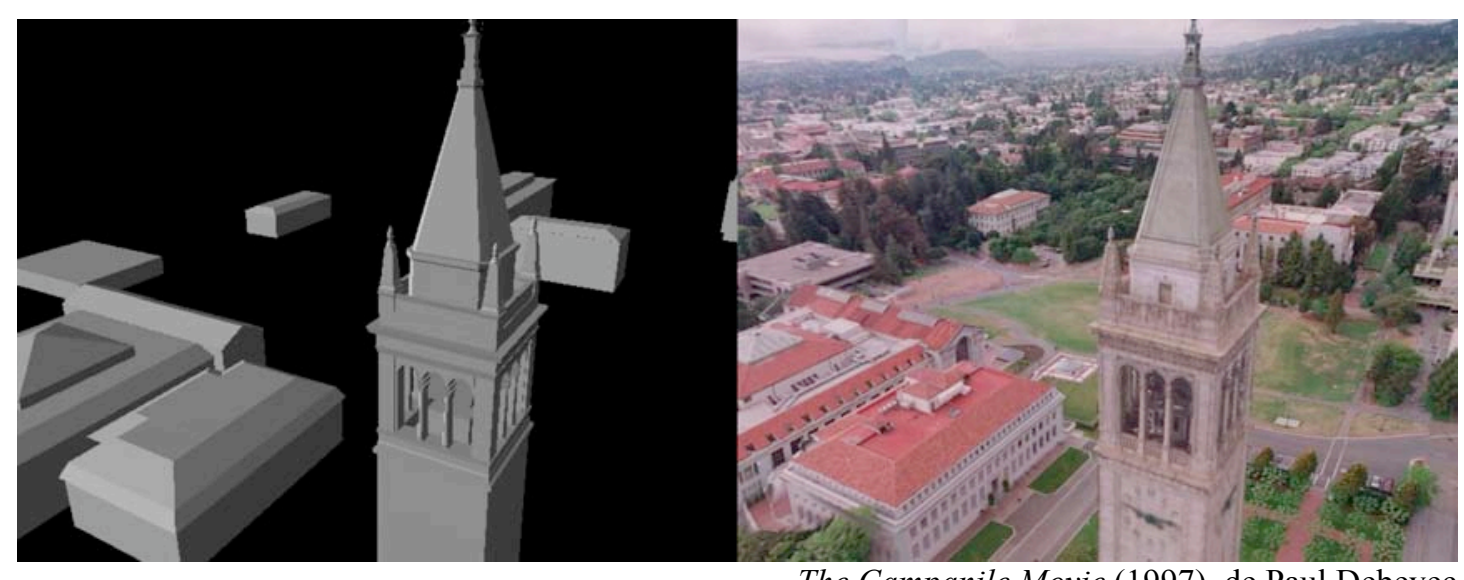

The Campanile Movie (1997), de Paul Debevec

Entre otros, este efecto inspirará a Andy y Lana Wachowski la elaboración del "bullet time" de The Matrix (1999). ${ }^{13}$ Sin embargo, la "multiple view reconstruction" es una reproducción de una escena tridimensional; en este sentido, la concepción espacial subyacente es la de un espacio euclidiano, mensurable matemáticamente. En la película, los Wachowski no se contentan con la mímesis fotorrealista. Como veremos en el próximo apartado, la construcción de esta cámara virtual permite explorar un espacio-tiempo específico de la imagen; un espacio caracterizado, nuevamente, por la estética del entre: entre los sujetos y los objetos, entre las dos y las tres dimensiones, entre la imagen fija y la animada.

\footnotetext{
${ }^{12}$ Las técnicas de "multiple-view reconstruction" difieren según el número de imágenes-fuente de las que se dispone y los datos de partida sobre las relaciones espaciales tridimensionales. En este sentido, ver: SHUM, Heung-Yeung; KANG, Sing Bing. A Review of Image-based Rendering Techniques [En línea]. Institute of Electrical and Electronics Engineers, June 2000. Disponible en Web: $<$ http://research.microsoft.com/apps/pubs/default.aspx?id=68826>

13 "When I saw Debevec's movie, I knew that was the path." John Gaeta, supervisor de los efectos visuales de The Matrix. Apud. SILBERMAN, Steve. MATRIX ${ }^{2}$. Bullet Time was just the beginning. F/x guru John Gaeta reinvents cinematography with The Matrix Reloaded. [En línea]. Wired, May 2003. Disponible en Web: <http://www.wired.com/wired/archive/11.05/matrix2_pr.html>
} 


\section{LA INSTANTÁNEA TRIDIMENSIONAL}

Gracias al hecho de que la cámara virtual es un constructo espacial, es posible extirpar el movimiento del cuadro de toda lógica temporal ligada al registro. En el apartado anterior, veíamos cómo Le foto dello scandalo y Apnée exploran la elasticidad de los márgenes para introducir variaciones que permiten hacer avanzar el relato. Más aún, en ambas animaciones sintéticas, la construcción espacial no sólo permite condensar el tiempo, sino que el cuadro se desplaza libremente en contraste con la congelación de los personajes.

Landscape (1997), de Tamás Waliczky, es una animación por ordenador que presenta un pueblo alemán (Busenbach), en el que los seres están paralizados mientras la cámara virtual recorre el espacio, fuera de ese tiempo, no sometida a sus leyes, como el único ser viviente de la imagen. El artista húngaro se concentra en la tensión entre fijación y movimiento, proponiendo una suerte de "instantánea tridimensional". Frente a la condensación temporal de los planos secuencia citados, Waliczky explora la dilatación espacial de un único momento.

Creada con el programa de animación en 3D Softimage (co-desarrollado por la artista Char Davies), la construcción partió de varias fotografías, tomadas con una separación de un metro entre cada una de ellas. A la hora de unir digitalmente las distintas capturas, Waliczky y su asistente de animación, Christina Zartmann, acudieron al morphing: las interpolaciones entre las imágenes fijas permitieron crear 700 frames a partir de, tan sólo, 7 fotografías. ${ }^{1}$ Es decir, a pesar de su apariencia de registro, el $99 \%$ fue construido mediante el cálculo informático del espacio intermedio. Así, en Landscape, la cámara virtual no sólo subraya el espacio entre los seres (vivientes o no), sino que la mismísima construcción de la imagen remite a ese espacio entre los fotogramas.

Aquí, la cámara virtual es el producto del cálculo sintético entre las imágenes de partida, que funcionan como materia prima para la transformación. Con todo, conviene matizar que, en el proceso de construcción, la "instalación multicámara" juega también un rol fundamental. La clave está en partir no de una única perspectiva, dinamizada gracias al desplazamiento físico del aparato de registro, sino de varios

\footnotetext{
1 Landscape, Tamás Waliczky. [En línea]. Ars Electronica Archive. Prix Ars Electronica 1998. Disponible en Web: <http://90.146.8.18/en/archives/prix_archive/prix_projekt.asp?iProjectID=2442>
} 
puntos de vista sobre un mismo objeto o escena. ${ }^{2}$ Esta técnica se remonta a la obra del fotógrafo Eadweard Muybridge.
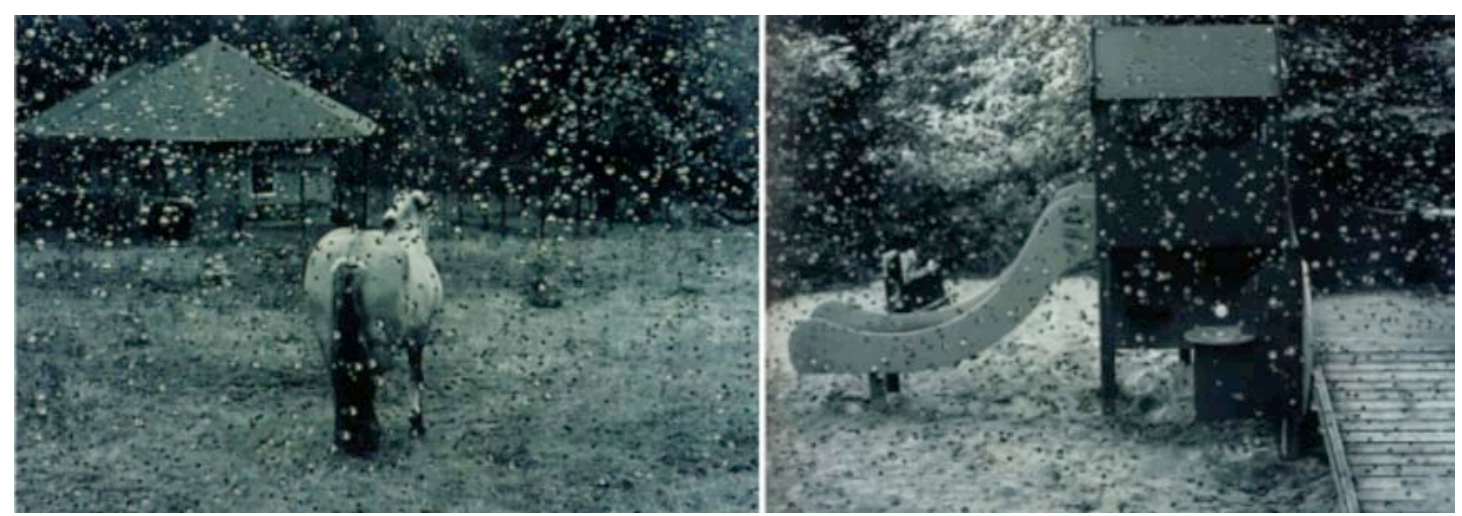

Landscape (1997), de Tamás Waliczky

\section{Los orígenes de la idea}

Muybridge es recordado por un experimento considerado como un antecedente del cinematógrafo. En 1872, Leland Stanford, presidente de la Central Pacific Railroad de California y apasionado del mundo ecuestre, pidió al reputado fotógrafo que le ayudara a despejar una incógnita relacionada con el movimiento de un caballo al galope, imposible de resolver contando tan sólo con el ojo "desnudo". La cuestión tenía como fondo el debate provocado por un químico francés contemporáneo, Étienne-Jules Marey (1830-1904), quien afirmaba que el animal queda suspendido en el aire, con sus cuatro extremidades al vuelo, en alguna de las fases de su desplazamiento. ${ }^{3}$ Los primeros intentos de Muybridge por captar el instante misterioso fracasaron a causa de la lentitud de las emulsiones. Sin embargo, en 1878, en Palo Alto, ingenió un procedimiento que le haría célebre: colocó doce cámaras que se disparaban al paso del caballo sobre unos hilos vinculados entre sí. Como resultado, la serie de tomas sucesivas permitía reconstituir el movimiento. Apenas un año después, el fotógrafo presentaba su "zoopraxiscopio", artefacto decisivo en la

\footnotetext{
2 En este sentido, Mark J. P. Wolf constata: "Along with the growth of digital special effects technology, there seems to be a renewed interest in physical camerawork and the way in which physical cameras can be extended by and combined with virtual cameras." WOLF, Mark J. P.. "Space, Time, Frame, Cinema: Exploring the Possibilities of Spatiotemporal Effects". New Review of Film and Television Studies. December 2006, vol. 4, núm 3, p.167.

${ }^{3}$ Muybridge se hizo con un ejemplar de La machine animale. Locomotion terrestre et aérienne (1873), de Marey. En 1881, tras recibir una carta de éste, viajó a París, donde físico y fotógrafo se encontraron. A partir de ese momento, Marey reorientó sus investigaciones hacia la fotografía.
} 
transición al cinematógrafo, junto a los experimentos de Marey, el "mutoscopio" de Herman Casler (1894) o el "kinetoscopio" de Thomas Edison (1895), entre otros.

No obstante, en paralelo al encargo de Stanford, Muybridge tanteó un experimento diferente. Su estudio de la locomoción animal (1887) contiene varias series de fotografías tomadas a la vez desde distintos puntos de vista. ${ }^{4}$ Aunque no llegó a animar las secuencias, el experimento le convierte en pionero de un concepto fundamental en la práctica digital contemporánea: la instalación multicámara.

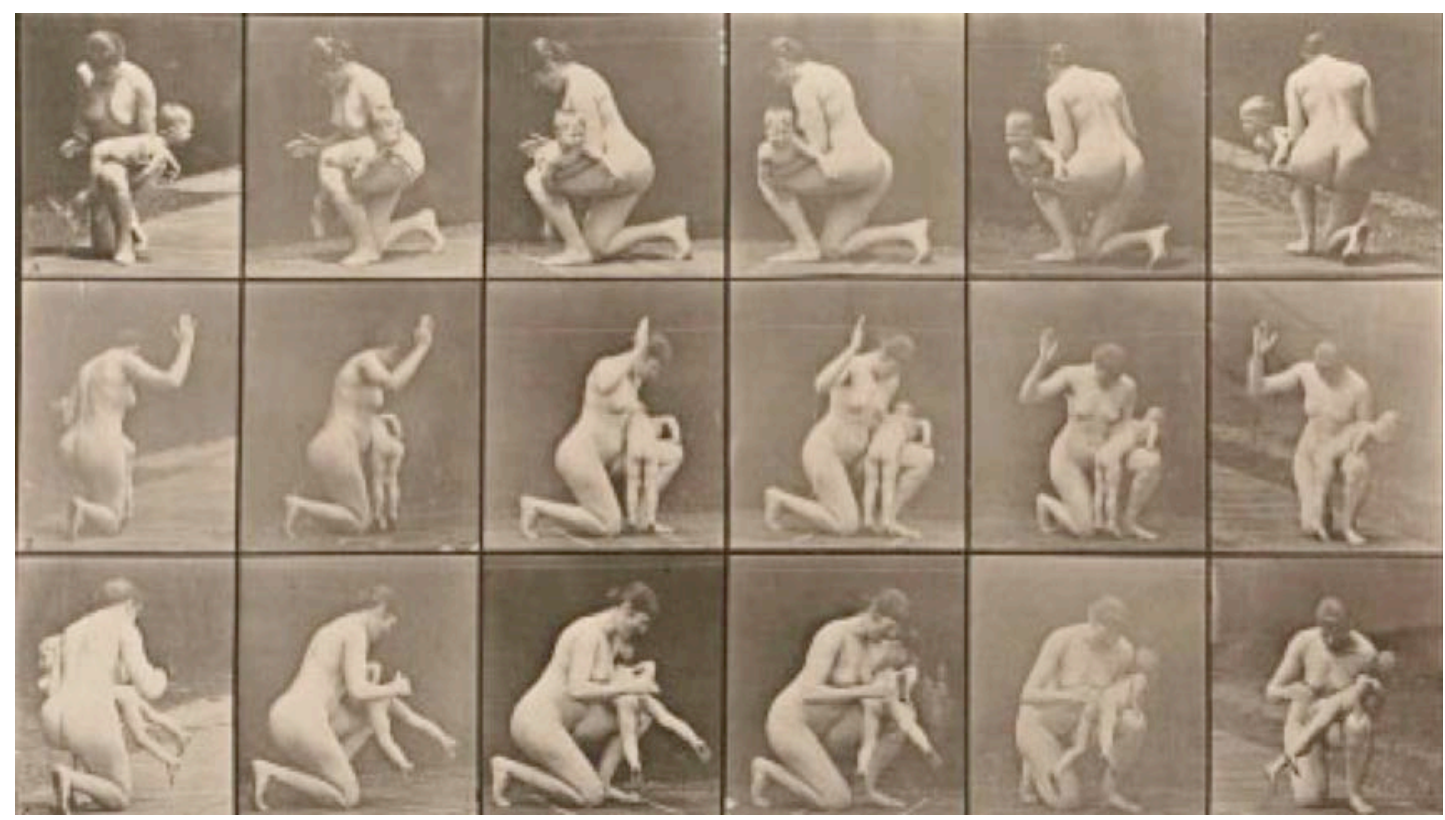

Eadweard Muybridge: “Animal Locomotion”, placa 527 (1887)

Aproximadamente un siglo después, el artista y fotógrafo inglés Tim Macmillan dio a luz un proceso fotográfico al que llamó "time slice" ("loncha de tiempo"). Admirador de los experimentos de Muybridge y del cubismo pictórico ${ }^{5}$, Macmillan construyó una gran cámara circular, cargada con película cinematográfica y cientos de

\footnotetext{
${ }^{4}$ De acuerdo con un artículo publicado por The New York Times en 1881, el fotógrafo habría intentado ya en otra ocasión un experimento semejante: "Mr. Muybridge hastened back to Palo Alto, arranged five cameras in a semicircle and concentrating upon one point, galloped a horse over the point where the electric current was completed, and produces a perfect picture of a horse at fullest speed, as seen from five different points of view, all at the same instant of time and while, of course, the horse was in one and the same position desired." "Instant photography. Results of the California experiments". The New York Times. February 19, 1881. Disponible en Web: $<$ http://query.nytimes.com/gst/abstract.html?res=9B00EED61F3AE533A2575AC1A9649C94609FD7 CF\&scp $=18 \&$ sq $=19+$ february $+1881 \&$ st $=p>$

5 "Tim invented frozen time as an artist studying the cubist movement, which in turn found inspiration in Eadweard Muybridge's early photographic work using multiple exposures of a galloping horse." Slicing time - Tim Macmillan. "Learn to freeze time from the wizard who invented the effect for The Matrix. [En línea]. Timeslicefilms.com. Disponible en Web:

$<$ http://www.timeslicefilms.com/press/encyclopedia-of-visual-effects>
} 
lentes apuntando al centro. ${ }^{6}$ Los disparos se producían a la vez de modo que, al reproducir la secuencia, las acciones quedaban congeladas mientras la cámara se desplazaba dibujando un círculo. En el ejemplo elegido, el agua queda suspendida en el aire como una masa tridimensional. La fuerza visual de la imagen se basa, precisamente, en la captura volumétrica de esa forma fluida. Basta compararla con la placa 524 de Animal Locomotion para constatar la clara inspiración en el experimento de Muybridge. Ahora bien, aquella serie de seis imágenes fijas presenta sendas vistas de manera aislada, como una especie de croquis bidimensional. La aportación de Macmillan radica en la animación de la secuencia y la construcción de una tridimensionalidad asociada al movimiento.

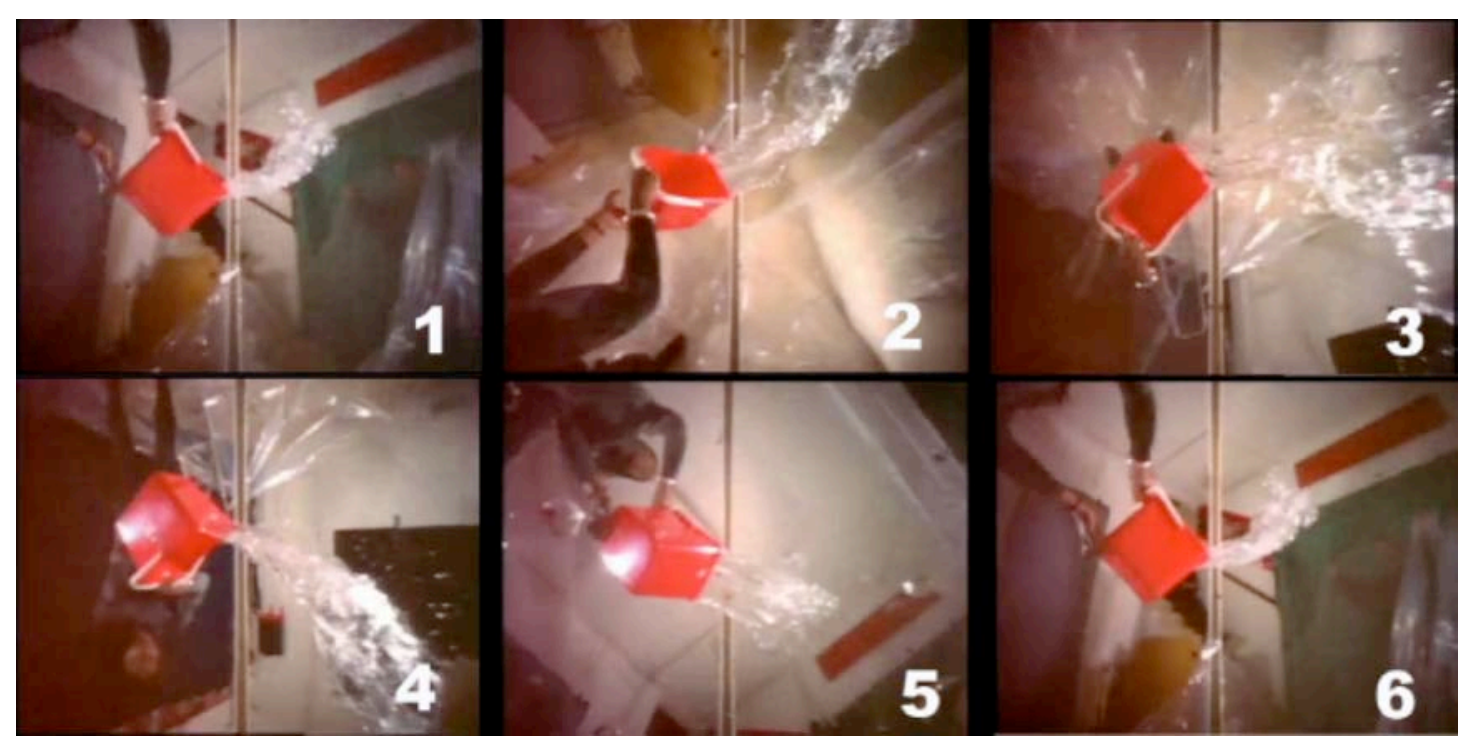

Time-slice, de Tim Macmillan

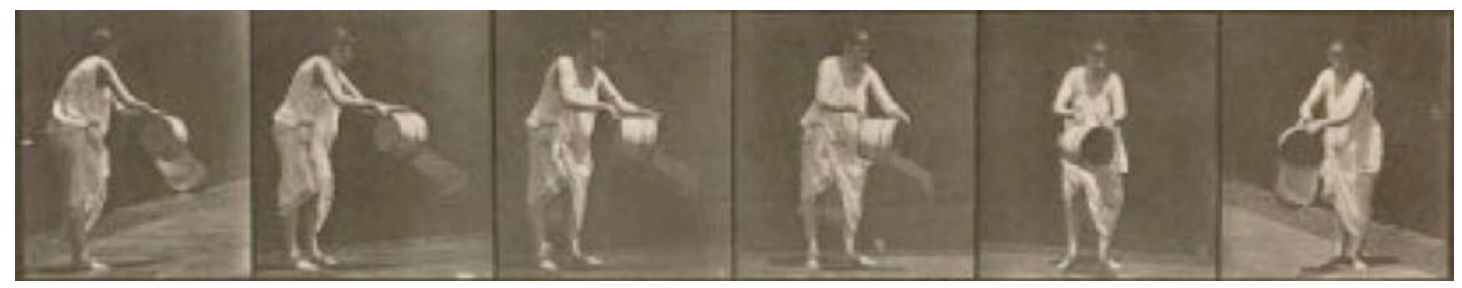

Eadweard Muybridge: “Animal locomotion”, placa 524 (1887)

Como hemos tenido oportunidad de recordar en este trabajo, la multiplicación del punto de vista es una de las claves estéticas del cubismo pictórico. En realidad,

\footnotetext{
${ }^{6}$ Esta disposición circular y centrípeta es propia de la "photosculpture" o "escultura fotográfica", inventada por François Willème (1830-1905) en París en 1859. Básicamente, la técnica consistía en la realización de una escultura en barro a partir de la información tridimensional que procuraba una primera fase fotográfica. Como en el proceso digital, las cámaras se disponían alrededor del objeto y se disparaban al mismo tiempo. Cfr. BOURGOUGNON, Eric. Paris en 3D, de la stéréoscopie à la réalité virtuelle, 1850-2000. Catalogue de 1'exposition. Paris: Paris Musées/ Booth-Clibborn Ed., 2000.
} 
varias décadas antes de Macmillan, Serguei Eisenstein proponía ya la traslación de esta exploración plástica a la imagen cinematográfica. Eso sí, mientras el time-slice subraya la continuidad, el cineasta soviético potencia el contraste a través del montaje temporal.

Lejos de la transparencia cinematográfica que se convertirá en una de las claves del lenguaje clásico, Eisenstein propone un cine cuya noción básica es el "fragmento", al que se da forma mediante el "conflicto", con el objeto de lograr la “atracción” del espectador. El espacio fílmico se subordina a este último concepto, que privilegia la percepción por encima de la narración. En este contexto, la acción puede ser interrumpida al incluir distintos puntos de vista del mismo objeto. Como en la creación de Macmillan, éstos no aparecen de forma simultánea en la imagen, sino que se suceden en los planos a través del tiempo de proyección, congelando la acción dentro del tiempo diegético y generando un ente distinto: un momento capturado y desplegado; una "espacialización del tiempo".

Así, en Stachka o "La huelga" (1924), la rueda que golpea al espía se presenta sucesivamente desde varios puntos de vista. De modo semejante, en la escalera de Odessa de Bronenósets Potiomkin (1925), cuatro planos prácticamente iguales muestran a la misma mujer agitando la cabeza efusivamente. En ambos casos, el desarrollo de la historia se congela momentáneamente a favor de la expresión dramática.

En el montaje temporal, el punto de partida es el plano. ${ }^{7}$ En cambio, en la animación del time-slice, es el fotograma. Macmillan no se contenta con la ya asentada gramática audiovisual, sino que retrocede hasta el germen del movimiento. Al modo de las instantáneas de Muybridge, la unidad mínima es, pues, la fotografía. En este sentido, no es de extrañar que sea, precisamente, un fotógrafo uno de los primeros en experimentar con la instalación multicámara. A lo largo del siglo XX, la búsqueda de un lenguaje cinematográfico parece haber aparcado esta concepción atómica de la imagen (el fotograma como unidad mínima que compone el movimiento), a favor del plano, el corte y el montaje temporal.

\footnotetext{
${ }^{7}$ Tal y como afirma Eisenstein: "Short and montage are the basic elements of cinema." EISENSTEIN, Sergei. Film Form: Essays in Film Theory. Op. cit., p. 140

La teorización sistemática del montaje temporal tendrá que esperar hasta los años 20 y las ricas aportaciones de cineastas como el propio Eisenstein. No obstante, la construcción del espacio fílmico a partir de la suma de varios planos se remonta a los inicios del cinematógrafo con Grandma's Reading Glass (1900), de George Albert Smith. BRISELANCE, Marie-France. Op. cit., p. 67.
} 


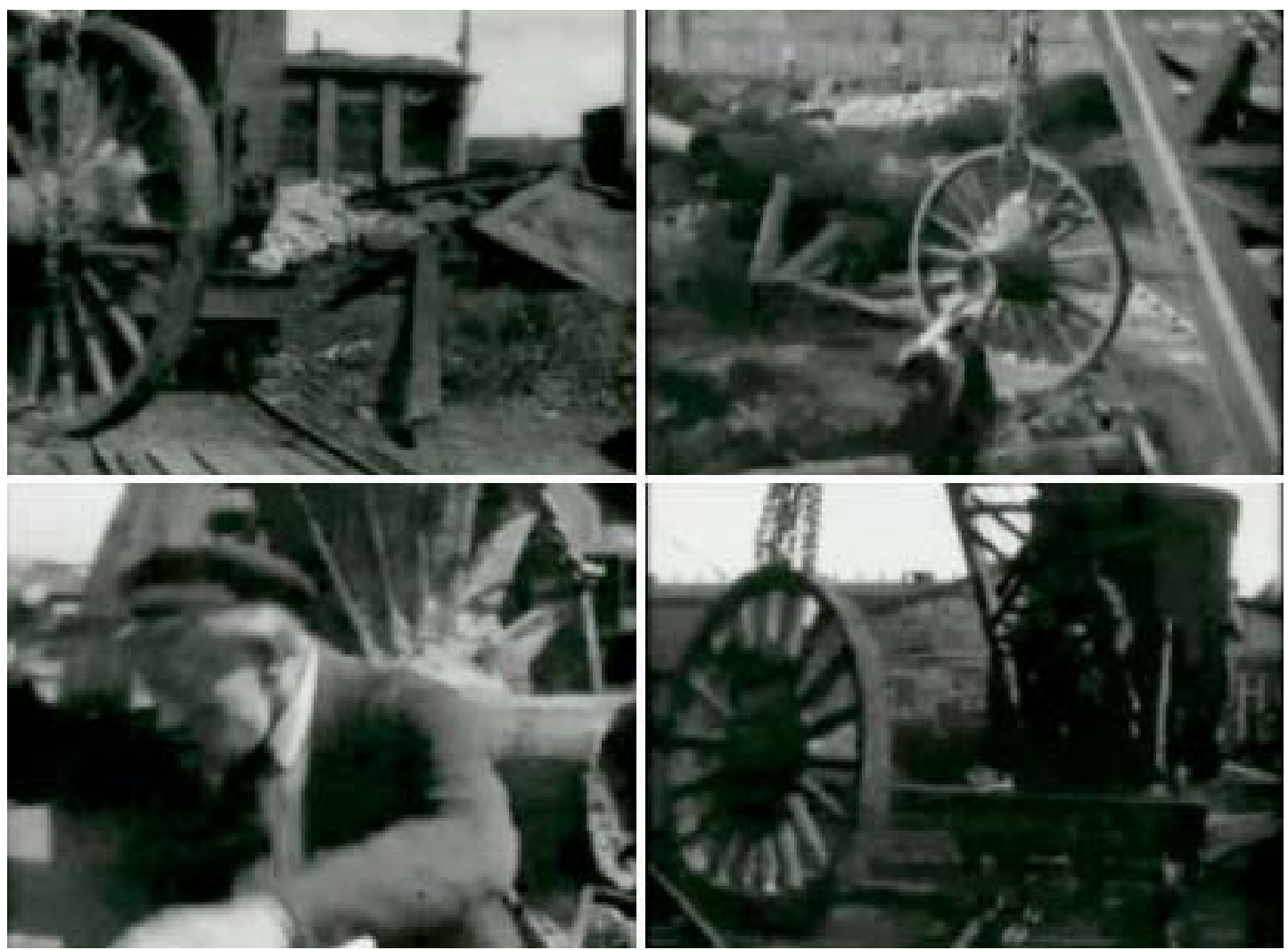

Stachka (1924), de Eisenstein

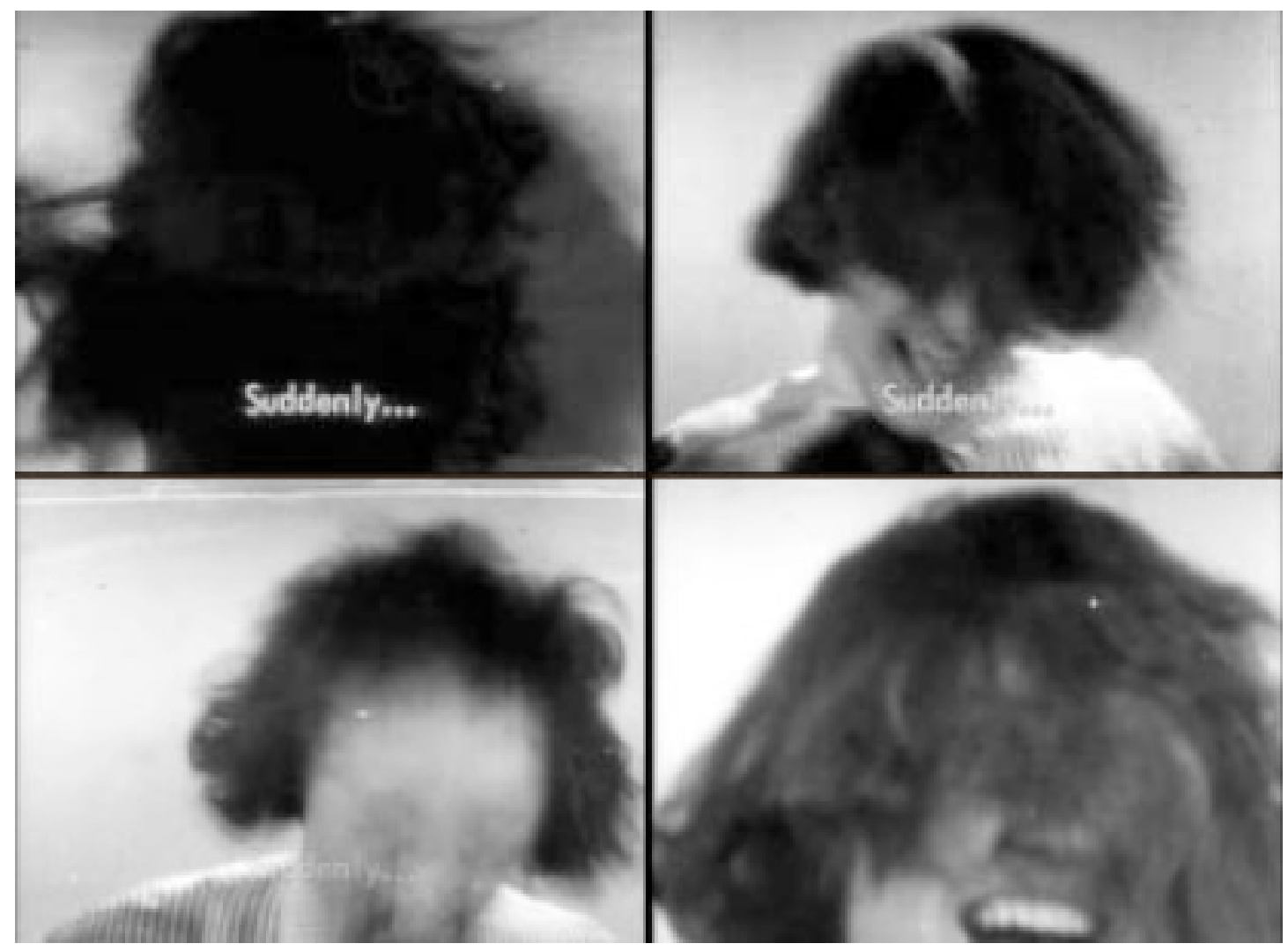

Bronenósets Potiomkin (1925), de Eisenstein 
Esta recuperación del frame como unidad espacial, frente al concepto puramente temporal y abstracto del fotograma, es característica de la era digital. ${ }^{8}$ Como veíamos en relación al montaje espacial, los programas de edición conceden la misma importancia a la construcción en el interior del cuadro que a la secuencia temporal. En este contexto, el time-slice da una vuelta de tuerca al efecto visual que es el cinematógrafo. Allí donde éste reproduce el movimiento de la/s figura/s o del aparato físico en el espacio, la instalación multicámara construye un movimiento que nunca tuvo lugar.

Frente a la fragmentación de Eisenstein, Macmillan busca la continuidad. Así, no es de extrañar que el artista inglés explote la figura del plano secuencia. En 1996, realiza un anuncio de televisión para la radio Capital FM, bajo el eslogan “London's static without". El movimiento del cuadro se produce de derecha a izquierda, en una panorámica horizontal a través de diversas escenas. Como en los casos descritos en el apartado anterior, la continuidad del movimiento entre éstas se consigue disimulando los empalmes. No obstante, mientras el videoclip Imagine de Rybczynski partía de tomas en movimiento, Macmillan se deleita en el instante compartido por los personajes congelados en sus acciones cotidianas.

Tres años después, el artista retoma la misma idea en un corto de casi cinco minutos: Ferment (1999) presenta un "corte transversal" de una ciudad. Como en la congelación de Source Code, en el instante en el que un hombre cae muerto al suelo, las acciones se paralizan mientras la cámara "se desencadena", mostrando los quehaceres de la gente en ese momento. La serie de escenas finaliza con el nacimiento de un bebé, claro homenaje al ciclo vital. Como en la publicidad anterior, el plano secuencia se construye mediante un montaje espacial que permite saltar sin ruptura entre los diversos "actos". Aunque de una admirable factura, los empalmes analógicos entre las imágenes impiden hablar de una verdadera continuidad espacial.

Durante los años siguientes, Macmillan mejorará su técnica gracias al ordenador. En Animal Tragic (2003), se aleja del plano secuencia y se concentra en la creación de instantáneas tridimensionales. Con los testimonios en voz en off, la serie muestra tres enfrentamientos entre personas y animales.

\footnotetext{
8 "Thinking of motion picture footage as a frame based entity, completely divorced from reality's unattainable level of temporal consistency is a mind-set of the digital era." HAMMER, Owen. Bedtime For Deadtime [En línea]. Visual Effects Headquarters. June 1998. Disponible en Web: $<$ http://www.vfxhq.com/spotlight98/9806b.html>
} 


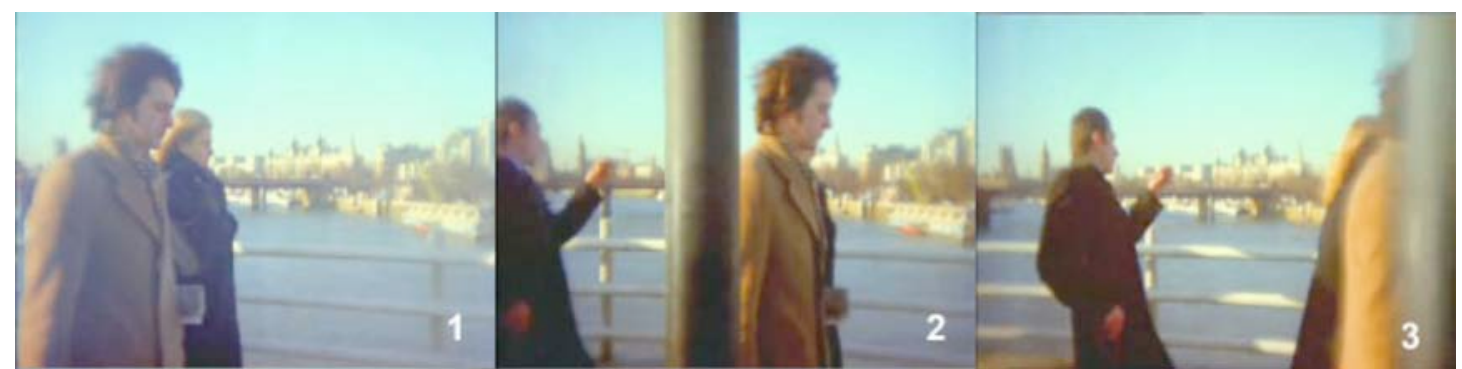

London's static without (1996), para Capital FM Radio de Tim Macmillan
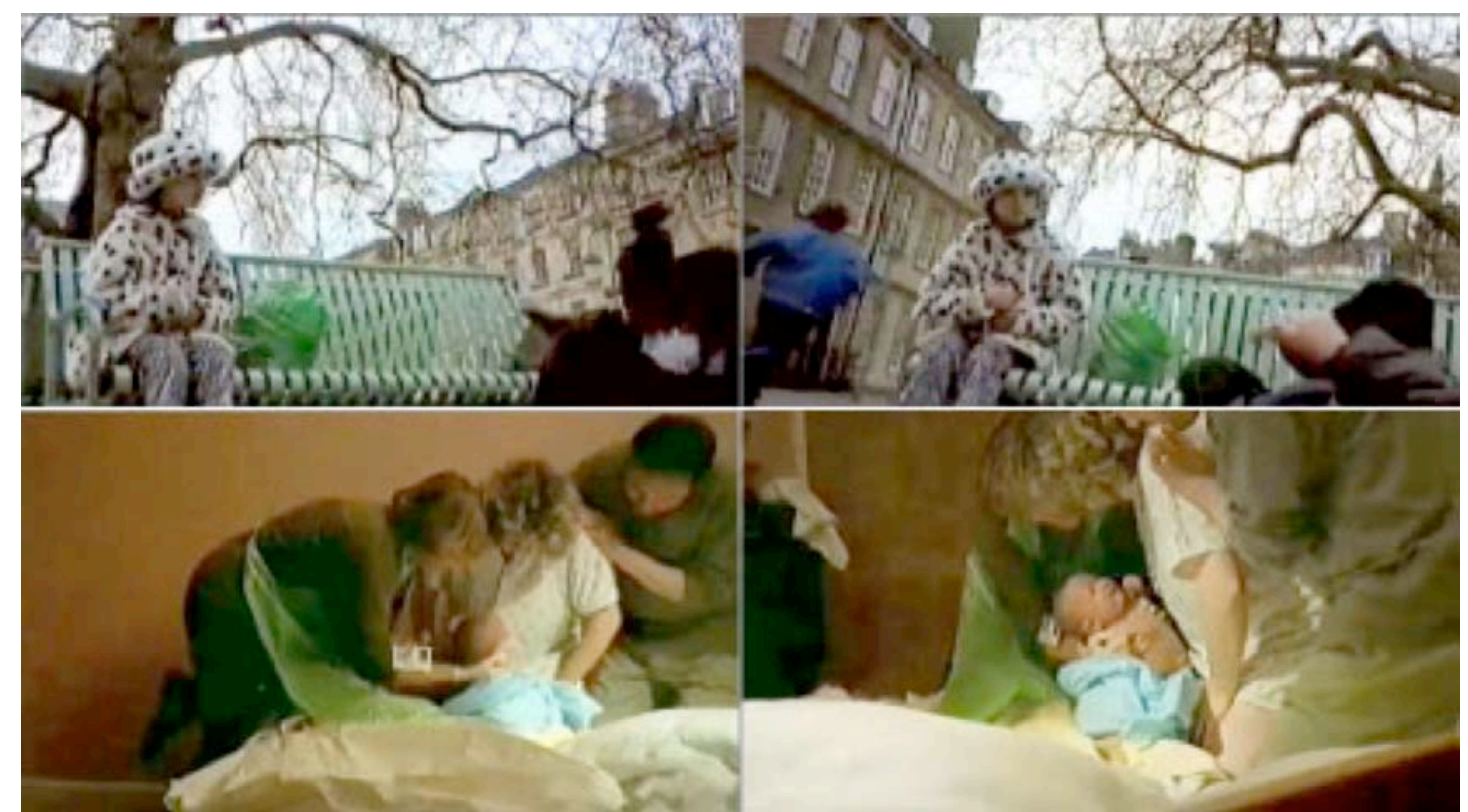

Ferment (1999), de Tim Macmillan

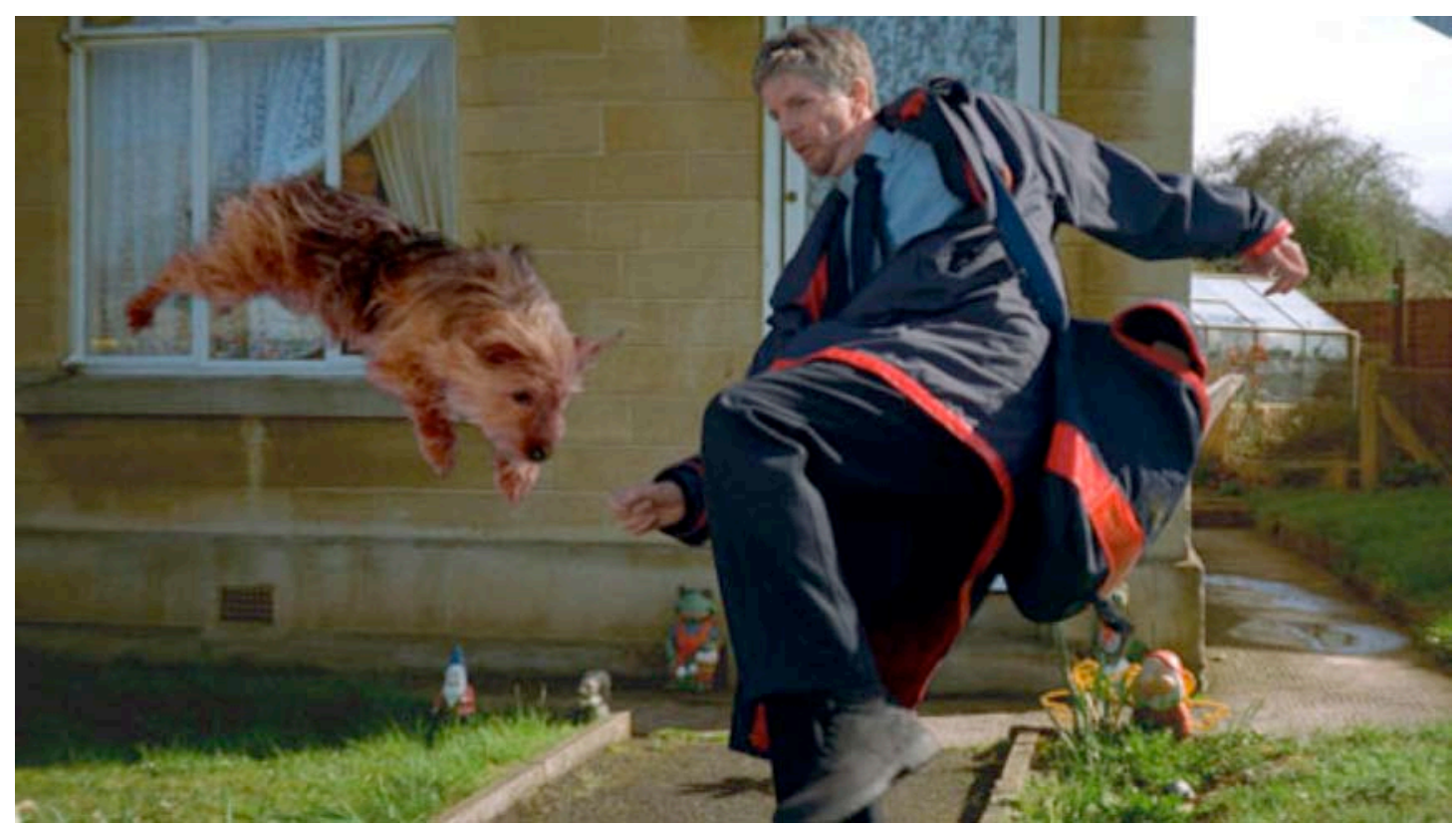

Animal Tragic (2003), de Tim Macmillan 


\section{La independencia de la cámara virtual}

Al tiempo que Macmillan, otros artistas y realizadores desarrollan la instalación multicámara. Si bien es cierto que existen ejemplos anteriores ${ }^{9}$, la expansión del efecto se produjo a mediados de los años 90 . De hecho, la idea no fue patentada hasta 1994 cuando Dayton Taylor y su compañía Digital Air registraron el prototipo "Flexible sixty lens Timetrack camera". Por un lado, el término "track" remite a la hilera de cámaras físicas que marcan el camino que será construido mediante la síntesis digital y que irá desvelando poco a poco la cámara virtual. Por otro lado, la instalación es "flexible" en cuanto la postproducción digital permite no sólo congelar el movimiento, sino crear todo tipo de alteraciones temporales y efectos fotográficos como la multiexposición, que veremos en el próximo capítulo.

La cámara virtual es el producto de la interpolación entre varias vistas y, en tanto que construcción, es un ente espacial independiente, que no tiene por qué participar del espacio-tiempo del registro. O dicho de otro modo, el objetivo de la instalación multicámara es, justamente, "separar el punto de vista de una cámara virtual de las limitaciones temporales y espaciales de una cámara real." ${ }^{\prime 10}$

Taylor rebautizó el efecto de "time slice" como "dead time"11, elección que redunda en el aspecto eminentemente espacial del constructo. Con el mismo título en francés, Emmanuel Carlier presentó en la III Biennale de Lyon (1995) su propia versión de la instalación multicámara. Continuando con aquella primera intuición de Macmillan y su cámara centrípeta, Carlier explota la profundidad cinética mediante giros de $360^{\circ}$. Como resultado, su Temps mort destaca sobre las propuestas contemporáneas por su impactante sensación escultural. El artista francés utilizó unas setenta cámaras, colocadas a la misma distancia unas de otras, formando un círculo alrededor de modelos desnudos.

Como en el recorrido en torno a una escultura, el desplazamiento se centra en la contemplación del bulto y sus distintos puntos de vista. En ese movimiento continuo, las fotografías originales y el cálculo del espacio intermedio se funden en una animación fluida. El efecto volumétrico de las figuras se ve potenciado por un fondo

\footnotetext{
${ }^{9}$ Así, ya en 1985, el videoclip Midnight Mover, del grupo de heavy metal Accept, presenta giros y cabeceados basados en el efecto. Sin embargo, no se explota la continuidad del desplazamiento, que queda eclipsado por el rápido montaje temporal.

${ }^{10}$ Ver la página web oficial de la compañía: $<$ http://www.virtualcamera.com/>

${ }^{11}$ PAUL, Joshua. Digital Video Hacks. Sebastopol: O’Reilly Media Inc, 2005, p. 118.
} 
negro; el fuerte contraste lumínico provoca una sensación ambigua en el espectador: ¿es la cámara virtual la que recorre el espacio o son los cuerpos los que giran en torno a su propio eje? En realidad, este efecto prueba, una vez más, que la cámara virtual es un constructo fruto de la mutación de la imagen.
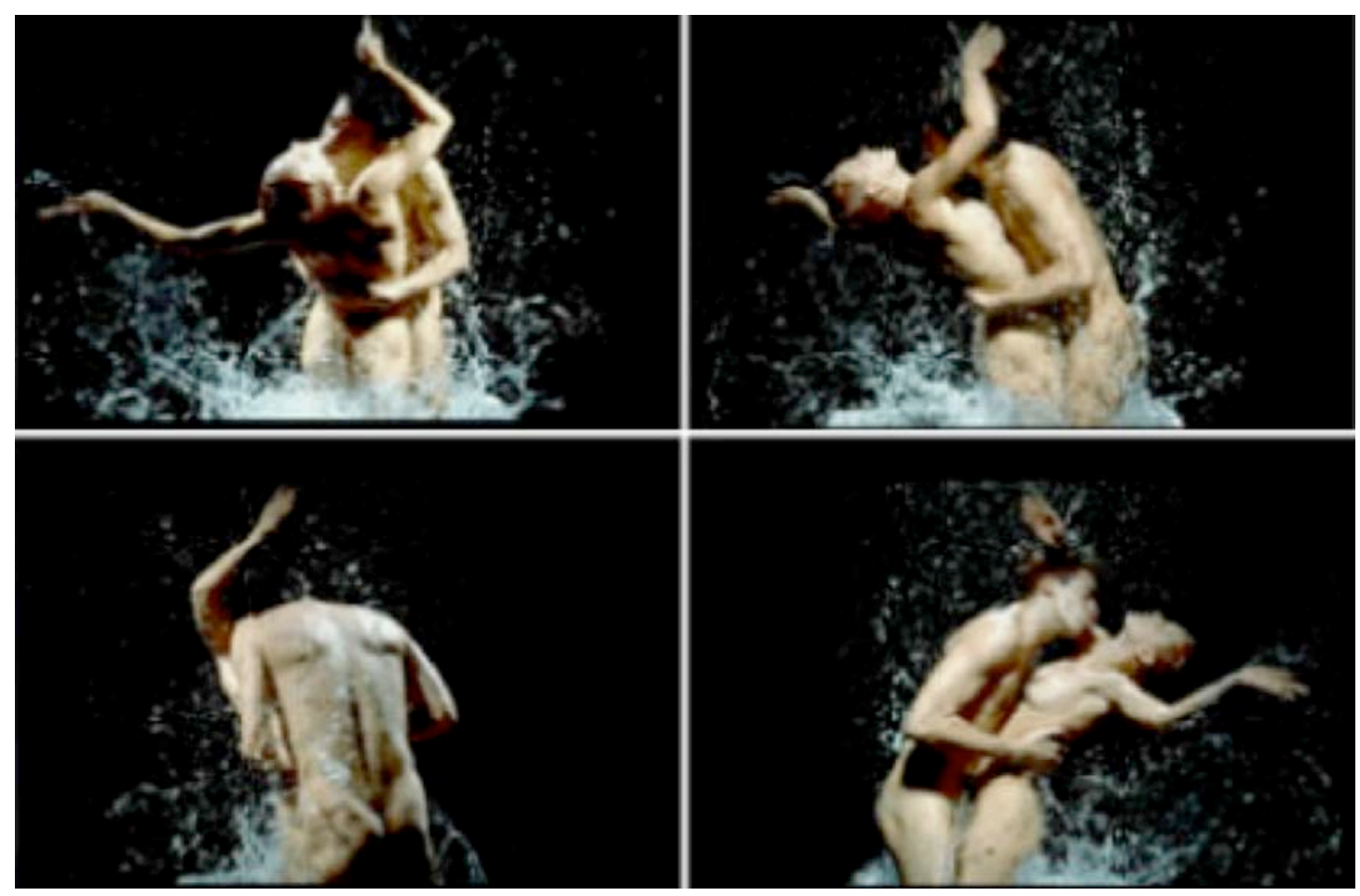

Temps mort (1995), de Emmanuel Carlier

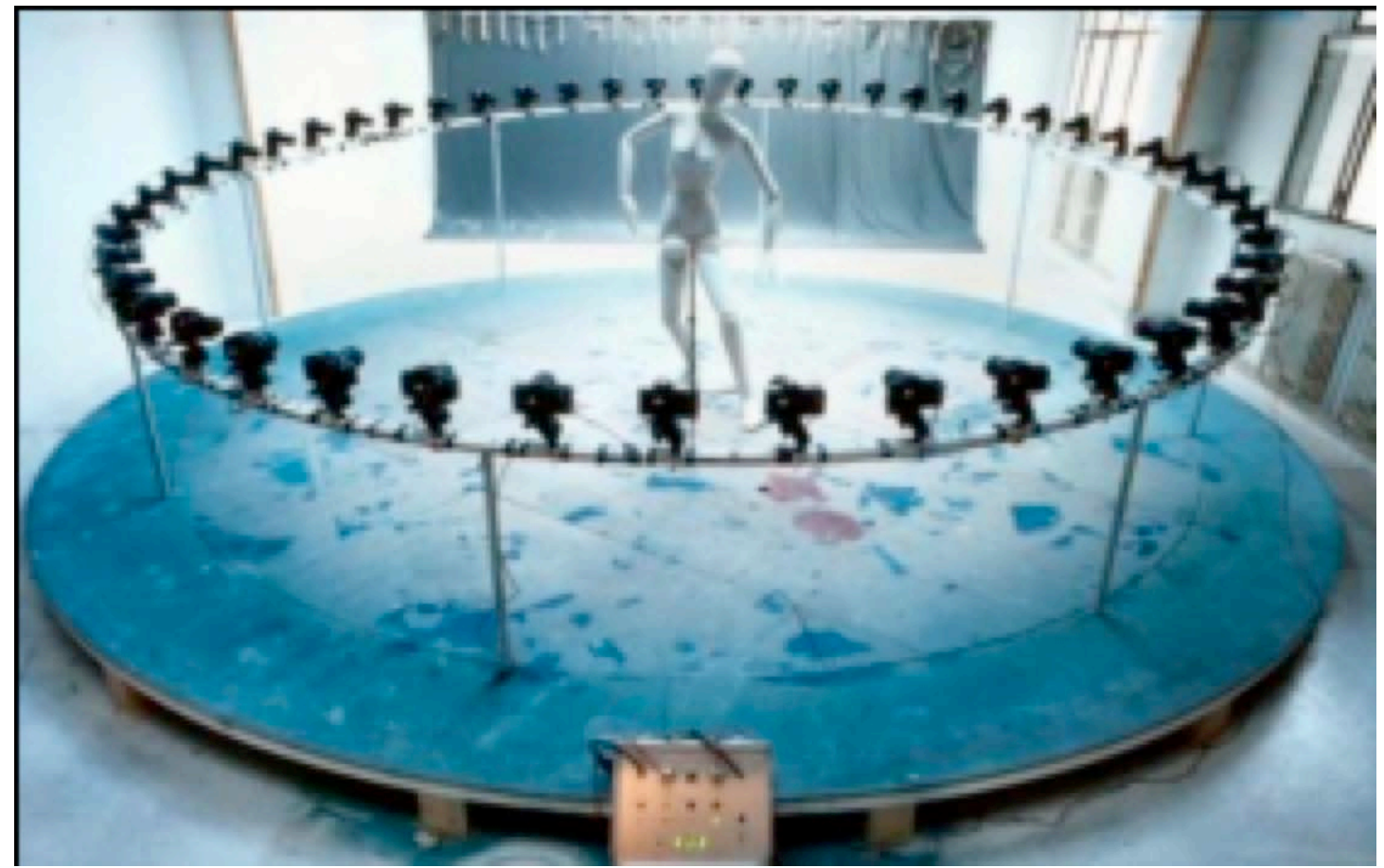

Plató para la elaboración de Temps mort, de Emmanuel Carlier 
En la misma época, la construcción multicámara es utilizada por la compañía BUF Inc. en publicidad y en varios vídeos musicales; entre otros, Michel Gondry se sirve de ella en el videoclip Like a Rolling Stone (1996) y en un anuncio de Vodka Smirnoff (1996). Éste comienza con una construcción semejante a las escenas de Animal Tragic, con el protagonista suspendido en el aire en pleno salto. No obstante, frente al corto de Macmillan, Gondry alterna la congelación y el ralentí, en la línea de la propuesta de Dayton Taylor.

A diferencia de la instantánea tridimensional propiamente dicha, en la cual las cámaras fotográficas disparan al mismo tiempo, en este tipo de ralentí, las fotografías de partida contienen un ligero desfase temporal entre ellas. Aunque congelación y ralentí responden a dos usos distintos de la instalación multicámara, muestran una concepción espacial común, marcada por el desplazamiento continuo de la cámara virtual y la independencia de ésta con respecto al tiempo del registro. ${ }^{12}$

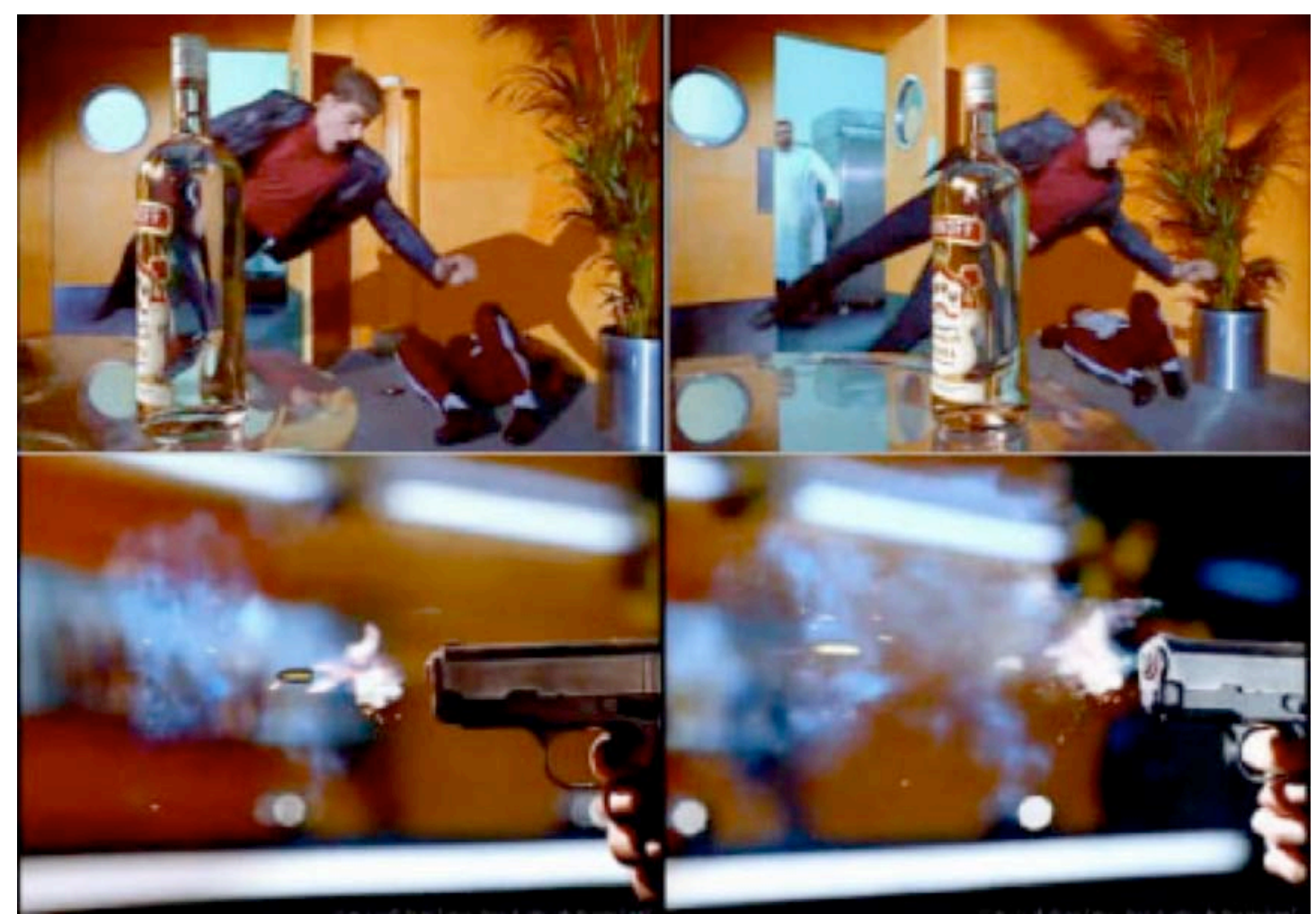

Publicidad para Vodka Smirnoff (1996), de Michel Gondry

\footnotetext{
12 "With our systems the effect of the high frame rate (across the system) on the speed of the subject is completely independent from the speed of the camera movement. This is because the camera movement is virtual and the speed of the virtual camera movement is dependent only upon the spacing of the cameras". Techniques - Slow Motion. [En línea]. Digitalair.com. Disponible en Web:

$<\mathrm{http}: / /$ www.digitalair.com/techniques/slow_motion.html $>$
} 
Para la creación del videoclip, Gondry acudió a las últimas innovaciones en materia de procesamiento de la imagen. En lugar de utilizar un gran número de cámaras situadas unas junto a otras, partió de menos tomas e interpoló las fotografías mediante "view morphing"13. En una mera instalación multicámara, sin postproducción digital, la sensación de desplazamiento es el resultado de la variación del punto de vista entre las fotografías. Aunque esta discontinuidad de las capturas pueda disimularse gracias a la velocidad de proyección, entre las diversas fotografías no hay más que un vacío: el de los huecos físicos entre las cámaras. Por el contrario, el efecto digital llena los intersticios y fluidifica el desplazamiento de la cámara virtual. La generación potencialmente infinita de fases intermedias exalta la continuidad como principio estético: más allá del efecto de desplazamiento ininterrumpido, esta continuidad afecta a la imagen a un nivel atómico, el que permite el acceso independiente a cada píxel. De este modo, frente a la congelación o el ralentí cinematográficos, manifestaciones de la maleabilidad del tiempo cinematográfico, las versiones digitales descritas dan prueba de una concepción de la imagen distinta: eminentemente espacial.

Con todo, merece la pena detenerse un momento en el ralentí cinematográfico, cuyo nacimiento está profundamente ligado a la instantánea fotográfica y la mirada analítica de los pioneros del cine científico. Hemos visto ya la trascendencia de la obra fotográfica de Eadweard Muybridge tanto en la génesis del cinematógrafo como en la instalación multicámara. En realidad, ninguno de sus experimentos habría sido posible sin su admirable conquista de la instantánea. Muybridge destacó pronto por su trabajo con placas de cristal gigantes, impregnadas de colodión húmedo. Este material le permitía reducir el tiempo de exposición de la fotografía y fijar el movimiento en la imagen de manera más o menos precisa, varias décadas antes de la invención definitiva (y mucho más eficaz) del gelatino-bromuro, alrededor de 1880.

Unos años después, el inglés Arthur Mason Worthington exploró el registro de varias instantáneas consecutivas de un fenómeno muy corto. Desde 1894, persiguió la captura de la caída de una gota sobre un líquido (una mezcla de leche y agua) y el bello efecto de corona que forman las gotas salpicadas. ${ }^{14}$

\footnotetext{
${ }^{13}$ En la misma época, Seitz y Dyer presentan su técnica de interpolación de imágenes, que bautizan como "view morphing". SEITZ, S.M.; DYER, C.R.. "View morphing". En: ACM SIGGRAPH'96, Proceedings of the 23rd Annual Conference on Computer Graphics. August 4-9, 1996, New Orleans, LA, USA, pp. 21-30.

${ }^{14}$ WORTHINGTON, A. M.. A study of splashes (1852-1916). New York: Macmillan, 1963.
} 
Más tarde, en los años treinta del siglo XX, el ingeniero Harold Eugene Edgerton (1903-1990) continuó con la vía abierta por Muybridge y Worthington e inventó la "fotografía estroboscópica". La explosión luminosa de un flash electrónico le permitió aumentar la velocidad de obturación y registrar con toda nitidez movimientos imperceptibles por excesivamente rápidos. Recordemos, por ejemplo, sus famosas fotografías "Death of a Light Bulb/.30cal. Bullet" y "Milk-Drop Coronet Splash", ambas tomadas en 1936.

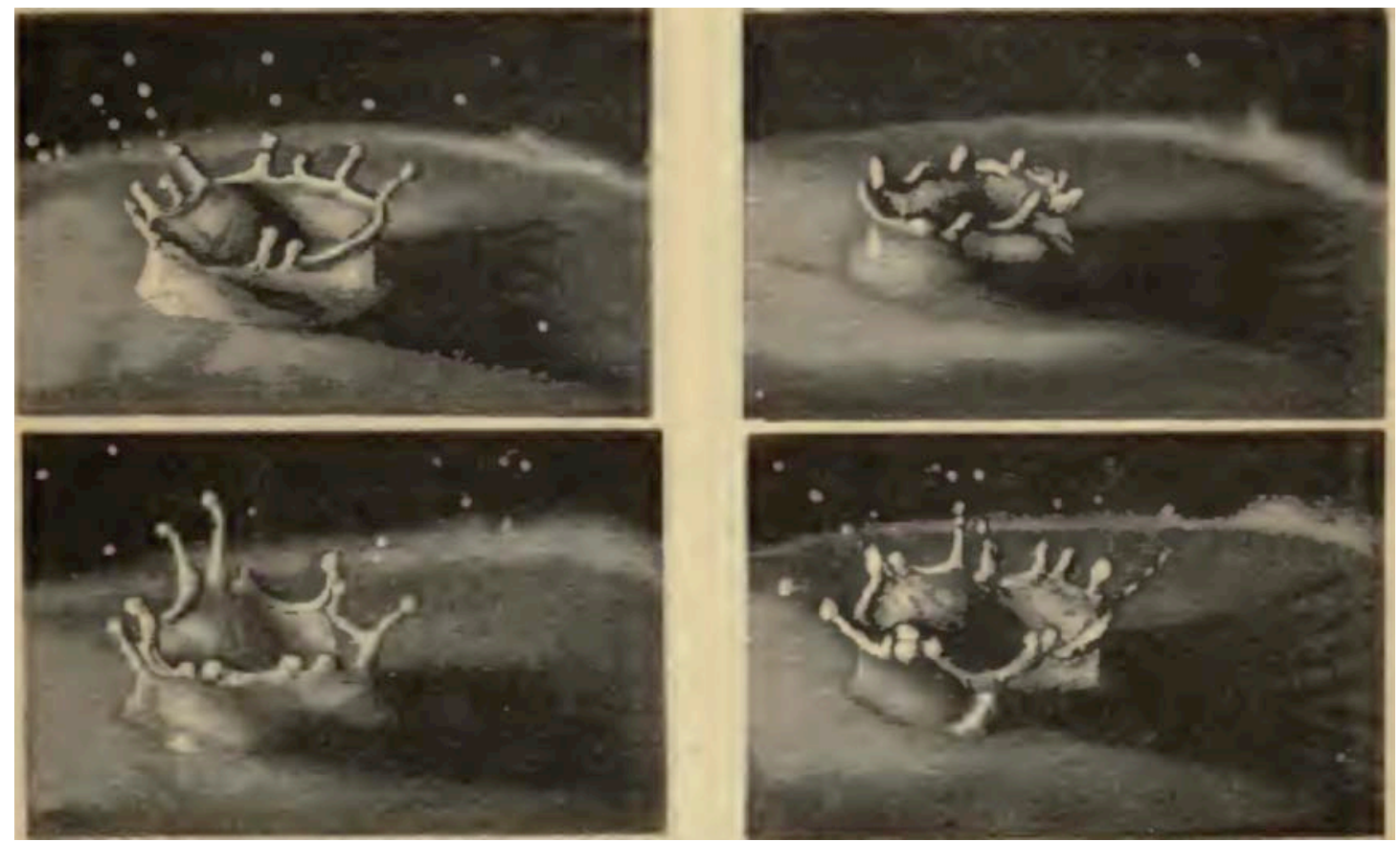

Instantáneas de la serie "The splash of a drop" (1894), de A. M. Worthington

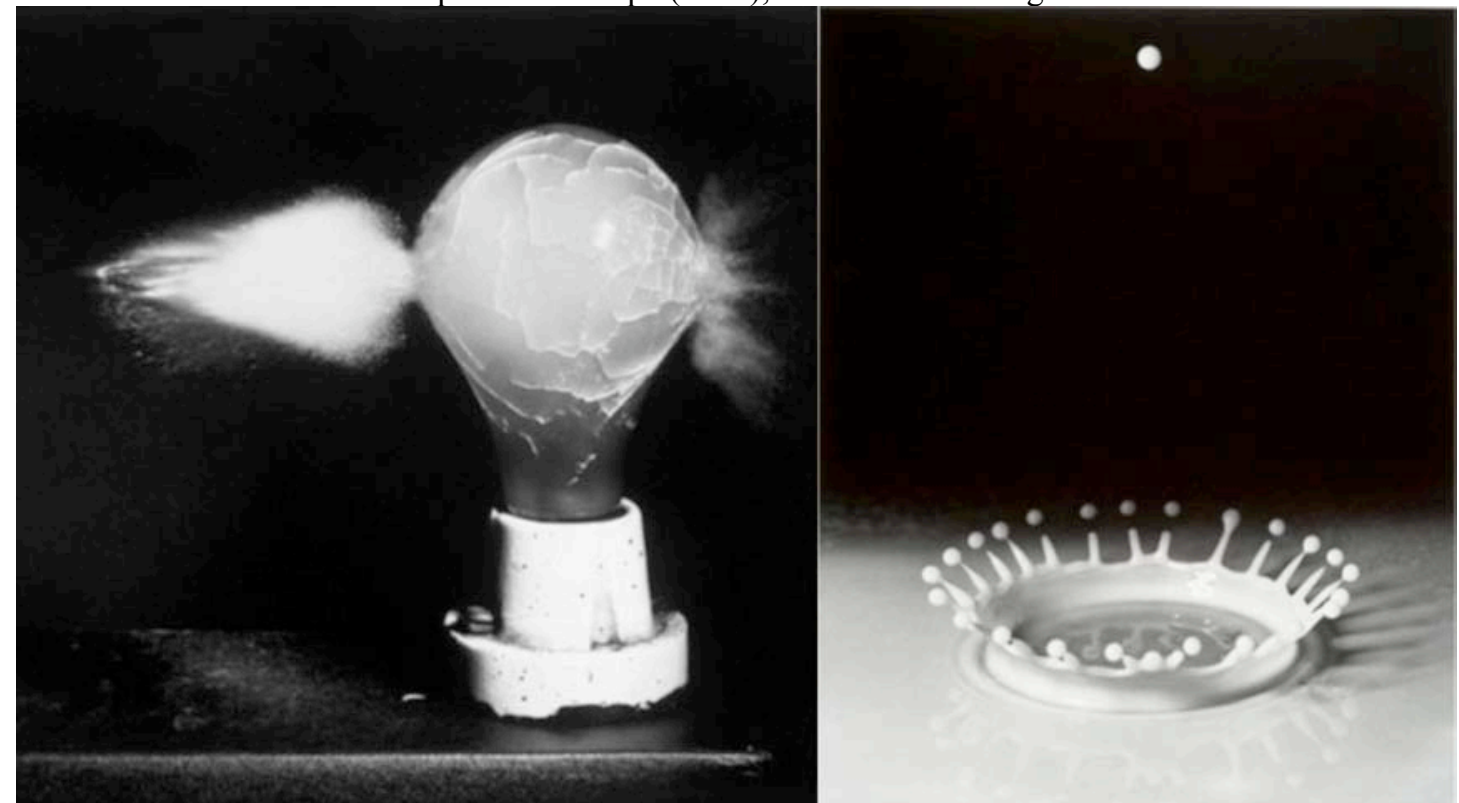

H. E. Edgerton (1936): izquierda, "Death of a Light Bulb/.30cal. Bullet"; derecha, "Milk-Drop Coronet Splash" 
Evidentemente, como intuyó ya Worthington, una composición tan ajustada no suele corresponder a una toma aislada, sino a una serie de disparos consecutivos, entre los cuales el fotógrafo podrá elegir los instantes más representativos o de mayor expresividad. Para conseguir hasta el más mínimo detalle del cambio, se registra la mayor cantidad posible de imágenes por segundo. De proyectar la secuencia a una velocidad menor, el movimiento se desarrolla en ralentí.

El ralentí nace ligado a la experimentación científica como instrumento para la contemplación y el estudio de eventos físicos. Aunque suele considerarse al austriaco August Musger (1868-1929) como inventor del efecto a principios del siglo XX ${ }^{15}$, el físico francés Étienne-Jules Marey se le adelantó algunos años. Como complemento a su "cronofotografía" (que recuperaremos en el próximo capítulo), Marey llegó a registrar hasta 100 imágenes por segundo. Con todo, recordemos que su objetivo no era la recreación del movimiento, sino el análisis de las fases aisladas del mismo.

Uno de sus alumnos, Lucien Bull (1876-1972), desarrolló este registro a alta velocidad, con un objetivo explícito de reproducción del movimiento en la imagen. En 1904, tras la muerte de su maestro, Bull grabó a 4.000 imágenes por segundo el recorrido de un proyectil a través de una bola de jabón. Diez años después, en el departamento de balística de la armada inglesa, consiguió registrar a 10.000 imágenes por segundo una bala que atravesaba una plancha de madera.

En paralelo a este registro ultrarrápido, Lucien Bull se aplicó, también, al proceso inverso: grabando a una velocidad muy baja (una imagen cada 15 minutos), consiguió acelerar movimientos excesivamente lentos para la visión humana. De igual modo, dentro de este empeño por sacar a la luz lo imperceptible, Bull desarrolló la microcinematografía, una adaptación del microscopio, ya explorada por su maestro.

Las prácticas digitales que nos ocupan recuperan los experimentos del cine científico, pero lo hacen con un objetivo distinto. Bull pretendía capturar el evento, hacerlo visible y mesurable: la imagen era, pues, un instrumento. El cuadro inmóvil de los primeros ralentíes permite concentrar la atención en el desplazamiento del perdigón. En cambio, en el efecto digital, la clave reside en la dinamización del punto de vista y la presencia paradójica de la cámara virtual.

\footnotetext{
${ }^{15}$ ACHAM, Karl (ed.). Naturwissenschaften, Medizin und Technik aus Graz: Entdeckungen und Erfindungen aus fünf Jahrhunderten vom "Mysterium cosmographicum" bis zur direkten HirnComputer-Kommunikation. Viena: Böhlau, 2007, pp. 187-188.
} 


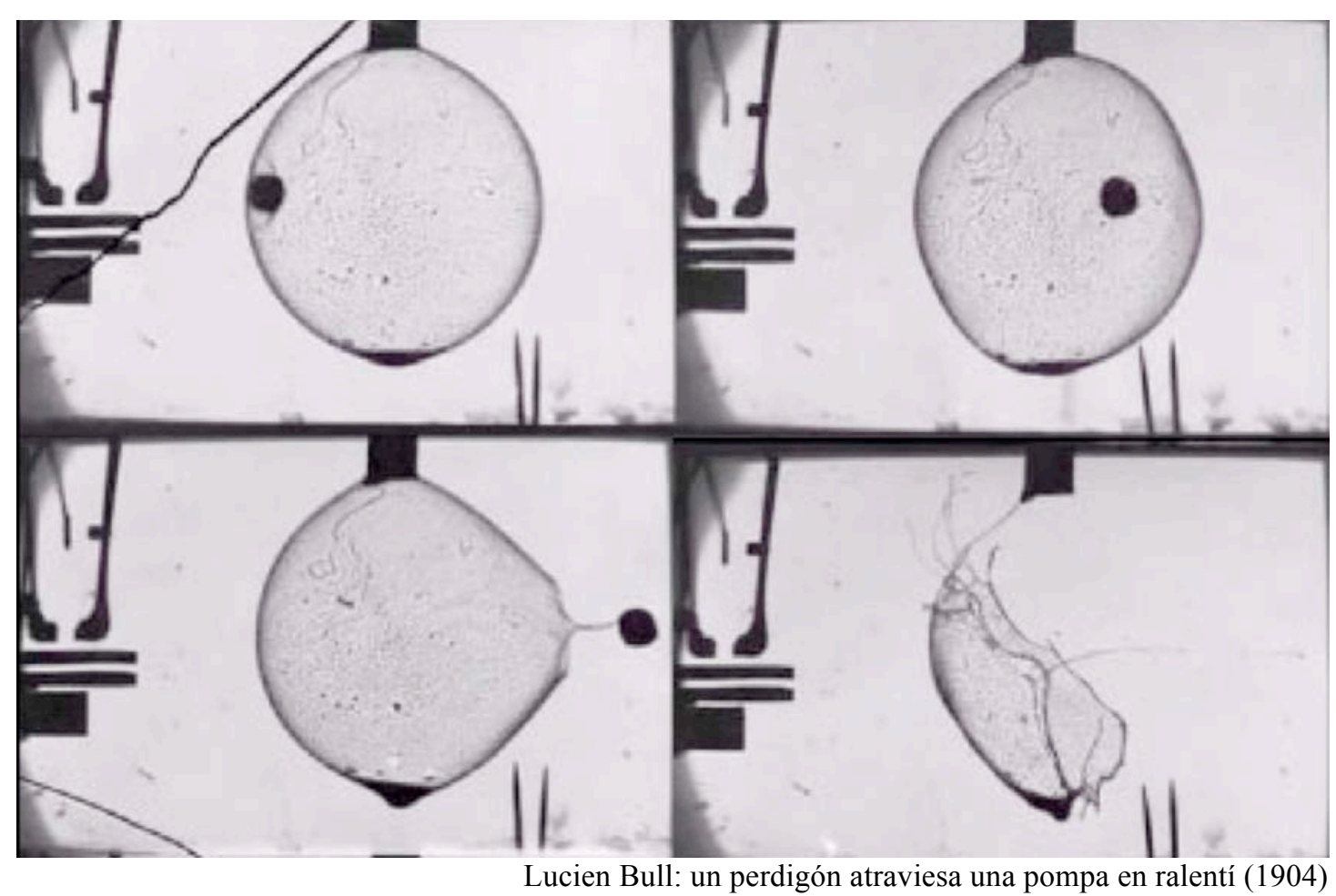

Frente a la importancia del aspecto temporal en el registro científico, las prácticas digitales se regodean en la exhibición del espacio. Hallamos un buen ejemplo en el videoclip Freak on a Leash (1999), dirigido por Todd McFarlane para el grupo musical Korn. Como veíamos en el apartado dedicado a la omnipotencia de la cámara virtual, la obra es paradigmática de la sustitución de un cine de sujetos y una perspectiva antropomórfica por el punto de vista desde un objeto en movimiento. La cámara virtual persigue el desplazamiento de una bala perdida, atravesando con ella los límites físicos que se interponen a su paso.

Ese punto de vista desde el objeto hace referencia, también, a la velocidad del movimiento: en comparación con la rapidez del perdigón, los sujetos en la escena aparecen en ralentí o congelados. En la composición creada por McFarlane, la omnipotencia de la cámara virtual se exhibe, por un lado, en tanto que ente inmaterial no antropomórfico; por otro, el constructo prueba la autonomía total de esa entidad espacial con respecto al tiempo del registro. Al modo de la publicidad de Smirnoff, de Gondry, congelación y ralentí se alternan, como dos aspectos de la misma concepción espacial. 


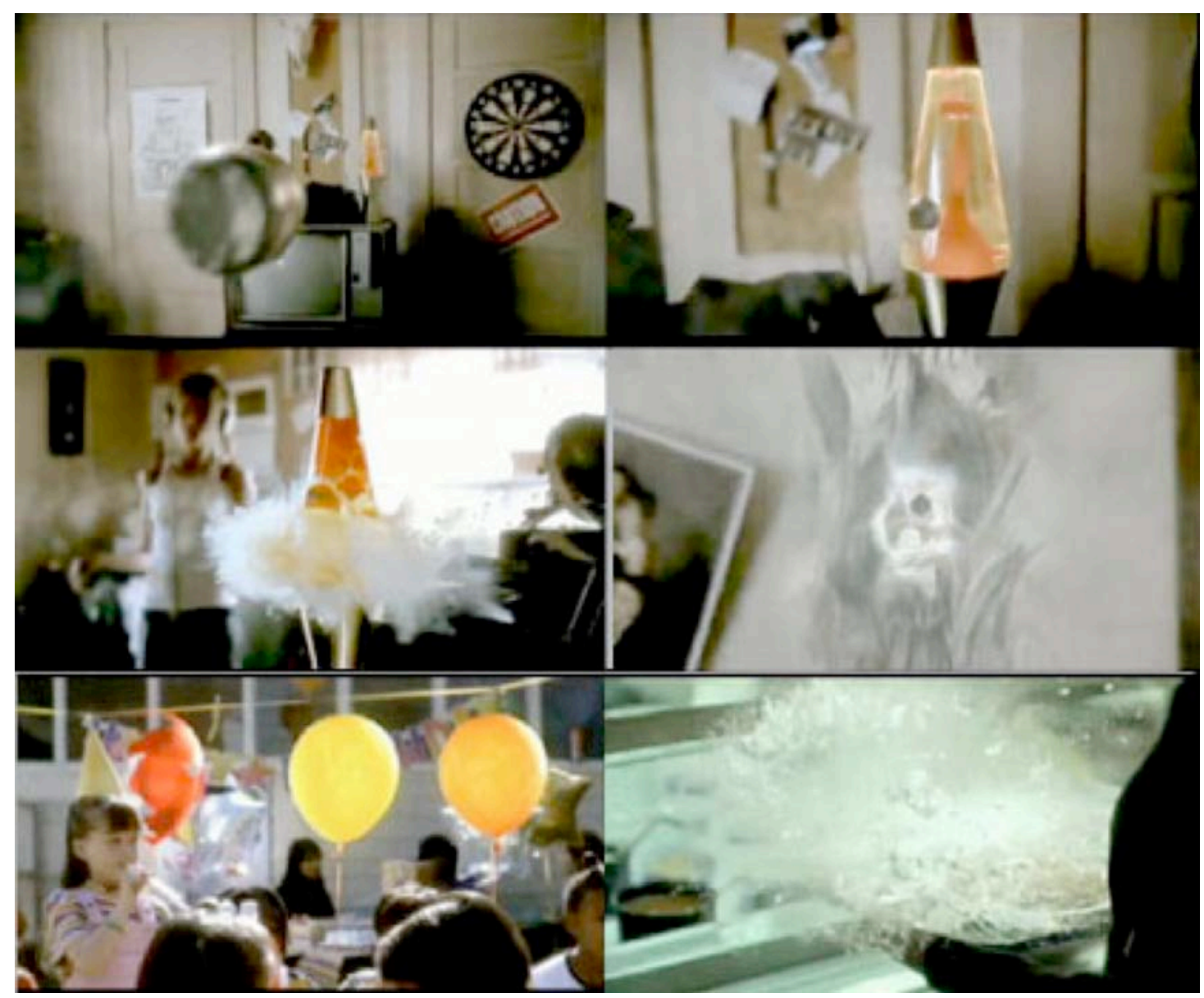

Freak on a Leash (1999), de Todd McFarlane para Korn

Los proyectiles aparecen a menudo en el cine científico y la fotografía ultrarrápida como test de la captura instantánea. Freak on a Leash contiene numerosas referencias a aquellas imágenes: entre ellas, "Death of a Light Bulb/.30cal. Bullet" (1936) y "Bullet Passing Through Three Balloons" (1959), de H. E. Edgerton. Esta asociación de la figura de la bala con la instantánea tridimensional y el ralentí digital llega a tal punto que la expresión "tiempo de la bala" acabará por imponerse a las anteriores "tiempo muerto" y "loncha de tiempo". La popularización definitiva del término "bullet time" se produjo gracias a la película The Matrix (1999) de los hermanos Lana y Andy Wachowski, con John Gaeta al cargo de los efectos especiales.

En la escena en la que el protagonista esquiva las balas, el punto de vista varía a una velocidad distinta, desconectada del ralentí que afecta al personaje. Consciente de las posibilidades de la imagen código, Gaeta colocó 120 cámaras fotográficas, de acuerdo con una previsualización en el ordenador. Aparatos y actores se dispusieron en el interior de un cilindro verde, un green screen que permitió la posterior 
composición de la imagen. Las cámaras se situaron a una distancia mínima unas de otras y las tomas se multiplicaron mediante interpolaciones. Como resultado, un segundo en la captura se estira hasta 5 en la imagen final. ${ }^{16}$

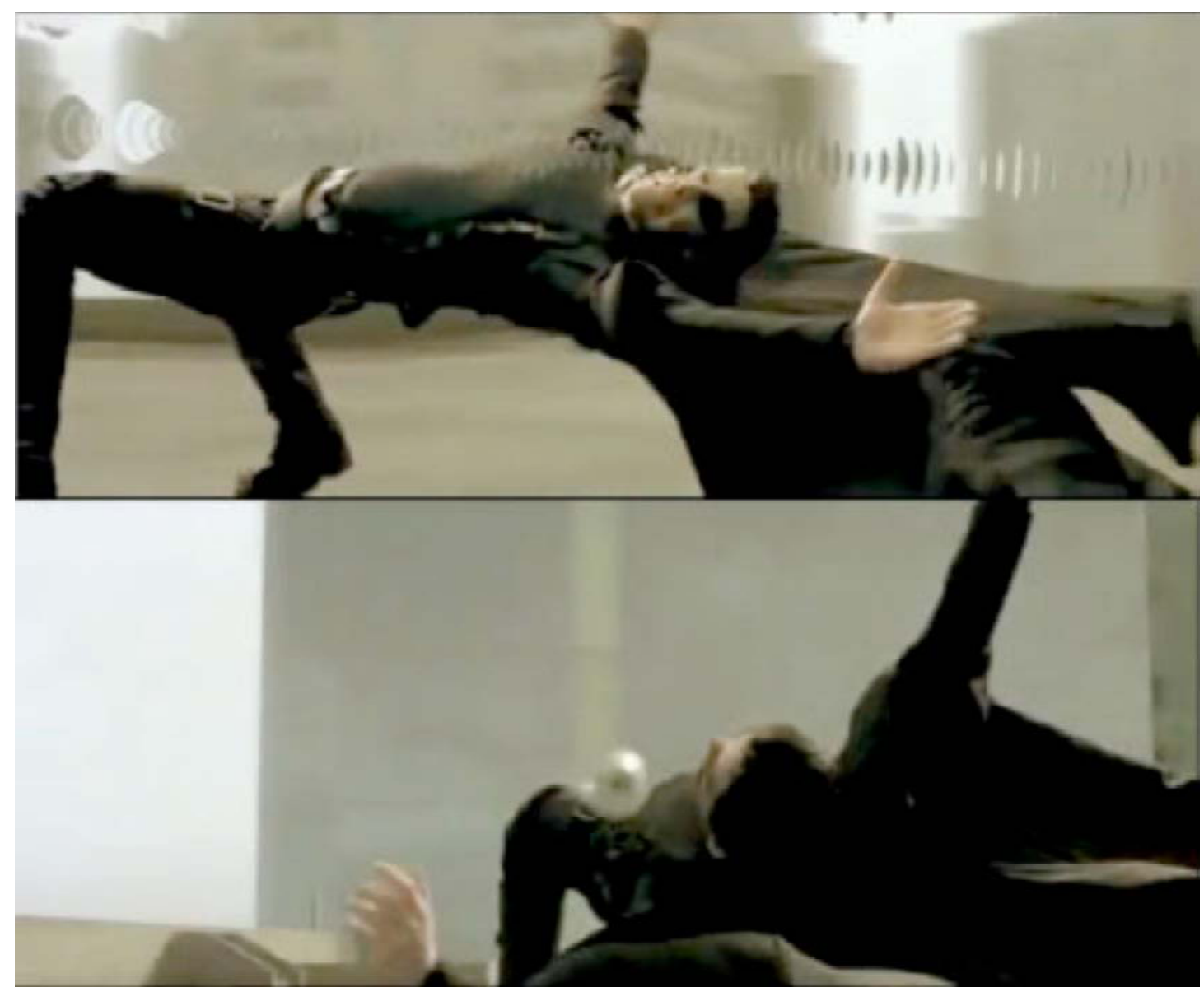

The Matrix (1999), de los hermanos Wachowski

Curiosamente, es la lentificación de las acciones la que crea la sensación de velocidad, permitiendo, de paso, percibir con toda nitidez los proyectiles en el aire. Ahora bien, frente al videoclip de Korn, en la famosa escena de The Matrix, el punto de vista no es exactamente el de la bala, sino que la cámara virtual se sitúa entre los objetos y los personajes, en un claro ejemplo del espacio "del entre".

En The Matrix, la lentificación de la acción se relaciona con las habilidades sobrehumanas del héroe, Neo (Keanu Reeves), capaz de moverse a la misma velocidad que la bala. De modo semejante, en Spider-man (2002) de Sam Raimi, la técnica evidencia las capacidades ultradesarrolladas de Peter Parker (Tobey Maguire): su sentido arácnido le permite percibir los estímulos mucho más rápido que un ser

\footnotetext{
${ }^{16}$ RICKITT, Richard. Op. cit., p. 110.
} 
humano corriente, por lo que los movimientos se muestran ralentizados hasta congelar la escena. Aunque Raimi retoma el efecto macro de Freak on a Leash, en lugar de perseguir un solo objeto, la cámara virtual explora el espacio intermedio, saltando de un estímulo a otro y variando sin ruptura de escala y foco. De un avión de papel a una mosca y de ésta a la saliva propulsada a través de una pajita, la cámara virtual hace presente el aire entre los personajes, en un tratamiento espacial más próximo al entorno que al vacío.

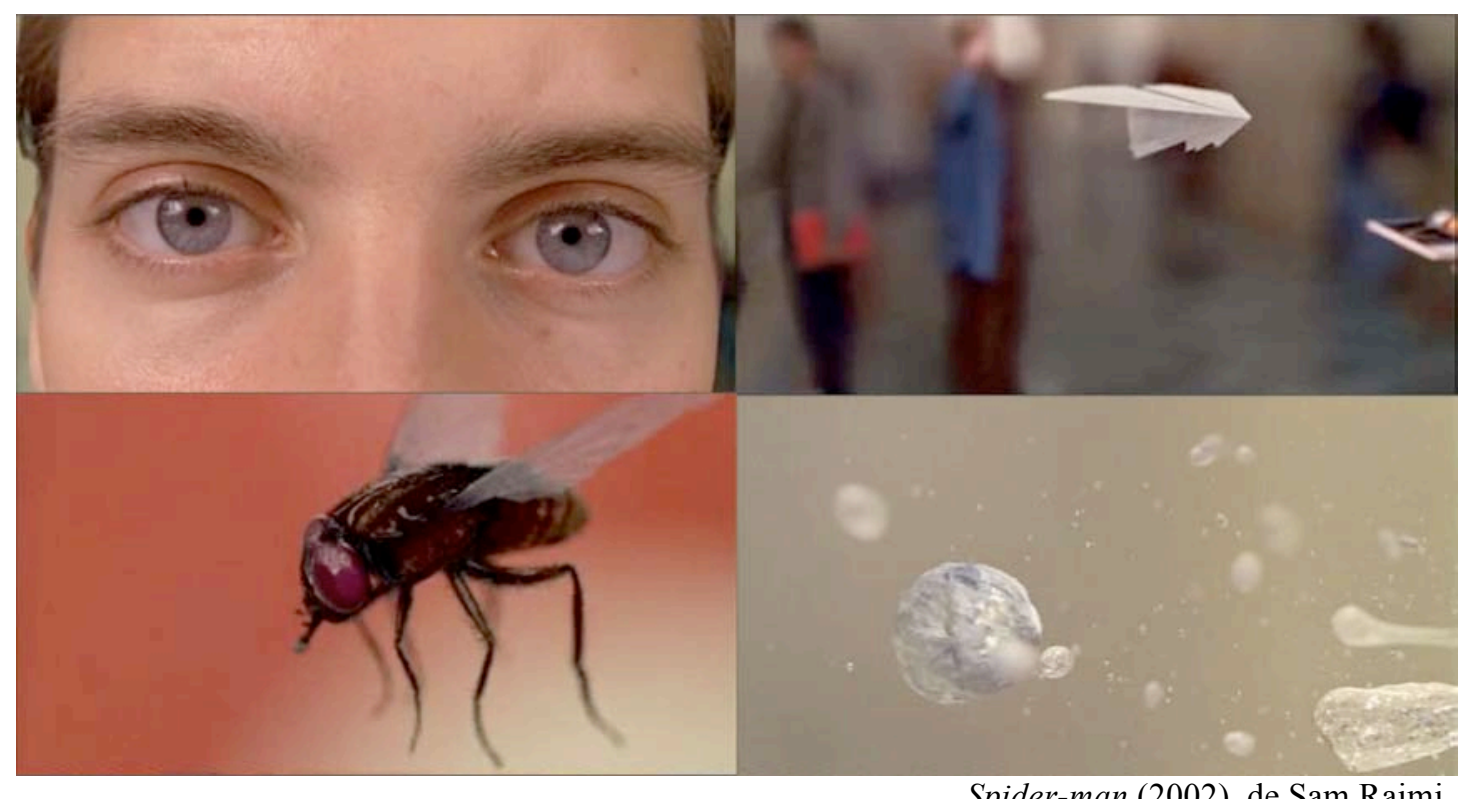

En Spider-man, el agua en suspensión cumple una función semejante a la figura de la bala en los ejemplos anteriores; de hecho, la congelación del líquido se repite en casi todos los ejemplos citados. Al modo de las instantáneas fotográficas de Worthington o Edgerton, el tiempo de obturación de las cámaras es tan corto que incluso las gotas de agua quedan flotando en el aire.

En su publicidad para la marca de diseño alemana Dornbracht, Daniel Askill propone una serie de esculturas muy semejantes al Temps mort de Carlier. Transforming Water (2010) lleva al máximo este anhelo de captura del fluido, petrificado en medio de un fondo negro. La comparación con "Milk-Drop Coronet Splash" evidencia el estado híbrido del constructo digital: entre escultura e instantánea. Aunque los giros de $360^{\circ}$ producen un efecto de bulto esculpido, la inclusión del líquido en suspensión se asocia a la fotografía; dicho de otro modo, en principio, una escultura en el espacio físico no consigue congelar el flujo del agua... 
Así, la fuerza visual del efecto reside en ese estado entre la instantánea fotográfica, esencialmente bidimensional, y el volumen de la profundidad cinética; entre la imagen fija y la animada. En este contexto, el concepto de "movimiento" aparece ligado al espacio de la imagen, como un síntoma más de su plasticidad. En forma de ralentí extremo o de instantánea tridimensional, bajo cualquiera de sus múltiples denominaciones ("bullet time", "time slice", "timetrack", etc.), la cámara virtual de la instalación multicámara se regodea en el recorrido del espacio. ${ }^{17}$

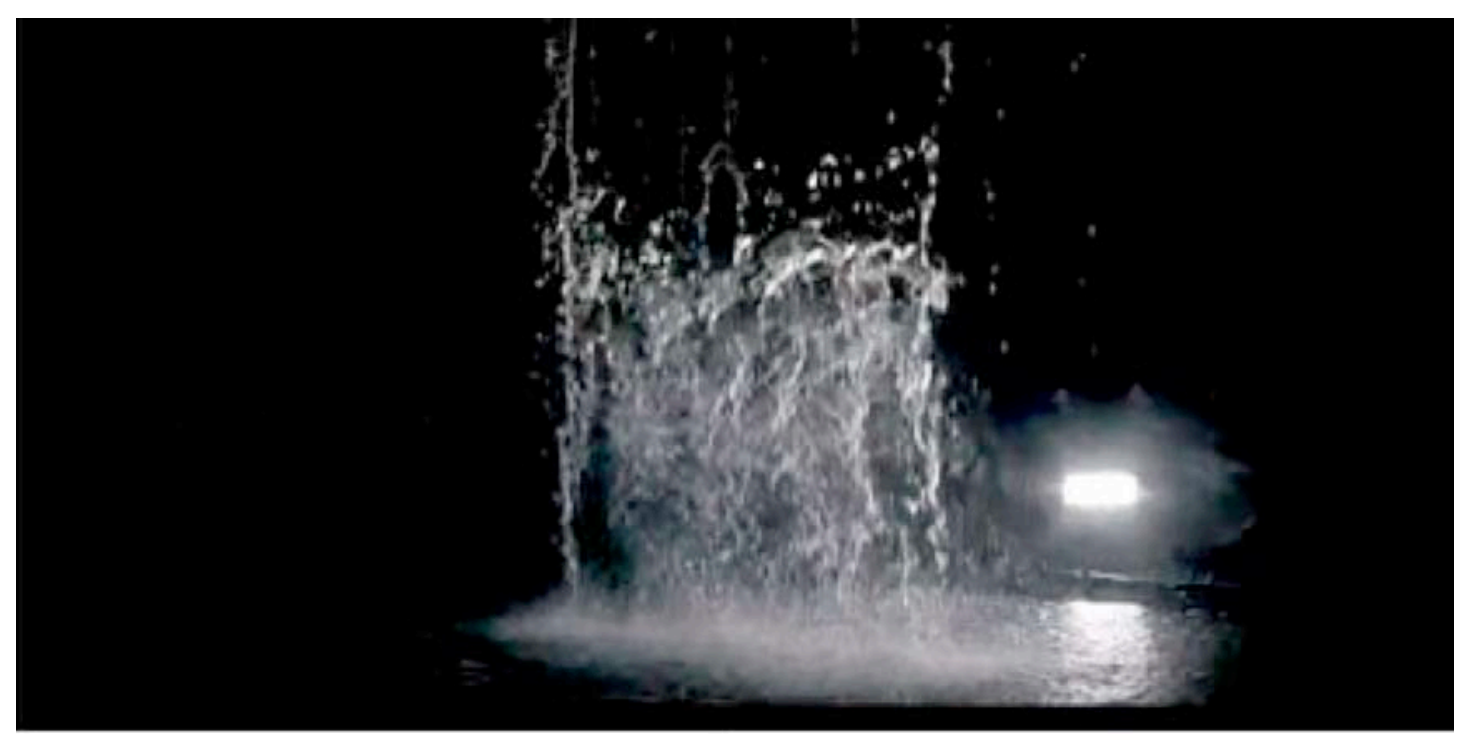

Transforming Water (2010), de Daniel Askill para Dornbracht

Esta "conquista" del líquido está presente también en Landscape, de Tamás Waliczky, con la que dábamos inicio al apartado. La cámara virtual se desplaza entre las gotas de lluvia frenadas en el aire. Este control pormenorizado de la suspensión de las partículas no hace sino subrayar el recorrido espacial de un instante. En realidad, la animación digital es la visualización que el artista húngaro propone del corto $E l$ milagro secreto (1944), de Jorge Luis Borges. El compositor ecuatoriano Mesías Maiguashca adaptó la obra del escritor argentino en su ópera Los enemigos y encargó a Waliczky una pieza visual para el espectáculo. ${ }^{18}$

Merece la pena transcribir el fragmento referido. Antes de ser arrestado y condenado a muerte por su ascendencia judía, el protagonista de El milagro secreto

\footnotetext{
${ }^{17}$ En Transforming Water, Askill incluye otros efectos fotográficos como la sobreimpresión o el motion blur. Con ello, el artista explora un aspecto de la continuidad que va más allá del desplazamiento de la cámara virtual o de las interpolaciones: la continuidad del movimiento mismo de las figuras y su captura en un espacio lleno, que veremos en el próximo apartado.

${ }^{18}$ El estreno de la ópera tuvo lugar el 31 de octubre de 1997 en la ceremonia inaugural del KZM (Zentrum für Kunst und Medientechnologie) en Karlsruhe (Alemania).
} 
(Hladík) pide a Dios un año de prórroga para poder acabar la obra dramática que estaba escribiendo, titulada precisamente "Los enemigos". Borges describe así el milagro que tiene lugar frente al pelotón de fusilamiento:

"El piquete se formó, se cuadró. Hladík, de pie contra la pared del cuartel, esperó la descarga. Alguien temió que la pared quedara maculada de sangre; entonces le ordenaron al reo que avanzara unos pasos. Hladík, absurdamente, recordó las vacilaciones preliminares de los fotógrafos. Una pesada gota de lluvia rozó una de las sienes de Hladík y rodó lentamente por su mejilla; el sargento vociferó la orden final.

El universo físico se detuvo.

Las armas convergían sobre Hladík, pero los hombres que iban a matarlo estaban inmóviles. El brazo del sargento eternizaba un ademán inconcluso. En una baldosa del patio una abeja proyectaba una sombra fija. El viento había cesado, como en un cuadro. Hladík ensayó un grito, una sílaba, la torsión de una mano. Comprendió que estaba paralizado. No le llegaba ni el más tenue rumor del impedido mundo. Pensó estoy en el infierno, estoy muerto. Pensó estoy loco. Pensó el tiempo se ha detenido. Luego reflexionó que en tal caso, también se hubiera detenido su pensamiento." 19

La cuestión que se planteaba a Waliczky era cómo poner en imágenes la idea subyacente al fragmento: esa congelación de las acciones mientras una conciencia omnipotente continúa observando la escena desde fuera. Fiel a su exploración de espacios distintos a la perspectiva y el registro mimético, Waliczky decide dinamizar la imagen más allá de la simple reproducción del movimiento. Sujetos y objetos quedan paralizados, degradados a un puesto secundario, a favor de una entidad espacial intermedia: el entorno mismo que los engloba. El extraño constructo corresponde a una suerte de corte transversal del continuo espacio-temporal. O dicho de otro modo: la instantánea tridimensional de Waliczky es, en realidad, una cristalización de la cuarta dimensión.

\footnotetext{
${ }^{19}$ BORGES, Jorge Luis. "El milagro secreto" (1944). En: Ficciones. Madrid: Alianza Editorial, 2004, pp. 173-183.
} 
En este segundo capítulo, hemos insistido en la omnipotencia de la cámara virtual. Esta característica es consecuencia directa de su condición de constructo espacial. Gracias a su inmaterialidad, la cámara virtual se deshace del lastre del aparato físico, no halla frontera a su paso, permite adoptar todo tipo de puntos de vista y cambiar de uno a otro de forma fluida. En este flujo continuo, subraya el "espacio del entre": entre sujetos y objetos, entre imagen fija y animada, entre las dos y las tres dimensiones.

La cámara virtual se libera de las limitaciones del "testigo antropomórfico". En este sentido, hemos constatado cierta continuidad entre la imagen digital y el cine de las vanguardias históricas, principalmente, en la corriente de la "cámara desencadenada". Ahora bien, en las prácticas digitales, este interés por el espacio intermedio afecta, también, a las mismísimas dimensiones de la imagen: tanto en lo que respecta a la síntesis de imágenes-media en la interpolación como a la exploración de una "dimensión 2'5", a menudo, acompañada por la tensión entre fijación y movimiento. Aunque la cámara virtual genera una sensación de volumen, ésta no implica un espacio euclidiano, tridimensional u homogéneo: la "profundidad cinética" permite construir entidades espacio-temporales específicas de la imagen.

Así, hemos definido las figuras del "zoom digital" y el "plano secuencia digital" por oposición a sus homónimas en la imagen registro: lejos del efecto óptico y la reproducción, estas construcciones exhiben la potencia plástica del espacio. Si en la primera, hemos destacado la mutación continua de la escala (que permite, entre otros, construir fractales), en la segunda, hemos analizado obras que añaden a esta dilatación en profundidad la elasticidad de los cuatro fueras de campo laterales de la imagen.

Por último, hemos descrito la figura de la "instantánea tridimensional" como un paradigma de la independencia de la cámara virtual con respecto al tiempo del registro. La animación de la imagen corresponde, exclusivamente, a la dinamización del punto de vista; es decir, se trata de construir un movimiento que nunca tuvo lugar.

Hemos visto cómo esta figura, caracterizada por una tridimensionalidad paradójica, puede ser interpretada como un "corte" transversal del espacio-tiempo: un homenaje a la cuarta dimensión. En el próximo y último capítulo, profundizaremos en la construcción tanto de hiperespacios como de dinámicas de la imagen más allá de la reproducción del movimiento. 


\section{CAPÍTULO III}

LA CONSTRUCCIÓN DE ESPACIOS NO-EUCLIDIANOS E HIPERESPACIOS 


\section{EL MOVIMIENTO COMO FORMA CONTINUA}

Generalmente, en las teorías cinematográficas centradas en el aspecto temporal de la imagen, el movimiento es entendido como acción, como traslación de un objeto de una posición A a una posición $\mathrm{B}$ en un espacio vacío. Lejos de esta idea, las prácticas digitales analizadas a continuación parten del movimiento como forma continua en el espacio. Este proceso de transformación, caracterizado por la exaltación de las fases intermedias, se manifiesta desde la reinterpretación de efectos fotográficos como el motion blur ${ }^{1}$ o la multiexposición hasta el morphing como técnica de animación.

\section{El motion blur o la influencia del futurismo}

En la escena de The Matrix (1999) gracias a la cual los hermanos Wachowski popularizan el bullet time, los poderes sobrehumanos de los personajes se revelan como un extraordinario dominio del espacio-tiempo. En menos de un minuto, se suceden en la pantalla tres manifestaciones distintas de una misma concepción espacial del movimiento: una metamorfosis digital, un efecto de exposición múltiple y el bullet time. Así como la encarnación del agente Smith en el cuerpo de otro ser humano se figura gracias a la viscosidad de un morphing, la velocidad de reacción de los personajes se muestra mediante dos tipos distintos de espacialización temporal. En el apartado anterior, veíamos cómo la lentificación máxima del movimiento de Neo corresponde, grosso modo, al "tiempo de la bala"; es decir, la velocidad de reacción del héroe es tal que los gestos serían imperceptibles al ojo desnudo. Al disminuir la velocidad de la acción hasta poder seguir nítidamente la trayectoria del proyectil, es posible contemplar la increíble reacción del protagonista.

Apenas unos segundos antes del famoso ralentí, otra espacialización del tiempo figura una velocidad semejante: en esta ocasión, a la hora de mostrar la extraordinaria habilidad del personaje al esquivar las balas, los Wachowski presentan un efecto fotográfico entre el motion blur y la multiexposición. Es como si la rapidez del

\footnotetext{
${ }^{1}$ A menudo, el motion blur se añade a la imagen de síntesis para darle la apariencia de un registro fotográfico. Sin embargo, el efecto no nos interesa aquí como técnica fotorrealista, sino, exclusivamente, como espacialización del tiempo.
} 
desplazamiento fuera tal que la cámara no alcanzara a registrar nítidamente el movimiento. Sin embargo, los actores no pudieron moverse a tal velocidad.

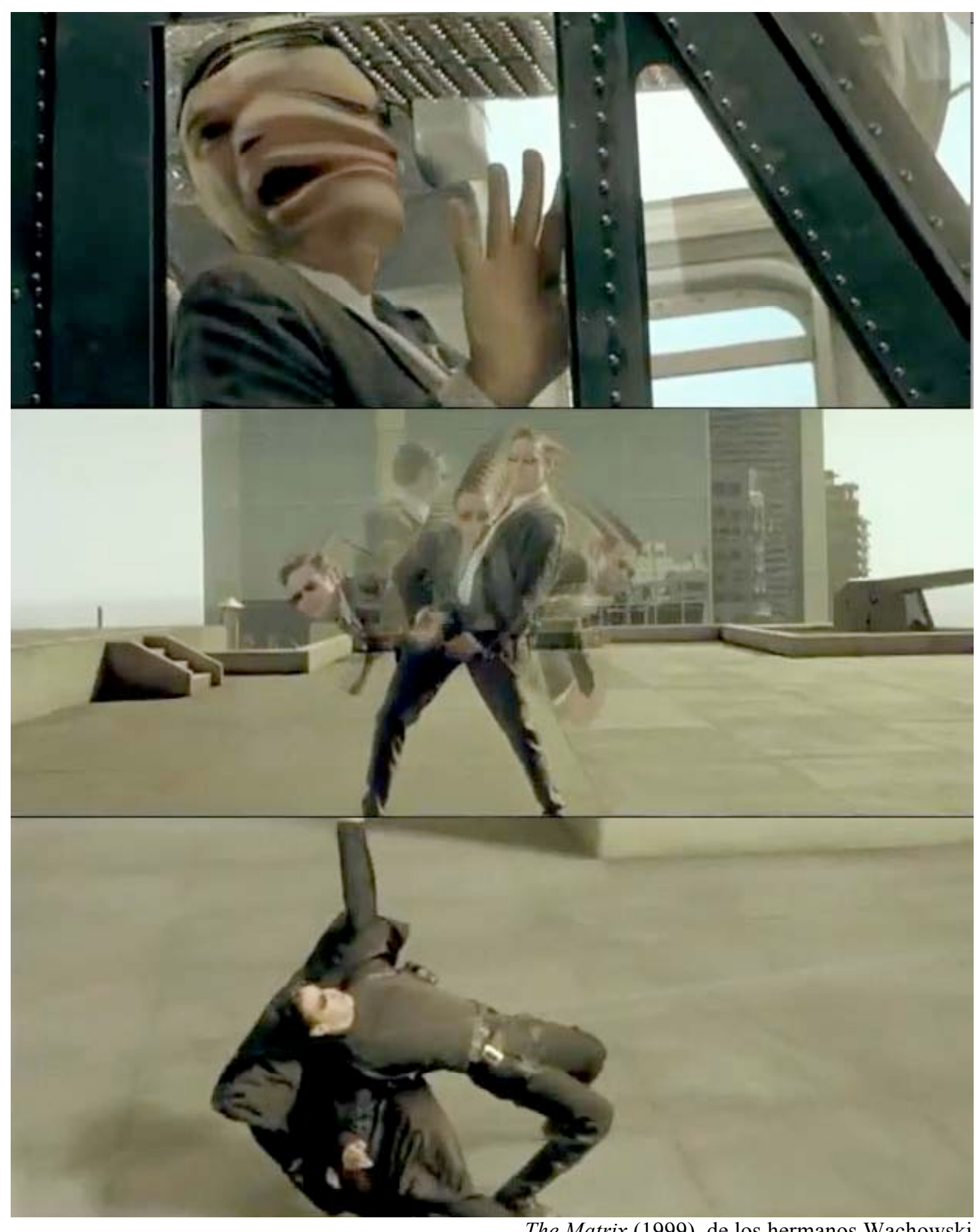

Arriba, morphing. En el medio, efecto entre la multiexposición y el motion blur. Abajo, bullet time

En el registro fotográfico, el motion blur es el producto de una exposición larga o de un movimiento relativo excesivamente rápido. Este último caso es el que falsea el efecto en The Matrix. En lo que concierne a la exposición, la fijación de la imagen 
depende del tiempo que el objetivo permanece abierto, permitiendo la entrada de luz y su impresión en la película. Hasta el descubrimiento del gelatino-bromuro alrededor de 1880, ese tiempo de exposición debía ser tan largo que el más mínimo movimiento se traducía en un borrón en la imagen. Tal resultado solía considerarse como un error. No obstante, ya el propio Muybridge parece haber experimentado conscientemente con la potencia visual del efecto. En sus fotografías de la dinámica del agua, el fluir del líquido como una entidad esencialmente cambiante queda perfectamente reflejado en la masa informe de la imagen. Más allá de las series descritas en relación al timeslice, la perseverancia del fotógrafo al intentar capturar el movimiento se manifiesta en otro tipo de instantánea mucho menos asociada a su figura: estas largas exposiciones capturan el cambio de la forma en el tiempo.

La corriente futurista es una de las primeras en reivindicar el uso estético del motion blur. Guiados por su tendencia al hórror vacui, los artistas acuden a la fotografía en sus experimentos acerca de la continuidad de la materia. Así, en Fondamento plastico della scultura e pittura futuriste (1913), Umberto Boccioni (1882-1916) reflexiona sobre el espacio en las artes plásticas:

\begin{abstract}
"Las distancias entre un objeto y otro no son espacios vacíos, sino continuaciones de materia de intensidad diferente, que nosotros revelamos con líneas sensibles que no corresponden a la verdad fotográfica." ${ }^{2}$
\end{abstract}

Como explicábamos ya en el primer capítulo, las vanguardias históricas reflejan en sus construcciones espaciales la experiencia visual de la metrópoli. En este contexto, la relación entre movimiento y fijación fascina a los futuristas, que intentan atrapar el desplazamiento fugaz de los cuerpos:

\footnotetext{
“Todo se mueve; todo corre; todo se torna veloz. Una figura nunca está inmóvil ante nosotros, sino que aparece y desaparece incesantemente. Por culpa de la permanencia de la imagen en la retina, las cosas en movimiento se multiplican, se deforman, sucediéndose, como si de vibraciones se tratara, en el espacio que recorren."3
}

\footnotetext{
${ }^{2}$ LISTA, Giovanni. Cinéma et photographie futuristes. Milan: Skira, 2008, p. 20.

${ }^{3}$ BOCCIONI, U.; CARRÀ, C.; RUSSOLO, L; BALLA, G.; SEVERINO, G.. "La pintura futurista. Manifiesto técnico" (1910). En: CALVO SERRALLER, F.; GONZÁLEZ GARCÍA, A.; MARCHÁN FIZ, S.. Escritos de arte de vanguardia, 1900/1945. Madrid: Ediciones Turner, 1979, p. 145.
} 
Boccioni no considera ni la fotografía ni el cine como parte del arte futurista. De hecho, el montaje temporal cinematográfico choca frontalmente con su concepción de la imagen como continuo ${ }^{4}$. Sin embargo, la imagen mecánica es asimilada por el arte moderno y los propios futuristas se abren (de forma no oficial) a las posibilidades de la reproducción. Así, por ejemplo, los hermanos Anton Giulio (1890-1960) y Arturo Bragaglia (1893-1962) se sirven de la cámara fotográfica para mostrar "lo invisible", ampliando las fronteras de la reproducción mimética naturalista. Sus "fotodinámicas" muestran el espacio como un ente lleno, en el cual el desplazamiento de los cuerpos se petrifica, dando lugar a una forma nueva: la forma del movimiento.
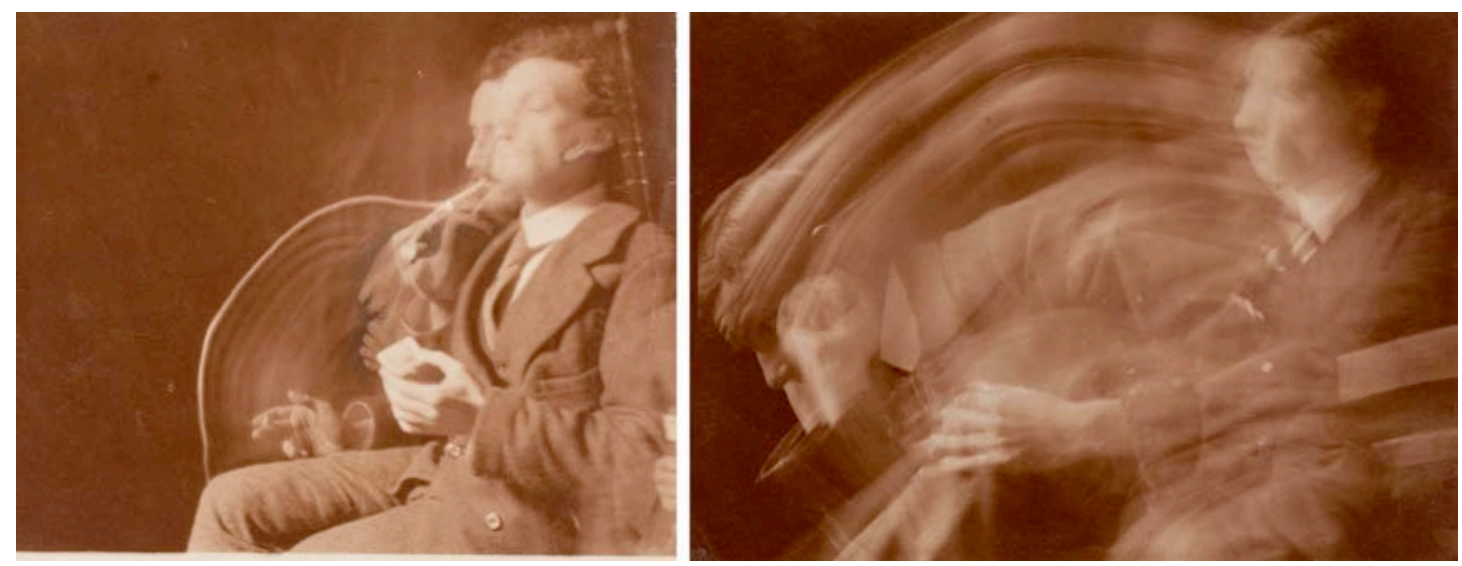

Anton Giulio Bragaglia: izquierda, "Il fumatore" (1911); derecha, "Cambiando di postura" (1911)

Casi un siglo después, el artista estadounidense Jim Campbell reinterpreta la instantánea fotográfica en la era digital. La serie "Dynamism" (2000-2002) presenta seis imágenes impresas en inyección de tinta, caracterizadas por una falta de nitidez voluntaria. Ésta no es debida a la baja velocidad de obturación del objetivo (como en el futurismo o en Muybridge), sino a un tratamiento informático. Primero, Campbell graba la escena en vídeo y, después, la trata digitalmente. Cercano a la lógica del morphing y a la visualización de datos de Jason Salavon, que veíamos en el primer capítulo, el proceso condensa el total de frames en una sola imagen estática, que es la media aritmética de sus componentes. El experimento, homenaje explícito a la fotografía futurista, podría ser interpretado como la cara opuesta del zoopraxiscopio

\footnotetext{
4 "L'accusation de cinématographie nous fait rire comme une vulgaire imbécillité. Nous ne subdivisons pas les images visuelles, nous cherchons un signe, ou mieux, une forme unique qui substituerait aux vieux concept de division le nouveau concept de continuité." Umberto Boccioni. Apud. LISTA, Giovanni. Op. cit., p. 20.
} 
de Muybridge: en lugar de animar las instantáneas, se trata de condensarlas en una imagen fija.

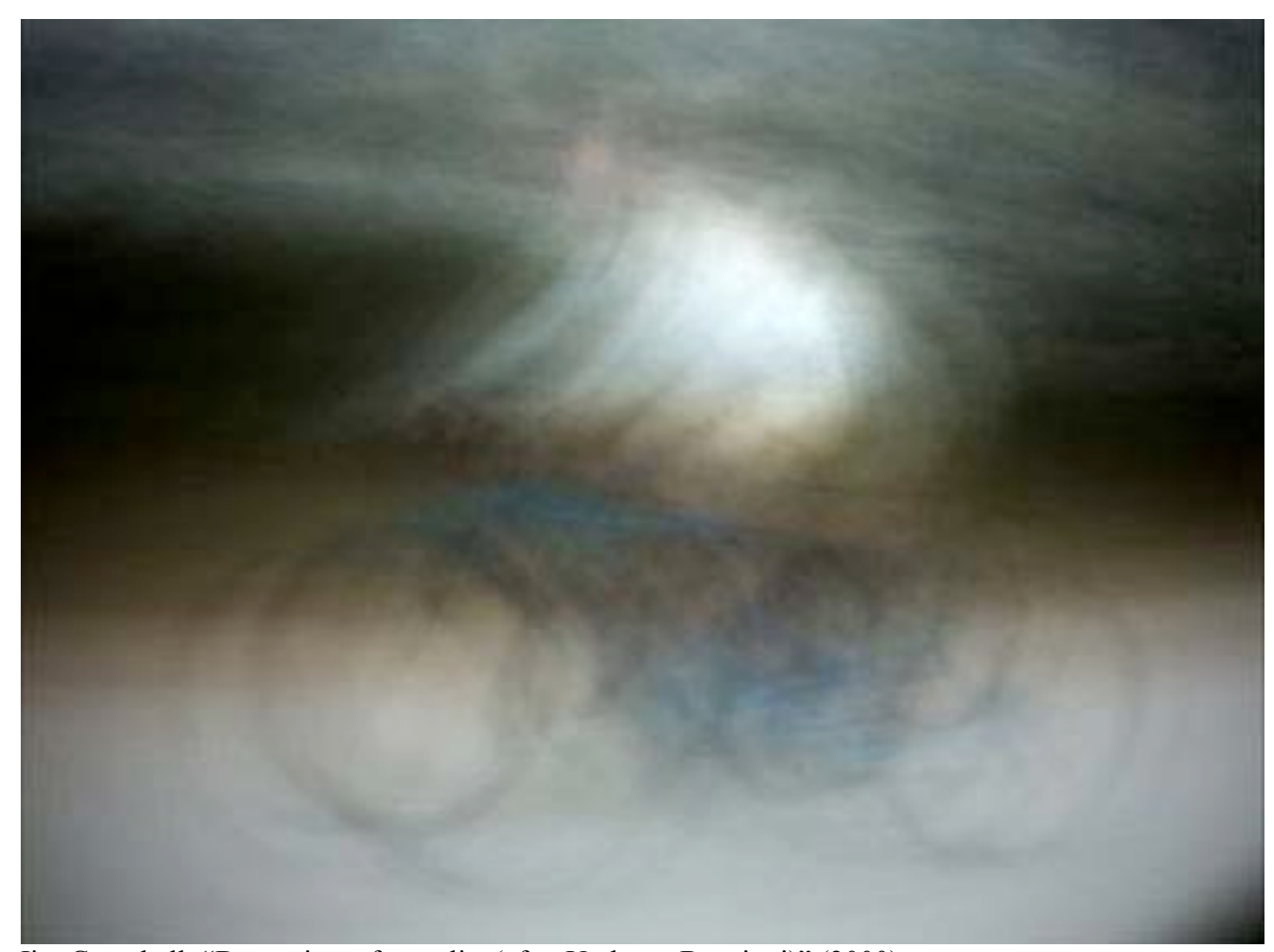

Jim Campbell: “Dynamism of a cyclist (after Umberto Boccioni)” (2000)

En las fotodinámicas futuristas, el tiempo queda espacializado siguiendo la línea de desplazamiento de la figura. Esta trayectoria suele corresponder con el eje horizontal o vertical de la fotografía, de modo que su registro subraya la bidimensionalidad de la imagen. Al contrario, la imagen-media de Campbell es un constructo sintético que presenta todas las fases al mismo tiempo, unas sobre otras, destacando el eje perpendicular del espesor de la imagen. Así, en realidad, estas “instantáneas" no corresponden a ningún instante preciso, sino a una impresión general. Despojado de su temporalidad, el movimiento se presenta como un agente de la plasticidad espacial.

La "instantánea tridimensional” (que describíamos al final del capítulo anterior) puede contener todo tipo de efectos fotográficos, entre ellos, el motion blur. En tal caso, varios tipos de movimiento conviven en la imagen: el de la cámara virtual y el de la/s figura/s. Si el primero anima la escena gracias a la dinamización del punto de vista, el segundo aparece como un rastro fijado en el espacio. 
Hallamos un buen ejemplo de esta combinación de time-slice y motion blur en la publicidad de Orange Photo Messaging (2002), dirigida por Chris Cunningham. En los cuarenta segundos que dura el anuncio, se suceden cinco instantáneas tridimensionales, ligadas entre sí por un desplazamiento común de izquierda a derecha, que produce la impresión de un plano secuencia semejante al trabajo de Macmillan. En cada una de las cinco escenas, la cámara virtual se desliza mostrando masas borrosas que corresponden al movimiento descrito por las figuras. El resultado es un producto híbrido entre el momento desplegado gracias a la cámara virtual y la captura de la forma del movimiento descrito por cada figura.

La imagen contrasta con la voz en off que da instrucciones sobre cómo evitar que las figuras aparezcan borrosas en la imagen. La ironía de la discrepancia entre el material audio y el visual acentúa el mensaje final, resumido en la invitación al juego, a la experimentación: “Come on, muck about!”. Como el arte de vanguardia, el vídeo digital parte de la aceptación del "error" en tanto que elemento estético, específico de la imagen y de su espacio plástico.

A la hora de construir la imagen, Cunningham se sirvió de una de las técnicas multicámara desarrolladas por la compañía Digital Air y el pionero Dayton Taylor, que apuntábamos ya en el apartado anterior. La propuesta se basa en una reinterpretación digital de efectos fotográficos, combinados entre sí en un espacio tridimensional. Así, por ejemplo, la técnica usada en el ejemplo citado se denomina “open flash" y resulta de la suma de la congelación producida por el destello luminoso y las largas exposiciones.

Ese aspecto lumínico de la huella en el espacio se hace explícito al final del anuncio cuando las figuras humanas dejan paso a líneas de colores suspendidas en el aire. La técnica, conocida como "light painting"5 o "fisiograma", se basa en el mismo principio del motion blur, es decir, en el desfase entre la velocidad de obturación del objetivo y el movimiento de la fuente luminosa. Una idea presente ya en la fotografía de Bragaglia Il fumatore (1911).

Frente a las borrosas instantáneas de Campbell, en el vídeo de Cunningham, los fondos aparecen perfectamente nítidos. Este contraste dota de un carácter escultural a la forma del movimiento, a pesar de la transparencia y la escasa densidad del rastro dejado por el cuerpo. Comparada con las fotodinámicas futuristas, la publicidad de

\footnotetext{
5 En 1889, Georges Demenÿ (colaborador de Étienne-Jules Marey) crea la que es considerada comúnmente como la primera instantánea de light painting.
} 
Orange pierde la connotación casi fantasmagórica que conlleva la revelación de lo oculto, y sitúa al observador prácticamente entre las figuras gaseosas.

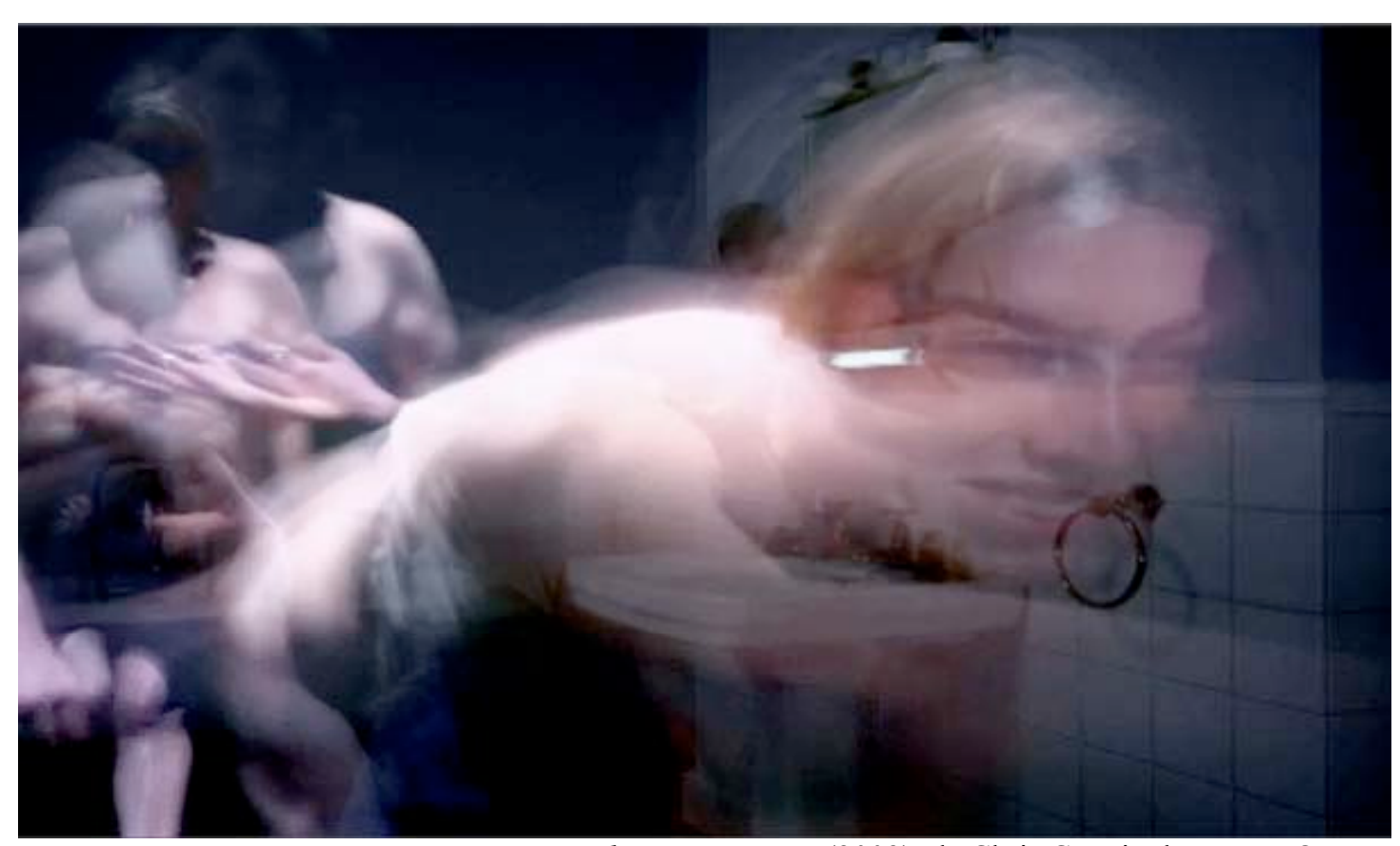

Photo Messaging (2002), de Chris Cunningham para Orange

Mientras que en The Matrix la forma del movimiento y el bullet time aparecen en la misma escena, pero asociadas a dos personajes distintos, Cunningham mezcla ambos efectos en una única construcción visual. De modo semejante, Olivier Gondry combina las dos técnicas en su videoclip You Gonna Want Me (2005) para el DJ Tiga. Con todo, el realizador francés se sirve de la disposición multicámara para crear sus objetos tridimensionales, sin congelar por ello la acción. Los miembros del grupo se mueven siguiendo la coreografía del baile urbano conocido en Francia como "tectonique"; un tipo de danza tecno caracterizada por giros de $360^{\circ}$ al tiempo que los brazos realizan torsiones y dibujan ondulaciones en el espacio.

En este sentido, la concepción espacial es semejante a la Unnamed soundsculpture (2012) de Daniel Franke, que analizábamos en relación a la omnipotencia de la cámara virtual. Veíamos entonces que el constructo remite más bien a la danza que al teatro, en cuanto el espacio se presenta como el reverso del movimiento, como un medio lleno, sometido a los seres que lo habitan.

Los gestos de los bailarines se despliegan en el aire dejando en el espacio una huella: un motion blur similar a las fotodinámicas futuristas. Sin embargo, allí donde los fotógrafos de las vanguardias históricas reforzaban la linealidad del 
desplazamiento y con ella la bidimensionalidad de la imagen, Gondry consigue crear una escultura en acción: la forma de un movimiento en $360^{\circ}$.

Las huellas son tan borrosas que se acercan a la abstracción. De hecho, los trazos cromáticos dan paso a una serie de efectos de light painting. La comparación explícita de la forma del movimiento descrita por los cuerpos y el dibujo con luz remite a la misma asociación en la publicidad de Cunningham.

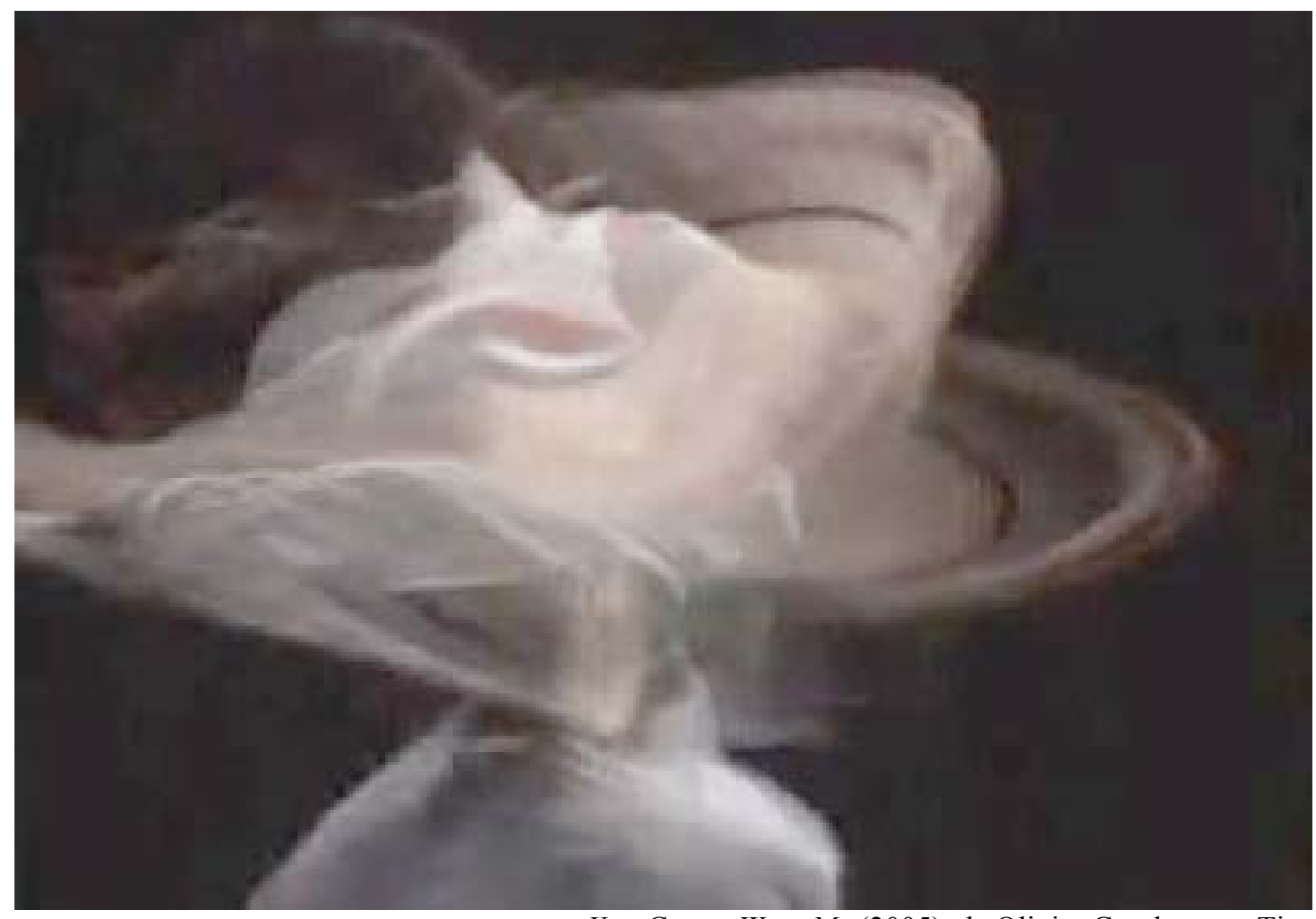

You Gonna Want Me (2005), de Olivier Gondry para Tiga

En la imagen animada, la espacialización del tiempo tiene la particularidad de poder presentar, a la vez, el movimiento de un cuerpo y su condensación. Es decir, aunque el desplazamiento continúa, el recorrido se acumula en el espacio como una precipitación de la forma. Éste es el caso en The Matrix: mientras el personaje regatea las balas en todas direcciones, las posturas grabadas en el aire se amontonan y desaparecen poco a poco, como imantadas en el cuerpo del actor.

El videoclip Show Me The Light (2010), de Tell No One (Luke White y Remi Weekes) para el grupo musical Mystery Jets, contiene varios ejemplos de esta captura dinámica de la forma del movimiento. De modo semejante a la pieza de Gondry, los desplazamientos de los miembros de la banda dejan un rastro lumínico, escultural. En ocasiones, la deformación es tal que se aproxima a un warping de la figura. 
Un efecto similar a la multiexposición en la película de los hermanos Wachowski muestra un ejercicio de gimnasia rítmica masculina. En el "caballo con arcos", el deportista se apoya con sus manos sobre un potro mientras hace girar las piernas en forma de tijera, sin que éstas toquen el caballete. Los componentes de Tell No One explotan la belleza de la ejecución para crear un efecto de desfiguración y abstracción cromática.

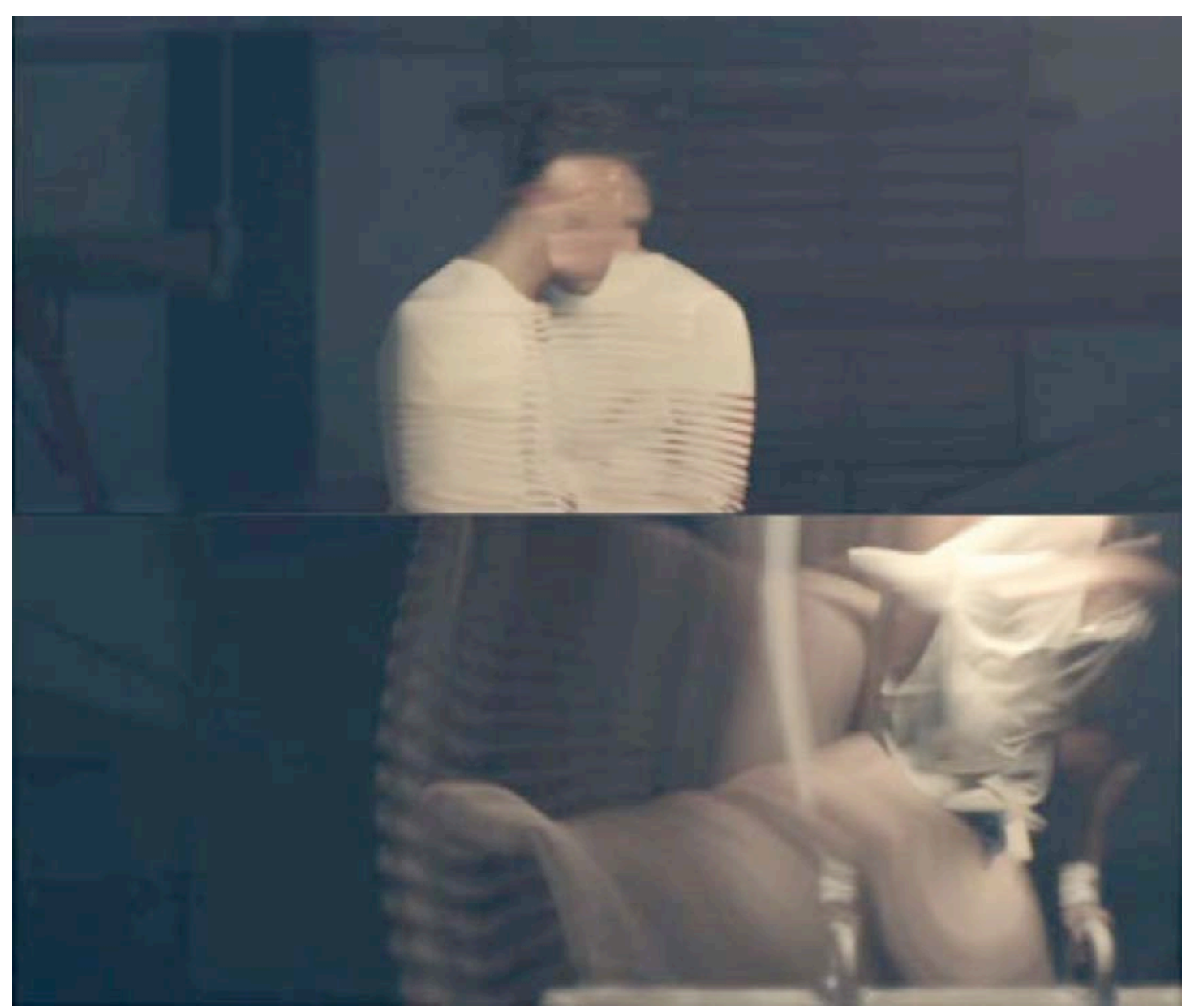

Show Me The Light (2010), de Tell No One para Mystery Jets

Comparemos esta imagen con otra de la misma temática en Naqoyqatsi (2002). La película de Godfrey Reggio contiene numerosas referencias a las series de Eadweard Muybridge sobre la locomoción animal y humana, de modo que la inspiración en la fotografía pre-cinematográfica es explícita. En el fragmento que nos interesa, el director americano muestra las fases intermedias de un desplazamiento: el cuadro inmóvil permite contemplar el abanico gestual, que se despliega como si el ralentí de la imagen produjera una saturación de la forma. 
Aunque el tema es el mismo que en la pieza de Tell No One, videoclip y película difieren ligeramente en el tratamiento espacial: mientras el primero tiende a la abstracción y la borrosidad, el segundo permite diferenciar diversas fases del movimiento. El efecto es muy similar a la exposición múltiple creada por el realizador británico-canadiense Norman McLaren en su Pas de deux (1968). El parecido incide, una vez más, en la continuidad entre la creación digital y determinadas propuestas del videoarte centradas en la exploración del espacio de la imagen.
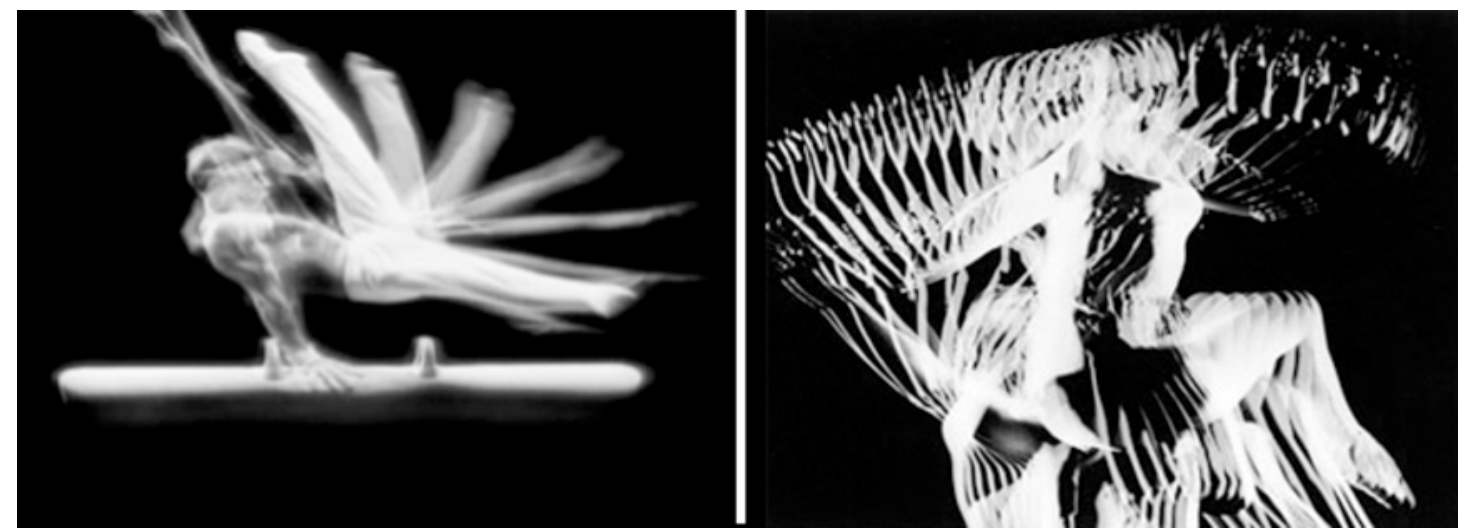

Izquierda, Naqoyqatsi (2002), de Godfrey Reggio. Derecha, Pas de deux (1968), de Norman McLaren

Del mismo modo que existe una influencia clara de las largas exposiciones de Muybridge y el futurismo en los efectos de motion blur de las prácticas digitales analizadas, estas multiexposiciones remiten a la cronofotografía, inventada alrededor de 1881 por Étienne-Jules Marey. Basta comparar los ejemplos citados en The Matrix y Naqoyqatsi con las siguientes dos imágenes, realizadas por Georges Demenÿ (18501917), alumno y colaborador del químico francés, para comprender la comparación de la propuesta digital con los experimentos fotográficos, un siglo antes.

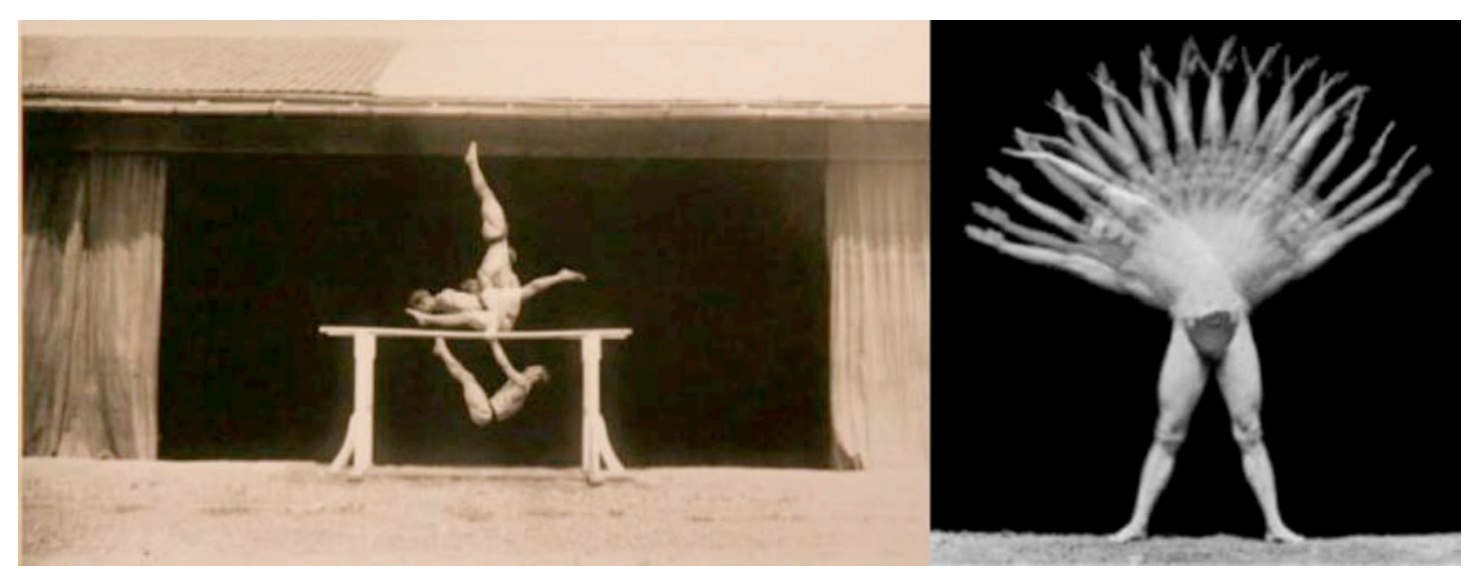

Georges Demenÿ: "Gymnastique. Un exercice aux barres parallèles"; "Un exercice d'assouplissement du corps". Serie "Chronophotographie" (1906), conservada en la iconoteca del INSEP (París) 


\section{La multiexposición o la influencia de la cronofotografía}

Étienne-Jules Marey inventa la técnica de la "cronofotografía" como instrumento para su análisis de la locomoción animal y humana. Descubierto ya el gelatino-bromuro, el científico francés trabaja con exposiciones cortas, de mayor nitidez, y se decanta por una multiexposición en la misma placa, hecho que le permite comparar los distintos gestos de la acción. En el caso de desplazamientos con cambio de posición, las cronofotografías de Marey no se diferencian sustancialmente de las series de Eadweard Muybridge. Como muestra ya el experimento de Palo Alto, la presentación contigua de las instantáneas permite relacionar las fases sucesivas del movimiento.

Aunque para Marey se trata ante todo de una cuestión científica, no estética, sus experimentos han inspirado a multitud de artistas en distintas disciplinas, desde la pintura y la fotografía hasta la imagen animada. Así, por ejemplo, los fotógrafos Harold Eugene Edgerton y Gjon Mili (1904-1984) continúan de manera directa con la cronofotografía. Su técnica estroboscópica consiste en la aplicación de un fogonazo de luz (semejante a lo que será, después, el flash), que atrapa la forma en un instante. La sucesión de varios de estos rápidos destellos mientras el obturador permanece abierto permite grabar las tomas en el mismo espacio, superponiéndolas. El resultado es una aplicación de los experimentos científicos de Marey a la composición fotográfica, artística.

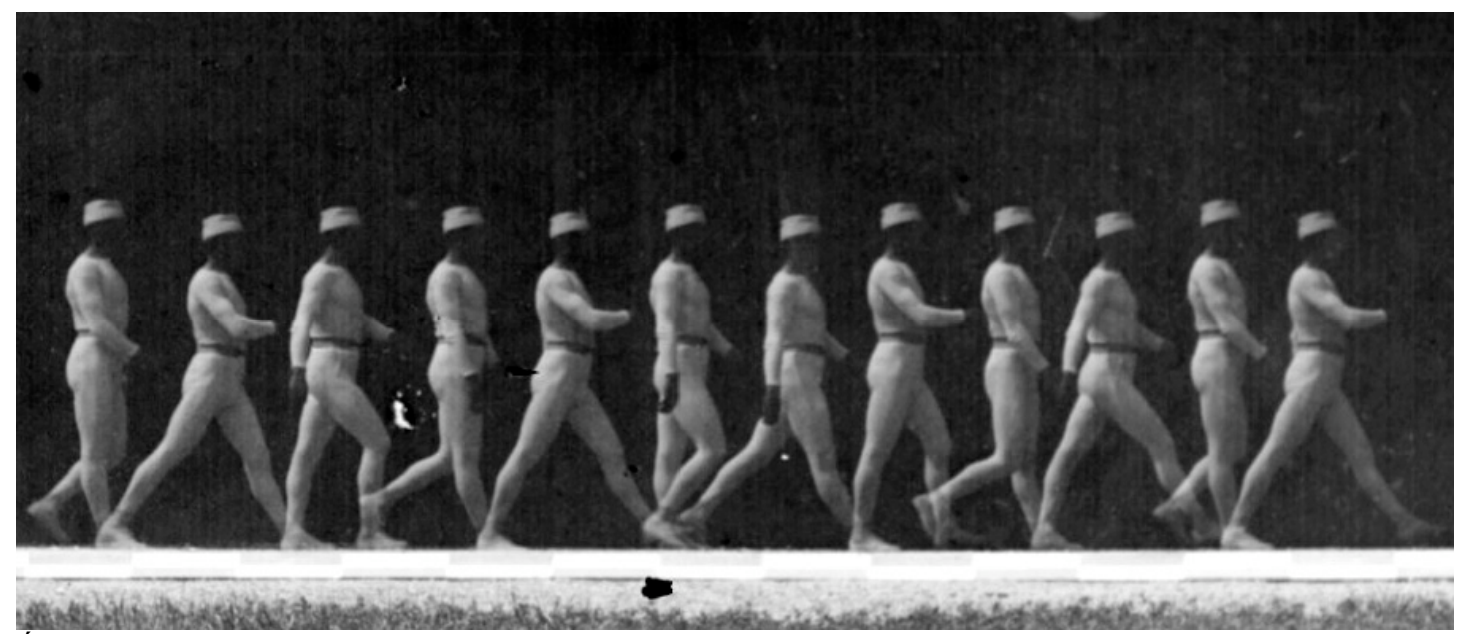

Étienne-Jules Marey: “Locomotion de l'homme” (1883) 
A menudo, los estudios del movimiento realizados por Marey y Muybridge se descontextualizan y mezclan entre sí. Así ocurre, por ejemplo, en las numerosas reinterpretaciones de "Nude Descending a Staircase" (1887), del fotógrafo inglés. Tanto en la pintura de Marcel Duchamp como en la fotografía de Gjon Mili, las diversas fases del movimiento (correspondientes a placas diferenciadas en los originales de Muybridge) se compactan en una única imagen, al modo de las multiexposiciones de Marey. Los experimentos digitales continúan más bien con estas reinterpretaciones artísticas que con la instantánea pre-cinematográfica en sí: en general, no se trata tanto de un análisis del movimiento, sino de una exhibición de la plasticidad de la imagen.

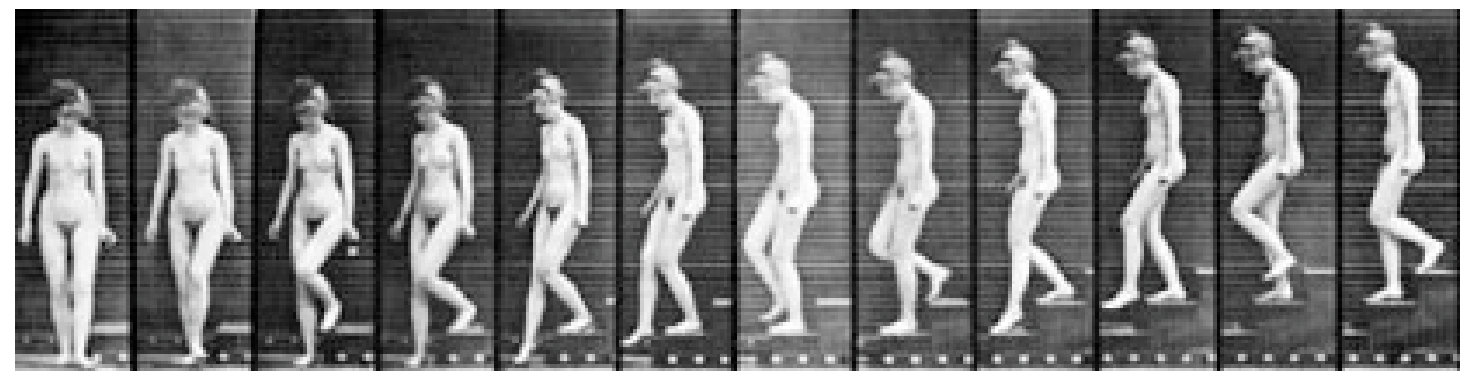

Eadweard Muybridge: "Nude Descending a Staircase" (1887)

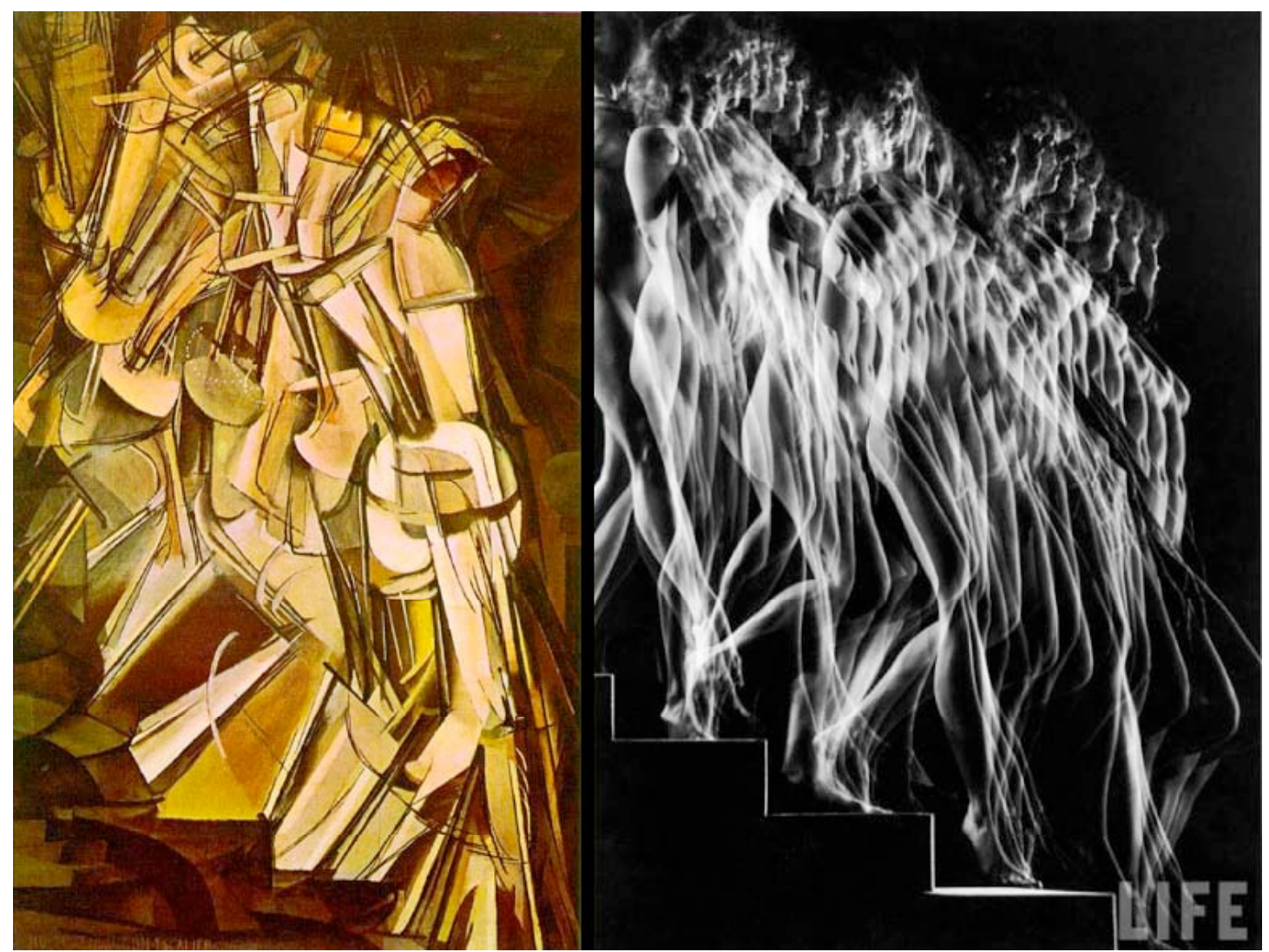

Izquierda, Marcel Duchamp: "Nu descendant un escalier n²" (1912)

Derecha, Gjon Mili: "Stroboscopic Study of Nude Descending a Staircase" (1942) 
Esta concepción del registro como materia prima maleable puede ir hasta la construcción de "monstruos" visuales: más allá de la tendencia a la desfiguración, a la abstracción como reivindicación del espacio plástico, típica del motion blur, la imagen fantástica puede ser de una nitidez extrema. Este es el caso, por ejemplo, de las extrañas construcciones de Tell No One Seaweed y Forest. Presentadas en 2010, su potencia visual reside en la extrema definición de la composición escultural.
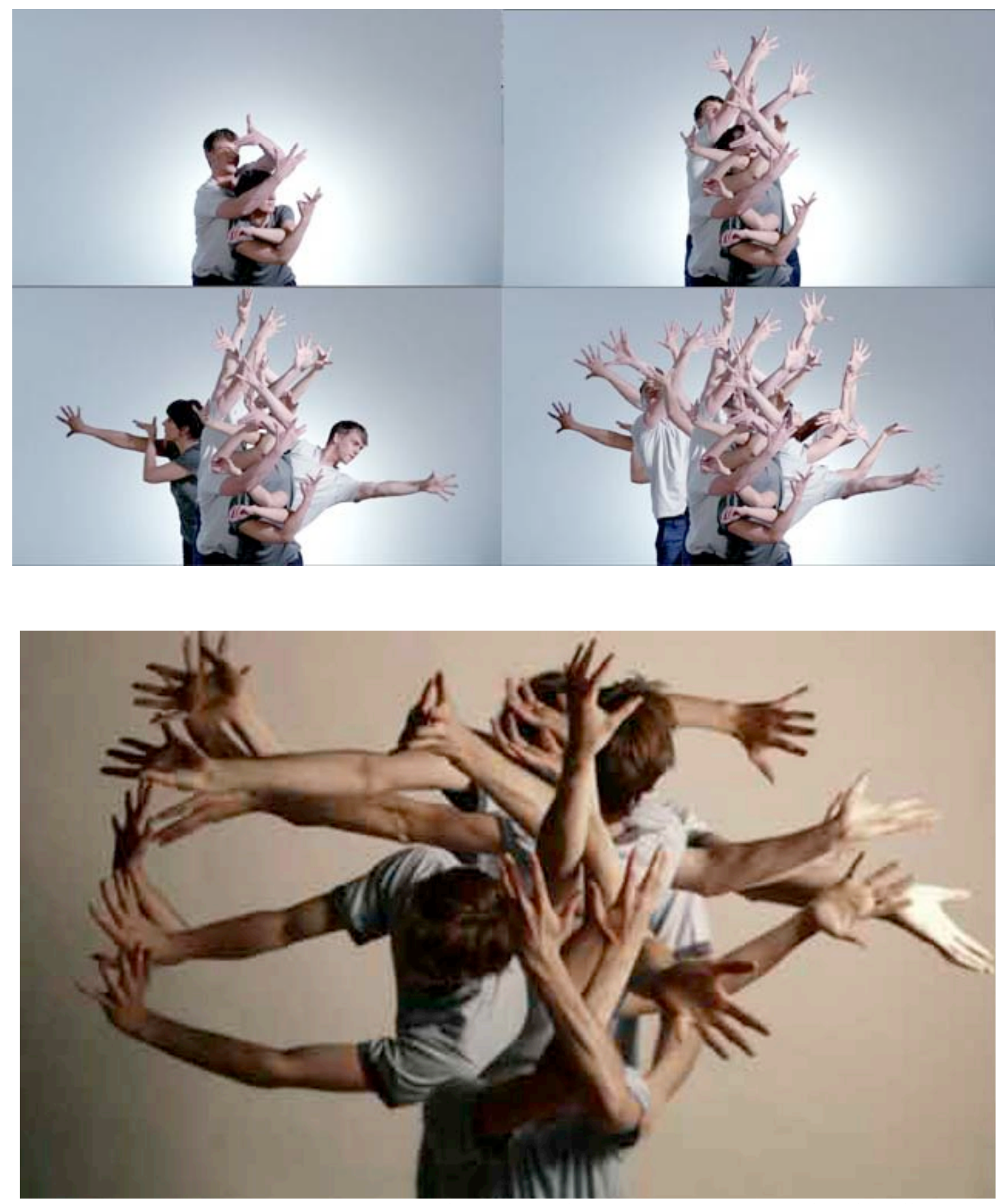

Arriba, Forest; abajo, Seaweed (2010), ambas de Tell No One 
En los pocos segundos que dura cada pieza, las personas adquieren diferentes posturas, que van sumándose hasta crear una composición arbórea. La nitidez de las formas podría hacer pensar en la cronofotografía de Georges Demenÿ, en la cual los intersticios entre las fases del movimiento permiten diferenciar los instantes capturados. No obstante, las construcciones de Tell No One no congelan los gestos, sino que las extremidades continúan agitándose como con vida propia. Ese ligero movimiento aumenta la sensación de volumen al tiempo que contribuye a la creación del espectáculo. Es como si, al presentar el proceso de construcción, los autores se comportaran como el mago que muestra el interior del sombrero antes de sacar el conejo: "no hay trampa" -parecen querer decirnos- "tan sólo, magia".

La multiplicación de las extremidades no dibuja el recorrido descrito por el movimiento: no se trata de la capacidad de atrapar el tiempo, sino del dominio total del espacio. De hecho, frente a la multiexposición o la sobreimpresión, las formas no se apilan en capas transparentes, sino que el efecto se sustenta en la opacidad. La expresividad del constructo radica, precisamente, en la corporeidad, en la solidificación de esa adición imposible. Las "huellas" se suman unas a otras, despojadas de toda temporalidad en aras de una creación puramente estética. Así, mientras que la fijación de la luz en los haluros de plata de la fotografía se comporta como un indicio, como un registro temporal, en el experimento de Tell No One, el sello de la forma es síntoma de la plasticidad del espacio digital.

Encontramos un ejemplo muy anterior de esta diferencia sustancial con el espacio fotográfico en la obra del videoartista Ed Emshwiller. El corto Sunstone (1979) marca un antes y un después en la creación de un espacio tridimensional en la imagen por ordenador. La pieza, de apenas tres minutos de duración, comienza con una serie de metamorfosis lumínicas de un sol antropomórfico. La imagen bidimensional resulta ser uno de los seis lados de un cubo que rota sobre un fondo negro. Un zoom in sobre otra de las caras del poliedro muestra una masa fluida de colores vibrantes y ondulaciones luminosas.

Una figura masculina atraviesa el cuadro en ambos sentidos, dejando tras de sí un rastro semejante a las huellas en la arena de una ola que se retira. Aunque la nitidez de las siluetas hace pensar en la cronofotografía, la continuidad espacial de las fases, apiladas unas sobre otras, remite al motion blur en tanto que flujo constante de variaciones. Como en los experimentos creados por Tell No One, la construcción no hace referencia al análisis de las fases del movimiento, sino al juego plástico de la 
dinamización espacial. Frente a la noción temporal del desplazamiento de la forma en un espacio vacío, Sunstone muestra un espacio lleno, conductor de las transformaciones.

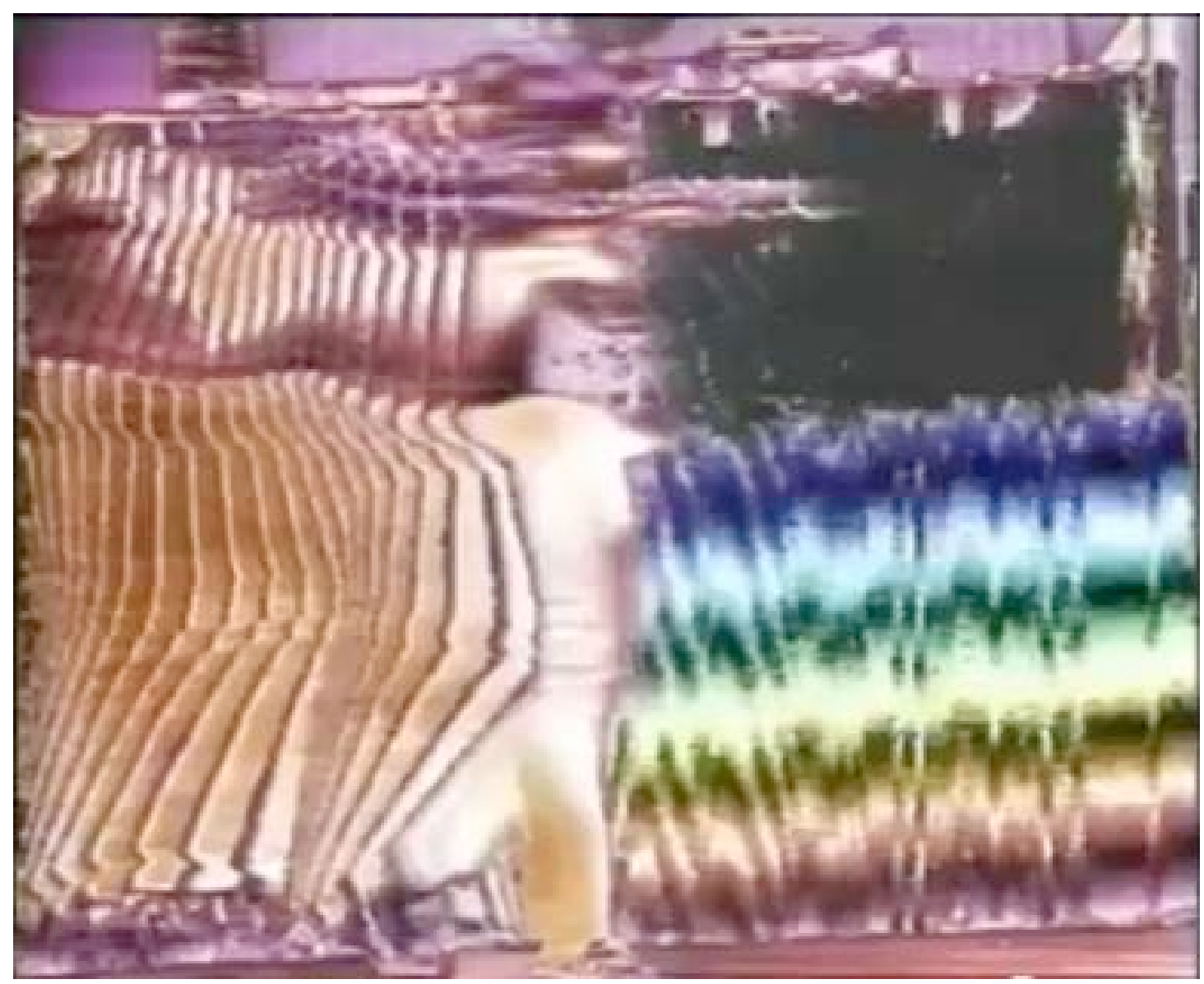

Sunstone (1979), de Ed Emshwiller

La publicidad para Lux Shower Gel (2004), dirigida por Vaughan Arnell, identifica el registro de la forma del movimiento con la secuencia de una metamorfosis. El vídeo presenta la transformación metafórica de una joven en la actriz Sarah Jessica Parker. La transición se produce a través de una multiexposición que sigue el desplazamiento de la figura. Entre la imagen fija y la animada, las instantáneas conviven en el espacio con un fondo activo, en el cual varios fotógrafos disparan con flash, atrapando las fases del desplazamiento en primer plano. En el proceso, la figura de la primera mujer se desvanece, dando paso a la famosa actriz.

Para la construcción de la imagen, el director británico acudió a la tecnología timetrack desarrollada por la compañía Digital Air. La técnica del "flash trail" consiste, básicamente, en una iluminación semejante a la fotografía estroboscópica, sincronizada con las ochenta cámaras que forman el sistema. Como veíamos ya con 
respecto a la publicidad dirigida por Cunningham dos años antes, la disposición multicámara permite añadir la profundidad cinética a los efectos fotográficos. De manera semejante a Sunstone, el rastro de tonos psicodélicos se deposita como una imprenta sobre un material plástico; sin embargo, mientras que Emshwiller subraya el espesor del espacio, el efecto de volumen en el anuncio es fruto del desplazamiento de la cámara virtual.

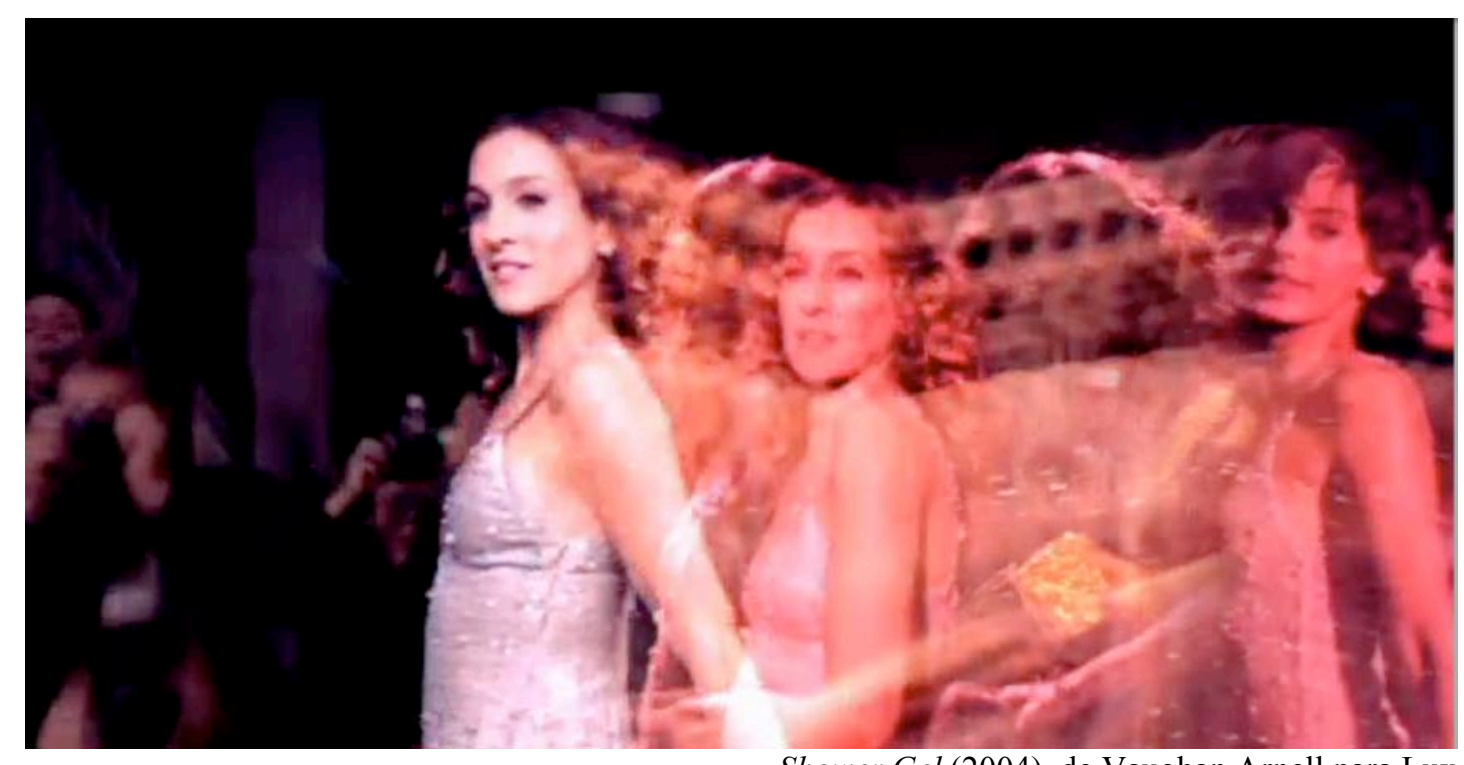

Shower Gel (2004), de Vaughan Arnell para Lux

Aunque la cadena de instantáneas remite al medio fotográfico de manera explícita (las capturas se presentan como el fruto mismo de los flashes provenientes del fondo de la imagen), no hay estudio pormenorizado del desplazamiento, sino exaltación de la continuidad de la transformación. Frente al análisis fotográfico, la síntesis digital permite pasar de un ser a otro mediante la costura artificial de las formas. El caso más paradigmático de esta sutura es, sin duda, el morphing.

Comparemos este efecto en The Matrix y el anuncio que nos ocupa. Aunque las dos metamorfosis comparten una misma concepción del espacio digital, existe entre ellas un matiz diferenciador significativo: mientras que en la película de los hermanos Wachowski se produce una verdadera encarnación de un personaje en otro, en la publicidad dirigida por Arnell, se trata, tan sólo, de un símil; de una figura estilística. En esta ocasión, sería excesiva una continuidad tan lisa como la lograda mediante la combinación del warping y el cross-dissolve. 


\section{La animación mediante morphing}

Más allá de la figuración de una metamorfosis dentro de la ficción, el morphing puede servir como técnica de animación de dos o más imágenes fijas. En este caso, movimiento y transformación son equivalentes. La instalación $T u(1994)^{6}$ del artista francés Thierry Kuntzel (1948-2007) consta de una serie de ocho instantáneas del mismo niño con ligeras variaciones posturales y un vídeo que presenta una animación digital de dichas fotografías. ${ }^{7}$ Kuntzel calcula las fases intermedias entre las poses mediante varias interpolaciones. El corto, de apenas un minuto y medio, comienza y acaba con la misma imagen fija, como un ente elástico que adoptara todo tipo de formas para recobrar, más tarde, su estado original. Así, la dinamización de la imagen no corresponde a la acción o al desplazamiento del objeto, sino que se basa en la plasticidad del espacio continuo. El movimiento artificial no reproduce un registro ni remite al referente humano, sino que construye un artificio cercano al monstruo: la activación es tan innatural que el niño ni siquiera parpadea. ${ }^{8}$

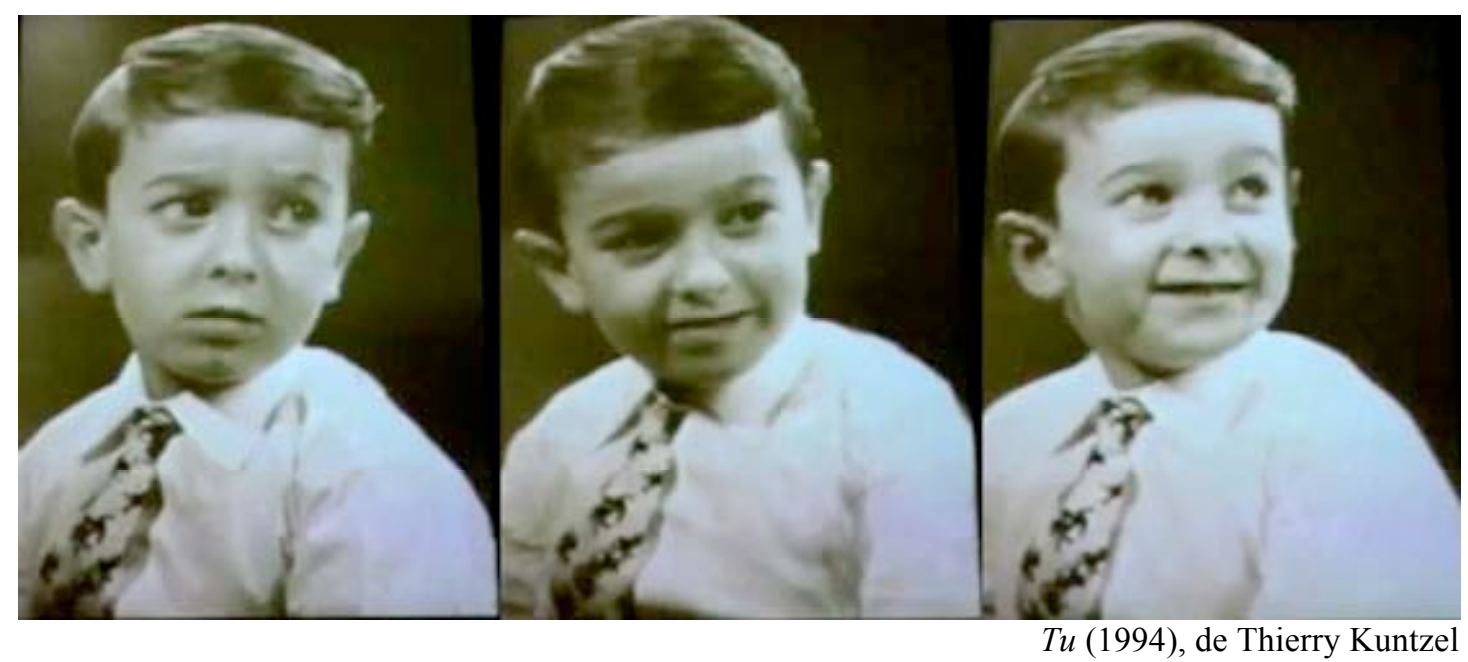

\footnotetext{
${ }^{6}$ La exposición tuvo lugar en el Musée départemental d'art contemporain de Rochechouart (Francia), del 15 de octubre al 31 de diciembre de 1994.

7 "C'est de la réussite de cette assimilation relative que peut naître la surprise du mouvement. Excentrée à une extrémité de la série, l'image vidéo ne se remarque pas nécessairement d'emblée.” DUGUET, Anne-Marie. Déjouer l'image. Créations électroniques et numériques. Nîmes: Jacqueline Chambon, 2002, p. 87

8 "Saura-t-on que ce que je fais n'est absolument pas charmant, que l'esthétique n'est que la face visible d'une terreur secrète ?" Thierry Kuntzel. Apud. DUGUET Anne-Marie (ed.). Thierry Kuntzel. Paris: Galerie nationale du Jeu de Paume, 1993, p. 10.
} 
El mismo año, el japonés Nobuhiro Shibayama presenta su "Bio-Morph Encyclopedia" (1994). El CD-ROM contiene una reinterpretación digital del estudio de la locomoción animal de Muybridge que demuestra que el morphing de las instantáneas anima las series de manera distinta a como pudiera hacerlo el zoopraxiscopio en 1879 o, más tarde, el cinematógrafo. Basados en el "efecto phi", estos dos dispositivos disimulan el vacío entre los fotogramas al pasarlos a una velocidad tal que la secuencia se perciba como un continuo. En lugar de ocultar el intervalo, Shibayama concentra toda la atención en ese espacio perdido entre las tomas. Como en la obra de Kuntzel, la interpolación de las imágenes fijas permite construir un espacio no capturado en la imagen.

Lejos de la reproducción temporal, la síntesis digital subraya el carácter eminentemente espacial de la imagen código. Frente a la dicotomía “imagen fija/imagen en movimiento", la animación sintética se concentra en la transformación, en la elasticidad de un espacio lleno. El artificio es tal que Shibayama propone, incluso, la posibilidad de encadenar distintos animales o los géneros humanos, como en el videoclip Black or White de John Landis tres años antes. Los morphing entre las criaturas se asemejan a la metáfora evolutiva de la película Mission to Mars (2000), que veíamos en el primer capítulo. Sin embargo, frente a la cadena de metamorfosis propuesta por Brian de Palma, en la Bio-Morph Encyclopedia, los vínculos pueden establecerse fuera del orden señalado por la teoría científica. ${ }^{10}$

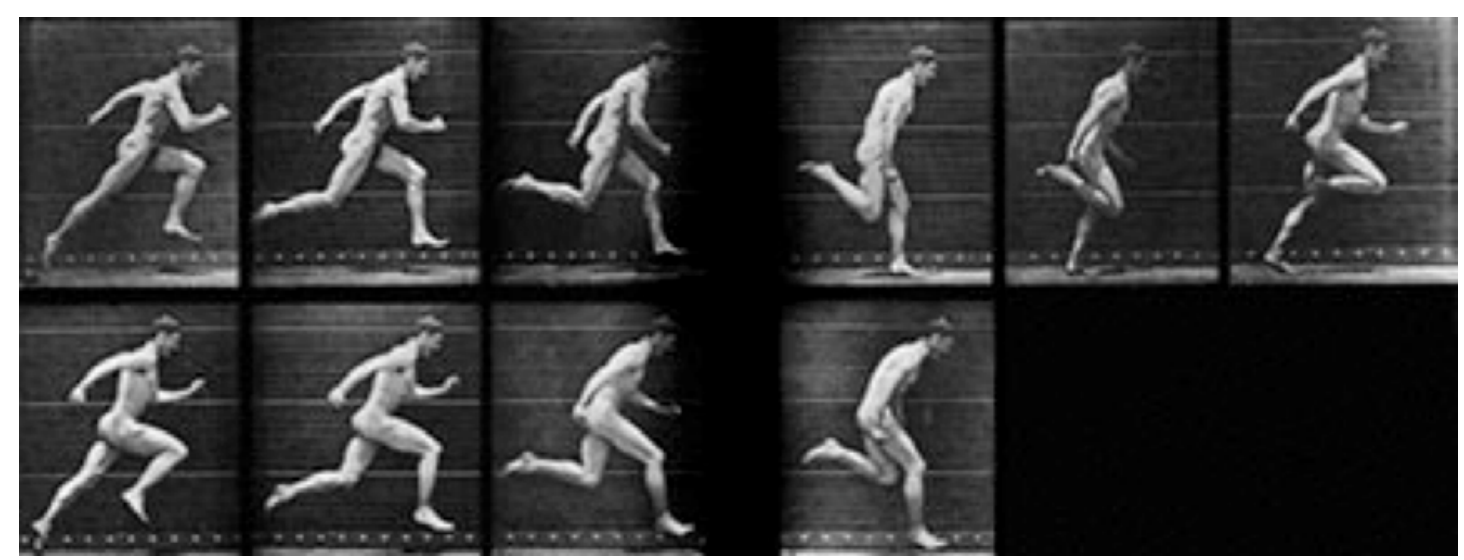

Serie de Eadweard Muybridge en la Bio-Morph Encyclopedia (1994), de Nobuhiro Shibayama

\footnotetext{
${ }^{9}$ El "efecto phi" no debe confundirse con la "persistencia retiniana". "La persistance rétinienne existe bel et bien, mais si elle jouait un rôle au cinéma, elle ne pourrait que produire un brouillamini d'images rémanentes.” AUMONT, Jacques. L'image (1990). Paris: Nathan, 2000, p. 33.

10 "Shibayama also allows the user to morph chains of Muybridge sequences, bringing the gap between animal species and human genders. And so the sequences are continues yet unstable: this is hardly a 'natural' order of movement." BUKATMAN, Scott. Op. cit., pp. 232-233.
} 
La animación mediante morphing identifica el movimiento con un continuo de transformaciones, en el cual, el factor tiempo no es más que otra dimensión del espacio. En este sentido, la técnica digital puede ser interpretada como una visualización de un hipercubo o "teseracto", figura paradigmática de un espacio de cuatro dimensiones. Así, por ejemplo, Kevin Fischer considera que las geometrías noeuclidianas teorizadas en el siglo XIX forman parte de la "prehistoria conceptual" del morphing. ${ }^{12} \mathrm{El}$ autor toma el teseracto como caso de estudio en cuanto comparte con el efecto digital una persistencia de la forma en el tiempo. Más allá de la concepción matemática, aboga por un uso más laxo del término y remite al que Hollis Frampton (1936-1984) hace en su análisis de las largas exposiciones de Muybridge. El realizador experimental ve en el motion blur un "teseracto del agua"13.

Para Fisher, el fundamento del morphing encaja con la definición que Oscar Domínguez y Ernesto Sábato dieran de sus "lithochroniques". En los años 40, el pintor y el escritor surrealistas teorizaron una manifestación de la cuarta dimensión como "solidificación del tiempo":

\begin{abstract}
"Imaginemos por un momento cualquier cuerpo tridimensional, un león africano, por ejemplo, entre dos momentos cualesquiera de su existencia. Entre el león Lo o león en el momento en el que $t=O$, y el momento $L f$ o león en el momento final, se sitúa un número infinito de leones africanos, de aspecto y de formas diversas. Si consideramos, ahora, el conjunto formado por todos los puntos del león en todos los instantes y en todas las posiciones, y dibujamos la superficie envolvente, obtenemos un superleón envolvente de características morfológicas extremadamente delicadas y llenas de matices." 14
\end{abstract}

\footnotetext{
${ }^{11}$ Término popularizado por el matemático inglés Charles Howard Hinton (1853-1907) en A new era of thought: "Let us suppose there is an unknown direction at right angles to all our known directions, just as a third direction would be unknown to a being confined to the surface of the table. And let the cube move in this unknown direction for an inch. We call the figure it traces a Teeseract." HINTON, Charles H.. A New Era of Thought. London: Swan Sonnenschein \& Co , 1888, p. 118. Disponible en Web: <http://archive.org/stream/anewerathought00falkgoog\#page/n6/mode/2up>

${ }^{12}$ FISHER, Kevin. “A Conceptual Prehistory of the Morph”. En: SOBCHACK, Vivian. Op. cit., pp. 103-129.

13 "Yet Muybridge, in some of his earliest landscape work, seems positively to seek, of all things, waterfalls; long exposures of which produce images of a strange, ghostly, substance that is in fact the teeseract of water: what is to be seen is not water itself, but the virtual volume it occupies during the whole time interval of the exposure." FRAMPTON, Hollis. "Eadweard Muybridge: Fragments of a Tesseract”. En: Circles of Confusion: Film, Photography, Video, Texts, 1968-1980. New York: Anthology Film Archives, 1982, pp. 75-76.

${ }^{14}$ DOMÍNGUEZ, Oscar. "La pétrification du temps". En: La conquête du monde par l'image. Paris: La Main à Plume, 1942. Apud. SERRANO, Véronique. La part du jeu et du rêve, Óscar Domínguez et le surréalisme 1906-1957. Paris: Éditions Hazan, 2005, p. 73.
} 
Fisher propone extender esta definición de modo que el primer y el último momento correspondan a objetos distintos. De acuerdo con el autor, el morphing resultante podría ser considerado como un tipo de lithochronique. ${ }^{15}$ Sin duda, ambos comparten la concepción del espacio como un medio plástico y continuo; sin embargo, lo cierto es que el morphing no figura la "superficie envolvente" descrita por los surrealistas, ya que no hay acceso simultáneo al conjunto de todos los instantes, sino que la transformación se desarrolla secuencialmente, en una animación de la forma. En el morphing, no hay "petrificación del tiempo", sino flujo ucrónico.

La animación digital Sculptures (1996), de Tamás Waliczky, sí parece adaptarse a la definición de "lithocronique". Como Landscape, la pieza fue creada para la ópera Los enemigos de Mesías Maiguashca, adaptación del corto de Borges El milagro secreto. Frente a la instantánea tridimensional, Sculptures presenta de manera simultánea el desarrollo temporal como una solidificación de la forma del movimiento, que encaja a la perfección con la "superficie envolvente" de las lithochroniques. A diferencia de la sensación etérea de las fotodinámicas futuristas, Sculptures se compone de volúmenes opacos, bultos tallados en un material plástico como la arcilla de alfarero. Waliczky llama a estas esculturas digitales "cristales de tiempo", expresión casi idéntica a la "petrificación del tiempo" de Sábato y Domínguez.

En su ilustración del relato de Borges, el artista húngaro imagina un punto de vista externo (el punto de vista de Dios), desde el cual el tiempo no sería más que otra dimensión del espacio. ${ }^{16}$ A la hora de introducir esa cuarta extensión en la imagen bidimensional, el tiempo toma forma en una dilatación del contorno de la figura, mientras que ésta queda reducida a una simple silueta. Así, la tridimensionalidad afecta, exclusivamente, a la forma continua del movimiento; por su parte, el perfil humano parece un corte transversal de la escultura: un instante preciso de ese "cristal de tiempo".

\footnotetext{
15 "This is essentially the principle behind the digital morph: between any two or more objects (still or moving) may be generated a lithochronic surface that graphically connects the two objects and, in that connection, travels the formal difference between them through time". FISHER, Kevin. Op. cit., p. 117.

16 "But for God, who is eternal and in His dimensions infinite, time is perhaps a four-dimensional quantity; (...) From His perspective, temporal measures such as a second, an hour, a year or even eternity are identical. I believe this may be a possible interpretation of the quotation from Koran with which Borges precedes his tale: 'And God made him die during the course of a hundred years; and then He revived him and said: How long have you been here? A day or a part of a day, he replied."' WALICZKY, Tamás. Sculptures [En línea]. Waliczky.net, 1996. Disponible en Web:

$<$ http://www.waliczky.net/pages/waliczky_sculptures1-frame.htm>
} 


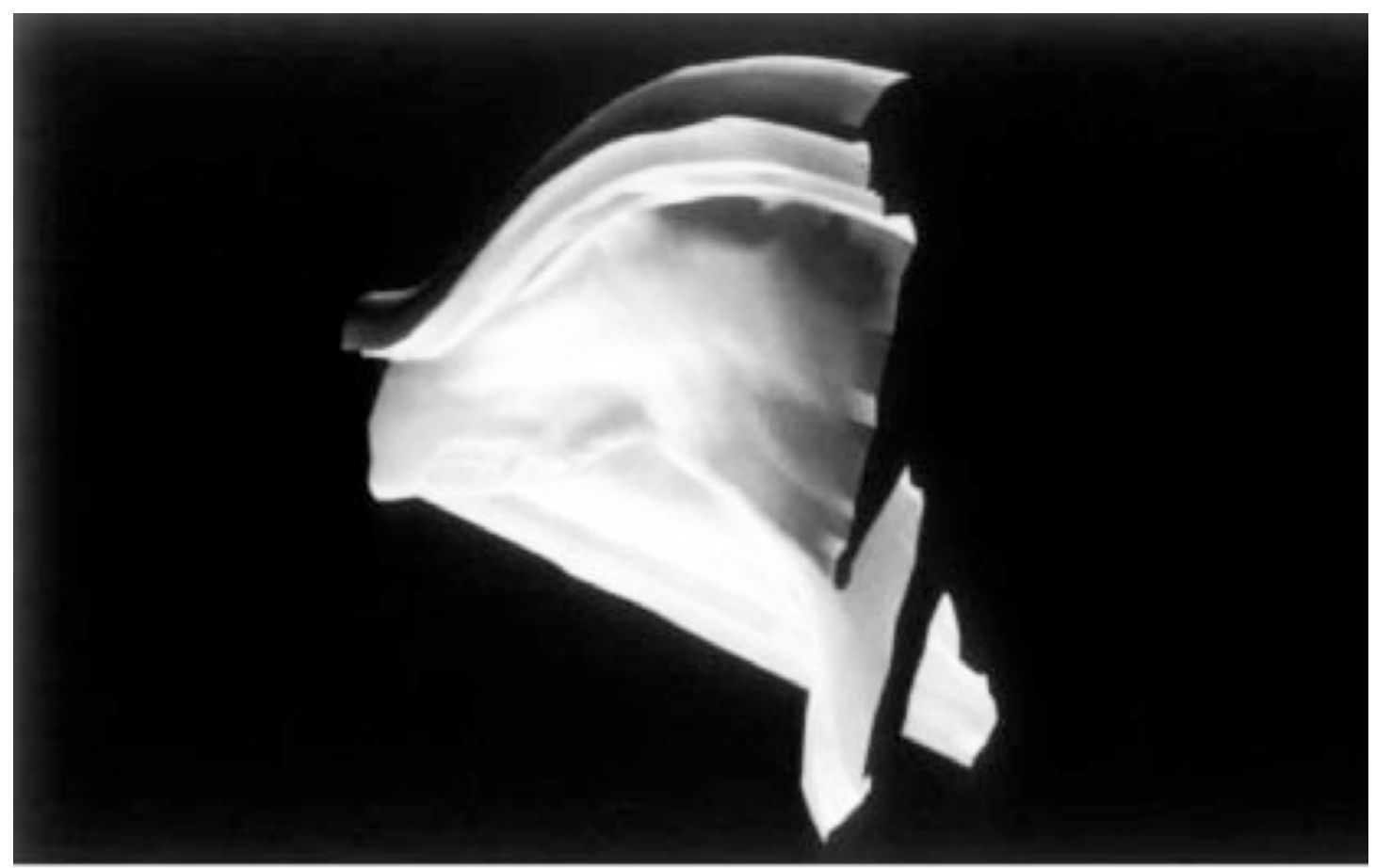

Sculptures (1996), de Tamás Waliczky

A finales del siglo XIX, filósofos y escritores inventaron diversos mundos y parábolas en su intento de visualizar hiperespacios más allá de las complejas explicaciones matemáticas. Entre todos ellos, destaca el inglés Edwin Abbott Abbott y su libro Flatland: A Romance of Many Dimensions (1884). ${ }^{17}$ Aunque su objetivo principal fuera la crítica social, la obra es citada, aún hoy, como una de las metáforas más populares para explicar espacios de más de tres dimensiones, y da nombre a uno de los modelos matemáticos más extendidos: el "Flatland model" o "slicing model".

Imaginemos un objeto tridimensional que atravesara un plano bidimensional; cada uno de los cortes progresivos correspondería a la manifestación de aquél en éste. Si procedemos de manera análoga, podemos imaginar los objetos tridimensionales como manifestaciones de entes de cuatro dimensiones en un espacio euclidiano.

Aunque no es el caso de la novela de Abbot, a menudo, el tiempo se identifica con esa cuarta dimensión espacial, de modo que la captura de la forma del movimiento puede ser interpretada como un teseracto o hipercubo. ${ }^{18}$ Entre otras

\footnotetext{
${ }^{17}$ ABBOTT, Edwin A.. Flatland: A Romance of Many Dimensions (1884). New York: Barnes and Noble Books, 1963.

18 Así, en Scientific Romances (1884), Charles Howard Hinton considera el desplazamiento de un objeto tridimensional en el tiempo como parte de la geometría de cuatro dimensiones. "Is it possible to suppose that the movements and changes of material objects are the intersections with a threedimensional space of a four-dimensional existence?" HINTON, C. H.. "What is the fourth dimension?" (1880). En: Scientific Romances. London: W. Swan Sonnenschein, 1884, p. 23. Disponible en Web: $<$ http://archive.org/stream/scientificroman01hintgoog\#page/n6/mode/2up $>$
} 
muchas obras de las vanguardias históricas, $\mathrm{Nu}$ descendant un escalier $n^{\circ} 2$ de Duchamp y las fotodinámicas futuristas de Boccioni se basan en el slicing model. De igual modo, las lithochroniques de Domínguez y Sábato, y las "esculturas" de Waliczky responden a una concepción del tiempo como cuarta dimensión del espacio. En el caso del artista húngaro, no sólo la alusión al punto de vista divino coincide con la mirada omnipotente de los visitantes de dimensiones superiores en Flatland: $A$ Romance of Many Dimensions ${ }^{19}$, sino que el marcado corte transversal de la silueta es prácticamente un homenaje al modelo. No en vano, una imagen muy semejante aparece en el documental La quatrième dimension (1937), en el cual, el francés Jean Painlevé explica visualmente el slicing model.

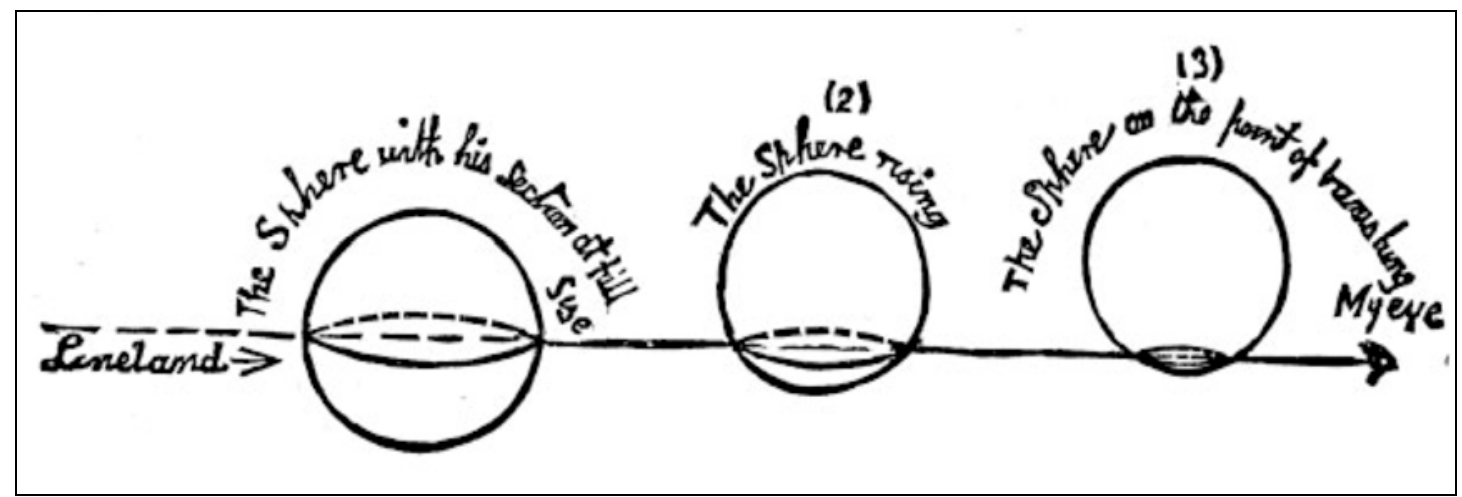

Ilustración de Edwin Abbott Abbott en Flatland: A Romance of Many Dimensions (1884)

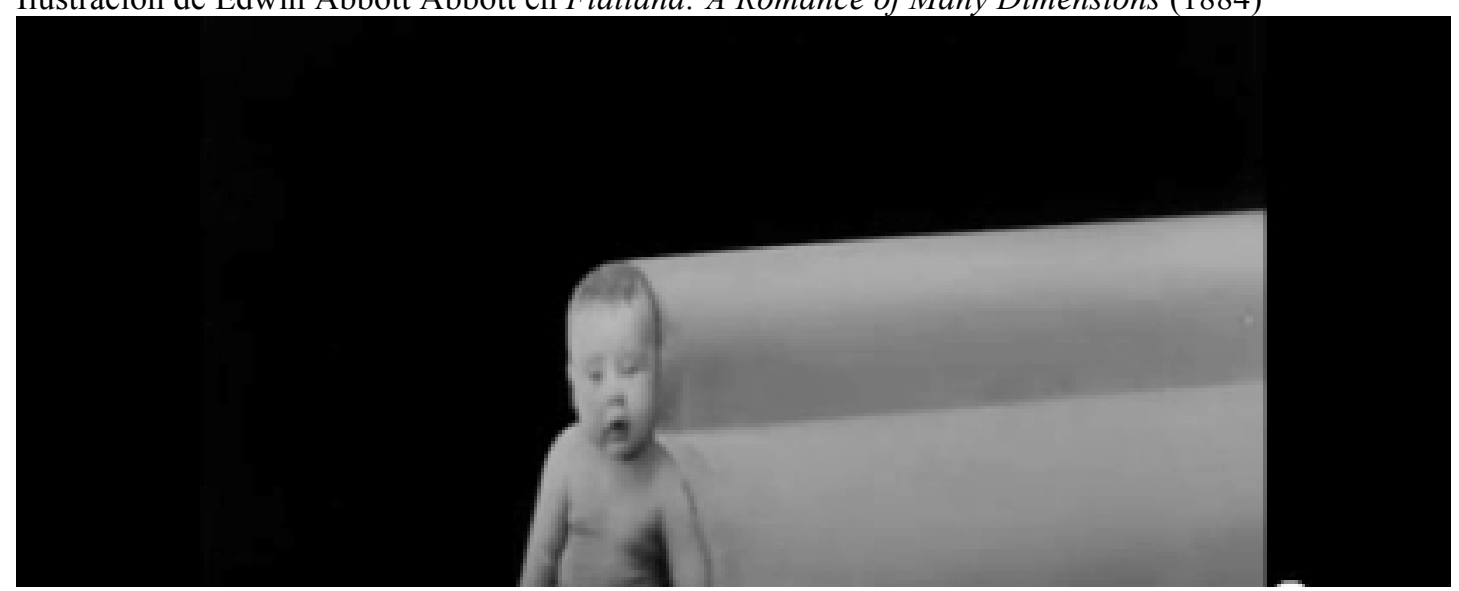

La quatrième dimension (1937), de Jean Painlevé

Ya un siglo antes, algunos autores conciben la posibilidad de identificar el tiempo con la cuarta dimensión del espacio. Así, por ejemplo, la idea es esbozada por D’Alembert (1717-1783) en la entrada "Dimension" (1754) de su Encyclopédie: “J'ai dit plus haut qu'il n'était pas possible de concevoir plus de trois dimensions. Un homme d'esprit de ma connaissance croit qu'on pourrait cependant regarder la durée comme une quatrième dimension, et que le produit du temps par la solidité serait en quelque manière un produit de quatre dimensions ; cette idée peut être contestée, mais elle a, ce me semble, quelque mérite, quant ce ne serait que celui de la nouveauté." D’ALEMBERT, Jean le Rond. "Dimension". En: DIDEROT, Denis; D'ALEMBERT, Jean le Rond. Encyclopédie. Paris: Le Breton, Durand, Briasson, Michel-Antoine David, 1754, vol. 4, pp. 1009-1010.

19 "I am become as a God. For the wise men in our country say that to see all things, or as they express it, omnividence, is the attribute of God alone." ABBOTT, Edwin A.. Op. cit., p. 125. 
Con todo, una diferencia fundamental revela la especificidad del tratamiento digital frente a la imagen cinematográfica de Painlevé: Waliczky concibe sus piezas como esculturas, como objetos accesibles en todas sus dimensiones. La cámara virtual omnipotente (que el autor identifica con aquel punto de vista ventajoso) ${ }^{20}$ permite reconstruir y deshacer el movimiento a voluntad, como en una reinterpretración digital del "forward" y del "rewind" del magnetoscopio. Es como si, al espacializar el tiempo, no sólo lo capturáramos, sino que se pudiera acceder a él y, desde él, a las otras dimensiones del espacio. La imagen bidimensional se vuelve, así, un "objeto espacio-temporal" que permite todo tipo de manipulaciones.

\footnotetext{
20 "A virtual camera (whose viewing angle is to some extent the lofty vantage point of God) can observe them from any desired location. By travelling through the time crystals, the camera can reproduce the original movement, but from a diverse range of perspectives and at varying speeds." WALICZKY, Tamás. Sculptures. Op. cit.
} 


\section{EL CONTINUO ESPACIO-TEMPORAL}

Decíamos en el apartado anterior que el desarrollo temporal de un objeto tridimensional puede ser considerado como un teseracto, en el que el tiempo sería la cuarta dimensión del espacio. Sculptures, de Waliczky, presenta un conjunto de sólidos, en los que la profundidad del objeto corresponde a la forma del movimiento descrito por la figura, quedando ésta reducida a una simple silueta. Este último carácter bidimensional remite a la estructura subyacente a las piezas: a pesar de su aspecto totalmente sintético, el artista partió de los frames de un vídeo digital como materia prima para la construcción de la obra.

Para comprender el proceso de fabricación de Sculptures, nos servimos del trabajo (posterior) de Martin Hilpoltsteiner Recreating Movement (2005). El diseñador alemán propone una interfaz gráfica que permite analizar secuencias fílmicas o registros vídeo mediante la ordenación cronológica de los frames en un espacio tridimensional interactivo. ${ }^{1}$ El programa incluye todo tipo de herramientas para el estudio detallado de la imagen: cambio del punto de vista, de color, de luminosidad, selección de fragmentos, separación entre las unidades...

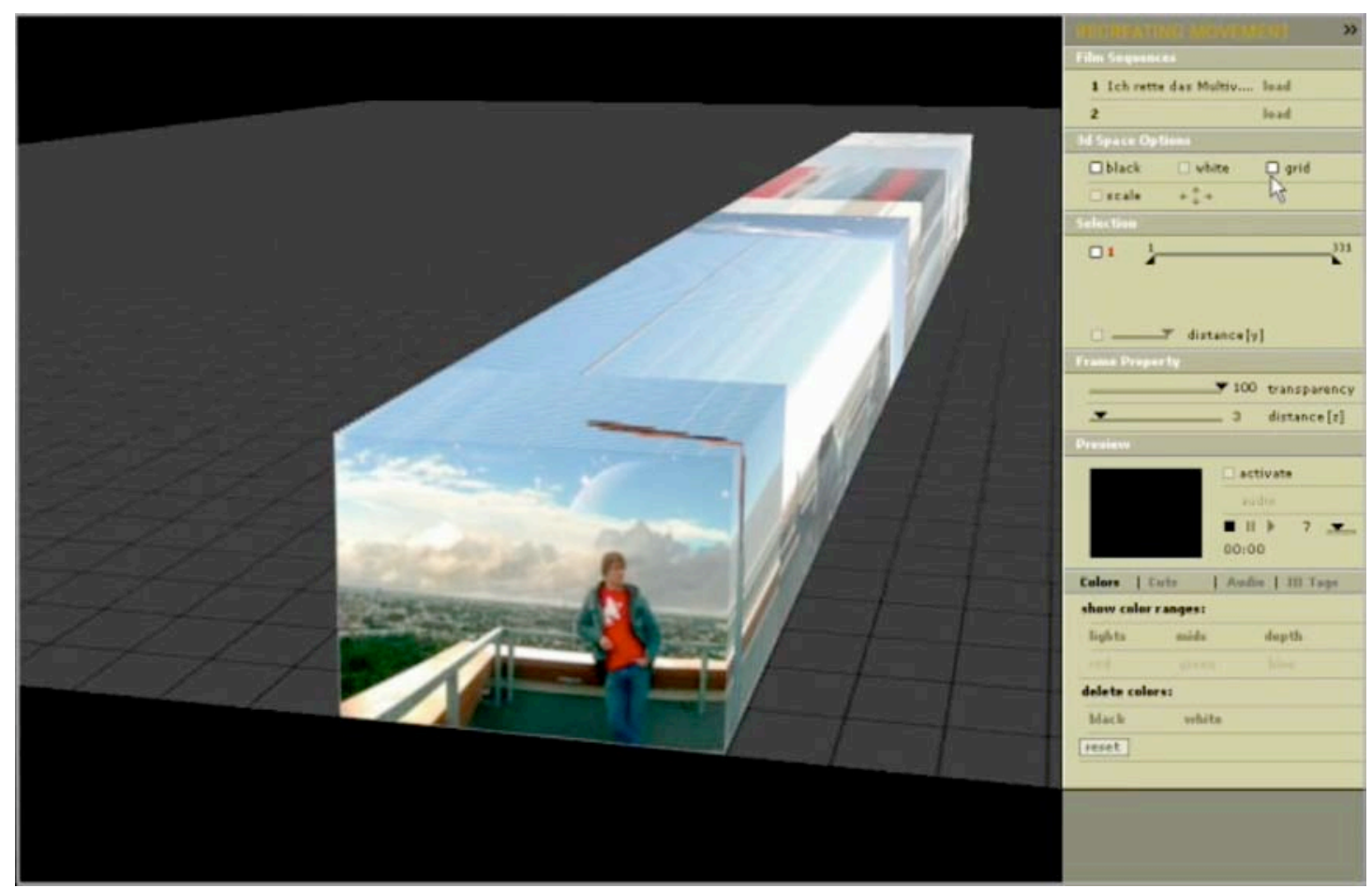

Martin Hilpoltsteiner: interfaz gráfica de Recreating Movement (2005)

\footnotetext{
${ }^{1}$ En este caso, se trata de un útil de observación y no de una propuesta estética determinada.
} 
Entre todas las aplicaciones posibles, el autor destaca el análisis del movimiento. ${ }^{2}$ La interfaz aparece, así, como una reinterpretación digital de la cronofotografía. El procedimiento es el siguiente: una secuencia del desplazamiento de una o varias figuras se descompone en las imágenes fijas subyacentes; a continuación, se disponen éstas en un espacio tridimensional, formando un taco ordenado cronológicamente. La eliminación del fondo en cada frame permite concentrarse en las siluetas, que se amontonan unas tras otras, respetando la distancia entre las imágenes.

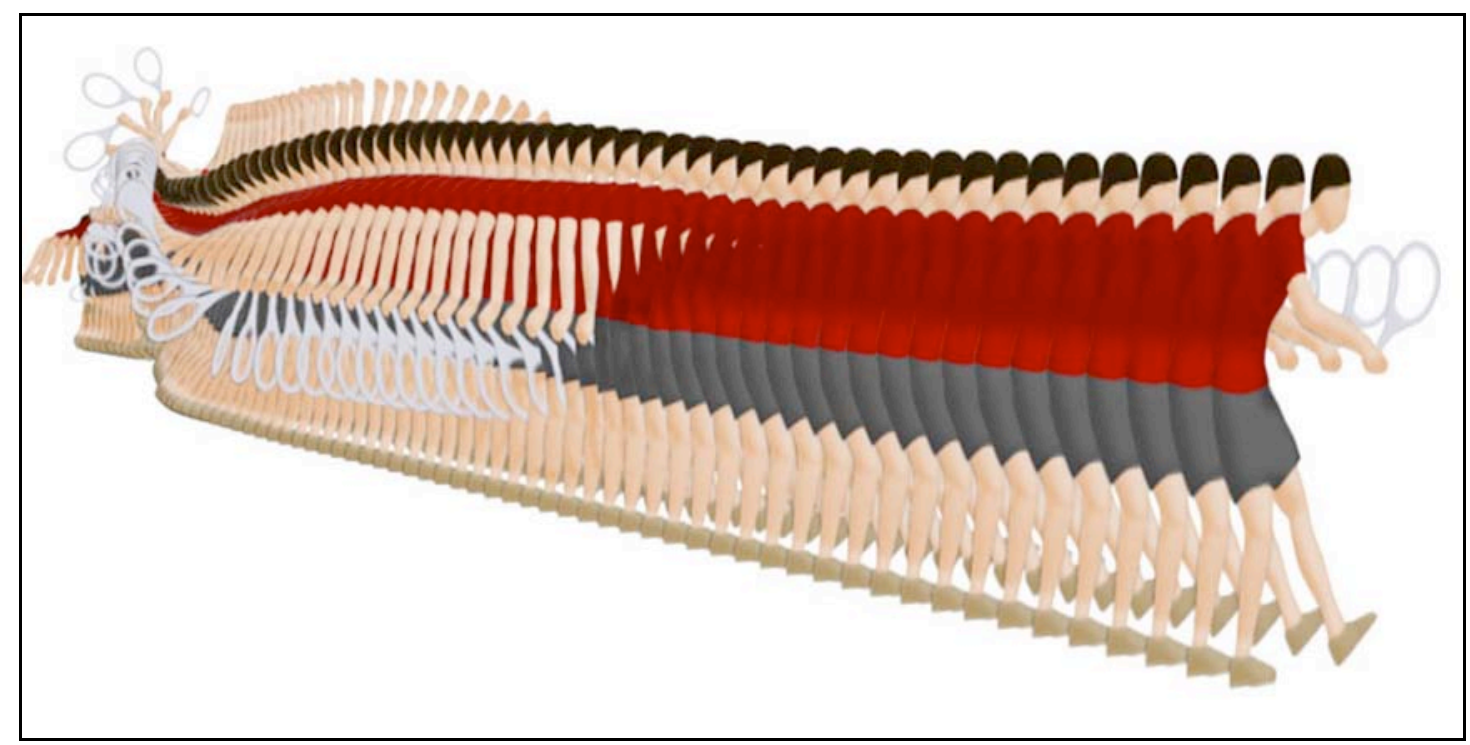

Recreating Movement (2005), de Martin Hilpoltsteiner

Si echamos la vista atrás y observamos las cronofotografías reproducidas en el apartado anterior, comprobaremos que éstas suelen presentar dos tipos de composición: horizontal (las fases del movimiento quedan aisladas y son, así, fácilmente legibles) o en abanico (las fases se apilan sobre el mismo eje). Más allá del espesor que pudiera comportar la exposición múltiple, la técnica desarrollada por Hilpoltsteiner añade a la imagen la tridimensionalidad propia a la pila de frames. Este carácter volumétrico se pone en evidencia mediante la variación del ángulo; es decir, frente al punto de vista fijo de la fotografía, en el constructo digital, el punto de vista de visionado no tiene por qué coincidir con el de registro. Es precisamente este

\footnotetext{
2 "A complex movement is being captured in its whole length and turned into graphic information that displays readable values, so that the facts related to the movement can be captured, recognized and interpreted." HILPOLTSTEINER, Martin. Recreating Movement. Documentation [En línea]. Recreating-movement.com. Disponible en Web:

$<\mathrm{http}: / /$ www.recreating-movement.com/05_exuse_a_en.html $>$
} 
escorzo del bloque espacio-temporal el que resalta la separación entre los frames bidimensionales, haciendo aparecer el intersticio.

A la hora de elaborar sus Sculptures, Waliczky siguió un procedimiento semejante; sin embargo, frente a la herramienta de análisis desarrollada por Hilpoltsteiner, el artista húngaro se decantó por la forma continua del movimiento, trazando el contorno que envuelve las diversas siluetas como una tangente curvilínea. Lejos del intervalo propio a la cronofotografía, modeló el espacio entre las tomas, creó artificialmente las suturas, en una lógica espacial cercana a la interpolación. El resultado es un sólido en el que la profundidad corresponde al eje temporal del taco de imágenes fijas.

La elección de Recreating Movement para explicar el proceso de construcción de Sculptures se justifica por el silueteado en cada frame y la referencia clara a la cronofotografía. No obstante, en lo que respecta a la interfaz en sí, la propuesta de Hilpoltsteiner no se diferencia sustancialmente del "Video Streamer"3, concebido una década antes. En 1994, Edward Elliott presenta en Boston un programa informático que permite el acceso espacial al bloque tridimensional formado por el registro vídeo. A la hora de explicar el funcionamiento de la nueva herramienta, el autor la compara con un juego óptico muy popular a finales del siglo XIX: el folioscopio o flip book ${ }^{4}$.

Del verbo "to flip through" (en español "hojear"), el flip book consiste en una pila de dibujos con ligeras variaciones entre las imágenes sucesivas, de modo que el pasar las hojas a cierta velocidad produce un efecto visual de movimiento continuo. Bautizado primero como "kineograph" (1868) en la patente firmada por el inglés John Barnes Linnett, el invento se diferencia de otros experimentos ópticos anteriores por la disposición de las imágenes fijas: frente al cilindro del zoótropo o el disco del fenaquistiscopio, el kineógrafo se presenta como un taco de hojas paralelas. La sustitución de los dibujos por fotografías no consta hasta tres décadas después, al tiempo que aparecen los primeros instrumentos mecánicos, como el mutoscope (1894) en EE.UU o el folioscope mécanique (1896) en Francia. ${ }^{5}$

\footnotetext{
${ }^{3}$ ELliOTT, E.; DAVENPORT, G.. "Video Streamer". En: Proceedings CHI 94 ACM Conference on Human Factors in Computer Systems. Boston, MA. April 24-28, 1994, pp. 65-66.

${ }^{4}$ Adoptamos el término americano frente al inglés "flick book", de igual significado.

${ }^{5}$ Para una descripción detallada de aquellos experimentos ópticos, remitimos a: WILLOUGHBY, Dominique. Le cinéma graphique. Une histoire des dessins animés : des jouets optiques au cinéma numérique. Paris: Textuel, 2009.
} 


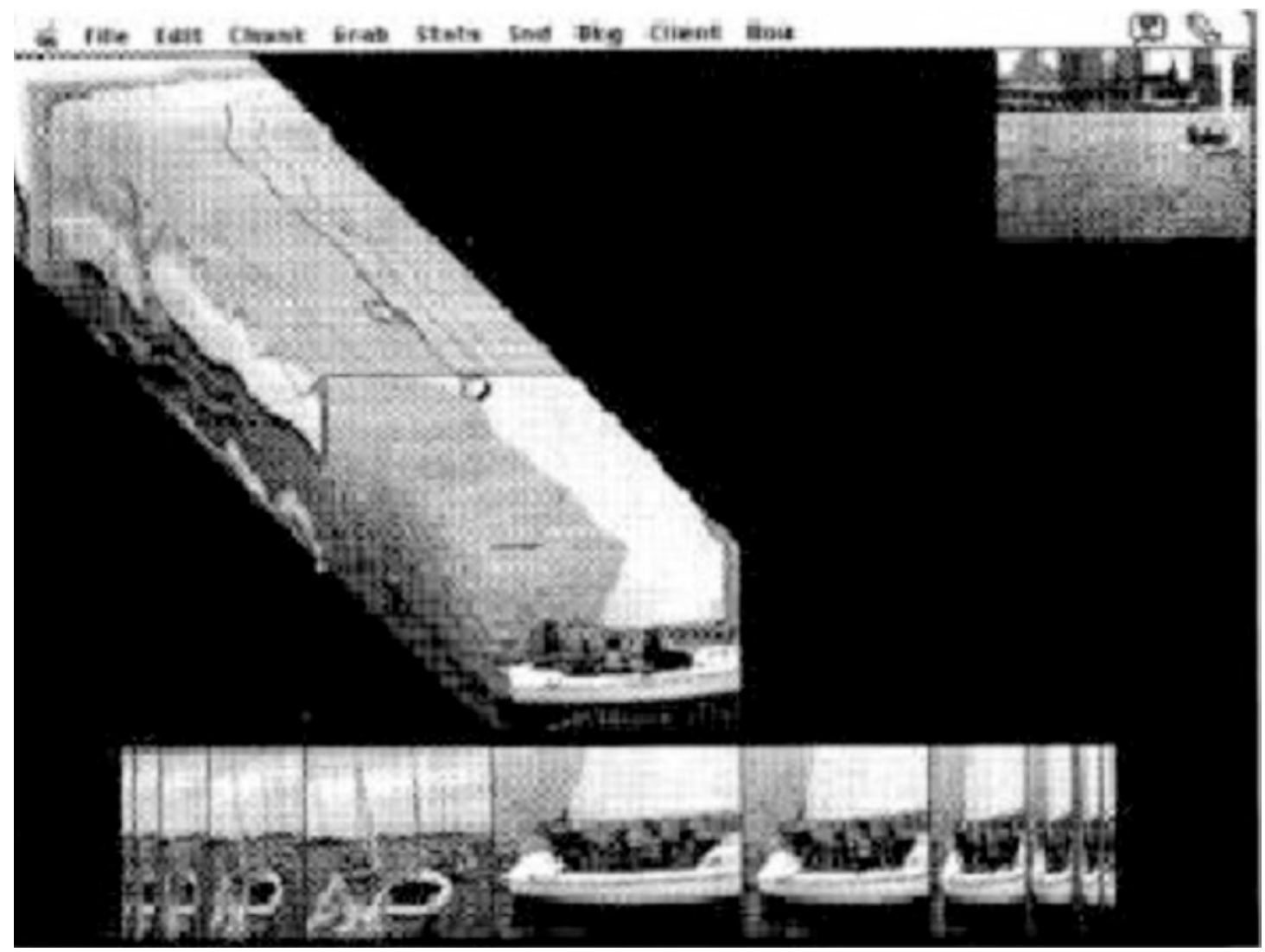

Edward Elliott: interfaz gráfica del Video Streamer (1994)

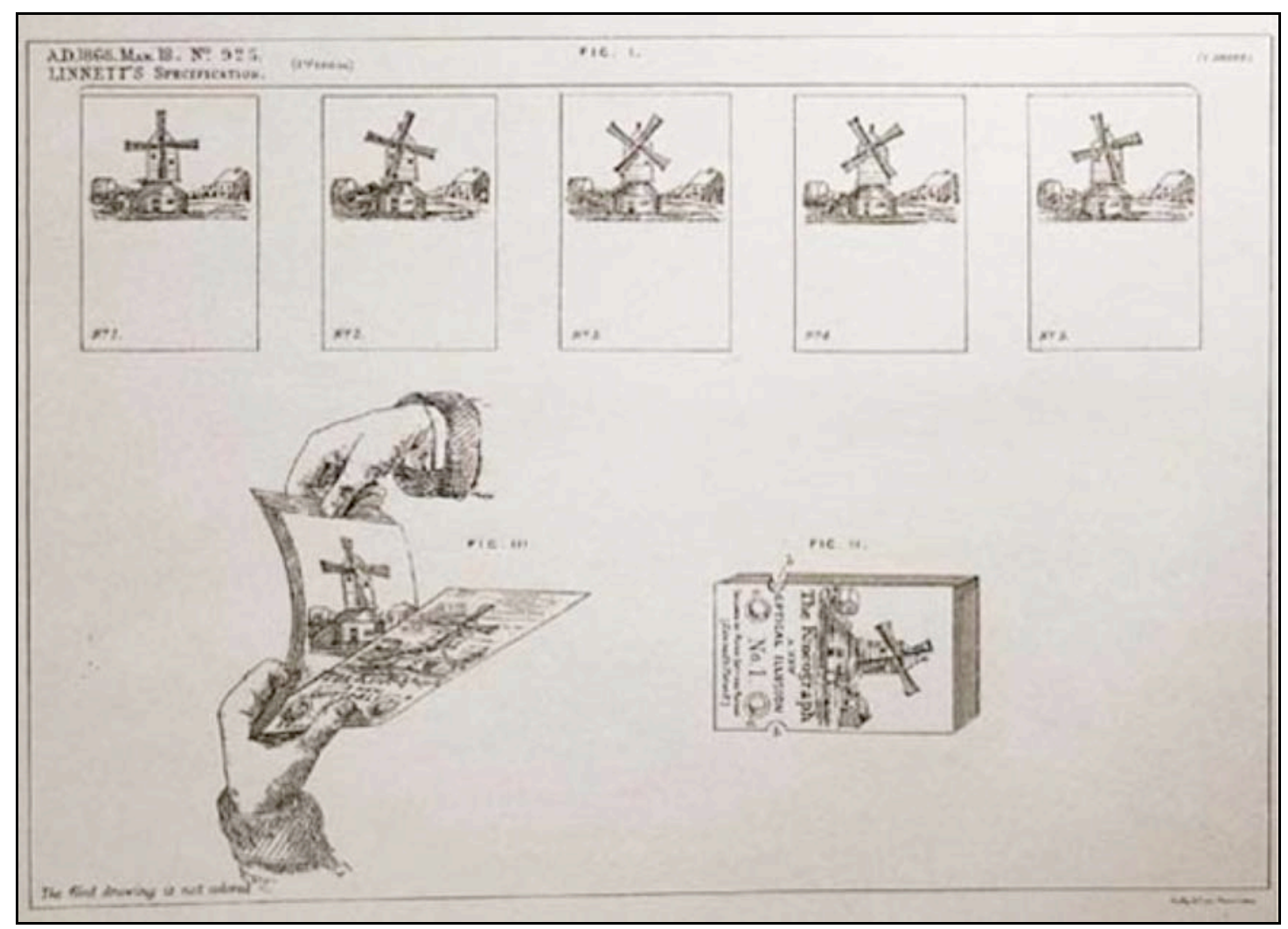

John Barnes Linnett: explicación gráfica del kineograph en la patente de 1868 
Si bien la comparación con el folioscopio ayuda a visualizar la disposición de los frames en el bloque tridimensional del Video Streamer, éste tiene la particularidad, exclusiva al espacio digital, de poder ser manipulado en otra dirección. A diferencia del flip book, el acceso no se produce, tan sólo, a través de lo que podríamos llamar el "eje temporal", sino de manera perpendicular al mismo. Y esto, gracias a una característica específica de la imagen código: frente al haluro de plata de una fotografía, la información contenida en un píxel puede ser "leída" en todas direcciones. Es decir, la tridimensionalidad del bloque espacio-temporal lo es, antes que nada, a nivel atómico.

Ya en 1989, Tamás Waliczky daba la bienvenida a este cambio de paradigma en su "Manifesto of Computer Art":

\begin{abstract}
"Mientras que un vídeo o un proyector de película tan sólo pueden funcionar hacia delante o hacia atrás, los frames almacenados en la memoria de un ordenador pueden ser proyectados en un orden aleatorio. Un ordenador no sólo puede ir hacia delante o hacia atrás, sino también hacia los lados, hacia abajo o hacia arriba. Hasta ahora, ningún otro instrumento ha sido capaz de esto. No dejemos pasar esta nueva forma de proyección y aprovechémosla." 6
\end{abstract}

Si bien no disponemos de las imágenes descritas por Elliott en el artículo citado, tras él, numerosos artistas han seguido explorando la vía abierta por el Video Streamer. Entre ellos, destacamos el trabajo de Tania Ruiz Gutiérrez por cuanto aúna práctica y teoría. Su tesis doctoral, defendida en 2004 y titulada "Études sur le temps et l'espace dans l'image en mouvement. Tissage vidéo, objets spatio-temporels, images prédictives et cinéma infini" ${ }^{\prime 7}$, contiene un recorrido histórico a través de todo tipo de constructos espacio-temporales ${ }^{8}$ que la autora relaciona con su propia obra. Ésta se compone, entre otros, de una serie de "objetos espacio-temporales" u "OST", muy semejantes a las interfaces gráficas que describíamos arriba: "los objetos espacio-temporales son objetos tridimensionales obtenidos mediante la interpretación

\footnotetext{
${ }^{6}$ WALICZKY, Tamás. Manifesto of Computer Art [En línea]. Budapest, January 15, 1989. Disponible en Web: <http://www.waliczky.net/pages/waliczky_manifest_eng.htm>

${ }^{7}$ RUIZ GUTIÉRREZ, Tania. "Études sur le temps et l'espace dans l'image en mouvement. Tissage vidéo, objets spatio-temporels, images prédictives et cinéma infini”. Directeur: Anne-Marie Duguet. Université Panthéon-Sorbonne, Paris, 2004.

${ }^{8}$ A este respecto, ver también: JASCHKO, Susanne. "Space-Time Correlations Focused in Film Objects and Interactive Video". ISEA 2002, 11th International Symposium on Electronic Art. Nagoya (Japan), 2002. Disponible en Web:

$<$ http://www.arpla.fr/canal20/adnm/?p=250>
} 
volumétrica del tiempo capturado en un registro cinematográfico, videográfico o, incluso, fotográfico". Ahora bien, frente al Video Streamer (o a versiones más actuales del mismo como Recreating Movement), la artista de origen chileno presenta el bloque interactivo como una propuesta estética en sí misma. Éste es el caso, por ejemplo, de la pieza Éphémère II (2000).

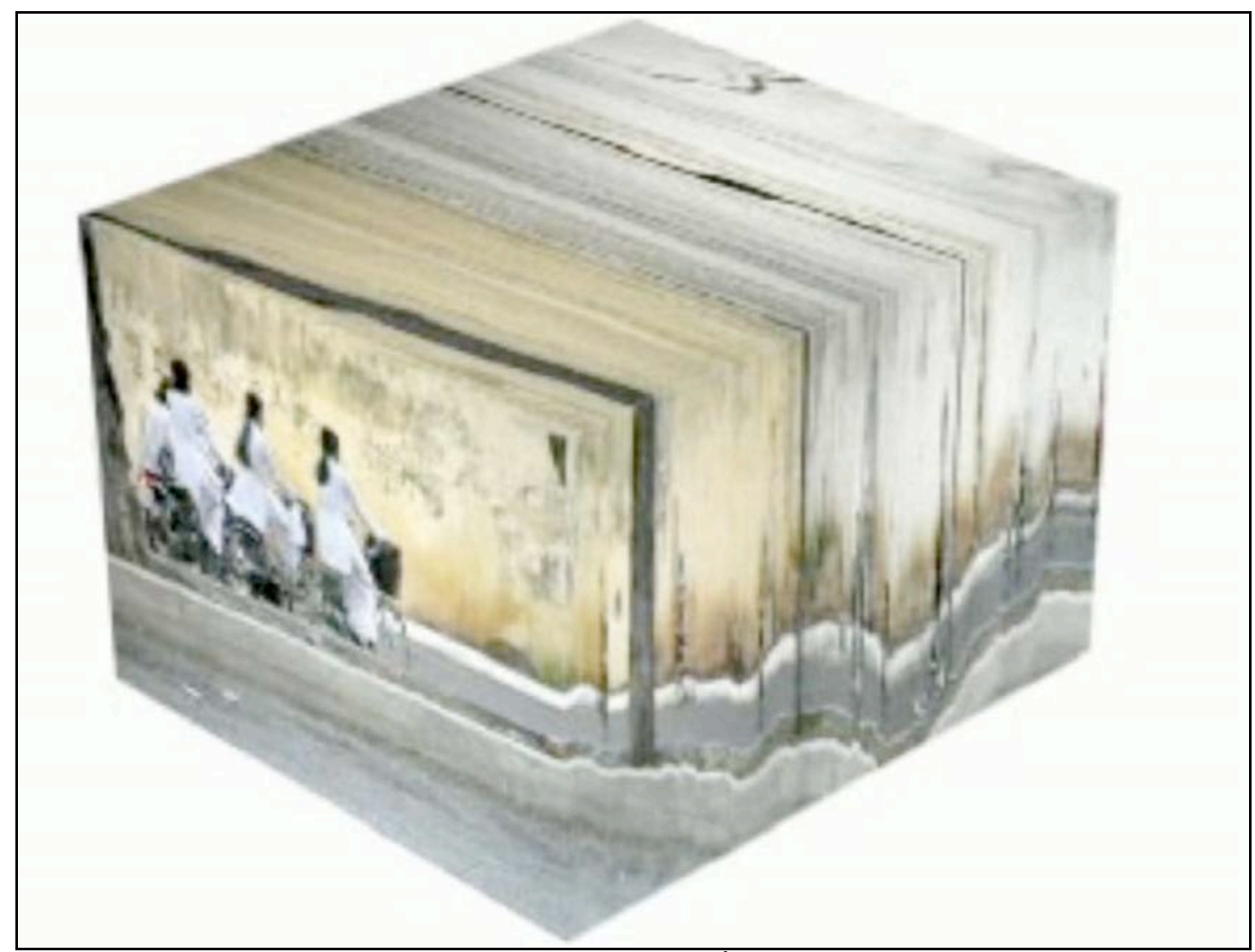

Éphémère II (2000), de Tania Ruiz Gutiérrez

Tras descomponer la secuencia animada en las imágenes fijas correspondientes, éstas fueron tratadas digitalmente con una herramienta de análisis tridimensional. Adaptación del programa ZEN 3D Color para el estudio de la corteza cerebral, la técnica se asemeja a los escáneres utilizados en tomografía, consistentes en la captación de imágenes bidimensionales o cortes transversales continuos, que se agrupan para reconstituir una versión tridimensional del cuerpo humano. El CAT scan o el MRI (Magnetic Resonance Imaging) son técnicas digitales de visualización anatómica. Mientras que el primero se sirve de rayos X, el segundo usa resonancias magnéticas. En cualquier caso, una vez recuperada la información tridimensional, el

\footnotetext{
${ }^{9}$ RUIZ GUTIÉRREZ, Tania. Op. cit., p. 153.
} 
usuario puede desplazarse a través del modelo virtual y cambiar a voluntad su punto de vista.

La particularidad de los objetos espacio-temporales frente a estas imágenes radica en que, en aquéllos, cada una de las secciones corresponde a una captura temporal. Así, el conjunto resultante no es tan sólo un sólido tridimensional (como en el escáner médico), sino una suerte de teseracto: a las tres dimensiones que reproduce cada fotograma o frame, se une el eje temporal. Como en Sculptures de Waliczky, el corte bidimensional remite al slicing model.

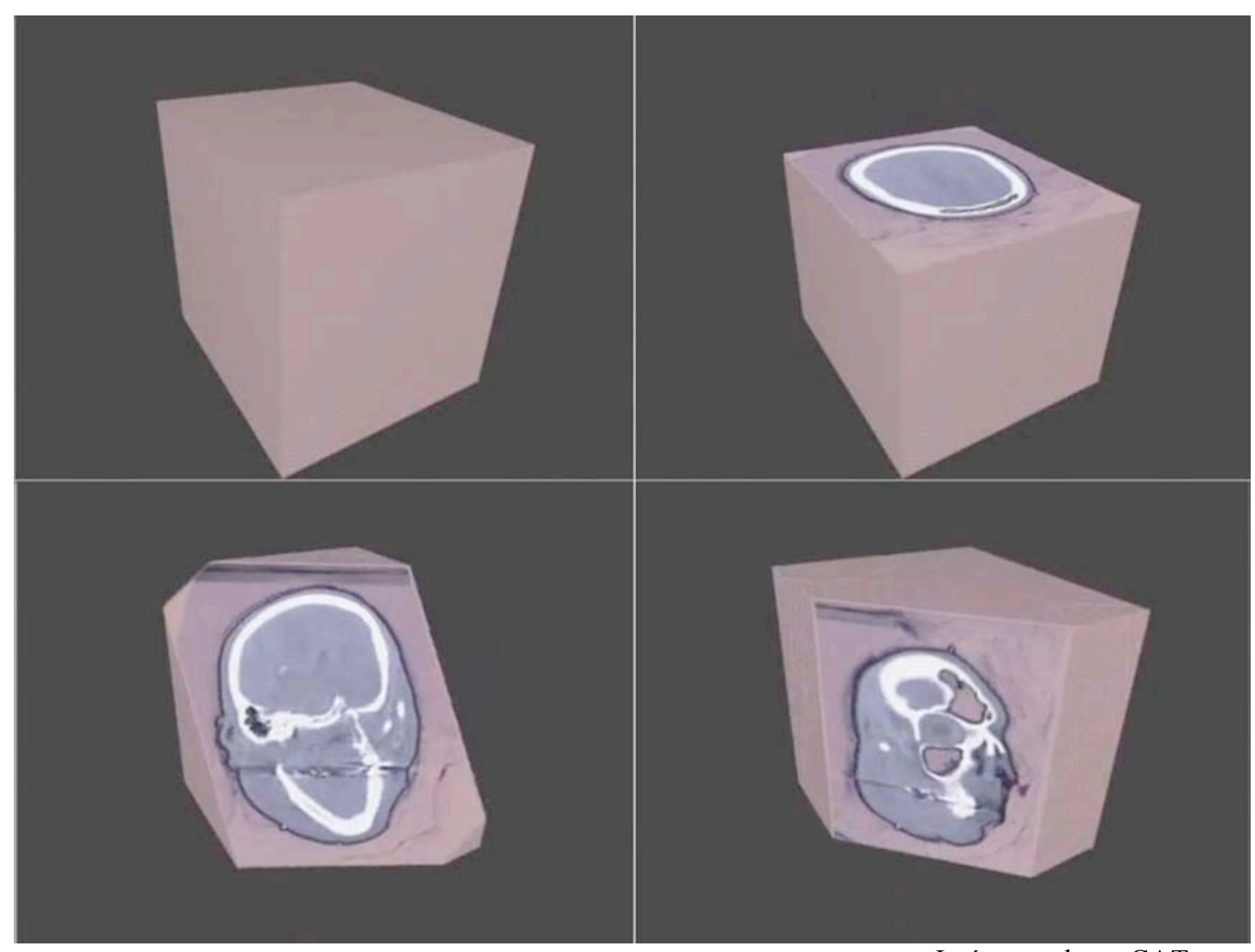

Imágenes de un CAT scan

En Éphémère II, la artista propone una reflexión sobre "la petrificación del tiempo y su licuefacción"10. En este sentido, compara sus objetos espacio-temporales con las lithochroniques de Oscar Domínguez. Ahora bien, si los OST son claramente cuatridimensionales, la artista no duda en negar cualquier pretensión científica al

\footnotetext{
${ }^{10}$ Ibídem, p. 168.
} 
respecto, y se concentra en el juego de deconstrucción del espacio-tiempo del registro y la construcción de nuevas entidades digitales. ${ }^{11}$

Frente a un objeto sintético (es decir, un gráfico computacional 3D), cuya naturaleza es vectorial, el objeto espacio-temporal consiste en un conjunto de vóxeles (píxeles volumétricos), legibles en todas direcciones. Así, si en lugar de hacer sucederse las imágenes en el eje temporal, el bloque espacio-temporal es abordado lateralmente, no se reproduce la secuencia registrada, sino que se construyen collages a partir de fragmentos de distintos frames. Tanto Edward Elliott como Tania Ruiz Gutiérrez asocian las imágenes así creadas con la llamada "slit-scan photography”.

\section{La slit scan}

Bajo esta denominación, suelen agruparse varias técnicas fotográficas que, si bien divergen en el proceso de fabricación de la imagen, producen efectos semejantes. ${ }^{12}$ Desde las técnicas fotográficas tradicionales ${ }^{13}$ hasta las últimas versiones digitales, se trate de un registro controlado o de un trabajo en postproducción, todas ellas tienen la particularidad de espacializar el tiempo a lo largo de la superficie bidimensional. Sirvan como ejemplo dos de las primeras fotografías en presentar un uso artístico de estas técnicas: "Hammer thrower" (1960) de George Silk y "Couple tire-bouchon" de Robert Doisneau (1961). Aunque resultado de dos procesos distintos ${ }^{14}$, ambas destacan por la impactante deformación de la figura. Buena parte de la producción artística digital emparentada con estas técnicas continúa en esta vía, explotando la potencia visual de la distorsión.

\footnotetext{
11 "Nos OST, pour leur part, ne se situent ni du côté spirituel, ni du côté scientifique de l'interprétation ou de la vulgarisation de la quatrième dimension, ils se limitent à déplier l'espace-temps cinématographique". Ibídem, p. 165.

12 Andrew Davidhazy explica la diferencia entre la "slit scan" propiamente dicha, la "strip photography" y la "streak photography". Grosso modo: mientras la "slit scan" depende del obturador, es decir, del espacio por el que entra la luz en la cámara fotográfica, la "strip photography" y la "photo finish" se basan en el desplazamiento de la superficie de registro. Por último, la "streak photography" se refiere al proceso de composición de la imagen mediante la suma de fragmentos de distintas fotografías. DAVIDHAZY, Andrew. Slit Scan and Strip Photography Overview. [En línea]. Rochester Institute of Technology. Disponible en Web:

$<$ http://people.rit.edu/andpph/text-streak-strip-scanning-imaging-overview.html >

${ }^{13}$ Éstas se remontan a mediados del siglo XIX. En 1843, el austriaco Joseph Puchberger utiliza un daguerrotipo panorámico, considerado hoy como el primer ejemplo de strip photography. VANVOLSEM, Maarten. The Art of Strip Photography: Making Still Images with a Moving Camera. Leuven: Universitaire Pers, 2011, p. 11.

${ }^{14}$ Si bien Silk se sirve de la técnica llamada "photo finish", Doisneau parece haber creado su imagen mediante el procedimiento de la slit scan.
} 


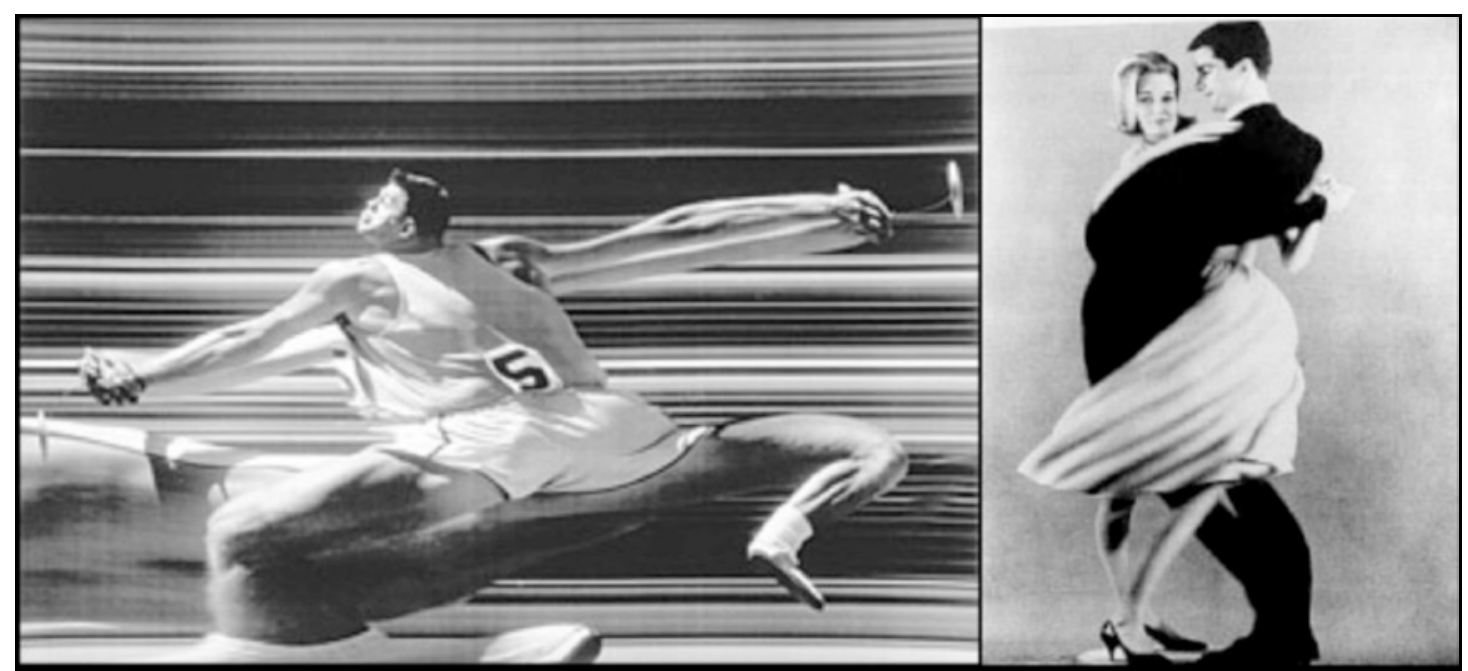

Izquierda, Silk: "Hammer thrower" (1960). Derecha, Doisneau: “Couple tire-bouchon” (1961)

El resultado de la lectura transversal de un cubo espacio-temporal puede asemejarse a una imagen de tipo "slit scan". La explicación es la siguiente: al elegir una de las caras laterales de modo que el cuadro de la imagen no corresponda a los ejes "X" e "Y", sino a "X" y "T" (o a "Y" y "T"), en lugar de reproducir íntegramente cada uno de los fotogramas o frames, el ordenador interpreta el espesor de las imágenes (el "canto del flip book") y reproduce una franja de cada frame, visualizando simultáneamente diversos momentos del registro de partida.

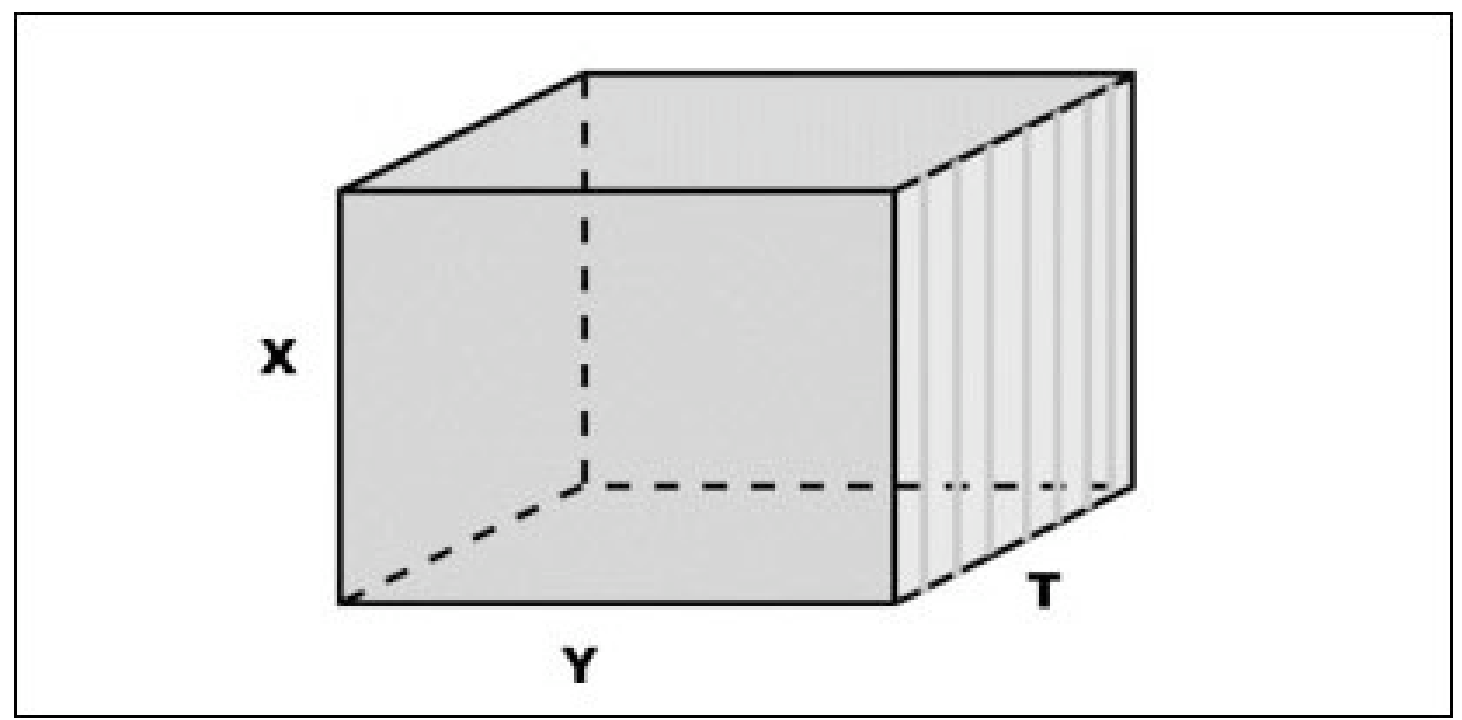

Una de las primeras experimentaciones con esta forma de edición digital es el TX-Transform, presentado por Martin Reinhart en 1998 en el festival Ars Electronica de Linz (Austria), apenas cuatro años después del Video Streamer. Partiendo igualmente del símil del folioscopio, el artista vienés se concentra en la 
transformación del registro. Una vez interpretado el vídeo de partida como un objeto tridimensional, el programa lee los datos así agrupados, intercambiando el eje del tiempo ("T") y el del espacio ("X"). De este modo, si en la imagen cinematográfica cada fotograma representa el espacio encuadrado en un momento de tiempo determinado, el TX-Transform produce el efecto opuesto: cada fragmento muestra de forma simultánea en la imagen todos los momentos que se suceden en una porción del espacio. Como resultado, el tiempo se despliega en la superficie: la parte izquierda de la pantalla corresponde al "antes" y la derecha al "después".

A diferencia de la obra posterior de Tania Ruiz Gutiérrez, en la que los cortes transversales pueden seguir todo tipo de direcciones, Reinhart se limita a acceder al bloque espacio-temporal a través del plano formado por los ejes " $T$ " y " $\mathrm{X}$ ". Tal restricción permite controlar las variantes y clasificar los diversos efectos obtenidos; éstos están íntimamente relacionados con el movimiento relativo entre la cámara y los objetos en el momento de registro, pudiéndose diferenciar, al menos, tres grandes categorías de construcciones espacio-temporales distintas:

CASO A- Si la cámara se mueve a una velocidad constante, el fondo permanece inalterado, mientras que los objetos móviles sufren diversas deformaciones.

CASO B- Al contrario, si la cámara permanece estática, todos los objetos inmóviles desaparecen en una masa informe, mientras que los objetos móviles continúan siendo identificables, si bien pueden sufrir distorsiones. Nótese el parecido del fondo con el del "Hammer thrower" de George Silk.

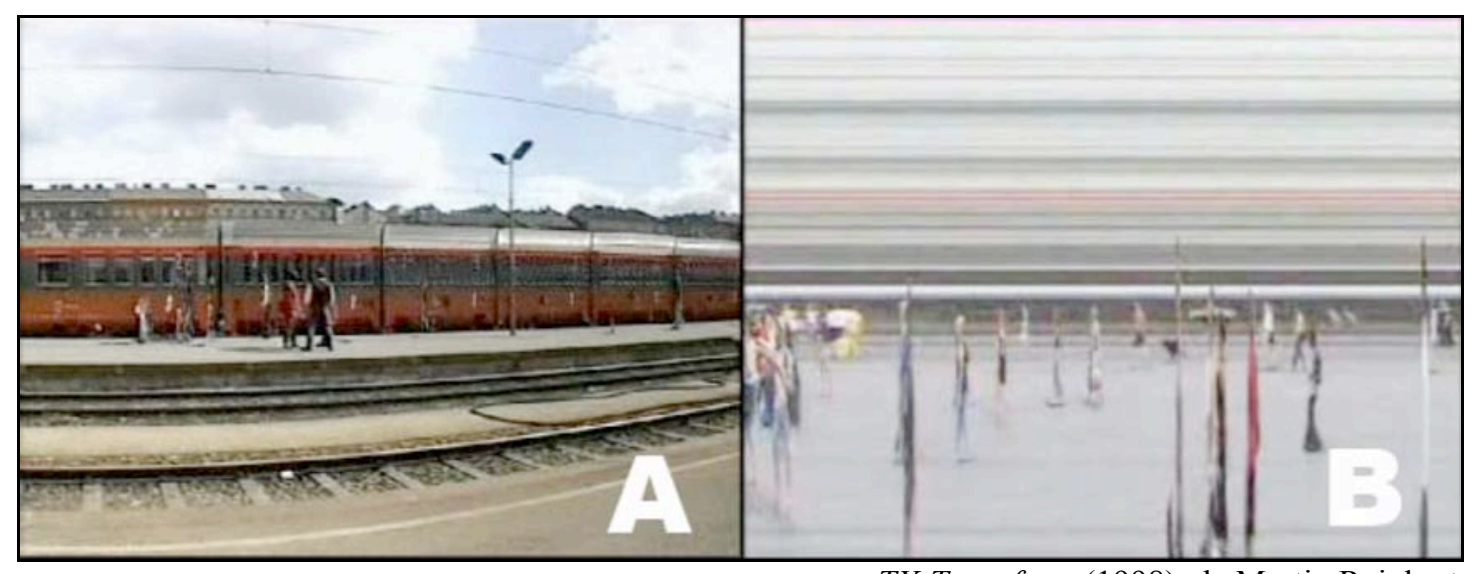

TX-Transform (1998), de Martin Reinhart 
CASO C (variante del caso B). Si la cámara permanece estática y un objeto rota frente a ella, todos los puntos de vista del objeto aparecen de forma simultánea en la imagen, como un globo de $360^{\circ}$ desplegado. Poco a poco, la figura va desapareciendo en un movimiento centrífugo hacia los lados. En esta ocasión, la utilización de un fondo neutro permite concentrarse en las mutaciones de la forma. De hecho, el propio Doisneau recurre a la misma estrategia para resaltar la anamorfosis de los cuerpos en su "Couple tire-bouchon".

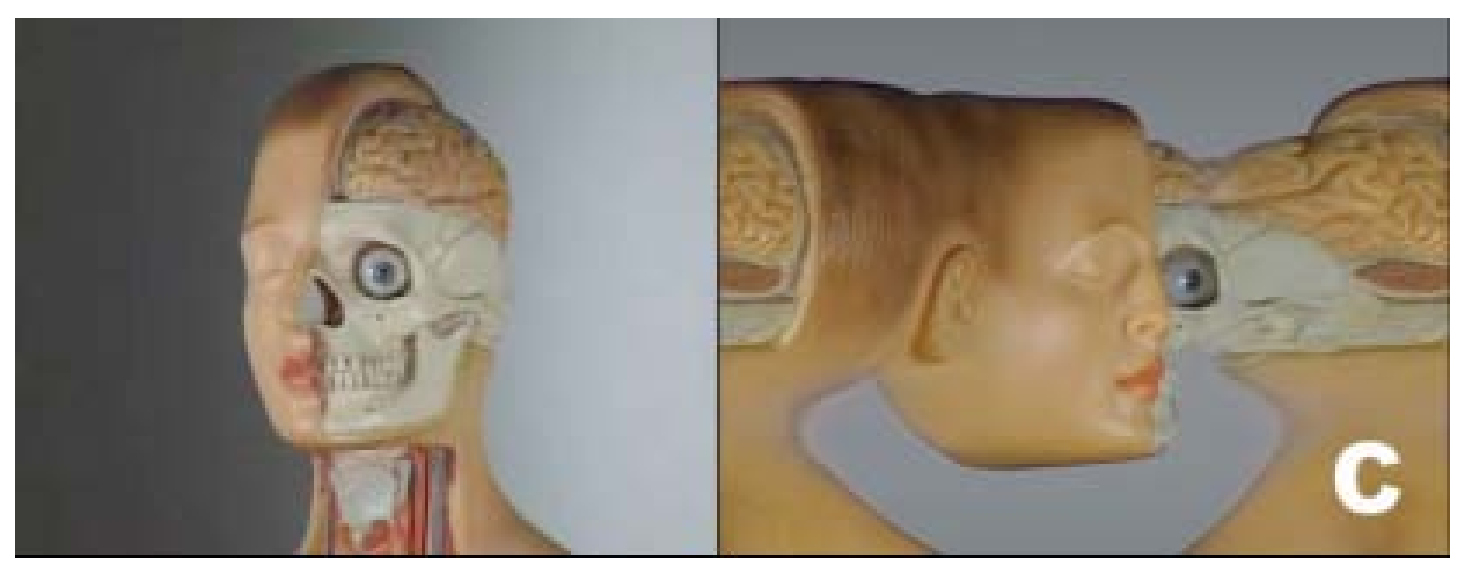

Izquierda, imagen antes de la transformación. Derecha, constructo realizado mediante el $T X$-Transform

Las imágenes reproducidas forman parte de la explicación gráfica de la técnica digital presentada por Reinhart en Linz. Cuatro años después, el artista crea la pieza TX-dance. Motion studies in space and time (2002) como una propuesta estética específica a partir de la herramienta descrita. El artista recurre al fondo neutro haciendo sobresalir la figura y permitiendo, así, apreciar la mutación de la forma. Ésta fluye en la superficie de la imagen sin mostrar cicatriz alguna del corte entre los frames originales: la forma se cuela a través de las rendijas, de los poros, entre las franjas invisibles y permeables. Por ósmosis, por contagio, en ese espacio de intersticios invisibles, el cuerpo de un hombre aparece, desaparece y reaparece, en un flujo constante de transformaciones.

La pieza se basa en la creación de una continuidad distinta a la del material de partida. Mientras la interpolación se fundamenta en la construcción de fases intermedias que colman el vacío entre las imágenes sucesivas, los constructos digitales como el que nos ocupa permiten el flujo de la forma sin necesidad alguna de crear un puente entre los frames. Así, si la continuidad de la interpolación se basa en 
el cálculo del espacio intermedio, la continuidad que revela $T X$-dance. Motion studies in space and time es la de una interdimensionalidad: la continuidad de las mismísimas dimensiones espaciales, entre las cuales, se cuenta el tiempo.
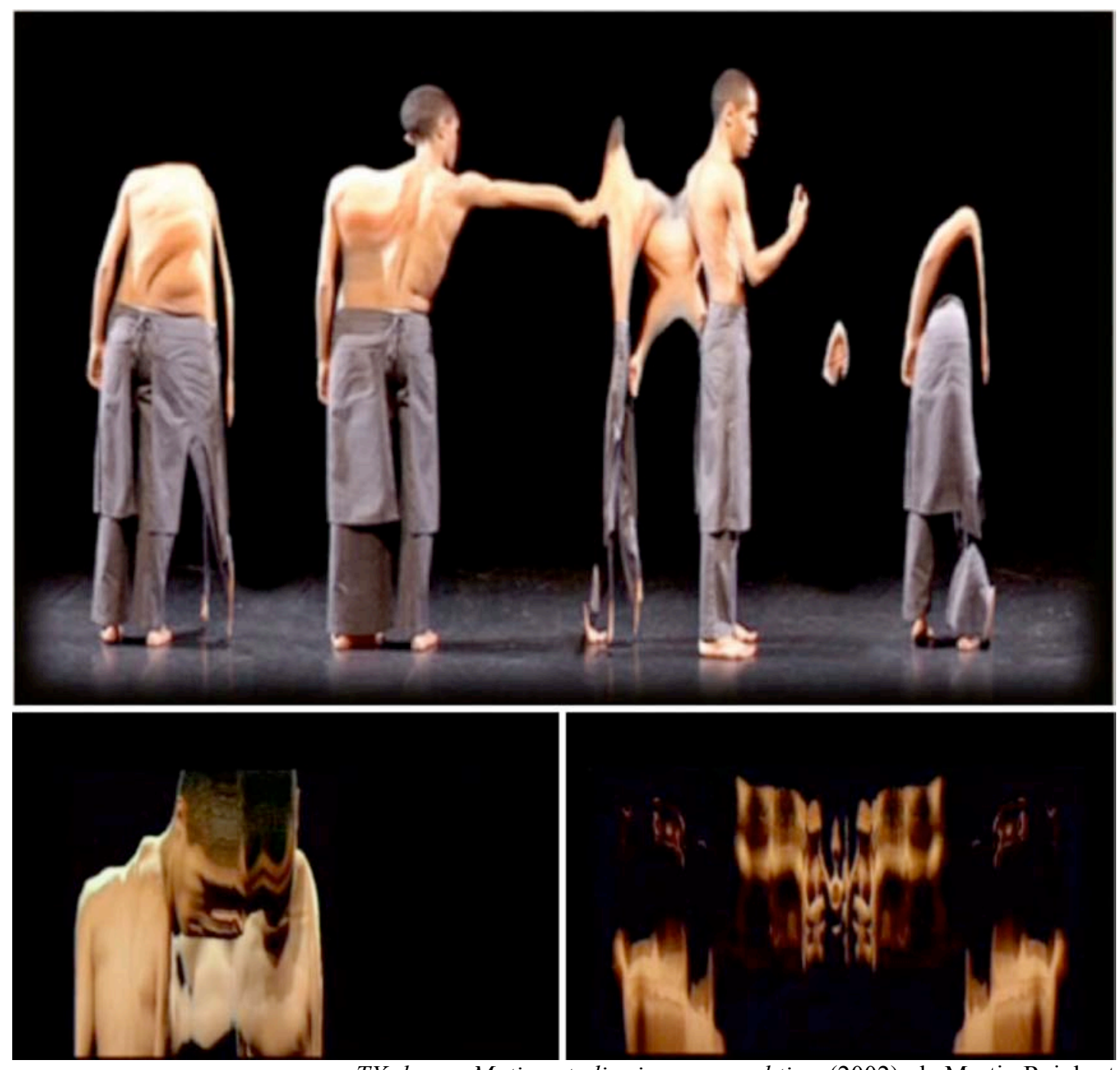

TX-dance. Motion studies in space and time (2002), de Martin Reinhart

Aunque, como veíamos, el resultado del TX-Transform está íntimamente relacionado con las condiciones del registro de partida, el movimiento en la imagen no reproduce la acción profílmica o la movilidad de la cámara originales, sino que presenta una entidad nueva, fruto de la redistribución de la información contenida en los píxeles. El movimiento en este constructo es una activación espacial, una dinamización distinta a la reproducción del registro.

Al mismo tiempo que Reinhart, Steina Vasulka explora la potencia plástica de la distorsión en su instalación Warp (2000). Las imágenes fueron creadas con el programa "Image/ine", desarrollado en 1997 por la propia artista en colaboración con 
el programador Tom Demeyer. Para su instalación, Vasulka exploró dos efectos del Image/ine: el "time-warp" y la "slit scan". Como su nombre indica, el primer modo "retuerce" el espacio: el cuerpo de la artista se mueve en una habitación vacía, dibujando movimientos de una sinuosidad imposible. El modo "slit scan" difiere del anterior; la activación de la imagen no presenta una figura (monstruosa) en movimiento, sino el mismísimo barrido de la imagen: en una grafía dinámica, trazos de la figura inmóvil se expanden hacia los lados, subrayando el carácter plano de la pantalla. ${ }^{15}$ Como resultado, varios puntos de vista del rostro de Vasulka aparecen simultáneamente, efecto que remite al cubismo pictórico.

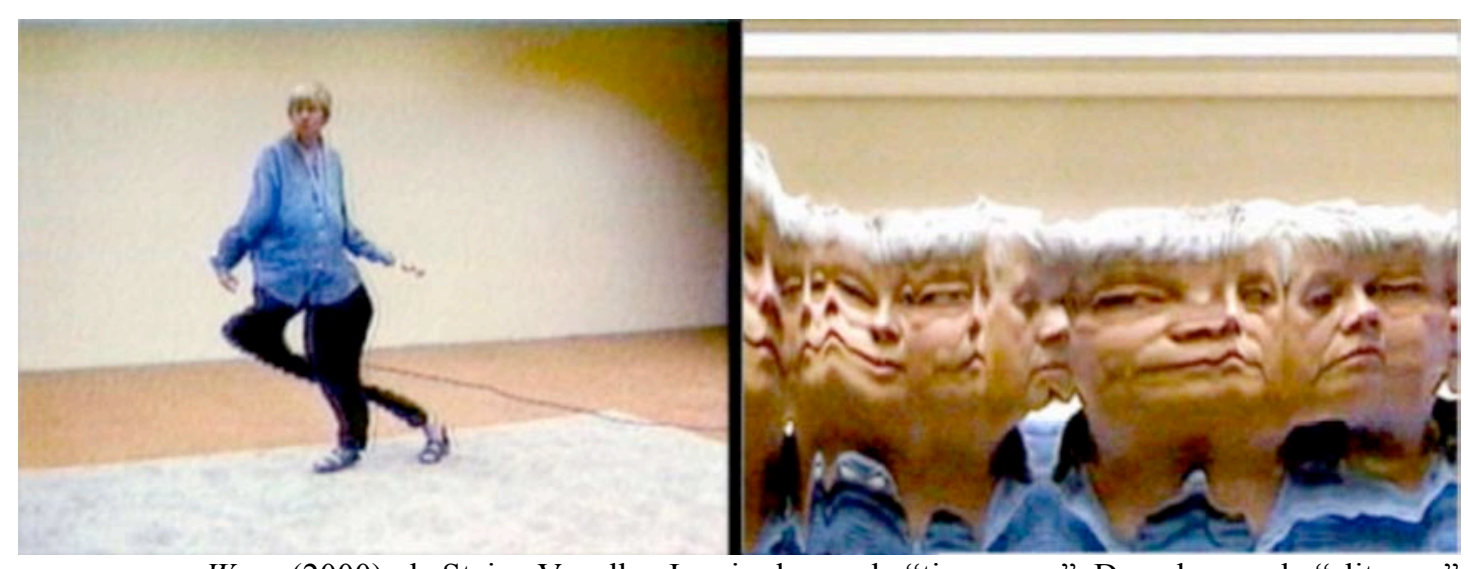

Warp (2000), de Steina Vasulka. Izquierda: modo "time warp". Derecha: modo "slit scan"

Tanto el modo "time warp" como el "slit scan" responden al interés de la artista por la distorsión de la imagen. En el primer apartado de este trabajo, subrayábamos la tendencia del videoarte hacia la transformación espacial y la deformación electrónica, frente a la representación en perspectiva y la mera reproducción del registro. La clave de esta propuesta, decíamos, reside en la plasticidad de la imagen videográfica frente a la mecánica y la óptica cinematográficas. En palabras de Woody Vasulka : “puedes retorcer una imagen de televisión como si fuera materia."16. De hecho, tras sus primeras experimentaciones con la señal analógica, Steina y Woody acogen con los brazos abiertos la tecnología digital. En este sentido, la pareja de artistas personifica el paralelismo entre el aspecto espacial del videoarte y las construcciones que analizamos en la imagen código. ${ }^{17}$

\footnotetext{
${ }^{15}$ El efecto recuerda al usado por Pipilotti Rist en I'm Not The Girl Who Misses Much (1986).

${ }^{16}$ Woody Vasulka. Apud. KLONARIS, Maria; THOMADAKI, Katerina. Technologies et imaginaires. Art cinéma / vidéo / ordinateur. Paris: Dis Voir, 1990, p. 23.

${ }^{17}$ Yvonne Spielmann subraya el vínculo entre la naturaleza del vídeo y de la imagen código, y pone como ejemplo la obra de Steina y Woody Vasulka: "I find that the Vasulkas were very aware of the
} 


\section{La cuarta dimensión del espacio}

Algunos años después, Daniel Crooks explora la relación entre fijación y movimiento en la imagen. ${ }^{18}$ Static $N^{\circ} 12$ (Seek stillness in movement) (2010) parte de un vídeo de un anciano practicando taichi en Shanghai; tras someterlo a la transformación digital, el efecto resultante se acerca al modo "slit scan" de Vasulka o al caso B del TX-Transform. Ahora bien, frente a sus predecesoras, la obra de Crooks combina la reproducción "normal" del registro y su mutación. Contra todo pronóstico, la cohabitación de ambas no presenta corte alguno, sino que la distorsión nace en el centro mismo de la imagen, expandiéndose hacia los lados al modo de una dilatación espacial. Esta elasticidad del espacio digital se exhibe como una brecha en el continuo espacio-tiempo: un "portal"19 interdimensional.

Frente a otros experimentos semejantes, Static $N^{\circ} 12$ (Seek stillness in movement) destaca por la lograda correspondencia entre forma y contenido. El título retoma el $10^{\circ}$ mandamiento del taichi: "busca la quietud en el movimiento" ${ }^{20}$. Lejos de cualquier dualismo, el arte marcial subraya la continuidad entre ambos estados. A la hora de dar forma a tal concepto, Crooks no se conforma con el juego visual entre la fijación del frame y el efecto de movimiento en la secuencia, sino que acude a una espacialización del tiempo que permite la convivencia en la imagen de los dos estados. Este tratamiento del tiempo como una dimensión espacial pasa por la creación de un ente nuevo, distinto al frame de partida.

\footnotetext{
state of media development, namely that a new medium was grasping for articulation and acknowledgement. This awareness guided the early use of image processors, mixers, and computers for modulating, keying, and switching. The concept of generating and organizing electronic signals directly via machine control is grounded in the idea of programmability as a way of interfering and radically transforming the status of an 'image'. In this view, electronic images when they develop complex layers and produce a spatial order through prioritizing image keys, clearly hold a position that foregrounds the matrix of digital space." SPIELMANN, Yvonne. Video and Computer, The Aesthetics of Steina and Woody Vasulka. [En línea]. Fondation Langlois, 2004. Disponible en Web:

$<$ http://www.fondation-langlois.org/html/e/page.php?NumPage=461>

${ }^{18}$ Como Tania Ruiz Gutiérrez o Tamás Waliczky, Daniel Crooks se sitúa entre los muchos artistas contemporáneos que se sirven de la tecnología digital para reflexionar sobre la relación entre fijación y movimiento en la imagen. Para profundizar en este aspecto de la creación contemporánea, remitimos a: CHIK, Caroline. L'image paradoxale. Fixité et mouvement. Villeneuve d'Ascq: Presses Universitaires Septentrion, 2011.

19 El propio autor utiliza el término "portal" en la entrevista previa a la entrega de los premios Signature Art Prize 2011, en el Singapore Art Museum. StudioArt Break: Daniel Crooks. [Vídeo en línea]. Studio132. 2011. Disponible en Web:

$<$ http://www.studiotv.com.au/arts-news/stvdio-artbreak-daniel-crooks/>

${ }^{20}$ CHENGFU, Yang. The Essence and Applications of Taijiquan (1934). California: North Atlantic Books, 2005, p. 11.
} 
Si en el dispositivo cinematógrafo, la unidad mínima de registro coincide con la de proyección, los constructos digitales que nos ocupan se basan en una ruptura con la lógica de la RE-producción: la clave es, precisamente, el desfase entre la unidad de registro (el fotograma o frame) y la unidad del constructo final (el corte transversal que liga varias capas del bloque espacio-temporal).

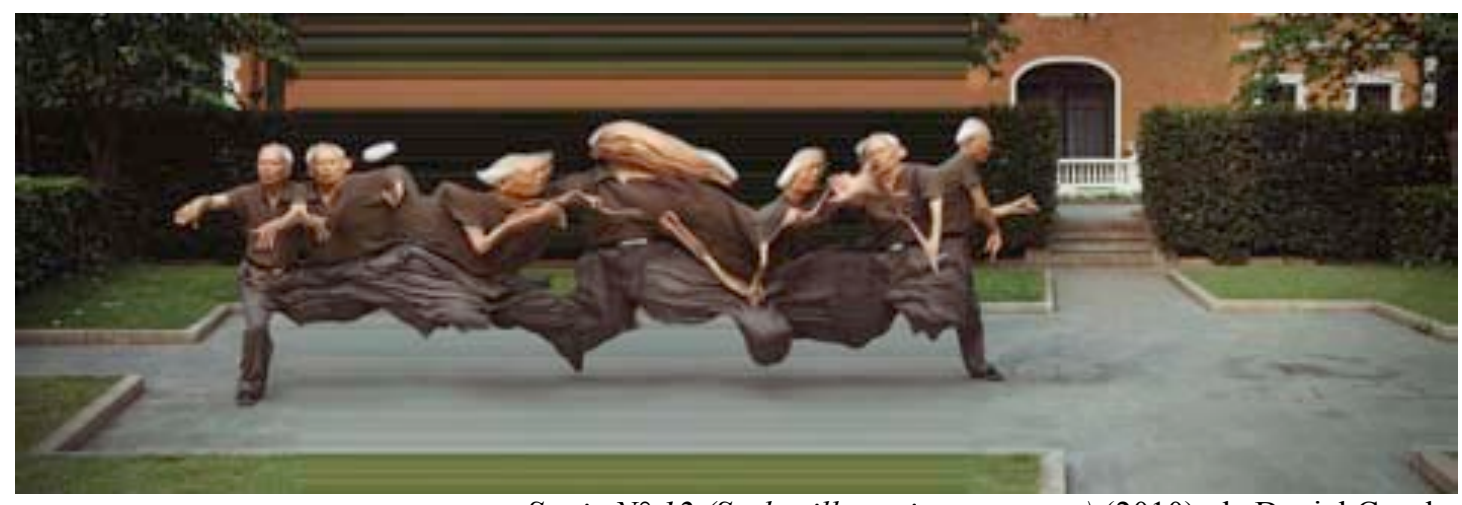

Static $N^{\circ} 12$ (Seek stillness in movement) (2010), de Daniel Crooks

En su ensayo titulado "Sobre la atemporalidad", el artista Kurt Ralske narra dos "revelaciones acerca de la naturaleza del vídeo" en la era digital. La primera, redunda en la intuición de Waliczky, quince años anterior: el orden de visionado de los frames es una convención; en realidad, éstos pueden ser leídos aleatoriamente o siguiendo cualquier otro criterio más allá de la mera reproducción cronológica de la secuencia. La segunda revelación supone el abandono de otra limitación: el frame en tanto que unidad mínima. Ésta corresponde, en realidad, al píxel:

\begin{abstract}
"En adelante, cada píxel no es definido por su rol en un determinado frame; su papel y relación con otros píxeles es definido, exclusivamente, por las reglas que yo creo. Una vez almacenado en la memoria de un ordenador, el vídeo digital es una gran masa de datos, y estos datos pueden ser manipulados o analizados de innumerables maneras." 21
\end{abstract}

A la hora de redistribuir los píxeles (liberados de su dependencia a un frame en particular), el artista los interpreta formando un bloque tridimensional. Ralske se refiere a esta técnica como " $4 \mathrm{~d}$ mapping", siendo el tiempo esa cuarta dimensión espacial. Así, por ejemplo, la instalación Times Square Timeshare (2006) está

\footnotetext{
${ }^{21}$ RALSKE, Kurt. On atemporality. [En línea]. Retnull.com, May 2005. Disponible en Web: $<$ http://www.retnull.com/atemporal.html $>$
} 
formada por cuatro canales de vídeo que muestran varias imágenes "atemporales". Éstas fueron creadas a partir de la transformación de un registro de dos minutos de duración en la célebre plaza neoyorkina. Los píxeles que constituyen el conjunto de la toma fueron interpretados como datos en un espacio tridimensional. Frente a los OST de Tania Ruiz Gutiérrez, Ralske no presenta el objeto espacio-temporal en su conjunto, sino tan sólo una serie de cortes transversales del mismo.

Puesto que la toma de los viandantes y los coches se realizó con la cámara estática, el resultado se asemeja al caso B contemplado en el TX-Transform. En esta ocasión, las figuras, inicialmente en movimiento, aparecen prácticamente congeladas, mientras que los elementos antes fijos se animan en un flujo de mutaciones abstractas. La imagen resultante se caracteriza por un flujo horizontal que Ralske potencia mediante la elección de un formato apaisado.

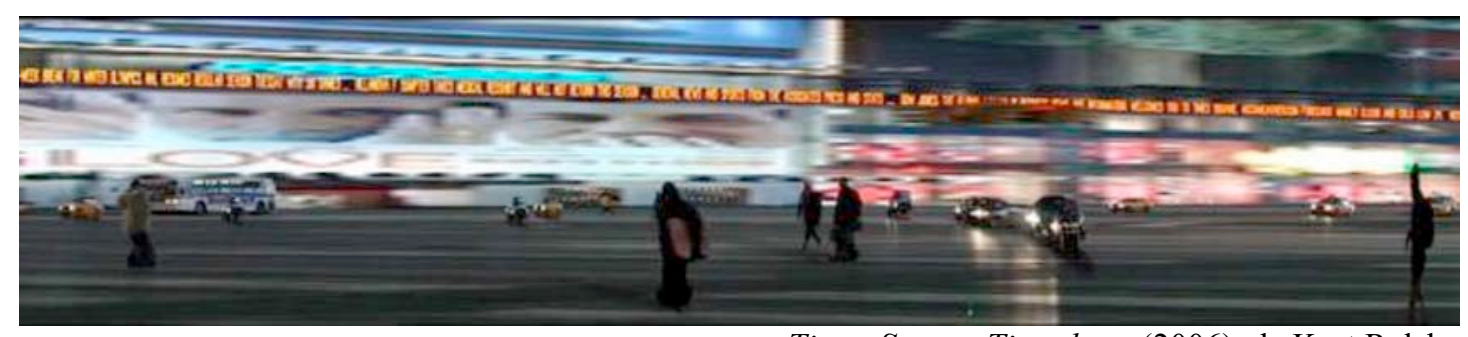

Times Square Timeshare (2006), de Kurt Ralske

Un aspecto a tener en cuenta en los objetos espacio-temporales que analizamos es que (como bien destaca Tania Ruiz en su definición) el registro de partida puede ser fotográfico, cinematográfico o videográfico. En los dos primeros casos, las imágenes fijas que componen el "folioscopio digital" vienen dadas de antemano en el propio material bruto, ya sea como instantánea o como fotograma. No obstante, la imagen videográfica no está constituida de unidades semejantes, sino que es, en sí misma, una imagen flujo: la señal electrónica se traduce en un escaneo de líneas paralelas que se suceden en la pantalla, normalmente, de arriba a abajo y de izquierda a derecha. Mientras que en el dispositivo cinematográfico los fotogramas se suceden en bloque, la imagen vídeo se conforma a partir del barrido de la pantalla.

En realidad, esa "no sujeción al frame en tanto que unidad mínima" a la que apela Ralske es inherente a la tecnología vídeo. Curiosamente, la construcción del objeto espacio-temporal a partir de este tipo de imagen pasa por la fabricación artificial de frames, que serán descompuestos subsecuentemente en la interpretación transversal del bloque de imágenes fijas. 
Así, no es de extrañar que, seis años antes del Video Streamer, el especialista de la imagen electrónica Zbig Rybczynski presentara su The Fourth Dimension (1988). En ella, la linealidad subyacente a la construcción de tipo "slit scan" se hace explícita al final de la cinta, cuando el artista exhibe las franjas horizontales que estructuran la imagen. Aunque no fue rodada directamente en vídeo, sino en película de $35 \mathrm{~mm}$, la lógica subyacente de descomposición de los fotogramas y recomposición de los frames hace eco al barrido videográfico.

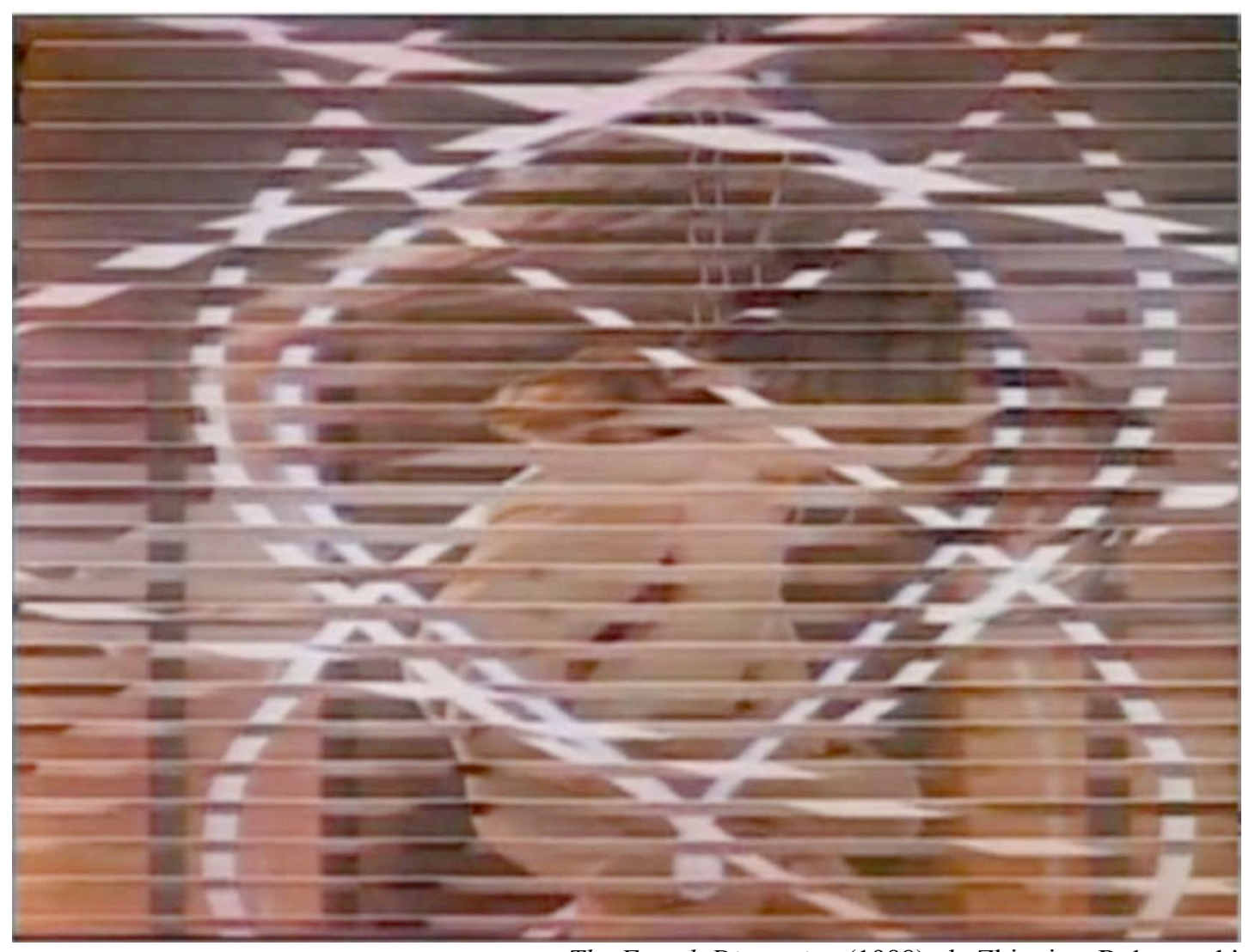

The Fourth Dimension (1988), de Zbigniew Rybczynski

Tras registrar los actores en sus acciones respectivas, el material recogido no se reprodujo tal cual, sino que el autor manipuló digitalmente la imagen: cada una de las 480 líneas que se suceden en la pantalla corresponden a un frame original distinto. ${ }^{22}$ Como resultado, no sólo la estructura ósea de la pareja de enamorados se somete a todo tipo de contorsiones, sino que los entes inanimados se activan. Lejos de la lógica temporal de la reproducción mimética, la dinamización de la imagen no corresponde al movimiento profílmico, sino a una activación nueva, específica de la imagen.

\footnotetext{
${ }^{22}$ KERMABON, Jacques. “Zbigniew Rybczynski, l'autre dimension”. Magazine Bref. Mai 1990, núm 5, pp. 8-11.
} 
Basta comparar el dúo protagonista de The Fourth Dimension con la "pareja sacacorchos" de Doisneau para comprender las asociaciones de los constructos digitales que analizamos con la slit scan photography. Ahora bien, frente a la imagen fija creada por el fotógrafo francés, la animación de Rybczynski añade a la fuerza visual de la deformación el flujo continuo de la forma.

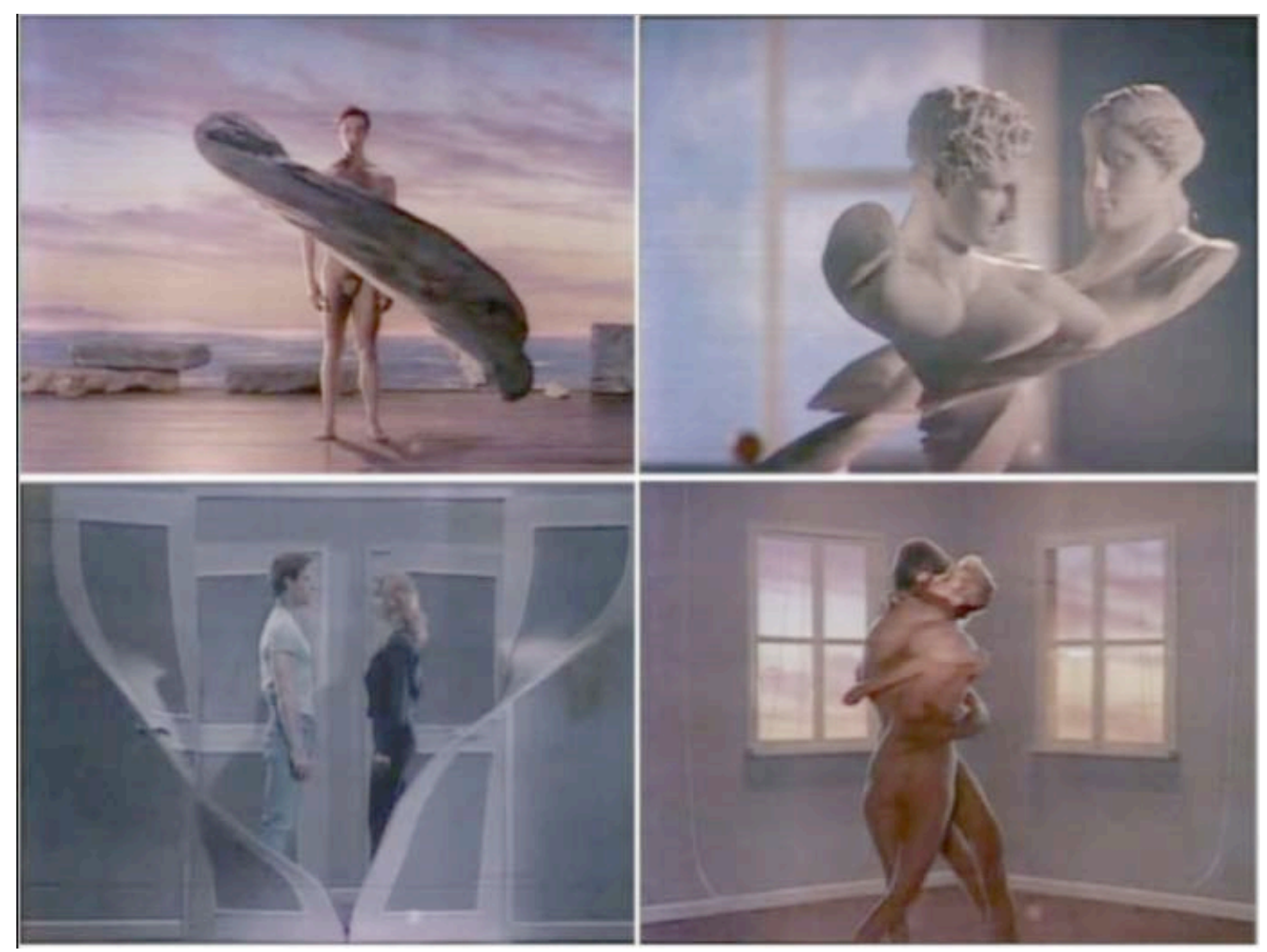

The Fourth Dimension (1988), de Zbigniew Rybczynski

Tal y como indica el título de la obra, esta construcción digital se presenta como una visualización de la cuarta dimensión. Así, por ejemplo, la presencia de espejos, puertas y ventanas (igualmente ondulantes) remite inequívocamente al portal interdimensional. La equiparación de esa cuarta dimensión con el tiempo es explícita al final de la pieza, cuando un reloj barroco se retuerce sobre su propio eje: por un lado, la maleabilidad inesperada del objeto recuerda el óleo de Salvador Dalí "La persistencia de la memoria" (1931); por otro, la sombra proyectada en la pared, cuya transformación comienza antes que la del objeto, revela una descomposición de la unidad del espacio tridimensional y de la relación causa-consecuencia, ligada al flujo temporal antes-después. 


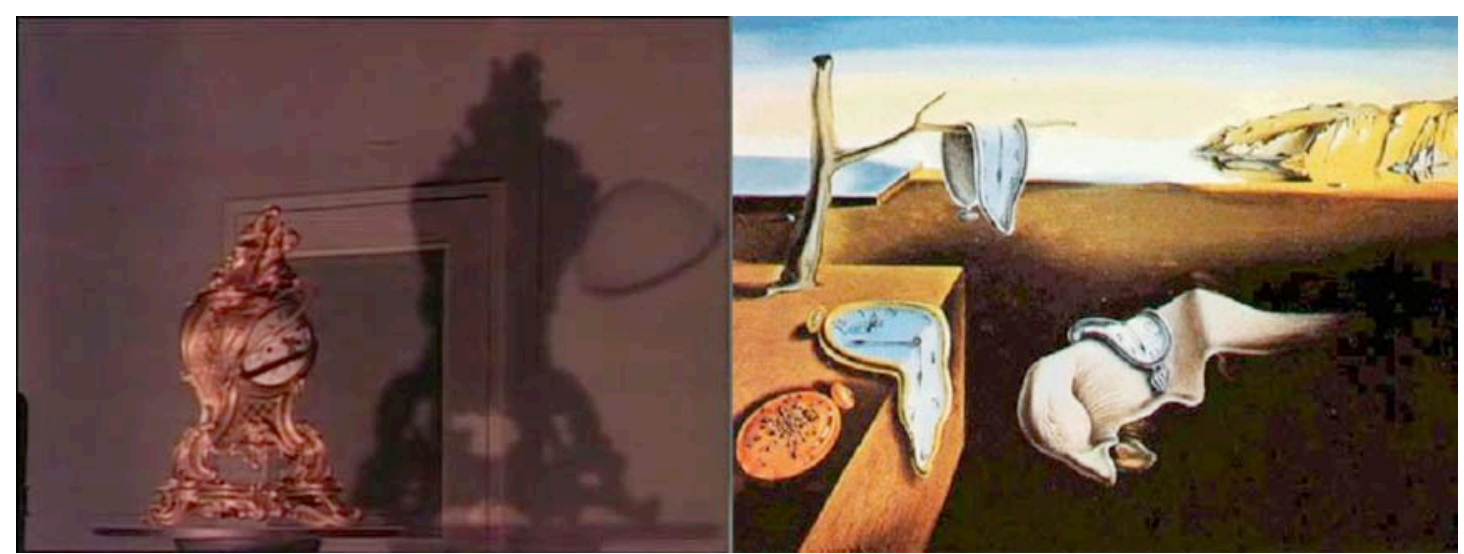

Izquierda, The Fourth Dimension (1988), de Rybczynski. Derecha, Dalí: "La persistencia de la memoria" (1931)

Decíamos al principio de este apartado que el folioscopio permite visualizar un teseracto, en el que la cuarta dimensión correspondería al tiempo. El continuo espacio-temporal así definido es un sólido estático; es decir, el hecho de añadir el eje temporal a las tres dimensiones del espacio no impide que el bloque resultante continúe siendo un espacio euclidiano. No es de extrañar, pues, que el cineasta Jean Painlevé acuda a la metáfora del flip book para explicar el slicing model: como veíamos al final del apartado anterior, la bidimensionalidad de los fotogramas casa a la perfección con el corte transversal del teseracto. A esta misma interpretación del tiempo como la cuarta dimensión de un espacio-tiempo continuo estático corresponden las Sculptures de Tamás Waliczky.

Curiosamente, el corte transversal de un objeto espacio-temporal se aleja del símil anterior. Frente al frame (que correspondería a un momento determinado dentro del flujo lineal y cronológico del tiempo), la sección alternativa del bloque espaciotemporal evidenciaría la mezcla indisoluble, la continuidad no ya del flujo temporal, sino de las cuatro dimensiones entre sí. Las transformaciones que nos ocupan presentan una imbricación, una interdependencia del espacio y el tiempo, de modo que la espacialización de éste afecta a todo el conjunto cuatridimensional. En este sentido, es frecuente que los propios artistas apelen al espacio-tiempo continuo relativista. Así, si Elliott y Davenport comparan los cortes del Video Streamer con las "líneas del mundo"23 teorizadas por Hermann Minkowski (1864-1909), el TXTransform se asocia con la teoría de Albert Einstein (1879-1955).

\footnotetext{
23 "The Streamer is also a visualization of the concept of 'world lines' in physics. World lines trace our passage through spacetime." Elliott y Davenport. Ver página web del proyecto: $<$ http://www.lightmoves.net/videostreamer/intro/intro2_origins.htm>
} 


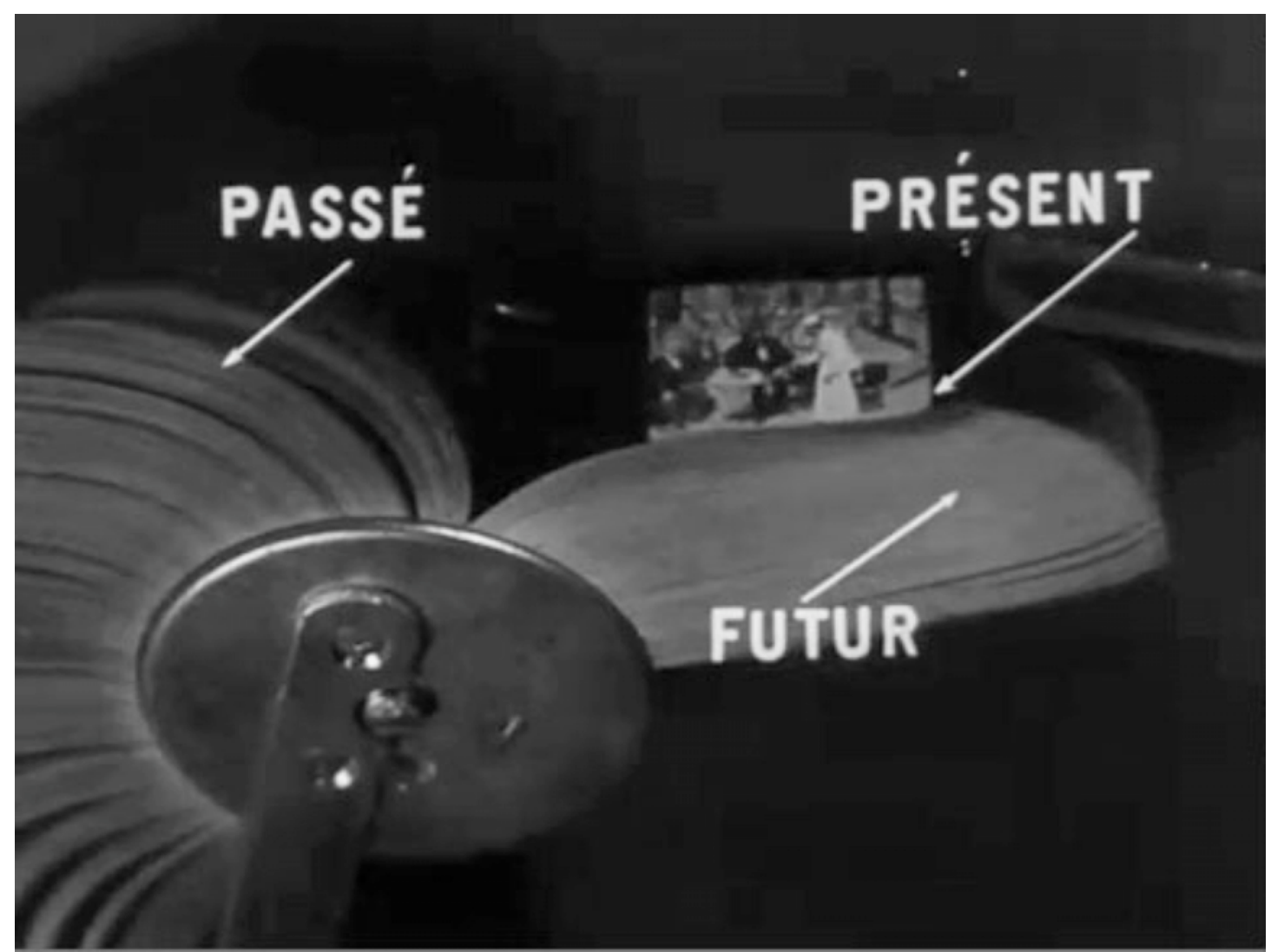

La quatrième dimension (1937), de Jean Painlevé

De hecho, Martin Reinhart acompañó la presentación de esta técnica de un corto de ficción que sugería la potencialidad estética y narrativa del efecto mediante una adaptación de las ideas del científico alemán. Realizado en colaboración con Virgil Widrich, TX-Transform, the film (1998) se basa en un texto del libro The ABC of Relativity, en el que el filósofo Bertrand Russell (1872-1970) explica mediante diversas analogías la compleja teoría de Einstein. ${ }^{24}$ En realidad, para ilustrar las estructuras espacio-temporales descritas por éste, los autores se conforman con mostrar la plasticidad del espacio de la imagen, que pone en evidencia la continuidad interdimensional. ${ }^{25}$ La referencia al pensamiento revolucionario del físico alemán (a través de la metáfora de Russell) no responde a una motivación científica, sino a una constatación de la "congruencia" 26 entre dicha teoría y el efecto digital que nos ocupa.

\footnotetext{
${ }^{24}$ RUSSELL, Bertrand. The ABC of Relativity (1925). London: Routledge, 2002, pp. 36-37.

25 "The theory of relativity reduces everything to relations; it emphasizes structure, not material. We've been taught by modern science that the so-called objective world is a relationship between the observer and the observed, so that ultimately we are able to know nothing but that relationship. Extra-objective art replaces object-consciousness with metaphysical relation-consciousness. Romance is born in the space between events." YOUNGBLOOD, Gene. Op. cit., p. 127.

${ }^{26}$ REINHART, Martin; WIDRICH, Virgil. TX-Transform [En línea]. Ars Electronica Archive 1998. Disponible en Web:

http://90.146.8.18/en/archives/festival_archive/festival_catalogs/festival_artikel.asp?iProjectID=8408
} 

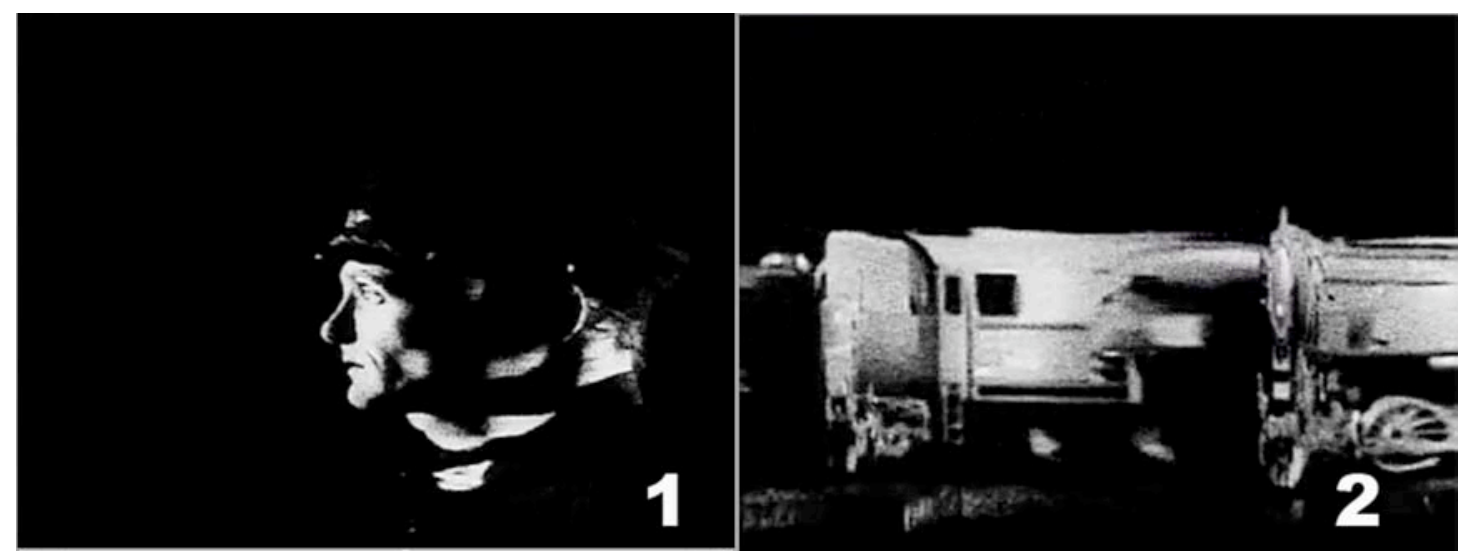

TX-Transform, the film (1998) de Martin Reinhart y Virgil Widrich

Lo cierto es que, si bien las referencias a la cuarta dimensión son constantes, en general, se trata de una alusión libre, no sujeta a una comprensión estricta de las teorías científicas correspondientes. Como veremos en el próximo apartado, buena parte de las construcciones digitales de hiperespacios se inspiran tanto en la física del siglo XX como en las teorías no-euclidianas del XIX. En realidad, el atractivo de aquellas propuestas para los artistas contemporáneos reside en la liberación de las rígidas normas de la perspectiva y la reproducción mimética. Nuevamente, este hecho permite relacionar buena parte de estas (y otras) creaciones con los experimentos de las vanguardias históricas.

Citábamos más arriba el surrealismo de Salvador Dalí. Si recuperamos el caso C de los ejemplos gráficos del TX-Transform, comprobaremos cómo la convivencia de varios puntos de vista del mismo objeto en la imagen remite al cubismo pictórico. De hecho, no son pocas las referencias a la corriente de vanguardia en la literatura asociada a técnicas de procesamiento de la imagen. En este sentido, hay quien habla, incluso, de un "video cubismo"27.

En el primer capítulo, veíamos ya algunos ejemplos de cohabitación de imágenes que exploran la presentación simultánea de varios puntos de vista. No es de extrañar que el propio Rybczynski ideara The Fourth Dimension al tiempo que creaba su Nowa ksiazka (1975). ${ }^{28}$ Recordemos que esta última pieza presenta un teselado

\footnotetext{
${ }^{27}$ Pensamos, por ejemplo, en la instalación interactiva Liquid Time Series (2000-2002), de Camille Utterback: "The resulting imagery can be described as video cubism. To create this imagery Utterback's software deconstructs the video frame as the unit of playback. This piece destabilizes a basic premise of time based media - that the unit of recording is also the unit of playback." Ver la página web del proyecto: <http://camilleutterback.com/projects/liquid-time-series/>

$\mathrm{O}$ en el artículo titulado "Techniques for Interactive Video Cubism”. FELS, Sidney; LEE, Eric; MASE, Kenji. "Techniques for Interactive Video Cubism". En: Proceedings of ACM Multimedia. October 2000, pp. 368-370.

${ }^{28}$ KERMABON, Jacques. Op. cit.
} 
compuesto por varias imágenes de una misma escena, contemplada desde diversos puntos de vista. Si el tiempo es común a todas las secciones, la perspectiva difiere en cada una. El "cubismo" de la pieza radica, así, en la cohabitación, en la simultaneidad, pero no hay deformación alguna. Frente a esta obra, la asociación de The Fourth Dimension con la corriente pictórica se justifica tanto por la multiplicación de vistas como por la deformación del conjunto. Lejos de cualquier matiz peyorativo, esa “deformación” es potencialidad creadora, reivindicación de un espacio plástico propio a la imagen.

Pongamos por caso el dibujo de Juan Gris titulado "Tête de femme" (1911): el diseño cubista se basa en una concepción de la cuarta dimensión puramente espacial y que poco o nada debe a la asociación temporal. En este caso, nos aproximamos a otro tipo de metáfora del hiperespacio, que veremos con detenimiento a continuación: el projective model o shadow model. Mientras que el slicing model basa la analogía dimensional en lo que una parte dice del todo (lo que el frame dice de la secuencia, por ejemplo), el shadow model subraya la relación entre las partes. Desde un punto de vista matemático, la pega del primer modelo sería la descontextualización de la información, mientras que la del segundo sería la deformación espacial. ${ }^{29}$ En lo que concierne al arte, tal deformación está lejos de suponer un "pero" y es explotada por su impacto visual y su asociación con la plasticidad de la imagen código.

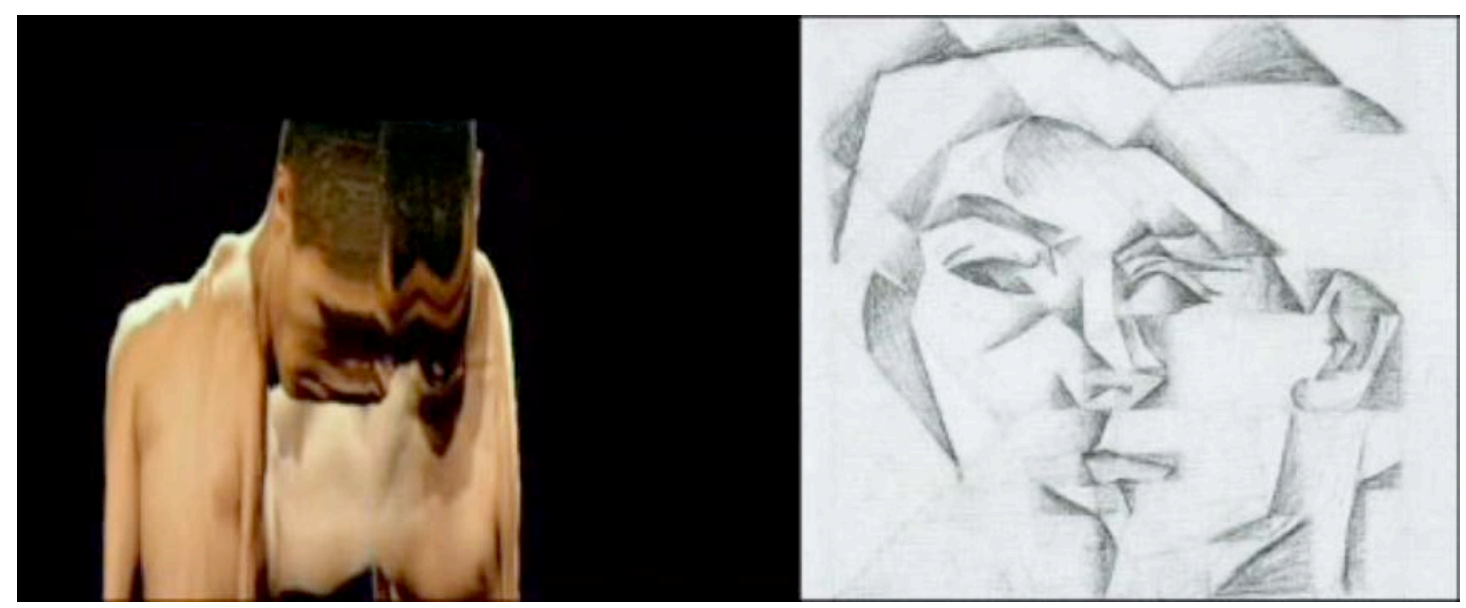

Izquierda, TX-Dance (2002), de Martin Reinhart. Derecha, Juan Gris: “Tête de femme“ (1911)

\footnotetext{
${ }^{29}$ ROBBIN, Tony. Shadows of Reality: The Fourth Dimension in Relativity, Cubism, and Modern Thought. New Haven: Yale University Press, 2006, pp. IX-X.
} 
Los efectos como el TX-Transform que hemos estudiado en las últimas páginas se hallan a medio camino entre el slicing model (por el corte de un bloque cuatridimensional) y el modelo proyectivo (por cuanto subrayan la continuidad entre las partes al tiempo que deforman el espacio). En el próximo apartado, profundizaremos en la visualización de espacios de más de tres dimensiones y veremos cómo este tipo de construcciones son especialmente frecuentes entre los pioneros del computer art. 


\section{DEL POLITOPO AL VIAJE INTERDIMENSIONAL}

Durante la década de los años 60, los pioneros del arte por ordenador experimentaron con el nuevo medio, continuando con las cuestiones del arte moderno y planteando otras nuevas entre la investigación audiovisual y la matemática. Por aquel entonces, los Bell Laboratories (New Jersey, EE.UU.) alimentaron el interés por la informática balbuciente y promovieron la interdisciplinariedad para tantear la nueva y compleja herramienta. A este grupo híbrido, perteneció el ingeniero estadounidense A. Michael Noll ${ }^{1}$, cuya experimentación estética es un paradigma de la visualización de politopos ${ }^{2}$ durante la infancia de la imagen digital. Sus Fourdimensional hyperobjects se cuentan, además, entre las primeras animaciones estereoscópicas por ordenador.

Tomemos como ejemplo la animación Rotating four-dimensional hypercube (1965): sobre un fondo negro, destacan dos vistas de la proyección de un hipercubo o teseracto. Más allá del efecto estereoscópico, la gran aportación de Noll es el hecho de poder contemplar la rotación imposible: los lados no mantienen sus relaciones tridimensionales, sino que se desplazan como lo harían en ese espacio de cuatro dimensiones.

Aunque, de acuerdo con el propio autor, ${ }^{3}$ el resultado no alcanzó las expectativas fijadas, el efecto plástico llamó la atención de artistas y animadores, que valoraron la innegable fuerza visual de la extravagancia. Tanto es así que, más adelante, Noll sustituyó el prisma geométrico por letras: el corto 4-D Hyper Movie (ca 1967) presenta la rotación de los monemas "4D”, "hyper" y "movie” en un espacio cuatridimensional. La misma técnica le sirvió para la elaboración de los créditos de la película Incredible Machine (1968) y The Unexplained (1970), especial del programa Encyclopedia Britannica, producido por la NBC (National Broadcasting Company). Gracias a experimentos visuales como los de Noll, el hipercubo consta entre las primeras animaciones sintéticas realizadas con un verdadero objetivo estético.

\footnotetext{
${ }^{1}$ NOLL, Michael. "The Beginnings of Computer Art in the United States: A Memoir". Leonardo. 1993, vol. 25, núm 1, pp. 39-44.

${ }^{2}$ Los "politopos" de la geometría de cuatro dimensiones fueron definidos en 1852 por Ludwig Schläfli (1814-1895) y equivalen a los "sólidos platónicos" o "regulares" del espacio en tres dimensiones: el tetraedro, el cubo, el octaedro, el icosaedro y el dodecaedro. SCHLÄFLI, Ludwig. Theorie der vielfachen Kontinuität (1852). Cornell University Library (1901).

3 NOLL, Michael. "Computer Animation and the Fourth Dimension". En: AFIPS Conference Proceedings. 1968, vol. 33, p. 1281.
} 

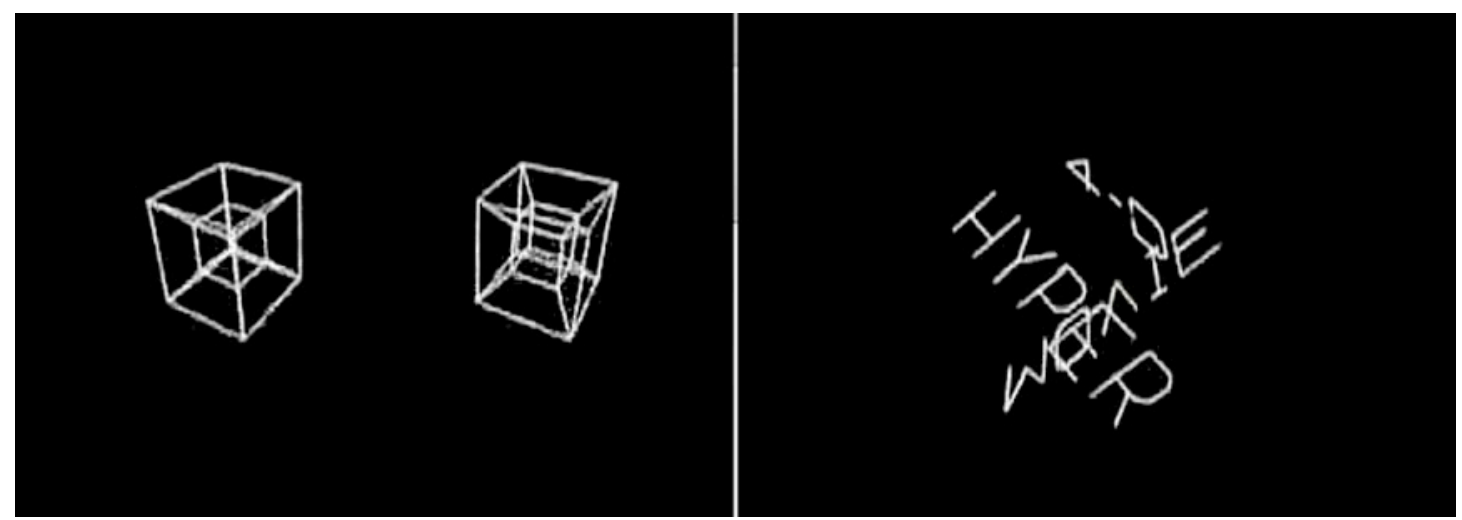

Izquierda. Rotating four-dimensional hypercube (1965). Derecha. 4-D Hyper Movie. (ca 1967), de Noll

El ingeniero devenido artista se empeñaba en demostrar las posibilidades plásticas del medio informático. Entre las piezas contemporáneas a su investigación hiperdimensional, destaca un duplicado del cuadro de Piet Mondrian (1872-1944) “Composition With Lines" (1917). “Computer Composition With Lines" (1964) formaba parte de un experimento sociológico que retaba al espectador a diferenciar entre la obra del pintor y la de la máquina. ${ }^{4}$ Más allá del hecho de que la distinción no fuera evidente, su creador abogaba por la condición artística de la pieza y la potencia "creativa" del ordenador. En realidad, a pesar del azar ${ }^{6}$ aparente, aquél no creaba la composición de la nada, sino que aplicaba un algoritmo programado con antelación por un ser humano.

Noll se percató rápido de que la imagen informática se adapta perfectamente a la composición con un componente matemático o por medio de ritmos pautados. Así, las posibilidades de las nuevas imágenes encajaban con las ramas del arte moderno que tendían a la abstracción geométrica; entre ellas, el suprematismo y el constructivismo, pero también una corriente más tardía: la imagen de síntesis apareció en pleno apogeo del op art. De modo semejante a su homenaje a Mondrian, Noll hizo un guiño a este movimiento artístico versionando la pintura de Bridget Riley "Current" (1964). ${ }^{7}$

\footnotetext{
${ }^{4}$ NOLL, A. Michael. "Human or Machine: A Subjective Comparison of Piet Mondrian's 'Composition with Lines' and a Computer-Generated Picture”. The Psychological Record. January 1966, vol. 16, núm. 1, pp. 1-10.

5 "If 'creativity' is restricted to mean the production of the unconventional or the unpredicted, then the computer should instead be portrayed as a creative medium." NOLL, A. Michael. "The Digital Computer as a Creative Medium". IEEE Spectrum. October 1967, vol. 4, núm. 10, p. 91.

${ }^{6}$ La cuestión del azar/control es clave en el computer art, como muestra la obra de Roman Verostko, Charles Csuri, John Stehura, Vera Molnar o Manfred Mohr, por citar algunos ejemplos.

7 "Many 'Op Art' are very regular and mathematical in design. The computer is very adept at constructing purely mathematical pictures and hence should be considerable value to 'Op' artists." A. Michael Noll. Apud. REICHARDT, Jasia. Op. cit., p. 159.
} 


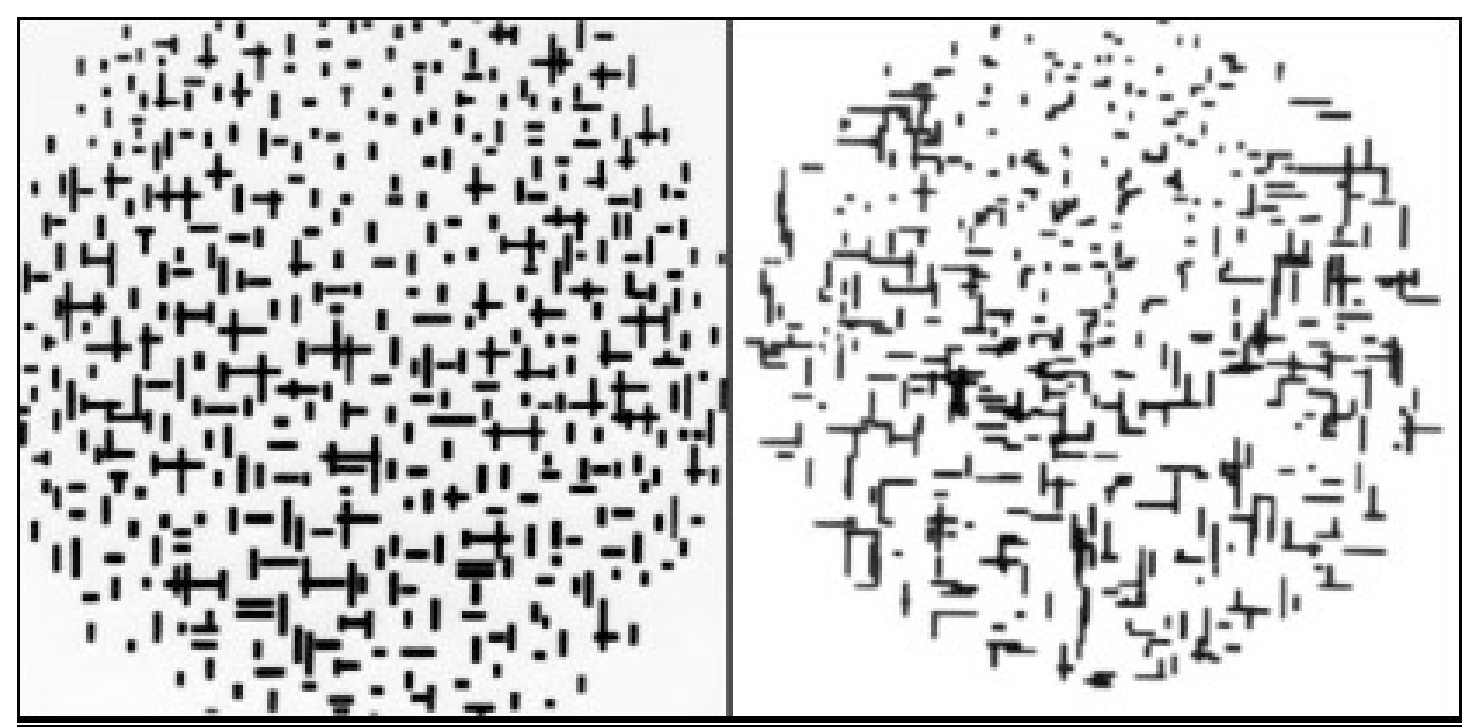

Izquierda, Mondrian: "Composition With Lines" (1917). Derecha, Noll: "Computer Composition With Lines" (1964)

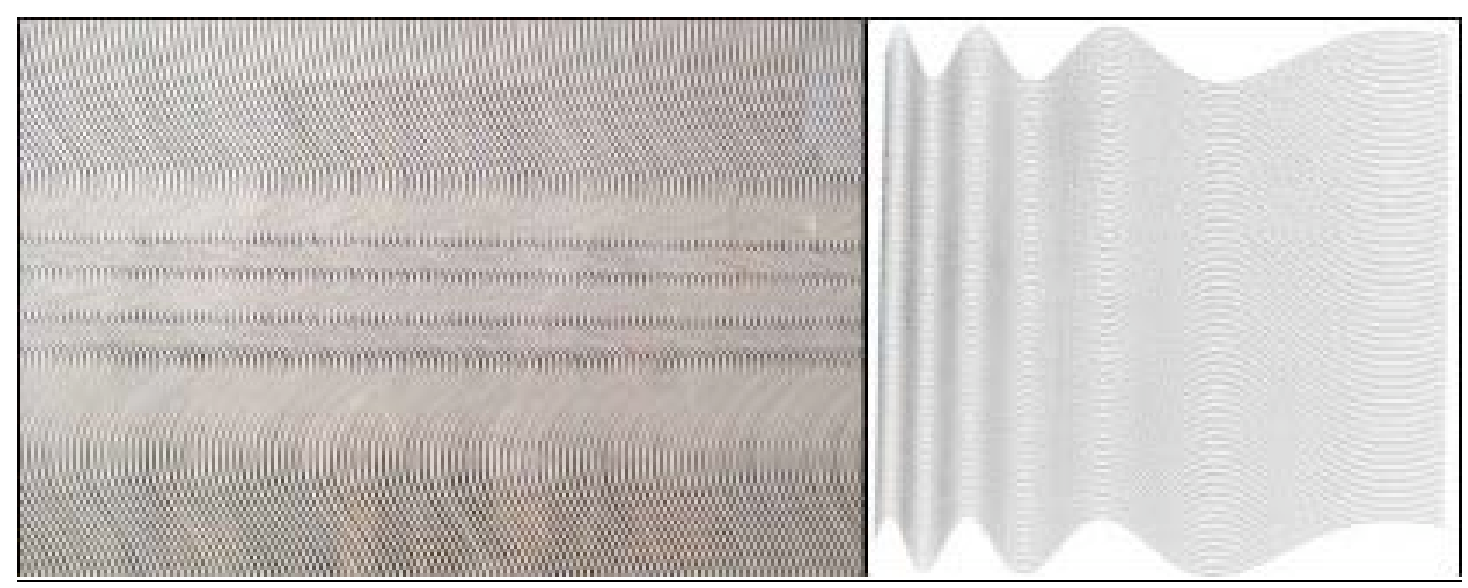

Izquierda, Riley: "Current" (1964). Derecha, Noll: "Ninety Parallel Sinusoids With Linearly Increasing Period" (1967)

En este contexto, con el imaginario de un admirador del arte moderno, el ingeniero creó su serie de objetos hiperdimensionales. Con todo, la idea de visualizar en el ordenador el hipercubo no fue suya, sino del científico Doug Eastwood, un colega de Noll en los Bell Labs. ${ }^{8}$ Lo cierto es que el tema de la cuarta dimensión, que tanto había marcado a las vanguardias históricas, fue prácticamente olvidado por los artistas de los años 50 y 60 , quedando relegado al campo matemático. ${ }^{9}$ Así, aquel interés renovado por la potencia estética de los hipersólidos parece tener que ver con las características específicas de la imagen sintética, con las nuevas posibilidades que brindaba el medio informático, y no, exclusivamente, con la recuperación de los

\footnotetext{
${ }^{8}$ NOLL, Michael. "A Computer Technique for Displaying n-Dimensional Hyperobjects". En: Communications of the ACM. August 1967, vol. 10, núm. 8, pp. 469-473.

${ }^{9}$ Con algunas excepciones como Dalí o Rice Pereira.
} 
experimentos de las vanguardias históricas. Tal y como constata el propio Michael Noll:
"Al ordenador no le afectan los problemas de la visualización humana y es capaz de tratar objetos en un espacio cuatridimensional tan fácilmente como realiza cálculos para objetos tridimensionales." ${ }^{, 10}$

\section{La proyección de hiperobjetos}

Los científicos en el terreno no tardaron en constatar que la nueva herramienta se mostraba especialmente apropiada para visualizar politopos, tanto por el lenguaje matemático que sustenta las composiciones como por la simplificación considerable que ofrece el cálculo informático. Es más, la posibilidad de rotar el objeto permite contemplar el comportamiento del mismo en un espacio hiperdimensional.

Tras los pioneros del computer art, otros científicos y artistas han acudido y acuden a la informática para construir objetos hiperdimensionales. Entre ellos, ya en los años 70, Thomas Banchoff y Charles Strauss añadieron la interactividad a la visualización de politopos. Ambos son autores del vídeo The Hypercube: Projections and Slicing (1978), que explica los dos grandes modelos de espacios hiperdimensionales: el slicing model, que veíamos ya en el apartado anterior, y el modelo proyectivo, que explicamos a continuación.

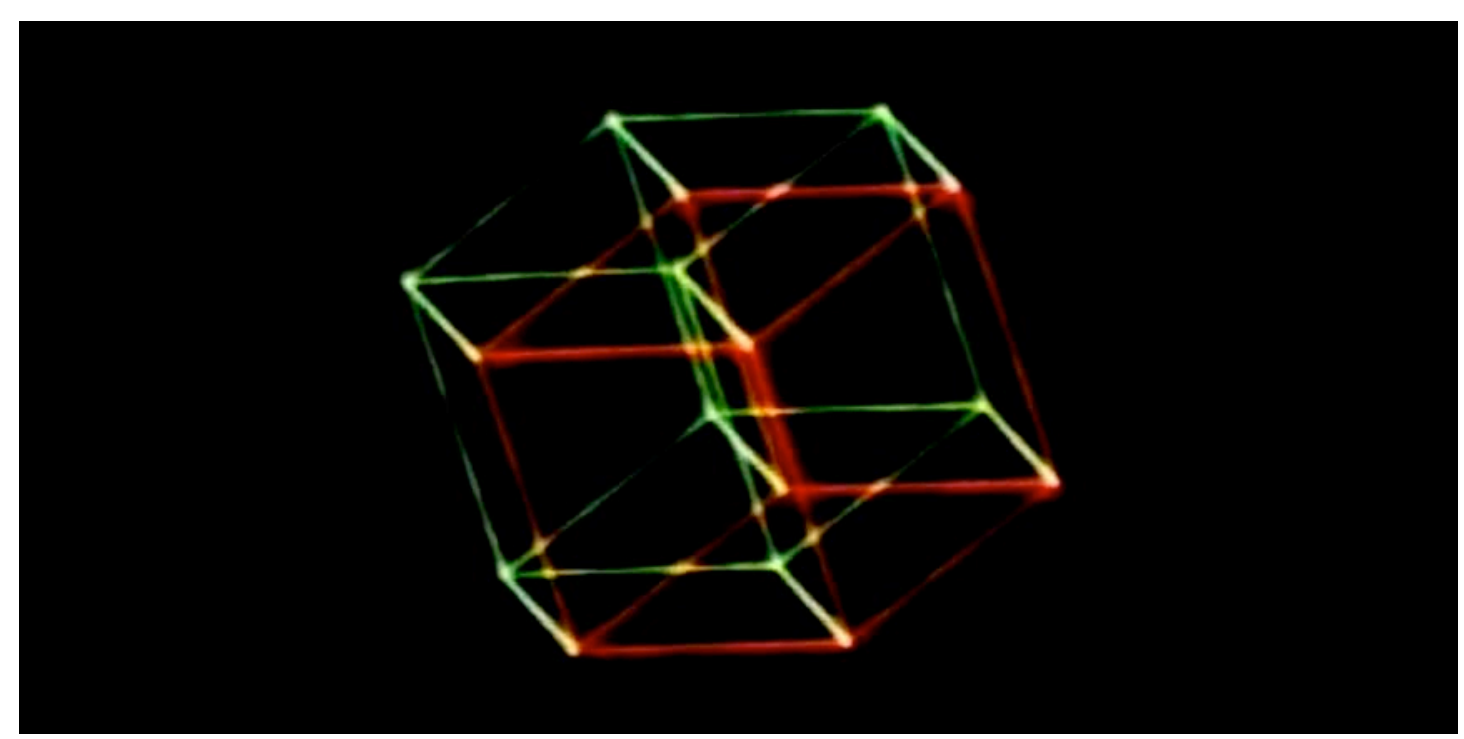

The Hypercube: Projections and Slicing (1978), de Thomas Banchoff y Charles Strauss

\footnotetext{
${ }^{10}$ NOLL, A. Michael. “Computer Animation and the Fourth Dimension”. Op. cit., p. 1279.
} 
Como se habrá constatado ya, las animaciones de Noll poco tienen que ver con los “cristales de tiempo" de Waliczky; de hecho, responden a una metáfora distinta de la cuarta dimensión. Ya hemos visto que las esculturas del artista húngaro parten de la concepción del tiempo como dimensión espacial y recuperan la iconografía de la novela Flatland: A Romance of Many Dimensions, quedando así inscritas dentro del slicing model. Sin embargo, frente a esta metáfora del corte trasversal, otro símil ha potenciado el desarrollo de las geometrías hiperdimensionales más allá de la identificación de la cuarta dimensión con el tiempo: el modelo proyectivo o shadow model concibe las tres dimensiones como una "sombra" o proyección de un espacio hiperdimensional. Partiendo de la geometría proyectiva, que permite crear la ilusión de profundidad en el plano bidimensional, se procede de modo equivalente, abatiendo un espacio cuatridimensional en un área tridimensional ${ }^{11}$.

Aunque ambos modelos son consistentes desde un punto de vista científico, el Flatland model es el más popular, tal vez, por su mayor simplicidad. Sin embargo, tal y como explica el artista estadounidense Tony Robbin, defensor a ultranza del modelo proyectivo, es éste el que ha revolucionado el pensamiento científico. ${ }^{12}$

A finales del siglo XIX, la visualización de las teorías matemáticas sobre el hiperespacio se concentró en la proyección tridimensional de politopos o hiperobjetos. Estas construcciones geométricas tomaban distintas formas, pero partían, casi siempre, de la proyección de los lados y vértices del prisma en una multiplicación volumétrica del mismo. En realidad, no se trataba tanto de construir un espacio de cuatro o más dimensiones como de imaginar qué forma presentaría un objeto perteneciente a tal mundo en el espacio pseudo-tridimensional de una imagen bidimensional.

Entre todos los científicos que volcaron su imaginación en la visualización de politopos, destacamos el matemático estadounidense Washington Irving Stringham (1847-1909). Ya en 1880, ilustró su artículo Regular Figures in n-Dimensional

\footnotetext{
11 "Three-dimensional viewing is the task of projecting the three-dimensional scene onto a twodimensional rectangle. In the same manner, four-dimensional viewing is the process of projecting a 4D scene onto a 3D region, which can then be viewed with regular 3D rendering methods." HOLLASCH, Steven Richard. Four-Space Visualization of 4D Objects [En línea]. Arizona State University, 1991. Disponible en Web: $<$ http://steve.hollasch.net/thesis/chapter3.html\#s3.2>

12 "Projected figures are whole, sliced figures are not, and more and more the disconnected quality of the Flatland spatial model presents problems. Even time cannot be so simply described as a series of slices." ROBBIN, Tony. Op. cit. pp. IX-X.
} 
Space $^{13}$ con una serie de dibujos realizados por él mismo y que marcaron la pauta de las visualizaciones sucesivas; entre ellas, las de Noll o las de Banchoff y Strauss.

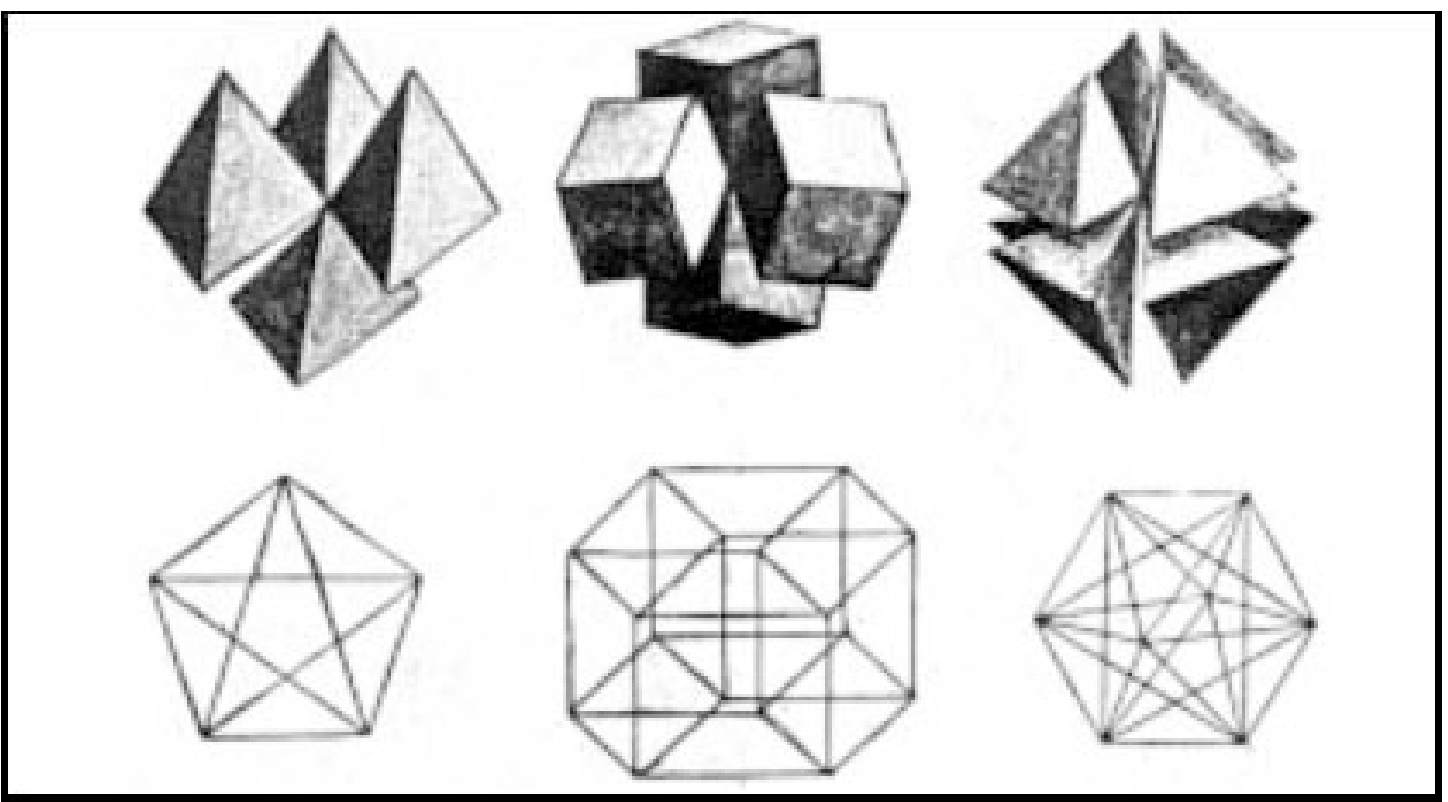

W. I. Stringham (1880). Arriba: visualización tridimensional de un hipertetraedro, un hipercubo y un hipericosaedro. Abajo: proyecciones de los mismos tres politopos en el plano bidimensional

Los informáticos no fueron los primeros en destacar la belleza de estas figuras geométricas; los artistas reaccionaron inmediatamente a la revolución filosóficomatemática que tuvo lugar a finales del siglo XIX. En The Fourth Dimension and Non-Euclidean Geometry in Modern Art $(1983)^{14}$, la historiadora del arte Linda Dalrymple Henderson profundiza en la relación entre el arte moderno y aquellas teorías. La autora redescubre los dibujos de Stringham (hasta entonces, caídos en el olvido) y establece un vínculo directo entre las ilustraciones del matemático y el cubismo analítico. Siguiendo esta misma línea argumentativa, compara el cuadro de Pablo Picasso "Ambroise Vollard" $(1910)^{15}$ con una proyección dibujada unos años antes por Esprit Jouffret en su Traité élémentaire de géométrie à quatre dimensions $(1903)^{16}$.

\footnotetext{
${ }^{13}$ STRINGHAM, W. I.. "Regular Figures in n-Dimensional Space". American Journal of Mathematics. March 1880, vol. 3, núm 1.

${ }^{14}$ HENDERSON, Linda Dalrymple. The Fourth Dimension and Non-Euclidean Geometry in Modern Art. Princeton: Princeton University Press, 1983.

${ }^{15}$ Tony Robbin recupera la comparación aunque matiza que el cuadro de Picasso que verdaderamente muestra el conocimiento por parte del pintor malagueño de la obra de Jouffret es otro retrato del mismo año: "Daniel-Henry Kahnweiler" (1910). ROBBIN, Tony. Op. cit., pp. 29-33.

16 JOUFFRET, Esprit. Traité élémentaire de géométrie à quatre dimensions (1903). Paris: GauthierVillars, 2003.
} 


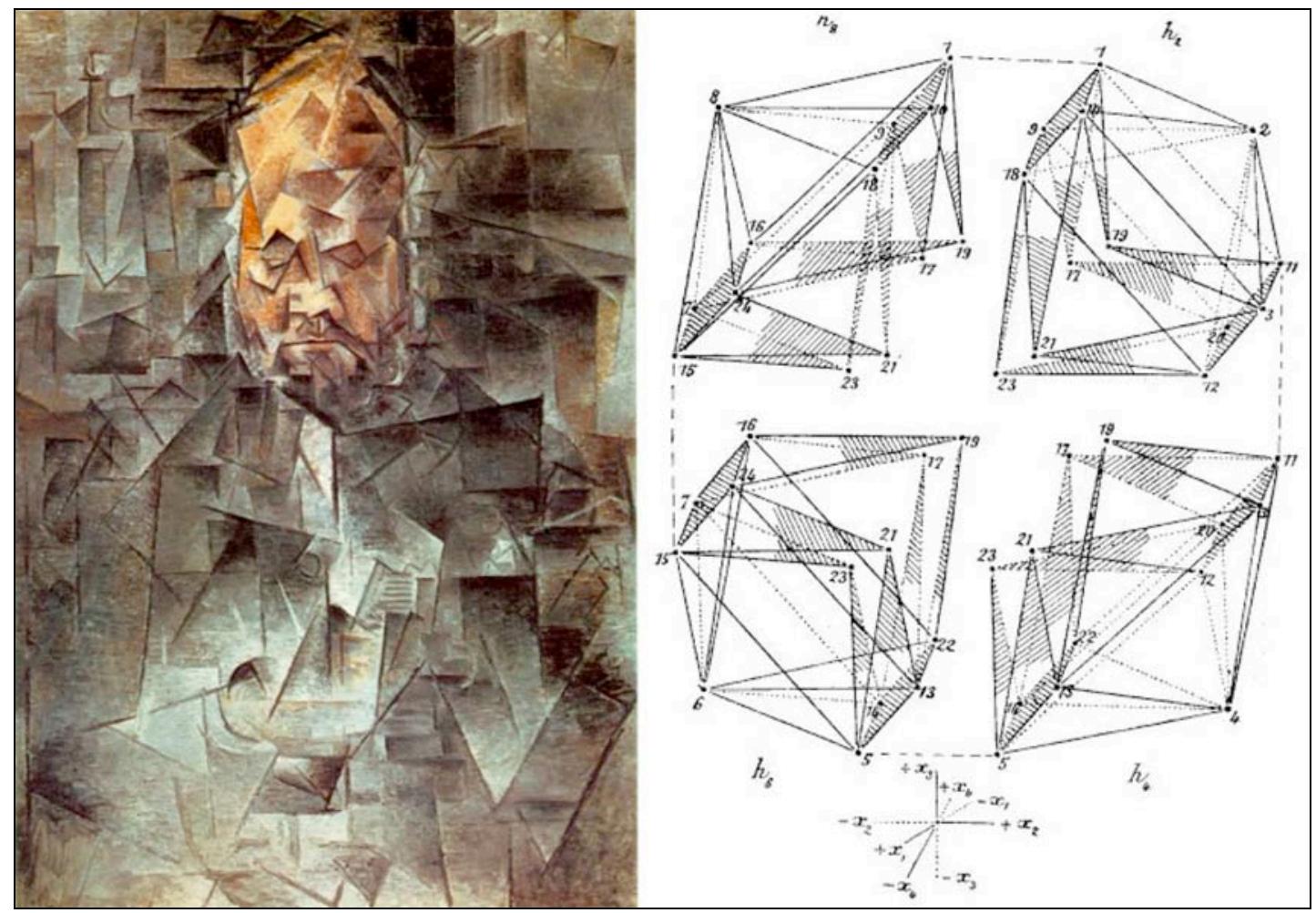

Izquierda, Pablo Picasso: "Ambroise Vollard" (1910)

Derecha, Esprit Jouffret: "Perspective cavalière des seize octaèdres fondamentaux" (1903)

Más allá de la revolución cubista, la cuarta dimensión explica numerosos experimentos figurativos del futurismo, el surrealismo o el dadaísmo, y subyace tras la abstracción geométrica de autores como Mondrian. Sea como reflejo de una espiritualidad del artista o de la búsqueda incesante de nuevos lenguajes plásticos, el hiperespacio se halla detrás de las más innovadoras propuestas del arte de las vanguardias. Con todo, el rigor de Picasso o Marcel Duchamp ${ }^{17}$ no es generalizable: en realidad, la gran mayoría tomó prestado un concepto laxo de la cuarta dimensión, inspirándose libremente en las visualizaciones descritas y mezclando sin complejo las distintas teorías de espacios multidimensionales ${ }^{18}$ con las geometrías no-euclidianas.

\footnotetext{
${ }^{17}$ En el apartado anterior, asociábamos $\mathrm{Nu}$ descendant un escalier $n^{\circ} 2$ (1912) con el slicing model, en cuanto el movimiento y el tiempo son clave en el análisis de la obra. Sin embargo, en La mariée mise à nu par ses célibataires, même o Le grand verre (1915-1923), el modelo de referencia para el estudio de la cuarta dimensión es la proyección: "Simply, I thought of the idea of a projection, of an invisible fourth dimension, something you couldn't see with your eyes. (...) any three-dimensional object, which we see dispassionately, is a projection of something four-dimensional." Marcel Duchamp. Apud. CABANNE, Pierre. Dialogues with Marcel Duchamp (1971). New York: Da Capo Press, 1987, p. 40.

${ }^{18}$ Entre las lecturas más populares, se contaban la obra del francés Henri Poincaré (1854-1912) y del inglés Charles Howard Hinton (1853-1907).

POINCARÉ, Henri. La science et l'hypothèse (1902). Paris: Flammarion, 2000.

HINTON, Charles H..The Fourth Dimension (1904). Kila, MT: Kessinger Publishing, 1997.
} 
Aunque no tan populares como la teoría de la cuarta dimensión, aquéllas "allanaron el camino para la aceptación de espacios alternativos", ; entre ellos, los hiperdimensionales. Dicho de otro modo, para la mayor parte de los artistas de principios del siglo XX, el verdadero hallazgo fue la liberación del arte con respecto a las férreas normas del espacio en perspectiva. Sin esta toma de conciencia, sería difícil imaginar las prácticas digitales que veremos a continuación.

Aunque, la imagen sintética se adapta perfectamente a la visualización de politopos, buena parte de la construcción de hiperespacios en la imagen digital tiene más que ver con esa revolución estética de principios del siglo $\mathrm{XX}$, que con un cálculo meticuloso. Si bien son frecuentes las referencias a los dos modelos (slicing model y proyectivo), a menudo, la figuración de espacios hiperdimensionales corresponde, más bien, a un espacio no-euclidiano que exhibe la potencia plástica de la imagen digital.

Con la excepción de las visualizaciones científicas citadas, hallamos un uso casi fetichista de los politopos. Las bellas formas geométricas aparecen como emblemas del ciberespacio, como una suerte de homenaje a los primeros pasos del computer art. Tomemos como ejemplo el videoclip de Black Eyed Peas Boom, Boom, Pow (2009), dirigido por Mathew Cullen y Mark Kudsi. Tal y como reza la letra de la canción, los miembros del grupo se sitúan en un futuro lejano (el año 3008), en el cual el mundo ha sido totalmente digitalizado. Dejando a un lado el mensaje pacifista, todo el imaginario del vídeo remite a ese espacio dentro del ordenador: las composiciones con código informático (“ASCII art”), la pantalla plana táctil de un HP Touch Smart, los wireframes como referencia a la imagen sintética tridimensional, etc. ${ }^{20}$

La metamorfosis digital parte de unos capullos, de los que nacen los miembros de la banda musical y que recuerdan las figuras hiperdimensionales descritas. Basta con compararlos a los dibujos del matemático alemán Victor Schlegel (1843-1905), quien, siguiendo con la técnica de Stringham, profundizó sistemáticamente en la proyección de politopos. $^{21}$

\footnotetext{
${ }^{19}$ HENDERSON, Linda Dalrymple. Op. cit., p. 205.

${ }^{20}$ El mismo motivo protagoniza la portada del disco y remite al videoclip Musique Non Stop (1986), dirigido por la artista Rebecca Allen para el grupo Kraftwerk.

${ }^{21}$ SCHLEGEL, Victor. "Quelques théorèmes de géométrie à $n$ dimensions". Bulletin de la Société Mathématique de France. 1882, Tome 10, pp. 172-207. Disponible en Web :

$<$ http://www.numdam.org/item?id=BSMF_1882_10_172_1>
} 

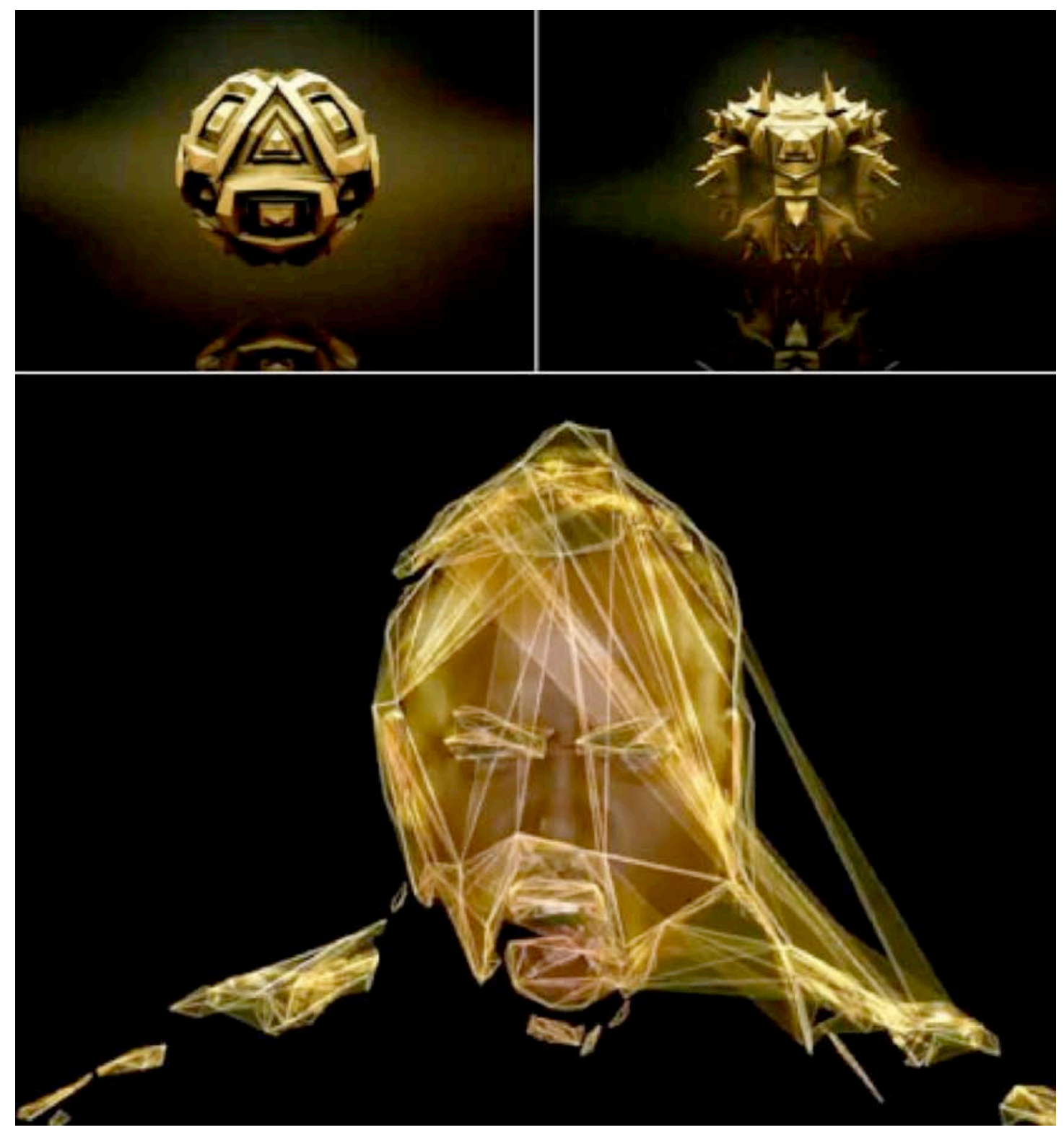

Boom, Boom, Pow (2009), de Mathew Cullen y Mark Kudsi para Black Eyed Peas

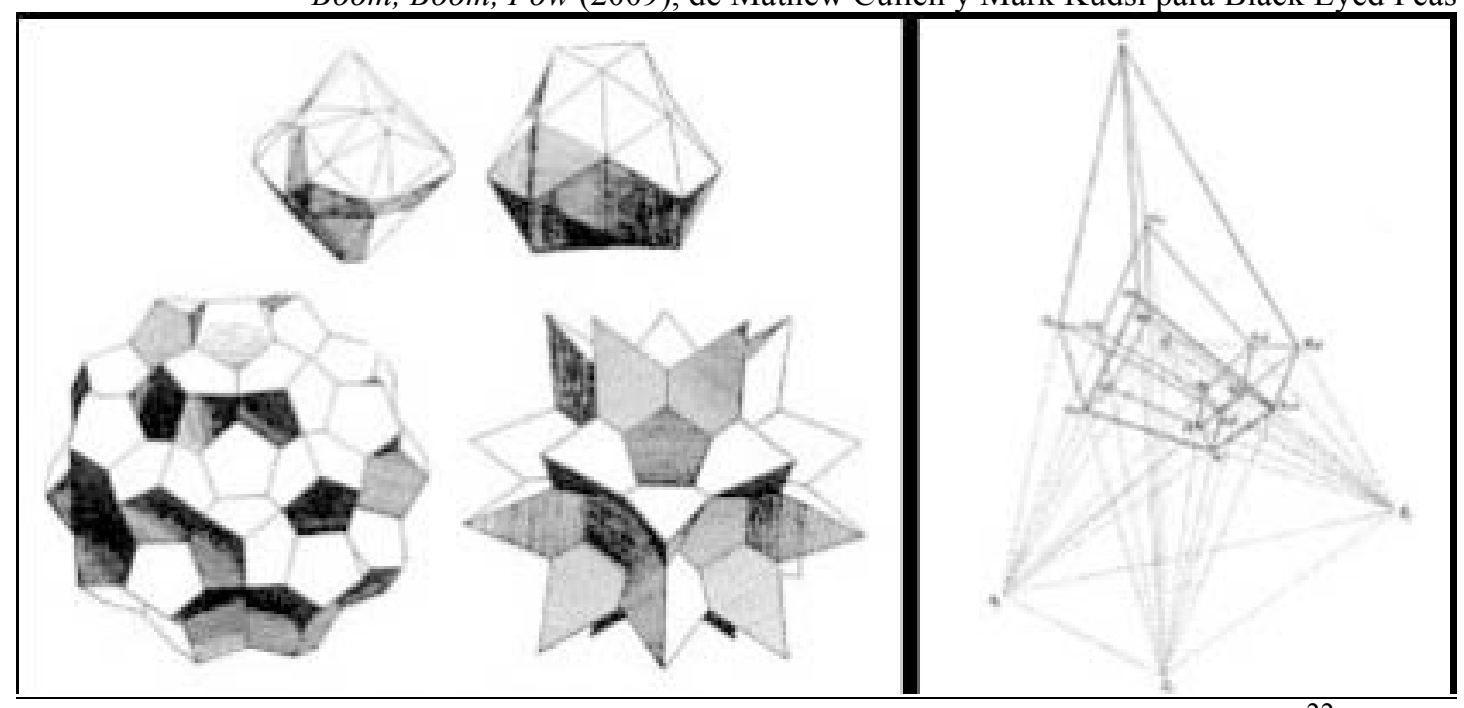

Schlegel. Izquierda, Proyecciones de politopos. Derecha, Proyección de un hipercubo $(1882)^{22}$

${ }^{22}$ Ilustraciones recuperadas por Tony Robbin. ROBBIN, Tony. Op. cit., p. 13. 
En varias ocasiones, los rostros de los cantantes son sometidos a una esquematización geométrica, símbolo de la inmaterialidad del ciberespacio. Aunque más sutil que la referencia a los hipersólidos, la superposición de unos rayos luminosos sobre la fisonomía de los músicos remite a las líneas proyectivas que permiten abatir la figura cuatridimensional en el plano bidimensional. De hecho, no sería descabellado comparar el resultado con el retrato de Ambroise Vollard de Picasso, que reproducíamos arriba.

Este uso puramente estético de los hiperobjetos aparece, también, en una de las películas más asociadas a la inmersión en el ciberespacio: Tron (1982), de Steven Lisberger. El personaje llamado "Bit" toma diversas formas geométricas, pasando de una a otra mediante un morphing. No por casualidad, las figuras así constituidas se asemejan a los bellos constructos hiperdimensionales.

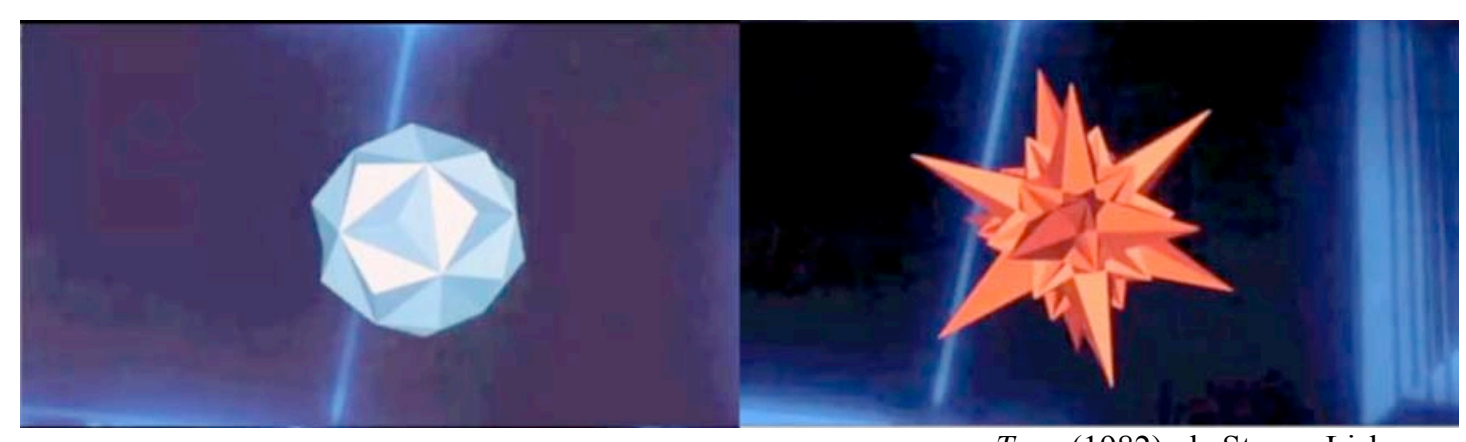

Tron (1982), de Steven Lisberger

Mientras el videoclip de Cullen y Kudsi se sitúa directamente en el "mundo digital", Tron se regodea en la transición al ciberespacio y la figuración de ese entre dos mundos. Así, más allá de la referencia a los hipersólidos, las imágenes descritas a continuación no se limitan a la construcción de figuras de cuatro dimensiones, sino que corresponden al intento de dar forma a todo un espacio hiperdimensional.

\section{La visualización del puente}

A la hora de dar forma al viaje interdimensional, Lisberger acude a una serie de entornos plásticos que recorre la cámara virtual. Nuevamente, la profundidad cinética permite dar forma a un espacio no-euclidiano, en esta ocasión, de más de tres dimensiones. Veamos con detenimiento el zoom in de Tron: el láser que escanea al personaje se multiplica en un haz de rayos que fugan en el centro de la imagen; a 
continuación, la cámara virtual se desplaza a través de un caleidoscopio geométrico de colores psicodélicos; finalmente, atraviesa una red de triángulos semejante a las construcciones sintéticas en wireframe.
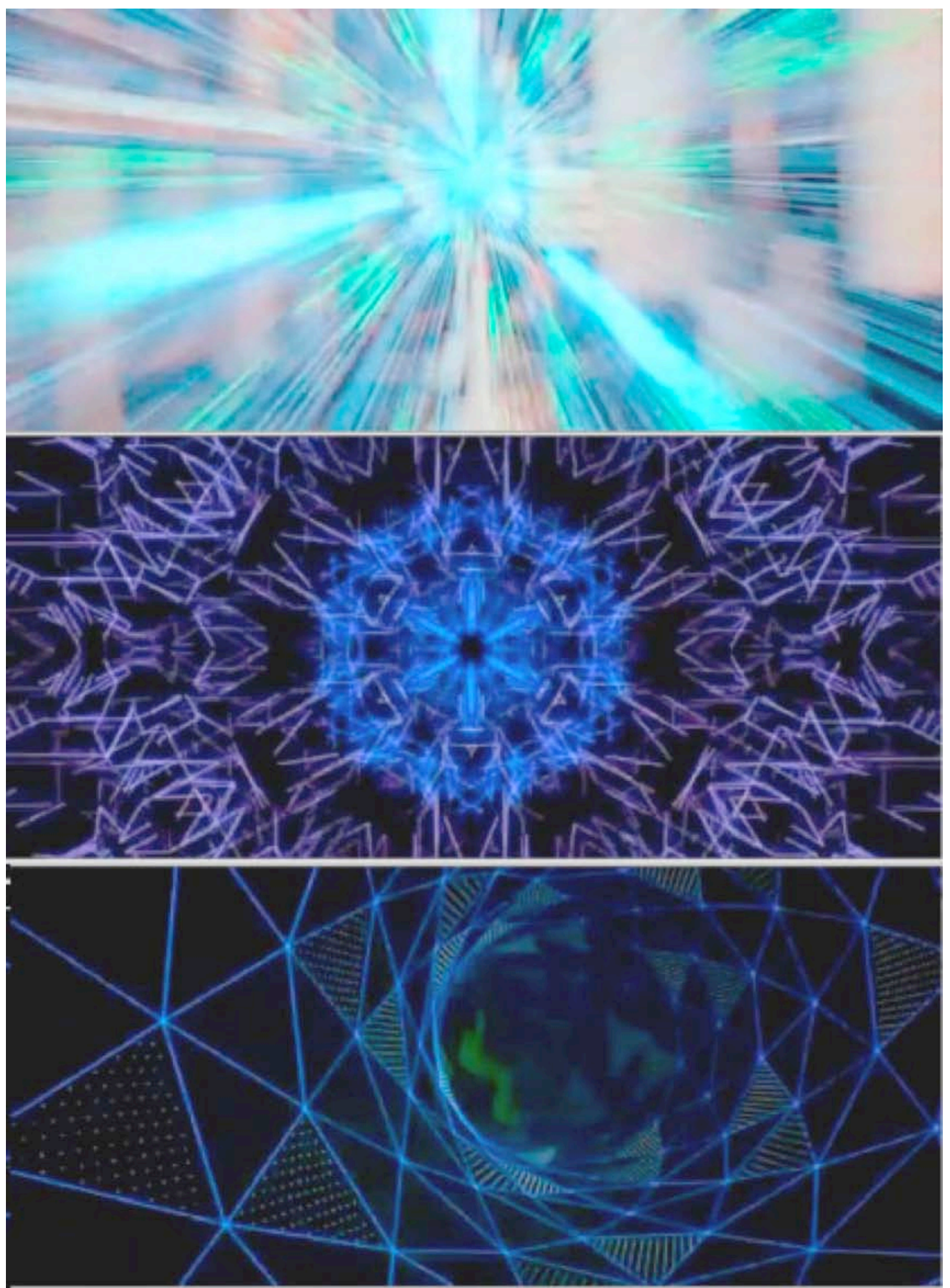

Tron (1982), de Steven Lisberger 
Esta última imagen remite a los créditos de otra película de Walt Disney, tres años anterior: The Black Hole (1979), dirigida por Gary Nelson. La secuencia corresponde a la visualización más popular del agujero negro. En el caso de Tron, la cámara virtual atraviesa, más bien, un "agujero de gusano". Sin querer entrar en complejas explicaciones científicas, que sobrepasan por completo nuestro objeto, a la hora de visualizarlos, la diferencia entre ambos radica en que el primero no tendría salida, mientras que el segundo permitiría, hipotéticamente, viajar a través de él. ${ }^{23}$

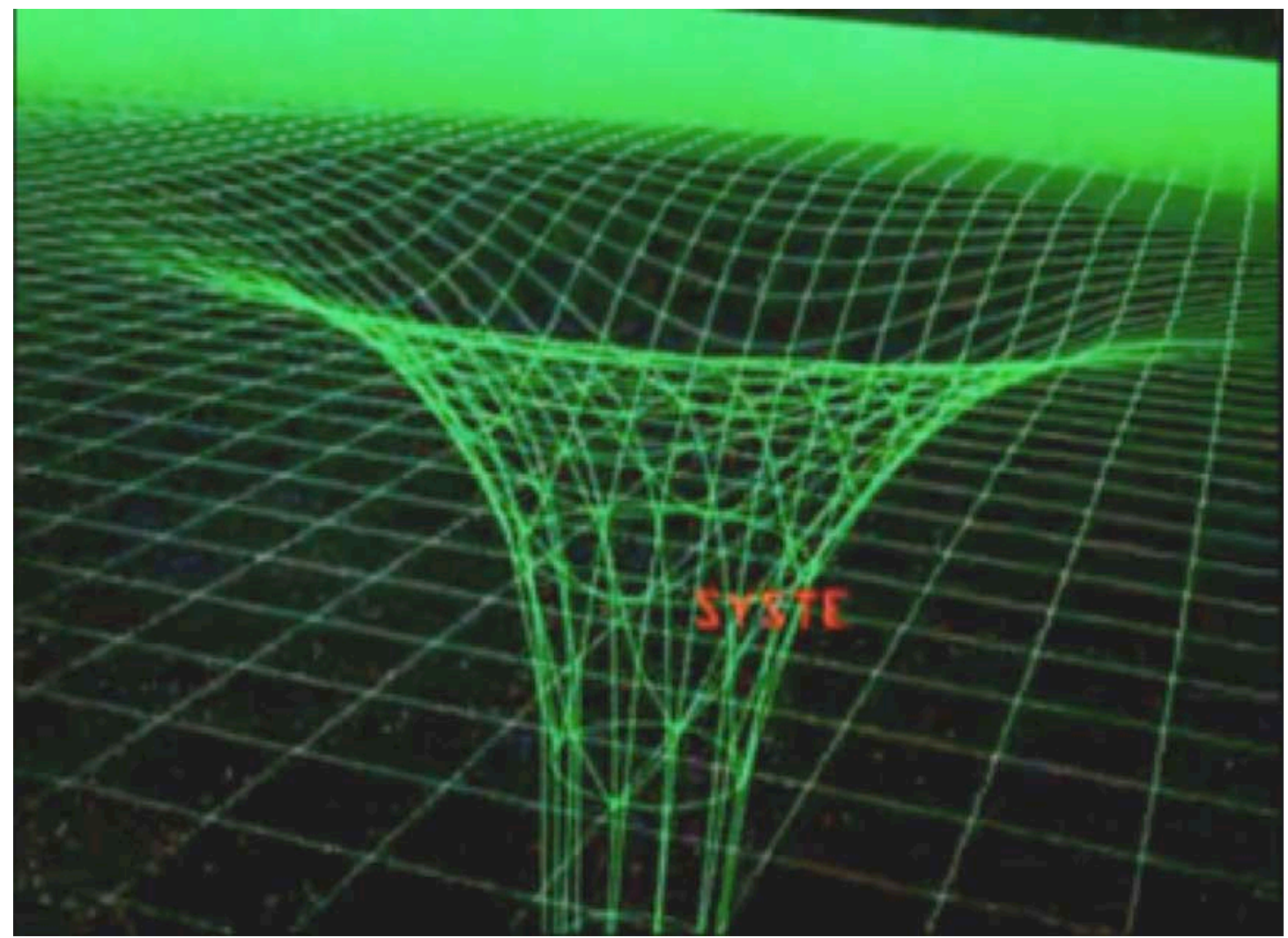

The Black Hole (1979), de Gary Nelson

El agujero de gusano o "Einstein-Rosen bridge" ${ }^{24}$ suele tomar la forma de un doble agujero negro, una especie de embudo con dos salidas a sendas superficies bidimensionales. En la imagen digital, el paso a través de dicho tubo se construye, casi siempre, mediante un zoom in. En Tron, el conducto se presenta como un wireframe, sinécdoque de la imagen sintética y ésta, a su vez, metáfora del ciberespacio. No obstante, con frecuencia, la estructura geométrica descrita se recubre

\footnotetext{
${ }^{23}$ Los términos "wormhole" ("agujero de gusano") y "black hole" ("agujero negro") fueron acuñados por el físico John Archibald Wheeler (1911-2008). WHEELER, J. A.. "On the nature of quantum geometrodynamics". Annals of Physics. New York, 1957, vol. 2, pp. 604-614.

${ }^{24}$ Según los nombres de Albert Einstein (1879-1955) y Nathan Rosen (1909-1995), autores del artículo: EINSTEIN, A.; ROSEN, N.. "The Particle Problem in the General Theory of Relativity". Physical Review. 1935, vol. 48, pp. 73-76.
} 
de una textura. Éste el caso de Naqoyqatsi (2002), de Godfrey Reggio. En ella, el puente se reviste de unos y $\operatorname{ceros}^{25}$, que dan paso a un cielo nublado. Aquí, el símbolo del ciberespacio es el lenguaje informático como "mar de datos". ${ }^{26}$
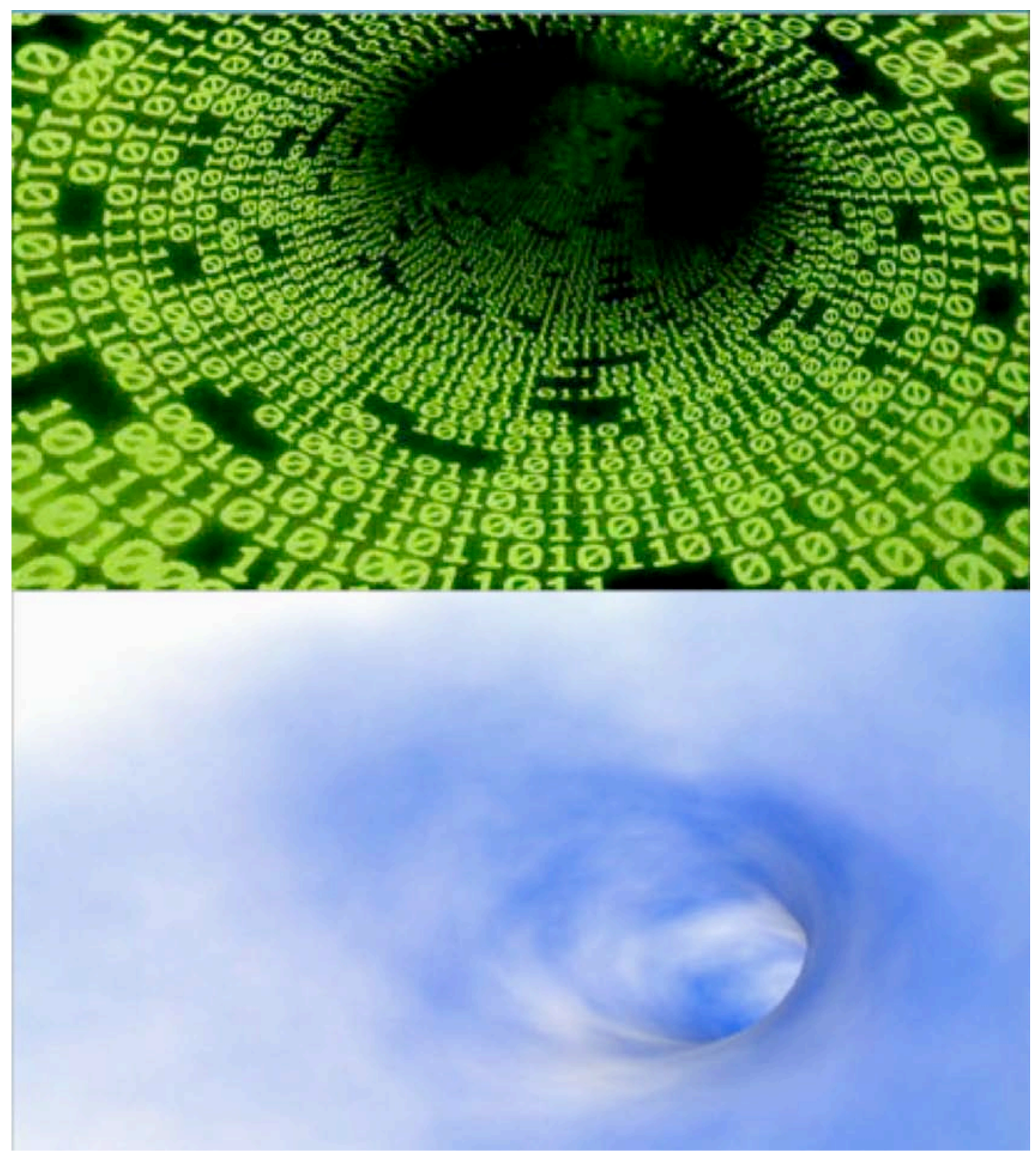

Naqoyqatsi (2002), de Godfrey Reggio

${ }^{25}$ El término "ciberespacio" apareció por primera vez en 1984 en la novela de ciencia ficción de William Gibson Neuromancer. Aquella descripción ha marcado las visualizaciones sucesivas: "Cyberspace. A consensual hallucination experienced daily by billions of legitimate operators, in every nation, by children being taught mathematical concepts... A graphical representation of data abstracted from the banks of every computer in the human system. Unthinkable complexity. Lines of light ranged in the non-space of the mind, clusters and constellations of data. Like city lights, receding..." GIBSON, William. Neuromancer. New York: Ace Books, 1984, p. 51.

${ }^{26}$ Sobre la metáfora líquida en relación al concepto de "ciberespacio", ver: MEZZETTI, Carlo; UNALI, Maurizio. "Rappresentazioni liquide nel ciberspazio. Verso una storiografia degli spazi fluidi della rete”. En: Acqua\&Architettura. Rappresentazioni. Roma: Edizioni Kappa, 2011, pp. 90-113. 
Otro aspecto en la secuencia de Naqoyqatsi subraya la figura del zoom in como penetración espacial y metáfora de un espacio hiperdimensional: Reggio combina los agujeros de gusano con la imagen de un fractal. Veíamos en el capítulo anterior que, de acuerdo con Benoît Mandelbrot, bajo este concepto se agrupan multitud de formas, cuya principal característica es la autosimilaridad o la repetición al infinito de su estructura. De ahí, la importancia del zoom: el cambio de escala permite constatar que la composición de cada parte es igual a la del todo.

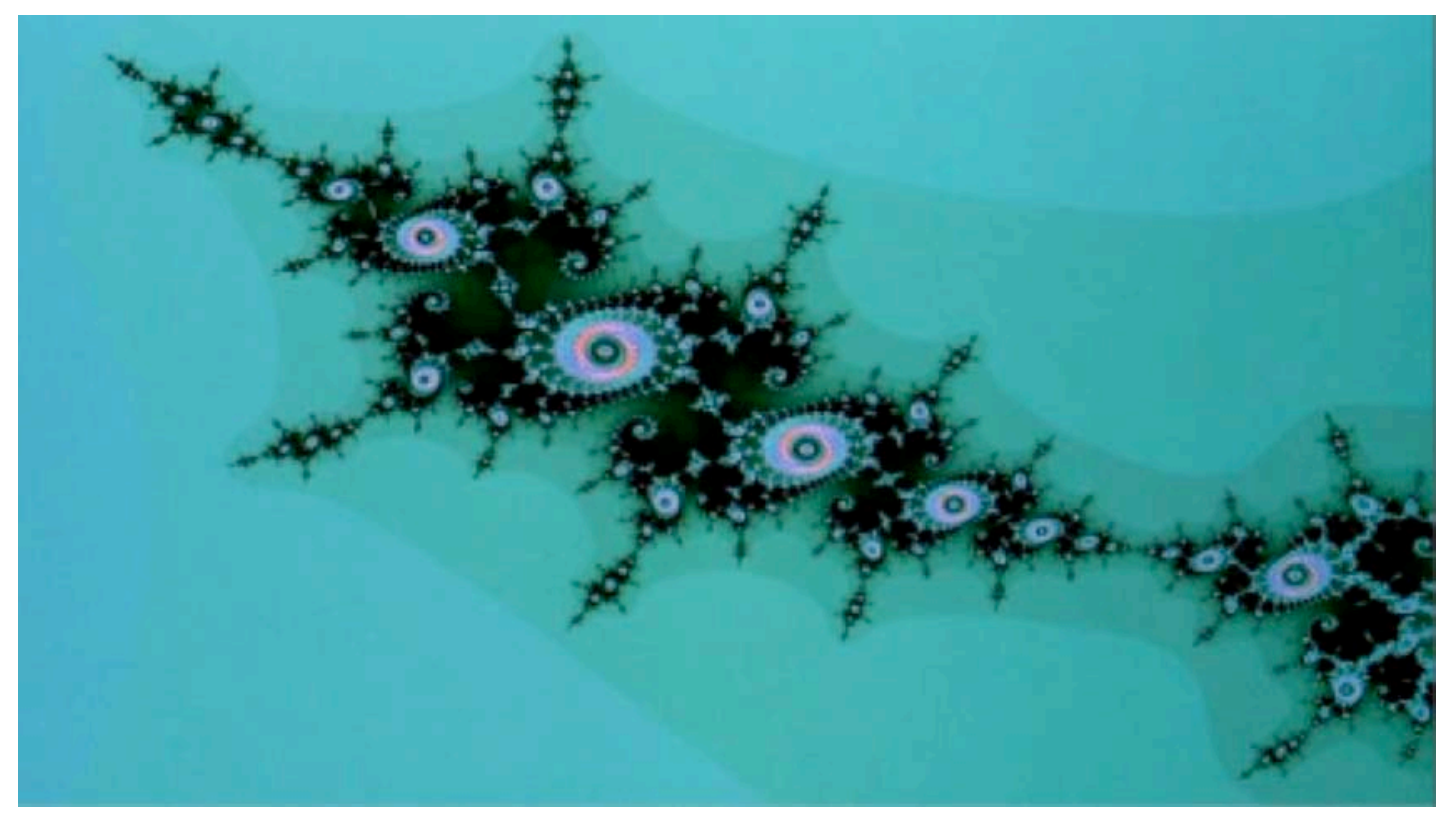

Naqoyqatsi (2002), de Godfrey Reggio

La elección del fractal tiene que ver con su innegable potencia visual. La escena referida en Tron comparte esta combinación de una bella textura geométrica con la figuración del agujero de gusano. En esta ocasión, Lisberger acude, precisamente, a las figuras cuatridimensionales. Como explicábamos más arriba, la inspiración artística en estas construcciones geométricas se remonta a principios del siglo XX. De hecho, ya en 1915, el arquitecto e ilustrador estadounidense Claude Fayette Bragdon (1866-1946) animaba a los diseñadores a tomar ejemplo de la geometría hiperdimensional ${ }^{27}$. En su búsqueda de un lenguaje plástico moderno, acudió, entre otros, al artículo de Stringham Regular Figures in n-Dimensional Space (1880) o al libro de Hinton The Fourth Dimension (1904).

\footnotetext{
27 "The decorative motifs of a new aesthetic may appropriately be sought in four-dimensional geometry." BRAGDON, Claude F.. Projective Ornament (1915). Kessinger Publishing, 1998, p. 12.
} 
Los diseños de Bragdon ayudan a desenredar la hermosa maraña en Tron. No obstante, mientras las piezas decorativas se despojan de sus referencias matemáticofilosóficas, la imagen digital dota de contenido al juego formal: la geometría hiperdimensional no sólo crea formas visualmente atractivas, sino que éstas figuran, precisamente, el viaje a través del agujero de gusano; es más, la animación de la secuencia aporta otra dimensión mediante la combinación de metamorfosis y zoom in en pro de la dilatación espacial.
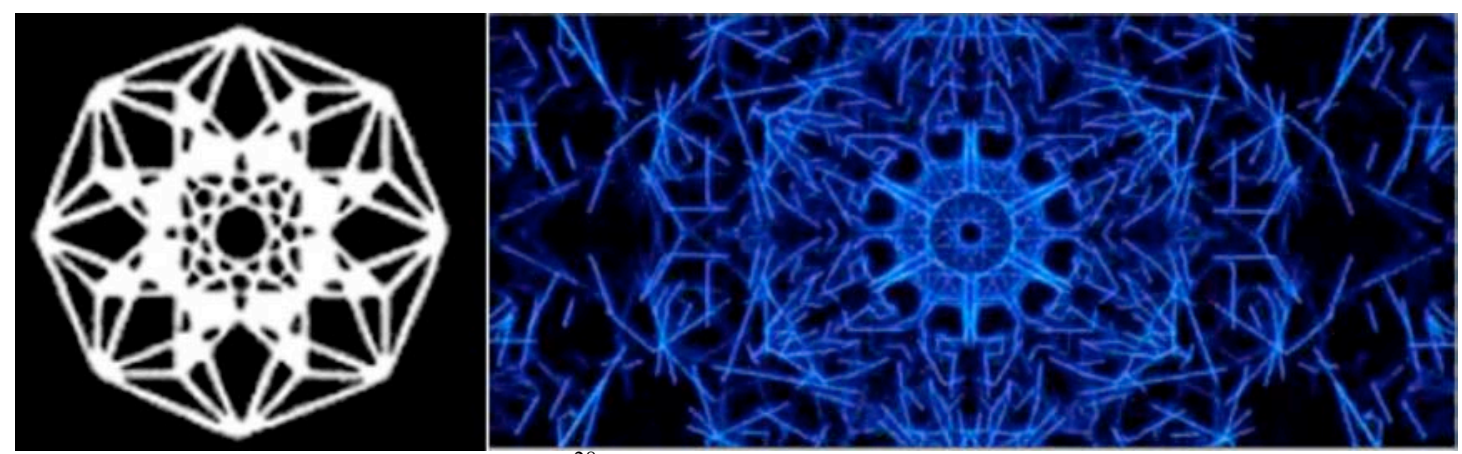

Izquierda: "Icositetrahedroid"28 (1915) de C. F. Bragdon. Derecha: Tron (1982), de Lisberger

Saúl Bass compuso los títulos de crédito de la película de Alfred Hitchcock Vertigo (1958) a partir de las animaciones creadas por John Whitney Senior (19171993), combinándolas con el metraje cinematográfico en una composición cercana al collage. Las bellas figuras geométricas encajan a la perfección con la temática de la cinta. Con todo, de manera aislada, las piezas creadas por Whitney con un ordenador analógico "M7" están más cerca de la animación abstracta y de la "música visual"29 que de la figuración de acuerdo con la trama narrativa. Si bien comparte la constante gráfica de la línea curva con los “Oscillons" ${ }^{\circledR 30}$ de Ben F. Laposky (1914-2000), la figura de la espiral remite, inevitablemente, a Anémic Cinéma (1926) de Marcel Duchamp.

El cine de las vanguardias históricas retoma las cuestiones de la pintura moderna relativas al cuadro rectangular. Ahora bien, si la imagen fija se concentra en subrayar la bidimensionalidad del lienzo frente a la simulación de la

\footnotetext{
${ }^{28}$ El icositetrahedroid es el análogo cuatridimensional del icositetrahedro.

${ }^{29}$ El oxímoron "música visual" describe la obra de artistas que exploran la traducción del lenguaje sonoro a la composición visual. Como veremos en el último apartado, tal experimentación se remonta, al menos, a los "órganos de colores" de Louis Bertrand Castel (1688-1757) y continúa, tras el descubrimiento del cinematógrafo, con la animación abstracta de las vanguardias.

${ }^{30}$ Los "Oscillions" deben su nombre al osciloscopio de rayos catódicos, del cual se sirvió Laposky.

LAPOSKY, Ben F.. “Oscillons: Electronic Abstractions”. Leonardo. 1969, vol. 2, núm. 4, pp. 345-354.
} 
tridimensionalidad, la imagen animada (portadora de la dimensión del movimiento) subraya la tensión entre ambas. Así, la animación abstracta se regodea en el juego óptico y construye espacios que se dilatan y contraen. En este sentido, la imagen en blanco y negro de Anémic Cinéma pone al límite la dicotomía figura/fondo en aras de un espacio continuo, sumido a diversas transformaciones.

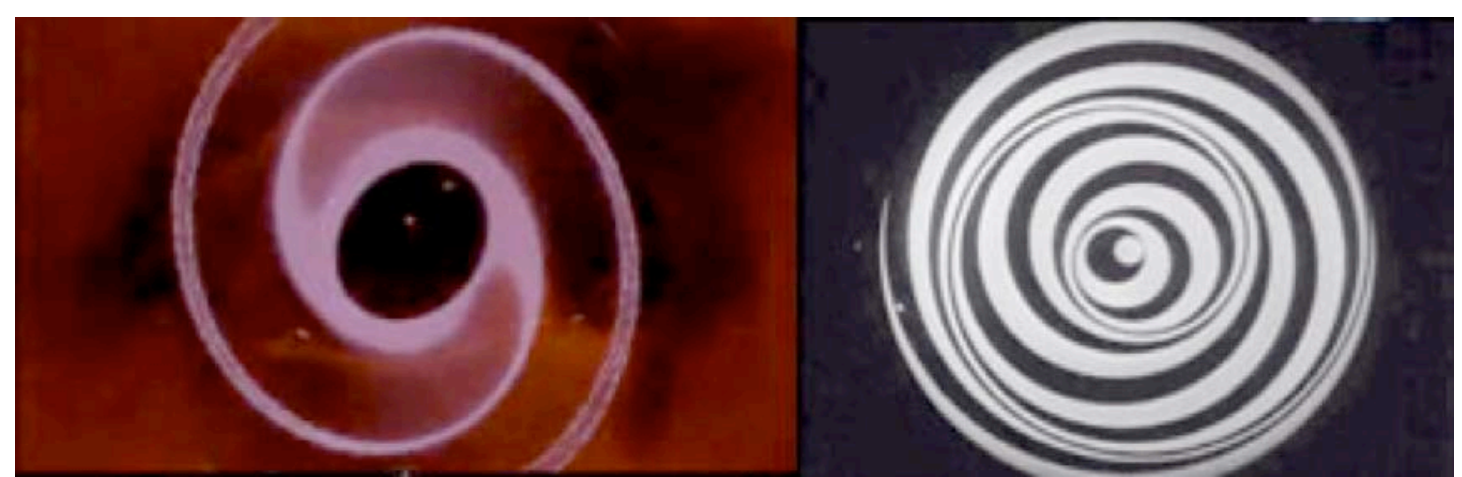

Izquierda, Vertigo (1958), de Alfred Hitchcock. Derecha, Anémic Cinéma (1926), de Marcel Duchamp

La espiral subraya el interés de Duchamp por la cuarta dimensión. ${ }^{31}$ En realidad, la asociación de esta forma curva con el hiperespacio se remonta a la antigüedad y se vincula al componente mágico del arte primitivo. ${ }^{32}$ De manera semejante, más allá del aspecto psicológico, las imágenes de Vertigo remiten al encuentro sobrenatural; ese “de entre los muertos", presente ya en el título de la novela que inspiró a Hitchcock: Sueurs froides : d'entre les morts (1954), de Pierre Boileau y Thomas Narcejac ${ }^{33}$.

El arte abstracto de John Whitney se aplicó con acierto a la visualización de hiperespacios. Así como Bass reinterpretó sus rosetones y espirales, ligándolos a la atmósfera sobrenatural de Vertigo, otra de sus técnicas se convirtió en símbolo del viaje interdimensional. En esta ocasión, el intermediario fue el maestro de efectos especiales Douglas Trumbull, quien, tras ver Catalog $(1961)^{34}$, escogió la slit scan para la famosa secuencia de 2001: A Space Odyssey (1968), de Stanley Kubrick. Esta construcción espacial marcará el imaginario del viaje interdimensional casi tanto como las ilustraciones de Stringham pautaron la visualización de politopos.

\footnotetext{
31 "The spiralling images abolish the naturalistic threedimensional perspectival space by inaugurating a fourth dimension (...)" JUDOVITZ, Dalia. “Anemic Vision in Duchamp: Cinema as Readymade”. En: KUENZLI, Rudolf E.. Dada and Surrealist Film (1987). Cambridge: The MIT Press, 1996, p. 52.

${ }^{32}$ Para profundizar en el simbolismo de la espiral ver: HARGITTAI, István. Spiral Symmetry (1992). London: World scientific publishing, 2000.

${ }^{33}$ BOILEAU, P.; NARCEJAC, T.. Sueurs froides : d'entre les morts (1954). Paris: Gallimard, 1999.

${ }^{34}$ Catalog se compone de una serie de efectos visuales creados gracias al ordenador M7, con los cuales Whitney pretendía hacerse un hueco en el mercado.
} 
Scott Bukatman resume así el trabajo de Trumbull:

\begin{abstract}
"Una secuencia de Trumbull no es tanto la descripción de un objeto como la construcción de un entorno. (...) En la secuencia de 2001 apenas aparece algún objeto; en lugar de ello, se enfatiza el continuo de transformaciones espaciotemporales. ${ }^{, 35}$
\end{abstract}

A grandes rasgos, la animación es el producto de varias imágenes fijas fotografiadas durante largo tiempo. Gracias a esta exposición especialmente larga, la profundidad de campo lograda es máxima; hecho que refuerza la sensación de tridimensionalidad de la imagen y el efecto de espacio infinito.

Comparemos la secuencia animada con la pintura del ruso Mijaíl Matiushin "Peremeshcheniye v prostranstve" ("Movimiento en el espacio", ca 1919). El título del cuadro encaja a la perfección con la descripción del movimiento como forma continua en el espacio. Con todo, frente a las fotografías futuristas contemporáneas, la imagen abstracta se reduce a una serie de líneas cromáticas. Tanto Trumbull como Matiushin recurren a la diagonal para dotar de dinamismo a la imagen. No obstante, la línea estructura dos espacios plásticos distintos: allí donde el pintor, fiel a las reflexiones estéticas de su tiempo ${ }^{36}$, destaca la bidimensionalidad del lienzo, la animación insiste en la penetración espacial, de modo que la diagonal alimenta el efecto de profundidad. Más allá, su uso tiene que ver con el punto de vista: externo en el óleo, el plano subjetivo de la película corresponde a la visión del protagonista. ${ }^{37}$

\footnotetext{
${ }^{35}$ BUKATMAN, Scott. "Kaleidoscopic perceptions". En: Matters of Gravity: Special Effects and Supermen in the 20th Century. Durham, NC, London: Duke University Press, 2003, pp. 94-95.

36 "In abstract painting line is a path of movement, a record of dynamic actions. (...) It did provide the formal language which scientists now use for multi-dimensional illustration." HALABY, Samia A.. "Rhythms. The Aesthetics of Electronic Painting". PAPERS of the Seventh International Symposium on Electronic Art. Minneapolis, Rotterdam The Netherlands, September 16-20, 1996. Disponible en Web: $<$ http://art.net/ $\sim$ samia/essays/fisea96.html $>$

37 "For the tunnel of light (...) director Stanley Kubrick simply told his effects crew that the camera should appear to 'go through something'.” RICKITT, Richard. Op. cit., p. 178.
} 


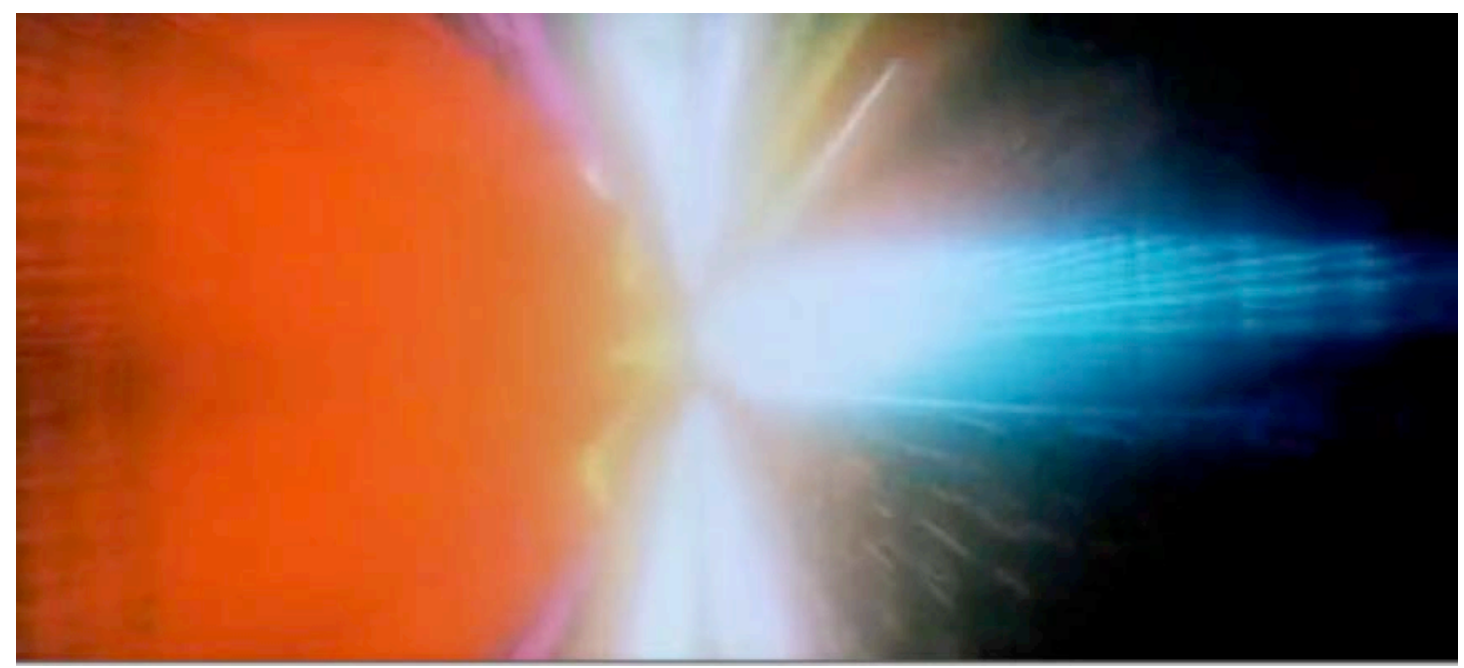

2001: A Space Odyssey (1968), de Kubrick

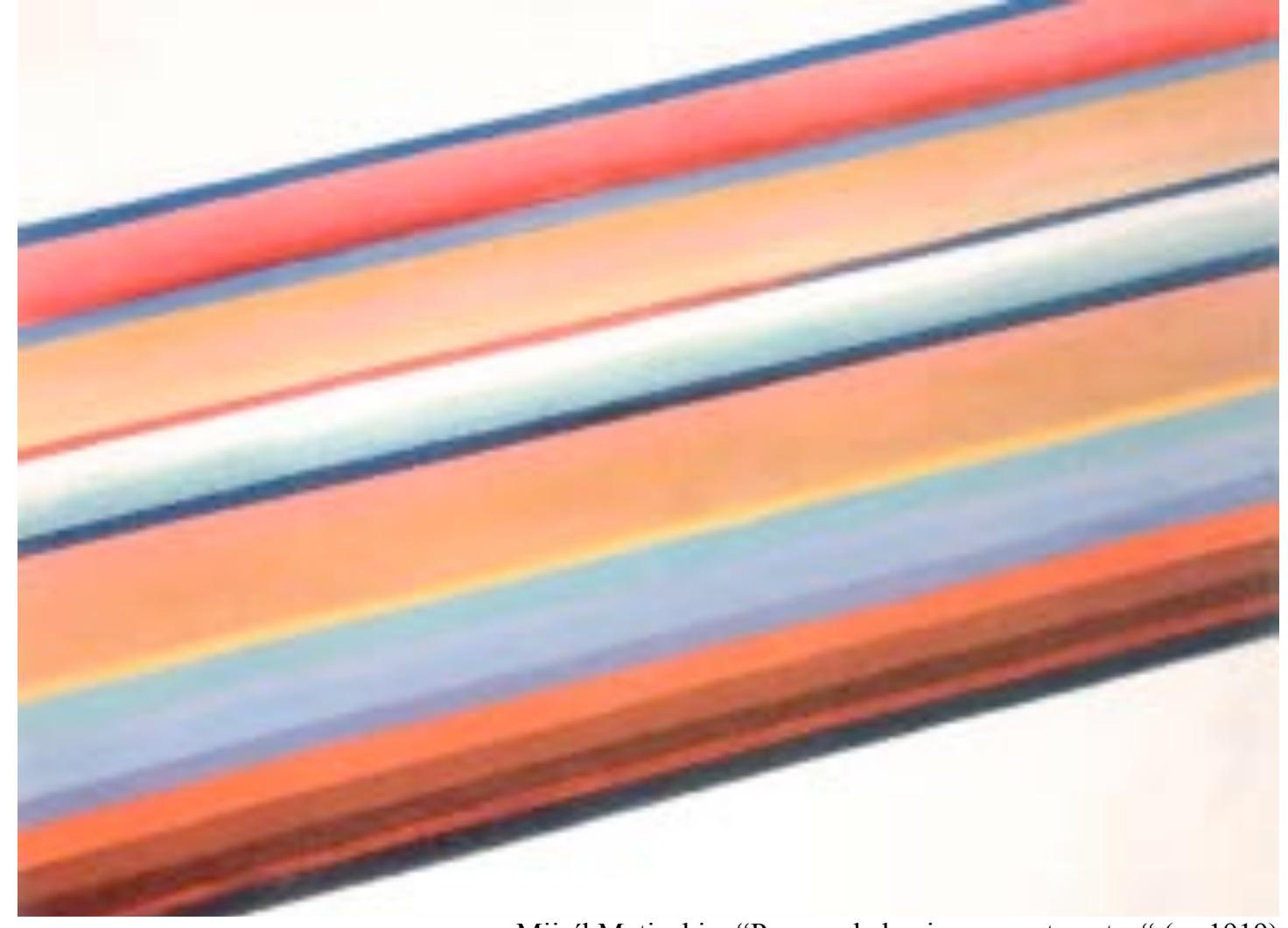

Mijaíl Matiushin: "Peremeshcheniye v prostranstve" (ca 1919)

El efecto logrado mediante la slit scan es tan impactante que la técnica fue usada después en varias películas como Superman (1978), de Richard Donner, o Star Trek (1979), de Robert Wise, con un objetivo semejante. Desde entonces, la figuración del viaje interdimensional como un entorno cromático que atravesar es un lugar común. Veíamos ya más arriba el caso de Tron (1982), pero podríamos citar otros ejemplos como The Cell (2000) de Tarsem Singh, Avatar (2009) de James Cameron o Contact (1997) de Robert Zemeckis. Éste último se revela especialmente interesante. 


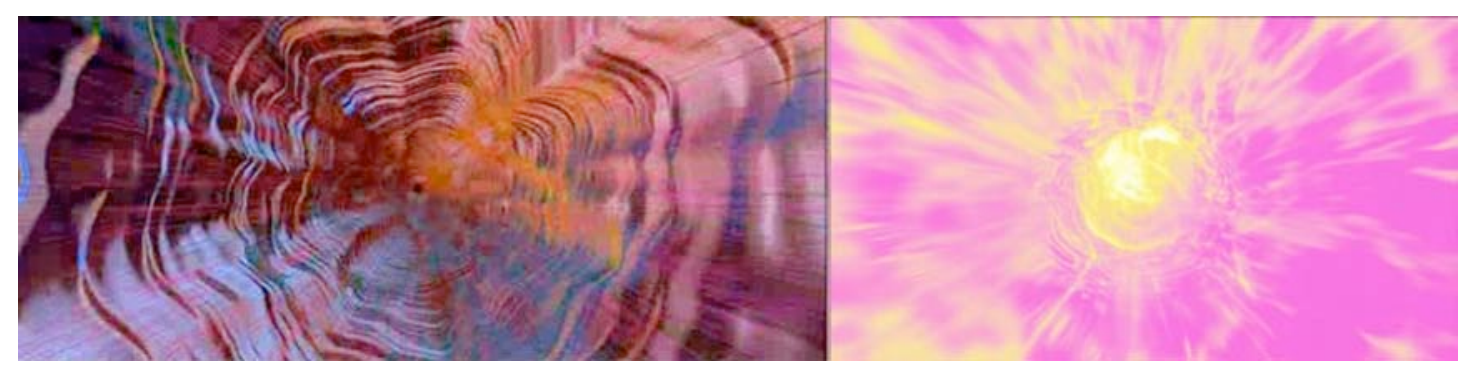

Izquierda, The Cell (2000), de Tarsem Singh. Derecha, Avatar (2009) de James Cameron

La novela homónima de Carl Sagan, en la que se inspira el guión, parte de la posibilidad de construir un agujero de gusano reversible y estable ${ }^{38}$, que permitiera a un ser humano un trayecto de ida y vuelta. A la hora de visualizar dicho viaje interdimensional, Zemeckis propone una larga secuencia, en un claro homenaje a 2001: A Space Odyssey. Ahora bien, frente a la slit scan usada por Kubrick, Zemeckis se decanta por un océano gaseoso.

El montaje temporal de ambas escenas alterna el primer plano del protagonista y el plano subjetivo consecuente. No obstante, a la hora de retratar la deformación del rostro del viajero (sometido a las condiciones extremas del puente interdimensional), cada autor acude a la especificidad de cada tipo de imagen. Así, las diversas propuestas podrían considerarse como una suerte de manifiesto de las características esenciales de cada medio: fotográfica y temporal, en la imagen cinematográfica de Stanley Kubrick; plástica y modelable a voluntad, en la imagen código de Robert Zemeckis.

En 2001: A Space Odyssey, la "agresión" es, por un lado, lumínica, reflejo en la escafandra del caleidoscopio de la slit scan; por otro lado, la excepción temporal en el interior del agujero de gusano toma forma en las congelaciones de la imagen, que subrayan el rictus monstruoso del personaje. En Contact, el ataque a la figura es, antes que nada, plástico, como evidencia el warping del rostro de Jodie Foster. Del mismo modo, la alteración del espacio-tiempo no equivale a una acción sobre el tiempo cinematográfico, sino a un montaje espacial que va desde la sobreimpresión al morphing.

\footnotetext{
${ }^{38}$ Sagan planteó la cuestión al científico Kip Thorne, quien publicó el artículo "Wormholes, Time Machines, and the Weak Energy Condition". MORRIS, M. S.; THORNE, K. S.; YURTSEVER, U.. "Wormholes, Time Machines, and the Weak Energy Condition". Physical Review Letters. September 26, 1988, vol. 61, núm 13.
} 
DEL POLITOPO AL VIAJE INTERDIMENSIONAL
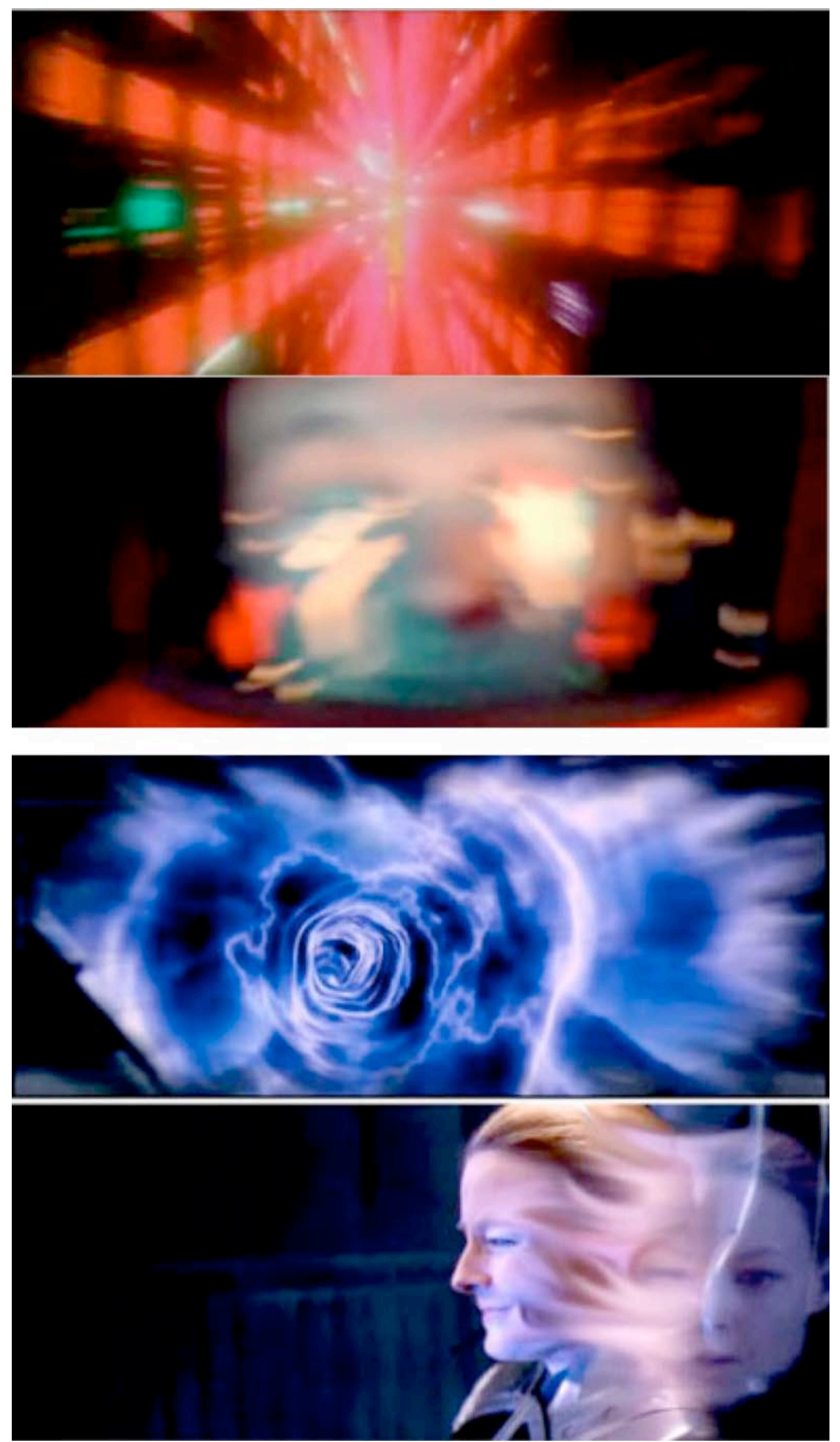

Arriba: 2001: A Space Odyssey (1968), de Kubrick. Abajo: Contact (1997), de Zemeckis 
En la película de Zemeckis, la elasticidad no afecta sólo a la figura de la protagonista, sino que se extiende al espacio en su conjunto, subrayando el continuo espacio-tiempo. La imagen se comporta como un tejido elástico que recuerda la obra del pintor Francis Bacon: así como el warping de Jodie Foster puede asociarse a los autorretratos del artista, la dilatación y contracción del conjunto recuerda el célebre "Study after Velázquez's Portrait of Pope Innocent X” (1953).

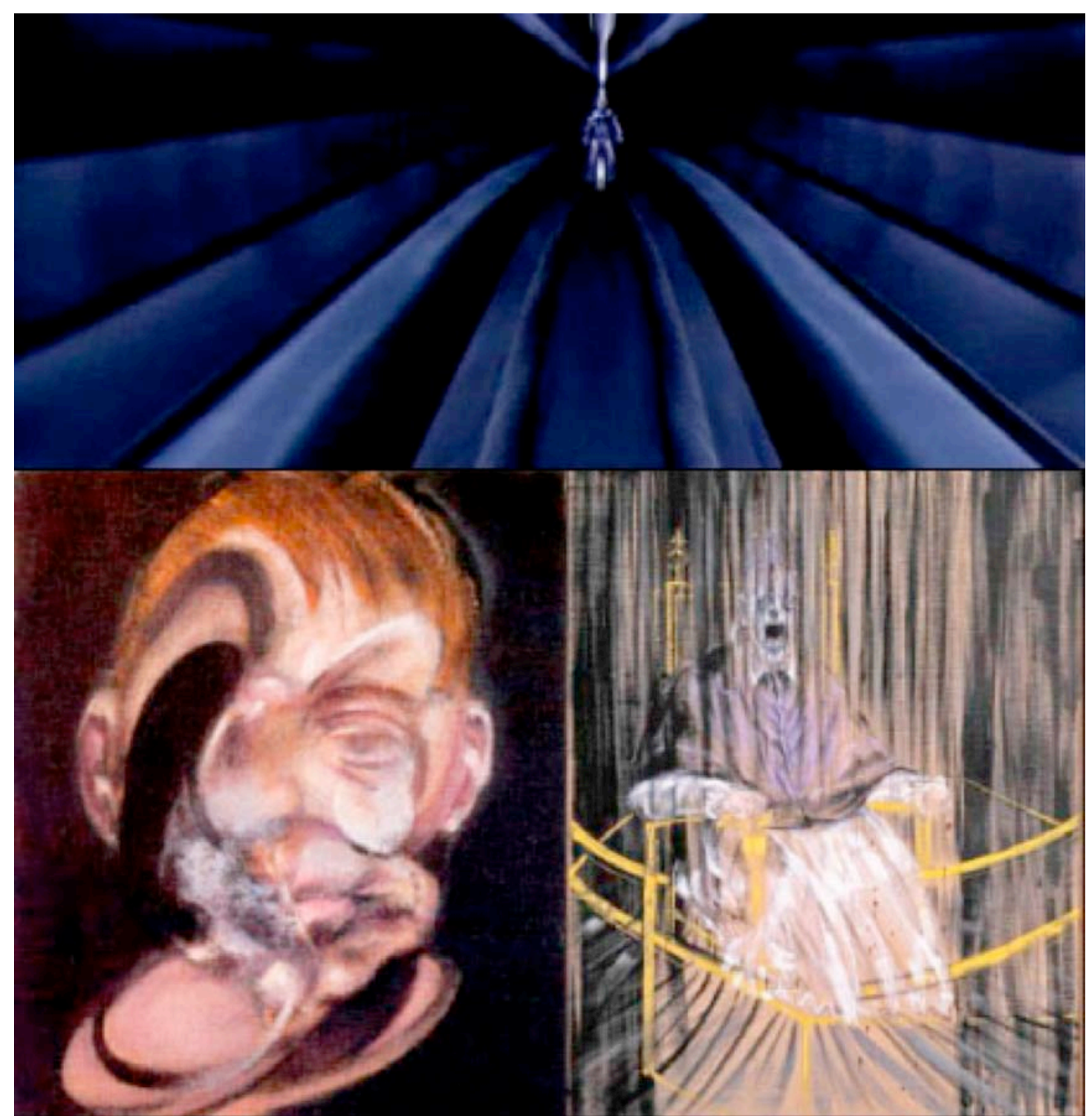

Arriba. Contact (1997), de Zemeckis. Abajo. Izquierda, "Autoportrait" (1972). Derecha, "Study after Velázquez's Portrait of Pope Innocent X" (1953). Ambas de Francis Bacon.

La salida del agujero de gusano toma forma en un ligero zoom in hacia el ojo de la protagonista: sobre la pupila negra, se recorta la silueta del cuerpo de la actriz. ${ }^{39}$ Este montaje espacial permite una transformación lisa de la escala. En el segundo

\footnotetext{
${ }^{39}$ La imagen recupera la sobreimpresión de la espiral sobre un ojo en los créditos de Vertigo.
} 
capítulo, describíamos el zoom out que abre la película como una convergencia del universo en el ojo de la protagonista, aún niña. El eco de aquella construcción resuena en la escena que nos ocupa, como si se tratara de un mismo movimiento en sentido opuesto: allí, hacia fuera; aquí, hacia dentro. De nuevo, la imagen remite a la dimensión fractal; aunque la geometría es sustituida por un collage figurativo, el zoom in revela una estructura que se repite tanto en la parte como en el todo (el cuerpo que contiene el ojo que contiene el cuerpo...) y que connota la idea de un espacio infinito.

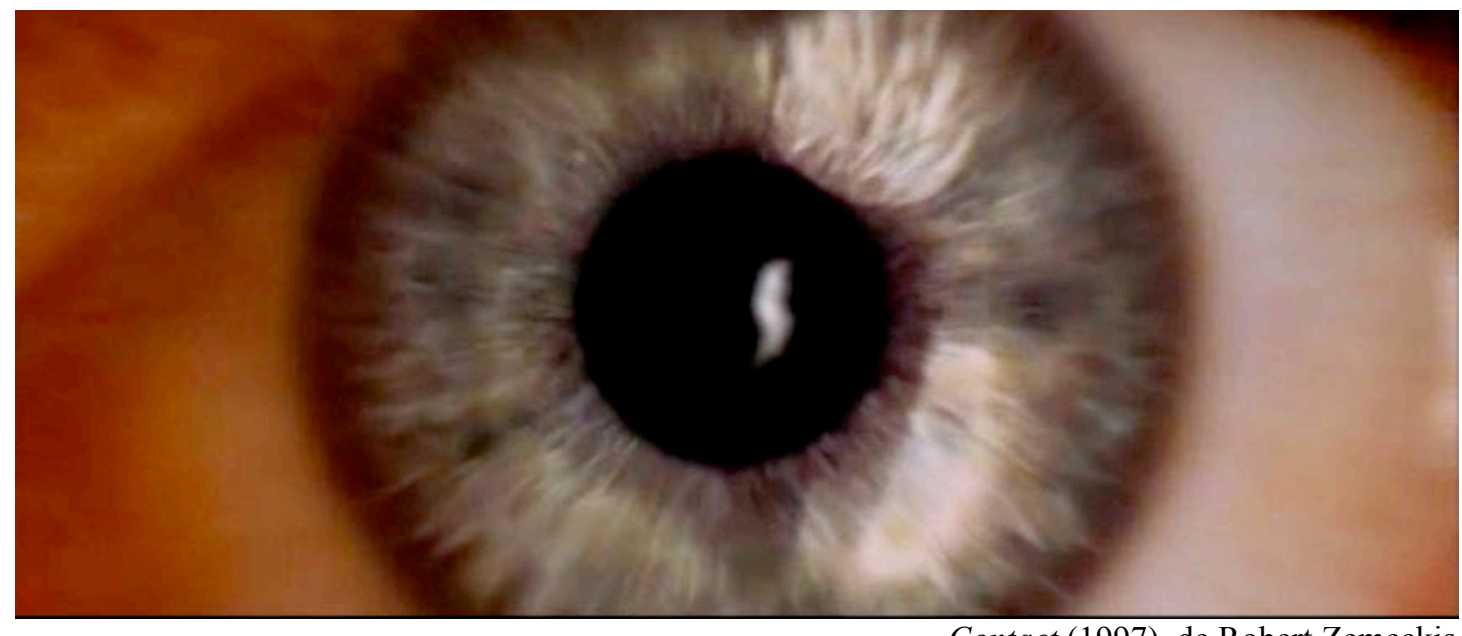

Contact (1997), de Robert Zemeckis

\section{La metáfora líquida}

Contact comparte con Naqoyqatsi la visualización del agujero de gusano como un fluido: un torrente tormentoso en la primera y un cielo nublado en la segunda. Esta "metáfora líquida" encaja a la perfección con la plasticidad de la imagen código. La misma asociación se repite en la película Donnie Darko (2001), de Richard Kelly; el realizador basa prácticamente todas sus referencias a la cuarta dimensión en la analogía con el espacio líquido.

Como en las películas de Zemeckis y Kubrick, el viaje interdimensional combina el plano subjetivo del zoom in con el rostro del protagonista. Aunque la desfiguración del actor comparte con su equivalente en Contact la exhibición de la plasticidad de la imagen digital, en la cinta de Kelly, la imagen gelatinosa parece como filtrada a través de la propia materia fluida del puente. 


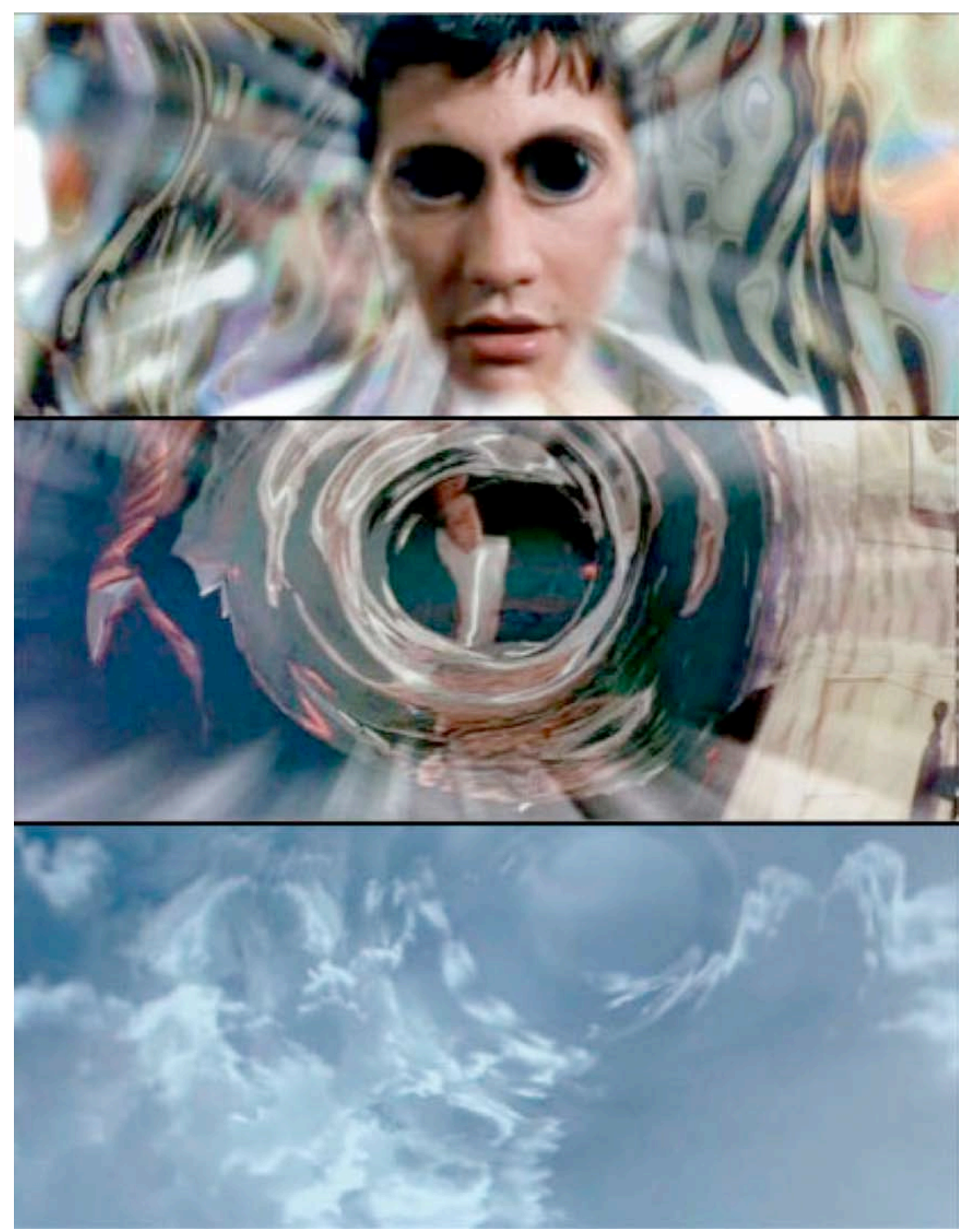

Donnie Darko (2001), de Richard Kelly

De hecho, el conducto espacio-temporal aparece visto desde fuera, como un personaje más de la trama. La figuración del reverso del agujero coincide con el "gusano" al que dio nombre el físico J. A. Wheeler a mediados de los años 50. El invertebrado, cual chorro de agua en suspensión, trae a la memoria la fascinante criatura creada por James Cameron para The Abyss (1989). 


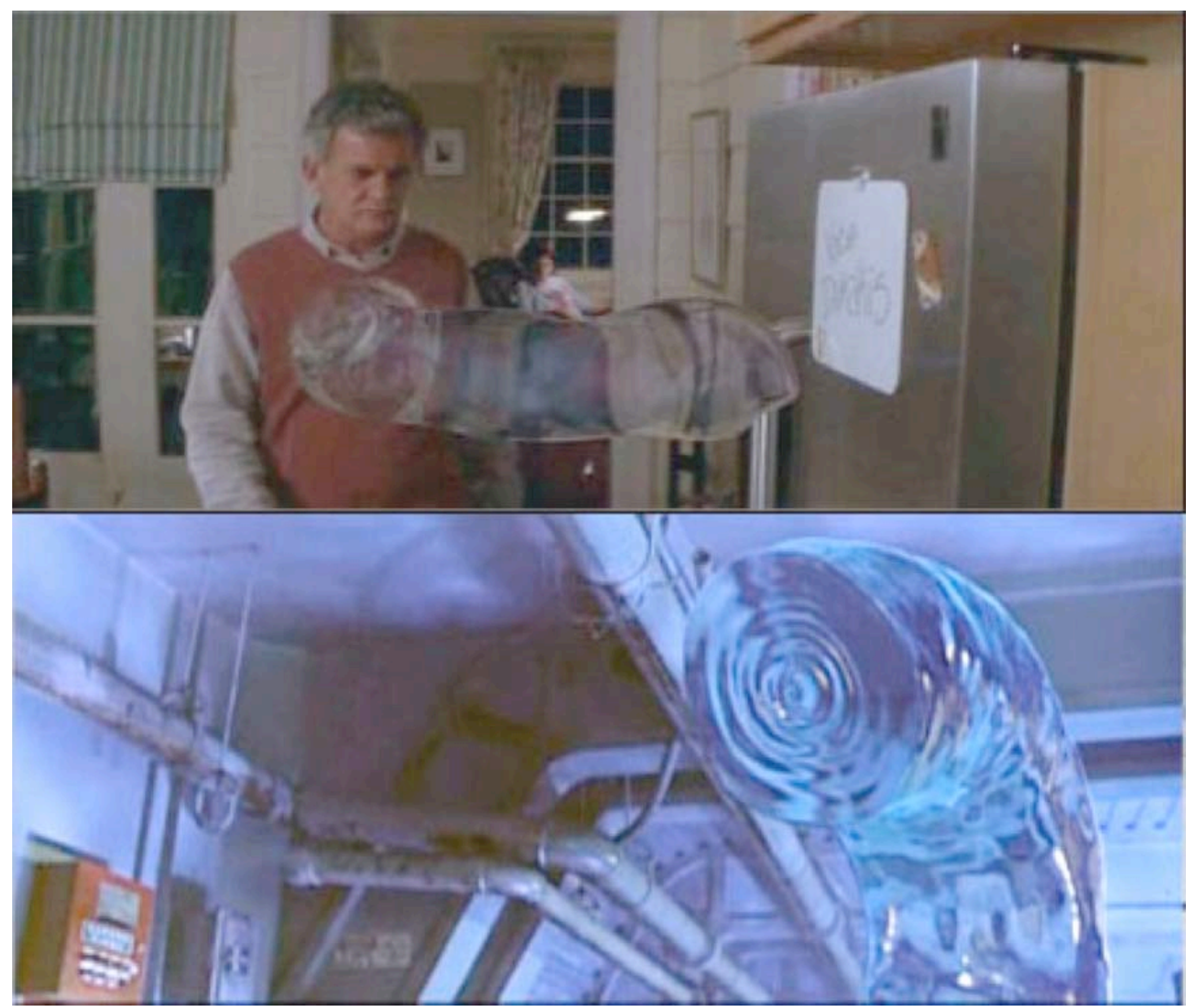

Arriba: Donnie Darko (2001), de Richard Kelly. Abajo: The Abyss (1989), de James Cameron

El gusano de agua en Donnie Darko funciona como vector del desplazamiento de los personajes y puede ser interpretado como una variación del teseracto. "Si pudieras ver tu camino, podrías ver tu futuro" 40 , afirma el protagonista. Este "camino", materializado en la lombriz transparente, da forma a una espacialización del tiempo; es decir, la línea cronológica se identifica con el recorrido espacial. Sin embargo, frente a los "cristales de tiempo" de Waliczky, la criatura no figura las fases intermedias, sino la trayectoria que seguirá el cuerpo. En este sentido, está más cerca de las cataratas borrosas de Muybridge que de las lithochroniques de Sábato.

La página oficial ${ }^{41}$ de la película contiene los apuntes titulados The philosophy of time travel, del personaje de ficción Roberta Sparrow. El texto, que bosqueja el contenido hiperdimensional del guión, contiene una referencia explícita al agua como

\footnotetext{
${ }^{40}$ En el original, "If you could see your path, you could see your future".

${ }^{41}$ Donnie Darko fue una de las primeras producciones en acompañar el estreno de la película en las salas de una experiencia en Internet, con el gancho de desvelar algunas claves de la historia. Ver la página web del proyecto: $<$ http://archive.hi-res.net/donniedarko/>
} 
materia constituyente de los "portales". ${ }^{42}$ Así, el símil acuático se repite en la figuración del límite permeable entre varias dimensiones.

En la escena del baño, en la cual tiene lugar el encuentro entre Donnie y el misterioso personaje de Frank, el estudio del raccord entre las miradas permite situar el portal en medio de la habitación. Aunque podría haber identificado la puerta interdimensional con el espejo ${ }^{43}$ en el que se mira el protagonista, el realizador se decanta, deliberadamente, por una solución distinta: una apuesta que dota a la superficie de la imagen de un protagonismo insólito.

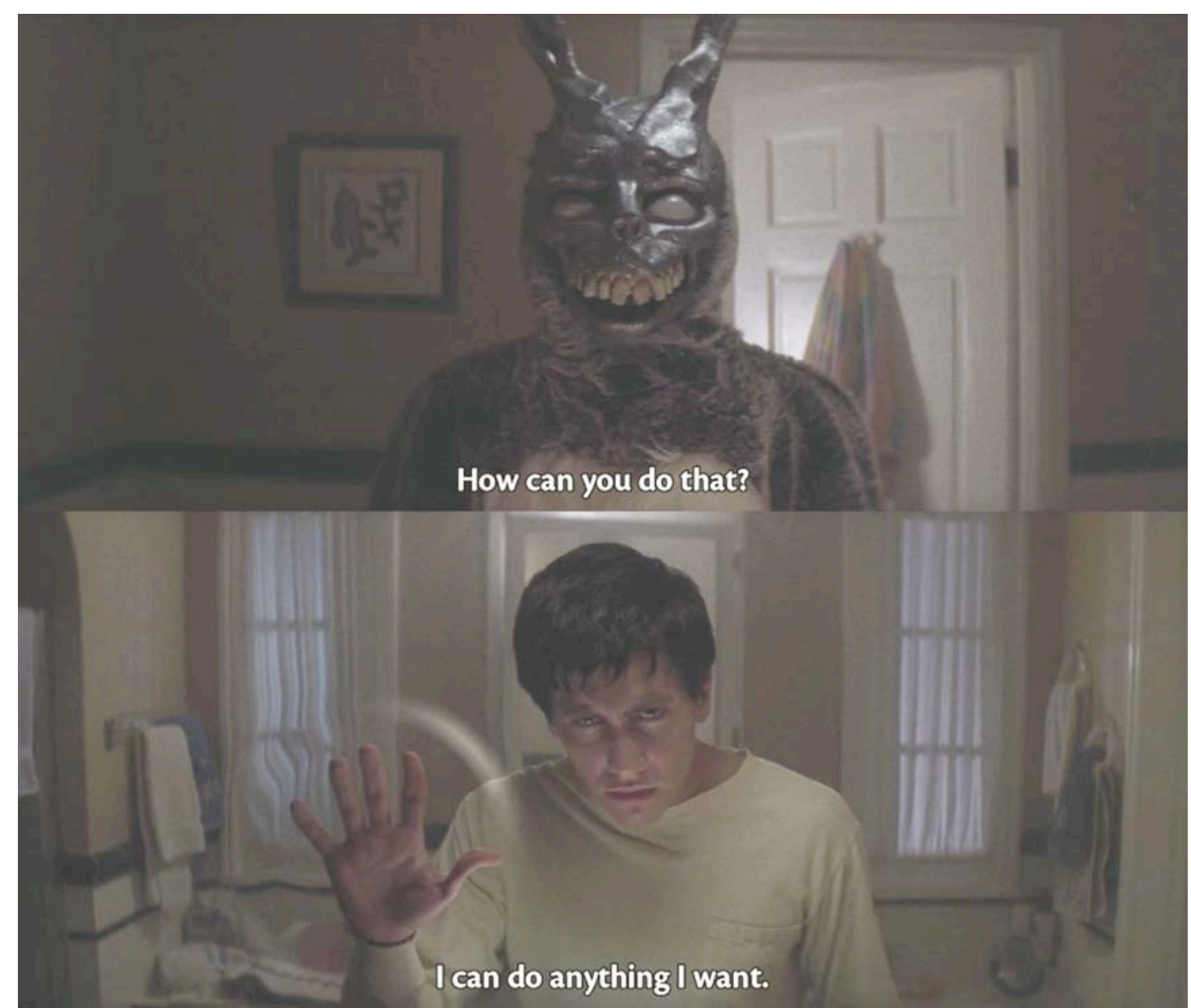

Donnie Darko (2001), de Richard Kelly

\footnotetext{
42 "Water is the barrier element for the construction of Time Portals used as gateways between Universes as the Tangent Vortex." Ver la página del proyecto:

$<$ http://www.donniedarko.org.uk/philosphy-of-time-travel/>

${ }^{43}$ La elección del conejo como disfraz de Frank es un claro homenaje al libro de Lewis Carroll Alice's Adventures in Wonderland. La asociación del espejo con la cuarta dimensión reforzaría la alusión a la obra de Carroll. CARROLL, Lewis. Alice's Adventures in Wonderland; and Through the LookingGlass (1865-1871). Harmondsworth: Puffin Books, 1962.
} 
Nuevamente, es posible establecer un paralelismo con The Abyss. En el encuentro entre el extraterrestre y el personaje protagonizado por Ed Harris, el portal se asemeja a un muro de agua. No obstante, la posición de la cámara en cada escena resulta en dos propuestas estéticas distintas: perpendicular a la pared en la película de Cameron, Kelly la hace coincidir con el cuadro de la imagen. La acertada elección remite al carácter plástico de la imagen digital.

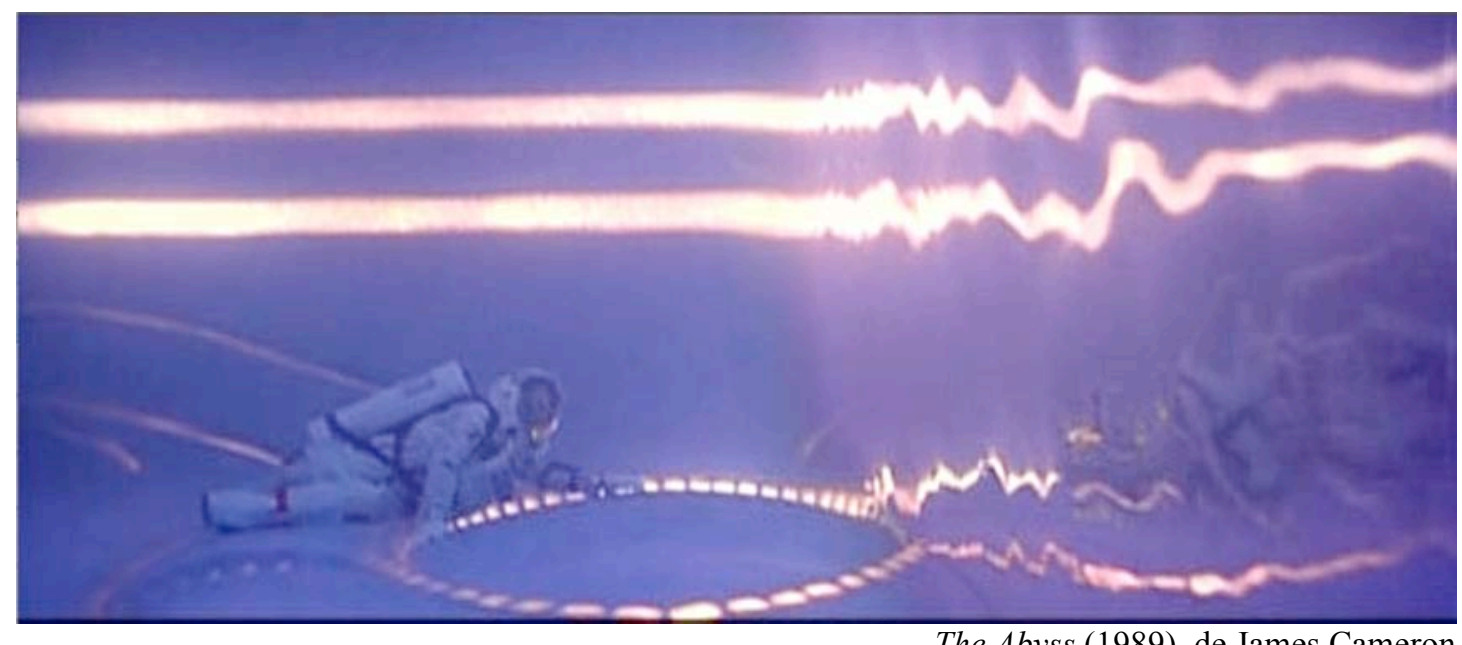

The Abyss (1989), de James Cameron

En The Abyss, la misma pared de agua torna en televisor improvisado, cuyas imágenes permiten al protagonista descodificar el mensaje extraterrestre. De modo semejante, en otra escena de Donnie Darko, el portal se identifica con una pantalla, esta vez, cinematográfica. "Has visto alguna vez un portal?" "44, pregunta Frank a Donnie mientras un agujero se abre en el centro del telón. El orificio, que deja entrever un cielo al otro lado de la pantalla, irradia luz y desmonta el dispositivo cinematográfico (normalmente, la película es proyectada desde fuera, sobre la tela). El embudo de energía absorbe, entre otras, la imagen de un reloj, metáfora de la excepción temporal en el interior del portal; a continuación, el agujero crece hasta quemar por completo la imagen, en una identificación de la sobreexposición fotográfica y el incendio físico de una casa, que Frank impone como tarea a Donnie. Mientras el zapping televisivo de The Abyss se presenta, simplemente, como parte de la argumentación del extraterrestre, la metamorfosis de la imagen en la pantalla cinematográfica remite, una vez más, a la plasticidad del espacio digital.

\footnotetext{
44 “Have you ever seen a portal?", en el original en inglés.
} 


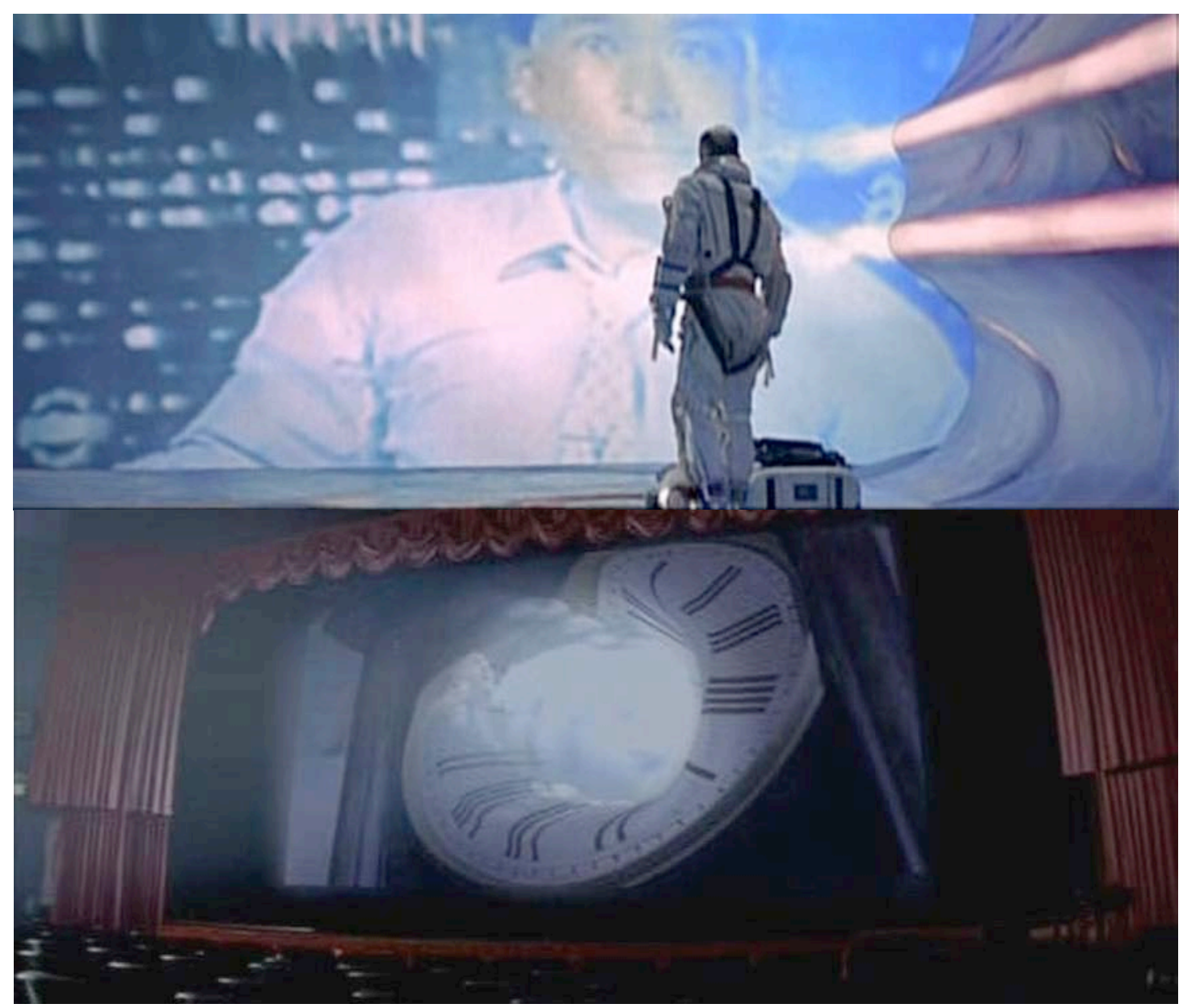

Arriba: The Abyss (1989), de James Cameron. Abajo: Donnie Darko (2001), de Richard Kelly

El videojuego Portal, lanzado al mercado en 2007, retoma esta visualización del puente como perforación en una superficie plana. La imagen interactiva en primera persona permite al jugador crear conexiones inmediatas entre espacios alejados, gracias a los agujeros interdimensionales. No por casualidad, los bordes de los orificios gotean agua. Con todo, el concepto de espacio fluido no se reduce al símil hídrico. La propuesta encaja con la definición de "arquitectura líquida" dada por el artista y teórico Marcos Novak:

"La arquitectura líquida es una arquitectura cuya forma depende de los intereses del que mira; es una arquitectura que se abre para darme la bienvenida y se cierra para defenderme; es una arquitectura sin puertas ni pasillos, donde la habitación de al lado está siempre donde la necesito y es como necesito que sea." ${ }^{45}$

\footnotetext{
${ }^{45}$ NOVAK, Marcos. "Liquid Architectures in Cyberspace". En: BENEDIKT, Michael. Cyberspace: First Steps. Cambridge: The MIT Press, 1991, pp. 251-252.
} 


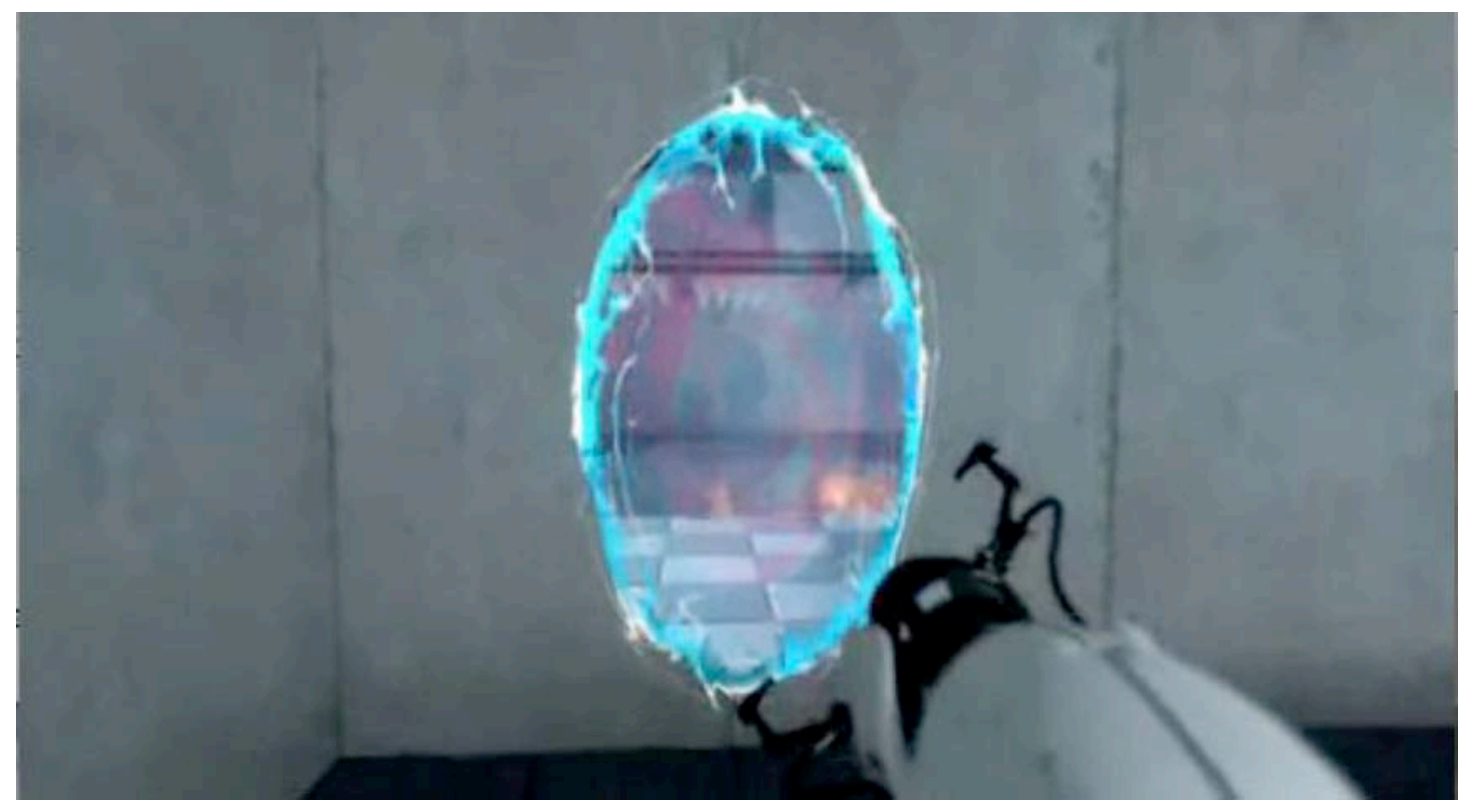

Captura de pantalla del videojuego Portal (2007)

Ese entorno que se amolda a las necesidades del ser que lo habita coincide con las metamorfosis del espacio en Heavenly Creatures (1994) y Dark City (1998), analizadas en el primer capítulo. En la película de Alex Proyas, las mutaciones del decorado reflejan la nueva identidad inyectada a los personajes. Por su parte, Peter Jackson se sirve de la transformación espacial para dar vida al "Cuarto Mundo", soñado por las protagonistas. De manera semejante, la dimensión al otro lado del agujero de gusano en Contact concuerda con la arquitectura líquida de Novak, en cuanto el espacio es diseñado al gusto de la protagonista para simplificar el "contacto". 46

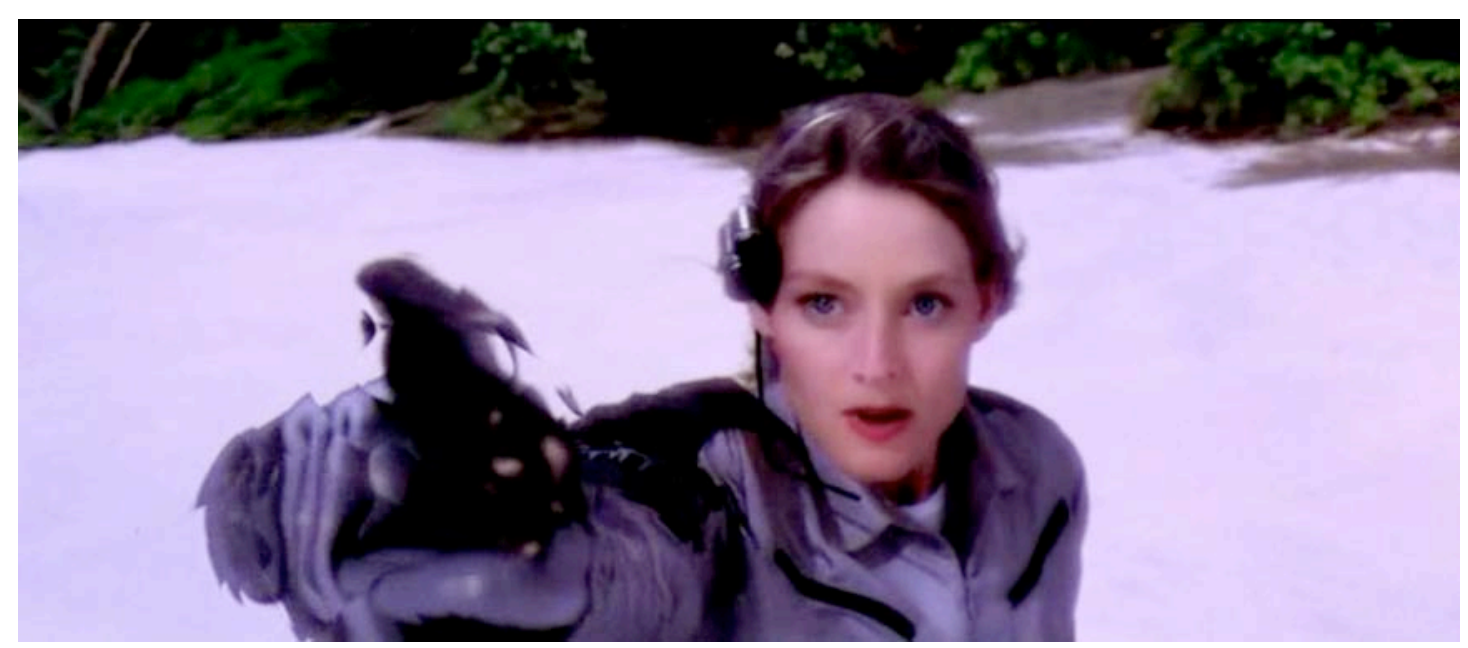

Contact (1997), de Robert Zemeckis

\footnotetext{
${ }^{46}$ Así, en el encuentro entre padre e hija, éste aclara en relación al extraño paisaje: "We thought this might make things easier for you".
} 
Aunque de gran parecido a un paisaje terrestre, la nueva dimensión se caracteriza por una atmósfera densa de colores artificiales, similar al mundo submarino de The Abyss. Zemeckis se deleita en la exhibición de esa bella sustancia que lo invade todo, haciendo vibrar la membrana transparente a cada caricia de la protagonista, atónita ante el espectáculo. Sin duda, la viscosa consistencia quedó, también, en la retina de Richard Kelly... 


\section{DINÁMICAS DE LA DISTORSIÓN Y DE LA METAMORFOSIS}

El presente apartado se concentra en el rechazo a la reproducción mimética del movimiento, al registro del desplazamiento de un cuerpo en un espacio vacío. Frente al análisis cinético de la locomoción, característico de los experimentos precinematográficos, la sintesis de dinámicas en estas prácticas digitales parte de la concepción del espacio como una entidad llena, en la que figura y fondo forman parte de la misma red mutante. De este modo, la animación de la imagen no reproduce una acción profílmica o la movilidad de la cámara física, sino que construye nuevas relaciones entre las formas gracias al cálculo informático.

Comenzaremos con dinámicas basadas en la elasticidad espacial, apuntando distintos efectos asociados a la interpolación de imágenes. A continuación, demostraremos cómo la plasticidad del espacio digital no hace referencia, exclusivamente, a esta capacidad de estirarlo a voluntad, sino que se manifiesta, igualmente, en la condensación, en la compresión de los datos.

\section{La elasticidad}

En su huida de la representación de un espacio tridimensional hacia la construcción de hiperespacios y espacios no-euclidianos, los creadores digitales acuden con frecuencia a la metáfora líquida. El espacio de la imagen se comporta como un fluido, compuesto de partículas independientes, que permiten la transformación y adaptación continua de las formas. En su Liquid Selves (1992), Karl Sims combina la creación de síntesis y la transición espacial mediante morphing. Así, sus "seres líquidos" hacen referencia no sólo a la membrana continua que veíamos en Contact o en Donnie Darko, sino a la mismísima animación de la imagen.

El espacio se activa gracias a una cadena de metamorfosis: al tiempo que la cámara virtual se desplaza por un entorno lleno, la atmósfera fluida conduce las transformaciones. Para Karl Sims, parece evidente que la potencia estética de la imagen digital no reside en el registro de movimientos externos ni en la edición del montaje cinematográfico de los planos: por el contrario, se trata de dar vida a la imagen, de la creación de nuevas dinámicas en un proceso continuo de mutación. 

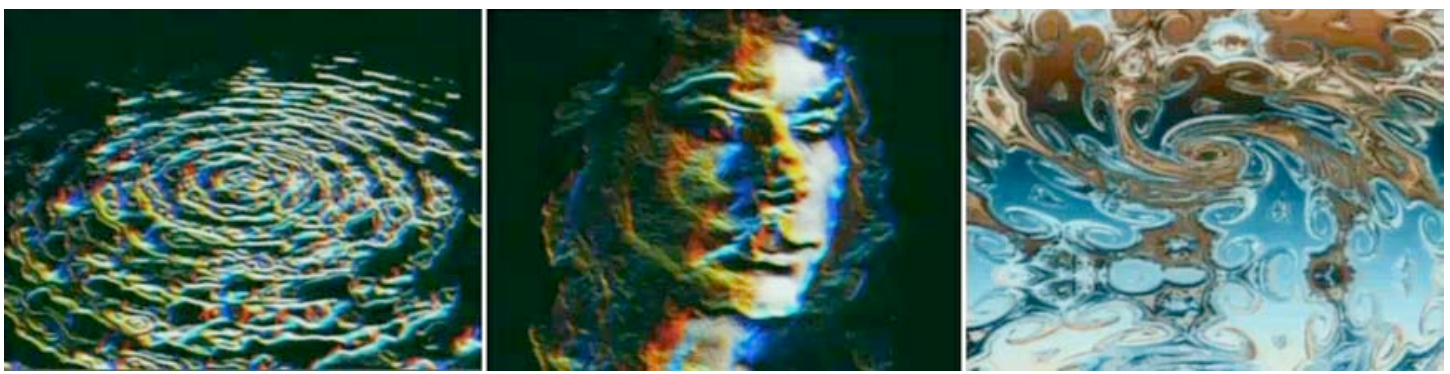

Liquid Selves (1992), de Karl Sims

Como llevamos insistiendo a lo largo de este trabajo, frente a la imagen cinematográfica, la imagen digital permite llenar el intersticio entre los frames, creando una continuidad en la transformación mediante el cálculo del espacio intermedio. En este sentido, el morphing se exhibe como paradigma de la metamorfosis digital, prueba de su incomparable plasticidad.

En el primer capítulo, señalábamos cómo el uso de la interpolación a principios de los años 90 se caracteriza por la metamorfosis lisa. No obstante, en su experimentación contemporánea, Sims se decanta por la distorsión, continuando con las propuestas de los pioneros del computer art como Charles Csuri. Hummingbird, Artist into Frog o Aging Process (1968) no pretenden imitar un desplazamiento, sino exhibir la dislocación de las líneas y su redistribución. Ahora bien, frente a aquel gusto geométrico, varias décadas después, Liquid Selves presenta formas orgánicas. ${ }^{1}$

En La faim (1974), la interpolación permite a Peter Foldes crear transiciones espaciales continuas, metáfora de la voracidad del protagonista. Si en la arquitectura líquida, el entorno se adapta al personaje que lo habita, aquí, es el protagonista el que muta en los objetos y la arquitectura, haciendo avanzar la historia. Siete años después, el también animador húngaro John Halas retoma la metamorfosis digital como transición espacial y metáfora. Con su obra Dilemma (1981), el autor llama a la utilización de la tecnología y la ciencia con fines estéticos, no destructivos: piezas de escultura, pintura y arquitectura se transforman en varias escenas de iconografía bélica.

Mediante una tableta electrónica, Halas introduce en el ordenador los dibujos realizados por el artista Janos Kass. Gracias al programa de animación digital "VideoCel", calcula las imágenes-media a partir de esos key frames, de manera

\footnotetext{
${ }^{1}$ En el próximo apartado, profundizaremos en ambas tendencias y recuperaremos la figura de Karl Sims en tanto que pionero del "arte evolutivo". Aunque la misma Liquid Selves contiene imágenes de síntesis creadas mediante "algoritmos genéticos", por el momento, nos limitamos al morphing como dinamización espacial.
} 
semejante a como hará más tarde el popular Macromedia Flash (1996). Frente a los garabatos que caracterizan las obras de Foldes y Csuri, Halas desplaza bloques cromáticos como las piezas de un puzzle.

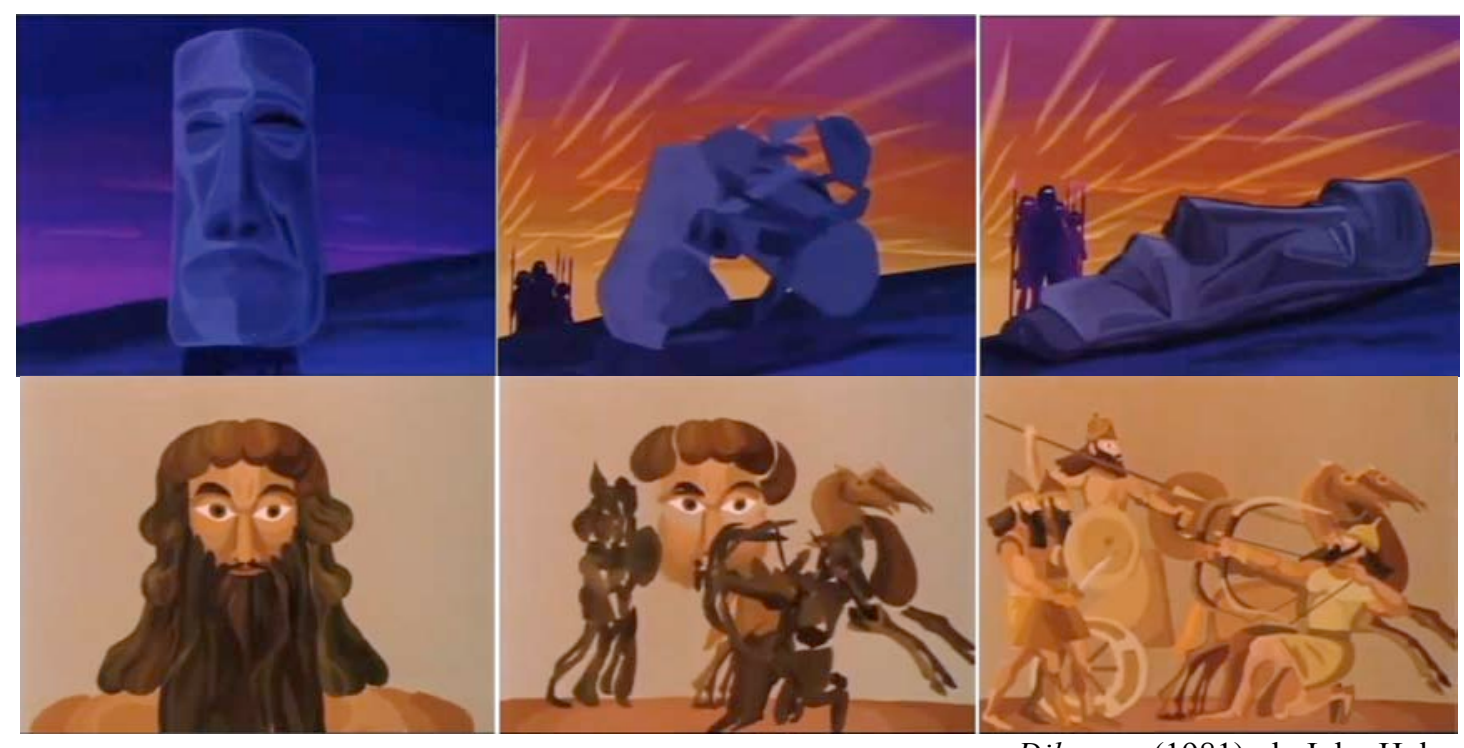

Dilemma (1981), de John Halas

Nada más clarificador a la hora de distinguir la construcción de nuevas dinámicas de la mera reproducción del movimiento que este partir de imágenes fijas como materia prima para la transformación. Uno de los artistas contemporáneos que más trabaja la activación de la imagen digital mediante interpolaciones es Philip Scott Johnson, cuya obra Faces of Fashion (2011) analizábamos ya en el apartado dedicado al morphing.

Decíamos entonces que el continuo entre las formas permite al artista comparar la belleza de diversas modelos internacionales; en este sentido, su propuesta se sitúa en las antípodas de la distorsión de los pioneros, lejos también de los Liquid Selves de Karl Sims. No obstante, en su exploración plástica de la potencia visual de la interpolación, Johnson propone otras dinámicas del espacio más allá de aquel uso transparente del morphing. Así, por ejemplo, en Monet (2009), el artista no parte de fotografías, sino (entre otros) de la serie de óleos "Les Meules" (1880-1881), del pintor francés Claude Monet (1840-1926). 


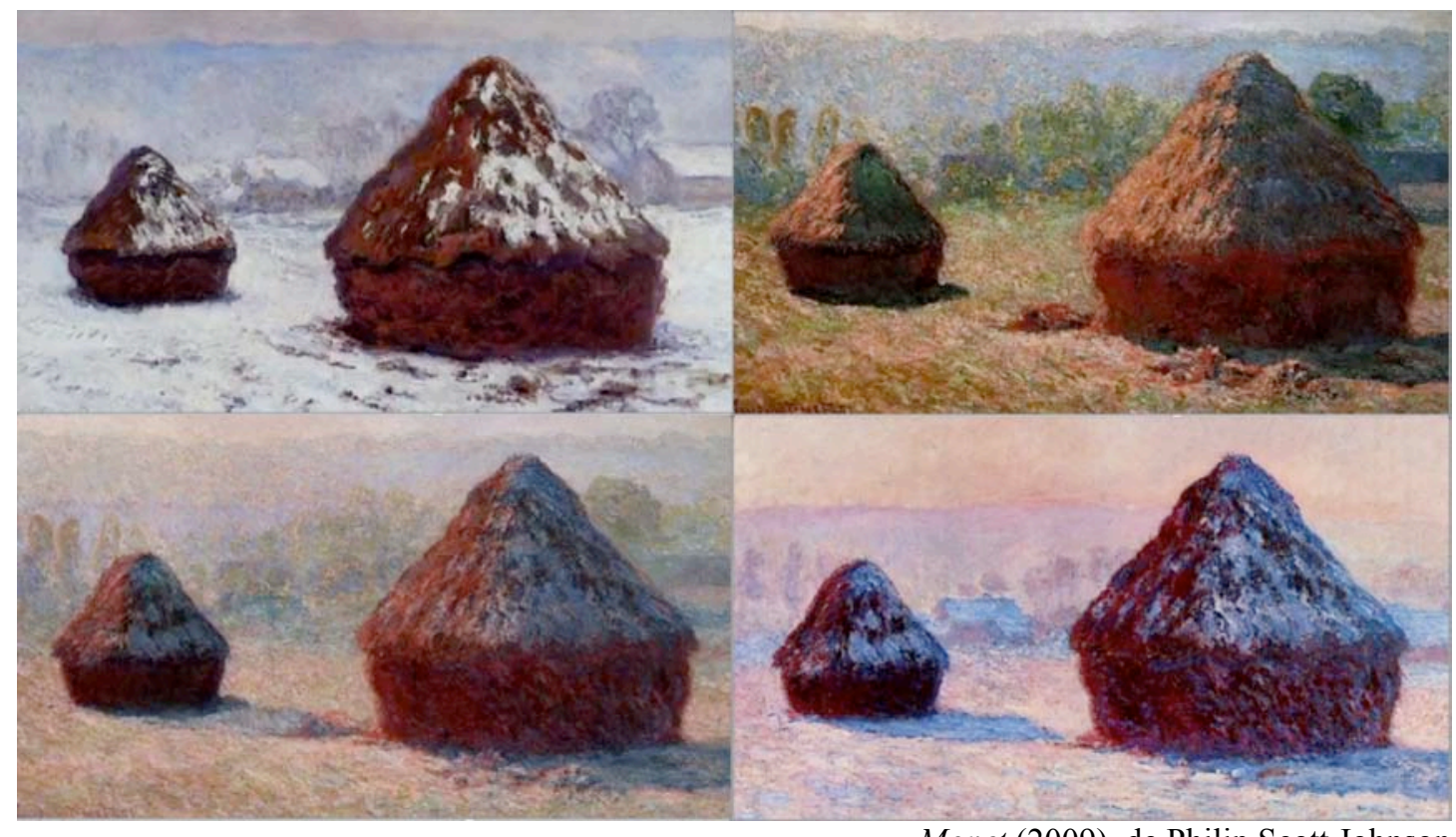

Monet (2009), de Philip Scott Johnson

El interés de la pieza reside en la comparación tácita entre la plasticidad del óleo y la del espacio digital, el cual puede no sólo adquirir cualquier aspecto (como el material plástico de la pintura ${ }^{2}$ ), sino fluir entre varias formas. Philip Scott Johnson establece de manera implícita un paralelismo entre las touches de color en los cuadros originales y la matriz digital que conduce las mutaciones: los píxeles que, accesibles de manera atómica, permiten la continuidad de las dinámicas. ${ }^{3}$ De este modo, la plasticidad del espacio digital no se refiere sólo a la potencialidad de transformación, sino a la exhibición misma del proceso de cambio. Con Monet, Johnson contradice a quienes piensan que la plasticidad es exclusiva de la pintura, del material físico del óleo. ${ }^{4}$

Aunque la pieza digital parte de cuadros claramente figurativos, la distorsión intermedia remite, más bien, a las últimas obras del pintor francés: los célebres

\footnotetext{
${ }^{2}$ Comúnmente, el término "plástico" se refiere a la capacidad de un material de ser modelado; en este sentido, dos disciplinas se definen como "artes plásticas": la escultura y la pintura. En ambas, el artista parte de un material maleable (arcilla, óleo...), que modela hasta dotarlo de una forma definitiva.

3 "L'image est devenue une image matrice. Ce qui lui confère une qualité particulière. Son contrôle morphogénétique ne se fait plus au niveau du plan - comme en peinture ou en photographie - , ni au niveau de la ligne - comme dans la télévision où le plan de l'image est découpé en ligne -, mais au niveau du point. La structure matricielle de l'image permet d'accéder directement à chacun de ses éléments et d'agir sur eux." COUCHOT, Edmond. La technologie dans l'art. De la photographie à la réalité virtuelle. Nîmes: Éditions Jacqueline Chambon, 1998, p. 135.

${ }^{4}$ Así, por ejemplo, Anne Hollander afirma: "Cinema can never do what Tintoretto or Rubens did. Such painters created figure styles and painting techniques and compositional ploys so flexible and interdependent that they may belong only to painting (...)." HOLLANDER, Anne. Moving Pictures. New York: Alfred A. Knopf, 1989, p. 104.
} 
nenúfares, cercanos ya a la abstracción. En ellos, las figuras no destacan sobre el fondo, sino que parecen formar parte de una misma masa cromática:

\begin{abstract}
"una sustancia coloidal, en la cual cada zona del cuadro se impregna de los colores de la vecina hasta abolir completamente las divisiones, las distinciones, los contornos (....). En Monet, el cuadro tiende hacia la isotropía de sus elementos; presenta las mismas propiedades en todos sus puntos."
\end{abstract}

Las pinturas de Monet muestran los cambios de luz sobre varios almiares, en medio del campo, cerca de la casa del artista en Giverny. Como otras series del pintor francés, la repetición del mismo motivo inerte permite concentrarse en los cambios lumínicos, verdadera obsesión del impresionismo, que abandona el taller por el caballete para pintar "d'après nature". En este empeño, la corriente pictórica pone punto final a la estructuración espacial de la perspectiva y abre el camino a la revolución de la pintura moderna.

Como llevamos insistiendo a lo largo de esta investigación, en sus exploraciones del espacio de la imagen, no son pocos los artistas digitales en inspirarse de aquellas propuestas pictóricas. Ahora, si Monet pretende atrapar instantes de luz ${ }^{6}$, Philip Scott Johnson se concentra en la mutación luminosa que vehicula la transformación espacial: la variación de un mismo tema como principio de la serie pictórica da paso, en la animación digital, a la variación como dinamización, como principio estético de la metamorfosis.

Se trate del conjunto de óleos de Monet o de las fotografías de modelos, en su empresa, Johnson parte de series de imágenes fijas, que cose en un flujo continuo de transformaciones. Éste es el caso también de Women in Film y Women in Art, ambas de 2007. En la primera, un morphing permite el paso continuo entre los rostros de una serie de actrices, ordenados cronológicamente desde los años 20 hasta el presente; en el segundo, la cadena de metamorfosis afecta a retratos de mujeres en la historia de la pintura.

En los morphing fotorrealistas, típicos de la ficción fantástica (Snow White and the Huntsman, de Rupert Sanders) y del tecnorromanticismo (Black or White, de John

\footnotetext{
${ }^{5}$ BOUDON, Pierre. "L'oeuvre d'art comme expression spatial”. En: SOBIESZCZANSKI, M. (dir.). Spatialisation en art et sciences humaines. Bruxelles: Collection Pleine Marge, Peeters, 2004, p. 19.

6 "Il faut savoir saisir le moment du paysage à l'instant juste, car ce moment-là ne reviendra jamais et on se demande toujours si l'impression qu'on a reçue a été la vraie." Claude Monet. Apud. SEIBERLING, Grace. Monet's series. New York: Garland Pub, 1981, p. 99.
} 
Landis), el éxito de la metamorfosis radica en la separación minuciosa entre figura y fondo. Por el contrario, Johnson aplica el morphing a toda la imagen en su conjunto. Los haluros de plata de las fotografías originales o las masas de pigmento de las pinturas, son, en su versión digital, una red de datos. Puesto que la imagen se compone de píxeles y que píxeles son también los contornos, las líneas que delimitan la figura se vuelven permeables. En la transición de una imagen a otra, se pierden las fronteras entre forma y espacio: en blanco y negro o en color, la mutación lumínica desborda la forma, diluye el contorno, fagocita el fondo.
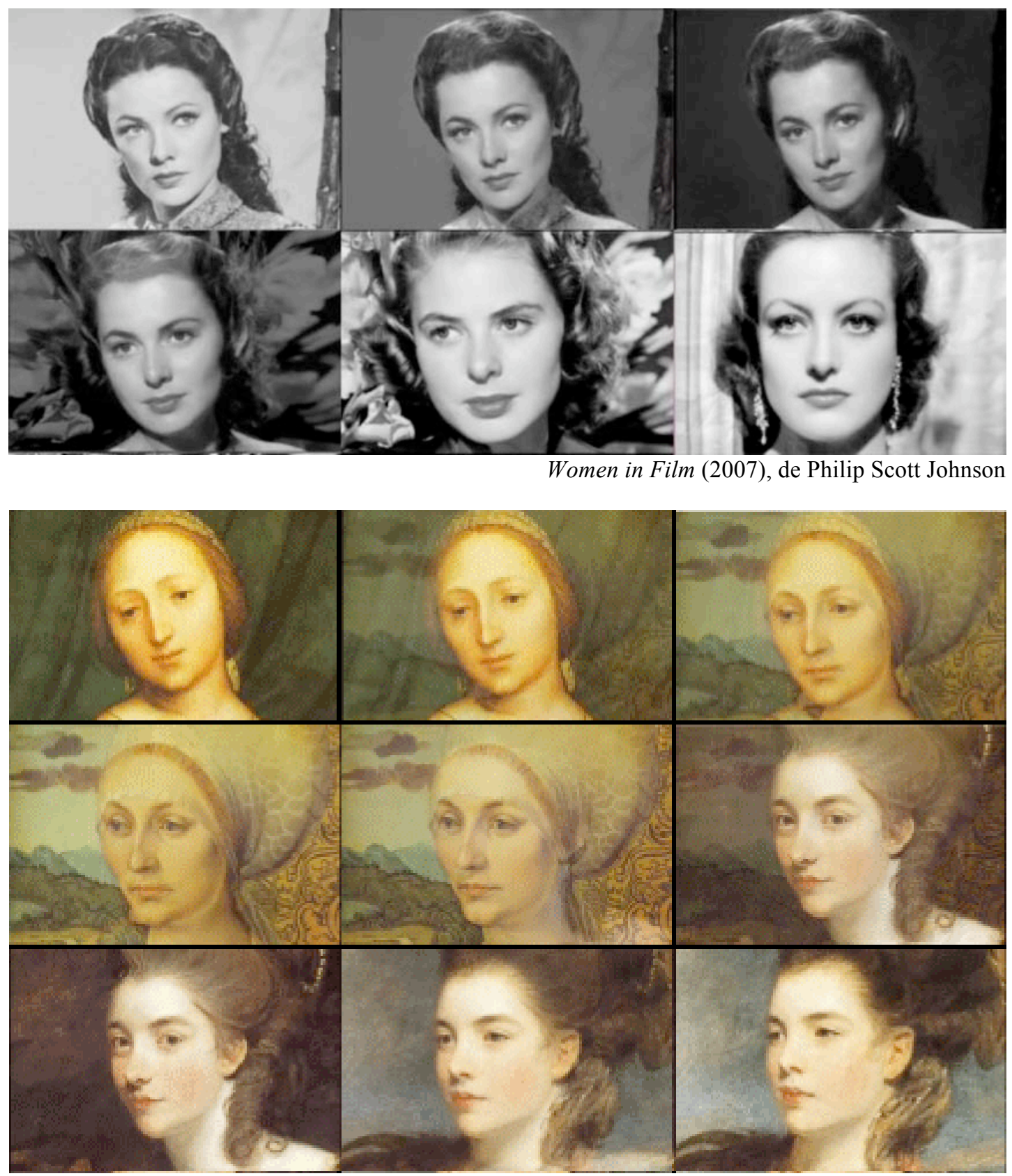

Women in Art (2007), de Philip Scott Johnson 
Monument (1967), de Ture Sjölander y Lars Weck ${ }^{7}$ cuenta con un antecedente videográfico del morphing. En él, una reproducción del cuadro de Leonardo da Vinci "La Joconde" (1503-1519) da paso a una fotografía de Sophia Loren. La metamorfosis entre las dos imágenes fijas se produce de manera gradual gracias a una incrustación electrónica. Este montaje espacial pone de relieve las semejanzas entre la actriz y la Mona Lisa, estableciendo un canon de belleza compartido, en la misma línea de las animaciones digitales de Johnson. Ahora bien, aunque el efecto analógico de transición lisa es uno de los más logrados hasta entonces, el proceso se basa en la sustitución del rostro de la Gioconda por el de la actriz: en ningún momento se produce un warping. La continuidad es el producto de una calculada composición: por un lado, se renuncia al color; por otro, se hace coincidir las dimensiones y el escorzo de las imágenes fuente. El efecto no hace sino subrayar ese sueño de metamorfosis, ese anhelo de transformar la imagen fotográfica con la facilidad de un dibujo animado, que apuntábamos ya en el primer capítulo.
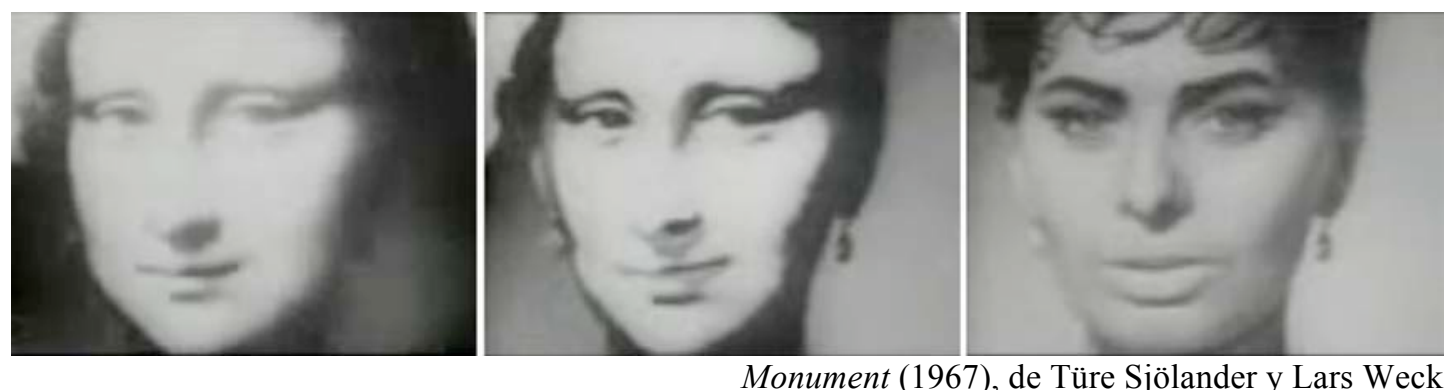

Un año antes de la Electronic Opera \#1 (1968-1969) de Nam June Paik, que sin duda inspira, Monument presenta todo tipo de distorsiones de imágenes de la cultura popular. Los autores seleccionaron una serie de personajes célebres o "monumentos": junto a Sophia Loren y la Gioconda, Charles Chaplin, los Beatles, Picasso... Las alteraciones de las imágenes fuente se realizaron durante el proceso de conversión a la cinta magnética de la película cinematográfica, en la que se habían registrado las fotografías y dibujos originales. ${ }^{8}$ Los rostros son fácilmente reconocibles, de modo que su simbología permanece a pesar de la deformación extrema.

\footnotetext{
${ }^{7}$ El programa experimental fue emitido en enero de 1968 en la Swedish Broadcasting Corporation de Estocolmo (Suecia). Poco antes, Sjölander había presentado la distorsión electrónica de una serie de pinturas en el programa de televisión Time (1966).

${ }^{8}$ YOUNGBLOOD, Gene. Expanded Cinema. Op. cit., p. 331.
} 
En el primer apartado de este trabajo, explicábamos ya cómo el videoarte de los años 60 y 70 comparte con los pioneros de computer art diversos aspectos estéticos: fundamentalmente, la búsqueda de espacios específicos de la imagen, el acceso atómico (eso sí, mucho más controlado en el código que en la señal analógica) y la exploración de dinámicas basadas en la distorsión, la variabilidad y la transformación de found footage.

En lo que concierne a la animación sintética de los pioneros, poníamos el ejemplo de Digital Einstein (1973), de Herbert Franke. Veíamos entonces cómo aquella manipulación de materiales encontrados continuaba con el pop art de artistas como Andy Warhol. A partir de los años 90, la tendencia rebautizada como "mashup" se asocia tanto al intercambio de información en la Web como a la popularización de la edición. En lugar de construir desde cero, se trata de partir de la imagen para transformarla: la intervención niega la mera reproducción mimética del espacio y ensalza la construcción de nuevas dinámicas específicas de la imagen.

En este contexto, Godfrey Reggio se sirve del found footage para realizar todo un catálogo de efectos digitales en la ya citada Naqoyqatsi (2002). El realizador americano acude, entre otros, a varios cuadros de artistas como Francis Bacon, Frida Kahlo o Vincent Van Gogh. Como en Monument, la elección de obras compartidas por el imaginario colectivo facilita el reconocimiento de las formas, condenadas a desaparecer de inmediato en una marea abstracta.

Las metamorfosis discontinuas de la imagen dotan de un extraño protagonismo a la superficie de la pantalla: ésta se comporta como una sustancia viscosa, entre el proceso líquido de mutación y el sólido de las figuras que se resisten a la transformación. Ninguno de los cuadros de la historia del arte aparece por completo (como primer y último momento de una interpolación), ni se apilan las capas de manera transparente (como en el encadenamiento de las imágenes por fundido). Lejos del morphing homogéneo, Godfrey Reggio muestra a la vez fragmentos de las imágenes de partida, creando un espacio de corrientes cambiantes en una mezcla heterogénea.

Hallamos un caso similar en el videoclip del grupo musical Blouse Ghost Dream (2012), dirigido por Gusti Fink y Helmut Ash Kaway. En él, una serie de fotografías se encadenan en un efecto de disolución. Si observamos las capturas 2 y 3 mostradas abajo, comprobaremos que el extraño cross-dissolve se sitúa a medio camino entre la sobreimpresión y la deformación de los estados intermedios, requisito 
del morphing. Las fotografías retocadas se asemejan a los óleos de Joaquín Sorolla y John Singer Sargent. Como en Monet de Philip Scott Johnson, este paralelismo con el impresionismo pictórico difumina los contornos y añade fluidez a la transición entre las imágenes.

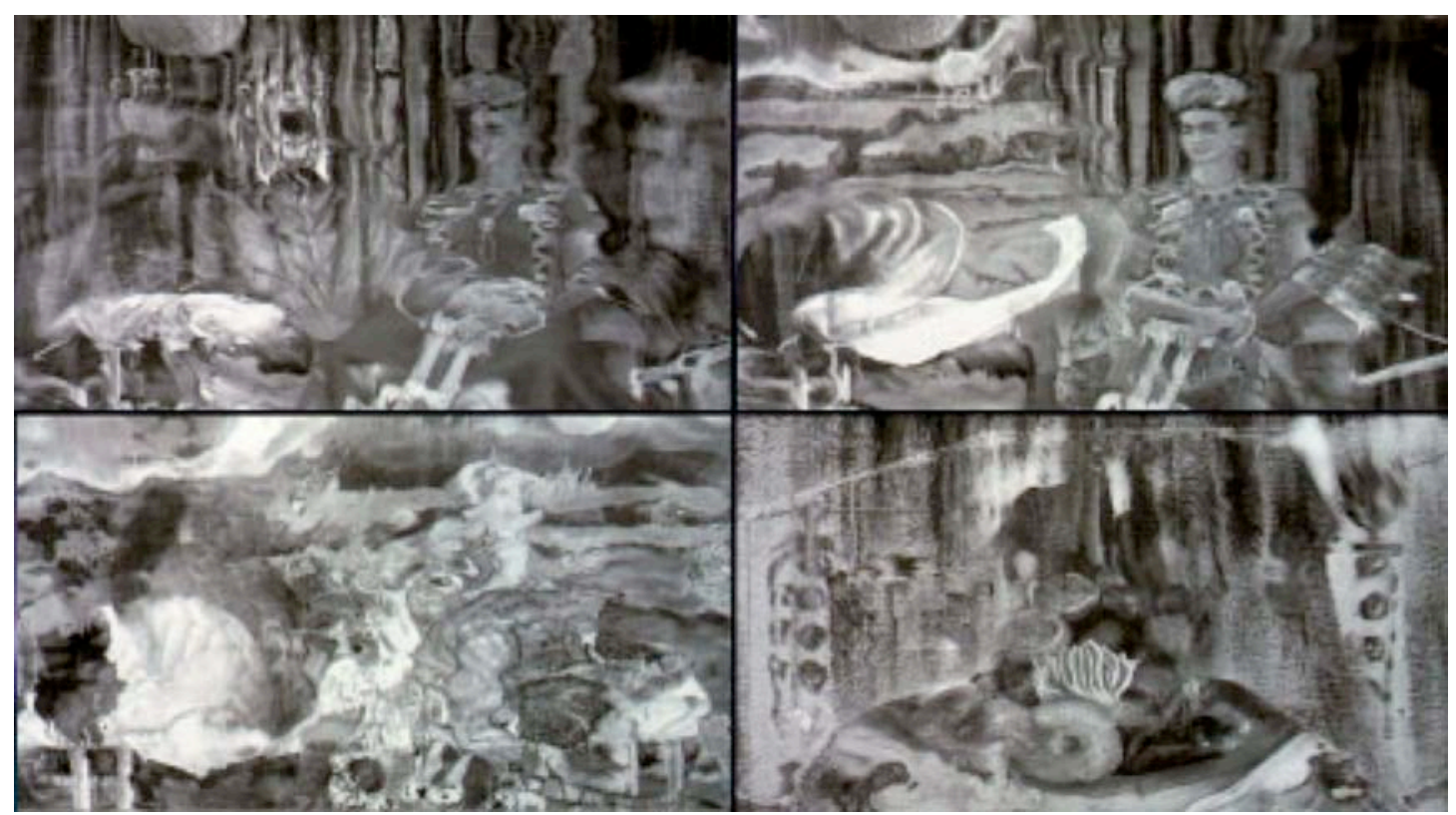

Naqoyqatsi (2002), de Godfrey Reggio

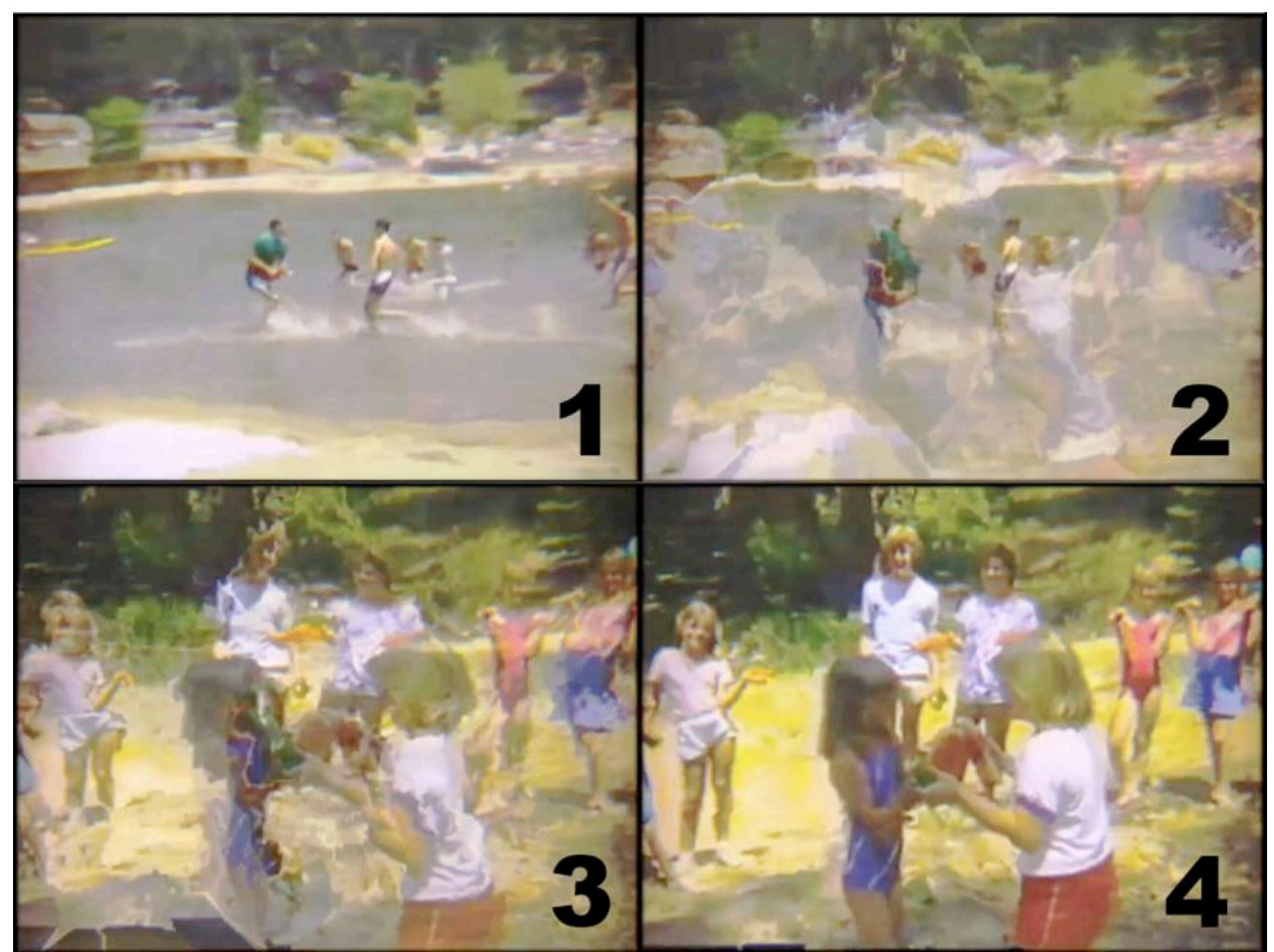

Ghost Dream (2012), de Gusti Fink y Helmut Ash Kaway para Blouse 
Retomemos el videoclip de Michel Gondry Like a Rolling Stone (1996), citado en relación a la instantánea tridimensional. Aunque partiendo igualmente de una serie de fotografías ${ }^{9}$, lejos de la transparencia de las costuras del bullet time, la activación de la imagen se basa en la distorsión espacial. Si bien la interpolación genera también una cámara virtual, en esta ocasión, el resultado es un entorno líquido caracterizado por la desestabilización del cuadro y las mutaciones interdimensionales: entre las tres dimensiones que figura el registro fotográfico y las dos dimensiones de la superficie de la imagen.
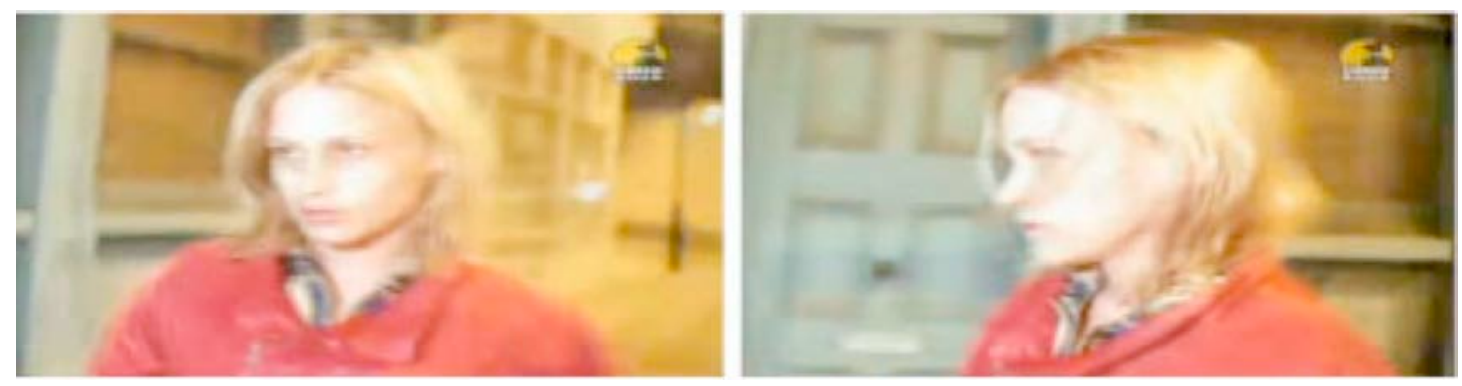

Like a Rolling Stone (1996), de Michel Gondry

Utilizando dos técnicas diferentes, las dos obras siguientes comparten la exploración de dinámicas de la imagen digital para dar forma a una problemática semejante: Darkness (Not Darkness), de Kurt Ralske (2005), y Ground (2011), de Ryoichi Kurokawa, parten del imaginario de la destrucción bélica. En la instalación de tres canales de vídeo Ground, el artista japonés anima las fotografías del reportero belga Daniel Demoustier. La obra destaca por la tensión entre figuración y distorsión provocada por la mutación entre las instantáneas.

Seis años antes, Kurt Ralske había concebido una pieza de unos 30 minutos de duración, que retrata el sinsentido de la guerra mediante una cadena de deformaciones fantasmagóricas. Construido a partir de fotografías y tomas que documentan la primera guerra del Golfo, el flujo de metamorfosis funde en una misma entidad espacial el desierto iraquí, el cielo nublado por el humo de las explosiones, el petróleo, el fuego... Si bien Ralske se cuida de no desmontar totalmente la figuración, el constructo atemporal destruye la cualidad de índice de las fotografías originales. El paisaje apocalíptico de Darkness (Not Darkness) es el producto de un proceso

\footnotetext{
${ }^{9}$ Las imágenes fijas de partida corresponden tanto a instantáneas como a frames aislados del registro videográfico. A partir de aquel material bruto, se crearon hasta 1.000 warping, que dieron lugar a la secuencia. Like a Rolling Stone [En línea]. Ars Electronica Archive. Prix Ars Electronica 1996. Disponible en Web: <http://90.146.8.18/en/archives/prix_archive/prix_projekt.asp?iProjectID=2438>
} 
semejante a la slit scan que veíamos en el apartado dedicado al objeto espaciotemporal: frente a la interpolación, que llena los intersticios entre los frames de partida, en la obra de Ralske se trata de redistribuir los píxeles ya existentes.
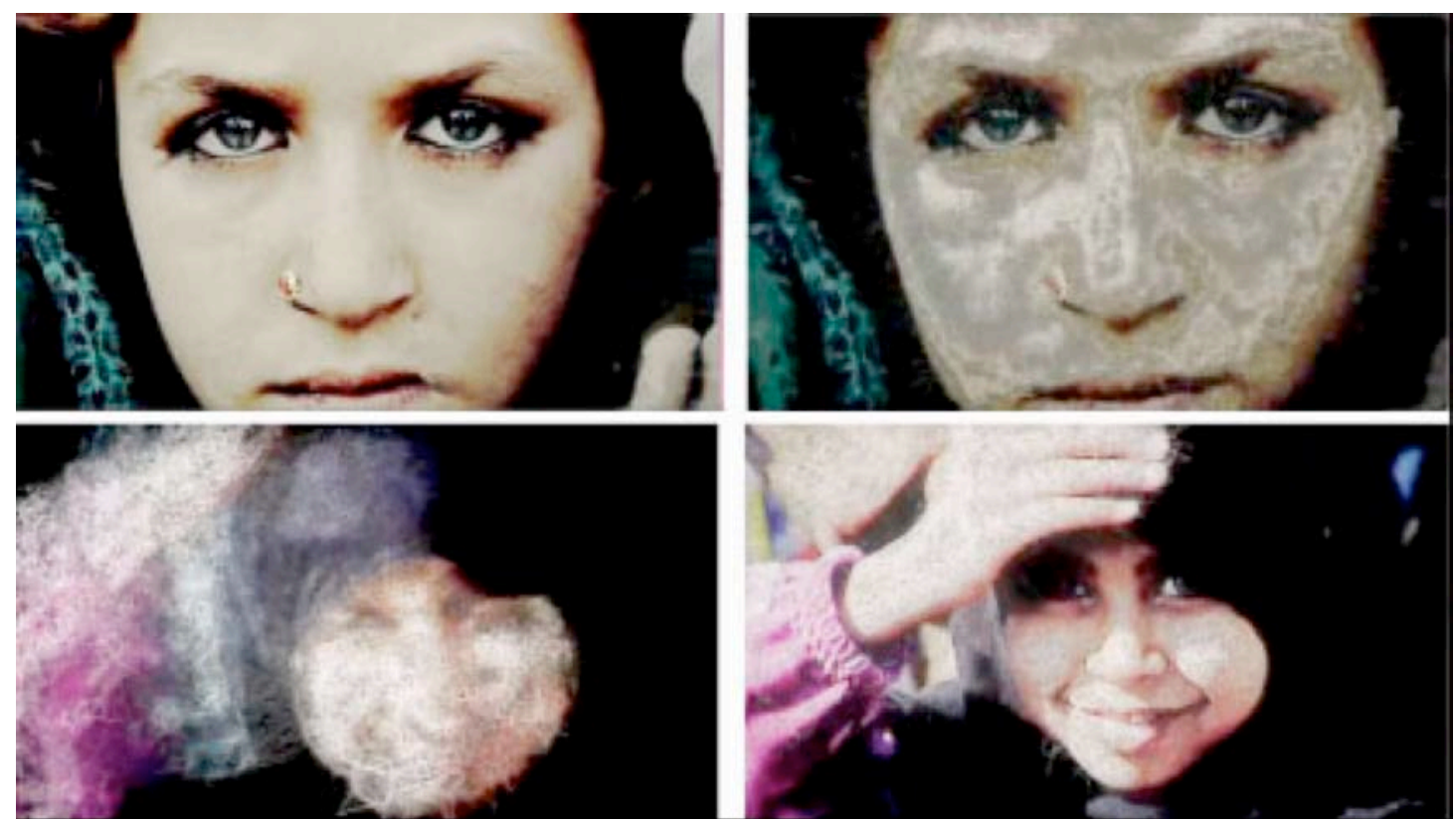

Ground (2011), de Ryoichi Kurokawa

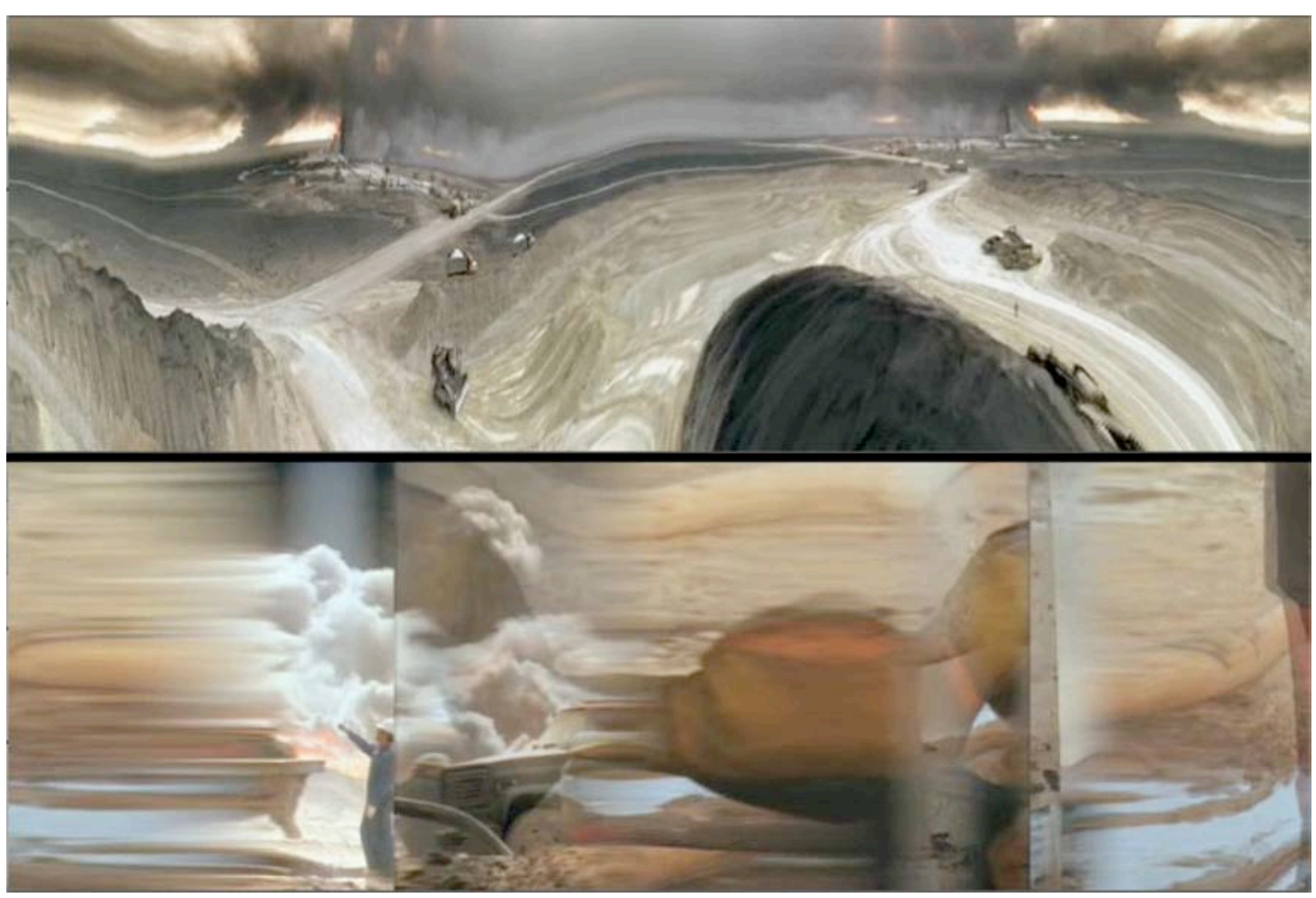

Darkness (Not Darkness) (2005), de Kurt Ralske 
Nótese que, si bien a lo largo de este trabajo hemos insistido en el carácter elástico del espacio digital ${ }^{10}$, no debemos por ello reducir a este aspecto la plasticidad de la imagen código. Precisamente, en este apartado, nos esforzamos por destacar la variedad de manifestaciones de estas dinámicas más allá de la reproducción del movimiento; o dicho de otro modo: se trata de mostrar la potencia plástica de la imagen digital en su multiplicidad. Plasticidad no es, tan sólo, elasticidad; es, entre otros, capacidad de condensación.

\section{La condensación}

En el primer capítulo, citábamos The Late Night Triad (2003), de Jason Salavon, como ejemplo de transformación de found footage mediante una visualización de datos: el algoritmo definido por el autor calcula imágenes media a partir de tres shows televisivos. La construcción resultante es una condensación de las emisiones de partida, que ensalza los aspectos permanentes y elimina los cambios particulares.

Cuatro años después de Darkness (Not Darkness), en Faust Golden Vivisection (2009), el mismo Kurt Ralske condensa la película Faust. Eine deutsche Volkssage (1926) de F. W. Murnau. Las casi dos horas de duración del original quedan reducidas a apenas tres minutos. Como en The Inevitable, que analizábamos en el aparatado dedicado a la "cohabitación de las imágenes", se trata de partir de la imagen como una base de datos. De este modo, la transformación no responde al cálculo de imágenes intermedias (como en la interpolación), sino al análisis de la información.

Al partir de found footage, Ralske pretende hacer aflorar aspectos ocultos en el material de partida y que pueden sorprender al mismísimo autor. En este sentido, su exploración plástica se relaciona con el "azar controlado" de los pioneros del computer art. Tal y como afirma con respecto a su serie de imágenes fijas Silent Accretions (2009): "Las imágenes fueron descubiertas, no creadas."11

Entre la mezcla y la cohabitación, Faust Golden Vivisection se compartimenta en regiones que presentan simultáneamente las escenas, a su vez, comprimidas. La nueva construcción descompone el espacio-tiempo diegético de la película muda: "Si

\footnotetext{
${ }^{10}$ Pensamos, entre otros, en los cambios de escala de la cámara virtual, en la animación por morphing o en las transiciones espacio-temporales continuas.

${ }^{11}$ RALSKE, Kurt. Silent Accretions [En línea]. Retnull.com, 2009. Disponible en Web:

$<$ http://retnull.com/index.php?/project/about-time/>
} 
del cine se elimina la narración, la duración y la coherencia del tiempo linear, ¿qué queda?" "12 se pregunta el autor. Queda el juego de figuración/distorsión; quedan nuevas relaciones entre las formas.

Lejos de la narración, su interés recae en la relación entre fijación y movimiento. En el apartado dedicado a "El continuo espacio-temporal”, citábamos el ensayo del mismo Ralske titulado "Sobre la atemporalidad" (2005). En él, el artista propone romper con el frame en tanto que unidad mínima e indivisible, a favor de la concepción de la imagen digital como un conjunto de datos manipulables, más allá de la mera reproducción de la secuencia del movimiento. Ahora, si en el corte del objeto espacio-temporal se trata de redistribuir los píxeles, en esta ocasión, Ralske se decanta por la condensación del material de partida.

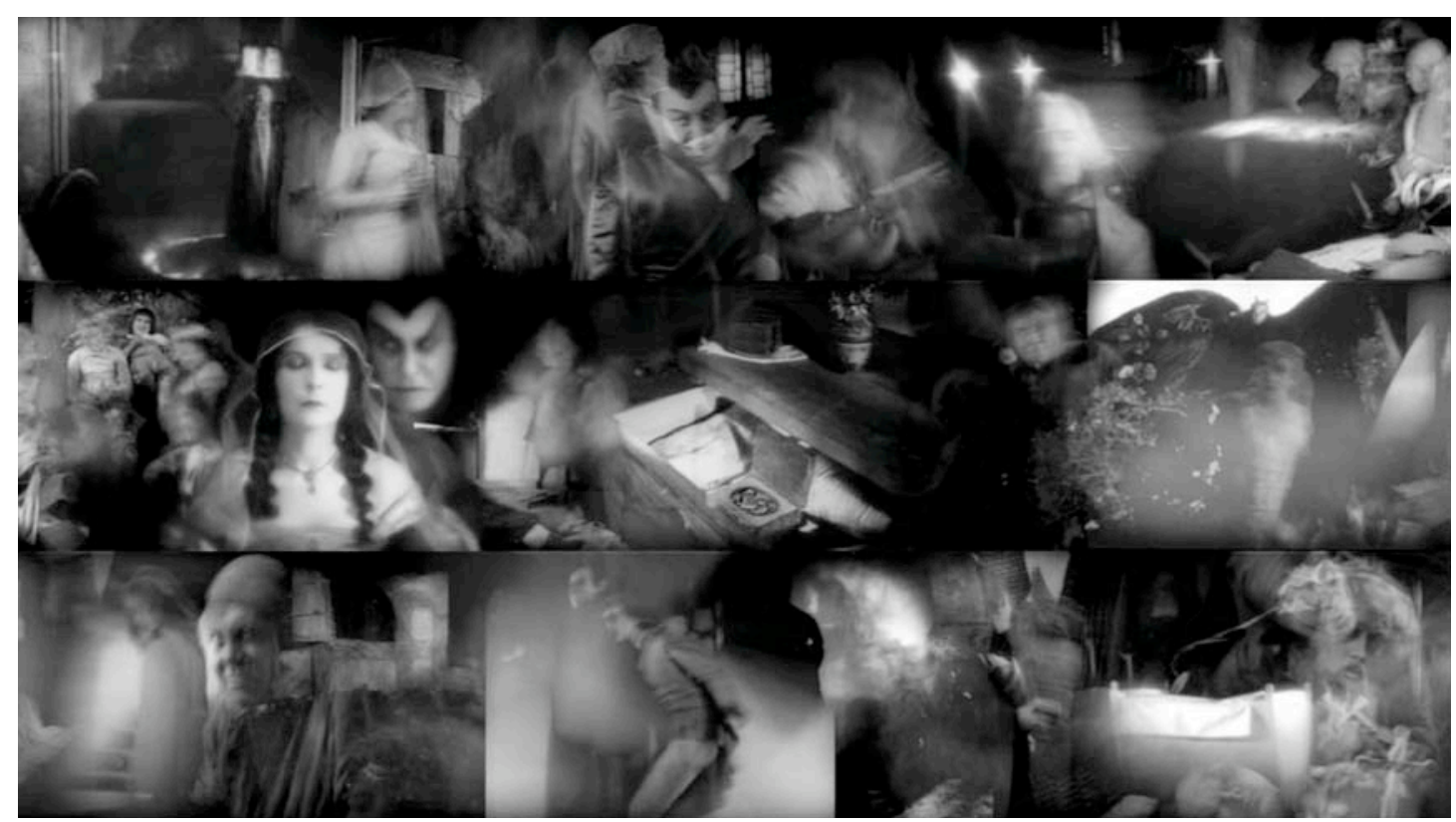

Faust. Eine deutsche Volkssage (2009), de Kurt Ralske

Veamos otro ejemplo de esta concentración espacial en tanto que dinamización y exaltación de las nuevas relaciones espaciales que ésta provoca: el efecto conocido como "datamoshing" o "pixel bleed", reinterpretación artística de la compresión de datos. Sin entrar en aclaraciones excesivamente técnicas, conviene hacer notar que los frames que componen una secuencia de vídeo digital se dividen en "I frames" y "delta frames". Los primeros corresponden grosso modo a los "key frames", mientras que los segundos no son más que pasos intermedios entre aquéllos: los delta frames

\footnotetext{
${ }^{12}$ RALSKE, Kurt. Faust (Murnau, 1926) [En línea]. Retnull.com, 2009. Disponible en Web: $<$ http://retnull.com/index.php?/selected-works/faust/>
} 
registran, tan sólo, las diferencias entre dos key frames, obviando la información redundante de una imagen a otra.

Normalmente, el hecho de comprimir un vídeo digital tiene como objeto aligerar el peso del archivo, para lo cual es necesario sacrificar cierta información; hablamos entonces de "compresión con pérdida". En principio, esta "pérdida" pasa desapercibida a ojos del espectador; no obstante, es posible manipular el procedimiento algorítmico de modo que la información desechada sí afecte a la figuración: en lugar de prescindir de la información superflua, se procede a la inversa, eliminando, justamente, los I frames. Así, en lugar de reproducirse el movimiento en la secuencia, se trata de concentrarse en las nuevas mutaciones que provoca el paso entre varios delta frames.

Más arriba, recordábamos el programa experimental Monument (1967), de Sjölander y Weck; veíamos entonces cómo el procesamiento de la imagen videográfica tenía lugar durante la conversión de la película fotográfica en la señal electrónica. En el efecto digital que nos ocupa, en lugar de tratarse de una alteración de dicha señal, se actúa en la codificación de los datos, en su almacenamiento.

Puesto que el datamoshing consiste en producir intencionalmente un error en la codificación de los datos, es considerado como una categoría de "glitch art"13. En el campo tecnológico, el término "glitch" hace referencia a una disfunción del sistema, un problema que interrumpe o arruina la comunicación. ${ }^{14}$ La apropiación artística del vocablo proviene del ámbito musical y designa la aceptación o imitación del ruido tecnológico como parte de la estética de un medio determinado. ${ }^{15}$ El videoclip Welcome to Heartbreak (2009), de Nabil para Kanye West, muestra bien el paralelismo entre esta interpretación artística del fallo y los experimentos de Fluxus o la corriente "estructuralista" de los 60 y $70 .{ }^{16}$

\footnotetext{
${ }^{13}$ Cfr. MORADI, Iman. Glitch Aesthetics [En línea]. Oculasm.org, 2004. Disponible en Web: $<$ http://www.oculasm.org/glitch/download/Glitch_dissertation_print_with_pics.pdf $>$

${ }^{14}$ De acuerdo con The American Heritage Dictionary, el uso del término "glitch" asociado a una interferencia tecnológica se remonta a 1962 y se atribuye al astronauta John Glenn. Disponible en Web: $<$ http://www.ahdictionary.com/word/search.html?q=glitch $>$

${ }^{15}$ CASCONE, Kim. "The Aesthetics of Failure: 'Post-Digital' Tendencies in Contemporary Computer Music”. Computer Music Journal. December 2000, vol. 24, núm. 4, pp. 12-18.

${ }^{16}$ Bautizada en 1969 por el crítico estadounidense P. Adams Sitney, la corriente estructuralista incluye autores como Michael Snow, George Landow, Hollis Frampton, Paul Sharits, Tony Conrad, Ernie Gehr o Joyce Wieland. SITNEY, P. Adams. Film Culture Reader. New York: Cooper Square Press, 1970, pp. 326-348.
} 

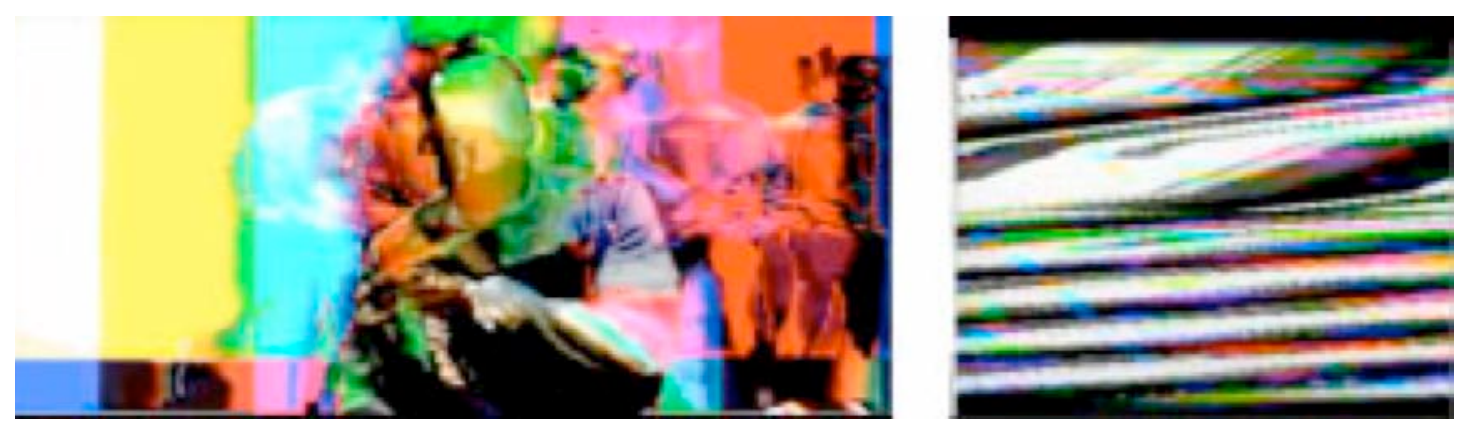

Izquierda, Welcome to Heartbreak (2009), de Nabil. Derecha, Wavelength (1967), de Michael Snow

El ruido ligado al medio evidencia el dispositivo y "habla" de la imagen en cuanto tal. Si el cine de las vanguardias históricas subraya el carácter fotográfico de la imagen, y el videoarte actúa sobre la emisión de la señal videográfica, el pixel bleed no hace sino destacar el carácter digital de la imagen: su condición de código. Ahora, en el caso de la imagen digital, esa búsqueda del ruido es aún más explícita, aún más voluntaria, en cuanto la tecnología avanza, al contrario, hacia una imagen cada vez más nítida. Tal y como afirma James Bridle en relación a su "New Aesthetic" ${ }^{17}$ :

\begin{abstract}
"Las imágenes pixelizadas son uno de los tótems de la Nueva Estética. (...) El píxel está a punto de desaparecer porque la tecnología ha avanzado tanto que se vuelve invisible, así que llegaremos a un punto en el que la Nueva Estética se convertirá en una suerte de nostalgia por un momento particular. ${ }^{18}$
\end{abstract}

En Pastell Kompressor (2003), Owi Mahn y Laura Baginski llevan al extremo la desfiguración del datamoshing. Aunque el título remite a la técnica pictórica del pastel, el efecto se antoja más cercano al acrílico diluido en aguarrás. Comparémoslo, por ejemplo, con el "dripping” ("goteo") de Morris Louis (1912-1962) en obras como "Beth Aleph" (1960). El pintor americano inclina el lienzo dejando al pigmento correr por la tela; el arcoíris resultante subraya la superficie del lienzo. Frente a esta exaltación de la bidimensionalidad típica de la pintura moderna ${ }^{19}$, el pixel bleed no

\footnotetext{
17 "In a sense, what the New Aesthetic truly represents is the eruption of a new kind of banality. It is the arrival of digital motifs, glitches and artefacts in the realm of the commonplace and the trivial." James Bridle. Apud. WILES, Will. The machine gaze. As the boundaries between digital and physical dissolve, can the New Aesthetic help us see things more clearly? [En línea]. Aeonmagazine.com, September 17, 2012. Disponible en Web: <http://www.aeonmagazine.com/world-views/will-wilestechnology-new-aesthetic/>

${ }^{18}$ BRIDLE, James. Entrevista realizada por Robert Urquhart. An interview with James Bridle of the New Aesthetic [En línea]. Huffington Post UK., 8 de mayo de 2012. Disponible en Web: $<$ http://www.huffingtonpost.co.uk/robert-urquhart/an-an-interview-with-jame_b_1498958.html>

19 "It was the stressing of the ineluctable flatness of the surface that remained, however, more fundamental than anything else to the processes by which pictorial art criticized and defined itself
} 
aniquila la profundidad; por el contrario, subraya el carácter multidimensional del espacio digital. En el próximo y último apartado, volveremos sobre el expresionismo abstracto y veremos cómo algunas construcciones digitales comparten con la action painting la importancia del proceso plástico.

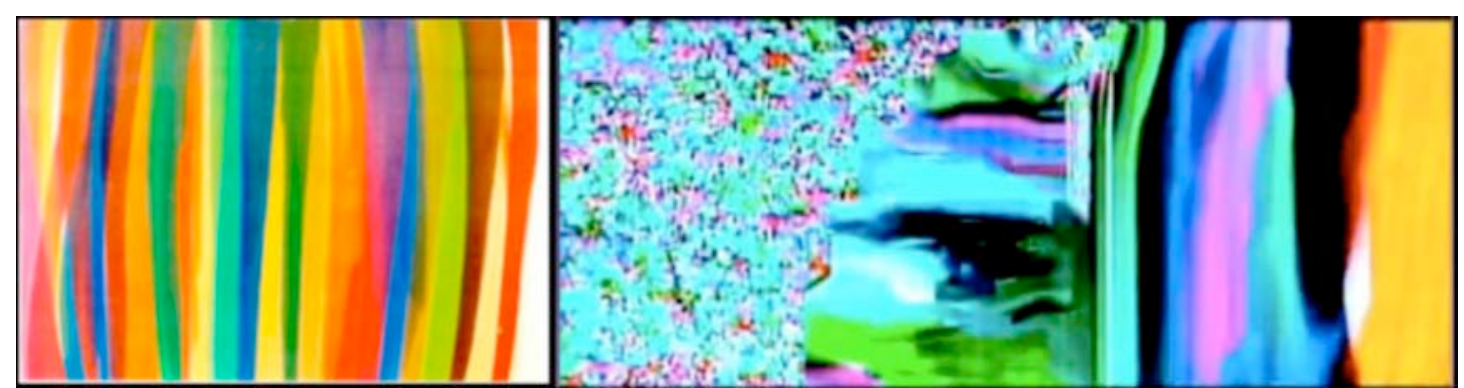

Izquierda, Morris Louis: "Beth Aleph" (1960). Derecha, Pastell Kompressor (2003), de Mahn y Baginski

La producción intencional de un error en la codificación de la imagen hace brotar la matriz digital: la potencia estética del pixel bleed reside, precisamente, en la paradoja $^{20}$ de la contemplación de esa estructura subyacente. El datamoshing libera el píxel o lo reagrupa siguiendo la lógica vectorial de los delta frames. La metamorfosis de la imagen permite apreciar la matriz, que se debate entre la bidimensionalidad de la red de píxeles y la tridimensionalidad de la figuración, en una fiesta de adaptabilidad y potencia plástica.

El corto Losing Touch (2002), de Maximilian Jaenicke, es un buen ejemplo de esta exposición de la textura de la imagen digital mediante el trucaje en la compresión del found footage: aunque la pixelización hace brotar la malla bidimensional, la imagen conserva cierta tridimensionalidad del registro de partida (ver captura 1). Las siluetas se recortan sobre masas de píxeles, que inundan la figura, redefiniendo una y otra vez los contornos. Si aquélla tiende a ganar de nuevo la superficie plana de la red, nuevos volúmenes resurgen de la membrana como un líquido en ebullición. La estructura subyacente se hace explícita mediante un giro de la cámara virtual (ver

\footnotetext{
under Modernism." GREENBERG, Clement. "Modernist painting”. En: The Collected Essays and Criticism, Volume 4: Modernism with a Vengeance. Chicago: University of Chicago Press, 1995, p. 87. 20 "Digital noise artifacts thus exist as a paradox; while they are often negatively defined, they also have a positive, generative or redefining quality. (...) a system exhibiting its formations, inner workings and flaws." MENKMAN, Rosa. "Glitch Studies Manifesto". En: LOVINK, Geert; MILES, Rachel Somers (eds). Video Vortex Reader II: moving images beyond YouTube. Amsterdam: Institute of Network Cultures, 2011, pp. 335-347. Disponible en Web:

$<$ http://networkcultures.org/wpmu/portal/publication/video-vortex-2/>
} 
captura 2): el escorzo desliga la matriz de la pantalla, desvelando la estratificación de los conglomerados de píxeles, que flotan en el negro del espacio sintético.
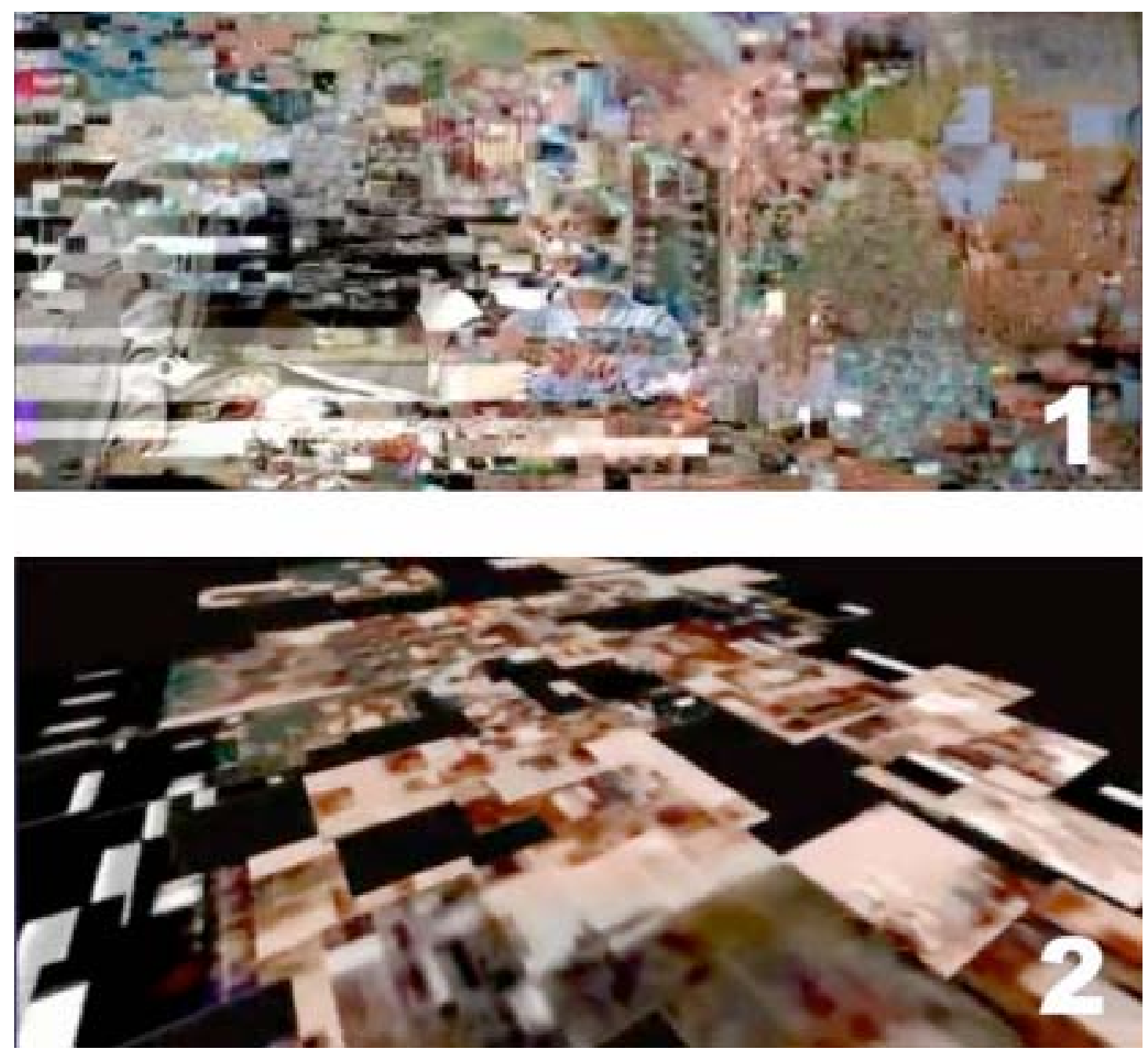

Losing Touch (2002), de Maximilian Jaenicke

Tras Jaenicke, varios artistas acuden al found footage para experimentar con las transformaciones que permite el pixel bleed. Así, por ejemplo, en Monster Movie (2005), Takeshi Murata "recicla" la película de serie B Caveman (1981) de Carl Gottlieb. Murata combina el bucle y la repetición con el efecto que nos ocupa, llevando un paso más allá la deconstrucción típica de obras como Alone: Life Wastes Andy Hardy (1998), de Martin Arnold. Ahora, si éste opera sobre el tiempo cinematográfico $^{21}$, la manipulación del codec afecta fundamentalmente al aspecto espacial.

\footnotetext{
${ }^{21}$ Martin Arnold selecciona escenas que repite en bucle, descomponiendo el entramado diegético del original.
} 


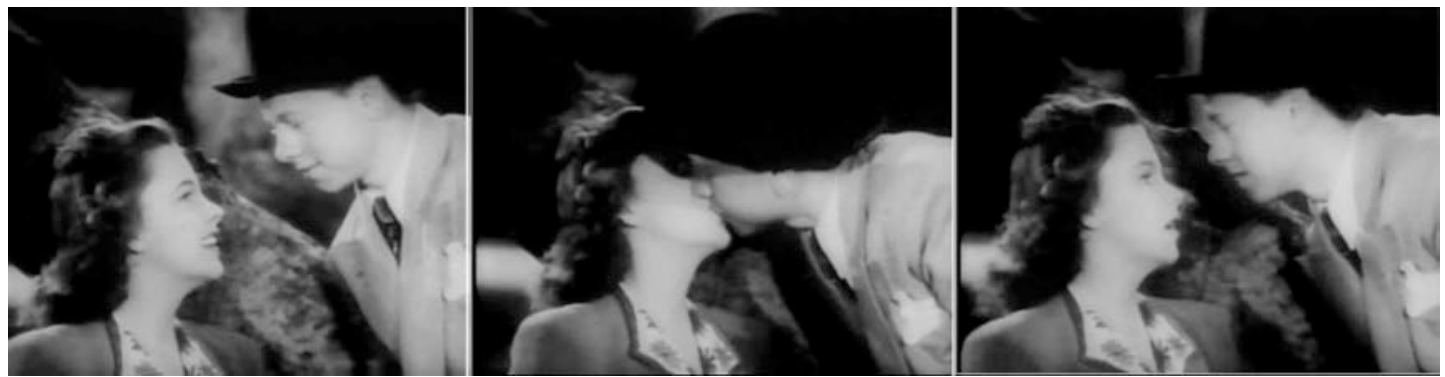

Alone: Life Wastes Andy Hardy (1998), de Martin Arnold
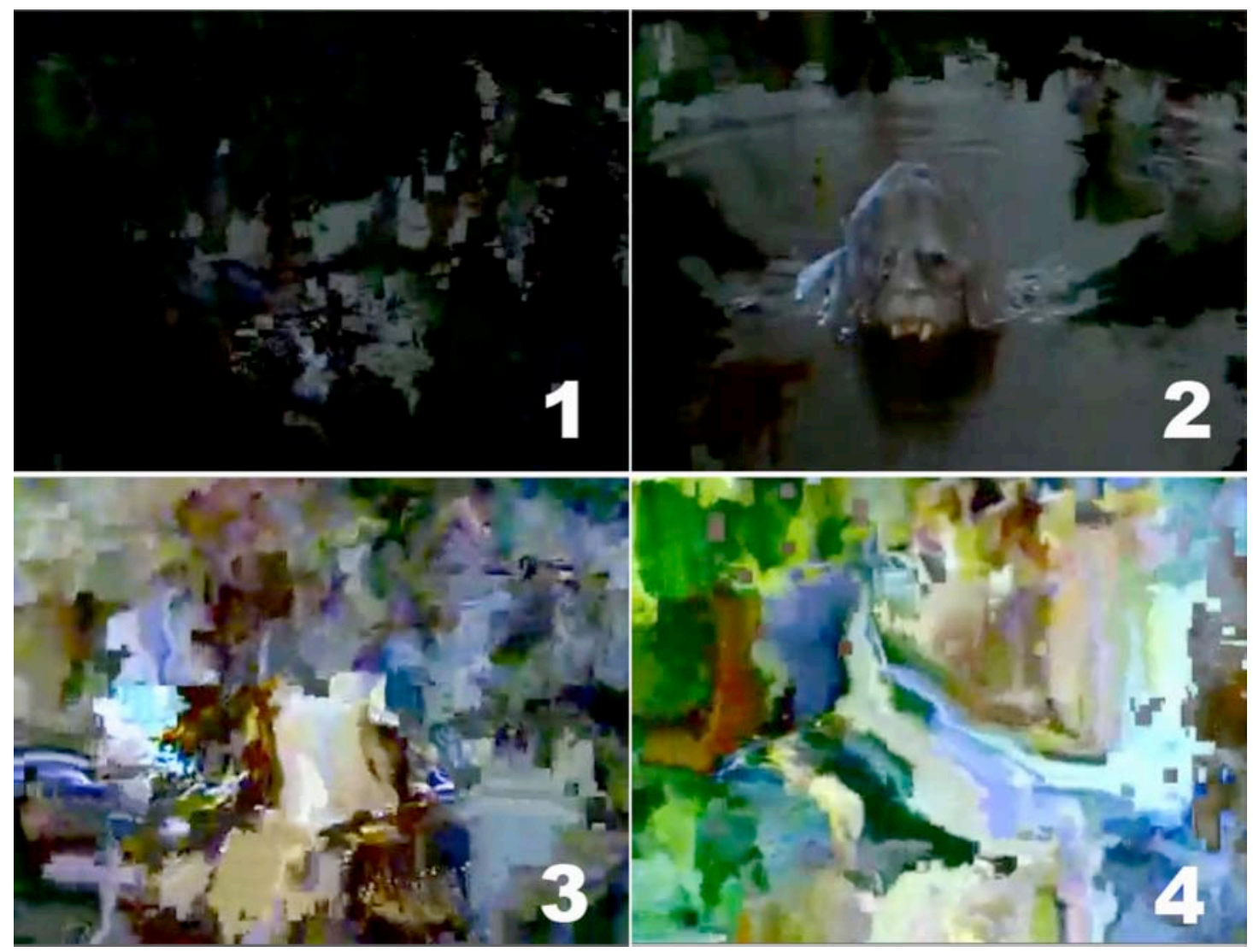

Monster Movie (2005), de Takeshi Murata

Así, no es de extrañar que Murata elija, precisamente, un plano en el que el monstruo que da título a la obra emerge del agua: el elemento se identifica con el flujo del juego plástico. La acción se repite hasta diez veces, provocando una secreción de masas cromáticas que nacen en el centro del plano y se disuelven en los márgenes de la imagen. A medida que dichas repeticiones se encadenan, los píxeles se acumulan en un depósito de colores, semejante a la refracción lumínica en el agua turbia de un charco.

Esta idea de "acumulación" formal puede relacionarse con el canon visual de Zbig Rybczynski en Tango (1980). Eso sí, mientras que éste basaba su ruptura con el espacio homogéneo en la figuración de un "imposible" espacio-temporal, Murata tiende a la abstracción y a la descomposición espacial. Cada instante figurativo no es 
más que una nueva oportunidad de deformación: apenas se atisba una forma reconocible, el "sangrado de píxeles" disuelve el contorno en una maraña indescifrable.

Aunque en algunos casos el resultado del datamoshing podría asociarse con las mezclas estudiadas en el primer capítulo, lo cierto es que el proceso de elaboración subyacente no es exactamente un montaje espacial. Por un lado, mientras que la sobreimpresión se basa en la adición (una imagen se suma a otra), el pixel bleed se fundamenta en la sustracción (la clave está en eliminar información). Al comprimir los datos, la imagen se comporta como un fluido que se adaptara a su recipiente: allí donde se crea un vacío, el líquido viene a invadir automáticamente el espacio. Por otro lado, aunque esta sustitución de contenidos sea cercana al collage, las mutaciones del datamoshing provocan una tensión entre figura y fondo que nada tiene que ver con el silueteado de aquél.

Basta comparar dos videoclips de Ray Tintori para apreciar la diferentes construcciones espaciales en el collage de Time To Pretend (2008) para MGMT, y el pixel bleed de Evident Utensil (2009) para Chairlift. Los dos se caracterizan por el hórror vacui, el entorno y la explosión cromática, pero el trabajo en capas del primero conserva intacta la diferenciación entre figura y fondo, mientras que el segundo provoca una reversibilidad de ambos y, con ella, una continuidad interdimensional.

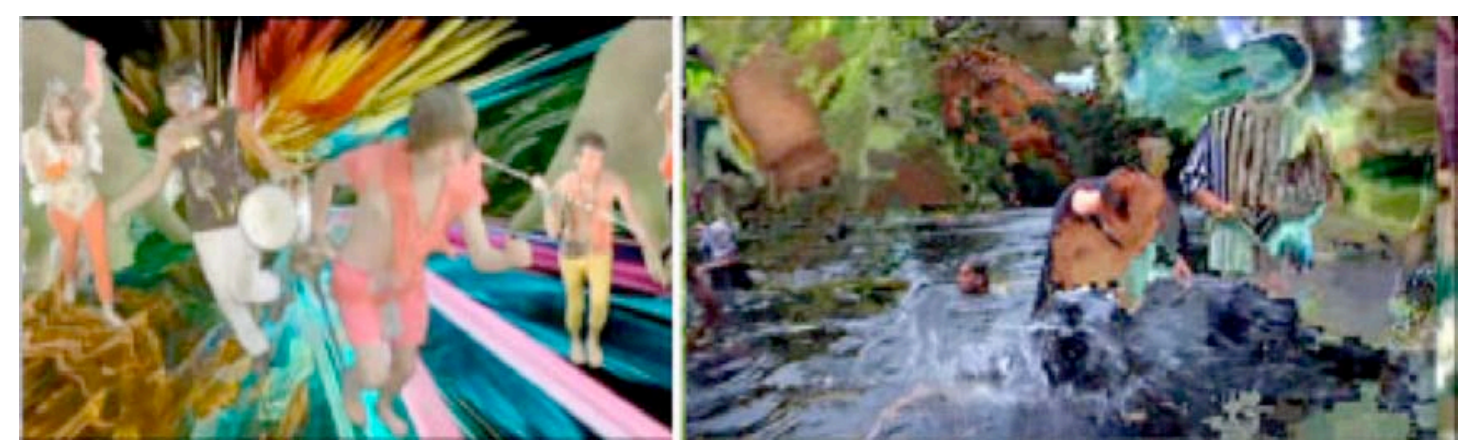

Izquierda, Time To Pretend (2008). Derecha, Evident Utensil (2009). Ambos de Ray Tintori

A este respecto, resulta clarificadora la comparación entre el pixel bleed en Untitled (Silver) (2006) ${ }^{22}$ de Murata y el desenfoque en L'étoile de mer (1928) de Man Ray. El contorno es el límite no material que separa la figura del fondo; si el contorno se difumina, el conjunto se aplana. Como muestra la obra de Ray, esta

\footnotetext{
${ }^{22}$ La transformación afecta a la película de Mario Bava The Mask of Satan (1960), en blanco y negro, hecho que facilita la comparación con L'étoile de mer.
} 
borrosidad provoca tanto una simplificación en masas lumínicas con menor detalle como una continuidad entre figura y fondo. Por su parte, la compresión de los datos produce una invasión de píxeles en el seno de la figura, pero no tiene por qué desaparecer totalmente el contorno o la profundidad de campo. La potencia visual del pixel bleed reside, justamente, en la extraña convivencia entre la desarticulación de la figura y su permanencia; una contradicción de la que nace una rica interacción entre las partes.

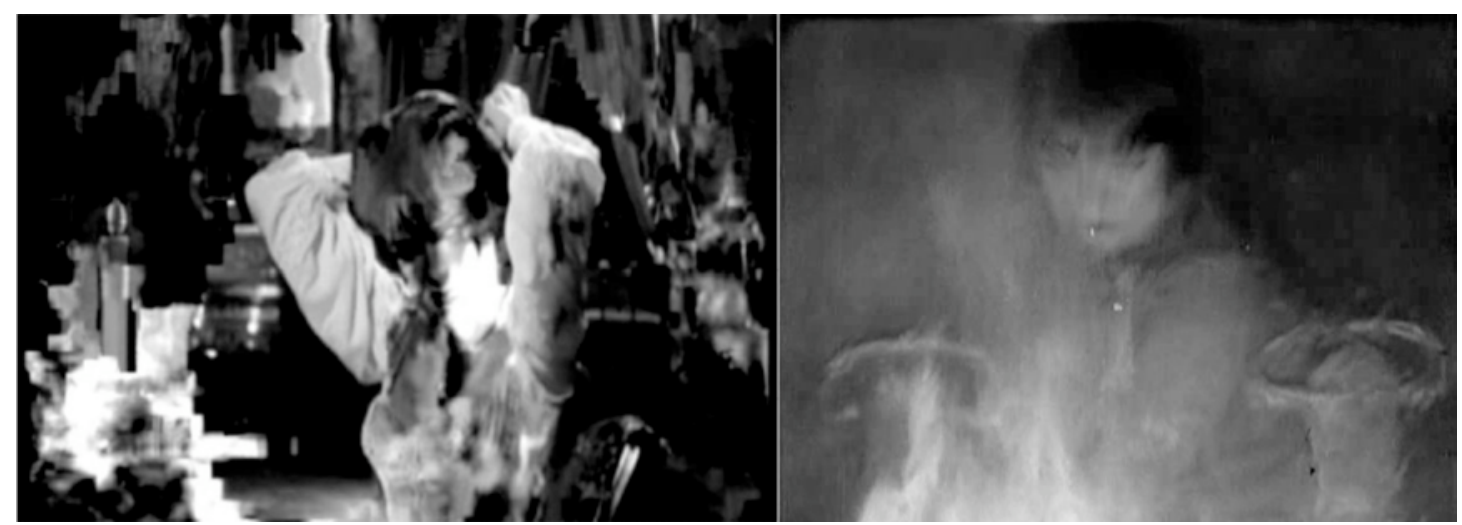

Izquierda, Untitled (Silver) (2006), de Takeshi Murata. Derecha, L'étoile de mer (1928), de Man Ray

Frente al desenfoque, la complejidad del datamoshing remite a la definición de “ambigüedad” dada por Semir Zeki en The neurology of ambiguity (2003). Lejos de la “confusión", la "ambigüedad" se refiere a la "certitud" de una diversidad de lecturas coexistentes:

"Una definición de ambigüedad basada en la neurobiología es lo contrario de la definición del diccionario; no es incertitud, sino certitud: la certitud de muchas e iguales interpretaciones plausibles, cada una de las cuales es soberana cuando ocupa el estado consciente. ${ }^{23}$

Zeki ejemplifica su análisis con una serie de obras de arte: los cuadros de Vermeer, la Piedad Rondanini de Miguel Ángel y el torso del Belvedere. Respeto a este último, el autor recupera el análisis que el historiador Johann Winckelmann (1717-1768) realiza de la obra griega y a la que dice admirar por "su continuo flujo

\footnotetext{
${ }^{23}$ ZEKI, Semir. "The neurology of ambiguity". Consciousness and Cognition. March 2004, vol. 13, núm 1, p. 175.
} 
de una forma a otra"24. Así entendido, el concepto de ambigüedad basado en la neurociencia encaja perfectamente con la imagen-metamorfosis.

Suele compararse la pixelización de la imagen digital con la corriente pictórica del puntillismo ${ }^{25}$, en cuanto la síntesis visual del color se produce únicamente a cierta distancia del cuadro; un acercamiento excesivo revela la matriz cromática que subyace al efecto óptico. No obstante, el datamoshing muestra una multidimensionalidad y una tensión figura/fondo, cuya complejidad sobrepasa con creces la mera pixelización. En este sentido, el efecto remite, más bien, al biomorfismo del pintor ruso Pavel Filonov:

\begin{abstract}
"Un cuadro de Filonov crece como un organismo vivo. Está constituido de todas esas partículas elementales, de todos esos átomos, de todas esas células que contribuyen a la formación del organismo. La estructura atómica de la composición es aparente por todos lados." 26
\end{abstract}

En Evident Utensil, el datamoshing provoca una imbricación de figura y fondo, una penetración del paisaje en el cuerpo mismo de los miembros de la banda musical. Esta continuidad espacial es característica de la pieza electrónica de Steina Vasulka Lilith (1987). La artista distorsiona el rostro de la pintora Doris Cross hasta sumergirlo en el paisaje frondoso que la envuelve. Más allá de las referencias al feminismo (que comparte con videoartistas como Ulrike Rosenbach), el contenido telúrico de la obra es similar al biomorfismo de Filonov.

El primer plano de la pintora es invadido por los tonos verdes de la vegetación, de manera semejante al cuadro de Henri Matisse "Portrait de Madame Matisse" (1905). Como hiciera Nam June Paik veinte años antes, Vasulka trata la imagen videográfica como un lienzo. Así, la liberación de la mujer encuentra un eco en la liberación artística, en la emancipación del espacio de la imagen de la mera reproducción del registro.

\footnotetext{
${ }^{24}$ Johann Winckelmann. Apud. Ibídem, p. 193.

${ }^{25}$ La comparación es recurrente desde que la pionera del arte por ordenador Lillian F. Schwartz utilizara la expresión "technological pointillism" para explicar el carácter artístico de sus primeras investigaciones en los años 60. SCHWARTZ, Lillian. Entrevista realizada por Leo Kent. Meet Lillian Schwartz: The mother of digital art [En línea]. Humansinvent.com, 20 de marzo de 2012. Disponible en Web: <http://www.humansinvent.com/\#!/6210/meet-lillian-schwartz-the-mother-of-digital-art/> Por su parte, Donald Kuspit llega incluso a considerar que "el puntillismo de Seurat le convierte en el primer artista digital." KUSPIT, Donald (ed.). Arte digital y videoarte: transgrediendo los límites de la representación. Madrid: Círculo de Bellas artes, 2006, p. 19.

${ }^{26}$ DINER, Simon. Op. cit., p. 13.
} 
En su afán por rearticular el espacio videográfico, la artista se sirvió de varias técnicas analógicas para la manipulación de la imagen y el sonido: por un lado, mediante un Vocoder, codificó la voz de Cross haciendo ininteligible su discurso sobre la pintura y la identidad femenina en el arte. Por otro lado, en lo que a la transformación visual se refiere, Vasulka utilizó una "clave de luz" ("luminance keyer"), que le permitió eliminar las partes oscuras del rostro e insertar en el hueco así reservado otras tomas ligeramente desfasadas. Como resultado, conviven en la imagen distintos tiempos. Vasulka exhibe el proceso de transformación como una activación de la imagen distinta a la reproducción del registro; con ello, renuncia a la temporalidad de la imagen-huella a favor de la estructuración espacial. En este sentido, la obra prueba una continuidad entre la estética del videoarte y las construcciones digitales que nos ocupan. ${ }^{27}$.

Ahora bien, al comparar detenidamente la mezcla electrónica en Lilith con el procesamiento digital de los datos en obras como Evident Utensil, comprobamos cómo la atomicidad del datamoshing es superior al acceso espacial que permite la incrustación electrónica. Aunque el paisaje verdoso inunda el rostro de la pintora, la obra de Vasulka conserva la estratificación de la imagen en capas. Por su parte, el pixel bleed ignora las fronteras no sólo entre figura y fondo, sino entre los mismísimos frames, provocando una continuidad interdimensional sólo posible en la imagen digital. Esta potencia plástica se explica gracias a su doble matriz: por un lado, la condición atómica de la imagen digital, la malla de píxeles individualmente accesibles; por otro, el código numérico subyacente, que permite forzar el error de almacenamiento, del cual el datamoshing es la manifestación visual.

Esta interpenetración de figura $y$ fondo puede ser asociada con las interpolaciones de Philip Scott Johnson, que analizábamos al principio de este apartado. No obstante, el proceso de construcción de dinámicas en la interpolación es exactamente el contrario del datamoshing: en el cálculo de las imágenes-media, el ordenador parte de los key frames; por el contrario, el pixel bleed elimina, justamente, estas "imágenes clave".

\footnotetext{
27 "Steina, in Lilith, presents the process rather than the results of transfiguration, because the constantly changing image fields perform, in real time, a smooth shifting from temporal to spatial organization - similar to digital articulation. (...) The flexible quality of the visual imagery emphasizes the spatial dimension, so that the image-as-object is overtaken by the medium of presentation. The result is an 'almost sculptural fusion of human figure and landscape'." SPIELMANN, Yvonne. Op. cit.
} 


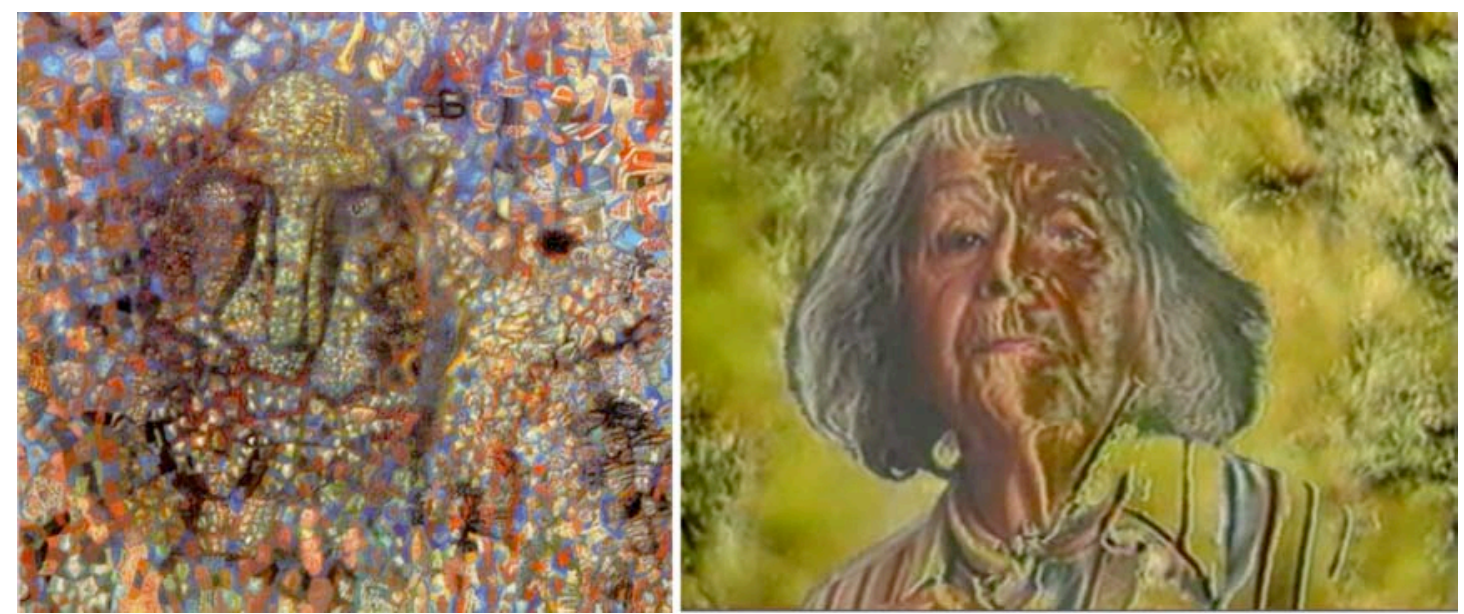

Izquierda, Pavel Filonov: "Head" (1930). Derecha, Lilith (1987), de Steina Vasulka
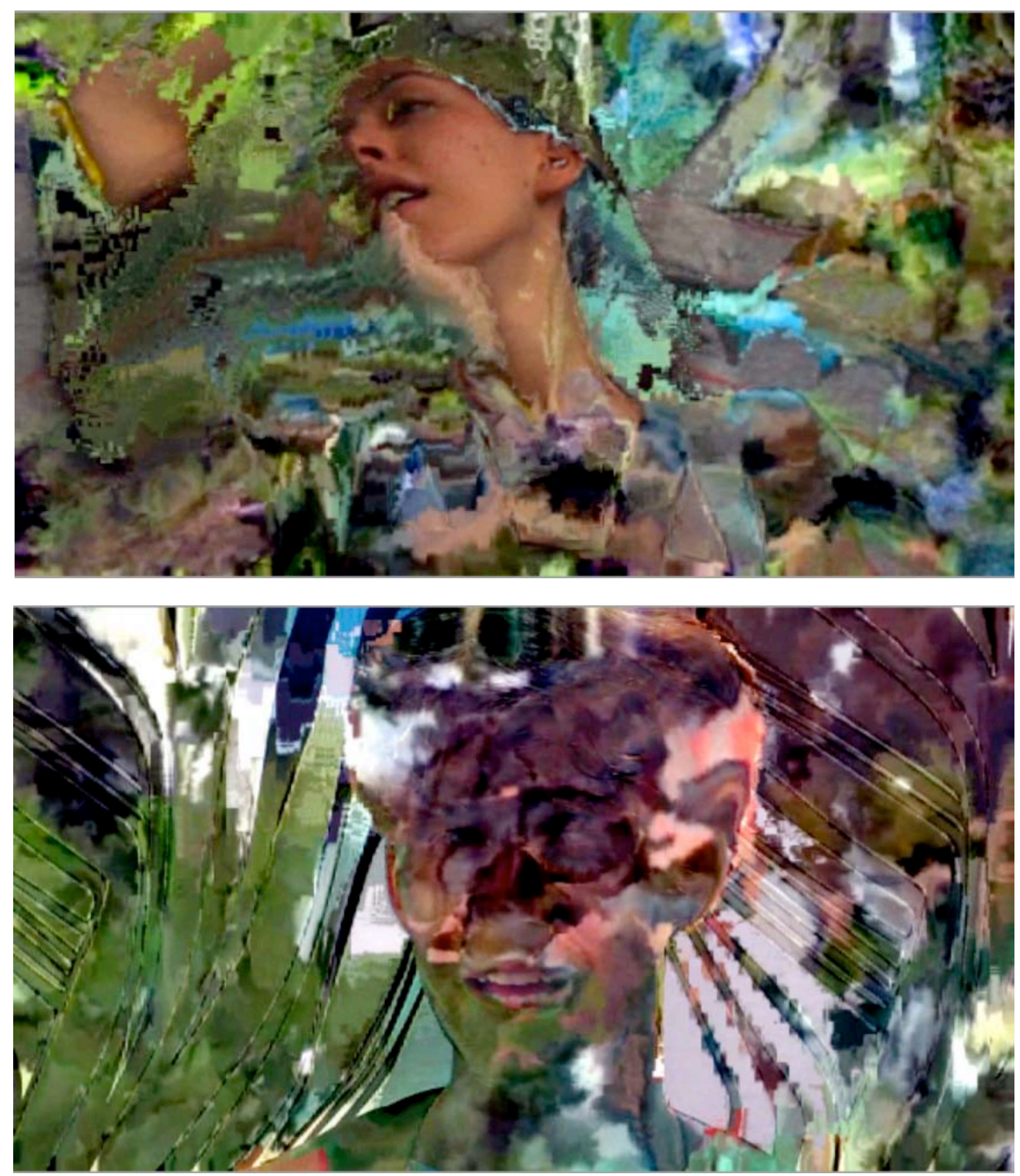

Evident Utensil (2009), de Ray Tintori 
En realidad, la imbricación extrema de figura y fondo fue explorada ya por la corriente de la abstracción geométrica en el computer art. Sirva como ejemplo la obra del español Manuel Barbadillo, a medio camino entre el op art y el arte por ordenador. En ella, el espacio no es condición a priori o soporte neutro, sino un elemento activo, a tal punto que la compartimentación figura/fondo se muestra insuficiente y da paso a la relación no jerarquizada entre módulos "positivos" (negro sobre blanco) y "negativos" (blanco sobre negro). El espacio se constituye de formas complementarias, opuestas pero interdependientes, más cercanas a la polaridad que al dualismo excluyente:

"Básicamente, mi pintura es una investigación del problema del espacio, el cual (...) es un elemento jerárquicamente igual a la forma, como una forma complementaria o antiforma." 28

Aún con todo, la lectura de las composiciones creadas por Barbadillo depende de la ley de la Gestalt, según la cual la percepción se basaría en una elección entre ver la figura significante o el fondo insignificante: es decir, ver alternativamente los módulos positivos o los negativos, pero nunca los dos al mismo tiempo. La inclusión del movimiento en la imagen puede agudizar esta tensión de modo que la reversibilidad de las figuras y el fondo dependa de las mutaciones del espacio. ${ }^{29}$ Éste es el caso, por ejemplo, de la animación Two Space (1979) de Larry Cuba. Las estructuras en blanco y negro se conforman a partir de la repetición y la variación de figuras simples.

Por muy lejanas que parezcan ambas construcciones espaciales ${ }^{30}$, el datamoshing comparte con la animación de Larry Cuba la puesta al límite de la díada figura/fondo como clave de interpretación del espacio percibido: la transformación

\footnotetext{
${ }^{28}$ BARBADILlO, Manuel. My way to cybernetics [En línea]. Atariarchives.org, August 1975. Disponible en Web: <http://www.atariarchives.org/artist/sec13.php>

29 "Cuando ninguna de las condiciones mencionadas [tamaño relativo de las partes, sus relaciones topográficas y sus tipos de márgenes] privilegia una parte del campo sobre la otra, se da, naturalmente, una situación de ambigüedad, en la cual domina la inestabilidad y la continua reversibilidad de la relación figura-fondo.” KANIZSA, Gaetano. Gramática de la visión. Percepción y pensamiento (1980). Barcelona: Ediciones Paidós, 1989, p. 27.

${ }^{30}$ Entre otras claras diferencias, Two Space es una imagen vectorial, mientras que el datamoshing resalta la condición "raster" de la imagen formada por píxeles.
} 
afecta a la imagen en su conjunto y, puesto que el contenido de la imagen es su propia transformación, figura y fondo son igualmente significantes. ${ }^{31}$
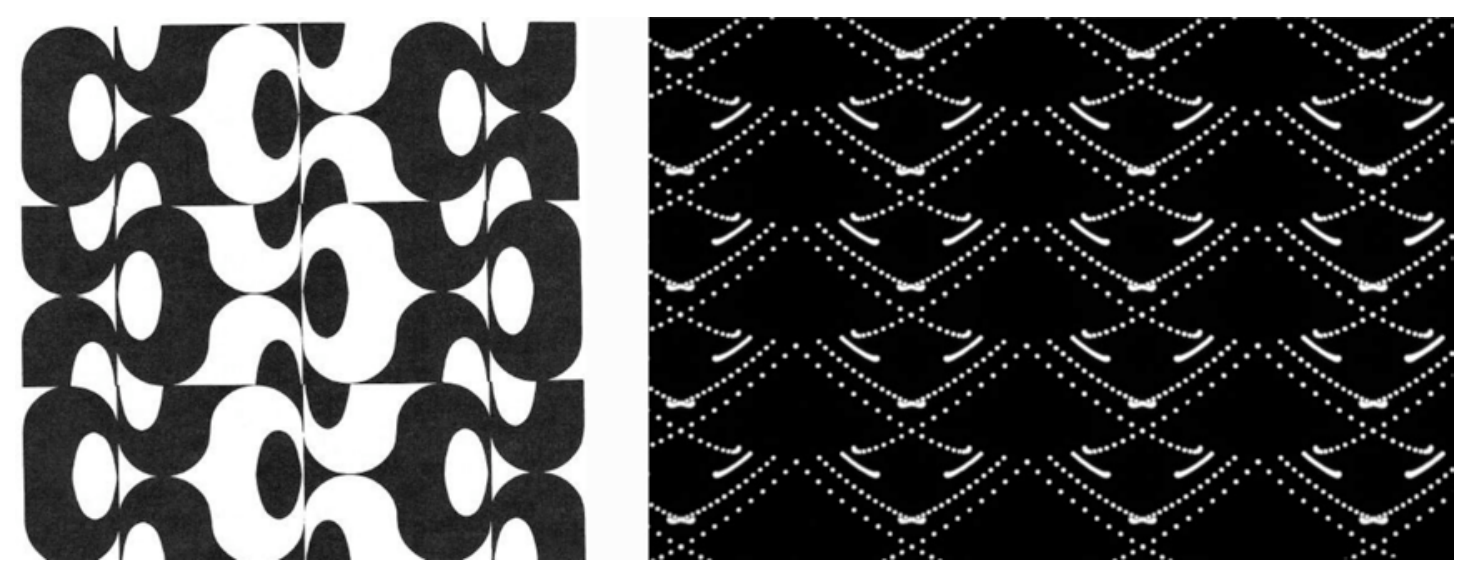

Izquierda, Manuel Barbadillo: "Tríptico" (1966). Derecha, Two Space (1979), de Larry Cuba

En las páginas que siguen, desarrollaremos la aportación de los pioneros del computer art a la construcción de nuevas dinámicas asociadas a la potencia plástica del código informático. Si los ejemplos analizados hasta aquí se basan en la distorsión como principio activador, en el próximo apartado, la exhibición del proceso plástico se funda en la génesis de la forma y su mutación.

\footnotetext{
${ }^{31}$ Tomamos prestada la expresión de Gene Youngblood a propósito del "synaesthetic cinema": "Synaesthetic cinema (...) contradicts the teachings of Gestalt psychology, according to which we must make an either/or choice: we can choose either to see the 'significant' figure or the 'insignificant' ground. But when the 'content' of the message is the relationship between its parts, and when structure and content are synonymous, all elements are equally significant." YOUNGBLOOD, Gene. Expanded Cinema. Op. cit., p. 85.
} 


\section{DE LA VARIABILIDAD A LA GÉNESIS ESPACIAL}

A partir de los años 60, los pioneros del arte por ordenador exploran la relación entre la matemática y la percepción visual. Inspirados por la cibernética y el arte contemporáneo, su investigación atañe no sólo a la díada figura/fondo, sino a las tensiones entre orden y caos, entre control y azar: aunque la obra sea concebida mediante algoritmos o reglas prefijadas, los autores insisten en el aspecto incontrolable del resultado, que es así producto de la comunicación entre el hombre y la máquina. La potencia plástica de tal cooperación reside en la multitud de posibilidades que abre el código informático. Abraham Moles se refiere a estas construcciones con la expresión "estética permutacional o combinatoria":

"La permutación es una combinación de elementos simples de variedades limitadas, que abren a la percepción la inmensidad de un campo de posibilidades."1

\section{La estética permutacional}

La permutación, la combinación y la variación son prácticas algorítmicas presentes en la composición visual y musical ${ }^{2}$, especialmente adaptadas al lenguaje matemático que sustenta las construcciones digitales. A. Michael Noll es uno de los primeros en experimentar con estos algoritmos en su obra "Gaussian quadratic" (1962) o en sus reinterpretaciones de los cuadros de Piet Mondrian; pero prácticamente todos los pioneros del computer art (Vera Molnar, Georg Nees, Manfred Mohr ${ }^{3}$...) se interesan por esta estética permutacional.

En cuanto a la animación se refiere, Stan VanDerBeek y Kenneth Knowlton exploran la potencia visual de la variación como mutación de la imagen. De su colaboración entre 1964 y 1967, quedan ocho animaciones por ordenador tituladas "Poem Fields" y caracterizadas por la metamorfosis continua de mosaicos luminosos. 4

\footnotetext{
${ }^{1}$ MOLES, Abraham. Art et ordinateur (1971). Paris: Blusson, 1990, p. 119.

${ }^{2}$ Artistas como John Cage, Sol LeWitt o Yoko Ono exploran la desmaterialización del arte conceptual, subrayando la metodología y las instrucciones a seguir para la consecución de la obra. LEWITT, Sol. "Paragraphs on Conceptual Art". Artforum, June 1967, vol. 5, núm 10, pp. 79-83.

3 Buena parte de aquella producción artística es recogida en 1969 por Manfred Mohr: MOHR, Manfred. Artificiata I. Paris: Éditions Agentzia, 1969.

${ }^{4}$ Las obras fueron creadas con el programa Beflix ("Bell Flicks"), desarrollado en 1963 en los Bell Laboratories por el propio Knowlton a partir del lenguaje de programación Fortran ("Formula Translating System").
} 

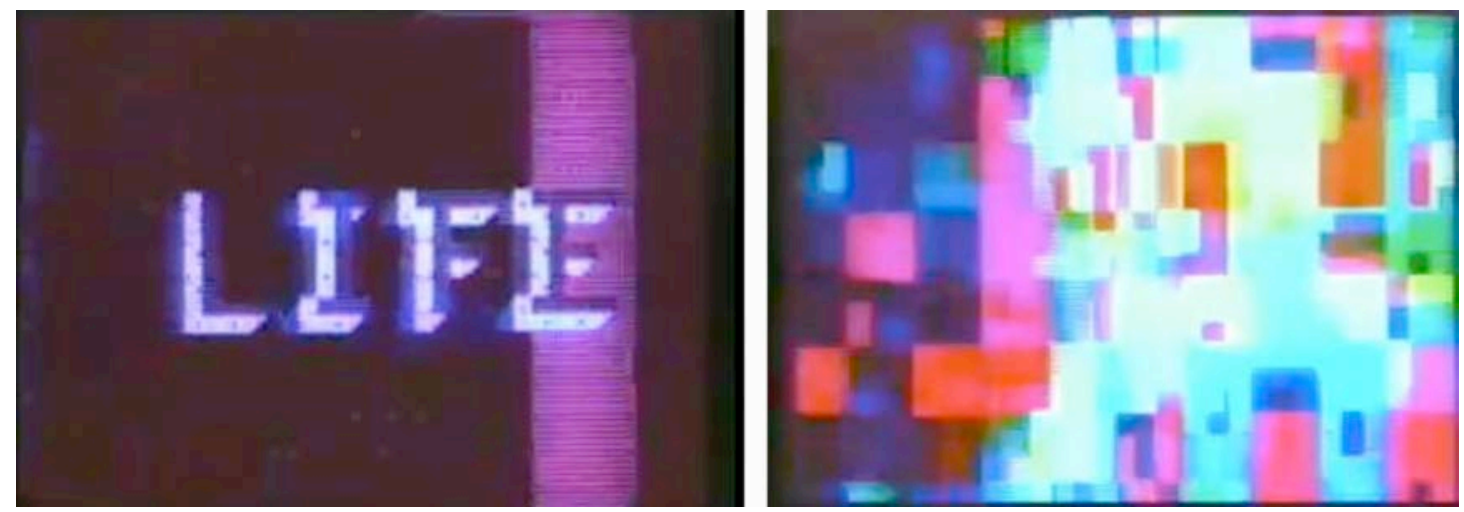

Poemfield \#2 (1966), de Stan VanDerBeek y Ken Knowlton

Con todo, tal vez sea la obra de John Whitney la que mejor ejemplifique esa exploración de la composición algorítmica en la informática naciente. Reconocido por su trabajo con un ordenador mecánico analógico, a mediados de los años 60, Whitney entra a formar parte de la empresa IBM (International Business Machines) con el cometido de explorar la estética de los gráficos computacionales.

Realizada ya con un ordenador digital, la animación Permutations (1966) presenta un conjunto de puntos de colores ${ }^{5}$ que, recombinados y sujetos a variaciones lumínicas, figuran bellos caleidoscopios al son de la música. Aunque Whitney partió tan sólo de un conjunto de puntos, las combinaciones de los mismos dan lugar a complejas estructuras mutantes. Las dinámicas así creadas se basan en la variabilidad de la composición de acuerdo con una serie de parámetros. Se trata de partir del punto no como coordenada en un espacio tridimensional, sino como unidad mínima para la composición. La simplicidad del elemento atómico evidencia la relación entre el todo y la parte: la estructura.
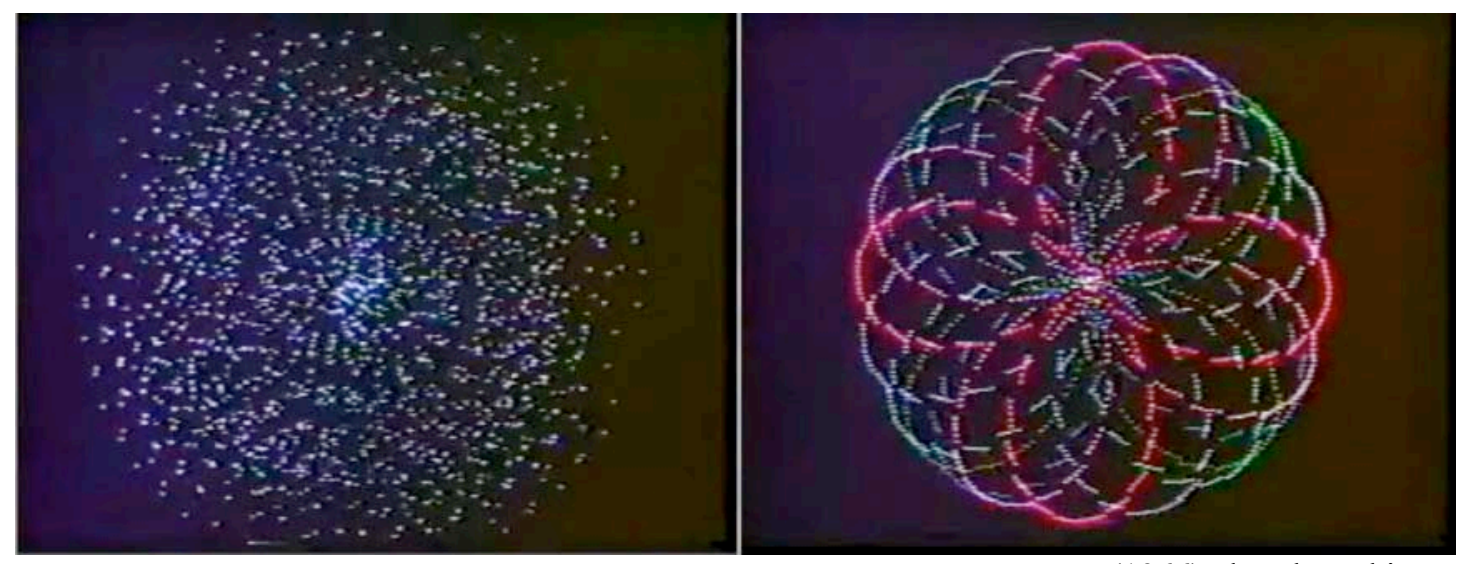

Permutations (1966), de John Whitney

\footnotetext{
${ }^{5} \mathrm{Si}$ bien la imagen fue construida en un ordenador con una pantalla en blanco y negro, Whitney añadió el color gracias a una impresora óptica.
} 
Whitney compara el proceso descrito con un alfabeto, en el cual las combinaciones de letras dan lugar a palabras y éstas, a su vez, a frases. No obstante, no contento con el paralelismo sintáctico, el artista acude al símil musical ${ }^{6}$, que condensa en la expresión "armonía digital"? . Con ello, inserta su obra en una tradición que se remonta, al menos, hasta el siglo XVIII y las investigaciones del jesuita Louis Bertrand Castel (1688-1757). Recuperada por los futuristas italianos a principios del siglo XX, la "música visual” marca la exploración plástica de la animación abstracta de los años 20 y 30, cuyos máximos representantes son Viking Eggeling, Hans Richter, Walter Ruttmann, Len Lye, Oskar Fischinger y Norman McLaren. ${ }^{8}$

El propio Ruttmann asegura que su investigación se basa en crear un nuevo arte entre la pintura y la música:

"Un arte concebido para el ojo, que se diferencia de la pintura porque se desarrolla en el tiempo (como la música) y porque el fundamento de lo artístico no está (como en el cuadro) en la reducción de un evento (real o formal) a un momento, sino precisamente en el desarrollo temporal de aquello que es formal."9

Frente al cineasta que era Ruttmann, Eggeling y Richter llegan al medio cinematográfico directamente desde la pintura. Así, no es de extrañar que éstos se acerquen al medio cinematográfico como una extensión del lienzo:

\begin{abstract}
"Los problemas del arte moderno llevan directamente al cine. La organización y orquestación de la forma, el color, la dinámica del movimiento, la simultaneidad, eran problemas con los que se enfrentaron Cézanne, los cubistas y los futuristas. Eggeling y yo salimos directamente de los problemas estructurales del arte abstracto hacia el medio cinematográfico." ${ }^{10}$
\end{abstract}

\footnotetext{
6 "My use of the parallel to language is only partially descriptive; I am moved to draw parallels with music. The very next term I wish to use is 'counterpoint'." John Whitney. Apud. YOUNGBLOOD, Gene, Op. cit., p. 215.

${ }^{7}$ WHITNEY, John. Digital Harmony: On the Complementarity of Music and Visual Art. New York: McGraw-Hill, 1980.

${ }^{8}$ Aunque existen experimentos anteriores, prácticamente todos han desaparecido o no llegaron nunca a superar la fase de proyecto. Patrick de Haas enumera los más importantes. Cfr. DE HAAS, Patrick. Cinéma intégral. De la peinture au cinéma dans les années vingt. Bruxelles: Transédition, 1985, p. 11.

${ }^{9}$ Walter Ruttmann. Apud. RONDOLINO, Gianni. "Ruttmann e il cinema astratto". En: QUARESIMA, Leonardo (dir.). Walter Ruttmann: Cinema, pittura, ars acustica. Calliano (Trento): Manfrini Editori, 1994, p. 83.

${ }^{10}$ RICHTER, Hans. "Un art original, le film". Cahiers du cinéma. Paris, Mars 1952, núm. 10, pp. 1115.
} 
Mientras que Eggeling permanece en la dinamización de la línea, Richter se sirve de cuadrados y rectángulos de todos los tamaños y tonalidades, desde el blanco al negro. La animación permite al artista reflexionar sobre el ritmo cinematográfico o “contrapunto visual" en tanto que organización de los movimientos de las figuras respecto al cuadro de la imagen. En su serie Rhythmus, el espacio está íntimamente relacionado con la mutación de las formas geométricas. El cine, según Richter, "no es tanto una forma en el plano como una forma en el tiempo"11.

Si la composición pictórica parte del color y la forma en relación al espacio, la musical, de los sonidos y su aspecto temporal. A medio camino entre ambas, es posible crear una composición visual mediante movimientos; éstos responden a mutaciones que tienen lugar en el tiempo, pero crean, ante todo, relaciones espaciales.

En la cuarta dimensión, está la clave para la comprensión de la metamorfosis de la figura como "forma en el tiempo" (Hans Richter) o "desarrollo temporal de aquello que es formal" (Walter Ruttmann). Como veíamos más arriba, en su cuestionamiento plástico del espacio tridimensional representado en el plano, las vanguardias históricas se inspiran de las teorías científicas de finales del siglo XIX. En este sentido, la animación abstracta de los años veinte supone una primera tentativa de construir espacios no-euclidianos e hiperespacios en la imagen animada.
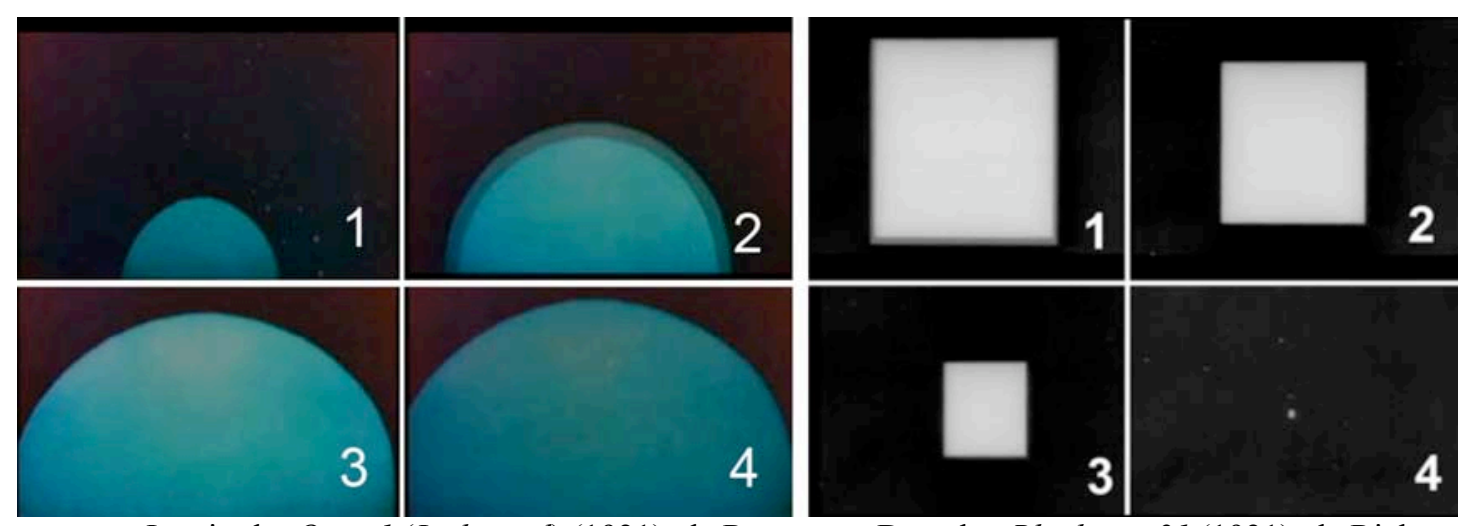

Izquierda, Opus 1 (Lichtspiel) (1921), de Ruttmann. Derecha, Rhythmus 21 (1921), de Richter

A finales de los años 60 , la recién nacida animación por ordenador retoma y desarrolla las cuestiones abiertas por aquel cine abstracto. Aunque la categoría "música visual" sobrepasa el dualismo analógico/digital, el ordenador aporta una "nueva dimensión" al constructo espacio-temporal. Ni las formas, ni las relaciones

\footnotetext{
${ }^{11}$ RICHTER, Hans. Hans Richter. Textes autobiographiques. Neuchâtel: Editions du Griffon, 1965, p. 56.
} 
entre las mismas reflejan un diseño preconcebido por el artista, sino que son producto de la colaboración entre éste y el ordenador; su complejidad depende tanto de la imaginación del hombre como del cálculo matemático de la máquina:

\begin{abstract}
“Al reflexionar sobre el proceso usado en la animación abstracta, es importante si estás usando un ordenador en cuanto afecta a tu vocabulario. Porque, si empiezas con estas estructuras matemáticas, puedes descubrir imágenes que no has previsualizado, sino 'encontrado' (...). Así que, en ese sentido, el ordenador añade una nueva dimensión a este campo de exploración." ${ }^{12}$
\end{abstract}

A la hora de justificar el uso de la metáfora musical, Whitney asegura que la clave reside en el carácter abstracto de la notación sonora. ${ }^{13}$ No obstante, en el caso de Permutations, la composición de la imagen antecedió al sonido y la banda sonora fue seleccionada después, de manera independiente. En este sentido, el autor dejó de lado un aspecto especialmente interesante de la creación por ordenador, ligado precisamente a aquel carácter abstracto: el uso del código subyacente como lenguaje común a la imagen y al sonido. Es decir, en lugar de conformarse con la metáfora musical o con una sincronía entre ambos, se trata de explotar el código informático como materia prima de la construcción plástica.

El pionero Herbert Franke exploró esta posibilidad en su obra Cascade (1978), una transformación "en vivo" de música en gráficos mediante un ordenador Apple II GS. Esta traducción del lenguaje sonoro al visual gracias al código binario compartido puede ser comparada a los programas utilizados hoy en las sesiones de $\mathrm{VJing}^{14}$ o de "live cinema". 15

El espacio digital permite aunar imagen y sonido como dos manifestaciones distintas de un mismo código subyacente. El proceso por el cual un conjunto de datos

\footnotetext{
${ }^{12}$ Larry Cuba. Apud. YOUNGBLOOD, Gene. Calculated movements. An interview with Larry Cuba [En línea]. Video and the arts magazine, Winter 1986. Disponible en Web: $<$ http://www.well.com/ cuba/VideoArt.html>

13 "What is a musical note? It's totally abstract. That's the essential point and that's why I use the musical analogy." John Whitney. Apud. YOUNGBLOOD, Gene. Expanded Cinema. Op. cit., pp. 220 221.

14 La expresión "videojockey" es una adaptación del "DJ" de la música electrónica al campo audiovisual. A partir de los años 90, el desarrollo de la tecnología informática permite la manipulación en "tiempo real" de grandes cantidades de datos en ordenadores portátiles. Cfr. BYRNE, Brendan; CARVALHO, Ana; HOUSTON, Lara; MUMFORD; Paul (eds). VJam Theory. Realtime Books, 2008.

${ }^{15}$ No entramos aquí en el concepto de "performance". Sobre el espectáculo audiovisual en directo, el lector podrá consultar la siguiente tesis doctoral: MAKELA, Mia. "Live Cinema: Language and Elements". Helsinki University of Art and Design, Media Lab, Helsinki, April 2006. Disponible en Web: <http://docs5.chomikuj.pl/295847970,PL,0,0,Live-Cinema-...\%E2\%80\%8E>
} 
digitales se convierte en otro, permitiendo con ello una traducción fluida y directa entre diversos medios se conoce como "transcoding", Así, por ejemplo, un sonido puede ser digitalizado como un conjunto de números que codifican sus propiedades (el timbre, el tono, la duración...) y, gracias a la transformación que permite el software, aquellas características pueden adquirir un aspecto visual definido por parámetros espaciales (la talla, el color, la posición...). En este sentido, el proceso podría ser considerado, también, como un caso más de visualización de datos.

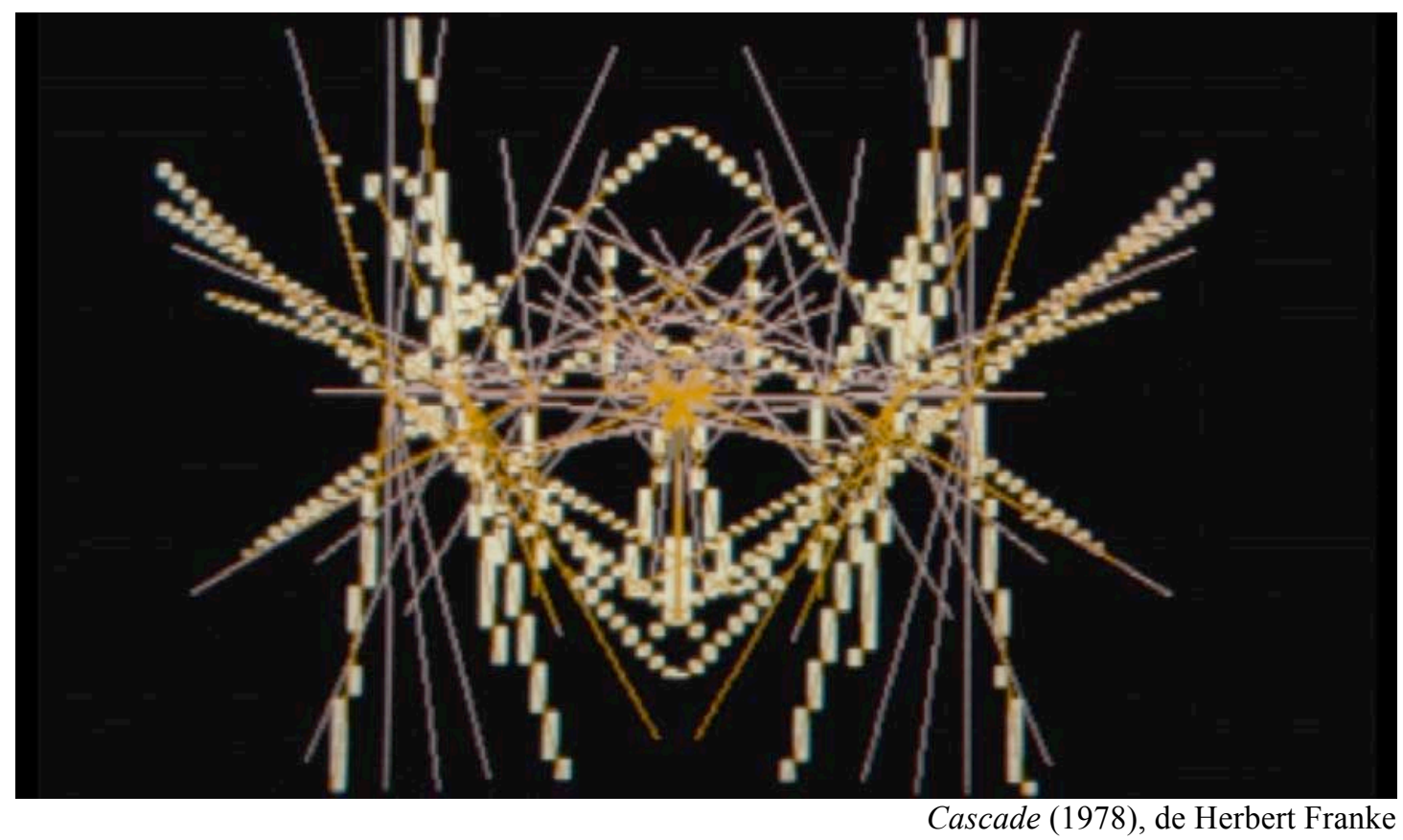

En realidad, diez años antes que Herbert Franke, John Stehura había concebido ya un metalenguaje para la construcción de obras audiovisuales: el llamado "Model Eight”. La emblemática Cybernetik 5.3 (1965-1969) debía haber contado con un sonido generado por el mismo programa con el que se crearon los gráficos por ordenador. No obstante, descontento con el resultado, el artista acudió, finalmente, al compositor de música electrónica Tod Dockstader para la adición de la banda sonora. $^{17}$

\footnotetext{
16 "One direct consequence of describing information numerically is transcoding or the conversion of one type of digital information into another (...). Transcoding can also be used to create completely new forms by interfering with how the computer handles a set of data. For example, it can allow the bits of an audio file to be read by a program that normally operates on the bits representing an image. Transcoding uses the file data as raw material for computation." MCWILLIAMS, Chandler; REAS, Casey. Form + Code in Design, Art and Architecture. New York: Princeton Architectural Press, 2010, p. 79.

${ }^{7}$ YOUNGBLOOD, Gene. Expanded Cinema. Op. cit., p. 241.
} 
Contemporánea a Permutations y Poemfield \#2, Cybernetik 5.3 comparte con ambas la exploración de dinámicas basadas en el juego azar/control. Ahora bien, frente a los mosaicos de Knowlton y al arte concreto de Whitney, Stehura mezcla la abstracción con la figuración del registro que usa como materia prima para la transformación. Aunque esta hibridación pudiera recordar a la exploración contemporánea en el videoarte, la obra que nos ocupa va un paso más allá en la construcción del espacio: en lugar de conformarse con el montaje espacial o con la intervención en la señal electrónica, el autor se lanza a la generación misma de las formas de la imagen. Inspirado por el descubrimiento de la estructura del ADN por James D. Watson y Francis Crick en 1953, Stehura decide hacer evolucionar la obra mediante algoritmos que permiten animar las formas de partida. Así, en esta ocasión, la potencia plástica de la imagen digital radica en su infraestructura como código: no se trata de diseñar o esculpir la forma, sino de generarla. ${ }^{18}$
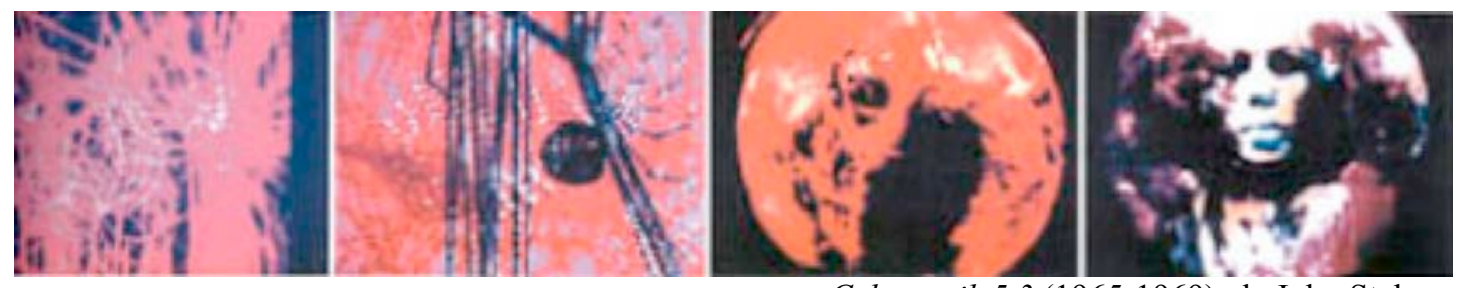

Cybernetik 5.3 (1965-1969), de John Stehura

Este proceso generativo depende tanto del ser humano que diseña los algoritmos como de la máquina (un ordenador IBM 7094) que calcula las variaciones de acuerdo con las reglas prefijadas por el autor. En el "field model", John Stehura define una serie de "campos de fuerza" que afectan a cualquier forma que entra en contacto con el área demarcada. De este modo, el movimiento en la imagen está relacionado con dinámicas internas y no, con las fases cinéticas de un desplazamiento.

\footnotetext{
${ }^{18}$ En la misma época, el artista alemán Georg Nees se refiere a sus diseños y esculturas como "generativas". NEES, Georg. Generative Computergraphik. München: Siemens, 1969.
} 


\section{El arte evolutivo}

En Particle Dreams (1988), de Karl Sims, la animación de la forma depende de fuerzas predefinidas como la gravedad o la fricción. De poco más de un minuto de duración, la pieza exhibe las múltiples combinaciones de un conjunto de partículas, cada una de las cuales contiene información acerca de su posición, su velocidad y su aceleración. Como hiciera Whitney en Permutations, Sims parte de una serie de puntos que recombina, haciendo variar la obra entre la sintropía (orden) y la entropía (desorden) ${ }^{19}$, entre el nacimiento de la forma y su desintegración.

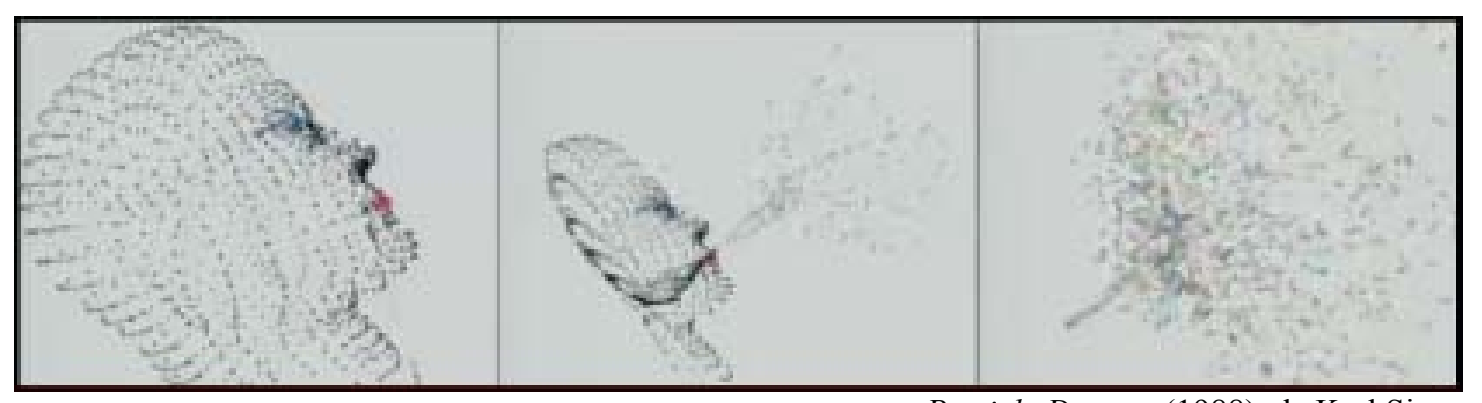

Particle Dreams (1988), de Karl Sims

Apenas tres años después, el mismo Karl Sims crea Primordial Dance (1991). La animación muestra la mutación de una serie de texturas y colores, semejantes al plasma sanguíneo observado a través de un microscopio. Frente a las dinámicas generadas por fuerzas en Particle Dreams, en esta ocasión, el artista acude a "algoritmos genéticos" ${ }^{20}$, a un proceso interactivo de evolución artificial:

"La evolución es un método para crear y explorar la complejidad que no requiere la comprensión humana del proceso específico involucrado. (...) permite a usuario y a ordenador trabajar juntos, de manera interactiva, en un nuevo modo de producir resultados que ninguno de ellos podría haber producido solo. ${ }^{21}$

\footnotetext{
${ }^{19}$ Esta aleatoriedad permite a Sims emular el comportamiento del agua o del fuego. SIMS, Karl. "Particle Animation and Rendering Using Data Parallel Computation". ACM SIGGRAPH'90 Computer Graphics. August 1990, vol. 24, núm. 4, pp. 405-413.

${ }^{20}$ El psicólogo e ingeniero estadounidense John Holland es considerado comúnmente como el padre de los algoritmos genéticos. HOLLAND, J. H.. Adaptation in Natural and Artificial Systems. Ann Arbor: University of Michigan Press, 1975.

${ }^{21}$ SIMS, Karl. "Artificial Evolution for Computer Graphics”. En: ACM SIGGRAPH '91 Proceedings of the 18th Annual Conference on Computer Graphics. Las Vegas, July 1991, vol. 25, núm 4, p. 328.
} 


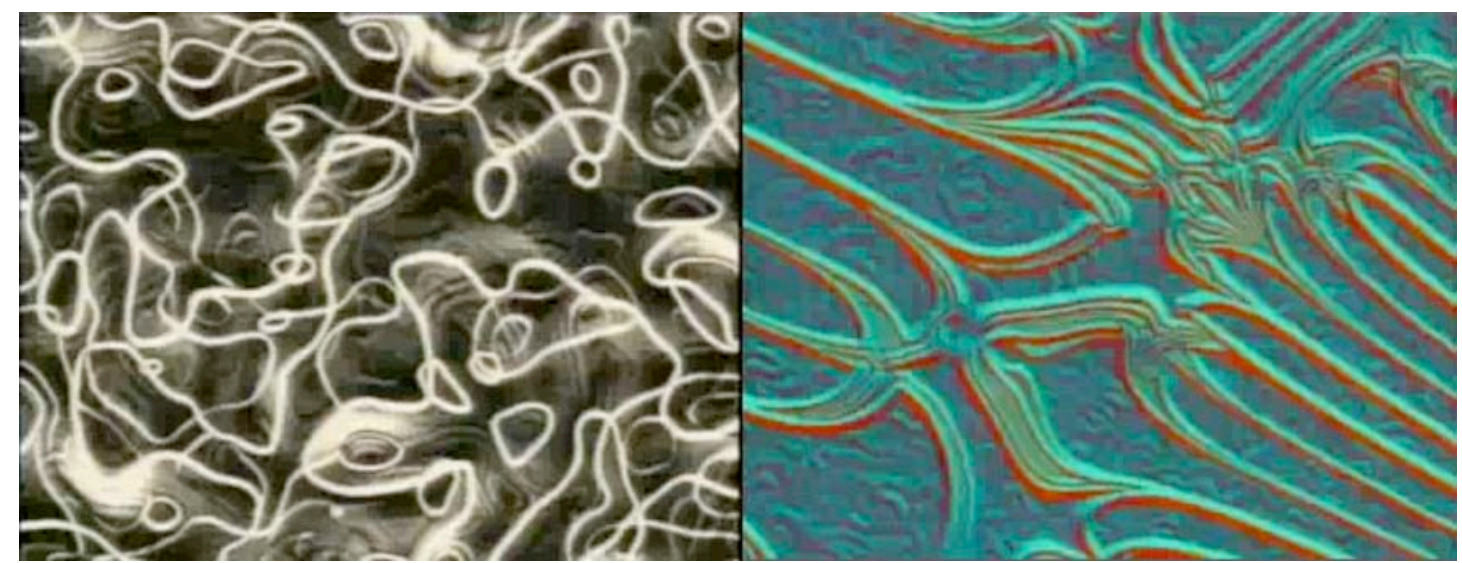

Primordial Dance (1991), de Karl Sims

Sin duda, el trabajo de Sims bebe de la obra de Richard Dawkins The Blind Watchmaker (1986) ${ }^{22}$; en ella, el biólogo británico explica el programa "Biomorph Land", que permite hacer evolucionar figuras simples bidimensionales o "biomorph"23. Aunque el objetivo de Dawkins era la comprobación de la teoría de Darwin $^{24}$, su obra tiene el aliciente de extrapolar el concepto mismo de "evolución" al dominio informático y, más interesante aún, sugerir la creación de objetos estéticos y nuevas formas visuales mediante este mismo proceso artificial.

Como veíamos en el zoom out de Fight Club, los algoritmos genéticos permiten imitar formas de la naturaleza como una planta o las conexiones del cerebro humano. No obstante, pueden dar forma también a espacios puramente imaginados por el artista. Este "arte evolutivo" se inspira de los principios de la naturaleza, pero no se limita a la copia mimética de su apariencia:

"La evolución, una idea que se ha convertido en la más poderosa organización narrativa de la cultura contemporánea, parece desplegarse en una pantalla. La Alife propone no una imitación servil de un ser vivo cualquiera, sino una síntesis abstracta de vitalidad: la vida misma en voltaje y silicio., 25

\footnotetext{
${ }^{22}$ DAWKINS, Richard. The Blind Watchmaker: Why the Evidence of Evolution Reveals a Universe without Design (1986). New York: Norton \& Company Inc, 1996.

${ }^{23}$ El vocablo había sido usado ya por el antropólogo inglés Alfred Cort Haddon en 1895. HADDON, Alfred Cort. Evolution in art: As illustrated by the life-history of designs. London: The Walter Scott Press, 1895, p. 126. Disponible en Web:

$<$ http://archive.org/stream/artevolution00haddrich/artevolution00haddrich_djvu.txt>

${ }^{24}$ DARWIN, Charles. On the Origin of Species by Means of Natural Selection, or the Preservation of Favoured Races in the Struggle for Life (1859). En: MAYR, Ernst (ed.). On the Origin of species: A facsimile of the first edition. Cambridge: Harvard University Press, 1964.

${ }^{25}$ WHITELAW, Mitchell. Metacreation: Art and Artificial Life. Cambridge: The MIT Press, 2004, p. 5. Disponible en Web: <http://fr.scribd.com/doc/105684327/Whitelaw-Mitchell-2004-MetacreationArt-and-Artificial-Life $>$
} 
Junto a Sims, William Latham es una de las grandes figuras de este arte evolutivo. En colaboración con el programador Stephen Todd, el escultor Latham se lanza, a finales de los 80 , a la creación de programas informáticos para la evolución de formas tridimensionales. Similar a Primordial Dance, Organic Television (1994) exhibe un entorno lleno mutante. Ambas comparten con Two Space de Larry Cuba la imbricación de forma y espacio en una estructura continua de relaciones cambiantes. Latham se refiere a ésta con la expresión "form space", cercana a la "forma/antiforma" de Barbadillo; ahora, frente a las imágenes fijas creadas por el español, el artista inglés se concentra en la evolución formal, en la animación de una "forma-espacio multidimensional". ${ }^{26}$ A medio camino entre la animación abstracta y la escultura, el procedimiento seguido por el artista se acerca más al arte cinético de Alexander Calder que al modelado clásico: más que de dar forma a una materia, se trata de "esculpir el movimiento",27.

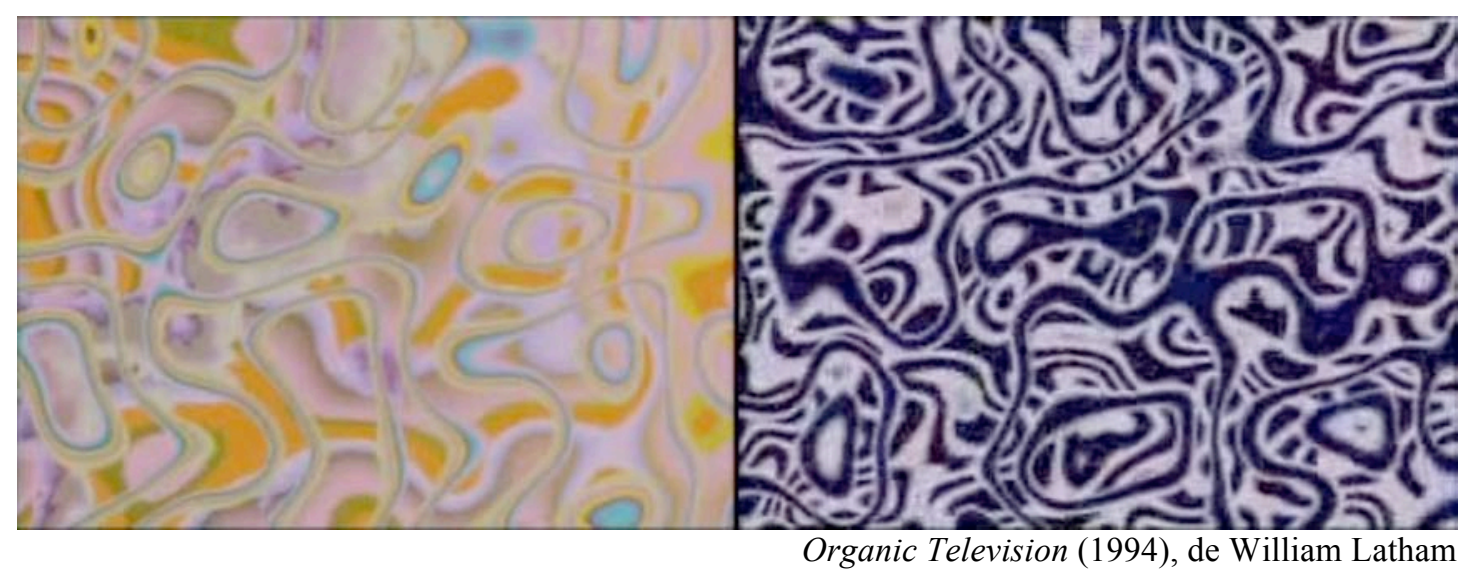

La animación evolutiva se aleja del keyframing para automatizar los cambios a partir del cálculo de fuerzas, funciones y leyes de desarrollo. En este sentido, es especialmente interesante el "growth model” del artista japonés Yoichiro Kawaguchi. Como su nombre indica, el proceso se funda en el "crecimiento" de la forma según patrones evolutivos de organismos vivos. Los algoritmos así diseñados permiten la construcción de formas complejas a partir de reglas simples gracias a una estructura

\footnotetext{
${ }^{26}$ LATHAM, W.; TODD, S.; “The Mutation and Growth of Art by Computers”. En: BENTLEY, Peter. Evolutionary Design by Computers. San Francisco: Morgan Kaufmann Publishers, 1999, pp. 221-222. 27 "Calder a sculpté du mouvement plutôt que de la matière." Gabrièle Buffet-Picabia. Apud. LIORET, Alain. Op. cit., p. 89.
} 
recursiva y acumulativa. En palabras de Edmond Couchot, la obra del artista japonés es paradigmática de la "potencia morfogenética de la imagen matriz"28.

En Mutation (1992) y Luminous Visions (1998), Kawaguchi se inspira en el mundo submarino; como en los Liquid Selves de Karl Sims, la metáfora líquida no se agota en la apariencia viscosa de los entornos y apela al concepto de flujo como inestabilidad, como "mujo" 29 . Semejante a la "forma-espacio multidimensional" de Latham, las construcciones digitales de Kawaguchi están marcadas por la continuidad de figura y fondo. Es más, la textura de las formas refleja el espacio envolvente, multiplicando el efecto de contaminación mutua.

Estas superficies reflectantes crean una interpenetración de forma y espacio similar a la que explora la escultura orgánica. ${ }^{30}$ Pensamos, por ejemplo, en la obra "Commencement du monde" (1924) de Constantin Brancusi: más allá del hecho de que el modelado ovoidal remite a lo orgánico, el mármol pulido deja ver el espacio físico en el que se halla la obra, de modo que ésta se alimenta de las mutaciones lumínicas del entorno.

La teoría de la evolución de Darwin deja su imprenta en el arte $^{31}$ : frente a la tendencia geométrica (inspirada en las teorías de espacios no-euclidianos e hiperespacios), otras estéticas se acercan a lo orgánico. Este "biomorfismo" está presente en corrientes como el surrealismo y el dadaísmo, sin formar por ello un grupo autoproclamado independiente. Si en la pintura destacan Kandinsky o Filonov, en la escultura, los grandes representantes son, junto a Brancusi, Henry Moore y Jean Arp. Una declaración de éste último condensa esta inspiración en la naturaleza que se aleja, no obstante, de la mera mímesis tradicional:

"No queremos copiar la naturaleza. No queremos reproducir, sino producir. Queremos producir como una planta que produce un fruto y no reproducir. Queremos producir directamente y no mediante intermediarios."32

\footnotetext{
${ }^{28}$ COUCHOT, Edmond. La technologie dans l'art. De la photographie à la réalité virtuelle. Op. cit., p. 182 .

29 "Sa conception de la métamorphose et de la fluctuation rejoint l'antique notion de mujo (l'instabilité des êtres dans un univers éphémère)." KLONARIS, Maria; THOMADAKI, Katerina. Technologies et imaginaires. Art cinéma / vidéo / ordinateur. Paris: Dis Voir, 1990, p. 56.

30 "Un des apports les plus extraordinaires du point de vue formel de la sculpture organique provient du bouleversement qu'elle opère dans le rapport de l'objet plastique avec l'intérieur de sa surface et avec l'espace qui l'entoure." DINER, Simon. Op. cit., p. 9.

${ }^{31}$ Cfr. BRAUER, Fae; LARSON, Barbara Jean (eds.). The Art of Evolution: Darwin, Darwinisms, and Visual Culture. London: University Press of New England, 2009.

${ }^{32}$ ARP, Jean. Jours effeuillés : poèmes, essais, souvenirs, 1920-1965. Paris: Gallimard, 1966, p. 183.
} 

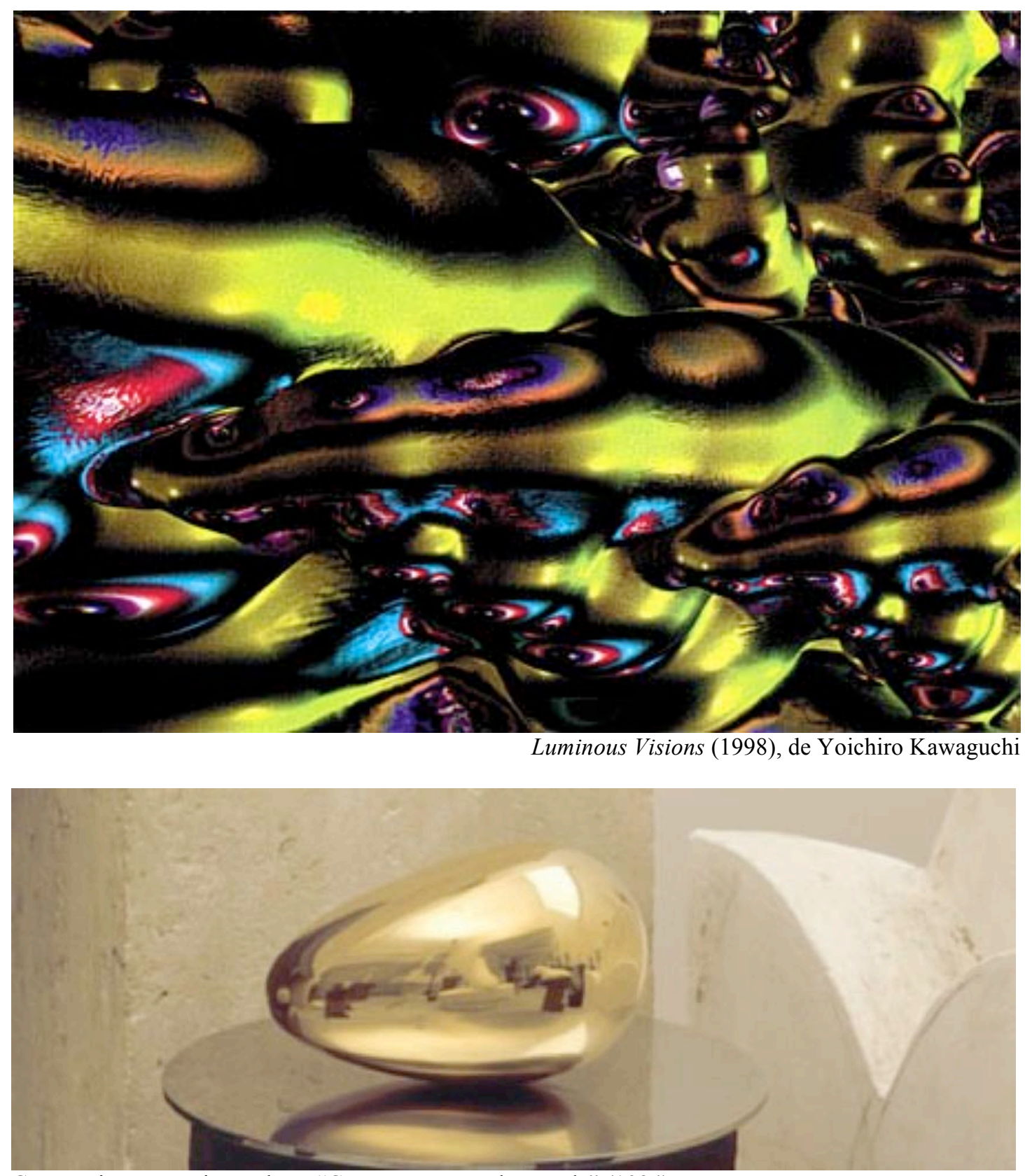

Constantin Brancusi: escultura "Commencement du monde" (1924)

En el arte evolutivo, en lugar de diseñar o tallar la forma, se trata de hacerla evolucionar. La forma es, así, resultado de su propio desarrollo y, en cuanto tal, está ligada al proceso mismo que la genera. Esta idea, presente ya en la obra del biólogo D’Arcy W. Thompson, es recuperada por el matemático inglés Alan Turing (19121954). Considerado como uno de los padres del ordenador moderno, su artículo sobre la "morfogénesis" (1952) propone una explicación de la diversidad de formas en la naturaleza mediante el llamado "sistema de reacción y difusión". ${ }^{33}$ Grosso modo, éste

\footnotetext{
${ }^{33}$ TURING, Alan. "The Chemical Basis of Morphogenesis". Philosophical Transactions of the Royal Society of London. Series B, Biological Sciences. August 14, 1952, vol. 237, núm. 641, pp. 37-72.
} 
describe, por un lado, una reacción de sustancias químicas y, por otro, su difusión o expansión en el espacio. De acuerdo con el autor, el modelo explica, entre otros, los patrones que se repiten en la pigmentación de animales como la cebra.

Inspirado por la teoría de la morfogénesis de Turing, el artista Jonathan McCabe extrapola las leyes que sustentan la formación de dichos patrones a un programa informático diseñado por él mismo y, a partir del cual, construye sus piezas audiovisuales. $^{34}$ Cercanos a los ambientes fluidos de Kawaguchi, sus entornos cromáticos se caracterizan por la asociación orgánica y la inestabilidad espacial. Sin embargo, frente a las superficies reflectantes del artista japonés, McCabe se decanta por una penetración espacial similar al fractal en Naqoyqatsi de Godfrey Reggio. Como veíamos, el zoom asociado a la geometría de Benoît Mandelbrot redunda en la recursividad de la forma autocontenida. Por su parte, las obras de McCabe como Inflating Turing pattern 1 o Into the colorflow muestran la dilatación constante de un espacio en expansión.

Con su proyecto Electric Sheep ${ }^{35}$, el programador y artista Scott Draves explora la estética de la geometría fractal. Frente al zoom de Naqoyqatsi, animaciones como 165 Star Oasis (2005) recuerdan los arabescos en Permutations, de John Whitney. De hecho, la descripción del proceso de construcción de las imágenes por parte del autor subraya la continuidad entre el arte generativo y aquella estética permutacional: "El objetivo de mi trabajo es mostrar que la creación no necesita control, de hecho, abandonar el control es el principio creativo". ${ }^{36}$ Esta introducción del caos en la composición permite acercar los fractales matemáticos a las formas semejantes en la naturaleza. $^{37}$

\footnotetext{
${ }^{34}$ MCCABE, Jonathan. Cyclic Symmetric Multi-Scale Turing Patterns [En línea]. Faculty of Arts and Design. University of Canberra. 2010. Disponible en Web:

$<\mathrm{http} / / /$ www.jonathanmecabe.com/Cyclic_Symmetric_Multi-Scale_Turing_Patterns.pdf $>$

${ }_{35}$ Electric Sheep es un proyecto colaborativo iniciado por Scott Draves en 1999 y que da la oportunidad a los participantes de generar formas fractales a partir de las instrucciones del "Flame algoritm". Ver la página web del proyecto: $<$ http://electricsheep.org/>

El título es un homenaje a la novela de Philip K. Dick Do androids dream of electric sheep?. DICK, Philip K.. Do androids dream of electric sheep? (1968). New York: Ballantine Books, 1996.

${ }^{36}$ Scott Draves. Apud. SPROTT, J. C.; TAYLOR, R. P.. Op. cit.

37 "These random variations preserve the fractal scaling properties while removing the artificial look of the exact Koch curve, allowing a radically different and more natural aesthetic value to emerge. Random fractals therefore represent a relatively simple mathematical method for generating 'naturallooking' fractal forms. In addition to randomness, introduction of another natural process - chaos - into the fractal generation is also effective.” Ibídem, p. 119.
} 


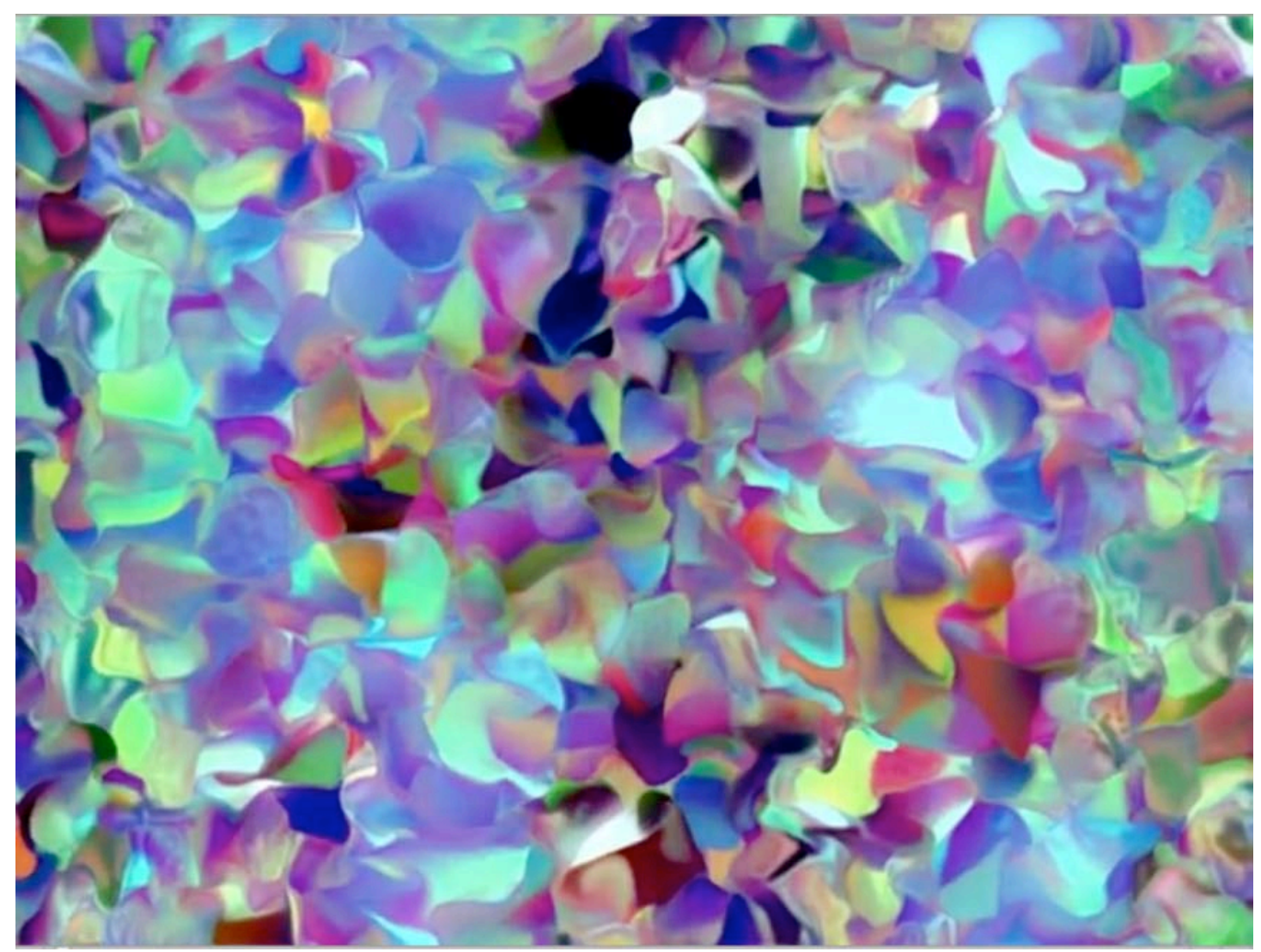

Into the colorflow (2011), de Jonathan McCabe

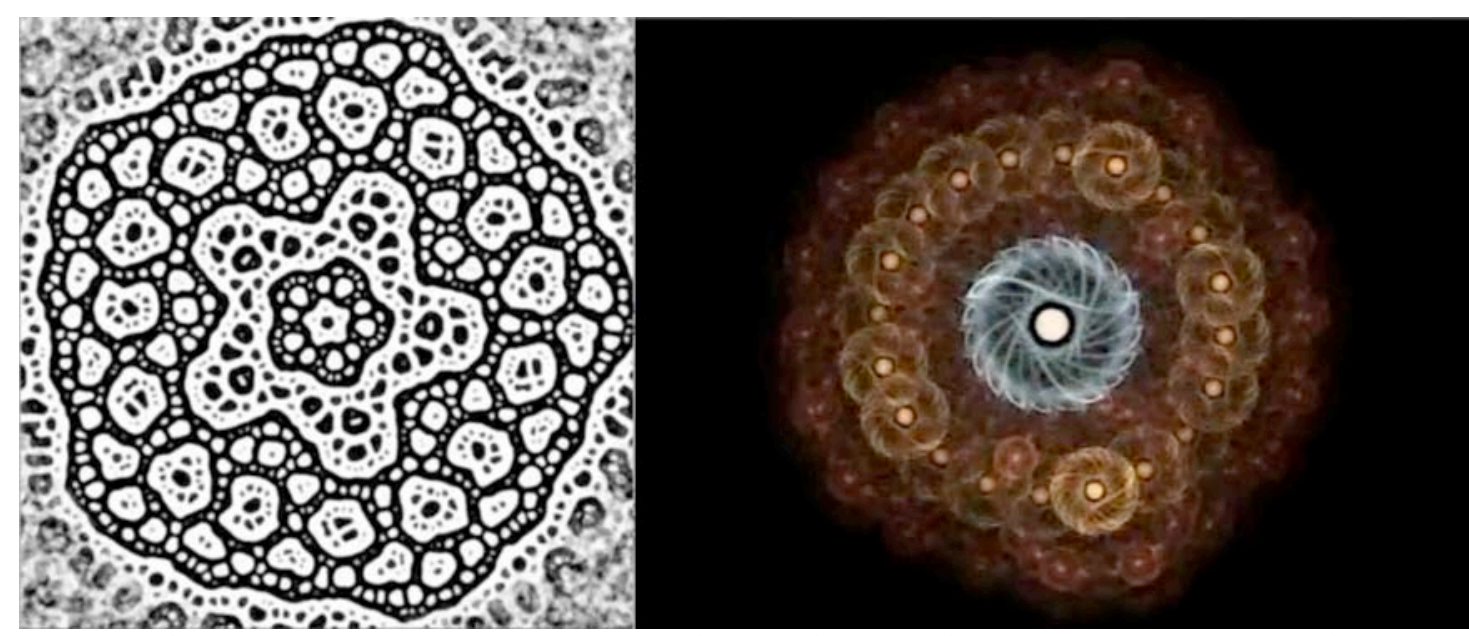

Izquierda, Inflating Turing pattern 1 (2010), de McCabe. Derecha, 165 Star Oasis (2005), de Draves

Con todo, no es la forma la que define el arte generativo, sino la metodología: el proceso. Como intuyeran ya los pioneros del computer art, éste se basa en la colaboración entre el artista y la máquina. Aquél diseña los algoritmos y aporta el juicio estético; ésta calcula, genera. Este automatismo comporta un grado de imprevisibilidad que caracteriza la tensión azar/control. ${ }^{38}$

\footnotetext{
38 "To be able to call a methodology generative, our first hard-and-fast rule needs to be that autonomy must be involved. The artist creates ground rules and formulae, usually including random or semirandom elements, and then kicks off an autonomous process to create the artwork. (...) The second
} 
En la serie Process as Design, Design as Process (2009), Lukasz Lysakowski explora, precisamente, este carácter impredecible de la creación semiautomática por ordenador. Una vez diseñadas las reglas de partida, el autor no interfiere en el proceso informático, dejando a la máquina la tarea de desarrollar la obra. La variedad de resultados así logrados subraya la potencia plástica de la imagen código. Si Motion Process crea un efecto de profundidad cinética cercano al viaje interdimensional, Process of Realtime recuerda a los patrones repetitivos de Two Space de Larry Cuba; por su parte, la figuración en Color Process podría asociarse con el estado híbrido del datamoshing, entre la bidimensionalidad de las imágenes que funcionan como materia prima y la fluctuación de los píxeles. Efectivamente, el proceso semiautomático de Lysakowski tiene algo de "glitch", de ruido y de la multidimensionalidad de un espacio no limitado por la lente fotográfica, abierto a la infinidad de posibilidades del código matemático.

El acertado título de la serie "Proceso como diseño, diseño como proceso" subraya la importancia estética del proceso plástico en sí. A este respecto, hay quien habla ya de una "estética procedural". ${ }^{39}$ En este sentido, es especialmente interesante el trabajo del artista estadounidense Casey Reas, cuyas animaciones toman el nombre del proceso que las sustenta: "cada proceso es un texto corto que define el espacio a explorar a través de múltiples interpretaciones." ${ }^{40}$ Así, por ejemplo, la obra Process 16 (2006) es la manifestación visual del "proceso 16" escrito por el autor.

\footnotetext{
hard-and-fast rule therefore is there must be a degree of unpredictability. It must be possible for the artist to be as surprised by the outcome as anyone else." PEARSON, Matt. Generative Art: A Practical Guide Using Processing. Manning Publications, 2011, p. 6.

39 Cfr. MATEAS, Michael. "Procedural literacy: Educating the new media practitioner". En: DAVISON, Drew (ed.). Beyond Fun: Serious Games and Media. Pittsburgh, PA: ETC Press, 2008.

${ }^{40}$ REAS, Casey. Process Compendium [En línea]. Catálogo de la exposición Process Compendium 2004-2010, Gallery [DAM], Berlín, 2010. Disponible en Web:

$<$ http://reas.com/texts/processcompendium.html>
} 

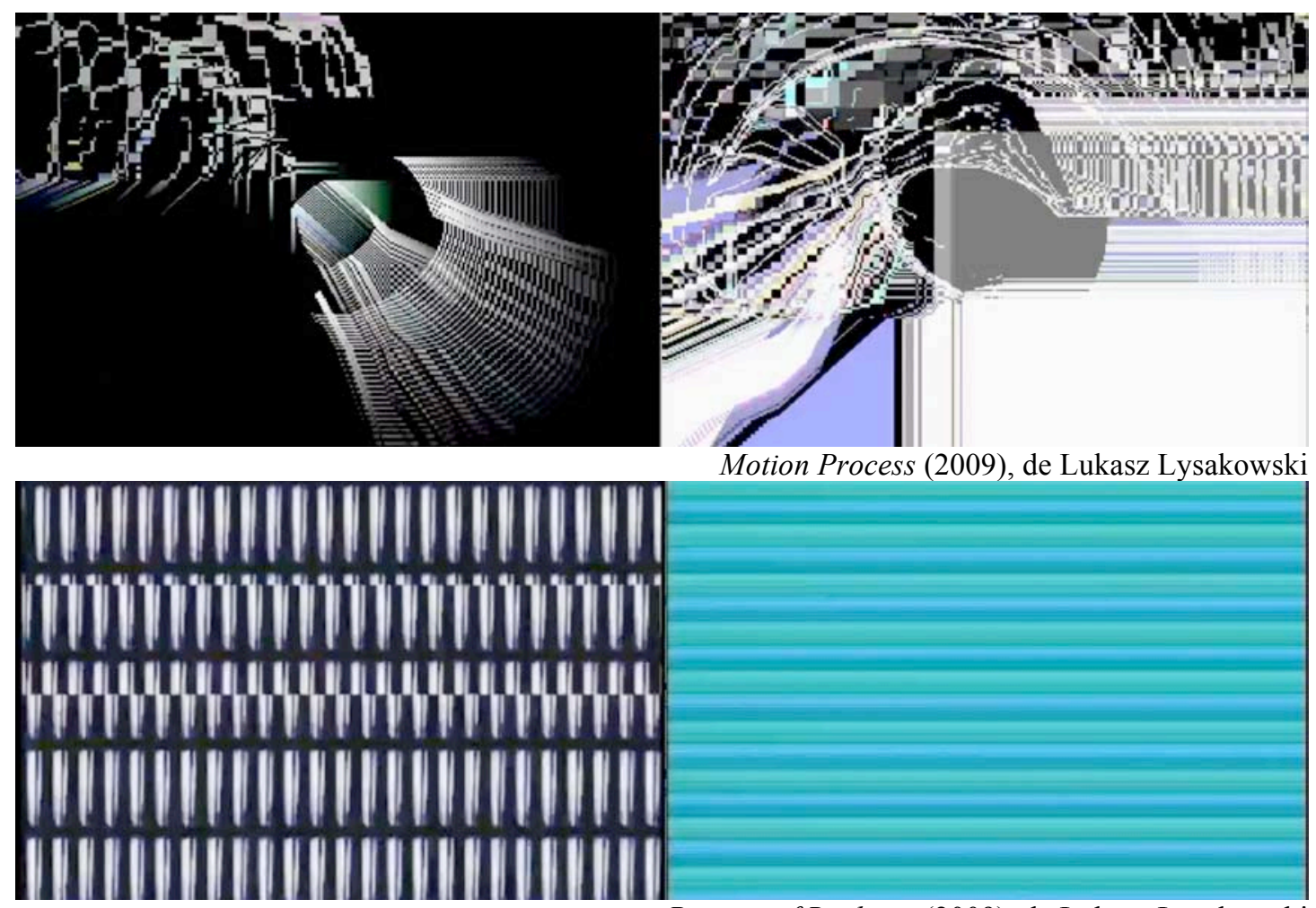

Motion Process (2009), de Lukasz Lysakowski
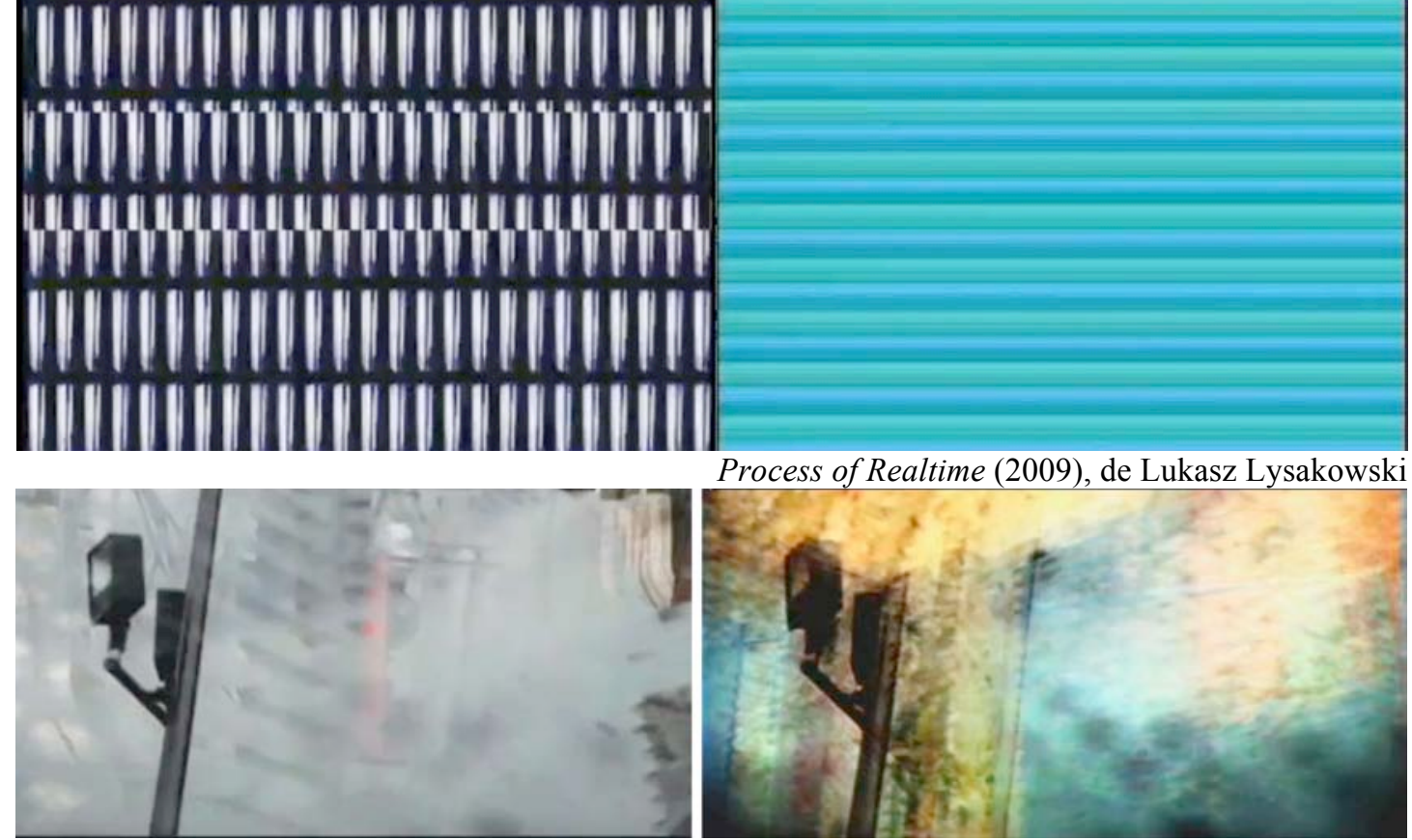

Color Process (2009), de Lukasz Lysakowski

Al principio de este apartado, veíamos cómo John Whitney acudía a la metáfora sintáctica para explicar las combinaciones de los puntos en Permutations. De manera semejante, el proceso seguido por Reas responde al símil del alfabeto que permite formar "palabras" y, a partir de estas, construir "frases". El artista parte de una unidad mínima o "forma" (un círculo o una línea), a la cual aplica hasta siete "comportamientos" asociados a su movimiento y que dan lugar a un "elemento". Por último, el "proceso" define el entorno en el que se relacionan estos "elementos".

No obstante, frente a los arabescos de Whitney, la obra de Reas continúa con la tradición del arte evolutivo de Sims, Latham, Kawaguchi o McCabe. Estos entornos orgánicos se caracterizan por una explosión cromática similar al primer periodo del expresionismo abstracto. Llamado "biomórfico", 41 éste agrupa a una serie de artistas

\footnotetext{
41 “Abstract Expressionism invites interpretation both as the end of an anthropocentric tradition of painting that goes back to the Renaissance, and as an attempt to leave the tradition behind in favour of
} 
que comparten, precisamente, la estrecha vinculación de la obra con su proceso de elaboración. Entre ellos, destacan Jackson Pollock, Willem De Kooning, Lee Krasner y Arshile Gorky.

De hecho, entre todas las animaciones citadas, es sin duda la pieza Process 16 (2006) de Reas la que remite más directamente a esta corriente pictórica. Lejos de la animación tridimensional de Kawaguchi o el zoom de Into the colorflow de McCabe, la maraña cromática subraya el carácter bidimensional de la pantalla como si se tratara de un lienzo de Jackson Pollock (1912-1956). Recordemos que, a finales de los años 40, éste se aleja de la tradición pictórica de caballete y pincel para inventar una nueva técnica basada en el chorreo de pintura sobre la tela extendida en el suelo. Las líneas de colores en Process 16 describen trayectorias y se superponen unas a otras de modo semejante a la acumulación de gestos en la action painting. ${ }^{42}$

Heredero de la escritura automática del surrealismo, este "gesto" quiere ser inconsciente, improvisado, azaroso... Como subrayara Jean Arp en relación a la escultura, no se trata de reproducir o mimetizar, sino de producir. ${ }^{43}$ El resultado de esta acción directa es tan improvisado que ha de sorprender al mismísimo $\operatorname{artista}^{44}$ En este sentido, la action painting comparte con el arte generativo la tensión azar/control.

No obstante, si tanto Pollock como Reas exaltan el proceso de elaboración como fundamento estético, la metodología difiere considerablemente en ambos. El trazo libre de la action painting aparece como una huella de la acción del artista, del movimiento de su cuerpo y de la fuerza física que proyecta la pintura sobre el lienzo. El interés del proceso plástico reside, así, en las posibilidades del individuo. Lejos de este rastro del movimiento humano, las dinámicas en la animación de Casey Reas son producto de los cálculos matemáticos realizados por el ordenador a partir de los “comportamientos" predefinidos por el autor en el "proceso" correspondiente.

\footnotetext{
what can be called a Biocentric approach." BOTAR, Oliver A. I.; WÜNSCHE, Isabel (eds.). Biocentrism and Modernism. Surrey, Burlington: Ashgate Publishing, 2011, p. 227.

${ }^{42}$ Bautizada así por el crítico estadounidense Harold Rosenberg (1906-1978). ROSENBERG, Harold. "The American Action Painters" (1952). En: The Tradition of the New. New York: Horizon Press, 1959.

43 "At a certain moment the canvas began to appear to one American painter after another as an arena in which to act-rather than as a space in which to reproduce, redesign, analyse or 'express' an object, actual or imagined. What was to go on the canvas was not a picture but an event." Ibídem, p. 25

44 "The painter no longer approached his easel with an image in his mind; he went up to it with material in his hand to do something to that other piece of material in front of him. The image would be the result of this encounter. (...) To the painter, she must be a surprise.” Loc. Cit.
} 


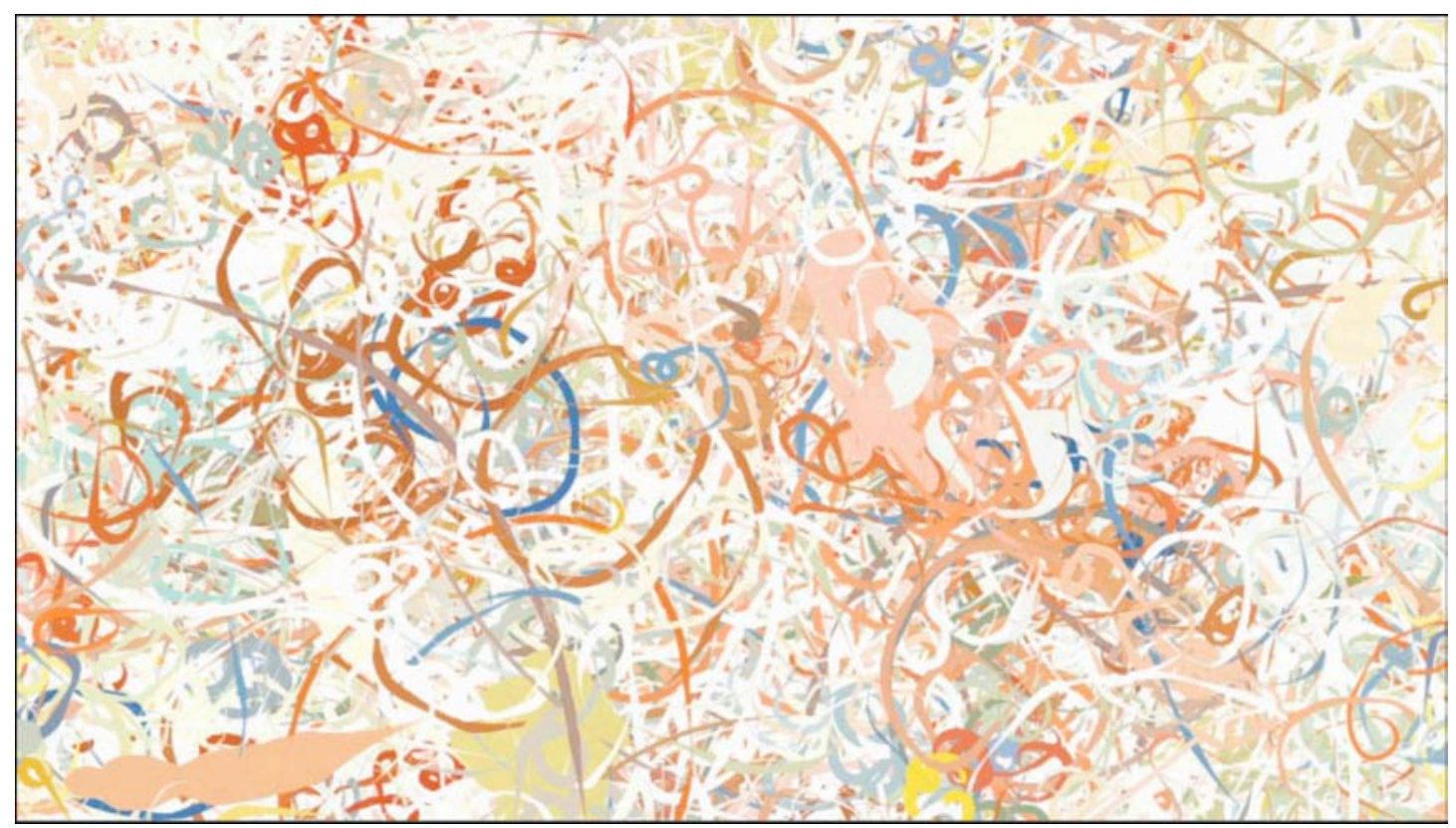

Process 16 (2006), de Casey Reas

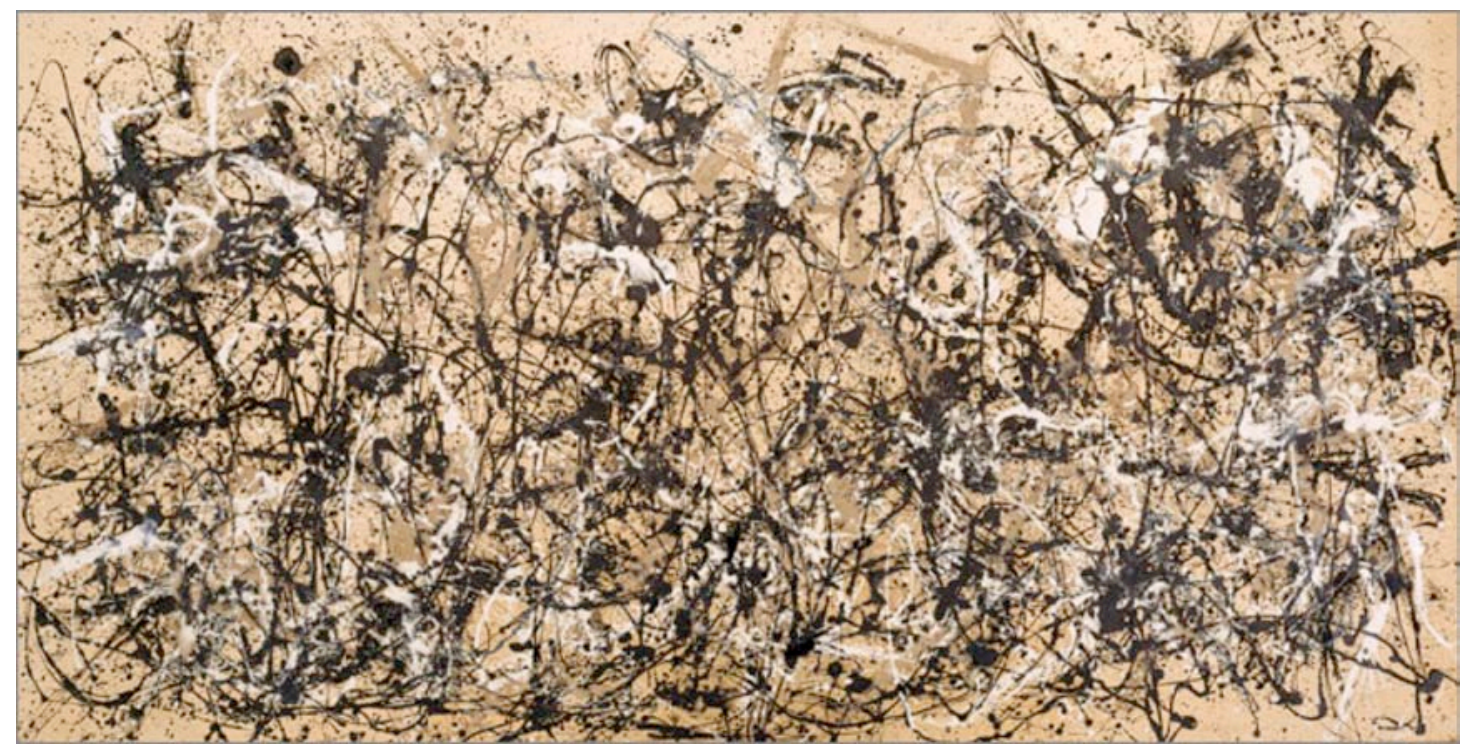

Jackson Pollock: “Autumn Rhythm” (Lumber 30) (1950)

De hecho, de acuerdo con el propio artista digital, el aspecto más importante de su investigación plástica es el texto. ${ }^{45}$ En este sentido, Reas subraya la influencia del arte conceptual de Sol LeWitt (1928-2007) sobre la exploración estética basada en el software. ${ }^{46}$ Los "wall drawings" del artista americano consisten en una serie de

\footnotetext{
45 "The most important element of Process $<$ NUMBER $>$ is the text. The text is the Process described in English, written with the intent to translate its content into software. (...) The software interpretation is secondary to the text. The text leaves many decisions open to the programmer, decisions that must be made using personal judgment.” REAS, Casey. Process Compendium. Op. cit.

${ }^{46}$ REAS, Casey. Software and drawing [En línea]. Software structures. Disponible en Web:

$<$ http://artport.whitney.org/commissions/softwarestructures/text.html>
} 
instrucciones que describen la obra a realizar. Así, por ejemplo, Wall Drawing \#69 (1971) reza:

\begin{abstract}
"Líneas no largas, no estrechas, sin tocarse, dibujadas al azar usando cuatro colores, uniformemente dispersas con densidad máxima, cubriendo toda la superficie de la pared." ${ }^{47}$
\end{abstract}

De modo semejante, el texto que subyace a Process 16 es el siguiente:

\begin{abstract}
"Una superficie rectangular rellenada con tipos de Elemento 3, con una talla y una saturación diferente. Dibujar un círculo diminuto y transparente en el centro de cada Elemento. Aumentar la talla del círculo y su opacidad mientras este Elemento esté tocando a otro Elemento y disminuirlo cuando no sea así." 48
\end{abstract}

Aunque la maraña cromática de Process 16 es aparentemente caótica, en ella subyacen las leyes algorítmicas. Frente al gesto directo de Pollock, la aplicación informática de éstas supone una fase intermedia entre la idea del artista y la imagen en la pantalla del ordenador. El método generativo tiene que ver, así, con la comunicación entre el hombre y la máquina, descrita por la cibernética. Mientras que el lienzo en la pintura es, en sentido estricto, un elemento pasivo, el ordenador es un colaborador activo. Las posibilidades estéticas ligadas al código sobrepasan la creación del individuo, sumando a la imaginación y la habilidad del hombre la abstracción matemática y la potencia calculadora de la máquina. Tal y como admite Reas:

"Siempre me siento constreñido por los límites de mi mente. Ésta es una de las razones por las que escribo software (...). Escribo software para dibujar millones de líneas en algunos segundos, para llevar a cabo miles de cálculos y decisiones en una fracción de segundo, para ir más allá de lo que mi mente puede imaginar sin su extensión digital." ${ }^{49}$

\footnotetext{
${ }^{47}$ LEWITT, Sol. "Doing Wall Drawings". Art Now, New York, June 1971, vol. 3, núm 2.

${ }^{48}$ REAS, Casey. Process Compendium. Op. cit.

${ }^{49}$ REAS, Casey. Entrevista realizada por Daniel Shiffman. Interview with Casey Reas and Ben Fry [En línea]. Rhizome, 23 de Septiembre de 2009. Disponible en Web:

$<$ http://rhizome.org/editorial/2009/sep/23/interview-with-casey-reas-and-ben-fry/>
} 
Casey Reas es, además, co-creador junto a Ben Fry del lenguaje de programación Processing ${ }^{50}$, que permite a otros artistas explorar estéticas visuales ligadas al software. Entre ellos, Marius Watz se sirve de Processing para la generación de sus animaciones sintéticas. Con el objetivo de explorar la potencia plástica del código asociado a la imagen, el artista se concentra en la abstracción formal a partir de la manipulación de algoritmos. Así como A. Michael Noll reinterpreta a Bridget Riley, Watz homenajea al padre del op art, Víctor Vasarely (1908-1997).

En ElectroPlastique \#1 (2005), la red horizontal que ocupa la pantalla se deforma haciendo brotar una suerte de burbujas, como en un líquido en ebullición. Las dos dimensiones de la malla se dilatan dando lugar a semiesferas tridimensionales, que se agolpan unas sobre otras en un espacio caracterizado por el hórror vacui. De este modo, la obra combina a la perfección la geometría y la inspiración orgánica, propias de la exploración óptica emprendida por Vasarely en los años 50.

Contemporáneo de John Whitney, el artista húngaro "programa” sus cuadros como si se tratara de un abecedario o de una partitura musical. El proceso de composición se acerca a la exploración algorítmica del arte conceptual, si bien con el objetivo añadido de explorar los mecanismos de la percepción visual. En este sentido, la obra de Vasarely es asimilable al arte cibernético, tal y como lo describíamos al principio de este apartado.

La "plastique cinétique" $" 51$ se basa en el contraste cromático de las formas geométricas. Cuadros como "Vega" (1957) o "Volans" (1979) provocan una ambigua sensación de pulsación en la imagen fija. Sin embargo, este "movimiento" no responde más que a una ilusión óptica. Por su parte, Marius Watz se lanza a la generación de esas dinámicas en la imagen animada; a la síntesis misma de las ondulaciones, contracciones y dilataciones de la matriz. Este cotejar el efecto visual de la imagen fija y la presentación del proceso mismo de mutación en la imagen animada redunda en la comparación que establecíamos entre los cuadros de Barbadillo y la animación por ordenador Two Space de Larry Cuba.

\footnotetext{
${ }^{50}$ Concebido en 2001, Processing es un lenguaje de programación "open source" dirigido a la creación visual. FRY, Ben; REAS, Casey. Processing: A Programming Handbook for Visual Designers and Artists. Cambridge, MA: The MIT Press, 2007.

${ }^{51}$ HABASQUE, Guy. Vasarely et la plastique cinétique. Bruxelles: QUADRUM, 1957.
} 


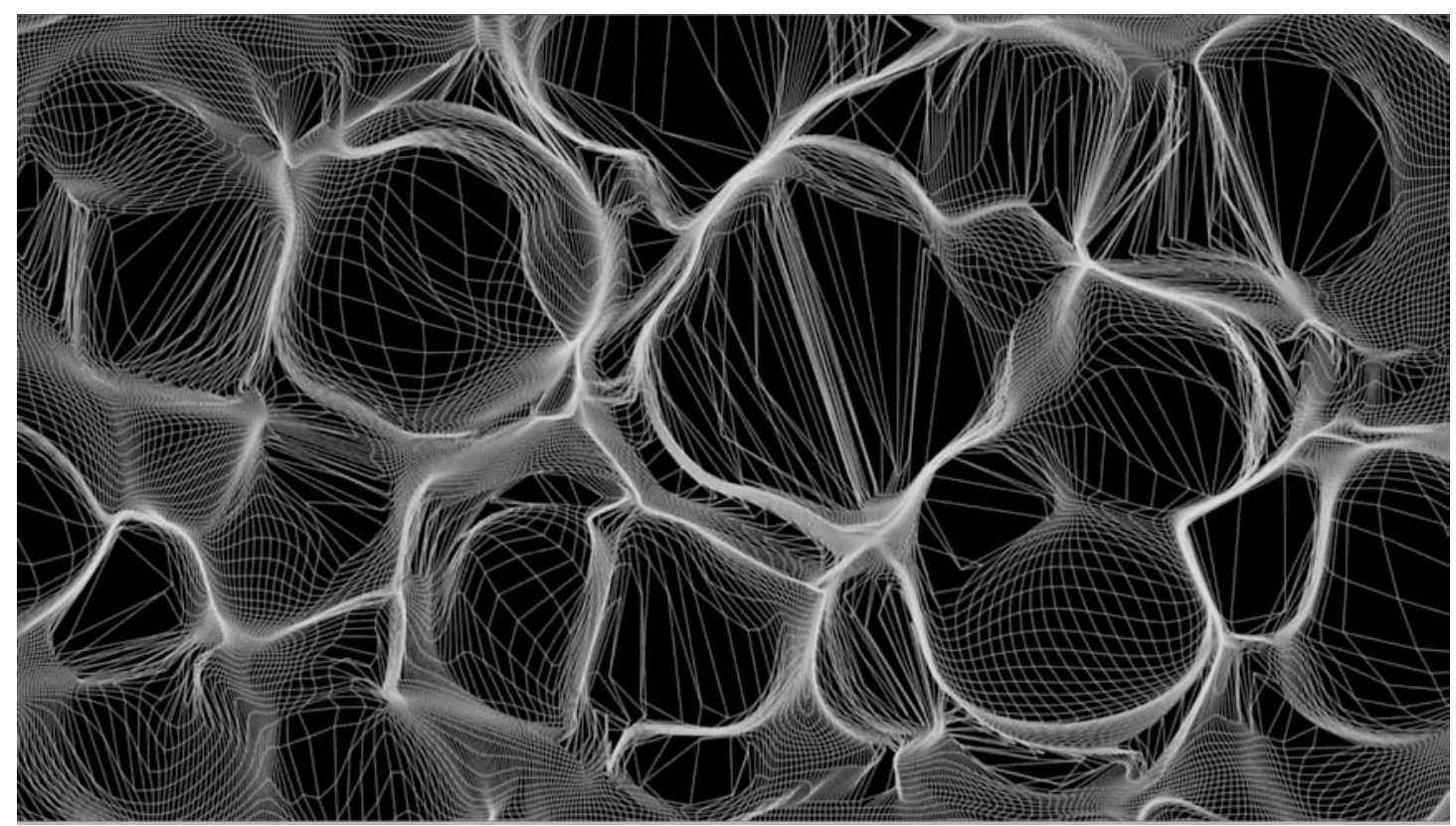

ElectroPlastique \#1 (2005), de Marius Watz
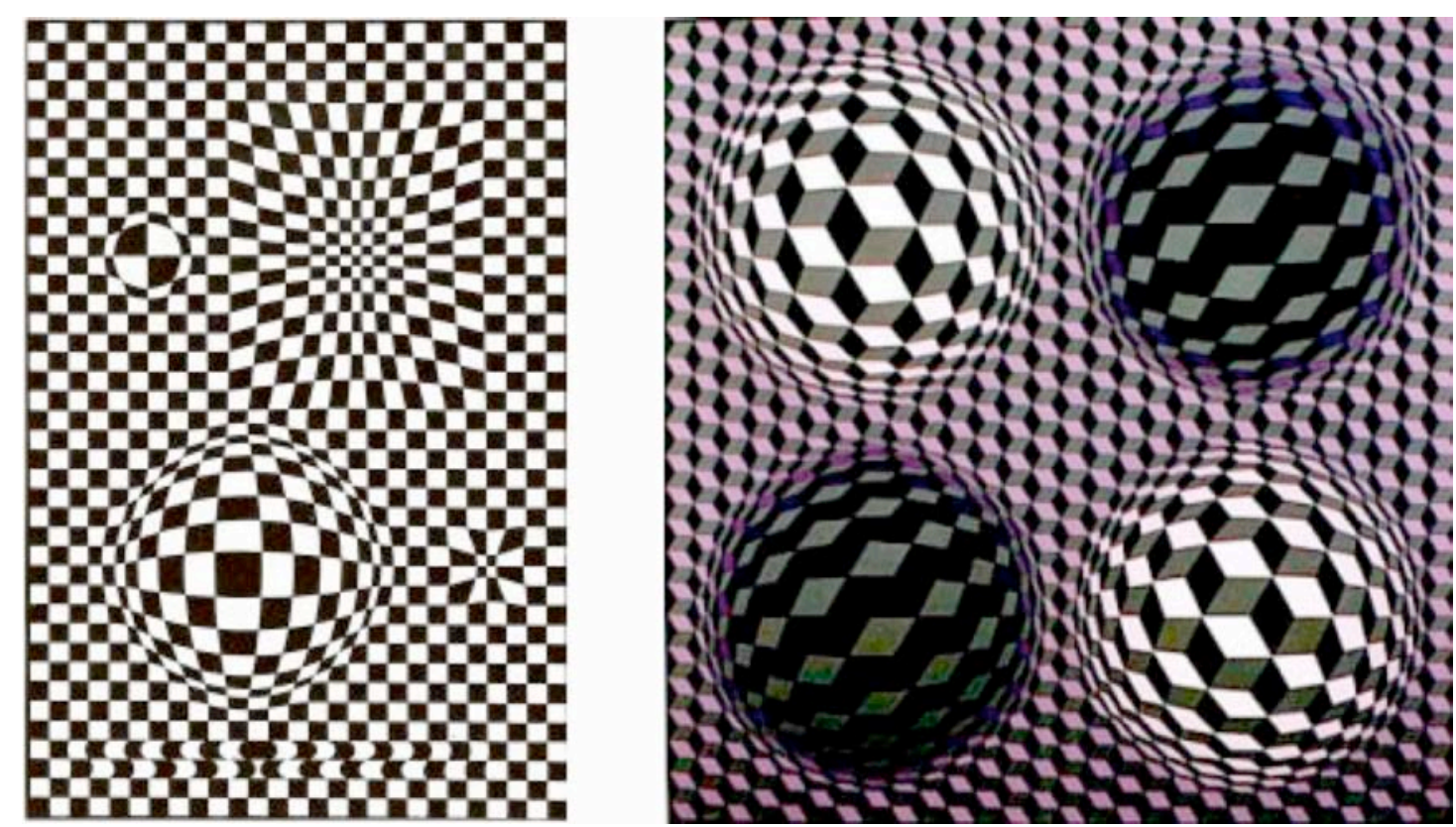

Víctor Vasarely: izquierda, "Vega" (1957); derecha, "Volans" (1979)

Marius Watz versus Víctor Vasarely; Casey Reas versus Jackson Pollock o Sol LeWitt; Michael Noll versus Bridget Riley o Mondrian... Los homenajes explícitos al arte del siglo XX son constantes. No obstante, sería un error limitar el carácter plástico de la imagen digital a un mero "echar a andar" la pintura moderna: las dinámicas logradas mediante los algoritmos genéticos no son las del trazo humano, son otras; son las de la evolución misma de la forma; las de la exhibición del proceso de transformación. 
Aunque, como constatara Noll, el espacio digital casa bien con la matemática subyacente al arte geométrico, aunque la propuesta del arte evolutivo se inserte en la tradición del biomorfismo, las obras que hemos analizado subrayan, ante todo, la potencia creadora de la cooperación entre el artista y el ordenador. Como afirma Marius Watz, la cualidad esencial de la imagen código es su "plasticidad, la habilidad de asumir cualquier configuración que se le pida." 52

A lo largo de toda esta investigación, hemos analizado construcciones que prueban, de uno u otro modo, esta plasticidad sin igual del espacio digital. Una plasticidad que no se agota en el efecto espectacular del morphing como mutación fotorrealista entre formas heterogéneas. La metamorfosis digital no es un mero efecto, es una dinámica que permite animar la imagen prescindiendo del aparato físico y la reproducción mimética del registro. Así, más allá de la interpolación, la plasticidad se manifiesta, también, en la capacidad de activar el espacio gracias a la compresión de los datos, a la permutación o a la génesis misma de la forma. "Plasticidad" es potencia de construcción espacial y ésta se ve enormemente ampliada gracias al código que subyace a la imagen.

\footnotetext{
52 WATZ, Marius. Random Thoughts on Code and Form. A brief survey of computational aesthetics [En línea]. Eyeo Festival, Minneapolis, 2011. Disponible en Web: $<$ http://fr.scribd.com/doc/58999061/20110628-Marius-Watz-Thoughts-on-Code-and-Form-EyeoFestival>
} 


\section{CONCLUSIÓN}

Hemos documentado prácticas espaciales en la imagen código desde los inicios del computer art hasta nuestros días. Con ello, creemos haber cumplido nuestro objetivo de partida: probar ese interés por el espacio y analizar aspectos fundamentales en la práctica, que no han hallado un eco consecuente en la literatura previa a nuestra investigación. Hemos comenzado por proponer el concepto de "construcción" frente al de "reproducción", como clave de una estética de la imagen código ligada a la potencia plástica del espacio. Ésta es fruto de la condición discreta (el píxel) y numérica (el código) que define la imagen digital: una matriz doble, que permite construir, transformar o generar todo tipo de espacios.

El protoespacio del ordenador no responde a una dimensión a priori: aunque puede funcionar como la perspectiva de un programa de diseño 3D o como el "folio en blanco" en 2D, puede ser también el negro hiperdimensional de A. Michael Noll, la "2'5" de la cámara virtual; puede ser un entorno lleno o una dimensión fractal; puede ser primero uno, luego otro y mutar entre ellos de forma continua. El espacio en el ordenador es el reino de la posibilidad.

Precisamente explorando estas posibilidades de construcción espacial, los creadores huyen tanto de la perspectiva como del cine clásico. Sin embargo, hemos constatado que estas rupturas comportan otras continuidades: al alejarse de la proyección central, los autores retoman caminos trazados por la pintura moderna y la "nueva visión" de las vanguardias históricas. De modo semejante, en su rechazo al lenguaje del cine clásico, las prácticas digitales continúan con la vía abierta por el videoarte en la imagen electrónica-analógica y rescatan los experimentos cinematográficos de los años 20: el montaje espacial, la cámara desencadenada, la animación experimental...

La perspectiva coloca al ser humano como centro de la realidad y de su representación. La revolución de la pintura moderna se fundamenta, justamente, en la renuncia al punto de vista fijo del espectador y la construcción de un espacio específico de la imagen. Es decir, la perspectiva pasa de objetivación a un mero artificio que asfixia la exploración plástica. Esta postura es compartida por buena 


\section{CONCLUSIÓN}

parte de las prácticas digitales analizadas: frente al espacio homogéneo, vacío y mensurable, hallamos construcciones heterogéneas, espacios llenos e inabarcables. En este sentido, podemos ver también un anhelo de liberación del punto de vista en la figura de la cámara virtual; esta construcción espacial sustituye aquella visión antropocéntrica por una estética que trata por igual personas y cosas, subrayando el espacio entre ellas como una entidad clave.

Los puntos de vista "desfamiliarizadores", típicos de la exhibición de la omnipotencia de la cámara virtual, tienen un antecedente en la "nueva visión" de principios del siglo XX. En ese contexto, el cine de las vanguardias históricas apuesta por el movimiento continuo del aparato de registro. Con todo, esta liberación de la cámara física es relativa en cuanto condicionada por su materialidad. Por el contrario, la cámara virtual es, en sí, una construcción espacial: este hecho le permite desplazarse más allá de toda frontera, cambiar de escala, unir lo distante y lo opuesto, coser el espacio, dilatarlo, contraerlo.

Como hemos probado en el segundo capítulo, con la cámara virtual, no se trata ya de la modernidad de un aparato que graba cuanto halla a su paso, sino de la exploración de espacios específicos de la imagen gracias a la concepción del cuadro como entidad unificadora. Si la cámara física se desplaza por el espacio profílmico en el tiempo, la cámara virtual es un constructo que permite visualizar lo "imposible". En este sentido, hemos visto el zoom digital como figura del viaje interdimensional y de la recursividad fractal, el plano secuencia como condensación temporal y collage en profundidad, así como la "instantánea tridimensional".

Más allá de la dinamización del punto de vista, constatamos una multiplicación del mismo: desde la cohabitación de imágenes hasta la instalación multicámara. Estas propuestas comparten una inspiración común en el cubismo pictórico; pero, si el montaje espacial permite la exploración de la fragmentación, el bullet time se presenta, en cambio, como un espacio integrado. El movimiento continuo es el resultado de la captura simultánea de diversas vistas del mismo objeto; así, la animación no corresponde al desplazamiento de un aparato físico en el espacio vacío, sino a la mutación de las formas en el interior del cuadro.

Hemos probado cómo la imagen código no es un mero sucedáneo de la imagen cinematográfica; de hecho, como decíamos, en su exploración del espacio digital, los creadores no sólo rompen con la perspectiva, sino con el cine clásico. Este alejamiento pasa por una revisión de los tres "espacios" reservados tradicionalmente a 


\section{CONCLUSIÓN}

la imagen cinematográfica: el bidimensional de la pantalla, el tridimensional de la escena y el "espacio fílmico", producto del montaje temporal de los planos.

La pantalla cinematográfica es considerada como apertura a un espacio representado en la película; esto es, normalmente, el espacio bidimensional se debilita a favor de la sensación de tridimensionalidad. Por el contrario, en la imagen digital, es frecuente la exhibición de su condición plana, sea mediante su compartimentación, sea mediante su activación en la metáfora líquida. La pantalla no se comporta ya como cristal transparente, medio pasivo e intermediario entre el espectador y el espacio representado en la imagen; con la tecnología digital, la pantalla se hace presente entre el receptor y el constructo que es el espacio de la imagen.

En lo que concierne al espacio escénico en el cine clásico, la tridimensionalidad es reproducida por la óptica fotográfica y alimentada, entre otros, por el movimiento del aparato. La cámara virtual explota también esta sensación de profundidad cinética, pero no tiene por qué corresponder a un espacio euclidiano: en su lugar, hallamos collages heterogéneos, cambios de escala o entornos llenos. Así, no es de extrañar la frecuencia con la que el zoom se usa para figurar el puente interdimensional.

Las prácticas digitales analizadas renuncian al plano como unidad mínima, descomponiendo el registro en entidades espaciales: el frame, la capa y, finalmente, el píxel. A este respecto, hemos comprobado cómo el carácter discreto de la imagen código permite un grado de continuidad en las transformaciones sin parangón en las prácticas anteriores. En sus diferentes manifestaciones, la continuidad se exhibe como prueba de la potencia plástica del espacio digital: por un lado, se presenta en continuidad lo distante en el espacio y/o en el tiempo (morphing, transiciones espaciotemporales continuas, plano secuencia digital...); por otro, se muestra la continuidad de lo esencialmente continuo, pero imposible de ser percibido por la visión humana o registrado como tal por la óptica fotográfica (el paso fluido entre escalas o más allá de límites físicos, el rastro del movimiento en un espacio lleno, los hiperespacios...).

Hemos probado cómo la potencia plástica de la imagen digital depende de su condición de constructo espacial frente a la de registro temporal. La constante exhibición de la omnipotencia de la cámara virtual aparece, así, como una celebración de la ruptura con el lastre del aparato físico. En el mismo sentido, el formato rectangular es una mera convención, que no funciona como "ventana", sino como entidad espacial unificadora. A este respecto, descubrimos dos tendencias: la tendencia a la construcción centrífuga y la tendencia a la construcción centrípeta. 


\section{CONCLUSIÓN}

La primera se caracteriza por la explotación de los seis fueras de campo: cuanto más se aleja la imagen de su vinculación al registro, más juega con el fuera de campo como sorpresa, como espacio infinito, como reunión de contrarios... De este modo, la elasticidad del espacio digital no se agota en el efecto espectacular del morphing, sino que hace referencia, también, al espacio que desborda los márgenes de la imagen.

En lo que concierne a la construcción centrípeta, si artistas como Peter Greenaway proponen componer la imagen en el interior del cuadro, otros van más allá al sintetizar dinámicas basadas en la metamorfosis. Así, por ejemplo, el corte transversal del objeto espacio-temporal provoca una mezcla a nivel atómico. Recordemos que, en menor grado, esta desintegración del frame en tanto que unidad mínima es consustancial a la imagen videográfica y las líneas de barrido de la pantalla. No obstante, de nuevo, el ordenador permite ir más allá al posibilitar la "lectura" de los píxeles en todas direcciones.

Centrífuga o centrípeta, en ambas tendencias, el objetivo es romper la equivalencia entre la unidad de registro y la unidad final. Este alejamiento de la imagen-huella permite controlar, también, el tiempo. Por un lado, gracias al montaje espacial, es posible esparcirlo a lo largo de la pantalla. Por otro, la plasticidad del espacio engloba la maleabilidad del tiempo: en las transiciones espacio-temporales continuas y en el plano secuencia digital, hemos comprobado cómo a una elasticidad espacial corresponde a menudo una contracción temporal. Por su parte, el caso específico del bullet time congela el tiempo o lo ralentiza.

Hemos analizado un caso extremo de este control espacial del tiempo: el corte del objeto espacio-temporal. Como explicábamos, el bloque del registro puede relacionarse con el "continuo espacio-tiempo estático": a las tres dimensiones, se une el tiempo sin alterar la naturaleza euclidiana del espacio. Por el contrario, el corte del objeto espacio-temporal remite al "continuo espacio-tiempo relativista" en cuanto revela la continuidad matricial de las cuatro dimensiones, que se contaminan entre sí.

Estas espacializaciones del tiempo comparten la ruptura con la reproducción de un movimiento registrado. La estrategia común a todas ellas consiste en mostrar de forma secuencial lo simultáneo o viceversa. En la "instantánea tridimensional", las capturas al mismo tiempo desde distintos puntos de vista aparecen gradualmente, mientras que, en el apartado "El movimiento como forma continua", explicamos cómo las capturas progresivas se presentan a la vez. Por su parte, el corte del objeto 


\section{CONCLUSIÓN}

espacio-temporal descompone la secuencia registrada en aras de una nueva activación de la imagen.

Como hemos visto en la última sección de este trabajo, la síntesis de dinámicas en un espacio lleno contrasta con el análisis cinético del desplazamiento de un objeto en un espacio vacío. Hemos probado cómo la estética de la imagen digital está ligada a la plasticidad del espacio no sólo en tanto que posibilidad de construcción, sino como proceso, como exhibición misma de la mutación; así, la forma de activación básica es la metamorfosis, sea como paso fluido de una forma a otra, sea como recombinación o permutación de una serie de elementos.

Hemos acabado nuestra investigación con una comparación entre las intuiciones de los pioneros del computer art, hace ya medio siglo, y el arte generativo, contemporáneo al presente trabajo. En ambos, el proceso plástico constituye un elemento clave de la estética de la obra, llegando incluso a la presentación de la metodología misma. Para comprender esta propuesta estética, hemos recuperado el arte conceptual, según el cual, la idea abstracta trasciende la materialización de la pieza, limitándose la obra a la definición de una serie de instrucciones. No obstante, hemos constatado cómo, en la creación digital, las órdenes formuladas por el hombre son, finalmente, ejecutadas por la máquina. La potencia plástica de la imagen código se manifiesta, así, en la capacidad de sorpresa del feedback informático: el techo de lo concebible, la posibilidad de otros espacios y dinámicas, se sitúa no sólo más allá de los límites del registro o de la visión, sino de los de la mente humana, de la imaginación.

Por todo ello, podemos afirmar que la imagen digital nos ayuda en nuestro empeño por comprender el espacio. Mientras que la maleabilidad del tiempo cinematográfico da acceso al concepto temporal, la plasticidad del espacio digital permite abarcar el concepto espacial. Gracias al dispositivo cinematográfico, es posible ralentizar, acelerar, congelar e invertir el tiempo; esto es: modelarlo (Jean Epstein), esculpirlo (Andrei Tarkovski); por ello, el cinematógrafo se compara a menudo con una "fábrica del tiempo". En contraste, podríamos hablar del ordenador como una "fábrica del espacio", en cuanto la informática permite dilatarlo, contraerlo,

\footnotetext{
1 "La fabrique du temps" es el título elegido para el ciclo de películas proyectado entre el 1 de diciembre de 2010 y el 24 de febrero de 2011 en el Forum des Images de París. En línea:

$<$ http://www.forumdesimages.fr/fdi/Cycles/Archives-Cycles/Archives-Cycles-saison-2010-2011/Lafabrique-du-temps $>$
} 


\section{CONCLUSIÓN}

revertirlo, generarlo, mutarlo... La exploración de los propios autores se acerca, así, al juego creativo de un niño que, para entender, primero toca, manipula, distorsiona...

Este trabajo se ha centrado en la "construcción espacial" ligada al proceso de elaboración de imágenes digitales. Quisiéramos acabar abriendo una nueva línea de investigación centrada, esta vez, en obras en sí interactivas. Nuestra propuesta consiste en la creación de piezas, en las cuales la interacción del usuario consista, precisamente, en una comprensión del espacio mediante la construcción y la dinamización de la imagen; es decir, que la experiencia del receptor pase por generar, transformar o variar el espacio, como parte de un conocimiento por la acción: de un “pensamiento en imágenes". Retomando la expresión de José Luis Molinuevo², se trata de permitir al usuario abordar el espacio construyéndolo, mezclándolo, experimentándolo. En la última década, algunos artistas han dado tímidos pasos en este sentido. Citamos aquí algunos ejemplos.

En 66movingimages (2002), Chris Ziegler crea una instalación a partir de fotografías de su viaje en moto por la Route 66. El artista monta una pantalla interactiva sobre un carril de once metros de largo, metáfora de la mítica carretera estadounidense. Al desplazar la pantalla, una cadena de morphing activa las instantáneas del paisaje, de modo que la interacción del usuario consiste en la dinamización de las imágenes fijas. Ésta remite a la distorsión del paisaje como consecuencia de la velocidad de la moto; a este respecto, el autor se refiere a la sustitución del desplazamiento de un objeto en un espacio vacío por la idea de un entorno lleno: "Al crear las metamorfosis de las instantáneas, transformo el movimiento físico de un vehículo en el espacio, en el movimiento pictórico de un paisaje en torno al receptor." 3 El género cinematográfico de la "road movie" se caracteriza por el paralelismo entre el desplazamiento físico y la transformación anímica del personaje. A la vivencia del protagonista de este cine subjetivo, Ziegler sustituye la experiencia del usuario como construcción espacial.

\footnotetext{
2 "A qué llamo pensamiento en imágenes. A tratar de comprender (sin conceptos emocionales, filosofía) este mundo (tiempo, espacio) encontrando, produciendo, mezclando, imágenes, no leyéndolas (semiótica) ni imaginándolas (platonismo), sino experimentándolas (modernidad estética). El pensamiento en imágenes es el mapa de experiencias poliestéticas en un momento dado. Sólo eso." José Luis Molinuevo. Ver blog:

$<$ http://joseluismolinuevo.blogspot.fr/2011/02/que-llamo-pensamiento-en-imagenes.html $>$

${ }^{3}$ ZIEGLER, Christian, "66movingimages. Interaction in Filmic Space”. En: BUSHOF, Brunhild (ed.). Developing Interactive Narrative Content. sagas_sagasnet_reader. Munich: High Text Verlag, 2005, p. 446.
} 


\section{CONCLUSIÓN}

El cristal transparente, pasivo e intermediario entre el espectador y el espacio representado en la imagen se convierte en una interfaz entre el receptor y el espacio que él mismo construye con su interacción. Con su instalación interactiva Khronos Projector (2005), Álvaro Cassinelli va un paso más allá al explotar la plasticidad de una pantalla táctil. Mediante un corte de un objeto espacio-temporal semejante a los analizados en el último capítulo de nuestro trabajo, la obra permite al usuario construir nuevas dinámicas de la imagen a partir de un registro temporal previo. La interacción provoca en el usuario "una fuerte sensación de estar realmente esculpiendo la sustancia espacio-temporal con sus propias manos". ${ }^{4}$ Cassinelli exalta la potencia de su proyector digital en comparación con el dispositivo cinematográfico: "Un magnetoscopio clásico permite un control simple del proceso de reproducción (parar, rebobinar, ir hacia delante y un control elemental de la velocidad de reproducción). (...) El objetivo del Khronos Projector es ir más allá de la exclusividad del control temporal, dando al receptor una dimensión con la que jugar totalmente nueva." En este sentido, el autor habla de una "audience's cut" en cuanto el usuario reedita el material de partida.

Como tantos artistas analizados en nuestro trabajo, Cassinelli relaciona su obra con la teoría de la relatividad de Albert Einstein; evidentemente, no pretende comprobar las afirmaciones del físico alemán, sino abrir la puerta a otras exploraciones del espacio más allá de las tres dimensiones y el tiempo. En cualquier caso, es innegable el parecido entre la pantalla táctil deformable del Khronos Projector y el portal líquido que veíamos en Donnie Darko (2001), de Richard Kelly.

Como en 66movingimages, la interactividad reside en la construcción misma del espacio; eso sí, con el importante añadido de que la obra de Cassinelli permite una interacción táctil que contribuye a la experiencia del usuario en cuanto construcción del espacio de la imagen. En este sentido, una nueva vía de exploración se abre con la popularización de las tabletas.

El webdocumental Alma (2012), de Miquel Dewever-Plana e Isabelle Fougère, ${ }^{5}$ presenta la confesión de una antigua miembro de una de las bandas más violentas de Guatemala. A lo largo de cuarenta minutos, el registro de su insoportable testimonio se presenta de manera neutra, con un primer plano de su rostro sobre un fondo negro. La interacción del usuario consiste en desplazar este "nivel de confesión", huir de él

\footnotetext{
${ }^{4}$ Ver la página web del proyecto: $<$ http://www.k2.t.u-tokyo.ac.jp/members/alvaro/Khronos/>

${ }^{5}$ Ver la página del webdocumental: $<$ http://alma.arte.tv/fr/
} 


\section{CONCLUSIÓN}

hacia el margen superior, haciendo entrar en el cuadro un "nivel de evocación"; éste sustituye el cara a cara con la excriminal por una serie de vídeos, fotografías y dibujos, que ilustran el relato de la protagonista, ya en off. Concebida por Sébastien Brothier en la productora web "Upian", la experiencia del usuario no es tanto una navegación como un montaje espacial interactivo, comparable al "audience's cut" de Cassinelli. En su versión iPad, la interacción táctil contribuye a la sensación de construir uno mismo el espacio de la imagen.

Los tres ejemplos citados aciertan al proponer una interacción que permita al usuario aprehender el espacio por la acción. No obstante, se trata de casos aislados; en general, los creadores de interfaces muestran un empeño contraproducente por adaptar el lenguaje cinematográfico a las obras interactivas. El resultado de esta traducción forzosa suele ser o bien una interactividad anecdótica, o bien una deslinealización y un acceso enciclopédico a los fragmentos. Este proceder ignora la potencia de la tecnología digital para la construcción espacial. Autores como Boyd Davis (2002) o Persson (1998) han probado ya de sobra las limitaciones del lenguaje cinematográfico en este sentido. Frente a la linealidad del cine de ficción, en el que el aspecto temporal es predominante, la imagen interactiva impone una espacialización explícita, no transparente, que permita al usuario acceder a la interfaz. Por consiguiente, a la hora de construir espacios interactivos, ¿por qué imponerles las convenciones de un lenguaje centrado en el aspecto temporal? Sin duda, la creación en este ámbito se vería enriquecida por una conciencia del aspecto eminentemente espacial no sólo de la interfaz, sino de la experiencia misma del usuario.

En este sentido, el análisis de construcciones que hemos llevado a cabo puede servir como "eslabón perdido" entre la imagen animada y el diseño de obras interactivas. Las prácticas de los últimos cincuenta años, desde los pioneros del computer art hasta los últimos efectos digitales o el arte generativo, prueban la potencia plástica de esta "fábrica del espacio", que no sólo permite mutar la forma a voluntad, sino visualizar lo impensable. El espacio en el interior del ordenador no responde a ninguna dimensión previa y, por ello, todo lo concebible es posible. 


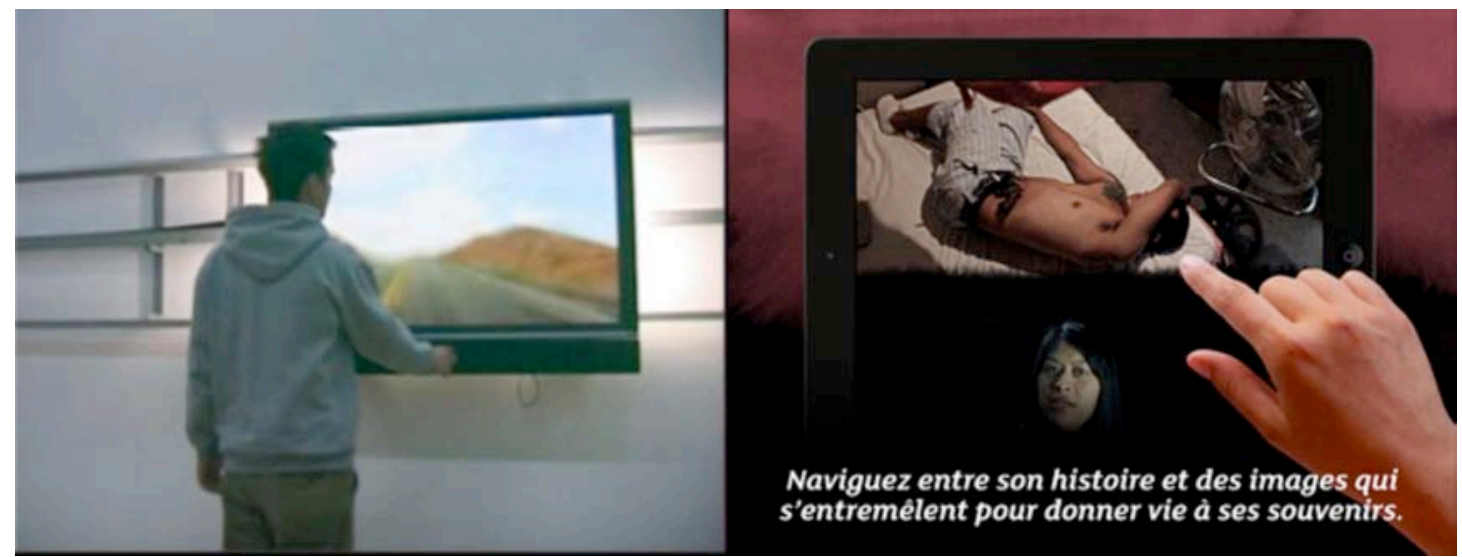

Izquierda, 66movingimages (2002), de Ziegler. Derecha, Alma (2012), de Dewever-Plana y Fougère
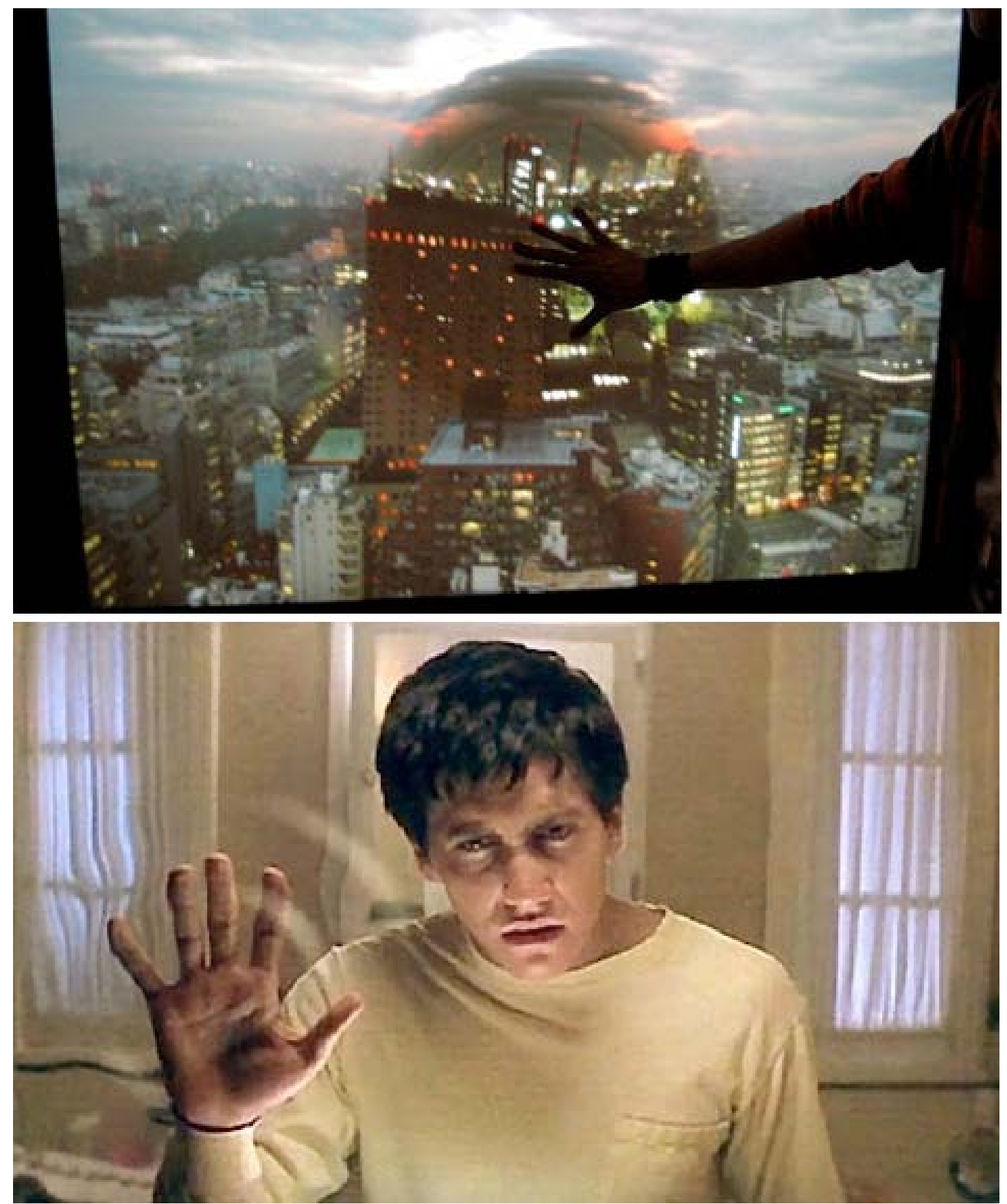

Arriba. Khronos Projector (2005), de Cassinelli. Abajo. Donnie Darko (2001), de Richard Kelly 


\section{MATERIALES UTILIZADOS}

La presente investigación ha partido del visionado de imágenes, la selección de aquéllas más representativas para el objeto de estudio, y su clasificación en el texto. Puesto que el enfoque es eminentemente práctico, subrayamos la importancia de las imágenes mismas como material fundamental de este trabajo.

En lo que concierne a la documentación que ha servido como apoyo teórico, comenzamos con una relación de obras bibliográficas. A éstas siguen los "recursos audiovisuales", en los que destacamos aquellas entrevistas, "extras" o "making of", en formato vídeo, que han servido como material. A continuación, la "webiografía" recoge las páginas web consultadas a lo largo de toda la investigación. Finalmente, presentamos un listado de las imágenes analizadas, ordenadas alfabéticamente por autor o director (apellidos, nombre), seguido del título de la obra.

De este modo, los materiales se agrupan en las siguientes cuatro categorías:
A. BIBLIOGRAFÍA
B. RECURSOS AUDIOVISUALES
C. WEBIOGRAFÍA
D. LISTADO DE IMÁGENES 


\section{A. BIBLIOGRAFÍA}

Para la elaboración de esta bibliografía, nos hemos adaptado en lo posible a la norma ISO 690-1987. En general, se ha consultado y se ha citado las fuentes en su idioma original o, en su ausencia, una traducción al español. Sin embargo, algunas excepciones responden a un interés específico; sirva como ejemplo la obra de Erwin Panofsky Die Perspektive als symbolische Form (1927), cuya versión francesa se ha preferido a la traducción española gracias al completo prefacio de Marisa Dalai Emiliani.

Respecto a las referencias de los documentos electrónicos, para facilitar su lectura, todas las páginas web han sido revisadas el 15 de mayo de 2013 y, por ello, no se incluye la fecha de la primera consulta.

En lo que concierne a la clasificación de la bibliografía, por un lado, diferenciamos entre libros, artículos/ensayos/entrevistas, y tesis. Por otro lado, hemos establecido los siguientes apartados con el fin de procurar un acceso temático a la relación de las obras:

A.1. Imagen digital, videoarte, animación y cine contemporáneo

A.2. Teoría de los nuevos medios y estética de las nuevas tecnologías

A.3. Teoría, estética e historia cinematográficas

A.3.1. Cine de las vanguardias históricas y experimental

A.4. Historia del arte y estética: pintura, escultura, arquitectura, fotografía, teatro, música y danza

A.5. Teoría de la imagen

A.6. Ciencias

A.6.1. Hiperespacio y espacios no-euclidianos

A.7. Giro espacial

A.8. Literatura

A.9. Otros

Comenzamos con las publicaciones sobre imagen digital, videoarte $\mathrm{y}$ animación, así como sobre la literatura concerniente al impacto de las nuevas tecnologías sobre el cine. Por separado, se agrupan los escritos sobre nuevos medios, 
software y estética de las nuevas tecnologías; contexto global, del cual la imagen digital animada es un ámbito específico. Ardua ha sido la tarea de hacer la criba entre ambas. Como solución, hemos optado por priorizar el grueso de la obra. Éste es el caso, por ejemplo, de The Language of New Media de Lev Manovich, que clasificamos en el segundo apartado. Si bien el autor dedica el último capítulo al "cine digital", la imagen animada es un aspecto minoritario de la obra, dedicada principalmente a los nuevos medios interactivos: web, videojuegos, interfaces, etc.

Tras estas dos primeras secciones, se encontrará otra dedicada a la teoría y estética cinematográficas, subdividida a su vez en un apartado sobre cine experimental; en éste se recogen, entre otros, las obras relacionadas con las vanguardias históricas. A continuación, agrupamos escritos sobre historia del arte y estética en general que atañen a otras disciplinas artísticas (pintura, fotografía, escultura, etc.). Destacamos, a su vez, las obras consultadas sobre teoría de la imagen.

Las publicaciones científicas que no tocan específicamente a la construcción digital de las imágenes (esto es, campos como la biología o la matemática) se han reunido bajo el título global de "ciencias". A este apartado, sigue un listado de textos sobre hiperespacios y espacios no-euclidianos. Nótese a este respecto que las publicaciones de los pioneros del computer art se recogen en el primer apartado, en cuanto conciernen directamente a la imagen digital.

Hemos reunido bajo el epígrafe "Giro espacial" aquellos textos que han marcado el interés por el concepto espacial en campos tales como la poética, la geografía, la política, la economía, la antropología, la sociología, la comunicación o el arte; así como las monografías y ensayos interdisciplinares que dan cuenta de esta tendencia. Con todo, los escasos trabajos sobre la representación espacial en la imagen cinematográfica se citan, ya, en el apartado dedicado a la estética del cine.

Para acabar la bibliografía y tras referir la literatura de ficción citada a lo largo del texto, incluimos un pequeño "cajón de sastre" u "Otros", en el que recuperamos obras mencionadas que no entran en ninguna de las categorías anteriores. 


\section{A.1. Imagen digital, videoarte, animación y cine contemporáneo}

- ALCALÁ MELlADO, José Ramón; NAVARRO OLTRA, Guillermo. Una introducción a la imagen digital y su tratamiento. Cuenca: MIDECIANT, 2008.

- ALFONSI, Laurence. Le cinéma du futur : les enjeux de nouvelles technologies de l'image. Paris: L'Harmattan, 2005.

- ALTENA, Arie; VAN DER VELDEN, Lucas (eds.). The Anthology of Computer Art. Amsterdam: Sonic Acts Press, 2006.

- ANDERSON, Scott. Morphing Magic. Indiana: Sams Publishing, 1993.

- ARDÉVOL, Elisenda; MUNTAÑOLA, Nora (coord.). Representación y cultura audiovisual en la sociedad contemporánea. Barcelona: Editorial UOC, 2004.

- ARMES, Roy. On video (1988). New York: Routledge, 2002.

- BAIGORRI BALLARÍN, Laura. El vídeo y las vanguardias históricas. Barcelona: Edicions Universitat Barcelona, 1997.

- BALPE, Jean-Pierre. Contextes de l'art numérique. Paris: Hermès, 2000.

- BARBOZA, Pierre. Du photographique au numérique : la parenthèse indicielle dans l'histoire des images. Paris: L'Harmattan, 1996.

- BARBOZA, Pierre. Les nouvelles images. Paris: Somogy, Cité des Sciences et de l'Industrie, 1997.

- BEAU, Frank; DUBOIS, Philippe; LEBLANC, Gérard. Cinéma et dernières technologies. Paris: De Boeck Université, 1998.

- BECKHAM, Karen; MA, Jean. Still Moving: Between Cinema and Photography (1994). Durham N.C: Duke University Press, 2008.

- BELloUR, Raymond. L'Entre-images. Photo, cinéma, vidéo. Paris: Éditions de la Différence, 1990.

- BELLOUR, Raymond. L'Entre-images 2, Mots, Images. Paris: Éditions P.O.L., 1999.

- BELlOUR, Raymond; DAVID, Catherine; VAN ASSCHE, Christine (eds.). Passages de l'image. Paris: Éditions du Centre Pompidou, 1989.

- BENTLEY, Peter. Evolutionary Design by Computers. San Francisco: Morgan Kaufmann Publishers, 1999.

- BERGER, Pierre; LIORET, Alain. L'Art Génératif. Jouer à Dieu ... un droit ? un devoir ?. Paris: L'Harmattan, 2012. 
- BERNARD, Hervé. L'image numérique et le cinéma. Paris: Éditions Eyrolles, 2000.

- BIZONY, Piers. Digital Domain. The Leading Edge of Visual Effects. London: Billboard Books, 2001.

- BLIN, Odile; SAUVAGEOT, Jacques (dir.). Images numériques : l'aventure du regard. Rennes: École régionale des beaux-arts de Rennes, Presses universitaires de Rennes, 1997.

- BONET, Eugeni; DOLS, Joaquim; MERCADER, Antoni; MUNTADAS, Antoni. En torno al video. Barcelona: Gustavo Gili, 1980.

- BUKATMAN, Scott. Matters of Gravity: Special Effects and Supermen in the 20th Century. Durham, NC, London: Duke University Press, 2003.

- BURGER, Wilhelm; BURGE, Mark. Principles of Digital Image Processing: Fundamental Techniques. London: Springer-Verlag, 2009.

- CAUX, Daniel (ed.). Peter Greenaway. Paris: Éditions Dis Voir, 1987.

- CHONG, Andrew. Basics Animation: Digital Animation. Lausanne: AVA Publishing, 2008.

- ClAYSSEN, D.; LOBSTEIN, D.; ZEITOUN, J.. Les nouvelles images. Paris: Dunod, 1987.

- COTTE, Olivier. Il était une fois le dessin animé. Paris: Dreamland, 2001.

- COUCHOT, Edmond. Images : de l'optique au numérique. Paris: Hermès, 1988.

- CUBITT, Sean. Timeshift: On video culture. London: Routledge, 1991.

- CUBITT, Sean. Videography: Video Media as Art and Culture. Gordonsville, Virginia, U.S.A.: Palgrave Macmillan, 1993.

- D'Agostino, Peter. Transmission: Theory and Practice for a New Television Aesthetics. New York: Tanam Press, 1985.

- DARRAS, Bernard; THONON, Marie. (dir.). Image et média. Paris: Éditions L'Harmattan, 1997.

- DONATI, Jason. Exploring Digital Cinematography. Clifton Park, NY: Delmar Cengage Learning, 2007.

- DRUCKREY, Timothy (ed.). Electronic culture: technology and visual representation. New York: Aperture, 1996.

- DUGUET, Anne-Marie. Déjouer l'image. Créations électroniques et numériques. Nîmes: Jacqueline Chambon, 2002.

- DUGUET, Anne-Marie (ed.). Thierry Kuntzel. Paris: Galerie nationale du Jeu de Paume, 1993. 
- DUGUET, Anne-Marie (ed.). Title TK. Nantes: Les Presses du réel, 2006.

- DUNN, David (ed.). Eigenwelt der Apparate-Welt. Pioneers of Electronic Art. Linz: Ars Electronica, 1992.

- EAMES, Charles; EAMES, Ray. A Computer Perspective. Cambridge: Harvard University Press, 1990.

- ESQUENAZI, Jean-Pierre (dir.). Cinéma contemporain, état de lieux. Paris: L'Harmattan, 2004.

- FARGIER, Jean-Paul (ed). Où va la vidéo?. Paris: Cahiers du cinéma, Éditions de l’Étoile, 1986.

- FAUGERAS, Olivier. Three-Dimensional Computer Vision: A Geometric Viewpoint. Cambridge, London: The MIT Press, 1993.

- FIFER, S. J.; HALL, Doug. Illuminating Video: An Essential Guide to Video Art. New York: Aperture, Bay Area Video Coalition, 1990.

- FLAKE, Gary William. The Computational Beauty of Nature: Computer Explorations of Fractals, Chaos, Complex Systems, and Adaptation. Cambridge, MA: The MIT Press, 2000.

- FOLEY, James D. Computer Graphics: Principles and Practice (1990). Reading, MA, USA: Addison-Wesley, 1997.

- FRANKE, H.W. Computer Graphics - Computer Art (1971). Berlin, New York: Springer-Verlag, 1985.

- GILMORE, Joe; MORADI, Iman; MURPHY, Christopher; SCOTT, Ant. Glitch: Designing Imperfection. New York: Mark Batty Publisher, 2009.

- GRAILLAT, Ludovic (coord.). De Tron à Matrix : réflexions sur un cinéma d'un genre nouveau. Actes du colloque des 2, 3 et 4 février 2004 à la Cinémathèque de Toulouse. Toulouse: Centre National de Documentation Pédagogique Midi-Pyrénées, 2006.

- HALAS, John (ed.). Computer Animation. New York: Focal Press, 1974.

- HAMUS-VALLÉE, Réjane. Les effets spéciaux. Paris: Cahiers du cinéma, 2004.

- HANHARDT, John. Video Culture: A Critical Investigation. Rochester, New York: Visual studies Workshop Press, 1986.

- HANSON, Matt. Reinventing Music Video: Next-Generation Directors, their inspiration and work. London: Focal Press, 2006.

- HANSON, Matt. The End of Celluloid: Film Futures in the Digital Age. Hove: Rotovision, 2004. 
- HARTLEY, Richard; ZISSERMAN, Andrew. Multiple View Geometry in Computer Vision. Cambridge: Cambridge University Press, 2003.

- HILDERBRAND, Lucas; HORSFIELD, Kate (eds.). Feedback: The Video Data Bank Catalog of Video Art and Artists Interviews. Chicago, Philadelphia, PA: Temple University Press, 2006.

- HOLTZ-BONNEAU, Françoise. L'image et l'ordinateur. Paris: Aubier/INA, 1986.

- JANKEL, Annabel; MORTON, Rocky. Creative Computer Graphics. Cambridge: Cambridge University Press, 1984.

- JULLIER, Laurent. L'écran postmoderne. Un cinéma de l'allusion et du feu d'artifice. Paris: L’Harmattan, 1997.

- JULLIER, Laurent. Les images de synthèse. Paris: Éditions Nathan, 1998.

- KLONARIS, Maria; THOMADAKI, Katerina. Mutations de l'image. Art cinéma / vidéo / ordinateur. Paris: ASTARTI, 1994.

- KLONARIS, Maria; THOMADAKI, Katerina. Pour une Écologie des media. Art cinéma / vidéo / ordinateur. Paris: ASTARTI, 1998.

- KLONARIS, Maria; THOMADAKI, Katerina. Technologies et imaginaires. Art cinéma / vidéo / ordinateur. Paris: Dis Voir, 1990.

- KLÜTSCH, Christoph. Computergraphik: Ästhetische Experimente zwischen zwei Kulturen. Die Anfänge der Computerkunst in den 1960er Jahren. Wien: Springer, 2007.

- KUSPIT, Donald (ed.). Arte digital y videoarte: transgrediendo los límites de la representación. Madrid: Círculo de Bellas artes, 2006.

- LAFON, Jacques. Esthétique de l'image de synthèse. La trace de l'ange. Paris: L'Harmattan, 1999.

- LATHAM, William; TODD, Stephen. Evolutionary Art and Computers. Winchester, UK: Academic Press, 1992.

- LEAVITT, Ruth (ed.). Artist and Computer. New York: Harmony Press, 1976.

- LEWIS, Jon. The End of Cinema as We Know it: American Film in the Nineties. London: Pluto Press, 2001.

- LIESER, Wolf. Digital Art. Innovative Logistics Llc, 2009.

- LINDER, Wilfried. Digital Photogrammetry: A Practical Course. Berlin, Heidelberg: Springer-Verlag, 2009.

- LIORET, Alain. Émergence de nouvelles esthétiques du mouvement. Paris: L'Harmattan, 2004. 
- LISTER, Martin (comp.). La imagen fotográfica en la cultura digital. Barcelona: Paidós Ibérica, S.A., 1997.

- LOUGUET, Patrick; MAHEU, Fabien (coords.). Cinéma(s) et nouvelles technologies : continuités et ruptures créatives. Paris: Editions L'Harmattan, 2011.

- LOUGUET, Patrick. Sensibles proximités : les arts au carrefours (Cinéma, danse, installation, vidéo-art). Arras: Artois Presses Université, 2009.

- LOVINK, Geert; MILES, Rachel Somers (eds.). Video Vortex Reader II: moving images beyond YouTube. Amsterdam: Institute of Network Cultures, 2011. Disponible en Web: <http://networkcultures.org/wpmu/portal/publication/videovortex-2/>

- MAEDA, John. Design By Numbers. Cambridge, MA: The MIT Press, 1999.

- MARTIN, Sylvia (ed.). Videoarte. Colonia: Taschen GmbH, 2008.

- MASON, Catherine. A Computer in the Art Room: The Origins of British Computer Arts 1950-80. Hindringham, Norfolk: JJG Pub., 2008.

- MASONI-LACROIX, Céline; SOBIESZCZANSKI, Marcin (dirs.). Du split-screen au multi-screen. La narration vidéo-filmique spatialement distribuée. Bern: Peter Lang, 2010.

- MCCLEAN, Shilo. Digital Storytelling. The Narrative Power of Visual Effects in Film. Massachusetts: The MIT Press, 2007.

- MCKERNAN, Brian. Digital Cinema: The Revolution in Cinematography, Postproduction, and Distribution. New York: McGraw Hill, 2005.

- MICHALKA, Matthias (ed.). X-Screen: Film installations and actions in the 1960s and 1970s. Cologne: Verlag, 2003.

- MITCHELL, William J. The Reconfigured Eye: Visual Truth in the PostPhotographic Era. Cambridge: The MIT Press, 1994.

- MOHR, Manfred. Artificiata I. Paris: Éditions Agentzia, 1969.

- MOLINUEVO, José Luis. Retorno a la imagen. Estética del cine en la modernidad melancólica. Salamanca: Archipiélagos, 2010.

- NEES, Georg. Generative Computergraphik. Berlin, München: Siemens, 1969.

- PAIK, Nam June. Videa 'n' Videology (1959-1973). Syracuse, New York: Emerson Museum of Art, 1974.

- PARENT, Rick. Computer Animation: Algorithms and Techniques. Burlington: Morgan Kaufmann, 2007.

- PARFAIT, Françoise. Vidéo : un art contemporain. Paris: Éditions du Regard, 2001. 
- PASQUIER, Florent. La vidéo numérique : techniques, usages pédagogiques et enjeux. Paris: L'Harmattan, 2000.

- PAUL, Joshua. Digital Video Hacks. Sebastopol, CA: O’Reilly Media Inc, 2005.

- PEARSON, Matt. Generative Art: A Practical Guide Using Processing. Manning Publications, 2011.

- PIERSON, Michele. Special effects: still in search of wonder. New York: Columbia University Press, 2002.

- PRÉDAL, René. Le cinéma à l'heure des petites caméras. Paris: Kincksieck, 2008.

- REISS, Steven; FEINEMAN, Neil. Thirty Frames Per Second: The Visionary Art of the Music Video. Boston, Massachusetts: Harry N. Abrams, 2000.

- RENOV, Michael; SUDERBURG, Erika (eds.). Resolutions: Contemporary Video Practices. London, Minneapolis: University of Minnesota Press, 1996.

- RICKITT, Richard. Special Effects: The History and Technique. London: Aurum, 2006.

- ROMBES, Nicholas. Cinema in the Digital Age. London: Columbia University Press, 2012.

- RONFARD, Rémi; TAUBIN, Gabriel. Image and Geometry Processing for 3-D Cinematography. Berlin: Springer-Verlag, 2010.

- ROSEN, Margit (ed.). A Little-Known Story about a Movement, a Magazine, and the Computer's Arrival in Art: New Tendencies and Bit International, 1961-1973. Karlsruhe, Cambridge: ZKM, The MIT Press, 2011.

- RUSH, Michael. Video Art (2003). London: Thames \& Hudson, 2007.

- RUSSETT, Robert; STARR, Cecile. Experimental Animation: Origins of a New Art. New York: Da Capo Press, 1976.

- SCEMAMA-HEARD, Céline. Histoire(s) du cinéma de Jean-Luc Godard. Paris: L'Harmattan, 2006.

- SCHLECHTWEG, Stefan; STROTHOTTE, Thomas. Non-Photorealistic Computer Graphics: Modeling, Rendering, and Animation. San Francisco: Elsevier Science \& Technology, Morgan Kaufmann Publishers Inc., 2002.

- SOBCHACK, Vivian. Meta-Morphing: Visual Transformation and the Culture of Quick Change. Minneapolis: University of Minnesota Press, 2000.

- SPIELMANN, Yvonne. Video. The reflexive medium (2005). Cambridge: The MIT Press, 2008. 
- STRAUVEN, Wanda (ed.). The Cinema of Attractions Reloaded. Amsterdam: Amsterdam University Press, 2006.

- TAYLOR, Norman. Cinematic Perspectives on Digital Culture: Consorting with the Machine. Basingstoke, New York: Palgrave Macmillan, 2012.

- TRYON, Chuck. Reinventing Cinema: Movies in the Age of Media Convergence. New Brunswick, N.J.: Rutgers University Press, 2009.

- VAZ, Mark Cotta. Industrial Light \& Magic: Into the Digital Realm. New York: Del Rey Books, 1996.

- VIOLA, Bill. Reasons for Knocking at an Empty House. Writings 1973-1994. Cambridge: The MIT Press, 1995.

- WHITNEY, John. Digital Harmony: On the Complementarity of Music and Visual Art. Nueva York: McGraw-Hill, 1980.

- WILLIS, Holly. New Digital Cinema: Reinventing the Moving Image. London: Wallflower Press, 2005.

- WILlOUGHBY, Dominique. Le cinéma graphique. Une histoire des dessins animés : des jouets optiques au cinéma numérique. Paris: Textuel, 2009.

- WILSON, Mark. Drawing With Computers. New York: Perigee Books, 1985.

- YAMAGUCHI, Fujio. Computer-Aided Geometric Design: A Totally FourDimensional Approach. Tokyo: Springer-Verlag, 2002.

- YOUNGBLOOD, Gene. Expanded Cinema. Toronto, Vancouver: Clarke, Irwin \& Company Limited, 1970.

- ZIELINSKI, Siegfried. Audiovisionen. Kino und Fernsehen als Zwischenspiele in der Geschichte. Reinbek: Rowohlt Verlag, 1989.

- ZIPPAY, Lori (ed.). Artists' Video: An International Guide. New York: Cross River Press, 1991.

Artículos/ensayos/entrevistas:

- AlBUQUERQUE, Georgia; LINZ, Christian; MAGNOR, Marcus; STICH, Timo. "View and Time Interpolation in Image Space". En: Computer Graphics Forum (Proc. of Pacific Graphics). February 2008, vol. 27, núm. 7, pp. 1781-1787.

- BARBADILlO, Manuel. My way to cybernetics [En línea]. Atariarchives.org, August 1975. Disponible en Web: <http://www.atariarchives.org/artist/sec13.php> 
- BEIER, Thaddeus; NEELY, Shawn. "Feature-Based Image Metamorphosis". En: SIGGRAPH '92, Proceedings of the 19th annual conference on Computer graphics and interactive techniques. July 1992, vol. 26, núm 2, pp. 35-42.

- BLANCHARD, Gérard. "Métaphores et métamorphoses. Hommage à Peter Foldès". Communication et langages. 1977, núm 34, pp. 118-119.

- BRIDLE, James. Entrevista realizada por Robert Urquhart. An interview with James Bridle of the New Aesthetic [En línea]. Huffington Post UK., 8 de mayo de 2012. Disponible en Web: <http://www.huffingtonpost.co.uk/robert-urquhart/an-aninterview-with-jame_b_1498958.html>

- CAMACHO, Verónica. Quels univers sont nés avec l'animation numérique ? [En línea]. Leonardo/Olats, octobre 2008. Disponible en Web: $<$ http://www.olats.org/livresetudes/basiques/animationnumerique/7_basiquesAN.php>

- CASCONE, Kim. "The Aesthetics of Failure: 'Post-Digital' Tendencies in Contemporary Computer Music”. Computer Music Journal. December 2000, vol. 24, núm. 4, pp. 12-18.

- CHEN, Shenchang Eric; WILLIAMS, Lance. "View Interpolation for Image Synthesis". En: ACM SIGGRAPH '93, Proceedings of the 20th annual conference on Computer graphics and interactive techniques, ACM SIGGRAPH Computer Graphics. Vol. 27, pp. 279-288.

- “Cinéma et numérique : une révolution ?”. Positif. Mai 2011, núm 603.

- CREMER, James F.; STEWART, A. James. "Beyond Keyframing: An algorithmic Approach to Animation”. En: Graphics Interface, Conference proceedings. Vancouver, B.B., May 1992, pp. 273-281.

- CSURI, Charles; SHAFFER, James. “Art, computers and mathematics”. En: AFIPS, Conference Proceedings. Columbus, Ohio: Ohio State University. December 1968, vol. 33, 1293-1298.

- DAVIDHAZY, Andrew. Slit Scan and Strip Photography Overview. [En línea]. Rochester Institute of Technology. Disponible en Web:

$<\mathrm{http}$ //people.rit.edu/andpph/text-streak-strip-scanning-imaging-overview.html >

- DEBEVEC, Paul E. et al. "Digital Reunification of the Parthenon and its Sculptures". En: Proceedings of VAST 2003, the 4th International conference on Virtual Reality, Archeology and Intelligent Cultural Heritage. Aire-La-Ville, Suisse: Eurographics Association, 2003, pp. 41-50.

- DEBEVEC, Paul E.; MALIK, Jitendra; TAYLOR, Camillo J.. "Modeling and 
Rendering Architecture from Photographs: A hybrid geometry- and image-based approach”. En: ACM SIGGRAPH'96, Proceedings of the 23rd annual conference on Computer Graphics and interactive techniques. New Orleans. August 1996, pp. 1120.

- DIAMOND, Sara. Lenticular Galaxies: The Polyvalent Aesthetics of Data Visualization [En línea]. Ctheory. Essays in Critical Digital Studies, January 6, 2010. Disponible en Web: <http://www.ctheory.net/articles.aspx?id=651>

- DIETRICH, Frank. "Visual Intelligence: The First Decade of Computer Art". Leonardo. 1986, vol. 19, núm 2, pp. 159-169.

- ELLIOTT, E.; DAVENPORT, G.. "Video Streamer". En: Proceedings CHI 94 ACM Conference on Human Factors in Computer Systems. Boston, MA. April 24-28, 1994, pp. 65-66.

- FRANKE, Daniel. Unnamed soundsculpture [En línea]. Daniel-franke.com, May 6, 2012. Disponible en Web: <http://daniel-franke.com/?p=6>

- FRANKE, Herbert W.; HELBIG, H. S.. "Generative Mathematics: Mathematically Described and Calculated Visual Art”. Leonardo. 1992, vol. 25, núm. 3/4, pp. 291294.

- FRANKE, Herbert W.. "The New Visual language: The Influence of Computer Graphics on Art and Society”. Leonardo. 1985, vol. 18, núm. 2, pp. 105-107.

- GREENAWAY, Peter. Cinema Militants Lecture. Toward a re-invention of cinema [En línea]. September 28, 2003. Disponible en Web:

$<\mathrm{http}$ ://petergreenaway.org.uk/essay3.htm>

- HALABY, Samia A.. "Rhythms. The Aesthetics of Electronic Painting". PAPERS of the Seventh International Symposium on Electronic Art, Minneapolis, Rotterdam The Netherlands, September 16-20, 1996. Disponible en Web:

$<$ http://art.net/ samia/essays/fisea96.html>

- HAMMER, Owen. Bedtime For Deadtime [En línea]. Visual Effects Headquarters. June 1998. Disponible en Web: <http://www.vfxhq.com/spotlight98/9806b.html>

- HOLLASCH, Steven Richard. Four-Space Visualization of 4D Objects [En línea]. Arizona State University, 1991. Disponible en Web:

$<\mathrm{http}: / /$ steve.hollasch.net/thesis/chapter3.html\#s3.2>

- HORRY, Y.; ANJYO, K.; ARAI, K.. "Tour Into the Picture: Using a Spidery Mesh Interface to Make Animation from a Single Image". ACM SIGGRAPH'97 Proceedings of the 24th annual conference on Computer graphics. Los Ángeles, CA, 
August 1997, pp. 225-232.

- HYNEK, Joel. Entrevista realizada por Bill Dawes. Jumping Around with Weta [En línea]. Fxguide. 23 de febrero de 2008. Disponible en Web:

$<$ http://www.fxguide.com/featured/Jumping_Around_with_Weta/>

- KENNEDY, Randy. Apropos appropriation [En línea]. The New York Times, December 28, 2011. Disponible en Web:

$<$ http://www.nytimes.com/2012/01/01/arts/design/richard-prince-lawsuit-focuses-onlimits-of-appropriation.html?pagewanted $=a l l \& \_r=0>$

- KERMABON, Jacques. “Zbigniew Rybczynski, l'autre dimension”. Magazine Bref. Mai 1990, núm 5, pp. 8-11.

- KING, Mike. “Computers and modern art: digital art museum”. En: Proceedings of the 4th conference on Creativity \& cognition, New York, October 13-16, 2002, pp. 88-94.

- KNOWLTON, K. C.. "A Computer Technique for Producing Animated Movies”. En: Proceedings of the Spring Joint Computer Conference, Spartan, Washington, D.C., 1964.

- Landscape, Tamás Waliczky. [En línea]. Ars Electronica Archive. Prix Ars Electronica 1998. Disponible en Web:

$<\mathrm{http}: / / 90.146 .8 .18 /$ en/archives/prix_archive/prix_projekt.asp?iProjectID=2442>

- LANDRETH, Chris. Entrevista realizada por Gregory Singer. Landreth on Ryan [En línea]. Animation World Network, 4 de junio de 2004. Disponible en Web: $<$ http://www.awn.com/articles/profiles/landreth-iryani/page/3\%2C1>

- LAPOSKY, Ben F.. “Oscillons: Electronic Abstractions”. Leonardo. 1969, vol. 2, núm. 4, pp. 345-354.

- LEE, Seungyong et al. "Polymorph: Morphing Among Multiple Images". IEEE Computer Graphics and Applications. 1998, vol. 18, núm. 1, 1998, pp. 58-71.

- LINZ, C. et al. "Space-Time Visual Effects as a Post-production Process". En: $A C M$ Multimedia 2010 Workshop - 1st International Workshop on 3D Video Processing (3DVP). October 2010, vol. 1, pp. 1-6.

- Like a Rolling Stone [En línea]. Ars Electronica Archive. Prix Ars Electronica 1996. Disponible en Web:

$<\mathrm{http} / / / 90.146 .8 .18 /$ en/archives/prix_archive/prix_projekt.asp?iProjectID=2438>

- MANOVICH, Lev. Image Processing and Software Epistemology [En línea]. Software Studies, November 20, 2012. Disponible en Web: 
$<$ http://lab.softwarestudies.com/2012/11/image-processing-and-software.html>

- MANOVICH, Lev. What is Visualization? [En línea]. Manovich.net, MarchOctober 2010. Disponible en Web: <http://manovich.net/2010/10/25/new-articlewhat-is-visualization/>

- MATSUMOTO, Toshio. Entrevista realizada por Aaron Gerow [En línea]. Yamagata International Documentary Film Festival, 2009. Disponible en Web:

$<$ http://www.yidff.jp/docbox/9/box9-2-e.html>

- MCCABE, Jonathan. Cyclic Symmetric Multi-Scale Turing Patterns [En línea]. Faculty of Arts and Design. University of Canberra. 2010. Disponible en Web:

$<$ http://www.jonathanmccabe.com/Cyclic_Symmetric_Multi-

Scale_Turing_Patterns.pdf $>$

- MORADI, Iman. Glitch Aesthetics [En línea]. Oculasm.org, 2004. Disponible en Web:

$<$ http://www.oculasm.org/glitch/download/Glitch_dissertation_print_with_pics.pdf $>$

- NOLL, A. Michael. "A Computer Technique for Displaying n-Dimensional Hyperobjects". En: Communications of the ACM. August 1967, vol. 10, núm. 8, pp. 469-473.

- NOLL, A. Michael. "Computers and the Visual Arts”. Design Quarterly. 1967, núm. 66/67, pp. 65-71.

- NOLL, A. Michael. “Computer Animation and the Fourth Dimension”. En: AFIPS Conference Proceedings. 1968, vol. 33, pp. 1279-1283.

- NOLL, A. Michael. “Computer-Generated Three-Dimensional Movies”. Computers and Automation. November 1965, vol. 14, núm. 11, pp. 20-23.

- NOLL, A. Michael. "Human or Machine: A Subjective Comparison of Piet Mondrian's 'Composition with Lines' and a Computer-Generated Picture". The Psychological Record. January 1966, vol. 16, núm. 1, pp. 1-10.

- NOLL, A. Michael. "The Beginnings of Computer Art in the United States: A Memoir”. Leonardo. 1993, vol. 25, núm. 1, pp. 39-44.

- NOLL, A. Michael. “The Digital Computer as a Creative Medium”. IEEE Spectrum. October 1967, vol. 4, núm. 10, pp. 89-95.

- PACI, Viva. Ce qui reste des images du futur. [En línea]. Fondation Daniel Langlois pour l'art, la science et la technologie, 2005. Disponible en Web:

$<$ http://www.fondation-langlois.org/html/f/page.php?NumPage=687> 
- PROVOST, Nicolas. Entrevista realizada por Fabrice Marquat. Nicolas Provost, le cinéma revisité par notre imaginaire [En línea]. Bref Magazine, Avril 2008, núm 83. Disponible en Web: <http://www.nicolasprovost.com/text/>

- RALSKE, Kurt. On atemporality. [En línea]. Retnull.com, May 2005. Disponible en Web: <http://www.retnull.com/atemporal.html>

- RALSKE, Kurt. Zero Frames per Second [En línea]. Exhibition Notes for Zero Frames per Second. MFA Computer Art Gallery, New York City. August 18 September 19, 2008. Disponible en Web:

$<$ http://www.retnull.com/crit_ZeroFrames.html>

- REAS, Casey. Entrevista realizada por Daniel Shiffman. Interview with Casey Reas and Ben Fry [En línea]. Rhizome, 23 de Septiembre de 2009. Disponible en Web: $<\mathrm{http}$ //rhizome.org/editorial/2009/sep/23/interview-with-casey-reas-and-ben-fry/>

- REAS, Casey. Process Compendium [En línea]. Catálogo de la exposición Process Compendium 2004-2010, Gallery [DAM], Berlín, 2010. Disponible en Web:

$<$ http://reas.com/texts/processcompendium.html $>$

- REAS, Casey. Software and drawing [En línea]. Software structures. Disponible en Web: <http://artport.whitney.org/commissions/softwarestructures/text.html>

- REINHART, Martin; WIDRICH, Virgil. TX-Transform [En línea]. Ars Electronica Archive 1998. Disponible en Web:

$<$ http://90.146.8.18/en/archives/festival_archive/festival_catalogs/festival_artikel.asp? iProjectID $=8408>$

- ROBERTS, Lawrence G.. "Machine Perception of Three-Dimensional Solids". MIT Lincoln Laboratory, May 22, 1963, núm. 315.

- SCHWARTZ, Lillian. Entrevista realizada por Leo Kent. Meet Lillian Schwartz: The mother of digital art [En línea]. Humansinvent.com, 20 de marzo de 2012. Disponible en Web: <http://www.humansinvent.com/\#!/6210/meet-lillian-schwartzthe-mother-of-digital-art/>

- SEITZ, Steve M.; DYER, Chuck R.. "View morphing”. En: ACM SIGGRAPH'96, Proceedings of the 23rd Annual Conference on Computer Graphics. August 4-9, 1996, New Orleans, LA, USA, pp. 21-30.

- SHUM, Heung-Yeung; KANG, Sing Bing. A Review of Image-based Rendering Techniques [En línea]. Institute of Electrical and Electronics Engineers, June 2000. Disponible en Web:

$<$ http://research.microsoft.com/apps/pubs/default.aspx?id=68826> 
- SILBERMAN, Steve. MATRIX². Bullet Time was just the beginning. F/x guru John Gaeta reinvents cinematography with The Matrix Reloaded. [En línea]. Wired, May 2003. Disponible en Web:

$<$ http://www.wired.com/wired/archive/11.05/matrix2_pr.html>

- SIMS, Karl. “Artificial Evolution for Computer Graphics”. En: ACM SIGGRAPH '91 Proceedings of the 18th Annual Conference on Computer Graphics. Las Vegas, Nevada, July 1991, vol. 25, núm 4, pp. 319-328.

- SIMS, Karl. "Particle Animation and Rendering Using Data Parallel Computation". ACM SIGGRAPH'90 Computer Graphics. August 1990, vol. 24, núm. 4, pp. 405-413. - Slicing time - Tim Macmillan. "Learn to freeze time from the wizard who invented the effect for The Matrix. [En línea]. Timeslicefilms.com. Disponible en Web:

$<$ http://www.timeslicefilms.com/press/encyclopedia-of-visual-effects>

- SMYTHE, Douglas B.. "A Two-Pass Mesh Warping Algorithm for Object Transformation and Image Interpolation”. ILM Technical Memo \#1030, Computer Graphics Department, Lucasfilm Ltd., 1990.

- SNORRI BROS. Entrevista realizada por Bran Dougherty-Johnson [En línea]. Motionographer. 11 de noviembre de 2009. Disponible en Web:

$<\mathrm{http}: / /$ motionographer.com/theater/by-and-by-qa//>

- SOBCHACK, Vivian. "Nostalgia for a Digital Object: Regrets on the Quickening of QuickTime". Millennium Film Journal. Fall 1999, núm. 34, pp. 4-23.

- SPIELMANN, Yvonne. Video and Computer. The Aesthetics of Steina and Woody Vasulka. [En línea]. Fondation Langlois, 2004. Disponible en Web:

$<$ http://www.fondation-langlois.org/html/e/page.php?NumPage=461>

- SPROTT, J. C.; TAYLOR, R. P.. "Biophilic Fractals and the Visual Journey of Organic Screen-savers". Nonlinear Dynamics, Psychology, and Life Sciences. 2008, vol. 12, núm. 1, pp. 117-129. Disponible en Web:

$<$ http://sprott.physics.wisc.edu/pubs/paper311.pdf $>$

- SZEPESI, Anna. Der Wald (The Forest) [En línea]. Waliczky.net, 1995. Disponible en Web: <http://www.waliczky.net/waliczky_start.htm>

- TALEN, Julie. Entrevista realizada por Cara O'Connor. When You Cut Up the Frame: An Interview with Julie Talen [En línea]. Senses of cinema. 17 de febrero de 2004. Disponible en Web:

$<$ http://sensesofcinema.com/2004/feature-articles/julie_talen/> 
- TALEN, Julie. '24': Split screen's big comeback [En línea]. Salon, May 14, 2002. Disponible en Web: <http://www.salon.com/2002/05/14/24_split/>

- The New Face of America: How Immigrants Are Shaping the World's First Multicultural Society. Time, Nov. 18, 1993. Disponible en Web:

$<\mathrm{http}: / /$ www.time.com/time/covers/0,16641,19931118,00.html>

- Tron then and now [En línea]. Creativeplanetnetwork.com. Disponible en Web: $<$ http://www.creativeplanetnetwork.com/node/41956>

- VASULKA, Woody. "The Theater of Hybrid Automata". En: Artifices 2. SaintDenis: Direction des affaires culturelles de la Ville de Saint-Denis, 1992. pp. 52-60.

- WALKER, Jessica. Only Screen Deep: Racial Morphing [En línea]. Jessicawalker.net, 2006. Disponible en Web:

$<$ http://www.jessicawalker.net/screendeep.htm>

- WALICZKY, Tamás. Manifesto of Computer Art [En línea]. January 15, 1989. Disponible en Web: <http://www.waliczky.com/pages/waliczky_manifest_eng.htm> - WALICZKY, Tamás. Sculptures [En línea]. Waliczky.net, 1996. Disponible en Web: <http://www.waliczky.net/pages/waliczky_sculptures1-frame.htm>

- WATZ, Marius. Random Thoughts on Code and Form. A brief survey of computational aesthetics [En línea]. Eyeo Festival, Minneapolis, 2011. Disponible en Web: <http://fr.scribd.com/doc/58999061/20110628-Marius-Watz-Thoughts-onCode-and-Form-Eyeo-Festival>

- WEIBEL, Peter. Gesänge des Pluriversums [En línea]. Ars Electronica Archiv 1986. Disponible en Web:

$<$ http://90.146.8.18/de/archives/festival_archive/festival_catalogs/festival_artikel.asp? iProjectID=9269>

- WILES, Will. The machine gaze. As the boundaries between digital and physical dissolve, can the New Aesthetic help us see things more clearly? [En línea]. Aeonmagazine.com, September 17, 2012. Disponible en Web:

$<$ http://www.aeonmagazine.com/world-views/will-wiles-technology-new-aesthetic/> - WILlEMEN, Paul. The Zoom in Popular Cinema. A Question of Performance. [En línea]. Inter-Asia Cultural Studies. 2012. Vol. 14, núm 1. Disponible en Web: $<$ http://www.rouge.com.au/1/zoom.html>

- WOLF, Mark J. P.. "Space, Time, Frame, Cinema: Exploring the Possibilities of Spatiotemporal Effects". New Review of Film and Television Studies. December 2006, vol. 4, núm 3, pp. 167-181. 
- WOLBERG, George. “Digital Image Warping”. IEEE Computer Society Press. Los Alamitos, CA: IEEE Computer Society, 1990.

- WOLBERG, George. “Image Morphing: a Survey”. The Visual Computer. 1998, vol. 14, núm. 8/9, pp. 360-372.

- YOUNGBLOOD, Gene. “Art of Memory". En: Catálogo de la exposición Steina and Woody Vasulka. Denver: Denver Art Museum. January 25 - March 22, 1992.

- YOUNGBLOOD, Gene. Calculated movements. An interview with Larry Cuba [En línea]. Video and the Arts Magazine, Winter 1986. Disponible en Web:

$<$ http://www.well.com/ cuba/VideoArt.html $>$

- ZAJAC, Edward E.. “Computer animation: a new scientific and educational tool”. Journal of the Society of Motion Picture and Television Engineers, November 1965, vol. 74, pp. 1006-1008.

$\underline{\text { Tesis }}$

- FURIÓ VITA, Dolores. "Posibilidades artísticas de la imagen electrónica: el chroma key". Directora: Amparo Carbonell Tatay. Universidad Politécnica de Valencia, Departamento de Escultura, Valencia, julio 2008. Disponible en Web:

$<$ http://riunet.upv.es/bitstream/handle/10251/3343/tesisUPV2900.pdf.txt;jsessionid=D 7DFEE1D3AFEE8386FAA074F01CDE0C4? sequence=6>

- JACKSON, Rebecca. “The Glitch Aesthetic”. Advisor: Ted Friedman. Georgia State University, College of Arts and Sciences, Atlanta, Georgia, USA, 2011. Disponible en Web: $<$ http://digitalarchive.gsu.edu/communication_theses/80>

- JACOBSON, Brian R.. "Constructions of Cinematic Space: Spatial Practice at the Intersection of Film and Theory". Advisor: William Uricchio. Massachusetts Institute of Technology, Department of Comparative Media Studies, Cambridge, September 2005. Disponible en Web: <http://dspace.mit.edu/handle/1721.1/39189>

- ROGGE, Lorenz. "Integration of visual effects into the Virtual Video Camera System”. Supervisor: Christian Linz. Technische Universität Braunschweig, Computer Graphics Lab, Braunschweig, December 2009. Disponible en web:

$<$ http://graphics.tu-bs.de/people/rogge/>

- RUIZ GUTIÉRREZ, Tania. “Études sur le temps et l'espace dans l'image en mouvement. Tissage vidéo, objets spatio-temporels, images prédictives et cinéma infini”. Directeur: Anne-Marie Duguet. Université Panthéon-Sorbonne, Paris, 2004. 


\section{A.2. Teoría de los nuevos medios y estética de las nuevas tecnologías}

- BALPE, Jean-Pierre. Contextes de l'art numérique. Paris: Hermès, 2000.

- BENEDIKT, Michael (ed.). Cyberspace: First Steps. Cambridge: The MIT Press, 1991.

- BENTKOWSKA-KAFEL, Anna; CASHEN, Trish; GARDINER, Hazel (eds.). Digital Art History: A Subject in Transition. Bristol: Intellect Books, 2005.

- BLANCHET, Alexis. Des pixels à Hollywood: cinéma et jeu vidéo, une histoire économique et culturelle. Paris: Pix'n love, 2010.

- BOISSIER, Jean-Louis. La relation comme forme. L'interactivité en art. Genève: Mamco, 2004.

- BOLTER, Jay David. Writing Space: Computers, Hypertext, and the Remediation of Print. New York: Routledge, 2001.

- BÖTTGER, Matthias; VON BORRIES, Friedrich; WALZ, Steffen P. (eds.). Space Time Play: Synergies between computer games, architecture and urbanism. Basel, Boston, Berlin: Birkhauser, 2007.

- BOURGOUGNON, Eric. Paris en 3D, de la stéréoscopie à la réalité virtuelle, 1850-2000. Catalogue de l'exposition. Paris: Paris Musées/ Booth-Clibborn Ed., 2000.

- BROECKMANN, Andreas. The Art of the Accident. Rotterdam: V_2 Publishing, 1998.

- BUSHOFF, Brunhild (ed.). Developing Interactive Narrative Content. sagas_sagasnet_reader. Munich: High Text Verlag, 2005.

- BYRNE, Brendan; CARVALHO, Ana; HOUSTON, Lara; MUMFORD; Paul (eds). VJam Theory. Realtime Books, 2008.

- CANDY, Linda; EDMONDS, Ernest A.. Explorations in Art and Technology. London: Springer-Verlag, 2002.

- CHIK, Caroline. L'image paradoxale. Fixité et mouvement. Villeneuve d'Ascq: Presses Universitaires du Septentrion, 2011.

- CLARKE, Bruce; HENDERSON, Linda Dalrymple (eds.). From Energy to Information: Representation in Science and Technology, Art and Literature. Stanford: Stanford University Press, 2002. 
- COBLEY, Paul (ed.). The Communication Theory Reader. London: Routledge, 1996.

- COLSON, Richard. The Fundamentals of Digital Art. Lausanne: AVA Publishing, 2007.

- COOKE, Lynne; WOLlEN, Peter (eds.). Visual Display: Culture Beyond Appearances (1995). New York: New Press, 1998.

- COUCHOT, Edmond. La technologie dans l'art. De la photographie à la réalité virtuelle. Nîmes: Éditions Jacqueline Chambon, 1998.

- COUCHOT, Edmond. L'art numérique : comment la technologie vient au monde de l'art, Paris: Éditions Flammarion, 2003.

- CUBITT, Sean. Digital Aesthetics. London: Sage Publications, 1998.

- DANIELS, Dieter. Vom Readymade zum Cyberspace: Kunst/Medien Interferenzen. Ostfildern-Ruit: Hatje Cantz Verlag, 2003.

- DARLEY, Andrew. Visual digital culture: Surface play and spectacle in new media genres. London, New York: Routledge, 2000.

- DAVIDSON, Drew (ed.). Beyond Fun: Serious Games and Media. Pittsburgh, PA: ETC Press, 2008.

- DE KERCKHOVE, Derrick. La civilisation vidéo-chrétienne. Paris: Retz, 1990.

- DE KERCKHOVE, Derrick. The skin of culture: investigating the new electronic reality (1995). London: Kogan Page Publishers, 1997.

- DE MÈREDIEU, Florence. Arts et nouvelles technologies: art vidéo, art numérique. Paris: Larousse, 2003.

- DI CROSTA, Marida. Entre cinéma et jeux vidéo : l'interface-film: Métanarration et interactivité. Armando Editore, 2009.

- DODGE, Martin; KITCHIN, Rob. Atlas of cyberspace. London: Adisson Wesley, 2001.

- DODGE, Martin; KITCHIN, Rob. Code/Space: Software and Everyday life. Cambridge: The MIT Press, 2011.

- DOVEY, John; GIDDINGS, Seth; GRANT, Iain; KELLY, Kieran; LISTER, Martin. New Media: A Critical Introduction. New York: Routledge, 2003.

- DURING, Simon (ed.). The Cultural Studies Reader (1993). New York, London: Routledge, 1999.

- FISHWICK, Paul A. (ed). Aesthetic Computing. Cambridge, MA: The MIT Press, 2006. 
- FOREST, Fred. Pour un art actuel, l'art à l'heure d'internet. Paris: L'Harmattan, 1998.

- FRIEDBERG, Anne. The Virtual Window. From Alberti to Microsoft. Cambridge: The MIT Press, 2006.

- FRY, Ben; REAS, Casey. Processing: A Programming Handbook for Visual Designers and Artists. Cambridge, MA: The MIT Press, 2007.

- FRY, Ben. Visualizing Data: Exploring and Explaining Data with the Processing Environment. Sebastopol, CA: O’Reilly Media, Inc., 2008.

- FUCHS, Philippe (dir.). Le traité de la réalité virtuelle (2001). Paris: Les Presses de l'Ecole des Mines de Paris, Collection Sciences Mathématiques et Informatique, 2006.

- FULLER, Matthew (ed.). Software Studies/A Lexicon. Cambridge, London: The MIT Press, 2008.

- GERE, Charlie. Digital Culture (2002). London: Reaktion Books, 2009.

- GIANNETTI, Claudia (ed.). Arte en la era electrónica, perspectivas de una nueva estética. Barcelona: L’Angelot, 1997.

- GIANNETTI, Claudia. Reflexiones acerca de la crisis de la imagen técnica, la interfaz y el juego. Barcelona: Anàlisi 27, 2001.

- GOODMAN, Cynthia. Digital Visions: Computers and Art. New York: Abrams, 1988.

- GRAU, Oliver. Virtual Art: From Illusion to Immersion. Cambridge: The MIT Press, 2003.

- HANSEN, Mark B. N.; MITCHELL, William J.. Critical Terms for Media Studies. Chicago: University of Chicago Press, 2010.

- HANSEN, Mark B. N.. New Philosophy for New Media. Cambridge: The MIT Press, 2004.

- HAYWARD, P; WOLLEN, T (eds.). Future visions: new technologies of the screen. London: British Film Institute Press, 1993.

- HERNÁNDEZ SÁNCHEZ, Domingo (ed.). Arte, cuerpo, tecnología. Salamanca: Ediciones de la Universidad de Salamanca, 2003.

- HUMPHREYS, Lee; MESSARIS, Paul (eds.). Digital Media: Transformations in Human Communications. New York: Peter Lang Publishing, 2006.

- JACOBS, Corinna. Interactive Panoramas: Techniques for Digital Panoramic Photography. Berlin, Heidelberg: Springer-Verlag, 2004. 
- JOHNSON, Steven. Interface Culture: How New Technology Transforms the Way we Create and Communicate. San Francisco: Harper Edge, 1997.

- JONES, Steve (ed.). Encyclopedia of New Media: An Essential Reference to Communication and Technology. Thousand Oaks, CA: SAGE Publications, Inc, 2003. - JORDAN, Ken; PACKER, Randall (eds.). Multimedia: from Wagner to virtual reality. New York: Norton, 2002.

- KING, Geoff; KRZYWINSKA, Tanya. (eds.). ScreenPlay: Cinema/Videogames/Interfaces. London, New York: Wallflower Press, 2002.

- LÉVY, Pierre. Qu'est-ce que le virtuel ? (1995). Paris: La Découverte, 2010.

- LEVY, Steven. Artificial life: The quest for a new creation. New York: Pantheon Books, 1992.

- LIETAERT, Matthieu (ed.). Webdocs. A survival guide for online filmmakers. Bruxelles: Not so crazy! Productions, 2011.

- LORD, Susan; MARCHESSAULT, Janine (eds.). Fluid Screens, Expanded Cinema. Toronto: University of Toronto Press, 2007.

- LUNENFELD, Peter. Snap to Grid: A User's Guide to Digital Arts, Media, and Cultures. Cambridge, London: The MIT Press, 2000.

- LUNENFELD, Peter (ed.). The Digital Dialectic: New Essays on New Media. Cambridge: The MIT Press, 1999.

- LYNN, Greg. Animate Form. New York: Princeton Architectural Press, 1999.

- MAEDA, John. Creative Code: Aesthetics + Computation. London: Thames \& Hudson, 2004.

- MACKAY, Hugh; O’SULLIVAN, Tim (eds.). The media reader: continuity and transformation. London: Sage Publications, 1999.

- MALLOY, Judy. (ed.). Woman, Art and Technology. Boston: The MIT Press, 2002.

- MANOVICH, Lev. The Language of New Media (2001). Cambridge: The MIT Press, 2005.

- MCCullough, Malcolm; MITCHELl, William J.. Digital Design Media. New York: John Wiley \& Sons In., 1995.

- MCLUHAN, Marshall. Understanding Media: The Extensions of Man (1964). London/ New York: Routledge Classics, 2004.

- MCROBERT, Laurie. Char Davies' Immersive virtual art ant the essence of spatiality. Toronto: University of Toronto Press, 2007. 
- MCWILliAMS, Chandler; REAS, Casey. Form + Code in Design, Art and Architecture. New York: Princeton Architectural Press, 2010.

- MEALING, Stuart (ed.). Computers and art (1997). Bristol: Intellect books, 2002.

- MEZZETTI, Carlo; UNALI, Maurizio (dir.). Acqua\&Architettura. Rappresentazioni. Roma: Edizioni Kappa, 2011.

- MOLES, Abraham. Art et ordinateur (1970). Paris: Blusson, 1990.

- MOLES, Abraham. Théorie de l'information et perception esthétique. Paris: Denoël-Gonthier, 1972.

- MOLINUEVO, José Luis. Humanismo y nuevas tecnologías. Madrid: Alianza Editorial, 2004.

- MONTFORT, Nick; WARDRIP-FRUIN, Noah (eds.). The New Media Reader. Cambridge: The MIT Press, 2003.

- MORSE, Margaret (ed.). Hardware, Software, Artware: die Konvergenz von Kunst und Technologie $=$ Confluence of art and technologie. Ostfildern: Cantz, 1997.

- MUNT, Sally R. (ed.). Technospaces: Inside the New Media. London: Continuum International Publishing Group, 2001.

- NEGROPONTE, Nicholas. Being Digital. New York: Alfred A. Knopf, 1995.

- NITSCHE, Michael. Video Game Spaces: Image, Play, and Structure in 3D Worlds. The MIT Press, 2008.

- NUNES, Mark (ed.). Error: Glitch, Noise, and Jam in New Media Cultures. London, New York: Continuum International Publishing Group, 2011.

- PAUL, Christiane. Digital Art. London: Thames \& Hudson, 2003.

- PELÉ, Gérard. Art, informatique et mimétisme. Paris: L'harmattan, 2002.

- PICKOVER, Clifford A.. Visions of the Future: Art, Technology and Computing in the Twenty-First Century. New York: St. Martin's Press, 1992.

- POISSANT, Louise (dir.). Dictionnaire des arts médiatiques. Montréal: Presses de l'Université du Québec, 1997.

- POISSANT, Louise. Esthétique des arts médiatiques. Québec: Presses de l'Université du Québec, 1995.

- POISSANT, Louise; TREMBLAY, Pierre. Prolifération d'écrans. Québec: Presses de l'université du Québec, 2008.

- POPPER, Frank. Art of the Electronic Age. Boston: Harry N. Abrams, 1993.

- POPPER, Frank. From Technological to Virtual Art. Cambridge: The MIT Press, 2007. 
- POSCHARDT, Ulf. DJ Culture (1995). London: Quartet Books, 1998.

- REICHARDT, Jasia. Cybernetics, art and ideas. Greenwich, Connecticut: New York Graphic Society, 1971.

- REICHARDT, Jasia (ed). Cybernetic Serendipity: The Computer and the Arts. London: Studio International, 1968.

- RIESER, Martin; ZAPP, Andrea (eds.). New screen media: cinema/art/narrative. London: British Film Institute, 2002.

- RONCHI, Alfredo M.. ECulture: Cultural Content in the Digital Age. Berlin: Springer-Verlag, 2009.

- RUSH, Michael. New Media in Art (1999). London: Thames \& Hudson, 2005.

- SCHÖPF, Christine; STOCKER, Gerfried (eds.). Ars Electronica 2003: Code: The Language of our Time. Linz: Hatje Cantz Publishers, 2003.

- SHANKEN, Edward A.. Art and Electronic Media. London: Phaidon Press, 2009.

- SHAW, Jeffrey; WEIBEL, Peter. (eds.). Future Cinema: The Cinematic Imaginary after Film. Cambridge: The MIT Press, 2003.

- SPALTER, Anne Morgan. The Computer in the Visual Arts. Reading, MA: Addison-Wesley Longman, 1999.

- TAVINOR, Grant. The Art of Videogames. Oxford: John Wiley \& Sons, 2009.

- THOMAS, Paul. Reconfiguring space: From perspective to the virtual. Saarbrücken, Germany: VDM Verlag, 2009.

- TRIBE, Marc; JANA, Reeva (eds.). Arte y nuevas tecnologías. Madrid: Taschen, 2008.

- VELTMAN, Kim. Understanding New Media: Augmented Knowledge and Culture. Calgary: University of Calgary Press, 2006.

- VERHOEFF, Nanna. Mobile Screens. The Visual Regime of Navigation. Amsterdam: Amsterdam University Press, 2012.

- VIRILIO, Paul. La machine de vision : essai sur les nouvelles techniques de représentation. Paris: Galilée, 1988.

- WHITELAW, Mitchell. Metacreation: Art and Artificial Life. Cambridge: The MIT Press, 2004. Disponible en Web: <http://fr.scribd.com/doc/105684327/WhitelawMitchell-2004-Metacreation-Art-and-Artificial-Life>

- WIENER, Norbert. Cybernetics: or Control and Communication in the Animal and the Machine (1948). Cambridge: The MIT Press, 1973. 
- WOLF, Mark J. P.. The Medium of the Video Game. Austin: University of Texas Press, 2001.

\section{$\underline{\text { Artículos/ensayos/entrevistas }}$}

- BAR-ZEEV, Avi. Geography 2.0: Virtual Globes: Notes on the origin of Google Earth and Ogle Earth: Google Earth Origin Myths. [En línea]. RealityPrime, July 24, 2006. Disponible en web: <http://www.realityprime.com/blog/2006/07/notes-on-theorigin-of-google-earth/>

- BUSH, Vannevar. As we may think [En línea]. Atlantic Monthly, July 1945. Disponible en Web:

$<$ http://www.theatlantic.com/magazine/archive/1945/07/as-we-may-think/3881/>

- CERDA SEGUEL, Diego. El mundo según Google. Google Earth y la creación del Dispositivo Geosemántico Global [En línea]. Septiembre, 2005. Disponible en Web:

$<$ http://Geosemantica.gearth.googlepages.com>

- DAVIES, Char. "Osmose: Notes on Being in Immersive Virtual Space”. Digital Creativity. 1995, vol 9, núm. 2, pp. 65-74.

- DAVIS, Stephen Boyd. "Interacting with pictures: film, narrative and interaction", Digital Creativity. Jun 2002, vol. 13, núm. 2, pp. 71-82.

- ELLIOTT, Eddie; DAVENPORT, Glorianna. "Video Streamer". En: Proceedings of CHI'94 Conference Companion. Boston, April 24-28, 1994, pp. 65-66.

- FARMAN, Jason. Mapping the Digital Empire: Google Earth and the Process of Postmodern Cartography [En línea]. Washington State University, New Media \& Society, 2010. Disponible en Web: <http://nms.sagepub.com/content/12/6/869>

- FELS, Sidney S.; LEE, Eric; MASE, Kenji. “Techniques for Interactive Video Cubism”. En: Proceedings of ACM Multimedia. October 2000, pp. 368-370.

- HERTZ, Paul. “Art, Code, and the Engine of Change”. Art Journal. Spring 2009, vol. 68 , núm. 1 , pp. 58-75.

- JASCHKO, Susanne. Process as aesthetic paradigma: a nonlinear observation of generative art [En línea]. Generator.x conference, September 23-24, 2005, Oslo, Atelier Nord. Disponible en Web:

$<$ http://www.generatorx.no/20051115/text-process-as-aesthetic-paradigm-anonlinear-observation-of-generative-art/\#more-312> 
- JASCHKO, Susanne. "Space-Time Correlations Focused in Film Objects and Interactive Video". ISEA 2002, 11th International Symposium on Electronic Art. Nagoya (Japan), 2002. Disponible en Web:

$<$ http://www.arpla.fr/canal20/adnm/?p=250>

- MANOVICH, Lev. Arte digital/arte contemporáneo [En línea]. ArtFutura, 2003. Disponible en web: $<$ http://www.artfutura.org/02/Lev.html $>$

- MANOVICH, Lev. Avant-garde as software [En línea]. ArtNodes, December 2002. Disponible en Web:

$<$ http://www.uoc.edu/artnodes/espai/eng/art/manovich1002/manovich1002.html >

- MANOVICH, Lev. Software takes command [En línea]. Softwarestudies.com. November 20, 2008. Disponible en web: <www.softwarestudies.com/softbook>

- MANOVICH, Lev. “Ten Key Texts on Digital Art: 1970-2000”. Leonardo. 2002, vol. 35, núm. 5. Disponible en Web:

$<$ http://www.jstor.org/discover/10.2307/1577262?uid=3738016\&uid=2\&uid=4\&sid= 21102148605281>

- PERSSON, P. “A Comparative Study of Digital and Cinematic Space with Special Focus on Navigational Issues". En: ECCE-9, Proceedings of 9th European Conference on Cognitive Ergonomics. University of Limerick, Ireland, August 24-26, 1998.

- SUTHERLAND, Ivan Edward. "A head mounted three-dimensional display”. En: AFIPS'68, Proceedings of the fall joint computer conference. New York, December 9-11, 1968, part I, pp. 757-764.

- SUTHERLAND, Ivan Edward. Sketchpad: A man-machine graphical communication system [En línea]. University of Cambridge, 1963, Technical report, núm 574. Disponible en Web: <http://www.cl.cam.ac.uk/TechReports/>

$\underline{\text { Tesis: }}$

- BOYD DAVIS, Stephen. "Media Space. An analysis of spatial practices in planar pictorial media". Supervisors: Huw Jones and Gordon Davies. Middlesex University, Lansdown Centre for Electronic Arts, London, June 2002. Disponible en Web: $<$ http://eprints.mdx.ac.uk/4970/>

- MAKELA, Mia. "Live Cinema: Language and Elements". Helsinki University of Art and Design, Media Lab, Helsinki, April 2006. Disponible en Web: 
$<$ http://docs5.chomikuj.pl/295847970,PL,0,0,Live-Cinema-...\%E2\%80\%8E>

- MONTALVO GALLEGO, Blanca. "La narración espacial: una propuesta para el estudio de los lenguajes narrativos en el arte multimedia". Directora: María José Martínez de Pisón Ramón. Universidad Politécnica de Valencia, Departamento de Escultura, Valencia, noviembre de 2003. Disponible en web:

$<$ www.upv.es/laboluz/blanca/textos/T_blanca.pdf $>$

- STOCKBURGER, Axel. "The Rendered arena: Modalities of Space in Video and Computer games". Supervisors: Dr. Angus Carlyle (LCC), Alan Sekers (LCC), Prof. Clive Richards (Coventry University). University of the Arts, London, 2006. Disponible en Web: <www.stockburger.at/files/2010/04/Stockburger_Phd.pdf>

\section{A.3. Teoría, estética e historia cinematográficas}

- ALBERA, François; BRAUN, Marta; GAUDREAULT, André (dir.). Arrêt sur image, fragmentation du temps - Stop motion, Fragmentation of Time. Lausanne: Éditions Payot Lausanne, 2002.

- AlBERA, François; TORTAJADA, Maria (eds.). Cinema Beyond Film: Media Epistemologie in the Modern Era. Amsterdam: Amsterdam University Press, 2010.

- AMIEL, Vincent. Esthétique du montage (2001). Paris: Armand Colin, 2010.

- ALSINA THEVENET, Homero; ROMAGUERA I RAMIÓ, Joaquim (eds.). Textos y manifiestos del cine: estética, escuelas, movimientos, disciplinas, innovaciones. Madrid: Cátedra, 2007.

- ARROWSMITH, William. Antonioni, the poet of images. Oxford, New York: Oxford University Press, 1995.

- AUMONT, Jacques; BERGALA, Alain; MARIE, Michel; VERNET, Marc. Esthétique du film. Paris: Nathan, 1983.

- AUMONT, Jacques ; MARIE, Michel. L'Analyse des Films. Paris: Nathan, 1988.

- AUMONT, Jacques. Le cinéma et la mise en scène (2006). Paris: Armand Colin, 2010.

- AUMONT, Jacques. Les théories des cinéastes. Paris: Nathan, 2002.

- AUMONT, Jacques. L'OEil interminable (1989). Paris: Librairie Séguier, 1995.

- AUMONT, Jacques. Matière d'images. Paris: Images modernes, 2005. 
- AUMONT, Jacques. Matière d'images. Redux. Paris: Éditions de la Différence, 2009.

- BARRON, Craig; VAZ, Mark Cotta. The Invisible Art: The Legends of Movie Matte Painting. San Francisco, Cal.: Chronicle Books, 2002.

- BAZIN, André. Qu'est-ce que le cinéma ?. Paris: Les Éditions du CERF, 1985.

- BONFAND, Alain. Le cinéma saturé. Essai sur les relations de la peinture et des images en mouvement. Paris: Presses Universitaires de France, 2007.

- BONITZER, Pascal. Peinture et cinéma, décadrages. Paris: Éditions de l'Étoile, 1985.

- BORDWELL, David. Figures traced in light. On cinematic staging. Berkeley, London: University of California Press, 2006.

- BORDWELL, David; THOMPSON, Kristin. Film Art: An Introduction. New York: McGraw-Hill, 2007.

- BORDWELL, David. Narration in the fiction film. London: Routledge, 1985.

- BORDWELL, David; STAIGER, Janet; THOMPSON, Kristin. The Classical Hollywood Cinema: Film Style and Mode of Production to 1960. London: Routledge, 1985.

- BRANIGAN, Edward. Narrative Comprehension and Film. New York: Routledge, 1992.

- BRANIGAN, Edward. Point of view in the cinema. A theory of narration and subjectivity in classical film. Berlin, New York, Amsterdam: Mouton Publishers, 1984.

- BRISELANCE, Marie-France; MORIN, Jean-Claude. Grammaire du cinéma. Paris: Nouveau Monde Éditions, 2010.

- BURCH, Noël. Praxis du cinema (1969). Paris: Folio Essais, 1986.

- BURGOYNE, Robert; FLITTERMAN-LEWIS, Sandy; STAM, Robert. New Vocabularies in Film Semiotics: Structuralism, Post-structuralism, and Beyond (1992). London: Routledge, 2002.

- CHATEAU, Dominique. Cinéma et philosophie. Paris: Armand Colin, 2005.

- CHATMAN, Seymour. Story and Discourse: Narrative Structure in Fiction and Film. Ithaca, London: Cornell University Press, 1978.

- COOK, David. A History of Narrative Film (1990). New York: Norton, 2003.

- CRETON, Laurent; FEIGELSON, Kristian. Villes cinématographiques : ciné-lieux. Paris: Presses Sorbonne Nouvelle, 2007. 
- DOANE, Mary Ann. The Emergence of Cinematic Time. Cambridge, London: Harvard University Press, 2002.

- ELSAESSER, Thomas (ed.). Early cinema: Space-Frame-Narrative. London: BFI Publishing, 1990.

- EVERETT, Wendy E.; GOODBODY, Axel. (eds.). Revisiting Space: Space and Place in European Cinema. Bern: European Academic Publishers, 2005.

- FABER, Liz; WALTER, Helen. Animation Unlimited: Innovative Short Films Since 1940. London: Laurence King Publishing, 2004.

- FITZMAURICE, Tony; SHIEL, Mark (eds). Screening the City, London: Verso, 2003.

- GARDIES, André. L'espace au cinéma. Paris: Méridiens Klincksieck, 1993.

- GAUDREAULT, André; JOST, François. Le récit cinématographique. Paris: Nathan, 1990.

- KERMAREC, Roland. Lynchland. Paris: Editions Objectif Cinéma, 2004.

- LAMSTER, Mark (ed.). Architecture and Film. New York: Princeton Architectural Press, 2000.

- L'HERMINIER, Pierre. L'art du cinéma. Paris: Seghers, 1960.

- MACKENDRICK, Alexander. On Film-making: An Introduction to the Craft of the Director. New York: Macmillan, 2005.

- MARTIN, Marcel. Le langage cinématographique (1955). Paris: Les Éditions du Cerf, 2001.

- MONACO, James. How to Read a Film: Movies, Media and Beyond: Art, Technology, Language, History, Theory (1997). New York: Oxford University Press, 2009.

- MURCIA, Claude; TAMINAUX, Pierre (dir.). Cinéma, art(s) plastique(s). Paris: L'Harmattan, 2004.

- NEALE, Steve. Cinema and Technology: Image, Sound, Colour. Bloomington: Indiana University Press, 1985.

- ORTIZ, Áurea; PIQUERAS, María Jesús. La pintura en el cine: cuestiones de representación visual (1995). Barcelona: Paidós, 2003.

- PALACIO, Manuel; PERUCHA, Julio Pérez (coords.). Historia general del cine. Madrid: Cátedra, 1997.

- PASOLINI, Pier Paolo. Empirismo eretico (1972). Milano: Garzanti, 1991. 
- RITTAUD-HUTINET, Jacques. Le cinéma des origines : les frères Lumières et leurs opérateurs. Seyssel: Éditions du Champ Vallon, 1985.

- ROHMER, Eric. L'organisation de l'espace dans le Faust de Murnau. Paris: Ramsay, 1977.

- SOBCHACK, Vivian C.. Screening space. The American science fiction film (1987). New Brunswick, New Jersey, London: Rutgers University Press, 1999.

- STAM, Robert. Film Theory: An Anthology. Oxford: Wiley-Blackwell, 2000.

- TARKOVSKI, Andrei. Esculpir en el tiempo. Reflexiones sobre el cine. Madrid: Editorial Rialp S. A., 1997.

- VANCHERI, Luc. Cinéma et peinture. Paris: Armand Colin Cinéma, 1982.

- VERHOEFF, Nanna. Mobile Screens: The Visual Regime of Navigation. Amsterdam: Amsterdam University Press, 2012.

- VERNET, Marc. Figures de l'absence. De l'invisible au cinéma. Paris: Cahiers du cinéma, 1988.

- ZUNZUNEGUI DÍEZ, Santos. Paisajes de la forma. Ejercicios de análisis de la imagen. Madrid: Cátedra, 1994.

\section{A.3.1 Cine de las vanguardias históricas y experimental}

- ALBERA, François. Eisenstein et le constructivisme russe. Lausanne: L’âge d'homme, 1990.

- ALBERA, François. L'Avant-garde au cinéma. Paris: Armand Colin, 2005.

- AUMONT, Jacques (dir.). Jean Epstein. Cinéaste, poète, philosophe. Paris: Cinémathèque française, 1998.

- AUMONT, Jacques. Montage Eisenstein (1979). Paris: Images modernes, 2005.

- BORDWELL, David. The Cinema of Eisenstein. Cambridge: Harvard University Press, 1993.

- BOUHOURS, Jean-Michel; DE HAAS, Patrick; DUSINBERRE, Deke. Man Ray, directeur du mauvais movies. Paris: Centre Georges Pompidou, 1997.

- BRENEZ, Nicole. Cinémas d'avant-garde. Paris: Cahiers du cinéma, Les petits cahiers, CNDP, 2006. 
- CABANNE, Pierre. Dialogues with Marcel Duchamp (1971). New York: Da Capo Press, 1987.

- CANUDO, Ricciotto. Manifeste des Sept Arts (1923). Paris: Séguier, 1995.

- COLVILE, Georgiana. Vers un langage des arts autour des années vingt. Paris: Klincksieck, 1977.

- DARIA, Sophie. Abel Gance, hier et demain. Paris: Ed. La Palatine, 1959.

- DE HAAS, Patrick. Cinéma intégral. De la peinture au cinéma dans les années vingt. Bruxelles: Transédition, 1985.

- EISENSTEIN, Sergueï . Au-delà des étoiles. Paris: Union générale d'édition, 1974.

- EISENSTEIN, Sergueï. Cinématisme, peinture et cinéma. Bruxelles: Éditions Complexe, 1980.

- EISENSTEIN, Sergei. Film Form: Essays in Film Theory (1949). New York: Harcourt, 1969.

- EISENSTEIN, Sergueï. Walt Disney (1941). Strasbourg: Circé, 1991.

- EISNER, Lotte H.. L'écran démoniaque. Paris: Le terrain vague, 1981.

- EPSTEIN, Jean. Bonjour cinéma (1921). Paris: Maeght édition, 1993.

- EPSTEIN, Jean. Écrits sur le cinéma (1921-1953). Paris: Seghers, 1975.

- ESQUENAZI, Jean Pierre (dir.). Vertov, l'invention du réel, actes du colloque de Metz (1996). Paris: L’Harmattan, 1997.

- FAURE, Élie. Fonction du cinéma. De la cinéplastique à son destin social (1937).

Paris: Éditions d'Histoire et d'Art, 1953.

- FRAMPTON, Hollis. Circles of Confusion: Film, Photography, Video, Texts, 19681980. New York: Anthology Film Archives, 1982.

- ILES, Chrissie. Into the light: the projected image in American art, 1964-1977. New York: Whitney Museum of American Art, H.N. Abrams, 2001.

- JEANNE, René; FORD, Charles. Abel Gance. Paris: Éditions Seghers, 1963.

- KOULECHOV, Lev. Écrits (1917-1934). Paris, Lausanne: L'age d'homme, 1994.

- KRACAUER, Siegfried. De Caligari a Hitler (1947). Barcelona: Paidós, 1985.

- KUENZLI, Rudolf. Dada and Surrealist Film (1987). Cambridge, MA: The MIT Press, 1996.

- LÉGER, Fernand. Fonctions de la peinture (1924). Paris: Gallimard, 1996.

- LISTA, Giovanni. Cinéma et photographie futuristes. Milan: Skira, 2008.

- MICHALKA, Matthias (ed.). X-Screen: Film Installations and Actions in the 1960s and 1970s. Cologne: Verlag, 2003. 
- MICHELSON, Annette. Kino-eye: The writings of Dziga Vertov. Berkeley: University of California Press, 1984.

- MITRY, Jean. Le cinéma expérimental, histoire et perspectives (1971). Paris: Éditions Seghers, 1974.

- MORITZ, William. Optical poetry: the life and work of Oskar Fischinger. Bloomington: Indiana University Press, 2004.

- NILSEN, Vladimir. The cinema as a graphic art. New York: Hill and Wang, 1937.

- NOGUEZ, Dominique. Éloge du cinéma expérimental. Paris: Centre Georges Pompidou, 1979.

- PALMIER, Jean-Michel. L'expressionnisme et les arts. Paris: Payot, 1979.

- PETRIC, Vlada. Constructivism in film, The man with the movie camera: $a$ cinematic analysis. New York: Cambridge University Press, 1987.

- PUDOVKIN, Vsevolod I.. Film technique and film acting (1926). New York: Grove Press, 1970.

- QUARESIMA, Leonardo (dir.). Walter Ruttmann: Cinema, pittura, ars acustica. Calliano (Trento): Manfrini Editori, 1994.

- RENAN, Sheldon. An Introduction to the American Underground Film. New York: Dutton, 1967.

- RICHTER, Hans. Hans Richter. Textes autobiographiques. Neuchâtel: Éditions du Griffon, 1965.

- RUSSETT, Robert; STARR, Cecile. Experimental animation. New York: Van Nostrand Reinhold Co., 1976.

- SÁNCHEZ-BIOSCA, Vicente. Sombras de Weimar: contribución a la historia del cine alemán 1918-1933. Madrid: Verdoux, S.L, 1990.

- SCHEUNEMANN, Dietrich. Expressionist film: new perspectives. Rochester, NY: Camden House, 2003.

- SITNEY, P. Adams (ed.). Film Culture Reader. New York: Cooper Square Press, 1970.

- SITNEY, P. Adams (ed.). The Avant-Garde Film: A Reader of Theory and Criticism. New York: New York University Press, 1978.

- VERTOV, Dziga. Articles, journaux, projets (1926). Paris: Cahiers du cinéma, 1972. 
$\underline{\text { Artículos/ensayos/entrevistas }}$

- AUMONT, Jacques. "Eisenstein par les autres et par lui même”. Cahiers du cinéma. Février 1976, núm. 264, pp. 65-66.

- AUMONT, Jacques. "Le concept de montage". Cahiers du cinéma. Avril 1969, núm. 211, pp. 46-51.

- EISENSTEIN, Sergueï. "La quatrième dimension du cinéma". Cahiers du cinéma. Septembre-octobre 1976, núm 270, pp. 5-28.

- MALEVITCH, Casimir. "Les lois picturales dans les problèmes du cinéma". Cinémathèque. Automne 1995, núm. 8, pp. 71-77.

- MEUSY, Jean-Jacques. La Polyvision, espoir oublié d'un cinéma nouveau [En línea]. 1895. Mille huit cent quatre-vingt-quinze, 2000, núm. 31, pp. 153-211. Disponible en Web: <http://1895.revues.org/68>

- RICHTER, Hans. "Un art original, le film”. Cahiers du cinéma. Paris, Mars 1952, núm. 10, pp. 11-15.

\section{A.4. Historia del arte y estética: pintura, escultura, arquitectura, fotografía, teatro, música y danza}

- AlBERro, Alexander; STIMSON, Blake. Conceptual Art: A Critical Anthology. Cambridge, MA: The MIT Press, 2000.

- ALBERTI, Leon Battista. De la pintura y otros escritos sobre arte (1436). Madrid: Ed. Tecnos, 1999.

- APOLLINAIRE, Guillaume; EIMERT, Dorothea. Le Cubisme. New York: Parkstone International, 2012.

- ARNHEIM, Rudolf. New Essays on the Psychology of Art. Berkeley: University of California Press, 1986.

- ARP, Jean. Jours effeuillés : poèmes, essais, souvenirs, 1920-1965. Paris: Gallimard, 1966.

- BARTHES, Roland. La chambre claire. Notes sur la photographie. Paris: Gallimard, 1980. 
- BELTING, Hans. Bild-Anthropologie: Entwürfe für eine Bildwissenschaft. München: W. Fink, 2001.

- BENJAMIN, Walter. L'œuvre d'art à l'époque de sa reproductibilité technique (1939). Paris: Gallimard, 2000.

- BOTAR, Oliver A. I.; WÜNSCHE, Isabel (eds.). Biocentrism and Modernism. Surrey, Burlington: Ashgate Publishing, 2011.

- BOURRIAUD, Nicolas. Postproduction (2003). Paris: Les Presses du réel, 2009.

- BRAGDON, Claude F.. Projective Ornament (1915). Kessinger Publishing, 1998.

- BRAUER, Fae; LARSON, Barbara (eds.). The Art of Evolution: Darwin, Darwinisms, and Visual Culture. London: University Press of New England, 2009.

- BRAUN, Marta. Picturing Time: The Work of Etienne-Jules Marey (1830-1904). Chicago: University Of Chicago Press, 1992.

- BRETON, André. Manifestes du surréalisme (1924). Paris: Gallimard, 1965.

- CABANNE, Pierre. Dialogues with Marcel Duchamp (1971). New York: Da Capo Press, 1987.

- CALVO SERRALlER, Francisco; GONZÁleZ GARCÍA, Ángel; MARCHÁN FIZ, Simon. Escritos de arte de vanguardia 1900/1945. Madrid: Ediciones Turner, 1979.

- CRAIG, E. Adcock. Marcel Duchamp's Notes from the Large Glass: An NDimensional Analysis. Michigan: UMI Research Press, 1983.

- DE MÈREDIEU, Florence. Histoire matérielle et immatérielle de l'art moderne. Paris: Larousse, 1999.

- DELEUZE, Gilles. Francis Bacon, logique de la sensation (1981). Paris: Édition de la différence, 1994.

- DÜRER, Albrecht. Hierin sind begriffen vier Bücher von menschlicher Proportion, Verlag Bibliophile Drucke von Josef Stocker (1528). Dietikon-Zürich: Verlag Bibliophile Drucke von Josef Stocker, 1969.

- ECO, Umberto. Opera aperta (1962). Milano: Bompiani, 2011.

- EDGERTON, Harold Eugene. Flash!: Seeing the unseen by ultra high-speed photography (1939). Boston: Charles T. Branford Co., 1954.

- FOSTER, Hall (ed.). The Anti-Aesthetic: Essays on Postmodern Culture. Seattle: Bay Press, 1983.

- FRANCASTEL, Pierre. Peinture et société : naissance et destruction d'un espace plastique de la Renaissance au cubisme (1951). Paris: Gallimard, 1965. 
- FRIZOT, Michel (dir.). Nouvelle histoire de la photographie. Paris: Larousse, 2001.

- GARCÍA VARAS, Ana (ed.). Filosofía e(n) imágenes. Interpretaciones desde el arte y el pensamiento contemporáneos. Zaragoza: IFC, 2012.

- GERVEREAU, Laurent. Dictionnaire mondial des images. Paris: Nouveau Monde éditions, 2006.

- GOMBRICH, Ernst Hans. Art and Illusion: A Study in the Psychology of Pictorial Representation (1960). London: Phaidon, 2004.

- GOMBRICH, Ernst Hans. The Story of Art (1950). London: Phaidon, 2006.

- GOODMAN, Nelson. Languages of Art. Indianapolis: Hackett Publishing, 1976.

- GREENBERG, Clement. The Collected Essays and Criticism, Volume 4: Modernism with a Vengeance, 1957-1969. Chicago: University of Chicago Press, 1995.

- GUBERN, Román. Del bisonte a la realidad virtual. La escena y el laberinto. Barcelona: Anagrama, 1996.

- HABASQUE, Guy. Vasarely et la plastique cinétique. Bruxelles: QUADRUM, 1957.

- HADDON, Alfred Cort. Evolution in art: as illustrated by the life-history of designs. London: The Walter Scott Press, 1895. Disponible en Web:

$<\mathrm{http}$ //archive.org/stream/artevolution00haddrich/artevolution00haddrich_djvu.txt>

- HAECKEL. Ernst. Kunstformen der Natur (1904). Bremen: Books on Demand, 2011.

- HAMBOURG, Maria Morris; PHILlIPS, Christopher. La nueva visión. Fotografía de entreguerras. Ford Motor Company Collection, Metropolitan Museum of Art. Valencia: IVAM Centre Julio González, 1995.

- HARRIS, John. Fractal Architecture: Organic Design Philosophy in Theory and Practice. Albuquerque: University of New Mexico Press, 2012.

- HAUS, Andreas. Moholy-Nagy, photographies, photogrammes. Paris: Chêne, 1979.

- HAUSMANN, Raoul. Courrier Dada (1958). Paris: Éditions Allia, 2004.

- HENDERSON, Linda Dalrymple. Duchamp in Context: Science and Technology in the Large Glass and Related Works. Princeton: Princeton University Press, 1998.

- HENDERSON, Linda Dalrymple. The Fourth Dimension and Non-Euclidean Geometry in Modern Art. Princeton: Princeton University Press, 1983.

- HOFFMAN, Katherine (ed.). Collage: Critical Views. Ann Arbor: UMI Research Press, 1989. 
- HOLLANDER, Anne. Moving Pictures. New York: Alfred A. Knopf, 1989.

- KAPLAN, Louis. László Moholy-Nagy: Biographical writings. Durham, NC: Duke University Press, 1995.

- KARMEL, Pepe; VARNEDOE, Kirk. Jackson Pollock: Interviews, Articles, and Reviews. New York: The Museum of Modern Art, 1999.

- KEMP, Martin. The Science of Art: Optical Themes in Western Art from Brunelleschi to Seurat. Yale University Press, 1990.

- KEMP, Martin. Visualizations: The Nature Book of Art and Science. University of California Press, 2000.

- KEPES, Gyorgy (dir.). Nature et art du mouvement. Bruxelles: La connaissance, 1968.

- KOSTELANETZ, Richard (ed.). Moholy-Nagy. New York: Praeger, 1970.

- KRAUSS, Rosalind. Passages in Modern Scultpture (1977). Cambridge, London: The MIT Press, 1981.

- KRAUSS, Rosalind. The Originality of the Avant-Garde and Other Modernist Myths. Cambridge: The MIT Press, 1985.

- LARTIGUE, Jacques Henri. Mémoires sans mémoire. Paris: Ed. Robert Laffont, 1975.

- LIPPARD, Lucy. Six Years: The Dematerialization of the Art Object from 1966 to 1972. Berkeley: University of California Press, 1997.

- LYNTON, Norbert. The Story of Modern Art. Oxford: Phaidon, 1986.

- MALABOU, Catherine (dir.). Plasticité. Paris: Éditions Léo Scheer, 2000.

- MARCHÁN FIZ, Simón. Contaminaciones figurativas. Madrid: Alianza Forma, 1986.

- MEISEL, Louis K.. Photo-realism. New York: Abradale Press, 1989.

- MIßELBECK, Reinhold et al. La fotografía del s. XX. Museum Ludwig Colonia, Colonia: Taschen, 1997.

- MOHOLY-NAGY, László. La nueva visión y Reseña de un artista (1929). Buenos Aires: Ediciones Infinito, 1985.

- MOHOLY-NAGY, László. Peinture, photographie, film, et autres écrits sur la photographie (1925). Nîmes: Jacqueline Chambon, 1993.

- MOLINUEVO, José Luis (ed.). A qué llamamos arte. El criterio estético. Salamanca: Ediciones Universidad de Salamanca, 2001. 
- MOLINUEVO, José Luis. Magnífica miseria. Dialéctica del romanticismo. Murcia: CENDEAC, 2009.

- MORGAN, Robert. Vasarely. New York: George Braziller, 2004.

- NELSON, Robert S.; SHIFF, Richard (eds.). Critical Terms for Art History (1996).

Chicago: University of Chicago Press, 2003.

- NOTARIO RUIZ, Antonio (ed). Estética: perspectivas contemporáneas. Salamanca: Ediciones Universidad de Salamanca, 2008.

- ONO, Yoko. Grapefruit: A Book of Instructions and Drawings by Yoko Ono. New York: Simon \& Schuster, 2000.

- PANOFSKY, Erwin. La perspective comme forme symbolique (1927). Paris: Les Éditions de Minuit, 1975.

- PANOFSKY, Erwin. Three essays on style. Cambridge: The MIT Press, 1995.

- PAVIS, Patrice. L'analyse des spectacles. Paris: Nathan Université, 1996.

- PELLETIER, Louise; PÉREZ GÓMEZ, Alberto. Architectural representation and the perspective hinge. Cambridge: The MIT Press, 2000.

- POPPER, Frank. Origins and development of kinetic art. Greenwich, Conn: New York Graphic Society, 1968.

- ROSENBERG, Harold. The Tradition of the New. New York: Horizon Press, 1959.

- SEIBERLING, Grace. Monet's series. New York: Garland Pub, 1981.

- SERRANO, Véronique. La part du jeu et du rêve, Óscar Domínguez et le surréalisme 1906-1957. Paris: Éditions Hazan, 2005.

- VANVOLSEM, Maarten. The Art of Strip Photography: Making Still Images with a Moving Camera. Leuven: Universitaire Pers, 2011.

- VOGEL, François. Nouveau traité du sténopé. Bastia: Éditions Éoliennes, 2011.

- WEINRICHTER, Antonio. Metraje encontrado. La apropiación en el cine documental y experimental. Navarra: Festival Punto de Vista/Gobierno de Navarra, 2009.

- WORTHINGTON, Arthur Mason. A study of splashes (1852-1916). New York: Macmillan, 1963.

\section{$\underline{\text { Artículos/ensayos/entrevistas }}$}

- BELKIN, Alan. A Practical Guide to Musical Composition [En línea]. 2008. Disponible en Web: 
$<$ https://www.webdepot.umontreal.ca/Usagers/belkina/MonDepotPublic/bk/>

- DINER, Simon. Le biomorphisme dans la culture artistique moderne [En línea]. Texto para la exposición "Sculpture numérique et biomorphisme". Nancy, Octobre 2007. Disponible en Web: <www.peiresc.org/DINER/Biomorphisme.pdf>

- GALEYEV, Bulat. “Mikhail Matyushin's Contribution to Synthetic Art”. Leonardo. April 2005, vol. 38, núm. 2, pp. 151-154

- GALL, Jean-Luc. Photo/sculpture [En línea]. Études photographiques. 3 Novembre 1997. Disponible en Web:

$<$ http://etudesphotographiques.revues.org/index95.html>

- "Instant photography. Results of the California experiments". The New York Times. February 19, 1881. Disponible en Web:

$<$ http://query.nytimes.com/gst/abstract.html?res=9B00EED61F3AE533A2575AC1A9 649C94609FD7CF\&scp=18\&sq $=19+$ february $+1881 \& s t=p>$

- LEWITT, Sol. "Doing Wall Drawings”. Art Now, New York, June 1971, vol. 3, núm 2.

- LEWITT, Sol. "Paragraphs on Conceptual Art”. Artforum, June 1967, vol. 5, núm 10, pp. 79-83.

- ZEKI, Semir. "The neurology of ambiguity”. Consciousness and Cognition. March 2004, vol. 13, núm 1, pp. 173-196.

\section{A.5. Teoría de la imagen}

- ALPERSON, Philip (ed.). The Philosophy of the Visual Arts. Oxford: Oxford University Press, 1992.

- ARNHEIM, Rudolf. Arte y percepción visual. Madrid: Alianza Editorial, 1995.

- ARNHEIM, Rudolf. Visual Thinking. Berkeley: University of California Press, 1969.

- AUMONT, Jacques. L'image (1990). Paris: Nathan, 1994.

- DONDIS, Donis A.. La sintaxis de la imagen. Introducción al alfabeto visual (1974). Barcelona: Gustavo Gili, 2000.

- KANIZSA, Gaetano. Gramática de la visión. Percepción y pensamiento (1980). Barcelona: Ediciones Paidós, 1989.

- ZUNZUNEGUI DÍEZ, Santos. Pensar la imagen. Madrid: Cátedra, 1989. 


\section{A.6. Ciencias}

- ACHAM, Karl (ed.). Naturwissenschaften, Medizin und Technik aus Graz: Entdeckungen und Erfindungen aus fünf Jahrhunderten vom "Mysterium cosmographicum” bis zur direkten Hirn-Computer-Kommunikation. Wien: Böhlau, 2007.

- DAWKINS, Richard. The Blind Watchmaker: Why the Evidence of Evolution Reveals a Universe without Design (1986). New York: Norton \& Company Inc, 1996. - DESCARTES, René. La Geometría (1637). Buenos Aires: Espasa-Calpe, 1947.

- EUCLIDES. Elementos (ca 300 a C). Madrid: Biblioteca clásica. Editorial Gredos, 1994.

- HOLLAND, John H.. Adaptation in Natural and Artificial Systems. Ann Arbor: University of Michigan Press, 1975.

- JOHNSON, Steven. Emergence: The Connected Lives of Ants, Brains, Cities, and Software. New York: Scribner, 2002.

- LINDENMAYER, Aristid; PRUSINKIEWICZ, Przemyslaw. The Algorithmic Beauty of Plants. New York: Springer-Verlag, 1994.

- MAREY, Étienne-Jules. Le mouvement (1894). Nîmes: Jacqueline Chambon, 1994.

- MAYR, Ernst (ed.). On the Origin of Species: A Facsimile of the First Edition. Cambridge: Harvard University Press, 1964.

- PICKOVER, Clifford A.. The Math Book. New York: Sterling Publishing CO, 2009.

- THOMPSON, D’Arcy. On Growth and Form (1917). Cambridge: Cambridge University Press, 2004.

\section{$\underline{\text { Artículos/ensayos/entrevistas }}$}

- TURING, Alan. "On computable numbers, with an application to the entscheidungsproblem”. En: Proceedings of the London Mathematical Society, series II, vol. 42, 1936-37, pp. 230-265. Disponible en Web:

$<$ http://www.lms.ac.uk/content/alan-turing-year-2012>

- TURING, Alan. "The Chemical Basis of Morphogenesis". Philosophical Transactions of the Royal Society of London. Series B, Biological Sciences. August 14, 1952, vol. 237, núm. 641, pp. 37-72. 
- WHEELER, J. A.. "On the nature of quantum geometrodynamics". Annals of Physics. New York, 1957, vol. 2, núm. 6, pp. 604-614.

\section{A.6.1. Hiperespacio y espacios no-euclidianos}

- HARGITTAI, István. Spiral Symmetry (1992). London: World Scientific Publishing, 2000.

- HAWKING, Stephen. A Brief History of Time: From the Big Bang to Black Holes (1988). London: Bantam, 2008.

- HINTON, Charles H.. A New Era of Thought. London: Swan Sonnenschein \& Co., 1888. Disponible en Web:

$<$ http://archive.org/stream/anewerathought00falkgoog\#page/n6/mode/2up>

- HINTON, Charles H.. The Fourth Dimension (1904). Kila, Mont: Kessinger Publishing, 1997.

- JOUFFRET, Esprit. Traité élémentaire de géométrie à quatre dimensions (1903). Paris: Gauthier-Villars, 2003.

- MANDELBROT, Benoît. Les objets fractals. Forme, hasard et dimension (1975). Paris: Flammarion, 1995.

- MANDELBROT, Benoît. The fractal geometry of nature. W. H. Freeman and Co., New York, 1982.

- MANNING, Henry P.. Geometry of Four Dimensions. New York: The Macmillan Company, 1914. Disponible en Web:

$<$ http://www.archive.org/details/geometryoffourdi033495mbp >

- OUSPENSKY, Peter D.. New Model of the Universe (1931). Kessinger publishing, 1999.

- PEITGEN, Heinz-Otto; RICHTER, Peter H.. The Beauty of Fractals: Images of Complex Dynamical Systems. Heidelberg: Springer-Verlag, 1986.

- POINCARÉ, Henri. La science et l'hypothèse (1902). Paris: Flammarion, 2000.

- ROBBIN, Tony. Shadows of Reality: The Fourth Dimension in Relativity, Cubism, and Modern Thought. New Haven: Yale University Press, 2006.

- RUSSELL, Bertrand. The ABC of Relativity (1925). London: Routledge, 2002.

- SCHLÄFLI, Ludwig. Theorie der vielfachen Kontinuität (1852). Cornell University Library, 1901. 
- SMOOT, George; DAVIDSON, Keay. Wrinkles in Time. New York: William Morrow, 1994.

$\underline{\text { Artículos }}$

- EINSTEIN, Albert; ROSEN, Nathan. "The Particle Problem in the General Theory of Relativity". Physical Review. 1935, vol. 48, pp. 73-76.

- MORRIS, Michael S.; THORNE, Kip S.; YURTSEVER, Ulvi. "Wormholes, Time Machines, and the Weak Energy Condition”. Physical Review Letters. September 26, 1988, vol. 61, núm 13.

- NEWCOMB, Simon. "The philosophy of hyperspace". Bulletin of the American Mathematical Society. 1898, vol. 4, núm. 5, pp. 187-195.

- PENROSE, Lionel S.; PENROSE, Roger. "Impossible objects: A special type of visual illusion”. British Journal of Psychology. February 1958, vol. 49, pp. 31-33.

- SCHLEGEL, Victor. “Quelques théorèmes de géométrie à $n$ dimensions”. Bulletin de la Société Mathématique de France. 1882, Tome 10, pp. 172-207. Disponible en Web: <http://www.numdam.org/item?id=BSMF_1882_10_172_1>

- SPROTT, Julien C.; TAYLOR, Richard P.. "Biophilic Fractals and the Visual Journey of Organic Screen-savers". Nonlinear Dynamics, Psychology, and Life Sciences. 2008, vol. 12, núm. 1, pp. 117-129.

- STRINGHAM, W. Irving. "Regular Figures in n-Dimensional Space". American Journal of Mathematics. March 1880, vol. 3, núm 1.

\section{A.7. Giro espacial}

- BACHELARD, Gaston. La poétique de l'espace. Paris: Les Presses universitaires de France, 1958.

- COULDRY, Nick; MCCARTHY, Anna (eds.). Mediaspace: Place, Scale, and Culture in a Media Age. New York: Routledge, 2004.

- DAVENPORT, Elisabeth; TURNER, Phil (eds.). Spaces, Spatiality and Technology. Dordrecht: Springer-Verlag, 2005.

- HARVEY, David. Explanation in Geography. London: Edward Arnold Publishers Ltd., 1973. 
- HARVEY, David. The Condition of Postmodernity. An Enquiry into the Origins of Cultural Change. London: Blackwell, 1991.

- HOWELL, Robert; PENZ, François; RADICK, Gregory (eds.). Space: in Science, Art and Society. Cambridge: Cambridge University Press, 2004.

- HUBBARD, Phil; KITCHIN, Rob; VALENTINE, Gill (eds.). Key Thinkers on Space and Place (2004). London: Sage, 2010.

- HUGGETT, Nick. Space from Zeno to Einstein (1999). Cambridge: The MIT Press, 2002.

- JAMESON, Fredric. Postmodernism, or, The Cultural Logic of Late Capitalism. Durham, NC: Duke University Press, 1991.

- JAMESON, Fredric. The Geopolitical Aesthetic: Cinema and Space in the World System (1992). Bloomington: Indiana University Press, 1995.

- JAMMER, Max. Concepts of Space: The History of Theories of Space in Physics (1954). New York: Dover, 1993.

- LAWRENCE-ZÚÑIGA, Denise; LOW, Setha M. (eds.). The Anthropology of Space and Place. Oxford: Blackwell, 2003.

- LEFEBVRE, Henri. La production de l'espace (1974). Paris: Anthropos, 2000.

- MCLUHAN, Marshall; PARKER, Harley. Through The Vanishing Point: Space in Poetry and Painting. New York: Harper \& Row, 1968.

- SOBIESZCZANSKI, Marcin (dir.). Spatialisation en art et sciences humaines. Bruxelles: Collection Pleine Marge, Peeters, 2004.

- SOJA, Edward. Postmodern Geographies: The Reassertion of Space in Critical Social Theory. London, New York: Verso, 1989.

- SOJA, Edward. Thirdspace: Journeys to Los Angeles and Other Real-and-Imagined Places. Oxford: Blackwell, 1996.

- SUDERBURG, Erika (ed.). Space, Site, Intervention: Situating Installation Art. Minneapolis: University of Minnesota Press, 2000.

- WERTHEIM, Margaret. The Pearly Gates of Cyberspace. A History of Space from Dante to the Internet. New York, London: Norton \&Company, 1999.

$\underline{\text { Artículos }}$

- FOUCAULT, Michel. "Des espaces autres" (1967). Architecture, Mouvement, Continuité. Octobre 1984, núm 5, pp. 46-49. 


\section{A.8. Literatura}

- ABBOTT, Edwin A.. Flatland: A Romance of Many Dimensions (1884). New York: Barnes and Noble Books, 1963.

- BLAKE, William. “Auguries of Innocence” (ca 1803). En: The selected poems of William Blake. Ware: Wordsworth Editions, 2000.

- BOILEAU, Pierre-Louis; NARCEJAC, Thomas. Sueurs froides : d'entre les morts (1954). Paris: Gallimard, 1999.

- BORGES, Jorge Luis. Ficciones (1944). Madrid: Alianza Editorial, 2004.

- CARROLL, Lewis. Alice's Adventures in Wonderland; and Through the LookingGlass (1865-1871). Harmondsworth: Puffin Books, 1962.

- DE SAINT-EXUPÉRY, Antoine. Le Petit Prince (1943). Paris: Gallimard, 2004.

- DICK, Philip K.. Do androids dream of electric sheep? (1968). New York: Ballantine Books, 1996.

- DICK, Philip K. Selected Stories of Philip K. Dick. Boston: Houghton Mifflin Harcourt, 2013.

- GIBSON, William. Neuromancer. New York: Ace Books, 1984.

- GOULD, Steven. Jumper (1992). New York: Starscape Books, 2002.

- GROOM, Winston. Forrest Gump (1986). Knopf Doubleday Publishing Group, 2012.

- HINTON. Charles Howard. Scientific Romances. London: W. Swan Sonnenschein, 1884. Disponible en Web:

$<$ http://archive.org/stream/scientificroman01hintgoog\#page/n6/mode/2up>

- PALAHNIUK, Chuck. Fight Club (1996). New York: W. W. Norton \& Company Inc, 2005.

- ROWLING, J. K.. Harry Potter and the Chamber of Secrets. London: Bloomsbury, 1998.

- SAGAN, Carl. Contact. New York: Simon and Schuster, 1985. 


\section{A.9. Otros}

- BOEKE, Kees. Cosmic View: The Universe in 40 Jumps. New York: John Day Company, 1957.

- CHENGFU, Yang. The Essence and Applications of Taijiquan (1934). California: North Atlantic Books, 2005.

- DIDEROT, Denis; D’ALEMBERT, Jean le Rond. Encyclopédie. Paris: Le Breton, Durand, Briasson, Michel-Antoine David, 1754.

- GALTON, Francis. Inquiries into human faculty and its development (1883). London: JM Dent \& Co., Everyman, 1907. Disponible en Web:

$<$ http://www.archive.org/stream/inquiriesintohum00galtuoft/inquiriesintohum00galtu oft_djvu.txt>

- STYGALL, Gail (ed.). Academic Discourse: Readings for Argument and Analysis. Mason, OH: Thomson Custom Publishing, 2002.

- YATES, Francis A.. The Art of Memory (1966). London: Pimlico, 1992.

\section{B. RECURSOS AUDIOVISUALES}

- BBC Tomorrow's world. Time-slice films [Vídeo en línea]. BBC, May 1993. Disponible en Web: <http://www.youtube.com/user/timeslicefilms?feature=watch>

- CROOKS, Daniel. StudioArt Break: Daniel Crooks [Vídeo en línea]. Studio132. 2011. Disponible en Web:

$<$ http://www.studiotv.com.au/arts-news/stvdio-artbreak-daniel-crooks/>

- CUBA, Larry. Larry Cuba and other classics from the iotaCenter Collection [Vídeo en línea]. Retrospectiva en el Festival Punto y Raya, Arts Santa Mònica, Barcelona, 27-28 de noviembre de 2009. Disponible en Web:

$<$ http://www.youtube.com/watch?v=kcXim0ZrlPs $>$

- FRY, Ben; REAS, Casey. Processing 2.0. (Or, the modern Prometheus). Eyeo Festival 2011. [Vídeo en línea]. Eyeofestival.com, 2011. Disponible en Web: http://vimeo.com/28117873 
- GREENAWAY, Peter. New Possibilities: Cinema is Dead, Long Live Cinema [Vídeo en línea]. Avenali Chair in the Humanities, September 13, 2010. Disponible en Web: <http://townsendcenter.berkeley.edu/media/peter-greenaway-filmmaker $>$

- KOKARAM, Anil. The Mathematics of Bullet time. From Muybridge to the Matrix [Vídeo en línea]. TEDxDublin, Science Gallery, Dublin, September 2010. Disponible en Web: <http://tedxtalks.ted.com/video/TEDxDUBLIN-Anil-Kokaram-The-Mat>

- LANSKAYA, Yelena. The Making of 'Dreamkeeper' [DVD]. Hallmark Home Entertainment, 2004.

- NARDONE, Robert. Lucien Bull. Monsieur cent mille images [Vídeo en línea]. Cité des sciences et de 1 'industrie, 2009. Disponible en Web:

$<$ http://www.universcience.tv/video-lucien-bull-monsieur-cent-mille-images534.html>

- SALAVON, Jason. Currents: Jason Salavon [Vídeo en línea]. Columbus Museum of Art. Columbus, Ohio, January 18-May 4, 2008. Disponible en Web: $<$ http://www.youtube.com/watch?v=rzFuYf2_s8Q\&list=PL583A9C43EA2FDDB9>

- SHIBAYAMA, Nobuhiro. Bio-Morph Encyclopedia [CD-ROM]. Tokyo: 4D Corporation, 1994.

- SOMMER, Astrid (ed.). The complete Artintact. Artists' Interactive CDROMagazine. Vols. 1-5. (1994-1999). [DVD-ROM]. Ostfildern: Hatje Cantz, 2002.

- SPIELMANN, Yvonne. Video Aesthetics: from Technology to Medium. [Vídeo en línea]. Medea Malmö University. May 4, 2011. Disponible en Web: $<$ http://medea.mah.se/2011/05/lecture-yvonne-spielmann-video-aesthetics-fromtechnology-to-medium/>

- WACHOWSKI, Andy; WACHOWSKI, Larry. The Matrix DvD Extras [DVD]. Roadshow Entertainment, 1999.

- WATZ, Marius. Eyeo Festival [Vídeo en línea]. Eyeofestival.com, 2011. Disponible en Web: <http://www.wired.com/beyond_the_beyond/2011/10/showtime-mariuswatz-eyeo-festival-2011/>

- WENDERS, Wim. Chambre 666 (1982) [DVD]. Paris: Wild Side Vidéo (ed.), 2004. 


\section{WEBIOGRAFÍA}

Con el deseo de facilitar la consulta de las páginas web referidas a continuación, todas han sido revisadas el 15 de mayo de 2013. De igual modo, para una mayor claridad, se han agrupado bajo los siguientes epígrafes:

C.1. Sitios web de artistas y proyectos en línea

C.2. Blogs y tumblr

C.3. Compañías de efectos especiales, productoras y distribuidoras

C.4. Institutos, laboratorios y departamentos

C.5. Organizaciones dedicadas a la investigación y la difusión del cine, el arte y los nuevos medios.

C.6. Museos, galerías, catálogos de festivales y exposiciones

C.7. Publicaciones en línea sobre arte y nuevas tecnologías, cine y efectos especiales

C.8. Otras publicaciones

C.9. Diccionarios y bases de datos

\section{C.1. Sitios web de artistas y proyectos en línea}

http://www.abcdcd.com/

http://www.acenorton.com/

http://alanparker.com/

http://alem3d.obidos.org/en/

http://alma.arte.tv/fr/

http://archive.hi-res.net/donniedarko/

http://artport.whitney.org/commissions/softwarestructures/map.html

http://www.bewitched.com/about.html

http://brysonian.com/

http://camilleutterback.com/projects/liquid-time-series/

http://cinemagraphs.com/ 
http://chriscunningham.com/

http://chrislandreth.com/

http://www.csurivision.com/

http://www.dance-tech.net/

http://www.danielaskill.com/

http://danielcrooks.com/

http://daniel-franke.com/

http://www.dataisnature.com/

http://davidoreilly.com/

http://diotima.infotech.monash.edu.au/ jonmc/formgen/

http://doc.gold.ac.uk/ latham/

http://www.donniedarko.org.uk/philosphy-of-time-travel/

http://eamesoffice.com/charles-and-ray/

http://edgerton-digital-collections.org/

http://elastic.tv/

http://electricsheep.org/

http://www.emohr.com/

http://www.everynone.com/

http://www.flong.com/

$\mathrm{http}: / /$ francoisvogel.com/fr

http://www.generatorx.no/

http://www.geom.uiuc.edu/ banchoff/projects.html

http://gustifink.com/

http://hollisframpton.org.uk/

http://infosthetics.com/

http://www.jimcampbell.tv/

http://www.jonathanmccabe.com/

http://www.karlsims.com/

http://www.kenknowlton.com/

http://www.k2.t.u-tokyo.ac.jp/members/alvaro/Khronos/

http://lightmoves.net/

http://lillian.com/

http://www.luc-besson.com/

http://www.lukaszlysakowski.com/ 
http://mariuswatz.com/

http://www.miamakela.net/text.html

http://www.michelgondry.com/

http://www.mikefiggis.co.uk/

http://www.motiontheory.com/

http://www.movingimages.de/

http://www.nabil.com/

http://nancyburson.com/pages/fineart.html

http://www.nickknight.com/main.html

http://www.nicolasprovost.com/

http://www.nimanourizadeh.com/

http://noll.uscannenberg.org/

http://www.oculasm.org/glitch/

http://www.olivierotoscani.com/

http://www.oneinthree.tv/

http://www.oskarfischinger.org/

http://www.owimahn.de/

http://www.petergreenawayevents.com/petergreenaway.html

http://www.peter-weibel.at/

http://www.processing.org/

http://www.reas.com/

http://www.recreating-movement.com/index.html

http://retnull.com/

http://robchiu.com/

http://www.ryoichikurokawa.com/

http://salavon.com/

http://scottdraves.com/

http://smugglersite.com/adam-berg

http://www.specialproblems.com/

http://www.stanvanderbeek.com/

http://www.steve-barron.com/

http://www.taniaruiz.info/

http://www.tarsem.org/

http://tellnoone.co.uk/ 
http://timrichardson.tv/

http://tonyrobbin.net/

http://www.tulselupernetwork.com/basis.html

http://www.tx-transform.com

http://www.upian.com/

http://vasulka.org/

http://www.verostko.com/menu.html

http://www.visualcomplexity.com/vc/

http://www.waliczky.net/

http://wearechopchop.com/

http://www.wearefromla.com/

http://www.well.com/ cuba/index.html

http://www.widrichfilm.com/

http://www.zbigvision.com

\section{C.2. Blogs y tumblr}

http://andre.gunthert.fr

http://www.animationblogspot.com/

http://beta.imaginefx.com/tag/blog

http://blog.lecollagiste.com/

http://blogs.alfaguara.com/fernandezmallo/category/general/

http://cameracontrol.org/blog/

http://cinemadocumentaire.wordpress.com/

http://www.computerarts.co.uk/blog

http://www.creativeapplications.net/posts/

http://culturevisuelle.org/

http://cyberbadger.blogspot.com/

http://www.davidhazy.com/blog/

http://digitalimagingandphotography.blogspot.com/

http://expandedcinema.blogspot.com/

http://www.flight404.com/blog/ 
http://www.fxphd.com/blog/

http://glitchaesthetics.blogspot.fr/

http://joseluismolinuevo.blogspot.fr/

http://lab.softwarestudies.com/

http://lux.org.uk/blog

http://motionographer.com/

http://new-aesthetic.tumblr.com/

http://www.realityprime.com/

http://rosa-menkman.blogspot.fr/

http://www.topoftheclips.com/

http://www.touchsmarter.com/

http://www.triangulationblog.com/

http://vjculture.blogspot.fr/

http://www.visionaryfilm.net

\title{
C.3. Compañias de efectos especiales, productoras y distribuidoras
}

\author{
www.arte.tv \\ http://www.buf.com/main.php \\ http://www.diginfo.tv/about/ \\ www.digitalair.com \\ http://jdp.co.uk/ \\ http://www.movia.com/ \\ http://www.nfb.ca/ \\ http://www.pixar.com/ \\ http://www.platige.com/ \\ http://www.radicalmedia.com/ \\ http://www.submarine.nl/\# \\ http://www.timeslicefilms.com/ \\ http://timetrack.com/ \\ http://www.virtualcamera.com/
}




\section{C.4. Institutos, laboratorios y departamentos}

http://www.arpla.fr/

http://artnodes.uoc.edu/ojs/index.php/artnodes/

http://artsandsciences.osu.edu

http://www-artweb.univ-paris8.fr/

http://www.cg.cs.tu-bs.de/

http://cias.rit.edu/schools/photographic-arts-sciences

http://www.cl.cam.ac.uk/

http://cms.mit.edu/

http://www.culturavisual.uji.es/

http://filosofiausal.usal.es/

http://gl.ict.usc.edu/

http://www.icinema.unsw.edu.au/

http://www.ieee.org/index.html

www.insep.fr/

http://www.kit.edu/english/

http://medea.mah.se/

http://www.media.mit.edu/

http://www.mee.tcd.ie/ sigmedia/

http://shc.stanford.edu/

http://www.univ-paris3.fr/ea-185-institut-de-recherche-sur-le-cinema-et-1-

audiovisuel-ircav--3445.kjsp

http://vecg.cs.ucl.ac.uk/home/

C.5. Organizaciones dedicadas a la investigación y la difusión del cine, el arte y los nuevos medios.

http://www.aec.at/news/

http://www.anarchive.net/

http://www.animateprojects.org/

http://www.archive.org/ 
http://www.atariarchives.org/

http://www.banffcentre.ca/

http://www.cfmdc.org/

http://cinemaproject.org/about/

http://www.cinematheque.fr/

http://computer-arts-society.com/

www.digiarts.com

http://digitalartmuseum.org/intro.htm

http://www.eai.org/index.htm

http://www.fondation-langlois.org/html/e/

http://www.imaionline.de/

http://www.ina.fr/

http://www.leonardo.info/

http://lux.org.uk/

http://www.mediaarthistory.org/

http://motionographer.com/

http://networkcultures.org/wpmu/portal/about/

http://www.neural.it/

http://www.newworlddesigns.co.uk/

http://www.olats.org/

http://on1.zkm.de/zkm/e/institute/bildmedien/

http://www.rappresentazione.it/?p=5198

http://rhizome.org/

http://www.robots.ox.ac.uk/ vgg/

http://www.sculpture.org/

http://see-this-sound.at/en

http://showstudio.com/\#punk_diy

http://www.siggraph.org

http://thecreatorsproject.vice.com/en_us

http://www.ubuweb.tv/

http://www.vdb.org/

http://www.vfxhq.com/index.html

http://www.visualeffectssociety.com/

http://visualmusic.ning.com/ 
http://www.virtual-circuit.org/

http://www.v2.nl/

http://webdocu.fr/web-documentaire/

http://www.zkm.de/

\section{C.6. Museos, galerías, catálogos de festivales y exposiciones}

http://www.aec.at/news/.

http://www.annecy.org/

http://www.artfutura.org/v2/

http://www.centerforvisualmusic.org/

http://www.centrepompidou.fr/

http://www.cibervision.org/

http://www.columbusmuseum.org/

http://www.computerhistory.org/

http://dam.org/gate

http://www.doclab.org/

http://eyeofestival.com/

http://www.forumdesimages.fr/

http://www.grandpalais.fr/fr

http://www.heure-exquise.org/

http://www.louvre.fr/h

http://www.moma.org/

http://www.movingimage.us/

http://www.museoreinasofia.es/

http://www.nationalmediamuseum.org.uk/

http://www.njpartcenter.kr/en/

http://on1.zkm.de/zkm/e/

http://www.puntoyrayafestival.com/index.php/en/

http://whitney.org/

http://worldsciencefestival.com/

http://www.yidff.jp/home-e.html Yamagata International Documentary Film Festival 


\title{
C.7. Publicaciones en línea sobre arte y nuevas tecnologías, cine y efectos especiales
}

\author{
http://artjournal.collegeart.org/ \\ http://www.artsjournal.com/ \\ http://www.awn.com/magazines \\ http://www.brefmagazine.com/ \\ http://www.cgw.com/ \\ http://www.ctheory.net/ \\ http://datagarden.org/about/ \\ http://www.digitalarti.com/fr \\ http://www.digitalartsonline.co.uk/ \\ http://www.expcinema.com/site/en \\ http://www.film-philosophy.com/index.php/f-p \\ http://www.fxguide.com/ \\ http://gamestudies.org \\ http://www.icgmagazine.com/wordpress/ \\ http://www.medienkunstnetz.de/mediaartnet/ \\ www.microfilmmaker.com/ \\ http://www.nouveauxmedias.net/ \\ http://sensesofcinema.com/ \\ http://www.vjtheory.net/ \\ http://www.3dyanimacion.com
}

\section{C.8. Otras publicaciones}

http://www.aeonmagazine.com/

http://www.anothermag.com/

http://www.huffingtonpost.co.uk

http://www.humansinvent.com/\#!/

http://www.newyorker.com

http://www.nytimes.com/ 
http://observer.guardian.co.uk/

http://www.salon.com/

http://www.time.com/time/

http://variety.com/

http://www.wired.com/

\section{C.9. Diccionarios y bases de datos}

http://www.ahdictionary.com/

http://archive.org/index.php

http://dada.compart-bremen.de/

http://design.osu.edu/carlson/history/lessons.html

http://esteticayteoriadelasartes.org/

www.imdb.com

http://newmedia-art.org/

http://www.rae.es/rae.html 


\section{LISTA DE IMÁGENES}

- AB/CD/CD. Difficult (2010)

- AMENÁBAR, Alejandro. Ágora (2009)

- ARNELL, Vaughan. Publicidad Lux Shower Gel (2004)

- ASKILL, Daniel. Transforming Water (2010)

- AVERTY, Jean-Christophe. Histoire de Melody Nelson (1971)

- BANCHOFF, Thomas; STRAUSS, Charles. The Hypercube: Projections and Slicing (1978)

- BARRON, Steve. Money for nothing (1986); Dreamkeeper (2003)

- BERG, Adam. Carousel (2009)

- BERGMAN, Ingmar. Smultronstället (1957)

- BERMAN, Shari Springer; PULCINI, Robert. The Nanny Diaries (2007)

- BESSON, Luc. Love Profusion (2003)

- BLAKE, Jeremy. Round The Bend (2002)

- BOYLE, Danny. 127 hours (2010)

- BULL, Lucien. Ralentí de un perdigón atravesando una pompa (1904)

- BUÑUEL, Luis; DALÍ, Salvador. Un chien andalou (1929)

- BURSTEIN, Nanette; MORGEN, Brett. The Kid Stays in the Picture (2002)

- BURTON, Tim. Big Fish (2003)

- CAMERON, James. The Abyss (1989); Terminator 2: Judgement Day (1991);

Titanic (1997); Avatar (2009)

- CARLIER, Emmanuel. Temps mort (1995)

- CHABOT, Claude. Apnée (2006)

- CHAPMAN, Christopher. A Place to Stand (1967)

- CHIU, Rob. Black Day to Freedom (2005)

- COHL, Emile. Fantasmagorie (1908); The Hasher's Delirium (1910)

- COLUMBUS, Chris. Harry Potter and the Chamber of Secrets (2002); Percy Jackson \& the Olympians: The Lightning Thief (2010)

- COURTES, Alex. Seven Nation Army (2003), en colaboración con Martin Fougerol; Get On Your Boots (2009)

- CROOKS, Daniel. Static $N^{\circ} 12$ (Seek stillness in movement) (2010) 
- CSURI, Charles. Hummingbird (1968); Aging Process (1968); Artist into Frog (1968); Hommage II (2006)

- CUBA, Larry. Two Space (1979)

- CULLEN, Mathew; KUDSI, Mark. Boom, Boom, Pow (2009)

- CUNNINGHAM, Chris. Publicidad de Orange Photo Messaging (2002)

- DE PALMA, Brian. Sisters (1973); Mission to Mars (2000)

- DEBEVEC, Paul. The Campanile movie (1997); The Parthenon (2004)

- DRAVES, Scott. 165 Star Oasis (2005)

- DULAC, Germaine. La coquille et le clergyman (1928)

- DUPONT, Ewald André. Varieté (1925)

- DUSOLLIER, Hendrick. Obras (2004)

- EAMES, Ray y Charles. Powers of Ten (1977)

- EISENSTEIN, Serguei. Stachka (1924); Bronenósets Potiomkin (1925); Staroe i novoe (1929)

- EMSHWILLER, Ed. Crossings and Meetings (1974); Sunstone (1979)

- ENE. Publicidad para la obra social de La Caixa (2011)

- EVERYNONE (Will Hoffman, Daniel Mercadante y Julius Metoyer). Symmetry (2011)

- FIGGIS, Mike. Timecode (2000)

- FINCHER, David. Love Is Strong (1994); Fight Club (1999); Panic Room (2002)

- FINK, Gusti; ASH KAWAY, Helmut. Ghost Dream (2012)

- FOLDES, Peter. Metadata (1971); La faim (1974)

- FRANKE, Daniel. Unnamed soundsculpture (2012)

- FRANKE, Herbert. Digital Einstein (1973)

- GANCE, Abel. La folie du Docteur Tube (1915); La Roue (1922); Napoléon (1927)

- GILLIAM, Terry. Twelve Monkeys (1995); Tideland (2005); The Imaginarium of Doctor Parnassus (2009)

- GODARD, Jean Luc. Histoire(s) du cinema (1997)

- GODLEY \& CREME (Kevin Godley y Lol Creme). Cry (1985)

- GONDRY, Michel. Je danse le Mia (1994); publicidad para Vodka Smirnoff (1996); Like a Rolling Stone (1996); Sugar Water (1997); How are you doing (2011)

- GONDRY, Olivier. You Gonna Want Me (2005)

- GREENAWAY, Peter. Prospero's Books (1991); The Pillow Book (1996); The Tulse Luper Suitcases (2003) 
- HALAS, John. Dilemma (1981)

- HILPOLTSTEINER, Martin. Recreating Movement (2005)

- HITCHCOCK, Alfred. Rope (1948); Rear Window (1954); Vertigo (1958)

- HOWARD, Ron. Willow (1988)

- ISHII, Katsuhito. Cha no aji (2004)

- JACKSON, Peter. Heavenly Creatures (1994); The lord of the rings: The fellowship of the ring (2001); The Lovely Bones (2009)

- JAENICKE, Maximilian. Losing Touch (2002)

- JEUNET, Jean Pierrre. Micmacs à tire-larigot (2009)

- JEWISON, Norman. The Thomas Crown affair (1968)

- JOHNSON, Philip Scott. Women in Film (2007); Women in Art (2007); Monet (2009); Faces of Fashion (2011)

- JONES, Duncan. Source Code (2011)

- JORDAN, Neil. Interview with the Vampire: The Vampire Chronicles (1994)

- KAWAGUCHI, Yoichiro. Luminous Visions (1998)

- KEATON, Buster. Sherlock Jr. (1924)

- KELLY, Richard. Donnie Darko (2001)

- KUBRICK, Stanley. 2001: A Space Odyssey (1968)

- KUNTZEL, Thierry. Tu (1994)

- KUROKAWA, Ryoichi. Ground (2011)

- KUROSAWA, Akira. Dreams (1990)

- L’HERBIER, Marcel. El Dorado (1921)

- LANDIS, John. Black or White (1991)

- LANDRETH, Chris. Ryan (2004)

- LATHAM, William. Organic Television (1994)

- LÉGER, Fernand. Ballet mécanique (1924)

- LIMA, Kevin. Enchanted (2007)

- LIMAN, Doug. Jumper (2008)

- LISBERGER, Steven. Tron (1982)

- LITTLE X. Coming Undone (2006)

- LUHRMANN, Baz. Moulin Rouge (2001)

- LUNGHINI, Daniele; ZUELLI, Diego. Le foto dello scandalo (2001)

- LYE, Len. Rainbow Dance (1936)

- LYNCH, David. Lost Highway (1997) 
- LYSAKOWSKI, Lukasz. Colour process (2009); Motion process (2009); Process of realtime (2009)

- MACMILLAN, Tim. Publicidad London's static without (1996); Ferment (1999); Animal Tragic (2003)

- MAHN, Owi; BAGINSKI, Laura. Pastell Kompressor (2003)

- MARTINS, Giovanni. Manifesto (2011)

- MATSUMOTO, Toshio. Mona Lisa (1973)

- MCCABE, Jonathan. Inflating Turing pattern 1 (2010); Into the colorflow (2011)

- MCFARLANE, Todd. Freak on a Leash (1999)

- MCLAREN, Norman. Pas de deux (1968)

- MCQUEEN, Steve. Hunger (2008)

- MÉLIÈS, Georges. Le voyage dans la lune (1902)

- MEYER, Nicholas. Star Trek II: The Wrath of Khan (1982)

- MURATA, Takeshi. Monster Movie (2005); Untitled (Silver) (2006)

- MURNAU, Friedrich Wilhelm. Der letzte Mann (1924); Sunrise (1927)

- NABIL. Welcome to Heartbreak (2009)

- NELSON, Gary. The Black Hole (1979)

- NOLAN, Christopher. Inception (2010)

- NOLL, Michael. Rotating four-dimensional hypercube (1965); 4-D Hyper Movie (ca 1967)

- NORTON, Ace. Thinking About You (2007)

- NOURIZADEH, Nima. Over and over (2006)

- ODENBACH, Marcel. Dans la Vision périphérique du Témoin (1986)

- ONEINTHREE. Brave Bulging Buoyant Clairvoyants (2008)

- PAIK, Nam June. Electronic Opera \#1 (1968-1969); Global Groove (1973)

- PAINLEVÉ, Jean. La quatrième dimension (1937)

- PARKER, Alan. Pink Floyd. The Wall (1982)

- PORTER, Edwin S.. Life of an American Fireman (1903); Dream of a Rarebit Fiend (1906)

- PROVOST, Nicolas. Pommes d'amour (2001); Papillon d'amour (2003)

- PROYAS, Alex. Dark City (1998)

- RAIMI, Sam. Spider-Man (2002)

- RALSKE, Kurt. Darkness (Not Darkness) (2005); Times Square Timeshare (2006); The Inevitable (2007); Faust Golden Vivisection (2009) 
- RAMOS, Márcio. Vida Maria (2006)

- RAY, Man. Emak Bakia (1926); L'étoile de mer (1928)

- REAS, Casey. Process 16 (2006)

- REGGIO, Godfrey. Naqoyqatsi (2002)

- REINHART, Martin. TX-Transform, the film (1998), en colaboración con Virgil

Widrich; TX-dance. Motion studies in space and time (2002)

- REINIGER, Lotte. Die Abenteuer des Prinzen Achmed (1926)

- RICHARDSON, Tim. Nars Pure Matte (2010)

- RICHTER, Hans. Rhythmus 21 (1921); Filmstudie (1926); Vormittagsspuk (1928)

- RITCHIE, Guy. Sherlock Holmes (2009)

- RITCHIE, Michael. The Golden Child (1986)

- ROMANEK, Mark. One Hour Photo (2002)

- ROSALES, Jaime. La soledad (2007)

- ROSS, Gary. Pleasantville (1998)

- RUIZ GUTIÉRREZ, Tania. Éphémère II (2000); La Plaza II (2004)

- RUTTMANN, Walter. Opus 1 (Lichtspiel) (1921)

- RYBCZYNSKI, Zbigniew. Nowa ksiazka (1975); Tango (1980); Imagine (1986); Steps (1987); The Fourth Dimension (1988)

- SALAVON, Jason. The Late Night Triad (2003); Still Life (Vanitas) (2009)

- SANDERS, Rupert. Snow White and the Huntsman (2012)

- SCHWARTZ, Lillian. Mutations (1973); Metamorphosis (1974); Morphing of the Telephone (1997)

- SCORSESE, Martin. Hugo (2011)

- SEKINE, Kosai. Maledict car (2008)

- SHIBAYAMA, Nobuhiro. CD-ROM: “Bio-Morph Encyclopedia” (1994)

- SILLECK, Bayley. Cosmic Voyage (1996)

- SIMS, Karl. Particle Dreams (1988); Primordial Dance (1991); Liquid Selves (1992)

- SINGH, Tarsem. The Cell (2000); The Fall (2006)

- SJÖLANDER, Ture; WECK, Lars. Monument (1967)

- SMALLEY, Phillips; WEBER, Lois. Suspense (1913)

- SNORRI BROS. By and By (2009); Life moves fast, don't miss a thing (2010)

- SNOW, Michael. Wavelength (1967)

- SNYDER, Zack. 300 (2006) 
- SPIELBERG, Steven. Indiana Jones and the Last Crusade (1989); Schindler's List (1993); Minority Report (2002)

- STEHURA, John. Cybernetik 5.3 (1965-1969)

- STEVENSON, Robert. Mary Poppins (1964)

- SZASZ, Eva. Cosmic Zoom (1968)

- TALEN, Julie. Pretend (2003)

- TARANTINO, Quentin. Inglourious Basterds (2009)

- TELL NO ONE (Luke White y Remi Weekes). Show Me The Light; Seaweed; Forest (2010)

- TINTORI, Ray. Time To Pretend (2008); Evident Utensil (2009)

- TRUFFAUT, François. Les quatre cents coups (1959)

- TYKWER, Tom. Lola rennt (1998)

- VANDERBEEK, Stan; KNOWLTON, Kenneth. Poemfield \#2 (1966)

- VASULKA, Steina. Lilith (1987); Warp (2000)

- VASULKA, Woody. Art of Memory (1987)

- VERTOV, Dziga. Chelovek s kinoapparatom (1929)

- VOGEL, François. Trois petits chats (2002)

- WACHOWSKI, Lana y Andy. The Matrix (1999)

- WALICZKY, Tamás. Pictures (1988); The Forest (1993); The Way (1994); The Garden (1992-1996); Sculptures (1996); Landscape (1997)

- WATZ, Marius. ElectroPlastique \#1 (2005)

- WE ARE FROM L.A. La musique (2010)

- WEBB, Marc. (500) Days of Summer (2009)

- WEIBEL, Peter. Gesänge des Pluriversums (1986)

- WEITZ, Chris. New Moon (2009)

- WELLES, Orson. Citizen Kane (1941)

- WHITE, Paul. Hunter (1997)

- WHITNEY, John. Catalog (1961); Permutations (1966)

- WILLIAMS, Hype. Viva la vida (2008)

- XX Lager. Campaña Dos equis iguales diferentes (2007)

- ZAJAC, Edward E.. Simulation of a Two-Gyro Gravity-Gradient Attitude Control System (1963)

- ZEMECKIS, Robert. Forrest Gump (1994); Contact (1997)

- ZHANG, Yimou. Hero (2002); House of Flying Daggers (2004) 